Universitat Jaume I

Facultat de Ciències Humanes i Socials

Departament d'Història, Geografia i Art

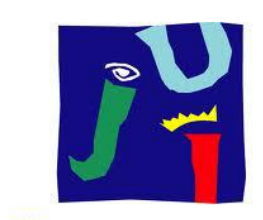

UNIVERSITAT

JAUME•I

El poblamiento romano en Saguntum y su

territorium:organización urbana y explotación agrícola

José Manuel Melchor Monserrat

Tesis doctoral dirigida por los Doctores:

Juan José Seguí Marco

Ramón Járrega Domínguez

Castellón, 2013 
TESIS DOCTORAL

\section{EL POBLAMIENTO ROMANO EN SAGUNTUM Y SU TERRITORIUM: ORGANIZACIÓN URBANA Y EXPLOTACIÓN AGRÍCOLA}




\section{ÍNDICE TESIS}

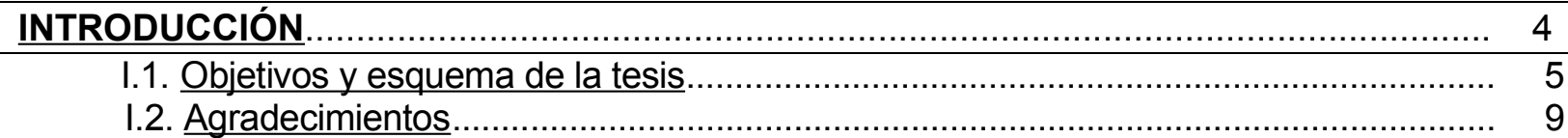

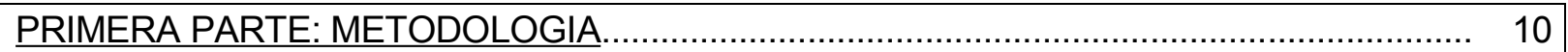

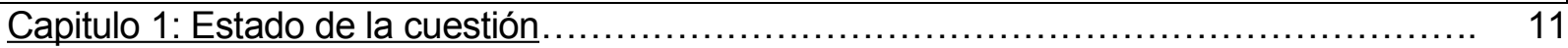

1.1. La problemática metodológica en la arqueología ............................................... 12

1.1.1. Estudio matemático de variables humanas...................... 14

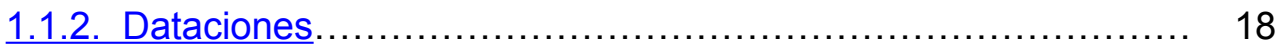

1.1.3. Intervenciones segmentadas o parciales........................ 20

1.1.4. La problemática de los criterios interpretativos.................. 22

1.1.4.1. Los yacimientos ibéricos de la costa de Castellón............ 23

1.1.4.2. La necrópolis de Lledó (Castellón de la Plana)............ 31

1.1.5. Cronologías parciales, poco ajustadas o erróneas................. 41

1.1.6. Ausencia de coordinación entre Arqueología e Historia Antigua... 36

1.1.7. La gestión administrativa y la gestión científica...................... 34

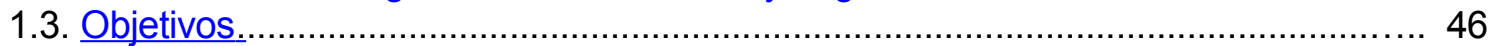

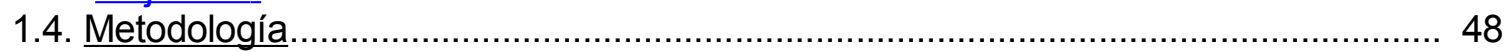

Capitulo 2: Marco para el estudio de asentamientos romanos................................. 54

2.1. Antecedentes para el estudio del mundo urbano.................................................. 55

2.2. Antecedentes para el estudio del mudo rural...................................................... 72

2.3. Datos sobre vías de comunicación al sur del Conventus Tarraconensis.................. 82

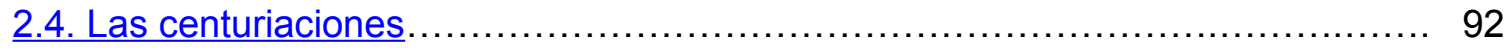

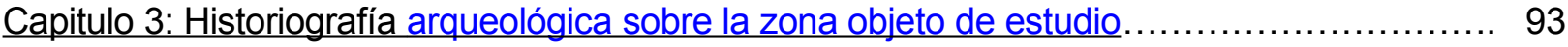

3.1. El caso valenciano ..................................................................................... 99

3.2. Un ejemplo local: Burriana.......................................................................... 105

SEGUNDA PARTE: DATOS ARQUEOLOGICOS ........................................................... 108

Capitulo 1: Problemática arqueológica de las ciudades romanas: Saguntum a partir de

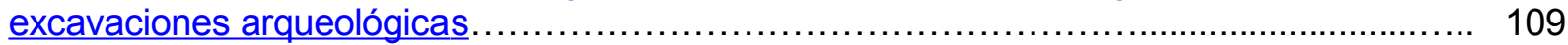

1.1. Resultados de las intervenciones arqueológicas en Saguntum........................... 111

1.1.1. plaza de la Morería......................................................................... 113

1.1.2.calles Huertos - Ordóñez- Remedio (solar Quevedo)................. 132

Capitulo 2: Poblamiento rural del Ager Saguntinus ........................................ 139

2.1. Resultados de las intervenciones arqueológicas................................................. 140

2.1.1.Els Terrers (Faura-Sagunto) ..................................................... 142

2.1.2. Partida de Santa y su entorno (L'Alcora)......................................... 147

2.1.3. El Palau (Burriana)................................................................... 158

2.1.4. Sant Gregori y su entorno (Burriana).......................................... 175

2.1.5. Torre d'Onda (Burriana)............................................................ 181

2.1.6.Carabona (Burriana)..................................................................... 195

2.1.7. Cami Corrent (Burriana) .............................................................. 201

2.1.8. Vinarragell (Burriana)..................................................................... 203

2.1.9. La Regenta (Burriana) ............................................................... 205

2.1.10.Otras intervenciones - Centro Histórico de Burriana..................... 207

TERCERA PARTE: ESTUDIO DE LA CULTURA MATERIAL Y LA EPIGRAFÍA.................. 211

1.1. La plaza de la Morería (Sagunto) …........................................................ 213

1.2. El Palau (Burriana).................................................................................... 220 


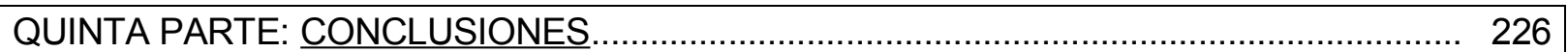

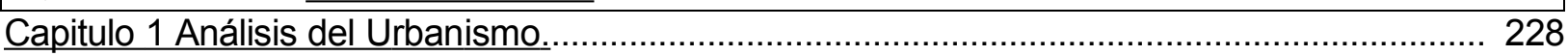

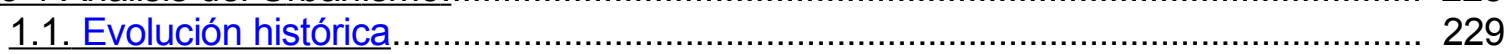

1.2. Antecedentes y primer asentamiento urbano romano...................................... 233

1.3. El principio del imperio y la reforma augústea.................................................. 237

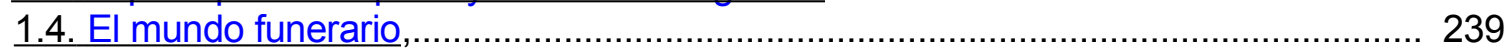

1.5. La gran reforma del siglo II d. C........................................................................ 244

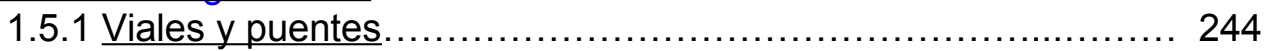

1.5.2. El anfiteatro................................................ 248

1.5.3. Los templos y edificios monumentales de la Morería.............. 253

1.5.4. El foro "Bajo" ............................................... 259

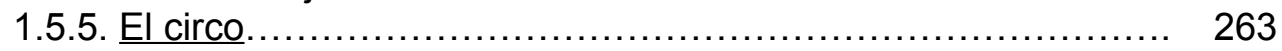

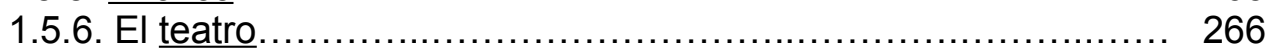

1.5.7. La domus del solar de la Lira Musical........................ 267

1.5.8. Las necrópolis................................................. 269

1.6. Servicios públicos de agua y desagües......................................................... 277

1.7. La urbanización del siglo III d. C..................................................................... 283

1.8 La decadencia y la época visigoda.................................................................. 292

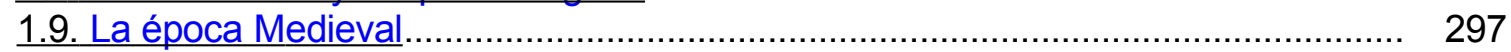

Capitulo 2 Análisis del poblamiento rural...................................................................... 299

Capitulo 3 Consideraciones globales.............................................................................. 309

Capitulo 4 Hipótesis de trabajo........................................................................................... 322

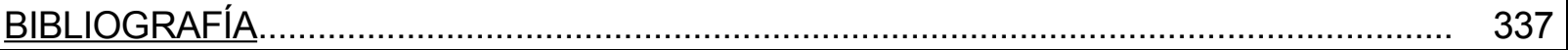

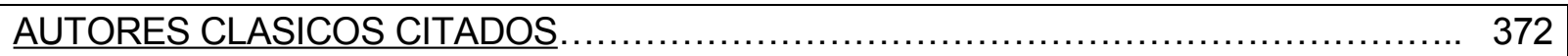

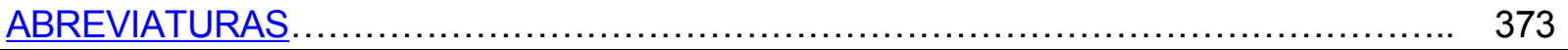

IMÁGENES 


\section{INTRODUCCIÓN}




\section{I.1. OBJETIVOS Y ESQUEMA DE LA TESIS}

El objetivo de esta tesis doctoral es realizar un análisis profundo de la romanización del territorio, haciendo especial hincapié en los distintos aspectos económicos que caracterizan la explotación del agro en época romana, y estudiando la interrelación entre el núcleo urbano de la ciudad y los asentamientos rurales. Para ello hemos elegido la zona comprendida entre Sagunto y la zona del río Mijares, que correspondería al Sur de la provincia romana Tarraconensis. Hispania Citerior, en la que venimos realizando trabajos arqueológicos desde hace más de veinte años. Incluimos también en este conjunto algunas intervenciones realizadas en la ciudad de Valencia, pues nos pareció oportuno reforzar los datos referidos al urbanismo romano con otra importante urbe junto a la ya citada Sagunto. También pretendemos actualizar el análisis historiográfico desde una perspectiva de género en la zona geográfica y periódico histórico abordado por nuestra tesis, y analizar los reflejos de esta situación en el estadio actual de los conocimientos y la interpretación de los datos.

Los datos aportados en este trabajo son en su mayor parte fruto de excavaciones de urgencia que no tuvieron su vertiente científica desarrollada con la profundidad que sería deseable, a causa en gran parte de la rapidez con la que deben trabajar los arqueólogos profesionales que se enfrentan a las mismas, y que tienen que sortear en muchas ocasiones presiones de todo tipo para llevar adelante su trabajo en el menor tiempo posible. En otras palabras, la necesidad de mantener un ritmo profesional continuo hace que las memorias científicas se realicen de forma digna pero escueta.

Las excavaciones utilizadas para el desarrollo de nuestra tesis doctoral son fruto de las campañas que dirigimos o codirigimos durante nuestra faceta como profesional autónomo y posteriormente como arqueólogo municipal de Burriana, entre los años 1992 y 2012. Los resultados aportados en el presente trabajo son inéditos, si bien ya se han publicado algunas referencias en diversos artículos sobre las citadas intervenciones. Básicamente han sido dos las principales excavaciones cuyos resultados han llevado a plantearnos el desarrollo de esta tesis doctoral. La primera de ellas, cronológicamente hablando, es la actuación arqueológica en el Palau de Burriana 
(Castellón), que corresponde a una serie de intervenciones sobre el yacimiento desarrolladas entre los años 1992 y 2011. La segunda es la de la plaza de la Morería, en el casco urbano de Sagunto, llevada a cabo entre 2002 y 2005. La primera de ellas nos llamó la atención por la complejidad a la hora de interpretar las distintas fases de un yacimiento que resultó clave para entender el origen de la propia Burriana, como ya detallaremos en su momento. La otra es, sin duda, esencial para proponer un cambio profundo en la interpretación de la ciudad romana de Sagunto; de hecho, los restos recuperados indican claramente que era necesario plantear un nuevo modelo urbanístico para toda la ciudad.

También haremos referencia a las excavaciones desarrolladas en el término municipal de L'Alcora (Castellón), concretamente en el yacimiento del Pujolet de Santa durante el año 2004, en Els Terrers (Faura y Sagunto) en 2005 o en Torre d'Onda (Burriana) en 2007. Los resultados de las citadas excavaciones nos llevaron a pensar que podíamos realizar un estudio profundo con vistas al establecimiento de un modelo, por un lado para ciudades y por otro para los asentamientos rústicos ubicados en nuestra zona, que estén cronológicamente adscritos al periodo romano.

Dentro de esta dinámica también tuvimos en cuenta que hoy en día aún hay asignaturas pendientes que arrancaron en el pasado y que permanecen vigentes, básicamente debido a la falta de experiencia y de autocrítica de algunos investigadores, lo que ha llevado a establecer teorías y conclusiones supuestamente consolidadas que en ocasiones son fruto de una falta de investigación en profundidad, de contraste de los hallazgos, de espíritu crítico (y también autocrítico) y, sobre todo, de análisis comparativos a mayor escala. Esta situación ha provocado que, en algunos casos, se haya establecido una línea intelectual inmovilista, muy significativa en nuestra zona, que defiende a ultranza las teorías revisionistas de los años 70 y que ahora se encuentra colapsada ante la deficiencia en la recuperación y análisis de los restos existentes y que, además, no es capaz de gestionar los elementos cada vez más abundantes obtenidos de intervenciones arqueológicas. Es especialmente llamativa la práctica ausencia de trabajos locales realizados por investigadoras hasta bien entrada la segunda mitad del siglo XX, pero sin embargo solamente cambia la situación a nivel institucional, no es esta hasta final de siglo cuando cambia el panorama.

Antes de entrar en el primer apartado de esta investigación queríamos hacer una breve reseña sobre las ideas que nos guiarán a lo largo de esta tesis doctoral. Tenemos todavía mucho por resolver y solamente si somos conscientes de que aún estamos muy lejos de descubrir la verdad sobre nuestro pasado, seguiremos con el ímpetu necesario para progresar y alcanzar metas que verdaderamente nos permitan llegar a entender la complejidad del espíritu humano y su evolución a lo largo de la historia. Y no debemos olvidar nunca que, en la mayor parte de los casos, estamos intentando 
descubrir los pensamientos, sentimientos y emociones de seres humanos únicamente a través de sus restos materiales.

Nosotros asumimos los errores que podamos cometer, que sin duda existirán, pero al menos intentaremos utilizar todos los recursos de los que disponemos para obtener unos resultados que sean mínimamente útiles a la arqueología y que pasen con alguna dignidad la criba de la perspectiva histórica. Sobre todo pensamos que no somos dueños de la verdad, pero tampoco lo puede ser nadie. Sólo los hechos son inamovibles, por ejemplo, una cerámica sigillata lo será siempre, es un dato irrebatible, sin embargo el por qué apareció en un contexto determinado es el factor que admitiría múltiples interpretaciones y quizá nunca se pueda llegar a una conclusión tan irrefutable como su variable material. Asimismo esta tesis no alcanzará nunca su verdadera dimensión sino es formando parte de un conjunto más amplio de discusión, critica y debate.

En este estudio vamos a hacer en primer lugar una reseña de los conceptos teóricos y el marco físico de esta tesis a lo que añadimos un breve repaso al estado actual de los estudios sobre la ocupación del territorio en el mundo romano, donde se puede comprobar que aun son escasos los ejemplos con los que podemos contar en la zona de la Comunidad Valenciana que nos ocupa. Posteriormente desarrollaremos el apartado metodológico, sobre la base de algunas cuestiones de la problemática metodológica actual de la arqueología, ya que afectan directamente el desarrollo de este trabajo. Esto nos permitirá su comprensión como disciplina por medio del conocimiento de su propia historiografía, ya que lleva arrastrando una carga importante de siglos anteriores. Una de las principales reflexiones se sustenta en la necesidad de una depuración intensa de los datos arqueológicos antiguos, como por ejemplo interpretaciones, cronologías, tipologías etc., que son aún hoy en día de interés, pero que precisan de una adaptación a los recursos actuales y a la magnitud de hallazgos arqueológicos que se están realizando en nuestra zona, especialmente desde de los últimos veinte años del siglo $X X$, con el auge de las campañas de urgencia que aportan una cantidad ingente de datos que muy raramente son debidamente analizados.

Más adelante proponemos soluciones a esta dicotomía existente entre la arqueología de investigación y la de urgencia, ya que no podemos dejar de citar a lo largo de nuestro trabajo este problema, que es uno de los más significativos a la hora de la depuración de los testimonios que pretendemos utilizar, pues como ya comentamos, muchos de los datos carecen de la fiabilidad que sería deseable, fruto quizá de la falta de preparación, medios, recursos u otros aspectos similares que impiden al arqueólogo profundizar en el estudio de los restos recuperados en sus intervenciones y que, además, por motivos sociales o económicos deben ser realizadas con extrema rapidez. Con esto no pretendemos cargar las tintas solamente sobre los profesionales que ejercen de forma autónoma; también en los centros de investigación como museos, 
universidades $u$ otras entidades similares existen, en ocasiones, deficiencias a nivel de revisión crítica de antiguas intervenciones. De hecho, podemos considerar que la falta de especialización en algunos casos o la carencia de recursos en otros (incluso en administración pública), también pueden ser factores decisivos en esta cuestión. Un ejemplo sería que el ejercicio de la arqueología profesional puede obligar a un especialista en Prehistoria a realizar una intervención que sólo afecte a niveles romanos y medievales, lo cual, si bien no tiene que ser un problema insalvable, puede significar por parte del experto un mayor esfuerzo del que seria necesario a la hora de interpretar los resultados. Sin embargo esta "apertura" del mercado favorece de introducción masiva de la mujer a nivel laboral y de investigación, situación que anteriormente estaba solamente reservada al mundo funcionarial.

Seguidamente analizamos los conceptos metodológicos aplicados a las excavaciones, concretamente las fuentes científicas sobre las que apoyamos esta investigación y nos hallamos entonces con una serie de deficiencias que nos llevan a realizar una reflexión en profundidad respecto a los antecedentes y un intento de ajuste de la metodología general de aplicación con ejemplos de una revisión crítica de intervenciones antiguas.

Una vez sentada la base metodológica de este trabajo, iniciaremos un análisis profundo de los antecedentes historiográficos de la zona objeto de mismo, de tal forma que aplicaremos una depuración de los resultados conocidos sobre la base metodológica antes citada. Esto nos permitirá que desarrollemos esta tarea investigadora en dos apartados: en el primero de ellos presentaremos los datos como tales y eliminaremos, en la medida de lo posible, cualquier injerencia de criterios o conjeturas. En el segundo desarrollaremos libremente nuestras hipótesis sobre los datos anteriormente aportados. En nuestra opinión esta división permitirá observar los testimonios de forma aséptica y fiable, obtenidos con rigurosidad científica y con los medios actuales disponibles. Frente a ellos presentaremos las hipótesis, que como fruto de nuestro intelecto son totalmente rebatibles y discutibles, al igual que las teorías desarrolladas por cualquier investigador.

Una vez depurados y analizados los antecedentes globales de la zona a nivel historiográfico, pasaremos a realizar una descripción detallada de las intervenciones que sirven de corpus a nuestro trabajo, cada una de ellas tratadas de forma individual, como las de la plaza de la Morería y calle Huertos -calle Ordóñez- calle Remedio en Sagunto; todas ellas en el ámbito urbano y la intervenciones rurales de El Palau, Sant Gregori y Torre d'Onda en Burriana y la de Santa y su entorno en L'Alcora.

Gracias a estos últimos datos podremos pasar a analizar un sistema de asentamientos con una clara vertiente cronológica, además de la macroespacial, y que finalizaremos con la constatación de unas consideraciones globales que nos permiten plantear la aplicación una patrones generales para la época romana. 


\section{I.4. AGRADECIMIENTOS}

Antes de desarrollar el trabajo no podemos olvidar a todos aquellos que han ayudado de forma significativa al desarrollo de esta tesis, sin lo cuales esta no hubiera sido posible. En primer lugar debemos agradecer a los Drs. Juan José Seguí y Ramón Járrega, co-directores de esta tesis, por sus sabios consejos, su soporte decidido, y porque no decirlo, su apoyo en los momentos difíciles. Quiero también agradecer a mi mujer, la Dra. Trinidad Pasies, por su paciencia, ánimos constantes y por haber oído mis teorías, a veces poco heterodoxas, y aportar ese aire critico tan habitual en los restauradores. Al Dr. Juan José Ferrer, director del Departamento Historia, Geografía y Arte de la Facultad de Ciencias Humanas y Sociales de la Universitat Jaume I, por su respaldo incondicional a esta tesis. A Josep Benedito "amicus certus".

A Demetrios Crisopoulus, exdirector del Servicio de Restauración de Mosaicos del ministerio de cultura griego, gran amigo e inmejorable guía para conocer los restos arqueológicos más importantes de Grecia. A Carmelo Fernández del Museo de Palencia, por su amistad y ayuda en lo que a la arqueología romana se refiere.

Al personal del Consorcio Monumental de Mérida, especialmente a Pedro Mateos y Félix Palma, que además de sumergirnos en la arqueología emeritense, nos han permitido desarrollar buena parte de nuestra teoría en esta bella ciudad. Al personal de la Escuela Española de Arqueología de Roma, el Ministerio del Aire Italiano, del SIP de la Diputación de Valencia y del SIAP de la Diputación de Castellón, por su amabilidad y paciencia. Al ayuntamiento de Burriana, y especialmente a José Ramón Calpe y Josep Palomero, por su apoyo. Al Centro Arqueológico Saguntino por las facilidades a la hora de consultar la valiosa información que atesora esta asociación, especialmente a D. Facundo Roca, Amadeo Rivelles, Manuel Civera y Sergio Vela por su apoyo.

A nuestros colegas y amigos: Mónica Claramonte, Sandrine Delaporte, Fernando López, María del Mar Pascual y Esther Marin que nos han permitido utilizar los materiales y la información que obtuvimos juntos en excavaciones arqueológicas.

En fin, a todos ellos nuestro más sincero agradecimiento

$$
\text { Burriana - Mérida - Atenas - Roma - Petrés, (fecha) }
$$




\section{PRIMERA PARTE: METODOLOGIA}




\section{CAPITULO 1: ESTADO DE LA CUESTIÓN}




\subsection{LA PROBLEMÁTICA METODOLÓGICA EN LA ARQUEOLOGÍA}

En esta sección pretendemos describir los principales problemas con los que nos encontramos a la hora de definir los datos que forman parte de un estudio arqueológico. Desde nuestro punto de vista, es importante establecer estos condicionantes de forma previa a la exposición del núcleo principal del trabajo, para que podamos comprender la dificultad con la que nos hemos enfrentado a la hora de hallar antecedentes y paralelos en nuestro estudio.

Bajo nuestro criterio era necesario llevar a cabo un cuerpo teórico que explicase y al mismo tiempo propusiera una serie soluciones que, una vez aplicadas a las investigaciones arqueológicas que sirven de base a esta tesis, pudieran de alguna forma dar un peso específico mucho más grande a los datos, avalando el rigor científico de los mismos. Así pues, conforme íbamos avanzando en nuestro estudio, mayor era la complejidad del trabajo de revisión al que nos veíamos abocados. Para mayor claridad hemos decidido exponer las principales dificultades en un primer apartado y tratar en un segundo algunas propuestas resolutorias a estos temas; estas soluciones son, sin duda, una parte importante del estudio de las excavaciones y yacimientos que forman la base de esta investigación doctoral.

La decisión de incluir estos apartados es importante, no sólo para el conocimiento actual de los problemas sobre el modelo teórico de ocupación del territorio en época romana, sino para que todo aquel que lea este trabajo pueda entender las vicisitudes y dificultades teóricas existentes. Además, desde nuestra forma de ser y pensar, no podíamos simplemente presentar una serie de problemas y críticas sin intentar, al menos en parte, adelantar alguna propuesta constructiva para solucionar estos avatares. Ésta es pues la causa de que tanto la introducción como la parte inicial de esta tesis se refieran a problemas teóricos y generales de la arqueología y al consiguiente planteamiento resolutorio aplicado posteriormente sobre los yacimientos romanos que utilizamos en el presente documento. 
Existe una problemática actual en algunos campos de la Arqueología que es la ausencia de una crítica científica profunda de las bases y antecedentes metodológicos de las investigaciones actuales. El panorama actual de la Arqueología ofrece una formación académica "en serie" de técnicos en buena parte escasamente cualificados para las tareas de campo, que tienen que completar su formación de forma autodidacta sobre el terreno, con el riesgo que ello conlleva ante una demanda cada vez mayor, lo que a su vez comporta una falta de tiempo para ampliar conocimientos y profundizar en la investigación científica. Quizá si contáramos con un colectivo menos compartimentado y receloso de sus intervenciones y con unas instituciones que fomentaran y desarrollaran la pesquisa de una forma verdaderamente democrática y plural, empezaríamos a ver la luz al final del túnel. Creemos verdaderamente que estamos en una comunidad científica que sólo puede progresar aunando esfuerzos. Lamentablemente no existe un estudio estadístico de la cantidad de excavaciones arqueológicas que se realizan anualmente en la Comunidad Valenciana, con lo cual es imposible hablar con fundamento de la evolución cuantitativa de las intervenciones sobre patrimonio desde que se traspasaran las competencias a la Generalitat Valenciana por parte del Estado Español en el año 1982. De modo totalmente aproximativo podríamos decir que hoy en día las actuaciones multiplican fácilmente por diez a las que se realizaban en los años 80 del siglo $X X$, y éstas a su vez multiplicaban por diez a las de la segunda mitad de ese mismo siglo. Al mismo tiempo es destacable la importante cantidad de mujeres que se suman al mercado laboral, y en menor cantidad al campo de la investigación.

Así pues, una de las bases de este trabajo es la revisión total y absoluta de todas las fuentes que utilicemos, ya sean escritas o se trate de material de excavaciones antiguas. Utilizando métodos de análisis actuales mucho más seguros a nivel de cronología o interpretación podemos refrescar y actualizar elementos antiguos que aparentemente puedan ser discordantes o tengan poca utilidad. También es necesario decir que si es criticable todo aquel que en su momento no utilizó los medios de que se disponía a nivel científico y profesional, es igualmente patente y notorio que algunos aficionados destruyeron y arrasaron nuestro patrimonio arqueológico. De la misma forma algunos arqueólogos se convierten en meros devastadores del patrimonio al no publicar los resultados de sus intervenciones, porque de esta forma todo lo que hicieron se perdió irremediablemente.

Acto seguido nos encontramos con la problemática de los conceptos metodológicos aplicados a las excavaciones. Algunos de ellos no nos parecieron lo suficientemente actualizados o concretos para poder establecer una base sólida sobre la cual desarrollar nuestro estudio. Así pues, realizamos una primera búsqueda de fuentes científicas sobre las que apoyar esta investigación y nos hallamos entonces con una serie de nuevos problemas entre los que podemos citar, por ejemplo, la amplitud de cronologías, la escasa rigurosidad de algunas intervenciones antiguas, la falta de 
publicaciones de excavaciones, etc. Por ello, en la primera parte de esta tesis, consideramos la urgente necesidad de realizar una reflexión en profundidad respecto a los antecedentes y un intento de ajuste de la metodología general de aplicación. Esto ha implicado una actualización de parte de los propios conceptos arqueológicos, sin dejar de hacer una revisión crítica previa muy necesaria en favor del carácter científico de la arqueología.

\subsubsection{Estudio matemático de variables humanas}

Introduciremos aquí una variable muy importante, que nos va a acompañar en buena parte del desarrollo de este trabajo y que es también el origen de algunas de las matizaciones que queremos aplicar a buena parte de los estudios arqueológicos consultados. Como ya hemos constatado en nuestra introducción, los orígenes de la arqueología están claramente asociados a una disciplina humanística alejada de las convenciones científicas de otras materias como las matemáticas, la física, la química, etc. Los primeros contactos con estas ciencias aportaron sin duda una inestimable ayuda para la arqueología, ya que es evidente que todos los procesos físicos, químicos, matemáticos, biológicos, etc. que sirven para analizar, esquematizar y reflejar de forma coherente los datos arqueológicos, son ciencias absolutamente necesarias para el desarrollo de la arqueología. El problema se plantea cuando estos resultados son los únicos que se utilizan para desarrollar hipótesis y es que, en los últimos años, esta aportación ha pasado de ser una simple colaboración a una línea maestra que rige la Arqueología, en un vano intento de transformarla en una ciencia de cariz exacto y matemático en todos los casos. Llegamos a encontrarnos con una expresión que podemos calificar al menos de curiosa, cuando a ciencias como la Física, la Química o la Estadística entre otras más, se las considera como ciencias auxiliares de la Arqueología. Y no deja de parecernos curiosa por la presunta preponderancia semántica que tendría la Arqueología como gran ciencia hasta el punto de utilizar las demás como auxiliares.

Dejando a un lado estas expresiones anecdóticas debemos analizar la relación entre esas disciplinas llamadas exactas y esta sapiencia tan inexacta llamada Arqueología; para otras que no tienen la consideración de exactas, como la Etnoarqueología, también mantenemos las mismas reservas que con las demás sobre su aplicación directa al registro arqueológico, en este caso concreto por la diferencia crono-espacial entre los modelos comparados. 
Es comprensible que muchos investigadores, ante la falta de datos y de restos, intenten obtener resultados utilizando todo aquello que tienen a su alcance; pensemos que muchos estudios basados en análisis cuantitativos de dispersión de materiales, corren el peligro de aportar datos que carezcan de un valor objetivo si no utilizan de una forma razonable las fórmulas matemáticas.

Un ejemplo lo podemos encontrar en las prospecciones donde se intenta, por medio de análisis cuantitativos o cualitativos, establecer cronologías o estudios de densidad de ocupación. ¿Alguien puede realmente creer que el hecho de que existan diez fragmentos de cerámica romana en la parcela 42 del polígono 20 de cualquier término municipal puede implicar la existencia de un asentamiento y, más aún, que éste sea el núcleo más importante porque en la parcela 41 del mismo polígono existen cinco fragmentos y en la parcela 40 existen solamente dos? De la misma forma, ¿se puede pensar que por encontrar 40 fragmentos de terra sigillata en la cima de un montículo y sólo 15 en el siguiente, sea el primero más importante?

Como ejemplo de los errores que pueden acarrear elementos tan a priori "exactos" como el georadar, citaremos un caso reciente ocurrido en el yacimiento de Les Palmeres (Vilafamés - Castellón) previamente fichado por la Conselleria de Cultura y Deporte de la Generalitat Valenciana y citado en la bibliografía al uso (ARANEGUI, 1996, ARASA, 2004) ${ }^{1}$. En el año 2004 se encargó, por parte de la Universitat Jaume I, un estudio de la zona de Les Palmeres en Vilafamés a una empresa catalana dedicada a la utilización del georadar en yacimientos arqueológicos, en unas parcelas donde se observaba en superficie una cantidad significativa de restos cerámicos de época romana. Pudimos consultar el informe, que no sólo aseguraba la existencia de estructuras subterráneas como presuntos aljibes y canalizaciones, si no que además establecía mapas de dispersión y concentración de restos cerámicos y señalaba el núcleo del yacimiento.

Sobre la base de estos datos se realizaron una serie de sondeos arqueológicos que revelaron que por debajo de la capa superficial del terreno de unos 20 a $30 \mathrm{~cm}$. aparecía un claro nivel geológico estéril sin el menor indicio de los restos arqueológicos que había señalado el georadar (ver Foto $\underline{582}$ ).

Nuestra interpretación es clara, se trata de una aportación de tierras exógenas con materiales romanos sobre un terreno que sufrió lo que se conoce en la Plana de Castellón como "rompuda", es decir, el levantamiento por medios mecánicos de estratos geológicos de roca para extraer niveles de arcilla inferiores, en donde los huecos formados entre las placas de rocas y el terreno serían las inexistentes estructuras subterráneas (ver Foto $\underline{581}$ ). Como conclusión podemos observar como la

\footnotetext{
${ }^{1}$ Nuestro agradecimiento al Dr. Juan José Ferrer, profesor de la Universidad Jaume I y al Dr. Ramón Járrega, director de la intervención arqueológica, que nos facilitaron el acceso a la documentación y a la propia intervención.
} 
extrapolación literal de datos científicos lleva a errores importantes. De hecho en este caso, si no se hubiera tenido el buen criterio de realizar sondeos manuales, tendríamos otro yacimiento "fantasma" más, con estructuras y hasta un posible núcleo de varias hectáreas. Casos de similar índole son el yacimiento de Camí Nou, en Nules, donde los únicos restos antiguos apreciables solo aparecen en una tapia moderna (ver Foto $\underline{585}$ ) y no en los huertos circundantes, con lo cual es probable que sean elementos transportados desde la vecina villa romana de Benicató. También podríamos mencionar el caso de El Palmar en Borriol, donde algunos autores (como Fletcher y Alcacer, 1956) desplazan el asentamiento romano a una zona sin restos en superficie, cuando a escasos 200 metros existen abundantísimos restos (inclusive constructivos - Foto $\underline{584}$ ).

Siguiendo esta línea de raciocinio sobre los análisis del territorio, si en una zona de un término municipal existen cuatro parcelas con restos romanos y en el término municipal vecino existen otras tres parcelas con elementos similares, ¿ya podemos considerar que existen dos asentamientos? $Y$ si en una excavación arqueológica urbana nos encontramos con que existen restos de época romana, musulmana e ibérica, ¿ya podemos pensar que existen niveles arqueológicos de estos periodos? ¿Y que su potencia estratigráfica y cantidad de restos están directamente relacionados con la importancia de la ocupación de estos periodos? Y no solamente eso, cabría hacerse otra pregunta más, ¿podemos permitirnos clasificar las estructuras y darles una funcionalidad si solamente hemos excavado (en el mejor de los casos) un $10 \%$ de todo un yacimiento urbano? $\mathrm{Y}$ esto lo podemos aplicar a la mayor parte de las ciudades, como por ejemplo Valencia, Castellón, Alicante, Burriana, Segorbe, Onda, etc.

Existen algunos ejemplos de estudios del territorio con un exagerado protagonismo de las cifras matemáticas y de los datos estadísticos, de tal forma que parece ser que los establecimientos antiguos se limitaban por polígonos matemáticos y no que estas formas geométricas sean un simple indicio para ayudar al arqueólogo a encontrar las verdaderas demarcaciones de estos asentamientos adaptados a la orografía del terreno. $Y$ aún hoy en día tenemos ejemplos de casos donde se establecen proporciones matemáticas sobre hallazgos de prospección para establecer modelos de ocupación, con los que no estamos de acuerdo, entre otras cosas por lo endebles que son los datos de superficie. Mas aun si existe una superposición multiplicadora de topónimos e intervenciones, como La Torrasa / Pla Redó en Betxí (ver Foto $\underline{583}$ ) según en que término municipal actual aparezcan los restos.

Veremos más adelante de una forma más detallada y con ejemplos prácticos de las excavaciones objeto de esta tesis, cuán alejadas de la realidad pueden estar este tipo de especulaciones matemáticas que no tienen en cuenta todo su entorno.

También debemos recordar que la presencia de cerámica en un nivel no asegura que pertenezca a un determinado periodo cultural; concretamente tenemos casos evidentes de utilización de materiales romanos en yacimientos musulmanes, con innumerables 
ejemplos recurrentes en toda la Península Ibérica. En cuanto a hallazgos de época romana, tampoco podemos afirmar que artefactos del siglo I d. C. puedan haber sido reutilizados en el siglo IV d. C. si no tenemos un contexto amplio y claro, pues a lo largo de toda la cultura romana es conocida la reutilización y reciclado de material constructivo, monedas, cerámicas, etc. Podríamos citar muchos otros casos, aunque esto supondría extendernos demasiado en este campo.

En definitiva, creemos que es muy arriesgado utilizar las variables matemáticas y aplicarlas literalmente al comportamiento humano, que es en si mismo difícilmente impredecible y no se ajusta a fórmulas estandarizadas y concretas. Recordemos además que para obtener resultados fiables es necesario tener muestras completas 0 significativamente completas de las variables, cosa que en Arqueología rara vez podemos obtener, puesto que para ello seria necesario excavar completamente un yacimiento o una serie de ellos. Pensamos que el ser humano actúa por sentimientos y razones que pocas veces se pueden ver reflejados en una tabla de multiplicar; nos parece más cierto dejar las matemáticas para evidenciar únicamente los datos cuantitativos y cualitativos, sin que formen parte de las interpretaciones.

Hacer pasar las hipótesis del comportamiento de cualquier asentamiento o acción humana a través de un coeficiente matemático (ORTON, 1980) es intentar asemejarnos a máquinas, para hacer de la Arqueología una ciencia exacta. Pensamos que esto es imposible, porque el ser vivo no es exacto ni lineal en su comportamiento, y aún no pueden ser cuantificadas sus acciones y variables relacionadas con los sentimientos, los deseos, las voluntades o los instintos; ante todo debemos recordar que la Arqueología es una disciplina que estudia a este mismo ser humano. Las matemáticas y la informática son aliados poderosos a la hora de almacenar y clasificar la información, no para establecer modelos que puedan apuntalar teorías inductivas sobre cómo será o cómo fue el comportamiento del individuo o de la comunidad.

Si hoy en día ya es prácticamente imposible predecir la actuación de los seres humanos individuales o en grupo, más difícil será aplicarlo en la Antigüedad, sobre la que disponemos de muchísimos menos datos. Justamente por este motivo las Ciencias del Comportamiento o la Etnología deben ser aplicadas con reservas a la Historia.

Otro ejemplo claro es el hallazgo de monedas; es difícil establecer una cronología para un hallazgo cerrado (las llamadas ocultaciones, tesoros o monederos) por la pervivencia de las acuñaciones, pues no sabemos cuál fue su período de circulación real (el desgaste por uso sólo es una apreciación generalista, no concreta fechas), pero además es más difícil aun saber el origen de las acumulaciones de monedas, pues si empezáramos un listado de posibles causas no acabaríamos: ocultación al fisco, almacenamiento de ahorros, inseguridad ciudadana, diferencias familiares, robo, falsificación, etc. Si a esto sumamos que el origen de algunos tesoros actuales es más que dudoso (por ejemplo la antigua costumbre de algunos investigadores de adjudicar 
el producto de compras, incluidas falsificaciones, a hallazgos in situ en yacimientos). Aún así los estudios que se basan en el análisis de estos materiales pueden aportar datos interesantes, aunque con las lógicas reservas (JÁRREGA, 2008).

\subsubsection{Dataciones}

Sin duda la cronología es uno de los factores más importantes para la ciencia arqueológica. Desde un principio se intentó definir una línea para establecer la evolución temporal de la Historia de la Humanidad sobre la base de sus restos materiales. Como ya hemos comprobado en otros puntos de esta tesis, en los primeros momentos de Arqueología acientífica y de recolección de artefactos solamente se utilizaban criterios históricos para dar una cronología a las piezas recuperadas, lo cual sin duda era poco concreto. Aún hoy en día somos herederos de esta forma de citar cuando nos referimos a cerámicas de época julio-claudia, asentamientos prehistóricos, ciudades romanas republicanas, etc. y es evidente que este tipo de dataciones solamente se podían sustentar en hechos o en fuentes antiguas.

Ante la vaguedad de estos márgenes temporales se intentó establecer fases o etapas más ajustadas al registro material, coincidiendo su inicio con aportaciones científicas a la Arqueología como la de la Geología a finales del siglo XIX.

Mucho se había evolucionado desde la pionera teoría de las tres edades del Hombre de Thomsen y se establecieron fases y subfases, no tan sólo asociadas al registro, sino a culturas. Seria interminable hacer el listado, pero podemos citar ejemplos terminológicos como: Alto Imperio, Bajo Imperio, Hierro Antiguo, Ibérico Pleno, Ibérico Tardío, Ibérico Final, etc. que en algunos casos se cambia por cifras (como Hierro I, Hierro II, etc.), la mayor parte de ellas establecidas sobre criterios tecnológicos y evolutivos de la cultura material, donde las fechas absolutas o las citas de las fuentes son escasas o imposibles de obtener. Pero este tipo de datación relativa no cumplía las expectativas de la joven ciencia arqueológica y se pasó a la fechación absoluta por medios físicos y químicos que cada vez permiten obtener una cronología más exacta.

Si bien debemos tener en cuenta que estas apreciaciones son válidas para todo tipo de objetos arqueológicos, nosotros nos vamos a ceñir a la cerámica de época romana, por ser la más ajustada al objetivo de nuestra tesis, pero nos centraremos en la terra sigillata (en adelante TS), sin duda el principal fósil director para el estudio de la cerámica romana. Su estudio tipológico podemos decir que se inicia con $\mathrm{H}$. 
Draggendorf en su trabajo publicado en 1895. A pesar de la forma rápida como se expandió su uso, encontró una mayor resistencia por parte de los investigadores ingleses y algunos orientalistas. Durante la primera mitad del siglo XX podemos citar numerosos estudios como los de Loeschcke en 1909, Hermet en 1934, Knorr en 1912 y 1952, Oxé en 1933, Oswald y Price en 1920, hasta llegar a Lamboglia en los años 50. En los años posteriores de este mismo siglo son abundantes las obras de referencia sobre la TS, entre las que podemos citar Pucci en 1985, Hofmann en 1986, Goudineau en 1968, Hayes en 1972, 1980 y 1985, Carandini en 1981, Peacock en 1982, Mezquiriz en 1985, Vernhet en 1986, Ettingler en 1990, Passelac en 1993; Fulle en 1997, Kenrick y Polak en 2000 y un largo etcétera (BANHA, 2005).

La más reciente tipología para la TS itálica ha sido publicada en el Conspectus Formarum Terrae Sigillata Italico Modo Confectae (ETTLINGER, et al.1990). La obra propiamente dicha se organiza retomando en gran medida el esquema de los "servicios", propuesto hace casi un siglo atrás por Loeschcke para Haltern, que es rehabilitado y que tiene como base la noción de que a un plato estaría asociada una taza y, eventualmente a un gran plato o fuente, con características morfológicas idénticas (BANHA, 2005). El Conspectus parte de la premisa de que las diferentes formas de TS no tuvieron una evolución unilineal y que su sucesión no siempre tuvo un significado cronológico claro.

Después de este breve resumen del estado de la cuestión, plantearemos un ejemplo que esperamos sea clarificador: imaginemos que un arqueólogo encontrase unos fragmentos de TS sudgálica (en adelante TSS) de las formas Drag 30 y 37 . Al realizar su estudio instantáneamente establecerá una cronología entre el 10 y el 80 d. C., pero existen algunos factores básicos que no se han tomado en consideración para establecer esta cronología:

Fecha exacta de la producción de la pieza.

- Tiempo del traslado desde el punto de producción hasta la ubicación donde se produjo el hallazgo.

- Periodo de conservación desde la producción hasta su deposición en el yacimiento.

Si analizamos los factores correctores que podemos introducir según el tipo de piezas, encontramos un abanico cronológico que puede ir entre el cambio de era y el $130 \mathrm{~d}$. C. (siempre presuponiendo que el contexto general no sea de una deposición secundaria, concepto bastante difícil de descubrir, por ejemplo, en una prospección o un sondeo puntual), según se trate de una pieza de lujo, una pieza de uso cotidiano, una pieza de transporte, un ajuar funerario, etc.; o sea, un abanico de más de un siglo para datar una pieza, especialmente si no nos encontramos con un contexto cerrado. 
Esta datación solo se podría ajustar con una importante inversión en costosos análisis como los que ya reseñamos anteriormente, pero evidentemente valoramos que nos encontramos ante una situación de clara dicotomía; la Arqueología de "alto nivel", que requiere un importante coste económico para obtener datos concretos y concisos (como por ejemplo la Termoluminiscencia o el Arqueomagnetismo) frente a otra que podíamos llamar de "baja intensidad", donde se utilizan otros métodos más asequibles y sencillos para obtener las dataciones, con la consiguiente pérdida de fiabilidad o de seguridad a la hora de establecer fechas.

Así pues, pensamos que es necesario incidir en una mejora y perfeccionamiento de estos métodos básicos, de forma que se ajusten más en la obtención de resultados porque, por más que intentemos obviar la cuestión, sigue existiendo una mayor disponibilidad pecuniaria en los grandes proyectos o en los países que invierten más económicamente en la investigación, que en la otra arqueología, más cotidiana y con menos recursos.

\subsubsection{Intervenciones segmentadas o parciales}

Otro gran problema es la realización de prospecciones o excavaciones que no abarcan la totalidad de un yacimiento. De hecho, es muy delicado interpretar unos restos arqueológicos basándose solamente en una muestra del total.

Como ya explicamos es difícil extrapolar unos datos tremendamente parciales a todo un conjunto, más aún cuando están implicados seres humanos que no tienen un comportamiento homogéneo o lineal como las variables matemáticas. Así pues, cuando una excavación actúa sobre una parcela no significa que sus resultados sean idénticos o extrapolables ni siquiera a la parcela vecina, aunque forme parte de una misma unidad, como una villa romana, pues ésta tiene muchos y variados ambientes.

Peor todavía es cuando se establecen teorías generales sobre datos poco precisos, lo que lleva a un proceso inductivo, a veces llevado a tal extremo que se intenta que los resultados de intervenciones muy puntuales y dispares se adapten a un modelo global, llegando a distorsionar los propios resultados de la intervención con el objeto de cuadrar el citado modelo. Esta necesidad que tenemos la mayoría de los arqueólogos de obtener respuestas, es la que conduce, en ocasiones, a teorías un tanto temerarias. No podemos, por ejemplo, interpretar en profundidad restos antiguos o superficiales sin 
una excavación arqueológica; ni tampoco podemos pretender que un pequeño sondeo sea significativo sobre una superficie a veces 100 veces superior.

Otras soluciones, como el muestreo de sondeos, nos parece en la mayor parte de los casos un elemento de relativa utilidad para interpretar un gran yacimiento, ya que con seguridad es más significativa una excavación en extensión más amplia que muchas excavaciones de pequeña superficie. La mala utilización de este sistema, que puede formar verdaderas parrillas y llegar a recordar sistemas tan antiguos como el de Wheeler, en verdad no deja de ser una auténtica "lotería", porque un sistema aleatorio de sondeos difícilmente puede servir para interpretar totalmente un enclave. De las prospecciones sólo podemos decir que la muestra de superficie no es significativa ni siquiera de la existencia de un yacimiento en el subsuelo, como ya comprobamos.

El problema básico que arrastra la interpretación de este tipo de actuaciones es que, aunque las mismas hayan tenido el rigor científico necesario, en muchos casos se tratan de hipótesis (nosotros consideramos esencial que siempre se reflejen claramente como tal y admitan una posterior validación o refutación). El inconveniente surge cuando otros investigadores reproducen de forma continuada estas hipótesis, dejando a un lado su cariz de suposición como tal; de este modo, al repetirla constantemente, puede llegar a convertirse en hecho dado por cierto, que las siguientes generaciones de investigadores ya no se plantearán rebatir. Algunos casos son bastante ilustrativos sobre esta equivocación, al intentar que una muestra ínfima aclare un panorama global; baste citar algunos ejemplos en Burriana o Sagunto.

En el caso de Burriana nos encontramos con que un sondeo realizado en el casco urbano en los años 70 (MESADO, 1986) dejó su impronta sobre los estudios arqueológicos locales durante más de treinta años; ello es más grave aún si tenemos en cuenta que todo el proceso de investigación fue absolutamente endogámico durante casi 40 años, lo cual implica una falta de diálogo y renovación que quedó reflejada en un retraso importante de la Arqueología en esta zona. Aquello resultados dieron origen a una línea de investigación que defendía que la estratigrafía arqueológica de Burriana alcanzaba bastante más de 4 metros de profundidad. Estas publicaciones fueron la semilla de teorías que irían alcanzando cotas de evidente alejamiento de la ciencia al hablar de posibles niveles romanos fundacionales. El hallazgo de materiales romanos reutilizados, el paralelismo forzado con otras estratigrafías tan profundas en ciudades romanas como Valencia, etc. iban moldeando esta especulación, llegando a extremos realmente sorprendentes al hablar, sin ningún tipo de apoyo científico, de estratigrafías de 6 a 8 metros de profundidad o de la existencia de una isla fluvial donde se asientan los pobladores romanos, teorías estas que nunca se han publicado con la debida justificación o rigor científico. Justamente por tratarse de publicaciones locales generalistas de carácter ocasional como la Revista de Burriana y panfletos similares, 
junto a información oral, no vamos a darle un carácter bibliográfico a esta información, que citamos con carácter puramente anecdótico.

En los últimos 8 años llevamos a término varias excavaciones en Burriana; de ellas pudimos sacar varias conclusiones importantes, entre las que destacamos que la profundidad máxima de los niveles arqueológicos en Burriana no supera los 2,5 metros, solamente unos grandes silos de grano alcanzaban los 4,20 metros de profundidad, y en el fondo de ellos un nivel deposicional donde aparecen materiales, fruto posiblemente de la colmatación del silo en su abandono (MELCHOR, 2005). Ésta quizá sea la explicación más plausible para la aparición de presuntos niveles musulmanes a tan gran profundidad. En ningún caso aparecieron niveles romanos infrapuestos.

En el caso de Sagunto tuvimos la fortuna de realizar la excavación más amplia a nivel de superficie realizada hasta el momento de forma unitaria en la ciudad, lo que permitió demostrar que el nivel romano se encuentra a una profundidad mínima muy inferior a lo que se presuponía para el resto de la urbe. De la misma forma, esta excavación en extensión permitió documentar niveles del Alto Imperio y republicanos que no habían sido alcanzados en excavaciones parciales, alguna de ellas realizadas en solares vecinos y en donde, en algunos casos, la escasez de la superficie excavable impidió que se interpretaran correctamente (MELCHOR y BENEDITO, 2005). Allí realizamos 4 sondeos sobre una superficie de unos $1.200 \mathrm{~m}^{2}$ sin detectar la presencia de un templo, una calzada y una necrópolis, que se documentaron en cambio al poder llevar a cabo una excavación en extensión.

Estos dos ejemplos nos parecen bastante significativos en referencia a una variación importante de niveles estratigráficos que es imposible analizar y explicar sin una excavación en extensión. Estas observaciones por sí mismas y en ningún momento pueden ser objeto de reproche: el problema surge cuando se utilizan para interpretar un contexto más amplio, y peor aún, cuando se olvida su carácter de conjetura.

Quizá deberíamos desterrar la idea de que una mala hipótesis es mejor que ninguna hipótesis.

\subsubsection{La problemática de los criterios interpretativos}

En este apartado vamos a considerar la utilización de distintos criterios a la hora de evaluar o de proponer teorías. Debemos tener en cuenta que el investigador puede 
utilizar los datos existentes de la forma que crea más oportuna pues, como ya evidenciamos, cualquier hipótesis seria es válida hasta que se demuestre lo contrario.

El problema lo encontramos a la hora de establecer qué datos utilizar o cuáles son fiables para realizar los estudios, como ya reflejamos en la introducción; consideramos necesaria la constante critica y revisión de los datos que utilizamos, incluyendo los que uno mismo obtiene. Plantearemos dos casos que hemos vivido muy de cerca, uno referido a excavaciones arqueológicas y otro a prospecciones. Con estos dos ejemplos pretendemos demostrar cómo se puede caer en el engaño de un análisis superficial y poco crítico de los restos parciales o antiguos. Con ello no queremos decir que estos datos no sirvan para nada; tienen la utilidad que se les quiera dar dentro de unos parámetros críticos muy severos.

Nuestra opinión es que la exigencia de un rigor científico, de una constante revisión y de una evolución de los conocimientos arqueológicos, no nos permite utilizar estos datos más que como anécdotas o indicios que deben y merecen ser aclarados para su definitivo descarte o su adaptación y utilización como verdaderos hechos científicos.

\subsubsection{Los yacimientos ibero-romanos de la costa de Castellón de la Plana}

En cuanto a las exploraciones de superficie vamos a exponer una situación que es bastante elocuente para ejemplificar nuestra opinión sobre la fiabilidad de este tipo de intervenciones.

Sobre la zona costera del término municipal de Castellón podemos encontrar aún hoy en día bastantes autores que reflejan la existencia de un número aproximado de quince yacimientos conocidos como pujolets; se trata de pequeñas elevaciones, posiblemente a modo de verdaderos tell artificiales, que destacan entre la llanura del marjal costero de Castellón. No deja de sorprender tan elevada densidad de restos cuando en otros términos municipales, como puedan ser Burriana, Nules u otros de características análogas, podemos encontrar como máximo cuatro o cinco asentamientos similares reflejados en la bibliografía.

Lamentablemente no hay constancia de ninguna excavación arqueológica científica que se hubiera realizado en cualquiera de estos pujolets; por ejemplo, J. B. Porcar en los años treinta del siglo $X X$ fue un pintor, que sin ningún tipo de preparación arqueológica, utilizaba referencias antiguas de excavaciones que él no llegó a conocer realizadas en el llamado Pujol de Gasset, extrapolando estos resultados a una serie de hallazgos superficiales que él presuntamente realiza en otros enclaves; de tal forma 
que no conocemos un estudio detallado de los materiales y, a veces, ni siquiera una representación gráfica extensa de los hallazgos, por lo cual la cronología o análisis arqueológico de estos enclaves se encuentran en citas bibliográficas muy sencillas, como las que reproducimos a continuación a modo de resumen de los datos conocidos sobre cada uno de ellos.

\section{PLAYA VINATXELL-ALMALAFA}

Porcar cita el hallazgo de fragmentos de teja y dolium de época romana, procedentes de una pequeña elevación (PORCAR, 1933). D. Fletcher y J. Alcácer recogen la noticia del hallazgo de tejas, dolia y ánforas, que provenían de un montículo hoy cubierto por las aguas (FLETCHER y ALCACER, 1956).

\section{PUJOL DE BURGALETA}

En las proximidades del Camino de Rafalafena había una pequeña elevación en la cual apareció cerámica hecha a mano y a torno, esta última de carácter ibérico (ESTEVE, 1956 y GUSI, 1991).

\section{PUJOL DE GASSET O PUJOLET D'EN GASSET}

Pequeña elevación en el terreno que estaba situada a unos 100 metros de la línea costera, entre el llamado Estany dels Patos y Sotanella. Entre los materiales arqueológicos allí recogidos, en el año 1851 se dio a conocer la primera inscripción sobre plomo conocida en la Península. Después de este descubrimiento la Comisión Provincial de Monumentos realizó en 1867 un informe sobre las pequeñas elevaciones que habían existido antes de rebajarlas para el cultivo. F. Esteve cita un primer nivel de ocupación correspondiente al Neolítico, del cual quedaría algún fondo de cabaña con escaso sílex y un brazalete de glycymeris (ESTEVE, 1956). Porcar dice que en todo el montículo aparece gran cantidad de cerámica ibérica y que por los hallazgos habría que pensar en un poblado ibérico (PORCAR, 1933 y GUSI, 1991).

En 1905 se hizo una excavación para ampliar la zona de cultivo; los testimonios recogidos por J. B. Porcar dicen que la parte norte se rebajó unos 3 metros, apareciendo numerosas paredes de piedra seca y abundantes fragmentos de huesos y cerámica de barniz negro. También se encontraron piezas de plomo en forma de almendra. En 1928, en la parte de mediodía del Camí Nou de la Mar que cruzaba el montículo por su parte meridional, se realizó una nueva excavación, donde aparecieron fragmentos de dolia y teja a 1,50 metros de profundidad (PORCAR, 1933: 81)

Hasta el inicio de la década de los 40 se mantuvo una tercera parte del montículo intacto, realizándose después dos campañas de excavación (PORCAR, 1948). La segunda fue organizada por la Comisaría Provincial de Excavaciones y se desarrolló en 
1949; se encontraron abundantes fragmentos de cerámica decorada con motivos geométricos campaniense, pesas de telar y fusayolas (ARASA, 1979). El yacimiento se identificó desde el momento del hallazgo de la inscripción con una necrópolis, pero incluso F. Esteve dudaba del carácter funerario del hallazgo. De los restos encontrados, D. Fletcher y J. Alcácer destacan la presencia de restos de edificaciones y variadas cerámicas romanas sobre un poblado ibérico (FLETCHER Y ALCACER, 1956). Por su parte, F. Arasa fecha la cerámica de barniz negro y las monedas entre los siglos II y I a. C. (AA. VV., 1999).

\section{PUJOLET ALMASSORÍ}

Porcar encuentra sílex trabajado (PORCAR, 1933) y F. Gusi cita que se recogió material de época eneolítica (GUSI, 1991).

\section{PUJOLET DE MATAMOROS}

Situado en la costa del Grau, J. B. Porcar cita el hallazgo de pequeños fragmentos de sílex (PORCAR, 1933). Como en el ejemplo anterior F. Gusi cita el hallazgo de material de época eneolítica (GUSI, 1991).

\section{PUJOLET DE LES OLIVERES}

Se encontraron fragmentos de dolia y ánforas en las capas superiores de un silo de 2 metros de profundidad, cuyo interior contenía restos de varias épocas. Según los autores está ubicado a $4 \mathrm{Km}$. de Castellón, aunque actualmente se desconoce la situación exacta (FLETCHER y ALCÁCER, 1956).

\section{PUJOLET DE LA TORRE}

Localizado muy próximo al Pujol de Gasset, prácticamente en el borde del mar, y donde apareció abundante cerámica ibérica. Porcar dice que en este enclave pudo estar la necrópolis del poblado del Pujol de Gasset (PORCAR, 1933) y F. Gusi sitúa en este yacimiento el hallazgo de la inscripción en lengua ibérica en el año 1851 con restos de un enterramiento, formando parte de su ajuar, eso hizo pensar que tuviera una finalidad funeraria (GUSI, 1991).

\section{QUADRO DE CASTELLÓ}

En 1878 se excavaron unos terrenos, no muy lejos del Pujol de Gasset, encontrándose una urna funeraria con huesos humanos (ARASA, 1979). A. Balbás explica que el 20 de febrero de 1878 se encontró un ánfora con un esqueleto dentro junto a varios restos de construcción de época romana (BALBÁS, 1887: 430). Sin embargo, según F. Esteve se trataría de un pequeño poblado ibérico parecido al del Pujol de Gasset (ESTEVE, 
1956). Para F. Arasa, teniendo en cuenta los restos de construcciones y restos romanos descritos por Porcar en la playa de la Caseta de Carabineros, podría tratarse también de un establecimiento romano con enterramientos tardíos en el interior de ánforas, localizado en el borde de la supuesta vía del camino Serradal (ARASA, 1979).

En su momento realizamos un estudio global sobre todos los yacimientos del término municipal, que nos fue encargado por el Ayuntamiento de Castellón de la Plana, con el objetivo de revisar los datos conocidos y proponer una delimitación de los mismos para incluirlos dentro del programa de protección de yacimientos arqueológicos del PGOU del año 2000, trabajo que desarrollamos con el arqueólogo J. Benedito.

Los únicos datos disponibles de esta época son muy básicos; la escasa documentación sobre el conocido como Pujol de Gasset o de Les Oliveres la encontramos gracias a las noticias inéditas de los años 60 del siglo XIX en las que aparece citada:

Título: Copia del informe del Anticuario de la Real Academia de la Historia acerca de los seis túmulos existentes en el lugar llamado Puchol término de Castellón de la Plana cerca del mar.

Autor: Anónimo - Fecha: 1863/12/18

Lugar de emisión: Madrid

Signatura: CACS/9/7950/03(01)

Provincia: Castellón

Tipo de documento: Informe

(...) existían en el termino de Castellón de la plana más próximo a la orilla del mar, seis túmulos antiquísimos de tierra, que conocidos en el País con el nombre de Puch, equidistantes entre si, que en otro túmulo igual fue destruido hace algunos años y dentro del se encontraron varios objetos (...) una Lámina de plomo enrollada (...)

Finalmente la Real Academia de Historia propone:

Título: Minuta de oficio en la que se informa del hallazgo de seis túmulos en el Puch, en uno de los cuales, se encontró una lámina de Plomo con Inscripción ibérica, se solicita la creación de una comisión que, de acuerdo con la Real Academia de la Historia, examine los túmulos y proponga la realización de excavaciones

Autor: Real Academia de la Historia - Fecha: 1864/01/12

Lugar de emisión: Madrid

Signatura: CACS/9/7950/03(02)

Provincia: Castellón

Tipo de documento: Minuta

(...) nombrar una comisión que pase en viaje literario a examinar dichos túmulos (...) y proponga las exacciones convenientes (...) 
De este interés por organizar excavaciones podría haber derivado otra intervención en 1878, tampoco documentada y citada por A. Balbás:

20/02/1878 - Practicando excavaciones el Vicepresidente y Secretario de la Comisión de Monumentos en el terreno comprendido entre la punta del Pinar del Grao de Castellón y la acequia de la Obra, encuéntrase un ánfora con un esqueleto dentro y varios restos de construcción de la época romana (BALBÁS, 1892: 430).

La descripción más completa es la de 1867, con motivo de los informes sobre el hallazgo de las sepulturas arriba citadas, donde destacamos: Título: Oficio de traslado del Gobernador Civil de Castellón en el que se
da cuenta de las noticias detalladas acerca del hallazgo del Plomo con
inscripción ibérica y de los trabajos de excavación realizados en los
túmulos. Adjunta copia de la Inscripción del plomo ibérico del Puch,
hecha por la Comisión de Monumentos de Castellón. También informa
de los restos de un templo dedicado a Venus en las lagunas de
Almenara

Autor: Catalina, Severo

Fecha: 1867/06/01

Lugar de emisión: Madrid

Signatura: CACS/9/7950/03(05)

Provincia: Castellón

Tipo de documento: Oficio

(...) junto al camino nuevo de esta ciudad [Castellón] al Grao y muy cerca de la playa se halla a la izquierda una pequeña eminencia que en dialecto del país se escribe Pujol (...) que es circular, 180 palmos de diámetro en la base y doce de altura poco más o menos. No es obra de la naturaleza y si del arte, lo que se desprende al considerar que se halla situado en la gran planicie que se llama la Plana, (...) en este terreno se hallaban hace algunos años cimientos de paredes de piedra y argamasa de cuatro palmos de espesor las que desaparecieron cuando el actual propietario Don José Gaset, puso en cultivo estas tierras (...) que dicho Puchol no es otra cosa que las ruinas de una antiguo edificio, tal vez de algún fuerte avanzado para proteger la costa a la manera de las torres que posteriormente se edificaron y que actualmente son de servicio, esta opinión se robustece en vistas de otros dos Puchols que existen a la izquierda del que hablamos, como a distancia de un cuarto de hora uno de otro paralelos a la costa y formando línea con el que nos ocupa. Con el objeto pues de extraer piedra se han practicado excavaciones en el dicho Puchol en otras ocasiones, y se han hallado algunos esqueletos, pero no se han cuidado de examinarlos ni de observar el sitio y circunstancias de este hallazgo. Pero no sucedió así por fortuna en el desmonte que se practicó en el año 1851 por D. 


\begin{abstract}
Vicente Roca, con el objeto de trasladar tierra del Puchol que eran entonces propiedad de Antonio Enrich, a un huerto que se estaba formando en la playa junto al Grao el activo Señor Roca para beneficiarle con una capa de tierra vegetal. Entonces se encontraron dentro de lo que al parecer fue edificio algunos cuencos de barro cocido como a un palmo de profundidad, que a pesar de haberse sacado en fragmentos, se conoce que tenían 3 palmos del altura y lo mismo de diámetro en la boca, no tenían orificio y si unas tapas o coberteras del mismo material con su pezón o asidero en medio, la tierra del alrededor parecía calcinada y no se observa ningún objeto dentro de los cuencos sino es la misma tierra. En el mismo sitio se hallaron dos hebillas de bronce, al parecer de correa o ceñidor estrecho, una tacita de tierra gris oscura entera y bien labrada y un pedacito del mismo material en forma de cono y taladrado por medio de su base hasta su altura, como si fuera un orificio de tinaja o de otro baso grande, y dos monedas de cobre, en una se ve una cabeza y al reverso un ginete montado. Empero lo más notable que se ha descubierto junto a los cuencos fue una magnifica inscripción en plomo el día 30 de agosto de 1851 (...) entre los cascos de los cuencos, o junto a estos de que arriba se han hecho mención, un rollo de plomo que desarrollado se vio que era una faja (...) Los demás Pucholes todos ellos situados en la costa se encuentran hoy día reducidos a cultivo, y es tan poca su importancia que en ninguno de ellos se encuentra el menor vestigio o ruina ni se sabe que haya existido en tiempo alguno (...)
\end{abstract}

Otra de las personalidades que avalaba estos hallazgos era F. Esteve, como recordaremos empezó su labor autodidacta como aficionado en los años 20 del siglo XX. Con este respaldo, la información sobre los pujolets fue repetida por investigadores que no pudieron observar ningún resto que confirmara estas afirmaciones.

Dentro de nuestras labores de investigación en el término municipal de Castellón tuvimos la fortuna de realizar una serie de sondeos arqueológicos en la costa. En un primer momento se planteó conocer la estratigrafía, ya que sabíamos muy poco sobre el estado del subsuelo. Para ello se realizaron seis sondeos distribuidos en tres zonas diferenciadas: la costa Norte de Castellón, el casco urbano del Grao (donde se incluye el Pujol de la Torre y el Pujol de la Sal) y en el yacimiento del Pujol de Gasset. No apareció ningún resto arqueológico en el sondeo 1 (que coincidiría con el antiguo Pujolet de la Sal y junto al presunto camino romano d'Entrilles). En el sondeo 2 (correspondiente al Pujolet del Comú de la Torre) y 3 (Vinatxell-Almalafa) sólo encontramos indicios de un nivel estratigráfico con materiales de época contemporánea. En los sondeos 4 y 6 apareció sobre el nivel estéril una capa de tierra arcillosa con escasos materiales cerámicos, que indican claramente la influencia del yacimiento del Pujol de Gasset. 
Fue en el sondeo 5 donde encontramos materiales arqueológicos (ver Lámina Cerámica 1), pues ya desde la primera capa superficial muy compactada de grava y tierra de color beige, había abundantes fragmentos de cerámica moderna e ibérica. Por debajo encontramos un nivel de color rojizo y textura arcillosa (UE 5002), donde surgió cerámica ibérica, romana y musulmana. Inmediatamente por debajo apareció un estrato donde abundaba el carbón y algo de grava (UE 5003) y donde se detectó mayoritariamente cerámica ibérica y en menor cantidad griega, púnica y de la Edad del Bronce; estos estratos están junto a un recorte del terreno natural. Directamente por debajo de los niveles arqueológicos afloró un estrato estéril compuesto de arena amarillenta mezclada con la fragmentos de la misma, pero muy compactados.

Los tres sondeos realizados en el yacimiento de Pujol de Gasset o de Les Oliveres indican que el subsuelo aún conserva un potencial arqueológico medio de $50 \mathrm{~cm}$ desde la superficie, donde además se detectan abundantes restos en toda la zona que no se encuentra cubierta por edificaciones contemporáneas (ver Lámina LXIX).

Contrastando los planos de J. B. Porcar de la campaña arqueológica del año $1946^{2}$ con la información actual, conseguimos situar los restos excavados en aquella época (hoy en día se encuentran bajo las calles y las edificaciones construidas en aquel momento), de tal forma que la identificación del yacimiento es total. Además estamos en condiciones de afirmar que, en contra de lo que defienden algunos de los investigadores actuales, este yacimiento aún se conserva en parte y no ha sido destruido en su totalidad (lamentablemente esta presunción ha permitido que se realizaran actuaciones urbanísticas impunemente), aunque el estado actual del mismo requiere una protección y vigilancia extremada.

Otro dato muy importante corresponde a una serie de fragmentos cerámicos que permiten aportar datos inéditos, como por ejemplo la presencia de cerámica musulmana, griega y púnica, además de piezas y fragmentos de adobe claramente quemados, que indican la posible existencia de un nivel de incendio en este yacimiento, que podíamos situarlo próximo al siglo III o II a. C., ya que la mayoría de las piezas afectadas por el fuego son de esta cronología, aunque tampoco podemos descartar la presencia de una necrópolis de incineración.

Lamentablemente el reducido tamaño del sondeo no ha permitido establecer una clara diferenciación cronológica entre los estratos arqueológicos antiguos (UE 5002 y 5003), a lo que debemos sumar la remoción constante que ha sufrido el terreno.

La situación en la que aparecieron los niveles coincide en parte con la descripción de J. B. Porcar, en la que hace referencia a zanjas y depresiones excavadas en el suelo y rellenadas con materiales, además de una serie de estructuras poco definidas

\footnotetext{
${ }^{2}$ Documentación original depositada en el Servicio de Investigación Arqueológica y Prehistórica de la Diputación de Castellón.
} 
(PORCAR, 1948). Nosotros encontramos por primera vez cerámica musulmana que señala la existencia de un asentamiento árabe hasta hoy desconocido en el lugar y puede que algunas de las estructuras excavadas en los años 40 también pertenezcan a este momento cultural, por lo que es posible que fuera la reocupación medieval del lugar la que provocara el arrasamiento de las estructuras íberas y romanas, de forma muy similar a lo sucedido, por ejemplo, en Vinarragell (Burriana).

Finalmente queremos enumerar brevemente algunos de los materiales más interesantes recuperados en esta intervención: recuperamos 11 fragmentos de cerámica ibérica en la UE 5001 y en la UE 500281 fragmentos, a los que acompañaron 2 de posible cerámica jonia, 6 de púnico-ebusitana, un posible fragmento de cerámica jonia junto a 3 de cerámica del Bronce y uno de TSS; añadiremos que entre la malacofauna uno era nácar. La UE 5003 es sin duda la más interesante y por ello reproducimos el inventario:

UE 5003

- 10 fragmentos de arena compactada con rubefacción.

- 9 fragmentos adobe quemado. Época lbérica / Bronce

- Fragmento de piedra. Posible talla de sillar

- 6 esquirlas de piedra

- 6 fragmentos de piedra indeterminados quemados

- 2 fragmentos de cerámica reductora. Época Ibérica

- 13 fragmentos de ánfora, algunos quemados.

- 15 fragmentos de cerámica oxidante. Época Ibérica

- Fragmento de cerámica a mano bruñida. Edad del Bronce

- Fragmento de canto de rodeno con superficie ennegrecida

- 6 fragmentos de tinaja. Edad del Bronce

- Fragmento de gran tinaja - cordón aplicado. Edad del Bronce

- Fragmento de cerámica púnica con restos de adobe

- Fragmento de gran tinaja de cerámica muy compactada

- 3 fragmentos de cerámica. Posible Bronce Final /Hierro

De este sencillo análisis puntual podemos extraer unas conclusiones bastante precisas; en primer lugar invalidamos las antiguas descripciones que hablaban de una cantidad desproporcionada de yacimientos, es muy posible que personas sin la debida preparación científica tomaran como yacimientos la tierra extraída del Pujol de Gasset y extendida en distintas parcelas de la zona. Si en un principio la documentación sólo cita a este pujolet y a dos más (sin restos), documentos posteriores los citan como 6 túmulos, cantidad que se ve ampliada en el siglo XX.

Por otro lado, nuestras excavaciones han permitido arrojar una nueva luz sobre los datos de esqueletos encontrados en la zona y las grandes cimentaciones, quizá 
pertenecientes a niveles medievales.

A falta de que se realicen las intervenciones en los sitios donde posiblemente puedan aparecer los restos citados en la bibliografía antigua, nosotros creemos que de los aproximadamente 15 yacimientos citados, no más de 2 ó 3 puedan serlo realmente. Por ejemplo es evidente que, contrastando las noticias históricas, los pujolets de Gasset, de les Oliveres y de la Torre son el mismo yacimiento. A falta de la comprobación definitiva de esta hipótesis, ésta nos parece mucho más ajustada a la realidad que la anterior.

Por lo que podemos observar, el Pujol de Gasset puede tener el carácter de necrópolis y así se podría contextualizar el plomo ibérico encontrado como perteneciente a un ajuar funerario, como es habitual en la cultura ibérica. Poco más podemos extrapolar con los escasos datos de los que disponemos, a falta de demostrar la existencia de un poblado en este espacio, ya que lo único que de momento podemos emitir como hipótesis es la presencia de una necrópolis. El modelo que hemos citado demuestra claramente nuestra crítica a las teorías simplistas que repiten estudios antiguos y no discriminan el tipo de datos utilizados.

\subsubsection{La necrópolis de Lledó (Castellón de la Plana)}

En el año 2005 aparecieron en las obras realizadas junto a la basílica de Lledó en Castellón una serie enterramientos revueltos por maquinaria pesada y donde apreciamos la existencia de forma exclusiva de material constructivo romano (ver Foto 586). A estos datos sumamos el hecho de que la bibliografía regional acostumbraba a ubicar un yacimiento romano junto a la citada basílica. Propusimos esta zona para el PGOU de Castellón del año 2000 como zona de vigilancia arqueológica, pero el retraso en la aprobación de dicha propuesta ocasionó que se diera licencia de obra a la empresa promotora para la construcción de un asilo sin el previo estudio arqueológico. En cumplimiento de la legislación vigente la empresa constructora notificó el hallazgo al ayuntamiento, que paralizó las obras.

Los hechos nos llevaron a priori a la conclusión lógica de que nos encontrábamos ante una necrópolis de inhumación de época romana; llegamos a esta en una inspección previa realizada de forma conjunta con los servicios territoriales de Castellón de la Conselleria de Cultura. Además, esta suposición venía también apoyada por una serie de posibles hallazgos arqueológicos romanos en el entorno, que repite constantemente la bibliografía local (PORCAR, 1935, ESTEVE, 1956, ARASA, 1979). Era también interesante una noticia de 1398, la única referencia al Pujol de Santa María del Lledó, 
montículo que ha desaparecido totalmente, pues se debió rebajar para la construcción de la actual basílica (AA. VV, 1999).

En el año 1981 el SIAP de la Diputación de Castellón había llevado a cabo una campaña de excavaciones arqueológicas delante de la puerta de la basílica. Se abrieron dos sondeos que revelaron un momento de ocupación de época romana y otro musulmán. Sin embargo, la totalidad de materiales estaban revueltos en un mismo estrato, en un interesante paralelismo con la vecina necrópolis musulmana. También aparecieron los restos de un posible horno que no fue identificado en su momento por el excavador F. Arasa, que lo cita como silo con la paredes quemadas, así como un silo que alcanzó la profundidad de 2,90 metros relleno de piedras, fragmentos de molino, placa de mármol, fragmentos cerámicos de diversas épocas, etc. (GUSI coord., 2000:154). Los autores opinaban que se trataba de una primera ocupación de época romana (una villa agrícola de los siglos I y II d. C.) arrasada por la construcción de pozos y silos de una alquería musulmana, que fueron a su vez destruidos por la construcción de las distintas ermitas (AA. VV, 1999:116).

Cerca de Lledó, en los huertos situados entre la ermita y el camino de la Plana hay noticias del descubrimiento de algunas monedas romanas y medievales. En una alquería de esta misma zona se conserva una basa y un tambor de columna (ARASA, 1979:153). En nuestras prospecciones en la zona, el único hallazgo identificable con esta cita es una basa gótica y una estela discoidea medieval que estaban empotradas en la entrada del Segon Molí de Castellón.

Si la investigación arqueológica se hubiera detenido aquí tendríamos un área cementerial romana más que añadir a la bibliografía local. Afortunadamente siguió la excavación del asilo de ancianos y nos encontramos con la evidencia contundente de que estábamos ante una necrópolis musulmana que había reutilizado exclusivamente elementos constructivos romanos. Durante las excavaciones arqueológicas realizadas entre junio y julio de 2005 (en la que participamos personalmente) y en una segunda fase entre marzo y abril de 2006, se documentó un nivel de gran importancia arqueológica que concierne a una necrópolis hispano-musulmana, ya que el ritual funerario entra dentro de los parámetros pertenecientes a esta comunidad.

El aspecto más interesante es el número de individuos hallados, y los restos de un ovicáprido, tratándose en todos los casos de inhumación individual en fosa simple. Se registraron un total de 38 inhumaciones completas y 4 parciales; no se han documentado superposiciones de individuos. Los enterramientos se caracterizaban por reutilizar como cubierta abundantes elementos constructivos de época romana: ladrillos de tipo bessalis, fragmentos de tegulae y de opus signinum, etc. Respecto a los límites de este área de necrópolis quedaron marcados por el Este por los márgenes del Caminàs. El límite Oeste se ha podido determinar a escasos 50 metros del camino. Por el Sur no continuaría la zona de enterramientos, pues durante los trabajos de 
excavación arqueológica salió a la luz una zona de vertidos con material constructivo de época romana (ladrillos, opus spicatum y fragmentos de opus signinum, tegulae, etc.), y un nivel con restos cerámicos de época bajo medieval y moderna. En cuanto al límite Norte, éste iría más allá del sector acotado por la excavación arqueológica.

Las tumbas no presentaron ningún tipo de ajuar, circunstancia ésta que ha imposibilitado establecer una datación más concreta. Estas están muy agrupadas en todo el sector y son en todos los casos tumbas individuales, mientras que las fosas eran en líneas generales muy estrechas, unos $35 \mathrm{~cm}$. Todo el conjunto de esqueletos presentaba una misma orientación que variaba entre $270-305^{\circ} \mathrm{N}$ y una disposición de decúbito lateral izquierdo, con la cabeza mirando al E-SE, no habiendo documentado en ningún caso tumbas elaboradas.

La concentración de los enterramientos en esta estrecha franja parece indicar la existencia de una delimitación intencionada de este espacio, que discurría de forma paralela al Caminàs. Este fue otro de los factores que llevó también al error interpretativo inicial; hemos de tener en cuenta que este es un camino que en buena parte de la bibliografía se le hace coincidir con la vía Augusta, así pues, si sumábamos el presunto yacimiento romano de la basílica de Lledó a la citada vía y la orientación de las tumbas hacia ella, esto parecía avalar la hipótesis de una cronología romana para los sepulcros. Conforme nos alejamos del mismo hacia el Oeste desaparecen los enterramientos; de la misma forma, al otro lado del camino no tenemos noticias de enterramientos, allí está la basílica, cuyos hallazgos arqueológicos corresponden a una tipología de zona artesanal, como ya citamos, y hacia el Sur los enterramientos dejan de aparecer antes del final de la zona excavada. Tal era la profusión elementos, que podemos destacar la presencia de dolía, tegulae, imbrex, mampostería, opus signinum, opus caementicium, opus spicatum, fragmentos de pintura mural, etc. que probablemente se extrajeron hasta las cimentaciones de los muros y los pavimentos romanos para la cubierta de las tumbas. Encontramos también un elemento muy interesante que correspondía a una acumulación sin uso aparente de buena parte de estos elementos constructivos (BENEDITO et al., 2008).

Nuestra hipótesis es que, evidentemente, hay un yacimiento romano muy cercano a la ubicación de la excavación, de tal forma que a los habitantes musulmanes de la alquería, que posiblemente se encontraba también muy próxima, les era tan fácil obtener estos restos constructivos que los utilizaron de forma exclusiva, hasta tal punto que los acumulaban en un punto de la necrópolis para su utilización inmediata cuando ocurriera un enterramiento. Esta posible facilidad podría fundamentarse en el hecho de que fuera más cómodo extraer los cimientos de un muro que utilizar para la cubierta de las tumbas adobes, tejas u otros elementos de su propia época. Como hipótesis quizá deberíamos pensar en una extrema cercanía al cementerio, lo que abarataría el transporte. Al no haber sido excavada la totalidad del área funeraria, desconocemos si 
esta acumulación se podría encontrar junto a la entrada de la misma, aunque su situación no permite descartar esta teoría.

En este caso, como en el anterior del Pujol de Gasset, volvemos a encontrarnos con el hecho de que la relectura de las fuentes documentales junto a excavaciones científicas recientes pueden cambiar la interpretación de un yacimiento, una vez queda clara la existencia de una hábitat musulmán (horno, enterramientos) que altera un yacimiento romano muy cercano y aún sin ubicar, aunque recientemente, en el año 2010, se han dado a conocer las excavaciones de una villa romana cercana en el camino de Vinamargo, y que por el momento permanecen inéditas.

\subsubsection{Cronologías parciales, poco ajustadas o erróneas}

Enlazando con el tema anterior tenemos la problemática de las etapas temporales. No pretendemos incidir en el tema de las fechas poco ajustadas, ya que las tratamos en un apartado concreto; solamente recordar los márgenes demasiado amplios cuando se aplican dataciones relativas y no absolutas. Pero a este tema debemos sumar otras cuestiones como las cronologías parciales; cuando hablamos de ellas nos referimos a aquéllas que tratan únicamente de una parte de los yacimientos o de una excavación, ya que creemos que no se puede entender un estrato sin la interacción del mismo con las capas inferiores y superiores. Obviar esta relación entre las varias épocas que ha vivido un yacimiento puede, en muchos casos, dificultar extremadamente la interpretación del mismo. Dejaremos a un lado el tema de los sondeos y las prospecciones, a las que nos hemos referido en otros apartados; donde citamos que en una cata arqueológica se desconoce totalmente un elevado porcentaje del yacimiento.

Así pues, si hablamos de las grandes intervenciones, es muy fácil entender cómo un nivel superior afecta de forma importante al inferior, ya que son muchos los elementos que demuestran esta relación, como por ejemplo las zanjas de saqueo, la reutilización o reocupación de estructuras, la relación entre dos épocas distintas por medio del reciclaje de restos materiales, etc. y es precisamente esa afección mutua la que explica la evolución del conjunto de estratos. Un ejemplo de interacción que podemos citar es la comentada excavación de Lledó (Castellón), donde podemos especular sobre si uno de los polos de atracción para la ocupación musulmana de este espacio fue la existencia previa del yacimiento romano que sirvió de cantera. En definitiva, pensamos que un yacimiento es un conjunto único, tanto sincrónica como diacrónicamente. 
La problemática de las cronologías erróneas es algo distinto; su origen está en un cúmulo de circunstancias ya citadas en este trabajo, a las que debemos añadir la súper-especialización o la diametralmente opuesta, la falta de preparación especifica. En el caso de la cerámica es evidente que no es posible tener un conocimiento exhaustivo de todo tipo de producciones desarrolladas por la Humanidad a lo largo de los siglos. Así es lógico que un investigador pueda encontrarse con casos en los que sus conocimientos no lo capaciten para catalogar o clasificar algún tipo cerámico concreto. El problema lo tenemos cuando este investigador no reconoce esta imposibilidad y omite o clasifica mal alguna pieza, lo cual genera un error de cronología que puede arrastrarse o afectar a un conjunto más amplio. No entraremos en las causas de este comportamiento, que pueden ir desde la presión socio-profesional hasta un error involuntario.

También inciden sobre el contexto historiográfico general algunos errores de interpretación que se dieron en otras épocas, como es la confusión con producciones de TS cuando realmente se trata de barniz rojo fenicio, griego, ibérico, etc.; también la presunta ausencia en la provincia Castellón de cerámicas tardías romanas, a causa del desconocimiento de estas producciones por parte de los que practicaban intervenciones a principio del siglo pasado, o la ignorancia de excavadores antiguos acerca de que la cultura musulmana también producía cerámica a mano, lo que llevó a la clasificación de niveles o de yacimientos medievales como pertenecientes a épocas prehistóricas o protohistóricas. Hemos comprobado personalmente estos errores y otros al revisar materiales de intervenciones antiguas anteriores a los años 70 del siglo XX en los almacenes del SIAP de Castellón o en el Museo Arqueológico Municipal de Burriana. No sólo había errores de cronologías, también podemos detectar errores de funcionalidad debidos a la deficiente preparación del investigador implicado. Un ejemplo lo tenemos en piezas de Sagunto: bisagras de hueso como flautas, molduras de mármol giallo antico como molduras de rodeno, elementos militares como pinzas de depilar, adornos de caballería como amuletos fálicos, etc. (ARANEGUI, 1991).

Otra base de errores cronológicos es la falta de comunicación e intercambio de datos, sin considerar la interdisciplinariedad dentro de la propia arqueología. Es decir, el intento de abarcar conocimientos que no se dominan completamente o el intentar alcanzar una imposible macro-especialización, por ejemplo, a nivel de una tipología cerámica. Estas mismas observaciones podrían aplicarse a muchos otros materiales o estudio de yacimientos. Hacen falta muchos años de experiencia para alcanzar un alto perfil de análisis de las producciones cerámicas antiguas; evidentemente eso no es tarea fácil y a menudo implica sacrificar el conocimiento en otros campos de la Arqueología. En otras palabras, hemos de ser conscientes que el investigador que alcance un alto nivel de preparación en algunas facetas difícilmente podrá alcanzar este mismo horizonte en demasiados campos. Por ello sería justo y necesario 
intercambiar información o solicitarla a otros compañeros especialistas en otras áreas en la línea de estudio global que se está siguiendo.

Desde nuestro punto de vista no es malo intentar llegar a un alto nivel de especialización en determinados campos de la Arqueología, siempre y cuando exista un amplio diálogo y un fluido intercambio de información que permita generar un conjunto de conocimientos de uso común a todos los investigadores, logrando así establecer los grandes corpora o bases de datos sobre los estudios de los yacimientos. Se conseguiría así que no se perdiese u omitiera información con motivo de esta falta de diálogo entre colegas, en favor de mantener el control de un yacimiento o de unos elementos que algunos atesoran como si fueran de su propiedad. Lamentablemente nadie empuja para que se rompa esta dinámica, ni la administración pública, ni las universidades, ni tan siquiera parte de los propios investigadores. No deja de ser sorprendente que, en un siglo donde prima la comunicación, escaseen tanto los elementos de intercambio de información como son los congresos de Arqueología, a menudo con una deficitaria asistencia de profesionales y con ausencia de debates. Estos fallos se cometieron en los primeros momentos de la arqueología local, pero aun se siguen cometiendo, aunque afortunadamente con menos frecuencia, y nos sirven al menos para poder entender la magnitud del problema. Sería necesario revisar en profundidad todas las excavaciones antiguas y algunas de las actuales para valorar hasta qué punto venimos arrastrando una serie de errores cronológicos y tipológicos. Pero la solución no pasa en ningún momento por recriminar equívocos pasados, sino que es esencial hacer una crítica constructiva de las fuentes que citamos.

De la publicación de excavaciones casi es mejor no hablar. Es inadmisible que hoy en día, con los medios materiales y electrónicos que existen, nos encontremos con arqueólogos que no publiquen una sola intervención. Esto produce una falta importante de intercambio de conocimientos y, al mismo tiempo, nos pone al mismo nivel que los eruditos de siglos pasados, a los que precisamente se reprocha el realizar intervenciones sin reflejar científicamente los resultados. Como ya dijimos anteriormente, a nuestro modo de ver, un profesional que nunca publica no es mucho mejor que un furtivo o un aficionado que después "dona" sus hallazgos a un museo.

\subsubsection{Ausencia de coordinación entre Arqueología e Historia Antigua}

Otro de los problemas, cuando hablamos de las intervenciones arqueológicas que afectan a etapas históricas, es la falta de coordinación e intercambio de información 
entre las disciplinas que estudian la Historia y la propia Arqueología. Nosotros nos vamos a centrar en la Antigüedad por ser la que afecta al período objeto de esta tesis.

El primer problema al intentar contextualizar los artefactos recuperados aparecerá si no conseguimos lograr que tengan unas cronologías lo suficientemente exactas para que coincidan con datos históricos reflejados en las fuentes, y no hace falta recordar que estos hechos tienen a priori una cronología muy exacta. Evidentemente, con un abanico que a veces puede abarcar dos o tres siglos, es muy difícil conseguir encajar los restos y acontecimientos históricos de una forma mínimamente aceptable.

Surgen entonces conatos más o menos afortunados de hacer coincidir hechos y fechas. En este caso la Arqueología intenta de alguna forma aproximarse a acontecimientos antiguos en casos con escasa o nula fortuna. Algunos ejemplos, por lo que se refiere a hallazgos arqueológicos que intentan adaptarse a la Historia, los encontramos en el yacimiento de Torre d'Onda (Burriana), que trataremos con más detenimiento en otro capítulo de esta tesis. De la revisión de los artículos puntuales publicados (ARASA, 1987 y AA. VV., 1990), además de material inédito del Museo Arqueológico de Burriana, podemos deducir una cronología para el asentamiento entre el siglo III a. C. y el II d. C. Sin embargo, se adjudica la destrucción y abandono del yacimiento al paso de las tropas de Julio César por la zona, sin ningún tipo de prueba arqueológica (AA. VV., 1990).

El camino inverso también es dificultoso, ya que las fuentes históricas son parciales (recordemos la expresión la "versión del vencedor", como aquélla que ha perdurado) e incompletas y algunos historiadores prefieren no tener en cuenta el hallazgo de elementos y datos arqueológicos que podrían venir a matizar o poner al día los conocimientos que tenemos sobre la Antigüedad.

Es importante tanto para el arqueólogo como para el historiador que se trabaje en equipo en la obtención de resultados dignos a nivel científico. Y con esto volvemos a insistir en la necesidad de que los expertos intercambien datos y conocimientos, de tal forma que la especialización en un campo no habría de ser sinónimo de pérdida de información en los demás. Pero lamentablemente nos encontramos a menudo con una serie de equivocaciones ocasionadas porque un arqueólogo interpreta a la ligera las fuentes históricas, de la misma forma que un historiador no siempre acepta los nuevos datos arqueológicos.

La conjunción de ambas realidades puede ser nefasta, cuando se realizan estudios desde el campo de la Historia y se asumen datos arqueológicos que deberían haber sido actualizados previamente por los profesionales, ya que la falta de conocimientos especializados del historiador le impide hacer una crítica fiable. Así, cuando estos datos son asumidos por la bibliografía especializada de la Historia Antigua, pueden servir de base teórica para la interpretación de excavaciones por parte de otros arqueólogos, 
cuya falta de conocimientos especializados les impide hacer una crítica ajustada del apartado histórico. Es un círculo vicioso difícil de romper.

\subsubsection{La gestión administrativa y la gestión científica}

Este apartado queremos dedicarlo a la problemática de la gestión de la Arqueología por parte de la administración pública, y cómo las deficiencias originadas desde ahí son la causa de una parte importante de los problemas que hemos reflejado más arriba. Nos centraremos en Valencia, aunque sabemos que algunos de los conceptos que criticamos son similares a los existentes en otras partes de España.

En la actualidad, en la Comunidad Valenciana la gestión de la cultura material aún no ha alcanzado los niveles de eficacia que podemos observar en otros países de nuestro entorno europeo. Esto, en líneas generales, se debe a que aún es reciente el descubrimiento del potencial, tanto económico como social, que tienen los restos materiales relacionados con el patrimonio cultural, hecho que ya han detectado otros países de nuestro entorno y por lo tanto se encuentran en un estadio avanzado de su explotación, inclusive turística.

Los principales cauces en los que se mueve la cultura, como elemento rentable social y económicamente, son el turismo de medio y alto nivel, el ocio, la enseñanza y la investigación científica. Muchos son los aspectos concretos en los que se plasman estas actividades; quizás las más destacadas sean las de los museos, parques temáticos, turismo rural, entornos protegidos, cascos urbanos singulares, elementos únicos dentro de rutas turísticas, exposiciones temporales monográficas o monotemáticas, actividades didácticas, campos de trabajo o de vacaciones, paradores nacionales o viviendas en lugares de interés histórico y artístico, catálogos y publicaciones, coleccionismo, etc. Junto a estos encontramos otros indicadores del interés social despertado por el mundo de la cultura, significativamente por su aparición constante en los medios de comunicación, siempre en un aspecto favorable en lo referente a la divulgación, conservación y protección del mismo y de protesta social por su destrucción. Así pues, hace falta que la administración pública esté preparada para adaptarse a la rápida evolución de este campo, con un futuro muy prometedor.

La legislación vigente sobre la gestión del patrimonio cultural es breve y concisa. Citaremos la reglamentación autónoma y de rango superior, sin entrar en facetas 
más específicas. Pasaremos a resumir los aspectos más destacados de las leyes a las que haremos referencia a lo largo del presente trabajo de investigación.

La legislación internacional por medio de la UNESCO, presenta algunos conceptos que más tarde se plasmarían en la legislación europea y española, siendo su base la Recomendación que define los principios internacionales que deberán aplicarse a las excavaciones arqueológicas aprobada en Nueva Delhi en 1956 y la Recomendación sobre la conservación de los bienes culturales que la ejecución de obras públicas o privadas pueda poner en peligro aprobadas en París en 1968. Se trata de textos con un profundo trasfondo científico y no administrativo, pero su carácter no vinculante resta eficacia de por sí a las mismas.

A nivel europeo, tampoco vinculante y con aspiración orientativa, tenemos por ejemplo la creación en 1981 del Comité directivo para la conservación integrada del Patrimonio Histórico del Consejo de Europa y su Recomendación relativa a la protección del patrimonio arqueológico en el contexto de las operaciones urbanísticas en el ámbito urbano y rural de 1989 y el Convenio Europeo para la protección del patrimonio arqueológico de 1992. Ambas se centran más en aspectos científicos y jurídicos que propiamente administrativos.

La legislación española tiene como base el artículo 46 de la Constitución Española donde aparece la obligación de los poderes públicos de conservar y promover el enriquecimiento del patrimonio histórico, cultural y artístico de los pueblos de España y de los bienes que lo integran. Una cita muy breve merecen otras leyes que tratan de forma marginal temas que pueden relacionarse con elementos del patrimonio cultural, como podrían ser el Código Civil, la Ley 60/1962 de Régimen de Auxilio, Salvamento, Remolques, Hallazgos y Extracciones Marítimas, la Ley de Expropiación Forzosa de 16/1985, el Código Penal y el texto refundido de la Ley sobre el Régimen del Suelo y la Ley Reguladora de Bases de Régimen Local. La principal ley que regula el patrimonio cultural español es la Ley 16/1985 de Patrimonio Histórico Español junto al Real Decreto 111/1986.

Al tratar la legislación autonómica conviene matizar que la gestión arqueológica depende exclusivamente de la Generalitat Valenciana, que es la que concentra todo el poder y obliga a la realización de una serie actuaciones que, en nuestra opinión, ocasionan una especie de efecto cascada que tienen como principales resultados el estancamiento de la arqueología a nivel científico y de la propia gestión administrativa que se sumerge en una burocracia inútil.

La ley que rige la arqueología en la Comunidad Valenciana es la Ley 4/1998 del Patrimonio Cultural Valenciano (en adelante LPCV) ${ }^{3}$ y sus dos modificaciones (Ley

${ }^{3}$ Es conveniente destacar que la legislación sobre el patrimonio cultural se encuentra también reglada por la Ley 2/1989 del 3 de marzo de la Generalitat Valenciana sobre impacto ambiental y la Orden del 31 de julio de 1987 de la Conselleria 
7/2004 y la Ley 5/2007) que no cambian significativamente el apartado arqueológico original de la ley. La LPCV dispone de un título exclusivo de normas acerca del patrimonio arqueológico y paleontológico (Título III, Art. 58 al 67). Según la LPCV, "es competencia de esta administración establecer los procedimientos de inspección oportunos para comprobar el desarrollo de las intervenciones según el programa previsto y ordenar su suspensión cuando no se ajusten a lo autorizado o se considere que la actuación profesional no alcanza el nivel adecuado" (Art. 60.3). También se determina en la Ley, la obligación del promotor, a su cargo, de presentar, en la Conselleria de Cultura y Deporte, dentro del plazo fijado por la administración, o en su defecto en el de dos años, una memoria científica de los trabajos desarrollados, suscrita por el arqueólogo director de los mismos (Art. 60.4).

En la actualidad, bajo el manto protector de esta ley, cada dirección territorial (en esta caso Valencia, Castellón y Alicante) exige a su albedrío una serie de requisitos para otorgar permisos y aceptar informes o memorias científicas, que comunica esporádicamente a los arqueólogos mediante correo o de forma telemática. Esto, además de generar una inestabilidad constante, ya que los cambios en los requisitos llegan a variar de un año a otro, provoca que el corpus científico que almacena la Conselleria de Cultura y Deporte sea de lo más heterogéneo y dispar.

En primer lugar podemos ver claramente cómo la investigación va unida al trámite administrativo, ya desde las labores previas a las intervenciones arqueológicas. Esto genera que la principal preocupación de la mayor parte de los arqueólogos sea cumplir con los plazos y trámites burocráticos, para poder seguir con sus labores profesionales de excavación o de estudio.

Éste es un problema ya enquistado en el mundo científico, donde se mezclan las labores investigadoras, docentes y técnicas de tal forma que no queda clara la función de cada uno. Así pues, cualquiera de las partes implicadas debe realizar todas estas tareas, con la consiguiente pérdida de tiempo y esfuerzos; pero no solamente eso, ya que esta redundancia de recursos físicos e intelectuales, e incluso económicos, hace que se pierda un importante caudal que podría dedicarse a la ampliación y mejora de cada una de las facetas citadas anteriormente. Esta situación, sumada a la escasez de recursos económicos, hace que los investigadores tengan que aplicar ellos mismos, a veces de forma autodidacta, técnicas como la informática, estadística, topografía, etc., que en manos de profesionales del ramo permitirían un rendimiento mayor.

En segundo lugar conviene recordar que a menudo la supervisión de las intervenciones está realizada por personal sin la especialización suficiente para abarcar todos los campos de la Arqueología, adoleciendo además de falta de evolución, ya que las tareas administrativas impiden que se disponga de recursos para mantenerse al día

de Cultura y Deporte, reguladora de las actividades arqueológicas, ya desfasada pero aun no derogada. 
sobre los avances científicos en todas las singularidades de la Arqueología, dándose la paradoja de que el que inspecciona y supervisa tiene en ocasiones una experiencia y cualificación muy inferior al inspeccionado. Así, en el mejor de los casos, es necesaria la búsqueda de colaboración voluntaria por parte de especialistas que asesoren en la supervisión arqueológica llevada a término por la administración pública.

Esto implica un total subjetivismo a la hora de elegir las fuentes de esa asistencia y volvemos a caer otra vez en la problemática de la endogamia y la falta de contraste y diálogo a nivel de información científica, debido a que el asesoramiento no está reglamentado y no hay mecanismos que aseguren la eficacia del mismo.

Dentro de esta misma cuestión podemos también decir que no se dejan claros los criterios técnicos y científicos por los cuales debe regirse la administración, y no hablamos solo de la Generalitat Valenciana, sino también de los servicios provinciales, comarcales o municipales, que igualmente adolecen de esta falta de criterios unificados a nivel administrativo, legal y técnico. Esta incertidumbre hace que se acabe dejando al criterio personal de un reducido número de funcionarios lo que debería representar el amplio espectro científico de la comunidad investigadora valenciana.

Finalmente se produce una acumulación inmensa de materiales y datos a los cuales es prácticamente imposible sacar resultados científicos dignos, a expensas de la voluntad investigadora de la persona que realiza cada intervención. Paradójicamente la ley blinda de una forma incomprensible los resultados y los materiales casi en propiedad indefinida del arqueólogo director y al mismo tiempo no obliga a dar a conocer los resultados científicos obtenidos de las mismas. Teóricamente existe la obligación de solicitar la autorización del director de la intervención para estudiar los materiales depositados (Resolución del 21 de marzo de 1996 articulo quinto) sin establecer una caducidad para esta obligación, que sin embargo la UNESCO establece desde hace más de 50 años en un plazo limite de 5 años (Nueva Delhi, 1956 - art. 24b).

La legislación vigente hace además que los museos sean meros depositarios de piezas, con nulas o muy escasas posibilidades de autogestión a nivel científico. Un ejemplo de esto es la citada Resolución de 21 de marzo de $1996^{4}$ de la Dirección General de Patrimonio Artístico, de la Conselleria de Cultura Educación y Ciencia de la Generalitat Valenciana, por la que se establecen determinados criterios para los depósitos de materiales obtenidos en actividades arqueológicas y paleontológicas en la Comunidad Valenciana. En su artículo segundo exige que permitan la adecuada conservación y mejor cumplimiento de la función cultural y científica de los materiales, especificando para ello que dispongan de instalaciones con espacio suficiente, con condiciones de seguridad y ambientales que permitan su perfecta conservación, facilitando su exposición y difusión; y no solo eso, también exige que los museos

\footnotetext{
${ }^{4}$ Esta ley fue publicada en el Diario Oficial de la Generalitat Valenciana, número 2.745 de 10 de mayo de 1996.
} 
delimiten una zona de estudio y consulta que facilite el trabajo con los materiales depositados y que dispongan de fondo bibliográfico mínimo, susceptible de ser ampliado. Igualmente, deberá contar con talleres de restauración en los que se puedan limpiar o tratar las piezas que integren los fondos depositados. Esto evidentemente no se cumple en la gran mayoría de los museos de la Comunidad, especialmente en lo que se refiere a la designación de museos con condiciones mínimas y a la documentación que se requiere al arqueólogo. Esta situación es hasta tal punto nefasta, que nos encontramos con museos que no tienen ni siquiera el inventario de los materiales que fueron depositados, menos aún, planos, diapositivas, etc.

Una vez expuesta la principal problemática administrativa de la arqueología actual en la zona objeto de esta tesis, no podíamos seguir adelante sin realizar al menos una breve reflexión sobre esta cuestión que nos afecta, ya que la gran mayoría de los datos científicos obtenidos por la ciencia arqueológica no provienen de entidades científicas y académicas, si no que se originan por un proceso meramente administrativo.

La legislación sobre el patrimonio cultural valenciano es heredera de otras antiguas leyes que la precedieron y es evidente que algunos de los defectos que arrastra se originaron a partir de ellas, fruto de su época, y además no ha sabido evolucionar a nivel administrativo ni científico de acuerdo a su tiempo.

Creemos que es necesario separar claramente la gestión administrativa de la investigación científica, es una tarea difícil, pero no imposible; no se puede pedir a instituciones científicas que gestionen a la perfección y tampoco viceversa, es decir, requerir un elevado cariz científico a las entidades administrativas. Esto no impide que ambas puedan coexistir; de hecho sólo se trataría de repartir de forma clara sus competencias, puesto que están condenadas a entenderse y ampararse mutuamente. El problema parte de la falta de delimitación de competencias a consecuencia del intrusismo y de la duplicación de esfuerzos, con la consiguiente pérdida de calidad y funcionalidad en todos los campos.

Otra cuestión importante es la separación entre la docencia y la investigación; siempre hemos creído que un buen profesor y pedagogo no tiene porque ser un buen científico (ni viceversa). Una separación parcial entre los medios académicos e investigadores, de tal forma que no se obligara a un estudioso a dar clases como condicionante para proseguir en su tarea, podría sin duda mejorar el nivel de las facetas investigadora y la docente. No entraremos a debatir esta cuestión en profundidad, ya que a un trabajo como el nuestro sólo le afecta de forma colateral.

Así pues, proponemos que la administración tenga la capacidad de diferenciar claramente entre lo que es la obtención de restos arqueológicos y su posterior estudio. Esto no implica que unos profesionales tengan un nivel superior o inferior con respecto a aquellos que ejercen como investigadores; simplemente se trata de optimizar 
recursos económicos y personales en favor de obtener unos resultados mucho más satisfactorios para la sociedad en general y la Arqueología en particular. Este problema se solucionaría fácilmente con una simple y pequeña modificación en la ley actual, dejando que el arqueólogo que realiza la excavación decidiese, o no, desarrollar la memoria científica, de tal forma que existiera la opción de delegar este trabajo en una institución científica previamente homologada por la administración pública y con capacidad investigadora acreditada; así pues, museos, universidades e instituciones científicas podían asumir esta tarea y desarrollar de forma única y conjunta estudios globales de yacimientos o de territorio.

Si por otro lado el arqueólogo que realiza la excavación cree tener suficientes recursos para llevar a cabo esta memoria científica, evidentemente es la persona más indicada para hacerlo; pero si no tiene interés, ni medios, ni tan siquiera capacidad suficiente como para necesitar la colaboración de estas entidades científicas, la legislación debería favorecer esta doble alternativa. La mayor parte de la financiación seguiría siendo aportada, como hasta ahora, por particulares y promotores, a los cuales debería informarse previamente del coste estimado de toda la intervención y a quién se dirigirán los recursos económicos, sea al propio arqueólogo, a la administración para que lo gestione o directamente a la institución científica pertinente. Enlazando con la cuestión anterior, el ente público también debería dar luz a una serie de requisitos técnicos muy estrictos y concretos, previamente elaborados por todas las instituciones investigadoras representativas y reconocidas en la Comunidad Valenciana, con el objetivo de obtener memorias científicas de calidad que así tendrían mayor utilidad.

No es necesario decir que una constante revisión de estos requisitos científicos es vital para actualizar la investigación y asegurar que siempre se obtenga la mayor cantidad de datos posible. Este método también permite a los arqueólogos que inicien una intervención el saber de antemano qué recursos técnicos y científicos pueden necesitar, si tienen capacidad para obtenerlos y si es necesaria la colaboración de otras entidades científicas. Se puede así determinar, con un margen de error mucho menor, el tipo de gestión económica necesaria para la intervención completa.

El trabajo de la administración pública consistiría en la inspección para que se aplicara correctamente la metodología exigida en el permiso administrativo, siendo absolutamente estricta en su cumplimiento, ya que un error aquí significaría una pérdida irreparable de información. Pero una vez recogida de forma fiable e inteligible, las labores de interpretación ya podrían ser realizadas por cualquier profesional debidamente preparado.

La exactitud en la documentación reduce en gran medida los márgenes de error y, además, el hecho de que ésta circule puede disminuir los fallos interpretativos gracias al debate abierto y al contraste de hipótesis. 
Como podemos deducir, esta forma de trabajar también solucionaría la problemática de las excavaciones segmentadas o parciales, ya que se crearían grandes centros donde se almacenarían y gestionarían los resultados de todas las intervenciones arqueológicas que afectaran un mismo yacimiento, facilitando a cualquier investigador el acceso a una visión de conjunto. Una vez solucionado el tema administrativo, la cuestión científica dependería exclusivamente de la calidad de los centros implicados en la investigación. La forma de evitar cuestiones de falta de calidad o de endogamia es sencilla; bastaría con que la administración facilitase la información obtenida a varios centros a la vez y que cada uno de ellos desarrollase el estudio acorde con sus medios o su especialidad. El contraste de las distintas hipótesis es lo que haría crecer la calidad de la propia investigación.

Finalmente debemos incluir entre las exigencias a profesionales e investigadores el que preparasen su intervención para la publicación. Quizá debería condicionarse la concesión de nuevas autorizaciones o subvenciones a la publicación y difusión de los resultados, estableciendo un plazo administrativo fijo para la entrega de artículos, libros, comunicaciones, etc. Hoy en día ya no son admisibles excusas de tipo económico; para hacer pública una intervención en Internet por parte de la administración el coste es ridículo y hacer lo mismo en soporte electrónico representa una inversión mínima. Solamente sería necesario poner una fecha de caducidad a la disponibilidad ilimitada de los restos arqueológicos fruto de una excavación para, de este modo, permitir la circulación de los mismos en los medios científicos y facilitar su análisis a otros investigadores. Dentro de este margen temporal de exclusividad es cuando el investigador debería tener tiempo más que suficiente para confeccionar la memoria y la publicación.

La elaboración de la pertinente memoria y su publicación, así como la discusión en congresos, dependerían única y exclusivamente de la capacidad del autor, de tal forma que cuanto antes finalice el trabajo antes podrá seguir con otras intervenciones. Si el trabajo que realiza es de baja calidad o insuficiente, quedará en evidencia con su exposición y difusión; pero la administración pública habrá asegurado que la recuperación de los artefactos se haya realizado con una metodología válida y compatible con la utilizada por el resto de los científicos y que las deficiencias serán todas en las hipótesis e interpretaciones, que podrán ser subsanadas a posteriori tanto por el mismo investigador como por colegas que tengan acceso a los restos obtenidos y que puedan elaborar otras teorías distintas, al mismo nivel de fiabilidad que la interpretación original.

Otro factor necesario para elevar el caché científico de las intervenciones arqueológicas implicaría reducir la presión que sufren los profesionales en cuanto a los plazos administrativos, especialmente si nos referimos a la llamada arqueología de urgencia, fuente de la casi totalidad de las actuales intervenciones reconocemos que es 
un método muy poco recomendable a nivel investigador, pero lamentablemente no hay alternativa por el momento; sería necesario cambiar la arqueología de urgencia por la preventiva. El funcionamiento de la administración pública puede permitir unos plazos mucho más amplios a la hora de realizar el pertinente estudio arqueológico; de hecho, en el plazo de tiempo existente entre la redacción del proyecto arquitectónico y la obra, hay espacio suficiente para permitir que la excavación arqueológica vaya por delante de las actuaciones urbanísticas. Se podría crear un mapa de delimitación de yacimientos y de solares, lo que permitiría a la empresa realizar intervenciones con meses de antelación, empezándolas cuando se inicie el proceso administrativo de la obra, sabiendo ya de antemano lo que este proyecto afectará a nivel arqueológico. La viabilidad de este sistema está confirmada y funciona en lugares como Mérida, donde la arqueología de urgencia es minoritaria respecto a la de prevención, optimizando los recursos disponibles a través del Consorcio de la ciudad monumental de Mérida.

Nunca se va a poder suprimir la urgencia, ya que siempre surgirán restos en lugares donde no estaba prevista su aparición. Pero en cualquier caso somos concientes de que la aplicación de este sistema preventivo lograría reducir a niveles aceptables la presencia de esta modalidad arqueológica. Si la legislación elaborada por la administración pública puede solucionar las cuestiones que hemos señalado más arriba, a nivel de comunidad investigadora deberíamos empezar a decidir qué baremos y qué nivel científico deseamos para desarrollar con eficacia y validez la Arqueología.

En resumen, con un sencillo cambio legislativo se podrían solucionar problemas relacionados con la gestión administrativa, excavaciones parciales, presión de los plazos, falta de criterios interpretativos, dispersión de recursos y medios humanos y la falta de diálogo entre instituciones y arqueólogos. 


\section{3 OBJETIVOS}

Desde nuestro punto de vista el hombre y la naturaleza van totalmente asociados en el pasado y es imposible entender el uno sin el otro. Por este motivo creemos que para la comprensión de los distintos grupos humanos que han formado parte de nuestra Historia es más importante el conocimiento del entorno natural que las ciencias exactas; porque mientras la influencia del medio es determinante en la evolución de los asentamientos, es obvio que las variables matemáticas no entienden de sentimientos ni condicionantes personales. Consideramos también que el estudio de estos antecedentes de tipo geográfico y físico deben extenderse hasta el momento preciso de la excavación, prácticamente hasta el instante de empezar la intervención y sobre todo en zonas urbanas, ya que un paisaje que, por ejemplo, haya permanecido estable durante más de 2000 años, puede verse alterado en un solo día por todo tipo de factores, especialmente los humanos.

Finalmente, como concepto queremos defender a ultranza la utilización de la interpretación deductiva, porque nos parece lo más coherente con la ciencia arqueológica, ya que depende de los restos que se exhuman para realizar sus hipótesis y aún así muchas veces es bastante difícil llegar a teorías serias y aceptables. La interpretación inductiva es, desde nuestro punto de vista, muy negativa para el estudio arqueológico, porque en nuestra labor no sirven las adivinanzas ni las predicciones. La nuestra es una investigación que evoluciona con el tiempo y paso a paso, sin acelerarse más de lo necesario ni pretender grandes invenciones o golpes de efecto que, en muchos casos, sólo buscan la gloria o persiguen sentar líneas maestras. Nosotros pensamos que este tipo de teorías son poco válidas, porque de nada sirve predecir la existencia de unos restos que no se pueden constatar. Sin embargo, los errores mayúsculos que este tipo de interpretaciones han ocasionado han originado en algunos casos importantes retrasos y datos erróneos en la investigación científica, provocando incluso la perdida irremisible de información. Muchos podrían ser los ejemplos de zonas donde se presuponía que no había restos y han resultado ser muy ricas en hallazgos, con lo cual tienen que excavarse (en el mejor de los casos) tarde y mal. Igualmente incongruente es el hecho de invertir recursos en zonas que se presuponen fértiles a nivel arqueológico, cuando finalmente los resultados son 
negativos. Interpretar una necrópolis como romana, aún estando dentro de un recinto urbano de este periodo o confundir veredas medievales con vías romanas, son sólo dos ejemplos de los errores que se pueden cometer.

No queremos dejar a un lado el tema de la didáctica y de la divulgación a un nivel social amplio, por lo que nuestra metodología debe desembocar en este tipo de actuaciones, que son un punto esencial para exponer a la sociedad, de una forma amena y correcta, todos los avances realizados en Arqueología, ya que ésta no se entiende sin una función social que persiga dar a conocer nuestro pasado a los ciudadanos. Quizá por medio de ella lleguemos a tener una visión de nuestro pasado como especie y, al mismo tiempo, demos un impulso para un futuro común en una koiné cultural. De hecho, como ciencia exclusivamente ceñida a unos círculos muy estrictos, sería una materia anquilosada y caduca, con sus días contados.

La divulgación de resultados técnicos dentro de la misma comunidad científica, debe tener como objetivo primordial que esta información circule y que, por medio de intercambios entre profesionales, se vaya enriqueciendo y ampliando a través de aportaciones o debates. Existe actualmente en la Arqueología una tendencia al monopolio de la información y a la falta de discusión, ejemplificada como ya comentamos en la decadencia de los congresos y debates frente al auge de los seminarios y conferencias. Algunas publicaciones temáticas no tienen un cariz muy diferente, ya que la línea editorial influye fuertemente y rara vez admite teorías contrapuestas. Nuestro punto de vista es que deberían al menos publicarse todos los resultados de interés en publicaciones técnicas y hacer circular esta información en todos los medios científicos actuales.

Es lamentable que no vean la luz la cantidad de datos que tenemos hoy en día en museos y archivos. Se acumulan así innumerables intervenciones, a veces sobre un mismo yacimiento, con más datos desconocidos que resultados publicados; o enclaves ya desaparecidos de los cuales lo único que resta son campañas o hallazgos sin divulgar. Esto además va en detrimento de los estudios generales o globales y hace que sea temerario lanzar hipótesis de interpretación amplia cuando ni siquiera se puede llegar a conocer todo lo que ha sido excavado.

Así pues, sobre estas premisas pretendemos establecer una depuración total de los datos conocidos hasta hoy, a los que sumaremos las aportaciones la las intervenciones arqueológicas que hemos realizado. Con ello pretendemos llegar a proponer unos patrones para la época romana en una zona de la antigua Hispania Citerior, la parte meridional del conventus Tarraconensis, comprendida entre el río Mijares y Sagunto, concretamente en la zona más cercana a la costa. Estos patrones explicaran, además, desde un punto de vista espacial y cronológico las distintas formas de ocupación del territorio entre el final del periodo Ibero y el inicio del Medioevo. 


\section{4 METODOLOGÍA}

Nuestra dilatada experiencia en el campo de la Arqueología y el haber tenido la fortuna de colaborar y observar el trabajo de varios expertos en múltiples ciencias afines, nos permite proponer una serie de requisitos básicos sobre los cuales se pueden llevar a cabo estudios de un cierto nivel. Serán estos los que más adelante aplicaremos a una serie de ejemplos que desarrollaremos en esta tesis; es por ello que creemos conveniente exponer esta propuesta, que más bien podemos considerar como una plantilla sobre la que reflejar los resultados de una intervención.

En primer lugar debemos obtener la documentación previa necesaria que nos ponga al día de los antecedentes conocidos sobre el espacio donde vamos a intervenir. No podemos olvidar que el conocimiento del territorio y los condicionantes físicos de la zona son esenciales para la realización de un buen estudio arqueológico, más aún cuando es evidente que el panorama que hoy en día observamos en muchos casos no tiene absolutamente nada que ver con el paisaje histórico que estamos intentando investigar. Más sangrante es el caso de una ciudad, donde la urbanización supone la pérdida de gran cantidad de datos de enorme interés, como por ejemplo la topografía, la orografía, la vegetación, etc., elementos que fueron importantes en su momento, pero que han desaparecido por completo a raíz de la homogeneización que suponen las obras urbanas. Recordemos por ejemplo grandes ciudades romanas como Sagunto, Valencia, Tarragona o Mérida cuyas murallas y calles se adaptaron a una serie de elevaciones, ríos, barrancos y desniveles que, en general, ya han desaparecido.

Es muy importante rastrear todo estos indicios en la actualidad; por ejemplo, el desnivel de una calle puede señalar la existencia de algún montículo que pudo influenciar en el desarrollo de la ciudad antigua; los casos de Sagunto y Burriana los expondremos con detenimiento en esta tesis y podemos citar el ejemplo de Mérida, donde la muralla se adapta a alguna elevación, como es la zona donde encontramos el anfiteatro y el teatro. También la cerca defensiva romana de Valencia tiene que adaptarse a un brazo fluvial completamente desaparecido. 
A la vista de esta cuestión debemos intentar conocer la zona objeto de intervención y su entorno inmediato por medio de todos los análisis disponibles, incluso aquellos que a priori no parecían tener relación directa con la actuación arqueológica, como pueden ser la topografía del terreno, el clima, la vegetación, la hidrología, etc. No debemos olvidar que estos datos solamente se están estudiando desde fechas muy recientes, siendo la Arqueología del territorio una especialidad que arrancó con fuerza a partir de los años 80 del siglo XX; así pues, estos elementos no se tuvieron en cuenta en antiguos estudios que aún sirven de base a teorías actuales.

Una vez conocidos los factores físicos pasaremos a los humanos, que también son de gran importancia para establecer los antecedentes conocidos de cualquier intervención. Nosotros abogamos por una asepsia total a la hora de analizar los elementos obtenidos en intervenciones anteriores sobre las cuales debamos realizar un nuevo estudio y no limitarnos únicamente a repetirlos sin que puedan ser discutidos o criticados. Esto no quiere decir que el análisis de intervenciones y teorías ajenas a la nuestra no puedan servir de punto de comparación y apoyo a los trabajos que estamos realizando; si acreditamos la fiabilidad científica del investigador y de los datos consultados, sus hipótesis pueden servirnos para desarrollar nuestra tarea. Una vez matizado este aspecto debemos señalar que, en intervenciones antiguas, nos podemos encontrar con todo tipo de errores a nivel tipológico y cronológico, fruto unas veces de la falta de preparación y otras de la falta de medios.

Solamente echando un vistazo a las actuales fichas de inventario de yacimientos arqueológicos, de la Conselleria de Turismo, Cultura y Deporte de la Generalitat Valenciana podemos comprobar como muchas tienen errores de bulto y en otras se repiten datos equivocados' algunas corresponden a hallazgos contemporáneos y otras a asentamientos que simplemente no existen. Nos referimos concretamente, por ejemplo, a aquellas fichas que confunden formaciones geológicas con estructuras (muros ciclópeos en Sagunto, losas hincadas en Benicassim, etc.); en otros casos se limitan a describir datos bibliográficos, identificando aljibes o cabañas de pastor con estructuras romanas en Vila-real, caminos vecinales con vías romanas en Borriol, torres de telecomunicación del siglo XIX con estructuras medievales en Cabanes, etc. Depurando alguno de estos casos tenemos tres tipos básicos de deficiencias en las fichas: las que corresponden a yacimientos destruidos, aquellas en las que, a pesar de que el terreno esté intacto, no se encuentra ningún tipo de huella que demuestre la existencia de un sitio arqueológico y finalmente las indicaciones de aquellos lugares que son inventariados como si fueran distintos, cuando en verdad son dos o más fases de uno mismo. No entraremos a analizar en profundidad las causas de estas deficiencias, que pueden ser debido a la falta de medios o de capacidad de quienes las realizaron, por imperativo legal o por fines económicos, ya que el pago por ficha podía crear la necesidad de alcanzar los mínimos cuantitativos que no cualitativos. 
Si todas esas deficiencias las encontramos en las fichas actuales ¿qué podemos decir de los estudios antiguos, supuestamente realizados con una preparación más baja y una menor disponibilidad de medios científicos? Queda con ello demostrado fehacientemente que es muy necesaria la refinación y la separación entre los hechos y las conclusiones a la hora de utilizar estudios antiguos, ya que estos datos pasaron por la criba subjetiva del arqueólogo o el historiador. Lo ideal sería consultar directamente los elementos obtenidos; pero si esto no es factible debe tenerse la prudencia necesaria para intentar estudiar los hechos en base a la documentación existente. Es necesaria una aproximación objetiva y sin prejuicios: un buen investigador puede ser objeto de críticas injustificadas por parte de algunos profesionales y no por ello nuestra opinión sobre él debe verse mediatizada. Por el contrario la alabanza indebida puede estar detrás de un profesional nefasto.

Las teorías de la Historia Antigua sufren un problema similar, porque muchas veces utilizan datos que han pasado por un factor subjetivo, como es la extracción e interpretación del arqueólogo. A esto sumamos que cuanto más amplio es el supuesto y más elementos arqueológicos de distintas fuentes se utilizan, mayor es también la cantidad de errores que pueden acumularse.

Otro factor humano del paisaje es la interacción del individuo o de la comunidad con el entorno. Debemos tener siempre presente en estas investigaciones y especialmente en las realizadas en zona urbana o en áreas de cultivo muy alteradas, que el paisaje que observamos no tiene nada que ver con el que existía en la Antigüedad. El primer paso es intentar rescatar la mayor parte de los datos que podamos obtener. En una ciudad, por ejemplo, los mínimos desniveles ocultos parcialmente por la acción constructiva pueden significar una interesante aportación respecto a las cotas de altura que existían en este espacio antes de la expansión del centro urbano. Otro ejemplo es la vegetación o los cultivos antiguos; olvidemos que el nivel de observación y control del territorio en un campo de trigo es muy distinto al de un viñedo, que a su vez es diferente al de un campo de naranjos y que no tienen nada que ver con una zona de bosque.

Observamos nuevos ejemplos en la desecación de marjales y cauces fluviales o en la nivelación de superficies para cultivo, entre otros. Debemos tener presente que cuanta más maquinaria industrial se utiliza más rápida es la metamorfosis del paisaje natural y, de hecho, en el último siglo esta transformación ha sido brutal.

Así pues, es esencial que todos los estudios arqueológicos tengan en cuenta desde el principio cómo era el paisaje y el entorno en el cual se encontraba el asentamiento, porque creemos que una investigación seria y profunda siempre puede rescatar algún dato; y estamos hablando de una información asequible únicamente en archivos y fuentes históricas, aunque también somos conscientes que sería deseable que se realizaran todo tipo de análisis físicos y químicos para poder interpretar el paleopaisaje. Volvemos a recordar lo que mencionamos al principio de esta tesis sobre la falta 
recursos económicos, que impide a veces la realización de análisis edafológicos, paleobotánicos, sedimentológicos, etc.

Un agente importante a tener en cuenta es el ya citado sobre la separación entre el proceso de documentación y el de interpretación. Desde un principio la mayor parte los arqueólogos mezclan lo que es el hecho puro y simple con la disquisición que sobre él se realiza. Esto se refleja a lo largo de la intervención e incluso en la publicación de los resultados. De hecho, algunas veces encontramos artículos que exponen una larga descripción de unidades estratigráficas que, por escuetas o confusas, de poco o nada valen al lector; una descripción, por ejemplo, del tipo:

UE 1001 - Muro de mampostería trabado con mortero de cal de $5 \mathrm{~m}$
de largo por $80 \mathrm{~cm}$. de ancho, corta la UE 1002, colmatado por UE
1015.
Cota inicial $-20 \mathrm{~cm}$. Cota final $-90 \mathrm{~cm}$. Cronología romana
$\underline{\text { UE } 1020}$ - Diez fragmentos de cerámica de cocción oxidante
cubiertos de engobe blanco y decorados con pintura de óxido de
hierro formando dibujos geométricos. Cronología ibérica.

En ambos casos podemos observar que se aportan dos tipos de información muy distinta; por un lado la meramente descriptiva que puede ser irrelevante a nivel de interpretación; y por otro lado aparece una conclusión de tipo cronológico, que es la que tiene una gran importancia en el grado de análisis. Si en la descripción solamente es necesario tomar los datos, la cronología no deja de ser una interpretación subjetiva. Nosotros pensamos que la documentación exhaustiva debe ser correcta y estar disponible a todos aquellos que quieran consultarla, pero lo que verdaderamente debe ser debatido son las conclusiones y la interpretación de cada investigador. Así pues, es más coherente una publicación o estudio con un corpus de datos y una interpretación, de tal forma que podía quedar así:

\section{DESCRIPCIÓN}

UE 1001 - Muro de mampostería trabado con mortero que corta la UE 1002 y esta colmatado por la UE 1015. Cota inicial $-20 \mathrm{~cm}$, Cota final $-90 \mathrm{~cm}$.

INTERPRETACIÓN

Muros de cronología romana de un templo (UE 1001, 1005, etc.)

\section{DESCRIPCIÓN}

UE 1020 - Diez fragmentos de cerámica ibérica de cocción oxidante y decorados con pinturas de óxido de hierro formando dibujos geométricos. Pasta fina, de fracturas antiguas y rodadas INTERPRETACIÓN

Se constata en la UE 1020 la presencia de cerámica de mesa de cronología ibérica, perteneciente al menos a 3 piezas distintas. 
Esta separación permite evaluar más rápidamente los criterios utilizados, concretar y ampliar la información disponible a la hora de mostrar la interpretación y conocer qué datos están disponibles para los investigadores. La misma forma de divulgar, publicar o presentar cada uno de estos segmentos variará mucho según los recursos de que se disponga. También incluiríamos dentro de este bloque los análisis físicos y químicos realizados sobre muestras obtenidas en las intervenciones arqueológicas, cuyos resultados, siempre que sean obtenidos con las garantías científicas necesarias, son en sí datos indiscutibles desde el punto de vista de la analítica y de los márgenes de error aplicables. Generalmente se habla de "divulgar los datos", cuando quizá sea mucho más importante "divulgar la interpretación".

Un ejemplo también seria el hecho de que en la actualidad gran parte del estudio de la cerámica romana se encuentra anquilosado; los estudios metodológicos son un simple recuento de formas asociadas a una cronología, sin ningún tipo de depuración de tipo funcional, histórico, analítico, etc. Hay algunas variables olvidadas en el estudio de la cerámica, como el tiempo (perduración de la cerámica, desplazamiento y comercio de la misma, etc.) y el espacio (almacenamiento, usos funcionales, etc.), de cara a aportar nuevos cauces para el análisis de la misma.

Finalizados los apartados referidos a los antecedentes y a la obtención y exposición de los datos arqueológicos, será el momento de dar entrada a un nuevo capítulo, el correspondiente a la interpretación, donde sí cabe el recurso de la subjetividad. Un claro ejemplo es el llamado fósil director de la Arqueología, o sea, la cerámica. Este caso es de especial interés para nosotros por las cronologías que abarcamos en este estudio. El problema inicial en las dataciones empieza en la misma elaboración de las tipologías de elaboración antigua, en algunas ocasiones de más de 100 años, y que en su momento no contaron con las variables científicas que hoy podemos aplicar (análisis de pastas, dataciones físicas), ni con una mayor amplitud de muestra suministrada por una gran cantidad de excavaciones. Tampoco incluyeron factores pre-deposicionales (transporte comercial de las piezas, conservación y uso de las mismas, etc.) o posdeposicionales (remoción de niveles, reutilización de piezas, etc.). Esto implica que muy posiblemente estemos fechando niveles que no tienen una duración de más de 40 años dentro de márgenes de más de 100 años, si los incluimos por ejemplo en época julio-claudia, lo que puede provocar desfases importantes si los comparamos con hechos históricos muy concretos y acotados en el tiempo.

El siguiente problema lo tenemos en los análisis comparativos. Entendemos este punto como aquél que da cabida a todo tipo de comparaciones entre distintas intervenciones arqueológicas; otras hipótesis, otros estudios, en fin, el trabajo realizado por otros investigadores o por uno mismo en situaciones distintas. En este trabajo no vamos a adentrarnos demasiado en aspectos filosóficos que incidan en valores de tipo ético y profesional; esto debería desarrollarse en otros medios, pero sí queremos recordar que 
para mantener la fiabilidad de este tipo de interpretaciones nunca debemos realizar una injerencia previa en las muestras. Nos estamos refiriendo, por ejemplo, a no descartar parcialmente o mutilar interpretaciones ajenas para que puedan asimilarse a nuestra propia teoría. De la misma forma, tampoco podemos omitir conjeturas por el simple hecho de que no coincidan con las propias. Hoy en día creemos que es mejor exponer creencias contrapuestas y sobre ellas justificar su posible ausencia de validez; esto enriquece sin duda el debate y permite que se pongan sobre la mesa más argumentos.

Dentro de este apartado debemos hacer especial hincapié en la comparación y colaboración con las fuentes antiguas y la Etnología. Somos conscientes de que, en el marco histórico en el cual nos movemos en esta tesis, las fuentes pueden significar una interesante aportación y la Etnología o la Etnoarqueología considerarse en un segundo plano. Estas facetas deben tomarse siempre con prudencia, porque estamos entrando de nuevo en un apartado subjetivo e interpretativo por parte del investigador.

Por ejemplo, un nivel de destrucción que ha sido encontrado en una excavación no tiene por qué asociarse a episodios bélicos conocidos, ya que en ocasiones es difícil hacer coincidir un estrato que comprenda un margen cronológico de más de un siglo con un hecho histórico que pudo tener unos pocos años de duración. Incluso cuando se realizan análisis científicos existe un margen de error y solamente en intervenciones verdaderamente afortunadas es posible hallar restos que remitan a una fecha histórica concreta. De la misma forma la etnología también debe tomarse con reservas, ya que las condiciones de vida han cambiado sustancialmente desde el mundo romano. Los procesos mentales siempre son distintos. Podemos recurrir a la comparación de soluciones técnicas, elementos de uso cotidianos, etc.; pero siempre sin hacer una transliteración completa y manteniendo muchas reservas sobre su validez, considerándolo como un simple dato orientativo más que como un elemento definitivo. 


\section{CAPITULO 2: MARCO PARA EL ESTUDIO DE ASENTAMIENTOS}

\section{ROMANOS}




\section{1 ANTECEDENTES PARA EL ESTUDIO DEL MUNDO URBANO}

Al hablar de antecedentes históricos de la investigación acerca de modelos de ocupación del territorio de época romana, debemos remontarnos a los primeros momentos de los estudios de esta cultura. En cualquier caso más bien podemos hablar de conceptos básicos relacionados con los asentamientos, que de una forma intuitiva eran asociados a las variables que se presuponía deberían haber sido tenidas en cuenta a la hora de seleccionar la ubicación de los asentamientos. Podríamos citar innumerables ejemplos referidos al suministro de agua, posicionamiento estratégico, accesibilidad a nivel marítimo o fluvial, fertilidad del terreno, facilidad para el desarrollo de vías de comunicación, etc. Este tipo de noticias las encontramos abundantemente en cualquier publicación al uso asociada a la arqueología, la historia antigua, la historia del arte, la epigrafía, etc. desde el principio del siglo XIX. Consideramos excesivo relacionar aquí a todos los autores que han utilizado referencias a los condicionantes geográficos a la hora de explicar el origen o evolución de asentamientos, ya que incluso hoy en día es difícil encontrar un investigador que no se haya referido a estos factores. Sin embargo, podemos relatar algunos ejemplos significativos, como el de A. J. Cavanilles quien afirmaba que "En la cumbre de este monte (Mollet - Villafamés) se encuentran restos de población antigua (...) Parece extraño que se habitase aquella mole de peñas descarnadas, sin agua ni tierra, y cercada de precipicios (...)" (CAVANILLES, 1795:57) o V. Boix “ (...) Su primitivo asiento era reducido (Valencia) y ocuparía talvez el punto mas culminante, que pareció mas apropiado entre los varios que ofrecía entonces el terreno sobre la orilla del Turia" (BOIX, 1962:XI).

Otra importante referencia asociada a estos antecedentes de los modos de ocupación es la constante búsqueda de apoyo en las fuentes antiguas, donde podemos trazar dos ejes vertebradores principales; uno se refiere a las citas con datos técnicos y administrativos asociados a la construcción de ciudades o viviendas rurales, como por ejemplo Vitruvio, Plinio, Frontino, etc., y que indudablemente sirvieron a muchos investigadores como guión a la hora de interpretar los restos arqueológicos. El otro eje es el que hace referencia a hechos históricos relacionados con la fundación de ciudades, fortificaciones y obras de ingeniería que aparecen no solamente en fuentes escritas por autores como Cesar, Suetonio, Tito Livio, etc., sino también en fuentes 
epigráficas o de tipo similar, que acaban generando bien resultados acertados 0 tan equívocos como la asociación Segorbe-Segóbriga, Turis-Valencia, etc. Así por ejemplo P. A. Beuter utiliza elementos etimológicos (...) Romo edificà la ciutat de Roma en Spanya (...) Aquesta ciutat de Roma d'Espanya, venint en poder de romans fou nomenada València (...); los romans mudaren lo nom a esta ciutat dient-li València perquè no y hagués altra Roma en lo món sinó la sua (...) lo significat del primer nom en lo segon que ells li posaven; per què, segons dihuen Proaza y Venero, roma en Ilengua aramea vol dir València en llengua latina (...) (BEUTER, f. XXV v.).

Mediado el siglo XX se inicia el periodo mas fecundo de los estudios de territorio, que en el caso de la cultura romana se centran en su mayor parte en la detección de centuriaciones y vías, cuyos primeros estudios fueron recopilados por G. Lugli (LUGLI, 1939) y, posteriormente, por J. Bradford (BRADFORD, 1947), aprovechando en gran parte el auge de la fotografía aérea como medio auxiliar de la Arqueología. Aunque los estudios iniciales tienen origen italiano, pronto se extienden por toda Europa, llegando muy tardíamente a España, donde tenemos a A. Balil (BALIL, 1960), que realiza las primeras síntesis y reflexiones modernas sobre los parcelarios romanos en Hispania.

No será hasta bien entrado el siglo XX cuando podemos hablar de un estudio del paleopaisaje y del análisis del territorio, aunque aplicados de forma casi exclusiva a las culturas prehistóricas o protohistóricas, de tal forma que podemos afirmar que hasta el ultimo tercio del siglo la aplicación de este tipo de análisis a los patrones de ocupación en época romana fue prácticamente residual y se mantuvo los esquemas antiguos basados en conceptos directos de la relación entre el territorio y los asentamiento romanos (por ejemplo BAZZANA, 1987). Recientemente se produjo una eclosión de nuevos trabajos (LEVEAU et al., 1999, PALET et al, 2004, GONZÁLEZ VILLAESCUSA, 2007), con enfoques multidisciplinarios de los cuales presentaremos ejemplos a lo largo de este trabajo, especialmente a los que afectan la zona objeto de estudio (GARCíA PRÓSPER et al, 2006, GONZÁLEZ VILLAESCUSA, 2006 y JÁRREGA 2011).

Gracias a la arqueología se empiezan a introducir actualmente una serie de variables importantes que permiten conocer el desarrollo de los patrones urbanos; por un lado lo que podemos llamar macro-patrones, relacionados con el asentamiento de las localidades, con su entorno y con la propia analogía entre varias ciudades de una misma región (BEDON, 1999) y, por otro lado, unos patrones internos de evolución del propio núcleo (ALARÇAO, 1992). A nivel de relación con el territorio podemos apuntar que, en algunos casos, se interrelaciona a la ciudad con la explotación de su entorno (LEVEAU, 1999), lo que permite presuponer unas distintas necesidades a la hora de crear cada núcleo urbano ex novo o de potenciar antiguos asentamientos. Confluyen aquí varias condiciones que influyen en la elección de un determinado enclave, lejos de una tendencia excesivamente lineal que caracterizaba los estudios anteriores. Citamos algunos trabajos de la zona de Tarragona que versan sobre la necesidad de una salida 
a los productos del interior donde se aúnan condiciones estratégicas, comerciales o de nudos de comunicación (REVILLA, 1995, DUPRÉ, 2002 y PREVOSTI y GUITART, 2010). Encontramos ejemplos en las importantes poblaciones que han rodeado al núcleo de producción cerámica de la Graufesenque, donde a los condicionantes del terreno para la obtención de materia prima se suma un potente eje de comunicación fluvial y terrestre que desemboca en varios núcleos de población o en otras redes de comunicación marítima. Otros estudiosos también asocian una amalgama de centros urbanos y coligados a otros de mayor importancia en el caso del limes germánico, donde se desarrolla todo un entramado alrededor de las ciudades fundadas por una eminente necesidad estratégica y defensiva (AA. VV., 2009).

Por lo que se refiere a la propia evolución urbana, se establecen nuevos patrones que asocian, por ejemplo, la evolución de las sendas según necesidades urbanas y la vida social que se realice en ellas, como sería la utilización de porticados como espacio público frente a la privatización de los mismos o a la adaptación de las vías enlosadas a un uso comercial (ALBA, 2001). Estas teorías acaban evolucionando hacia un análisis diacrónico que permite entender de forma más clara la evolución hacia la decadencia de los núcleos urbanos romanos.

A nivel de Comunidad Valenciana no existe ningún estudio de largo espectro que trate de estos temas, quizás los mas aproximados sean los que abarcan las vías romanas o las centuriaciones, (destacamos entre otros: CHABRET, 1978, MUÑOZ, 1972, PIQUERAS Y SANCHIS, 1992, GONZÁLEZ VILLAESCUSA, 2006, GARCÍA PROSPER et al 2006, ARASA y ROSELLÓ, 2005, BAZZANA, 1978 y 1987, PINGARRON, 1981, LLOBREGAT, 1983, ESTEVE, 1986, MOROTE, 1979 y 2002, GONZÁLEZ VILLAESCUSA, 2002 y 2007 y LEDO, 2005) pero que se quedan en una exploración literal de los restos, con un rasgo bastante cuantitativo, sea de yacimientos o de microespacio, pero que nosotros no consideramos un verdadero análisis de modos de asentamiento, pues no consideran todos los múltiples factores (Geográfica física, Historia, análisis regresivo, etc.) que implican estos estudios.

En la zona objeto de esta tesis, si que podemos afirmar que no hay publicaciones previas de los patrones de asentamiento, así pues, por lo novedoso de este enfoque es por lo que tuvimos que buscar paralelos alejados de nuestro territorio.

Al hacer mención de los modelos urbanos debemos reseñar en primer lugar que la mayor parte se refieren en gran parte a las relaciones entre los núcleos urbanos y su entorno, y no a un desarrollo intrínseco de la ciudad. Para este último apartado, el estudio de las fuentes escritas fue la línea básica a seguir, principalmente aplicando de forma lineal las normas jurídicas y religiosas romanas que podrían asociarse al urbanismo. Respecto a este tema queremos también señalar la interesante propuesta de R. Bedon (BEDON, 1999:121), donde presenta un análisis de la situación de 
asentamientos importantes de la Galia, de diferentes estatutos, relativos a su continuidad o desplazamiento, en los que identifica las siguientes situaciones:

\section{a) Ciudades peregrinas}

a.1) Desplazadas.

a.1.1) Próximas a oppida anteriores (<2-3 m. p.).

a.1.2) Lejos de oppida anteriores (>2-3 m. p.).

a.2) Continuación de otros asentamientos.

a.3) Fundaciones ex novo.

a.4) Historia desconocida.

\section{b) Colonias}

Sobre las colonias, este autor afirma: Existía una tradición romana de establecer las colonias en asentamientos preexistentes, con la finalidad de suministrar de forma inmediata a los colonos un abrigo y una protección (...) se mantuvo hasta época de Augusto, que vino a desarrollar los asentamientos en terreno yermo pero en territorio no expuesto a los ataques. (BEDON, 1999:132)

Como ejemplos cita las colonias de Noviodunum/Equestris, Raurica y Lugdunum, sin restos de ocupación anterior, la colonia Agrippinensis fundada junto al oppidum Ubiorum y la Colonia Augusta Treverorum, que era la capital indígena de los Treveri. Otro caso interesante de rápida romanización lo tenemos en Portugal, donde las civitates peregrinae, rápidamente comienzan a romanizarse, lo que parece adquirir concepto de urbanismo de base a partir de Claudio. En el caso de las civitates turdetanas del Algarve, con fuerte influencia romana desde el final de las guerras púnicas (con ocupaciones efectivas por lo menos desde el 100 a. C.), este proceso fue más precoz que en la Bética, aunque a mayor escala, de forma que siendo peregrinas se convierten en municipios de derecho latino (pero que sólo empezará a reflejarse en términos urbanísticos a partir de Domiciano), aunque su estructura urbana anterior ya tendrá desde muy pronto en la mayoría de los casos foros, templos y baños públicos, especialmente en los lugares donde hay un historial de guarniciones romanas (caso de los puertos y distritos mineros). No hay dicotomía entre población indígena y romana o entre peregrinos y estatutos romanizados; se reconstruyen las ciudades sobre los oppida, desplazando el centro de la ciudad desde la acrópolis a la media montaña. Por el contrario, en el Algarve los patrones territoriales de la romanización son muy delimitados, casi de manual gromático (ALARÇAO, 1992). Sin embargo, las poblaciones desplazadas a la fuerza y reemplazadas son paradigma de las zonas de resistencia a la conquista y de pacificación militar posterior, como en Portugal hasta la derrota de Sexto Pompeyo en la Turdetania y Sur de la Lusitania.

Respecto a las grandes transformaciones urbanas se detectan al menos en el SW de Portugal, en dos fases distintas: después de Augusto y de la promoción latina Flavia. En el Sur algunos desplazamientos y desapariciones pueden ser anteriores, del tiempo 
de las guerras turdetanas (caso de Conistorgis) y de las guerras civiles (caso de la desaparición de Lacobriga y del desplazamiento geográfico de Balsa) (ALARÇAO, 1992). Es muy probable que, en el caso portugués que hemos citado, veamos reflejado un claro ejemplo de unas fases de transformación urbanística, aunque con distintos objetivos, la pacificación y el control del territorio en etapas antiguas, y la propaganda imperial de Julio-Claudios y Flavios.

No es éste el momento de volver a entrar en un tema bastante conocido como es la distinta clasificación de los asentamientos romanos según su entidad y finalidad, como los campamentos, praesidia, ciudades de veteranos, etc., pero sí queremos citar algunos ejemplos de la implantación de núcleos latinos sobre asentamientos ibéricos, por su semejanza con los casos paradigmáticos que analizaremos posteriormente. Esto iría, por ejemplo, en línea con Tarragona, ciudad dispuesta sobre una pendiente irregular con una altura máxima en torno a los 80 m.s.n.m., donde el colector que drenaba parte de las aguas de la vertiente meridional parece construirse a final del II a. C., coincidiendo con la definición de un perímetro unitario, fruto de la reunión en un mismo recinto urbano de los núcleos indígena y romano precedentes (MACIAS, 2000). A este momento correspondería una planificación regular de la red urbanística, con calles en torno a los 6 metros de anchura, enlosadas intramuros y formadas por gravas compactadas en las áreas suburbanas (DUPRÉ ,2002). Algo similar al caso de Ampurias, que es el resultado del proceso de unificación, consumado en época augústea, de la antigua ciudad focea de Emporion (Neapolis) y la ciudad romana que se establece ex novo, hacia el 100 a. C., en torno al praesidium del II a. C. La primera se adapta a una topografía de ladera de suave pendiente; la ciudad romana, de 22,5 ha, se funda siguiendo una planificación ortogonal en una planicie elevada que domina la Neapolis, el puerto y la Palaiapolis (AQUILUÉ et al., 1984). En la ciudad latina la reforma augústea comportó nuevas pavimentaciones viarias y la sistematización de la red de eliminación de aguas residuales (DUPRÉ, 2002).

Después de estos importantes cambios estructurales republicanos, el siguiente gran momento de reformas urbanísticas lo podemos encontrar en época augústea. Además de los ya citados, tenemos algunos ejemplos de esta actividad reformadora en el caso de Zaragoza, fundación de planta ortogonal situada en la intersección de los ríos Huerva y Ebro donde, aunque el sistema de cloacas se construye en el momento fundacional, es posteriormente ampliado (primera mitad del siglo I d. C.) a raíz de la renovación y monumentalización de gran parte del sector oriental (AGUAROD y MOSTALAC, 1998). El alcantarillado sigue la distribución ortogonal de las calles, pavimentadas en su fase tiberiana con losas y cantos rodados apoyados sobre una preparación de gravas. De las reformas de época de Tiberio destaca el gran colector del foro, que se construye sobre el mercado augústeo (BELTRÁN y FATÁS, 1998). A este ejemplo podemos añadir los de Tarragona, Barcelona, Ampurias, etc. 
Siguiendo con las etapas de gran desarrollo municipal, entramos en el siglo II d. C., donde tenemos varios ejemplos documentados de ampliación urbanística en esta época; en Tarragona es posible que hasta la ejecución del ambicioso proyecto de monumentalización de la parte alta de la ciudad, culminado precisamente con la construcción del circo (sobre vertederos del siglo I d. C.), esta zona tuviera un comportamiento suburbial al ser el punto de contacto entre el núcleo residencial en torno al foro de la colonia y el recinto militar que ocupaba la parte alta (DUPRÉ y REMOLÀ, 2002). En Tarragona los enterramientos del siglo I d. C. más próximos a la ciudad son las incineraciones documentadas bajo los niveles constructivos de la arena del anfiteatro (REMOLÀ, 2003), de la misma forma que aparecen incineraciones bajo el teatro y el anfiteatro de Mérida.

Este desplazamiento de usos funerarios lo tenemos en Tarragona donde, con los datos actuales, parece confirmarse la cronología augústea de los niveles inferiores de los ejes viarios que conforman los accesos meridionales a la ciudad del Alto Imperio. Los enterramientos se sitúan en los laterales de los tramos de las vías principales y secundarias más próximos a la urbe. Pero a partir de final del siglo I d. C. y en relación con el desplazamiento de los equipamientos portuarios hacia el río, se aprecia una notable densificación urbanística que comporta el alejamiento de las áreas funerarias hacia la periferia, de tal forma que no es inusual la convivencia entre enterramientos y edificios (almacenes, ámbitos artesanales u residencias suburbanas) que, en algunos casos, modifican su planta para hacerla compatible con monumentos funerarios preexistentes y con la utilización para usos funerarios de terrenos contiguos, más alejados de las vías (REMOLÀ, 2003), de la misma forma que ocurre en Ostia y Roma, donde conviven los restos de antiguos monumentos y villas suburbanas, aunque únicamente a partir del siglo II d. C. (ver Fotos $\underline{342}$ y $\underline{343}$ ).

La superposición de enterramientos es otro factor que observamos en Tarragona, al Oeste y al Norte de la vía romana en la actual intersección de la calle Eivissa con la avenida Vidal i Barraquer. De los tres monumentos identificados, el mejor conservado (¿mediado el siglo I d. C.?) presenta un ámbito interior pavimentado en opus signinum al que se accedía mediante una puerta situada en el muro oriental. La incineración se dispuso, sin urna, en el interior de una caja hecha con bipedales y situada bajo el pavimento, junto al muro meridional. Las recientes excavaciones en esta zona han permitido observar cómo la intensa urbanización que experimenta este espacio suburbial a partir de la $2^{a}$ mitad del siglo I d. C. forzó el desplazamiento de los usos funerarios hacia el Oeste, un espacio periférico y escasamente afectado por este proceso. En ella los enterramientos fueron ocupando progresivamente los espacios existentes entre monumentos y sepulcros precedentes, con fachada a la vía y sectores adyacentes, conformando congregaciones funerarias de densidad variable en las que, además de los citados monumentos, se localizaban inhumaciones dispuestas en el interior de fosas y contenidas en cajas de tegulae, ataúdes de madera y plomo, etc. 
(REMOLÀ, 2003). También en Valencia, en la excavación de la calle San Vicente 26 a 32 se observa una clara superposición de enterramientos, con ejemplos importantes también de reutilización de elementos constructivos en tumbas, como una hoja de acanto monumental (ver Fotos $\underline{322}$, 323 y $\underline{324}$ ) (MELCHOR Y BENEDITO, 2001). Esta concentración también aparece en Mérida, donde se han documentando nuevos momentos de ocupación funeraria en el siglo II d. C., cuya cronología absoluta está por definir. Entorno al Este de la ciudad se documentó un área de enterramientos de incineración en la zona de espectáculos (MÁRQUEZ, 1998).

Algunos autores, como por ejemplo C. Aranegui, apuntan que el papel de los foros, cuyo auge llegaría hasta la época flavia, cambió en el siglo II y en especial con los Antoninos al desplazarse la diplomacia y parte de la gestión oficial hacia la residencia imperial que salió del centro de la metrópolis y cita el ejemplo de la Villa Adriana de Tivoli, a pocos kilómetros de Roma (ARANEGUI, 2004). Pero también disentimos cuando señalan que ese cambio se dejó sentir también en las provincias occidentales, afirmando que son excepción los complejos forenses que llegan como tales al final del siglo II d. C. (ARANEGUI, 2004). En nuestra opinión sigue siendo necesario un centro oficial, pero desplazado a otro enclave con mayor facilidad de acceso (el caso saguntino es bastante atípico, con su foro en lo alto de la colina, aunque tiene algunos paralelos, como el caso de Bilbilis), o bien que la masificación a nivel comercial a partir del siglo III d. C., en concomitancia con lo que ocurre en general en la mayoría de las grandes ciudades, satura el espacio y acaba transformando los cánones iniciales del foro romano clásico con un aumento desproporcionado de tabernae, reutilización de materiales, aparición de vertederos, colapso progresivo de servicios públicos, etc.

En relación con el análisis del paleourbanismo romano como fuente de patrones de asentamiento, los ejemplos más próximos son los análisis topográficos y fotográficos en la detección de restos importantes, como el caso de Burdeos (PINON, 1990), donde en la fotografía aérea se aprecia cómo se ha fosilizado, en el tejido urbano actual, la mitad de la fachada elíptica del anfiteatro romano a lo largo de varias medianeras, mientras que los ejes, que ya en la construcción romana constituían accesos al espacio descubierto de la arena, se han transformado en calles (ver Foto 193 y Dibujo $\underline{27}$ ). La tipología de estas transformaciones ha sido analizada de forma global por P. Pinon; de su estudio se deduce alguna pauta en la mayoría de procesos:

- El límite del edificio aparece bordeado por calles curvas.

- El espacio de la arena se mantiene abierto (patios, callejas o plazas) en mayor medida que la cavea (habitaciones).

- Los ejes suelen perdurar convertidos en calles.

- Las construcciones modernas presentan medianeras radiales a la corona de la elipse. (PINON, 1990: 112) 
Una disposición de teatro y anfiteatro juntos y próximos a la muralla es muy habitual en el mundo romano. En paralelo se constata en ciudades como Mérida o Autun. Ambos edificios intramuros y en el mismo eje se documentan en Aosta y Garsulae (VENTURA, 2003) (ver Dibujos 트, 17, 18, 19, $\underline{20}, \underline{21}$ y $\underline{24})$.

Citamos aquí un estudio similar en la detección de un anfiteatro, como es el caso de Córdoba (ver Dibujo 23). Varios autores apuntan que allí un edificio de tan gran tamaño y difícil inserción en la trama viaria ortogonal debió implantarse en la ampliación augústea meridional de la ciudad y no en la parte alta septentrional, densamente ocupada por las construcciones Republicanas, máxime atendiendo a la cronología del Alto Imperio en la que se levantan la totalidad de los anfiteatros de las provincias occidentales (VENTURA, 1996). Este razonamiento se ha probado como correcto, con el reciente descubrimiento en 2003 del anfiteatro cordobés en la antigua facultad de veterinaria, en la zona del ensanche y lejos del núcleo de la urbe romana. Sin embargo, el mismo autor observaba que al Sur del teatro existe en el parcelario una calle que adopta un peculiar trazado curvo con forma de cuarto de elipse, la calle Cabezas, mientras otros callejones y barreras delimitan el cuarto de elipse radialmente. Acto seguido superpone sobre este plano varias plantas de anfiteatros a la misma escala, resultando ser el de Arles el ejemplar que mejor ajusta en cuanto a dimensiones. Más significativo todavía resulta que el hipotético anfiteatro quedase exactamente alineado y en eje con el cercano teatro, cuya localización y disposición es segura, señalando el paralelo para este tipo de implantación de teatro y anfiteatro juntos en eje en el norte de Italia en Aosta (Colonia Augusta Praetoria) de época augústea. Así establece la planificación de un verdadero barrio de espectáculos, en la Córdoba romana de época de Augusto, con un complejo aterrazado donde las escalinatas localizadas alrededor del mismo permitirían el acceso fluido a ambos edificios de espectáculos desde la parte alta de la ciudad (VENTURA, 2003). Nosotros pensamos que los recientes hallazgos ponen en entredicho que el edificio de la calle Cabezas pueda ser un anfiteatro, aunque la teoría sigue siendo correcta, si pensamos que otros edificios monumentales pueden dejar improntas semicirculares en el urbanismo actual, como ninfeos, termas, etc.

Algunos ejemplos, que más adelante nos servirán en el desarrollo de esta tesis, son los relacionados con los enterramientos. Enterrar a un difunto en un lugar y convertirlo automáticamente en lugar sacro generaba inmediatamente una serie de condiciones de derecho civil: la servidumbre de paso hasta la tumba, el iter ad sepulcrum y una potestad legislativa en las más altas esferas:

Quien enterraba un cadáver en un lugar ajeno sin la autorización del dueño estaba obligado a desenterrarlo, sin embargo el dueño del terreno no podía desenterrarlo sin la autorización de los pontífices o del Príncipe (Dig., 11.7.7). 
La distinción entre los conceptos de sepulcro y monumento definían lo que era verdaderamente sacro: Sacro es pues sólo el lugar exacto donde reposan los restos, (...) no es sacro ni un cenotafio ni un monumento sepulcral en el que aún no se ha enterrado a nadie. Quien poseía tierras podía enterrarse en su propiedad, y de ello son testimonio los monumentos sepulcrales difuminados por los campos (REMESAL, 2002:372).

El Digesto cita que existían sociedades funerarias dedicadas a construir tumbas (Dig. $17,2,52$ y 7 ), lo que explicaría que los programas decorativos y constructivos de las tumbas sean muy similares a lo largo del imperio. Un lugar sacro podía ser violado de muchas maneras, por ejemplo, cubriendo una tumba con tierra (Dig. 43, 2415 y 2), o bastaba que alguien edificara el alero de un tejado de forma que cubriese la tumba (Dig. 43, 2422 y 4). Como sacro era sólo el lugar de la deposición, quien dañara el monumento o las estatuas que lo decoraban incurría en injuria, no en violación (Dig. 47, 10 y 27$)$.

Algunos estudios puntuales también reflejan una aproximación a un patrón urbano, por ejemplo sobre una base económica, como en el caso de Ostia y sus corporaciones profesionales que ocuparían mas del $10 \%$ de la ciudad (MAR, 1996).

Estas reflexiones también abarcan al concepto de lo público y lo privado. En el Digesto se observa que los intereses particulares no deben imponerse al del bien común, ni perjudicar siquiera a alguien (Dig., 43, 8, 2 y 10), pero se parte del hecho de que el lugar público es susceptible de cambiar de usos si lo autoriza la ley, un senadoconsulto o un edicto del emperador. Con respecto a los intereses privados compete al magistrado preservar las vías públicas para que ni sean estrechadas ni cortadas al paso (Dig., 43, 8, 2-25) bajo pena de multa al ciudadano que acometa la obra y se ejecute la orden de derribo (Dig., 43, 10, 1-2). Esto aparentemente contradice los restos arqueológicos detectados en ciudades de todo el imperio, por lo que se refiere a la ocupación de los pórticos de las calles. Pero la explicación la tenemos en que la decisión queda a dictamen del pretor:

"Si alguien hubiera edificado en lugar público sin que nadie se lo impidiera, no se le debe obligar a que derribe, pues no hay que afear la ciudad con ruinas, $y$ el interdicto es prohibitorio pero no restitutorio; pero si tal edificio estorba al uso público, es cierto que el procurador de las obras públicas deberá abatirlo o, si no estorba, imponer un solario" (Dig. 43, 8, 2-17 y 43, 8, 7).

Esto evidentemente comportaba una importante cantidad de ingresos para el municipio. Este espacio sería adquirido sobre la base legal romana que hacía responsable a cada propietario del mantenimiento de espacios de interés público anexos a la vivienda, según consta en el Digesto. Con una reglamentación tan estricta y detallada no parece 
probable que la ocupación de los pórticos haya sido un acto espontáneo, sino a razón de un plan autorizado por el poder público local.

Esto puede llevar a algunas interpretaciones dispares, como en el caso de Mérida, donde el hecho de que la ocupación no afectara a todos los vecinos, ni lo hiciera al mismo tiempo, apunta a que se trató de una ocupación del suelo público, lo que hace pensar en una segunda fase en el IV d. C. (ALBA, 2002), cuando en verdad pensamos que todas forman parte de una misma etapa. También debemos destacar que lo que antes se consideraba indicios de crisis o decadencia en el III d. C. (cubrición de losas de calzadas, reutilización de elementos arquitectónicos, colmatación de cloacas, etc.) ahora se interpreta como signos de colapso de las funciones urbanas por sobreexplotación. Por ejemplo, en Mérida la incorporación de los pórticos se generalizó en el Bajo Imperio y terminó en época visigoda con la práctica desaparición de los mismos, conquistando el espacio superior del mismo para habilitar dependencias o terrazas. La solidez de las columnas convencionales posibilitarían sin mayor refuerzo estos voladizos habitables, prolongación de las viviendas ya existentes (ALBA, 2002). Volviendo al tema de la invasión de la calzada ( $\mathrm{y}$ a veces de la propia vía - ver Fotos $\underline{81}, \underline{99}, \underline{106}, \underline{110}, \underline{111}, \underline{117}, \underline{118}$ y 131 ) este espacio de uso público anexo a las viviendas, que contribuía a la monumentalidad de la urbe, comienza a ser asaltado por intereses privados, tal y como sucede en Mérida en fechas inconcretas del siglo II d. C. que se suponen muy avanzadas; allí interesa subrayar que la privatización opcional de los pórticos (ver Fotos 125, 161, 162, 163, 164, 165, 169 y 170) se hace siempre a partir del inmueble anexo y no origina viviendas independientes de nueva planta adaptadas a dicha banda de terreno. Cada vecino tenía derecho a adquirir su espacio porticado, la zona limítrofe a la fachada de su vivienda. Esto podría ser una consecuencia de la legislación vigente, ya que entre las obligaciones el Digesto (Dig. 50, I) se señala que le correspondería a cada vecino el mantenimiento y reparación del tramo de calle colindante a su casa, como si la imposición de deberes hubiese legitimado su conversión en un usufructo que acaba en propiedad (ALBA, 2002). En este sentido hay que sacar a colación el edicto imperial que establece que el transporte de mercancías, debido a los problemas de tráfico, debe pasar a horario nocturno. En periodo diurno en la calle la tracción animal era restringida a labores propias de la ciudadanía y de los constructores, los únicos autorizados a transitar desde la salida a la puesta de sol (CARCOPINO, 1995). Con el tiempo, los pórticos habrían dejado de ser un espacio útil, ocupado poco a poco por las viviendas (FERNÁNDEZ VEGA, 1999), mientras el ruido provocado por el denso tráfico nocturno habría llevado a los emeritenses a cubrir las calles con tierra para amortiguar el ruido (ALBA, 2001).

Otra teoría sobre la cubrición intencionada del enlosado de calzadas encuentra ejemplos muy literales otra vez en Mérida, donde junto a la fachada lateral del templo del foro municipal se ha conservado la pavimentación marmórea de la plaza bajo un nivel de tierra compacta, uniforme y con una superficie arenosa; sobre esta superficie 
se acumulará después el escombro del desmonte de los edificios (MATEOS y ALBA, 2000), de forma prácticamente idéntica a la calzada de la Morería de Sagunto. Los investigadores de Mérida apuntan a que no es una formación natural, por lo que señalan que este estrato está indicando un cambio de uso del lugar, quizás el hacerlo accesible a caballerías $u$ otros animales de carga o tiro cuyas pezuñas no resbalaban tanto sobre este tipo de superficies (MATEOS y ALBA, 2000). Los ejemplos de relleno sobre las calles existentes en distintas ciudades no se ha analizado desde este punto de vista, por lo que en ellos se podría evidenciar la deposición por varios motivos, como la ausencia de cloacas que evacuen el aporte (ver Foto $\underline{83}$ ), la nivelación del terreno de origen antrópico (ver Fotos 137 y 138, la reocupación de la ciudad (ver Fotos 139 y 146), la puesta en cultivo del terreno, etc.

Otro punto de inflexión importante sería el triunfo del Cristianismo como religión oficial, lo cual sin duda planteó algunos cambios de usos de los espacios sagrados paganos al que debemos sumar el hecho de que hacía ya años (desde el 342 ó 346 d. C. aproximadamente) que el imperio había dejado de preocuparse por la conservación de los templos suburbanos y de los santuarios situados extramuros (CASEAU 2001). Los templos urbanos comenzaron a cerrarse $y$, por tanto, a perder sus funciones públicas a partir de mediado el IV d. C.; aunque se intentó preservarlos como referencia urbanística, el imperio no estaba ya en condiciones de cargar con la conservación de los templos que se encontraban bajo su jurisdicción, de ahí su proceso de privatización a lo largo del IV-V d. C. "(...) una de las fórmulas de secularización o privatización adoptadas por los emperadores a partir de 398, (...) fue la de instalar en ellos corporaciones profesionales o bien cedérselos o venderlos a particulares, incluidos los obispos" (LÓPEZ Y MARTÍNEZ, 2006: 130).

Algunos autores apuntan que la conservación de los edificios públicos y de los templos dependía de su propietario, pero son muy pocas las noticias ofrecidas por textos e intervenciones arqueológicas respecto a la destrucción de templos paganos en Hispania ya que sólo "Hay constancia de la destrucción de algunos santuarios paganos por orden de Constantino, aunque ninguno en Hispania (...). La clausura de los templos urbanos, pero no de los rurales, así como la prohibición de celebrar ceremonias paganas serán medidas recogidas por varias "constituciones imperiales" (LÓPEZ Y MARTínEZ, 2006: 124). Por otro lado en el 399 d. C. el emperador occidental Honorio se dirige a su vicarius Macrobius, (cuya sede era Emérita Augusta) para instar a la protección y conservación de los edificios públicos, señalando además que cualquier petición para destruir o desacralizar un templo pagano debía ser estudiada personalmente por el emperador, ya que éste ostentaba la posesión de algunos de ellos y disfrutaba de sus rentas (LÓPEZ Y MARTíNEZ, 2006: 126). Sin embargo, en el 399 d. C. Arcadio ordena la destrucción de los templos que se encuentran en los campos, lo que dio paso a un progresivo abandono de los espacios cultuales paganos. Estos acontecimientos explicarían el que los templos de la Morería 
de Sagunto pervivieran urbanísticamente transformados en viviendas, ya que su carácter municipal o privado hizo que perdieran pronto su signo sacro, posiblemente cuando Teodosio en el $391 \mathrm{~d}$. C. prohíbe las ceremonias paganas en todo el imperio, de tal forma que no pasaron tardíamente a manos de la iglesia.

El saqueo de templos con el fin de reutilizar sus materiales fue duramente sancionado a lo largo del IV d. C., pero el alto valor económico del material constructivo procedente de los edificios públicos hizo que fueran los emperadores y las élites eclesiásticas los que promovieran su expoliación, ante la necesidad de encontrar recursos para sufragar sus empresas militares u obras, tal como se señala en las constituciones de los años 397 y 399 d. C. en el reinado de los emperadores Teodosio y Arcadio, o la de Graciano del año $376 \mathrm{~d}$. C., con la que se pretende impedir la dilapidación del patrimonio constructivo antiguo en provecho de nuevas obras (LÓPEZ y MARTíNEZ, 2006). En el mismo sentido van las leyes del Codex Theodosianus del año 382.

Algunos autores piensan que la legislación relativa al expolio de los edificios públicos con fines edilicios sugiere que se trataba de una medida excepcional y no de una práctica habitual (REMOLÀ, 2004), por la abundante legislación imperial sobre la necesidad de preservar los edificios. Parece más que probable que la práctica del expolio se desarrollase con cierta asiduidad a partir de la constitución imperial del 15 de noviembre del 407, al prefecto del pretorio Curcio, donde se declara: "de utilidad pública" todos los templos públicos; se retiran los subsidios annonios a los templos; se ordena retirar las estatuas, destruir las arae y los templos privados y se autoriza a que puedan ser utilizados como "cantera" para reparar edificios públicos. (LÓPEZ y MARTÍNEZ, 2006: 68).

La fórmula por la que la Iglesia se hacía con la propiedad de los templos paganos y con su patrimonio dependía de si los templos eran urbanos o imperiales; por un lado había que solicitarla al emperador si estos se encontraban bajo su dependencia. De no ser así, se debía hacer la petición a la curia municipal, que era la encargada del mantenimiento de los templos públicos urbanos situados intramuros. Esta última era la opción más utilizada y rápida. Una vez concedido, la transformación desde el punto de vista constructivo solo requería abrir un ábside en la cabecera. Pero estos casos de conversión no eran habituales en Occidente. "No resultaba nada fácil para la Iglesia justificar la reutilización de un espacio impuro" (LÓPEZ y MARTíNEZ, 2006: 100). Pero no solo los templos fueron reutilizados, también debemos tener en cuenta que ya en el año 315 d. C. Constantino calificó la conversión al judaísmo como crimen capital, castigado con la hoguera (tanto para el convertido como para toda la comunidad judía que lo acogiese). Luego, los emperadores hasta Constante los privaron de derechos civiles y comerciales en todo el imperio: decretaron la confiscación de bienes a los cristianos que judaizaran, anunciaron la pena de muerte para los judíos que se casaran con cristianas, establecieron la limitación de la capacidad para testar, así como la 
prohibición de la posesión de esclavos y la expulsión de numerosas profesiones, de los cargos palatinos, de la abogacía y del ejército (PASTOR, 1998).

Un paradigma de la situación de la iglesia como nueva potencia económica es la expropiación de templos y de sus recursos económicos asociados. Esta cuestión la desarrolla J. Arce en una tipología para la desaparición de los templos paganos de la Antigüedad:

- Destrucción por fanatismo e intolerancia de cristianos.

- Desmantelamiento paulatino, para reutilización (espolia) o para otros propósitos (hacer cal).

- Abandono urbano, que puede comenzar antes del Cristianismo; el edificio vacío de contenido y significado y se respeta, por razones urbanísticas o reocupación (habitaciones, casas, fabricas, talleres, horrea), Plinio, Ep. X. 96.10 habla de templos abandonados en su época: ... iam desolata templa coepisse celebrari et sacra sollemnia diu intermissa repeti...

- Transformación en iglesias. (ARCE, 2006:36)

Así pues, algunos historiadores y arqueólogos han observado que el fenómeno de la cristianización de las ciudades de Hispania y concretamente la ocupación de los espacios intramuros para edificar iglesias, es un fenómeno muy tardío. Además, durante los siglos IV y V d. C. la presencia de iglesias es periférica y extramuros, como presuponemos sucede en el caso de Sagunto. Esto contradice una posible cristianización masiva de templos paganos que, por otro lado, no ha dejado restos materiales:” ¿Qué sentido tiene construir en los arrabales si cabía la posibilidad de hacerlo intramuros, en plena ciudad? Si los territorios hispanos del siglo $V$ son tan inseguros como al parecer hacen ver las fuentes, ¿no se habría intensificado el proceso de cristianización de los templos urbanos?” (LÓPEZ y MARTÍNEZ, 2006: 100).

Debemos tener presente que la expropiación de edificios paganos por los cristianos no implica únicamente su transformación en iglesias. Conocemos, a partir de la epístola 11 de Consentius del 419 d. C. (AMENGUAL, 1987), la existencia de una serie de edificios civiles y religiosos (eclesia, secretarium, monasterium, praetorium, etc.), por lo que algunos edificios paganos pueden haber pasado a tener esta utilidad.

La norma en Hispania era la lenta ocupación de los templos, como en el caso de los dos más importantes templos de Emérita en los foros emeritenses, cuya destrucción afectó también a los pórticos, mediado el siglo $\mathrm{V}$ d. C., en el templo de la Concordia, tras el expolio de sus mármoles, se adosan unas viviendas "en época visigoda" (MATEOS, 2006: 364). En el pórtico del Augusteum, conocido antes como templo de Diana, ocurrió algo parecido: expolio de mármoles y ocupación con viviendas también 
en el periodo Tardo Antiguo (MATEOS, 2006). Ejemplos de rápida ocupación de templos los tenemos en otras ciudades: Carteia que no sobrevivió mucho tiempo en sus funciones, el Traianeum de Itálica, de corta duración y que en época romana tardía fue reocupado por viviendas-refugios adosadas al pórtico reutilizando los materiales del templo, el templo de Augusto en el foro de Barcelona, intacto hasta el VI d. C., o el templo de Isis en Baelo Claudia, invadido por casas probablemente durante el transcurso de la segunda mitad del siglo IV y que fueron habitadas durante unos dos siglos, al menos durante el $\mathrm{V}$ y el $\mathrm{VI}$ d. C. (en general para Baelo se señala un abandono casi completo de sus edificios más importantes en el III d. C. y una reocupación con otros tipos de viviendas y fabricas a partir del IV). En Córdoba, el templo de la calle Claudio Marcelo es reocupado por casas entre los siglos IV y $\mathrm{V}$ y finalmente señalaremos el caso de Zaragoza, aunque en esta ciudad no hay datos suficientes para afirmar la transformación de templos paganos en iglesias (ARCE, 2006). Estas referencias vagas respecto a la cronología no nos impide pensar que se trata de un lento proceso de ocupación de los terrenos sagrados para la construcción de viviendas (demandadas por el aumento de población), cuyo último exponente es la propia ocupación del templo en un momento final de esta urbanización, que según los casos ya sería posterior al IV d. C.

Los recintos públicos de la parte alta de Tarragona, aparentemente inalterados desde época flavia, fueron destinados parcialmente a un uso doméstico desde un momento inicial, asociados a las nuevas élites urbanas, en las que el Cristianismo tiene un protagonismo ascendente (DUPRÉ y REMOLÀ, 2002). Sin embargo, la única posibilidad de transformación en iglesia sería el templo de dedicado a Roma y Augusto, situado en la ciudad alta, presidiendo la gran plaza o foro de representación, construido en época flavia. Aunque dudoso, ése sería el único caso de transformación de un templo pagano en iglesia en Hispania, aunque no obstante parece que en el siglo VII sí que se construyó una iglesia o un palacio episcopal en las proximidades del templo (ARCE, 2006). Otros autores sí apuntan casos en los que podemos encontrar esta transformación, como los ejemplos de Astigi (Écija), Iluro (Mataró) y Egitania (Idanha-aVelha, Beira, Portugal) o Riba-Roja del Turia, (GARCÍA MORENO: 1977-1978) y también otros de la Comunidad Valenciana (ROSELLÓ, 2000). Aunque todos estos edificios están datados en los siglos VI y VII los autores suponen que el expolio tuvo lugar en siglos anteriores (IV-V d. C.), lo que sin duda no deja de ser una contradicción que pone en duda una cristianización directa de los mismos, por lo que podrían haber pasado por una fase intermedia de uso privado. De lo que sí hay testimonio, aunque ya en el siglo VI, es de la erección de iglesias en edificios o espacios públicos, como en la arena del anfiteatro de Tarragona. También en la Neapolis de Ampurias, la primera construcción cristiana, una cella memoriae, fue erigida reaprovechando el antiguo edificio termal tardorrepublicano (LÓPEZ y MARTÍNEZ, 2006); P. Palol la excavó y comprobó sus estructuras rectangulares, construida encima de pequeñas habitaciones greco-romanas y siguiendo exactamente sus medidas, pero sin que pueda atestiguarse 
un primer momento de ábside rectangular y una modificación en círculo superpuesta (PALOL, 1967). El muro Norte de esta aula contiene todavía los cubicula del apoditherium termal romano aprovechado. Su pavimento fue roto para colocar algunos enterramientos y el espacio ocupado por ellos se recomponía con el mismo tipo de opus testaceum del ábside y sanctuarium. La puerta es lateral al Sur y comunica el vestíbulo con el templo. Entre las últimas reformas arquitectónicas de todo este conjunto hay que señalar la escalera de entrada al vestíbulo, por el Oeste, salvando el desnivel de la ciudad destruida que había ido aumentando en relación al antiguo que mantenía el templo. Esta pequeña y pobre cella memoriae fue centro de un amplio cementerio de época Visigoda (PALOL, 1967). En general podemos decir que es un hecho común en la Península Ibérica y en el resto del imperio la existencia de edificaciones religiosas sobre estructuras termales. Estos son los conjuntos conocidos en Hispania, por lo que no existe por el momento otro testimonio que avale la posibilidad de transformación en edificio cristiano durante la Antigüedad Tardía.

Finalmente tenemos algunos ejemplos de cómo el proceso de decadencia urbana de la cultura romana se aplica a distintas urbes. En el caso de Mérida existe la idea de un lento deterioro de estas primeras obras fundacionales, con tendencia a agravarse durante el siglo III d. C., cuando se fechaba la desaparición de las domus extramuros y se habrían producido los desperfectos en los edificios de espectáculos que justificarían su restauración en la centuria siguiente (ALMAGRO, 1961). Si bien para los arqueólogos habría que suponer un declinar progresivo a partir del siglo III d. C., los historiadores defendieron un panorama muy diferente para el siglo $\mathrm{V} \mathrm{d}$. C. gracias a las consecuencias derivadas del nombramiento de Emerita como capital de diócesis un siglo antes (ALBA, 2002). La expansión y posterior regresión del casco urbano de Mérida a sus límites fundacionales puede ser seguida mediante su relación con la dispersión de los enterramientos que, a grandes rasgos, deben haber sufrido un alejamiento del centro cada vez mayor durante el siglo I y el II d. C, hasta puntos tan lejanos como el puente de la Alcantarilla y más allá de la ermita de la Antigua o el centro comercial situado en el polígono Nueva Ciudad (MÁRQUEZ, 1998); en el siglo III d. C. se inicia la reducción del área urbana en un proceso documentado en casi toda la zona extramuros, con sucesivas inhumaciones y mausoleos amortizando o reutilizando los espacios de las domus y que han sido descritos en varias publicaciones (MATEOS y MÁRQUEZ, 1999). Mediado el siglo IV se crea el área cementerial de Santa Eulalia, también sobre las casas preexistentes o los enterramientos situados sobre la casa de la Rambla y la casa de Pontezuelas (MATEOS, 1999).

Estas variaciones en la extensión del entramado urbano afectarían a la extensión de la muralla. Uno de los casos mejor documentados lo encontramos en Mérida, donde en la actualidad se acepta que la fábrica de mampostería de la muralla es de origen fundacional, aunque algunos autores disientan en considerar la totalidad de la cerca un elemento unitario (MATEOS, 1995). Mayor controversia suscita la interpretación del 
refuerzo de sillares, aparecido en excavaciones realizadas en la Alcazaba en los años 70 , al que se le asigna una cronología del siglo III d. C. en relación a las incursiones de francos y alamanes por la Península o, en cualquier caso, dentro del contexto de crisis de este siglo (FERNÁNDEZ UBIÑA, 1981), como sucedió con la construcción de las murallas de Coria, Cáceres o Caparra en consonancia con las teorías de Balil (GARCíA MORENO, 1986). Otros investigadores le atribuyen una cronología del siglo IV d. C. (BERROCAL, 1987) o romano tardía (ALMAGRO, 1983; ÁLVAREZ, 1991 y ENRIQUEZ et al., 1994) y $\mathrm{P}$. Mateos lleva su construcción a comienzo del último cuarto del $\mathrm{V} \mathrm{d}$. C. (ALBA, 1998), sobre la base de una inscripción que se fecha en el 483 para recordar la restauración del puente a cargo del dux Salla donde se mencionan las obras llevadas a cabo con anterioridad en la muralla bajo el patrocinio de dicho gobernante y a instancia del obispo Zenón en tiempos del rey Eurico (ORLANDIS, 1987). Indicios posibles de esta muralla fueron documentados recientemente en un pequeño solar de la calle Augusto, fechándola su excavador entre el siglo III y el IV d. C. (SÁNCHEZ, 1997). Otros autores apoyan una cronología vaga comprendida en el siglo $\mathrm{V} \mathrm{d}$. C., pero con anterioridad a que Mérida se viese afectada por las invasiones, pues resultaba más lógico emprender tan enorme obra en una etapa de fortaleza que no en una fase de debilidad crónica, tal y como manifestaba el conjunto de viviendas deshabitadas y destruidas de Morería (ALBA, 1998). Sin embargo, consideran que sigue siendo válida la interpretación como "muralla del miedo" (CERRILLO, 1985), dentro de la inestabilidad que caracteriza al siglo $V \mathrm{~d}$. C. El temor es suficiente para evitar que se reproduzcan hechos de ciudades saqueadas o arruinadas (como Conimbriga, asolada por los suevos) o impedir que acontecimientos ya vividos en Mérida se repitan (ALBA, 1998). La obra de la cerca defensiva debió suponer una inversión económica considerable y una movilización enorme de mano de obra para el acopio de materias primas, reunida quizás por el poder que pudo tener la Iglesia. Serían necesarias numerosas cuadrillas. Sobre la procedencia del material para llevar a cabo la obra P. Mateos apunta que en Mérida la destrucción de las áreas funerarias cristianas de Santa Eulalia y Santa Catalina presenta una cronología del siglo $V$ d. C., atribuible a las depredaciones producidas por las invasiones (MATEOS, 1999). Algunos autores consideran poco probable que se hubiesen derribado viviendas del interior, puesto que se respetaron siempre todos los inmuebles romanos de la Morería, a pesar de que las viviendas adosadas a la muralla constituían un obstáculo para defenderla. Más factible parece el desmantelamiento de edificaciones públicas romanas intramuros, que estaban virtualmente ya en desuso (ALBA, 1998).

Respecto al tema de la crisis del siglo III d. C., en Tarragona encontramos que varios autores apuntan que los vertederos intramuros son un indicio de la incapacidad de los poderes públicos para gestionar los residuos urbanos y, también, una muestra de la abundancia por la variedad de cerámicas y productos alimenticios procedentes de todo el Mediterráneo. Así mismo, por citar solo un ejemplo, junto a la inutilización, al menos parcial, de una de las torres de acceso a la plaza de Representación (DUPRÉ y 
CARRETÉ, 1993), detectan la adaptación de una parte significativa de los criptopórticos de la citada plaza para un uso hidráulico (DUPRÉ y REMOLÀ, 2002). Aunque se desconoce con precisión el comportamiento de la parte baja intramuros de Tarragona, éste indicaría una tendencia progresiva a la concentración de la población en dos sectores fundamentales: la parte alta y el suburbio portuario. Una configuración urbana articulada en dos núcleos que se consolidará durante la Antigüedad Tardía prefigurando el comportamiento desde época bajo medieval hasta la reunión en una misma área urbana durante el siglo XIX (DUPRÉ Y REMOLA, 2002). Ésta es una forma muy similar a la de Murviedro/Sagunto y a la de muchas otras ciudades del imperio. En el caso de Tarragona, recientes excavaciones arqueológicas en la ciudad muestran que ésta experimenta una revitalización urbanística a partir de final del siglo IV / inicio de $\mathrm{V}$ d. C. DUPRÉ Y REMOLÀ, 2002), después de un periodo de abandono o de escasa ocupación, que se extiende entre final del siglo III y gran parte del IV d. C., documentado en la zona portuaria, que es un espacio con menos posibilidades defensivas que la parte alta de la ciudad.

En Tarragona el abandono de gran parte del suburbio NE a final del siglo III d. C. permitió que surgieran, entre las ruinas de edificios precedentes, nuevas áreas funerarias más próximas a la urbe. Con la parcial reactivación urbanística de inicio del siglo $\mathrm{V}$, muchas de estas nuevas áreas de enterramiento desaparecieron, concentrándose la actividad mortuoria en la franja más próxima al río (necrópolis paleocristiana). A partir de mediado el siglo $V$ los enterramientos se asocian a edificios y recintos religiosos situados tanto dentro como fuera de los límites urbanos de la ciudad (REMOLÀ, 2003).

Finalmente queremos señalar los intentos de recuperación y restauración de edificios públicos a lo largo de este periodo, de manera que en el caso del ninfeo de la ciudad de Valencia éste fue repavimentado "en un momento indeterminado" (sic) del siglo IV, tal vez durante el mandato del emperador Juliano, lo que testimonia la pervivencia entonces del culto al dios de la aguas (RIBERA 2000), aunque simplemente puede también responder a la voluntad imperial de restaurar los monumentos, claramente demostrada por las fuentes. Un claro ejemplo de conservación, incluso de rehabilitación de espacios públicos (como el foro, sede del culto imperial, las termas, etc.) lo encontramos en Complutum (Alcalá de Henares) y Tarragona a partir de final del siglo III o principio del IV d. C. (RASCÓN-SÁNCHEZ, 2000 y MACIAS, 2000). Lo habitual en ciudades de Hispania, como en otras provincias, es la larga pervivencia de la edilicia pública romana durante la Antigüedad Tardía, al menos hasta el siglo $\mathrm{V}$, momento en el que el foro y otros edificios públicos (circos, anfiteatros, hipódromos, etc.) perderán su función original (GROSSE, 1947; FUENTES, 1999; RIBERA y ROSELLÓ, 1999). 


\subsection{ANTECEDENTES PARA EL ESTUDIO DEL MUNDO RURAL}

Si analizamos las estructuras rurales propiamente dichas, un aspecto que debemos tener en cuenta es la variedad del registro material urbanístico de un asentamiento romano rural, ya que siempre se ha limitado el análisis del territorio a los restos de la villa, obviando el resto de los elementos característicos de un fundus. Las fuentes literarias latinas ofrecen un cierto número de términos empleados (tugurium, casa repentina o, con un valor más genérico, aedificium) y no pretenden ofrecer una definición rigurosa. Estas construcciones se contraponen claramente en su arquitectura y su aspecto a la villa. En primer lugar, se trata de construcciones muy modestas. De esta forma se califican en fuentes tan diversas como Vitruvio, Cicerón, Varrón, Columela y la legislación (Dig. 50.16.180). Todas ellas coinciden en destacar como aspecto fundamental la utilización de materiales perecederos, la fragilidad, las pequeñas dimensiones y la pobreza en contraste con la solidez y el decoro que deben caracterizar la construcción de una villa (REVILLA, 2004). Vitruvio (De Architectura, Lib. 2, I, 4), de modo más particular, relaciona la diversidad de formas y materiales de construcción conocidas (arcilla, encañizados, postes de madera) con las tradiciones de los pueblos integrados en el Imperio. Esta visión cultural se repite en Salustio, Varrón (indicando un estadio de primitivismo) o Tácito. Éstas son calificadas negativamente por la ausencia de los elementos de progreso que definen la arquitectura romana (por ejemplo, las cubiertas realizadas con tejas) (REVILLA, 2004).

Por otro lado, tugurium y casa repentina constituyen la forma de residencia y el lugar de trabajo de un grupo humano definido por su condición social y jurídica humilde, como el de un campesino y su familia que cultivan una reducida parcela. Tito Livio establece una relación directa entre residencia modesta y pequeña propiedad campesina, similar a la dignitas del propietario y los edificios, las posibilidades y las dimensiones del fundus, entre el conjunto de necesidades sociales, económicas e ideológicas del dominus (esenciales para su autorepresentación y la manifestación de su posición social). A su vez, este patrimonio se organiza y exhibe de acuerdo a unas normas precisas (PURCELL, 1995). Otra situación es la del grupo de esclavos subordinado a la villa residencia del propietario. Varrón menciona a individuos que: "sunt in saltibus et silvestribus locis pascunt et non villa, sed casis repentinis" (RR, 2.10.6). 
Al margen de la remodelación de las edificaciones domésticas tardo imperiales mediante la apertura del ábside, la villa romana de lujo contenía aulas de planteamientos arquitectónicos muy próximos a los de la basílica cristiana. Las villas palaciegas dispusieron de aulas de cabecera absidiada de grandes pretensiones; en Hispania, habitaciones similares que evocan salones del trono son reconocibles en las villas de Cuevas de Soria, Quintanares de Rioseco, de Aguilafuente (Segovia), de Almenara de Adaja (Valladolid), de Prado (Granja de José Antonio, Valladolid), de Sádaba (Zaragoza), etc. (FERNÁNDEZ CASTRO, 1981: 385). No sería sorprendente que las reuniones que se celebraban en las villas, tuvieran lugar en salas de tipo basilical. Ya Vitruvio (VI, 8, 32) señalaba la conveniencia de disponer de basílicas: (...) para dar audiencia a los ciudadanos (...) de manera que puedan rivalizar por su magnificencia con las de los edificios públicos, porque con frecuencia en estas casas se celebran asambleas, reuniones particulares y juicios arbitrarios (...)

Las basílicas privadas y las salas absidiadas espaciosas según algunos autores acomodarían con facilidad a la liturgia cristiana hecho que se repetiría en numerosas construcciones domésticas de ciudades norteafricanas (FERNÁNDEZ CASTRO, 1981: 387). Otros lugares del Imperio, como la Galia del siglo III d. C., se caracterizarían por una detención de las creaciones de nuevos asentamientos y por numerosos abandonos, que habían ya comenzado en el transcurso del siglo II d. C. y que se multiplican en el transcurso del siglo III d. C. al V d. C. Sin embargo, la superficie ocupada por el conjunto de los asentamientos de los siglo III y IV d. C. todavía es importante, indicando la polarización en yacimientos de gran superficie, que corresponderían a hábitats agrupados (JUNG, 2006).

Factores como la transformación o antropización del terreno son analizados en zonas como Tricastin (Francia), donde se han estudiado la mayor parte de las redes de drenaje que quedan abandonadas hacia el siglo $\mathrm{V}$ y $\mathrm{VI}$ d. C. Dichos abandonos preceden de poco la deposición de una capa de aluvión de 20 a $40 \mathrm{~cm}$. de grosor que sella el conjunto de la red centuriada de la baja llanura del Tricastin en el transcurso de los siglos VI a VIII. Esta crisis hidro-sedimentaria podría estar vinculada a un empeoramiento climático agravado por el abandono de las estructuras de fosos que regulaban las aguas de la llanura (JUNG, 2006). Uno de los conceptos mas importantes de los últimos años, el del análisis regresivo del paisaje (LEVEAU, 1999), que básicamente consiste en hacer un recorrido desde la actualidad e ir retrocediendo por niveles en el estudio de los procesos físicos y culturales del entorno, ha sido aplicado con cuentagotas en la Península (VICENT, 1991, OREJAS, 1995 y OREJAS et al., 2002, PALET, ORENGO y RIERA, 2011, FLORÉZ y PALET, 2011, etc.). Sin embargo, actualmente es una de las herramientas más útiles a la hora de interpretar los patrones de asentamiento en el mundo rural romano. En esta corriente podemos señalar una interesante línea de investigación, pues si trasladamos a un plano realizado mediante SIG la superficie media de explotación de una villa romana (ver 


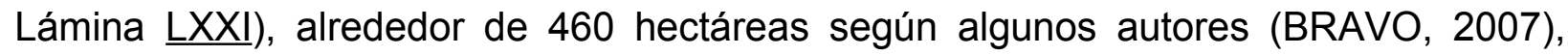
comprobaremos que la existencia de accidentes geográficos (barrancos, playas, ríos, marjales, etc.) deberán condicionar de forma importante futuros estudios en la zona, pues las explotaciones romanas sin duda se adaptarían a condicionantes espaciales que hoy no son visibles, lo que hará variar la percepción de su extensión.

En la Península Ibérica no será hasta final del siglo XX cuando empezaron a aplicarse los modelos teóricos de captación de recursos en el entorno de yacimientos agrícolas que se lanzaron en el mundo anglosajón en los años 80; así, por ejemplo los trabajos de T. J. Wilkinson que se publican en el Journal of Field Archeology (WILKINSON, 1982 y 1989). Ya en el presente siglo tenemos interesantes estudios, por ejemplo en Andalucía, donde se cuestiona la hipótesis del abonado, que indicaba que la mezcla de estiércol y fragmentos de cerámica utilizada para fertilizar los campos en época antigua era un índice exclusivo del uso del territorio, aportando referencias sobre el uso de recipientes para la protección de frutos, la fabricación de colmenas o el uso de fragmentos de tegulae y cerámica para proteger plantones, entre otras citas que encontramos en las fuentes antiguas sobre posibles orígenes de estos fragmentos. También tenemos en este estudio un análisis de las relaciones territoriales entre las necrópolis y los asentamientos, tomando como base la ciudad ibero-romana de Tugia en el Guadiana (MAYORAL, et al., 2006).

Otro interesante ejemplo está en la zona de Lusitania, con la aplicación de técnicas multidisciplinares a la totalidad del paisaje, incluyendo la explotación de zonas de montaña por medio de abancalamientos en época romana (concretamente en la sierra de Francia - Salamanca) en los trabajos de M. Ruiz (RUIZ, 2006), o los que infieren una relación entre núcleos urbanos y su entorno rural, sobre la base de un análisis multifuncional de la explotación de recursos, concretamente aplicado a la zona de la Bética (SÁEZ et al., 2006). Tenemos también ejemplos en la zona emeritense e incluso encontramos algunos trabajos recopilatorios sobre otras zonas (PALET et al., 2004).

A lo largo de una serie de excavaciones arqueológicas en las provincias de Valencia y Castellón hemos podido intuir la existencia de una serie de fases dentro del mundo romano que implican cambios sustanciales, especialmente en la ocupación del territorio y el urbanismo, pero también respecto a etapas anteriores y posteriores a este periodo histórico. Encontramos paralelos muy interesantes en el Norte de la Tarraconensis, donde se citan algunas fechas en las que se producen cambios significativos en los yacimientos; grosso modo pueden reseñar una en el siglo II d. C. y otra al final del III d. C. Algunos ejemplos en medios urbanos y rurales los encontramos en Casa Blanca (Tortosa) (ARBEOLA, 1990, REVILLA, 1998 y 2004), Barcelona en la plaza Sant Miquel y Palau Centelles (BELTRÁN DE HEREDIA, 2001) Badalona (PADRÓ, 1985) Llivia (Cerdanya) (PADRÓ, 2000), Mataró (REVILLA Y CELA, 2006), Guissona (LLINAS y SAGRERA, 1993), Tarragona (AQUILUÉ, 1993), etc. 
En la Comunidad Valenciana estas fases no han sido estudiadas o desarrolladas con amplitud. Un estudio más detenido y profundo de algunas de las excavaciones que hemos llevado a cabo y que solamente se han publicado o estudiado en parte, nos permitirá determinar con bastante exactitud la extensión y cronología de estas fases de cambios en la ocupación romana.

Iniciaremos la cuestión por los antecedentes más inmediatos del periodo de romanización que provienen, aparte de los testimonios arqueológicos, de los textos y documentos clásicos, aunque éstos algunas veces resultan discutibles, pues la interpretación de las fuentes resulta algo resbaladiza ya que se pueden basar en especulaciones de difícil constatación. Sólo sobre la base de resultados arqueológicos, que nos proporcionen los distintos yacimientos ibéricos de esta etapa, podremos corroborar o no tales hipótesis. Los núcleos ibéricos contemporáneos a las guerras romano-cartaginesas citados por varios autores latinos, entre otros son:

Onussa (Livio, 22, 20, 3) hipotéticamente próxima al delta del Ebro, entre Alcanar y Peñíscola.

Intibilis, citada en los vasos Apolinares, se ha situado entre los ríos Cenia y Cérvol, próxima a Benicarló, a Vinaroz, Sant Mateu, Traiguera, etc. (AA. VV. 1985)

Iliturgi (Livio, 23, 49, 5) se identificó con la Ildum de los vasos Apolinares (AA. VV., 1977), situada entre Intibilis y Sagunto, quizá próxima a Cabanes.

Mentissa, también mencionada por Livio $(26,17,2)$ en la región de los ilercavones, se la puede suponer entre Borriol y Cabanes.

Los años transcurridos desde la ocupación militar romana hasta la muerte de César corresponden a una etapa de transición que culminará con la total romanización del mundo ibérico. Las tribus ibéricas de las costas orientales soportaron con cierta pasividad el colonialismo romano, pues si existieron rebeliones contra el invasor éstas fueron de escasa entidad, ya que no aparecen reflejadas en las crónicas clásicas. Un único indicio al respecto viene dado por las revueltas de las tribus que ocupaban la zona septentrional del Ebro, aunque a partir del 197 a. C. los ejércitos enviados por Roma acaban con estas sublevaciones. Los territorios iberos entrarán a formar parte de una de las dos extensas provincias romanas, concretamente de la Hispania Citerior. Los patrones culturales indígenas no sufren ninguna ruptura con este cambio político; lo que sí se deja entrever es la acompasada asimilación de las nuevas pautas latinas. La actitud aborigen será, en muchos casos, recompensada por Roma, concediendo la ciudadanía a aquellos que colaboraban con ella.

Durante los años 76 al 72 a. C., los pueblos contestanos, edetanos e ilercavones serán testigos y partícipes de los enfrentamientos entre Sertorio y Pompeyo. El escenario bélico, pues, queda situado en las tierras valencianas. La batalla de Lauro del año 76 
constituye uno de los primeros testimonios de este período. Un año más tarde, Pompeyo conseguirá conquistar Valencia, dirigiéndose por el valle del Júcar donde se refugian las tropas de Sertorio. El dirigente popular se cobija en Sagunto, después se retirará al norte del Ebro. Posteriormente las rivalidades por el poder, establecidas entre Pompeyo y César, afectarían a la situación de las tribus ibéricas. En el año 46 a. C., este último atravesará con su ejército las tierras valencianas para dirigirse hacia la Bética. Con Augusto, el imperio conseguirá estabilizar la anterior situación hasta transformar la cultura indígena.

Algunos autores señalan que es posible que la expansión de la viticultura de la Tarraconensis en época augústea deba relacionarse con una importante reorganización de la estructura socio-económica que actuó en un doble sentido. Por un lado, hacia la constitución de una pequeña o mediana propiedad como resultado de la colonización oficial en ciertas áreas, como el asentamiento de veteranos de Barcino, en la línea de una política más amplia, iniciada con César. Por otro, la práctica de Augusto de recompensar a sus partidarios y la consecuente intervención de éstos en la administración de los territorios provinciales, que permitiría la aparición de la gran propiedad (REVILLA, 1995).

Este proceso de cambio geoestratégico alrededor del siglo I d. C. viene atestiguado por algunos ejemplos, siendo los más cercanos los documentados en la zona catalana, como la villa de Torre Llauder (Mataró), donde la construcción de un gran edificio con peristilo, hacia el final del I a. C., supone el abandono de un horno cerámico, aunque la actividad parece desplazarse hacia un sector periférico de la propiedad y continuaría hasta mediado el siglo I d. C. Otro ejemplo lo tenemos también en la Vila Vella de San Boi, donde un conjunto de tres hornos parece haber estado en actividad desde época augústea hasta el final del siglo I d. C. sobre los que se construyen termas hacia las postrimerías del siglo II d. C. (REVILLA, 2004). Igualmente en la villa de Darró (Vilanova i la Geltrú) se aprecia la coexistencia entre un sector residencial del siglo II d. C. con una compleja arquitectura y situado al otro lado de un torrente, y algunos espacios artesanales claramente segregados y con una cronología diferente, que se construyen cerca de la playa hacia la última etapa del siglo I a. C., y el alfar cesaría su actividad a final del I d. C. En la villa de Cal Ros de les Cabres (Ocata - el Masnou) se conoce una primera ocupación, en época augústea; a partir de mediado el siglo II d. C. el lugar fue reorganizado y se construyó un edificio, que parece seguir ocupado hasta el siglo IV d. C. Finalmente, en Can Jofresa (Terrassa), se distinguen dos sectores: una instalación formada por tres hornos, un vertedero y un silo, ocupado entre Augusto y época flavia, y un conjunto de dependencias de función imprecisa que incluían un lacus y varias canalizaciones que se datan entre los Flavios y mediado el siglo II d. C. (REVILLA, 2004). Respecto a los cambios ocurridos entre el siglo II y el III d. C. tenemos paralelos en las villas extraurbanas de Tarragona ubicadas en función de los tres principales tramos de vía que convergen en la ciudad: desde Barcelona, Valencia e 
Ilerda, que tienen unas fases de ocupación similares e interrelacionadas con la urbe cercana. Por ejemplo en la vía Tarraco-Barcino, de las cuatro villas identificadas Els Munts, (Altafulla) es destruida en el siglo III d. C. Las otras (EI Moro-Torredembarra, El Vilarenc-Creixell y El Rincón del César-Creixell) son abandonadas entre la segunda mitad del siglo II d. C. y la primera mitad del III d. C. la primera y en un momento impreciso las otras dos. A partir de final del siglo III ó inicio del IV d. C. estas villas sufren una profunda transformación, en algún caso asociada a un proceso previo de destrucción. Sólo una de ellas parece recuperar un elevado nivel de suntuosidad a inicios el siglo V, si se acepta la datación vigente para la villa de Centelles. Otras, como el Moro o el Vilarenc desaparecen (REMOLÀ, 2002). En la de Cal-lipolis (Vila-seca) se reduce progresivamente el espacio destinado al caldarium. En Els Munts (Altafulla), la ocupación, de carácter primordialmente rural, continúa entre las ruinas de la ocupación del Alto Imperio. Éste podría ser también el caso de la villa de la Llosa (Cambrils), aunque los datos disponibles son poco concluyentes (REMOLÀ, 2002).

El proceso final de la decadencia de la explotación agraria romana es la concentración en las ciudades de la población y de los núcleos económicos; uno de los ejemplos es la concentración del comercio oriental en determinados puertos donde existirian asentamientos de comerciantes. Se señala como prueba de esas colonias la abundante presencia de inscripciones sepulcrales griegas (el griego era un idioma que prácticamente no se hablaba en la Península y también se asocia a monjes y judíos orientales) y materiales orientales. Para la costa se apunta a Tarragona y Elche como los dos centros más importantes (FERNÁNDEZ CASTRO, 1981). Se mantiene un importante comercio en todo el Mediterráneo hasta el siglo V / VI d. C. (hasta la conquista árabe de la Península, norte de África y Sicilia) cuando disminuyen los contactos entre Oriente y Occidente.

El poder entre la caída del Imperio romano y los musulmanes estaría repartido entre la oligarquía hispano-romana (descendiente de antiguas familias senatoriales terratenientes que pasan a ser los nobles), los reyes invasores visigodos, alanos, vándalos, etc. y los bizantinos (GARCÍA MORENO, 1972). Los visigodos siguen manteniendo una importante fiscalidad centralizada sobre el comercio, donde en los teloneum de los puertos se cobraba los vectigalia (FERNÁNDEZ CASTRO, 1981) lo que seguramente iría en detrimento del pequeño comercio local.

En el caso concreto de las comarcas castellonenses la romanización fue un proceso lento, y actuó de forma diferenciada. Por una parte, algunos de los antiguos asentamientos indígenas fueron prácticamente abandonados para ocupar las zonas llanas de los valles. Por otra, en cambio, continuaron existiendo establecimientos en el mismo lugar, o bien se trasladaron a corta distancia. Sin embargo, la característica más generalizada del uso de zonas bajas ha sido la causa fundamental que dificulta nuestro conocimiento sobre las poblaciones indígenas romanizadas en tierras de Castellón, ya 
que la mayoría de vestigios han desaparecido a causa de las modernas labores agrícolas. Tenemos que esperar a la plena ocupación romana para un conocimiento más completo sobre los asentamientos agrícolas, que hoy tenemos por las excavaciones arqueológicas realizadas en la zona objeto de nuestro estudio en Benicató (Nules), el Palau (Burriana) y Santa (l'Alcora). La primera se trata de una villa rural ligada a la explotación agrícola que tuvo su comienzo mediado el siglo I a. C.; en el I d. C. tuvo un período de estancamiento, pero durante el siglo II y parte del III d. C. conoció un auge económico. Este momento, que duró unos 80 años, corresponde a las edificaciones más nobles: estanque, reconstrucción del peristilo y mosaicos. La inestabilidad política de época de los Severos, repercutió probablemente en estos establecimientos de explotación agrícola. En este sentido vemos que hubo un cierto abandono, que se producirá a partir de los últimos cuarenta años del siglo III d. C. Los mosaicos se presentan recubiertos por una gruesa capa de mortero en un momento posterior al año 256. Esto sería para algunos autores un indicio de decadencia (ESTEVE, 1956, GUSI y OLARIA, 1977) se también se reflejaría en sus edificaciones; pese a todo pervivió hasta mediado el siglo IV d. C., con la cual se sabría que la crisis del siglo III no provocó su pérdida, y probablemente su destrucción se introduciría en un abanico que podría alcanzar según algunos autores el final del siglo IV d. C., gracias al análisis de los materiales muebles (GUSI y OLARIA, 1977) ${ }^{5}$. Las otras dos intervenciones las desarrollaremos en esta tesis.

Los núcleos urbanos son desconocidos y siempre ha constituido una cuestión problemática la explicación de la ausencia de municipios romanos en nuestra provincia. La razón por la cual gran parte de las ciudades quedan sustituidas o reabsorbidas en época medieval no parece ser demasiado convincente. El yacimiento de la Moleta dels Frares (Forcall) fue uno de estos municipios romanos, concretamente Lesera, según algunos investigadores (ARASA, 1996-1997), aunque no podemos descartar que dicho municipio estuviese en Morella. Este asentamiento se conoce desde el siglo pasado. La zona meridional de la provincia de Castellón resulta de gran interés, dada su proximidad con los centros romanos de mayor entidad como Sagunto y Valencia.

Los restos romanos en la Plana Baixa, si bien muy dispersos, son numerosos. Entre éstos cabe destacar los localizados en Burriana, donde parece que se asentaron numerosas villas agrícolas como El Palau, la más importante de todas ellas, cuyo momento de esplendor se sitúa entre el siglo II y III d. C. o Sant Gregori, La Regenta y Virrangues cuya datación comprendería desde mitad del siglo I a mediado el IV d. C. EI período romano en nuestras comarcas queda señalado especialmente por los hallazgos sueltos fuera de contexto arqueológico, como lo demuestran los abundantes restos epigráficos de lápidas con inscripciones conmemorativas u honoríficas, como las

\footnotetext{
${ }^{5}$ Entre los fondos del Museo de Burriana analizados en la tesis de $\mathrm{J}$ Benedito, leída en el año 2011, hay importaciones africanas (Hayes 99) de pleno siglo VI correspondientes a materiales recolectados en esta villa; lo que implica en la necesidad de una revisión a fondo de los estudios sobre la villa de Benicató.
} 
de Viver y Jérica, de tipo monumental en memoria de la construcción de un edificio que podría ser público, también en Onda, Segorbe y Jérica, las de carácter votivo y las funerarias son frecuentes (CORELL, 2002). Santa Bárbara (Vilavella) ha ofrecido unos hallazgos que podrían ser asimilados a la función de un santuario (VICENT, 1979).

Mediado el siglo III d. C. el imperio romano estaba debilitado, ocasión que aprovecharán los pueblos germánicos para invadir sus posesiones, de tal forma que municipios, poblados, mansiones, villas y pequeños núcleos habitados se ven afectados, desde la frontera del Rhin hasta Andalucía, no siempre por acción directa, sino también por el efecto del miedo propagado por las noticias que llegaban de las zonas afectadas directamente. Este pánico sin duda llevaría a buscar refugio y protección mediante obras nuevas o la migración a lugares más seguros como las ciudades. Recordemos que las invasiones serían un duro golpe psicológico a la población, pues después de casi 200 años de paz y seguridad no existía en la memoria colectiva de la sociedad ningún recuerdo de guerras o invasiones que afectaran a su entorno inmediato. En nuestra comarca se tienen evidencias de esta situación, por ejemplo, en Benicató (Nules), en Sant Josep (La Vall d'Uixó) o en Santa Bárbara (Vilavella) (ARASA, 2004). Algunos autores apuntan una importante cantidad de ocultaciones monetales y una disminución de casi el $90 \%$ de los yacimientos romanos durante el siglo III en la provincia de Castellón (JÁRREGA 2008 y 2011). F. Esteve cita en la villa de Benicató: Monedas (...)encima del mosaico anejo a la galería oriental (...) con una fecha tope que no puede pasar del año 256 (...)visigodo a cuya época pertenecen platos de arcilla fina y color rojizo que, en un caso, se decoran por signos cristianos estampillados (ESTEVE, 1956: s. p.)

En las escasas descripciones publicadas de la villa romana de Uixó se habla de la superposición de estructuras, aunque sin ningún hiato que supusiera un abandono: (...) enmarcar el yacimiento cronológicamente entre mediados del siglo Il a. C., y el ultimo tercio del II d. C. (...) fase de mayor actividad entre la segunda mitad del I d. C. y la primera del II d. C. (GÓMEZ et al., 1989: 763).

Esta crisis se supera en parte cuando el emperador Diocleciano inaugura un nuevo período: el llamado Bajo Imperio. Desde el final del siglo III- principio del IV d. C., una transformación social se produce a través del Cristianismo, que alcanzó a un Imperio que se encontraba en un proceso de cambio, al salir de un enriquecimiento y una ampliación entre el siglo II y III d. C. Lamentablemente en la provincia de Castellón no existen indicios arqueológicos de la implantación del cristianismo antes del siglo VI d. C. (JÁRREGA, 2011), y aún así estos son bastante endebles. Hace pocos años se ha publicado un crismón estampillado sobre TS y una moneda con el mismo símbolo, ambos hallados fuera de contexto en Benicató (FELIP. 2000); aunque el autor solamente publica una foto de cada objeto, sin mas datos, el aspecto de los mismos parece indicar una cronología anterior al siglo VI d. C.. 
Desde el final de la época romana a la invasión musulmana se produce un retroceso demográfico y económico, que se constata en las áreas más intensamente pobladas en aquellos tiempos, como Sagunto. Por tanto, cabe admitir que la zona castellonense se encontraba en una situación muy precaria cuando se produce el avance islámico por la Península, tanto en la red de caminos como a nivel de población y por la ausencia de núcleos urbanos de una entidad relativa.

Es difícil intentar aproximarse a la delimitación administrativa en época musulmana. Se podría suponer que las tierras que hoy forman la provincia se dividieron entre los grandes centros de Tortosa y Valencia, pero no se encuentra información abundante sobre ambas ciudades costeras hasta el siglo $\mathrm{X} \mathrm{d}$. C. lo que induce a creer que el área estuvo poco poblada hasta final de la citada centuria y principio del siglo XI. Después de la conquista musulmana de los bereberes, éstos conservaron las ciudades o municipios ya existentes, manteniendo sus nombres aunque arabizados, como por ejemplo: Valentia (Valencia), Saetabi (Játiva), Dianium (Denia). En la provincia la primera cita a una medina data del siglo XI y se refiere a Onda ( $\mathrm{HUICl}, 1970)$. En el siglo XII aluden los textos árabes a la ciudad o medina de Buryana, describiéndola como bonita, habitada y con tierras fértiles en las que abundaban los árboles y las viñas. Principalmente Al-Idrísí en siglo XII habla sobre el espacio costero comprendido entre Burriana y Sagunto; allí, según aquéllos, se encuentran, situados cerca del mar, pequeños despoblados (¿antiguas villas?), árboles diseminados y afloramientos de agua (GAYANGOS, 1850). La importancia de Burriana estaba relacionada con el abastecimiento de las poblaciones del interior y aunque su tamaño se encontraba muy lejos de ser el de una urbe populosa, posiblemente alcanzó cierta categoría al desempeñar ciertas funciones.

Con la conquista cristiana a lo largo del siglo XIII la primera y apremiante razón que justifica la acción repobladora es la necesidad de asegurar la posesión y defensa del territorio mediante la instalación en él de una nueva población cristiana, en ocasiones compartiendo la ocupación con los antiguos habitantes musulmanes. Existía, en segundo lugar, la necesidad de premiar a los colaboradores de la corona en la acción reconquistadora, especialmente a los grandes señores feudales y las órdenes militares. Esto llevó a la fundación de nuevas ciudades (Nules, Vila-real, Castellón de la Plana) y a la creación de diferentes caminos que transformaron el entorno de una forma que no se había llevado a cabo desde época romana. 


\subsection{DATOS SOBRE VÍAS DE COMUNICACIÓN EN EL SUR DEL- CONVENTUS TARRACONENSIS}

Con este apartado pretendemos realizar una aproximación al estado de la cuestión, recopilando todas las hipótesis actuales que presenten cierto fundamento y sobre ellas estructurar una tesis aceptable. Uno de los principales elementos que articularían los asentamientos rurales serían las vías romanas, tema que en nuestra opinión necesita en esta zona una revisión de cara a redefinir la interpretación actual, uniendo los restos arqueológicos y las fuentes literarias de época antigua al análisis geográfico. Sin pararnos a enumerar los abundantes estudios puntuales existentes, podemos destacar al ingeniero de caminos e historiador E. Saavedra, que ingresó en la Real Academia de la Historia (1862) como el primer investigador español que trazó un mapa general de las vías hispánicas del imperio romano, deducidas del Itinerario de Antonino. A él debemos sumar el Corpus Inscriptionum Latinarum con su sección dedicada a los miliarios. A partir de ésta se fueron desarrollando otras recopilaciones y estudios epigráficos desde una perspectiva provincial o regional. Hacemos nuestras las palabras de G. Arias: En las obras generales de historia, y en no pocas de las obras dedicadas a la caminería romana, los mapas de vías romanas hispánicas se copian unos a otros, perpetuando en el papel vías que nunca han existido u omitiendo otras que merecen figurar entre las más importantes. Y están por otra parte quienes toman en serio las nuevas ideas sobre las claves de los itinerarios romanos. (ARIAS, 2002:200). Generalizando podríamos decir que hoy en día hay dos grandes grupos o escuelas entre los estudiosos de la red de vías romanas. Por una parte están los tradicionalistas, herederos de la perspectiva adoptada por E. Saavedra. El segundo grupo es más innovador, al utilizar como base diversos estudios, entre los cuales nos incluimos.

El dominio e influencia romana, tanto a nivel político como económico, dependía de unas comunicaciones rápidas y seguras. Para ello tenemos la antigua vía Heraclea, cuya existencia sería bien conocida por los pueblos iberos como vía principal de transporte y relaciones comerciales, y la vía Augusta, importante arteria de comunicación que puso en contacto a Hispania con Italia y la Galia. El reconocimiento del trazado a su paso por la provincia de Castellón resulta también de difícil solución. A este respecto existen dos opiniones contrapuestas. La primera sostiene un trazado paralelo a la costa, que partiendo de Sagunto llega a Almenara, Xilxes, Vilavella y el Grau y desde este punto pasaría por Albalat, Miravet hacia Torreblanca, desviándose por el interior en la zona montañosa de Alcalá de Xivert. Ya a la altura de Benicarló vuelve a correr paralela al mar, pasa por Vinaroz, hacia Ulldecona (PORCAR, 1935, 
BRU y VIDAL, 1963). La segunda, por el contrario, sostiene que el recorrido de esta vía debía pasa por el interior, basándose en los hallazgos de miliarios de Borriol, Coves de Vinromá y La Pobla Tornesa, en parte por los restos del puente del Mijares próximo a Onda, en el llamado "Camí dels Romans" de Cabanes, en el miliario del camino de Tortosa a Traiguera, los caminos próximos a Els Hostalets cercanos al río Cenia y en la calzada que traspasaba el puente de La Rambla de la Viuda. A estos argumentos añaden el itinerario seguido por Jaime I desde Valencia a Francia usando un camino interior. Aún dentro de la unidad de opinión sobre el recorrido de la vía Augusta por tierras interiores, existen numerosas disensiones acerca de la exacta localización de las mansiones, según los itinerarios (ARASA, 2002, MOROTE, 2002, MOROTE y MELCHOR, 2008 y JÁRREGA, 2011). La Augusta estaría sin duda atravesada por una serie de vías de menor importancia, que penetrarían hacia el interior, probablemente por Morella y Forcall, para enlazar pasando por Alcañiz con la vía de Caesaraugusta; y por el valle del Palancia, pasando por Segorbe, Viver, Begís, Barracas, Teruel hasta Bilbilis (Calatayud), enlazándose a la vía de Aragón (JÁRREGA, 2000b). Otra sería la denominada senda de la costa, el actual Caminàs, y enlazaría con la vía Augusta a la altura de Burriana. Las centuriaciones parecen corroborar su existencia (MOROTE, 2002, MOROTE y MELCHOR, 2008 y BAZZANA, 1987), mientras otros autores mantienen trazados más al Oeste (JÁRREGA, 2011) que son compatibles con una variante de la vía Augusta. Otras hipótesis son mas difíciles de mantener por no encontrase asociadas a yacimientos excavados y reconocidos (ARASA, 2004).

La principal referencia es la de los Itinerarios; en estas relaciones de ciudades o de mansiones las distancias entre las localidades señaladas se encuentran entre las 16 y las 25 millas (con pocas excepciones), por lo que en nuestra opinión pueden incluir tanto mansiones como mutationes, además de ciudades, ya que los textos no establecen ninguna diferencia entre ellas. Según los trabajos de P. Sillieres realizados sobre la tabla Peutingeriana y el itinerario de Burdeos a Jerusalén, las mansiones, utilizadas para etapas como reposo por la noche, distan una media de 30 a 35 millas romanas entre sí y las mutationes, usadas sólo para cambiar caballos, a cada 8 a 12 millas (SILLIERES, 1983). La investigación actual apunta a que existen excepciones en la distancia entre estos enclaves, por ejemplo en los casos de accidentes geográficos o de cruces importantes que afecten a la vía (montañas, cauces de ríos, etc.), lo que dificultaba el recorrido al hacerlo más arduo. El que exista la necesidad de utilizar un desvío para facilitar el acceso, hace que las paradas se establezcan a más corta distancia, respondiendo a la necesidad del viajero y no a una separación estándar.

Cuatro son las fuentes que atañen al espacio de nuestro interés: el Itinerario de Antonino, los Vasos Apolinares o de Vicarello, el Anónimo de Ravena y la Guidonis Geographica. Los dos únicos enclaves identificables de forma incontestable en los extremos de la zona estudiada son Tortosa y Sagunto. Las demás ubicaciones tienen una situación variable según el investigador que las aborde. 
El llamado Itinerario de Antonino, documento que se suele datar en torno al 290 d. C., tiene un engañoso aire de guía de caminos. En su parte hispánica consta de 34 supuestas vías de longitud muy variable, desde seis hasta varios cientos de millia. Se enuncia el punto de partida, de llegada y distancia total, y a continuación las etapas, de longitud también diversa, con distancias parciales (ARIAS, 2002).

\begin{tabular}{|lll|}
\hline SAGUNTO & $M P$ & $X V I$ (desde Valentia) \\
SEBELACI & $M P$ & $X X I I$ \\
ILDUM & $M P$ & $X X I I I$ \\
INTIBILI & $M P$ & $X X I I I I$ \\
DERTOSA & $M P$ & $X X V I I$ \\
\hline
\end{tabular}

Itinerario de Antonino (ROLDÁN, 1973)

Los Vasos Apolinares son cuatro vasos cilíndricos de plata, hallados en 1852 en las Termas de Vicarello, no lejos de Roma, en cuya superficie está grabado el itinerario de Cádiz a Roma con etapas, distancias totales y parciales. Su cronología es incierta, pero se apunta a alrededor de los siglos I-II d. C. Se trata de los documentos más fiables sobre los itinerarios, ya que son los únicos originales que nos han llegado, y no sobre la base de copias medievales como los demás.

\begin{tabular}{|llll|}
\hline Vaso 1 & SAGYNTUM & $M P$ & $X V I$ (desde Valentiam) \\
& ADNOULAS & $M P$ & $X X I I I$ \\
& $I L D U M$ & $M P$ & $X X I I$ \\
& INTIBILIM & $M P$ & $X X I I I$ \\
& DERTOSAM & $M P$ & XXVII \\
\hline
\end{tabular}

\begin{tabular}{|llll|}
\hline Vaso 2 & SAGYNTO & $M P$ & XVI (desde Valentia) \\
& ADNOULAS & $M P$ & $X X I I I$ \\
& ILDUM & $M P$ & $X X I I$ \\
& INTIBILI & $M P$ & $X X I I I$ \\
& DERTOSA & $M P$ & $X X V I I$ \\
\hline
\end{tabular}

\begin{tabular}{|llll|}
\hline Vaso 3 & SAGUNTO & $M P$ & $X V I$ (desde Valentia) \\
& SEBELACI & $M P$ & XXII \\
& ILDUM & $M P$ & XXIIII \\
& INTIBILI & $M P$ & XXIIII \\
& DERTOSA & $M P$ & XXVII \\
\hline
\end{tabular}

\begin{tabular}{|llll|}
\hline Vaso 4 & SAGUNTO & $M P$ & $X V I$ (desde Valentia) \\
& ADNOVA & $M P$ & XXIIII \\
& $I L D U$ & $M P$ & XXII \\
& INTIBILI & $M P$ & XXIIII \\
& DERTOSA & $M P$ & XXVII \\
\hline
\end{tabular}

Vasos de Vicarello (CIL XI, 3281-3284) (ROLDÁN, 1973) 
Aún dentro de los Itinerarios, encontramos algunos que no reflejan la distancia entre las distintas localidades, por lo que la referencia tiene que tomarse en comparación con los citados anteriormente. Es el caso del Ravennate, redactado en el siglo VII d. C. sobre datos del III o IV d. C. donde es interesante observar que la localidad de Rubricantum sustituye exactamente a la Intibili de los anteriores. En este caso podemos suponer que el autor, al recoger distintas fuentes, incurre en el error de introducir la localidad de Intibili en un lugar equivocado (antes que Ildum). En esta relación también desaparecen (como en el Guidonis) las localidades de Ad Noulas y Sebelaci.

\begin{tabular}{|l|}
\hline SAGUNTUM \\
INTIBILI \\
ILDUM \\
LUBRICANTUM (Laubricantum) \\
DERTOSA \\
\hline
\end{tabular}

Anónimo de Ravena, V-2-4, 340 (ARIAS, 2002)

En la Guidonis geographica, posible copia del Anónimo de Ravena, realizada en fechas muy similares, encontramos en dos nombres muy parecidos, que ejemplifican los errores que se comenten en transcripciones (Rubricantum/Laubricantum), así como la desaparición de Intibili.

\begin{tabular}{|l|}
\hline SAGUNTUM \\
HILDUM \\
RUBRICANTUM \\
DERTUSA \\
\hline
\end{tabular}

Guidonis Geographica, 83-130, 514 (ROLDÁN, 1973)

La obra de Claudio Ptolomeo presenta serias dudas de interpretación, por lo que se refiere a la ubicación exacta de las localidades que él cita. Añadiremos que un dato importante es la diferenciación que hace el autor en cuanto a las ciudades costeras y a las del interior. Por ejemplo, a Sagunto la considera como una ciudad del interior, mientras que a Valencia la considera costera (SANZ, 1959). Solo encontramos una cita, la de Tenebrius portus (Geografia, 2, 6) como un puerto, entre el Ebro y Sagunto; Esteban de Bizancio, algunos siglos después también cita de forma muy similar una población llamada Tenebria (Ethnika, p.615). Sobre las ciudades del interior no podemos aventurar una identificación, pero nos parece interesante observar una cierta acumulación de localidades al sur del Ebro, como Leonica, Osicerda, Lassira y Etebema/Etobesa (Geografia, 2, 6).

El caso de Estrabón sería similar, ya que cita a su vez una serie de ciudades casi exclusivamente costeras o que pudieran identificarse desde la costa (o remontando ríos, como el caso de Tortosa) en una fecha alrededor del siglo I d. C.: 
(...) hállase Saugóunton (...) En sus cercanías están las ciudades de Cherronesos, Oleastron y Kartalias. Luego, en el paso del Iber, la colonia Dertossa (...) (Estrabon, III, 4, 6) (RABANAL, 1985:49)

Y respecto a las vías romanas, sólo describe la exterior o paralela a la costa, y como se realizaban cambios en los trazados antiguos:

(...) la vía que llaman "exterior" y que va de Italia a Ibería: concretamente, a la Baitiké. Esta vía se acerca a veces al mar; otras, se aleja de él, sobre todo en los tramos occidentales. (...). De Tarrákon va al paso del íber, en la ciudad de Dertóssa; de aquí, por la ciudad de Sagoúnton y la de Saítabis, apártase paulatinamente de la costa, (...). Antes la vía cruzaba por medio del "Campo" y por Egelástai; más era difícil y larga. Ahora, por ello, transcurre junto a la marina y no cruza más que una pequeña parte del espartizal. Luego pasa, como la antigua vía, por Kastoulón y Oboúlkon (...) (Estrabón, III, 4, 9) (RABANAL, 1985:43)

Así pues debemos tener en cuenta que cada fuente conservada (obviando las mutilaciones o errores de copistas) da una versión particular del autor sobre la zona que describe: Tito Livio, por ejemplo, cita a la ciudad de Onussa, próxima al delta del río Ebro (XXII, 20,3), que los romanos toman después de cruzar el río en dirección a Sagunto y que no aparece en ninguna otra que hemos citado. En esta línea debemos pensar que el Itinerario de Antonino no es una guía exhaustiva de caminos; un investigador suizo, Denis van Berchem, en 1936 (confirmado y completado con nuevos datos en 1974) identificó al Itinerario como una recopilación de listas de etapas sobre la base de numerosos edictos por lo que conviene pues hablar de "rutas" más bien que de vías (ARIAS, 2002). Tales edictos anunciaban el trayecto del emperador o algún personaje importante, o marcaban los lugares para ir recogiendo el impuesto de la annona. Así, esas rutas, aparte de no coincidir necesariamente con vías, no siempre seguían caminos principales, sino que podían tomar otros menos importantes $A$ esto debemos sumar que las ciudades mencionadas no están necesariamente en la ruta descrita; de hecho, cuando un itinerario romano menciona una localidad, ello no significa que la vía atraviese la propia urbe o pase lamiendo sus muros, sino que con frecuencia el punto escogido como fin de una etapa y comienzo de la siguiente es una statio o mansio situada en una encrucijada a una distancia variable de la ciudad de la que toma el nombre. Las rutas no siempre empiezan o terminan en la ciudad citada como punto de partida o de llegada, sino en el límite de su jurisdicción (ARIAS, 2002)

Fue en 1963 cuando se formuló por primera vez la llamada teoría de los empalmes, basada en una interpretación gramatical del Itinerario de Antonino. El principio es muy sencillo: cuando el lugar se cita en ablativo o locativo, está contiguo a la vía como Carthagine; cuando se cita en acusativo, como Saguntum ó Ad Noulas, el lugar puede 
estar bastante apartada, incluso diez o más millas, y se llega a ella por una ramal que empalma con la vía principal en el punto hasta el que se cuentan las millas de la etapa; para los casos como Sebelaci, que podría ser un dativo ${ }^{6}$, quizá podríamos optar por una ubicación intermedia para los asentamiento citados respecto a la vía. En el caso de Sagunto esto reforzaría la teoría de que la vía Augusta pasa por las afueras de la ciudad, por alguno de los caminos que aún se pueden apreciar parcialmente en las fotos aéreas (ver Fotos $\underline{202}$ y $\underline{203}$ ), y que siguieron los caminos medievales hasta las reformas de época bajo medieval y moderna que buscaron aproximar los caminos al centro urbano. Algunos autores (ARIAS, 2002) apuntan que la preposición ad expresa contigüidad a la vía, mientras según otros es un indicador de direccionalidad (MOROTE, 2002, ARASA y ROSELLÓ, 1995 y ROLDÁN, 1976).

La transposición directa de las distancias desde las fuentes a planos actuales se dificulta porque en algunas rutas se utiliza una unidad de medida distinta de la milla. Por ejemplo, una vía secundaria en Galicia que conduce de unas minas de estaño a la costa se mide en estadios y una vía transpirenaica se cuenta en leguas gálicas (1 legua $=1,5$ millas), sin duda porque fue construida por legionarios galorromanos. Añádase que la búsqueda equivocada de una vía romana allí donde nunca existió, por mala interpretación de las fuentes, explica algunas de las decepciones de los investigadores (ARIAS, 2002). Otras opciones son el uso de la milla olímpica (equivalente a 1.538 metros) o los millia passuum (equivalente a 1.480 metros). Finalmente contemos que no todas las vías son de origen romano; por ejemplo, en la Bética los romanos habrían encontrado ya una red relativamente tupida de caminos no empedrados que sencillamente aprovecharon (ARIAS, 2002) o, como ya vimos en la cita de Estrabón, reforman parte de estas vías o de las que ellos mismo construyeron. Los tipos de vías son muy variados; Siculus Flaccus, mensor del siglo I d. C. en su De condicionibus agrorum, clasifica las calzadas en:

Viae publicae que eran las principales vías del Imperio, llamadas viae praetoriae, viae militares o viae consulares. Era el Estado quien se hacía cargo de su construcción, pero las ciudades y los propietarios de las zonas atravesadas debían garantizar su mantenimiento. El promedio constatado del ancho era de 6 a $12 \mathrm{~m}$.

Viae vicinales que partían de las vías públicas y permitían unir entre ellas varios vici en la misma región. Eran la mayoría de las vías de la red. La anchura media era de alrededor de $4 \mathrm{~m}$.

Viae privatae que unían las principales villas con las viae vicinales y publicae. Eran privadas, reservadas para uso exclusivo del propietario que las financiaba en su totalidad. La anchura media era de 2,50 a 4 m. (CASTILLO, 1998)

\footnotetext{
${ }^{6}$ En este caso el nominativo sería Sebelacum o Sebelaco, según información oral del Dr. R. Járrega. 
La complejidad se acentúa si tenemos en cuenta que entre las privatae existen los derechos de servidumbre, que sirven para clasificar el tipo de senda, hasta las necrópolis generan caminos de acceso::

(Dig. 8,1)(...)Si fuese concedida una servidumbre de camino habiéndose señalado un lugar tan angosto que ni un vehículo ni una caballería puedan pasar por él, más bien se considerará adquirida la servidumbre de senda que la de camino o la de paso de ganado (...)

(Dig. 19,1) 53. (1) Si vendiste el fundo en que tenías un sepulcro y no te lo reservaste expresamente, insuficiente ha sido tu cautela. Dice Paulo: pero no si pasa un camino público hacia el sepulcro.

Otro factor que fomentó la confusión en la historia de la investigación fue la obsesión de identificar vías enlosadas con caminos romanos, cuando sabemos que las formas de los mismos son muy variados, ya que o bien se enlosaban (viae sílice stratae), estaban realizados con firme de grava y canto rodado compactado (viae glarea stratae) o eran simplemente de tierra (viae terrenae). Muchas carreteras modernas se han superpuesto a las viejas calzadas: (...) en ambas mesetas centrales y en las tierras llanas en general, si no se encuentran muchas calzadas romanas es sencillamente porque la historia las ha disfrazado de carreteras modernas (ARIAS, 2002: 208).

La principal causa de que no se encuentren hoy muchas calzadas en su forma primitiva es que han sido reparadas repetidamente a través de los siglos hasta transformarse en carreteras modernas. De ahí la importancia de otras fuentes de épocas más recientes, que nos pueden servir de complemento a la hora de analizar las anteriores, especialmente por lo que se refiere a las vías de comunicación, ya que permite hipotetizar sobre la evolución de los caminos romanos hasta llegar a la actualidad. Las fuentes árabes (en este caso de los siglos IX y $X$ respectivamente) son muy interesantes, al igual que las medievales, ya que se ha aceptado normalmente que las vías de comunicación durante el Medioevo difieren muy poco de las romanas (ROLDÁN, 1976) y hasta casi el siglo XIX las rutas terrestres que seguían siendo utilizadas tenían un origen romano. Algunas de las reformas que se realizaban se limitaban a seguir la antigua orientación, con ligeros desvíos, prácticamente sólo mejorando la calzada. Para el periodo musulmán podemos citar:

(...)Tortosa a Valencia ha ciento et cinquenta migeros, si fueren por el camino de Mastronia que es más luengo que de los hijos de Darache (...)

Crónica del moro Elrazis (GAYANGOS, 1850:58)

Por lo que se refiere ya al final del Medievo, más exactamente en año de 1546, el camino real que discurría paralelo a la costa, según el Repertorio de todos los caminos de España, por Pedro de Villuga, autor que reflejaba los caminos más importantes, que 
en muchos casos coinciden casi completamente con antiguas calzadas romanas (hasta cruces o variantes en las mismas como en la Puebla Tornesa), era el siguiente:

(5) Hay de Barcelona a Valencia XLIX.

(...)Tortosa III, a la Salera II, a los Mesoncillos II, a la Traiguera II, San Mateo II, Salsadella I, a Cuevas II, a Cabanes II, a la Puebla II, a Borriol I, a Villarreal II, a MIles II, a Almenara I, a Morvedre I (...)

(126) Hay de Valencia a Monzón XLIIII.

(...) a Morvedre II, Almenara I, a Nules II, a Villa Real I, a Borriol II, a la Puebla II, a la venta la Barona III, a la venta la Pelejana media, a la venta los pejoles I y media, a la venta la Ciguarra I, a Cati II, (...)

(VILLUGA, 1546)

No debemos olvidar que la supervivencia de una vía depende de su funcionalidad. De hecho, cuando una calzada romana queda fuera de servicio, su destrucción es cuestión de muy pocas décadas: (...) todavía en la primera mitad de este siglo, eran utilizadas por arrieros, ganaderos, traficantes y caminantes. En cuanto dejan de ser transitadas (...) su desaparición es ineludible. (ARIAS, 2002: 209)

La riqueza del entorno, otro factor no tenido en consideración en muchas hipótesis, refuerza algunas teorías sobre los emplazamientos de vías, tal y como tenemos en el caso francés de Tricastin: Determinados ejes destacan del conjunto de la red viaria y parecen tener una importancia económica mayor que se traduce en la perduración y la riqueza de los yacimientos que se instalan en sus orillas (JUNG, 2006: 42).

Analizando los caminos de la zona, podemos descartar una gran cantidad de caminos medievales y modernos, que unen además enclaves de ese periodo (como Nules o Vila-real), de modo que podemos detectar los caminos de gran recorrido y que unen asentamientos antiguos. Este análisis lo reforzamos con un estudio hipercrítico de los yacimientos del entorno, descartando aquellos no contrastados y depurando redundancias (por ejemplo el Pla Redó, El Salt, La Bassa Seca o la Torrasa - que aparecen como varios en la bibliografía - en verdad son una única villa romana en la unión de los términos de Betxí Les Alqueries y Vila-real), de tal forma que podemos asociar vías de comunicación al "hinterland" de estos asentamientos (ver Lámina LVII).

Como ya citamos anteriormente, la proximidad entre dos mutationes o dos mansiones, que encontramos en alguno de los Itinerarios, se debe a un accidente natural, como en este caso es el río Mijares. Sería su paso el que obliga a situar una parada como Ad Noulas en un importante cruce (que por otro lado es un claro indicio de una dirección a tomar hacía el enclave de Noulas), en este caso como única posibilidad de alcanzarlo fácilmente antes de cruzar el citado cauce, viniendo de Sagunto, ya que efectivamente es prácticamente imposible a partir de este desvío cruzar el Mijares sin una gran obra de ingeniería como las que solamente se realizaron ya en el siglo $\mathrm{XX}$. 
Por este motivo es por el que se explica fácilmente que nos encontremos con dos enclaves tan cercanos como Ad Noulas y Spelaco, y lógicamente cada uno situado a un lado del Mijares. Respeto a ésta última, varias son las evidencias que apuntan a su ubicación en el yacimiento del Palau, (sin olvidar algunas interpretaciones sobre su nombre, como un origen latino de significado lugar hondo respecto, tal vez, al desnivel que existe desde la zona del puente, algo más alta, hasta el yacimiento) por su situación estratégica junto a la vía Augusta, en un enclave privilegiado por su fertilidad y fácil acceso al mar. Los restos descubiertos hasta la fecha (MELCHOR y BENEDITO, 2005) señalan un importante edificio termal (ver Foto $\underline{558}, \underline{559}, \underline{560}$ y $\underline{561}$ ) con unos claros paralelos en el mundo romano, sobre todo alrededor del I d. C. (ver Fotos $\underline{538}$, $\underline{539}$, 541 y $\underline{542}$ ), que muestra una importante pervivencia del enclave con su transformación aproximadamente en el siglo IV d. C. (MELCHOR y MOROTE, 2008), con el añadido de un ábside y de una serie de estancias que anulan y modifican el edificio termal (ver Fotos $\underline{553}, \underline{554}, \underline{563}, \underline{564}$ y $\underline{565}$ ). Los paralelos de este tipo de evoluciones son abundantísimos en el mundo romano, por lo cual solamente seleccionamos las más similares en planta y en lo que sería el alzado de nuestro yacimiento. Destacamos el cerramiento de ventanas y añadido de habitaciones (ver Fotos $\underline{542}$ y $\underline{543}$ ), las moradas con ábside (ver Fotos $\underline{544}, \underline{545}, \underline{546}, \underline{547}, \underline{548}$ y $\underline{549}$ ), el uso de columnatas y la reutilización de asentamientos anteriores (ver Fotos $\underline{550}, \underline{51}$, $\underline{552}$ y $\underline{556}$ ) y algún modelo similar al que podría seguir la construcción del Palau (ver Fotos $\underline{533}, \underline{534}, \underline{535}$ y $\underline{536}$ ). Finalmente no debemos olvidar que solamente el Palau se encuentra en una distancia admisible para compararla con la ubicación de Spelaco, aún más si tenemos en cuenta que el trazado de la vía Augusta entre Sagunto y esta mansio no seria tan rectilínea como se pensaba, ya que debe realizar importantes curvas para desviarse de los marjales de Almenara y Nules y, además, mantener al máximo las cotas de nivel evitando elevaciones montañosas (ver Lámina LIII).

Se observan grandes discrepancias entre los estudiosos sobre un largo tramo mal conocido que atraviesa toda la comarca de la Plana Baixa hasta Almenara. En esta zona debían estar situadas las estaciones de Ad Noulas/Nova, a 22 millas $(32,5 \mathrm{Km}$.) al Sur de Ildum, y Sebelaci, a 2 millas $(2,9 \mathrm{Km}$.) al sur de Ad Noulas/Nova y a $22(32,5$ $\mathrm{Km}$.) al Norte de Sagunto. Evidentemente las distancias dependen de la ruta elegida para medir los recorridos conocidos por las fuentes. La tendencia de medir sobre caminos actuales o trazados hipotéticos lleva a errores importantes en la ubicación de las paradas, como por ejemplo las que ubican a ambas en los términos municipales de Castelló de la Plana y Almazora (ARASA, 2006), al mismo lado del cauce del Mijares, hecho inviable ya que, como citamos, la aparente diferencia de sólo 2 millas entre ambas se debería a la presencia de un gran obstáculo natural entre ellas.

Otro punto de error es el introducido por la creación de las líneas de ferrocarril. El objetivo de reducir gastos, por parte de los constructores de los primeros ferrocarriles, incluye varios aspectos. En primer lugar, "...la elección del camino que menores 
imponderables físicos presentase a la hora de ejecutar las obras, por lo que se eligieron, en la práctica totalidad de los recorridos, las rutas tradicionales de paso existentes, cuando no tramos de carretera, como ocurrió, especialmente, en algunas peticiones de líneas de vía estrecha, con lo que se preveían sustanciales ahorros en las obras de explanación y de construcción, mantenimiento y rendimiento del conjunto del trazado..." (CORDERO y MENÉNDEZ, 1978: 192) obligando a la construcción de caminos paralelos al ferrocarril para suplir la eliminación de antiguos caminos (ALCALDE, 2001), lo que lleva a algunos autores a confundirlos con la vía Augusta.

El tramo más litoral de la vía Augusta entre Ad Noulas y Almenara perderá su importancia geoestratégica cuando se inicia un proceso donde se busca un alejamiento de la costa con la caída del Imperio romano. Además, con la disminución de la demanda ya no es prioritaria la obtención de recursos agroalimentarios excedentes y lentamente se van buscando las zonas del interior con mejores recursos estratégicos. De esta forma es como los emplazamientos del interior en Alcora, Onda, La Vall d'Uixó, etc. suplantan a los de la costa que acaban por desaparecer a partir del $\mathrm{V} d$. C. Estas referencias al retraimiento, aunque estudiadas sobre datos cuantitativos y algunas veces no contrastados sobre el terreno, ya las refleja $F$. Arasa, pero sin alcanzar una conclusión más acertada. Este autor fija en 175 los yacimientos ocupados durante el Alto Imperio en la provincia de Castellón (la referencia al subjetivismo la tomamos en relación a la necesidad de un análisis critico de prospecciones, estudios antiguos, etc. que ya reflejamos en esta tesis) y argumenta que el numero experimenta una drástica reducción en el siglo III d. C., hasta los 17. Posteriormente un total de 33 yacimientos habrían proporcionado evidencias de ocupación (ARASA, 1996-1997).

Durante época musulmana se reproduce parte del esquema romano de uso del territorio, pasando de una fase inicial de cierta tranquilidad y expansión territorial durante el emirato y el califato, donde la inseguridad estaba en unas fronteras relativamente alejadas, hasta llegar a un período de constante decadencia y retraimiento con la fragmentación del poder y la consecuente inestabilidad social y económica durante el periodo de las taifas. En una primera etapa se recupera la explotación extensiva del territorio y la importancia del eje Norte-Sur (Tortosa y Sagunto volvían a ser dos importantes ciudades unidas por la antigua vía Augusta). En estos momentos se reocupan enclaves costeros como Palau, Sant Gregori, se funda Burriana, etc. Debemos tener también en cuenta la comunicación con importantes ciudades y asentamientos del interior que siguen manteniendo su importancia, con alguna población que creció durante el periodo visigodo como Onda, Alcora o Vall d'Uixó. Un dato que apoya la ocupación selectiva de zonas de interés es el relato de AlIdris, que menciona despoblados a lo largo de la vía Augusta entre Burriana y Sagunto: "Desde Peñíscola al monte, subida ó cuesta de Abisa, montaña muy alta que se eleva encima de la costa, y sobre la cual pasa el camino, de manera que hay precisión de ascender aunque es muy escarpado, 7 millas. (Lo que demuestra el desvío desde la 
vía Augusta). De allí á Burriana, al O., 25 millas. (...) De Burriana á Murviedro, reunión de varios despoblados rodeados de huertos, regados por aguas corrientes y situados cerca del mar, 20 millas". (GAYANGOS, 1850:12)

Con ello ya nos alejamos demasiado del objetivo de este estudio, pero para entender la evolución final del territorio y los restos que allí permanecían de la era romana debemos hacer un último inciso para ver que la época cristiana es un momento de ruptura importante con los esquemas anteriores, ya que se modifican trazados de las antiguas vías para atender a las necesidades económicas y estratégicas, como por ejemplo la vía Augusta, con algunos tramos abandonados en favor de nuevos caminos conocidos como Cami Real que buscaban pasar por las fundaciones de esta época (Castellón, Vila-real, Nules, etc.). Hay pruebas documentales, en el caso de Sagunto, donde se abandona uno de los ramales de la antigua vía de Caesaraugusta, utilizado desde época musulmana, en favor de un camino mucho más cercano al recinto amurallado de la villa en razón de mayor control y recaudación de peaje. De la misma forma en la Plana se anulaba el valor estratégico de Burriana con la fundación de nuevas ciudades y el desvío del camino utilizado desde época romana. Lo único que no se puede anular es la función idónea de fondeadero, de tal forma que sigue siendo el puerto medieval y llegan a instalarse unas salinas, favorecidas sin duda por la facilidad de comunicación marítima y terrestre. Por un lado en el medioevo se recuperan viejos caminos romanos para comunicarse con el interior, como el camino Dels Bandejats (que comunicaba Spelaco y Noulas) entre Alcora y Burriana o el de Artana, viejo camino carretero que, naciendo en el Arrabal de Valencia, pasaba por el yacimiento romano de la Regenta (Burriana), tras rebasar el yacimiento ibérico de Sant Antoni y el romano del Pla Redó (Betxí) y llevaba a la villa de Artana. Por otro lado se anula la vieja vía Augusta. Según N. Mesado, Gilabert de Centelles, al fundar La Pobla (Nules), pide al Rey Jaime II abrir un nuevo camino desde Xilxes a Burriana, con la intención de impulsar el enclave, el cual debió cerrar el Caminàs, por lo que el tránsito procedente de Valencia para llegar a Burriana tenia que pasar por Nules (MESADO, 1991).

En resumen, cambian los esquemas de ocupación por motivos estratégicos y también se modifican definitivamente las improntas que dejaron los romanos y después reutilizaron los árabes en este espacio. En otras palabras, se varía la geografía humana, pero la geografía física sigue inalterable; por ejemplo, el punto más idóneo de cruce del Mijares sigue siendo el mismo y las facilidades portuarias también. Como anécdota diremos que el intento infructuoso de construir un puente (de les Tres Viles), aguas abajo del Mijares, para satisfacer antiguos intereses de la que aún era una villa medianamente importante como Burriana, resultó un fracaso por lo efímero de la obra, seguramente debido a su ubicación en un espacio poco apropiado. 


\subsection{LAS CENTURIACIONES}

La base de los análisis de posibles centuriaciones se fundamenta en primer lugar en detectar la pertica $u$ orientación de la centuriación El siguiente paso es determinar el tamaño de las parcelas ortogonales de dimensiones idénticas mediante la medida del actus (las más habituales eran de 20 actus), que presentaban algunas variaciones ${ }^{7}$

Los antecedentes al estudio de las centuriaciones en la zona objeto de esta tesis se puede resumir en unos escasos intentos (por ejemplo LÓPEZ, 1975 BAZZANA, 1987, GONZÁLEZ, 2006 y JÁRREGA, 2011), con mayor o menor fortuna. En la actualidad algunos estudios del siglo XX han quedado algo desfasados, ya que la tendencia actual del estudio del paleopaisaje es mucho mas critica con el uso indiscriminado de indicadores como parcelarios agrícolas, sendas o similares con un dudoso origen histórico (ver capitulo sobre antecedentes para el estudio del mundo urbano). Así pues, están sujetos a reinterpretaciones estudios como el que utiliza caminos medievales (LÓPEZ, 1975), el que cita un actus poco usual para adaptarlo a una centuriación (BAZZANA, 1987) y que finalmente se trataba de una catastro medieval (JÁRREGA, 2011), o el que propone una centuriación sobre un marjal apoyandose en una vía contemporánea (GONZÁLEZ, 2006)

A la hora de determinar los ejes centuriados tenemos problemas en nuestra zona. Si la orientación partía muchas veces de una vía o calzada importante, o de canales de riego (JÁRREGA, 2011), en nuestro caso la vía pudo ser la vía Augusta, aunque con dos variantes documentadas (MOROTE y MELCHOR, 2008, JÁRREGA, 2011) además del Caminás (BAZZANA, 1987) lo que provocaría superposiciones distorsionadoras. Las villae, tenían a efectos de propiedad y fiscales una delimitación que podía rastrearse por la epigrafía, viales, análisis del paleopaisaje, etc. Pero en nuestro caso las excavadas en una superficie significativa son escasas (El Palau y Sant Gregori en Burriana, Benicató en Nules y Vinamargo en Castellón) y el estudio de sus entornos es prácticamente inexistente. Con esta escasez de datos se han realizado algunas propuestas interesantes para la zona de la Plana, siendo la más reciente la que plantea una posible centuriación del siglo I a. C. donde los yacimientos conocidos se encuentran casi siempre adyacentes a los cardines y los decumani (JÁRREGA, 2011).

\footnotetext{
${ }^{7}$ Solamente en Italia se detecta gran variedad de módulos, desde las de $5 \times 5$ hasta las de 36 × 40 actus (JÁRREGA, 2011). 
CAPITULO 3: HISTORIOGRAFÍA ARQUEOLÓGICA SOBRE LA ZONA OBJETO DE ESTUDIO 
Haremos solamente una breve cita a las referencias más antiguas que conocemos y que de alguna forma serían un antecedente muy remoto de la Arqueología, como por ejemplo el romano Lucrecio en De Rerum Natura (VALENTI, 1962) que recoge una idea anterior, citada en la Biblia y por Homero, sobre la utilización sucesiva de la piedra, el bronce y el hierro como materia fundamental de las herramientas, modelo correcto de sucesión cronológica, todavía hoy utilizado (las Tres Edades: Piedra, Bronce y Hierro) (DANIEL Y RENFREW, 1988).

La revolución de las mentalidades que supuso el Renacimiento afectó al estudio del pasado, especialmente del período clásico o grecorromano, gracias a la recuperación de gran cantidad de restos, especialmente escultóricos, con lo que se estudian e imitan los ejemplos arquitectónicos de la Antigüedad. No olvidemos el impulso al coleccionismo de obras antiguas que implicó el descubrimiento de Pompeya y Herculano, sobre todo en la Iglesia y la monarquía, sin dejar de lado la nobleza.

Entre los siglos XVI a XIX, aunque utilizaban ya el nombre de Arqueología en época decimonónica, e incluso antes, no hay el menor atisbo de ciencia en las intervenciones, si bien debemos agradecer que en algunos casos puntuales la documentación y recuperación de los restos, aunque bastante rudimentaria, sin duda aportó un cierto grado de conocimiento y fue la base sobre la que después empezó a construirse la arqueología como ciencia.

Durante los siglos XVII y XVIII el epicentro coleccionista italiano se traslada a Francia. La llustración no sólo significó la base científica sobre la que se desarrollarían la Arqueología y la Antropología, también crea la tradición de los anticuarios que recogían restos del propio país, interesados en los orígenes de su nación (DANIEL, 1974). Esta corriente supone el origen de la Arqueología de corte tradicionalista; tras una época de auge desde el siglo XIX hasta los nacionalismos extremados del XX (nazismo, fascismo y franquismo), hoy está totalmente desprestigiada por su escaso carácter científico.

En 1836 Thomsen escribió su Guía de las Antigüedades Escandinavas, libro que tuvo gran influencia durante todo el siglo XIX y fue continuado en los países nórdicos por Worsaae y Montelius, quienes comprobaron en sus excavaciones y análisis de los materiales el sistema propuesto y también la posibilidad de ordenar cronológicamente sin datos estratigráficos, en función de la tipología de los objetos, lo que conocemos como seriación (DANIEL Y RENFREW, 1988). No debemos olvidar que es al final del siglo XIX cuando la Geología aportaría los conocimientos necesarios para que la estratigrafía sea el concepto básico que impulse la primera etapa científica de la arqueología. El problema es que la primera es una ciencia natural y por lo tanto no asume la injerencia humana y de los acontecimientos históricos, con lo cual en los 
momentos de la adaptación del concepto de superposición de los estratos a la Arqueología no se tuvo en cuenta elementos como niveles invertidos, intrusiones, ocultaciones y contaminación de capas, lo que provocó graves confusiones y errores en las interpretaciones hasta bien entrado el siglo XX.

Sobre esta base de conocimientos teóricos, el auge del Romanticismo en Europa y América provocó un impulso importante de búsqueda de elementos de historia nacional, en la mayor parte de los casos siguiendo las fuentes antiguas, como ya hicieron otros desde principio del siglo XIX, en una reedición a gran escala de la recuperación de restos romanos durante el Renacimiento italiano. Ahora en la etapa decimonónica son los gobiernos y la burguesía acomodada las que inician un coleccionismo con afanes nacionalistas o de prestigio económico, pero con la diferencia añadida de que pretendían dar un aspecto científico a la recuperación de estos restos, cosa que no siempre sucedía ante el afán por llenar los museos, como es el caso del British Museum, Louvre, Prado, Berlín, etc., ya que se llegaba en algunos casos incluso al saqueo que no eran más que un ejemplo de colonialismo científico. Podemos decir que lo que empezó como un afán de buscar restos de las raíces históricas de los pueblos degeneró en una carrera por obtener elementos de valor artístico e histórico como factor de prestigio nacionalista.

Este panorama siguió hasta que la Segunda Guerra Mundial provocó una gran ruptura y dejó como responsables de la investigación y recuperación de restos a importantes instituciones y coleccionistas americanos como el Metropolitan Museum de Nueva York, la Hispanic Society, el Instituto Smithsonian, la Getty, etc., que siguieron la tónica de llenar sus museos, a veces con criterios dudosos.

Esta merma de recursos en Europa, sumada al despertar de los nacionalismos y a la descolonización en los países que habían sido los principales suministradores de antigüedades como Egipto, Grecia, Turquía y naciones de Oriente Medio, que impidió o dificultó el saqueo continuo de sus bienes, hizo que los países europeos más desarrollados se centraran en la recuperación de su propio pasado como objetivo primordial. Esto implicó también una concentración de los recursos disponibles y la concienciación de que los elementos arqueológicos son un recurso limitado, por lo que debería sacarse la máxima información de ellos. Además, es entonces cuando empieza un importante interés sobre la conservación y restauración de los artefactos, ya que no era tan fácil encontrar piezas enteras y en perfecto estado y había que recurrir a otras "más imperfectas".

Hasta la década de los años 60 del siglo XX en Europa, o poco antes en la Arqueología americana, no se produjeron avances sustantivos en la forma de enfocar los datos arqueológicos, si exceptuamos la aportación teórica de V. Gordon Childe, el concepto de "cultura arqueológica"(CHILDE, 1956). Hacia mediado el siglo XX, la teoría antropológica comienza el giro hacia posturas evolucionistas y la búsqueda de leyes 
generales. Este movimiento aparece primero en los Estados Unidos, la llamada Nueva Arqueología, que supuso una revolución, dando origen a la Arqueología Espacial, el Análisis Territorial, la Arqueología Económica o la Arqueología de la Muerte (DANIEL Y RENFREW, 1988).

De todas las contribuciones positivas de la Nueva Arqueología la fundamental, es que el tratamiento de la información arqueológica se ve como algo internamente estructurado y ninguna de sus partes ha de ser estudiada olvidando las demás. Es en este momento de los años 60 y 70 cuando prolifera el uso de medios científicos, como los análisis químicos y físicos, la matemática (y posteriormente la informática), la fotografía y la documentación exhaustiva, en un afán por la recuperación de la mayor cantidad posible de restos y de información. En relación con esto hay que entender la eclosión de los métodos cuantitativos. A partir de este periodo de los 80 el debate arqueológico y la teoría alcanzan cotas que superan con creces las anteriores décadas, con personalidades destacadas como Glyn Daniel, Colin Renfrew, Lewis Binford, Adam Clarke o lan Hodder (FERNÁNDEZ, 1991).

A través de este breve resumen de la Historia de la Arqueología queremos apuntar la problemática de la utilización de recursos científicos y matemáticos a unos restos que son de origen humano y que no permiten una aplicación lineal de conceptos matemáticos, ya que el ser humano no se rige por conceptos lineales y sí por impulsos algunas veces bastante imprevisibles. Otro factor que debemos tener en cuenta es que la gran cantidad de artefactos e información recopilada amenaza con provocar un colapso por la falta de medios para almacenar los restos e interpretarlos de una forma conjunta, que acabará perdiéndose por el desconocimiento de su existencia, acuñando la expresión de que será necesario "volver a excavar en los almacenes de los museos".

Este panorama, que ya empezaba a vislumbrarse antes del desarrollo económico que se inicia al final de los años 70 una vez sobrepasada la crisis petrolera del año 73, provoca que la vorágine constructiva y urbanística empuje a la Arqueología a una carrera desesperada para intentar salvar los restos que se verán afectados por las obras. Como ya se arrastraba la herencia de una falta de criterio claro a la hora de recuperar y documentar, se elevó a límites inauditos la saturación de museos y centros de investigación, que acabaron en algunos casos por guardar directamente los restos recuperados en sus almacenes, "volviendo a enterrarlos" y llegando a veces prácticamente a olvidarse de su existencia. Esto también implicó el sacrificio de restos sin excavar en el campo o de bienes que se perdían por ausencia de la conservación preventiva de los mismos. Llegamos a la paradoja de que se invierte en investigación para detectar nuevos hallazgos, mientras hay restos prácticamente inéditos que se van perdiendo lentamente en los propios museos, faltos de unas medidas de conservación y restauración adecuadas.

\section{ESPAÑA}


Haremos solamente un breve resumen actualizado de esta etapa de la evolución de la Arqueología, que ya publicamos de forma más extensa en otros artículos (MELCHOR, 1993, 1996 y 2007) pues pensamos que no debemos extendernos demasiado en este aspecto dentro de nuestra tesis

Los siglos XVI y XVII se caracterizan por un interés generalizado en la búsqueda de antigüedades. La Real Academia de la Historia, fundada por Felipe V en 1738, es la institución encargada durante los siglos XVIII y XIX de proteger el patrimonio histórico y arqueológico de la nación y a ella se vinculan la mayor parte de los viajes de anticuarios subvencionados por la Corona y realizados por los eruditos más importantes de la época. La Historia Natural del siglo XVIII supone una nueva faceta, donde los restos arqueológicos y arquitectónicos pierden su papel protagonista y se realizan estudios de carácter algo más localista.

En un principio la tónica general es la misma que hemos apuntado en lo que se refiere a la recuperación de bienes que calificamos de "búsqueda de tesoros", con la diferencia de un hecho diferenciador respecto al resto de Europa, que fue la ocupación musulmana de la Península. Ello implicó la creación de un concepto que seguirá vigente prácticamente hasta nuestros días: la asociación de que todo lo que es anterior al presente pertenece a la "época de los moros"; esta idea ya figuraba en muchos escritos a lo largo de la época medieval y moderna (MELCHOR, 1996). Muy posiblemente hasta bien entrado el siglo XVIII, cuando desde la Corona y la Iglesia se empieza a impulsar un interés hacia lo romano, influenciado por los hallazgos italianos de Pompeya y Herculano, podemos decir que empezó a cundir entre los ciudadanos y eruditos la asociación de lo antiguo con el "tiempo de los romanos" en condición de igualdad o hasta de superioridad en comparación con la "época de los moros".

Debemos tener en cuenta que las abundantes riquezas de América dejaron en un segundo plano la búsqueda de tesoros en la Península, y que ésta empezó a agudizarse también con el inicio del ocaso del imperio español, que coincidió con la dinámica de recuperación de restos de la antigüedad romana en la Península.

El principal efecto de esa decadencia generalizada y de la crisis de la sociedad española fue que en todo el siglo XVIII y XIX España se convirtió en la cantera del resto de Europa para la obtención de bienes arqueológicos, situación que no disminuyó hasta que mediado el siglo XIX el impulso nacionalista burgués, unido al interés de los gobiernos, intentaron empezar a formar museos y colecciones nacionales. La ley estatal de 1911 sin duda fue un freno a las exportaciones ilegales. Independientemente del éxito parcial conseguido, era evidente que frente al resto de Europa, que ya se abastecía de los principales centros productores de bienes arqueológicos (como Sudamérica, África y Próximo Oriente), España llegó tarde a estos lugares que ya se encontraban ocupados por las potencias europeas y Estados Unidos. Esto sin duda obligó a una especie de autarquía arqueológica que además se cerró a las ideas y a 
los avances foráneos, con solamente algunas excepciones, en las que eruditos extranjeros o nacionales con formación en el exterior, destacaron en intervenciones puntuales.

Este nacionalismo romántico también fue impulsor del conocimiento de las culturas autóctonas de la Península, aunque matizadas por las modas de la época, básicamente en relación con las fuentes históricas clásicas o bíblicas. De ahí el interés por Tartessos, Sagunto, Numancia, etc.

Lamentablemente este panorama siguió durante muchos años, además con el agravante de que la guerra civil de 1936 y el franquismo reforzaron sobremanera el tradicional aislamiento científico. Solamente a partir del último tercio del siglo $X X$ se empezaron a generalizar y divulgar los avances y las teorías en boga en Europa y América. Pero en ese momento surge el problema de que el auge económico de final del siglo XX provoca el fenómeno ya citado de despegue urbanístico, que en el caso español implica que la cantidad de arqueólogos debidamente formados y con experiencia fuera insuficiente y la propia formación que reciben aún no está completamente madura. Muchos centros intentan asimilar demasiado rápido los conceptos científicos y matemáticos aplicados en el extranjero y acaban trasladando linealmente su uso a los restos arqueológicos, dando como resultados un auge de las teorías inductivas y neo-positivistas, generando estudios que en algunos casos son simples listados tratados por medios estadísticos.

A esto debemos sumar que las antiguas estructuras de poder formadas durante el franquismo y escasamente modificadas durante la transición generan centros de influencia que concentran los recursos disponibles en manos de unos pocos, lo que implica que en los puntos geográficos donde no hay medios se da una irremisible pérdida de información y de yacimientos. La relativamente reciente incorporación de la democracia a la administración pública (comparada con nuestro entorno europeo) y su fragmentación en distintas administraciones locales y autonómicas han provocado la proliferación de esquemas de gestión y funcionarios que en algunos casos no son los idóneos, lo que a veces constituye una traba para la recuperación, conservación y estudio de los bienes arqueológicos. 


\subsection{EL CASO VALENCIANO}

El área territorial que actualmente corresponde con la Comunidad Valenciana fue desde un principio un gran centro productor de bienes arqueológicos, debido a su situación privilegiada en el Mediterráneo, en muchos casos fácilmente asociables a las fuentes históricas como en los casos de Sagunto, Elche, Valencia, etc. Esta riqueza atrajo durante varios siglos a muchos eruditos, Escolano, Beuter, Cavanilles, el padre Flórez o el padre Mariana, entre otros.

A partir del siglo XIX prolifera la realización de obras monográficas. Los eruditos tienden a diferenciar lo "típicamente valenciano" dentro del núcleo romántico liberal de nuestra zona. Otro ejemplo de la literatura de la época es una obra de B. Mundina, una de las que más divulgación alcanzó en su momento, y que sirve de ejemplo de las características de este período, esencialmente una glorificación del presente por medio de su pasado: (...) fundada (Burriana) por Sicorio, rey de España, en el año 726 después del diluvio, ó sea 1600 años antes de J. C., Beuter opina que su nombre es palabra corrompida de Brigiana, dándole por fundador al rey Brigo de España (...) (MUNDINA, 1873:150). (En este caso el autor está copiando el Atlante Español)

Debemos buscar las raíces de unos estudios arqueológicos propios dentro de la citada reacción nacionalista de mediado el siglo XIX con la Sociedad Arqueológica Valenciana, que colabora con la Comisión Provincial de Monumentos y cuyas únicas referencias escritas las encontramos en los breves informes que se enviaban a la Real Academia de Historia o en notas de prensa. Para la provincia de Castellón solo tenemos noticias de excavaciones en el Grao de Castellón en 1851 y 1867 y en el castillo de la Magdalena en 1885. Esta Sociedad también mantiene una importante labor en defensa de las antigüedades de Sagunto (MELCHOR, 1996).

El inicio del siglo XX marca un punto de inflexión cuando se ordena el primer reglamento estatal de excavaciones en 1911, donde una de las normas más destacables establece la obligatoriedad de presentar un informe de la intervención para 
aquellas campañas que pretendían subvención estatal. Algunas de las excavaciones más significativas empezaron en Sagunto a partir del año 1921 bajo la dirección de Manuel González Simancas, así como en el poblado de La Serreta, excavado por Camilo Visedo Moltó en 1920. La Comisión de Monumentos de Castellón coordinó abundantes intervenciones, por ejemplo en 1924 en Villa Filomena (Vila-real), en el río Mijares, en Cabanes, San Mateo, etc. ${ }^{8}$

Pero el ya citado panorama regionalista valenciano sin duda colaboró a cerrar las puertas a buena parte de la investigación foránea, dejando a un lado casos puntuales de investigadores destacados como Bosch Gimpera. Como tónica dominante destacaban los sabios locales autodidactas, como Roque Chabás, José Sanchís Sivera o Nicolau Primitiu Gómez Serrano, entre otros. Esto ocasionó que la investigación fuera en gran parte autárquica y centrada en el núcleo valenciano alrededor de la Universidad, el Servicio de Investigación Prehistórica (SIP) de la Diputación de Valencia y el Centro de Cultura Valenciana.

En 1915, la Diputación Provincial de Valencia, fundó el Centro de Cultura Valenciana que contó con la colaboración del Ayuntamiento de Valencia que pronto se sumó a este proyecto; desde 1926 su estructura interna quedó configurada en las siguientes secciones: Lengua-Literatura, Etnografía-Folclore, Historia-Arqueología y PrehistoriaAntropología. Después de la guerra civil de 1936 prácticamente desaparecieron las actividades de la institución relacionadas con la Arqueología. También la Universidad se interesó por la Arqueología científica a través de la creación del laboratorio de Arqueología en 1924, dentro de la cátedra de Arqueología, Epigrafía y Numismática de la Universidad de Valencia, donde se realizaban prácticas de Paleografía, Numismática y Arqueología, pero que se vio rápidamente truncado por la guerra civil de 1936. Por otro lado, el Servicio de Investigación Prehistórica, creado junto al Museo de Prehistoria por la Diputación de Valencia en 1927, desarrolló en sus inicios una investigación totalmente amateur, en la que los que verdaderamente excavaban eran los capataces y los aficionados locales, y donde primaba la recolección de piezas de valor sobre la pesquisa científica. Su unión a los poderes políticos permitió que gran parte de los investigadores continuaran su labor después de las purgas franquistas en medios académicos (BONET et al., 2008).

Carlos Sarthou Carreres, dentro de la Geografía general del Reino de Valencia, publica en $1913^{9}$ una gran obra, concretamente el tomo de Castellón, con un carácter científico de recolección de datos y contrastación, preludio y base de muchos estudios posteriores.

\footnotetext{
${ }^{8}$ Referencias a esta documentación original la localizamos en el archivo de la Real Academia de Bellas Artes de San Fernando. Legajo Comisión Provincial de Monumentos de Castellón (años 1910-1935).

${ }^{9}$ Aunque en la edición original del libro no figura el año de publicación.
} 
De esta época cabría resaltar la creación de una escuela de investigación "culta", originada en las asociaciones de estudios o en las universidades, en contraste con la exploración aficionada, donde cronistas locales rescataban restos que sólo en algunas ocasiones trascendían a niveles superiores de investigación. De hecho, este modelo es el que ha venido repitiéndose hasta prácticamente el final del siglo XX. En Lo Rat Penat algún socio afín a la Arqueología alcanzó altos cargos en la entidad, como Manuel González Martí, elegido presidente en 1929, que había colaborado anteriormente con otros socios como Roque Chabás y José Sanchís Sivera; también Nicolau Primitiu Gómez Serrano tuvo su etapa de presidente, iniciada en 1932 (BONET et al., 2008).

Durante mucho tiempo la Comunidad Valenciana fue coto de estos cronistas que según su círculo de amistades se decantaban por centros de investigación catalanes o valencianos; pocos fueron los que se relacionaban con los centros madrileños para otra cosa que no fuese el depósito de objetos extraídos en excavaciones arqueológicas. En la actualidad se han perdido la mayoría de los materiales, los datos obtenidos por el excavador o incluso la localización de algún yacimiento (MELCHOR, 1996).

Durante el periodo correspondiente al primer tercio del siglo $\mathrm{XX}$ dos entidades, con importantes actividades arqueológicas, realizaron diversas actuaciones en la provincia de Castellón; en primer lugar la Associació Catalana d'Antropologia, Etnologia i Historia, que llevó a cabo importantes trabajos en la zona, entre 1910 y 1920 en colaboración con cronistas locales, sirviendo de intermediaria para que sus hallazgos llegasen a manos de estudiosos como Juan Colominas o Pere Bosch Gimpera. Conocidas son sus intervenciones en Xert, Morella, Miravet, Salsadella, Cuevas de Vinromá, Torre Endomenech, Pobla Tornesa, Borriol, Lucena del Cid, Cabanes y Traiguera, entre otras. Es destacable el buen nivel de estas publicaciones y el análisis de los hallazgos por parte de científicos destacados de la época (MORA y DÍAZ-ANDRÉU, 1997).

El Centro de Cultura Valenciana, con una importante implantación en Valencia y Alicante, estaba formada por eruditos locales y tomaría el relevo de la asociación catalana, dedicándose a la recolección de piezas que eran enviadas a la capital del Turia; esta actividad se complementaba con visitas y observación de los sitios arqueológicos para obtener más materiales. Entre ellos destacamos los yacimientos de Artana, Toga, y Torrechiva, con restos humanos, microlitos, puñales de bronce, etc. (MELCHOR, 1996).

Ciertamente un estudio profundo de la historiografía arqueológica de la Comunidad Valenciana podría de por sí ser objeto de una tesis doctoral, pero desde luego ésta no es nuestra finalidad; simplemente nos conformamos con presentar una muestra puntual que nos sirva para alcanzar el objetivo principal de este apartado: conocer la problemática de las investigaciones antiguas y la recuperación de restos en épocas acientíficas y de cómo esta situación afecta a la investigación actual. Entre las personas que actuaron en la zona objeto de esta tesis destacamos a Pascual Meneu, catedrático de árabe en Madrid, Salamanca y Granada, que gracias a su formación académica y a 
los contactos universitarios con arqueólogos, como por ejemplo José Ramón Melida, es considerado uno de los primeros excavadores con una mínima metodología científica de la Comunidad Valenciana. En Castellón descubre y excava los yacimientos ibéricos de Conena y Solaig (en Betxí), del Bronce como Serretes (Betxí) y el yacimiento romano del Pla Redó (Vila-real) (MELCHOR, 1996); de la misma época es Juan José Senent que fue inspector de primera enseñanza de la provincia de Castellón, Alicante y Valencia; gracias a su afición a la Arqueología realiza descubrimientos en este campo en toda la Comunidad. Recibía piezas y solicitudes de investigadores de la provincia y llevó a cabo excavaciones entre los años de 1910 a 1920 (DÍAZ-ANDRÈU et al., 2009).

Capitulo a parte merece Francisco Esteve Gálvez, maestro de escuela, inicia su trabajo como aficionado en 1920, abarcando la provincia de Castellón y las comarcas catalanas del Baix Ebre y Montsià. En 1926 ingresa en la Universidad de Barcelona para cursar estudios de Historia, donde desde un principio colabora con la sección arqueológica del Institut d'Estudis Catalans. Fue alumno de profesores como Pere Bosch Gimpera y Hugo Obermaier. Uno de sus primeros trabajos fue el presentar a un concurso de la Comisión Provincial de Monumentos de Castellón dos trabajos sobre estaciones prehistóricas en la Plana y en Borriol, por lo que obtuvo un premio en $1924^{10}$. En 1930 recibió el encargo de organizar el Museo Provincial de Castellón y es nombrado director del mismo, donde destacó por la salvaguarda del patrimonio durante la guerra civil de 1936. En 1982 donó a la Diputación de Castellón sus colecciones etnográficas y de cerámica (DÍAZ-ANDRÉU et al., 2009).

De este periodo es también Juan Bautista Porcar un pintor que en 1931 lleva a cabo un estudio sobre el término municipal de Castellón, donde realiza investigaciones arqueológicas. En 1939, es Comisario Provincial de Excavaciones Arqueológicas y prosigue las actuaciones en Castellón (MELCHOR, 1996). José María Doñate Sebastiá, archivero y cronista de Vila-real, hace estudios especialmente en su zona, pero abarca también buena parte de la provincia de Castellón. Debido a su falta de preparación en el campo de la Arqueología comete varios errores; por ejemplo en sus publicaciones expone que los tubuli romanos utilizados en las termas en verdad eran soportes para cirios o que las tapaderas ibéricas se colgaban de una cuerda para evitar que los ratones alcanzaran los jamones (DOÑATE, 1972).

Para la zona de Sagunto queremos destacar a Antonio Chabret especialmente por su obra Sagunto, su historia y sus Monumentos, que editó en Barcelona en 1888. Es éste su trabajo de juventud y ya prácticamente no publicará más estudios arqueológicos de peso, excepto el de su excavación de la necrópolis de la estación del ferrocarril. Chabret había estudiado Humanidades y Filosofía en el Seminario de Valencia, y Medicina en su universidad. Se presenta con un objetivo menos especializado y académico, pero su obra adquiere mayor valor histórico al hacer la valoración de las

\footnotetext{
${ }^{10}$ Real Academia de Bellas Artes de San Fernando. A-B. Legajo Comisión Provincial de Monumentos Cs. Años 1910-1935
} 
fuentes epigráficas, numismáticas y monumentales, que incluyen descripciones de excavaciones y, sobre todo, de piezas arqueológicas que son en la actualidad la única constancia de su existencia (DÍAZ-ANDRÉU et al., 2009). Otra personalidad saguntina es Facundo Roca Ribelles, restaurador y arqueólogo aficionado se le debe, junto a otros entusiastas por la Arqueología, la fundación del Centro Arqueológico Saguntino en 1957. Se le ha reconocido su labor en Sagunto, Teruel, Tarragona, Mérida, Sevilla o Zaragoza, donde restauró mosaicos, cerámicas, utensilios metálicos, inscripciones, monumentos, etc. En los años cincuenta realizó importantes trabajos, entre ellos la recuperación de mosaicos romanos hallados en las obras del mercado municipal y la sede de la Sociedad Musical Lira Saguntina. Fue también el descubridor y primer excavador del poblado del Bronce en el Pic dels Corbs (MELCHOR, 2007).

Volviendo al panorama general, lamentablemente la guerra civil de 1936 hizo que se perdiera la mayor parte de la documentación y de los restos arqueológicos fruto de estas décadas tan prolíficas para la Arqueología valenciana. A partir de este periodo se produce un cambio brusco en la mentalidad y en la línea de investigación de muchos profesionales; podemos citar artículos como el del Boletín del Centro de Cultura Valenciana de 1940: Nuestra adhesión al Caudillo y al nuevo régimen y La actuación del archivo-biblioteca municipales durante el periodo rojo ${ }^{11}$, donde el encabezado ya refleja toda una tendencia. Así, desde el golpe de Estado y durante casi 3 décadas se vuelve a una etapa similar a la que imperaba hacia final del siglo XIX, con una carga de romanticismo heroico y poca exactitud científica. También se truncó la mayor parte de las líneas científicas desarrolladas, un ejemplo claro es el de Pere Bosch Gimpera, ya que el franquismo primó el poder político y el nepotismo, lo que llevó al objetivo de contentar al régimen por encima del desarrollo de la propia investigación.

Esto sumió a la Arqueología valenciana en un periodo de estancamiento aislada del resto de Europa. Para que se inicien algunos trabajos puntuales en Castellón habrá que esperar prácticamente hasta Domingo Fletcher Valls, a final de los años 50, y Miquel Tarradell a final de los 60 , ya que anteriormente las actividades se centraban casi exclusivamente en Valencia, especialmente por medio del Servicio de Investigación Prehistórica. Estos investigadores ya tienen un nivel científico más elevado debido a su amplia experiencia profesional de campo y su formación universitaria, pero seguían dejando en manos de cronistas locales o capataces la recuperación de restos e incluso algunas veces la publicación e interpretación de los datos obtenidos. El caso que mejor conocemos es el de Castellón, donde la Arqueología ha estado mediatizada por la visión personal de estos intermediarios, como Nicolau de Sueca, José María Doñate, Antonio López, Norberto Mesado, Francisco Esteve, etc. También queremos matizar que no pretendemos hacer una crítica tajante a estas personas, que realizaron una importante colaboración al conocimiento de nuestro patrimonio, pero que entraron en un terreno criticable cuando se excedieron del campo de sus conocimientos o pensaron que la

\footnotetext{
${ }^{11}$ Ambos artículos aparecen en Anales del Centro de Cultura Valenciana en su edición de 1940.
} 
Arqueología es una "propiedad privada", tanto a nivel físico como intelectual.

La primera reacción que buscaba renovar la arqueología valenciana empezó tímidamente en los últimos años del franquismo, al inicio de los años 70 , personalizada en la figura de Miquel Tarradell, que creó una escuela en la Universidad que fue el germen que cristalizaría en la transición y se consolidaría durante la creación de la Generalitat Valenciana. Herederos de esta línea los podemos encontrar no sólo en las universidades valencianas, sino también en las diputaciones y en servicios municipales. En estos momentos surge otro elemento de gran importancia en el contexto de la historiografía reciente de la arqueología, la mujer empieza a tomar un papel destacado en el mundo de investigación académica, podemos citar a Carmen Aranegui Gascó y Milagros Gil-Mascarell como dos de las pioneras en los estudios de la cultura lbera y Romana que también realizaron estudios en la zona de Castellón.

La problemática que surge es que esta corriente siempre buscó una ruptura total con las anteriores, lo que fue en algún caso muy acertado pero en otros no tanto. Sin duda fue beneficiosa la quiebra con la influencia política e ideológica fascista y la entrada de nuevos aires europeizantes en la búsqueda de la profesionalización y del carácter más científico de la Arqueología, y sin embargo fue prejudicial el desprecio radical a muchos estudios anteriores y el establecimiento de nuevas teorías a modo de dogmas sobre la base de unos recursos científicos disponibles que aún no eran los idóneos, pues no debemos olvidar que la Arqueología es una ciencia que está en una constante evolución directamente proporcional al aumento de los conocimientos provenientes de las excavaciones, y justamente en el periodo de los años 70 las intervenciones eran mínimas comparadas con las que empezaron a partir de aquel momento.

Mediados los años 70 en Castellón surgen el SIAP de la Diputación y el Laboratorio de Arqueología del Colegio Universitario de Castellón ${ }^{12}$, dirigidos respectivamente por Francesc Gusi y Carmen Olaria, siendo esta última la primera mujer con responsabilidad institucional al frente de un organismo vinculado a la arqueología en Castellón. Estas entidades fueron durante casi dos décadas las únicas fuentes de estudios y publicaciones que abarcaban la provincia, con la excepción del Museo Comarcal de Burriana. Lamentablemente la clara formación de prehistoriadores de estos provocó algunas deficiencias en la arqueología romana y medieval de la provincia. Además de la eclosión de estudiosos locales y museos en la provincia a partir de finales de los 80 , nos resta hacer mención a dos investigadores que realizan abundantes estudios que abarcan amplias zonas de Castellón. Se tratan de Ferrán Arasa y Ramón Járrega, ambos empiezan a destacar a principio de los 90 y centran sus estudios en el periodo ibero y romano.

\footnotetext{
${ }^{12}$ Este siguió bajo el mismo formato y denominación cuando el citado Colegio pasó a ser la Universitat Jaume I de Castellón. 


\subsection{UN EJEMPLO LOCAL: BURRIANA}

Queremos destacar como paradigma el caso de Burriana, caso que conocemos bien, donde hay una sucesión de estudiosos desde el inicio del presente siglo. Desconocemos por el momento cual fue el principio de las investigaciones arqueológicas, tan solo tenemos referencias indirectas, pero es muy probable que el impacto que generó el hallazgo de restos arqueológicos en la vecina Vila-real entre 1921 y 1924, concretamente en Villa Filomena, y que despertaron un amplio interés a nivel nacional, fuera un importante aliciente que espoleó a los eruditos locales. Respecto a las sutiles referencias que citamos antes, Vicente Forner (FORNER, 1933) cita excavaciones en Vinarragell, que encontraríamos referenciadas en las actas de la Comisión de Monumentos de Castellón del 30 de Octubre de $1924{ }^{13}$ cuando Benito Traver propone que se hagan investigaciones arqueológicas, en la zona del puente de Vila-real, donde él intuye que existen restos arqueológicos; su propuesta fue aceptada, pero no sabemos nada más. Es muy probable que restos interesantes en la desembocadura del Mijares, aguas abajo de Vila-real, como el Castell Vell de Almazora y Vinarragell, fueran objetivo de estas exploraciones. De los principales eruditos que tuvo Burriana en el siglo XX haremos un breve resumen biográfico:

Vicente Forner Tichell (Burriana, 1850-1928). Uno de los primeros estudiosos locales de los que tenemos noticia; abogado republicano que publicó dos libros sobre la familia Viciana y su relación con Burriana, y posiblemente el primer artículo sobre Vinarragell en la bibliografía de Castellón (FORNER, 1933). Colaboró con Francisco Roca y Alcaide, según el cual dejó dos obras inéditas sobre la ubicación de yacimientos ibéricos y los primeros pobladores de Burriana (ROCA, 1932). Este estudio se publica a titulo póstumo en 1933, de cuya lectura se desprende que se redactó alrededor de 1926 (FORNER, 1933), coincidiendo con los trabajos de Traver, antes citados. A través de sus publicaciones podemos observar su falta de preparación arqueológica, aunque el proceso deductivo y analítico a nivel histórico no carece de valor. Sus trabajos también tienen el interés de haber consultado documentos que ya no existen.

\footnotetext{
${ }^{13}$ Real Academia de Bellas Artes de San Fernando. Archivo Biblioteca. Legajo Comisión Provincial de Monumentos de Castellón años 1910-1935. Signatura 4-58-15.
} 
Joaquín Peris y Fuentes (Burriana, 1854 - 1939). Abogado y político republicano, era un terrateniente de la zona. Sus actividades documentadas se inician entre 1910 y 1912 , pero podemos suponer que ya desde 1900 realiza descubrimientos en toda la provincia, llegando a colaborar indirectamente con la Associació Catalana d'Antropologia. Nunca llegó a publicar ningún estudio extenso de sus numerosos hallazgos, entre los cuales destacamos la excavación de más de 50 incineraciones en la zona de Cabanes con urnas (AA. VV, 1915-1920:627). Contaba con una abundante colección de antigüedades, entre las que podemos citar restos eneolíticos, puntas de lanza de hierro, etc. C. Sarthou cita su colección como "pequeño museo" (SARTHOU, 1913: 773). Realiza diversos estudios inéditos sobre las aguas del río Mijares, documentos de la Corona de Aragón, sobre el carlismo o el plano de la ciudad en época musulmana, los cuales se encuentran en el Museo de Burriana ${ }^{14}$, tenía además una inmensa biblioteca de consulta. Sus publicaciones fueron muy breves, por ejemplo, citamos: (...)encontré seis urnas cinerarias, y en una de ellas un objeto cilíndrico de $6,5 \mathrm{~cm}$ de largo por $1 \mathrm{~cm}$ de diámetro, objeto que no conozco y supongo un adorno ibero (...) aparecieron dos piedras que componen un molino de los primeros de la venida de los iberos; (...) y debe de ser de más de mil años antes de Cristo, porque Homero en la Odisea ya habla de esta clase de molinos (...) En una finca mía encontré una urna cineraria que tenía dentro una planchita de cobre atacada por los microbios (...)se diferencia de todas las demás que he visto en el país por ser la única con dibujos (...) (PERIS, 1922: 221). Como hemos podido observar se trata de un erudito que se dedicaba a variados campos de la Historia; su falta de especialización en la Arqueología le llevaba a cometer errores. Otra característica suya era no desvelar el lugar de los hallazgos, fuente de materiales para su colección, sobre la cual ejercía celosamente su derecho de propiedad: (...) Cometiendo un abuso de confianza un señor mandó una fotografía de dicho cipo a la Academia de Historia como descubrimiento suyo (...) (PERIS, 1922: 219). Al sufrir persecuciones políticas en la guerra civil de 1936 su colección ha desaparecido en parte sin ser estudiada. Hombre con grandes recursos económicos, se sabe que pagaba a los investigadores para que localizasen datos sobre Burriana.

Manuel Peris y Fuentes (Burriana, 1857-1932). Pariente de Joaquín, de profesión abogado, publica una serie de artículos históricos sin base arqueológica, muy en la línea del romanticismo del siglo XIX. En 1920, en el Boletín de la Sociedad Castellonenca de Cultura, Manuel Peris (que seguía puntualmente los pasos de su pariente en la Arqueología y en su primera etapa le donaba incluso los restos encontrados por él mismo) habla de una estación eneolítica, cuyos restos entrega a J. J. Senent y al Laboratorio de Arqueología de Valencia (PERIS, 1920). Fue miembro de Lo Rat Penat.

Francisco Roca y Alcaide (Puzol, 1881 - 1973). Maestro de escuela en Burriana, presenta en 1931 la primera publicación histórica que pretende centrarse únicamente en Burriana. Director de las Escuelas Graduadas de la ciudad realiza un compendio donde

\footnotetext{
${ }^{14}$ Museo Arqueológico Municipal de Burriana. Legajo JP 
repite los errores de la época. Pero la importancia de la obra está en la descripción de una serie de restos encontrados en los años en los que se edita el libro y donados al museo municipal que existía en la ciudad en 1932 donde podrían existir más piezas no comentadas por el autor. Entre estos materiales podemos citar las lanzas romanas, una inscripción ibérica de Cabanes, dos lápidas romanas, dos capiteles y los dos molinos de trigo presuntamente romanos de Joaquín Peris y Fuentes, una inscripción romana, monedas antiguas, etc. En la actualidad pocos de estos hallazgos se encuentran en el Museo de Burriana.

Tomas Utrilla (Soria 1921 -Campello 2000). Religioso salesiano, es el primer investigador conocido después del interregno en la Arqueología local que significa la guerra civil de 1936; su actividad se da a conocer en los primeros años de los 60 del siglo XX, cuando realiza estudios arqueológicos en Burriana, en yacimientos como Torre de Onda, Vinarragell y el Palau. Publica la necrópolis ibérica de Tirao, el yacimiento Eneolítico de Llombay y un nivel neolítico en el Palau y da a conocer sus resultados someramente en la revista local BurisAna. En la actualidad no se conoce el paradero de estos materiales.

Norberto Mesado Oliver (Burriana, 1938). Empieza sus tareas arqueológicas como aficionado colaborando con Tomás Utrilla y pronto toma la dirección en solitario, ampliando sus investigaciones en el término municipal con nuevos yacimientos. Retoma la tradición de los investigadores burrianenses de principios de siglo y recupera materiales prácticamente de toda la provincia de Castellón, a lo largo de sus visitas a distintos yacimientos. Gracias a él se conserva en el Museo de Burriana el Hermes de Xilxes, ya que después de haber estado en propiedad de su descubridor como elemento decorativo encima de un armario, logró convencerle para que lo vendiese por 2.000 pesetas en 1967. Administrativo encargado del archivo, biblioteca y museo, este último reabre sus puertas en el año 1967 con el reconocimiento oficial de la Administración. Siguió actuando como amateur hasta que al final de los 70 se licencia en Arqueología.

Observamos que gran parte de los descubrimientos importantes a nivel arqueológico se remontan al final del siglo XIX y primera mitad del siglo XX, y evidentemente aquellas épocas no eran las más idóneas en rigor científico y criterio en las intervenciones; a raíz de esto podemos intuir algunos problemas de los que adolece la Arqueología local hoy en día: la creación de teorías o análisis que tienen una base poco rigurosa y que pueden originar vicios interpretativos que acaben surgiendo en la actualidad. Como en los casos anteriores podemos comprobar que la presencia de la mujer en la labores de excavación o de investigación son prácticamente nulas, es solamente a partir de principio de los años 90 cuando empiezan a surgir en el panorama local; en un primer momento como investigadoras relacionadas con la historia medieval o moderna, como el caso de Carmen Corona o María Dolores Agustí. Pero no es hasta finales de la citada década cuando surgen las primeras intervenciones arqueológicas dirigidas por mujeres, y que desembocan poco después en varias publicaciones. 


\section{SEGUNDA PARTE: DATOS ARQUEOLÓGICOS}


CAPITULO 1: PROBLEMÁTICA DE LAS CIUDADES ROMANAS: SAGUNTUM A PARTIR DE EXCAVACIONES ARQUEOLÓGICAS 
En este apartado de la presente tesis describiremos las excavaciones arqueológicas (ver Láminas $\underline{\underline{I}}$ y $\underline{\mathrm{L} L V}$ ) que nos sirvieron de base para establecer una teoría general, aplicable a la ocupación romana del territorio objeto de este estudio y citaremos puntualmente aquellas realizadas en Valencia que puedan servir de complemento a las primeras. Parte de estas permanecen inéditas, ya que en el mejor de los casos sólo se han publicado resúmenes de las mismas. Todas ellas han sido dirigidas o co-dirigidas por nosotros. Éstas serían:

- Plaza de la Morería (Sagunto) - Aquí apreciamos tres fases constructivas de época romana. En este solar destacamos dos grandes edificios del Alto Imperio asociados a una calzada porticada con cloaca central y, al menos, dos casas de época del Bajo Imperio.

- Calles Huerto s- Ordóñez - Remedio (Sagunto) - En esta intervención destacamos un gran edificio del Alto Imperio excavado sin metodología científica en los años 70 del siglo XX y reexcavado por nosotros.

- En la ciudad de Valencia citamos las intervenciones de la Calle Santa Rita esquina Cronista Rivelles (aparecen restos de una traza urbana de época romana en la zona extramuros de la ciudad antigua); Calle San Vicente 26-32 (con una necrópolis asociada a la vía Augusta con tres fases de época romana) y Calle Serranos 26 (con restos de una probable necrópolis en hipogeos). 


\subsection{RESULTADOS DE EXCAVACIONES ARQUEOLÓGICAS EN} SAGUNTUM

Parte de las informaciones que permiten reconstruir la historia de la ciudad provienen de la Arqueología; sin embargo, los datos de que hoy en día disponemos en ese campo no proceden sólo de las actividades actuales, vienen también de la erudición de los viajeros que desde el siglo XVI acudieron a la ciudad en busca de sus antigüedades, describiendo y dibujando monumentos que estaban en pie y que luego fueron derribados, como el circo, el teatro romano, mausoleos o el foro del castillo. Sagunto es una ciudad donde se han realizado múltiples intervenciones arqueológicas y la búsqueda de sus antiguos restos se remonta como mínimo al siglo XVIII, como ya reflejamos en otros apartados de esta tesis

Respecto al castillo y el foro la zona fue fruto de varias excavaciones, las primeras documentadas las tenemos en el siglo XVIII, como las del irlandés Conyngham a las que podemos sumar de Antonio Despuig (RIPOLLES, 2007). Sin duda se produjeron mas intervenciones en la zona, pero no han quedado documentadas, y debemos esperar a González Simancas, que entre los años 20 y 30 del siglo XX realizó varias intervenciones en la zona de las Plazas de Armas, de Estudiantes y San Fernando y no será hasta después de la guerra civil cuando Pío Beltrán realice nuevas excavaciones las Plazas de Estudiantes y San Fernando (BELTRÁN, 1956) que no verán continuidad hasta 1976 con Pierre Rouillard, que excava una zona alejada del foro, en la parte de la muralla ibérica en la zona de Tres Pouets. Ya en 1987 y hasta 1995 es cuando el equipo de Carmen Aranegui retoma las excavaciones en el foro romano y en la Plaza de Armas (ARANEGUI, 2004). Otro edificio monumental excavado fue el circo, primero por Chabret a finales del siglo XIX y posteriormente Santiago Bru en los años 60 aún pudo documentarlo antes de su práctica destrucción. La segunda excavación arqueológica fue en él fue en el año 1988 en la calle Obispo Miedes (HERNÁNDEZ, 1988). El resto de intervenciones conocidas son las de Ignacio Pascual en 1994 en el solar de la calle Huertos 27 esquina Obispo Miedes 12 y en la puerta del circo en la calle Huertos en 1996, en el mismo solar donde después actuarían Ricardo González y 
Carlos Verdasco en 2007. También tenemos noticias de una intervención en 1993 en la calle Huertos esquina General Canino (PASCUAL, 1998).

Respecto al resto del casco urbano, son innumerables las excavaciones realizadas, pero lamentablemente la información disponible sobre la mayoría de ellas es inexistente o muy escasa, pues Sagunto no cuenta con un Servicio Municipal de Arqueología al uso, que centralice o coordine la arqueología urbana de la ciudad. Un vaciado de esa información y su actualización supondría en si misma una tesis doctoral

Respecto al Grau Vell, antes del inicio de las excavaciones, del año 1974, Santiago Bru ya había iniciado los trabajos de localización del puerto de Saguntum. Las noticias anteriores sobre este enclave portuario eran escasas, destacando el artículo de González Simancas en "Las Provincias" del año 1945 donde comunica la existencia de una necrópolis romana en el Grau Vell basándose en las inscripciones aparecidas durante la construcción en 1938 de los refugios para las baterías de costa, depositadas por Mariano Gómez en el Museo de Sagunto y publicadas por Pío Beltrán. El yacimiento ha sido objeto de 16 campañas de excavación arqueológica en tierra firme desde el año 1974, la mayor parte de ellas financiadas por la Conselleria de Cultura de la Generalitat Valenciana, de 3 prospecciones y una campaña de excavación subacuática coincidiendo, esta última, con las obras de ampliación del actual puerto de Sagunto. La abundante obra sobre el yacimiento despega con las noticias iniciales a cargo de su primera excavadora Carmen Aranegui, pasando por una continuidad de publicaciones sobre las distintas campañas llevadas a cabo en el enclave (ARANEGUI, 2004), llegando a interesantes investigaciones subacuaticas o geomorfológicas (ARANEGUI et al. 2005). 


\subsection{PLAZA DE LA MORERÍA}

\section{DATOS HISTÓRICOS}

El nombre de Sagunto es citado en los escritos clásicos fundamentalmente a raíz de la segunda guerra púnica, convirtiéndose en el episodio más importante del largo enfrentamiento por la hegemonía en el Mediterráneo occidental. Este terminó, en favor de Roma, con la tercera guerra púnica y la destrucción de la ciudad de Cartago en 146 a. C. A lo largo del siglo II a. C., tras la destrucción sufrida por la ciudad durante la segunda guerra púnica, Roma no sólo restituye la ciudad sino que también la amplía, ocupando nuevas zonas todavía sobre la cima del cerro. Dos siglos más tarde, en época julio-claudia, la construcción del foro y el teatro suponen un nuevo impulso urbanizador que anula parte de la planificación monumental anterior, a la vez que la ciudad comienza a extenderse por la ladera norte de la montaña, hasta el último gran salto de roca, en la línea formada entre la puerta Ferrisa y el ayuntamiento (ARANEGUI y OLCINA, 1983).

La ciudad se amplia hasta aproximadamente el siglo IV d. C., cuando entra en decadencia y se repliega hacia la falda de la montaña en época visigoda. Esta configuración urbana permanecerá hasta el periodo musulmán, cuando la urbe vuelve a extenderse por las terrazas del Palancia. En la Edad Media todo el terreno que ahora ocupa la estación de ferrocarril tenía la denominación de la partida de Cabañal, por sus características de zona abierta y poco poblada (CHABRET, 1898). No es hasta la última etapa del siglo XVIII cuando Sagunto empieza a expandirse, aunque a un ritmo bastante lento, y solamente despega con la introducción del ferrocarril y la construcción del puerto comercial a finales del siglo XIX y principios del XX.

\section{ANTECEDENTES ARQUEOLÓGICOS}

Las primeras intervenciones se refieren al hallazgo del mosaico de Baco y de una serie de paredes asociadas al mismo durante la segunda mitad del siglo XVIII. A final de la 
centuria siguiente A. Chabret documenta la aparición de una necrópolis y otras estructuras durante las obras realizadas en la estación de ferrocarril (CHABRET, 1899).

En el siglo XX el Ayuntamiento de Sagunto proyectó dotar a la ciudad de un alcantarillado nuevo y las primeras obras, hechas en 1943, consistieron en la construcción de un colector que recogiese las aguas residuales y de lluvias en la calle Camí Real para darles salida al río, siguiendo la carretera de Barcelona. P. Beltrán, en la zanja abierta para el alcantarillado en el trozo comprendido entre las calles de la Rosa y Alorco (aproximadamente $40 \mathrm{~m}$ ), documentó varias hiladas de sillares romanos consecutivos, de las cuales la más profunda estaba asentada sobre la roca; los atribuyó a los restos de la antigua muralla romana, coincidiendo casi con el centro de la calle (BELTRA, 1951). De este muro se veían salir otras paredes perpendiculares, más estrechas y no descubiertas totalmente, que pasaban por debajo de las casas números $126,128,130,134$ y 138, sin que pudieran ser determinadas sus características ni su época. Suspendidas las obras a partir de la esquina de la calle Alorco, fueron reanudadas desde el río siguiendo la carretera de Barcelona; pero la zanja dio únicamente niveles sin restos arqueológicos y más abajo la roca propia del subsuelo, dándole al autor la sensación de que se trataba de arrastres llevados por una corriente de agua. En la calle de Almenara, frente a la casa número 7, entre los cantos rodados y la tierra, salió una losa plana de piedra azul negruzca del terreno (BELTRÁN, 1951), con una inscripción funeraria de los siglos I-II d. C., que tiene sus letras teñidas de rojo (IRSAT, 159 - CORELL, 2002). En esa misma zona J. Corell cita el hallazgo de un plato con inscripción votiva a Venus (CORELL, 2002).

Durante las excavaciones realizadas para la instalación del alcantarillado y pavimentado de la calle Alorco el año 1956 o 1957, aparecieron hasta ocho silos. Cinco de ellos estaban intactos, vacíos y con tapa, mientras que los otros tres estaban rellenos de escombros debido a que se habían hundido. Estos fueron documentados por F. Roca, que cita noticias de hundimientos debido a otros silos que hay debajo de las casas de esta calle (ROCA, 1976).

Este investigador exploró alguno de ellos y tomó las medidas dentro de lo posible debido a una cañería de agua que reventó. Todos tenían las mismas características, aunque de diferentes tamaños. Sus medidas aproximadas son: altura de 2 a $3 \mathrm{~m}$ y la anchura de 2,30 a 2,40 $\mathrm{m}$. Son de forma ovoidal, teniendo en el centro una boca estrecha como un cuello de botella, cuyas medidas son de 30 a $35 \mathrm{~cm}$ de altura y de $1,5 \mathrm{~m}$ a $50 \mathrm{~cm}$ de anchura. La mayoría estaban tapados con losetas de rodeno y sólo dos con teja romana. En el escombro caído al fondo de uno de ellos, se recogió parte del arco decorado de una fíbula probablemente del siglo I o II d. C. (ROCA, 1976).

En el año 1964, F. Roca procede a la excavación de la estructura conocida como monumento funerario del colegio Romeu (ROCA, 1964), que analizamos detenidamente en otro apartado de esta tesis. 
En octubre de 1991 y debido a las obras que se realizaban en la calle Camí Real 86, se dio aviso al Museo Arqueológico, por parte del propietario de dicho inmueble, de la aparición de unos restos constructivos de grandes dimensiones y de época presumiblemente romana. El descubrimiento tuvo lugar al ser derribada la pared sur de la casa, comenzando a partir de ahí en dirección Norte-Sur y por debajo de la calle Muralla, I. Pascual documentó el hallazgo, que se sitúa sobre una marcada curva de nivel de la falda del cerro del Castillo, en pleno trazado de lo que después fue la muralla medieval de la ciudad de Sagunto. Se trata de los restos de dos paramentos que se cortan en ángulo recto, realizados en opus quadratum a base de grandes bloques de piedra caliza dolomítica, perfectamente escuadrados y de dimensiones regulares de $1,20 \times 0,60 \times 0,40 \mathrm{~m}$ (PASCUAL, 1991). En el año 1992, I. Hortelano excavó en la iglesia del Salvador, donde detectó niveles republicanos hasta el Bajo Imperio (HORTELANO, 1993).

Las excavaciones realizadas en el solar del Romeu de Sagunto por M. López y P. Chiner en la primera mitad de los 90 del siglo XX dieron a conocer restos de época romana, medieval y moderna (ver Foto 147). Los principales son los conocidos como domus $\mathrm{A}$ y domus $\mathrm{B}$, limitadas por sendas vías enlosadas. Ambas se abandonaron en época del Bajo Imperio en un momento situado entre final del siglo III d. C. y la primera mitad del IV d. C. Cubriendo estas estructuras romanas existe una ocupación medieval y moderna que parece mantenerse hasta final del siglo XVI (LÓPEZ y CHINER, 1994).

Las excavaciones llevadas a cabo por C. Antoni, F. J. Hernández y J. M. de Antonio en el año 2002 en el solar del cine Marvi, documentan cuatro estancias de un recinto doméstico del siglo II d. C., con una remodelación del siglo III y una fecha de abandono del siglo IV d. C., con un conjunto de pintura mural ornamental, entre las que destaca el tema marino del estanque (De ANTONIO et al., 2002).

\section{INTERVENCIÓN ARQUEOLÓGICA}

Desde el mes de junio del año 2002 hasta mayo del 2005 se realizó en el solar situado entre las calles Alorco, Huertos y plaza de la Morería de la ciudad de Sagunto una importante excavación arqueológica, tanto por su extensión $\left(1.700 \mathrm{~m}^{2}\right)$ como por la cuantía y calidad de los hallazgos, que la sitúan muy por encima de cualquier otra efectuada hasta el momento en el casco antiguo de la ciudad (ver Lámina XXIV). La secuencia estratigráfica es compleja, desde la época republicana hasta la actualidad.

El estrato superficial tiene mucho espesor, aproximadamente $1 \mathrm{~m}$, y presenta las mismas características en todo el solar. Se trata de una capa de tierra arcillosa de color pardo poco compacta, en la que se incluyen algunas piedras menudas y cantos. Ésta cubre un segundo nivel de colmado de unos $50 \mathrm{~cm}$ de espesor, de tierra arcillosa relacionada con una zona de huerta (ver Foto 492 ). Bajo este estrato hay un tercero 
que enrasa la mayor parte del solar, formado como consecuencia de la ruina y posterior derrumbe de los muros y bajo el cual están los cimientos de época bajo medieval.

La interacción entre los estratos de construcción es muy frecuente en la excavación, ya que casi todas las estructuras arrancan sobre niveles de cronología anterior. Así los cimientos se construyeron sobre acumulaciones de tierra de composición arcillosa y gran cantidad de piedras, mampuesto de mortero o lechadas de mortero de cal, para de este modo equiparar el nivel de suelo de las diferentes estancias.

De forma paralela a la excavación arqueológica se han elaborado distintos estudios analíticos y trabajos complementarios: conservación y restauración de cerámica y monedas, consolidaciones in situ, extracción de restos de pintura mural, estudios paleopatológicos de las incineraciones, etc.

La excavación de los diferentes estratos y/o niveles arqueológicos nos ha permitido distinguir ocho periodos cronológicos claramente diferenciados.

\section{ETAPA REPUBLICANA E IBÉRICA TARDÍA}

El nivel de cronología más antigua descubierto es de época republicana (Ver Lámina $\underline{X X V})$. En el sector Sur y SE del solar este nivel corresponde a un conjunto bastante homogéneo de cimentaciones de mampuesto de barro, por otro lado muy arrasadas, que hallamos localizadas bajo un recinto cementerial del Alto Imperio. La zanja de cimentación de las mismas está abierta directamente sobre el nivel estéril basal de arenas y zahorras, pero debido a su mal estado de conservación no hemos podido establecer la cronología exacta. Con todo, es significativa la presencia en la zona de numerosos fragmentos informes de cerámica ibérica, púnica y campaniense $A$ y $B$. Es destacable la anchura de las cimentaciones, que varían de 50 a $70 \mathrm{~cm}$, tratándose en todos los casos de construcciones de planta y disposición rectilínea.

\section{ETAPA IMPERIAL JULIO-CLAUDIA}

En época romana del Alto Imperio, aproximadamente alrededor del cambio de Era, encontramos una fase de ocupación distinta (ver Lámina $\underline{X X V I}$ ), cuyo espacio estaba organizado en torno a una vía. Las losas de piedra caliza cubren gran parte del trazado de la vía; no obstante, en los tramos donde estas no se conservaban, procedimos a excavar bajo las mismas. Los estratos de construcción se reducen a dos niveles realizados para asentar las losas. El primer nivel aparece justamente por debajo de las mismas, tiene $40 \mathrm{~cm}$ de espesor y está compuesto por arenas amarillentas, gravas, zahorras y pequeños cantos de fracción fina muy rodada; bajo este nivel de construcción aparece otra capa de gravas de granulometría media y arenas amarillentas, que tiene una potencia de 30 a $40 \mathrm{~cm}$ de espesor y que hallamos extraordinariamente compactada. Debajo de éste se suceden los estratos de origen 
natural formados por arenas, zahorras y gravas. Los materiales cerámicos recuperados en los niveles de construcción de la calzada son escasos, entre ellos podemos destacar fragmentos de TSS y de cerámica común; su presencia y, por otro lado, la ausencia de TS Africana, señalan una fecha provisional anterior al siglo II d. C.

Al Este de esta vía se localizaron restos constructivos pertenecientes a un mínimo de ocho estructuras funerarias en distinto estado de conservación, donde se practicó el rito de incineración. Este hallazgo es de gran importancia, pues es la primera vez que en el núcleo de la población actual se excava científicamente un recinto de carácter cementerial romano con este ritual. También se identificaron restos de otros inmuebles funerarios, pero en un estado de conservación bastante deficiente, lo que no nos ha permitido hasta el momento concretar su morfología. Estos se levantan sobre un nivel de relleno de composición arenosa caracterizado por la presencia de gran cantidad de cantos de río, algunos de gran tamaño, escasos fragmentos de cerámica ibérica, púnica y republicana, así como abundantes pellas de hierro. Este estrato fue aportado durante este periodo para rellenar y nivelar el terreno sobre el que se construirían las estructuras del Alto Imperio.

En algunos loculi se han registrado ajuares, siendo el denominador común la presencia de ungüentarios de vidrio, vasos de paredes finas e instrumental de hueso. Los más cercanos a la vía parece que se han construido a la par, como lo demuestra el hallazgo de monedas de la misma época en su interior, y ocupan una posición bastante centrada respecto al espacio cementerial. La fecha de edificación de estos monumentos se sitúa a principio del siglo I d. C., gracias a los ajuares (que analizamos mas adelante), y forma parte de un momento de expansión y de florecimiento urbanístico que tiene lugar en la parte baja del ámbito urbano de Sagunto.

\section{DESCRIPCIÓN DE LOS ÁMBITOS FUNERARIOS}

\section{Monumento funerario " $A$ "}

El ambiente funerario estaba originalmente ocupado por las UEs. 1119, 1156 y 1040, que se hallaban situadas en el centro de la construcción. Ha sido imposible determinar las dimensiones de la misma, pues se hallaba completamente transformada por dos construcciones de la domus posterior, que afectó de forma directa al enterramiento; así por ejemplo, entre el barro que traba los muros del Bajo Imperio, se observaban abundantes fragmentos de hueso. Una fosa medieval afectó parcialmente este espacio.

Corresponde a la UE 1194, donde la incineración (UE 1195) la documentamos en posición bastante centrada en el interior de la estancia, junto al paramento oeste del muro, por debajo del nivel del suelo -cuya impronta aparece en el interior del edificio- y en el interior de una cista elaborada con losas de rodeno. Las dimensiones del interior del habitáculo son de 2,75 m de longitud por 1,80 m de anchura. 
Toda la planta conservada de la estructura funeraria apareció cubierta por una habitación del Bajo Imperio, lo que sin duda ha permitido su conservación parcial, pues posiblemente con anterioridad se saquearon todos los materiales nobles que pudiera contener el enterramiento. En época medieval se practicó una gran fosa que afortunadamente sólo afectó de manera colateral a este espacio funerario.

El enterramiento se encontraba intacto y aportó una estratigrafía completa que reproduce parte del ritual romano. El ajuar apareció depositado sobre un estrato de tierra de color beige, en el que se encontró la mayor cantidad de huesos calcinados, concretamente huesos grandes (corresponderían a los huesos recogidos de la pira funeraria y lavados antes de su deposición en la tumba). Bajo esa capa aparece un nivel gris con ceniza y abundantes huesos de pequeño tamaño (posiblemente recogidos directamente de la pira) acompañados de restos de la fauna; en el nivel inferior apareció una cantidad importante de carbones.

El loculus (UE 1220) estaba originalmente situado en el centro de la construcción, junto al paramento oeste del muro (UE 1219), del que sólo se conserva un fragmento de adobe rubefacto con carbones y cenizas dispersos alrededor de él. Las dimensiones interiores del departamento son 2,98 $\mathrm{m}$ de longitud por 1,86 $\mathrm{m}$ de anchura. Toda la estructura apareció amortizada por una habitación de la domus del Bajo Imperio. La gran fosa medieval arrasó prácticamente la totalidad de este ambiente, de tal forma que los escasos restos del enterramiento aparecieron dispersos dentro del edificio.

En la última dependencia los huesos aparecen en el loculus rectangular (UE 1119), mezclados con abundantes cenizas y carbones, junto a parte del ajuar (instrumentos de hierro, vasos de paredes finas, moneda y lucerna), tratándose del enterramiento más rico de los tres. Por la composición del estrato podemos suponer que se trata del fondo de la fosa y que los estratos superiores fueron arrasados en época del Bajo Imperio. En el extremo Noroeste de la sepultura, aparecen enterrados en una cista circular (UE 1147) varios animales de pequeño tamaño acompañado de un pondus (UE 1156); junto a la incineración aparecieron los restos de una masa rectangular de adobe, pero el muro de la domus del Bajo Imperio había destruido gran parte de la misma. Junto al adobe apareció una fosa circular (UE 1040) de $86 \mathrm{~cm}$ de diámetro, con ungüentarios de vidrio que no habían sufrido la acción del fuego, y abundantes carbones.

Respecto a la interpretación de las estructuras podemos encontrarnos ante un monumento funerario de carácter familiar, con tres espacios funerarios con idéntica disposición, uno de ellos mucho mayor y más rico. La cronología aportada por los ajuares, analizados más adelante en esta tesis, que situamos entre el cambio de Era y el final del reinado de Tiberio junto con la construcción de ambos espacios prácticamente adosados, podría avalar la teoría de la edificación en un corto periodo. 
Así pues, hemos excavado un enterramiento femenino completo con su ajuar (UE 1196) y claras muestras de ritual y ofrendas de animales neonatos (unidad 1157). También documentamos un enterramiento doble, quizá de un hombre (UE 1119) por la riqueza del ajuar y otro femenino (UE 1128) por su similitud formal con el enterramiento 1196; que es muy posible que la presencia de restos humanos documentada en UE 1041 y UE 1157 sea fruto de la mezcla de materiales desde la fosa UE 1119, durante las reformas que sufre el edificio a lo largo del siglo III o IV d. C. La fosa UE 1119 correspondería a un bustum, al observarse una importante rubefacción in situ.

\section{Monumento funerario " $B$ "}

En líneas generales es una edificación de planta rectangular (UE 1073) elaborada con cimientos de mampuesto de barro y muros de adobes que presentan un revestimiento de mortero de cal.

En el interior del edificio documentamos dos fosas de morfología rectangular (UE 1427 y 1428). La primera se trata de un hoyo posiblemente de carácter votivo que hallamos en el sector septentrional del mismo. La otra está centrada en la construcción en su parte meridional a 2,29 $\mathrm{m}$ de la primera. Ambas están rellenadas con abundantes carbones y cenizas, junto a fragmentos de piezas de marfil o hueso trabajadas, semillas carbonizadas, elementos de bronce y fragmentos cerámicos (en su mayor parte ungüentarios y cuencos). Al Sur de la UE 1248 y también en el interior del edificio, documentamos una fosa circular (UE 1429) con carbones y escasísimo material. Había al Norte de la edificación una piedra de forma rectangular, dispuesta en posición vertical sobre un pavimento de opus signinum que une la habitación y la piedra. Se trata de una piedra caliza de grandes dimensiones desbastada toscamente, localizada frente a la cabecera de la habitación de adobe UE 1073; desempeñaría una posible función de altar. Tiene una longitud de $64 \mathrm{~cm}$ y anchura de $42 \mathrm{~cm}$.

El posible edificio cultual (UE 1179) desempeña una función similar a la construcción UE 1073, situada en su flanco occidental. Tiene también planta rectangular con una orientación Norte-Sur. Las dimensiones son: 7,10 m de longitud por 5,89 m de anchura. La amplitud de sus muros es de $58 \mathrm{~cm}$. El paramento interior del muro de mampuesto se quemó por la acción del fuego y posteriormente se procedió a revestirlo con calicostra de mortero de cal. La fosa UE 1410 tiene un contenido muy similar a las de la UE 1073, solamente destacamos una mayor abundancia de semillas de aceituna. Al Norte de la misma, también similar a la del vecino edificio UE 1073, aparecieron los restos arrasados de otro hoyo circular. Con una disposición pareja a la anterior, o sea junto al paramento exterior situado al Norte del edificio, encontramos los restos muy alterados de una gran piedra arenisca rojiza y un pavimento de opus signinum pintado del mismo color. Los paralelos formales que se dan entre las UE 1073 y 1179, plantean la posibilidad de que ambas podían formar parte de un mismo conjunto monumental de tipo funerario o cultual, rodeado por pequeñas habitaciones de planta rectangular, UE 
1437, 1438, 1439 y 1440, (muy arrasadas por construcciones bajo-medievales) que delimitarían un espacio deambulatorio.

\section{Monumento funerario "C"}

Restos de una estructura de adobe (UE 1143), de los que únicamente se conservan dos fragmentos de muro. El primero con una orientación Este-Oeste y mide 2,41 m de longitud por $21 \mathrm{~cm}$ de anchura; el segundo tiene una alineación Norte-Sur y mide $98 \mathrm{~cm}$ de longitud y $20 \mathrm{~cm}$ de anchura. Están relacionados con un loculus (UE 1189) que apareció centrado en la citada construcción. Conserva revestimiento de cal. Los materiales recuperados se limitan a fragmentos de hierro y muy escasa cerámica, pues se encontraba prácticamente destruido por otras construcciones posteriores.

\section{Monumento funerario " $D$ "}

Es una cimentación de mampuesto de barro correspondiente a una estructura maciza de morfología cuadrangular (UE 1180), que amortizaba los restos de una incineración que ocupaba una fosa de forma circular. En el interior del loculus se pudieron recuperar restos de huesos y material cerámico.

\section{Monumento funerario " $E$ "}

Se trata, en líneas generales, de fosas que documentamos muy arrasadas y afectadas tanto por las construcciones de época romana del Bajo Imperio, como por haber sido excavadas parcialmente en la campaña de 1994, por lo que no permiten establecer una interpretación fiable. Con todo, por la tipología que presentan podemos pensar que se asociarían al espacio cementerial. Son especialmente significativas las acumulaciones de derrumbe de adobes con improntas in situ. Además existe un ambiente con fosas (UE 1045) asociadas a algunos muros subyacentes a las estructuras de los siglos II a IV d. C. que podrían corresponder a un monumento funerario.

\section{Otras estructuras funerarias}

Por debajo de alguna de las habitaciones de la ínsula situada al Norte del solar, aparecen restos de estructuras, muy afectadas por las construcciones del Bajo Imperio, que podrían pertenecer también a la fase cementerial.

Este espacio funerario también se extendería por debajo de los edificios monumentales del Sur del solar, pero al ser excavados de forma incompleta en 1994 es difícil interpretar sus restos.

\section{Los ajuares funerarios ${ }^{15}$}

\footnotetext{
${ }^{15}$ Mas detalles del estudio de los ajuares y las ofrendas los desarrollaremos en el apartado del mundo funerario. 
Corresponde a los restos de un loculus rectangular (UE 1119), rellenado con cenizas y carbones. Lamentablemente se encontraba muy afectado por las cimentaciones de la domus que se construyó sobre este espacio durante el Bajo Imperio. Sus dimensiones son: $1,84 \mathrm{~m}$ de longitud por $49 \mathrm{~cm}$ de anchura, y su ajuar es el siguiente:

- Clavos de hierro.

- Fragmentos cerámicos y de lucerna.

- Denario de plata de Augusto acuñado en Lugdunum; se fecha desde el año 2 a. C. hasta la muerte de Augusto.

- Fragmentos de vidrio.

- Fragmentos óseos.

- Cinco a seis cuencos de cerámica de paredes finas Mayet XXXIV. Es una forma muy similar a las producidas en los talleres militares del Norte de Hispania desde la época de Tiberio hasta la segunda mitad del siglo I d. C. (MELCHOR Y BENEDITO, 2009).

- Varios fragmentos de hierro y planchas del mismo material que, posiblemente, formarían parte de algún tipo de elemento complejo cuya forma no es posible determinar hasta que no prosiga la investigación tras su restauración.

Restos de una fosa circular (UE 1040) de $0,86 \mathrm{~m}$ de diámetro, rellenada con cenizas y carbones. Como sucede con la incineración anterior, la cimentación de un muro de época del Bajo Imperio la afectó de una forma notable. Ajuar:

- Fragmentos de cerámica de paredes finas.

- Fragmentos pertenecientes a 6 ó 7 ungüentarios de vidrio.

- Fragmentos cerámicos y de adobes.

- Clavos de hierro.

Enterramiento en cista circular (UE 1156), elaborada con cantos rodados y cubierto con una doble capa de fragmentos de tegulae. Conservaba un diámetro de $52 \mathrm{~cm}$. Ajuar:

- Fragmentos cerámicos.

- Un pondus.

- Fragmentos de vidrio.

Un loculus (U E 1220) que lamentablemente se encontraba destruido por una gran fosa medieval y por las estructuras del Bajo Imperio de la domus. Ajuar:

- Fragmentos de adobe.

- Fragmentos de vasos de paredes finas. 
- As de bronce de Tiberio acuñado en Sagunto del 14 d. C. al 37 d. C. (RIPOLLES, 2002).

- Peine de hueso o marfil, extremo en forma de hoja lanceolada y cuerpo con decoración trenzada.

Incineración en forma de cista cuadrangular (UE 1195), elaborada con losas de rodeno. Se conservaba intacta, con la excepción de la cubierta que, por los restos conservados, podría tratarse de tegulae. Mide $56 \mathrm{~cm}$ de longitud por $54 \mathrm{~cm}$ de anchura. Ajuar:

- Una pequeña cuchara o espátula de bronce.

- As de bronce de ceca indeterminada posiblemente de época de Tiberio. Extremadamente gastado, con una perforación circular encima de la efigie del emperador.

- Semis de bronce de ceca indeterminada. Totalmente gastado con una perforación circular en el centro que además tiene el aspecto de haber sido pulida.

- As de bronce de Tiberio acuñado en Segóbriga entre el 16 d.

C. al 27 d. C. (RIPOLLES, 2002).

- Anillo de bronce de $2 \mathrm{~cm}$ de diámetro y sección $0,5 \mathrm{~mm}$.

- Plancha de plomo de forma circular de $4 \mathrm{~cm}$ de diámetro y 2 $\mathrm{mm}$ de espesor medio.

Seguidamente se realizó la restauración alguno de los elementos; de la misma forma, se tomaron diferentes muestras de carbones, preparadas para futuros análisis químicos y físicos.

\section{ETAPA DE MONUMENTALIZACIÓN DEL SIGLO II d. C.}

Alrededor del siglo II d. C. esta parte de la ciudad de Sagunto estaba organizada en torno a una calzada de $5,40 \mathrm{~m}$ de anchura máxima y $60 \mathrm{~m}$ conservados de su recorrido de orientación Norte-Sur (ver Lámina $\underline{\mathrm{XXVII}}$ ).

La intervención arqueológica ha puesto al descubierto una amplia estructura vial enlosada, una cloaca en buen estado de conservación, los desagües y las aceras con pórticos sostenidos por pilares. La amplitud de la misma debió estar condicionada por la situación de los edificios públicos, más que por las previsiones sobre el volumen de tráfico, como demuestra el hallazgo de varios edificios y, entre ellos, construcciones de carácter monumental. Tampoco podemos descartar que la propia vía sufriera algún tipo de reforma en este proceso de monumentalización, como podría ser la construcción de la gran cloaca central o de los pórticos.

Hemos incluido el estudio de la calle dentro del apartado sobre los edificios públicos por ser precisamente de este tipo de uso, aunque su construcción bien pudo ser 
financiada a cargo de particulares La ubicación de los pilares en uno y otro lado de la calle no es simétrica y las distancias conservadas entre ellos tampoco son iguales. Este hecho nos está indicando la falta de uniformidad que se da en la construcción de los pórticos, como se ha documentado en Itálica o Carteia (ROLDÁN, 1993 y 1992).

Casi la totalidad de los pilares conservan las basas de piedra caliza originales, con al menos una hilada de sillares. Algún derrumbe de la segunda línea del pórtico y del capitel se hallaba sobre la propia calzada. Son visibles nueve pilares en el lado Oeste del solar, separados por distancias de 2,95, 4,04, 4,20, 3,20, 2,83, 3,08, 3,11 y 1,92 m respectivamente. Con respecto al lado Este, las distancias intermedias son muy semejantes: $3,14,3,50,3,45$ y $2,90 \mathrm{~m}$ en los cinco excavados del pórtico. La altura original recogida es considerable en todos excepto en tres de ellos de los que sólo se conserva la basa (sillar de piedra caliza que varía de 60 a $75 \mathrm{~cm}$ ). En cuanto al tamaño, sus medidas son homogéneas dentro de cada grupo y las características constructivas de los pilares también son semejantes. Respecto a los componentes del pórtico, la forma de aparejo es el opus quadratum y las medidas de los bloques son bastante regulares, ya que todos se mueven entre los 44 y los $62 \mathrm{~cm}$ de anchura. Los sillares estaban almohadillados, al menos los que se emplearon en las partes más visibles; se trata de un canteado prominente de tipo rústico.

La construcción en piedra es muy abundante en Sagunto, sobre todo en forma de sillares y formando parte de la estructura de los muros, en los pavimentos de la calle y en algunos edificios. Con todo hay que tener en cuenta el notable expolio que han sufrido estas construcciones.

La calzada presenta una anchura que está sujeta a ciertas variaciones, en función de la presencia o no del pórtico sobre la acera. Las dimensiones mínimas son de 4,10 m para el sector Norte de la excavación, que no dispone de pórtico, y de 5 o 5,40 m en la parte Sur. Incluido el citado porche las dimensiones se mueven entre 7,50 y $8 \mathrm{~m}$.

Respecto a la acera, que se ha excavado íntegramente en el lado Este, conserva hasta el muro una anchura próxima a los $4 \mathrm{~m}$. El lado Oeste coincide con el límite del solar, por lo que desconocemos la anchura global. Por tanto, hay una unidad aproximada para esta entrada a la ciudad si la comparamos con otras vías principales del resto del Imperio. En Pompeya, las rutas importantes tenían una anchura de $4 \mathrm{~m}$ y de muro a muro $8 \mathrm{~m}$; en Paestum, en el cruce que se halla cerca del foro, para el kardo se conserva una anchura de calzada de $5,30 \mathrm{~m}$; entre 4 y $5 \mathrm{~m}$ tienen de anchura las calzadas de Ostia. Con pórtico la anchura puede pasar de los $12 \mathrm{~m}$, como en Vaison, Timgad y Tipasa (ADAM, 1984).

La cloaca sigue la dirección de la calzada. La conducción subterránea se encuentra en buen estado y conserva una anchura interior de $0,68 \mathrm{~m}$ y una profundidad superior a 1,20 m. La construcción de todo el canal se realizó mediante el empleo de opus 
vittatum y losas para el suelo; la cubrición se hizo con las mismas lápidas de la calzada, todas ellas de piedra caliza dolomítica gris.

En los tramos donde hemos podido excavar el relleno del conducto, que se encontraba colmatado en su totalidad, observamos una alternancia de estratos de coloración beige, con escasos materiales, y gris fruto de la descomposición de materia orgánica aportada por los distintos desagües abiertos posteriormente en la calzada. Debido a los escasos materiales recuperados en el interior de la cloaca, solo podemos establecer unos márgenes cronológicos para el uso y colmatación de la citada estructura que varían del siglo II al IV d. C. Debido al excelente estado de conservación de la calzada y de la propia cloaca, solamente pudimos excavarla en la zona afectada por una fosa musulmana y por la necrópolis visigoda, donde no existía la cubierta, allí los materiales eran sumamente escasos, por lo cual las cronologías ante y post quem las ajustamos al funcionamiento de la cloaca entre su monumentalización y su uso como tumba.

\section{TEMPLO 1}

Al Este de la calzada y en su flanco Norte, se ha excavado un edificio de grandes dimensiones. Estructuralmente presenta unas características arquitectónicas que merecen ser destacadas, pero lamentablemente fue saqueado en épocas posteriores de tal forma que sólo documentamos parte de la esquina noroeste del muro perimetral del recinto en su lado más largo excavado (UE 1136). El edificio continúa hacia el Este por debajo de la calle Alorco. Mide $24,35 \mathrm{~m}$ de longitud y se levanta a partir de una cimentación de mampostería de 1,53 m de anchura (UE 1155). Los muros miden 1,53 $\mathrm{m}$ de anchura máxima y están elaborados con cantos de río de gran tamaño, sillares y piedras. Sólo la esquina NW del inmueble, por otro lado la mejor conservada, presenta sillares almohadillados de grandes bloques de piedra caliza gris dispuestos de forma regular. Es una técnica que situamos entre el opus quadratum y el opus siliceum. El muro con orientación NS tiene 8,47 m de longitud y el de orientación EW 10,98 m.

El edificio es de carácter monumental y conserva dentro de los límites del solar una planta de un podio rectangular del que se documentó la primera hilada del arranque en la esquina NW. Del resto sólo se conserva la cimentación compuesta por grandes bolos de origen fluvial desbastados toscamente por una de sus caras.

En esa misma esquina NE se conserva la huella de un canalón con su imbornal. El relleno del podio presenta un nivel arenoso, que amortiza los cimientos de varias construcciones funerarias previas datadas en el siglo I d. C., que habían sido previamente enrasadas.

En un momento cronológico tardoantiguo o altomedieval que aportó materiales muy escasos y que no permiten establecer una cronología concreta (por la posición estratigráfica fue posible situarlo en un momento posterior a las reformas del siglo III y 
IV d. C. y anterior a la construcción de las viviendas musulmanas), se arrasó el acceso del edificio, ubicado en la parte central del muro oriental, del cual sólo hemos podido documentar un preparado de grandes cantos de río dispuestos de forma regular, que serviría de asiento a la escalinata.

El podio se levanta junto a otra estructura de carácter quizá votivo, que está formada por los restos de un pavimento de adobes (UE 1348) que, por otro lado, delimitaría un espacio de planta rectangular anexo a la esquina NW del podio. En él se excavaron varias fosas de morfología circular y ovalada (UE 1129) que contenían gran cantidad de carbones y escaso material cerámico (este no aportaba cronología), las cuales fechamos en el inicio del siglo II d. C. por una moneda de Trajano del año 98/99 encontrada en la UE 1129 (PASCUAL-AHUIR, 2005).

También asociado a este edificio hallamos un conjunto de estructuras semisubterráneas, posibles balsas o depósitos relacionados quizá con el agua, muy similares a las documentadas en otros templos, como por ejemplo el llamado de Diana (dedicado al culto imperial), en Mérida (ÁLVAREZ y NOGALES, 2003), o el también denominado templo de Diana, en Évora (Portugal) (HAUSCHILD, 1994 y REIS, 2010). Éstas formarían parte de un espacio de hábitat posterior y se encontraban adosadas a la cimentación Norte del podio.

\section{ARCO MONUMENTAL}

En el flanco norte de la calzada, al Oeste del Templo 1, se levantó la cimentación de una estructura que corresponde a un arco ubicado sobre la misma. De este sólo se conserva la cimentación de opus caementicium, de más de 1,80 $\mathrm{m}$ de profundidad (indicio de que debería soportar una estructura de grandes dimensiones) y los restos de la primera hilada de sillares de piedra caliza gris.

Esta construcción fue arrasada prácticamente hasta el nivel de cimentación y únicamente se conservan tres grandes losas de piedra caliza y la impronta sobre el mortero de ocho más. El arco, con dos apoyos de 3 por $3 \mathrm{~m}$ y 2,80 por 3,5 m respectivamente, debía situarse transversalmente sobre la calzada. Su situación coincide con el final de los pilares del pórtico y marca el inicio de una suave inflexión en la orientación de la calzada, en dirección NE.

En la zona donde se descubrió el arco y formando parte de una fosa medieval que cubría parte de su cimentación y que perforaba la cloaca de la vía, aparecieron los restos de entre 10 y 15 fragmentos de varias inscripciones sobre mármol. Debido a su escasez no es fácil la interpretación de las piezas originales, como citaremos mas adelante (CORELL y SEGUÍ, 2008).

\section{TEMPLO 2}


Durante la campaña de excavación llevada a cabo en el año 1994 se documentó parte de la planta de un edificio de época romana que presentaba muros de opus vittatum (podemos observar la técnica constructiva en la foto $\underline{431}$ y un paralelo en la foto $\underline{465}$ ). En nuestra excavación hemos podido comprobar que este muro del podio (UE 4002) amortiza otras estructuras de época del Alto Imperio, probablemente de la necrópolis descrita mas arriba. A este muro se adosan construcciones del Bajo Imperio por lo que, debido a las relaciones estratigráficas registradas en sectores no contaminados y a la buena factura del mismo, nos motivan a plantear la hipótesis de que podría tratarse de un edificio que pertenecería a esta fase del siglo II d. C.

ETAPA DE URBANIZACIÓN DEL SIGLO III d. C.

Los hallazgos correspondientes a la época del Bajo Imperio no son menos interesantes (ver Lámina $\underline{X X V I I I)}$. En este momento se lleva a cabo una reestructuración muy importante en este espacio urbano. Es un hecho aceptado que, tras el periodo de florecimiento urbanístico que se da en época del Alto Imperio, en Sagunto se manifiesta un cambio en la topografía urbana, al igual que lo hace en otras ciudades cercanas como Valencia o Liria. En nuestro caso las obras de reforma se evidencian, en primer lugar, en el arrasamiento de buena parte de las estructuras anteriores. Por el Norte, también se edifican otros departamentos con balsas o depósitos adosados a los edificios de la etapa anterior, lo que podría implicar la pérdida de su funcionalidad original. Es muy significativa la presencia de numerosos sillares, fragmentos de mármoles, tejas y otros materiales reutilizados. En un momento alrededor del siglo III d. C., cuando se construyen las dos insulae que aparecen en el solar, se cierra buena parte del pórtico con una serie de muros para crear nuevas habitaciones, eliminado la acera existente hasta el momento y con la implantación de una nueva red de desagües que vertían a la cloaca de la vía.

Con el objeto de abrir estas canalizaciones se rompió la calzada y, posteriormente, se reutilizaron fragmentos de losas de la misma o de bloques de otras estructuras próximas para repararla, como por ejemplo, molduras de sillares que fueron reutilizadas como cubierta del desagüe de una fuente de tipo bauletto. Por otro lado, es interesante la importancia que sigue manteniendo la cloaca todavía en este periodo, pues son muy numerosos los drenajes que cruzan el solar con el objetivo de verter en ella.

Dentro de esta reestructuración llevada a cabo en este ámbito urbano, se construye una zona de servicios en la acera del pórtico de la calzada. Destaca, por un lado, la documentación de los cimientos de una fuente con desagüe (UE 1083 y 1251) junto a la vía en su flanco oriental; por otro lado, en la acera opuesta, aparecen los restos de una conducción de agua potable de plomo (UE 1216) y una estructura cuadrangular, posiblemente un sifón con compuerta (UE 1357) sobre un desaguadero. 
Respecto a la topografía urbana, en el solar se han documentado dos grandes conjuntos que formarían parte de sendas insulae, una al Norte y otra al Sur, a ambos lados de la vía principal. En la primera los escasos materiales datables con alguna certeza recuperados en el interior de la habitación que había sido profundamente saqueada (no había pavimentos, restos de revestimiento, etc. y los desagües aparecían directamente bajo los niveles de saqueo, que entremezclaban materiales desde el siglo I a. C. hasta época tardoantigua) corresponden a la UE 1310 (ver tabla de materiales). En la segunda el saqueo (datado por las UU. EE 1110 y 1111 - ver tabla de materiales) sumado a las grandes fosas medievales y la excavación parcial del año 1994 no permiten establecer una cronología exacta para la perduración de esta insula.

Los descubrimientos de esta fase demuestran claramente que Sagunto seguía en pleno auge por lo menos hasta mediado el siglo III d. C., en contra de la teoría que suponía que la ciudad se encontraba ya por entonces en decadencia, para la datación podemos tomar el ejemplo de las UU EE 1056 (el estrato de contacto con la capa de arena que cubre toda la calzada) y 1052 que cubre a la anterior y que probablemente se parte de la misma (ver tabla de materiales), entre ambas suman 181 monedas del bajoimperiales (además de 21 ibéricas y altoimperiales), además de 41 de Claudio II y 8 de Galieno. La estructuración urbana identificada confirma por primera vez la progresiva expansión de la urbe hasta prácticamente la margen derecha del río Palancia. En efecto, a partir de los restos excavados se puede hablar de un desarrollo urbano hacia el NE de la ciudad ya en época del Alto Imperio, que se afianza en el siglo III. La técnica constructiva más utilizada en esta fase cronológica es el opus africanum, como sucede con el edificio que se levanta en el sector NW del solar.

En la insula Norte se ha excavado la planta de un edificio con cuatro estancias: dos habitaciones o estancias rectangulares (UE 1331 y 1335), un estrecho pasillo (UE 1333) en la parte posterior que unía ambas y un soportal (UE 1225) que precede a la entrada principal desde la vía y que corresponde a un espacio cubierto y con columnas. La esquina SE de este porche se hallaba protegida por un machón de piedras amontonadas con el objeto de evitar posibles impactos de carros, pues se encontraba junto al arco y en el inicio de la inflexión de la calzada en dirección NE. Esta insula fue saqueada antes de su derrumbe, por lo que sólo pudimos registrar restos de pavimentos, preparados de opus caementicium e improntas del enlucido de los muros. En su construcción se reutilizaron restos de pilares, columnas y capiteles del pórtico.

En la insula Sur los resultados fueron todavía más pobres; una gran fosa de época medieval acabó por destruir gran parte de la misma, ya que debajo de la base del hoyo documentamos directamente los restos muy arrasados de las estructuras cementeriales del Alto Imperio. La construcción mejor conservada (UE 1142) aparece adosada al Sur del podio del Templo 1 y presenta pavimento de opus caementicium y 
ladrillos en las esquinas. El resto de construcciones se hallan en un mal estado de conservación. Entre los elementos relacionados con esta insula se conservaba un fragmento de pavimento de grava (UE 1090), con desagüe cerámico junto al umbral (UE 1048), así como los restos de una balsa cuadrangular (UE 4036) revestida con opus signinum que había sido excavada en el año 1994.

En todas estas construcciones, como en el resto del solar, también se constata la reutilización de sillares, mármol, tejas, etc. y, fuera de contexto por la acción de otras fosas de saqueo, fragmentos de pavimentos de opus signinum, de mármol de revestimiento y pintura mural con motivos geométricos. Como ya describimos, el Bajo Imperio conlleva una transformación en el planeamiento urbanístico de la parte baja de Sagunto y en este solar se manifiesta en la eliminación las áreas de culto y cementerial, pasando a ser zona de viviendas. Los estratos más fiables para la datación genérica de este conjunto son las UU. EE. 1056 y 1052 que abarcan, salvo alguna intrusión, toda la primera mitad del siglo III d. C. (ver tablas de materiales), alcanzado también el primer tercio del siguiente siglo. Recordemos el carácter deposicional de estas UU. EE., ya que rellenan la calzada, por lo que serían estratos de vertido o relleno extraídos de viviendas cercanas.

Los hallazgos materiales son muy variados, desde agujas de hueso y restos de su proceso de fabricación, fragmentos óseos con marcas de carnicero, numerosas pesas de telar, agujas para coser y husos para hilar, escoria de bronce, restos de muebles y cerraduras, etc. Destacamos el hallazgo de más de 300 monedas que aparecieron dispersas, pero que se pudieron recuperar gracias a la minuciosidad con la que se llevó a cabo la excavación (ver la clasificación de las mismas en el apartado de tablas).

\section{ETAPA DE ABANDONO (SIGLOS IV al VIII d. C.)}

A partir de final del siglo IV o principio del $\mathrm{V} d$. C. se da en esta parte de la ciudad un periodo de abandono (ver Lámina $\underline{X X X I I I)}$ ), momento en el que sufre un progresivo saqueo de materiales. Así, por ejemplo, se colmatan las habitaciones adosadas al podio del Templo 1 por su paramento Norte con pedazos arrasados de esa misma estructura. Los restos de estas viviendas también se relacionarían con el derrumbe de una construcción de ladrillos huecos que cayeron sobre la calzada cuando ésta se hallaba cubierta por una fina capa de tierra arcillosa (UE 1056 -ver tablas de materiales) con materiales cerámicos del siglo III-IV d. C.

En el interior del flanco Sur de la cloaca de la calzada se ha localizado un enterramiento múltiple de inhumación como único elemento de ocupación de la cultura tardoantigua o visigoda encontrado en este espacio. Este sepulcro aparece cortado y arrasado puntualmente por una fosa de época musulmana. Se ha identificado un individuo en posición primaria y otros tres en posición secundaria. Todos aparecen sin 
ajuar y con claras evidencias de haber sido removidas durante el proceso de descomposición en vacío.

Posiblemente en este periodo se amortiza completamente la vía enlosada con abundantes restos constructivos (fragmentos de ladrillos, tegulae, opus signinum, etc.) que proceden de la zona inmediata. No obstante, hasta el momento no se ha asociado cronológicamente ninguna otra estructura a este periodo con absoluta certeza; por otro lado, la cerámica registrada durante el proceso de excavación correspondiente a esta época es muy escasa.

Es probable que gran parte de las estructuras del Bajo Imperio pudieran permanecer arruinadas y en superficie a causa del progresivo abandono de esta zona, con la consiguiente retirada de la población a un perímetro de menor tamaño, en dirección hacia lo que posteriormente sería la ciudad medieval. Éste sería un proceso muy similar a lo ocurrido en otras grandes ciudades romanas, como Zaragoza (BELTRÁN y FATAS, 1998), Mérida (ALBA, 1998) o Tarragona (MAR y GUIDI-SÁNCHEZ, 2010).

\section{ETAPA MEDIEVAL}

De época hispanomusulmana se han excavado dos casas que posteriormente son

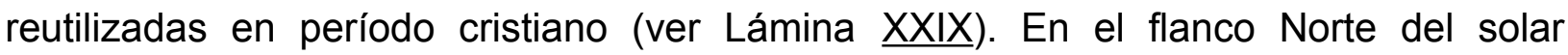
documentamos un muro con pilastras adosadas sobre el que se construyeron varias balsas en la Edad Moderna. Destacan también dos pequeñas fosas realizadas sobre la calzada romana en los extremos Norte y Sur de la misma, así como otras mayores en el sector meridional del solar. Reaprovechando parte de los muros de la insula Norte se construyen dos estructuras hidráulicas revestidas de mortero de cal, posiblemente balsas o depósitos que solamente se excavan parcialmente, pues se prolongan por debajo de la calle Huertos.

Al Este del terreno se levanta una vivienda que reutiliza parte de las cimentaciones de las estructuras del Templo 1 (ver Foto 494) y del Bajo Imperio, rellenándose las fosas del entorno sobre el que se construye el patio de esta casa y colmatándose también las antiguas estructuras adosadas al templo para nivelar el terreno existente entre la acequia Mayor y el nuevo hábitat. Las grandes fosas que se rellenan y sobre las que se edifican las casas, indican que durante un primer momento la zona aún no había sido utilizada como hábitat.

A falta de contrastar los datos con la vecina excavación del solar del Romeu (ver Lámina $\underline{\mathrm{XLIII}}$ ), ya que ésta significaría el nexo de unión hacia la muralla medieval de la ciudad, la ocupación musulmana correspondería a un tipo extraurbano.

Existe la posibilidad de que una tercera casa se desarrollara más al Sur, reaprovechando parte de los cimientos del Templo 2 y creando nuevas estructuras a 
ambos lados, una de ellas sobre la calzada, y que reutiliza parte de los cimientos del muro del Bajo Imperio (UE 4002) para construir un aljibe enlucido con mortero de cal.

Las construcciones correspondientes a época bajomedieval corresponden a la planta de una vivienda que estaba formada por varias estancias y un corral en su parte posterior. Junto a la misma hallamos dos ambientes sin estructuras, uno al Sur, que desempeñaría una función de patio o área abierta y el otro al Norte, que se trataría de los restos de una zona artesanal con balsas, la cual se prolonga más allá de los límites del solar. Al Sur, con una disposición paralela a la otra construcción, documentamos una edificación de similares características arquitectónicas pero que, sin embargo, no podemos alcanzar a interpretar pues la hallamos enmascarada por la excavación que tuvo lugar en el año 1994. El material cerámico que acompaña a estas estructuras nos da una fecha de ocupación de los siglos XIV y XV.

\section{ETAPA MODERNA/CONTEMPORANEA}

Después de un periodo de abandono, la zona sufre una importante transformación en época moderna, cuando se nivela completamente para el cultivo y se construyen lindes de huertos y nuevas acequias para el riego. A final del siglo XIX empiezan a aumentar las edificaciones en esta zona de Sagunto. En el año 1938, con motivo de la guerra civil, sufre el bombardeo aéreo que afecta a las estructuras más superficiales. En los años 80 se inicia el proceso de urbanización actual.

\section{CONCLUSIONES}

Esta importante excavación arqueológica demuestra irrefutablemente que el entramado urbano de Sagunto en época romana era mucho más extenso de lo que se admitía hasta este momento en la investigación (ARANEGUI, 1994, CHINER y LÓPEZ, 1994, HERNÁNDEZ, LÓPEZ y PASCUAL, 1995 y JIMÉNEZ, 1989 entre otros - ver Lámina XVIII), alcanzando prácticamente el cauce del río Palancia. La excavación en extensión se ha llevado a cabo desde el inicio de forma manual y sólo se han usado medios mecánicos para las labores de limpieza previa de los niveles superficiales carentes de cualquier valor arqueológico, así como para los trabajos de transporte de las tierras. La intervención arqueológica que se ha realizado en el solar ha permitido documentar un conjunto de estructuras y una serie de niveles estratigráficos que han aportado suficientes datos para plantear la correcta interpretación y la cronología de los restos.

Respecto a las características formales y técnicas de las estructuras documentadas, pese al nivel de arrasamiento que presentan algunas, son totalmente homogéneas dentro de las distintas etapas, circunstancia que ha permitido establecer su correcta adscripción cultural, ya se trate de época republicana, Alto Imperio, Bajo Imperio, época visigoda, e hispanomusulmana, bajomedieval o moderna. La estratigrafía del solar está determinada inicialmente por la presencia de potentes niveles de relleno que amortizan 
las construcciones bajomedievales. En otros casos colmatan grandes fosas excavadas en los niveles romanos y que llegan a afectar el subsuelo geológico, sobre las que se cimientan, entre otros, algunos de los muros de época medieval o moderna.

Entre el conjunto de materiales recuperados en los estratos de relleno destacan las importaciones de TS africana y de cerámica común también de origen africano. Junto a éstas se encuentran también representadas formas de TSI y $T S H$, así como gran cantidad de fragmentos de cerámica común, de cocina, vidrio, clavos de bronce y de hierro y abundante fauna (sobre todo ovicáprido, bóvido y équido), que aparecen mezclados con gran cantidad de cerámica bajomedieval e hispano-musulmana. La naturaleza de estos rellenos apunta, en algunos casos, al carácter de vertido de tierras y elementos procedentes de los niveles romanos del propio solar (material laterício, tegulae, opus signinum, piedras, etc.). El resto de material cerámico aparece formado por fragmentos de TSH, TSI, TSS, TS clara A, C y D, fragmentos de paredes finas, cáscara de huevo, etc. Más antigua es la cerámica ibérica, que aparece mezclada también con material romano. De forma paralela a la excavación arqueológica se han realizado, como comentamos, distintos estudios analíticos y trabajos complementarios. Además, cuando la muestra era suficientemente significativa o no se hallaba contaminada, se han tomado una buena cantidad de muestras de carbones, adobes, restos de fundición de metal, etc. También se han almacenado de forma individualizada los siguientes elementos para su posterior restauración los restos óseos humanos, el instrumental metálico y óseo, la pintura mural, la malacofauna y las monedas.

La excavación de los diferentes estratos arqueológicos nos ha permitido distinguir ocho periodos cronológicos claramente diferenciados. El más antiguo de época republicana (siglos II-I a. C.) y el mas reciente alcanza el siglo XVIII (ver Láminas $\underline{X X V I I}, \underline{X X X}$, $\underline{X X X I}, \underline{X X X I I}$ y $\underline{X X X I V)}$. 


\subsection{CALLE HUERTOS - C/ ORDÓÑEZ - C/ REMEDIO (SOLAR DE QUEVEDO)}

\section{DATOS HISTÓRICOS}

Este espacio corresponde a las terrazas cercanas al río Palancia y ocupa la zona intermedia del semicírculo aproximado que forma la montaña donde se asienta el castillo. A lo largo de la época romana, visigoda y musulmana la ciudad sufre los vaivenes de continuas expansiones y contracciones de la población y no es hasta bien entrado el siglo XV cuando empieza a tener una ocupación estable a nivel urbanístico, gracias el efecto potenciador del extinto convento de la Trinidad, alcanzando su desarrollo pleno a lo largo del siglo XIX.

\section{ANTECEDENTES ARQUEOLÓGICOS}

A. Chabret ya apuntaba la existencia de un mosaico en blanco y negro en esta zona (CHABRET, 1899). En 1953 muy cerca, bajo el mercado, apareció otro en forma de cruz del que solamente pudo extraerse algo menos de la mitad del pavimento, que era lo único que quedaba, pues el resto había desaparecido al construirse la acequia de desagüe del alcantarillado (VALL, 1961). El mosaico del castigo de Dirce, encontrado en 1955, junto al mosaico floral y los otros sectile en los locales de la Lira Musical Saguntina, tenía en el nivel superior al de los pavimentos una tumba individual atribuible a un siglo IV avanzado (VALL, 1961).

Lamentablemente, en el caso del propio solar de Quevedo la excavación parcial del terreno en el año 1981 (ver Fotos 190 y 191) se hizo con medios mecánicos, por lo cual solamente hemos podido recuperar algunas noticias orales, gracias a la colaboración del Centro Arqueológico Saguntino.

Se realizaron algunas intervenciones en el circo de Sagunto, como las de A. Chabret a final del siglo XIX (CHABRET, 1899), las de E. Hernández en el año 1987 sobre el solar de la calle Obispo Miedes 12 (HERNÁNDEZ, 1990) y la de I. Pascual en la puerta del circo en el año 1996 (HERNÁNDEZ, LÓPEZ y PASCUAL, 1996), a la que debemos 
sumar la reciente intervención arqueológica de 2007 realizada en el mismo solar a cargo de R. González y C. Verdasco y que permanece inédita.

\section{Intervención arqueológica}

Nuestras actuaciones corresponden a tres fases llevadas a cabo a lo largo de los meses de agosto y noviembre de 2004 y diciembre de 2005, para las cuales se contó con el apoyo del Ayuntamiento y de la Universidad Popular de Sagunto, y del Departamento de Restauración de la Universidad Politécnica de Valencia.

En una primera fase se inició la intervención delimitando un sondeo de 7 × $5 \mathrm{~m}$ situado en el interior del espacio de los muros de opus quadratrum que se encontraban a la intemperie desde los años 80 del siglo XX, cuando se realizó la excavación parcial del terreno. Posteriormente limpiamos una zona de $1 \times 2,8 \mathrm{~m}$ del margen que existe a lo largo del solar, con el objetivo de obtener una sección fiable. En adelante llamaremos Zona 1 al sondeo y Zona 2 a la estratigrafía. En la segunda fase se realizó un sondeo de $30 \mathrm{~m}^{2}$ en el interior del edificio de sillares, al mismo tiempo que se ampliaban los datos de la primera intervención. La tercera fase consistió en la realización de dos sondeos, uno de 2 × $5 \mathrm{~m}$ en el interior de la obra monumental y otro de 1,5 x 1,5 m en el exterior de la misma.

Las excavaciones fueron manuales y se realizaron por estratos naturales. Los trabajos se centraron en la parte del solar de propiedad municipal, buscando alcanzar siempre el nivel estéril cuando fue posible. Detallaremos a continuación los puntos esenciales que se desarrollaron en estas actuaciones:

- Se procedió a la limpieza de una superficie de $35 \mathrm{~m}^{2}$ en el interior del edificio para intentar detectar niveles y estructuras arqueológicas. Se comprobó que aún existían abundantes restos en el solar, incluida la cimentación de todo el edificio de sillares, destacando la detección de una serie de cimentaciones cuadrangulares de pilares. Se documentó mediante una limpieza superficial el nivel del suelo del edificio monumental, cuyos restos estaban en el solar desde hace más de 30 años.

- Se procedió a la excavación de $30 \mathrm{~m}^{2}$ junto a la primera para encontrar más elementos arqueológicos. Se detectó un nivel con material en parte del solar y restos de una estructura subterránea moderna; bajo ella se documentaron cimentaciones muy arrasadas de piedras trabadas con barro. No aparecieron restos de otras hiladas de pilares paralelas a la primera.

- Se documentó parte de la estratigrafía en una zona que se había conservado intacta, la cual aportó al menos 3 niveles. 
- La tercera y ultima campaña se inició con un sondeo de 2 × $5 \mathrm{~m}$ en el interior del espacio delimitado por los muros de sillería del edificio monumental romano, donde apareció una cloaca de buena factura, similar a la de la vía enlosada de la Morería. Posteriormente limpiamos una zona al exterior del inmueble romano, con el objetivo de obtener más información sobre los restos del desagüe descubierto en el anterior sondeo.

- Una vez excavada una pequeña sección de esta cloaca, intentamos realizar un último sondeo de $1,5 \times 1,5 \mathrm{~m}$ sobre la rampa de tierra que da acceso al solar, pero la falta de tiempo y recursos no permitió sobrepasar la capa superficial

En adelante llamaremos Zona 3 al sondeo interior y Zona 4 al espacio donde se realizan los sondeos en el exterior del edificio. Durante el proceso de limpieza del solar obtuvimos una serie de informaciones respecto al edificio monumental que, sin duda, aportan datos muy interesantes a su interpretación. Descubrimos al Sur del inmueble los restos de las losas y de la impronta del gozne del acceso (que no se puede documentar completamente, ya que penetra en el corte y sigue por debajo de las casas existentes en la actualidad en la calle Ordóñez). Si a esto sumamos la existencia de un gran pilar de dimensiones monumentales delimitando este acceso, suponemos que nos encontramos ante la fachada principal de la construcción (ver Láminas $\underline{\mathrm{XLVI}}$ y $\underline{\mathrm{XLVII}}$ ).

\section{INTERVENCIÓN ARQUEOLÓGICA}

\section{$1^{\text {a }}$ Fase de excavación C/ Huertos - C/ Remedios - C/ Ordóñez}

En el frontis Norte aparecieron los restos de lo que serian dos grandes pilastras adosadas a la fachada. La Zona 1 aportó la existencia de hasta 3 cimentaciones cuadrangulares de pilares (UE 1004, 1005 y 1006), muy arrasadas por la maquinaria pesada que en su momento excavó el solar, lo que sin duda contribuyó a la destrucción de buena parte de los restos de la parcela, así como de elementos del edificio romano (pudimos comprobar durante el proceso de limpieza las huellas de su uso en la estructura conservada) y que formó un estrato revuelto con materiales de todas las épocas. La disposición regular de las citadas cimentaciones indicaría la existencia de un porticado en el interior del edificio.

La Zona 2 aportó una estratigrafía compleja donde se observa una serie de niveles arqueológicos, que en su momento ocuparon posiblemente todo el terreno (los niveles se encontraban limitados por la UE 2004 que corresponde a un sótano que ocupaba parte del solar). Estas capas correspondían a la ocupación medieval y moderna (UE 2001), coincidiendo con la cota del antiguo convento de la Trinidad que cubre a los niveles de época bajomedieval (UE 2002) y el estrato de abandono del relleno para la puesta en cultivo de la zona (UE 2003). Estos horizontes cubren al nivel de ocupación 
de época altomedieval, que concordaría con la cota de arrasamiento del edificio romano (UE 2005) bajo el cual tendríamos el de época tardoantigua de abandono del monumento (UE 2006). El primer estrato de ocupación correspondiente a época del Bajo Imperio (UE 2007), solamente pudo ser limpiado parcialmente al seguir por debajo del nivel del solar en esa zona. Los materiales de esa campaña fueron extremadamente escasos, de tal forma que solo pudimos establecer una cronología general para estos estratos después de acabadas las tres campañas.

\section{$2^{a}$ fase de excavación C/ Huertos - C/ Remedio - C/ Ordóñez}

Se detectó un nivel arqueológico que se extendería por todo el solar, directamente sobre un estrato estéril de origen claramente fluvial. Éste, del que sólo pudimos recuperar una potencia de 30 a $40 \mathrm{~cm}$ de espesor, viene marcando una clara cronología entre el siglo II a. C. y final del I a. C., ya que gran parte de la cerámica ibérica, al igual que la púnica o ática recuperada, presenta claros índices de erosión por agua, lo que podría indicar un efecto de arrastre. Sin embargo, toda la cerámica republicana común de la Campania, ibérica tardía o TSI presenta un buen estado de conservación, lo que nos lleva a pensar que la alteración contemporánea sufrida por estos niveles arrasaría uno pre-estéril anterior al siglo I a. C. y otro del cambio de Era.

Excavadas en este nivel aparecieron un serie de cimentaciones de piedras trabadas con barro, sin relación con la estructura monumental romana posterior y por debajo del nivel de suelo de la misma, para las cuales podemos establecer un margen cronológico entre el cambio de Era y final del siglo I d. C. o principio del II d. C. según las UU. EE. 1001 y 1012 (ver tabla de materiales).

\section{$3^{a}$ fase de excavación C/ Huertos - C/ Remedio - C/ Ordóñez}

Durante el proceso de excavación obtuvimos una serie de informaciones respecto al edificio monumental que, sin duda, vienen a aportar datos muy interesantes en su futura interpretación. En primer lugar detectamos que al final de las hiladas de sillares de la fachada existía una gran cloaca, justo por debajo de la rebaba de mortero que estaba conservada sólo en la parte interior del edificio y que correspondía al nivel de suelo original del mismo. Además, descubrimos que los restos de las losas de la cubierta (que no se pueden documentar completamente, ya que la cloaca penetra en el corte y sigue por debajo de las casas existentes en la actualidad en el centro del solar) se encontraban perfectamente integradas en la cimentación de la fachada principal del edificio. Lamentablemente en la parte que corresponde al interior de este frontis no fue posible detectar restos similares a la cimentación de pilares de la fachada Norte.

En la Zona 3 se comprobó la existencia de hasta 3 niveles arqueológicos, muy distintos a los observados en la parte exterior del edificio. Por desgracia, la acción de la maquinaria pesada formó una capa revuelta con materiales de todas las épocas que 
alcanzaba justo hasta la cubierta de la cloaca, hasta el punto que parte de la misma se vio afectada por esta actuación. Los estratos sólo se pudieron recuperar en el corte del margen de seguridad.

La Zona 4 aportó una estratigrafía alterada por la maquinaria, pero donde aún se observa un nivel arqueológico, que ocuparía todo el solar y donde estaría excavada la cloaca. En la excavación de dos secciones del desagüe se separó el sedimento superficial más alterado (UE 3004 y 3008) del que se encontraba intacto (UE 3005 y 3006) en un intento de fechar el proceso de relleno y obstrucción final de la estructura.

Dentro de la estratigrafía realizada en el margen de seguridad, el primer nivel de ocupación (UE 3001), correspondiente a la época medieval y moderna, coincidiría con la cota del antiguo convento de la Trinidad. Se compone de un preparado de tierra arenosa de color beige muy depurada, sobre el que se levanta un pavimento de mampostería. Bajo este primer estrato detectamos otro de color pardo y textura arcillosa con abundante gravilla (UE 3002), correspondiente al hábitat de época medieval y que coincide con un periodo de abandono y relleno para la puesta en cultivo de la zona, previo arrasamiento del edificio romano. Dentro de este nivel, en el contacto con la UE 3005, señalamos un subnivel (UE 3002b) que se caracteriza por un color más claro, textura más compacta y sin gravilla.

En esta intervención pudimos detectar una capa (UE 3001 - ver tabla de materiales) de saqueo y destrucción superficial de la cloaca y del edificio monumental, correspondiente a época del Bajo Imperio o visigoda, lamentablemente muy alterada por la excavación mecánica del solar. La existencia de abundantes bolos y restos constructivos parece indicar la presencia de cimentaciones en este periodo. También señalamos un nivel (UE 3003 - ver tabla de materiales) en la zona que correspondería a la cubierta del desagüe y al pavimento del edificio, el cual se caracteriza por una textura más compacta, con abundantes esquirlas de piedra. Lo escaso del espacio excavado y su deterioro no permiten caracterizarlo como un estrato independiente.

El hallazgo más interesante corresponde a la cloaca (UE 3007) realizada en mampostería de mortero de cal, de $80 \mathrm{~cm}$ de ancho y $70 \mathrm{~cm}$ de profundidad, que cruza en sentido oblicuo la fachada de la gran edificación. La cubierta del desagüe corresponde a grandes losas de piedra caliza gris, de 1,2 m de ancho (la longitud no se puede determinar al no haberse conservado ninguna intacta) y se le apoya claramente la cimentación del frontis del edificio monumental y los restos de mortero del pavimento del citado inmueble. El nivel de relleno (UU EE 3004 y 3006 - ver tabla de materiales) de la cloaca corresponde al Bajo Imperio, que coincidiría con el abandono del edificio.

En la excavación de la Zona 4 detectamos, en el nivel superficial de la rampa, un estrato moderno (UE 3010), que lamentablemente se encontraba muy alterado por la excavación mecánica del solar. 


\section{CONCLUSIONES}

Es evidente que, entre la información que se perdió cuando se excavó la mayor parte del terreno en los años 80 y la escasa superficie sobre la cual hemos podido actuar hasta el momento, aventurar cualquier tipo de interpretación definitiva es cuanto menos arriesgada. Por otro lado, si tenemos en cuenta la minuciosidad con la que se han recuperado los datos y que contamos con unos elementos mucho más completos y perfectamente asimilables en el cercano solar de la plaza de la Morería, verdadero paradigma para las excavaciones en la zona urbana de Sagunto, sí podríamos lanzar algunas hipótesis científicas con bastante fundamento.

Respecto al edificio monumental, del cual realizamos por primera vez una planimetría más ajustada a la realidad, no pudimos recuperar elementos que nos permitieran establecer una cronología concreta, por lo que nosotros manejamos una fecha posterior al siglo d. C. y otra anterior al III d. C. por los escasos datos estratigráficos. Con ello, es posible pensar en una fecha del siglo II d. C., básicamente por paralelos con el vecino circo y con la plaza de la Morería, más aún si incluimos este edificio dentro de este periodo de monumentalización de la parte baja de la ciudad. Observarmos que el edifico fue arrasado aproximadamente en época altomedieval

Respecto a la cloaca, la técnica constructiva y su disposición claramente sincrónica con el edificio monumental (recordemos que la cimentación de la fachada y la cloaca fueron construidas de forma conjunta) nos permite fecharlas en un mismo periodo. En relación a la colmatación de la estructura de saneamiento, ésta empieza alrededor del siglo III d. C., aunque lamentablemente la destrucción que sufre la parte superior de esta estructura no nos permite establecer una fecha definitiva para su obstrucción total.

Comparando este nuevo hallazgo con la cloaca excavada en la plaza de la Morería, de características y tamaño similares, la colmatación definitiva pudo ocurrir alrededor del siglo IV d. C. La función de la misma no se ha podido establecer de una forma definitiva, pero por su disposición y orientación se trataría de un elemento para la evacuación de aguas y detritos del edificio monumental.

Es también probable que a lo largo del siglo III d. C. se construyeran estructuras en el interior del edificio, como lo demuestran los restos de cimentaciones observadas justo en el nivel de arrasamiento del pórtico en la UE 3003.

Por los datos cronológicos recuperados en estas campañas al refrescar estratigrafías, pudimos constatar que el edificio sufrió un importante saqueo que alcanza hasta el pavimento, de tal forma que en época musulmana ya había desaparecido de la superficie, coincidiendo con el nivel de la UE 3003, y siendo parcialmente rellenada para cultivo en época bajomedieval. Por el momento podemos observar la presencia de rellenos en el interior del edificio que nos dan una cronología de final del siglo III d. C., 
lo que marcaría un posible momento en que se reutiliza o desmantela parte del inmueble. Posteriormente tenemos un nivel de abandono que alcanzaría la época altomedieval, seguido de otro periodo similar hasta el siglo XV-XVI.

Una vez más tenemos claros paralelos con la zona de la plaza de la Morería, pues los niveles del siglo III d. C. corresponderían al entramado urbano en expansión, ocupando parte del antiguo espacio publico y que después se abandona hasta época altomedieval, cuando pasa a convertirse en una zona de viviendas extraurbanas. En este caso el factor distintivo es la presencia del convento de la Trinidad, que ocupará la zona inmediata desde época bajomedieval. Sus paralelos serían:

- Un nivel de época romana tardorrepublicana y del Alto Imperio asentado en niveles anteriores, que en la Morería era una necrópolis de incineración y que en este caso podría serlo también (la escasez de fragmentos de cimentaciones, no nos permite confirmar esta hipótesis), pero arrasado por el proceso de monumentalización del siglo II d. C. El hallazgo de inscripciones funerarias fuera de contexto en la zona, y escasos fragmentos de adobe quemados aparecidos en esta excavación apoyarían esta teoría, más aún si tenemos en cuenta que esta era una zona extraurbana. Próxima a este espacio, existiría una vía de acceso a la ciudad, lo cual justificaría enterramientos junto a ella.

- En el siglo II d. C. se construye un inmenso edificio de sillares, con entrada de grandes dimensiones flanqueada por pilares monumentales (similar a la que observamos en algún edificio del foro de Zaragoza) de losas de caliza gris, con la impronta del gozne de la puerta. Las dimensiones impresionantes de esta construcción, sumadas a la tipología de los restos encontrados hasta el momento, nos hablan de un gran edificio monumental de carácter público, con patio y pórtico a modo de peristilo, sin descartar que en el centro pudiera existir alguna construcción. La orientación de la entrada simétrica a la Porta Triumphalis del circo, y su desarrollo paralelo a este edificio lúdico nos permiten pensar que nos encontramos ante un importante cruce de calles.

- En un momento del siglo III d. C., la expansión urbana de la ciudad amortiza y reutiliza parte de este edificio o conjunto monumental. Prueba de ello son los restos constructivos recuperados en el interior del inmueble durante este periodo.

- Entre los siglos III y IV d. C. esta zona es abandonada y saqueada en época visigoda. Es posible que los restos que alcanzan la época altomedieval fueran arrasados o reutilizados en este periodo, como parte de viviendas u otras estructuras. 
CAPITULO 2:POBLAMIENTO RURAL DEL AGER SAGUNTINUS 


\subsection{RESULTADOS DE LAS INTERVENCIONES ARQUEOLÓGICAS}

En este apartado pasaremos a describir de forma resumida las intervenciones que nos sirvieron de base para establecer una teoría general, centrándonos concretamente en el espacio rural, para lo cual incluimos excavaciones tanto de la provincia de Valencia como de la de Castellón. Parte de éstas permanecen inéditas, ya que representan una caudal de información muy superior al que habitualmente se puede dar a conocer en los medios al uso, aunque en el peor de los casos se han publicado resúmenes de las mismas, ya representan una muestra significativa de algunos de los más interesantes yacimientos romanos de la zona.

Por otro lado, también añadimos algunos análisis puntuales de excavaciones que, si bien presentaron resultados colaterales por lo que se refiere al horizonte cultural romano, apuntan como conjunto interesantes datos para la comprensión del territorio en este periodo. Estas actuaciones ya contaban con una planimetría parcial, inventario y estudio de una parte de los hallazgos, pero carecían de contextualización histórica y de un estudio profundo de los materiales romanos. Contamos con varias excavaciones que ejemplifican cada sistema o modo de ocupación del territorio, como por ejemplo:

Els Terrers (Faura-Sagunto) - Se trata de la excavación de parte de una villa romana asociada a unos restos iberos. Su posición, muy cercana a Sagunto y a la vía Augusta, permite aportar datos interesantes para la comprensión del Hinterland saguntino.

Santa (Alcora) - Este importante yacimiento, situado en un enclave estratégico, ha aportado unos baños romanos, a los que debemos sumar los restos detectados en su entorno, en zonas como El Saltador

El Palau (Burriana) - Corresponde a la excavación en una zona rústica de un edificio termal romano con su planta completa, en el que se aprecian al menos tres fases constructivas. Existen 
otras estructuras anexas de la villa, pero no se encontraron en buen estado.

Sant Gregori (Burriana) - Este asentamiento se encuentra en estos momentos en proceso de excavación, que por el momento ha permitido delimitar la parte residencial de un importante fundus romano.

Torre d'Onda (Burriana) - Se trata de un enclave comercial ibero-romano de gran importancia en el ámbito de la comarca y que refleja claramente el principio de la ocupación romana.

Otros yacimientos de Burriana - Una serie de intervenciones puntuales, como Carabona, Cami Corrent o la Regenta aportaron datos que, una vez puestos en común, permiten entender mejor la ocupación del territorio durante la época romana en el término municipal de Burriana. 


\subsubsection{ELS TERRERS (FAURA - SAGUNTO)}

\section{DATOS HISTÓRICOS}

El yacimiento ubicado en la zona conocida como la Vall de Segó o Les Valls, fue excavado entre abril y agosto del año 2005 con motivo de la realización de las obras de construcción de la Autovía N-340 (actual A-7), en su tramo entre Almenara y Sagunto. Algunas fuentes citan que en época musulmana existían once pequeños pueblos o alquerías en la comarca: Santa Coloma, Els Frares, Alquería Blanca, Quart, Benifairó, Faura, Benavites, Quartell, Quèmalo, Rubau y Benicalaf. Ahora sólo quedan cinco pueblos que forman la Vall de Segó (GARCíA PROSPER et al, 2006).

El espacio geográfico lo podemos describir como un gran anfiteatro natural llano rodeado por las primeras estribaciones montañosas de la sierra Calderona, que cierran sus extremos en Sagunto y Almenara. Otros dos elementos geográficos que afectan esta zona son, por un lado, el gran marjal, hoy en franco retroceso, que se extendía por la costa entre el río Palancia y Almenara y por otro la Font de Quart, un manantial natural bastante caudaloso que ha permitido el abastecimiento de agua para los municipios que integran el valle y Almenara (AA. VV., 1977).

El poblamiento diseminado de época musulmana sin duda colaboró en la reutilización y dispersión de los abundantes restos romanos de la zona, especialmente los del yacimiento de Els Terrers. Un ejemplo es el despoblado de Benicalaf, que tenía origen en una alquería musulmana que aparece en el Llibre del Repartiment, con conocidas citas de la aparición de lápidas romanas sepulcrales entre sus ruinas. También Quart de les Valls, la antigua alquería islámica de Quarcel, en cuyo entorno aparecen abundantes restos romanos. Los habitantes del lugar dicen que el nombre del pueblo es de origen romano y quiere decir que faltan cuatro millas para Sagunto (AA. VV., 1985-2010).

\section{ANTECEDENTES ARQUEOLÓGICOS}

Hasta el momento los indicios referentes a la ocupación romana de esta zona se limitaban a elementos dispersos registrados en superficie y a una serie de estudios realizados, siendo uno de los más completos la prospección intensiva que delimita una serie de ambientes donde aparecen artefactos arqueológicos romanos (GARCÍA 
PROSPER et al, 2006). Este análisis señala una amplia dispersión de restos, pero detecta una serie de núcleos donde se observa una mayor densidad de los mismos; en efecto, el yacimiento de Els Terrers es uno de ellos.

Otro ejemplo de la presencia romana en la zona es la propuesta de existencia de un parcelario de tipo centuriado en el territorio de Sagunto, en la llanura litoral y también en la zona de la Vall de Segó (GARCÍA PROSPER et al, 2006). Esta hipótesis se apoya en la identificación de $\mathrm{V}$. Rosselló y F. Arasa del trazado de la vía Augusta en el camino paralelo a la vía de ferrocarril a su paso por la ciudad (ARASA y ROSELLO, 1995). G. Villaescusa ha identificado indicios de un parcelario que tendría como kardo la carretera N-340 entre Almenara y Sagunto, separada del posible trazado de la vía Augusta por una distancia aproximada de $710 \mathrm{~m}$, y que se prolonga al sur del río Palancia hasta la cercanía de Puzol (GONZÁLEZ, 2006). Para otros autores dicho eje, aunque sigue la orientación general del parcelario, presenta un trazado bastante irregular que sólo en algún tramo coincide con la retícula teórica y apuntan que posiblemente corresponde al Camí Real que fue reconstruido en el siglo XVIII (ARASA, 2006). Por último, encontramos la restitución del paso de la vía Augusta realizada por varios autores, que pasaría por las montañas de Almenara, atravesándolas por el mismo lugar que el ferrocarril. Desde ahí presuponen que puede seguirse su trazado casi rectilíneo por el Camí Vell, paralelo al ferrocarril, hasta Sagunto, pasando muy próximo al yacimiento de Els Terrers. Otros autores (ARASA y ROSELLÓ, 1995) proponen que en la proximidad de Sagunto, el Camino de Palmosa se desvía hacia el Oeste buscando los restos del puente que se conservan frente al circo de la ciudad, por lo que podría tratarse de la entrada principal de la misma.

No debemos olvidar que en Els Terrers en la década de 1920 fue descubierta una escultura de un toro de época lbérica hallada a metro y medio de profundidad (SIMANCAS, 1924), que actualmente se conserva en el Museo de Sagunto, junto al cual apareció material ibérico correspondiente a un margen cronológico situado entre los siglos IV y II a. C. Su longitud es de $60 \mathrm{~cm}$ y su altura de $53 \mathrm{~cm}$. Lamentablemente éste fue un hallazgo casual al extraer tierras para un ladrillar, por lo que carece de cualquier contexto arqueológico, pero su ubicación se encontraba a menos de 200 metros de la zona excavada.

Tras la consulta de la base de datos de la Dirección General de Patrimonio Cultural Valenciano se observó la existencia de dos yacimientos arqueológicos a tener en cuenta, y que se localizaban en un espacio próximo al trazado de la antigua $\mathrm{N}-340$, como es el caso del Cabeçolet de Morvedre (montículo de escasa altura que se sitúa en la partida de Montíber, al NW de Sagunto), donde se pueden apreciar restos de muros medievales $\mathrm{y}$, en superficie, aparecen fragmentos de cerámica romana, ibérica pintada, helenística y pondera. Por otro lado está el yacimiento de Els Terrers.

\section{INTERVENCIÓN ARQUEOLÓGICA}


En primer lugar se realizó una campaña de prospección arqueológica, que se orientó a la localización de los asentamientos presentes en el área de afección de la futura carretera. Debido al abundante material cerámico registrado en la superficie de algunos tramos de la traza, se delimitaron diferentes sectores donde se apreciaba una cierta concentración, lo que provocó la realización de sondeos mecánicos para poder identificar posibles niveles arqueológicos o estructuras arquitectónicas.

A la vista de los resultados con abundantes fragmentos de cerámica romana e ibérica en una franja adyacente a la carretera entre Faura y Canet de Berenguer, se planteó la excavación en extensión de dicha superficie del terreno. El terreno es un depósito cuaternario formado por arcillas rojizas transformado notablemente por el cultivo.

Durante el proceso de la intervención arqueológica se procedió a delimitar dos sectores claramente diferenciados. En el primero de ellos aparecieron restos de estructuras de época romana, junto a otro donde afloraron vertederos con abundante material ibérico. Ya en el inicio de los trabajos constatamos los graves problemas sufridos por el prolongado cultivo de cítricos y la constante roturación de los terrenos, que afectaron en gran medida tanto a la conservación de los niveles estratigráficos como de algunas de las cimentaciones, y generó una capa superficial con abundante material revuelto y amplia cronología. Tal fue la destrucción del mismo, que de los horizontes arqueológicos romanos solamente se conservaba un estrato de escasa potencia respecto al subyacente nivel ibérico (ver Foto $\underline{577}$ ).

Lamentablemente el citado estado de ruina del yacimiento no ha permitido definir con claridad en algunos sectores la diferenciación cronológica de estructuras, si bien algunos restos por su posición estratigráfica podrían pertenecer a unas cimentaciones de época ibérica, demolidas por la posterior ocupación romana. En el ambiente donde aparecieron estructuras romanas (sector $A$ ), junto a donde afloraron restos iberos (sector B), los hallazgos fueron los siguientes:

\section{SECTOR A:}

- Balsa rectangular de mampostería de mortero de cal con juntas de cuarto de bocel en las esquinas, revestimiento de opus signinum pintado de color rojo y un desagüe cerámico en su paramento Sur. En el interior documentamos abundantes fragmentos de ánfora. Sus dimensiones son: 5,20 m por 3,10 $\mathrm{m}$. El grosor de sus muros es de $55 \mathrm{~cm}$. Presenta una orientación E-W (ver Foto $\underline{578}$ ).

- Restos de seis cimentaciones de piedras de gran tamaño trabadas con tierra que forman habitaciones. Están asociados a diversos niveles de derrumbe. 
- Fosa de morfología irregular, rellena con cenizas, que documentamos junto a la balsa de opus signinum y donde no aparece material arqueológico.

- Restos de un pavimento de opus signinum con la impronta de balsa de decantación. Conservaba $1,95 \mathrm{~m}$ por $90 \mathrm{~cm}$ y presentaba una orientación E-W.

El material recuperado está formado mayoritariamente por tegulae, dolia, ánforas y cerámica común, con fragmentos de TSI, TSS y Campaniense B. El conjunto indicaría una cronología entre el cambio de Era y el siglo I d. C.

\section{SECTOR B:}

- Vertedero excavado en el terreno estéril. Presenta una morfología circular y sección irregular y se encontraba rellenado de abundante material ibérico, púnico, campaniense y de forma más residual ático y del Hierro Final. El diámetro máximo es de 6,25 m.

- Cámara de combustión de un horno de planta rectangular. Conserva $3 \mathrm{~m}$ por $76 \mathrm{~cm}$, siendo la altura conservada de 38 $\mathrm{cm}$. Presenta una orientación E-W.

Los materiales corresponden al período ibérico, del cual tenemos un amplio repertorio de formas. Se han identificado, dentro de este grupo más antiguo, diferentes clases cerámicas; la común, mayoritaria en el cómputo, son las ánforas. Tenemos también las importaciones, constituidas por material griego, fenicio y púnico, y finalmente, la cerámica a mano del Hierro Final.

En la clasificación de la loza común destacamos las tinajas, que son junto a los platos y tapaderas los tipos más abundantes. También destaca la presencia de las llamadas urnas de orejetas y urnas de tipo Cruz del Negro. Los trípodes de producción indígena están representados por dos ejemplares y son una clara muestra de las estrechas relaciones con los comerciantes fenicios.

El grupo de las ánforas recoge desde producciones locales a importadas; estas últimas, aunque no son el espécimen más numeroso, demuestran un contacto comercial directo. Entre ellas destacan ejemplares adscritos a producciones fenicias y otros de producciones púnico-ebusitanas. Dentro de los materiales de importación destaca la aparición de dos trípodes de fabricación fenicia. El conjunto indicaría una cronología entre el siglo V a. C. y el II a. C.

\section{CONCLUSIONES}


Nos encontramos con un yacimiento notablemente arrasado por la puesta en cultivo del terreno, primero para viñedos y después para cítricos. De los niveles romanos solamente se conserva un estrato de escasa potencia, parte de las cimentaciones posiblemente del impluvium de la villa y una balsa. Los materiales cerámicos romanos recuperados durante el proceso de excavación son escasos si los comparamos con los de época Ibérica de los vertederos.

El estado de destrucción del yacimiento no nos ha permitido definir con claridad, en algunos ambientes de la excavación, la diferenciación de estructuras entre los niveles romanos e ibéricos. Los materiales cerámicos indicarían a priori una cronología entre el cambio de Era y el siglo I d. C. Debemos sin embargo considerar algunos fragmentos de fecha posterior que aparecieron en los niveles superiores, por lo que no podemos descartar una mayor pervivencia del asentamiento, que también estaría en funcionamiento en los siglos II y III d. C. Esta hipótesis viene avalada también por la reutilización de fragmentos de ánforas del siglo I d. C. en la construcción de la balsa.

Respecto a la funcionalidad de las estructuras de época romana, nos encontramos ante los restos de una balsa y cimentaciones de cubicula que podrían pertenecer a una villa extraurbana que tiene su fase inicial a lo largo del siglo I d. C. El ya citado mal estado de las estructuras no nos permite más que una hipotética restitución del trazado de algunos muros (MELCHOR et al., 2008). Tal es el nivel de destrucción que de una balsa para decantación elaborada en opus signinum sólo encontramos parte de su fondo. Esta villa, dependiente de la ciudad de Sagunto, se establece sobre los restos de un asentamiento ibérico de los siglos VI y $\mathrm{V}$ a. C., que fue arrasado probablemente alrededor del siglo III a. C. Se encontraría junto al trazado de la vía Augusta y en los límites del antiguo marjal. Gracias a su posición estratégica en el centro del valle y su cercanía al suministro de agua de la Font de Quart sería sin duda el asentamiento más importante de la zona, situado prácticamente a "cuatro millas de Sagunto". 


\subsubsection{PARTIDA DE SANTA Y SU ENTORNO (L'ALCORA)}

\section{DATOS HISTÓRICOS}

Alcora es una localidad situada a $19 \mathrm{Km}$. al NW de Castellón, con una altitud de $279 \mathrm{~m}$. En su término municipal se han encontrado numerosos yacimientos, pero es de la cultura ibérica de la que existen más restos. Perteneciente al horizonte de contacto entre el Bronce Final y el inicio de la cultura lbérica es el yacimiento de la Ferrissa, cercano a la Foia, relacionado con la explotación minera de la zona, el cual ha sido excavado y, entre otros materiales arqueológicos, ha proporcionado restos de ánforas fenicias así como evidencias de un pequeño horno de fundición (AA. VV., 1985).

Es a partir de la cultura ibérica cuando Alcora presenta una relativa abundancia de yacimientos, destacando de entre ellos los poblados de Montmirá y el Tossal de les Foies, la Illeta y el Carapito. El primero ha proporcionado hasta la fecha restos de varios recintos adosados a una muralla, así como evidencias significativas del urbanismo del asentamiento. También existen restos de la dominación romana en las partidas de Montmirà, la Perereta y Santa (AA. VV., 1985 - 2010). De la presencia musulmana es el castillo del Alcalatén. El 24 de julio de 1233 la fortaleza y sus territorios son tomados por Ximén d'Urrea. El 1305 se otorga Carta Puebla a Alcora (AA. VV., 1977). El siglo XVIII viene marcado por el nacimiento, desarrollo y declive de la Real Fábrica de Loza y Porcelana creada en 1727 por el noveno conde de Aranda, que tuvo su etapa de mayor esplendor durante los casi 125 años en los que permaneció bajo manos nobiliarias, hasta que finalmente fue demolida en 1944. Durante el siglo XIX se ve envuelta en los avatares de la invasión napoleónica y de las guerras carlistas (AA. VV., 1985).

\section{ANTECEDENTES ARQUEOLÓGICOS}

Nunca se había realizado una intervención arqueológica en esta zona de Alcora, si bien se conocía de antiguo la existencia de restos. Por ejemplo, Carapito-La Santa se cita como un poblado adscrito a la cultura ibérica y romana (siglos II a. C. al II d. C.) (AA. VV., 1985). Este yacimiento limita con la partida de La Santa por el Este, sobre un montículo llano de unos $20.000 \mathrm{~m}^{2}$ con la pendiente más suave prolongándose hasta la confluencia del río Alcora con la Rambla de la Viuda. Los materiales cerámicos (ibérica pintada y $T S H$ ) se encuentran en superficie muy rodados por las labores agrícolas. En 
la ficha de inventario de yacimientos de la Conselleria de Cultura y Deporte (AA. VV., 1985 - 2010) se hace constar que no existen indicios de alineaciones de muros y no parece probable que se den por la escasa potencia estratigráfica entre el nivel superficial de arcillas y margas sueltas y el inferior de margas compactas.

La Santa se conocía como una necrópolis romana donde se han hallado según F. Arasa y M. Rosas un mínimo de 5 lápidas funerarias. Según estos autores el yacimiento de Santa no se trata de una simple villa, sino de un núcleo mayor situado en un importante cruce de caminos, atendiendo a la extensión del yacimiento, el número de inscripciones encontradas y la diversidad onomástica que presentan (ARASA y ROSAS, 1992). El Pla de Santa es un asentamiento en llano adscrito culturalmente a la época romana que presenta un mal estado de conservación. En esa misma partida, en las proximidades del asentamiento citado, se encuentra Sitges de Santa, yacimiento romano de silos, uno de los cuales está completamente vacío. Junto a estos depósitos se pueden apreciar algunos restos arquitectónicos dispersos, como piedras trabajadas formando parte de las paredes de bancales (AA. VV., 1985 - 2010).

El enclave está emplazado principalmente en un pequeño altozano, apenas algún metro más alto que las tierras circundantes. A principio del siglo XX se vio afectado por obras de abancalamiento para la plantación de almendros y olivos y más recientemente el lugar fue totalmente nivelado para transformar las fincas. La realización de las labores de desmonte y remoción de tierras generó la mezcla de los materiales arqueológicos, entre ellos abundantes materiales de construcción y tegulae, ladrillos, fragmentos de opus caementicium y opus signinum, gran cantidad de fragmentos de dolia, etc. (AA. VV., 1977)

El Pujolet de Santa es un asentamiento romano imperial de tipo rural, como demuestra el hallazgo de piedras de molino y varios silos actualmente cubiertos, formando una pequeña elevación artificial. Su considerable extensión hace suponer que pueda tratarse de un importante centro agrario. En la proximidad se han encontrado inscripciones funerarias, la mayoría de ellas perdidas (AA. VV., 1985-2010).

Respecto al yacimiento de Carapito es un amplio asentamiento en llano adscrito culturalmente a la época ibérica y musulmana. En la ficha de yacimientos arqueológicos de la Dirección General de Patrimonio Artístico (AA. VV., 1985 - 2010) se hace constar que se ubica en una zona elevada respecto al Pla de Santa y al cauce de la Rambla de la Viuda, de óptimas condiciones para el asentamiento humano y para la explotación agrícola, motivo por el cual proporciona restos materiales de las culturas ibérica y musulmana, muy degradados por el uso agrícola a lo largo de los siglos.

La Perereta es un enclave romano de medianas dimensiones localizado en un pequeño montículo, a escasos 300 metros del lecho actual de la rambla de la Viuda, en el 
extremo de la amplia llanura de Santa. Por las características del yacimiento y de los materiales encontrados se puede incluir dentro del grupo de asentamientos rurales.

El yacimiento de Les Eres está entre la carretera de Ribesalbes y la calle Tinent General Michavila, en Alcora, en una zona de reciente urbanización. En unos solares se han encontrado escasos fragmentos cerámicos ibéricos y romanos, entre los que destaca una pequeña copa con pie anular. Al tratarse de una zona de vertiente muy transformada no se puede precisar si los restos proceden de un área más elevada o si estaban en el lugar original.

El Tapàs es un asentamiento romano, ubicado en ligera pendiente hasta el barranco de Les Foies. Los trabajos agrícolas han propiciado la destrucción de todo vestigio arqueológico, no quedando a simple vista más que restos cerámicos en superficie (AA. VV., 1985-2010).

Finalmente, en el área agrícola más importante de Alcora, entre el río Lucena y la Rambla de la Viuda, se conserva parte del trazado de una antigua vía que comunicaba esta zona de la costa con el interior. El camino dels Bandejats presenta la anchura típica de las vías romanas e incluso en uno de los tramos está enmarcado por losas. No se ha podido constatar el lugar por el que el camino atravesaba la Rambla de la Viuda. El último tramo localizado se utiliza como vía de paso y rodea el Pujolet de Santa y, más al interior, el camino se pierde antes de cruzar el río Lucena en dirección al castillo del Alcalatén. Una tradición oral apunta a que esta misma ruta era el antiguo camino de Costur a Castellón, según la citada ficha de la Conselleria de Cultura y Deporte. Por otro lado, se da el mismo topónimo, Bandejats, para designar un camino del término municipal de Lucena, lo que hace suponer que fue una importante vía de penetración hacia las tierras del interior (AA. VV. 1985-2010). Queremos señalar que, justo lindando con el yacimiento del Palau en Burriana, tenemos un tramo del camino dels Bandejats, lo que podría ser un indicio más de la existencia de una senda hacia el interior que uniera estas dos zonas.

\section{INTERVENCIÓN ARQUEOLÓGICA}

La actuación consistió en la realización de una excavación arqueológica en relación con las obras de la carretera de Alcora-Sant Joan de Moró. Las tareas se iniciaron con la realización de 16 sondeos arqueológicos distribuidos a lo largo de la traza en las inmediaciones del Pujolet de Santa, más concretamente en las zonas con presencia de materiales arqueológicos documentadas durante los trabajos de prospección.

El siguiente paso, en función de los resultados positivos de la intervención en cuatro de los sondeos, fue ampliar la actuación con la excavación en área. La superficie total intervenida es de $3.230 \mathrm{~m}^{2}$ (ver Fotos $\underline{579}$ y $\underline{580}$ ). Pese al nivel de arrasamiento que presentan las construcciones del sector Sur, detectamos unas cimentaciones de 
mampuesto como el cierre perimetral de las dependencias de los baños y de departamentos de servicios anexos.

El sector Norte, Este y la parte más oriental del sector Sur de la excavación están caracterizados por potentes niveles de relleno que amortizan depresiones naturales o artificiales del terreno, sobre las que se cimientan algunos muros. Entre el conjunto de materiales recuperados en estos estratos destacan la TS Africana, cerámica común y plato-tapadera africanos. Junto a éstas se encuentran representadas formas de TSH y TSI, así como gran cantidad de fragmentos de loza común y de cocina, vidrio, clavos de bronce y de hierro y abundante fauna (sobre todo ovicáprido, bóvido, équido, suido, cérvido y en menor cantidad cánido, microfauna, etc.).

La naturaleza de estos rellenos y el estudio de los restos de cultura material hallados en su interior, apuntan al carácter de vertedero de tierras y elementos procedentes del propio asentamiento (concentraciones de cenizas, ladrillos, piedras, etc.). La datación post quem de estos vertidos nos la proporciona la $T S C D$ formas Hayes 59, 61 y 78; el resto de material aparece formado por fragmentos de TSH, TSI, de paredes finas cáscara de huevo, TSCA, TSS, campaniense A y $\mathrm{B}$, etc. Más antigua aún es la cerámica adscrita culturalmente al Bronce Final/Hierro Antiguo, que aparece mezclada también con material ibérico.

El estrato superficial no tiene mucho espesor, unos $25 \mathrm{~cm}$, y cubre un segundo nivel de relleno que enrasa los cimientos de mampostería de las distintas construcciones. Se forma como consecuencia de la ruina y posterior derrumbe de los muros y, por tanto, presenta como rasgo característico una composición heterogénea causada por la mezcla de tierra y fragmentos de ladrillo, abundante teja y piedra. Casi todas las construcciones arrancan desde el nivel natural de base, sólo se documenta en parte de los baños que los cimientos se construyen sobre una acumulación de tierra de composición arcillosa y gran cantidad de piedras, para de este modo equiparar el nivel de suelo de estas estancias (MELCHOR y BENEDITO, 2007).

El asentamiento tiene al menos dos momentos constructivos: el original y una serie de construcciones que amplían el espacio de las termas o transforman la distribución de otras estancias con la construcción de un nuevo acceso desde el vestíbulo y la amortización del posible frigidarium con la construcción de nuevos departamentos. La planta total del edificio tiene una superficie aproximada de $175 \mathrm{~m}^{2}$. Excavado en su totalidad, es posible reconocer su distribución en seis estancias. La primera, orientada al Norte y con muros construidos de encofrado de mortero, corresponde al vestíbulo, que conserva una planta de $18,2 \mathrm{~m}^{2}$. La segunda, de la que sólo se conservan los restos de la cámara de fuego del hipocausto, se identifica con el caldarium, con una planta rectangular de $12 \mathrm{~m}^{2}$. La habitación contigua corresponde igualmente a otra sala caliente, el tepidarium, que es de planta rectangular de $8,2 \mathrm{~m}^{2}$ separada de la anterior por unas pilas de ladrillo. Al Sur del vestíbulo se documentó la natatio, que aparece 
dividida en cuatro departamentos con una planta cuadrangular de $30,7 \mathrm{~m}^{2}$. Al Este del hipocausto se documentó la habitación correspondiente al praefurnium que conserva una planta de $12,4 \mathrm{~m}^{2}$. Por último, adosado al paramento Oeste del vestíbulo, se abren dos pequeños edículos o departamentos, de 1,6 y 1,76 $\mathrm{m}^{2}$ respectivamente, que conservan pavimento y revestimiento en las paredes de mortero hidrófugo, $y$ conformarían dos bañeras o piscinas de agua fría. Y también asociadas al vestíbulo, pero esta vez por su flanco Norte, se hallaron dos nuevas estancias que pudieron formar parte del complejo de los baños. En el segundo de estos ambientes documentamos la base de un recipiente cerámico relacionado con uno de los muros. En un momento cronológico entre el siglo II y III d. C. el edificio termal sufrió importantes reformas. Se amortizaron los cimientos de muros mampuesto con un potente nivel de relleno de tierra; sobre este nivel se levantaron los muros encofrados del vestíbulo y del hipocausto (MELCHOR y BENEDITO, 2007) y se dispuso el pavimento de opus tessellatum policromo del que se recuperó un pequeño fragmento con representaciones florales y de un par de sandalias junto a restos de una inscripción ilegible datado estilísticamente entre el siglo II y el III d. C. (SAN NICOLÁS, 2007 y BENEDITO, MELCHOR y PASIES, 2012). El fragmento de mosaico se encontraba bajo una acequia contemporánea que había arrasado los niveles arqueológicos, así que la datación arqueológica se ha llevado a cabo por el contexto del conjunto de las estructuras asociadas al pavimento musivo.

El resto del asentamiento sólo conserva parte de sus cimientos, que alcanzan en líneas generales una altura de 15 a $20 \mathrm{~cm}$ y únicamente de manera excepcional los $82 \mathrm{~cm}$. Esta zona del yacimiento ha sido excavada sólo en parte, siendo posible reconocer su distribución en seis departamentos. Este conjunto parece articularse en relación a un área abierta con un cierre perimetral; quizá alguna de las estructuras anexas estaba destinada a albergar el combustible.

Una vez que se abandona el hábitat, las construcciones se van arruinando, se desmoronan completamente y no se vuelven a habitar. Tan sólo en el nivel superficial se encuentran escasos fragmentos cerámicos de época hispanomusulmana, moderna y contemporánea, mezclados con los romanos, que proceden de las tareas agrícolas llevadas a cabo en fechas recientes (ver Láminas LXXII, LXXIII y LXIV).

\section{CONCLUSIONES}

En la construcción de los baños se han seguido al parecer planes lineales simples, que permitieron la sucesión de, en principio, una sala fría y dos calientes; la primera de las cuales está adosada al extremo Norte del edificio; de esta habitación se accedía al tepidarium o a otra estancia calefactada. Al Oeste de ésta se abre el frigidarium, con piscina cuadrangular. La zona propiamente termal se limita al sector Este del edificio, siendo la dependencia más oriental de planta rectangular con restos de un mosaico de opus tessellatum en su extremo Oeste. El acceso a los baños se realizaría desde este 
último aposento. El vestíbulo actuó como eje organizador del conjunto, las salas calientes ocuparon el flanco occidental mientras que las estancias frías (frigidarium y natatio) se ubican en el oriental (MELCHOR y BENEDITO, 2007).

En cuanto al desarrollo cronológico del inmueble hemos diferenciado dos fases constructivas, la fecha de su construcción ha podido ser determinada entre el siglo I y el II d. C. gracias a los materiales recuperados en unos niveles muy afectados por las reformas posteriores En la estancia correspondiente al vestíbulo de los baños, en un momento cronológico que situamos entre el siglo II y el III d. C., este sector del edificio termal sufrió importantes obras de reforma. Se amortizaron los cimientos del muro de mampuesto (UE 1048 y 1049) con un potente relleno de tierra arcillosa (UE 1040) cuyos materiales cerámicos escasos y fragmentados (TSH y cerámica africana de cocina) nos dan la cronología; sobre este nivel se dispuso el pavimento de opus tessellatum y se levantaron los muros encofrados del vestíbulo (UE 1009).

Analizando las características cronológicas de la cerámica de importación presente en el yacimiento, podemos observar que el despegue de la presencia de las mismas se da en el siglo I d. C., coincidiendo con la dominación completa de la Península durante la época augústea y julio-claudia. Pero, sin embargo, es durante el siglo II d. C. cuando observamos que aumenta de una forma significativa la presencia de la TS africana A y de la cerámica africana de cocina lo que podría indicar el despegue social y económico del yacimiento, acorde con lo que se puede observar en las grandes urbes romanas de la Península como Sagunto o Valencia. Este auge sigue de una forma significativa a lo largo del siglo III d. C., donde los materiales continúan apareciendo en una cantidad muy indicativa. Respecto a la decadencia y desaparición del enclave, debemos tener en cuenta que la mayor parte de las piezas fechadas en el siglo $\mathrm{V} \mathrm{d}$. C., principalmente TSCD Hayes 78 y 59, además de otros fragmentos de presencia esporádica o de clasificación mas compleja (CLARAMONTE et al, 2007) también se encuentran en el siglo IV d. C. Si rebajamos la cronología de aquéllas, podríamos suponer que el asentamiento inició un rápido declive en el siglo IV d. C., que acabó con una

relativamente vertiginosa desaparición. Este dato estaría acorde con los acontecimientos que marcaron el Imperio romano en este periodo, caracterizado por la anarquía y la decadencia de los municipios, iniciándose un periodo de inseguridad y recesión demográfica, con tendencia a la desaparición de asentamientos rurales, que se reducen favoreciéndose aquéllos que contaban con mejores condiciones defensivas y estratégicas

\section{EXCAVACIÓN EN EL CAMÍ DELS BANDEJATS}

Los trabajos se llevaron a cabo en el año 2004 y se centraron en la realización de cinco sondeos arqueológicos distribuidos a lo largo del camino dels Bandejats. 
El resultado de los trabajos arqueológicos fue negativo en todos los sondeos, excepto en el cuadro "C". En los restantes la intervención únicamente ha proporcionado escasos fragmentos de cerámica revuelta de arrastre, que presenta una cronología romana, por lo que no se ha encontrado estratigrafía ni una seriación cronológica fiable.

En el cuadro "C" la excavación ha proporcionado un único nivel arqueológico, pero este estrato no forma parte de la estratigrafía de una vía de comunicación sino que, por el contrario, está amortizando los cimientos de un muro de mampuesto de cronología romana que evidenciamos en el cuadro $\mathrm{n}^{\circ} 7$ de la excavación de la partida de La Santa. En la excavación en área llevada a cabo en este punto, documentamos también los fundamentos de un muro de mampuesto que se hallaba justo por debajo del camino dels y perpendicular a este último, a escasos $63 \mathrm{~cm}$ de la superficie.

Con respecto a la vía romana, la realización de labores de desmonte y remoción de tierras para la adaptación del suelo al cultivo, bien pudo generar la destrucción total del camino romano en este sector. Así, el trazado actual del camino dels Bandejats que hoy en día se conserva en este punto de Alcora es contemporáneo y posterior a las labores de desmonte realizadas en este punto.

\section{EXCAVACIÓN EN LA PARTIDA DE SANTA}

Los trabajos de excavación se centraron en la realización de 25 sondeos arqueológicos distribuidos a lo largo de la partida de Santa, más concretamente en las zonas con presencia de materiales documentadas durante los trabajos de prospección. En ningún punto se registraron niveles arqueológicos, con la excepción del Pk. 2+420. Seguidamente, en función de los resultados negativos obtenidos en casi todos los sondeos, ampliamos el área de actuación a la zona alta del montículo, donde únicamente hallamos escasos fragmentos de cerámica revuelta de arrastre que presenta una cronología situada entre la Edad del Bronce, época iberoromana, romana, hispanomusulmana, bajomedieval, moderna y contemporánea. Posteriormente se pasó a la intervención en área, como consecuencia de la aparición en el sondeo $n^{\circ} 7$ de los cimientos muy arrasados de un muro de mampuesto relacionado con material romano.

La superficie excavada comprendió una extensión de $462 \mathrm{~m}^{2}$ y puso al descubierto la planta de una edificación. Los materiales romanos recuperados (fragmentos de ánforas, cerámica común, TSH, TSCA, TSI, Campaniense, etc.), dan una amplia cronología para la utilización de la construcción (MELCHOR y BENEDITO, 2007).

La estructura exhumada es de planta rectangular y está excavada en el suelo geológico. Sus dimensiones aproximadas exteriores son de 5,41 m de longitud máxima por 4,52 m de anchura máxima. El grosor de los muros varía escasamente de 64 a 72 
$\mathrm{cm}$. Al Norte de esta construcción documentamos los restos de una nueva dependencia adosada a ésta que, como el resto del edificio, está realizada en mampuesto de piedras trabadas con barro. En el flanco Oeste de ambas dependencias documentamos los restos de dos hogares. En segundo término, en el espacio inmediato a la edificación principal, se constataron los restos de dos cimentaciones de mampuesto de barro. La construcción se encuentra ubicada aprovechando una pronunciada pendiente en la vertiente Norte del montículo. Carece de solidez, los muros presentan tres hiladas irregulares de piedra calcárea y cantos rodados. Los escasos elementos conservados dificultan una interpretación precisa su funcionalidad.

\section{EL SALTADOR}

\section{Antecedentes arqueológicos}

Anteriormente se había llevado a cabo una excavación arqueológica de urgencia bajo la dirección de E. Grangel y A. Oller. En ella, sobre el nivel geológico, se documenta un primer estrato deposicional al NW del yacimiento, un enterramiento infantil junto con el fuego asociado a él y quizá también se encontrarían los restos de otro enterramiento infantil y del hogar relacionado con él, documentados en la zona SE del sector II, todos asociables a momentos culturales tardo-ibéricos.

Posteriormente se construyen una serie de muros cuya cimentación se introduce en el nivel tardoibérico que delimitan una primera estancia. Después se hacen cambios en la zona, documentándose así una segunda fase constructiva y una tercera fase del mismo muro. Es una estructura que presenta un sistema constructivo irregular; en la mitad Este un aparejo de sillarejo con piedras regulares, la mitad Oeste con grandes piedras en la base y sobre ellas piedras irregulares de menor tamaño. Previo a su construcción existe un paquete de depósitos de relleno con muchos restos de materiales de desecho (huesos, cerámica, etc.) y gran cantidad de piedras que podrían indicar el uso de este espacio como basurero. Cuando todas las estructuras pierden su funcionalidad, en un momento indeterminado, esta parte del yacimiento se abandona y los muros comienzan a desmoronarse. Por último, ya arruinada la zona, se utiliza como vertedero. Los materiales arqueológicos recuperados indicarían una ocupación desde la $2^{\mathrm{a}}$ mitad del siglo II o final del I a. C. hasta la época tardo-romana (III-IV d. C.), por la presencia de TS Clara en los niveles de relleno-vertedero (AA. VV., 1985-2011).

En una segunda fase se amplia el área excavada; en el cuadrante NE de la parcela es la zona en la que se ha encontrado el mayor volumen de material y donde se concentran las estructuras que, una vez abandonadas, se convierten en un lugar para vertidos, como se ha documentado en la mitad Este del área intervenida. No obstante este espacio de vertedero se reutiliza, pues sobre estos niveles se construye un tabique. Fuera de estos muros, al Sur y al Oeste, sólo se han documentado dos estructuras. En cuanto a su funcionalidad, parece que estamos en una zona periférica 
del yacimiento. Las dependencias podrían corresponder, según los excavadores, a un espacio de servicios como corrales o almacenes. Respecto a los trabajos realizados en la segunda campaña, la excavación dio como resultado la aparición de nuevos tramos de cimentaciones y una serie de depósitos; todos ellos corresponden a vertidos con gran cantidad de carbones, capas de cenizas y de arenas con restos de mortero, bolsadas con material constructivo que estarían delimitados al Sur y al Oeste por muros. Estos niveles descansan directamente sobre el estrato geológico.

En cuanto al material mueble recuperado, estos depósitos son los más ricos del yacimiento: materiales de construcción (tegulae, imbrices, ladrillos), fragmentos de recipientes cerámicos y restos óseos de fauna. La cerámica corresponde a vajilla de cocina y mesa (TSH, TS Clara, paredes finas, etc.), dolia y ánfora ${ }^{16}$.

\section{Intervención arqueológica}

En el año 2007 se excavó en el espacio que ocupa el proyecto de construcción de la piscina infantil en el yacimiento de El Saltador, bajo la dirección de J. Benedito y M. Claramonte y en la que colaboramos puntualmente a nivel científico. Esta actuación atañe a una tercera fase de los trabajos arqueológicos que E. Grangel y A. Oller dirigieron en las dos campañas que resumimos arriba. La profundidad máxima alcanzada es de 2,95 m, variando según zonas entre los 0,63 m y 2,95 m respecto a la cota inicial de la excavación. Se ha excavado un ambiente delimitado por dos muros (ver Fotos $\underline{587}$ y $\underline{588}$ ), donde se ha documentado un nivel de relleno, que podemos relacionar con toda la serie de depósitos, muy heterogéneos en su composición, correspondientes a una zona de vertidos documentados en las intervenciones previas.

En cuanto al material recuperado, los hallazgos más frecuentes son restos de material constructivo (tegulae, ladrillos, ímbrices), restos óseos de fauna (sobre todo bóvida y équida) y respecto a la cerámica ésta presenta una amplia cronología: ibérica, del Hierro Antiguo, púnica y romana. Las formas de época romana corresponden a recipientes de cerámica común, TSI, africanas, etc.

La actuación prosiguió con la excavación arqueológica en extensión de 1.403,97 m² que abarcarían el vaso de la piscina infantil y zonas adyacentes. Dada la orografía del terreno y la existencia de un camino que dividía la zona, se diferenció la superficie a excavar en dos sectores:

SECTOR 1: Correspondiente a la mitad Sur del ámbito del proyecto. Está limitado al Oeste por la $1^{\text {a }}$ fase de la piscina, al Sur por la pista polideportiva y al Este por el camino de acceso al Ecoparque.

\footnotetext{
${ }^{16}$ Información sobre la intervención facilitada por los excavadores y por las fichas de inventario de la Conselleria de Cultura (A. VV., 1985-20010).
} 
SECTOR 2: Pertenece a la mitad Norte. Antiguamente dedicada al cultivo actualmente yerma se encuentra a una cota más elevada que el Sector 1.

Respecto a las características técnicas de las estructuras documentadas podemos decir que se trata de un conjunto que presenta un sistema constructivo irregular; todas ellas son de mampuesto de piedras trabadas con tierra. Con todo, la estructura UE 5007 está realizada con grandes piedras en la base y sobre ellas otras irregulares de menor tamaño, mientras que el resto de muros, de los cuales conservamos casi exclusivamente la base, carecen de bloques de gran volumen, con lo que es muy probable que la citada UE corresponda a una fachada.

No se han podido documentar restos de un momento anterior a las cimentaciones aparecidas en el sector 2, ya que se asientan directamente sobre el subsuelo geológico. No se han conservado tampoco niveles de ocupación asociados a esta primera etapa constructiva, lo que dificulta la posibilidad de establecer un marco cronológico para la edificación de este conjunto y la longevidad de su uso. Con la excavación de este sector 2 , se documentó toda un área de vertidos que se extendería alrededor de las únicas estancias documentadas en esta tercera fase de intervención. Estos se producen en un momento indeterminado en el que toda esta parte del yacimiento se abandona, donde se documentan una serie de hogueras (UE 5005 y 5006) y derrumbe de los muros. Con posterioridad a dicho abandono, pasará a utilizarse como lugar de sumidero ocasional $\mathrm{y}$, posteriormente, como grandes almacenes de desperdicios. En este proceso encontramos un depósito donde se concentran bolsadas con material constructivo junto a escasos restos cerámicos, abundantes carbones y hierro (UE 5004). Con posterioridad se observa ya un tercer periodo de uso generalizado de dicha zona como basurero, documentando un nivel donde aparecen escasos carbones y material constructivo junto a grandes cantidades de fauna y material cerámico (UE 5003). Estos estratos descansan directamente sobre el geológico, que en esta zona tiene un marcado desnivel.

En cuanto al material cerámico recuperado los hallazgos son los más ricos del yacimiento: materiales de construcción, fragmentos de recipientes cerámicos y restos óseos de fauna. La cerámica corresponde sobre todo a recipientes de cocina, vajilla de mesa (TSH, TS Africana A, paredes finas), dolia y ánfora procedente de la Campania. Estos conjuntos nos proporcionan un marco cronológico del uso como vertedero que llega hasta el siglo III-IV d. C. El problema es que toda la zona se vio alterada precisamente por estos depósitos, lo que hace imposible concretar cuáles de estos materiales pertenecen a los aportes como vertedero y cuáles podían ser restos de momentos de ocupación destruidos y transformados por el uso posterior de dichas estructuras, ya que no se ha podido documentar ningún nivel asociado a los muros.

\section{CONCLUSIONES}


Con la tercera campaña se pusieron al descubierto una serie de cimientos que completaron los resultados de excavación de los años 2004 y 2005 y que ampliaron la distribución espacial de los restos arqueológicos. Estas estructuras, como ya hemos señalado, pertenecen a un asentamiento de cronología romana Imperial y se encuentran asentadas directamente sobre el nivel geológico cuya cota varía según zonas, debido a un marcado desnivel del terreno, entre $1,18 \mathrm{~m}$ y $1,95 \mathrm{~m}$.

Posteriormente, en un momento indeterminado, las edificaciones se abandonan. La utilización de dicho lugar como lugar de grandes depósitos de desperdicios se prolonga hasta época tardorromana, como demuestra el registro de fragmentos de TS Africana. Por último esta zona sufre, al igual que muchas otras del término municipal, la aportación de tierra vegetal para la puesta en cultivo en extensión, lo que ha conllevado en algunos casos su terraplenado.

Respecto a la secuencia estratigráfica, los materiales cerámicos obtenidos en los basureros nos proporcionan un marco cronológico amplio que va desde el siglo I a. C. hasta llegar al siglo III-IV d. C., con unos estratos muy alterados. En relación a la funcionalidad de estas estructuras, tal y como apuntaron E. Grangel y A. Oller en las primeras campañas del yacimiento (AA. VV., 1985-2010), podemos pensar que podrían pertenecer a zonas de servicios periféricas del yacimiento. Esta hipótesis estaría avalada por el hecho de que no se han documentado niveles claros de ocupación. Además, entre los rellenos tampoco se han registrado fragmentos de revoco de mortero, ni ningún otro tipo de material de revestimiento de una cierta calidad. Este hecho también se constató en las campañas previas de excavación. 


\subsubsection{EL PALAU (BURRIANA)}

\section{DATOS HISTÓRICOS}

Cerca de esta zona estaba el conocido como molino del Palau, que estuvo de pie hasta el año 1975 y que pertenecía al barón de Terrateig, por lo que también se llamó molino del Barón y, posteriormente, Molí Ginero. Se ubicaba sobre la acequia del Palau y está asociado al señorío de Palau y Palamarinar, según el testamento otorgado por Narciso Juan Albiol, el día 3 de abril de 1607 (MESADO, 1991).

Otra referencia del 12 de junio de 1773 explica que no había quienes cultivasen la zona a causa de la expulsión de los moriscos, de la peste que sufrió y de haberse casi despoblado Burriana y los lugares del contorno por contagio y por las enfermedades que causaba la siembra de arroces, viéndose precisados los pocos habitantes de la villa y pueblos circunvecinos a otorgar escritura de concordia, comunicándose a través de ella que no se recomendaba hacer semejante siembra (MESADO, 1986). También tenemos una escritura que, con fecha 16 de mayo de 1676 cita el molino de harina nombrado del Palau, con 2 muelas y doce cahizadas de tierras anexas, así como un huerto rodeado de pared. Por último, posiblemente mediado el siglo XVII, se cita que el trapiche estaba arruinado y fue reformado por los hermanos Ignacio y Jacinto Ferrando al haber entrado en dominio y posesión del lugar del Palau, tierras y molino.

Buscamos referencias sobre el origen o primera ocupación de este enclave y encontramos un documento del 3 de febrero de 1321 donde aparece una cita de una alquería que fue de la Orden del Hospital y que según el padre R. de María estaba ubicada "en la parte de arriba de Burriana, junto al río Seco" (De MARÍA, 1935: 181) y por la ubicación de la misma podría corresponder a la del Palau.

En relación a un documento anterior, con fecha 25 de marzo de 1320, hallamos una referencia a las alquerías del término de Burriana que pasan de la Orden del Hospital a la Orden de Montesa; menciona la de Beniham en la cual "podem estar tro a VIII lauradors" (De MARÍA, 1935: 179). El mismo autor comenta este manuscrito y habla de la despoblación de la alquería de Beniham que se había producido a los 93 años de ser reconquistada Burriana, cuando la Orden de Montesa recibió de la Orden de San Juan del Hospital la citada posesión. También establece algunos de sus lindes, que serían: el río Seco, la acequia de la Villa, la acequia Mayor, la acequia de los Huertos, el brazal 
de la acequia, el camino del Molino, el ladrillar y caminos innominados (De MARÍA, 1935). Estos lindes parecen coincidir en gran parte con los de El Palau también llamada alquería del Hospital (también llamada del río Seco); y en época árabe con el nombre de Beniham. Posteriormente, en época medieval, pasó a conocerse con el nombre del Palau o Palamarinar (SARTHOU, 1913).

Los datos históricos son pocos; por nuestro lado, encontramos la cita de la donación por Jaime I en 1238 de Beniham o Alquería del Riu Sec antiguo enclave musulmán. Bernardo Mudina cita los restos de tres antiguas poblaciones, Palau, Casabona y Llombay, ignorando la época y la causa de su destrucción (MUNDINA, 1873).

\section{ANTECEDENTES ARQUEOLÓGICOS}

El yacimiento del Palau está situado en un terreno marcado por la notable calidad de los suelos arcillosos, circunstancia que ha hecho que estas tierras presenten desde la Antigüedad una destacada capacidad de aprovechamiento agrícola. El relieve local está constituido por la gran llanura aluvial de la costa.

Después de varios años de investigación, se ha hecho evidente la existencia de una ocupación muy amplia de la zona antiguamente vertebrada alrededor del río Anna y sus barrancos, junto al antiguo camino de Vila-real y que coincidiría con la vía Augusta (MOROTE, 1976). Estas culturas son las siguientes:

- Un hábitat neolítico que llegaría hasta el inicio de la Edad del Bronce, de características aún hoy poco claras.

- Una necrópolis ibérica, de cronología aproximada entre el siglo IV y el II a. C.

- Un hábitat romano de cronología del siglo I al IV d. C., que tiene en el yacimiento excavado parte de su emplazamiento central. Junto a este punto se extrajo arcilla el año 1942 y el propietario del terreno recuerda que aparecieron restos antiguos (MESADO, 1969), por lo que sería el solar donde $\mathrm{F}$. Esteve tuvo noticias de la existencia de un mosaico romano.

- La alquería musulmana de Beniham, con inicio en el siglo IX o $X$ d. C. y con posterior ocupación hasta época moderna conocida como Palau o Palamarinar. Se ubica en la zona más próxima a la ciudad, con la necrópolis de cronología musulmana en su espacio inmediato.

- Los estratos que aparecen en el yacimiento de El Tirao se han documentado también en El Palau. El estrato de arcillas y arena citado en 1969 por N. Mesado aparece en la zanja de un cercano gasoducto, y el nivel de piedras de la alquería 
musulmana aparece también en la citada trinchera. Además, han aparecido restos de materiales ibéricos en ambas zonas.

Otro importante núcleo de época ibérica lo encontramos en la partida del Tirao / Palau; un conjunto de yacimientos donde venimos realizando trabajos de investigación científica desde 1992. Hasta el momento, los pocos estudios sobre la zona recopilados a lo largo del siglo XX aportaban sólo una breve visión del interesante potencial histórico, arqueológico y etnológico de este espacio. De entre los datos conocidos y publicados podemos reseñar:

- Recolección de piezas en la zona y breve descripción de J. Peris y F. Roca entre 1920 y 1931 (ROCA, 1933).

- Noticias dispersas a cargo de F. Esteve en la década de los años 40 (MESADO, 1969).

- Seguimiento de obras realizadas en la zona y recolección de materiales a cargo de T. Utrilla y N. Mesado entre 1961 y 1965 (UTRILLA, 1964 y 1965).

- Noticias de hallazgos esporádicos a cargo de N. Mesado entre 1968 y 1990 (MESADO et al., 1991).

- Denuncia por parte del Centro de Estudios de Burriana de la destrucción de inhumaciones en 1991 por los trabajos del gasoducto Castellón-Valencia, ante la omisión del arqueólogo responsable de la obra.

- Actividades arqueológicas (prospección y excavación) llevadas a cabo por nosotros en los años 1993 y 1994, subvencionadas en parte por el Ayuntamiento de Burriana y autorizadas por la Conselleria de Cultura y Deporte. Estas contaron con la colaboración del Servicio de Prehistoria y Arqueología de la Diputación de Castellón y del Museo Arqueológico de Burriana.

- Excavación arqueológica con motivo de las obras de la Variante de Burriana.

En el aspecto arqueológico los datos eran escasos, ya que prácticamente no se habían realizado estudios profundos, solamente algunas observaciones y extracción de materiales realizados por $\mathrm{N}$. Mesado en su época de estudiante, que originan una de las primeras publicaciones científicas sobre el tema en 1969 en el APL XII, Los yacimientos arqueológicos de Burriana, en el donde respecto a este enclave solamente se citan la donación de unos fragmentos cerámicos y algunas vasijas medievales extraídas en la zona. El autor identifica los restos como pertenecientes a una antigua alquería musulmana, quizás Beniham, basándose en estudios anteriores en los que participó junto al párroco salesiano T. Utrilla y que fueron publicados (UTRILLA, 1964 y 1965). Estos fueron los únicos datos conocidos durante casi 30 años, pues los 
posteriores (MESADO, 1986 y ARASA, 1986) se limitan a repetir los mismos de 1964, que resumimos a continuación. En la publicación de F. Roca y Alcayde encontramos: (...) en nuestro museo dos vasos ibéricos, de cocción incompleta y sin influencia exótica, de forma hecha a mano. Estos han sido encontrados en lo que fue el poblado de Palaminar, hoy fábrica de ladrillos de don Bautista Ripolles, al hacer excavaciones para la extracción de tierra (...) (ROCA, 1933:33). En verdad se tratan de cerámicas musulmanas, de posible producción local.

Posteriormente, en los años 60, T. Utrilla entró en contacto con el propietario del terreno, que era muy joven en la época en que se extrajeron las tierras, y en entrevista personal obtuvo los siguientes datos (UTRILLA, 1964b):

- Los materiales aparecieron en una franja muy estrecha de terreno posteriormente rellenada (aproximadamente de $7 \times 7 \mathrm{~m}$ ) hasta una profundidad de metro y medio.

- Aparecieron enterramientos de 4 ó 5 personas a un mismo nivel y a un metro aproximadamente unos de otros.

- $\quad$ Silo de ladrillos planos circulares (sic) y que alcanzaba hasta los dos metros de profundidad.

- $\quad 50$ flechas (sic) de hierro soldadas por la oxidación, con $75 \mathrm{~cm}$ de longitud y 3 ó $4 \mathrm{~mm}$ de diámetro.

- Balas de plomo (sic) dispersas, de $2 \mathrm{~cm}$ de diámetro.

- Los vasos citados por Roca y Alcayde.

- Una moneda, perdida y sin identificar.

En el entorno solamente cita la presencia de estructuras de ladrillos y cantos fluviales de gran tamaño a aproximadamente 2 metros de profundidad, aparecidos en excavaciones para obras, sin más datos que puedan identificar su origen. En una zona próxima, al lado del mojón que señala el kilómetro 18 del Camí Vell de Vila-real (antigua vía Augusta) se produjo otra extracción de tierras, que el mismo T. Utrilla pudo seguir de cerca. El autor sitúa las piezas encontradas en una profundidad de 3,5 m; en estas investigaciones aparecieron restos muy importantes de un cementerio de época ibérica, con cremaciones y la fosa central donde se incineraban los muertos; resumidamente la intervención es la siguiente (UTRILLA, 1964b):

- Desde la superficie hasta aproximadamente $1 \mathrm{~m}$ de profundidad una capa de tierra con algunos fragmentos de cerámica indeterminada ${ }^{17}$.

\footnotetext{
${ }^{17}$ En el mismo articulo el autor las cita como posteriores a la etapa ibérica (UTRILLA, 1964b). 
- De $1 \mathrm{~m}$ hasta los 3,45 $\mathrm{m}$ de profundidad, estrato de arcillas con abundante loza, metal y carbones y una supuesta fosa crematoria con fragmentos cerámicos.

- A $1 \mathrm{~m}$ del inicio, dentro del estrato anterior, se encuentra un nivel de arcillas mezcladas con arena, posiblemente de carácter intrusivo, donde los restos son muy escasos, pero al parecer de tipo ibérico.

- Por debajo de este nivel aparece un nivel de piedras.

En la zona del Cementeri dels Gossos (nombre popular del enclave), observamos unos cortes producidos por el Camí Vell de Vila-real que cruza estas parcelas (ya que desciende por las terrazas fluviales hasta llegar al cauce del río vecino), alcanzando en su máxima altura los 2 metros aproximadamente, donde se descubre una cantidad notable de restos cerámicos y óseos que la erosión y la acción del hombre van extrayendo y destruyendo lentamente. Otra anomalía observada es el hundimiento de casi 1,5 m de algunos tramos de un huerto próximo, sin causa aparente.

Al desconocer la verdadera extensión del yacimiento y ya que las noticias eran muy incompletas, pues hablaban de hasta seis horizontes culturales distintos (neolítico, ibérico, romano, musulmán, medieval y moderno), en la prospección arqueológica intensiva realizada por nosotros mediado el año 1993 decidimos abarcar un amplio espacio y considerar todos los hallazgos como parte de un gran conjunto arqueológico. El área a prospectar quedaba limitada de la siguiente forma: al Este por el casco urbano de Burriana, al Norte por un margen aproximado de 150 metros a partir de la carretera de Vila-real a Burriana; al Sur por un margen aproximado de 200 metros a partir de la carretera de Vila-real a Burriana; y al Oeste hasta una distancia de $2 \mathrm{Km}$. del casco urbano. El medio físico donde se integra el yacimiento está formado por abundantes terrazas de origen fluvial que fueron aprovechadas para cultivos, en la actualidad de cítricos; el suelo es arcilloso, con escasos cantos fluviales en superficie.

Los trabajos de prospección se limitaron a documentar lo mejor posible todos los hallazgos que aparecían en superficie y a recoger una pequeña muestra de material arqueológico aparecido en la zanja del gasoducto de Castellón a Valencia, que depositamos en el Museo Arqueológico Municipal de Burriana. Estos últimos restos son los que a continuación detallamos:

- Restos de 5 inhumaciones, orientadas con la cabeza al SW y paralelos a la vecina vía Augusta.

- Tres fragmentos informes de cerámica a mano de la Edad del Bronce, con la superficie espatulada o bruñida.

- Fragmento de borde de vaso globular de cerámica a mano de difícil datación. Superficie beige-negra. 
- Fragmento informe de cerámica de cocina ibérica. Pasta reductora y desgrasante grueso.

- Dieciséis fragmentos informes de cerámica ibérica y dos bordes muy fragmentados de pasta de color beige.

- Fragmentos informes de cerámica ibérica de pasta gris y superficie beige.

- Borde de ánfora ibérica (posiblemente Tipo I-2 de Ribera).

- Borde de pequeño cuenco de cerámica ibérica.

- Borde saliente moldurado de cerámica ibérica.

- Dos fragmentos de cerámica púnica.

- Fragmento de base de TSS, forma Drag. 29.

- Fragmento de borde de dolium, forma Ober. 114.

- Tres fragmentos informes de dolia.

- Fragmento de TSS indeterminado.

- Fragmento de borde de TSI posible Goudineau 29.

- Fragmentos de tegulae.

- Borde de ánfora Dressel 2-4 de la Tarraconensis.

- Tres bordes de cerámica común oxidada $\left(2^{a} 1 / 2\right.$ II d. C.).

- Base de cerámica común oxidada de la (2a $1 / 2$ II d. C.).

- Tres bordes de platos tapadera (inicio del III d. C.).

- 52 fragmentos de cerámica musulmana, dos arranques de cuello y dos bases planas.

- Asa plana de pasta gris.

- Asa plana de pasta de color gris con canal central.

- Borde de cuenco con cubierta vítrea verde y pasta gris.

- Ocho fragmentos de cerámica con decoración floral en azul (siglos XVI y XVII).

- Cincuenta fragmentos de cerámicas contemporáneas.

- Alrededor de 50 fragmentos de huesos humanos.

En el año 1994 pudimos dirigir una excavación cuyo objeto era recuperar unas inhumaciones en riesgo de desaparición por la fuerte erosión del terreno, ya que éstas se encontraban prácticamente a nivel de la superficie, debido principalmente a los rebajes artificiales producidos en el terreno, en parte por las obras realizadas en las terrazas fluviales y en parte por el acondicionamiento de los huertos próximos. Al mismo tiempo se buscaba la identificación cronológica de la necrópolis que había sido parcialmente arrasada dos años antes y cuyos hallazgos citados arriba no permitían conocer su adscripción cultural.

En las dos primeras décadas del siglo $X X$ los propietarios del terreno donde se realizaría la excavación donaron al Ayuntamiento de Burriana la parcela para la 
construcción de una edificación utilizada posteriormente como matadero, por lo que en los años 40 el terreno ya presentaba la configuración actual; esta información fue obtenida de los actuales labradores y de fotografías aéreas del año 1938. Con las obras para terraplenar y construir la edificación fue cuando se produjo el rebaje artificial del huerto, con la consiguiente aparición de restos óseos. Desde entonces no se dan obras de importancia hasta la realización de la zanja del gasoducto en el año 1991.

Iniciamos la excavación sobre los restos óseos que aparecían en el corte estratigráfico. Nos encontramos con un terreno arcilloso, con algunas intrusiones arenosas en niveles más profundos. Se realizó un sondeo de $2 \mathrm{~m}$ de longitud por $1 \mathrm{~m}$ de anchura donde aparecieron dos inhumaciones (ver Fotos $\underline{572}$ y $\underline{573}$ ). A aproximadamente dos metros de la zona excavada, en el corte, aparecían más restos óseos, por lo que decidimos realizar una cata allí, donde documentamos otra inhumación, aunque lamentablemente ninguna se encontraba completa.

\section{NIVELES ESTRATIGRÁFICOS DE LA EXCAVACIÓN}

- Nivel superficial. Textura arcillosa y color rojizo. Tiene un espesor medio de $1,20 \mathrm{~m}$, se trata de un nivel revuelto por el cultivo con abundantes materiales cerámicos de entre los siglos XVIII y XX, muy rodados y fragmentados.

- Estrato 1. Textura arcillosa con intrusiones arenosas de color amarillento. Espesor medio de $23 \mathrm{~cm}$, con escasos fragmentos cerámicos.

- Estrato 2. Tierra arcillosa con intrusiones arenosas y escasos fragmentos cerámicos. Se inicia a $50 \mathrm{~cm}$ desde la superficie y está asociado con un agujero que afecta a todos los niveles hasta el estrato 6.

- Estrato 3. Composición areno-limosa, con abundantes cantos rodados. Tiene un espesor medio de $38 \mathrm{~cm}$

- Estrato 4. Textura arcillosa y tonalidad grisácea; espesor medio de $45 \mathrm{~cm}$; se trata de un nivel compacto irregular con escasos fragmentos cerámicos.

- Estrato 5. Tiene un espesor medio de $4 \mathrm{~cm}$; se trata de un nivel compacto irregular.

- Estrato 6. Composición arcillosa con intrusiones arenosas de color amarillento. Tiene un espesor medio de 1,13 m. Es un nivel compacto con escasos fragmentos cerámicos e inhumaciones que aparecen a distintas profundidades: la primera se encuentra en el inicio del estrato, mientras que la segunda a $80 \mathrm{~cm}$ de la anterior.

Restos muebles

- Tres fragmentos de dolia. 
- Fragmento de tegula.

- Fragmento de TSS.

- Fragmento de TSS decorada con relieves que representan aspas.

- Fragmento de asa martilleada, posiblemente de cobre.

- Fragmento de lámina de hierro.

- Cilindro de hierro con fondo en una de las extremidades.

- Cilindro y arandela de hierro.

- Inhumación 1 (incompleta).

- Inhumación 2 (incompleta.

- Inhumación 3 (incompleta).

Se trata de unas inhumaciones depositadas en el interior de fosas sin ajuar aparente. Están orientadas en posición SW-NE; dos de ellas sobre el costado derecho y las manos juntas al lado mismo lado, y la primera con las piernas flexionadas en un ángulo aproximado de $90^{\circ}$. La tercera parece encontrarse en posición decúbito dorsal con las manos juntas sobre la pelvis. Lamentablemente no pudimos determinar si las inhumaciones rompían el nivel perteneciente a la época bajomedieval, lo que en su momento hubiera aportado unos datos muy interesantes sobre su cronología. Los restos romanos se encuentran fuera de contexto y removidos por los enterramientos.

La primera parte de los trabajos arqueológicos de la campaña del año 2000 consistió en excavar un área aproximada de $450 \mathrm{~m}^{2}$. Se trataba de documentar los niveles bajomedieval y modernos de las diferentes dependencias del molino del Palau. Es un trapiche hidráulico instalado sobre la acequia de riego del mismo nombre. Los materiales de construcción observados son de piedra, alguna escuadrada, y mortero de cal. Las modificaciones en la estructura del molino son muy difíciles de diferenciar, habiéndose reutilizado durante posiblemente todo el siglo XIX y el primer tercio del XX.

La segunda parte de los trabajos arqueológicos ha consistido en documentar los niveles hispano-musulmanes. Estos últimos aparecen por debajo de alguna de las estructuras del molino, más concretamente bajo el suelo y en una extensa zona situada al Norte del muro perimetral (ver Foto $\underline{574}$ ). No obstante, estos estratos subyacentes en ningún momento se relacionan con las estructuras del edificio.

Se trata de un horizonte de arrasamiento de época islámica, con numerosos fragmentos de ladrillo, teja, mortero de cal, cantos de río y piedra, cerámica azul turquesa, de cocina y con cubierta vítrea de tonalidad verde y melada. Este mismo nivel ha llegado a alterar, en toda la extensión excavada, otro sedimento más antiguo de cronología romana, pues son muy abundantes los fragmentos de tegulae, doliae, ladrillos de opus spicatum (ver paralelo en la foto $\underline{469}$ ), escasos fragmentos de TS y de cerámica común. No obstante, en el espacio ocupado por el molino, este estrato de época romana no ha podido individualizarse respecto al musulmán. 
Así pues, el primer asentamiento en la zona excavada se adscribe a un nivel adscrito culturalmente a la época romana, que está relacionado con la nivelación y reocupación del terreno que tuvo lugar en período musulmán, más concretamente en el siglo IX o X d. C. cuando en el espacio inmediato se funda la alquería de Beniham, en funcionamiento hasta los siglos XVI o XVII cuando es conocida como Palau.

\section{EL CONJUNTO ARQUEOLÓGICO DE EL PALAU}

yacimiento presenta unos problemas que han afectado en gran medida a la conservación de las estructuras. La zona ha sido objeto de distintos cultivos de secano (viñedos, olivos, etc.) y más tarde de regadío (cítricos). La tierra ha sufrido periódicas labores de arado; además, respecto a las cimentaciones, no siempre se utilizó mortero para unir los materiales, hecho que ha provocado una destrucción bastante generalizada de algunas estructuras. Por otro lado, la despoblación de la alquería dio lugar a que parte de estas construcciones se desmantelaran para llevarse los materiales y ser reaprovechados en la cercana alquería del Batle, por ejemplo (ver Foto $\underline{540}$ ). Por último, la ausencia puntual de estratigrafía es otro de los problemas que presenta el yacimiento.

Los trabajos han consistido, primero, en la realización de varios sondeos en una amplia zona delimitada durante la prospección arqueológica previa, en cuyo informe destacamos la presencia de abundantes fragmentos cerámicos en superficie.

Durante la excavación apreciamos un nivel superficial revuelto por las labores agrícolas, en la que aparecen abundantes fragmentos de loza contemporánea, moderna, medieval y romana. Bajo este relleno aparecieron los primeros indicios del yacimiento, mediante una cimentación de muro (UE 2002), elaborada con cantos de río de pequeño tamaño trabados con escaso mortero de cal y arcilla y un estrato revuelto por la acción del cultivo con escasos fragmentos medievales asociados al arrasamiento de las estructuras: abundante grava y restos de mortero de cal, fragmentos de ladrillo y teja. Bajo este nivel empezó a surgir la primera estructura medieval (UE 5003) con un preparado de pavimento, restos de un suelo de mortero de cal y grava (UE 5004) y un vertedero con materiales musulmanes y romanos (UE 4002).

El primer nivel propiamente romano (UE 2004, 3002, 4002b y 6002) está compuesto por gran cantidad de piedras, cantos de río, fragmentos de tegulae y dolia, opus signinum y de mortero de cal, fragmentos de ánfora africana, cerámica común romana, $T S H$, etc., todo ello asociado a los restos de una zona de vertido. Por debajo de estos aparecía el nivel estéril, de arenas y limos con alguna bolsada de gravas.

La posterior campaña de excavaciones arqueológicas se desarrolló entre los meses de septiembre a diciembre del año 2000 y enero del 2001, con unas estructuras halladas que cubren una superficie aproximada de unos $2.000 \mathrm{~m}^{2}$. 


\section{SECTOR 1}

Una vez finalizados los sondeos se inició la excavación en extensión; en un primer lugar se intervino en un sector $\left(\mathrm{n}^{\circ} 1\right)$, de aproximadamente $250 \mathrm{~m}^{2}$, partiendo de la información proporcionada por la excavación del sondeo 1. La cota de profundidad máxima alcanzada en este sector es de 1,66 $\mathrm{m}$. Se amplió el conocimiento sobre la UE 2003, que corresponde a un nivel de tierra de textura arcillosa, con abundantes fragmentos de cerámica islámica: común, de cocina (ollas y cazuelas), bases de ataifor, loza azul turquesa, asas trenzadas, etc. Está relacionado con el arrasamiento de los niveles musulmanes de la alquería de Beniham, al que corresponden la cimentación de piedras trabadas en seco (UE 2007) y el muro, elaborado con piedras de mediano tamaño trabadas con abundante mortero de cal (UE 2008).

El nivel de vertido de notable extensión (UE 2004) esta compuesto por gran cantidad de piedras, cantos de río, gran cantidad de fragmentos de tegulae, dolia, tegulae mammatae, tubos espaciadores, opus signinum, mortero de cal, ánforas africanas, greco-itálicas y tipo Dressel 2-4; loza común romana, TSH, TSS, escoria cerámica, fragmentos con defectos de cocción (especialmente ánfora) etc. (ver Fotos $\underline{567}$ y $\underline{575}$ ).

La alineación de grandes piedras trabadas en seco (UE 2006) se encontraba muy afectada por las labores agrícolas, por lo que no ha sido posible interpretarla. Este estrato romano es similar al documentado junto al molino del Palau y descrito con las UE 1026 y 1028, y aparece totalmente arrasado por la nivelación del terreno en época musulmana. Sobre este enrasamiento se construyen dos muros designados con la UE 2007 y 2008, cuyas cimentaciones cortan el nivel anterior. En el periodo bajomedieval se arrasan las estructuras y los niveles musulmanes para dar pie a la construcción de una nueva edificación, la UE 2006.

Cuando se levanta la alquería del Batle se amortiza el inmueble anterior y se crea un nuevo muro de linde o separación que recorre longitudinalmente el trazado de la futura variante en dirección a la citada hacienda. En época contemporánea se extinguen las anteriores parcelas con un nuevo estrato de tierra para cultivo.

El punto más alejado de hallazgos en esta campaña correspondió a la zona donde se extrajo gran cantidad de arcilla en el año 1942. Podría tratarse del solar donde F. Esteve tuvo noticias de la aparición de un mosaico romano, monedas y otros materiales y también donde $\mathrm{N}$. Mesado cita el hallazgo de material arqueológico en el año 1969. Con el vaciado del huerto se perdió la posibilidad de que pudieran aparecer niveles arqueológicos y únicamente ha sido posible documentar un silo localizado justo en el mismo trazado de la carretera de Vila-real a Burriana. Se trata de un depósito de forma troncocónica invertida que tiene unos $2,5 \mathrm{~m}$ conservados de altura por 2,10 m de anchura máxima. Apareció rellenado con materiales cerámicos de entre los siglos IX-XI d. C., abundantes ollas, gran cantidad de fragmentos de cazuelas, platos, ataifores, 
fragmentos de piedras de molino, huesos de équido y ovicáprido, etc. Este silo sin duda esta relacionado con la alquería islámica de Beniham.

En cuanto a los restos encontrados del citado enclave árabe el yacimiento sólo conserva parte de ellos, que alcanzan en líneas generales una altura de 40 a $80 \mathrm{~cm}$, únicamente de manera excepcional el 1,60 m; se trata de la cimentación descrita con la UE 5008, donde se han diferenciado tres fases constructivas. Los materiales utilizados en la alquería de Beniham eran variados y hemos documentado la presencia de piedra, grava, cal, tierra y muy escasamente yeso.

El yacimiento ha sido excavado sólo en parte, siendo posible reconocer su distribución en varios departamentos. El conjunto de las estructuras halladas parece articularse en relación a un patio central o área abierta (UE 5056) de $120 \mathrm{~m}^{2}$ de superficie.

\section{SECTOR 2}

Las estructuras musulmanas exhumadas (ver Foto $\underline{570}$ ) corresponden a dos departamentos que delimitan por el Norte el conjunto arqueológico junto a dos balsas rectangulares y una base circular de las piedras para moler, que formaban parte del complejo de un área fabril. Con la reestructuración del espacio que tiene lugar entre el siglo XIII y XIV se levanta un muro relacionado con otros tres departamentos más pequeños, un suelo de mortero de cal y grava y una canalización de mampostería.

En cuanto a las estancias de los baños romanos, se documentan pequeños hornos en la sala fría, la sala tibia y finalmente la sala caliente, uno por habitación, además de un silo excavado en una de las salas; fruto de una reutilización de las diferentes estancias en época musulmana.

En el transcurso de los trabajos se descubrieron los restos de una gran construcción de la cual se conservaba de manera representativa un espacio o cabecera de planta absidiada, que formaba parte del conjunto constructivo de una villa (ver Foto $\underline{560}$ ). La planta excavada del edificio tiene una superficie de $220 \mathrm{~m}^{2}$ y su extensión se prolonga por debajo de la vía de servicio de la actual carretera. La técnica constructiva que utiliza es el mampuesto de piedras trabadas con barro mediante la alineación de grandes ripios, algunos escuadrados y en el centro otras más pequeñas o barro, así como mampostería de cantos trabados con mortero de cal.

Excavado el edificio sólo en parte, es posible reconocer su distribución en cuatro estancias. La primera con muros construidos en obra de mampuesto de piedras trabadas con barro, de la que sólo se conservan los restos de la cámara de fuego del hipocausto que se identifica con el caldarium, con una planta cuadrangular de $18 \mathrm{~m}^{2}$. La habitación contigua corresponde igualmente a otra sala calentada por el sistema de hipocaustum, posiblemente el tepidarium. Se trata de una estancia de planta 
rectangular de $27 \mathrm{~m}^{2}$ separada de la anterior por una pila de mampostería. Por último, el frigidarium presenta un pavimento de opus signinum.

La UE 5015 es la sala con hemiciclo semicircular que está en el extremo SW del edificio. La técnica constructiva utilizada es la mampostería de piedras trabadas con argamasa. El ábside está delimitado por un muro de mampostería y ambos se relacionan con un suelo de cemento de cal y grava. En el interior de esta estancia también se han documentado las cimentaciones de dos pilares. La primera corresponde a un basamento de piedra caliza sobre la que se construye una columna de mortero (ver Foto $\underline{566}$ ). La habitación UE 5016 es el límite NW del edificio y está asociada a un muro de mampuesto de barro, que delimita una estancia cuadrangular de la que sólo se conservan los restos de la cámara de calor del hipocausto, asociada con una sala cálida.

La cimentación de muro UE 5009 delimita por el NE la planta del edificio. La técnica constructiva que usa es el mampuesto de piedras trabadas con barro. Está edificado sobre otro anterior de cronología también romana, pero esta vez de piedras trabadas con mortero de cal. Esta cimentación delimita junto al muro descrito con la UE 5010 una nueva habitación (frigidarium) que se prolonga por debajo de la vía de servicio de la carretera actual. Las UE 5027 y 5036 son pilae de mampostería, de comunicación entre las dos estancias calientes.

La balsa rectangular UE 5021 excavada en el suelo es de mampostería con piedras irregulares. Se trata de unos muros de $44 \mathrm{~cm}$ de anchura, revestidos con capas de opus signinum que los hacen impermeables. Las juntas de unión de las paredes con la base están elaboradas con la técnica de media caña, con el objetivo de evitar filtraciones.

Los restos conservados han permitido documentar el tipo de construcción de la cámara de calor mediante el sistema de hipocausto con pilae de ladrillo refractario o de mampostería para soportar el peso de la suspensura. Por otro lado, los materiales recuperados permiten concretar el uso de concamerationes: tegulae mammatae, tubuli, (de forma tubular troncocónica y paredes rectas) y clavi coctiles, entre otras. En cuanto a los ladrillos registrados la morfología y los tamaños son variados: rectangulares, cuadrados de tipo bessalis y en su gran mayoría redondos.

En la construcción de los baños (ver paralelos en el dibujo $\underline{49}$ ) se han seguido planes lineales simples de recorrido retrógrado, que permitió la sucesión del frigidarium y de dos salas calientes. La primera de las estancias calefactadas está adosada en el extremo Norte del edificio; de esta sala se accedía posiblemente al tepidarium o a otra sala cálida. El suelo de la cámara de calor se compone de un lecho de fragmentos de piedra y restos de talla producto de la acción de desbastar la cara interna de las 
piedras de los muros del edificio (UE 5035). Al Este de la última estancia se abre el frigidarium, con balsa o piscina rectangular en su flanco Norte.

El conjunto termal que alberga los baños de la villa se sitúa inmediatamente al Norte de la dependencia con ábside en la cabecera. A falta de excavar la totalidad del edificio, el acceso a los baños se realizaría desde esta última estancia. En principio todo parece indicar que los baños ya estuvieron en uso entre el siglo I y III d. C. (según las UU. EE. 5007 a 5065, que corresponden a los estratos aparecidos dentro de los baños y bajo los niveles medievales - ver tabla de materiales)

Actualmente el conjunto de estructuras asociadas a los baños romanos y a la alquería medieval se encuentran bajo la ronda de Burriana, para lo que previamente han sido cubiertas con geotextil y rellenado con grava.

\section{SEGUNDA FASE DE EXCAVACIÓN DEL EDIFICIO TERMAL}

Esta intervención arqueológica llevada a cabo en el año 2002, pretendía en un primer momento descubrir la totalidad del edificio de los baños romanos, que se excavaron parcialmente el año anterior.

En primer lugar retiramos de forma mecánica los $60-70 \mathrm{~cm}$ de grava y arena que la empresa constructora había utilizado para rellenar la zanja que abrió de forma ilegal sobre el yacimiento y que supuso la destrucción de una importante parte de la estratigrafía del enclave. Al llegar al nivel arqueológico empezamos la excavación manual de los niveles y constatamos que estos habían sido arruinados casi en su totalidad; solo restaban los cimientos y agujeros excavados ya sobre el nivel estéril. A la vista de esta situación nos limitamos a realizar zanjas perimetrales para delimitar las estructuras y excavar los depósitos de materiales.

Los hallazgos más modernos correspondían el primero a una zanja de forma irregular que se perdía en el corte y que arrasaba parcialmente una cimentación de grandes piedras. Los materiales del relleno correspondían en su mayor parte a piedras, materiales romanos y musulmanes mezclados, apareciendo en menor cantidad fragmentos de loza del siglo XVI y XVIII; el segundo correspondía a un surco de forma aparentemente rectangular que seccionaba un muro de encofrado de mortero con cimentación de grandes bolos que se perdía en el corte; contenía restos cerámicos romanos y musulmanes y, en menor cantidad, a los siglos XV y XVI.

Dos silos realizados en el edificio romano tenían abundante material constructivo y cerámico musulmán y en menor cantidad romanos. Uno de ellos tenía forma semicircular (ya que era perimetral a un ábside) y otro circular; ambos cortaban los pavimentos de opus signinum de las habitaciones (ver Foto $\underline{563}$ ). Finalmente nos encontramos con un derrumbe que sellaba el pavimento de opus signinum del 
frigidarium (incluida una importante mancha de carbón) con abundantes materiales constructivos de los baños romanos y donde destacamos la práctica ausencia de elementos de épocas posteriores. Lamentablemente la escasa cerámica común no permite una datación exacta, por lo cual la incluimos dentro de la datación general del siglo III d. C. de amortización de los baños

Respecto a las estructuras, solamente los restos muy afectados de un muro de encofrado fueron descubiertos, por lo que se refiere al periodo musulmán o cristiano. Para la época del Bajo Imperio tenemos un departamento casi cuadrangular de grandes bolos trabados con tierra, pero enormemente alterado por zanjas de saqueo de materiales constructivos practicadas entre los siglos XVI y XVIII. Del mismo periodo es una habitación con ábside que reaprovecha las estructuras anteriores (para ello se derribó parte de los baños), como puede ser el vestíbulo de las termas. Lamentablemente otro surco de depredación, esta vez realizado en época musulmana, ha dejado pocos indicios del ábside, pero la impronta de esta trinchera nos permite restituir el mismo.

Finalmente en época romana tenemos unos cimientos de piedras desbastadas, trabadas con abundante mortero de cal y dos pavimentos de opus signinum superpuestos (ver Foto $\underline{554}$ y $\underline{555}$ ) que completan la planta del edificio termal.

Queremos destacar que todos los elementos constructivos aparecidos en este edificio (excepto en la zanja del ábside y en el agujero circular) son de época romana (tegulae, dolia, imbrices, tubuli, opus latericium y signinum, fragmentos de pintura mural, restos anfóricos, tegulae mammatae, etc.), lo que sin duda permitirá restituir buena parte del programa constructivo de los baños (ver Láminas LXII, LXIII, LXIV, LXV, LXVI, LXVII).

\section{SONDEOS ARQUEOLÓGICOS EN EL PALAU (ZONA ROTONDA)}

Con motivo de unas tareas de limpieza realizadas en una parcela del término municipal de Burriana, se constató que se habían afectado los restos del yacimiento del Palau. A la vista de los hechos, el ayuntamiento de Burriana nos solicitó en el año 2004 la realización de unos sondeos para evaluar el estado de esta zona del yacimiento.

Bajo el nivel superficial ya aparecieron las primeras cimentaciones, el tercio inferior de una gran tinaja con decoración plástica en cordón digitado (UE 1005), amontonamientos de cantos fluviales con escasa cerámica y material constructivo (UE 1006), una zanja de forma rectangular con cantos fluviales, elementos constructivos y cerámica romana y musulmana (UE 1010). Básicamente nos encontramos con el límite Oeste de la alquería musulmana de Beniham junto al actual río Seco. En este caso con dos fases claramente diferenciadas dentro de la propia etapa medieval, además por la posibilidad de haber detectado la impronta de las riadas que habrían afectado a estructuras del enclave. Los materiales recogidos son básicamente lozas musulmanas 
fechadas entre los siglos $\mathrm{X}$ y XI, y algunos fragmentos dispersos de cerámica romana correspondiente a tejas y restos de un pavimento de opus spicatum; también aparecieron restos de mortero y opus signinum que podría corresponder a la base de un mosaico. Este dato es interesante, pues de una de las parcelas colindantes existen noticias de la destrucción de un mosaico en los años 40 del siglo XX (MESADO, 1969).

Posteriormente, en los años 2008 y 2009 ampliamos la excavación del sondeo inicial del 2004, buscando mayor información sobre la posible existencia de restos romanos bajo las estructuras detectadas en la anterior campaña. Los resultados fueron negativos para este periodo, aunque siguió la tónica de aparición de abundantes elementos constructivos de esta etapa depositados en posición secundaria, casi exclusivamente en fosas (se repetía también la tipología de los materiales: tegulae, imbrex, ladrillos de spicatum y fragmentos pequeños de sillares), siendo la aparición de vajilla romana prácticamente simbólica. Realizamos una serie de sondeos mecánicos que descartaron la existencia de niveles arqueológicos bajo el último estrato islámico, ya que la aportación de grava y arena en estas capas tenía un claro carácter fluvial.

Por lo que respecta al periodo musulmán, las estructuras exhumadas apuntan a un gran edificio, en cuyo interior se encontraron tinajas semienterradas con posible función de depósito, lo que podría indicar su utilidad como zona de almacenaje o manufactura. También queremos señalar que este edificio se ve afectado por una importante riada, ya que tiene asociada una fina capa de arena de río, y además sufre una importante reforma dentro de la misma etapa Hispano-musulmana, señalada por la compartimentación del inmueble y destrucción de parte de sus muros.

\section{CONCLUSIONES}

El yacimiento del Palau está situado en un terreno marcado por la notable calidad de los suelos arcillosos, circunstancia que ha hecho que estas tierras presenten desde la Antigüedad una destacada capacidad de aprovechamiento agrícola. El relieve local está constituido por la gran llanura aluvial de la costa.

Después de varios años de investigación, se ha hecho evidente la existencia de una ocupación muy amplia de la zona antiguamente vertebrada alrededor del río Seco y sus barrancos, junto al antiguo camino de Vila-real, coincidente con la vía Augusta (ver Foto 557 ). El elemento más destacado del yacimiento es el gran edificio termal romano en el que identificamos tres fases cronológicas distintas (ver Lámina LXVIII).

Haremos un inciso refiriéndonos a las estructuras musulmanas construidas casi anexas al edificio de los baños (ver Foto $\underline{562}$ ), de tal forma que su cierre correspondería a un pequeño muro de encofrado de mortero que apareció en el extremo NE de la excavación, junto a los muros romanos. 
También queremos señalar la existencia de al menos tres zanjas de saqueo en épocas distintas; una correspondería a época musulmana, otra bajomedieval y la última moderna. Todas afectaron a los estratos subyacentes de la alquería árabe y el edificio romano respectivamente. La tipología de las mismas es muy característica, pues corresponde a fosas u orificios claramente delimitados, dentro de los cuales se encuentran abundantes fragmentos cerámicos de épocas anteriores $y$, en menor medida, del momento prácticamente contemporáneo al que se hizo el agujero, junto a elementos constructivos claramente desechados por aquellos que buscaban materiales con características muy determinadas y más fácilmente reutilizables como ladrillos, sillares, losas, etc.; esto nos ayuda a interpretar la ausencia de parte de las estructuras excavadas. Prueba de la reutilización es la vecina alquería del Batle del siglo XVII, ya que en sus paredes encontramos abundantes fragmentos provenientes del yacimiento.

Muy distinta situación es la que se refiere a la mezcla generalizada de materiales romanos y musulmanes, sin duda fruto de la reorganización del asentamiento llevado a cabo por estos últimos, donde sólo podemos diferenciar una mayor concentración de restos antiguos en lugares puntuales, como por ejemplo la superficie del frigidarium.

Volviendo al inmueble de los baños, éste consta de tres fases constructivas claramente diferenciadas:

Fase 1 o romana (siglos I al III d. C.): En un primer momento tenemos un edificio termal compuesto de cinco estancias de forma prácticamente cuadrangular, donde sólo la habitación del praefernium tiene una situación destacada del conjunto; las demás corresponderían a una gran sala rectangular absidiada que tiene adosadas en su cara norte tres estancias (caldarium, frigidarium y tepidarium), de la que pudimos excavar el acceso o umbral de las dos primeras (sobre ambos aparecieron claras manchas de carbón y cenizas con materiales). Estos aposentos tendrían un pavimento que no podemos precisar, ya que fue totalmente destruido, excepto un suelo de opus signinum de la sala fría, sobre el cual se construyó otro que tenía grandes piedras como base. La habitación rectangular al final de la absidiada correspondería al vestíbulo o apoditherium, de tal forma que aquélla podría acomodar un triclinio, como es habitual en las villas señoriales de Hispania.

Fase 2 del Bajo Imperio o tardoantigua (siglos III al ¿V? d. C.): La segunda fase correspondería a la anulación de los baños como tales, ya que se añade al menos una habitación en el extremo Este y se anula parte del aposento con ábside. Además, en su parte exterior se construye un refuerzo de forma rectangular. En esta sala también se implanta una columna y quizá un pilar, los cuales formarían un nuevo acceso, debido a que la parte Oeste de la residencia había sido anulada, ya que se construye un hemiciclo sobre parte de la misma y del vestíbulo. De la misma forma se levanta una estructura rectangular maciza dentro del praefernium y otra cimentación aún parcialmente desconocida en el extremo Oeste del nuevo edificio. En este mismo 
momento se construye otro suelo con base de grandes piedras en dos de las habitaciones (sala absidiada y sala fría), que hace desaparecer en una de ellas cualquier indicio de pisos anteriores. La técnica constructiva de este momento es totalmente distinta (piedra unida con tierra frente a cantos escuadrados trabados con mortero) y parte de los antiguos muros son derribados exactamente hasta el nuevo nivel de suelo. Los materiales de cronología posterior al siglo III d. C. son bastante escasos y aparecieron en contextos de prospecciones o sondeos en el yacimiento (UU. EE 4002, prospección y les Moreres - ver tabla de materiales) o un fragmento de dudosa clasificación de la UE 5020; por ello esta fase tiene un margen cronológico incierto.

Antes de la última fase podemos suponer algún período de abandono, ya que encontramos restos de fuego y carbón en un punto muy localizado, prácticamente en el acceso a la habitación de la sala fría y que no coincide a priori con otro momento de ocupación.

Fase 3 o musulmana (siglos IX al XIII d. C.): La última fase implica claramente un abandono de parte de las estructuras de la segunda etapa y la construcción de algunos hornos, posiblemente de uso doméstico, donde se reutilizan algunas habitaciones y abundantes elementos de obra. En este momento se hace al menos una zanja de saqueo que indica claramente la extracción de material constructivo, ya que es totalmente perimetral a un ábside que prácticamente ha desaparecido hasta su penúltima hilada de piedras de cimentación; también es significativo que se realice un agujero de vertido, similar al silo excavado por nosotros en otro lugar del yacimiento y que indicaría el pleno abandono de parte de estas estructuras. 


\subsubsection{SANT GREGORI Y SU ENTORNO (Burriana)}

\section{DATOS HISTÓRICOS}

Sabemos por escritos antiguos que en la Edad Media la zona del Grao tenía un amplio bosque, ya que muchas veces el mismo rey Jaime I venía a cazar en él; posiblemente debería envolver una zona pantanosa costera. En época moderna, el mismo Viciana cita la importante cosecha de juncos y cañas en la zona litoral de Burriana, así como una buena pesca (VICIANA, 1574).

En el siglo XIV fue introducido el cultivo del arroz y la población contaba con 597 fuegos. En el siglo XVI tenemos noticias de la existencia de unas salinas en la zona, junto al poblado marítimo y al puerto donde se acercaban los barcos para desembarcar mercancías y abastecerse de agua en el Clot de la Mare de Deu; se trata del único tramo acuático del río alimentado por resurgencias y manantiales, donde se construyó una torre defensiva conocida como la Torre del Mar. En el siglo XIX se eliminaron los terrenos pantanosos, comenzando a introducir el cultivo del naranjo, lo cual produjo un cambio notable en el desarrollo de la población (AA. VV., 1986).

El yacimiento más cercano a la villa romana corresponde a las salinas medievales de Burriana. La gabela de la sal, que se hallaba establecida en la ciudad desde el siglo XIII, constituía el distribuidor a una amplia zona geográfica. El topónimo aún en uso de Camí de les Salines y los restos arqueológicos del canal del agua del mar a las salinas, visible durante una tormenta en los años 80 (VILLALMANZO, 1987), nos señalan su ubicación. Según J. Villalmanzo, en el libro n. ${ }^{\circ} 9.261$ de la Sección del Mestre Racional del Archivo del Reino de Valencia correspondiente al año 1489, en este año se realizaron importantes obras de acondicionamiento en las salinas, lanzándolas de nuevo a la plena producción, siendo posteriormente de nuevo restauradas en los años 1570 al 1580. Bernat Salzes, obrer de la vila, manifestó que dicha casa de las salinas estaba en ruinas y que no convenía reedificarla en el mismo lugar sino en otro, un poco más arriba, en un alto, cerca del stany y enfrente de la torre de la costa, donde había unos cimientos que podrían ser utilizados (VILLALMANZO, 1987), en una posible referencia a restos arqueológicos.

Curiosamente ninguno de los autores del siglo XVII hace referencia a las salinas de Burriana, lo que podría indicar la fecha ante quem para el abandono de las mismas. 


\section{ANTECEDENTES ARQUEOLÓGICOS}

La única intervención que se desarrolló en algunos huertos en el entorno del yacimiento romano de Sant Gregori, fue entre los años 1978 y 1987. Los datos conocidos sobre ella son muy exiguos, ya que podemos calificar de lamentable la ausencia casi total de documentación gráfica (planimetrías, fotos, croquis, etc.) y de estudio de materiales (no existe inventario ni clasificación de los mismos). Las publicaciones también escasean, de tal forma que reproducimos resumidamente la única realizada hasta el momento (AA. VV., 1989: 115-117):

[Campaña 1978]
Nivel 1:(...) fragmentos cerámicos de época romana.
Nivel 2:(..) entre $70 \mathrm{~cm}$. y los $113 \mathrm{~cm}$. de profundidad. Al constituir el
nivel fértil del yacimiento alto imperial, tributaría los hallazgos
principales (...).
Nivel 3:(...) rebasados los $150 \mathrm{~cm}$., dejaba al descubierto el manto
freático (...)
[Campaña 1987]
(...) un muro que, con dirección $\mathrm{N}$, demarcó dos departamentos. (...)
arrasados durante la Alta Edad Media para nuevas obras, como así lo
demuestra el horno que se detectó en el ángulo NO del sondeo, cuyas
jambas de la boca se construirían con trozos de tégulas y ladrillos de
la villa romana, cronología que confirmarían varios trozos de olla
islámica aparecidos en su interior.
(...) en cuanto a las estructuras parcialmente descubiertas,
pertenecen a diversas habitaciones de tamaño regular, parece que
corresponden a un área de cubicula que debía extenderse alrededor
de un atrio o peristilo, sin que podamos precisar más (...) una datación
(...) entre los siglos l-ll.

Poco más podemos añadir a lo publicado en este artículo, excepto breves referencias como la reproducida a continuación: (...) se ha podido recoger algunos fragmentos de mosaico en blanco y negro, cerámica y algunas monedas, como un as republicano (...) en la vecina partida de Les Salines se encontró un as del emperador Trajano (104-111) (ARASA, 1986: 53).

Así tenemos que guiarnos por una descripción compleja y enrevesada de los hallazgos, lo cual no clarifica en absoluto la funcionalidad del yacimiento. Un ejemplo es la descripción de un horno presuntamente musulmán, pero curiosamente no encontramos ni un solo fragmento cerámico de este periodo entre los materiales del almacén; en cambio sí tenemos algunas cerámicas tardías y de cocina romanas que podrían dar margen a confusión. Esto pone en tela de juicio no sólo la datación, sino también la funcionalidad de la estructura exhumada. 
Respecto a otros yacimientos, la distancia hacia el Calamó es de 2,7 Km. y respecto a Torre d'Onda 3,7 Km. De estos, el Calamó parece tener hondura de fondeadero, según se puede deducir de los hallazgos submarinos de ánforas. Los materiales recuperados pertenecen a varios tipos, entre los que hay algunos tardíos; estos permiten determinar un amplio período de utilización del lugar como a ancladero, que se extiende entre el siglo I y el IV-V d. C. y que de momento no encuentra su correspondencia en los yacimientos terrestres. En el yacimiento de Sant Gregori, por lo que respecta al material mueble, bastante escaso en general, se encontraron algunos fragmentos de cerámica TSH, TS Africana A, paredes finas y comunes. A partir de los materiales recuperados, la cronología de este conjunto la establecieron los excavadores de manera aproximada entre mediados del siglo I y el II d. C.

\section{LA REVISIÓN DE LOS FONDOS DEPOSITADOS EN EL MUSEO}

Al analizar los restos depositados en el Museo de Burriana referidos a las campañas realizadas en el yacimiento de Sant Gregori y contrastarlos con los datos publicados hemos llegado a las siguientes conclusiones:

- Existiría al menos un mosaico de opus sectile en el yacimiento, ya que los restos de mármol recuperados corresponden a elementos geométricos (abundan los cuadrados y los rectángulos) recortados sobre placas mayores reutilizadas; además las huellas de mortero indican su utilización como pavimento. Tenemos varios ejemplos de este tipo de obra, uno de los más cercanos en el Museo Arqueológico de Tarragona (ver Foto $\underline{571}$ ).

- Lo que se publicó como posible canalización cerámica de agua o toberas, en verdad corresponden a tubuli, que formarían parte de la concameratio de unas termas, lo que indica la existencia de unos baños en esta villa. La cantidad de fragmentos de tubuli es tal que corresponde a más del $75 \%$ de los hallazgos cerámicos recogidos durante la excavación.

- Otras evidencias de la existencia de unos baños es la presencia de ladrillos con retícula incisa típicos de las concametario y abundantes fragmentos de mortero con moldura en media caña muy característicos de las piscinas o balsas romanas.

- Menos significativa, pero no descartable, es la presencia de mosaicos de opus sectile y de tessellatum en blanco y negro, muy característicos de termas y baños romanos (como por ejemplo Ostia Antica, Pompeya, Rimini, Roma, etc.) 
Estas evidencias también señalan la necesidad de delimitar el yacimiento y de revisar su cronología e interpretación, ajustándola a una visión más moderna y científica.

\section{INTERVENCIÓN EN SANT GREGORI}

En la actualidad la intervención que estamos desarrollando en Sant Gregori muestra una riqueza material considerable pues además de una importante cantidad de mármol detectado en la excavación y de muy distintas variedades (Serpentino, Saetabensis, Giallo Antico, etc.), se está recuperando un amplio espectro de restos de pintura mural, donde básicamente podemos destacar al menos un ambiente decorado en el tercer estilo pompeyano u ornamental, con predominio del fondo blanco, lo que nos llevaría a una cronología del siglo I d. C.; todo ello apuntaría al momento de auge del asentamiento, entre el final o mediado del siglo I d. C., a falta de detectar el momento de reforma y reutilización de parte de sus estructuras, quizá alrededor del siglo III / IV d. C., de forma similar al vecino yacimiento del Palau.

Otro factor interesante observado en esta campaña, es que gracias al estudio geomagnético del subsuelo, hemos podido detectar la configuración primigenia del enclave, situado en un pequeño islote enmarcado por dos barrancos, que a su vez delimitan el espacio de la senda que unía este yacimiento con la vía Augusta a la altura del yacimiento del Palau (ver Lámina $\underline{L X X}$ ); además los sondeos realizados en la zona también han permitido comprobar la situación del yacimiento en un pequeño altozano rodeado de marjales y protegido del mar por un cordón dunar fósil.

Hasta el momento, y a falta de futuras campañas de excavación, se esta cerrando la delimitación de la parte residencial del asentamiento, pues además de una serie de estructuras de un más que probable peristilo con estanque central (ver Fotos $\underline{154}, \underline{530}$ y $\underline{30}$ ) se ha detectado un monumento funerario (probablemente un columbario familiar de tipo turriforme (ver Fotos $\underline{531}$ y $\underline{532}$ ) asociado a restos de incineraciones arrasadas alrededor del siglo II d. C en la periferia de la villa y cerca de una zona de importantes vertederos.

Un último dato interesante es la presencia residual de cerámica campaniense $A$ y $B$, junto a fragmentos de cerámica ibérica, que más que el indicio de un poblado de esta cronología podría apuntar a la aportaciones de tierra con finalidad constructiva que contenían materiales del cercano yacimiento de Torre d'Onda.

\section{ARQUEOLOGÍA SUBACUÁTICA DEL ENTORNO DE SANT GREGORI}

Durante toda la República y hasta casi el comienzo del Imperio, el comercio del vino lo comprobamos en las ánforas greco-itálicas, representadas por dos ejemplares en Torre d'Onda y otro en el Calamó. También de una cronología tardorrepublicana en el Calamó aparecen cuatro ánforas Dressel 1, de las cuales una es de claro origen 
campano; las otras tres se las identifica como tarraconenses, y según A. Fernández hay que hacer hincapié también en la semejanza de estas últimas formas con las del horno del vecino yacimiento de la Punta en la Vall d'Uixó ${ }^{18}$ (FERNANDÉZ, 1991).

Durante el período Imperial en el Calamó tenemos hasta 7 ejemplares de ánforas Gauloise 3 y 4 . El número de cuellos aparecidos en las costas de Burriana, constituyen un tanto por cien muy elevado comparándolo con la cantidad de material de época republicana y abren una nueva vía de ruta comercial para este producto. En el citado yacimiento del Calamó tenemos dos ejemplares de ánforas béticas Dressel 20.

También se han recuperado de forma casual ejemplares de anclas romanas en la costa de Burriana, pero para atribuirles una cronología es preciso que hayan sido encontradas in situ y documentadas en su posición original, para relacionarlas con el contexto. Según A. Fernández hallazgos de final de los 80 del siglo XX en la zona arqueológica de El Calamó confirman la teoría de que nos encontramos ante un primitivo embarcadero, ya que han sido encontradas ánforas con una dilatada cronología: greco-itálicas, Dressel 2-4 y 20, e incluso del siglo IV y V d. C. Sobre estas últimas la autora comenta un cuello muy peculiar que se puede asimilar a la clase 47 de Peacock, que las ha denominado Hollow Foot, equivalente a la Ostia VI, Kapitan II o Benghazi MR-7 (FERNANDÉZ, 1991). Otros autores citan la presencia de Dressel 30 africana (JÁRREGA, 2011). El hallazgo del Calamó atestigua la continuidad de los contactos comerciales en los últimos siglos de la romanización.

\section{YACIMIENTOS DEL ENTORNO: EL MARJALET}

Este nuevo yacimiento ha sido descubierto recientemente, en el año 2008, y excavado por L. Salvador con motivo de la creación de una cantera de arcillas (Cantera Ángela) en la zona conocida como el Marjalet de Burriana.

A la espera de que la arqueóloga responsable de la intervención publique los resultados definitivos, solamente podemos avanzar algunos datos genéricos que amablemente nos ha facilitado.

Los restos exhumados corresponden a un vertedero cerámico con una gran variedad de formas: dolia con sus tapaderas, cerámica de paredes finas, TSI, ánforas, loza común, botellas, lucernas, elementos domésticos de bronce, vajilla de cocina, etc. Todo el contexto lo podríamos ubicar provisionalmente en la primera mitad del siglo I d. C., aunque tienen unas características peculiares que deberíamos valorar; todas las piezas están incompletas en un $20 \%$ aproximadamente, pero con fracturas antiguas muy homogéneas, esto nos podría llevar a pensar que los materiales fueron depositados en

\footnotetext{
${ }^{18}$ Este yacimiento es conocido en la bibliografía como la Punta de Orleyl, Orleyl, Orleil y Orlell (JARREGA, 2011), ante la falta de argumentos definitivos a favor de cualquiera de ellos, mantendremos el nombre la "La Punta" el único reflejado en la cartografía desde principio del siglo XX.
} 
el vertedero algún tiempo después de su abandono, ya que tal cantidad de faltantes no es habitual en estos vertederos.

A esto debemos sumar que parte de piezas tienen abundantes lañados en plomo, lo que indica claramente un uso prolongado de las mismas. Así pues podemos proponer una fecha alrededor de mediado o final del siglo I d. C. para la formación de este relleno. A falta de conocer el contexto del vertedero, como por ejemplo su pertenencia a una villa aún desconocida, es interesante observar que los materiales presentes son los que no encontramos en los dos yacimientos más cercanos, el Palau y Sant Gregori, que empiezan a destacar a partir del siglo II d. C., Por ultimo señalar que en la excavación la arqueóloga detectó una serie de canales o zanjas que muy bien podían tener que ver con la desecación del entorno aprovechando el vecino barranco del Marjalet o del Hospital, rellenado a principio del siglo XX y situado a escasos 100 metros del yacimiento. 


\subsubsection{TORRE D'ONDA}

\section{DATOS HISTÓRICOS}

Lo que por los autores contemporáneos es citado como la "Olla" frente al yacimiento, correspondería en buena parte a terreno firme hasta bien entrado el siglo XX (cuando se inicia un fuerte proceso regresivo con la construcción del puerto de Burriana), por lo cual la línea de costa este caso seria muy distinta a la de época ibérica. Nosotros planteamos la existencia de un pequeño altozano en la zona del cordón litoral fósil que permitió un asentamiento privilegiado y que se encontraría rodeado de marjales. En el plano de C. Sarthou el autor dibuja claramente restos de pequeñas lagunas en la zona, que podrían ser los últimos restos del terreno inundable de la Olla y que al mismo tiempo marcan la zona de la cinta de dunas fósiles (SARTHOU, 1913: 775). Entre éste y los mapas de la primera mitad del siglo XVII (BLAEU, 1640) se puede observar claramente la progresiva desaparición de la pequeña ensenada o laguna. Así pues la Olla no estaría frente al yacimiento, sino al Sur del mismo.

El avance de la costa lo constatamos en la excavación arqueológica, donde detectamos la grava de la playa por debajo de la primera línea de chalets, como también podemos comprobar en las fotos de los años 70 del siglo XX; estos guijarros corresponderían a la obra de acondicionamiento del litoral descrita por T. Utrilla, con su pendiente, gravas, etc. (UTRILLA, 1966). A esto debemos sumar que el propio oleaje habría destruido cualquier huella de la configuración original del terreno; además, parte del propio yacimiento formó una línea defensiva contra la erosión marina que impidió al mar acceder a la parte posterior del asentamiento.

La configuración del conglomerado fosilizado evidencia que el punto más alto del mismo corresponde a la actual línea de costa; prueba de ello es que esta superficie fósil fue rebajada y nivelada en algunos casos en época antigua para utilizarla como plano habitable. Si suponemos que la pendiente detectada por nosotros en la parte Oeste del yacimiento se reproducía en la parte Este (ahora enterrada) nos encontraríamos con el perfil de una pequeña elevación similar a la de una duna fósil, sobre la que se asentó el poblado.

A estos datos debemos sumar las referencias que aportan los estudios geológicos, que señalan la ubicación de Torre d'Onda justo en el límite de una zona donde los terrenos 
de marjal y humedales penetran de una forma muy importante hacia el interior. Independientemente de futuros estudios edafológicos que permitan establecer una cronología concreta para la desecación del espacio de la "Olla" citada por los cronistas de los siglos XVI y XVIII y que vemos reflejada en algún plano de la época (ver Dibujos $\underline{50}$ y $\underline{56})$, pensamos que Torre d'Onda no se encontraba en el centro de esta ensenada, si no en su extremo Norte, sin duda un sitio idóneo para el control visual del entorno. A esta posición estratégica debemos sumar que el emplazamiento del yacimiento se encuentra en la zona más cercana a tierra firme, tras cruzar una breve franja de marjal.

La primera gran transformación sufrida por el entorno, además del retroceso o avance de las aguas del mar, la tenemos ubicada por los planos y fotos aéreas entre 1937 y 1957 y consistió en:

- Nivelación artificial del terreno su cultivo.

- Construcción de canales de desecación como el Rajolí, que circundaban el yacimiento.

- Creación de la senda de Torre d'Onda.

- Ampliación del camino del Serrallo o Serratella.

La segunda etapa de cambios en la zona entre 1970 y 1980 fue la que dio forma definitiva a este espacio y correspondió a las siguientes actuaciones:

- Enterramiento y canalización de la acequia del Rajoli.

- Creación de una serie de caminos, acequias y sendas perpendiculares al camino de la Serratella.

- Desaparición de la playa en primera línea de costa y construcción de abundantes casas.

- Construcción del paseo marítimo de la Serratella.

Estas actuaciones convirtieron completamente el enclave y su entorno, que ahora en nada se parece al de los planos de final del siglo XIX, donde podemos observar claramente que todo el espacio del antiguo hábitat no se encontraba atravesado por caminos, acequias o desagües, lo que posiblemente nos daría la configuración del altozano o tell que ocupaba el asentamiento.

Todas las transformaciones citadas hacen difícil contrastar esta hipótesis y solamente podemos observar en la actualidad un importante desnivel entre el yacimiento y la zona sur del litoral (junto a la actual depuradora) que quizá marcaría el inicio de la "Olla" y que podría ser una zona donde el cordón de dunas fósiles estuviera más hundido o fuera irregular y permitiera el paso de las aguas del mar. Esta disposición orográfica conformaría el espacio como un punto idóneo para un asentamiento humano en la 
costa, relacionado con el aprovechamiento de recursos marítimos como la pesca o el comercio.

\section{ANTECEDENTES ARQUEOLÓGICOS}

Nuestra primera labor fue analizar los datos históricos conocidos hasta el momento y después de un profundo examen de los mismos pudimos constatar que hay una serie de imprecisiones en los estudios publicados hasta la fecha.

En primer lugar solamente dos autores (F. Arasa y N. Mesado) se han ocupado de hacer estudios amplios sobre el yacimiento, intentando en ambos casos dilucidar acerca de su funcionalidad y su cronología. Entre ellos hay varios puntos de coincidencia, pero donde básicamente encontramos la diferencia es en la interpretación desfasada y en las conclusiones poco fundamentadas de N. Mesado, como los apartados donde se refiere a la destrucción del poblado por Julio César, la existencia de una muralla o la utilización del enclave para la reparación de barcos (MESADO et al., 1991). Los puntos en común en los estudios de ambos autores son el hecho de destacar la singularidad del yacimiento por estar asentado en la costa y la composición de los elementos muebles encontrados, al corresponder a una tipología concreta, tanto por lo que se refiere a las ánforas como a la vajilla campaniense.

La interpretación de F. Arasa es bastante más científica, pero centrada en aspectos cuantitativos tomando como base la cerámica (ARASA, 2002) y con el problema de trabajar sobre los datos obtenidos por otros investigadores, que en este caso adolecen de una cierta falta de rigor científico y de preparación ( $\mathrm{T}$. Utrilla no era arqueólogo y $\mathrm{N}$. Mesado cuando realizó su primera excavación en el asentamiento aún era un estudiante). Esto provoca errores de base en la interpretación de autores posteriores. Estas equivocaciones las podemos encontrar en la cita de una muralla en el poblado, las referencias a un "monumento funerario turriforme", o en los niveles arqueológicos, donde se presentó una estratigrafía con algunos errores (ARASA, 2002).

La presencia de abundantes sillares en la zona también es discutible, pues el único documento gráfico (MESADO et al., 1991) muestra unos bloques de talla aparentemente reciente, que podrían pertenecer a los restos constructivos del puerto. El propio topónimo de Torre d'Onda no aparece en los planos hasta bien entrado el siglo XX, siendo conocido como el Serradal, Les Tancades o la Serratella. Algunos autores de principio de la misma centuria asociaban el antiguo topónimo medieval de Alcaramit a este espacio, lo cual nos viene a reafirmar que los nombres de Torre d'Onda y Torreredona son una invención del siglo XX. Así tenemos margen incluso para pensar que una antigua senia con base de sillares podría haber dado origen a la confusión con una torre redonda y de ahí, la imaginación de algunos aficionados se puede haber inventado una torre, nunca vista o descrita, y que acaba transformándose en un monumento funerario turriforme. 
Nos sorprende la cantidad de información que se intercambian N. Mesado y F. Arasa que no se encuentra reflejada en ninguna publicación ni en los archivos del museo, lo cual impide contrastarla. Afortunadamente las intervenciones que hemos realizado nos permiten matizar parte de estas conclusiones; lamentablemente no podemos decir lo mismo respecto al contraste de noticias sobre estructuras defensivas como torres o calles de trazado hipodámico.

A la hora de analizar científicamente el yacimiento en primer lugar debemos estudiar el emplazamiento del poblado ibérico; como ya hemos citado anteriormente la visión actual del mismo difiere mucho de lo que podía existir en el momento de ocupación del asentamiento, debido en gran parte a la trasgresión marina. Sobre esta base buscamos los primeros restos que nos puedan indicar el primer momento de hábitat. Lo restringido de la zona excavada por nosotros no nos permite asegurar con certeza la existencia de restos que se puedan asociar a un primer asentamiento del siglo VII o VI a. C., quizás asociados al final de la Edad del Hierro. Desde luego se trataría de un asentamiento puntual con construcciones perecederas, ya que los restos detectados (cerámica a mano y posibles indicios de estructuras) son muy escasos.

Evidentemente el establecimiento más importante lo tenemos en época ibérica, donde se puede documentar abundante material de esta cronología, concretamente a partir del siglo III a. C.; se trata de unos restos muy homogéneos compuestos básicamente por grandes recipientes como ánforas, kalathoi, ollas, tinajas, etc. y de forma residual algunas pequeñas vasijas. Todos estos artefactos aparecen en un contexto general de arrasamiento de estructuras y niveles y los encontramos casi exclusivamente en acumulaciones cerámicas. Solamente en casos puntuales podemos pensar en materiales de este periodo que están cubriendo algunas cimentaciones de época anterior y que podían asociarse con calles y muros de pequeña entidad. Cortando todos los estratos inferiores aparece una importante estructura de forma posiblemente rectangular a la que rodea una zanja perimetral, quizá con función de aislar el muro y las zonas de hábitat de la humedad. Las características de esta pared difieren de todo lo que se construyó con anterioridad en la zona, conteniendo en su interior una serie de departamentos con accesos sencillos.

Los paralelos más cercanos para esta obra surgen con la irrupción de Roma en el valle medio del Ebro a lo largo del siglo II-I a. C. y la inclusión del territorio como parte del mundo romano, lo que conllevaría una serie de cambios en la vida indígena. De este modo aparecerán con profusión elementos itálicos en yacimientos sedetanos e ilergetes, como pavimentos de opus signinum y, sobre todo, cerámicas de importación, como las campanienses. En esta época se asienta definitivamente el fenómeno urbano, consolidándose la presencia de ciudades, en el sentido actual del término. Será en ellas donde se detecten algunos cambios defensivos; en primer lugar una ampliación de la anchura de los fosos, pasando de entre 4 y 8 metros de anchura, como los de La 
Tallada (Caspe-Aragón) o Els Castellans (Cretas-Teruel), a más de 20 metros, como Valdetaus (Tauste-Aragón). El Cabezo de Miranda (Juslibol-Aragón) presenta al NW un foso con un mínimo de 16 metros y un máximo de 25 (MAGURÁN, 1997).

El importante arrasamiento de nuestro yacimiento a principio del siglo $X X$ no nos permite interpretar con seguridad su momento final. La presencia de materiales del Alto Imperio, en algunos casos mezclados con bolsadas de cerámicas ibéricas y campanienses, podría indicar que fue cantera de asentamientos inmediatamente posteriores que no ocuparon el mismo espacio (La Regenta, El Palau o Sant Gregori). La presencia de fragmentos bajomedievales y modernos podría indicar un último momento de utilización de la zona antes de la definitiva desecación de la "Olla" mediado el siglo XVIII.

\section{INTERVENCIÓN ARQUEOLÓGICA}

Los elementos recuperados en nuestra intervención apuntan a una estratigrafía compleja por lo que se refiere a su interpretación, ya que señalan un asentamiento de escasa dimensión y de cortos periodos de ocupación (ver Lámina Cerámica 6 a 17).

El primer horizonte detectado apareció solamente en dos de los sondeos realizados (sondeos 1 y 4) y corresponde a un nivel donde se aprecia la aparición de cerámica a mano o a torno lento en muy escasa cantidad, asociada a capas de tierra rojiza o grisácea de textura arenosa. La única estructura asimilada a este estrato (ver Foto $\underline{590}$ ) corresponde a una cimentación de dos hiladas paralelas de bolos y cantos rodados entremezclados con fragmentos arrancados al pinyó o estrato fosilífero y que deberían sustentar unas estrechas paredes de material perecedero (madera o adobe). Estos fundamentos alcanzan escasamente los $30 \mathrm{~cm}$ de alzado conservado. Es posible que estas estructuras estuvieran orientadas hacia sendas o caminos, a modo de protocalles, recubiertas por una fina capa de gravilla asentada directamente sobre el citado pinyó. En todos los casos este nivel se encuentra totalmente arrasado y afectado por zanjas y trincheras rellenadas principalmente de material ibérico. Los fragmentos recuperados en estas fosas (sondeos 1 y 4 ) presentan una gran homogeneidad, ya que básicamente se componen de ánforas y grandes recipientes y, de forma más puntual, de pequeñas vasijas (cuencos, cubiletes, caliciformes, etc.) y cerámica campaniense. Los materiales ibéricos también aparecieron esparcidos en amplias zonas (sondeo 9) con el material más fraccionado y con la presencia residual de ánforas púnicas y grecoitálicas.

Es posible establecer un tercer horizonte correspondiente a la gran estructura construida sobre el asentamiento (ver Foto $\underline{589}$ ); en verdad es una gran plataforma de forma rectangular construida en el centro del yacimiento; contaría con una fosa perimetral de evacuación o drenaje de agua, pero no descartamos que esta zanja también pueda ser parte de su cimentación, que haya sido rellenada con grava para 
formar el apoyo del muro ataludado (ver Foto $\underline{32}$ ). Tendría una serie de accesos desde el exterior (ver Foto 334 ) que darían a un gran recinto con departamentos perimetrales y centrales.

La interpretación global del asentamiento es bastante compleja, debido en parte a la pérdida de información de anteriores intervenciones arqueológicas y a que ha sido excavado en una proporción muy ínfima. Nosotros realizamos un primer esbozo de restitución hipotética del enclave en su ultimo momento de ocupación (ver Lámina

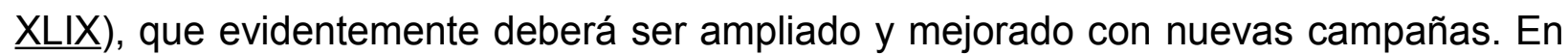
primer lugar apuntamos la posibilidad de la existencia de varias entradas al recinto principal del yacimiento, algunas ya documentados (letras A y C del plano), otra probable (letra $D$ ) debido a las características similares de acumulaciones de materiales cerámicos detectadas en esta campaña, y otras deducibles por indicios más indirectos, como capas de grava (letra B) o pasos interiores (letra F). Finalmente proponemos otro posible acceso por simetría con los ya existentes (letra E).

En segundo lugar planteamos que a cada acceso le pueda corresponder una calle, como las ya documentadas (letra A y C), presuponiendo un trazado pseudohipodámico. Por ultimo establecemos una hipótesis respecto a la existencia de grandes departamentos (números 1 ) y otros bastante más pequeños adosados a la cara interior del muro perimetral (números 2), a los cuales debemos sumar una estructura sobre la cual tenemos muy pocos datos y que los excavadores identifican con una presunta torre (número 3), pero de la que lamentablemente no tenemos ningún dato, excepto alguna foto muy general.

La gran estructura o podio corta todos los niveles anteriores y en su interior solamente pudimos detectar escaso material cerámico, en su mayor parte fragmentos informes de cerámica común republicana de la Campania e itálica Lamentablemente la asociación de un nivel de ocupación diferenciado para esta estructura es bastante complejo, ya que la zona excavada por nosotros es muy reducida.

El análisis de la fauna es sin duda significativo, dentro de la escasez de la muestra recuperada (lo que nos llevó a incluir algunos fragmentos recuperados en campañas anteriores que permanecían inéditos e inclusive ni siquiera estaban lavados desde hace casi 30 años). Pudimos comprobar que los fragmentos recuperados en la fosa UE 1019 corresponden exclusivamente a un bóvido y que la presencia de jabalí es bastante significativa. Por otro lado la abundancia de marcas de rodadura en la malacofauna nos lleva a pensar que la recolección no debería ser una actividad primordial, ya que al ser éstas las únicas con huellas de rodadura en todo su contexto, presuponemos que se recolectaron originariamente ya en este estado, con los animales muertos hace tiempo. De la misma forma la similitud cuantitativa entre animales domésticos (ovicápridos) y los de caza (jabalí), al que debemos sumar la presencia significativa de animales de tiro (bóvidos), nos señala la posibilidad de que 
nos encontremos en una zona donde la ganadería y la recolección marina, aunque sea de autoabastecimiento, no destaca demasiado en comparación con otros restos, lo que podría corresponder a una zona donde el hábitat fuera secundario respecto a una actividad comercial principal.

La desaparición del establecimiento se daría posiblemente con el cambio de Era, sea por causas culturales como la ocupación romana efectiva del territorio, o naturales, con el avance del mar tal y como se detecta en otros yacimientos costeros (Torre la Sal, Calamó, etc.). Desde la Antigüedad el enclave sirvió de cantera a los asentamientos más cercanos, ya que atestiguamos la presencia puntual de restos de cerámica romana de cocina africana y de paredes finas datable hacia el siglo I d. C. entre los restos iberos depositados en las fosas.

Finalmente documentamos un nivel de relleno con materiales de los siglos XIV o XV, momento en el que se vuelve a utilizar la zona de forma puntual, posiblemente para el desembarco de mercancías o como puesto de vigilancia (el puerto medieval de Burriana se encontraba al Norte, junto a las Salinas)

\section{CONCLUSIONES}

Partiendo del análisis del paleopaisaje de la zona podemos suponer que, desde antiguo, el enclave donde se asentó Torre d'Onda era un sitio privilegiado por su situación de control al borde de una pequeña bahía conocida en época moderna como la "Olla", ubicado al Norte de la entrada de la misma, mientras que su otro extremo al Sur lo tendríamos en la zona del Estany de Nules. El lugar formaría parte de este pequeño numero de enclaves a lo largo de la costa de la Plana favorecidos por estar en los puntos más elevados del cordón de dunas fosilíferas y que, además, contaban con un acceso relativamente fácil hacia el interior, atravesando por donde la zona de marjal que cubría buena parte de la costa era menos ancha.

No sería descabellado pensar que a final de la Edad del Hierro o principio del periodo ibérico Antiguo los habitantes de los yacimientos cercanos (El Solaig, San Antoni, la Vilavella, etc.) se acercaran a la zona para realizar intercambios comerciales puntuales y practicar la recolección o la pesca, ya que un hábitat permanente en la zona es impensable por la imposibilidad de establecer un punto defensivo, en un contexto sin protección natural ni visibilidad.

El primer gran cambio se produciría con la intercesión romana en la segunda guerra púnica, cuando desestabilizan el poder ibérico local al destruir a los enemigos de Sagunto al Norte de la ciudad (¿Quizá La Punta del la Vall d’Uixó?) y potenciar el poder de los saguntinos. Éste sería el momento en que los iberos incrementan el comercio costero por medio de Torre d'Onda y de ahí la casi exclusividad de productos itálicos, 
además en cantidades importantes. En este caso seguimos pensando que se trata de un hábitat temporal.

Con su definitiva victoria en la tercera guerra púnica y su posterior expansión y conquista de la Península Ibérica, los romanos sin duda pusieron su interés en este verdadero port-of-trade ibero que derivó en lo que en verdad debería ser un gran mercado (de ahí por ejemplo el fácil acceso a su interior). Además debemos tener en cuenta que, en estos momentos, la supremacía absoluta latina en el Mediterráneo occidental hace que los elementos defensivos y estratégicos pasen a un segundo plano, con lo cual es factible la construcción de un asentamiento de estas características. En la zona catalana tenemos abundantes ejemplos que tienen una ocupación previa de época ibérica plena y un hiato con reocupación a partir de finalmediado del siglo II a. C., finalizando al final del siglo I a. C. (L'Argilera, Les Guardies, Barranc del Prat, Les Guardies, Can Pons, etc.). Casos algo distintos a las nuevas construcciones del I a. C. (Casa del Racó, Cal Jardiner, Torrent de Piqueres, etc.), que tienen unas características itálicas más evidentes (uso de opus signinum, mampostería mortero de cal, uso de dolia y tegulae, etc.), un mayor tamaño y una clara función de explotación agrícola, y que se sitúan en la zona catalana que más pronto sufre el impacto romano, el entorno de Tarragona (REVILLA, 1995).

Si además recordamos algunos datos aportados por antiguas excavaciones en el yacimiento de Torre d'Onda, como las amplias vías de comunicación, grandes departamentos o almacenes, la ausencia de claras zonas de vivienda, la presencia de grandes contenedores y recipientes, los restos de plomo (posiblemente utilizados para reparar cerámicas, realizar tesserae, etc.); estos apoyarían nuestra tesis, que enmarcamos dentro de un contexto de modelos mediterráneos adoptados en franjas semi-urbanas a partir del siglo III a. C., con habitaciones cuadrangulares orientadas hacia un patio central. Pero además estos cambios en las estructuras de hábitat son un fenómeno generalizado, de imbricación entre lo ibero y lo itálico, bien documentado en la zona catalana, donde desde la segunda mitad del siglo II a. C., por ejemplo, se adoptan de forma mayoritaria zonas de almacenamiento (en algunos casos conviviendo con abundantes elementos importados) y distintas técnicas constructivas (sencillas estructuras junto a muros de mampuesto, revestimientos, pavimentos, etc.), de la misma forma que en un momento más avanzado conviven dolia y tegulae con silos de tradición indígena.

La circulación constante de mercancías y envases explicaría también este registro arqueológico tan homogéneo; por un lado gran parte de los restos detectados son objetos de comercio, de ahí su tipología limitada (ánforas y recipientes de exportación ibera, y por otro lado ánforas y vajilla de lujo como importación romana). El hecho de que fueran almacenes temporales y no un hábitat continuado provocó la ausencia de una gran superposición cronológica de materiales y desencadenó el que solamente se 
conservaran aquellos que estaban en los almacenes y tiendas en el momento de su abandono, posiblemente a final del siglo I a. C., cuando se traza en Hispania un plan de cinturón de vías, comunicando los centros más importantes del interior con la costa oriental.

Los puertos de los ríos eran más seguros que los marítimos, pudiéndose llegar a ellos aprovechando las mareas, mientras que para la construcción de dársenas en la costa se necesitaban adelantos técnicos de los que carecían. La importancia de estos fondeaderos fluviales se debía a que en la Antigüedad eran más baratas, fáciles, rápidas y seguras las comunicaciones por mar que las terrestres. Además, la centralización fiscal que se inicia con Augusto motiva una concentración del comercio en manos de determinados agentes y puertos (REMESAL, 1995 y PONS, 2004), pudo acabar eliminado o llevar a una profunda decadencia muchos pequeños port-of-trade de tradición indígena y republicana a favor de centros de almacenamiento y comercio de mayor calado.

Es importante destacar las diferencias existentes entre el registro arqueológico de tierra y el subacuático. Mientras el segundo muestra interesantes indicios desde el siglo II a. C. hasta final del I d. C., el terrestre muestra una substancial carencia para el siglo I d. C., siendo su muestra más significativa la del cambio de Era. Esto quizá venga a apuntar la posible destrucción del yacimiento, que eliminó buena parte del nivel superficial del siglo I d. C.

Al buscar un contexto que nos permita analizar nuestro asentamiento nos dirigimos a otras zonas más estudiadas. La Arqueología muestra que la viticultura es sólo una de las prácticas desarrolladas en la Cataluña romana y que se integra en un paisaje agrícola muy diversificado y similar a la franja de la Plana Baixa.

Según algunos autores la viticultura y las actividades asociadas parecen seguir un ritmo de evolución diferente, entre el siglo I a. C. y los siglos II-III d. C., en las diversas zonas afectadas por su implantación (REVILLA, 1995).

La diversidad extrema de situaciones en cada zona es el resultado de las condiciones particulares de evolución de cada explotación rural, de los intereses de los propietarios, de la situación de cada territorio, actividades económicas presentes (agrícolas y artesanales), tipos de cultivo y organización de los procesos productivos. Nosotros nos inclinamos por la viticultura como principal factor, por la proximidad geográfica a las grandes explotaciones catalanas de este periodo y por las citas del conocido vino saguntino citado por Juvenal $(5,29-30)$ y por Frontón (Ep. De Eloquentia I.1) y que algunos investigadores asocian a determinadas estampillas sobre ánforas (ARANEGUI, 1990) y la existencia de abundantes restos de ánforas de vino y noticias de hornos de producción de las mismas en el yacimiento de La Punta (Vall d'Uixó). 
Obviamente, esto no excluye que el desarrollo de la viticultura en algunas zonas haya supuesto reajustes reflejados tanto en el fin de ciertos enclaves, como en la reconstrucción de instalaciones. Estas circunstancias, a su vez, dependen de un conjunto de factores económicos de alcance más general: la demanda local y regional de productos agrícolas o manufacturados (que pueden proporcionar mercados para otros productos), la demanda interprovincial, unos circuitos de intercambio regulares (en los que se integrarían fácilmente los productos de la Tarraconensis) o la competencia de otras provincias.

En el caso de Torre d'Onda, cuando dejó de ser un exponente de enclave comercial, su abandono provocó que los restos que allí permanecían fueran cantera para los constructores de las villas relacionadas con la vía Augusta que ocupan el hinterland del yacimiento a lo largo del siglo I d. C. (Palau, Sant Gregori, Regenta, La Alcudia, Benicató, etc.). Esta podría ser la causa de que los materiales aparezcan rellenado fosas, muy fragmentados e incompletos (a diferencia de los que podemos esperar en un vertedero); nosotros pensamos que alguno de los "nidos cerámicos" detectados en anteriores excavaciones (MESADO, et al., 1991) en verdad son hoyos excavados o materiales vertidos para rellenar las zanjas perimetrales de la plataforma. El prolongado abandono formó un tell a veces afectado por las mareas, como podemos observar en los niveles costeros de grava, hasta que la gran plataforma del port-of-trade sirvió como una barrera que impidió que las aguas llegaran más hacia el interior.

Finalmente en época Medieval y Moderna se utiliza la zona como puesto de vigilancia de la "Olla" y para el desembarco puntual. La rápida desecación de este espacio lagunar a partir del siglo XVII hizo que dejara de tener valor como embarcadero, pasando a centrarse esta actividad en el Grao de Burriana, situado junto a la desembocadura del río Seco, con un importante aporte de agua dulce. Esto acaba por provocar un abandono de la zona hasta su revalorización a final del siglo XIX para el cultivo de naranja, por medio de la desecación de los últimos restos del antiguo marjal. El impulso definitivo a la recuperación del entorno se da con la construcción en los años 30 del siglo XX del puerto comercial de Burriana ubicado a escasos metros. Esta última construcción también significó un acelerado proceso de erosión marina que afectó profundamente el yacimiento. Todo este proceso de transformación fue el que provocó una importante aparición de restos a principio del siglo $\mathrm{XX}$; también propició a los investigadores y aficionados de la época (V. Forner, M. Peris, J. Peris, F. Roca, etc.) tejer toda una interpretación sobre Torre d'Onda que acabó por la adopción del propio topónimo en los primeros catastros del siglo; éste era inexistente anteriormente, ya que hasta el siglo XIX solo se conocía una referencia a la "gola del Cami d'Onda" (SARTHOU, 1913:775).

Así pues, hay que descartar a priori todas aquellas informaciones no contrastadas, básicamente sobre la existencia de una torre, habitaciones y de calles en la zona, ya 
que son meras interpretaciones de principio del siglo $X X$ realizadas por vecinos sin ningún tipo de formación científica y que fácilmente pueden confundir los sillares sobrantes de las obras del puerto con unos de factura antigua o interpretar los cimientos de una noria con la base de una torre redonda.

Otras informaciones deben ser contrastadas antes de darlas por ciertas, como es la existencia de capiteles o la ubicación de las zonas donde aparecen, o no, restos arqueológicos, ya que como citamos anteriormente, estos no han sido documentados y las referencias son solamente orales.

Finalmente destacamos las amplias deficiencias en la información conservada sobre excavaciones antiguas, a lo que tenemos que añadir la falta de preparación de los responsables de estas primeras intervenciones, como en el caso de N. Mesado, por ejemplo, que excavaba por niveles artificiales. Pero esta deficiencia se arrastró durante muchos años, ya que el material posteriormente publicado y estudiado por otros investigadores más preparados fue solo una muestra elegida de forma subjetiva por estas mismas personas.

A la vista de esto nos parece poco creíble la referencia constante a elementos como embarcaderos, murallas, monumentos funerarios del Alto Imperio, astilleros para la reparación de barcos, destrucciones violentas de asentamientos, etc., ya que carecen de cualquier apoyo y en algunos casos rayan lo inverosímil. Partiendo de esta base fue absolutamente necesario hacer un somero inventario de todos los materiales del museo pertenecientes a intervenciones anteriores. Esto lleva a otro hecho lamentable, la ausencia de cualquier tipo de inventario; tal es la magnitud de esta situación que aún no hemos podido finalizar este trabajo; para efectos de esta tesis daremos un avance, dejando para posteriores intervenciones el análisis completo de los materiales existentes en el almacén. Este estudio parcial de los restos de los años 80 del siglo XX, apoyado por los restos recuperados en nuestra campaña, nos lleva a las siguientes conclusiones:

- Los restos ibéricos en cantidades importantes se puede ubicar entre el II y I a. C. (destacamos la presencia de cerámica gris, como un cuenco casi completo que imita la forma Lamboglia 1), pero también existe un volumen significativo de materiales del siglo IV y el III a. C.

- La existencia de materiales púnicos señala un hábitat puntual en la zona hacia los siglos IV y III a. C.

- Existen muestras muy esporádicas de cerámica a mano o a torno lento que podrían señalar la presencia de un hábitat en la zona entre el los siglos VII y V a. C. 
- Los materiales romanos de la Campania, en su mayor parte fragmentos informes, se encuentran en mayor abundancia en una cronología cercana al siglo I a. C. La ausencia de restos óseos y malacofauna no puede achacarse a la presunta acidez del terreno, ya que se han recuperado ejemplares en buenas condiciones.

- Los restos de plomo, en cantidad no demasiado abultada, con marcas de recorte, junto a la presencia de lañados de plomo en cerámica demuestran una reparación in situ de estos materiales.

Los hallazgos de nuestra excavación coinciden con la muestra genérica de los materiales analizados hasta ahora en el almacén del museo. Esto viene a modificar puntos bastante imprecisos de los anteriores estudios:

- La existencia de un hábitat estable en el siglo II a. C. permite contextualizar perfectamente los materiales y descarta interpretaciones forzadas que hablaban de conservación de monedas ibéricas que estaban fuera de circulación, de campaniense $A$ adquirida cuando ya se encontraba prácticamente fuera del mercado (ARASA, 2002) o de un taller de reparación de barcos (MESADO et al., 1991), cuando se estaría reparando cerámica (el pequeño tamaño de las grapas, clavos y demás enseres hace evidente que no se pudieron usar para barcos).

- La escasez de fauna y malacofauna, junto a cantidad de grandes recipientes y monotonía en las formas cerámicas importadas puede explicarse por un asentamiento comercial, más que en un hábitat permanente.

- La mezcla de niveles y material (incluyen elementos medievales y modernos junto a ibéricos) de campañas anteriores no permite afirmar qué horizontes culturales diferenciados tenemos; sólo señalamos que los materiales del siglo II-I a. C. nunca han aparecido junto a los de época anterior, pero sí encontramos fragmentos del siglo I-II d. C. en estos conjuntos, concretamente una base y un borde de Drag. 35/37 de TSS, un informe decorado de $T S H$ y un fragmento carenado decorado de una posible Drag. 29 de TSI (ver Imagen 15). El material medieval y moderno aparecen en estratos distintos a los anteriores.

El siguiente paso fue analizar y comparar los escasísimos datos existentes de anteriores excavaciones, lo que nos llevó a las siguientes conclusiones: 
- Las excavaciones anteriores fueron deficientes y como muestra citamos que se excavó por niveles artificiales cada $10 \mathrm{~cm}$, zanjas perimetrales y cortes incompletos. Los escasos planos y secciones que se conservan en muchos casos fueron planteadas en lugares que no aportan ninguna información sobre el yacimiento.

- Es impensable que una muralla ibérica pueda tener un máximo de 60/70 cm de ancho de mampostería (MESADO, 1986), contando con una hipotética zanja o foso de escasamente 1 metro y además en una zona sin ninguna posibilidad de defensa. Los accesos son simples vanos abiertos sin ningún tipo de protección, lo que va en contra de la poliorcética ibérica en general.

- Coexisten dos técnicas constructivas: mampostería de barro con bolos desbastados y pavimentos de adobe, y por otro lado cantos de pequeño tamaño trabados con tierra, pero cuya interrelación no ha quedado clara.

- El análisis geológico del terreno y de los planos de los siglos XVII a XIX apuntan claramente a que el yacimiento se encontraba en el extremo Norte de una pequeña bahía o ensenada de escasa profundidad, que sería la "Olla" descrita por Viciana, cuya otra extremidad estaría en la Gola del Estany de Nules. Esta configuración seria la idónea para un establecimiento dedicado al comercio (port-of-trade) en detrimento de un hábitat permanente.

Los marjales que rodearían la zona son menos amplios en el espacio cercano al yacimiento, lo que facilitaría su comunicación con el interior. Esto, sumado a su posición ligeramente más elevada, hizo que fuera una zona idónea para la ocupación humana desde los primeros momentos del auge del comercio marítimo. Solamente con el control romano del Mediterráneo fue factible la construcción de estructuras permanentes de gran tamaño para el comercio, sin la necesidad de elementos defensivos o la búsqueda de protecciones naturales. Pero la brevedad de este período comercial a gran escala viene dado por la romanización efectiva en época imperial, con la desaparición del comercio indígena a favor de las macro-explotaciones romanas y el control de impuestos y aduanas en los grandes puertos. Esto hizo que el comercio de cabotaje a pequeña escala pasara a un plano secundario en el que abastecería algunas villas cercanas al litoral. La ausencia de excavaciones arqueológicas rigurosas y más amplias puede explicar la ausencia de la documentación de técnicas y materiales romanos como el signinum, tegulae y dolia que empiezan a implantarse en este periodo, ya que quizá sólo llegaron a utilizarse de forma puntual en Torre d'Onda, antes de su abandono en el cambio de Era. 
Nuestra propuesta interpretativa hace que este yacimiento se inserte en un panorama global, bien documentado y estudiado en el Norte de la Hispania Citerior con la diferencia de que el nuestro es uno de los pocos ejemplos de yacimiento comercial costero y no de explotación agropecuaria, lo que implicaría que tuvo una mayor importancia, ya que podría suministrar mercancías al menos a toda la zona entre Xilxes, La Vall d'Uixó y Onda, pues solo encontramos condiciones de desembarque semejantes en Almenara (Els Estanys ver dibujo $\underline{8}$ ), Castellón (Pujolet) o en Oropesa/Cabanes (Oropesa la Vella y Torre la Sal).

En este panorama el final de Torre d'Onda estaría relacionado con la existencia de grandes propietarios romanos con intereses en la viticultura de la Hispania Citerior, cuyo caso más conocido es el de Cn. Cornelius Lentulus Augur, cuya marca aparece sobre ánforas Pascual 1 en la costa catalana (REVILLA, 1995), y que significaron un cambio radical en los sistemas de explotación del territorio y de comercio republicanos a los que se podía asociar la razón de ser de Torre d'Onda. Este cambio es especialmente interesante, puesto que nos informa, además, sobre formas concretas de constitución de la gran propiedad en un medio provincial que podría tener paralelos en nuestra zona. El favor imperial, bien conocido en el caso de Augusto con respecto a sus partidarios, y los beneficios derivados del ejercicio de cargos políticos. También existe la posibilidad de relacionar a otros personajes identificados en la epigrafía sobre ánforas que, sin duda reflejan la presencia de familias importantes, en algunos casos asentadas en época republicana en la zona catalana como resultado de las migraciones itálicas a Hispania (REVILLA, 1995)

En otras palabras, nuestra teoría normaliza la condición del yacimiento de Torre d'Onda dentro del Mediterráneo antiguo, con su justa importancia, pero sin hacer de él un elemento a veces anacrónico. 


\subsubsection{CARABONA}

\section{DATOS HISTÓRICOS}

Carabona, antes llamada Alberg, fue el único núcleo habitado del término de Burriana citado por fuentes cristianas en un momento anterior a la ocupación de Jaime I. Se trata, según N. Mesado, de un nombre de origen catalán, citado en el documento de donación con el nombre antiguo 14 años antes de la conquista, lo que hace evidente que se trata de una alquería ya importante en época musulmana (MESADO, 1991).

Dentro de este dilatado término propio se citan otras unidades de hábitat como Alcaramit, Alcaula, Binanufeil, Binalchateni, Alcosayba, Benixoula y Coria, según consta en la carta de donación hecha por el rey Jaime I el 3 de noviembre de 1219. Esta donación no se hizo efectiva, pues en el asedio de Burriana (5 de junio de 1233) el propio rey donaba Carabona a la Orden Militar de S. Jorge de Alfama (DE MARIA, 1935) y al unirse con la de Montesa, en enero de 1400, Carabona quedó bajo el señorío de esta última.

En el siglo XVI su propiedad fue compartida por Martín de Viciana y Sancho de Cardona (MESADO, 1991). Otro dato histórico lo encontramos en un plano del término municipal de Burriana del año 1909, de sumo interés para el estudio del paleopaisaje ${ }^{19}$, donde podemos comprobar que la vecina alquería del Baró aparece reflejada aún como "Alquería del Barón de Andilla" y Carabona como "Casas de Carabona", una a cada lado del Camino Palmer.

\section{ANTECEDENTES ARQUEOLÓGICOS}

Los datos arqueológicos para el periodo ibérico sobre Carabona y su entorno son muy escasos, existiendo sólo algunas citas sueltas que reproducimos a continuación: (...) en el fondo (contiguo a dicho casal) que dejaron las extracciones de tierra para la autopista A-7, recogimos varios fragmentos de recipientes de tal Cultura [ibérica]. También aquí, hacia el año 1927, D. Joaquín Peris Fuentes encontraba un lote de

\footnotetext{
19 Dirección General del Instituto Geográfico y Estadístico - Trabajos Topográficos, serie Provincia de Castellón Ayuntamiento de Burriana - escala 1:25.000
} 
cerámicas ibéricas, hoy perdidas (...) (MESADO, 2004:48), (...) (de época ibera): El Alter de Vinarragell, el Palau, Carabona, (...) (ARASA, 2004: 81).

Durante este periodo el Caminàs pasaría a ser un camino vertebrador, gracias a una economía con una mayor base comercial. En época romana prolifera el asentamiento disperso de villas entre la costa y la vía Augusta, donde destacamos la mayor presencia de yacimientos (Sant Gregori, Palau, Regenta, El Palmeral) y asentamientos o embarcaderos costeros (Calamó- ver Imágenes $\underline{16}, \underline{17}$ y $\underline{18}$ - y Torre d'Onda), lo que indicaría, junto a las centuriaciones, la explotación agraria intensiva de toda la zona.

Alguna noticia dispersa hace referencia al hallazgo de un fragmento de inscripción romana en la zona, pero lamentablemente no se concreta demasiado el punto, describiéndose genéricamente como Cap de Terme y al mismo tiempo de forma contradictoria como Llombay (ARASA, 1986). El mismo aficionado que encontró la pieza la ubica junto al Caminàs, algo más abajo de Carabona (MESADO et al., 1991)

También destacamos el hallazgo arqueológico en la zona de dos lucernas de disco que cita F. Roca (ROCA, 1932). Respecto a la Regenta, el yacimiento más cercano, las citas de mayor fiabilidad las tenemos por parte de F. Arasa: (...) yacimiento fueron recogidas inicialmente por Utrilla (1962 y 1963a y b) y revisadas posteriormente por mí (...) F. Pérez Bayer (...) Peris y Fuentes (s. a.), (...) menciona: "Solo a titulo de curiosidad consignamos el hallazgo de un esqueleto de talla extraordinaria, con motivo de profundas roturaciones ejecutadas al finalizar el pasado siglo en la finca conocida por la Regenta, (...) y en donde aparecieron en buen número otros [restos] humanos, uno también y principalmente, la particularidad de que tenia como defendida la cabeza y cuello por dos losetas abiertas o separadas por bajo y unidas en la opuesta parte superior en forma de tejado de doble vertiente». (...) algunos fragmentos de paredes finas de la producción de "cáscara de huevo" y común, que pueden fecharse general en los siglos I-Il d. C. (...) (ARASA, 2004: 99-100).

Los hallazgos de T. Utrilla, citados por F. Arasa, son:(...) Si nos detenemos a examinar algunas de estas piedras, veremos que muchas de ellas están manchadas de cal. (...) cerámica muy escasa de nuestros días, también escasa, de los moriscos; muy abundante, de los romanos, e incluso de su época de esplendor. (...) Están hechas, la mayor parte, de tierra rojiza, bien tamizada y azulada en su interior, propias de la cultura indígena que convive con la romana, también hay algún fondo de tierra negruzca e impura. (...) aparecen en los huertos que flanquean a ambos lados del camino de la Regenta, cerca de la encrucijada, y disminuyen de cantidad hacia la alquería”. (UTRILLA, 1962 y 1963:12)

Las referencias a otros yacimientos cercanos son muy escuetas, porque no existen publicaciones o estudios sobre estos. Según las fichas de inventario de de la 
Conselleria de Cultura y Deporte (AA. VV., 1985-2010) encontramos los siguientes asentamientos:

\section{La Regenta II}

- Correspondería a la periferia del yacimiento de la Regenta. Aparecen restos cerámicos dispersos iberoromanos, medievales y modernos con algún vertido ocasional de restos constructivos.

\section{Llombay}

- Se trata de unos hallazgos de superficie en una gran área delimitada en los planos de la ficha. El núcleo central se podría situar en lo que se llamaba la Vela de Llombai. Se documenta ocupación humana con cronología eneolítica, neolítica, ibérica y romana. Aparecen puntas de flecha, esquirlas, hachas pulimentadas, cerámica ibérica decorada, dolia, etc.

Entre los fondos documentales del museo arqueológico de Burriana no pudimos encontrar ninguna cita o referencia que respalde esas afirmaciones, únicamente una caja de cartón que contenía materiales ibéricos (ver Lámina Cerámica 4 y 5 ), con una simple leyenda que transcribimos literalmente:

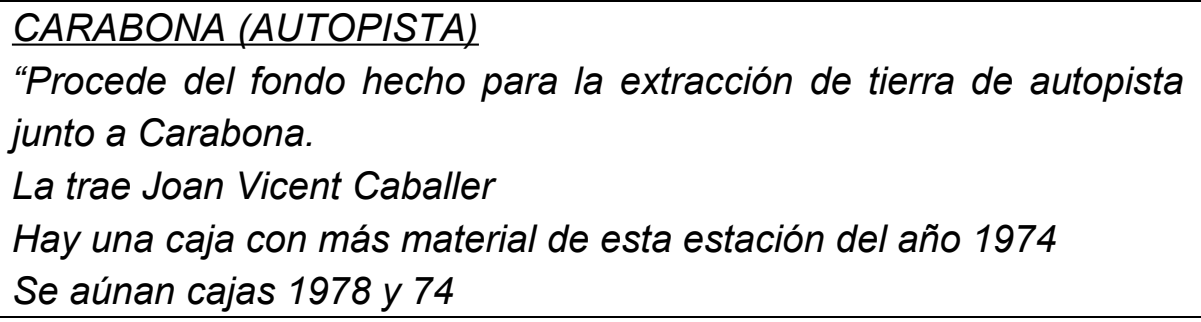

Nos encontramos con una falta de datos concretos que no nos permitía establecer con seguridad los antecedentes o las perspectivas de los restos con los cuales podemos encontrarnos a lo largo de la intervención. A la vista de esta situación decidimos hacer tabula rasa y empezar desde cero con un estudio de la estructura y de su entorno.

\section{Conclusiones}

En primer lugar queremos señalar que, a la vista de la escasa superficie excavada y de los pocos resultados materiales obtenidos en algunos de los sondeos, sería a todas luces temerario y poco docto elaborar unas conclusiones científicas especificas o establecer unas hipótesis interpretativas concretas. Así pues, pensamos que es más acertado disponer unas líneas de investigación a seguir en futuras actuaciones, 
dejando la puerta abierta a conjeturas más concretas, en el momento en que los datos recopilados sean más amplios.

En segundo lugar queremos recordar que el objetivo de la intervención no era de carácter exclusivamente científico, ya que la meta era detectar los posibles restos existentes en el subsuelo, de cara a establecer las pertinentes medidas de protección frente a futuras obras en el enclave.

Finalmente debemos apuntar que la investigación histórica sobre el asentamiento aún está en su inicio ya que, durante muchos años, toda la teoría interpretativa sobre la alquería se sustentó sobre unas simples pinceladas documentales, y nosotros demostramos que sólo son un porcentaje de lo que se puede recuperar. Así vamos intentar establecer una línea interpretativa conjunta entre los hallazgos arqueológicos y los nuevos datos históricos, a expensas de ampliar estos conocimientos.

Respecto a la época romana e ibérica no podemos establecer la existencia de un yacimiento en la zona concreta de Carabona, si bien debemos admitir que los materiales ibéricos almacenados en el museo no tienen en absoluto marcas de rodadura o erosión por el arrastre (a pesar de haber sido muy maltratados, posiblemente por una inmersión excesiva en ácido) y además su referencia geográfica concreta es la Autopista AP-7. Sin embargo mantenemos nuestras reservas sobre la posibilidad de adjudicar de forma definitiva la existencia de un asentamiento ibérico o romano en la zona hasta que se pueda concretar más sobre las circunstancias de su recolección. En líneas generales las formas nos llevan hasta un periodo ibérico tardío, con lo que grosso modo las podíamos ubicar entre los siglos II y I a. C. También es cierto que se observaron algunos fragmentos de esta cronología en los huertos ubicados alrededor de Carabona y de la alquería del Baró, pero no debe ser un indicio definitivo, ya que también recuperamos trozos superficiales de cerámica en otras intervenciones cercanas, como la prospección de la duplicación de la carretera CV-18 de Burriana a Nules (zona Cami Corrent) o en los sondeos arqueológicos en la Regenta con motivo de la construcción de la ronda de Burriana.

Sobre otras intervenciones cercanas, como la excavación en la que se extrajo un équido en el año 1991 por V. Verdegal, hay una polémica entre éste y N. Mesado, ya que el primero mantiene que es de cronología contemporánea y el segundo afirma que es ibérica (MESADO, 2004). En esta intervención el material de esta última cronología también es muy escaso o inexistente; las otras intervenciones ya se refieren a noticias pocos concretas de J. Peris (manuscrito del museo), F. Roca (ROCA, 1933) y T. Utrilla (UTRILLA, 1962, 1963 y 1963b) sobre enterramientos, mosaicos, lucernas, etc. en la misma zona de la Regenta.

Así pues, tenemos una amplia dispersión de materiales de época ibérica y romana sin que por ahora podamos concretar el núcleo del yacimiento. Solo podemos apuntar la 
posibilidad de que fuera un asentamiento asociado al Caminàs o vía Augusta, que en este tramo coincidiría con la orientación de la carretera de Burriana a Nules conocida, antes de su remodelación (posiblemente en el siglo XIX), como Cami Vell de València.

Tanto los materiales arqueológicos como los documentos escritos dejan un vacío cronológico hasta el siglo XII, donde sólo encontramos escasos fragmentos cerámicos musulmanes en la excavación y en el entorno. La cuestión se complica cuando el registro material sigue siendo muy escaso a lo largo del siglo XIII y gran parte del siglo XIV, cuando las fuentes hablan de un importante asentamiento con fueros propios. Este punto llama poderosamente la atención, de tal forma que empezamos a pensar que la ubicación de la Torre de Carabona no fuera el núcleo central del yacimiento y quizá fuera un espacio periférico del mismo o incluso zona de huerta asociada al poblado. La eclosión de cuantiosa loza de final del siglo XV y XVI nos permite reforzar esta opinión, ya que coincide con el impulso que da al lugar su nuevo propietario, Rafael Martí de Viciana. Esta línea interpretativa vendría ratificada por el estancamiento que sufre esta zona después de su venta por parte de Viciana, hecho éste corroborado por el registro material.

Por otro lado la toponimia empleada es muy interesante, ya que cita a la zona como "Alter" lo cual podría ser una clara referencia a su situación más elevada, a modo de tell despoblado y yermo por la tala del ejercito francés, y que Burriana utilizaba para pastoreo (ARROYAS, 2000). Otra referencia interesante es la existencia de un camino del ladrillar en la zona en el siglo XIX, ya que podemos pensar en la pervivencia de la fabricación de ladrillos a raíz de la abundante escoria de los mismos aparecida en los niveles del siglo XVI y según la referencia documental del "Azagador del ladrillar" en los documentos de 1827 (ARROYAS, 2000). Esto nos haría pensar que el límite de las tierras vendidas por Viciana a la villa de Nules se encontraría en este tell llamado alter que por su elevación correspondía a cultivo de secano, situado al Oeste de Carabona.

Así pues, quizá el núcleo histórico más antiguo se encuentre bajo de la actual alquería del Baró, que cuenta con estructuras muy similares constructivamente a las más antiguas documentadas en la zona, como el tapial valenciano del cercado exterior, y presenta una mayor riqueza de restos arqueológicos en superficie que los propios terrenos del entorno de la Torre.

Según N. Mesado el Campo Romero fue conocido por la calidad de sus viñedos (MESADO, 1991), con lo cual es posible que éstos se plantaran mediado el siglo XIX, lo que quizá proporcionara el desfonde del terreno. Este evento lo podríamos asociar al postrero momento importante de ocupación de la zona, concretamente de las viviendas del entorno de la torre. Con el fallecimiento del último barón se acentúa la crisis del enclave, lo que implica la desaparición a corto plazo de parte de las viviendas del interior del patio cerrado a final del siglo XIX, coincidiendo con el boom del cultivo de la naranja a partir de 1880 , quizá para ganar espacio para la citricultura. Esto habría 
implicado la destrucción de los últimos restos de lo que entonces sería el despoblado de Carabona, situado en el vecino alter o tell, con el objetivo de nivelar el terreno para ganar más espacio para el cultivo de regadío (tenemos noticias de que en las mismas fechas sucedió algo similar al despoblado de Vinarragell y posiblemente al Palau).

A la vista de lo expuesto, es posible pensar en la existencia de un yacimiento iberoromano, que fue reocupado durante el periodo musulmán, al igual que sucede en otros asentamientos del término como el Palau o Sant Gregori.

Este enclave acabaría formado un pequeño tell o alter que destacaría en la Plana de Burriana al igual que otros sitios arqueológicos, y que en época cristiana pasa a ser un señorío. Su ocupación fue continuada en el tiempo, lo que ocasionó la construcción de importantes edificios en la zona y en su periferia a lo largo de los siglos XV y XVI.

Con la decadencia del enclave se arrasó el despoblado y el tell que lo conformaba, para obtener una superficie apta para el cultivo primero de viñedos y después de naranjos a lo largo del siglo XIX, destino que sufrieron todos los lugares arqueológicos del termino, excepto la parte central de Vinarragell y parte del Palau. 


\subsubsection{CAMI CORRENT}

\section{Antecedentes arqueológicos}

La actuación desarrollada en el año 2004 consistió en una prospección arqueológica en relación con las obras relativas a la duplicación de la carretera CV-18 de Nules a Burriana, en los términos municipales de Burriana y Nules.

El terreno es llano, sin elevaciones montañosas y se halla transformado notablemente por el cultivo de cítricos. La zona se encuentra a escasamente $2 \mathrm{~km}$ del yacimiento arqueológico inventariado con el nombre de Virranges, un yacimiento estudiado por $\mathrm{N}$. Mesado y $\mathrm{F}$. Arasa donde se han descubierto en superficie cerámica romana y de cerámica de aspecto ibérico (sic), junto a vasos ibéricos (AA. VV, 1986). En los huertos próximos a la autopista AP-7 se dan numerosos fragmentos de cerámica ibérica y romana, algunas con decoración a molde, escasos restos de ánfora, fragmentos de opus signinum y de pintura mural, así como de tejas e ímbrices (ARASA, 1986). Otros yacimientos más cercanos publicados por J. V. Cavaller y V. Felip son:

Camí Real: En 1985 (...) se encontró una base de columna y abundantes fragmentos de cerámica, la cronología de los cuales abarcaría desde la segunda mitad del siglo I a. C. al III d. C.

L'Alcúdia: Mediado el siglo pasado, en el Alter de l'Alcúdia, fue encontrada una lápida romana (...) alrededor del tell de la Alcúdia se pueden ver fragmentos de tegulae, dolia y Sigillata que alcanzan, hasta el siglo IV d. C. (FELIP y CAVALLER, 1998)

\section{INTERVENCIÓN ARQUEOLÓGICA}

En líneas generales, no se halló ningún yacimiento arqueológico; no obstante, sí había indicios de material cerámico en superficie que puede indicar la proximidad de algún asentamiento. Los trabajos de prospección presentaron la dificultad añadida de haberse realizado en una zona donde el cultivo y la aportación de tierras en muchos casos pueden haber provocado la aparición en superficie de fragmentos de loza revueltos y fuera de contexto a lo largo de buena parte del trazado de la obra. Los sectores donde aparece una concentración más significativa de material son los siguientes: 
SECTOR 1 - Localizado en el término municipal de Nules, que se caracteriza por la presencia de algunos fragmentos cerámicos que aparecen en superficie, en su mayoría de época hispanomusulmana, moderna y contemporánea.

SECTOR 2 - Situado en el término municipal de Burriana, se determina por escasos trozos de loza. No se ha constatado ningún tipo de estructura. Respecto a los materiales, corresponden en líneas generales a fragmentos cerámicos informes de pasta oxidante, elaborados a torno, de época ibérica que aparecen mezclados con otros fragmentos de época hispanomusulmana, moderna y contemporánea. Entre los artefactos recuperados destacamos algunos fragmentos de cerámica ibérica:

A la vista de que el Sector 2 se encontraba junto al trazado del Caminàs, que coincidiría con la vía Augusta y estaba próximo al yacimiento arqueológico de Virranges, se propuso la realización de trece sondeos arqueológicos.

Con todo no estaba clara la relación de estos materiales con el asentamiento conocido. Situado junto al Cami Corrent se caracteriza básicamente por la presencia de escasos fragmentos cerámicos que aparecen en superficie, sobre todo de época hispanomusulmana (común y de cocina) y romana o ibero-romana, junto a un fragmento de restos de talla de sílex. No obstante, durante los trabajos de prospección observamos que el terreno había sufrido una importante transformación por el cultivo de cítricos y estos materiales aparecen mezclados con gran cantidad de cerámica moderna y contemporánea.

\section{CONCLUSIONES}

El resultado de los trabajos arqueológicos fue negativo en todos los sondeos arqueológicos. La intervención únicamente ha proporcionado exiguos fragmentos de cerámica, material de arrastre que presenta una cronología situada entre la época romana y contemporánea. No se ha encontrado estratigrafía ni una seriación cronológica en los escasos elementos registrados, pues aparecían revueltos en su totalidad. 


\subsubsection{VINARRAGELL}

\section{DATOS HISTÓRICOS}

El yacimiento esta situado en la ribera derecha del río Mijares a $80 \mathrm{~m}$ de su cauce actual y a $3,5 \mathrm{Km}$. de su desembocadura, junto al camino de Sant Pau. Se trata de un pequeño montículo que apenas llega a los $3,5 \mathrm{~m}$ de altura sobre los campos circundantes, de forma irregular tiene un diámetro máximo, NE-SW, de $80 \mathrm{~m}$, y un mínimo, NW-SE, de $60 \mathrm{~m}$, estando cortado por poniente por el camino de Sant Pau.

Hasta bien entrado el presente siglo existió, al SW del mencionado alter, un viejo eremitorio bajo la advocación de Santa Bárbara y San Juan. Al Sur del montículo, colindando con él, un cementerio y en la cima ruinas de estructuras modernas (MESADO, 1986).

\section{ANTECEDENTES ARQUEOLÓGICOS}

Resumimos a grandes rasgos las publicaciones de N. Mesado y O. Arteaga (MESADO, 1974 y MESADO y ARTEAGA, 1979) que es, sin duda, una síntesis de todos los trabajos realizados en el yacimiento (exceptuando una intervención en 1991 a cargo de V. Verdegal, con motivo de las obras del gasoducto Castellón-Valencia, que lamentablemente permanece inédita y los trabajos de M. Raga en 2008 también con motivo de una canalización de gas) ya que la última campaña conocida en el yacimiento fue en el año 1985 y no se realiza ninguna publicación con nuevos datos desde 1988. Las aportaciones de recientes intervenciones en el año 2008 sin duda señalan que el yacimiento se extendería hasta el cauce del río Mijares y contaría con una necrópolis musulmana en su espacio inmediato.

Tras diversas campañas de excavación en Vinarragell, N. Mesado sistematiza sus diversos horizontes culturales y de hábitat del siguiente modo: Las destruidas secuencias en las estratigrafía alta (...) un material arqueológico correspondiente al Horizonte Ibérico Antiguo, (...) los escasos hallazgos tardoibéricos (existe incluso cerámica aretina y sudgálica), el poblado pudo pervivir hasta los inicios del siglo I. (...) importante núcleo de población tribal libre (Cultura Ibérica Independiente), dentro ya del Hierro II, autonomía que se perderá definitivamente en nuestras tierras con la toma de Sagunto por Aníbal (...) (Cultura Ibérica Dependiente). (...) cerámica campaniense 
del nivel $V$ de tipo A (...) fragmento de la forma Lamboglia 31-Morel 2152 del nivel C, dos de la forma Lamboglia 36-Morel 1310, otro de la forma 68-Morel 3131 (...) base de una patera de la primera mitad del s. I a. E. De la Campaniense del tipo B, presenta cinco fragmentos cerámicos entre los cuales hay tres piezas de la forma Lamb. 5-Morel 2286, (...) de época republicana seria un ejemplar de ánfora Dressel 1A, (...) dos fragmentos de cerámica de paredes finas de la forma Mayet 11 (MESADO, 1986:30-31)

\section{INTERVENCIÓN ARQUEOLÓGICA}

La actuación del año 2002 es la prospección arqueológica que llevamos a cabo para delimitar el yacimiento, donde además de constatar que la extensión del mismo es muy superior a la que se suponía, observamos que todo su entorno había sido arrasado para renovar la plantación de cítricos. El propio enclave se encuentra en un estado de abandono y cubierto de maleza y escombro.

Durante el año 2003 realizamos un seguimiento arqueológico de la limpieza del entorno del yacimiento. Lamentablemente los resultados de la misma fueron escasos, ya que la propiedad del sitio no nos permitió actuar en su interior. La intervención se limitó a la adecuación y limpieza del tramo exterior del lugar, junto al camino de Sant Pau. Además del habitual descubrimiento de loza en superficie de cronología ibérica y romana (TSS), dos hallazgos no llamaron poderosamente la atención: la aparición de abundantes fragmentos de vajilla de paredes finas y de restos de opus signinum (ver Imagen 13), compuesto casi exclusivamente por trozos de cerámica ibérica triturada.

\section{CONCLUSIONES}

Por un lado es evidente que se hace necesaria una revisión profunda de los restos romanos de Vinarragell, ya que las condiciones de su descubrimiento no fueron las más idóneas y su estudio siempre ha sido relegado a un segundo plano. A esto debemos sumar que los planteamientos teóricos y las conclusiones de los trabajos antiguos están como mínimo bastante desfasados.

Nuestra intervención aporta indicios que señalan a un establecimiento estable en la zona, con estructuras de opus signinum y un repertorio cada vez mayor de materiales, lo que señalaría que la presencia romana en el yacimiento podría ser significativa por lo menos hasta bien entrado el siglo I d. C. 


\subsubsection{LA REGENTA}

\section{DATOS HISTÓRICOS}

El yacimiento de la Regenta se sitúa al SW del casco urbano de Burriana, junto al camino de Artana que con un recorrido de unos $10 \mathrm{Km}$. une al Caminàs con los yacimientos ibéricos de Sant Antoni y Solaig (Betxí), que también podríamos relacionar con asentamientos del mismo periodo en el Palau, Torre d'Onda y Vinarragell. Posteriormente esta misma vía uniría los enclaves romanos del Pla Redó/Torrasa (Betxí) con la necrópolis de la Creueta (Les Alqueries), El Palau y Sant Gregori (Burriana). Durante época medieval podemos ubicar allí un núcleo rural musulmán con una torre denominada La Regenta que se emplaza en un estratégico nudo de viejos viales, unos en sentido paralelo a la costa (Ratlla y Regenta) y el resto en sentido E-W (Monges y Palmeral). Siguió siendo un caserío durante época medieval y moderna, hasta que acabó por desaparecer, permaneciendo solamente la alquería al que le da nombre la torre y el vecino topónimo casas de la Regenta.

\section{ANTECEDENTES ARQUEOLÓGICOS}

Los estudios sobre la zona concretan muy poco sobre los restos arqueológicos del lugar; ya en el siglo XVIII P. Bayer "(...) habla de mosaicos y sepulturas fenicias hallados en Burriana (...)"(SARTHOU, 1913:775), esta cita fue adaptada posteriormente en por M. Peris "(...) Los fenicios de Tiro dejaron sus huellas en urnas cinerarias, sepulcros y pavimentos de mosaicos, registrados en La Regenta (...)" (PERIS, 1931:8), quizá en consonancia con la obra póstuma de V. Forner, (FORNER, 1933) que habría sido redactada en los años 20 del siglo XX. En la actualidad algunos autores no descartan la posibilidad de asociar estos restos a la Regenta (MESADO, 1986), frente a otros que la rechazan frontalmente (ARASA, 1986). Sin embargo, sí parece mas aceptado como fuente de otros hallazgos, concretamente de dos lucernas romanas y un pequeño falo de bronce (ROCA, 1932), así como una lápida sepulcral encontrada en Les Alqueries, a unos $200 \mathrm{~m}$. al W de La Regenta, próxima al Camí de les Monges (FLETCHER y ALCACER, 1955). Otra cita la tenemos hacia 1957, cuando al desfondar un campo junto al citado Camí de les Monges, tras su cruce con el Caminàs en dirección a les Alqueries, N. Mesado vio destruir muretes y desperdigar cerámicas (MESADO, 2000). Otro hallazgo arqueológico es el del équido de la Regenta, descubierto con motivo de las obras del trazado de un gasoducto y 
descartado en un primer momento por el V. Verdegal como contemporáneo; fue posteriormente excavado por N. Mesado e I. Sarrión y en la intervención no fue detectado objeto alguno salvo el freno; sólo a $80 \mathrm{~cm}$ al SE de la osamenta apareció una mancha y sobre el animal, pero procedente del segundo estrato, apareció algún fragmento de cerámica ibérica y un fragmento de Campaniense $\mathrm{B}$, lo que dio pie a los autores a identificar un asentamiento prerromano muy tardío destruido por las tropas de Julio César a final del 46 o principio del 45 a. C. (MESADO, 2000). Un reciente análisis de C-14 realizado a instancia del Museo de Burriana determinó que la cronología del équido se encuentra entre el siglo III y IV a. C.

\section{INTERVENCIÓN ARQUEOLÓGICA}

Con motivo de la obra de la Ronda de Burriana en el año 2000, se llevó a cabo una campaña de prospecciones arqueológicas previas que determinó dos zonas de interés arqueológico, una fue la del Palau (cuyos resultados ya expusimos en esta tesis) y la otra fue la de la Regenta. A la vista de los resultados se programó una campaña de sondeos arqueológicos en ambos puntos que tuvimos la oportunidad de dirigir. En la Regenta se llevaron a cabo catas manuales y posteriormente sondeos mecánicos en las zonas de mayor densidad de cerámicas en superficie. Los resultados fueron en gran parte negativos; solamente aparecieron restos muy arrasados de estructuras en niveles superficiales, mezclados con vajilla medieval y moderna, en lo que podríamos asociar a los restos arrasados de la antigua alquería. A nivel de otros elementos, destacamos la presencia de materiales revueltos, entre ellos cerámica moderna, medieval, ibérica, común romana, un fragmento de TSS (ver Imagen 12), dos de TSH, uno de cerámica de paredes finas de cocción reductora y tegulae (ver Lámina Cerámica 3 ).

\section{CONCLUSIONES}

Evidentemente los trabajos arqueológicos realizados hasta la fecha son muy escasos como para poder interpretar correctamente el yacimiento, pero queremos matizar que nuestra hipótesis actual se distancia de las reflejadas hasta el momento. La presencia de un gran estrato revuelto con materiales fechados entre el siglo IV a. C. y la época medieval tampoco facilitan el análisis contextual. Por el momento, y por paralelos cercanos hallados en los yacimientos de Carabona, Palau y Vinarragell, podemos suponer que nos encontramos ante un antiguo tell arrasado, que podría haber existido ya entre el siglo IV y el III a. C., en clara relación con una zona de paso entre Betxí y la costa, posteriormente reutilizado como asentamiento rural en época romana y medieval, para acabar siendo arrasado y nivelado entre final del siglo XIX y principio del XX, para el cultivo de naranja; así se crearía un gran nivel revuelto, sobreviviendo las partes mas profundas del yacimiento, que corresponderían a los enterramientos (el equino y la necrópolis romana). 


\subsubsection{OTRAS INTERVENCIONES-CENTRO HISTÓRICO DE BURRIANA}

El núcleo urbano de la actual Burriana formaría parte de una ruta comercial que alcanzaba a las montañas vecinas. Este camino se acercaba a la costa a la altura aproximada de Burriana al cruzarse con el Caminàs y con el trazado de la vía Augusta, el camino de Betxí, el de Onda y el Caminàs (todos originados desde sendos yacimientos ibéricos muy importantes).

Respecto al núcleo original de la ciudad, podemos aventurar su ubicación dentro del casco histórico en la zona limitada por las calles de San Cristóbal, San Joan, del Pujol y Mayor. El indicio que posibilita emitir tal hipótesis es la pequeña elevación que culmina la zona, señal evidente de que se trata de la cima de un pequeño otero o tell artificial, espacio ideal para levantar un asentamiento junto a un cauce fluvial. En el ámbito de restos arqueológicos sólo aparecen algunos materiales romanos, reutilizados en época árabe. Así, a título de resumen diremos que Burriana pudo tener sus orígenes en un recinto, construido allí por lo estratégico del cruce de caminos. Hasta el momento la única hipótesis sobre el origen romano de Burriana era como villa de Burrus ${ }^{20}$ (ARASA, 2004), sin embargo existe otra probabilidad, la de asociarla a una gens Burriena ${ }^{21}$, mucho mas acorde fonéticamente con el posterior nombre musulmán de Medina Buryena $^{22}$, es más fácil que este nombre correspondiera al enclave del Palau, por ser ésta una villa romana

Esta evidencia romana en el casco urbano, que aparece de una forma muy limitada, nos hace pensar en un núcleo próximo; en nuestra opinión éste se encuentra a escasos metros al otro lado del río Anna en la zona del Palau (donde se halla el asentamiento romano más cercano) y donde los árabes se asentaron casi directamente sobre los restos de una villa romana. Tengamos en cuenta que la superficie de los restos musulmanes del Palau casi duplica las 3 hectáreas de la Burriana amurallada.

La primera noticia que tenemos sobre la ciudad se debe al cronista árabe Al-Rizi, de mediado el siglo $\mathrm{X}$, y a partir de ahí aparece como amal (cabeza de distrito). Esta condición de importancia estratégica se vio reforzada por su proximidad a la entonces Marca Hispánica, o sea, la frontera con la cristiandad representada por el reino de

\footnotetext{
${ }^{20}$ Dejamos a un lado otros nombres como Brigiana (según Escolano de origen godo), Buris-ana (Viciana apunta como una mezcla de mozárabe y latín), etc. ya que hoy en día son simples anécdotas (MELCHOR, 2004)

${ }^{21}$ W. Smith cita un Gaius Burrienus, como miembro de esta gens, y que fue pretor en Roma en el 82 a.C. (SMITH, 1867).

${ }^{22}$ Según comentario personal del Dr. Ramón Járrega, los nomina suelen dar origen a los nombres de los fundi, mientras que Burrus es un cognomen,
} 
Carlomagno (GUICHARD y MESADO, 1976). Burriana sería entonces parte del sistema defensivo de la zona y de localidades tan importantes como Sagunto o Valencia. Es muy probable que se reaprovecharan asentamientos de épocas anteriores, manteniendo la importancia estratégica que siempre caracterizó a este espacio.

Sin duda los árabes fueron los fundadores de Burriana como ciudad, que dejó de ser quizá una simple alquería o albergue al borde de un camino para transformarse en una villa amurallada. A su condición de enclave estratégico sumamos su función de zona de paso en la ruta entre Valencia y Tortosa, importantes metrópolis musulmanas al borde de la antigua vía Augusta. También la progresiva caída en manos cristianas de las ciudades árabes del Norte recortó la ruta comercial, haciendo que Burriana pasara a ser un importante centro operativo y núcleo defensivo de carácter fronterizo, con el consiguiente enriquecimiento de la misma.

La pervivencia de la distribución urbanística medieval también viene confirmada por la presencia de pozos, corrales y huertas intramuros y la acequia del Ull de la Vila, que ya existían en época musulmana y se mantienen hasta bien entrado el siglo XVI

\section{INTERVENCIONES ARQUEOLÓGICAS}

Lamentablemente la mayor parte de las intervenciones arqueológicas en el casco urbano de Burriana permanecen inéditas o solo se han publicado resúmenes escuetos, lo que implica que buena parte de los datos sobre los restos romanos aparecidos en ellas permanecen desconocidos. Así resumiremos los hechos conocidos:

\section{Calle Racó de l'Abadía (antigua Virgen de la Candelaria):}

Intervención realizada por N. Mesado en 1981 que cita la presencia de abundantes tegulae y bordes de dolia reutilizados entre los cimientos de las casas musulmanas del "nivel fundacional" (sic) (MESADO, 1986), que presuponemos debería encontrase alrededor de los $2 \mathrm{~m}$ de profundidad.

\section{Plaza de las Monjas:}

Realizada por N. Mesado en los años 90 durante una remodelación en la citada plaza. En una nota encontrada entre los materiales del Museo de Burriana, se cita su presencia alrededor de los $3 \mathrm{~m}$ de profundidad. Apareció un fragmento de ladrillo romano

\section{Iglesia de la Sangre:}

Los restos presentes en el almacén del museo de Burriana corresponden a los recogidos por $\mathrm{T}$. Utrilla y $\mathrm{N}$. Mesado a raíz de las obras en el solar, publicadas 
parcialmente (UTRILLA, 1966b); en ellos se observa una tegula con evidentes marcas de erosión por agua.

\section{Calle Mayor 26 esquina calle Forn de la Vila:}

Realizamos esta intervención en el año 2003 y en ella destacamos la presencia de tegulae, dolia, fragmentos de mármol de revestimiento (posiblemente Buixcarró) y una emisión monetal augústea de la ceca de Celsa, en contextos musulmanes entre los siglos $\mathrm{X}$ y XIII, en algunos casos concretos en el interior de silos excavados en los viales.

\section{Excavación del Jardín y la casa Abadía de la parroquia del Salvador:}

Dirigimos dicha intervención en 2008 y aportó fragmentos de dolia y tegulae, siendo éstos más abundantes en los niveles musulmanes más profundos.

\section{San Agustín 6:}

Entre los restos de esta excavación encontramos un fragmento de base de TSS.

\section{Calle San Juan Bosco 18:}

Entre los materiales recuperados en este solar encontramos un fragmento de base de TSS.

\section{Terraza Paya:}

Dentro del contexto extraurbano respecto a la ciudad medieval aparecieron escasos fragmentos de imbrices, tegulae, dolia y mármol en contextos de vertederos medievales.

\section{INTERPRETACIÓN}

En líneas generales podemos constatar que la mayor parte de los restos corresponden a grandes fragmentos cerámicos como tejas, dolia, mármol y posiblemente otros componentes pétreos; en cualquier caso conviene recordar que se han encontrado lápidas y sillares en lugares de los que no provenían realmente. De hecho tenemos el ejemplo de una inscripción romana encontrada a principio del siglo XX en Les Alqueries que con el tiempo fue a parar a Burriana (ARASA, 2004).

Observamos que algunas de estas piezas tienen abundantes fracturas, marcas de arado y en algún caso señales de rodadura, lo que apuntaría a que fueron recolectadas años después de su abandono, y que por su volumen posiblemente su función fuera la de reutilización como material constructivo. 
El transporte de fragmentos relativamente pequeños podría indicar la facilidad de su acopio, por un lado por su abundancia y la comodidad de recolección a una profundidad relativamente escasa y, por otro, debido a su proximidad al lugar de uso. Independientemente a las excavaciones donde aparecen puntualmente algunos restos arqueológicos romanos, cuyo contexto deposicional es claramente secundario, queremos citar algunos hallazgos de materiales musulmanes que comparten una serie de características importantes, como es el hecho de haber sido encontrados a gran profundidad (al menos superior a los 2 metros) que los descartan como material de arrastre, pero que no desarrollaremos al no tratarse de intervenciones arqueológicas, y si hallazgos sin un contexto concreto.

- Papelera del Mijares

- Calle Juan XXIII, 47 (actual Carrer Jardi)

- Calle Mártires Católicos (actual calle la Bosca)

- Plaza de las Monjas

- Calle San Juan Bosco

- Calle San Blas

- Calatrava-Riu Sec

- Cap de Terme (ver Lámina Cerámica 2)

- Calle Iturbi, 3

La importancia de estos hallazgos, realizados por T. Utrilla y N. Mesado junto a sus colaboradores, es que jalonan las vías de comunicación del entorno de la ciudad, ya que en su mayor parte se encuentran muy alejados del núcleo medieval (ver Lámina $\underline{L X I}$ ). Si bien estos hallazgos son prueba evidente del trazado viario musulmán, nosotros pretendemos apoyar con ellos la hipótesis de que su trazado seguía utilizando parte de las vías romanas que cruzan el término de Burriana, como apuntaremos más adelante. 


\section{TERCERA PARTE: ESTUDIO DE LA CULTURA} MATERIAL Y LA EPIGRAFIA 
A la hora empezar el estudio de la epigrafía y los materiales de las dos intervenciones arqueológicas (concretamente los yacimientos de Sagunto y el Palau) que constituyen el conjunto más significativo de restos a los que tuvimos acceso y que pueden ser estudiados de forma independiente, y aunque nos centraremos en los elementos inéditos, incluiremos también nuevas aportaciones o revisiones de los materiales ya publicados. Recordemos que el estudio de los materiales de los demás yacimientos ha sido incluido puntualmente junto a la descripción de cada uno de ellos.

En este apartado veremos claramente reflejada la diferencia cuantitativa en el registro entre el asentamiento rural y el urbano, ya que el primero tiene una vida mas corta, sufriendo además un proceso de abandono y saqueo más acentuado que el segundo. Sin embargo, a nivel de diferenciación de las unidades, la remoción que sufren los estratos saguntinos a partir del siglo II d. C. es muy superior a los del yacimiento de Burriana para el mismo periodo. La inmensa cantidad de material obtenido en la Morería hace que nos centremos básicamente en el material cerámico que nos permite obtener alguna cronología más precisa, como son las TS y las importaciones, dejando para un futuro el estudio las cerámicas comunes y ánforas (excepto en los casos donde aporten una información vital). Por otro lado, en el caso del Palau sí se han estudiado exhaustivamente todos los materiales romanos. 


\section{2. LA PLAZA DE LA MORERIA (SAGUNTO)}

En primer lugar vamos a citar aquellos apartados que ya fueron publicados, como es el caso de los elementos epigráficos del yacimiento saguntino de la Morería, donde los investigadores J. Corell y J. J. Seguí identifican los restos de al menos tres inscripciones, todas ellas de tipo monumental (CORELL y SEGUI, 2008). Corresponderían, según la hipótesis de los citados autores, a una inscripción alusiva a un templo de Mitra, otra correspondiente a un personaje que quizá fuera un emperador y, finalmente, una tercera más difícil de interpretar. Respecto a la inscripción mitraica ha sido restituida por los autores como:

\section{[A]ed[es] [Mi]thrae}

- - - - - ?

(CORELL y SEGUI, 2008: 75)

Apuntan que tanto el gran módulo de la escritura y su excelente ejecución, como el tipo de soporte sobre una placa de mármol moldurada, les permiten pensar en una inscripción de carácter monumental y suponen que la misma estaría en la parte externa o en el porticus del recinto sagrado, en lo que sería el primer testimonio del culto a Mitra en Sagunto (CORELL y SEGUI, 2008). Nosotros presuponemos que este santuario aún no ha sido descubierto, pues las características de los dos templos conocidos en la excavación no alcanzan a coincidir con las de un mitreo. Sin embargo, siempre podemos pensar que el lugar de culto se encuentra muy próximo, quizá bajo la actual plaza de la Morería (donde estarían otras estructuras saqueadas que aportaron fragmentos a este mismo conjunto de hallazgos). La proximidad a este punto también vendría reforzada por la cercanía al posible enclave del anfiteatro saguntino.

La siguiente inscripción es restituida por los mencionados investigadores como:

$$
\begin{aligned}
& {[---] \cdot \operatorname{co}[(n)[\text { suli }) \cdot p(\text { atri) } p(\text { atriae })] ?} \\
& {[---] \cdot P[---] s \cdot d(e) \cdot s(\text { ua })[\cdot p(\text { ecunia }) \cdot f(\text { ecit })] ?}
\end{aligned}
$$


Otra vez por la excelente ejecución de la placa de mármol blanco, la calidad de las letras y el número total de líneas que debía incluir, resulta muy probable que se trate de una dedicatoria a un emperador, como sugiere la supuesta mención del consulado hacia el final de la inscripción y, a continuación, el título de pater patriae. En la última línea figuraría el nombre del dedicante del que se habrían perdido el praenomen y el nomen, conservándose tan sólo el principio y el final del cognomen, esto es, una $\mathrm{P}$ y una $S$ respectivamente (CORELL y SEGUI, 2008). Por otro lado la existencia de una inscripción de probable carácter imperial sí se puede relacionar con el arco (ver Foto 282), junto al cual se hallaron los fragmentos, más aún si esta estructura estuvo asociada al templo que tiene justo al lado (como se ve en el ejemplo de la foto $\underline{446}$ ), y que podría significar una dedicatoria de la estructura al propio emperador o del gobernante a la divinidad. Muchos son también los paralelos de la asociación entre santuarios y arcadas y aquí traemos a colación gráficamente el de Pompeya, donde además apreciamos una similitud formal y estilística muy elevada respecto a los restos saguntinos, concretamente con el conocido como arco de Calígula (ver Fotos $\underline{275}$ y 276) ubicado prácticamente junto a la aedes de la Fortuna Augusta situado en la Regio VII, Ínsula 4, 1 fue construido por el duunviro M. Tulio en honor al emperador. En el interior estaba la estatua de la diosa y en las hornacillas laterales la familia imperial y la de M. Tulio. El templo estaba dedicado al culto de la Fortuna Redux. Este tipo de advocación empezó cuando Augusto regresó de las campañas de los años 19-13 a. C.

Tampoco sería improbable que el paralelo con Sagunto fuera más allá de lo meramente formal, si aceptamos el hecho de que también nos encontramos ante un templo municipal y un arco de dedicatoria imperial, de formas muy sencillas como las pompeyanas, lo que además explicaría que el saqueo de la estructura saguntina hubiera sido bastante fácil, por la sencillez de los materiales constructivos.

Los restantes fragmentos epigráficos del conjunto tienen una interpretación más difícil, ya que podrían pertenecer a $\mathrm{B}, \mathrm{P}$ ○ R; la segunda, a $\mathrm{O}$ ó $\mathrm{Q}$. Dado el contexto arqueológico, los autores sugieren la posibilidad de restituir po[ntif(ici)] en una dedicatoria a un emperador o a un miembro del orden senatorial (CORELL y SEGUI, 2008). La ubicación que todos estos fragmentos en un mismo espacio, concretamente en una fosa situada bajo el sitio que ocuparía el arco monumental que estaba frente al Templo 1, excavada en la calzada, perforando la misma y llegando hasta la cloaca central, pueden fácilmente identificarse con los restos depositados dentro de un hoyo, fruto del saqueo que se produjo en los edificios monumentales de la zona alrededor del siglo IV d. C. Para ello debemos tener en cuenta que cuando se hizo esta fosa ya no existía ninguno resto del arco monumental, ya que por encima del agujero solamente constaba un estrato con muy pocos materiales cerámicos fuera de contexto y sin ninguna señal de elementos constructivos; la única traza de los mismos hay que 
buscarla en los abundantes fragmentos de esquirlas junto a la base de la arcada y que estaban presentes también de forma significativa revueltos junto a los fragmentos epigráficos citados.

Esto nos lleva a pensar que el conjunto es fruto del saqueo de al menos dos o tres estructuras distintas, correspondientes al templo de Mitra, al propio arco monumental y a otro inmueble no identificado (o que formaba parte de las anteriores). Finalmente la cronología de estas inscripciones coinciden grosso modo con el periodo de monumentalización de la zona en el siglo II d. C. (CORELL y SEGUI, 2008).

Respecto al los materiales cerámicos, debemos realizar un estudio bastante cauto, ya que los niveles de arrasamiento son muy importantes para cada período, de tal forma que descartamos realizar disertaciones de tipo cuantitativo, pues sus resultados sin duda poco podrían aportar, ya que los artefactos aparecen en un tejido general que ya conocemos, como son el de arrasamiento de las tumbas de la zona hacia final del siglo I d. C. y el gran conjunto que corresponde al establecimiento de viviendas sobre los templos del siglo II d. C.; exceptuamos los elementos que aparecen en contextos originales y aislados (fosas, tumbas, etc.) que se han reflejado en este trabajo de forma diferenciada junto al análisis de su respectiva unidad estratigráfica. Con estos niveles tan claros, únicamente podemos establecer algunas puntualizaciones que pueden corroborar datos sobre la evolución urbanística de esta zona, como por ejemplo el importante déficit de fragmentos a partir del siglo IV d. C., lo que implicaría un proceso de abandono y retirada de la población (que obviamente llevaría consigo sus enseres) frente al arrasamiento in situ de los restos de la necrópolis y la creación de abundantes vertidos durante la etapa de su uso como vivienda, así como la práctica desaparición de materiales de los siglos $\mathrm{V}$ al VIII d. C., con una presencia puntual mediante enterramientos y cimentaciones, que apuntaría a que el núcleo poblacional se encuentra bastante alejado de esta zona y que solamente se daba un uso concreto a parte de este espacio. Además, al no aparecer vertederos y sí fosas, seguimos pensando que se trata de una banda de extracción y no de deposición. Destacamos también en el importante contexto de materiales del siglo III d. C. la presencia de imitaciones de formas TS (ver Imágenes $21, \underline{22}$ y $\underline{24}$ ) y reutilización de fragmentos de TSCA como fichas (ver Imagen $\underline{25}$ ) entre otros tipos de cerámicas (ver Imágenes $\underline{23}$ y 48) de las que analizamos las formas mas significativas (ver Tablas $\underline{2}$ y $\underline{4}$ y Lámina Cerámica 43 a 54). Dentro de este contexto tomamos las UEs que se encontraban sobre la calzada, que como se puede comprobar aportaban con diferencia la mayor cantidad de fragmentos de todo el solar (ver Gráfico 2), y al mismo tiempo es un fiel reflejo de todas las etapas cronológicas del mismo (ver Gráfico 4). Realizando el mismo análisis para el solar de Quevedo (ver Gráficos $\underline{3}$ y $\underline{5}$ y Lámina Cerámica 33 a 42 ) podemos detectar un desarrollo similar por los que se refiere a parámetros temporales.

En el análisis epigráfico de otros elementos, podemos constatar la gran variedad de 
piezas importadas de distintos talleres según las sigillas detectadas, que además se tratan en algunos casos de piezas de gran valor, lo que sin duda apunta a la riqueza de esta zona de la necrópolis. Respecto a los grafitos, la mayor parte de ellos correspondería a temas votivos $u$ ofrendas, dentro del contexto funerario. Las demás unidades muebles, como vidrios, huesos, metal, etc., ya fueron objeto de un estudio puntual que resumiremos a continuación y un análisis exhaustivo en estos momentos implicaría desbordar los objetivos de esta tesis.

Respecto al material vítreo, la mayor parte del material corresponde a piezas de cronología entre el siglo II y el IV d. C., entre las que destacan formas como los tipos Isings 106.b.2 y 3b (siglo IV d. C.), 51 (I al III d. C.), 88 (siglo II-III d. C.), 80 y 89 (siglos II-IV d. C.), a los que debemos sumar otros artefactos como pulseras de vidrio, fichas circulares (calculi o milites), vidrio de ventana, etc. Pocos son los elementos que podemos asociar de forma exclusiva a la necrópolis, como las piezas tipo Isings 34 (siglo I-II d. C.) y 44 ( $1^{\text {a }}$ mitad del siglo I d. C.) y ungüentarios Isings 8-27 y 6 (siglo I d. C.) (FALOMIR, 2005) (ver Imagen 36).

A hablar de la numismática sucede un caso similar a los otros ejemplos citados; su aparición en contextos revueltos (prácticamente los mismos que las cerámicas, como hemos citado más arriba) hace que nos acerquemos con cautela a su estudio, por el que nos limitamos a exponer datos generales, ya que un estudio pormenorizado, volvemos a insistir, desbordaría este trabajo. Otra vez aquellos elementos aparecidos en un contexto intacto o al menos aislable se estudian en sus respectivos conjuntos.

Sobre la clasificación de los materiales, únicamente queremos señalar la existencia de tres conjuntos destacables: las monedas ibéricas, las romanas del Alto Imperio y un importante conjunto de final del siglo III d. C. (ver Gráfico 1 y Tabla $\underline{3}$ ) Respecto a las indígenas desconocemos su funcionalidad concreta y únicamente las podemos asociar a las escasas cimentaciones detectadas en el solar que se pueden incluir en ese periodo y que quizá también estén relacionadas con la total ausencia de monedas republicanas. Los numerarios del Alto Imperio los podemos agrupar en dos conjuntos; los que se afilian a la necrópolis, marcando un claro espectro cronológico entre el reinado de Augusto y el de Claudio (muchas muy desgastadas - ver Imagen 41) y las que se asocian a la familia de Trajano. Finalmente tenemos un importante conjunto de pequeñas monedas que empezarían aproximadamente en el año 231 d. C. y que tendrían su auge a final del siglo III d. C. (una de las últimas acuñaciones sería un sestercio de Severo Alejandro del 285 d. C.) (PASCUAL-AHUIR, 2005). Tampoco debemos olvidar la gran presencia de imitaciones de dineros de Claudio II, concretamente del modelo surgido a partir del 270 d. C., y que tuvieron una gran circulación hasta entrado el siglo IV d. C. ${ }^{23}$

\footnotetext{
${ }^{23}$ Agradecemos esta información oral de Dña. María del Mar Pascual-Ahuir, que en estos momentos se encuentra finalizando el estudio numismático.
} 
Respecto a la gran concentración de monetal de una cronología aproximada de la segunda mitad del siglo III d. C., depositadas en el estrato revuelto y sobre la calzada frente a la domus Sur, pensamos que posiblemente se trataría de un conjunto esparcido al saquearse la citada vivienda, virtualmente cuando el valor de estas monedas no fuera superior a la del propio metal que las componía, quizá en una fecha muy posterior al siglo IV d. C. De otro modo no comprendemos cómo no fueron recogidas, ya que es una cantidad muy importante cercana a los 200 ejemplares. Esto corroboraría la hipótesis del saqueo del siglo $\mathrm{V} d$. C. Sobre el origen de estas monedas del Bajo Imperio son tantas las posibilidades que preferimos reflejar sólo dos de las más factibles, según nuestro punto de vista; por un lado, podrían ser propiedad de alguno de los habitantes de la domus y, por otro, tratarse de depósitos. De cualquier modo queremos hacer un inciso en este punto y romper una lanza en contra de la tendencia a considerar que cualquier conjunto amplio de numerarios como una ocultación esté motivada por motivos de crisis o de miedo, ya que existen muchas más posibilidades dentro del mundo romano, como son los préstamos, las herencias (Dig. 7, 1, 28. cita el legado de monedas antiguas de oro y plata que se utilizan a modo de joyas), y como comprobamos en la legislación romana (Dig., 16, 3)

1. (35) Ocurre frecuentemente que la cosa o las monedas depositadas lo sean a riesgo de aquel en el cual se depositan, (...) (36) Si se hubiera depositado una cantidad en un saquete sellado, (...). El dinero ha de ser sacado o ante el pretor o interviniendo personas honradas...

18. Lo que se depositó por causa de tumulto, incendio, derrumbamiento o naufragio, (...)

20. Si hubieses perdido sin dolo malo la cosa en ti depositada, no quedarás obligado por la acción de depósito ni debes dar caución de que será devuelta si la llegas a encontrar (...).

Todos estos casos dan testimonio sobre el hecho de la acumulación de monedas que se ocultaban simplemente por seguridad, dentro de un entorno normalizado de la sociedad romana, y que no se recuperó al momento de abandonar la vivienda, aunque podía haber estado ya oculto por alguna de las generaciones anteriores a la que finalmente dejó la casa. Otra probabilidad es que nos encontremos ante un taller que se dedicara a fundir metal, como lo indicarían además algunos fragmentos de bronce encontrados en este espacio, que van desde fragmentos de esculturas, restos de apliques, fragmentos informes y quizá hasta las propias monedas. Este obrador trabajaría a pequeña escala, ya que no se han encontrado restos de trabajo de fundición de bronce a nivel industrial ó artesanal. Solamente algunos fragmentos de deshecho de fundición de pequeño tamaño y el fondo de una vasija (ver Imagen $\underline{50}$ ) con escorias de bronce adheridas a su fondo (muestra inequívoca de que se utilizó para fundir metales) indican este tipo de trabajos. Si a ello sumamos la presencia de 
monedas recortadas y fragmentos de las mismas, junto a ejemplares antiguos claramente marcados para corte, (ver Imágenes $\underline{40}, \underline{42}, \underline{43}$ y $\underline{44}$ ) esto podía significar que nos encontramos ante un pequeño laboratorio dedicado a al reaprovechamiento de monedas, con lo cual no sería una coincidencia la presencia de falsificaciones de Claudio II. Lamentablemente no hemos recuperado pruebas definitorias de esta actividad como podían ser cuños o moldes, únicamente hallamos monedas fabricadas por el método de fundición (ver Imagen $\underline{39}$ ).

Respecto al material óseo podemos destacar la amplitud del registro, ya que encontramos agujas, bisagras cucharas, espátulas, fichas, peines, etc. (ver Imagen $\underline{26}$ ) Sin embargo respecto a la cronología, encontramos un amplio abanico, desde el I d. C. al final del IV d. C. (LLORENS, 2005), por lo cual su aportación la consideramos en el conjunto de la cultura material del yacimiento.

Un caso similar al anterior lo tenemos en el análisis del material pétreo, puesto que no existe un contexto individual y únicamente podemos referirnos a la gran riqueza de los soportes marmóreos en Rosso Antico, Brocatello, fragmentos de la Bética, Saetabitanum etc. (CLARAMONTE et al., 2009), utilizados como cornisas (ver Imagen 38), revestimientos de pilares, columnas, metopas, pavimentos de sectilia, teselas de mosaico, fragmentos escultóricos (ver Imagen $\underline{33}$ ), fuentes, etc. (CLARAMONTE, 2005), sin que olvidemos citar ejemplares de capiteles de fuentes con simbología mística oriental (CORELL y SEGUI, 2008) (ver Imágenes $\underline{27}, \underline{28}, \underline{29}, \underline{30}, \underline{31}$ у $\underline{32}$ ) у relieves egiptizantes (ver Imagen $\underline{37}$ ) que se podrían asociar a un momento final del siglo I d. C. según algunos autores (VERSLUYS y SEGUI, 2008).

Cuando nos centramos en el estudio de los restos metálicos, la tónica es la misma que para los casos anteriores, un gran nivel revuelto en distintas fases. Por un lado tenemos aquellos elementos que por su datación pueden pertenecer al momento de la necrópolis, como alfileres, botones, clavos, cuchillos, fíbulas, anillos, amuletos fálicos, pendientes, stylus, escalpelos, espátulas etc., todos con una cronología del Alto Imperio. El siguiente conjunto es de más difícil caracterización y está formado por elementos de panoplia militar y de uso cotidiano, como anillo-llave, crotalos (ver Imagen 34), hebillas, apliques de puertas, etc. Finalmente tenemos un grupo importante de elementos muy fragmentados, como un pie de una estatuilla, fragmentos de jarras, (LOPEZ y DELAPORTE, 2005) un fragmento de escultura dorada (posiblemente toracata ver Imágenes $\underline{35}$ y $\underline{45}$ ), etc. En el primero de los conjuntos, según nuestra opinión, parece evidente que podemos encontrarnos ante los ajuares de las tumbas que aparecen revueltos, donde surgen elementos muy interesantes asociables a profesiones concretas, como la de médico (escalpelo, espátula, etc.), escriba o maestro (stylus) y militar (fíbula Iturissa) (LOPEZ y DELAPORTE, 2005). El siguiente grupo correspondería a los elementos de las viviendas (clavos, llaves, cerraduras, cuchillos, etc.) del siglo III d. C., y dejamos como probabilidad, pendiente 
de comprobación, el hecho de que los elementos militares pertenecientes a los siglos II-III d. C. puedan estar asociados al culto a Mitra. Finalmente queremos recordar que el amplio grupo de elementos de bronce muy segmentados, como por ejemplo los ya citados fragmentos de estatuas, apuntarían a la presencia de un pequeño taller.

También citamos de forma muy breve los estudios antropológicos realizados sobre todos los enterramientos excavados en el solar ${ }^{24}$. En primer lugar queremos destacar los indicios sobre la presencia de incineraciones a lo largo de todo el solar, como por ejemplo bajo las estructuras de la ínsula Norte; allí la UE 1315 sólo conservaba un minúsculo fragmento de hueso humano entre carbones y cenizas muy arrasados y en la UE 1326 aparecieron tres fragmentos informes de fauna incinerada junto a los restos de un adulto, posiblemente mujer (por la situación de ambos, ubicados junto a los restos muy arrasados de estructuras del I d. C. - UE 1317 y 1318 - formaron parte del mismo monumento funerario). Tenemos así la confirmación de que los hoyos frente al Templo 1 no son enterramientos, pues la fosa UE 1129 contenía abundantes carbones, restos de fauna no quemada de ciervo, ovicáprido y suido, sin la presencia de restos humanos y la UE 1353 únicamente tenia 3 minúsculos fragmentos informes de hueso humano sin fauna asociada (POLO y GARCIA, 2005), a lo que debemos sumar su pequeño tamaño. La primera se trataba de una pequeña fosa de forma hemisférica (diámetro de $47 \mathrm{~cm}$ y profundidad de $21 \mathrm{~cm}$ ) y estaba asociada a los hoyos UE 1351, 1352 y 1355 de tamaño y forma muy similar aunque rellenados únicamente con escasos carbones y cenizas. Todas ellas estaban excavadas sobre un nivel de adobe y rodeaban la UE 1129, por lo que apuntamos su posible carácter votivo.

Respecto a los estudios antropológicos de los enterramientos visigodos encontrados en la cloaca romana y afectados parcialmente por una zanja musulmana, sólo queremos constatar que nos encontramos ante una tumba familiar (dos adultos, individuo juvenil e individuo infantil-juvenil), donde los mayores fueron los últimos en fallecer (al ser los únicos que se encontraban en posición primaria) (POLO y GARCIA, 2005) mientras los demás huesos se encontraban amontonados a los pies de los otros. Así tendríamos la evidencia de un uso prolongado de la tumba, lo que nos lleva a pensar en un lugar de enterramiento de uso común, que dentro de la cultura tardoantigua debería estar asociado a un área de significación religiosa.

Finalmente recordar que el estudio de los miles de fragmentos de materiales de los mas variados tipos (ver Imágenes $\underline{46}, \underline{47}$ y $\underline{49}$ ) sin duda sería de por sí motivo para otra tesis.

\footnotetext{
${ }^{24}$ Para los elementos asociados a un contexto concreto nos remitimos al apartado pertinente de esta tesis y a la bibliografía ya publicada (POLO y GARCIA, 2005).
} 


\subsection{EL PALAU (BURRIANA)}

Este estudio es más breve, ya que las excavaciones arqueológicas solamente actuaron sobre unos $600 \mathrm{~m}^{2}$ de la zona más importante de la villa y otros $1000 \mathrm{~m}^{2}$ de la franja periférica de vertidos puntuales; frente a ellos se ha actuado sobre otros $1600 \mathrm{~m}^{2}$ de la alquería medieval, aunque solamente aporta datos secundarios respecto a materiales romanos. Así podemos entender la relativa escasez de restos muebles para este periodo (ver Imágenes $\underline{2}, \underline{3}, \underline{4}, \underline{5}$ y $\underline{9}$ ).

En primer lugar las cerámicas de mesa e importaciones nos aportan pocos datos, únicamente nos permiten mantener una cronología entre final del siglo I d. C. y el IV d. C. para la vida de este enclave, ya que los fragmentos de época anterior (material Iberoromano y campaniense B) y posterior (algún fragmento dudoso de TSCD) son testimoniales (ver Gráfico $\underline{6}$, Tabla $\underline{5}$ Lámina Cerámica 18 a 27).

Respecto a la epigrafía, ésta aparece únicamente sobre soporte cerámico ( $T S$, ánfora, dolia y tejas) y de forma escasa; únicamente la similitud entre algunos sellos sobre ánfora y tegula con probable lectura $L C_{¿} O$ ?M [...] (ver Imagen 7 ) podría indicar la presencia de un taller local (recordemos la existencia de vertederos con escoria de cerámica en la zona inmediata a la villa). Otra aportación interesante es la representación de marcas que indican la importación de materiales constructivos, quizá relacionados con la situación de cruce de rutas comerciales marítimas y terrestres de este enclave.

El material pétreo es sumamente escaso, debido al profundo saqueo que sufre la villa en época medieval; únicamente dos pequeños fragmentos de mármol Saetabitanum, otro blanco indeterminado, un trozo escultórico de pequeño tamaño de forma troncocónica y los restos de piedras de caliza gris ligeramente escuadradas (lamentablemente todas estaban muy recortadas y reutilizadas en cimientos musulmanes) son los únicos indicios que perviven hasta el momento de los artefactos pétreos con función decorativa de época romana. 
Los elementos numismáticos se limitan a tres monedas fustras, que por su módulo podrían corresponder a ases de época del Alto Imperio. Siguiendo con los elementos metálicos, los restos de hierro son escasos, pues si sumamos el saqueo medieval a la acidez del terreno, es normal que su presencia sea prácticamente nula, habiéndose sólo identificado por el momento restos de clavos y de un cuchillo. Respecto al bronce, volvemos a tener clavos y fragmentos informes.

El estudio de la fauna nos indica que son restos en bastante mal estado, ya que están muy fragmentados. A pesar de ello se han podido observar marcas debidas al fuego, a la corrosión por las raíces, al ambiente de conservación y a la acción humana. En algunos se ha podido estudiar la edad relativa de la muerte del animal, ya sea por el desgaste dental o por la formación de los huesos, sin poder asignar si los restos son de los mismos individuos. Destacamos que la presencia de ejemplares de más edad aparece entre los bóvidos y ovinos, de la misma forma que los ejemplares más jóvenes. Por lo demás tenemos un amplio repertorio habitual en las zonas rurales, como caballo, burro, aves, cerdo, conejo y gato.

Otro elemento interesante que podemos destacar es la abundante recolección de especies marinas, como las ostras, berberechos, caracol y almendra de mar, a las que sumamos la tortuga. Estos restos son una prueba inequívoca de la relación entre este asentamiento y el mar, constatado fehacientemente desde época musulmana. Además, queremos añadir un dato verdaderamente interesante; en el análisis paleopatológico de los enterramientos musulmanes de la necrópolis del Portal de Valencia (Burriana), uno de los individuos analizados, una mujer de 25 a 35 años, tenía enfermedades degenerativas en el oído, a causa de los cambios constantes de presión, lo que quizá se podría asociar a la recolección subacuática ${ }^{25}$. Otro dato comparativo es que, en la actualidad, en la costa de Burriana aún queda una colonia de tortugas cerca del yacimiento de Sant Gregori, que es una importante villa romana. Como ya citaremos en otros puntos de esta tesis, esta relación entre el Palau y la costa durante la época medieval muy probablemente sea el mantenimiento de un esquema de aprovisionamiento que ya funcionaría desde la etapa romana.

También es interesante señalar la cantidad de elementos romanos que aparecen reutilizados en niveles musulmanes (ver Imágenes 1 , $\underline{6}$, $\underline{8}$ y $\underline{10}$ ), e inclusive con importante huellas de erosión por agua (ver Imágenes $\underline{11}$ y $\underline{20}$ ).

Finalmente realizamos un breve estudio puntual de los materiales depositados en el Museo de Burriana de los yacimientos a los que hacemos referencia en esta tesis. A pesar de lo escaso de la muestra es posible apuntar que los resultados apuntan a un contexto homogéneo entre el cambio de Era y el siglo IV d. C. (ver Tabla 1 , Gráfico $\underline{7}$ y (ver Lámina Cerámica 30 a 32).

\footnotetext{
${ }^{25}$ Informe paleoantropologico original depositado en el Museo Arqueológico Municipal de Burriana, a cargo del Dr. Manuel Polo.
} 


\section{CUARTA PARTE: MAPAS Y PLANIMETRIAS}


Respecto al análisis de los planos que afectan al espacio rural y las vías de comunicación optamos por aplicar el concepto del análisis regresivo del paisaje (LEVEAU, 1999), de tal forma que podemos aproximarnos lo máximo posible al ambiente del periodo que nos ocupa en esta tesis.

En primer lugar utilizamos como base fotografías aéreas, en las cuales pudimos recuperar indicios de antiguos barrancos hoy en día desaparecidos, y también analizamos la impronta que han dejado muchos caminos y parcelarios, que en este último caso son de gran importancia en esta zona costera ya que nos permiten observar con cierta claridad el espacio ganado a las franjas pantanosas conocidas como marjales. La diferente orientación de las propiedades respecto a las del entorno inmediato y su pequeño tamaño es prueba evidente de una micro-propiedad con relación a las demás, un claro indicio de que son lo que podemos llamar "parcelas jóvenes", en el sentido de que son relativamente recientes o, como mínimo, posteriores al periodo bajomedieval. En esta etapa histórica es cuando en la Península lbérica se produjeron importantes donaciones que significaron el último gran momento de ruptura global en la titularidad/propiedad de la tierra. Aunque éstas se acabaron subdividiendo con el tiempo, mantienen un patrón uniforme, por ejemplo en una orientación acorde con los caminos de la época, a diferencia de estas nuevas parcelas, ubicadas según los límites de la marjal y que si las tomamos en su globalidad forman una evidente

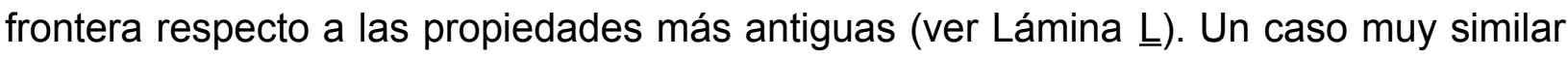
es el que se produce al rellenar antiguos barrancos, donde las nuevas posesiones siguen la orientación de su cauce y por supuesto presentan un tamaño mucho más pequeño que las de su entorno. Como ejemplo paradigmático tenemos el antiguo barranco del Hospital o del Marjalet en Burriana, rellenado a principio del siglo XX y cuyas características actuales son idénticas a las descritas más arriba.

Los esquemas de adaptación al terreno se reproducen a lo largo de toda la comarca y, aplicados al estudio del paleopaisaje, dejan unos pasillos muy evidentes por donde discurren las sendas de comunicación antiguas, tanto las terrestres como las marítimas (estas últimas respecto a las zonas donde atracar o simplemente acercarse a la costa). Debemos tener en cuenta que estos condicionantes solamente se superaron con facilidad a partir de la revolución industrial del siglo XIX, que aportó maquinaria y mano de obra en cantidad suficiente para, por ejemplo, desecar con facilidad marjales, desmontar montañas, construir terraplenes o puertos, etc. Analizando todos estos datos podemos observar que las vías romanas tiene claramente una ruta factible por su rapidez y economía, evitando marjales, elevaciones montañosas, cauces de barrancos y cruces dificultosos de ríos; sobre esta base, al plantear el recorrido de la vía Augusta, 
tenemos que con una variación no superior a los $500 \mathrm{~m}$ coinciden los asentamientos citados en los itinerarios (en nuestro caso Spelaco) con yacimientos actualmente conocidos. Pero no debemos olvidar que hay multitud de sendas y caminos romanos además de la citada vía, ya que los diversos asentamientos debían estar comunicados entre sí, como por ejemplo las vías de tipo vicinales o privatae, una de las cuales comunicaría los enclaves del Palau y Sant Gregori, pasando por el Marjalet. Así no debemos olvidar que al menos otros tres lugares (Vilavella, Torrasa y Vinarragell), que se encuentran relativamente alejados del camino principal, también deberían estar comunicados con el.

Con el análisis actual de las fuentes podemos además plantear otra hipótesis que explicaría la proximidad entre Ad Noulas y Spelaco. En primer lugar descartamos que exista una gran diferencia cronológica entre estos enclaves, ya que los vasos de Vicarello son estilística y arqueológicamente un conjunto homogéneo. Si nos atenemos a que la relativa cercanía entre ambos puntos se debe a la existencia de un obstáculo geográfico, como sería el cauce del río Mijares, es posible que la distancia lineal entre ambas siguiendo el camino no fuera exactamente de 2 millas, sino más bien que se utilizaran dos caminos distintos para llegar al Mijares, uno por la citada vía Augusta y otro por una variante cercana al interior y a sus yacimientos. Ya citamos en otro punto de esta tesis que existen pruebas en las fuentes de que los romanos realizaban desvíos en la carreteras antiguas para mejorar su trazado o adecuarlo a sus necesidades, por lo que podríamos pensar que la antigua vía Heraclea sería la que estaría más hacia el interior, por su proximidad a los yacimientos Ibéricos y del Bronce conocidos (Vilavella, Sant Antoni, La Punta, Torrelló), mientras que en la época de Augusto se introdujo una variante más cercana a la costa y a los asentamientos romanos (Palau, Sant Gregori, La Regenta/Carabona, Benicató, L'Alqueria de Moncofar), pero que no implicaba la destrucción o inutilización del trazado anterior, ya que seguían en uso, por ejemplo, la Vilavella y la Torrassa (ver Láminas 느, ㄴII, ㄴIII,

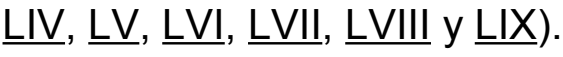

Si nos centramos en el aspecto urbano, realizando un análisis interpretativo del paleourbanismo de la ciudad de Sagunto, en primer lugar suprimimos toda aquella construcción claramente medieval y posmedieval (construcciones adosadas a muralla, sobre el foso rellenado, ábsides de iglesia, etc.) y de la misma forma también eliminamos todas aquellas calles y manzanas creadas por saturación del espacio disponible o para dar accesos al interior de antiguas manzanas de casas multidivididas.

Finalmente señalamos un espacio dedicado a elementos monumentales ya conocidos como el templo de Diana, los acueductos, el teatro y su posible pórtico detrás del escenario (ver las improntas del mismo en las fotos 182, 183, 184, 185 y $\underline{186}$ ) y edificios religiosos singulares; suprimiendo las estructuras adosadas, ya que estos predios públicos o infraestructuras no permitían este tipo de obras. También 
remarcamos los inmuebles conocidos hoy en día como edificios religiosos de época medieval que podían ser la pervivencia de otros similares; a todas estas zonas aplicamos el mismo sistema de interpretación para intentar suprimir todos los añadidos urbanísticos fácilmente detectables; y no solamente eso, ya que a los edificios romanos hemos añadido superficie, como el teatro o el conocido como templo de Diana, según las plantas conocidas para otros edificios similares a lo largo del imperio.

La interpretación de este urbanismo es algo compleja; en primer lugar es difícil analizarlo sobre la trama urbana actual ya que por ella han pasado prácticamente 2000 años y lógicamente es imposible identificar los restos que permanecen en el subsuelo, por lo cual tenemos dos puntos claros: por un lado ubicamos los restos excavados y por otro lado situamos la zonas donde podía haberse instalado preferentemente algún tipo de estructura.

También para el caso saguntino realizamos otro estudio del paleopaisaje, similar al realizado para la zona amurallada, para intentar determinar cómo se produjo esta expansión, con la premisa básica de la inexistencia de un trazado urbano preexistente saturado, como en el caso intramuros.

Pudimos constatar que existe una planificación global de esta ampliación por medio de la creación de una serie de grandes calles que coincidirían con las salidas preexistentes en el núcleo original de la ciudad. Estas sirven de ejes que se prolongan hasta llegar prácticamente el otro lado de río (y que aparecen fosilizadas en algunos de los caminos que hasta hace poco se conservaban, y que estaban documentados prácticamente desde el siglo XVII). Estas calles salen en ángulo recto desde la muralla.

Una vez obtenidas en Sagunto las orientaciones Norte-Sur, que acompañarían prácticamente todo el perímetro de la ciudad hasta llegar al trazado de la vía Augusta, se establecen otros ejes que corresponden a las manzanas que conformarían la retícula de insulae y que se desarrollarían paralelos al trazado de la muralla republicana o augústea. Sin duda fue muy importante el haberse documentado buena parte de una manzana en la excavación de la Morería, que sirve de eje y escala para esta restitución hipotética (ver Láminas $\underline{\mathrm{IX}}, \underline{\mathrm{X}}, \underline{\mathrm{XIV}}, \underline{\mathrm{XV}}, \underline{\mathrm{XVI}}, \underline{\mathrm{XVII}}, \underline{\mathrm{XX}}$ y $\underline{\mathrm{XXIII}}$ ) 


\section{QUINTA PARTE: CONCLUSIONES}




\section{CAPITULO 1: ANÁLISIS DEL URBANISMO}


Como base documental de este apartado seleccionamos en su momento diferentes intervenciones bajo nuestra dirección o codirección, representativas de la arqueología urbana de Sagunto, una de las ciudades más importantes de la Hispania Citerior. En el apartado correspondiente de esta tesis ya reprodujimos un resumen de los testimonios conocidos y publicados añadiéndole los datos inéditos y ahora realizaremos un estudio profundo y la reinterpretación de estos trabajos que serán la base del modelo general que pretendemos elaborar y que afectará a elementos como las necrópolis, el urbanismo, los edificios monumentales, etc.

Respecto al entramado urbano en Sagunto, por ejemplo, gracias los restos aparecidos en el ya citado solar de la Morería, podemos extrapolar los resultados de esta zona de la ciudad, al incluir en este análisis antiguas excavaciones que ahora podemos reinterpretar, como por ejemplo:

- Supuesto monumento funerario del colegio Romeu

- Circo romano

- Vía Augusta

- Muralla

- Monumento funerario de los Sergii

Las semejanzas locales entre los datos arqueológicos recuperados en Sagunto y Valencia son bastante evidentes, pero además es bastante fácil encontrar paralelos con otros asentamientos y acontecimientos históricos del Imperio romano sobre la base de estos ejemplos prácticos ya resumidos en otros capítulos de esta tesis. 


\subsection{EVOLUCIÓN HISTÓRICA}

En primer lugar presentaremos un breve resumen del desarrollo histórico de Sagunto. Esta evolución alcanzará hasta nuestros días, porque vamos a ser coherentes con lo expuesto en la primera parte de esta investigación, donde señalamos la importancia de conocer, aunque sea brevemente la evolución diacrónica hasta la actualidad para poder entender los contextos arqueológicos.

\section{EVOLUCIÓN HISTÓRICA DE SAGUNTO}

Para sintetizar los datos conocidos sobre la Arqueología y la Historia Antigua hasta el momento, resumiremos una interesante síntesis sobre la historia de Sagunto, sin entrar a analizarla por el momento: "El poblamiento ibérico estuvo instalado desde el siglo $\mathrm{V}$ a. C. en el sector occidental del Cerro del Castillo, en una privilegiada posición estratégica, dominando un cruce de caminos, tanto la vía Heraclea o vía Augusta que recorre el litoral como el camino que penetra hacia el interior (...) Las acuñaciones monetales de plata en el siglo III a C. tienen el topónimo de Arse. (...) La ciudad pasa a denominarse Saguntum. La intervención urbanística subsiguiente a la II Guerra Púnica se ciñe a la cima al este del Cerro del Castillo. (...) La planificación urbana, en el siglo I a. C. a raíz de la concesión del rango de municipium por Augusto, contempla que el foro y el teatro, situados en las terrazas superior e intermedia, guarden una relación axial que se prolonga al resto del trazado, determinando el punto donde se construye el puente romano sobre el río Palancia. Los hallazgos epigráficos nos muestran (...) un cinturón que rodea por su lado nororiental la ciudad, señalando un área de necrópolis. El puerto de la ciudad -Grau Vell- (...) confirman su ocupación desde el siglo V a. C. hasta el siglo $V d$. C. (...) Síntoma de la decadencia de la ciudad en el siglo VI d. C., fue la pérdida de su nombre y la aparición de la denominación de Murviedro (murus veteris)" (HERNÁNDEZ, 1998:22)

Sobre la evolución jurídica de la ciudad sólo conocemos la fecha ante quem del 75 a. C., de sus acuñaciones monetales con la mención de los ediles de la colonia (RIPOLLÉS y VELAZA, 2002), lo que implica un estatuto jurídico de colonia latina, y el 
56 a. C. donde aparece como ciudad federada en un discurso de Cicerón (Pro Balbo IX, 23), así como referencias a la municipalización de Sagunto (Plinio Nat. III, 3, 20) que, de acuerdo con la epigrafía local (CIL II, 2. 14, 305), estaba cumplida en los años 4-3 a. C. y fue probablemente consecuencia de la política establecida por Augusto en la segunda de sus estancias en Tarraco, hacia los años 15-12 a. C.

Las excavaciones en el solar del foro y en la plaza de armas del castillo remontan la historia al inicio del siglo II a. C., cuando tuvo lugar con la intervención romana la reconstrucción de la ciudad destruida por los cartagineses (ARANEGUI, 2004). Aquí queremos matizar que existe una evidente dificultad en al análisis de los restos, pues a la falta de rigor de muchas excavaciones antiguas, y a la ausencia de documentación conservada tenemos que añadir que los restos excavados fueron violentamente bombardeados durante la guerra civil de 1936 (MELCHOR, 2008). La unión de los ejes del foro y el teatro proyectados hacia la ciudad crearía un eje con orientación N-S o kardo que incluye el puente frente al circo; el eje formado por la conexión de los accesos a la población, como las Puertas Ferrissa y de Teruel, la recorre en sentido EW y formaría el decumanus. El punto donde confluirían ambos ejes se sitúa actualmente junto a la ermita de San Miguel, en la calle Mayor (ARANEGUI, 2004).

A lo largo de la década de los 80 del siglo XX la interpretación del urbanismo de Sagunto distaba mucho de la actual; C. Aranegui y M. Olcina, por ejemplo, dividen la ciudad de Sagunto en una serie de zonas topográficas:(...) dos áreas diferenciadas, una alta a 170 de altura, monumental, sede de la ocupación más antigua, y otra en la ladera que se extiende hacia el río Palancia (...). Existe una polémica sobre la coincidencia del recinto amurallado medieval y del romano (ARANEGUI y OLCINA, 1983:114).

Estos mismos autores trazan un eje que coincide con el arranque de la subida al castillo que delimitaría 2 áreas en el casco antiguo de la ciudad. En consecuencia piensan que la discontinuidad expresada por los viales urbanos es el resultado de una evolución de la ciudad y que un sector septentrional estuvo ceñido por una muralla más antigua que la medieval, tal vez, del Alto Imperio. Por lo que se refiere al área histórica extramuros mencionan la problemática del acceso de la vía Augusta a la ciudad, donde tres puentes se disputaban su asociación a la citada senda, inmersa en contradicciones como, por ejemplo, respecto a la presencia/ausencia de necrópolis en la zona del circo. Uno de esos puentes era el que estaba frente al circo (que según ellos sería anterior a la construcción del mismo en el siglo II d. C., pues su implantación cortaría esta senda); otro es el que se estaba frente a la puerta Mitjana y el último, más al Oeste, el que enlazaba con la carretera de Teruel: (...) una concentración de inscripciones (...) entre el cierre septentrional de la muralla y el circo romano constituye otra zona de necrópolis a largo de la vía (Cami Real) (...) del circo, no parece que su implantación ocupe terrenos que antes hubieran estado destinados a necrópolis porqué tampoco 
hay en las proximidades del circo vestigios funerarios (ARANEGUI y OLCINA, 1983:116).

El error se mantiene al creer que Sagunto fue una pequeña ciudad (antes de conocer la gran ampliación del II d. C. que hemos señalado) e intentar justificar una evolución particular (ARANEGUI, 2004) que singularizó su historia, cuando en verdad se trata de una historia absolutamente imbricada en el progreso general del Imperio.

Siguieron esta línea interpretativa las excavaciones realizadas en la plaza de la Morería en los años 90, citada por los autores como "del Romeu", lo que llevó a que el análisis de los restos fuera muy parcial, limitándose a identificar los elementos de dos domus de época imperial, de las que sólo se publicó la domus $A$, con restos correspondientes a la zona doméstica. Según la interpretación de los arqueólogos se habían identificado los siguientes ambientes: patio con salida a la calle, un almacén o granero, otro patio, la cocina y una dependencia en la parte noble de la domus (CHINER y LÓPEZ, 1994).

El material numismático que se analiza se centra básicamente en el depósito monetal que apareció en 1993 en la estancia E (RIPOLLES y LLORENS, 2002). Los investigadores piensan que su pérdida fue consecuencia de la destrucción del lugar en el que se encontraba y debió producirse muy poco después de la fecha de acuñación del sestercio de Balbino en el año 238 d. C., la cual atiende a criterios de desgaste. Apuntan a la pervivencia de monedas acuñadas con anterioridad al año 193 d. C. y que se encontraban en circulación y fue tesaurizado en la década de los años $240 \mathrm{~d}$. C. El numerario disperso aparecido en la estancia $\mathrm{E}$ y en la cloaca se fechan en el siglo I y el II d. C., si bien la cerámica sugiere una cronología del siglo III d. C. Los autores señalan que las piezas poseen un elevado desgaste bastante similar a las presentes en el depósito, con lo cual suponen que estuvieron en circulación hasta el momento de su pérdida, que por su conservación y por la datación de las cerámicas es posible acomodar en la misma época cronológica. Estos depósitos, aunque no se relacionan con un único periodo de inseguridad como las supuestas invasiones germánicas, sí las sitúan en un contexto de inestabilidad política y social (RIPOLLES y LLORENS, 2002).

El depósito de sestercios saguntino y el resto de los hallazgos comentados atestiguarían que en las décadas de los años 240 y 250 d. C. las monedas en circulación podían llegar a tener una vida media de unos 75 años. El hecho de que los radiados de vellón no formen parte de la composición del tesoro de Romeu indicaría que cuando se ocultó todavía no se acuñaban, por lo que su datación se fundamenta en un momento próximo a la fecha más moderna (LLORENS y RIPOLLES, 1998).

Los restantes hallazgos monetarios provienen de las estructuras conocidas como domus $\mathrm{A}$ y domus $\mathrm{B}$. Ambas se abandonarían en época del Bajo Imperio en un momento que se ha situado entre final del siglo III d. C. y la primera mitad del IV d. C. Llama la atención a los autores el contraste entre estos hallazgos aislados, 
concentrados en los dos primeros siglos de nuestra era, y el monetal del siglo III d. C., que no cuenta más que con una pieza de este mismo siglo, que justifican con una prolongada circulación de las piezas de los siglos I y II d. C. (CHINER, LÓPEZ y GOZALVES, 1998) Esta hipótesis debe ser descartada, ya que los autores desconocían la existencia de la necrópolis infrapuesta, fuente mayoritaria de esas monedas. El depósito del Romeu, según las citadas autoras, está formado en un $73 \%$ del mismo por piezas acuñadas antes del año 193 d. C. (LLORENS y RIPOLLES, 1998); a todos estos datos añaden la ausencia de ejemplares del siglo IV d. C., apuntan que las monedas con esta cronología son especialmente numerosas en cualquier lugar que haya permanecido ocupado y activo durante este siglo y su total ausencia entre los hallazgos del Romeu les sugiere un abandono del lugar con anterioridad a que comenzase la producción masiva de éstas. Así se inclinan a pensar que el material numismático recuperado apunta el cese de actividad de ambas domus romanas en algún momento del siglo III d. C. Piensan incluso que la pérdida del depósito monetal, cuyo ejemplar más reciente es del 238 d. C., es una prueba que apunta en la misma dirección, aunque con algún tipo de ocupación en la $2^{\mathrm{a}}$ mitad del siglo III y durante los años iniciales del siglo IV, y no creen que ésta se prolongase más allá del primer cuarto de este último (CHINER, LÓPEZ y GOZALBEZ 1998).

Como podemos comprobar este tipo de interpretaciones ocasionan cierta confusión acerca de los momentos finales del imperio romano en Sagunto. En época visigoda la urbe debería revestir cierta importancia y de hecho se acuña moneda de oro en la localidad en la época del rey Sisebuto (siglo VII), aunque los restos de este periodo son muy escasos. Alrededor el siglo VIII, cae bajo el dominio árabe. A partir de entonces el topónimo Saguntum cambia a Morbiter, que más tarde se denominará Murviedro en castellano y Morvedre en valenciano. En época musulmana conoce un nuevo esplendor y como resultado se construyen baños, palacios, una mezquita y escuelas. El centro edilicio, comercial y religioso, como evolución del antiguo foro, se sitúa en la plaza Mayor. Como en la antigüedad, el castillo jugó un papel decisivo en el control del camino costero (antigua vía Augusta), que conexionaba todo el territorio.

En el año 1098 fue ocupada por El Cid; la conquista cristiana definitiva se produjo en 1238 con Jaime I. Durante la época Moderna y Contemporánea sufrió duros ataques durante las guerras de las germanías, de sucesión (1701-1714), de la invasión francesa (1808-1814) y las carlistas (1833) (AA. VV., 1977). 


\subsection{ANTECEDENTES Y PRIMER ASENTAMIENTO URBANO ROMANO}

El momento inicial de la ocupación romana de Sagunto debemos ubicarlo en un contexto general de la Península Ibérica con la fundación de los primeros asentamientos de cierta entidad después de la victoria en la segunda guerra púnica.

En el caso saguntino, la implantación de una necrópolis romana en la zona llana más próxima al río Palancia se produce sobre una serie de restos de estructuras (ver Fotos $\underline{305}, \underline{306}, \underline{307}$ y $\underline{309}$ ) y abundantes materiales iberos (MARIN, 2005), que indicarían un hábitat de pie de monte, posiblemente dedicado preferentemente a actividades agropecuarias, favorecidas por ser una zona llana regada por el río y por tratarse de un espacio abrigado por la propia montaña.

De la misma forma Valencia tiene una serie de características geoestratégicas (junto a la existencia de un cauce fluvial que permite acceso al trafico marítimo y facilita la defensa del enclave) que apuntan a una creación romana con evidentes intereses de control de una población indígena, avaladas por abundantes restos ibéricos recuperados allí, lo que sin duda aporta importantes matices a un teoría simplista de fundación en el 138 a. C. sin relación con una población preexistente. M. Tarradell sentó las bases de la teoría al ser de los primeros en ir en contra de un asentamiento ibérico, apuntando que aparecía cerámica campaniense con la ibérica y que gran parte de la vajilla ibérica es posterior a la conquista, y afirmando también que los iberos nunca se instalan en zonas llanas y pantanosas; no acaba de descartar la existencia de una hábitat del Bronce, pero afirma que sería de poca entidad, tanto por la escasez de los hallazgos encontrados en una sola excavación, que además era la única que había llegado a esta profundidad, como por haber una discontinuidad, al existir un nivel de metro y medio estéril entre los restos ibéricos y los del Bronce. También establece la teoría de la isla fluvial y defiende la fundación de la ciudad por Junio Bruto, apuntando a una segunda fundación en época de Sertorio (esos serían los veteres, frente a los 
veterani de Bruto que aparecen en una inscripción valenciana). Finalmente interpreta erróneamente que Sagunto era superior a Valencia, pero que fue destruida en el siglo III y no se recuperó, pasando la primacía a ésta (TARRADELL, 1962).

Evidentemente todos estos argumentos actualmente ya se encuentran desfasados, pero siguen siendo la base de teorías que hoy en día ya pueden ser rebatidas. Sin embargo el mismo autor hace interesantes referencias sobre que entre las tumbas de la Boatella aparecen materiales reutilizados (TARRADELL, 1962), pero pensamos que más bien es la ruptura del siglo II d. C., ya documentada y explicada en esta tesis, la que le induce a errores en su interpretación de estos materiales.

No es éste el momento de volver a entrar en un tema bastante conocido como es la distinta clasificación de los asentamientos romanos (ver referencias a ejemplos portugueses y franceses en el apartado de antecedentes de esta tesis) según su entidad y finalidad, como los campamentos, praesidia, ciudades de veteranos, etc., pero dentro de ellos no podemos olvidar que en el caso de Sagunto los ocupantes itálicos se encuentran con una potente ciudad, que a pesar de su carácter de aliado tiene un importantísimo valor estratégico que es necesario dominar. En el caso de Valencia el valor podría venir por el control de las rutas de acceso desde la costa hacia la zona edetana en el interior y por su posible condición de punto de comercio costero (situación que, a menor escala, veremos repetida y documentada en el eje BurrianaBetxi-La Vall d'Uixó-Onda).

En Sagunto podemos aventurar un probable asentamiento en el castillo, que podría ser de tipo praesidium, con la finalidad de mantener una guarnición que controle y proteja la ciudad, pero poco más podemos saber de aquella época ya que los restos excavados son escasos. El caso de la Morería parece indicar que la zona inmediata de aprovechamiento de época ibérica y de la posterior ciudad republicana se encontraba en la zona llana, bajo el castillo, como atestigua la nutrida presencia de cerámica, monedas y algunas estructuras que se encuentran bajo la necrópolis Tardo republicana y del Alto Imperio. Aunque las evidencias no son de suficiente entidad, podemos suponer que esa explotación podía ser de carácter agropecuario, debido a la propia morfología del terreno y a que nos encontramos ante estructuras de grandes dimensiones similares a almacenes, corrales o grandes habitaciones; sin embargo, éste es un punto que debe aclarar la arqueología en el futuro. Esto permitiría suponer que en época Iberoromana la ciudad se encontraría en la falda de la montaña.

Para la Valencia republicana los escasos restos detectados al otro lado del río podrían apuntar también a una zona de explotación agropecuaria, en este caso ubicada alrededor de la calle de Sagunto, emplazamiento aproximado de la vía Augusta en su acercamiento a la ciudad, a la que podían también estar asociados los recientes hallazgos de este periodo detectados en las excavaciones de la calle Ruaya. 
Los marcadores de la extensión de la urbe saguntina tardo-republicana y de los primeros momentos del Imperio son bastante evidente, ya que las necrópolis y las calzadas de su entorno (como el ejemplo de la foto $\underline{344}$ ) nos llevan a una delimitación muy clara de un espacio amurallado alrededor de la montaña, estructura defensiva imprescindible, ya que el verdadero periodo de estabilidad social y política, sumada a la supremacía total sobre el Mediterráneo, no llegaría hasta el final del siglo I a. C. Hoy por hoy no existe otra posibilidad para la ubicación de esta cerca militar que un trazado muy similar al de la actual muralla medieval. Respecto a su construcción es difícil concretar una fecha, pero podemos aportar la inscripción de final de época republicana que hace referencia a la restauración de las murallas y de los torreones (CORELL, 2002, IRSAT, 82), y que pensamos se referiría a los que defenderían la ciudad baja y no a los del castillo, quizá menos operativos. A falta de estudios más detallados nos es imposible fechar con exactitud la muralla de la ciudad, pero es evidente que tendría funcionalidad entre el siglo II a. C. y el I d. C. Algunos autores comparten la opinión de que la cerca medieval se superpone a una romana; por ejemplo I. Pascual, que fecha la torre estudiada por él en la calle Camí Real por el tipo y la calidad de la obra en época del Bajo Imperio, asociada a la inestabilidad del siglo III d. C., dentro de un proceso global de reestructuración defensiva que sufren muchas ciudades. La estructura citada forma una especie de podio o basamento únicamente trabajado y visible por su cara externa almohadillada, la parte interna de los muros no queda uniforme y el interior de la estructura se rellena alternando capas de piedras con tierra y mortero (PASCUAL, 1991). Recordemos que restos de esta estructura aparecieron en el relleno de fosas de saqueo tardoantiguas en la Morería y en cimentaciones medievales (ver Fotos $\underline{517}$ y 518). También queremos destacar que hemos encontrado ejemplos de estas torres (construidas en aparejo idéntico) en algunas murallas romanas, concretamente en las puertas (ver Fotos $\underline{399}, \underline{400}$ y $\underline{406}$ ). El autor contextualiza esta estructura así: (...) una línea de muralla situada entre la calle Mayor que haría de ronda interior y la calle Camí Real que sería la ronda exterior ${ }^{26}$, a partir de la cual se extendería el área de necrópolis $y$ de villae suburbanas (...) Chabret describe la calle Cami Real (...) en el número 60 de esta calle, una gran torre cuadrada que defiende el recinto y a continuación un trozo del muro romano con base de sillares de mediano aparejo, lo que coincide grosso modo con la estructura menor que ahora nos aparece (PASCUAL, 1991:129).

Algunas citas de A. Chabret aportan descripciones interesantes sobre la muralla; para este autor está muy claro que árabes y cristianos siguieron el mismo trazado que sus antecesores romanos (como en otros ejemplos - ver Fotos $412, \underline{413}$ y $\underline{471}$ ), y al describir la calle Muralla cita junto a la cerca defensiva medieval la existencia de torres cuadradas y restos constructivos de época romana posteriormente reutilizados. Los textos del cronista arrojan mucha luz en este punto, ya que él aún pudo contemplar abundantes restos de las torres defensivas que circunvalaban la ciudad y que, según el autor, conservaban al menos la base de época romana. En la puerta Ferrisa, por

\footnotetext{
${ }^{26}$ Este concepto de doble muralla ya lo reflejaban autores del siglo XIX (GARZA, 1877: s. p.)
} 
ejemplo, describe una de las dos torres que la flanqueaban, como una torre cuadrada, con la base y ángulos de sillería y rellena de tierra; esta puerta desapareció debido a los bombardeos de la guerra civil de 1936 (MELCHOR, 2008). Describe también la puerta de Teruel y la base de una de sus torres de grandes sillares bien labrados y la torre de la calle Vitoria (hoy $\mathrm{Na}$ Marcena), cuyo zócalo se fundamenta en grandes bloques en aparejo semejante a opus quadratum. La torre del Hospital, en el ángulo noroccidental de la fortificación, es definida por A. Chabret como enteramente romana, de base cuadrada, construida hasta un tercio de su altura con enormes sillares de labrado regular y el resto de durísimo hormigón (CHABRET, 1888).

Recordemos que las puertas de las cercas romanas (ver Dibujos $\underline{43}$ y $\underline{44}$ ) son de doble lienzo (ver Fotos $\underline{326}, \underline{398}, \underline{401}$ y $\underline{402}$ ) flanqueado por torres para los accesos principales (ver Fotos $\underline{180}$, $\underline{395}$ y $\underline{396}$ ) aunque contaran con puertas monumentales (ver Fotos $\underline{397}, \underline{410}, \underline{411}$ y $\underline{528}$ ), sin olvidar otros accesos mas modestos (ver Fotos 178 y 278). Pero no solamente eso, se trataba además de un complejo defensivo importante al que debemos sumar el foso y un importante pasillo interior (ver Fotos $\underline{400}, \underline{405}$ y 412), similar a lo que posteriormente sería la barbacana en las tapias árabes, con torres adosadas (ver Foto 407 ). También debemos tener en cuenta que existen tramos del lienzo defensivo en la calle muro de Santa Ana que, como mínimo, cuentan con materiales claramente romanos (ver Foto $\underline{394}$ ).

Sin embargo pensamos que la muralla, construida en sus cimientos, portales y torres con elementos de sillería, podría ser de construcción distinta a lo largo de su lienzo, como por ejemplo anchos muros con rellenos (ver Fotos $\underline{403}$ y $\underline{404}$ ). Una vez perdida su función militar fue englobada en la trama urbana (un paralelo lo tendríamos en el Dibujo 42 y las Fotos 181 y $\underline{408}$ ). Las posteriores reformas para su recuperación en época visigoda y después en época medieval influyeron no solamente en el derribo de estructuras adosadas, sino también en la recuperación del foso y de parte del muro, con la aportación de elementos reutilizados (ver un prototipo en la Foto 413 ). Pero además esta reedificación exigiría la anulación o destrucción de parte de la trama urbana y la creación de puertas para dar salida a calles (ver Foto $\underline{116}$ ).

En el caso saguntino, solamente los restos de torres, huellas de saqueo, orientaciones de calles romanas y restos inéditos ya señalados (ver Fotos $\underline{409}$ y $\underline{415}$ ) son los débiles indicios que tenemos para intentar interpretar la muralla romana. Respecto a la de Valencia, podemos conjeturar que una pequeña parte de la muralla republicana podría también coincidir con la traza de la musulmana o de la visigoda, pero la escasez de los hallazgos no nos permite avanzar en esta línea. 


\subsection{EL PRINCIPIO DEL IMPERIO Y LAS REFORMAS AUGÚSTEAS}

La ciudad de Sagunto en época augústea presenta algunas características formales que nos permiten un análisis espacial mediante el paleourbanismo, concretamente del espacio intramuros hasta final del siglo I o principio del II d. C. El principal punto es la creación en época de Augusto de un eje monumental (ver Láminas XII y XIII), desde el foro Imperial en el castillo, pasando por el teatro y llegando a un gran espacio ocupado por al menos tres grandes estructuras (el llamado templo de Diana, iglesias de Santa María y de la Sangre Nueva). Esto sin contar la coincidencia entre calles interiores y exteriores, lo que podría indicar la presencia de puertas en la muralla (buena parte de ellas se fosilizaría en el parcelario posterior, con algunas variaciones ${ }^{27}$ ). Respecto a los viales, la pendiente de la ciudad en aquella época condicionaría el trafico rodado, ya que éste era impracticable en las sendas de pronunciado desnivel; podemos apuntar abundantes ejemplos a lo largo del imperio sobre este tipo de arterias estrechas con elevada pendiente que no están preparadas para la travesía de carros (ver Fotos $\underline{67}$, $\underline{68}, \underline{69}, \underline{70}, \underline{71}, \underline{73}$ y $\underline{75}$ ) con la consecuente adaptación de las viviendas (ver Fotos $\underline{74}$, $\underline{87}, \underline{89}, \underline{90}$ y $\underline{392}$ ). Sin embargo los ejes paralelos a la curvas de nivel se adaptan a suaves inclinaciones y a pasos más anchos para los vehículos (ver Fotos $\underline{50}, \underline{52}$ y $\underline{91}$ ). Nosotros nos limitamos a aplicar estos conocimientos a la topografía saguntina. El foro de carácter imperial en la cima del castillo es un hecho consolidado; lo que sí es evidente es que es un punto inviable como centro comercial o municipal y que la ciudad necesita imperativamente un espacio de estas características, fácilmente accesible pero aún intramuros. Es impensable que una ciudad de la entidad de Sagunto no contara con el conjunto formado por foro comercial, teatro, anfiteatro y circo, junto a una importante red de acueductos. Todos ellos son una realidad indisoluble con la cultura romana existente en todas las urbes destacadas del Imperio.

Tras los resultados del análisis podemos concluir que existe un importante espacio que respondería al foro de la localidad, el cual tenemos situado en un eje claro respecto al teatro. Asociado a él existe un gran edificio que posteriormente fue mezquita y templo de Santa María (ver Fotos $\underline{456}$ y $\underline{457}$ ); junto al mismo y en posición ligeramente más elevada hay un gran podio (ver Foto 458 ) -el llamado templo de Diana - (ARANEGUI, 1983) cuya función aún no está clara, pero es evidente su ubicación intramuros

\footnotetext{
${ }^{27}$ Un ejemplo sería el paso de los portales romanos de doble hoja a los retranqueados o con plaza posterior típicos del medioevo. 
(descartamos su función defensiva, ya que no forma parte de ningún eje paleourbano que pudiera indicar la presencia de una muralla). Por su situación junto a uno de los acueductos más antiguos de la ciudad y su configuración (se reutilizó su interior hueco como cisterna; CHABRET, 1898) nos encontraríamos ante un castellum aquae. Recordemos que los castella tenían tres grandes compartimentos internos (que recuerdan aljibes y que en algunos casos son reutilizados en época medieval como tal - ver Foto 463) y que sin embargo los podios de los templos normalmente en gran parte están rellenados, y vaciarlos para crear una cisterna es, sin duda, un trabajo encomiable. También podemos observar que en su parte superior se realizaron reformas (ver Lámina XLVIII); sobre el sillar almohadillado de la base tenemos un muro de opus africanum y si suponemos que la época de esta obra es la misma que para otras encontradas en la urbe, donde esta técnica constructiva se documenta con mayor intensidad, podemos pensar que se trata de una estructura hidráulica reformada a partir del siglo III d. C. Por otro lado su reconstrucción volumétrica como templo indicaría una altura y ubicación de podio difícil de compaginar con un acceso hacia el foro.

Es evidente que el poco espacio disponible en la población obligaría a que tanto el anfiteatro como el circo se encontraran en las afueras, lo que también coincide con la ubicación habitual en la mayoría de las ciudades, sin duda buscando la facilidad de acceso y de evacuación sin tener que cruzar la urbe. No tenemos evidencias que señalen una ubicación anterior al siglo II d. C. pues los restos conservados debemos situarlos en este período avanzado de monumentalización (PASCUAL, 1998), por lo que no descartamos que en un primer momento estos edificios hayan sido construidos parcialmente con materiales perecederos, como ya se hacía en otros lugares del Imperio (madera, adobe, tapial de tierra, etc. - ver Dibujo $\underline{26}$ ).

La situación del teatro tiene paralelos en el resto del imperio, como por ejemplo en Córdoba donde su construcción podría fecharse entre final de época augústea y mediado el siglo I d. C. y su abandono a final del siglo III o principio del IV d. C. a favor del circo y del anfiteatro (VENTURA, 1996); ello podría compararse con Sagunto, donde se impulsó una monumentalización de estos dos edificios en el siglo II d. C., en detrimento del teatro que contaría con menos público y acceso mas difícil. La gran reforma augústea saguntina monumentalizaría el foro imperial del castillo y crearía un espacio a modo de foro comercial o municipal dentro la ciudad, añadiendo a ésta una serie de edificios de espectáculos y construyendo o reformando infraestructuras, como pueden ser el acueducto y la propia muralla.

En el caso de Valencia, también se documentan importantes transformaciones (RIBERA, 1989), que alcanzarían las estructuras existentes al otro lado del río Turia (LLORENS et al., 1999) y se acondicionaría la necrópolis de la vía Augusta al Sur de la ciudad (SEGUÍ et al., 2003 y BENEDITO et al., 2007). 


\subsection{EL MUNDO FUNERARIO}

El ámbito de las necrópolis saguntinas es más fácil de ubicar en el sentido espacial que en el cronológico, pues el escaso número de enterramientos excavados con metodología científica impide situar los límites temporales de las mismas. Podemos pensar que desde el primer momento republicano hasta final del siglo I d. C. junto al Palancia hubo un área funeraria, y que ese uso sólo pervivió en la zona de ferrocarril, abriéndose nuevos espacios al otro lado del río hacia el siglo II d. C. Antes de entrar en la tipología de tumbas (ver Lámina XXXVI y XXXVII), queremos decir que la zona de la necrópolis de la Morería cumple a rajatabla los cánones de un espacio cementerial romano, donde se respeta el derecho de paso, la vía cuenta con una amplia acera (podemos observar paralelos en las Fotos $\underline{98}, \underline{337}$ y $\underline{339}$ ) y en los edificios adosados en casi todos los casos no existen puertas de acceso y no comparten medianera (ver Foto 338 ), señal evidente de que, aunque se trate de una misma propiedad, se construyen en un momento distinto (un ejemplo evidente también lo encontramos bajo el circo saguntino - ver Foto 241). Ésta sería una evidencia de que no se trata de la misma posesión, ya que la legislación obligaba a una separación:

(Dig. 10, 2,13) Si alguien fijara (...) junto a un fundo ajeno (...) una cerca, deje un pie; si un edificio dos pies; si cavare un foso o un hoyo deje tanto espacio como profundidad; si un pozo, un paso (...)

\section{EL USTRINUM MONUMENTAL}

La única tumba monumental encontrada en la zona de la Morería se conserva dentro del templo 1 y es el denominado "edificio funerario B" en la bibliografía. Se trata de un gran recinto, con un pavimento del que sólo resta el preparado de mortero (ver Fotos $\underline{357}$ y 418 ), delimitado por una serie de pequeños loculi (en una de ellas apareció en posición central el cuello de una ánfora Maña C2 en posición invertida, quizá con función ritual - Foto 358 ). En el centro del mismo hay dos habitáculos enlucidos en mortero blanco (ver Fotos $\underline{353}$ y $\underline{354}$ ) sin ningún acceso (un paralelo lo tendríamos en el dibujo 41) y al norte de cada uno de ellos encontramos una gran piedra de rodeno 
hincada verticalmente y rodeada de signinum; en el caso del edículo Este el elemento pétreo era rojo y el pavimento estaba pintado del mismo color (ver Foto 352). Sin embargo, la piedra situada al Oeste era más clara (ver Foto $\underline{351}$ ) y el piso era blanquecino (destacamos que durante el proceso de rellenado del podio del templo los altares de rodeno fueron enrasados hasta la altura necesaria, conservándose al pie de los mismos los restos arrancados - Foto 350). Algunos ejemplos de estructuras centrales, especialmente en tumbas de gran tamaño, aparecen a lo largo del mundo romano (ver Foto 333 y Dibujo $\underline{40}$ ), a lo que también debemos sumar la presencia de aras pétreas muy similares a las saguntinas (ver Fotos $\underline{327}, \underline{328}$ y $\underline{329}$ ).

Los datos disponibles hasta el momento indican que en el interior los restos humanos incinerados carecen de entidad y están asociados a fragmentos de marfil, clavos, ungüentarios y fauna. Concretamente en el edículo Este se apreciaron abundantes clavos mezclados con fauna y los restos de un varón maduro (UE 1229); en el edículo Oeste la fosa UE 1430 contenía los restos de un probable hombre adulto (sin fauna asociada) y su vecina, la UE 1432, contenía los restos de otro varón desarrollado con fauna asociada (POLO y GARCIA, 2005); el tercer hoyo de forma circular era el que contenía el resto de las ofrendas (ciervo, ovicáprido y suido - UE 1407). Otra pista importante es que en la habitación Este se realizaron las hogueras mencionadas (ver Foto $\underline{356}$ ) con la estructura en pie, pero ésta se enlució posteriormente (ver Foto $\underline{355}$ ). El hecho de que en dos edículos posiblemente intactos solamente encontremos escasos fragmentos de incineraciones y de las ofrendas, nos hace pensar en un ustrinum monumental o un cenotafio (por la retirada de los restos principales para su posterior enterramiento) más que en un bustum, incluido en una gran tumba monumental, quizá de una importante familia, cuyos votos se depositaban en las pequeñas habitaciones exteriores.

Por los escasos materiales encontrados, básicamente fragmentos informes de cerámica común, itálica e ibérica, solamente apareció in situ el citado cuello de ánfora Mañá $\mathrm{C} 2$, pensamos que es una de las tumbas más antiguas, ya que nos movemos entre el siglo II / I a. C., lo que cuadraría con su disposición preferente respecto a la vía y la posición secundaria que ocupan muchos sepulcros de su entorno. También debemos tener en cuenta que los adobes enlucidos (ver Foto $\underline{349}$ ) atestiguan una limitación de medios, a pesar de la monumentalidad del edificio, y una técnica constructiva relativamente antigua que no aparece en los posteriores.

\section{LA TUMBA DEL PATER FAMILIAS}

Denominada en la bibliografía como edificio funerario $A$, está compuesto de tres departamentos diferenciados pero adosados, lo cual indica tres momentos constructivos y de uso; también pensamos que tiene un carácter familiar porque contiene varios enterramientos; la única incineración intacta excavada, perteneciente a una mujer adulta con su respectivo ajuar, entre el que se incluye un suido neonato y 
otro juvenil, un zorro joven, un ratón y un pez (edículo Norte - Fotos $\underline{369}$ y $\underline{370}$ ). El segundo enterramiento estaba muy arrasado, pero por los restos de las pertenencias podría ser de una mujer (edículo central - Foto 362). Finalmente el sepulcro más cercano a la ciudad (edículo Sur - Fotos $\underline{365}, \underline{367}$ y $\underline{368}$ ) es el más grande y tiene una ajuar mucho más rico. Éste fue enterrado con restos de dos zorros de corta edad, dos suidos neonatos y uno juvenil junto a restos de otros animales (sapo, rana, dorada, zorzal, conejo y gallo) todos casi enteros y depositados en una cista (UE 1157) donde aparecían mezclados escasos fragmentos de un humano adulto incinerado, junto a ésta había una fosa hemisférica llena de carbones y ceniza (UE 1041) con fragmentos de al menos 7 ungüentarios de vidrio, restos de cerámica de paredes finas, de ciervo joven y gallo y las escasas partes de un varón y una mujer, uno de ellos juvenil. Las dos anteriores estaban relacionadas con la fosa principal (UE 1119) donde se recuperaron trozos de al menos 5 ejemplares de cerámica de paredes finas ${ }^{28}$, clavos, restos de planchas de hierro, fauna representada por toro, suido adulto, cabra y ovicáprido, todo ello acompañaba a los restos de un adulto de sexo indeterminado (POLO et al., 2005). La similitud entre los ajuares nos hace pensar en la tumba del pater familias, donde además tenemos indicios del enterramiento con animales domésticos. En el mundo romano tenemos alguna referencia a la costumbre de sacrificar y enterrar con animales domésticos:

(...) El muchacho poseía muchos ponis de silla y de enganches, tenía también perros de todos los tamaños, tenía ruiseñores, papagayos y mirlos; a todos los sacrificó Régulo delante de la pira funeraria. (Plinio, Ep. XI, 201).

Curiosamente el paralelo estilístico y formal más exacto es un enterramiento de un hombre y dos mujeres en Roma (ver Fotos $\underline{335}$ y $\underline{36}$ ). Muy posiblemente frente al sepulcro saguntino existiera un ara, de la cual solamente resta la cimentación circular (ver Foto 361 ). Este panteón también es un claro ejemplo de cómo la superposición de las estructuras urbanas posteriores en el siglo II y después en el III d. C. respetó los enterramientos (espacio sacro) pero no las tumbas (posiblemente desacralizadas para permitir la construcción). El pavimento de las casas se sobreelevó (ver Foto $\underline{363}$ ) y bajo el signinum y el pavimento de guijarros se conservaron los enterramientos, de tal forma que sólo las zanjas y el saqueo de época visigoda y musulmana fueron los que destruyeron totalmente el enterramiento central y parte del situado al Sur.

\section{LA TUMBA CÚBICA O TURRIFORME}

Descrito como monumento funerario $D$, es evidente que su cimiento cuadrado serviría de soporte para una base cuadrangular maciza (ver Foto $\underline{375}$ ), pues no existe ningún

\footnotetext{
${ }^{28}$ Estos ejemplares procederían de la zona Norte de la Península y tendrían claras influencias de la producciones militares de la zona, siendo muy similares a la forma Mayet XXXIV (MELCHOR y BENEDITO, 2009).
} 
otro tipo de resto cercano asociable a esta estructura (muros de delimitación, accesos, etc.), únicamente el gran tabique adosado que marcaría la división entre espacios, aunque pensamos que se relaciona con los templos posteriores. La impronta circular subyacente sin duda son los restos del bustum (ver Foto $\underline{376}$ ) correspondiente a un varón, acompañado de fauna, clavos, cuenta de collar y restos metálicos de indumentaria (UE 1450). Un posible paralelo lo podemos tener en las Fotos $\underline{341}$ y $\underline{345}$.

\section{LA TUMBA DEL PEQUEÑO EDÍCULO}

Descrito como "monumento funerario C" conserva claramente las improntas de las paredes de adobe que delimitan un espacio cuadrangular, a modo de pequeña habitación, en el centro de la cual se encuentran los restos del bustum, que quizá tuviera otro edículo adosado (ver Fotos $\underline{359}$ y $\underline{360}$ ). El paralelo más aproximado podría ser el de la Foto $\underline{340}$. Un dato interesante sobre la extensión de este modelo en la zona es la lápida que actualmente se encuentra en el museo de Burriana (ver Imagen 51) y que fue encontrada en Les Alqueries en 1907 (ARASA, 2004); en verdad se trata de uno de los lados de un sarcófago de mármol reutilizado donde la inscripción funeraria se enmarca en la representación esquemática de una tumba similar a la citada aquí.

\section{LA TUMBA FAMILIAR O COLUMBARIO}

Descrito como monumento funerario $\mathrm{E}$, esta denominación se la aplicamos por la gran cantidad de fosas ubicadas en el mismo edículo (ver Foto $\underline{379}$ ) y por los restos de un gran recipiente donde se habían depositado carbones y cenizas (ver Foto 372 ) y que posteriormente fue amortizado por una reforma (ver Fotos $\underline{371}$ y $\underline{380}$ ). Junto al mismo se excavaron los restos arrasados de un posible bustum con huellas de rubefacción (ver Foto 373 ); esto, probablemente, indica un espacio delimitado donde se sepultaban los restos de distintos enterramientos o de ofrendas que quizá se depositaran a modo de columbario en ese edificio. El nivel de arrasamiento y el hecho de que hayan sido parcialmente excavados en 1994 no permiten una interpretación más fundamentada.

\section{OTROS RESTOS}

Los demás elementos asociables a estructuras funerarias se encontraban en un estado de conservación exiguo, si exceptuamos los restos que se aun quedan por descubrir dentro del podio del templo 2 (ver Fotos $\underline{383}$ y $\underline{384}$ ) ya que al realizar una zapata para la obra actual se ha detectado un muro, probablemente de opus incertum enlucido en muy buenas condiciones, enterrado dentro del podio del santuario, (de forma idéntica a lo documentado en el templo 1) y cuyos restos, correspondientes al arrasamiento de su parte superior, podrían ser los derrumbes detectados al exterior de la base del edificio religioso (ver Foto $\underline{366}$ ), de forma similar a lo sucedido a las aras del ustrinum monumental en el ya citado templo 1. 
La mayor parte de los enterramientos se habrían conservado bajo las moradas, una vez fueron desmanteladas las tumbas, y fueron separados de los pavimentos de las viviendas por un nivel de arrasamiento compuesto por abundante material cerámico y escasos elementos constructivos (ver Fotos $\underline{374}$ y $\underline{381}$ ), indicio probable de la reutilización masiva de los componentes de los sepulcros. Una vez retirado este estrato aparece una capa asociada a los enterramientos (ver Foto $\underline{377}$ ).

Pero la zona entre los dos templos que coincide con la parte más oriental del solar fue afectada por una gran fosa de saqueo, probablemente en época musulmana, lo que arrasó la mayor parte de los restos. A esto debemos sumar que el $50 \%$ de esta superficie fue excavada de forma incompleta en el año 1994, con lo que nos encontramos con indicios de muros de adobe o de piedra (ver Fotos $\underline{364}, \underline{378}$ y $\underline{382}$ ) que señalan restos de tumbas, pero que no permiten su restitución completa.

En Sagunto existiría una gran variedad de tipos de monumentos funerarios, algunos ni si siquiera documentados en intervenciones arqueológicas, pero cuyos restos sí existen, como las cupae (ver Foto 325 ), que posiblemente desaparecieron en gran cantidad por su fácil reutilización como sillar (el ejemplo paradigmático es la Alcazaba de Mérida), o los mausoleos que pueden ser confundidos con otras estructuras monumentales, como muros de sillares o restos del anfiteatro, y que en verdad podrían ser estructuras más sencillas (ver Fotos $\underline{331}, \underline{346}$ y $\underline{347}$ ). Dado el paralelismo cronológico entre la ocupación romana en Valencia y Sagunto, tampoco descartamos la existencia de hipogeos en ambas ciudades, aunque sólo lo documentamos en la primera (ver Foto $\underline{385}$, con paralelos en el resto del mundo romano - ver Foto $\underline{348}$ ).

En el caso de Valencia excavamos en dos puntos distintos donde existían necrópolis. Además es muy probable que ambos estuvieran en relación con la vía Augusta, en su lado Norte (calle de Serranos) y Sur (calle de San Vicente). En el primer caso lo exiguo de solar y el arrasamiento del mismo no permite afirmar con total seguridad que nos encontremos ante enterramientos en forma de hipogeos, pero pensamos que por sus características morfológicas y por la cronología general del yacimiento, que los haría remontar a época republicana, la hipótesis de unos enterramientos junto a la ruta terrestre prerromana que después pasaría a vía Augusta, merece ser tenida en cuenta. En la excavación de la calle de San Vicente detectamos la disposición longitudinal de la necrópolis, paralela a la vía Augusta, con un acondicionamiento del terreno que aislaría la zona de tumbas del exterior mediante zanjas y muros. Respecto a las sepulturas, los datos ya conocidos presentan unos rituales muy similares a los de Sagunto, respecto a enterramientos con animales y la convivencia entre inhumaciones e incineraciones (SEGUÍ et alii, 2003 y BENEDITO et alii, 2007). 


\subsection{LA GRAN REFORMA DEL SIGLO II}

Las transformación augústea perdura aproximadamente 100 años, ya que a final del siglo I o principio del II d. C se produce una de las etapa de más grandes reformas en las ciudades del Imperio, tenemos como ejemplo la cita de que Vespasiano había impulsado de forma destacada las obras a lo largo del Imperio, ya que "hizo reconstruir (en todo el Imperio), mas hermosas de lo que eran antes, gran numero de ciudades destruidas por terremotos (ver Foto $\underline{86}$ ) o incendios" (Suetonio, Vesp., XVII). Dentro de un contexto general de necesidad de obtención de suelo la ciudad de Sagunto se expande hacía la orilla del río Palancia, superponiéndose a todas las estructuras anteriores y anulando hasta algunas necrópolis.

La expansión urbana del siglo II d. C. también repercutió en la parte más antigua de la ciudad; por un lado dejaría de ser núcleo principal a nivel administrativo y económico y por otro sufriría una serie de reformas ${ }^{29}$, siendo la primordial la pérdida de función de las murallas. No descartamos que posiblemente una parte o la totalidad del foso fuera rellenado o canalizado para dar origen a una calle (actual calle Camí Real), con el adosamiento de casas a la citada estructura defensiva. Este tipo de actuación que sufre la localidad la encontramos reflejada en muchas ciudades de la Península Ibérica (por ejemplo: Tarragona, Cádiz, Mérida, Barcelona, Baelo Claudia, Sevilla, Itálica, Conimbriga, etc.) e Italia (Roma, Ostia, Rimini, etc.) según señalamos en el apartado gráfico y quizá también posiblemente en el resto del Imperio (GROS y TORELLI, 1992).

\subsubsection{Viales y puentes}

Dentro de los hallazgos de viales en el casco urbano de Sagunto, la calle documentada por nosotros en la plaza de la Morería (ver paralelos de la técnica constructiva en Dibujos $\underline{5}$ y $\underline{6}$ ) era sin duda un importante eje, entre una puerta de la muralla y el anfiteatro de la ciudad, que fue monumentalizada en el siglo II d. C. Constaba de unas

\footnotetext{
${ }^{29}$ Esta expansión también se reflejaría posiblemente en el Grau Vell y en el entorno inmediato de la ciudad (ARANEGUI, 2004).
} 
amplias aceras porticadas (ver Fotos 135 y 136 ) de las que podemos encontrar abundantes ejemplos (ver Fotos 102, 109, 120, 123, 124 y 128), algunos algo camuflados por intervenciones de restauración desafortunadas (ver Fotos $\underline{129}$ y $\underline{130}$ ). Una de las calles laterales la tenemos documentada en la excavación del año 1994 (ver Foto $\underline{147}$ y $\underline{473}$ ) y otra similar en la reciente excavación de la avenida del País Valenciano (ver Fotos 131 y 132); en el primer caso nos encontramos ante una pequeña calle con estrecha acera (ver Fotos $\underline{76}, \underline{77}, \underline{78}, \underline{80}, \underline{84}, \underline{88}, \underline{103}$ y $\underline{114}$ ) y en el segundo una angosta calle con carriladas y sin margen (ver Fotos $\underline{92}, 112,113$ y 121). Respecto a éstas queremos matizar algunas cuestiones; existe un cruce entre la calle principal y el callejón que no ha sido excavado en la campaña de 1994 y del cual tenemos posibles paralelos (ver Fotos $\underline{79}$ y $\underline{82}$ ), descartando que se pueda tratar de una misma vía que forme una esquina, (como por ejemplo podemos ver en la Foto $\underline{96}$ ) ya que sus diferencias morfológicas son notables y sería más bien un cruce entre dos calles muy distintas (como por ejemplo vemos en las Fotos 159 y $\underline{160}$ ); las profundas carriladas de la avenida del País Valenciano no corresponden a un amplio tráfico rodado asociado a una ruta importante como la vía Augusta (lo que viene desmentido por su estrechez y desnivel), sino debido a la necesidad de superar con garantías una pendiente en una vía enlosada o sobre piedras (ver Fotos 153, 155, 156 y 157) y además basta con compararlas con las suaves marcas de una vía milenaria como la Apia en Roma (ver Foto 101).

Dentro del tema viario, en nuestra opinión, los hallazgos de losas debajo del puente del ferrocarril no pueden ser asociados a una senda romana sin una excavación previa que aclare que se encuentren in situ, ya que el riesgo de que hayan sido reutilizadas es muy elevado (ver Fotos 133 y 134) y podrían haber sido extraídas de la vía Augusta (MELCHOR, 2008). De la misma forma, la interpretación como calles de otros hallazgos urbanos (VIZCAINO, 2001) nos parece que son hipótesis a las que les faltan mas argumentos arqueológicos, una vez conocida la estructura viaria saguntina, gracias a los posteriores hallazgos de la Morería y de la Avenida del País Valenciá.

El caso de ampliación de la ciudad es algo similar al de Mérida extramuros durante el siglo I y II d. C., donde en contraposición a la visión de una campiña poblada por distintas villae se comienza a vislumbrar una autentica población urbanizada, con sus calles, cloacas, pórticos y fuentes, con un entramado bien organizado aunque sin trazado estrictamente hipodámico, ya que posiblemente ha sido fruto de una larga evolución en el tiempo. Esta zona comenzaría a poblarse en el siglo I d. C., a juzgar por los materiales que colmatan el foso de la muralla emeritense y por las casas aparecidas en la zona, y tuvo un desarrollo en principio continuo durante el siglo II y posiblemente parte del siglo III d. C. (FEIJOO, 2000).

En esta línea de urbanización extramuros recordemos que una traslación de los ejes de las calles al otro lado de los ríos la documentamos en Valencia y que se podría dar 
en Sagunto, donde la traza viaria del entorno se ve matizada por una serie de caminos que permiten la comunicación entre la ciudad y su zona periurbana, y entre ésta y su entorno; así se observa además una red de caminos de acceso a la vía Augusta y a la vía de Caesaragusta que en algunos casos evitan el núcleo poblacional, formando un espacio viario radial. No son escasos los ejemplos de ramales de la vía Augusta que comunican asentamientos con la citada vía (por ejemplo Barcino, según PALET, FIZ y ORENGO, 2009), propiciando la continuidad del camino, sin unos desvíos innecesarios a la hora de buscar rapidez y seguridad para el viajero.

Uno de los efectos distorsionadores respecto al diseño urbano romano es el constante cambio del trazado de las sendas más importantes a lo largo de los siglos, mudándose el recorrido de varias vías ya sea por motivos estratégicos o económicos. En la Sagunto medieval comprobamos cómo se desplaza el trazado de la ruta que utilizaban los musulmanes hacia el Puerto (camino dels Rolls) y coincide con a ampliación del siglo II d. C. (calle de Huertos), recuperando el antiguo tramo augústeo (calle del Camino Real): (...) que el camino pase siempre por la villa de Murviedro, cruzando la puerta central de la dicha villa, entre la olivera y la acequia, y pasando por el medio del raval, y que sea cerrado aquel lugar por el cual acostumbraba a ir el camino en tiempo de los sarracenos, por debajo de las casas de Pere de Na Miquela (...) (Carta puebla de Sagunto - CHABRET, 1988: 403)

También la vía Augusta (camino de Valencia) se traslada varias veces para alejarla o acercarla al casco urbano; el trazado del siglo XVII y XVIII, por ejemplo, no coincide con la traza romana, ya que A. Chabret cita textualmente: Este mosaico (de Baco) apareció en el centro de la actual carretera de Valencia; á cuatro palmos de profundidad hacia el Este, corrían varios muros (...) se practicó desmonte en la falda de la montaña, frente á las casas números 53 y 55 de la entrada de la población desde Valencia descubriéronse variados jaspes de hermosísimos y colores, pulimentados y taladrados (CHABRET, 1888:89) (...) se desvió la carretera de Barcelona y cruza el arrabal de San Salvador, haciendo la pasar por fuera de la población (año 1647) (CHABRET, 1888:406)

También debemos tener en cuenta que el cruce del Palancia tiene sus puntos más idóneos junto al casco urbano de Sagunto, ya que más hacia la costa nos acercamos a los marjales y se ensancha notablemente el cauce y al Norte la cuenca se encuentra rodeada de montañas. De ahí que los cruces se efectúen por ahí desde antiguo, como atestiguan las fuentes medievales: (...)E passan per Murvedre per un coll que hi ha e passan per lo Castell a tres trests de ballesta o Quatre (...) e quant fou prop de Murvedre dixem si pasarien per la collada que es sobre lo Castell (...) (CHABRET, 1888:199 nota 1) (...) Crónica Real Cap. LXIV - Haguen passat lo riu prop del comensament de la marjal que ve de la mar (CHABRET, 1888:200). 
Estas fuentes también marcan la posible existencia de algún ramal viario que alcanzaría la vía Augusta: (...) al pasar junto al castillo que obedecía a Zaen, podrían ser sorprendidos y esto motivó algunos pareceres sobre si debían pasar por allí o dirigirse desde Torres Torres a la Val de Segó para ganar la orilla del mar (...) (CHABRET, 1888:199)

Respecto al cruce del río, en la actualidad solamente se aprecian los restos de un puente en el cauce, de probable cronología romana, ya que su funcionalidad viene definida por los extremos de los puntos que une, por un lado el circo y por el otro la vía Augusta y la de Caesaragusta. Lamentablemente este puente se encuentra en muy mal estado, con restos esparcidos por todo el lecho del río (ver Fotos $\underline{14}, \underline{15}, \underline{16}$, y $\underline{19}$ ) y con buena parte del mismo oculta, como lo atestiguan las excavaciones de los años 60 (ver Foto 18). El nivel de arrasamiento del mismo nos permitiría reconstruir parte de su traza, pero su composición es más difícil de restituir y, por lo tanto, nos podríamos encontrar ante uno de madera (ver Dibujo $\underline{33}$ ) o de piedra (ver Dibujo $\underline{32}$ ).

Es más difícil establecer la cronología sobre otros indicios de pasos bajo el ferrocarril (ver Foto 17) y cerca del camino de Zaragoza, ya que es amplio el historial de puentes construidos y desaparecidos, de los cuales citamos algunos ejemplos: [Siglo XIV](...) construcción de un puente de mampostería sobre el río Palancia para facilitar el transito del camino real que desde la villa conduce a la Plana (...) (CHABRET, 1888:293) (...) alcanzaron los jurados de D. Carlos I en 1518, la licencia para construir un puente (...) (CHABRET, 1888:390) (...) el río Palancia (...) carece de puentes (...) (ANDRIANI, 1838: 80).

Es evidente que una vía como la Augusta debería contar con puentes que aseguraran la fluidez del tráfico y su seguridad (quizá podamos ver un indicio de su existencia en los caminos medievales y modernos que vemos en el dibujo 22 , que serían la fosilización de caminos romanos que desembocaban en puentes sobre el Palancia), como veremos también en el tema del Mijares y especialmente del Turia, pues en este caso la existencia de un presunto puerto fluvial obligaría a la existencia de un paso elevado para acceder a Valencia.

Dentro de esta gran reforma del siglo II d. C., hasta el momento solamente hemos podido detectar construcciones monumentales en la zona de ampliación urbana imperial de Sagunto, donde son mayoritarias (ver Láminas $\underline{X V}$ y $\underline{X L I I}$ ). Por el momento desconocemos si parte de esta expansión también se usó para la construcción de viviendas, ya que las excavadas hasta el momento son de una cronología posterior.

La utilización del espacio consiste en la construcción de edificios de espectáculos o públicos junto a la río, en el extremo más alejado de la ciudad, lo cual permitiría una fácil entrada a los visitantes, llegando a construirse un ramal de la vía Augusta y un puente que permitieron un cómodo acceso al circo desde el exterior de la ciudad (sin 
duda el edificio más concurrido y más importante), mientras que el acceso al anfiteatro se realizaría preferentemente desde la vía Augusta y desde el camino que iba al puerto (ver Lámina XII) por una calle que de adaptaría a su traza (ver un paralelo en foto $\underline{122}$ ).

Respecto a la red viaria, no debemos olvidar la modificación y creación de nuevas calles y vías hacia alguna de las obras monumentales, (como ya citamos anteriormente, su trazado genérico coincide con antiguos accesos a la muralla) dentro de la planificación de la expansión urbana del siglo II d. C., pues en la disposición teórica de algunas de estas calles, éstas darían servicio al circo, foro bajo, anfiteatro y a la zona sacra. En algunos casos tratan de salvar importantes desniveles por medio de la excavación de carriladas, como las que han aparecido recientemente junto al ferrocarril, lo que marcaría el límite de la expansión de la ciudad junto a la vía Augusta $^{30}$. Este desnivel ya lo acredita A. Chabret: (...) lo formaban materiales de aluvión, algo accidentado, en plano inclinado desde el mencionado arrabal hasta la línea del ferrocarril (...) (CHABRET, 1897b: s. p.)

Un factor que queremos señalar como de gran interés y que apoya la teoría de que nos encontramos ante una obra urbanística planificada y ejecutada en un breve lapso de tiempo es que, en el relleno que sirve de base a la acera de la calzada de la "vía Sacra" saguntina, aparecieron, entre la arena de río y la grava que lo componen, abundantes restos de pellas de hierro, posibles desechos de algún cargamento de mineral de hierro, ya que ésta es la forma de realizar una primera depuración del material para facilitar su transporte y posterior manufacturación. La extracción de este relleno y su transferencia para su uso en la acera llevó consigo el hierro. Esto lo podemos sumar a que tenemos noticias orales de que en el contexto de otras calzadas de Sagunto también aparecieron bastantes pellas de hierro. La técnica constructiva de los márgenes permite apoyar la teoría del uso de un relleno diferenciado para los mismos (ver Dibujo 7 ) respecto al preparado de la vía (ver Foto $\underline{143}$ ).

\subsubsection{El anfiteatro}

La existencia de un anfiteatro en la ciudad no está asumido por la historiografía local, solamente algunas citas antiguas hacían referencia al mismo. La inexistencia de evidencias epigráficas y arqueológicas reforzaba aparentemente la suposición de que una ciudad del rango de Sagunto no contaba con un edificio de estas características. Y si existía, se imponía plantear una hipótesis sobre su ubicación y para ello contamos con tres tipos de información. Por un lado, el contexto urbanístico de la Sagunto romana y su evolución, mucho mejor conocida hoy día; por otro la evidencia negativa

\footnotetext{
${ }^{30}$ Excavación del año 2006 aun inédita dirigida por J. C. Carreras
} 
proporcionada por las numerosas y dispersas excavaciones arqueológicas en las que no se han detectado restos de este edificio de espectáculos y por último, y no por ello de menor utilidad, la proporcionada por el análisis del parcelario actual, auténtico palimpsesto de fosilizaciones de la topografía urbana antigua. En este último caso las abundantes reformas sufridas por la ciudad nos obligaron a recurrir a la fotografía aérea antigua. Utilizamos fotos aéreas prácticamente cenitales de los bombardeos de los años 1937 y 1938 durante la guerra civil. Estas fueron consultadas en el Ufizzio Storico del Ministerio del Aire italiano, en Roma.

En primer lugar debemos tener en cuenta que los anfiteatros podían edificarse extramuros o intramuros, y en este último supuesto lo normal es que ocupen una posición periférica, cercana a las murallas. La mayor parte de estos edificios se encuentran en los alrededores de las ciudades y preferentemente en la cercanía de las principales vías de comunicación, como por ejemplo la vía Augusta, lo que en Sagunto nos lleva a la zona cercana al Palancia.

Durante el análisis del parcelario nos apoyamos en algunas premisas básicas al respecto; la primera, y casi obvia, es que una de las instituciones más conservadoras en todas las sociedades humanas evolucionadas es la propiedad del suelo. Las parcelas, una vez establecidas, han podido unirse o subdividirse lo largo de la historia, pero siempre respetando, al menos en parte, los límites que las definen. Por esa razón es muy frecuente que en las excavaciones arqueológicas, bajo las medianeras de los inmuebles recién derribados, se descubra que subsiste no sólo la traza, sino también el esqueleto de edificios en alzado, al haberse constituido en límites o medianeras, como ocurre con ciertos tramos de muralla, de acueducto o de un gran edificio.

La característica definitoria del anfiteatro romano es su propia forma elíptica. Aunque en muchas ocasiones los edificios en sí hayan desaparecido, siempre han dejado vestigios curvilíneos muy llamativos fosilizados en los parcelarios (ver Foto 193 y Dibujo 27). A partir de tales trazas se han identificado con éxito numerosos edificios de espectáculos en ciudades romanas. También constatamos las diferentes plantas de los anfiteatros y sus técnicas constructivas, que muchas veces aprovechan desniveles del terreno (ver Dibujos $\underline{12}, \underline{13}$ y $\underline{14}$ ) en casos fácilmente asimilables a Sagunto (como el ya citado de Burdeos - ver capítulo de antecedentes para el estudio del mundo urbano) ya que la posible ubicación del edificio lo situaría en una zona de suave pendiente junto al río, donde su construcción serviría para regularizar este desnivel en distintos planos y alturas (un ejemplo lo vemos en la fotos $\underline{72}$ y $\underline{258}$ ).

Con este análisis observamos en la fotografía aérea de Sagunto del año 1937 una mancha elipsoidal enmarcada por el cauce del río (ver Fotos 200, 201, 202, 203, 204, $\underline{205}$ y $\underline{594}$ ), la vía romana que podríamos llamar Ad Portus, el circo y la vía Augusta, cuya disposición y tamaño coincide con un anfiteatro (ver Lámina XXII y un paralelo en el dibujo 15), si a ello añadimos una foto de final del siglo XIX que muestra claramente 
una casa levantada sobre un gran montículo que hoy ya no existe (ver Foto $\underline{601}$ - letra B) junto a la Morería (ver Foto 601 - letra C) y a los restos de lo que propondremos como parte de la gradería (ver Foto 601 - letra A), este podría corresponder a los restos mas altos del anfiteatro antes de su arrasamiento y nivelación.. Recordemos los ejemplos ya citados en esta tesis de proximidad entre circos y anfiteatros y su situación periférica respecto a la ciudad (ver capítulo de antecedentes para el estudio del mundo urbano) (ver Dibujos $\underline{24}$ y $\underline{25}$ ), como parece ser éste el caso.

El origen de estos dos edificios saguntinos se puede ubicar fácilmente a partir de final del siglo I d. C. ya que ambos se encontrarían sobre estructuras anteriores que en el caso del circo corresponden claramente a parte de las necrópolis existentes alrededor de las vías de las antiguas salidas al Norte de la ciudad. Esto indicaría que, de existir con anterioridad edificios para espectáculos, estarían en ubicación distinta y posiblemente construidos con materiales perecederos, adobe (como Cáparra) madera o ladrillo (como en el caso de Roma, ver fotos $\underline{206}$ y 207) y evidentemente no estarían superpuestos a los enterramientos ya que solamente una situación excepcional permitiría la anulación de las necrópolis.

En el caso del anfiteatro saguntino, la ruta que une el Grau Vell con la senda a Zaragoza se desvía del trazado original para adaptarse a la forma del mismo, buscando la facilidad de acceso. Esta vía (calle Huertos) pasa a ser una gran travesía paralela a los edificios de espectáculos que permite un acceso fácil al resto de la zona monumental y que es prácticamente una variante paralela al anterior camino que en su momento bordeaba extramuros la urbe republicana, con lo que se intentaba en el siglo Il d. C. reproducir el mismo esquema viario anterior, pero alejando al máximo el tráfico rodado y la entrada de visitantes del centro de la ciudad.

De este eje viario hoy en día queda la huella fosilizada del acueducto construido en mampostería de mortero de cal que seguía paralelo a la calle (y que se siguió utilizando en época medieval), del cual pudimos documentar un pequeño fragmento en la esquina de la excavación de la Morería, cuya disposición urbanística respecto a los restos romanos sería muy similar, por ejemplo, al de la Casa del Anfiteatro de Mérida.

La probable desaparición de los últimos restos del anfiteatro en una fecha muy temprana hace que existan pocos documentos que pudieran reflejar su existencia: (...) ruinas de templos, teatro, anfiteatro y circo, gigantescos muros, preciosos mosaicos y numerosas inscripciones legítimas evidencian que allí estuvo Sagunto (...) (FERNÁNDEZ-GUERRA, 1867: s. p.); (...) la fortaleza de San Fernando abrazaba toda la cima del cerro, habiendo aprovechado para la construcción paredones de un castillo de moros y otros derribos (...) (ANDRIANI, 1838: 9); (...) el cauce del río, en el medio del cual se reconocen dos postes que sin duda formaban un ojo del puente para su transito del camino de Roma que llevaba aquélla dirección y pasaba por entre el Circo y el Anfiteatro (ver Foto 591), de este solo quedan vestigios y un pedazo de pared de 
secenta palmos a la parte del río y el resto de ella cahido dentro del cauce del mismo, a la parte de la ciudad a las inmediaciones del circo y del anfiteatro se reconoce un pedazo de pared con su borde de mampostería y hormigón del canal o conducto por el que introducía el agua en ambos edificios públicos para el juego de la Naumaquia. Al extremo del circo hacia la parte superior quedan dos ojos de otro puente antiguo y en el cauce del río tres postes de otros dos (PALOS, 1804: s. p.)

Alguna cita nos revela que permanece la memoria histórica de antiguas vías o restos monumentales romanos en la zona de expansión de la ciudad alrededor del río. En el Repartiment de Valencia, en las páginas 502-503-506-507 donde aparece una de las donaciones que hizo D. Eximeno Pérez de Arenós a los frailes de la Orden de la Merced de Valencia, una de las cláusulas dice así: (...) ortus predictus confrontatur in opere antiquo cequie via publica que itur ramblam et ad montem Tiberium, etc. (CHABRET, 1888: 131 nota 1)

En el caso de Sagunto, además debemos sumar el expolio que sufren los restos monumentales visibles a lo largo del siglo XIX y que afectaron a los más cercanos a la vía férrea (el anfiteatro y un posible ninfeo por ejemplo): Y que no pudiendo ser volados sin riesgo para la población que esta a su pie, se han ofrecido los despojos de esta ciudad venerada para que los aprovechen los vecinos y se han cedido luego al empresario del camino de hierro de Valencia a Tarragona, habiéndose todos negado a recibirlos... ... al tiempo de hacer que desaparezca el circo Romano que se mantuvo en pie desafiando a los siglos y sin que lo profanaran manos extranjeras, hasta que en la guerra de la independencia fue casi totalmente destruido por manos Españolas (CAVANILLES y CENTI, 1858: s. p.)

La única excavación realizada sobre el solitario resto visible (ver Dibujo $\underline{28}$ y paralelos en los dibujos $\underline{9}, \underline{10}$ y $\underline{11}$ ) de lo que ahora nosotros proponemos como la base de la gradería del anfiteatro, y que en las fotos aéreas coincide con esta estructura monumental, es la que resumimos a continuación, pues aporta datos muy interesantes: (...) piso firme de hormigón que marca el nivel del suelo en el interior de lo que fue edificación, habiendo tenido la suerte de encontrar "in situ» varios sillares labrados de piedra caliza gris, de los que formaban el revestimiento exterior de la edificación. (...) En un lugar situado cincuenta centímetros más abajo, a partir del piso firme debajo de la bóveda apareció la piedra que formaba el umbral de la puerta mencionada (...) aparecen, en informe montón, numerosos sillares bien labrados $y$, entre ellos, un capitel de base cuadrada, casi tronco-piramidal, idéntico a otros aparecidos en diversas construcciones de la misma época en Sagunto. (...) salió otra piedra de umbral de grandes proporciones que corresponde a una puerta mucho mayor que no hemos visto. (...) procedimos a ampliar la cata en el horizontal, llegando ha encontrar otra masa de hormigón paralela al resto visible y oculta hasta ahora por el escombro, dando la impresión de haberse desprendido del bloque que mantiene el fragmento de bóveda, 
quizás al ser socavado por el río (...) (ROCA, 1964:1-5) (Ver Fotos 195, 196, 197, 198 y 199). Este monumento ya estaba arruinado antes de la época de Chabret, que lo describe: (...) su descarnada mole otro monumento sepulcral, que representamos en la figura núm. 25, á espaldas del huerto nuevo. (...)(CHABRET, 1888:94)

J. L. Jiménez analiza el mismo monumento llamándolo "del centro escolar José Romeu"; por comparaciones con el mausoleo de Daimuz, y con una hipotética reconstrucción volumétrica defiende un uso funerario para el mismo, pero también hace referencia a los elementos asociables a viviendas, como el umbral de caliza gris, recuperado en la campaña de 1963 y en la actualidad desaparecido, con unos orificios a $1,34 \mathrm{~m}$ de distancia entre ellos y que, al aparecer incompleto en uno de sus extremos, hace que el autor no lo acepte como argumento válido.

Sin embargo debemos recordar la cita de la excavación (ROCA, 1964) sobre partes idénticas al porticado de la vecina plaza de la Morería, como una pieza que formaba parte de una acumulación de sillares y elementos (incluido el citado gran umbral), correspondiente a un capitel de base cuadrada, casi tronco piramidal, también hoy perdido (JIMÉNEZ, 1992). La interpretación de esta edificación como monumento funerario que siguen algunos autores es, en nuestra opinión, una posibilidad remota, en primer lugar por la propia forma del elemento, prácticamente idéntico a cualquier estructura de anfiteatro o de un edificio publico, donde observamos que la sección del mismo coincide con parte de los arcos sustentantes de un gran inmueble (ver Foto $\underline{177}$ ) sin olvidar que según el excavador (ROCA, 1964) la cimentación continuaba por todos los lados. De esta forma podemos encontrar semejanzas constructivas no sólo en arcos en su cara interior (ver Fotos 174, 175, 194, 212, 213, 214, 217, 219, 221, 228, $\underline{226}, \underline{229}, \underline{231}, \underline{232}, \underline{251}, \underline{254}, \underline{260}, \underline{286}, \underline{287}, \underline{288}$ y 289 ) sino además en el exterior, donde se apoyarían las gradas (ver Fotos 176, 187, 188, 189, 208, 209, 215, 220 y 262) y en la propia disposición interior (ver Foto 233). Por otro lado, es evidente que estamos ante una estructura de caementicium forrada de sillarejo, sobre un pavimento enlosado (también hay paralelos en Foto 218 y 234), y aunque desconocemos cómo es el resto del edificio, tenemos amplios ejemplos constructivos, desde sectores excavados en la piedra (ver Foto $\underline{211}, \underline{222}, \underline{224}$ y $\underline{227}$ ), realizados parcialmente con ladrillos (ver Fotos $\underline{206}$ y $\underline{223}$ ), de tierra o tapial (ver Foto $\underline{210}$, aunque en este caso de Mérida es probable que haya sufrido una posterior monumentalización con gradas, accesos y muros de caementicium). Finalmente lo que se identificaba como "ventana" podría ser perfectamente algún pequeño acceso (ver Fotos $\underline{235}$, 248 y 252 ). Además su tipología no coincidiría con un gran mausoleo del Alto Imperio (fecha en que funciona la necrópolis) y las primeras referencias al conjunto palacio-circo-mausoleo son de época del Bajo Imperio, (FRAZER, 1966 e HIDALGO, 1999) con seguridad a partir del siglo IV d. C., cuando no existe un cementerio en esta zona saguntina. 
Es difícil establecer el tamaño del anfiteatro, ya que la impronta observada en la foto aérea no indica concluyentemente la cantidad de restos; nos inclinamos sin embargo hacia un tamaño medio, similar a un ludus romano (ejemplos similares los podemos ver en las Fotos $\underline{225}$ y $\underline{230}$ ), y tampoco logramos saber si lo que se conservaba era sólo parte de la arena, del foso (como la zona de la Foto 216) o de la gradería. La restante documentación gráfica son planos o fotos no cenitales que imposibilitan una visión de conjunto (ver Fotos $\underline{591}, \underline{592}$ y $\underline{593}$ ), pero que podrían señalizar algunos restos del anfiteatro junto a los del circo (ver Dibujos $\underline{53}$ y $\underline{54}$ ).

La creación de edificios públicos sobre antiguas zonas funerarias la tenemos documentada también en Mérida, donde la aparición de una incineración en las antiguas excavaciones de Pous en el anfiteatro y la existencia de varias cremaciones en la zona situada entre la vía de unión entre este inmueble, el teatro y el muro de cierre del peristilo en su lado oriental, parece indicar que la construcción (o monumentalización) del anfiteatro en época flavia fuera acompañada de cambios sustanciales que también afectaron a estructuras relacionadas con el teatro, suprimiendo una necrópolis (MÁRQUEZ, 2000). En ese momento, mediada la primera centuria, ambos edificios se encontrarían situados extramuros, como ya se ha sugerido en algunas ocasiones (MATEOS y MÁRQUEZ, 1999). El anfiteatro de Cáparra se construye sobre una zona cementerial en el siglo II d .C. (CERRILLO, 1995) de la misma forma que el de Segóbriga y su circo (RUIZ et al., 2009).

Otro punto a favor de la existencia del ludus saguntino es que los teatros de Hispania decaen ( $y$ algunos se abandonan como el de Cartagena o Tarragona) en favor de los anfiteatros, lo cual obliga a que una ciudad como Sagunto contara con un edificio de este tipo, en contra de teorías aun no demostradas que suponen la existencia de juegos gladiatorios en el teatro (ARANEGUI, 2004), más aun cuando la ciudad ya cuenta con un área idónea de edificios de espectáculos para las masas.

\subsubsection{Los templos y edificios monumentales de la Morería}

En esta expansión del siglo II d. C. también se crean una serie de edificios religiosos a lo largo de al menos una de las vías de la ciudad que llamaremos "vía Sacra", debido a la gran cantidad de edificios religiosos que existían allí, y corresponde a la vía excavada en la Morería saguntina (ver Lámina XXXI y $\underline{\text { XXXVIII). }}$

En primer lugar pudimos restituir un gran edificio religioso (el templo 1 o templo cuadrangular) con podio y escalinata de acceso, y con su espacio sacro claramente delimitado, como es habitual en el Imperio. Un ejemplo lo tenemos en Ostia donde un 
autentico recinto rodeaba un conjunto de templos extraurbanos, progresivamente englobados en la ciudad, hecho que culmina en el siglo II d. C. (MAR, 1996). Su podio tiene formato cuadrangular, estaba construido en opus siliceum con relleno de tierra y arena (ver Foto 422 ) y con las esquinas de sillares almohadillados (ver Foto $\underline{419}$ ); su construcción arrasó y abrazó un edificio funerario anterior (el citado ustrinum monumental), de tal forma que se puede apreciar claramente la zanja de cimentación del podio recortando el preparado del pavimento de la estructura de la necrópolis con los restos de fosas de los sacrificios rituales (ver Foto $\underline{416}$ ). El enrasamiento de las estructuras anteriores englobadas nos permite pensar que el podio se conservó en buena parte de su altura, ya que además sus restos arrasados son escasos y se detectan en su lado Norte (ver Foto $\underline{425}$ ). Con todo ello podemos presuponer que el mismo alcanzaría escasamente los dos metros. Posteriormente se rellenó todo el espacio interior de la base con arena (ver Foto 417 ) y se construyó un imbornal por su cara Oeste, que iba a desaguar a la cloaca (ver Foto 424); en esta misma cara teníamos la fachada principal, ya que en el centro de la misma se conservaba la cimentación de la escalinata (ver Fotos $\underline{420}, \underline{421}$ y $\underline{423}$ ), entre los que destacamos la presencia de un oinochoe de pasta reductora y una moneda de Trajano del año 98/99 d. C. (PASCUAL-AHUIR, 2005); esta es la UE 1129, ya analizada en este trabajo, un hoyo rodeado de otras pequeñas fosas con restos de fauna, carbones y ceniza, y donde sólo de forma residual aparecen fragmentos humanos incinerados, que quizá tuvieran que ver con el ritual que permite asentar un templo sobre la antigua necrópolis.

Volviendo a hacer hincapié en el lado Norte de este templo pudimos observar una serie de estructuras adosadas al mismo, cuya interpretación es especialmente compleja, ya que se encuentran en un nivel más bajo que la propia calzada anexa (ver Fotos $\underline{484}$, $\underline{485}, \underline{486}$ y 487 ). Sufrieron, como el resto, un saqueo importante, pero no se pudieron identificar puertas o accesos, lo que nos hace pensar en posibles balsas 0 contenedores, independientemente que durante el siglo III d. C. fueran adaptadas a otro uso aún por determinar.

El profundo desvalijamiento al que fue sometido el conjunto de la Morería hace prácticamente imposible la total restitución del templo y su adscripción; únicamente se recuperó una basa de columna monumental como posible elemento de su fachada y restos de varias molduras de mármol rosso antico. Por el espacio disponible entre el anfiteatro y el acueducto (al que debemos sumar la aparición de un muro durante unas obras de canalización en la calle Alorco que podría corresponder al muro de cierre del recinto sacro), podemos extrapolar parte de su planta que tendría una tendencia cuadrangular, que nos recuerda parcialmente al templo de Divo Vespasiano del foro de Roma (ver Fotos $\underline{433}$ y $\underline{434}$ y Dibujo $\underline{47}$ ). Los fragmentos de la inscripción imperial encontrada (CORELL y SEGUI, 2008) junto al edificio, podría indicar un templo dedicado al culto imperial. 
Los paralelos constructivos son innumerables (ver Dibujos $\underline{45}$ y $\underline{48}$ ), como por ejemplo escalinatas sobre rellenos (ver Fotos 444 y $\underline{445}$ ) que desaparecen durante el proceso de saqueo de los peldaños de materiales nobles (ver Fotos $\underline{432}, \underline{435}$ y $\underline{448}$ ), podios con rellenos (ver Foto 267, 268, $\underline{393}, \underline{436}, \underline{437}, \underline{447}, \underline{452}$ y $\underline{529}$ ), la propia técnica constructiva (ver Foto 465 ), balsas y fuentes junto a pedestales de templos (ver Fotos $\underline{285}, \underline{443}, \underline{454}, \underline{464}$ y $\underline{468}$ ), themenoi o zonas sacras alrededor de los edificios (ver Fotos $\underline{440}, \underline{466}$ y $\underline{467}$ ) y su acceso a la calle (ver Foto $\underline{449}$ ).

Respecto a posibles paralelos a la hora de restituir la forma del edificio, éste sería sin duda muy similar, por ejemplo, a las Fotos $\underline{269}, \underline{451}, \underline{453}, \underline{455}$ y con una cella pareja a las Fotos $\underline{441}$ y $\underline{442}$, y en planta similar a las Fotos $\underline{459}, \underline{450}$ y $\underline{458}$ ).

Junto a este edificio de culto de la Morería y dentro de la misma manzana existe otro templo rectangular (Templo 2) que sólo excavamos parcialmente, pero que también contaría con un espacio sacro claramente delimitado en el que se puede observar su podio de forma rectangular y alargada (ver Fotos $\underline{429}$ y $\underline{430}$ ) donde, como en el templo 1 , se constató que en el relleno de la base se englobaron muros de época anterior (ver Fotos $\underline{383}$ y $\underline{384}$ ). Este pedestal es de opus vittatum (ver Foto $\underline{426}$ ) enlucido y pintado en rojo (ver Fotos 427 y 490 ) con una amplia escalinata (completamente saqueada de antiguo) y con una posible cella tripartita en el interior (lamentablemente la posterior reutilización del edificio y su excavación incompleta no nos permite asegurar este punto, que sin duda sería interesante de cara a proponer una advocación capitolina (sin olvidar el templo existente en el castillo) o alguna otra tríada) con los umbrales de acceso (ver Foto 428). Como en el caso anterior tenemos abundantes paralelos, para la cella (ver Fotos $\underline{438}$ y $\underline{460}$ ) y el podio (ver Fotos $\underline{439}, \underline{459}$ y $\underline{462}$ ).

También se recuperaron indicios de un tercer templo del que sólo tenemos el fragmento de inscripción con posible dedicación a Mitra. A falta del análisis del resto del espacio excavado podemos afirmar que existían al menos dos templos al lado Este de la vía, un tercero que aparece por referencias epigráficas, y un posible cuarto edificio religioso, pues hasta llegar a la zona urbana original intramuros se puede apreciar otro posible podio de opus vittattum (ver Fotos $\underline{473}$ y $\underline{489}$ ), pendiente de un futuro análisis de la excavación de 1994, ya que fue en este espacio donde aparecieron estos restos.

La evidencia de amplios recintos públicos y de varios templos ocupando una manzana es habitual en el mundo romano; por ejemplo, el santuario de Isis en Pompeya fue construido ocupando parte de la insula del vecino teatro y dentro de la misma se construyó el templo de Zeus Melichios y además se situaban allí edificios claramente públicos como el teatro, el odeón o el foro triangular.

Además de los edificios religiosos ya citados podemos reseñar la existencia de un espacio amplio con inmuebles, como la casa "romana" de A. Chabret (CHABRET, 1888), quizá otro edificio monumental o religioso, sin olvidar la existencia de los restos 
de la zanja abierta, coincidiendo casi con el centro de la calle Camino Real, para el alcantarillado en el año 1943, concretamente en el espacio comprendido entre las calles de la Rosa y de Alorco (aproximadamente $40 \mathrm{~m}$ ), donde aparecieron varias hiladas de sillares romanos consecutivos, de las cuales la más profunda estaba asentada sobre la roca. Según P. Beltrán eran los restos de la antigua muralla romana y se apreciaban otras paredes perpendiculares, más estrechas y no descubiertas, sin que pudieran ser determinadas sus características ni su época (BELTRÁN, 1951).

También tenemos documentación fotográfica de un importante edificio en el Camino Real a la altura del cruce con la calle de la Trinidad, en lo que parece tratarse de un podio de sillares (ver Fotos $\underline{414}, \underline{415}$ y Lámina $\underline{X X I I)}$ ).

Otro edificio monumental es el citado en el trabajo de M. Muñoz, que realizó la excavación en el siglo XVIII de dos inmuebles romanos situados en los alrededores. El primero de ellos se encontraría cercano al mosaico de Baco, donde cita un espacio a modo de callejón sin entrada ni salida de paredes con un repié oblicuo, indicando que podría ser parte de unos baños, porque en el espacio E-W se hallaron tres tinajas para agua caliente, tibia y fría (OLCINA, 1991). M. Olcina piensa que el callejón sin salida se trata de una cisterna estrecha con los característicos cuartos boceles de los ángulos, y que el compartimento con las tres tinajas bien pudo ser un lugar de almacenaje con dolia (OLCINA, 1991), aunque opinamos que este autor se equivoca al negarle el carácter urbano a esta domus. El otro edificio de grandes dimensiones donde M. Muñoz se limitó a descubrir el recorrido de las paredes perimetrales dejando intocado el interior estaba en un campo de algarrobos. La construcción presentaba una planta hexagonal, aunque en realidad es un semicírculo: (...) la planta podría definirse como "en forma de botella». El muro S. presenta unos engrosamientos rectangulares situados a cierta distancia entre sí que han de interpretarse como contrafuertes. (...) La entrada al recinto se practicaba a través del cuerpo rectangular saliente en cuyo muro N. aparece una interrupción y junto a ella, en el interior, unas gradas (...) cerca de la pared a septentrión se hallaron varios fustes de columnas, fragmentos de inscripciones y huesos humanos. (OLCINA, 1991)

Las medidas aproximadas del edificio, son:

- $\quad$ Pared Sur: 38,4 m,

- $\quad$ Longitudes de los muros de los lados $\mathrm{E}$ y W: 65,5 m

- Muro Norte del cuerpo rectangular del lado S: $5 \mathrm{~m}$

- Muros E y W del cuerpo rectangular del lado N: $12 \mathrm{~m}$

- $\quad$ Perímetro de todo el edificio sin contar los lados $\mathrm{E}$ y W de los contrafuertes y torre del lado oeste: 198,4 m (ver Dibujo $\underline{31}$ y un paralelo en el Dibujo 30) 
La anchura de las paredes era de 0,6 m y la denominada por M. Muñoz como torre, en la pared W junto al ángulo SW, se conservaba hasta una altura de 2,48 m. Los muros estaban realizados con piedra de la cantera de Alcublas y los cimientos eran de rodeno hasta una profundidad de 0,67 $\mathrm{m}$ y descansaban sobre una lechada de argamasa. En el interior del edificio, centrado y cerca del cuerpo saliente Norte, sobresalía una construcción cuadrada y aislada que Muñoz interpreta como la base de un obelisco. La interpretación del edificio es problemática según M. Olcina, que como paralelos cita el edificio naviforme de Clunia, el jardín de la villa de San Marco de Stabia, el patio de honor de la villa de Mont-Maurin o el santuario de Les Bolards. En todos ellos el interior está recorrido total o parcialmente por un pórtico. A la vista de los paralelos y por la situación aproximada en que se encontraba, el citado autor apunta que pudo ser el jardín de una villa suburbana, aunque el propio M. Muñoz había desechado su función como estanque, porque las paredes no estaban labradas para tal uso (OLCINA, 1991).

Nosotros creemos que por paralelismos estructurales y por su situación junto al río y a un importante acueducto que da servicio al circo y al anfiteatro, se trataría de un ninfeo monumental, puesto que su planta es muy similar a la de este tipo de edificios (ver Fotos 264 y 266). En Mileto, Efeso (YEGÜL, 1992) o Itálica, por ejemplo, se construyen unos importantes en el siglo II d. C. (HIDALGO, 2003). Por su ubicación probable pensamos que este gran edificio se podría encontrar próximo a la zona de la Morería, pero con esto no queremos descartar otras hipótesis, ya que la interpretación de un resto que no se puede contrastar sobre el terreno es muy compleja. La descripción de esta estructura también podría, por ejemplo, corresponder a un odeón con o sin gradas de madera (ver Fotos 259, 261 y $\underline{263}$ ) a un templo (ver Foto 267), a una biblioteca (ver Foto 265), a una exedra (ver Foto 274), a una palestra (ver Dibujo 37), etc. La cronología del edifico es compleja y según la descripción de la intervención parece que la estructura monumental se construyó sobre una necrópolis, y estuvo en uso hasta el siglo III d. C. (por los hallazgos monetales - OLCINA, 1991).

Volviendo a la excavación de la Morería, otro elemento que podría avalar las características monumentales de este espacio es la existencia del arco (ver Foto 282) y de una fuente baulletto frente al Templo 1 y que sin duda señalaría un hito importante. Según nuestro análisis de los restos este arco marcaría el cruce del acceso al anfiteatro con una importante vía (correspondiente a la actual calle Huertos) que se iniciaba en el puerto (Grau Vell) y proseguía hacia Bilbilis y Caesaraugusta pasando por el foro del solar de Quevedo y el circo. Son muy abundantes en el mundo romano los ejemplos de arcos que señalizan hitos, cruces, etc. (ver Foto 271); como por ejemplo en Pompeya, donde los arcos se implantan sobre la calzada y cuentan con fuentes en su inmediatez (GIUNTOLI, 1989) (ver Foto 275); además, los restos de la base de un posible miliario encontrado casi in situ (ver Foto $\underline{283}$ y paralelos en Foto $\underline{284}$ ) también marcaría el cruce, del mismo modo que muchos otros (ver Fotos $\underline{272}, \underline{273}$ y 277 ). La existencia de este tipo de estructuras delimitando espacios monumentales 
es muy habitual; podemos por ejemplo citar el Arco de Trajano de Mérida que daba acceso a un recinto sacro presidido por un templo relacionado con el culto imperial, erigido con posterioridad a la etapa fundacional augústea, en particular vinculado a la memoria de Augusto (MATEOS, 2006). A la vista de los restos conservados no podemos avanzar en la restitución definitiva del arco saguntino, pues únicamente conocemos su luz y que contaba con una base de sillares (ver Fotos $\underline{280}$ y $\underline{281}$ ), restos de la moldura de la misma (cuyo paralelo más inmediato lo vemos en Pompeya en el arco de Calígula (GIUNTOLI, 1989), como podemos apreciar en la Foto 276) y una impresionante cimentación de opus caementicium (ver Foto $\underline{279}$ ), con lo cual nos limitamos a hipotetizar sobre su volumen (ver Lámina $\underline{X L}$ ). Sin embargo, por el tamaño de la cimentación de 1,8 m de profundidad, destinada a soportar un gran peso, sí podemos suponer que todo el arco era de piedra labrada, y nos inclinamos por un modelo similar al de Medinacelli (ALFÖLDY y ABASCAL, 2002) (Foto 270). Recordemos que, entre los fragmentos epigráficos encontrados junto a su base, existiría una posible dedicatoria imperial del siglo II d. C. (CORELL y SEGUI, 2008) que se podría asociar a él.

El momento de monumentalización de la calzada saguntina también correspondería a esta fase, ya que los escasos restos recuperados en el preparado del enlosado y pórtico de la misma señalan una fase posterior al funcionamiento de las necrópolis. Además, sería un elemento muy poco habitual la presencia de un porticado en la calle en la zona cementerial, para el cual aún no hemos encontrado paralelos en entornos funerarios a lo largo del Imperio (ver Foto 104). La propia tipología cambiante de los monumentos funerarios, la necesidad de acceso y visibilidad desde la calle, difícilmente permitirían un elemento homogéneo y opaco como un pórtico. Las aceras de la vía eran espaciosas, con anchura de entre 2,5 y $3 \mathrm{~m}$, los bordillos y los pavimentos fueron totalmente saqueados y solo quedó un preparado de tierra batida del que se han documentado diferentes versiones de arcilla quemada, de limos prensados con o sin aditamento de cal, de cascotes compactados o de reformas practicadas en las viviendas (con tierra y enlucidos de cal o estuco procedentes de las paredes de tapial), con parte de elementos quizá provenientes de la necrópolis arrasada.

No hemos recuperado bordillos en el límite de la calzada que hacían de contención a las tierras de las aceras y lo protegían de golpes y otros deterioros. Estas piezas eran coetáneas a la aparición de los pórticos, pero las obras de acondicionamiento o mejora pudieron enterrar algunos bordillos y la mayoría fueron retirados, como durante la progresiva ocupación del espacio porticado por parte de las viviendas. Por ello también en Mérida restan muy pocos testimonios de estas piezas delimitadoras de cantería en sus emplazamientos originales, gracias a sus posibilidades de utilización y fácil extracción (ALBA, 1999). Respecto a los pórticos, su uniformidad de fábrica, material y generalización apuntan a una obra pública, aunque no obstante hemos advertido que hay una fluctuación en las medidas de las piezas que componen la columnata y en la 
distancia que media entre ellas, quizá para su adaptación a los accesos a las viviendas y edificios públicos.

Un paralelo a la evolución de esta estructura lo tenemos en que la práctica totalidad de las vías emeritenses irían flanqueadas por pórticos, salvo las fachadas de los edificios de espectáculos y la vía anexa a la muralla que sirvió de paso de ronda, donde apenas se conservan los pórticos porque fueron paulatinamente asimilados por las viviendas a lo largo de un proceso que se prolongó hasta la Alta Edad Media, con un origen que parece remontarse ya a una fase final del Alto Imperio, opcionalmente ocupados por importantes obras de ampliación practicadas en las domus (ALBA, 1999).

\subsubsection{El foro "Bajo"}

Dentro del programa monumental saguntino encontramos también la construcción de un posible foro junto al circo (ver Lámina XIX y paralelos en los dibujos $\underline{35}$ y $\underline{36}$ ); a falta de datos que nos permitan adjudicar si su función es municipal, comercial, honorífico, etc. lo nombraremos "foro Bajo" a diferencia de los anteriores que ocuparían cotas más altas. El principal elemento detectado hasta el momento es la gran columnata del solar de las calles Ordóñez, Huertos y del Remedio, cuyas características pueden corresponder fácilmente a este tipo de estructuras porticadas con acceso monumental y una gran cloaca de evacuación; recordemos su situación, junto a una importante vía de comunicación, aledaño a unas potenciales termas monumentales y al circo.

La presencia de pilares en la zona pertenecientes al pórtico de la estructura foral (o en todo caso, a una calle) viene reforzada por la noticia publicada en el boletín ARSE: Facundo Roca $R$ localiza y recupera de un vertedero de escombros de derribos una pieza cúbica de piedra gris labrada por cuatro caras, de 0'46 $\mathrm{m}$. de largo, ancho y grueso (ver Dibujo 34). El directivo José Antonio Esteve recupera de otro vertedero de escombros distinto al anterior, una pieza cúbica idéntica a la ya mencionada y el basamento (ARSE, 1981: 241).

Según información oral de S. Vela, (que estuvo presente en la recuperación de las piezas, bien trabajadas, a diferencia de las que componen los pórticos urbanos) fueron extraídas del solar de la calle Huertos esquina Ordóñez, durante las obras que se llevaron a cabo a principio de los 80 del siglo XX (ver Fotos $\underline{292}$ y $\underline{293}$ ).

Es interesante comprobar que en esta zona no es la primera vez que aparecen pilares similares a los del porticado de la Morería: (...) grandes columnas, que por allí se muestran en la cuadra que solía servir de Hospital, no labradas á lo romano, sino 
solamente desbastadas á lo muy antiguo: que como ellas, se van desenterrando muchas de cada día por aquellos contornos, en el camino real, lo mismo predican la infinidad de sepulcros y epitafios, que por las paredes del dicho monasterio, dentro y fuera se ven encajados (...) (CHABRET, 1888: 109-110)

Estas columnas por su aspecto basto parecerían antiguas, pero posiblemente estarían originariamente enlucidas. También nos manifestó M. Civera, que durante los trabajos de seguimiento arqueológico en la calle de Ordóñez aparecieron dos fustes de pilares muy similares a los de la Morería.

Lamentablemente es difícil poder contextualizar los restos perdidos del presunto mausoleo de los Sergii (JIMENEZ, 1989) con la estructura excavada, ya que solamente se cuenta con un dibujo del siglo XVI para interpretarlo. Algunos autores como Madoz nos reflejan las interpretaciones de su época: (...) en el local que ocupa este edificio (el convento de trinitarios) el antiguo y famoso templo de Diana, cuya ruinas sirvieron para la construcción de aquel y las más se vendieron y transportaron para la del de San Miguel de los Reyes de Valencia (...) (MADOZ, 1848:177).

Por nuestra parte sólo podemos apuntar que el nivel de arrasamiento que detectamos en la excavación (ver Foto $\underline{304}$ ) y su profundidad podrían avalar que si se hubiera conservado parcialmente una estructura sobre podio, ésta se encontraría en cota de superficie en el siglo $\mathrm{XVI}$, o sea, a más de 2 metros sobre el nivel del piso romano en esta zona, según lo documentado en nuestra intervención (ver Foto $\underline{299}$ ) y que habría sido reutilizada en este periodo como parte del convento. Recordemos que en Baelo, Mérida, etc. las casas que reutilizan la cima del podio de los templos corresponden a un segundo piso, ya que la planta baja se adosa a la citada base; concretamente en la excavación de la plaza de la Morería se detectó que las viviendas de época bajomedieval construidas sobre los podios de los templos estaban en contacto directo con los restos antiguos, mientras el verdadero nivel de calle romano en algunos casos se encontraba casi más de un metro por debajo.

Otro factor a tener en cuenta es que ninguna de las inscripciones conservadas del llamado mausoleo de los Sergii son claramente funerarias, ya que carecen de formulas clásicas de inscripciones mortuorias, pudiendo ser también dedicatorias o votivas. En este contexto, debemos recordar que la mayor parte de la decoración epigráfica de los foros está constituida por los programas de autorepresentación de las élites. De hecho, la mayor parte de los pórticos forenses y de sus espacios centrales estaban ocupados por este tipo de textos, normalmente zócalos para estatuas, que literalmente saturaban el espacio; donaciones y actos de evergetismo de todo tipo, conmemoraciones de magistraturas, homenajes a los patronos urbanos y a la familia imperial por parte de miembros de las élites, etc.; por eso fue el lugar idóneo para la colocación de los pedestales póstumos con laudationes de los miembros difuntos de la élite local, mediante autorizaciones decurionales para colocar basas en los foros locales. Una 
sencilla combinación de donaciones y homenajes podía hacer que un grupo familiar o un individuo fuera omnipresente en la vida de una ciudad, lo que podía allanar su carrera política o sus actividades comerciales de forma importante. Los foros de las grandes urbes de la costa mediterránea fueron escenario de esta generalización de los pedestales epigráficos y tenemos ejemplos en núcleos como Tarragona, Barcelona, Sagunto, Córdoba, Astigi, Segobriga, Valencia, etc. En otros casos, como en Cartagena, predominan casi exclusivamente sobre las placas, donde la presencia de pedestales es mínima, quizá debido a la capacidad adquisitiva de las élites locales y a sus aspiraciones políticas (ABASCAL, 2009).

En el caso saguntino, la descripción de los restos podría corresponder a un foro, como espacio de autorepresentación y ámbito de proyección de los Sergii, como manifestación de su fuerza y su poder económico. También podría tener un templete o aedes, pues son conocidos los ejemplos de templos construidos por particulares:

\section{(...) debo reconstruir el aedes de Ceres existente en mis posesiones (...) una gran muchedumbre procedente de toda la región se reúne en él se realizan muchas ceremonias (...) añadiese al templo un pórtico, el primero para el culto de la diosa, el segundo para beneficio de los hombres. (...) (Plinio, Ep. X, 39).}

En una ciudad podemos encontrar varios foros, en Córdoba, Mérida o Tarragona conocemos varios enclaves significativos: en el caso de esta última ciudad está el foro provincial en la parte alta, construido en época flavia, y en la parte baja el foro colonial modificado en época de Augusto y la dinastía julio-claudia (RODÁ, 2009).

En la urbanística romana el complejo del foro jurídico-administrativo constituye el núcleo de la vida urbana donde están los espacios bajo la tutela de un templo que evoca la concentración de todas las funciones cívicas y religiosas en torno a una plaza, de ahí su posición central en lo referente a los accesos y la vida social. Estos condicionantes en Sagunto descartarían el foro republicano y augústeo de la cima del castillo y el que debería existir en la parte baja intramuros hasta el siglo II d. C. ${ }^{31}$, ya que los haría poco funcionales. Si nos centramos en Tarragona algunos autores admiten que los grandes cambios corresponden a la época flavia, tanto en lo que a nivel administrativo como urbanístico se refiere; la reforma del culto imperial a nivel provincial encontraría en este momento las condiciones propicias para su culminación (ALFÖLDY, 1993). Por su parte, el viejo foro colonial, monumentalizado a partir de la época augústea y julio-claudia, continuaría en plenas funciones, según los restos escultóricos y las inscripciones halladas, bien en la misma área o reaprovechadas en la necrópolis, que evidencian una bien arraigada continuidad de la conmemoración de la figura del emperador (RODÁ, 2009). Una similitud con el cruce de vías y la ubicación

\footnotetext{
${ }^{31}$ C. Aranegui cita posibles evidencias epigráficas de un espacio foral en la zona de la puerta Ferrisa (ARANEGUI, 2004)
} 
de un foro comercial es el caso del sacellum de Hércules en Alba Fucens, donde la plaza rodeada por porticados constituye un mercado urbano presidido por una cella de culto (Herculis Salarii), con carácter de protector del comercio de la sal y ubicado junto a la vía Salaria (MAR, 1996).

Un posible foro saguntino en la parte más baja y accesible vendría a ser al menos el tercero de la ciudad; su creación sería totalmente necesaria debido al desplazamiento del eje central de la urbe, cada vez más próximo al cauce del río; así la actividad económica se alejaba de un centro de difícil acceso para el tráfico rodado y el comercio, a diferencia de las capitales provinciales, que tenían varios foros, pero en algunos casos por factores exclusivamente administrativos o políticos.

Las características del complejo saguntino son las de un gran recinto de sillares con acceso de grandes dimensiones (ver Fotos 294, 295, 296 y 298), muy similar al de otros foros, como por ejemplo el de Zaragoza (ver Foto $\underline{310}$ ) o Conimbriga (ver Foto 179) y pilastras monumentales, junto a una gran cloaca que por su orientación daría servicio al centro de la plaza (ver Fotos 301 y 302). Estos son elementos compositivos muy característicos de la edilicia romana foral. Lamentablemente la zona excavada del solar, su disposición y el nivel de arrasamiento hasta los cimientos de parte de las estructuras (como la fachada - Foto $\underline{300}$ - y el porticado - Foto $\underline{303}$ ) no permiten profundizar en los detalles del edificio (ver Lámina XLVII), pero evidentemente cumpliría con el requisito de plaza porticada cerrada al tráfico rodado con un templo preferentemente abierto en su eje longitudinal (ver Lámina $\underline{X X}$ ). Junto a esos edificios se desplegaba la estatuaria con su correspondiente epigrafía honorífica, las esculturas ecuestres, los togados y la retratística oficial, que proyectaban, en definitiva, la imagen propagandística del poder y que podrían verse en los restos del aedes de los Sergii.

Dentro de las demás opciones posibles para esta estructura estaría, por ejemplo, su consideración como un lugar sacro o santuario (tenemos un paralelo casi literal en el santuario de Avenches (GROS, 1996), o como un edificio funerario, aunque esta última se nos antoja la más remota, especialmente por su ubicación, ya que en el siglo II d. C., cuando posiblemente se construye este edificio, la zona ya estaba urbanizada, con la presencia entre otros del circo y del cercano edificio de la Lira Saguntina, con lo cual ya era delito enterrar en este espacio. Sólo en casos excepcionales era posible que existieran enterramientos dentro del pomoerium. En el mundo griego los enterramientos dentro de los muros de la ciudad estaban prohibidos, al igual que en Roma, excepto en el caso de héroes, fundadores de ciudades y, a veces, benefactores de las mismas (Plinio, Ep. ed 2005:547). Esto implicaría que el monumento funerario de los Sergii fuera anterior al siglo I d. C. y se conservara excepcionalmente en la amortización general y, en este caso, la tipología y la excesiva monumentalidad de la posible tumba no nos parece acorde con unas fechas tan tempranas. Sumemos además a estos datos la presencia de estructuras anteriores bajo el edificio (ver Foto 297), que al igual 
que sucede en el vecino circo, serían posiblemente funerarias y con una cronología cercana al siglo I d. C.

Debido a la falta de más datos arqueológicos, buscamos paralelos para la destrucción y abandono de esta estructura que muestra al menos dos fases de saqueo (primero el pavimento y otros elementos nobles, y posteriormente los sillares). En el foro municipal de Mérida, por ejemplo, este recinto en el siglo IV d. C. debía haber acusado una pérdida de su carácter sacro cuando se institucionaliza el Cristianismo y, en consecuencia, terminan por suprimirse los actos públicos que tradicionalmente allí se celebraban. La plaza, a diferencia de la del foro de la Colonia, no es lugar de reunión ni zona de paso, no acumula múltiples edificios oficiales, sino que encierra a un gran espacio abierto con un templo en el centro enmarcado por un pórtico. Éste repercute en el urbanismo al quedar abierto permanentemente al público, al igual que otros de carácter público atestiguados en la ciudad. A lo largo del siglo $\mathrm{V}$ d. C. los edificios terminan por ser aprovechados como cantera y su estado progresivamente expoliado sentó las bases para su completo desmantelamiento y posterior adecuación del espacio para su ocupación doméstica (MATEOS, 2006). Pensamos que esta descripción se ajusta a lo sucedido en Sagunto.

\subsubsection{El circo}

Respecto al circo saguntino, la proximidad entre el mismo y una gran conducción de agua es harto conocida; por ejemplo A. Delgado cita: (...) antiguo circo (...) por mí parte solo pude observar una dilatada pared de mortero romano, al lado de la cual corría una abundante acequia (...) (DELGADO, 1859:9)

Adjuntamos un resumen de la intervención más amplia realizada en el circo: (...) grandes avenidas lograron socavar el muro del Norte, derrumbándolo en toda su extensión. Consérvase todo el muro del Mediodía B, lamiendo sus cimientos la acequia de la villa. (...) Circuye todo el muro exterior del Circo una hilada de sillares, y sobre ellos todavía se levanta el coronamiento, que también es de tapiería de $1 \mathrm{~m} 40$ de altura (...) la porta triumphalis (...) hicimos excavar el terreno que la cubre dentro y fuera del edificio (...) Á la profundidad de $1 \mathrm{~m} 30$ aparece el pavimento de esta puerta, solado de grandes baldosas de piedra caliza azulada que se extienden hacia las segundas metas (...) el muro interior, enterrado por completo, era de tapiería, con una base de piedra azulada de mediano aparejo, corriendo por todo el Circo á una distancia de $3 \mathrm{~m} 60$ del exterior. Entre ambos, existen muros transversales (...) sobre ellos debió apoyarse la gradería de madera, puesto que no se ven rastros de bóvedas ni escalinatas (...) Exactamente en el mismo centro apareció el muro de la spina, enterrado á $1 \mathrm{~m} 20$ (...). 
Una capa de arena de 0m 40 de espesor cubría su base, lo mismo que en los demás puntos explorados, $y$ en el fondo gravas y cantos rodados cubren el suelo (...) Sobresale del muro exterior, hacia su extremo oriental, un conducto de cantería, y descubriendo todo su trayecto, vimos que desde el pavimento ó arena del Circo recorre todo el espacio comprendido por la gradería hasta desembocar en el río (...) (CHABRET, 1888:80-85)

La segunda excavación en la calle Obispo Miedes, del año 1988, confirma parte de esta información, en lo que respecta a las fases constructivas: La anchura total del euripus es de 4,35 m. (...) El sondeo ha barrido una zanja longitudinal de 70,3 m. que constata la anchura del edificio 73,3 m (...) confirmado la presencia de cimentaciones de apoyo de la cavea, con el sistema de muros paralelos y radiales formando celdas huecas, aunque no puede señalarse, debido al estado de arrasamiento la existencia de bóvedas (...) su construcción rompa el eje principal de circulación urbana en época alto imperial (HERNÁNDEZ, 1988: 126). Evidentemente este argumento ya no es valido, ya que existen varios ejemplos de puentes o viales asociados a edificios de espectáculos (por ejemplo: GROS, 1997, VENTURA, 1996 y CASTAGNOLI, 2003) que podrían tener la función de facilitar la afluencia al público de fuera o del extrarradio de la ciudad (ver Foto 202 y un paralelo en el dibujo $\underline{29}$. Si observamos la comparativa de circos en dimensiones máximas, podemos ver que las medidas del circo saguntino podemos comprobar que se trata de un circo de tamaño mediano

\begin{tabular}{|c|c|c|c|}
\hline & LONGITUD & & ANCHURA \\
\hline LEPTIS MAGNA - & 467,5 & - & 95 \\
\hline MÉRIDA - & 423 & - & 116 \\
\hline TARRAGONA - & 322 & - & 110 \\
\hline TOLEDO - & 421,1 & - & 100,8 \\
\hline CARTAGO - & 468 & - & 80 \\
\hline SAGUNTO - & 355 & - & 75 (290/300 y 73-según nosotros) \\
\hline SANTIAGO DO CACÉM & 380 & - & 81 \\
\hline CESÁREA - & 445 & & 91 \\
\hline GERASA - & 269 & - & 80 \\
\hline VÍA APIA - & 508 & - & 86 \\
\hline MILÁN - & 468 & - & 87 \\
\hline
\end{tabular}

(HUMPHREY, 1986:370)

A este listado podemos sumar dos circos detectados recientemente, aunque no excavados en su totalidad, sus medidas teóricas con $350 \times 70 \mathrm{~m}$ para el circo de Valencia (RIBERA, 2001) y 400 x 83m para el de Segóbriga (ABASCAL et al, 2008)

Respecto al circo, el análisis de las fotografías aéreas de la guerra civil de 1936 evidencian que es bastante más pequeño de lo que se suponía, nosotros creemos que 
una cifra cercana a los 300/290 x 73 metros sería más correcta (recordemos que las medidas son absolutamente teóricas, ya que ningún investigador pudo excavarlo o documentarlo en su totalidad) (ver Fotos 201 y 237). Por otro lado también comprobamos de una forma clara la existencia de estructuras posiblemente funerarias debajo del citado circo, por el análisis de la intervención arqueológica del año 1993 en la calle Huertos esquina calle del General Canino, mediante fotos conservadas en el Centro Arqueológico Saguntino, básicamente por su parecido total con las estructuras funerarias de la Morería (ver Foto 241). Lamentablemente esta intervención permanece inédita.

Como paralelo podemos citar que en la pared Sur del circo romano de Calahorra hay constancia de la existencia de una necrópolis aparecida al excavar la oficina del Insalud, fechable según U. Espinosa en los tres primeros siglos de nuestra era, pero que corresponde al interior del recinto del circo (CINCA, 1996). Así pues creemos que es fácil defender la hipótesis de que la construcción definitiva del circo saguntino se produce sobre una necrópolis anterior, que muy posiblemente la estructura del graderío sería de madera (por la total ausencia de restos de estructuras de caementicium asociables a esta funcionalidad) y que experimentaría una serie de reformas que indican que se repristinó o que quizá los envites del río hicieron necesarias varias reformas.

Observemos que, en aquellos circos donde las gradas no eran de madera y sí de caementicium, los restos conservados son muy distintos a los saguntinos (ver Fotos $\underline{243}, \underline{244}, \underline{245}, \underline{246}, \underline{247}, \underline{290}$ y $\underline{291}$ ), especialmente respecto a las bóvedas y arranque de las mismas. Así pues nos inclinamos por un exterior monumental, posiblemente recubierto de piedra (ver Fotos 236 y 238) o mármol, de la misma forma que la spina (ver Foto 239), sin descartar posibles reformas en épocas posteriores, donde se usó ladrillo (ver Foto 242) o piedras no trabajadas (ver Foto 240).

En Calahorra tenemos un paralelo con un circo de 375 × 80 metros (medición teórica) formado por muro de opus caementicium asentados sobre tres hiladas de vittatum con agujeros para la madera del graderío, según (CINCA, 1996). El mismo autor también cita el circo de Toledo, donde el maenianum summun es de madera y el maenianum primum es de obra de fábrica.

\subsubsection{El teatro}

El teatro romano saguntino fue durante siglos la obra romana mas aparente de la ciudad, tanto por su ubicación en la falda de la montaña que lo hacía muy visible, como 
por su estado de conservación. Si seguimos la opinión de varios autores, ya los musulmanes citaban la existencia del teatro como "palacio" (HERNÁNDEZ, 1989 y ARANEGUI, 2004 ), desde muy temprano ha sido objeto de expolio, pero no empieza a verse verdaderamente afectado hasta el siglo XIX (ver Fotos 249, $\underline{595}$ y dibujo $\underline{52}$ ), cuando sufre constantes destrucciones en las distintas contiendas bélicas por su valor estratégico junto al castillo, entonces aún podía apreciarse la adaptación del edificio a la pendiente de la montaña (ver Foto $\underline{250}$ ); esto acaba culminando con la construcción de un muro perimetral de protección a cargo de la Real Academia de la Historia los primeros proyectos de restauración a principio del siglo $\mathrm{XX}$; y también en este siglo sufre otro episodio de destrucción mediante los bombardeos de la guerra civil, que también castigaron a las excavaciones del castillo (ver Foto $\underline{311}$ de los restos en los años 30), que afectaron profundamente el monumento (MELCHOR, 2008) y obligaron a una serie de obras escasamente documentadas que culminaron en 1979 con el primer estudio serio para su restauración (ALMAGRO, 1979); y finalmente el monumento fue desvirtuado con la desacertada reconstrucción en los años 90 del siglo XX.

Pasaremos por alto los innumerables estudios sobre el teatro, desde época medieval y moderna; fruto de estos se produjeron abundantes teorías, sobre el origen griego de la obra, su cronología, sus constructores, etc., pero fue analizado con mas detenimiento desde final del siglo XVIII por personajes como Conyngham, Martí, Palos, pasando por innumerables eruditos y arqueólogos hasta llegar al ultimo estudio de C. Aranegui (ARANEGUI, HERNANDÉZ y PASCUAL, 1993), fruto de la única excavación realizada en el monumento, con motivo de la reconstrucción del mismo, intervención que curiosamente se llevó a cabo después de la redacción del proyecto (PORTACELLI, 1993), y no de forma previa como hubiera sido deseable, ya que gracias a los hallazgos se pudo restituir hipotéticamente toda la frons scenae, cosa no que era posible cuando se publicó el estudio sobre el teatro (HERNANDEZ, 1989).

La reconstrucción actual del teatro poco o nada tiene que ver con la estructura original de la escena, pues los datos sobre la misma solo se dieron a conocer con la obra ya en marcha; y aun así existen algunos puntos que no quedan bastante claros en la interpretación propuesta, especialmente respecto a la cloaca que se conserva a la altura de los viandantes y a las estructuras situadas detrás del cierre de la escena.

De la abundante documentación gráfica conservada sobre el teatro desde el siglo XVII podemos observar la lenta evolución del monumento hacia su degradación, pero también algunos detalles interesantes. La obra se adapta a la falda de la montaña, con su gradería excavada en la roca y la escena adaptada a la pendiente del monte. Si bien este sistema es claramente perceptible, no existe un propuesta que soluciones el tema de los accesos desde la población. En los grabados mas antiguos podemos observar algunos indicios de ruinas dispersas frente al teatro como los de Wijngaerde (MATEU y PALOMAR, 1990) o Laborde (DE LABORDE, 1811) y posteriormente algunas casas 
acaban adosándose a la parte baja del muro de la base del escenario. Ya en algunas de las primeras fotos de final del siglo XIX observamos como el muro levantado por la Real Academia engloba el teatro y una serie de muros y pavimentos situados donde antes estaban las casas; en otras de las fotos apreciamos también la distribución del terreno y de las casas del alrededor que presentan una forma relativamente regular(ver Fotos $\underline{596}$ y $\underline{597}$ ), cuyos restos mutilados a final del siglo XIX, desaparecieron completamente en el siglo XX.. Todo este conjunto se vio profundamente alterado con el derribo del muro de cierre y la reforma del camino de acceso, que junto a la construcción del museo llevó a la configuración que presenta actualmente la zona.

Nosotros proponemos que los restos que se observan en la documentación antigua son los indicios de la existencia de de lo que podría ser un pórtico post scaenam con un criptopórtico cuyos restos mutilados a final del siglo XIX, desaparecieron completamente en el siglo XX. Ésta era la demostración de cómo se adaptaba el inmueble y el acceso al mismo mediante terrazas, como podemos observar en otros teatros construidos en pendientes. Esta propuesta además solucionaría la cuestión que había quedado irresuelta con la hipótesis actual, ya que la cloaca que recoge el agua de dentro de teatro desembocaba al aire libre en plena pendiente. En este caso desembocaría en un criptopórtico que almacenaría y redistribuiría los vertidos a una red de cloacas. La citada estructura subterránea sería la base de una terraza que ejercería de pórtico post scaenam, pero además nivelaría y regularizaría la pendiente de la montaña junto a las entradas del teatro. Es muy probable que el acceso a este pórtico se realizara mediante escalinatas, pues el acceso del trafico rodado a la cima del castillo y a las cotas mas altas de la ladera donde se encuentra el teatro sin duda era muy diferente desde el siglo XIX a lo que fue en época romana. La demostración de cómo se adaptaba el edificio y el acceso al mismo mediante terrazas, la podemos observar en otros teatros (RAMALLO, 2000) (ver Fotos $\underline{253}, \underline{255}, \underline{256}$ y $\underline{257}$ ).

\subsubsection{La domus del solar de la Lira Musical}

Respecto a las estructuras descubiertas en 1956 durante las obras del edificio de la Lira Musical saguntina y anteriormente en el mercado municipal en 1953, es algo más complejo asociarlas a una funcionalidad, básicamente porque nos encontramos ante una ausencia total de documentación. No existen planos conocidos de las excavaciones, sólo un croquis muy sencillo (ver Dibujo $\underline{38}$ ) y las siguientes descripciones: (...) una profundidad de dos metros (...) se tropezó con un pavimento, de grandes dimensiones y con elementos decorativos figurados. (VALL DE PLA, 1961: 154) (...) algo menos de la mitad del pavimento, que era lo único que quedaba pues el resto desapareció, hace ya muchos años al construirse la acequia (...) Sobre la 
superficie que ocupa, aparecen también unas cimentaciones antiguas de fin no definido (...) dos piedras con cantos labrados, de color azulado han aparecido en esta pequeña excavación, así como dos fragmentos insignificantes de cerámica medieval (...) (BRU I VIDAL, 1953:s. p.)

A esta información solo podemos sumar un dibujo del propio mosaico de 1953 (ver Dibujo 39) y quizá pensar que la referencia a aquellos muros antiguos que obstaculizan el centro del mosaico podrían ser los restos de una fase de reutilización y compartimentación del siglo III d. C. (como en la Morería), o tal vez de época Medieval.

Sobre el cercano mosaico del castigo de Dirce algunos autores apuntan a que sufre la destrucción en el emblema central fruto de la construcción de una pequeña fuente y no debido a un acto intencionado; se indica que en el nivel superior al de los pavimentos se encontró una tumba individual atribuible a un siglo IV avanzado (sic) y que el mosaico floral y el opus sectile aparecen con numerosas reparaciones (VALL DE PLA, 1961). En el aspecto arqueológico sólo tenemos una nota: (...) dejado al descubierto una serie de cimentaciones, pavimentos de grandes losas de piedra azulada del país, quicialeras y corredores que hacen pensar en una antigua villa (...) (BRU, 21/10/1956).

Lamentablemente excavaciones más recientes aportan informaciones contradictorias, como la de P. Sánchez y E. Hernández, donde las estructuras del siglo XIII están en un nivel sobre los 2 metros de profundidad (cuando a esa profundidad debería aparecer el nivel romano) (HERNÁNDEZ y SÁNCHEZ, 1999), o las recientes excavaciones en la Glorieta, donde los restos romanos aparecidos son de muy poca entidad (VALOR, 2009). Quizá la diferencia la tengamos en los cambios en la zona durante época medieval y moderna, pues podemos apreciar en fotos antiguas que el espacio donde se construiría el edificio de la Lira Saguntina corresponde al patio del convento de San Francisco, mientras que las restantes excavaciones se han realizado en zonas más urbanizadas (ver Foto 312).

Al intentar restituir los hallazgos por medio de fotos antiguas observamos algunos datos interesantes; el primero era que ya existía una balsa asociada al pavimento de Dirce (ver Foto $\underline{315}$ ), con lo cual no tiene sentido una fuente central. Además esta alberca no se encuentra en posición medular, como sería de esperar en el impluvium de una domus. Seguidamente durante el desmonte total de las cimentaciones, advertimos la presencia de sillares y columnas (ver Fotos $\underline{316}$ y $\underline{317}$ ), de la misma forma podemos detectar la existencia de una gran balsa o depósito (ver Fotos $\underline{320}$ y $\underline{321}$ ) junto a otras estancias (ver Fotos $\underline{314}$ y $\underline{319}$ ). Finalmente, respecto a la estratigrafía, vemos la presencia de un posible umbral que da acceso a la habitación del mosaico de Dirce, la posición de los muros medievales y modernos respecto a los que delimitan las habitaciones romanas (ver Foto $\underline{313}$, detrás del grupo) y la presencia de un muro que quizá pudiera indicar una concameratio (ver Foto $\underline{318}$ ). Por supuesto no hace falta señalar que todas estas fotos (conservadas en el Centro Arqueológico Saguntino) nos 
permiten ubicar perfectamente los tres mosaicos recuperados (dos sectilia y el de Dirce) en su contexto espacial.

Así pues, con el análisis de estos documentos gráficos nos encontramos ante la hipótesis de un gran edificio con peristilo y una gran cisterna, al que debemos sumar algunos indicios muy tenues de una probable concameratio y una balsa asociada al mosaico de Dirce; en las fotos también encontramos la disposición de las salas alrededor de un patio y la aparición de un umbral y de restos de columnas. Únicamente no podemos saber dónde se situarían las "losas de piedra azul" que cita S. Bru en su nota en el periódico Las Provincias, pero probablemente fueran el enlosado de una vía. La única hipótesis por el momento es que coincidieran con los extremos Este u Oeste del solar, ya que las fotos no dejan otra opción (ver Lámina $\underline{\mathrm{XXI}}$ ).

Solamente con los restos observados no podemos afirmar que nos encontremos ante unas termas de carácter excepcional; esta hipótesis sólo puede sostenerse si pensamos que, como éstas, la mayor parte de las construcciones del siglo II $\mathrm{d}$. C. son de carácter monumental o público (ver Lámina $\underline{\mathrm{XIX}}$ ); de no ser así nos podemos encontrar ante una casa de lujo dentro de una insula, y sería la primera estructura privada excavada en la zona de esta ampliación de la urbe. Por lo demás, la datación de los mosaicos y su abandono es similar a la evolución cronológica de la Morería, inclusive con la presencia de inhumaciones tardías, como en la citada excavación, ya que creemos que en la época del descubrimiento se atribuyeron a un siglo IV avanzado (VALL DE PLA, 1961) bien puede corresponder en realidad al siglo $V$ d. C. Si observamos la estratigrafía, ésta coincidiría con la de la Morería, en el sentido de que encima de los elementos romanos existe una importante capa de tierra sobre la que están los restos medievales, que raramente contactan de forma directa con las estructuras de pavimento más antiguas (recordemos los muros musulmanes o medievales sobre la calzada de la Morería).

\subsubsection{Las necrópolis}

Como parte importante de esta gran reforma del siglo II d. C. constatamos un substancial cambio registrado en las necrópolis, que va desde el cambio de emplazamiento hasta el arrasamiento de tumbas, creando dos fases de uso. En el registro de los usos funerarios en Sagunto (ver Lámina $\underline{\mathrm{XI}}$ ) y Valencia tenemos claros paralelos en los dos casos: la anulación completa de un espacio mortuorio, su desplazamiento y la superposición de distintos períodos, en este caso con la anulación de las construcciones anteriores al siglo II d. C. Debemos tener en cuenta que la 
asociación entre zonas suburbanas y cementerios está significativamente documentada a partir del siglo II a. C. (RODRÍGUEZ, 1992).

Es probable que los recintos funerarios del sector Norte de Sagunto se vean desplazados a otro punto aún más al Norte; un indicio podrían ser los enterramientos del siglo II o III d. C. encontrados por F. Roca: En el cruce del antiguo Camí de Terol -vía romana a Teruel- con la carretera de Petrés (...) fueron descubiertas dos tumbas romanas, al parecer, de época muy avanzada (...). En la otra, cuya posición era perpendicular al camino de Teruel, mitad dentro de la finca y mitad debajo de dicha vía, tuvimos más suerte que en la anterior, al poder localizar los restos de un varón y de una mujer con un niño (ROCA, 1977:24).

En Valentia puede que se haya dado un caso similar, ya que en la calle Serranos 26 detectamos una necrópolis republicana sin aparente continuidad. La fase romana del Bajo Imperio presenta una destacada ausencia de restos constructivos. Únicamente se detectó un nivel de tierra de textura arenosa y color beige con fragmentos cerámicos y algunos elementos arquitectónicos, así como una fosa circular rellenada de tierra de textura arenosa y de color verdoso y beige. Durante la fase romana del Alto Imperio la ausencia de cimentaciones es muy similar, con la excepción de un canal de mampostería enlucido con mortero de cal (UE 1016 - ver Fotos $\underline{388}$ y $\underline{389}$ ) rellenado con material cerámico en su sector Este. En el caso de unas piedras posiblemente alineadas (UE 1022) con escasas cerámicas asociadas, estaban demasiado alteradas como para que podamos afirmar que se trataba del cimiento de un muro. A estos hallazgos podemos añadir tres fosas (UE 1024, 1025 y 1034) con escasos fragmentos cerámicos y abundantes restos constructivos y pintura mural. También es destacable la variedad de niveles: desde un nivel de tierra marrón, con poca cerámica y huesos, un relleno de tierra arcillosa parda oscura con bastante material cerámico en su sector Sur, restos de grava, un nivel verdoso y un estrato de textura arcillosa y color pardo claro con escasa loza. La poca entidad de los hallazgos aparentemente apunta a una zona escasamente habitada, entre los fragmentos utilizados para datar estos niveles, destacamos la TS Africana A, cerámica africana forma Ostia I, 262 y 263. En el sector Sur se documentó la única estructura romana, un canal de desagüe o de conducción de aguas, dentro del cual se recuperaron abundantes fragmentos de una Drag. 37 de TSH.

Durante la fase republicana el panorama es muy distinto a las épocas posteriores; destacamos dos grandes habitáculos subterráneos, aunque ambos muy arrasados. Uno de sección rectangular con abundante carbón y restos de adobe (UE 1027) y parte de un preparado o pavimento de gravas de forma rectangular (UE 1037 - ver Foto $\underline{386}$ ), así como carbones, cenizas y fragmentos de adobe. Otro enlucido (UE 1040), con pintura mural negra (ver Foto $\underline{385}$ y un paralelo interesante en la Foto $\underline{348}$ ) y con zanja de cimentación (ver Foto $\underline{387}$ ). No descartamos que pudieran tratarse de tumbas de 
tipo hipogeo, como se han documentado en otras necrópolis valencianas de este periodo. Lamentablemente la intervención únicamente ha proporcionado para este periodo escasos fragmentos de cerámica revuelta y material de arrastre de fosas de época musulmana que presenta una cronología situada entre la época republicana y la ibérica, destacamos una base de plato de Campaniense A, fragmentos de cerámica de engobe rojo pompeyano y ánfora de la Campania. No se ha encontrado una estratigrafía más precisa ni una seriación temporal en los escasos materiales registrados, pues las estructuras aparecían arrasadas casi en su totalidad. A falta de posteriores estudios o de la excavación del margen de seguridad, establecemos una cronología Republicana para estos posibles hipogeos.

Asociadas a los mismos encontramos restos de hogueras con rubefacción e indicios de adobes de forma rectangular (UE 1035 y 1044 - ver Foto $\underline{390}$ ), hemisférica (UE 1043) o indeterminada debido a su estado de arrasamiento (UE 1038, 1048 y 1049). Debido a su situación alterada no pudimos delimitar completamente los restos de un preparado o pavimento de gravas de forma rectangular (UE 1042) en posición simétrica a UE 1037 , sobre el cual había carbones, cenizas y restos de adobe.

El nivel pre-estéril estaba afectado por los estratos de época anterior, correspondiendo a un periodo que no hemos podido determinar por la escasez de restos recuperados y que llamaremos ante republicano, nos referimos a varios fragmentos de cerámica ibérica, gris ampuritana y alguno fragmento de cerámica ática. Únicamente se observaron restos de una mancha de cenizas de forma hemisférica (UE 1050), con escasos restos cerámicos, excavada sobre el nivel estéril de tierra arenosa de color amarillento (ver Láminas $\underline{\mathrm{IV}}$ y $\underline{\mathrm{V}}$ ).

Existen algunos ejemplos de zonas funerarias muy cercanas a las villas extraurbanas; en Mérida está el caso de la convivencia entre la conocida Casa del Mitreo con habitaciones fechadas en el siglo II d. C., y los edificios funerarios de los Columbarios, de la $2^{a}$ mitad del siglo I d. C. (BENDALA, 1976). Un caso similar es el de la domus de Santa Eulalia (CABALLERO y MATEOS, 1991) muy próxima al área funeraria de la estación de trenes, o la documentada durante la excavación en 1993 en solar de la avenida de la Rambla 22, muy próxima a la Puerta de la Villa. Con todo ello, además, se confirma la inexistencia del supuesto cinturón funerario emeritense (BENDALA, 1976), similar al lo que se pensaba para Sagunto. Esta idea no debe aplicarse no sólo al caso concreto de Mérida o Sagunto, sino a ninguna ciudad romana. En el ejemplo que nos ocupa esta configuración errónea del paisaje suburbano lo provoca el hecho de no haber realizado un estudio diferencial de las cronologías de los distintos espacios funerarios. Las áreas más próximas a la ciudad en torno a las vías, por cuestiones de economía de esfuerzo y de propaganda, se saturan en los primeros siglos, quedando libres los espacios intermedios que, poco a poco, se llenarán con enterramientos en momentos posteriores, contribuyendo a crear así la sensación de un verdadero cerco 
de estructuras funerarias. El lugar funerario es sacro, puesto que es la morada de los manes, y cada tumba es un templo en su propio espacio, ya que no sacraliza el terreno colindante. Esto explicaría la coexistencia de diversos usos compartiendo un mismo sitio, como la arquitectura doméstica o de instalaciones industriales (MÁRQUEZ, 2000).

Las propias necrópolis saguntinas y valencianas se ven afectadas, no sólo por su anulación propiamente dicha en el siglo II d. C., sino por que aquéllas que manteniendo su función se encontraban con una importante densificación, ven esta condición aliviada por una destrucción y reutilización de monumentos que reabre espacios anteriormente ocupados en zonas preferenciales junto a la salida de las ciudades y en primera línea de la vías, hecho que hemos documentado en la vía Augusta al Sur de Valencia, en la Morería de Sagunto y por A. Chabret en la necrópolis de la vía Augusta de la misma ciudad. Los de este último se ubican en: (...) camino dels Rolls, que arrancando del borde izquierdo de la carretera de Castellón á Valencia terminaba en otro camino denominado (...) Cami vell de Valencia, que corre paralelo á la moderna calzada, á unos $400 \mathrm{~m}$. hacia el $E$ (...) salieron á luz algunos grandes bronces imperiales pertenecientes á Trajano, Antonino Pío, Claudio, Faustina, algunas saguntinas del tiempo de Tiberio (...)encontrado á continuación un centenar de sepulturas individuales arregladas en fila, una tras otra, formadas por anchas tegulae puestas de canto (...) (CHABRET, 1897: 458)

Sin embargo, otra de las evidencias acerca de la existencia de al menos dos fases de uso de la necrópolis, es la reutilización de lápidas: (...) otra generación aprovechó la lápida y esculpió nueva inscripción sepulcral en el reverso (...) tumbas que pertenecen unas a la época de la incineración y a la de enterramiento (...) monedas encontradas aquí son (...) Segobriga, Bilbilis, Caesaraugusta, Valentia, Tarraco, etc. (CHABRET, 1897b: s. p.)

Comprobamos que en las descripciones del autor existe una clara mezcla de distintos tipos de restos. Si en el apartado anterior es evidente que nos encontramos ante una necrópolis, en otros casos la adscripción funcional es cuanto menos dudosa: (...) sillares bien labrados y aislados aquí y acullá, y parte de un muro de sillería cuya altura de 0,30 m. tenía la extensión de $8 \mathrm{~m}$. con dirección de E. á O. En el centro de este muro sobresalía una basa de 2,25 x 1,35 m., retirada $0,15 \mathrm{~m}$. del muro que la sustentaba, el cual conservaba huellas de haber estado en otro tiempo adosadas á él algunas gradas (...) (CHABRET, 1897: 463)

Por último tenemos una franja cuya descripción hace muy difícil pensar en una zona tumular, si bien tampoco queda clara su funcionalidad: (...) pequeña acequia, entre cuyos muros se distingue uno de sillería indudablemente de época romana. En las inmediaciones de este muro (...) aparecieron restos de una tumba (...) de grandes sillares de un labrado bastante grosero, encontrose una cámara sepulcral compuesta de dos bloques de 9,95 X 0,80 m. y 0,30 m. de espesor, puestos de canto y en 
dirección paralela, con una separación de 0,59 m. Que venían á encajar en otros dos sillares perpendiculares á éstos en una ranura que abrazaba todo su espesor. Todo había sido aquí profanado: ni las lajas que cubrirían el sarcófago, ni restos del esqueleto se han conservado (...) la última excavación puso de manifiesto fragmentos de varias tinajas enormes, á juzgar por el espesor de sus paredes, y un alfarje de piedra de moler aceitunas (...) Restos de muros de argamasa de más de $1 \mathrm{~m}$. de espesor (...) debieron estar enterrados en su mayor parte á una profundidad de más de $2 \mathrm{~m}$. El arranque de una bóveda que se conservaba en uno de ellos (...) (CHABRET, 1897:464-466)

Es evidente que el autor excavó en dos zona distintas, por un lado una necrópolis del siglo I d. C. (por el profuso monetario de la época y la aparición de urnas de vidrio, ungüentarios, etc. así como por la ausencia de ladrillos cuyo uso masivo no se documenta en Hispania hasta época flavia, alrededor del año 80 d. C.), que tiene una segunda fase a partir del siglo II o III d. C. ejemplificada por la presencia de abundante inhumaciones; y, por otro, una zona urbana con abundantes elementos monumentales. Es especialmente interesante la cita respecto a los dos metros de profundidad, donde aparecen los restos romanos del periodo de monumentalización. La característica urbana de esta franja viene claramente marcada por la aparición de otros restos de tipo doméstico, como por ejemplo en 1959: (...) próximo al lugar en que se encontrara en 1745 el "Mosaico de Baco", bajo una capa de tierra de un metro de espesor, formada por derrubios de otras edificaciones, se localizaron los restos de otros dos pavimentos de "opus sectile" (...) apareció otro pavimento de "opus sectile"; que en las obras para construir la estación del Ferrocarril, al ahondar para hacer el pozo de la placa giratoria, se encontraron muchas teselas sueltas y algunos trozos de mosaico, y que, al hacer los cimientos de las casas en la actual Avenida del Generalísimo, así como al realizar las obras de desviación de la carretera general de Valencia a Barcelona, en la misma zona, se encontraron fragmentos de pavimentos teselados (...) (VALL DE PLA, 1961:150)

Uno de estos pavimentos es el ajedrezado que apareció en una zanja de telefónica (ver Lámina XLIV). A estos hallazgos debemos sumar las recientes excavaciones en la avenida del País Valenciano (antigua del Generalísimo), donde aparecen una vía enlosada y habitaciones adyacentes. Una excavación del año 1986 ayuda a corroborar nuestra interpretación, pues se aprecia en ella que el trazado del actual Camí Vell de la Mar (bajo el cual aparecen las inhumaciones - ver Foto 472), no corresponde, por motivos obvios, exactamente con el trazado de la vía romana, aunque el enlosado señalaría el cruce con la vía Augusta:(...) enterramiento en una zona bastante marginal del centro de la necrópolis (más próxima a la ciudad) relacionado, tal vez, con la vía que conduciría desde la ciudad hasta la zona del puerto, de la que pudieran formar parte los restos de enlosado que se apreciaban al inicio de la zanja de alcantarillado y 
que no fueron excavados. Cronológicamente el conjunto se situaría, por el material aparecido, en torno al s. II-III d. C. (RIPOLLES, 1990: 191)

A. Chabret describe otro monumento funerario, relacionado con la zona de la Morería: (...) calle Real 129, se descubrió en 1886 una inscripción (...): Viventes fecerunt Cnaeus Baebius Eros Chilonianus, Oppia Montana uxor, in suis horteis siti sunt. Hoc monumentum haeredes non sequetur. In fronte pedes $X X$, in agro pedes $X X$. Se encontró en calle Real, número 121, (...) pudimos ver á 1 metro de profundidad los muros que formaban la cámara sepulcral, con fustes de columna rotos, trozos de ungüentarios de vidrio, etc. (CHABRET, 1888: 93)

Otro ejemplo mortuorio en esta zona lo tendríamos en el descubrimiento en 1963, en la antigua fabrica de conservas de la calle Almenara, de un plato imitación de la forma Ritt 5 de época de Tiberio-Claudio, con un grafito que indicaría su adscripción funeraria o votiva a la diosa Venus; el autor fecha la pieza por paleografía en el final del siglo I d. C. (CORELL, 1989). Finalmente tenemos otro posible caso de superposición de enterramientos en el Sur del castillo (lo que a su vez refuerza su ubicación como limite de la ciudad) en este caso descrito por F. Roca: (...) apareció parte de la antigua vía romana, conocida por el Camí de Lliria -(...) a ambos lados de la vía pudimos localizar hasta once tumbas de época romana, nueve de ellas en urnas cinerarias (...) enterrado fuera de la cripta, un esqueleto completo, cuya cabeza estaba colocada en una muesca hecha sobre el borde de la pieza lateral, donde descansa la tapa de dicha tumba, de forma que tan sólo la cabeza quedaba dentro, y el resto del cuerpo, en el exterior, guardaba una posición en sentido oblicuo a la susodicha cripta. $A$ unos dos metros de ésta había otro esqueleto en la misma posición que el anterior, no encontrándose ningún ajuar ni otros objetos (ROCA, 1977: 25).

Un interesante paralelo de superposición de enterramientos junto a la vía Augusta lo detectamos en la ciudad de Valentia lo encontramos en una excavación realizada por nosotros en el año 2002 en la calle San Vicente de Valencia en los solares 26 a 32 (SEGUí et alii, 2003 y BENEDITO et alii, 2007). El primer momento de ocupación en el solar corresponde a unos escasos indicios, concretamente algunas bolsadas de gravas, cimentaciones o posibles niveles de ocupación que aparecen por debajo de las incineraciones e inhumaciones romanas. Estos enterramientos ocupan una estrecha franja paralela a la actual calle San Vicente delimitada por muros fuera de los cuales se hallaban zonas de vertido lo que indicaría la existencia de una delimitación intencionada de este espacio de forma paralela a la vía Augusta (ver Láminas $\underline{\text { VI, }} \underline{\text { VII y }}$ $\underline{V I I I)}$. El aspecto más interesante no es el número de individuos hallados (diez), sino la variedad documentada en los rituales de enterramiento (cremación, bustum, inhumación en fosa, inhumación en tegulae, en cajas de madera, en ánfora y, por último, bajo cubierta de adobes), circunstancia que parece evidenciar una larga 
pervivencia acompañada de superposición entre enterramientos, incluida la reutilización de materiales.

El acondicionamiento de la superficie del terreno que consistiría en elevar la zona de paso de la franja paralela a la vía Augusta con la extracción de tierras del espacio inmediato. Podemos suponer la existencia de un primer momento de utilización de la necrópolis entre el I y II d. C., con varias incineraciones y una inhumación infantil.

Una segunda fase aprovecha la destrucción de los enterramientos anteriores para volver a ocupar el mismo espacio, esta vez exclusivamente con inhumaciones. Es significativa la presencia de fragmentos de lápidas de época del Alto Imperio en la fosa de la inhumación UE 1202. Esta inhumación se fecha gracias a la lucerna que apareció in situ bajo el brazo izquierdo del cadáver, tipo Dressel 28 del siglo IV d. C. No obstante, esta fase es más difícil de datar en el resto del solar debido a la falta de materiales. Sólo en la UE 1190 apareció una moneda fustra. La saturación del área próxima a la vía Augusta hace que se sepulten individuos fuera del espacio principal, como sucede con el enterramiento en ánfora africana o el que se encontraba en una sepultura con cubierta de adobes.

Las referencias históricas sobre la topografía del terreno en esta parte de la ciudad describen una zona fácilmente inundable y llana, sin entrar en matices más concretos sobre su función como zona de marjal o pastoreo. La propia estratigrafía del solar parece confirmar este hecho, ya que nos encontramos con abundantes bolsadas de gravas y arenas provenientes de posibles crecidas del río. De esta manera, es viable que ya en época romana se hubiesen realizado algunas obras destinadas a rellenar para elevar el terreno y a construir muros limítrofes de contención. Junto a este espacio se ubica la vía Augusta, que aparece rodeada por toda una serie de enterramientos.

Una vez ya analizados algunos ejemplos de estos cambios funerarios, nos encontramos ante una importante cuestión interpretativa. En primer lugar no vamos a abundar en el tema de la sacralidad del espacio funerario y en las responsabilidades que debería asumir el régimen, como por ejemplo las competencias del gobernador de la provincia para que no se afrente a los cadáveres o huesos de los muertos, o para que sean enterrados (Dig. 11, 7, 38). Pero la verdadera problemática surge con el tema de los enterramientos, si bien es abundante el tema de los traslados autorizados:

(Dig. 11, 7, 8). Se discute si es lícito al dueño del suelo desenterrar o echar fuera los huesos o el cadáver, que por otro fueron enterrados, sin el decreto de los pontífices o sin mandato del príncipe (...) debe esperarse se conceda el permiso (...) de otro modo se ejercitaría la acción de injurias contra el que los desenterró. 
39. Previnieron por un edicto los emperadores hermanos [Marco Aurelio y Lucio Vero] que no se remueve el cadáver enterrado en sepultura legítima, es decir, depositado en la tierra (...) circunstancias lo requieren no se debe negar la licitud del traslado de la misma caja a lugar más conveniente.

44. (1) Pero cuando se consigue permiso para trasladar los restos, el suelo deja de ser religioso.

El tema sería fácilmente comprensible si los enterramientos hubieran sido trasladados, pero éste no es el caso ya que algunos permanecían in situ y fueron recuperados en nuestra intervención de la Morería y, de la misma forma, en los casos en que aparecen superposiciones de enterramientos en distintas necrópolis. Aún teniendo en cuenta la referencia a monumentos funerarios que aún no fueran sacros:

(Dig. 11,7, 1.) (5) «Sepulcro» es el lugar donde están depositados el cuerpo o los huesos de un hombre. Pero (...) no es religioso todo el suelo que fue destinado a sepultara sino sólo el sitio en que fue inhumado el cuerpo. (6) Es "monumento» lo que se destina a conservar la memoria de una persona.

Siendo así parece invalidada la cuestión respecto a la desacralización del terreno, sea por traslado o porque no hay enterramiento. Estas leyes implican severas restricciones al uso del espacio y de los materiales o la compra-venta de los terrenos, aunque debemos tener en cuenta que la legislación romana aparentemente es contradictoria, ya que si por un lado impide el comercio de lugares sagrados, por otro deja implícito que alguien pudiera perder sus sepulcros:

(Dig. 6, 1, 34). (...) si ha de reintegrar el gasto, va a quedar privado del hogar y los sepulcros de sus antepasados (...)

Evidentemente somos conscientes de la limitación de la legislación como fuente histórica para interpretar hechos arqueológicos, pues podríamos pensar que, en el caso de la Morería "oficialmente" se pudo haber procedido al traslado de los cadáveres para desacralizar el terreno, cuando en verdad esto no se produjo. La complejidad de la cuestión es mayor si tenemos en cuenta que el nuevo uso de los terrenos no es sólo religioso (templos o necrópolis "remozadas"), sino que también se construyen edificios públicos como circos o anfiteatros sobre los enterramientos. 


\subsection{SERVICIOS PÚBLICOS DE AGUA Y DESAGÜES}

Una de las primeras referencias al acueducto de la parte alta de la ciudad romana de Sagunto, que aún se apreciaba a principio del siglo XX (ver Foto $\underline{4}$ y dibujo 1), lo citaba E. Palos: En la circunferencia del monte nombrado de la fuente de Santa Ana se reconocen varios trosos de una acequia o conducto antiguo para proporcionar agua a la parte superior de la ciudad pues dentro de ella siguiendo un nivel se encuentran pedazos de la misma acequia denominada de los Romanos (...)(PALOS, 1804: s. p.).

Y posteriormente A. Chabret también menciona el citado acueducto: Empezaba en la partida denominada de Figueroles, á dos kilómetros de la ciudad en donde se observan restos del muro del conducto, de durísimo hormigón, con una elevación de $2 m$ por $0,50 \mathrm{~m}$ de ancho. Es probable que al atravesar el barranco que forma actualmente el camino de la travesa, hubiera necesidad de algunos arcos que han desaparecido: el espacio que resta hasta la ciudad, lo recorre por la falda NO del monte (CHABRET, 1888: 114)

N. P. Gómez Serrano describe parte del trazado de un acueducto o de dos ramales del mismo; el llamado Acueducto de El Canet de Albalat de Segart (ver Foto 2), en el lecho del Palancia, aguas arriba del puente de entrada a Albalat, a la derecha del río y después de las ultimas casas del pueblo, donde había un canal de opus caementicium de unos $75 \mathrm{~cm}$ de diámetro que cruzaba el río a nivel. Estaba muy arrasado y lo que restaba del mismo estaba empotrado en un muro de un bancal (GÓMEZ SERRANO, 1961). El autor lo cita como perteneciente al mismo acueducto que aparece en Sagunto junto a la vía del ferrocarril de Aragón y al NE de la montaña del Castillo, junto al camino de Gilet, y que se perdía en la calle de Marià Mestre. Tendría la misma técnica constructiva y diámetro que el de Albalat y estaría recubierto de opus signinum. Además publica una foto del mismo en la calle Dos de Mayo, llamado por los vecinos la séquia del Moro (GÓMEZ SERRANO, 1961) (ver Foto 1)

La investigación indica que los castella aquae o castella dividicula están en una posición más alta que el resto de la ciudad, eran grandes torres con amplias piscinas 
interiores (ver Dibujo $\underline{3}$ ) que recibían el agua directamente de los acueductos o con piscinas limarias. En Pompeya estaba dividido en tres partes; una para las fuentes, otra para las termas y la tercera de uso doméstico. En otros lugares el agua llegaba directamente a espaciosas cisternas que la suministraban a grandes conjuntos termales (REMOLÀ y RUIZ DE ARBULO, 2002). Desde los depósitos ésta se distribuía a los edificios públicos como las termas, piscinas de recintos sagrados, jardines, surtidores ornamentales, letrinas y a las múltiples fuentes dispersas por la población. En Mérida una piscina limaria y el frontal de un castellum aquae fueron recuperados en los años 60 y 70, emplazados en el recinto conocido como casa del Anfiteatro y en el cerro del Calvario, con una fuente monumental en fachada que ha sido identificada como un ninfeo (BARRIENTOS, 1998). En esa ciudad las calles adaptadas a las laderas conforman la topografía, a modo de un peine, en ejes perpendiculares que aprovechan la caída natural del terreno hacia el río Guadiana con fuentes consecutivas conectadas, provistas de depósitos con rebosadero para asistir al siguiente punto de acopio y derivaciones a ciertos particulares (ALBA, 2001) (ver Dibujo 2). Éste podría ser un caso similar al de Sagunto, donde los acueductos serían los ejes paralelos a las curvas de nivel; además es evidente que la ciudad necesitaría al menos un castellum aquae por cada acueducto.

Con la expansión de la ciudad también es probable que se hiciera un sistema nuevo de suministro y evacuación de agua. Hasta el momento solamente se ha localizado en Sagunto una posible estructura hidráulica de abastecimiento de agua, que es la que recorre la parte alta de la población y que cumple todos las características canónicas de un acueducto romano (la zona del castillo posiblemente fuera alimentada por una serie de aljibes como el que existe en el foro a forma de criptopórtico). Este posiblemente sería anterior a la monumentalización del siglo II d. C.

A la vista de la importante expansión de la ciudad romana es evidente la necesidad de la ampliación del sistema de suministro hidráulico. Existe una alineación urbanística indudable en la parte interior de la muralla de la ciudad, lo que podría ser debido a que se adosaran edificios a la estructura defensiva, no sólo en su parte exterior, sino también en su interior. Por otro lado, aprovechando la pérdida de función del paso de ronda o muro, es muy probable que se construyera un segundo acueducto que pudiera suministrar agua a toda la zona situada al Norte la ciudad. Recordemos que estas canalizaciones se adaptan fácilmente a los lienzos militares (ver Foto $\underline{404}$ ).

Así cabe la posibilidad de que los restos fosilizados de esta estructura fueran confundidos con una segunda muralla en la actual calle Mayor por más de un erudito antiguo, como P. de la Garza: (...) calle real (...) que es línea divisoria entre la antigua Sagunto y la Moderna Murviedro (...) Tiene esta muralla la circunstancia de formar una línea exterior a la romana, que se halla visible en algunos puntos de la calle Mayor, marchando aquella casi paralela a esta, a una distancia de 45 m (GARZA, 1877: s. p.). 
Evidentemente, a efectos de huellas urbanísticas, solamente las estructuras aéreas de un porte significativo dejarían improntas que podrían confundirse con una muralla, pues otro tipo de elementos de menor porte también pueden dejar un rastro en el parcelario, aunque probablemente menos perceptible.

La otra posible conducción asociada a esta ampliación podía tratarse de un tercer acueducto destinado a suministrar agua a las grandes estructuras construidas en el límite la ciudad, como serían el foro, el circo, el anfiteatro, los templos, etc. y desde este punto de vista el suministro hacia el Sur de la urbe y el Grau Vell también quedaría garantizado. A este conducto asociamos el resto de muro de mampostería aparecido en la excavación de la plaza de la Morería (ver Fotos $\underline{126}$ y 127 ).

No olvidemos la posibilidad de existencia de varios castella en Sagunto y de las reformas que se aprecian en el conocido como "muro del templo de Diana". Éstas tendrían paralelos, por ejemplo, en Mérida, en la casa de la Torre del Agua que tiene varias fases constructivas; la primera de ellas debe situarse a final del siglo I d. C. y la segunda en el siglo II d. C. La reconstrucción de su vivienda asociada, según Almagro, se puede situar en la segunda mitad del siglo III d. C., en la que se data una gárgola y un canal (JIMÉNEZ, 1976), coincidiendo con la reparación del segundo piso de los arcos de San Lázaro (ALBA, 2002).

En la emeritense domus de los Mármoles se documentó un tramo de tubería de plomo que lleva la dirección del baño del frigidarium que invade la vía, lo que permite aventurar que esa casa se benefició del agua pública, a pesar de tener un pozo en el peristilo. En este caso y en el de la casa de la Torre del Agua se trataría de un uso autorizado a propietarios de grandes viviendas (superan los mil metros cuadrados habitables) mediante el pago de un impuesto (ALBA, 2001). El uso del agua y el mantenimiento de obras públicas como los acueductos, sin duda implica que la parte aérea de estas obras necesitara una protección, como refiere Sexto Julio Frontino en el siglo I d. C. en el caso de Roma, donde la autoridad local debía velar para que no se produjese la apropiación indebida del servicio de aguas:

(...) el fraude de los fontaneros, a los que he sorprendido desviando el agua de los conductos públicos para provecho de los particulares. Pero también la mayoría de los propietarios, al borde de cuyas tierras pasa un acueducto, agujerean las estructuras de los canales, de donde resulta que los conductos públicos interrumpen su recorrido normal en beneficio de particulares o para usos de sus jardines, o agujereando el plomo en el interior de la ciudad para conectar tubos de particulares (...) (Frontino, De Aquis, 7, 3) 
En el caso de Sagunto debemos apuntar la confluencia entre el trazado del acueducto, el foro augústeo y el conocido como templo de Diana, al cual se le han adjudicado múltiples funciones ${ }^{32}$. Sin embargo, la existencia de un espacio hueco en su interior, utilizado como bodega desde el inicio del siglo XIX o final del XVIII, podrían indicar su uso como castellum aquae: Este trozo de muralla, que sirve en el día de muro á una casa de la población y de pared interior de una bodega, principia el ascenso al castillo (DELGADO, 1877: 428)

Hasta época medieval y en algunos casos en periodos posteriores, parte de las citadas conducciones fueron utilizadas para el transporte de agua, en algunos casos hacia los baños árabes, cisternas y pozos que seguían obteniendo suministro de estos acueductos. Esto nos permite pensar que alguno de los depósitos de cronología medieval podría ser de origen romano, pero con amplias reformas posteriores, como el caso de los depósitos de la avenida del País Valenciano (ver Foto $\underline{5}$ ). Respecto a la fosilización de los restos debemos tener en cuenta que los canales hidráulicos son muy variados, desde simples canalizaciones a ras de suelo (ver Foto $\underline{8}$ ), grandes arcos (ver Foto $\underline{6}$ ), tuberías (ver Foto $\underline{7}$ ), galerías excavadas (ver Fotos $\underline{9}$ y $\underline{10}$ ) o arcadas de pequeño porte (ver Foto 12); tampoco debemos olvidar las tuberías de piedra (ver Foto 28) o de cerámica (ver Fotos $\underline{13}$ y $\underline{29}$ ).

En el caso saguntino podemos observar al menos tres importantes ejes paralelos a las curvas de nivel de la montaña. Lamentablemente los restos arqueológicos son muy exiguos o han desaparecido, pero serían fácilmente asociables a las tres principales etapas de desarrollo de la ciudad romana: republicana, augústea y flavia-trajanea.

La huella de este suministro de agua es evidente en las excavaciones de la plaza de la Morería; por un lado tenemos la tubería de plomo de la acera (ver Fotos $\underline{34}$ y $\underline{35}$ ) con claros paralelos (ver Fotos $\underline{30}, \underline{31}, \underline{32}$ y $\underline{33}$ ) en el suministro publico y privado (paralelos en la Foto $\underline{95}$ ), pero en el caso saguntino sólo podemos presuponer el uso privado, ya que todas las huellas de suministro público aparecen en la acera opuesta, como por ejemplo un desagüe de fuente (ver Fotos $\underline{26}$ y $\underline{27}$ con el proceso de excavación), la base de otra fuente (ver Foto $\underline{25}$ ) y la más interesante, una fuente tipo baulleto (ver Foto $\underline{20}$ y dibujo 4 ) que había quedado sin excavar en el año 1994 dentro de un sondeo mecánico (ver Foto 21), pero cuya base estaba casi completa (ver Fotos $\underline{22}, \underline{23}$ y $\underline{24}$ ), dentro de la cual aparecieron unos crotalos de bronce. Al ser un hallazgo poco frecuente en la Península nosotros lo confundimos inicialmente con unas letrinas.

Nos queda el tema de los desagües; teniendo un río tan cerca, es lógico pensar que las aguas residuales fueran a parar a él, pero con el único problema de que no nos encontramos ante un sistema fluvial con abundantes aguas que permitan un fácil transporte de estos residuos. Aún así no descartamos un acondicionamiento parcial del

\footnotetext{
${ }^{32}$ Como anécdota, citamos el dibujo de 1914 (ver Dibujo $\underline{51}$ ), que intuitivamente situó un foro en este espacio.
} 
cauce de una forma similar al de Mérida respeto al Guadiana, donde se excavó el cauce del río para crear una especie de canal junto a la ciudad (el Guadianilla) para facilitar las escorrentías de los desagües. Se trata de un brazo artificial que también sirvió para restar fuerzas al río en el cauce principal contra el puente; de su lecho excavado se extrajeron áridos para la elaboración de la argamasa de arena y cal, así como los cantos de río para preparar los rudus de las pavimentaciones de signinum y los asientos de cimentaciones de muros (ALBA, 2001). A la vista de estos datos no sería de extrañar que en Sagunto también se hubiera acondicionado el cauce. No olvidemos que la gran mayoría de las cimentaciones de la ciudad se basan sobre grandes cantos fluviales que pudieron ser extraídos del río y que quizá dejaron una huella similar a la de Mérida.

Esto también explicaría que no existiera ninguna gran canalización de vertidos en sentido Este-Oeste, ya que la propia pendiente Sur-Norte facilita la escorrentía hacia el río. En las imágenes del siglo XVIII (ver dibujo 54) podemos observar que el cauce junto a la ciudad es más profundo (sin poder afirmar que se trate de una consecuencia artificial o natural), lo que sin duda facilitó un mayor caudal en los desbordamientos y una mayor erosión que afectó profundamente al circo y al anfiteatro.

Son múltiples los ejemplos de asentamientos romanos que aprovechan las pendientes y los cursos de agua para verter; además de la ya citada Mérida, podemos citar también el caso de Iluro (Mataró), fundada en el siglo I a. C. en la vertiente de un promontorio costero, con una superficie aproximada de $7 / 8$ hectáreas y un urbanismo regular adaptado a la pendiente; el tramo viario identificado como el cardo maximus tiene una anchura, incluyendo las aceras, de aproximadamente 9 metros y cuenta con una cloaca central con canalizaciones oblicuas procedentes de las insulae (REVILLA y CELA, 2006). Otro ejemplo es Barcino (Barcelona), una ciudad de unas 10 hectáreas de extensión, fundada hacia el año 10 a. C. sobre un pequeño montículo costero de planta elíptica (una altura máxima de 12 metros) rodeado por torrentes; parte del recinto amurallado estaba circundado por un canal o foso de unos 23 metros de anchura y 6 metros de profundidad que recibiría las aguas procedentes de la red de saneamiento público y serviría para canalizar las aguas pluviales procedentes de la vertiente NW, evitando la acumulación de sedimentos (GRANADOS, 1991). También Baetulo (Badalona), una ciudad de planta próxima a la ortogonalidad y dispuesta sobre una moderada pendiente hacia el mar, que disponía de una red principal de colectores que recorrían el subsuelo de las calles perpendiculares a la línea de costa (las de pendiente más acentuada), recibiendo la acometida de cloacas menores que siguen la orientación de las calles transversales (GUITART, 1976).

Todos estos casos son similares al de Sagunto, donde hemos documentado dos cloacas principales, una de las cuales se halla en la plaza de la Morería (ver Fotos $\underline{55}$ y 56) y aunque no ha sido excavada en su totalidad se puede apreciar perfectamente su 
cubierta (ver Foto $\underline{54}$ ). Hacia la misma vierten los desagües de las distintas insulae, tanto la Sur (ver Fotos $\underline{58}, \underline{59}, \underline{60}$ y $\underline{66}$ ) como la Norte (ver Foto $\underline{64}$ y $\underline{65}$ ). De su consideración como cloaca principal también habla el hecho de que existan desagües que crucen prácticamente toda la manzana, por debajo de las habitaciones y esquivando el podio del Templo 1, para alcanzar la calzada (ver Fotos $\underline{62}$ y $\underline{63}$ ), y solamente en el límite Este del solar cambia de trazado para buscar verter en el lado opuesto (ver Foto $\underline{61})^{33}$.

Son múltiples los ejemplos de cloacas a lo largo del Imperio, no sólo de tipo central como la nuestra (ver Fotos $\underline{38}, \underline{39}, \underline{40}, \underline{42}, \underline{44}$ y $\underline{51}$ ) y podemos observar que la monumentalidad no es un requisito para decidir su posición central, con sus desagües laterales (ver Fotos $\underline{43}, \underline{47}$ y $\underline{49}$ ) y sus conexiones con las casas (ver Fotos $\underline{36}, \underline{37}, \underline{45}$ y 46) (ADAM, 1984, GROS y TORELLI, 1992 y GROS, 1996). En el caso saguntino podemos observar cómo las aportaciones de los desaguaderos tangentes colaboran con la colmatación de la cloaca, lo que constatamos claramente en la estratigrafía de misma, ya que los episodios de relleno (tierra arcillosa beige) se intercalan con los de aportación de las desembocaduras (tierra arcillosa gris/verdosa con materia orgánica) (ver Foto $\underline{57}$ ), lo que contrasta claramente con los episodios posteriores de vaciado del relleno para su utilización como necrópolis. Un paralelo extremo del mismo es el vaciado del acueducto romano de Siracusa para ser utilizado como la catacumba cristiana de San Juan (SGARLATA, 2003) (ver Foto 11). Para cerrar el tema queremos apuntar el caso del imbornal del templo 1 (ver Fotos $\underline{53}$ y $\underline{419}$ ) que va a parar a la cloaca central, que quizá siguió en uso cuando el edificio se adaptó para vivienda y del que tenemos un paralelo en la Cartago romana (LANCEL, 1994) (ver Foto $\underline{3}$ ).

${ }^{33}$ Este derecho lo salvaguarda la legislación romana: (Dig. 8, 1) El derecho de hacer pasar la cloaca es una servidumbre. 


\subsection{LA URBANIZACIÓN DEL SIGLO III d. C.}

En Sagunto la situación cambia de forma significativa aproximadamente alrededor del siglo III d. C., cuando la zona pública de la Morería adquiere un marcado carácter privado, señalado básicamente por la construcción de habitaciones pertenecientes a algunas domus o insulae y la adaptación de las infraestructuras para los servicios destinados a viviendas, donde podemos destacar la construcción de abundantes desagües laterales, tuberías de plomo, fuentes etc. Este proceso de sobreexplotación urbanística también marcará una lenta saturación de los servicios públicos, como lo señala la colmatación de la cloaca central de la vía Sacra, que al igual que el resto de desagües siguen una orientación lógica hacia el río Palancia.

Entre la funcionalidad de los departamentos ${ }^{34}$ no descartamos la presencia de una taller de metalurgia en la zona, ya que los abundantes y variados restos de bronce, que indican una acumulación para la reutilización (incluidos fragmentos de monedas recortadas), junto a restos de escoria y de vasijas utilizadas en la fundición, señalarían su presencia; como en Mérida, donde los residuos de fundición constituyen la evidencia más numerosa y orientativa sobre la existencia de estos talleres de la Morería, donde trabajaron indistintamente el bronce y el hierro, con preferencia hacia el primer metal, valiéndose del refundido de piezas romanas (ALBA, 1999). En el caso saguntino, la escasez del material y de huellas del taller (hornos, crisoles, rubefacciones, carbones y cenizas, etc.) nos indicaría una producción artesanal a pequeña escala.

Esta expansión contribuiría a la eliminación de elementos de la muralla como estructuras urbanísticas visibles, como por ejemplo el proceso de rellenar el foso durante el periodo en que no era necesario. Este mismo hecho lo encontramos en el foso que circundaba tres de los lados de la ciudad de Mérida, que se convierte en receptáculo de vertidos domésticos y escombros que sirvieron como relleno previo a la edificación, en el siglo I d. C., de la casa de la Torre del Agua (FEIJOÓ, 2000). En esta misma ciudad se documentó un vertedero formado en la $2^{\mathrm{a}}$ mitad del siglo I d. C. junto

\footnotetext{
${ }^{34}$ Una posible zona de almacenamiento sería la detectada bajo la calle Alorco en los años 60 del siglo XX (ROCA, 1976). 
al muro fundacional de la ciudad (calle Constantino 14). En Barcino, la fullonica y la tinctoria situadas en el cuadrante $\mathrm{N}-\mathrm{E}$ de la ciudad, con fachada al foso y cerca de uno de los accesos a la ciudad, vertían sus residuos en el mismo intervallum durante el siglo II d. C. (DUPRÉ, 2002). Sabemos por otros paralelos que se adosaban casas a las murallas romanas durante los periodos de paz (ver Dibujo $\underline{55}$ ), como la de Mérida, que poseía un paso de ronda que fue invadido de forma progresiva por las viviendas reformadas, hasta que acabaron por adosarse al muro defensivo (ALBA, 2001).

La expansión o urbanización de esta zona de la ciudad saguntina la encontramos condicionada por la forma en que se ocupa el espacio anteriormente dedicado a la religiosidad para usarlo como vivienda, lo que nos indica en sí misma una cierta velocidad en este proceso de cambio. Pensamos que se trata de un proceso común en este periodo de la Historia, donde, por ejemplo, los colegios sacerdotales itálicos obtienen ingresos construyendo viviendas en el entorno de los templos, pero manteniendo el culto; este proceso está documentado de forma preferente para los santuarios de carácter municipal (MAR, 1996), lo cual nos indicaría que en Sagunto nos encontramos en una zona devocional de este tipo. Además debemos sumar otro factor si pensamos que la disipación del espacio sagrado culmina con la desaparición del propio templo; sabemos que los santuarios imperiales son los últimos en desvanecerse al estar protegidos por leyes y posiblemente son estos los últimos que conservan su carácter sacro, de tal forma que son adoptados preferentemente en algunos casos como edificios cristianos, ya que los otros debieron haber desaparecido hacía tiempo, como por ejemplo en Baetulo (AQUILUÉ y SUBÍAS, 1986) o bajo la forma de casas o viviendas en Baelo (ARCE, 2006) (ver Dibujo 46) o como iglesias (ver Fotos $\underline{521}, \underline{522}$ y $\underline{547}$ ). En el caso saguntino se conservan algunos ejemplos de cimentaciones de casas construidas sobre los podios del Templo 1 (ver Fotos $\underline{477}, \underline{493}$ y 495 ) y del Templo 2 (ver Foto $\underline{429}$ ) y también adosadas a ellos (ver Fotos $\underline{475}$, 484 y 487), con los desniveles que generarían entre la calle y las distintas plantas bajas (como por ejemplo en la Foto 482). Es muy probable que, a pesar de que los templos de la Morería perdieron poco a poco su carácter sacro, conservaran su función urbanística, ya que una de las causas que favorecieron la pervivencia de los templos paganos durante la Antigüedad Tardía (al menos en la parte occidental del imperio donde se apoyó la conservación de los templos y santuarios urbanos), fue el miedo a colaborar en la desintegración de la topografía urbana clásica tradicional, ya que muchos de los principales espacios públicos de las ciudades todavía se encontraban organizados alrededor de las grandes áreas sagradas. En muchos otros casos, es a lo largo de los siglos VI y VII d. C. cuando tienen lugar la mayoría de las transformaciones, momento en el que los edificios ya se encontraban prácticamente en ruina (LÓPEZ Y MARTíNEZ, 2006). En Ostia tenemos ejemplos muy similares a los de Sagunto: (...) el Santuario de Hércules se había convertido en una estructura urbana, la mayor parte de su superficie permaneció sin edificar hasta el siglo II d. C solamente con la gran fase de especulación urbana de época Flavio-Trajanea se procedió a 
edificar el perímetro exterior (...) con la ola especulativa que triplicó el volumen edificado en la ciudad de Ostia en el inicio del II d. C. (MAR, 1996: 133).

En algunos casos como Mérida o Valencia, importantes sedes del poder religioso, la perdurabilidad en el tiempo de los templos paganos estaría en relación no sólo con el hecho de que estuvieran protegidos por su utilidad pública y su belleza, sino con la evidencia de su reutilización como edificios necesarios ante la importante expansión administrativa cristiana en las citadas ciudades, aunque en el caso valenciano los casos sólo significan que los edificios se colapsan en ese periodo, como la curia o el antiguo edificio administrativo donde se encontraría el lugar del martirio de San Vicente, derrumbado en el siglo $\vee$ d. C. (RIBERA y ROSELLÓ, 1999), aunque esto no implica que hayan sido reformados mucho antes.

La evolución de estas viviendas (ver Láminas $\underline{X X X I I}$ y $\underline{X X X I X)}$ no sólo significó una compartimentación del área o la reutilización de espacios abiertos, sino que sin duda supuso una lenta ampliación, empezando por el cerramiento del pórtico y la ocupación de la acera para la obtención de nuevos departamentos (ver Fotos $\underline{145}, \underline{483}, \underline{488}$ y 501) hasta llegar a invadir la propia calzada (ver Foto 476 ), como comprobamos en muchas ciudades del imperio (ver Fotos $\underline{48}, \underline{81}, \underline{93}, \underline{94}, \underline{97}, \underline{99}, \underline{100}, \underline{105}, 106,110,111$, $\underline{117}, \underline{161}, \underline{162}, \underline{163}, \underline{164}, \underline{170}, \underline{525}$ y $\underline{526}$ ) (ADAM, 1984, GROS y TORELLI, 1992 y GROS, 1996). Es significativa la acumulación de piedras en una esquina de la insula Norte con el fin de evitar el choque de los carros (ver Foto 152), según podemos observar en ciudades como Pompeya, Herculano u Ostia (ver Fotos 150 y 151(GROS y TORELLI, 1992). También tenemos el acceso a las viviendas, que en muchos casos es algo más alto que la acera al cubrir los restos de la necrópolis, para lo que fue necesario sobreelevar las viviendas (ver Fotos $\underline{361}, \underline{363}$ y 482), tal y como podemos observar en algunos ejemplos de los accesos (ver Fotos 107 y 108). Estas casas también se adosan a los podios de los templos, lo que posiblemente indica que en una última fase de expansión se construyó sobre estos la segunda planta de las domus. Lo que se identificó en 1994 como tirantes del muro que correspondía al podio del templo 2 , en verdad son los muros de los cubicula adosados; y lo que se describía como alguna pequeña taberna (CHINER y LÓPEZ, 1994 - ver Fotos 480 y 494) en verdad era un cubo de escalera, como los que, por ejemplo, apreciamos en Ostia (ver Foto 391) (BECATTI y GISMONDI, 1996) o en otras ciudades para acceder a la planta superior que correspondería con la cima del antiguo podio. Un ejemplo de casas adosadas a los templos lo tenemos en Mérida (MATEOS, 2006) (ver Foto $\underline{523}$ ).

También vemos cómo las casas que absorben el pórtico casi se adosan al arco situado sobre la calzada (ver Foto $\underline{508}$ ). Esto sin duda nos permite interpretar las distintas unidades de uso o viviendas creadas en este espacio, ya que deberían respetar una serie de normas legislativas, respecto a las plantas más altas levantadas sobre los podios, o de las nuevas edificaciones que no comparten medianera y dan acceso a la 
calle, lo que podría indicar que pertenecen a una misma propiedad al no apreciarse huellas de estas servidumbres en las construcciones:

(Dig. 8, 2, 1). Servidumbres prediales urbanas son: la de levantar o no la altura de un edificio y privar de luces al vecino, y la de verter o no el estilicidio del tejado en el techo o solar del vecino; también la de apoyar vigas en la pared del vecino $y$, en fin, la de cobertizo, la de voladizo y demás semejantes. Hay también la servidumbre, de no privar de vistas.

La propia acera se vio afectada, pues fue necesario habilitar los desagües por debajo de la misma (ver Foto 168) y ordenar los cruces con las tuberías de agua (ver Foto 167), cuya zanja es claramente apreciable por el cuidado con que se deposita y apuntala el tubo, como también podemos apreciar en otras ciudades (ver Foto 166); eso sin olvidar casos en que es necesario buscar la pendiente hacia el Palancia, pero evitando edificios monumentales, como los podios de templos.

Lamentablemente otras excavaciones cercanas aún no han sido divulgadas, o en su defecto la publicación no es tan precisa como desearíamos como para poder adjudicar los hallazgos, como el caso de los silos de la calle Alorco (ROCA, 1976) donde no podemos establecer una cronología para los mismos. Otro ejemplo de la expansión urbana del siglo III d. C. lo tenemos en las excavaciones arqueológicas en la iglesia de San Salvador de Sagunto, que permitieron la identificación de un ambiente doméstico del Bajo Imperio así como de un nivel republicano de difícil interpretación, según el autor. Es de destacar la total inexistencia de estratos que puedan datarse tanto entre los dos momentos mencionados como entre éstos y el medieval; el nivel republicano es de unos $80 \mathrm{~cm}$ de espesor, conformado en sucesivas tongadas por capas de piedras y bolos de tamaño medio y otras de tierra arcillosa rojiza, intercaladas hasta crear un compacto relleno de superficie correctamente enrasada. El nivel del Bajo Imperio consta de dos habitaciones con vano de comunicación fechadas entre el siglo III y el V d. C., con materiales del Alto Imperio bajo el pavimento y con un nivel de abandono entre el final del siglo IV y el inicio del V d. C., compuesto de cubierta de tegulae y derrumbes, que sufrió un progresivo deterioro tras su abandono (HORTELANO, 1993), lo que sin duda es muy similar a la evolución urbana de la zona de la Morería.

En el caso de la calzada saguntina podemos observar que la primera capa que cubre las losas de la vía es una tierra limpia (ver Fotos 140, 141 y 142), sobre la cual se documenta alguna reparación configurada por grandes fragmentos cerámicos acumulados horizontalmente (ver Foto 137), de forma similar al modo en que se arreglan baches hoy en día en los caminos rurales de tierra, como en los casos donde probablemente se echó tierra sobre la calzada con la finalidad de evitar ruidos molestos a los vecinos (de los que ya citamos ejemplos similares en esta tesis - ALBA, 2001) (ver Fotos 158 y 115 ); es encima de esa capa donde empiezan a depositarse 
escombros (ver Foto 138 ) y sobre la cual se producen derrumbes de paredes de ladrillo (ver Fotos 144, 149 y $\underline{498}$ ) o del propio pórtico (ver Foto 148), indicio del abandono del trazado de la antigua vía como ruta o camino.

Volviendo al tema del pórtico, en cualquier caso la pérdida de estos espacios a costa de inversiones privadas son síntomas de vitalidad, todo lo contrario a una degeneración urbanística supuestamente propia del Bajo Imperio o a la decadencia con la que se dibuja habitualmente este periodo. El proceso de privatización de los pórticos es muy activo en el siglo III y el IV también en Mérida, que allí siguió abierto hasta la inestabilidad del siglo V d. C. (ALBA, 2002).

Las tareas de limpieza se solían asignar a esclavos en época romana. Este mantenimiento periódico aseguraba el buen estado del alcantarillado, pero teniendo en cuenta el tratamiento dado a la zona en general a partir del siglo III d. C. en adelante, induce a poner en duda un cuidado equiparable. Además de todo lo que habitualmente iba a verter a las cloacas se sumaba una mayor cantidad de desechos orgánicos, tanto aquellos procedentes de las nuevas viviendas como una fina tierra de las nuevas pavimentaciones superpuestas a las vías empedradas, materiales todos ellos introducidos en los colectores por el agua de lluvia a través de los sumideros existentes en la calle, como sucede en el caso de Mérida (ALBA, 2001) La pérdida de la constancia de caudal de arrastre ocasionaría una progresiva y lenta colmatación de la red de conductos hasta llegar a la etapa visigoda. En Sagunto comprobamos la apertura de nuevos desagües hacia la cloaca, algunos de muy largo recorrido; es interesante comprobar las similitudes con Mérida, con la diferencia de que no hemos podido excavar insulae enteras como allí. Las manzanas en esta ciudad extremeña estarían ocupadas por seis domus puestas en dos bandas de a tres, cuatro de las cuales disfrutan de un emplazamiento esquinero (sin entrar aquí en viviendas menores habilitadas a partir de aquellas mayores). Las cuatro que poseen emplazamiento en esquina lindan con un kardo minor o preferentemente con un decumanus, según la topografía les fuera más favorable, en tanto que las dos domus interiores vertían necesariamente a la cloaca que transcurría frente a su fachada (suelen ser kardines). La topografía y el aterrazamiento artificial de los solares donde se levantan las viviendas creaba diferencias de cota entre los espacios domésticos y los de la calle; este contraste determina que haya una preferencia por verter siguiendo la caída del terreno (ALBA, 2001), como en el caso de Sagunto.

Curiosamente no se ha detectado prácticamente ningún resto constructivo de entidad asociable a los templos que haya sido desplazado y utilizado en estas reformas para viviendas; únicamente, como ya hemos señalado, se reutilizan restos del pórtico y unos escasos sillarejos fruto posiblemente de alguna reforma puntual o debido a la necesidad de crear zonas de paso o accesos en las antiguas estructuras. 
Esto apuntaría a que una buena parte de los elementos de los santuarios se mantuvo in situ para ser finalmente adaptado a viviendas (que evidentemente no pudieron desplazar elementos de los templos que aún estaban en buen estado y quizá en uso en un primer momento), factor que apoya la lenta ocupación de este espacio sagrado y su anulación final.

Otra señal importante de esta construcción por fases, que apunta a una propiedad múltiple, es la construcción de departamentos que no comparten medianera, lo que indica una diferencia de cronología y de propiedad. Muy explicito es el caso que se identificó como canal (CHINER Y LÓPEZ, 1994 - ver Foto $\underline{480}$ ), pero que en verdad son dos lindantes prácticamente adosados (ver Foto $\underline{479}$ ).

Lamentablemente buena parte de estas viviendas estaban arrasadas por las fosas medievales, por lo que los restos conservados son puntuales, aunque permiten identificar los accesos desde la calle, desde las habitaciones (ver Fotos $\underline{476}$ y $\underline{496}$ insula Norte, Foto $\underline{478}$ - insula Sur) y desde los departamentos interiores (ver Fotos $\underline{497}$ y 481 - insula Norte).

En la zona del foro bajo saguntino pueden existir indicios indirectos de la utilización de al menos parte del mismo como viviendas, como cita la Sociedad Arqueológica Valenciana según información de A. Chabret: (...) en el huerto del que fue convento de la Trinidad (...) vestigios de un mosaico (...) destruido al hacer la excavación, no habiéndose podido reconocer más que un fragmento de sobre medio metro de extensión, que presentaba en fondo blanco con una orla negra en forma de greca a manera de un tablero de ajedrez (...) (SAV, 1873: 6).

Este huerto corresponde a solar donde realizamos varios sondeos arqueológicos que nos permitieron detectar la existencia de este posible foro, de hecho pudimos localizar las estructuras semisubterraneas construidas a finales del siglo XIX citadas en el texto, y que se encontraban junto al muro perimetral del foro.

No existen aún datos concretos que expliquen el aumento poblacional en las ciudades durante el siglo III d. C.; por nuestra parte podemos apuntar una potencial línea de interpretación: las puntuales incursiones bárbaras de este siglo provocaron un flujo migratorio hacia las ciudades, tanto desde las villae como desde pequeños núcleos urbanos o semi-urbanos, fruto de un clima de inseguridad social que llevaba a buscar el refugio en las urbes más pobladas y con milicias. El posterior auge económico que pudo producirse en época teodosiana, junto a una posible mayor fecundidad entre las clases populares, sumado a la probable acumulación de propiedad rural en unos pocos propietarios que bloqueaba la vuelta al mundo agrario de los medianos o pequeños propietarios, ocasionaría que se mantuviera la antigua "fuga" hacia las ciudades en búsqueda de un mejor nivel de vida. Estos serian los factores que probablemente sostuvieron una superpoblación en las urbes más importantes, que obligaba, para 
satisfacer el aumento de la demanda, a la construcción de más viviendas y de menor calidad (por ejemplo, con reutilización de materiales) y acabaron fomentando el colapso de sus instituciones. Este es el contexto que propicia la conciencia acerca de la necesidad de preservar la ciudad y sus edificios llegando a formar parte de la legislación imperial tardía, donde constantemente los emperadores ordenan a los gobernadores provinciales ocuparse de conservar los edificios de las ciudades, de su reparación y de su mantenimiento antes de comenzar obras nuevas ${ }^{35}$. Sin olvidar la falta de capacidad económica de los curiales y la mengua de ingresos urbanos, que era vista con preocupación por el poder imperial que deseaba la preservación del patrimonio monumental de las ciudades.

Dentro de ese cambio de propiedades en búsqueda de nuevos espacios sociales y económicos, en el siglo IV d. C. tenemos la irrupción de la religión cristiana como fuente de poder y máximo exponente del cambio de manos del antiguo orden económico pagano. También es cierto que el señalado auge demográfico del siglo III d. C. no sigue de forma indefinida, como lo marcará el posterior repliegue urbanístico de centurias posteriores, con una posible paulatina disminución en la cantidad de habitantes que podía haber sido provocada, entre otras cosas, por la insalubridad y las malas condiciones generales en las urbes, lo que rebajaría la expectativa de vida, sin olvidar los posibles conflictos bélicos o la inmigración como factores de pérdida de población. Aunque no tengamos evidencias para este periodo, ejemplo algo anterior sería la gran peste del año 250 d. C., conocida como la "plaga de Cipriano" descrita por el entonces obispo de Cartago. En su fase aguda duró dieciséis años, durante los cuales la gente vivió presa del pánico. Millones de campesinos abandonaron el campo para refugiarse en ciudades superpobladas, ocasionando nuevos focos de infección y dejando que se echaran a perder grandes áreas de tierra de cultivo. Muchos pensaron que la raza humana no sobreviviría. La mortandad fue mucho mayor que en otras pestes $y$, de hecho, los muertos eran más numerosos que los sobrevivientes que debían enterrarlos (GARCIA, 1998).

En la zona sacra de la Morería de Sagunto es probable que al menos un único templo pudiera haber sido reciclado en época cristiana, como atestigua la presencia de enterramientos en la zona; pero en este caso se trataría de uno que aún no ha sido excavado, ya que lo que sí está claro es que el enterramiento familiar de época visigoda no se encuentra asociado a ninguno de los dos santuarios descubiertos hasta el momento y ocuparía una posición periférica respecto al núcleo principal de enterramientos, posiblemente situado bajo la plaza de la Morería. Es probable que los demás templos ya fueran viviendas desde hacía muchos años, cuando los cristianos tuvieron altas cotas de poder en el Imperio romano, sumado a las prohibiciones de Teodosio a finales del siglo IV.

\footnotetext{
${ }^{35}$ Codex Theodosianus 15, 1-53 -de operibus publicis
} 
En el caso de Sagunto la gestión de los templos de la zona de la Morería podría venir indicada por su posterior no-sacralización cristiana y su transformación en viviendas en época muy temprana, pues si estos edificios hubieran sido, como ya se ha dicho, propiedad del Estado y su patrimonio considerado por tanto res privata bajo el control directo del emperador, éstos se habrían conservado más tiempo y hubieran acabado siendo propiedad de la Iglesia.

Otros indicios de la expansión de la ciudad saguntina a lo largo del siglo III d. C. son la existencia de construcciones rurales entre el Grau Vell y el casco urbano, las verdaderas villae extraurbanas, como la detectada en 1976 en el Cami dels Rolls, donde junto a dos dolia in situ aparecieron: (...) gran cantidad de piezas de mármol de diversos colores procedentes de un mosaico de "opus sectile", así como también diversas piezas de emplacado con dibujos florales, geométricos y diversas molduras, todo ello en mármoles de buena calidad (...) fragmentos de tegulas, cerámica iberoromana y sigillata, restos de ánfora, etc. Lo que nos puede facilitar unas fechas entre el II y III siglo después de Cristo. (ROCA, 1977:24)

La detección de necrópolis tardías bastante alejadas del casco urbano, posiblemente asociadas a estas villas (como la del antiguo Camino de Teruel) es otro indicio de la extensión de las mismas. Tampoco olvidemos la importante presencia comercial en el Grau Vell a lo largo de los siglos III al V d. C. (LÓPEZ, 1991).

En Valentia hemos documentado en una excavación un interesante caso en que la ciudad se expande al otro lado del río Turia y donde las estructuras Alto Imperiales se ven claramente afectadas durante la etapa posterior. Concretamente nos referimos al solar de la calle Santa Rita esquina Calle Cronista Rivelles (LLORENS et alii, 1999). Allí la ultima fase romana corresponde al periodo del Bajo Imperio, cuyos hallazgos fueron bastante interesantes; se trata de una cimentación y parte del alzado de un muro de opus vittatum (UE 1229), una canal elaborada con la técnica de encofrado y posteriormente enlucida (UE 1235) y sellada por una cubierta de tegulae (UE 1234). Su relleno corresponde a la UE 1231 (ver Foto 171). Otro resto asociado se trataría de posibles restos del suelo adosado al desagüe (UE 1236 - ver Foto 173). Finalmente queremos destacar el nivel de destrucción formado por una capa de carbones y materiales cerámicos que marcaría el final de este hábitat. Las grandes fosas medievales redujeron ampliamente la superficie intacta y la cantidad de materiales contextualizables, por lo cual la datación de este nivel viene por el contexto general y la escasa presencia de fragmentos informes de TS Africana A o de cazuelas Lamboglia $10 \mathrm{a}$ y $10 \mathrm{~b}$.

Lamentablemente, los restos proporcionados por la fase romana del Alto Imperio son de escasa entidad y muy alterados, correspondiendo a un nivel de ocupación de color gris verdoso. Éste se puede asociar también con una etapa anterior a la de la estructura UE 1229; en ella parecen escasos fragmentos de cerámica (lucernas, 
grandes vasijas, TSS, tegulae, etc.), elementos malacológicos, fauna y restos constructivos (fragmentos de opus signinum, pintura mural, etc.). También detectamos sillares de un muro realizado con la técnica del opus quadratum que aparecen dispersos por el nivel (ver Foto 172).

Dejamos a un lado, debido a lo escaso de la evidencia material, la posibilidad de que en las proximidades exista una ocupación prerromana y del Bronce. El primer asentamiento en el lugar se da en el periodo de la fundación de Valencia, cuyos escasos restos no permiten una valoración completa; La fase de ocupación republicana solamente tiene asociado un suelo de grava y bolos apisonados en una doble hilada cortada por las estructuras superiores (ver Foto $\underline{600}$ ). El escaso contexto para fechar este nivel se ciñe a escasos fragmentos informes de cerámica ibérica, Campaniense A, cerámica a mano del Bronce junto al algún fragmento de cerámica itálica y ánfora de la Campania. Lo que sí podemos suponer es una ocupación permanente, pues el pavimento de rudus encontrado requiere un trabajo y una calidad que no sería compatible a priori con un asentamiento temporal.

No hemos podido documentar una etapa de abandono clara, pero sí es de lógica aceptarla, si pensamos que existe un hiato entre los restos del Alto Imperio y el empedrado, aunque se encuentren en contacto directo en algunos puntos. En él son abundantes los restos de fauna, escoria, vidrio y cerámica, posiblemente correspondiendo a un periodo final de abandono. Esto quizá evidencie un lapso de tiempo bastante corto entre las dos fases.

La ocupación imperial es larga y de gran calidad, podría tratarse de algún núcleo periurbano de la ciudad, ya que existen elementos de una construcción importante, como lo señalan los restos de sillares. La relación con la zona urbana al otro lado del río es muy evidente, si tenemos en cuenta que la cloaca y la calle se encuentran orientadas hacia la trama urbana del otro lado del río, en la zona monumental de Valencia.

Ésta finaliza con un nivel de arrasamiento muy claro, sobre el cual se inicia una nueva ocupación que posiblemente saquee los restos anteriores (recordemos que algunos sillares se encontraron esparcidos) y finalmente ocupe este espacio de una forma similar a la anterior.

Todos los hallazgos podrían indicar la presencia de un espacio periurbano ya ocupado desde momentos fundacionales de Valencia, pues la estratigrafía es similar a la de la zona más antigua de la ciudad, siendo un núcleo de gran importancia arqueológica que

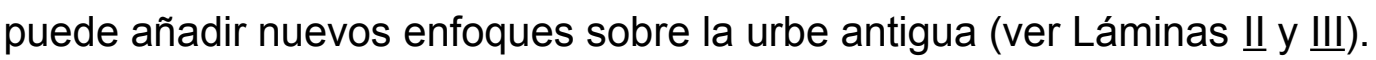




\subsection{LA DECADENCIA Y LA ÉPOCA VISIGODA}

Es probable que la decadencia de esta zona periférica de la urbe saguntina fuera provocada por el colapso de las instituciones y los servicios públicos de la ciudad, agravada por el período posterior de inseguridad y luchas surgidas a partir del momento de las invasiones bárbaras, y siguiera de forma continuada hasta el hundimiento del imperio romano en el siglo $V \mathrm{~d}$. C. El abandono de este espacio (ya que no hemos encontrado ninguna señal de destrucción del mismo, como podría ser, por ejemplo, algún incendio) se asociaría a un repliegue hacia la zona más poblada y defendible que correspondía a la antigua ciudad augústea. Precisamente, en los últimos años del siglo IV d. C. las localidades son conminadas por la autoridad imperial a construir o reconstruir las murallas y para ello se autorizaba el uso de materiales procedentes del derribo de los templos (ARCE, 2006). La decadencia de Sagunto probablemente no le permitió adoptar esta medida, donde el proceso de abandono culmina con un importante saqueo, llegando incluso a desaparecer hasta los cimientos la mayor parte de los elementos constructivos reutilizables.

Es muy probable que este expolio se produjera en dos fases, la primera señalada por los niveles de desplome que se producen cuando ya no existe pavimento, umbrales o cubiertas en las paredes, ejemplificada por la retirada de pavimentos de signinum que dejan el sustrato intacto (que en este caso corresponde al arrasamiento de la antigua necrópolis - Foto $\underline{491}$ ) y que son apilados cuidadosamente (ver Fotos $\underline{500}, \underline{501}$ y $\underline{505}$ con un interesante paralelo en la Foto $\underline{470}$ ), donde se buscan materiales de valor; y la segunda fase, donde se aprecia el abandono de sillares ya extraídos (ver Fotos $\underline{506}$ y $\underline{489}$ ) o los restos de recortar los bloques arrancados del arco (ver Foto 507), lo que nos documenta un saqueo a gran escala de los materiales de superficie que cuando la necesidad finaliza se interrumpe bruscamente (ver Lámina $\underline{\mathrm{XL}}$ ). Basta observar los derrumbes de ladrillos que permanecen in situ (ver Foto 499 ) o los pilares del pórtico de la acera Oeste de la Morería que están prácticamente intactos (ver Foto 502), mientras que los del lateral Este prácticamente han desaparecido. En Mérida el estrato que se genera al desmantelar las construcciones se ha registrado en las zonas 
aledañas al templo y bajo el arco de Trajano. Allí se depositó un nivel de escombro similar, con materiales cerámicos datados hacia mediado el siglo $\mathrm{V} \mathrm{d}$. C. que se acumularon hasta alcanzar entre $70 \mathrm{~cm}$ y $1 \mathrm{~m}$ sobre la pavimentación marmórea y adosada a los revestimientos, ocultándola a futuros expolios (MATEOS y ALBA, 2000).

Es sin duda interesante pensar cuál pudiera ser el motivo de esta necesidad constructiva en una ciudad en franca recesión y no existiendo ninguna otra urbe o enclave cercano que precisase tal cantera de materiales, si exceptuamos el caso de Valencia (recordemos que también sufre un proceso similar). Sería lógico suponer que alguna obra de gran envergadura fuera la que requiriera de una mano de obra y materia prima en cantidades ingentes, para lo que también haría falta un importante esfuerzo económico que solamente sería imperioso en estos momentos si tuviera una función de carácter general o público y, en este contexto cronológico de crisis e inseguridad, la única posibilidad la encontraríamos en la muralla de la ciudad y del castillo. En este sentido no debemos obviar la envergadura de los trabajos de desmonte y readaptación y lo costoso de tal empresa. En su discurso Pro Templis, Libanio se dirige al emperador Teodosio reprochándole su política de consentir la demolición de los templos, diciéndole: "la demolición [de un templo] fue tan laboriosa como su construcción- tales fueron las dificultades para separar las piedras que habían sido unidas con fortísimos cementos" (en el caso de Afrodisias) (ARCE, 2006:229).

A partir del 425 d. C. la legislación imperial dejará de preocuparse seriamente por la conservación de los edificios públicos, función que será asumida desde entonces por los obispos (ARCE, 2006). Las excavaciones arqueológicas en los templos romanos que subsisten en Hispania prueban que la mayoría de ellos fueron reutilizados como habitaciones u otras funciones, y que fueron paulatinamente desmontados de forma al menos parcial.

En Sagunto la cercanía al solar de los templos respecto a la muralla es un buen indicio de a dónde se llevó buena parte de este material. Un ejemplo claro es la presencia de algunos fragmentos de sillares almohadillados de la torre existente en la casa de la calle Camino Real (ya descrita en este estudio) en el relleno de una de las fosas del solar de la calle Morería y reutilizados en algunos cimientos medievales, lo que indica una clara circulación de materiales entre ambos puntos.

A esto debemos sumar el abandono de la vía como camino, colapsado por los derrumbes (como ya citamos anteriormente), afianzado por la construcción de estructuras sobre la propia calzada (ver Fotos 139, $\underline{512}$ y $\underline{516}$ ), situación que continuará hasta la época musulmana (ver Foto 146 y $\underline{515}$ ), de la cual tenemos paralelos (ver Foto 85 ). Recordemos también el enterramiento familiar existente dentro de la cloaca de la Morería (ver Foto $\underline{514}$ ) y que posiblemente se encuentre asociado a alguna de las estructuras construidas sobre la calzada (ver Foto $\underline{511}$ ), como índice de colapso de la vía de comunicación. 
Además también es probable que la única acuñación de oro conocida para época visigoda en la ciudad fuera para hacer frente a los gastos de esta recuperación de la muralla que consistía básicamente en reexcavar el foso, eliminar elementos adosados y acondicionar portales. Para recuperar la cerca defensiva también sería necesario demoler cualquier estructura cercana a la misma que pudiese ser un punto estratégico para los atacantes, y con más motivo se derribarían los restos monumentales de templos o edificios públicos (ver un ejemplo de reutilización en la foto 192). Aunque no sea un paralelo directo, tenemos documentado lo que sucedió en épocas muy posteriores con la misma finalidad estratégica de liberar la muralla, por ejemplo en las guerras medievales hasta las napoleónicas. Felipe II, tras la actuación de los piratas argelinos sobre la costa, ordenó la fortificación de Sagunto con la mayor brevedad. El trabajo fue realizado por el arquitecto Antonelli: (...) el 1596 destruyeronse varias casas, cubos y corrales que se levantaron en el año 1581, a fin de que quedaran expeditas las murallas (...) (CHABRET, 1888: 392) (...) la reparación de los muros de la villa, cuya altura debería ser de 59 palmos desde el foso, derribo de casas, árboles y cualesquiera otro estorbo en derredor del recinto a la distancia de 600 pasos (CHABRET, 1888: 387- nota 1) (...) La falda del castillo despejada absolutamente del sin numero de algarrobos que tenia, e igualmente limpia de ellos la llanura inmediata hasta tiro de fusil (...) [entre 100 y 200 metros] (ANDRIANI, 1838: 89 anexo B)

La actuación saguntina en época visigoda se diferencia de otras ciudades como Mérida o Valencia en que decidieron ampliar el perímetro de la antigua muralla para englobar estructuras o zonas de valía defensiva (como anfiteatros, teatros, circos, etc.). En Mérida mediado el siglo I d. C., tanto el anfiteatro como el teatro se encontrarían situados extramuros, pero en época visigoda aparecen intramuros. De hecho, el problema de la cronología de este tramo de muralla ha sido ampliamente debatido en los últimos años. Tanto Bendala y Durán como Mateos sugerían la ampliación del perímetro de la cerca defensiva en época posterior a Augusto, para situar dentro el teatro y el anfiteatro romanos, si bien discrepaban sobre la cronología de este engrandecimiento (MATEOS y MÁRQUEZ, 1999). Pero en Sagunto el valor estratégico correspondía al cerro de la montaña, que ya se encontraba englobado dentro de la antigua línea protectora, de ahí que era evidente la opción de abandonar y arrasar la zona extramuros (respecto a la muralla republicana/augústea).

Sin duda es entonces cuando surge el nombre de Morvedre, al referirse a la franja abandonada y en ruinas en las afueras de la ciudad, de la cual solamente pervivieron el trazado de algunas antiguas calles y de las vías principales transformados en caminos. Recordemos, por ejemplo, que en las monedas de Sisebuto acuñadas en esta ciudad la leyenda es Sagunto y en documentos de los siglos V, VI y VII d. C. aparece también el nombre Sagunto (CHABRET, 1888: 148), y es a partir de época medieval en la Hitación de Wamba del siglo XII, redactada presuntamente sobre documentos perdidos del siglo V d. C., cuando por primera vez aparece Murus-vetus (CHABRET, 1888: 147). 
En Mérida, como en el caso saguntino, no existen huellas de una destrucción y el gran peso de piezas como los fustes descartan un expolio no planificado; de hecho, en la estratigrafía se distinguen acumulaciones de escombros. En el caso de esta ciudad en el flanco del templo y bajo el arco de Trajano hay una presencia notable de cascotes y de limpiezas efectuadas en inmuebles exteriores al foro que utilizan este lugar como vertedero o para el desmonte de estructuras del recinto (MATEOS, 2000).

Es en el citado arco donde se observan huellas claras de saqueo, ya que en el estrato de ruinas depositado junto al templo se documentaron varios niveles de esquirlas y fragmentos de mármol. Los contextos creados por la depredación son de diferente naturaleza a los niveles de lascas asociados a la construcción fundacional del recinto, ya que durante la excavación de los niveles constructivos del pórtico del arco de Trajano sí aparecieron numerosos estratos con fracciones de mármol procedentes del deshecho al pie de obra; se trata siempre de pequeñas esquirlas sin carear, resultado del trabajo a cincel; pero los contextos de saqueo contenían restos de tamaños diversos de placas, molduras, entablamentos, etc., que habían sido golpeadas hasta destruirlas (MATEOS, 2006); al menos una parte pudo ser resultado de trocear mármol para facilitar su transformación en cal. El paralelo es claro con el arco saguntino, del que sólo queda la impronta cuadrangular de su base sobre la cual encontramos un estrato de esquirlas (ver Foto $\underline{507}$ ) y fragmentos marmóreos epigráficos de una posible dedicatoria a Mitra y una inscripción imperial (CORELL y SEGUI, 2008).

En Sagunto también es probable que sobrevivieran algunas de las estructuras de edificios de gran entidad, en parte por estar construidos en materiales de difícil reutilización como el cemento, o por encontrarse más alejados de la zona de la muralla y ser relegados frente a elementos más cercanos y de más fácil transporte. Además, al estar más separados del perímetro defensivo también perderían valor estratégico para unos posibles asaltantes y no sería necesario su arrasamiento ex professo; de ahí que se conservaran parte del anfiteatro, del circo, del foro bajo, de alguno de los templos en la zona de la Morería, posiblemente en la zona el convento de San Francisco y en el de la Trinidad, y en la misma línea quizás debíamos ubicar la casa romana de A. Chabret.

Desconocemos la descomposición de las domus en la etapa visigoda en la zona habitada intramuros, pero iría emparejada a una consecuente disfuncionalidad de las partes que la integraban. Los baños, la cocina, la bodega, el triclinium, etc., pierden su sentido utilitario original para pasar a desempeñar otros, como el de habitación, establo o taller. En el caso de Mérida ninguno de los cinco conjuntos termales privados documentados en la zona de la Morería conservó su uso, y tampoco las demás dependencias, salvo alguna coincidencia dentro del empleo multifuncional que se les dará en ese momento. En cambio, el patio comunal, antes peristilo, sigue siendo un elemento clave de articulación en el grupo de viviendas que lo flanquean y desde el que tienen acceso (ALBA, 1999). Lo que es evidente es que en las tres ciudades 
citadas, Valencia, Mérida y Sagunto (como en muchas otras de la Península) la población empieza a despegar, al menos en las metrópolis, a la sombra de la protección de estos núcleos urbanos, lo que conlleva una fragmentación ocupacional de los inmuebles romanos que ahora alojarán a diversas familias, sin que la distribución siga una pauta fija. Las domus romanas se transforman entonces en casas de vecinos.

Sin embargo conocemos que además del saqueo a gran escala de materiales de los edificios hay que una fase de rebusca donde se arrancan pavimentos enteros, de forma similar a la de Mérida, donde fueron picados los derrumbes que sepultaban los corredores y algunas estancias de la Morería, dejando múltiples marcas de pico en los pisos de signinum (ALBA, 1999). Caso también muy similar al de Sagunto en el saqueo inicial, donde algunos elementos que forman parte del pórtico permanecen in situ, mientras los de la acera de enfrente desaparecen, lo que indicaría un desvalijamiento rápido y programado que cesa cuando ya se completa el objetivo, que en este caso podría ser el de reconstruir la muralla.

En Mérida un inscripción hace referencia a la erección de los muros defensivos (más bien de una ampliación de la cerca fundacional) en los años inmediatamente anteriores al $483 \mathrm{~d}$. C., cuando los poderes civil y religioso se aúnan para remontar la crisis, (ALBA, 1998). Una seguridad que quizás interviniera como reclamo para atraer repobladores y que en líneas generales podemos suscribir para el proceso de ampliación y potenciación de Valencia, aunque lamentablemente sin tantos datos históricos y epigráficos, y menos para el caso de Sagunto, en franca decadencia, subsistiendo únicamente por su valor geoestratégico.

En Sagunto la escasa documentación de que disponemos sobre la ocupación de la zona extramuros nos indica que ésta sería muy puntual y quizá asociada a algunos lugares de culto que reutilizan parte de las estructuras romanas, el enterramiento familiar encontrado en la Morería. Además, podemos citar la presencia de restos en el antiguo convento de la Trinidad, San Salvador y San Francisco, pero la falta de datos en estas zonas no nos permite saber si el inicio de reutilización de las estructuras es de época musulmana o anterior (como el caso de San Vicente de la Roqueta en Valencia).

En este momento parte de los viales romanos saguntinos ya están abandonados, por ejemplo la "vía Sacra", cubierta por una potente capa de tierra y escombro fruto del saqueo (como en el caso de la insula Sur donde aparecieron amontonados restos de material constructivo) y sobre la cual se construyen estructuras. La calzada también presenta la cloaca totalmente colmatada por tierra y escaso material, de tal forma que en época visigoda ya se podrían realizar enterramientos en su interior. 


\subsection{LA ÉPOCA MEDIEVAL}

\section{EL PERIODO ALTOMEDIEVAL}

La llegada de los musulmanes a Sagunto mantiene el mismo estado de fosilización de parte de las estructuras y viales antiguos. Algunos como la "vía Sacra" que ya había sido cortada por edificaciones levantadas sobre ella, sigue siendo sepultada por nuevas construcciones (ver Foto 504 ). Sin embargo se reaprovechan parte de los cimientos más altos de la insula Sur, (levantados sobre los antiguos podios de templos - ver Foto $\underline{503}$ y dibujo 46) que se encontraban en una cota más alta, casi a nivel de superficie para los nuevos ocupantes; allí se cierran vanos y se adosan cimientos nuevos a los antiguos (ver Fotos $\underline{483}, \underline{488}, \underline{517}$ y $\underline{518}$ - un interesante paralelo medieval lo tenemos en el Foto $\underline{524}$ ). Este proceso también se daría en aquéllos que estaban adosados al templo rectangular de la Morería entre los que se construye un aljibe (ver Foto 515 ). En otros casos la orientación de los nuevos muros que no reutilizaban antiguos cimientos ya nada tenía que ver con los que se mantenían ocultos en el subsuelo (ver Foto $\underline{520}$ ). Este hallazgo de restos romanos en superficie por los musulmanes lo señala la crónica del "Moro Rasis": (...) Murviedro, que es logar mui presciado, et muí bueno, et muí fermoso, et mui deleitoso, et fallan en el rastros de población mui antigua. Et en Morviedro ha un palacio fecho sobre la mar por tan gran maestría, que mucho se maravillan las gentes de que lo veen por que arte fué fecho. (GAYANGOS, 1850:32)

Los musulmanes prosiguieron con el proceso de saqueo; como ya no era tan fácil la obtención de material en superficie, se cavaron fosas (ver Foto $\underline{509}, \underline{510}, \underline{513}$ y $\underline{519}$ ) buscando más objetos reutilizables, y en algunos casos ahondan hasta hacer desaparecer estructuras y sus cimientos, llegando casi al sustrato geológico, por ejemplo, al alcanzar el enlosado de vía romana, destruyendo parte del mismo y de la necrópolis visigoda; en otro caso arrasan buena parte de los elementos del cementerio romano que se habían conservado bajo las insulae del siglo III d. C. Esta depredación posiblemente se dio en los primeros momentos de la llegada de los musulmanes, ya 
que en un momento más avanzado se construyen varias estructuras sobre los restos romanos que habían permanecido, pero también sobre las fosas ya rellenadas.

\section{EL PERIODO BAJOMEDIEVAL}

Con la conquista cristiana pocas cosas cambian en la ocupación del territorio; el saqueo de estructuras es menos perceptible, ya que cada vez escasean más los materiales de fácil acceso, sin olvidar que las construcciones más importantes que correspondían a la muralla y al castillo ya estaban recuperadas en gran parte. Por otro lado, es evidente la decadencia y la pérdida de infraestructuras que quizá estuvieran en uso desde época romana o que, como mucho, fueron recuperadas en época árabe. Nos referimos por ejemplo a los acueductos (recordemos que al menos unos baños árabes se encontraban junto al segundo acueducto paralelo a la muralla), los puentes, las acequias, etc.

Las nuevas necesidades de control hacen que se cambien los antiguos accesos y caminos utilizados por los árabes. Tenemos documentado históricamente el caso del camino coincidente con la vía romana del camino de Aragón que pasaba junto al circo y que la carta puebla cristiana clausura obligando al paso junto a las murallas, que al fin y al cabo no implicaba más que el hecho de recuperar el primitivo trazado de época del Alto Imperio antes de la ampliación de la ciudad (como ya señalamos anteriormente en esta tesis).

No queremos dejar de apuntar que en época visigoda arrancan dos importantes eventos paralelos en el tiempo, pero diametralmente opuestos en sus consecuencias. Por un lado se inicia un proceso de importante saturación urbanística dentro de las murallas que duraría más de 1200 años y, por otro, durante un periodo similar las fuerzas de la naturaleza, cuyo mayor exponente es el río, actuaron en la degradación de las estructuras más cercanas al mismo, como son el circo, el anfiteatro y los puentes. 


\section{CAPITULO 2: ANÁLISIS DEL POBLAMIENTO RURAL}


Al contrario del apartado referido a los espacios urbanos aquí no pretendemos establecer modelos excesivamente estrictos, ya que el ámbito de las ciudades sí permite extrapolar los resultados con una cierta fiabilidad, debido a las características típicas y casi estandarizadas de los enclaves urbanos romanos, donde además se han realizado bastantes más excavaciones que permiten plantear hipótesis con más fundamentos prácticos.

En este caso las intervenciones rurales son solamente la muestra significativa de yacimientos mucho más amplios que no han sido excavados en su totalidad, con lo cual sólo nos limitaremos a intentar establecer unas pautas de ocupación diacrónica de estos asentamientos para identificar las fases objeto de esta tesis.

Antes de centrarnos en el período romano avanzaremos unas breves palabras sobre los antecedentes ibéricos de la zona. Debemos comprender que se introduce un importante cambio en el eje principal de comunicación, ya que hasta época romana el Mijares sería una importante frontera, tal y como atestiguan las estructuras defensivas y de control prehistóricas y protohistóricas situadas a ambos lados del río (Torrelló y Castell Vell de Almazora, Torrelló de Onda, Vinarragell, etc.). La zona llana más apartada del río no cuenta con importantes restos debido a su difícil defensa. Así, si nos alejamos de Vinarragell, solamente existe un punto importante que es Torre d'Onda, significativo centro comercial retirado de la frontera y sin valor estratégico; su configuración podría ser la de una statio que nos recordara a los pequeños puertos romanos (ver Foto 537) (NOGUERA, 1995-1996 y ESPINOSA et al, 2005) que no son más que una gran plataforma para atraque de barcos o barcazas. Este puerto es el que daría salida y entrada a productos de la zona de Onda (Castillo), Betxi (El Solaig y Sant Antoni) y la Vall d'Uixó (Orleyl y San Josep) por lo menos hasta el cambio de Era, como lo atestiguan los restos encontrados y la presencia de materiales romanos y púnicos en estos enclaves de interior que apoyaron la importancia de este eje comercial. Aquí destacamos el horno de ánforas vinarias del tipo Dressel 2-4 de La Punta (La Vall d'Uixó) y sin entrar en el caso de que se trate de autoabastecimiento o exportación, sí podemos observar la producción no sólo de ánforas, sino también de cerámica común, con una larga perduración, pues los materiales existentes en el museo de Burriana indican que este establecimiento sigue activo a lo largo del siglo I d. C. (ver Imagen 19). Producción que también aparece en las fuentes:

Dig. 8, 3, 3. (...) alfarerías en las que se hiciesen las vasijas en las cuales se exportase los frutos del fundo, (como en algunas fincas a fin de sacar de ellas el vino en ánforas, o disponer de tinajas), o bien tuvieses las alfarerías para construir en ellas tejas 
destinadas a la edificación del caserío del fundo; pero si tuvieses las alfarerías para vender las vasijas allí construidas (...)

Respecto al resto, solamente nos cabe citar elementos de un valor aún por determinar en la zona de Burriana en el Palau y Carabona, también posiblemente en Virrangues, aunque hay que tener en cuenta que éstas son franjas de paso próximas al camino que uniría la costa con el interior, verdadero núcleo de poder del período. El estudio detallado de estos enclaves sin duda aportará en un futuro interesantes datos. Un ejemplo es el reciente análisis de $\mathrm{C}-14$ encargado por nosotros y realizado sobre el enterramiento de equino de la Regenta (Burriana), que en un principio la bibliografía existente adjudicaba al periodo tardo-republicano en relación con Torre d'Onda (MESADO, 2004), pero que los resultados científicos lo sitúan alrededor del siglo III a. C., con lo cual habría que asociarlo al entorno cultural de Vinarragell, el Solaig o Sant Antoni (Betxí).

En época romana las cosas cambian radicalmente; la frontera fluvial deja de ser tal y se convierte en un espacio de paso. Es en estos momentos cuando surge la importante valoración estratégica y comercial de la zona de Burriana. Además queremos señalar un proceso de acercamiento al llano de los asentamientos de la zona; El Solaig (Betxí) pasa al Pla Redó, también conocido como la Torrasa, El Salt o la Bassa Seca (ver Foto 583), La Punta (Vall d'Uixó) pasa a la llamada villa de la avenida del Agricultor, Villavieja pasaría a Benicató, el Castellar a El Alter de Xilxes y así sucesivamente en otros ejemplos, dentro de un panorama de escasa permuta geoespacial. Como ya citamos anteriormente las primeras relaciones con la cultura romana implicaron un cambio en el sistema de ocupación y explotación del territorio: el comercio mediterráneo se potencia, se inician más asentamientos en llano o cerca de la costa y se fomenta un proceso de romanización desde los focos irradiadores de las grandes ciudades más latinizadas. Pero es a partir de época de Augusto cuando las diferencias son mucho más radicales. La primera y más importante de ellas es la potenciación de la vía Augusta como eje principal de comunicación, uniendo cuatro de las ciudades más importantes de la provincia romana: Tarragona, Tortosa, Sagunto y Valencia.

Si tomamos como ejemplo paradigmático el emplazamiento de los enclaves arqueológicos de la zona de la ciudad de Burriana, comprobamos que no son obra de la casualidad, sino más bien fruto de una serie de factores geográficos y sociales que condicionaron la existencia de asentamientos humanos.

En primer lugar tenemos la zona de la Plana, rodeada de montañas y con una amplia costa, lo cual generaba una franja apropiada para el asentamiento humano, donde se podía cultivar mucho terreno y muy fértil. Además las vías de comunicación entre Norte y Sur confluían en la Plana, ya que las montañas que la rodean forman un número limitado de "pasillos" que se unían en la zona de Burriana. La costa actual poco se parece a la de entonces, ya que existían abundantes marjales, lo que dificultaba el 
asentamiento humano en primera línea de playa. Estos pantanos, ya en retroceso, aún se aprecian en los planos de los siglos XVII a XIX. Por esos motivos los establecimientos humanos se situaban en sitios similares a lo largo del tiempo, eligiendo aquéllos donde las condiciones eran las más idóneas, y solamente ocupaban nuevos lugares cuando lo permitían las condiciones geográficas, por ejemplo, cuando se desecaban los marjales, se construían nuevos caminos de acceso a las zonas montañosas, cambiaba la línea de costa, etc.

Los factores humanos también eran decisivos, pues además de la riqueza de la zona (terreno fértil, recursos minerales, abundancia de caza y pesca, etc.) también era necesario tener en cuenta los factores defensivos (control del territorio, dificultad de acceso, facilidad de comunicación, etc.). Si sumamos todos estos aspectos llegaremos a la conclusión de que la franja de Burriana era un espacio idóneo para el asentamiento humano, especialmente desde época romana, de ahí que esta civilización se asentara en unos puntos clave de este término, y posteriormente musulmanes y cristianos adoptaran la misma situación, con pequeñas variaciones.

Dentro de esta revitalización y unificación del territorio es necesario un paso rápido y seguro sobre la frontera natural más importante desde el Ebro hasta el Palancia, o sea el río Mijares. El punto natural del paso más idóneo con una mínima inversión lo encontramos en la zona de Santa Quiteria, donde con dos pequeños puentes se puede cruzar el cauce de la rambla de la Viuda y del Mijares; aguas abajo sería necesaria una gran estructura, ya que se ensancha de forma importante el cauce (analizando fotos áreas actuales aún podemos observar importantes huellas de un gran paleocauce), y aguas arriba también sería necesario un gran viaducto ya que la cuenca además de ensancharse se encaja de forma muy señalada (ver Lámina LVIII).

Un paso en badén condicionaría de forma importante el cruce a las avenidas del río o a los periodos de mayor caudal de aguas. Como ejemplo anecdótico podemos citar un pequeño paso en badén que existe actualmente en la desembocadura del vecino río Seco. Pues bien, a pesar de su mínimo caudal y tamaño ínfimo si lo comparamos con el Mijares, viene siendo destruido con periodicidad casi anual por las avenidas fluviales o por las tormentas. El punto de Santa Quiteria, asimismo, se encuentra muy cercano al cruce entre los corredores naturales paralelos de la costa (San Mateo - Borriol y Oropesa - Almazora), junto a un tercero perpendicular en dirección al interior (Almazora - Alcora), siendo éste el punto que facilita el paso del río para estos caminos.

Una vez cruzado el Mijares, la vía debería acercarse al espacio más llano y próximo a la costa, buscando la franja más fértil y cercana a las zonas de cultivo, de ahí que describa una señalada curva que la aproxima al litoral, eso sí, evitando los marjales y la zona de mayor densidad de arroyos, ya que hemos detectado que entre la Vilavella, Betxí y Vila-real se encuentran numerosos barrancos cuyos paleocauces se pueden apreciar perfectamente en las fotos áreas actuales. El hecho de que estas ramblas 
disminuyan en cantidad más cerca de la costa, también influiría en la decisión de trazar la vía, ya que el cruce de barrancos en muchos casos implicaría la construcción de obras de infraestructura que impidieran el corte de la vía por avenidas, por lo cual a menor cantidad de hondonadas mayor facilidad de paso. Efectivamente el trazado de la vía busca el espacio donde menos cauces es necesario cruzar (ver Lámina LIX).

Por otro lado también ha sido una constante obviar el análisis del paleopaisaje, como en el caso de los pantanos que condicionan el desarrollo de la vía. Tenemos por ejemplo el caso de Sagunto, donde la desecación de zonas húmedas aleja el mar, respecto a lo citado en las fuentes:

Esa ciudad fue con mucho la más rica al otro lado del Ebro y está situada a casi mil pasos del mar; dicen ser originarios de la isla de Zacinto (...) (Tito Livio, XXI, 7)

Hoy en día se puede decir que la distancia entre el Grau Vell y Sagunto casi triplica la distancia que marcan las fuentes, Plinio, sin embargo, la sitúa a 3.000 pasos (Nat. Hist. III, 3), pero si observamos los marjales que rodean estos enclaves, podemos presuponer que nos encontramos en un caso similar al de Torre d'Onda, donde el puerto se ubica en una zona costera rodeada de pantanos. $Y$ entonces sería probable que estas ciénagas antes de su desaparición se acercaran a Sagunto a tres mil pasos. No olvidemos que la desecación existía en épocas antiguas, de la que tenemos documentación para Sagunto, donde el rey Jaime II ordena en 1303 que abran una acequia para desecar los marjales y que pudieran cultivarse (CHABRET, 1888).

De esta forma es muy evidente que el paso más claro de la vía es al Oeste de Almenara y al Este de Faura, en la zona donde el pantano se estrecha; como pudimos comprobar en la reciente excavación arqueológica en Els Terrers, que estaba asociada a un importante asentamiento ibero que reproduce - salvando las distancias - el caso de Torre d'Onda como enclave comercial, atestiguado por los abundantes restos cerámicos fenicios, púnicos y romanos encontrados allí donde se ha documentado una villa (ver Fotos $\underline{577}$ y $\underline{578}$ ), que posiblemente contaría con una importante necrópolis, como la inscripción funeraria que A. Chabret cita hallada en 1887 cerca de Benicalaf, con los restos del monumento (CHABRET, 1888).

Si ahora nos centramos en la posible ubicación del asentamiento de Spelaco en la villa romana del Palau, veremos que también está regida por algunos elementos naturales de mucha importancia. En primer lugar se encuentra enmarcado por el cauce natural de un barranco llamado del Hospital y por el cauce del río Seco, dentro de una especie de península que indicaría que nos encontramos con la zona perfectamente aislada de los marjales cercanos y relativamente protegida de las avenidas temporales (ver Lámina $\underline{\underline{L X}}$ ). Allí se desarrolla el asentamiento del cual hasta el momento se identificaron claramente los baños del yacimiento, una zona de vertidos cerca del citado 
río (ver Foto 567), una alquería islámica y la zona periférica con algunos enterramientos junto a la vía Augusta y al cauce fluvial. Un reciente análisis de Carbono 14 ha determinado que los restos humamos hallados corresponden al siglo IX, con lo que nos encontramos ante los restos coetáneos con la fecha de fundación de la ciudad de Burriana por los musulmanes. Esto se explicaría porque el asentamiento de Beniham/Palau es el origen de los habitantes que posteriormente fundarían Burriana, ya que este yacimiento era mucho más idóneo para el primer establecimiento árabe por sus condiciones geográficas y económicas de reutilización de la villa romana, pero quizá por motivos estratégicos el actual enclave de la ciudad de Burriana superó a todos los demás y despegó económicamente de una manera notable. Si tenemos en cuenta que el tamaño de este cementerio es considerable, es muy posible que estuviera ya en funcionamiento desde final del siglo VIII y hasta el siglo XIII, pero mucho más interesante es su ubicación junto a la vía Augusta, cuyo tramo aún se mantendrá en uso hasta el siglo XIII, (cuando la conquista cristiana altera profundamente el trazado viario en la zona); según lo atestiguamos al observar una mezcla de materiales musulmanes y romanos en hallazgos aislados aglutinados al lado

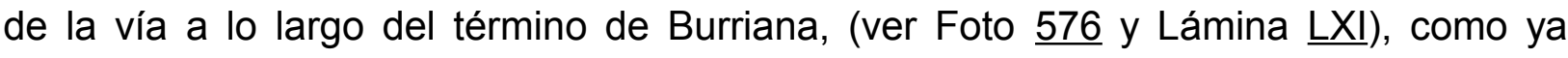
señalamos al nombrar otros ejemplos de traslado de materiales. Recordemos como paralelo inmediato el caso ya citado de la necrópolis musulmana de Lledó, junto al Caminàs, (antiguo camino romano o prerromano) que se relaciona con la reutilización de una villa romana muy cercana.

Así, cuando el eje económico y viario se reubica en el Palau desde Torre d'Onda, ya tenemos un ambiente plenamente romano, con apreciables variaciones en las condiciones de explotación de un amplio territorio.

Tal es la importancia del enclave que, después del periodo de recesión visigoda en la explotación intensiva del llano (con la consecuente recuperación de antiguos asentamientos iberos en alto y su entorno, por ejemplo la necrópolis del barrio de la Unión en la Vall d'Uixó, el Castellar en Xilxes, la montaña en Onda, Almenara y Sagunto, etc.), con la ocupación musulmana y el retorno a una explotación extensiva y una estabilidad similar al periodo romano, se vuelven a dominar puntos estratégicos con reocupaciones y reformas; como el Palau, enclave que sólo decae con el amurallamiento y auge de Burriana en el siglo XI.

Centrándonos en el asentamiento romano, evidentemente es necesario depurar el registro arqueológico para establecer las unidades de hábitat a la vista de las distintas estructuras de ocupación que componen un fundus, de tal manera que cada yacimiento que se descubra en una zona relativamente cercana no tiene por qué corresponder a un enclave distinto, sino formar parte de un gran asentamiento disperso. En el caso del Palau los distintos hallazgos en la zona apuntan a un fundus de gran tamaño, cercano 
a las 3 hectáreas, donde hasta ahora sólo se ha detectado la villa y queda aún por averiguar el resto de las dependencias.

Otro factor importantísimo para apoyar la ubicación de Spelaco en el Palau es que éste es hasta el momento el único yacimiento romano situado junto a la vía Augusta en el tramo entre Sagunto y Tortosa que cuenta con un enclave asociado en la costa, quizá con función portuaria a modo de embarcadero ${ }^{36}$ y que se encuentran unidos por una vía secundaria jalonada por importantes restos como los excavados recientemente en el Marjalet, sin olvidar que junto a este hábitat costero existe un importante manantial de agua dulce, conocido hoy en día como el Clot de la Mare de Deu. Esta singularidad se debe a que la zona de marjales que se extendía entre Nules y Sagunto implicaría la imposibilidad de que existiese un establecimiento cercano al litoral que actuase como receptor de mercancías. El arranque de esta vía desde la costa en Sant Gregori, pasando por el Palau hasta el interior, es un simple desplazamiento del antiguo centro de comercio costero ubicado en Torre d'Onda. Lamentablemente la escasez momentánea de excavaciones arqueológicas en Sant Gregori no nos permite saber si es parte del fundus de Spelaco o es un lugar independiente, con lo cual el camino que uniría ambas, paralelo al barranco del Hospital y pasando por el Marjalet, no podemos aún clasificarlo como una via vecinalis o privata. A esto debemos sumar las dificultades en identificar una antigua senda, aunque las servidumbres estaban bien señaladas:

1. (...) de senda, paso de ganado, camino y acueducto. (...) han de contarse además las siguientes: la de toma de agua, la de Ilevar a abrevar el ganado, el derecho de apacentar, de hacer cal y de extraer arena.

22. Puede constituirse servidumbre de camino de más o menos de ocho pies de ancho, siempre que tenga la anchura suficiente para que pueda pasar un vehículo; si no, será senda, y no camino. (Dig. 8, 3)

Con ello también podemos comprobar la importancia de este hábitat, pues el agua, arena y la posibilidad de abrevar seguramente se darían en este enclave. En las recientes excavaciones del yacimiento del Marjalet es posible que se hayan detectado una serie de zanjas que drenarían la superficie hacia los barrancos de la zona, permitiendo una ligera ampliación de los terrenos cultivables o quizá la contención de los mismos frente a la erosión. No debemos olvidar que este enclave se trata de un vertedero y en época tardo-republicana y del Alto Imperio, los vertederos de residuos sólidos suelen formarse en depresiones naturales o antrópicas (canteras, puntos de extracción de arcillas, etc.) localizadas en el entorno suburbano de las ciudades con el fin último, en muchas ocasiones, de regularizar o bonificar el terreno. En otros casos,

\footnotetext{
${ }^{36}$ No podemos saber, a falta de excavación arqueológica, si Sant Gregori era una statio o villa con embarcadero, como en las fuentes: (Dig. 19, 1, 52.) (3) Delante de una casa a orilla del mar, echaron unos bloques y se formó un muelle (...).
} 
los residuos se vertían en cursos o extensiones de agua próximos, por lo que resultan difícilmente identificables (DUPRE y REMOLÀ, 2002). Un ejemplo interesante es el de Tarragona, donde los humedales que ocupaban el margen izquierdo del río, próximos al puerto, fueron en parte desecados mediante la aportación de escombros y residuos sólidos (especialmente ánforas). Un proceso gradual que se inicia en época tardorepublicana y finaliza mediado el siglo I d. C., cuando este espacio es ocupado por almacenes portuarios (DUPRE y REMOLÀ 2002).

Otro punto que daría mayor importancia a la zona es que estaba a una jornada de desplazamiento de Sagunto por la vía, como venía marcado en los itinerarios. Esta primacía, además, vendría apoyada por el hecho de que sus asentamientos vecinos carecían de salida al mar; recordemos que Benicató está rodeado de marjales y además los habitantes de los asentamientos de Betxí, la Vall d'Uixó, Onda y Vila-real deberían necesariamente pasar por el Palau para llegar a la costa. Si el aliciente geoestratégico de Spelaco era el embarcadero esto no implica que cada enclave intentara poseer su polo de atracción, como en el caso de la zona de Benicató, donde tendríamos el santuario de la Vilavella y sus aguas termales. La conexión entre Spelaco y Sant Gregori se englobaría en un concepto que no sería ajeno al mundo romano, ya que de una forma similar y salvando las distancias, muchos otros asentamientos (de carácter urbano) tienen estas características bipolares entre puerto o embarcadero - vía de comunicación - núcleo del establecimiento, como por ejemplo Sagunto-Grau Vell, Rávena-Classe, Roma-Ostia, etc.

Así pues creemos que nuestra hipótesis es bastante sólida porque logra armonizar multitud de factores que apoyan la existencia de un importante centro junto a la vía Augusta, que se une a un significativo eje de recepción de mercancías por mar, además de poder seguir suministrando estos bienes a zonas del interior ampliamente romanizadas, como las del interior de la actual comarca de la Plana Baixa.

Desde su posible momento fundacional alrededor del siglo I d. C., el enclave de Spelaco vivió situaciones paralelas a las de su entorno (marcado por los extremos ya citados de Sagunto y Tortosa pues es muy posible que aparte del comercio y la agricultura local, su otro gran beneficio fuera el aprovechamiento del eje comercial significado por la costa y la vía Augusta entre las ciudades arriba citadas. Así, una persona o mercancía que desembarcara en Tortosa y siguiera por la senda citada, sólo podría volver a embarcar con cierta facilidad en Spelaco o más adelante, en Sagunto. De esta forma la gran expansión y monumentalización urbana del siglo II d. C. benefició claramente este enclave, pues son de este período la mayor parte de las estructuras excavadas hasta el momento y que coinciden con un edificio funcional pero también de un cierto lujo como lo indica la presencia de los baños.

Este despegue económico vendría reforzado también por ciertas actividades no agrícolas, integradas en el fundus, que proporcionan una rentabilidad que en algunos 
casos justifica el desplazamiento de la agricultura a un segundo término. Más o menos explícita subyace aquí una tendencia hacia la especialización en producciones y actividades más rentables, ya sean o no agrícolas, como sería el caso de Spelaco: En el mismo sentido deben interpretarse las alusiones de Varrón a la elevada rentabilidad que producen ciertos tipos de cultivos o la pastio villatica en fundi próximos a ciudades o bien comunicados. Esta rentabilidad solo se explica por la vinculación al consumo urbano y a las posibilidades que éste brinda: demanda a gran escala, diversificación, precios elevados (REVILLA, 1995: 330).

El segundo punto de inflexión de este flujo de influencias que afecta a Spelaco aparecería en este asentamiento con la construcción y reforma que lleva al surgimiento de un ábside y a la anulación de los edificios de los baños. Es difícil saber el momento exacto en el que se introducen los cambios en la villa, y si estaría relacionado con el culto cristiano, ya que no existen datos concretos sobre los primeros años del Cristianismo en Hispania (GODOY, 1989:369). De la misma forma recientes investigaciones que hemos llevado a cabo entre los materiales del enclave de Sant Gregori demuestran que también existieron procesos de reforma y reutilización de materiales entre el siglo II y el III d. C., lo que se podría situar en el mismo contexto del yacimiento del Palau y de muchas otras villas tarraconenses que citamos en otros apartados de esta tesis.

Es muy probable que la decadencia y posterior desaparición del enclave de Spelaco se diera a partir de mediado el siglo IV d. C., dentro del proceso de inmigración hacia la ciudades y se inicia el proceso de inseguridad general del siglo $\mathrm{V}$ d. C. Su primera víctima fue el comercio costero a menor escala ya que, por ejemplo, los productos orientales llegan casi exclusivamente, para su posterior redistribución, a los grandes puertos y colonias de comerciantes orientales en la orilla occidental de la Península en el siglo $\mathrm{V}$ d. C., con la presencia de clérigos orientales y corrientes orientalizantes como las nestorianas (CASTRO, 1990). Si exceptuamos la decadencia del pequeño comercio de cabotaje, que sí era pujante en época ibero-romana, tenemos una repetición de esquemas de este periodo, donde los ejes de comunicación hacia el interior vuelven a tener la importancia que tuvieron entonces. No debemos olvidar que la población autóctona se desplaza a sitios más defendibles frente a invasores bárbaros, que a su vez tardaron muchos años en ser asimilados por la gente local. Esta inestabilidad general y la disolución de fronteras debe también hacernos pensar que no sólo se echaron a perder grandes infraestructuras, como los acueductos, por la imposibilidad de un mantenimiento global, sino además en el caso de puentes o vías por una voluntad intencionada de suprimir puntos de paso fáciles y recuperar la capacidad estratégica de algunos accidentes geográficos naturales. Esto debería hacernos reflexionar sobre los restos materiales en la zona, que amén de escasos, no tienen por qué corresponder mayoritariamente a una tipología coincidente con la de un invasor 
visigodo, minoritario demográficamente, que durante siglos concentró su poder en núcleos urbanos. Más bien pensaríamos en una evolución local de la cultura material.

Por otro lado los sistemas de comunicación y transporte musulmanes no difieren mucho de los de la época romana, con lo cual las zonas de paso y parada serían similares. Esto ocasiona además que, a medida que la inestabilidad política medieval se acerca a la zona de Burriana, la ciudad adquiere un importante papel estratégico como llave de acceso a la zona de La Plana y de Sagunto, con lo cual necesita obtener la calidad de fortaleza, en paralelo con la fortificación y el uso de una línea de castillos defensivos en zonas como Castellón, Almazora, Alcora, Onda, Vilavella, La Vall d'Uixó, Almenara. El afianzamiento de este importante enclave comercial y agrícola, que logra carácter de plaza fuerte, explicaría que sea un sistema de hábitat rural disperso en el entorno de un sitio fuertemente defendido y urbanizado como era Burriana y las torres defensivas de su entorno (Beniham, Carabona, La Regenta, Llombay, Alcaramit, Les Alqueries), quedando los demás asentamientos dispersos y aislados (como por ejemplo Moncofar o Xilxes) cerca de la antigua vía Augusta para utilizarla como principal ruta de comunicación o de huida hacia recintos mejor defendidos. No olvidemos que la costa de Burriana sigue siendo el sitio más idóneo para desembarcar hasta llegar a Sagunto, lo que amplía su interés estratégico.

Otro factor que demos tener en cuenta es que en un principio la cultura musulmana también produjo una reactivación económica basada en la agricultura y la ganadería, lo cual sin duda significó la ampliación y puesta en valor de antiguas infraestructuras romanas asociadas a estas actividades, dentro de un contexto de ocupación del territorio y utilización de los recursos naturales para un mismo fin parejo entre ambas civilizaciones. De forma similar a lo que concurre en los centros urbanos donde, por ejemplo, se recupera la cultura del agua prácticamente abandonada en época visigoda. Durante el largo período de dominación islámica hubo un aumento demográfico que su vez repercutió en una mayor necesidad de explotación del espacio que, de forma similar al máximo momento de expansión durante la época romana, llevó a la utilización de terrenos menos idóneos que requerían una inversión mayor para su puesta en valor, como ocurre en las zonas montañosas o en los terrenos menos fértiles.

Con estos datos es fácil entender que los cristianos, en su guerra de conquista, tuvieran a Burriana como capital de la Plana, enclave estratégico de primer orden y objetivo primordial. De hecho su caída supuso el desmoronamiento de toda la defensa de la zona hasta Sagunto y la franja Norte de la Plana al quedar desarticulado su sistema defensivo septentrional. 


\section{CAPITULO 3: CONSIDERACIONES GLOBALES}


En el proceso de desarrollo de esta tesis doctoral hemos profundizado en el análisis de distintos factores relacionados con los restos arqueológicos y las fuentes históricas, asociados en su mayor parte a intervenciones antiguas pero también propias. Esta línea de trabajo ha demostrado que existe aún, en algunos casos, bastante retraso la hora de crear un sistema de análisis científico que permita alcanzar unos resultados más ajustados a lo que verdaderamente se espera de una ciencia.

Uno de los factores más perjudiciales para la Arqueología y la Historia Antigua ha sido la utilización de métodos inductivos. Esta línea de actuación, que es aceptable en otras ciencias, en nuestro caso ha derivado en errores de bulto causados básicamente por dos elementos: la utilización de fuentes poco fiables (estudios antiguos realizados con medios no apropiados hoy en día, uso de datos no contrastados sobre la existencia de yacimientos o restos, etc.) y el hecho de forzar el registro para adaptarlo a conclusiones o hipótesis (es característica la utilización de expresiones como: "debería ser", "el que no exista no quiere decir que no haya estado", "no se entiende el por qué", etc.), o aún cuando se intenta utilizar expresiones matemáticas para justificar teorías no contrastadas con materiales arqueológicos. Nosotros nos oponemos frontalmente a la utilización de fórmulas numéricas para interpretar el comportamiento humano, Pensemos que el hombre se rige por factores mucho más aleatorios a la hora de condicionar su vida y que los métodos matemáticos no son más que complementos útiles que pueden ayudarnos, pero que jamás han sido la panacea que nos permitiese entender al hombre antiguo.

Por otro lado también es interesante señalar que, en la zona objeto de este estudio, si bien se ha producido un cambio importante desde la perspectiva de genero en la aportación femenina al mundo laboral y de la investigación, donde en las tres última décadas ha conseguido alcanzar cotas muy destacadas, con tendencia a llegar a la igualdad; en el campo de la producción científica esto no se observa. Por un lado los estudios asociados a la Antigüedad, que bebe en buena parte de la fuentes clásicas escritas por hombres y que en su mayoría cuentan su historia - dan poco destaque a la mujer, y los estudios arqueológicos van poco mas allá del estudio antropológico o de la cultura material tradicionalmente asociada a la mujer. Así pues, las etapas de cambios, fases o periodos se estudian más bien desde un punto de vista asexuado.

Es el momento de reelaborar muchos de los estudios que actualmente se dan por ciertos y admitir de una forma crítica y sincera que en numerosos casos aún estamos lejos de establecer unas teorías amplias que nos permitan entender la historia de la ocupación romana y deberemos aceptar que aún existen algunos espacios vacíos que 
deberán ir siendo rellenados con la evolución de la ciencia arqueológica. Hemos demostrado que el análisis de factores asociados a la historia local de los distintos asentamientos conocidos pueden darnos pistas de acontecimientos de mayor calado y no debemos nunca olvidar que la historia del Imperio romano es la de una gran organización cuyas leyes y acontecimientos sociales dejaban una huella que, de una forma o de otra, aparecen reflejadas en todo el territorio que ha ocupado, de tal forma que a ambas orillas del Mediterráneo se pueden encontrar muchas veces respuestas similares a un mismo estimulo que parte de un foco central. Éste es uno de los primeros ejemplos de globalización de la cultura occidental.

Jamás deberíamos aceptar expresiones del tipo "porque sí", "así debería", "así sería", o dar por cierto aquello de lo que no existen pruebas físicas. $Y$ es que de hipótesis se han hecho muchas veces realidades. Todo esto no hace más que poner trabas a la Arqueología y a la Historia como ciencias; tal es la desviación en algunos casos respecto a la realidad que deberíamos empezar de nuevo con una Arqueología hipercrítica que nos obligase a reiniciar otra vez, pero solo sobre la base de los hechos.

La superposición de hipótesis o premisas teóricas no comprobadas acaba por alejar los resultados de los hechos, lo que a su vez permite la existencia de múltiples variables teóricas y a veces contrapuestas. Por ejemplo, en el caso de la zona Norte del Camp de Morvedre solamente tenemos un yacimiento excavado y publicado (villa romana de Els Terrers y su hábitat ibérico asociado), donde también se pudo documentar parte de la estratigrafía del terreno con motivo de las obras de la autopista A-7 en el año 2004, y se observó como los terrenos de marjal llegaban cerca de Faura y parte de los materiales documentados en superficie y citados como yacimientos son fruto de la aportación para relleno de cultivo de época moderna o contemporánea. Ésta, por el momento, es la única base contrastada para analizar la zona en época romana. En cambio existen recientes estudios (GARCÍA PROSPER et al, 2006) que son un ejemplo claro de acumulación de hipótesis, ya que sobre la base de una prospección de campo superficial e intensiva se proponen como yacimientos todas las zonas donde aparece abundante material romano (cuando ya vimos que no es cierto). Al existir una clara disfunción respecto al límite de la zona de antiguo marjal al aparecer restos romanos dentro de él, se plantea que los terrenos ya fueron bonificados en época romana; para ello también proponen una centuriación que afecta a esta zona, utilizando parcelas de pequeños huertos (GARCÍA PROSPER et al, 2006) que difícilmente pueden haberse conservado intactas 2.000 años, como ya justificamos en esta tesis. También existen diferencias respecto al trazado de la vía Augusta, ya que algunos yacimientos no parecen estar relacionados con la misma; se formula que un camino paralelo al ferrocarril (que pensamos que podría tener origen contemporáneo ya que no aparece documentado en planos del siglo XIX - ver Dibujo 57) sería la citada vía romana, que corta buena parte del marjal y además obliga a un desmonte en la montaña de Almenara (GONZÁLEZ VILLAESCUSA, 2006), presuponiendo que por mantener una 
vía rectilínea los romanos hicieron un importante esfuerzo constructor de terraplenes y desmontes, dejando a un lado un pasillo natural casi completamente llano que rodea el marjal y la montaña. Como podemos comprobar hemos contabilizado 3 apriorismos superpuestos para justificar una hipótesis. Frente a ella proponemos la alternativa de la existencia de una vía que atravesaría el monte por el paso natural que ya utilizaba el Camino Real hasta unirse con la variante interior de la vía Augusta, cruzaría el marjal por su parte más estrecha (la más próxima, la fuente de Quart), pasaría cercana a los yacimientos conocidos y permitiría así una fácil comunicación con la vía que va a Zaragoza (ver Lámina $\underline{\mathrm{LVI}}$ ), sin apenas obras de entidad a excepción del firme de la calzada, además estos caminos parecen perfectamente reflejados en los planos militares de principio del siglo XIX (ver Dibujo 58). Para explicar el resto de presuntos asentamientos cercanos proponemos la siguiente pregunta ¿Dónde fueron a parar las toneladas de tierra y materiales arqueológicos extraídos del tell de Els Terrers durante el siglo XIX para bonificar el marjal?

Siguiendo con nuestras consideraciones elaboradas sobre aspectos concretos de algunas intervenciones, gracias a los factores metodológicos que han guiado nuestra labor y que reflejamos al principio de nuestra tesis, queremos trazar una línea de estudio amplia que se puede aplicar de forma genérica a trabajos arqueológicos que afectan a zonas similares a las que nosotros hemos estudiado.

En primer lugar hay que deshacerse de conceptos erróneos, siendo el más perjudicial de ellos el análisis parcial del espacio. Nos hemos encontrado en muchos casos concretos con investigadores que no utilizan los condicionantes geográficos de las zonas y otros que se quedan en el análisis de aspectos actuales dando por sentado la inmutabilidad del lugar durante cientos o miles de años, craso error que nos lleva a conclusiones a veces bastante equivocadas. Debemos tener en cuenta que si por un lado a nivel geológico los cambios son bastante menos perceptibles para la civilización humana, por otro a nivel geográfico estos cambios son bastante importantes, no solamente en espacios rurales y urbanos, sino dentro de un contexto general de explotación del territorio.

Debemos contar con la intervención humana para la transformación del paisaje y adaptación del mismo a sus propias necesidades. Este cambio que citamos es continuo y por ello mismo debe ser analizado de forma sincrónica y diacrónica sin imponer a priori lo que no está contrastado sobre el terreno. Nosotros defendemos un análisis profundo y complejo realizado por equipos multidisciplinarios donde incluimos por ejemplo geógrafos y geólogos, pero sin olvidar a un nivel más básico que también es esencial depurar las anteriores observaciones o estudios sobre los que nos basamos, para así evitar desde un principio desviarnos del rumbo de la investigación.

Hay que establecer una escala de transformación del territorio donde la base significaría los cambios más sencillos y habituales, en otras palabras, aquéllos que 
requieren un menor esfuerzo económico y social y que, por ende, son más constantes y continuos a lo largo de la Historia. La cima de esta escala la constituía la metamorfosis que implica una inversión que sólo puede llevarse a cabo por una acumulación de esfuerzos de todo tipo, que generalmente responden a la voluntad de una organización social de tipo complejo o estatal.

Un ejemplo claro del mismo lo podemos encontrar en la transformación de la zona agraria. Es mucho más simple y habitual cambiar los cultivos, modificar las propiedades menores, variar el riego de zonas limitadas, abrir pequeños accesos o sendas, etc. donde simplemente se ven implicadas una o varias unidades familiares o de propiedad. Sin embargo, es mucho más difícil modificar trazas de caminos o carreteras, grandes canalizaciones de agua, obras de drenaje u otras estructuras de interés comunitario que afectan o benefician a un conjunto amplio de la población y cuya alteración ocasionaría perjuicios o beneficios sobre una gama más amplia de habitantes. De ahí que sea más fácil la conservación en el paleopaisaje de elementos de uso constante y cotidiano, lo que permite fosilizar su uso de forma más habitual.

De la misma forma en tramas urbanas es mucho más fácil la modificación puntual de pequeños sectores, como por ejemplo la apertura o cierre de accesos a casas, la división o la unión de viviendas, etc. frente a la anulación u ocupación de grandes espacios o arterias principales de la ciudad. Estas intervenciones más amplias sin duda dependen, como en los casos anteriores, de actuaciones e inversiones económicas dependientes de un esfuerzo superior al de unos pocos individuos.

Así pues, establecida esta premisa, es necesario hacer la depuración de los factores que han afectado al paisaje a lo largo de los años e intentar establecer una evolución coherente con el uso y transformación del espacio humano.

El siguiente elemento que debemos considerar es la propia capacidad humana para manejar en su beneficio los recursos de que dispone. Aquí nos encontramos otra vez con una diferenciación básica a la hora de analizar este factor; en primer lugar debemos tener en cuenta que los grupos y los individuos tienden a la utilización de recursos de forma que se obtenga el máximo beneficio con la mínima inversión de medios, y solamente factores ajenos a esta lógica puede suponer la realización de intervenciones aparentemente contradictorias con esta premisa, como pueden ser los casos de interés político, religioso, social, la saturación en la explotación de recursos o algún factor natural, como una catástrofe o un cambio climático.

Estas inferencias son las bases para entender la evolución histórica en el período que hemos analizado. También debemos recordar que muchos de los elementos que exponemos y expondremos también son fácilmente aplicables a las culturas anteriores y posteriores, por que los condicionantes geográficos y humanos en muchos casos 
permanecen de forma similar a lo largo de los siglos. Desglosaremos algunas de estas premisas interpretativas en una serie de subapartados dentro de esta línea general.

\section{EXPLOTACIÓN DEL TERRITORIO}

Como hemos observado en algunos ejemplos concretos, es muy importante poseer un conocimiento lo más completo posible del territorio, pero sobre todo teniendo en cuenta su estado en el momento que nos interesa, lo que actualmente se conoce como paleopaisaje; porque en época romana la explotación del espacio no se refiere solamente a los recursos naturales, sino a la propia configuración del terreno que propicia distintos valores, como por ejemplo la facilidad de comunicación y transporte (en este caso tenemos el uso de la llanura litoral de la Plana para el desarrollo de la vía Augusta) $o$ el control y visibilidad del entorno que podemos ejemplificar en asentamientos como Sagunto o Almenara.

También hemos podido comprobar que parte de los estudios contemporáneos se encuentran contaminados de forma importante por la observación actual del sitio, no sólo por lo que se refiere a la geografía física como en el caso de las distintas hipótesis sobre la implantación de vías romanas en la Plana, sino también a la humana, pues en considerables casos se dan como ciertos topónimos o se les atribuye una antigüedad que muchas veces no es cierta, como sucede en el yacimiento de Torre d'Onda.

No podemos tampoco olvidar conceptos que acaban deformando el análisis y las conclusiones actuales, priorizando ideas antiguas y desfasadas sobre la cultura romana respecto a la observación actual, como lo sería el paradigma de que las vías romanas son siempre rectilíneas (ARASA, 2006). Debemos imbuirnos de los conceptos romanos de economía de recursos, optimización de los medios disponibles y el más importante de todos, la existencia de un fondo cultural común que hace que muchas de las ideas y proyectos de implantación en una zona o territorio sea globales a lo largo de toda la extensión del Imperio, de tal forma que para un mismo problema, como puede ser la construcción de un acueducto, carretera o villa, tengamos la misma solución o muy similar tanto en Hispania como en Próximo Oriente.

A la hora de analizar o detectar restos romanos planteamos una serie de parámetros respecto a la ocupación del espacio que se basan en una lógica tajante y documentada a lo largo del Imperio en centenares de obras: la ocupación de un área nunca se da por un motivo subjetivo y siempre se buscan elementos que la favorezcan, como:

- La existencia recursos naturales, minerales o vegetales o la facilidad de cultivo.

- La necesidad de controlar un territorio o de asentar en él elementos afines a la cultura dominante.

- Motivos culturales/religiosos señalando un espacio concreto. 
- Facilidad de comunicación asociada al comercio/transporte

- Control o vigilancia y mantenimiento de estructuras o infraestructuras de interés estratégico

Ciertamente también debemos tener en cuenta que el proceso evolutivo seguido por cualquier cultura puede obligar a establecer una última inferencia. Nos referimos a la progresiva saturación de zonas según la ampliación demográfica, que lleva a la necesidad de asentar nuevos habitantes. Debemos tener en consideración los establecimientos primigenios, que ya tienen una posición de privilegio territorial en cumplimiento de las premisas anteriores. En otras palabras: el aumento de población puede obligar a que se ocupen espacios que en otro momento no fueron preferentes, pero que con una inversión económica y social pueden adquirir condiciones de habitabilidad. Quizá seria el caso del yacimiento de Sant Gregori, donde la necesidad de un enclave costero llevó a la necesidad de adaptar una zona situada entre marjales.

Este proceso de saturación se puede observar claramente en zonas urbanas con la reutilización y subdivisión de espacios en viviendas y franjas funerarias como ya ejemplificamos en Sagunto, y que posiblemente tenga su reflejo en las áreas rurales con la ocupación de zonas montañosas, con peor comunicación y posibilidad de explotación, pero que serían los únicos recursos disponibles frente a la conquista anterior de los espacios con mayor cantidad de medios y facilidades de uso. Aquí podríamos referirnos a los yacimientos romanos de la zona de Betxí (La Torrasa), Vilareal (Pla Redó), Castellón (Vilamargo), Sagunto (El Remei), etc.

Esto nos lleva a proponer el uso de un análisis diacrónico al pensar en la utilización del territorio en la época romana. Por encima de todo debemos tener en cuenta que el asentamiento en las tierras varió de manera importante a lo largo de los siglos, a veces de forma brusca, como el traslado del eje comercial entre Torre d'Onda y Sant Gregori, a veces lenta y perpetuada, como la ocupación de la zona de Sant Antoni y la Torrasa en Betxí. Así pues, no se pueden establecer estudios generalistas que congelan el tiempo en una valoración breve, sin ofrecer el examen de una evolución constante y transformación continuada del territorio.

\section{CONTROL DEL TERRITORIO}

Este es quizá uno de los aspectos que puedan presentar menos cambios a lo largo de la evolución cultural de la Humanidad, ya que la necesidad de vigilancia del espacio es directamente proporcional a la inseguridad que genera cada período histórico. Lo que debemos tener en cuenta es que una voluntad inicial de control del territorio puede quedar camuflada en periodos de estabilidad como el ya citado periodo de pax romana del siglo I al II d. C., donde se diluye esta sensación de incertidumbre, permitiendo una expansión no condicionada por caracteres defensivos u ofensivos, como puede ser la salvaguardia de vías de comunicación, la seguridad del tráfico marítimo, la necesidad 
de espacios amurallados o en alto, etc., del cual el paradigma es Sagunto, como ya desarrollamos en esta tesis. Lo que es evidente es que las condiciones geográficas son el máximo determinante a la hora de seleccionar puntos de control estratégicos, y esas condiciones territoriales se mantienen en una escala temporal muy superior a la de la duración de las sociedades humanas, ya que entramos en cronologías que llegan a magnitudes geológicas, como los lapsos de tiempo climáticos de gran amplitud, el relieve (asentamientos en alto como Sagunto, Almenara, siglo en Betxí, la Vilavella, etc.) las condiciones de sequía y humedad (avance y retroceso de marjales que afectan a los yacimientos de Torre d'Onda, Sant Gregori, etc.), los cauces de los ríos (tanto como frontera o paso como ejemplificamos con el Mijares), la realidad litoral con sus puntos de aguada (binomio Clot de la Mare de Deu - Sant Gregori) o de desembarco, etc. Estos perviven durante tanto tiempo que afectan a más de una cultura, por lo cual no nos sorprende que distintas civilizaciones busquen las mismas soluciones a la hora de controlar un territorio, de ahí la pervivencia de enclaves como Spelaco, Sagunto, Vinarragell, Sant Antoni - La Torrasa, etc.

Para el caso concreto que estamos analizando, la romana no fue una época de prolongada seguridad, sino que en su principio y final las decisiones estratégicas fueron las más importantes a la hora de dar forma a los medios de ocupación del territorio, y la presencia de unos periodos de estabilidad y paz son los que ocasionan una distorsión relativa sobre esa función estratégica, enmascarando parcialmente estas necesidades bajo un manto de ocupación aparentemente despreocupada, como cuando las murallas de Sagunto o Valencia son anuladas por la expansión urbanística del siglo Il d. C.

La visibilidad es importante para controlar, no sólo el entorno, sino las vías de comunicación marítimas y terrestres (los yacimientos de la Muntanyeta dels Estanys y la montaña de Almenara es un caso paradigmático, ya que controla visualmente tanto las rutas marítimas como las vías Heraclea y Augusta) con un margen suficiente para permitir una respuesta adecuada al tipo de aproximación, mayormente de carácter bélico, lo que implica facilidad de comunicación, rápida y segura para las tropas y que la información estratégica no se vea retrasada por ningún tipo de obstáculo (ríos, elevaciones, cruces lentos por ciudades $u$ otros estorbos humanos, confluencias con infraestructuras, posibles cortes intencionados de carreteras, etc.), así como la posibilidad de levantar o utilizar elementos defensivos con rapidez, como puede ser el aprovechamiento de pasos estrechos, cruces con riesgos, zonas de marjal que impidan el paso o en algunos casos la cercanía a puntos defensivos o amurallados.

\section{FACILIDAD DE COMUNICACIÓN}

Uno de los elementos esenciales de la articulación del Imperio romano son las vías de comunicación. En este campo aún nos encontramos hoy en día con algunas ideas y conceptos desfasados que, mezclados con interpretaciones personales, ocasionan una 
multiplicidad de teorías e hipótesis que contribuyen a formar un panorama que en algunos casos llega a ser bastante confuso.

Debemos fiarnos, a la hora de establecer alguna hipótesis, de los restos que sean clara y evidentemente de la cultura romana, descartando aquellos casos de excavación arqueológica de algún tipo de infraestructura donde la cronología no está claramente delimitada por materiales, con lo cual podemos encontrarnos ante obras viarias de cualquier periodo, casos de excavaciones en supuestas vías romanas que sólo se guían por la tipología de márgenes o empedrados o por elementos cerámicos residuales (GRANGEL y ULLOA, 1996, ULLOA, 2006 y ARASA y FLORS, 2006).

Las vías principales, de carácter imperial y administrativo, son fruto de una gran inversión, cuyo mayor objetivo es la rapidez y seguridad; en otras palabras, deben tener una pendiente y una homogeneidad del firme que se suma a la necesidad de cruzar sin problemas accidentes geográficos. Todo eso configura una forma de enfrentarse al paisaje típica y característica, como la búsqueda de franjas llanas y trazados rectos, cruces estrechos sobre ríos, alejamiento de zonas pantanosas y bordear núcleos poblacionales densos. En el caso del tramo de la vía Augusta que hemos estudiado se dan todos estos ejemplos, el acercamiento a la llanura costera con un perfilado rectilíneo en el área de la Plana, la búsqueda del paso mas sencillo y económico del Mijares por Santa Quiteria, el alejamiento del marjal de Almenara bordeándolo para evitar el cruce por dentro del casco urbano de Sagunto.

Las vías secundarias tienen la función de unir directamente núcleos poblacionales, sean urbanos o rurales, y su mantenimiento se debe a entidades administrativas de ámbito local; de ahí que las obras de infraestructura que requieran grandes recursos económicos serían menos abundantes. Además, cuentan con una limitación espacial más aguda, pues deben unir dos puntos concretos más cercanos, lo que reduce el abanico de posibilidad para elegir un trazado más canónico a la hora de evitar obstáculos; por ejemplo la senda entre Sant Gregori y Spelaco se encuentra encajonada entre espacios pantanosos y barrancos, lo que limita los posibles trazados.

Finalmente las vías locales que unen pequeños asentamientos entre sí o núcleos urbanos con su periferia, priman más aún la adaptación al medio con la finalidad de reducir gastos de construcción y mantenimiento. Las vías urbanas son evidentemente mecanismos de prestigio con características totalmente distintas en su forma de acabado, ya que se encuentran asociadas a otros elementos como son cloacas, acueductos, zonas monumentales, etc., dejando a un lado otros elementos que en su momento fueron importantes, como la velocidad de tránsito o la seguridad del mismo.

Estos conceptos se pueden aplicar a otras obras como los acueductos, diferenciando aquéllos que servían a grandes núcleos urbanos de aquéllos de menor entidad que valían como suministro a entidades rurales (como el que observamos en la villa de 
Quintili en Roma - AA. VV., 2000b), donde también podemos establecer una gradación similar a las vías sobre su entidad física.

En este caso tampoco olvidamos las premisas anteriores, ya que la transformación que sufre el terreno a lo largo de los siglos puede enmascarar parcialmente el trazado de estas infraestructuras, como el caso del abandono de los acueductos saguntinos a partir de época visigoda a favor de cisternas y pozos, y sus posteriores transformaciones a partir del periodo medieval.

\section{POSIBILIDAD DE TRANSFORMAR EL ENTORNO - OPTIMIZACIÓN DE RECURSOS}

No debemos dejar de lado que, en un primer momento, el uso de recursos se concentra en aquellos que se puedan explotar de forma más sencilla y económica, en otras palabras, con una mínima inversión de medios humanos y monetarios. Así los núcleos poblacionales se implantan en el centro o en la zona más próxima al territorio a usufructar. Factores como la fertilidad del terreno, la disposición de recursos naturales geoestratégicos, la fácil comunicación o, en los casos citados anteriormente, la faceta defensiva, señalan claramente los puntos preferentes para los asentamientos; como la ocupación agrícola intensiva de la Plana donde se suma su facilidad de acceso.

Una segunda fase haría referencia a la expansión de los núcleos primarios o a la creación de puntos secundarios dependientes o no de los primigenios, en zonas donde una inversión aceptable permite acceder a recursos importantes, por ejemplo la desecación o puesta en regadío del terreno, la ampliación de vías de comunicación o el hecho de encontrar medios desconocidos en un momento inicial. En este caso, siguiendo con el ejemplo anterior, podríamos señalar la ocupación de terrenos menos fértiles del interior de la comarca de la Plana, como Vila-real, Onda, Alcora, la Vall d'Uixó, que implican la necesidad de una mayor inversión, como por ejemplo el aterrazamiento o aporte de recursos hídricos.

Finalmente factores como la presión demográfica o económica pueden llevar a un intento de puesta en valor de terrenos donde es necesaria una gran inversión, por ejemplo, terraplenar zonas. En este caso tampoco debemos olvidar que al final del Imperio romano fueron motivos de inseguridad política y social los que llevaron a la ocupación de enclaves, entre cuyas características principales se contaba la capacidad estratégica y defensiva; ejemplos paradigmáticos los tenemos en Almenara (Castell) y la Vall d'Uixó (San Josep).

Aquí no debemos olvidar que las transformaciones del medio perduran en proporción directa a su magnitud y a su necesidad de uso, así pues cuanto mayor fuera la inversión en transformar el terreno, más fácil es que haya perdurado por los siglos. En otras palabras, es más factible que obras comunitarias como zanjas de desecación, abancalamiento, presas o caminos, perduren más que otras como las parcelas 
centuriadas, los caminos particulares, etc., ya que cada cultura cambia la distribución de la propiedad, pero tiende a mantener aquellos recursos comunes que les permiten reducir costes al evitar nuevas inversiones por parte de los recién llegados.

\section{APROVECHAMIENTO DE RECURSOS YA ESTABLECIDOS}

La existencia de recursos previamente explotados es un factor importante a la hora de seleccionar un asentamiento. En este caso es difícil establecer un parámetro, ya que en algunos casos la ubicación previa de un grupo humano se une a unas características físicas que se siguen manteniendo a lo largo de los siglos y que igualmente ejercen una atracción sobre los nuevos pobladores; una muestra pude ser la característica fronteriza del cauce del río Mijares, una constante en época prehistórica y protohistórica, y que algunos autores también proponen como límite del territorio saguntino (BELTRÁN, 1980 y JÁRREGA, 2011). Nos referimos por ejemplo a pequeños altozanos junto a franjas costeras como Vinarragell o los pujolets de Castellón, zonas de paso estratégico como Ad Noulas o Spelaco, puntos idóneos para el comercio marítimo como Torre d'Onda, terrenos fértiles, etc.

Evidentemente, si una sociedad encuentra restos de etapas anteriores, ello implica un ahorro por la obtención de material previamente trabajado, lo que reduce parcialmente el coste de materia prima. En época musulmana hemos comprobado constantes ejemplos en los yacimientos romanos del Palau, Castellón, Sagunto, etc. Así pues, nos encontramos ante una disyuntiva difícil de aclarar por el momento, ya que es muy difícil afirmar de una forma rotunda que los restos primitivos, por su reutilización, puedan ser un elemento capital en la decisión de situar un nuevo asentamiento.

\section{FACTORES SOCIALES Y CULTURALES}

En este apartado podemos incluir las necesidades propias de la población, como podían ser alimentación, seguridad o bienestar general y que son una constante bastante común a lo largo del periodo romano. Pero nos centramos en casos más puntuales como son el poder militar, religioso y social como elementos determinantes a la hora de establecer factores históricos.

El factor castrense es explícito a la hora de instaurar el control del territorio y mantener la facilidad de comunicación a lo largo del mismo, lo que se refleja, por ejemplo, en las grandes rutas terrestres, como la vía Augusta (tanto en los nuevos tramos construidos como en aquellos en que se reforma y amplia la antigua vía Heraclea), asentamientos ex novo en zonas estratégicas como Spelaco o la Muntanyeta dels Estanys de Almenara, o la implantación de estructuras sobre elementos anteriores estableciendo una posición dominante tipo praesidium, como podría ser el caso de la ocupación romana de Sagunto, con el añadido de que la mano de obra era aportada muchas veces por este mismo estamento militar, mediante sus propios soldados. El poder 
religioso no deja de ser también un elemento de control, ya que aglutina las creencias bajo la dominación de un liderazgo fáctico.

Esto implica elementos de prestigio como la asociación a la divinidad con objetivo de impresionar y reunir a los fieles, cuyo máximo exponente fue primero el culto a Roma y después al propio emperador; aquí es donde los templos y las curias ejercen un papel destacado en la elección de ubicaciones privilegiadas, tanto en la faceta urbana como rural, y que con el tiempo pueden dar origen a núcleos de determinada importancia como el de Hércules Victor en Tivoli (Tibur) o el de la Fortuna Primigenia en Praeneste (Palestrina). A diferencia del aparato militar no se busca la estrategia, sino la visibilidad y la riqueza.

Finalmente el poder social, representado por las élites dominantes del Imperio, también busca un papel de prestigio asociado a la faceta religiosa o militar, donde alcanzan posiciones de relevancia o ascendencia y un poderío económico y social con la creación de grandes infraestructuras o mejoras en las ciudades, como el caso de los benefactores públicos, que esperan favores políticos a cambio de inversiones.

No debemos olvidar que, como en los casos anteriores, aquí también observamos un proceso de saturación que lleva, a lo largo del Imperio, a la búsqueda de nuevos asentamientos en lugares no preferentes, como el caso de Sagunto, cuya población se va acercando poco a poco a la zona llana a partir del siglo II d. C., espacio menos defendible y más expuesto a las riadas y a las condiciones insalubres de los marjales.

Por motivos de prestigio se crean ciudades o estructuras en zonas sin un aparente valor y cuya manutención es demasiado costosa, lo que en muchos casos ha significado su rápida decadencia o desaparición, por ejemplo con los cambios religiosos; serían los casos de los santuarios de la Muntanya Frontera (Sagunto) y Muntanyeta dels Estanys (Almenara) donde además existiría una posible relación con aguas termales o salutíferas, como demuestra la presencia de cerámicas en la zona con importantes huellas de mineralización (ver Imagen 14)

Al mismo tiempo se produce el fenómeno de la recuperación o reutilización de elementos antiguos de notoriedad para intentar asociarse a la celebridad del imaginario del pasado, llegando hasta extremos de suplantar antiguos símbolos de poder haciéndolos desaparecer bajo las nuevas aportaciones miméticas, quizá con el ejemplo de la reforma en los edificios de espectáculos de Hispania (como ya citamos en Mérida y Sagunto). En algunos casos se da un proceso contrario a los que hemos visto, donde llegaría a ser tal la saturación en zonas urbanas que las propias necesidades de la sociedad, por ejemplo la vivienda, llegan a suprimir viejos elementos de prestigio, como las necrópolis o templos (Sagunto, Mérida, Baelo, Tarragona, etc.), sobre todo al final del imperio, a favor de una ocupación para el hábitat. 


\section{FUNCIONALIDAD}

Todo esto nos lleva a establecer unas particularidades para cada asentamiento relacionadas con sus funciones, de tal forma que la importancia del mismo viene dada por una suma de sus características que ya citadas, como la estratégica, la social, la económica, etc. Al crear una valoración esquemática para cada lugar, y darles una apreciación cualitativa, detectaríamos los puntos de mayor importancia, o sea, los de más variables:

- Control militar y estratégico (C): recinto defensivo, acuartelamiento, control de paso, etc.

- Explotación territorial (ET): explotación terrestre, ubicación junto a vía de comunicación, almacenamiento, etc.

- Comercio marítimo (CM): puerto, embarcadero, etc.

- Prestigio $(P)$ : zona monumental, valor histórico/religioso, etc.

Ahora proponemos un análisis solo para yacimientos con excavaciones arqueológicas:

\begin{tabular}{|l|c|c|c|c|}
\hline \multicolumn{1}{|c|}{ YACIMIENTO } & \multicolumn{4}{c|}{ VARIABLES } \\
\hline & C & ET & CM & P \\
\hline Saguntum & X & X & X & X \\
\hline El Palau (Burriana) & X & X & X & \\
\hline Sant Gregori (Burriana) & & $\mathrm{X}$ & $\mathrm{X}$ & \\
\hline Torre d'Onda (Burriana) & & & $\mathrm{X}$ & \\
\hline Santa Bárbara (Vilavella) & & & & $\mathrm{X}$ \\
\hline Benicató (Nules) & & $\mathrm{X}$ & & \\
\hline La Torrasa/ Pla Redo (Betxí) & & $\mathrm{X}$ & & \\
\hline El Alter (Xilxes) & & $\mathrm{X}$ & & \\
\hline La Alquería (Moncofar) & & $\mathrm{X}$ & & \\
\hline El Pla (La Llosa) & & $\mathrm{X}$ & & \\
\hline Castell (Almenara) & $\mathrm{X}$ & & & $\mathrm{X}$ \\
\hline Els Terrers (Faura) & & $\mathrm{X}$ & & \\
\hline
\end{tabular}

Podemos entonces comprender en parte el por qué de la ubicación y de la evolución de este espacio a lo largo de la época romana. Con esto queremos dejar claro que no se trata de un sistema predictivo, ya que rechazamos aplicar esta teoría a descubrir nuevos asentamientos o formas de uso. En este caso, la finalidad es simplemente intentar explicar la existencia de una serie de lugares y ponerlos en relación con otros, para incluirlos dentro de un área común de evolución a lo largo del Imperio romano que lleva a comprender mejor el microespacio, pero que al mismo tiempo hace que cada nuevo yacimiento estudiado sea una pieza más que, sumada al puzzle, nos permita comprender la evolución general del espacio objeto de nuestro estudio. 


\section{CAPITULO 4: HIPOTESIS DE TRABAJO}


Todos estos análisis y premisas teóricas que hemos estado planteando a lo largo de esta tesis nos llevan a proponer una hipótesis de trabajo, en lo que se refiere a la evolución del urbanismo romano en la zona objeto de este estudio y que pueden ser aplicables tanto al mundo rural como al urbano. Lógicamente los ejemplos con los que trabajamos, a pesar de ser significativos, deberán ser ampliados en el futuro, pues en coherencia con el espíritu de este trabajo, cuanto mayor la muestra analizada, mas probabilidades de tenemos de confirmar nuestra teoría.

Los modelos que proponemos los podemos calificar como sistemas de explotación macro-espaciales del territorio a largo plazo. Debemos también tener en cuenta que la rapidez de los cambios es relativa, con lo cual es probable establecer dos o tres fases de modificaciones en el urbanismo romano entre el siglo I y IV d. C. en nuestra zona.

\section{EL TERRITORIO EN EL PERIODO IBERO-ROMANO}

En un principio nos encontramos con una conquista militar puntual que sienta las bases para una posterior ocupación económica y social del mundo aborigen, el cual aún tiene cierta importancia como elemento productor y de uso del territorio, de tal forma que no podemos hablar de una cultura romana plena, sino más bien de la romanización del sustrato indígena.

Entre el siglo III a. C. y el cambio de Era nos encontramos en un punto donde aún podemos observar elementos locales en un claro proceso de asimilación por parte de la sociedad latina. En esta fase de dominio militar y económico prima el control sobre el aparato nativo y la rápida obtención de beneficios, siendo que ambos pasan por la expeditiva explotación de recursos ya existentes (como ya intentaron los cartagineses): mano de obra local, vías de comunicación, rutas marítimas, minería, agricultura, etc. De ahí el hecho de que se mantengan asentamientos ibero-romanos como Torre d'Onda (Burriana), cuya principal función era el comercio costa/interior, al ser el único puerto posible desde el Sur del Mijares hasta el Grau Vell (Sagunto) o que la gran abundancia de materiales latinos en sitios iberos tradicionales de interior, como Orleyl (Vall d'Uixó), Sant Antoni y Solaig (Betxí), Castell de Almenara, etc. sea un reflejo del lento proceso de aculturación que se ve reforzado por la presencia de colonos itálicos en las proximidades. No incidiremos en el sincretismo cultural, o más bien aculturación íbera respecto a la religión, idioma, costumbres, etc., ya que es un hecho que la romanidad acaba por imponerse, pero la velocidad y forma de este proceso es un tema de gran calado que merecería una tesis a parte. En el caso de los grandes núcleos de poder ibero o en los enclaves estratégicos, la dominación social o militar es más palpable; los ejemplos son bastante claros en zonas urbanas como Valencia, Sagunto o Tarragona, aunque yacen sepultadas bajo un potente urbanismo romano. 
En el caso rural es donde se puede detectar con una mayor facilidad la lenta evolución hacia la plena romanidad. Allí observamos como la pujanza de los núcleos urbanos cercanos potencia una red de comunicación y control territorial. El cambio de las estrategias de poder en distintos asentamientos indígenas, sometidos a una influencia globalizadora romana, permiten la supresión de obstáculos o lindes; por ejemplo, el río Mijares ya no es la frontera fortificada de época ibérica y del Bronce (con puntos de control en Torrelló de Onda, Torrelló de Almazora, Vinarragell, etc.) sino un obstáculo a superar para facilitar la fluidez del camino costero conocido como vía Heraclea; las sendas hacia el interior como Grau Vell - Sagunto - Segorbe/Liria, ó Torre d'Onda Betxí/Onda - La Punta - Teruel, ganan importancia ya que adquieren un espectro de comunicación y comercio costero que antes no tenían. Finalmente la introducción de formas de ocupación del territorio o de producción de tipo latino, como es el hábitat en llano o la explotación extensiva del espacio, se ven reflejados en la lenta ocupación y consolidación de los enclaves iberos más cercanos a la costa (Vinarragell, El Palau, La Regenta, Torre d'Onda en Burriana; Pujol de Gasset en Castellón; Torre la Sal en Cabanes, etc.) y en un lento desplazamiento hacia zonas mas llanas de los asentamientos en alto (La Punta en la Vall d'Uixó, Santa Bárbara en la Vila Vella, El Solaig en Betxí, el Castell de Almenara, etc.), que algunos autores ven como un cambio estructural asociado a la conquista romana (JÁRREGA, 2011). No profundizaremos más en los ejemplos, que ya hemos ilustrado con detalle en esta tesis, pues pensamos que este modelo es fácilmente aplicable a toda la franja que hemos estudiado.

\section{EL MODELO AUGÚSTEO}

El cambio de modelo de ocupación respecto a la primera fase se cierra con el cambio de Era y afianzamiento de la administración de tipo imperial, que también coincide con la completa pacificación de la Península Ibérica; podemos decir que en este momento se suprimen los intermediarios en la obtención de la riqueza local, que serían los pueblos indígenas, y se pasa a la explotación directa de los recursos por parte de las élites y de los colonos romanos, acabando por mezclarse con estos últimos el sustrato autóctono ya bastante romanizado, los cambios más significativos y aparentes se personificarían durante el imperio de Augusto. Existe un interesante debate sobre este proceso de romanización, su velocidad y la implicación de los colonos itálicos (OLESTI, 2000 y PRIETO, 1998)

En este momento aún no desaparece totalmente la necesidad estratégica, lo que lleva a la construcción de nuevos asentamientos de trazado augústeo (esto se refleja en ciudades fortificadas comunicadas por vías, con suministros e infraestructuras básicas de carácter claramente latino), reformas en casos de asentamientos que se habían superpuesto parcialmente a antiguos enclaves indígenas (Valencia, Sagunto, Tarragona) o enclaves de valor estratégico (Spelaco, Ad Noulas) y dándole un carácter totalmente latino en aspectos defensivos, religiosos y sociales (BELTRÁN, 2002). En el 
semblante urbano podemos citar reformas de las zonas de expansión de las ciudades ya totalmente romanas, como lo demuestran por ejemplo sus necrópolis, en cuyos enterramientos ha desaparecido cualquier rastro de la cultura material indígena. Los elementos de poder son renovados, tanto por la reforma de antiguos foros, cuya impronta es ahora claramente imperial, como por la creación de nuevos espacios forales más accesibles y funcionales (Tarragona, Sagunto, Mérida, etc.). Todo esto debería ir acompañado de nuevas infraestructuras, como acueductos, vías, murallas, necrópolis, etc., no sólo en viejos enclaves remozados y ampliados, ya que también fue un periodo de fundación de los últimos lugares de valor eminentemente estratégico, como Barcino ó Caesaraugusta.

A nivel rural también podemos apuntar una oleada de creación de villas, no tanto con valor estratégico, sino con valor económico de control de la producción y de las líneas de comercio (Spelaco, Ad Noulas, Ildum, Benicató, Pla Redó, Alter de Xilxes, Pla de la Llosa, Els Terrers, etc.) y que en muchos casos significa el abandono de antiguos establecimientos ibero-romanos creados a la sombra de pretéritos asentamientos indígenas cuyo único valor era el defensivo (El Solaig, Sant Antoni, El Castellar o El Castell de Almenara son algunos lugares en alto abandonados en detrimento de cercanas villas). Pero también decaen enclaves de época republicana que vivieron de un entorno nativo y del comercio tradicional indígena, como son el caso de Torre d'Onda o Vinarragell, mientras otros como el Grau Vell o Orleyl siguen actuando en algunos casos con funciones diferentes, como lo atestiguan el horno de ánforas y de cerámica común romana de este último yacimiento.

Estos cambios estratégicos se reflejaron también en las vías de comunicación. La renombrada vía Augusta, sin duda es fruto de una gran reforma de la antigua vía Heraclea, pues cubría casi la misma ruta, pero ahora debería acoplarse a nuevos terrenos llanos y a cruces de antiguas fronteras (por ejemplo el ya citado río Mijares), lo que sin duda dará origen a trechos ex novo; un ejemplo lo podríamos tener en el tramo entre Sagunto y Ad Noulas.

En primer lugar debemos partir de un punto inicial importante y novedoso, en la línea de los ejemplos metodológicos que ya citamos anteriormente en esta tesis, ya que tenemos que apuntar que no existe ningún documento que señale que entre Spelaco y Ad Noulas existen 2 millas de distancia, y eso es así porque no aparecen juntos en ninguna fuente. Lo que sí señalan éstas es que entre Spelaco y Sagunto hay 22 millas y entre Sagunto y $A d$ Noulas hay 24 y en un error arrastrado durante muchos años se tomó la cita de forma lineal y por una mera operación matemática se obtuvo la distancia entre una y otra. Tampoco tenemos ninguna cita que diga que existe una diferencia temporal entre ambas que justifique que una suplante a la otra, más bien todo lo contrario, ya que indica una similitud cronológica muy acentuada. 
La ubicación de Spelaco ya la hemos justificado con creces en este trabajo, al coincidir las fuentes y los restos arqueológicos en el yacimiento del Palau, pero el caso de $\mathrm{Ad}$ Noulas parecía bastante más complejo, ya que la cercanía entre ambas mansiones era bastante evidente (aunque no correspondiera a 2 millas lineales era claramente inferior a las 20/30 habituales), lo cual, como ya citamos, solo se explicaría por causas geográficas, como sería la necesidad de salvar el importante cauce del Mijares y comunicar con el ramal que va a la zona de Alcora; pero el problema es que entre Spelaco y el Mijares, por la vía Augusta, tenemos aproximadamente 5 millas.

La solución sería bastante obvia; se accedería desde Sagunto a Ad Noulas por una variante de la vía Augusta (quizá un tramo fosilizado de la antigua vía Heraclea) cuyo trazado estaría más hacia el interior, ya que la más reciente vía Augusta no deja espacio practicable entre ella y el marjal; el único abanico posible donde esto se podría producir, debido a las limitaciones de los distintos accidentes geográficos, es entre Benicató/Santa Bárbara y el punto de cruce del Mijares, en este sector es donde el llano se abre y se acerca a los antiguos yacimientos iberos del Solaig y Sant Antoni. Si tomamos esta variante del camino llegamos a Ad Noulas, situada junto al Mijares y en la vía Augusta, después de recorrer aproximadamente 24 millas desde Sagunto, esta variante ya fue acertadamente identificada por algunos autores (JÁRREGA, 2011). Y así la distancia geográfica entre Spelaco y Ad Noulas sería de aproximadamente 5 millas, y cada una se situaría a una orilla del Mijares.

Respecto a las vías marítimas, los grandes puertos de las urbes anulan el comercio de cabotaje a gran escala, manteniéndose únicamente aquellos puntos intermedios de aguada o para aprovisionamiento local de las villas, como sería el caso de Sant Gregori en Burriana. En líneas generales este sistema de ocupación se mantendría hasta el colapso del Imperio romano, lo que da idea de sus características óptimas para la explotación del territorio.

\section{EL MODELO FLAVIO-TRAJANEO}

La tendencia desarrollada a lo largo de aproximadamente 100 años transcurridos desde el gobierno de Augusto llevó a un lógico colapso de enclaves disponibles para recibir obras en ciertos espacios urbanos, y no sólo eso, esta saturación alcanzaba los propios asentamientos ya anteriormente ampliados ocasionado una carencia evidente de suelo urbanizable de calidad. Con este problema se encontraron las elites provinciales, en su intento de realizar obras de prestigio.

Si para la primera fase de gran transformación tenemos en Augusto el máximo responsable e impulsor, identificado gracias a la documentación histórica existente, para la segunda fase del siglo II d. C. no existe una constancia de quién fue la mano impulsora, si bien el envite constructor de la dinastía flavia fue notable, y un ejemplo lo tenemos en Vespasiano, que por ejemplo autoriza en el año 77 a los Saborenses a 
construir en el llano una ciudad con su nombre, para facilitar la ampliación de la urbe y dotarla de más servicios (MARTíN, 1994), y además concede el lus Latii a Hispania en el 75 d. C., lo que propició la aparición de buena cantidad de municipios flavios (ANDREU, 2007). Hay una serie de indicios que también señalan a dinastía de Trajano con un mayor empeño edilicio si cabe, pero este impulso se encontró con espacios urbanos colapsados, gracias al citado linaje que la precedió. Además debemos tener en cuenta que algunas obras del periodo flavio tienen un abanico de adjudicación que nos permite alcanzar el período trajaneo (como el anfiteatro de Paestum que empieza a ser reformado y ampliado en época flavia - TORELLI, 1999); más aún en el caso de la Península lbérica (donde podemos citar la construcción del acueducto de Segovia, el puente de Alcántara o el anfiteatro de Tarraco), donde la clase rica emergente necesitaba invertir en Roma, lo que sin duda implicaba un importante movimiento de capitales y tierras también en la provincia, además de fomentar un estamento social culto y altamente latinizado, cuyos ejemplos más próximos geográficamente son los saguntinos Voconius Romanus, la gens Baebii y Sergii (ALFÖLDY, 1977), además de senadores y miembros del orden ecuestre (BELTRAN, 1980) o el edetano Cornelius Nigrinus (ALFÖLDY, 1977). En el aspecto de la potenciación del culto imperial esto podría aplicarse también a Tarragona, donde gracias a la considerable cantidad de los testimonios epigráficos, nos es posible comprobar la potencia del culto imperial a dos niveles: el provincial y el municipal. El primero, centrado en la plaza de representación y en la terraza superior organizada en torno al templo; el segundo, alrededor del foro de la parte baja de la ciudad; allí todos los pedestales en honor a los diversos flamines son de entre época flavia y antonina, sin constancia de un auténtico culto provincial anterior a estos momentos. Según la cita de Tácito sobre la petición de los hispanos para edificar el templo provincial en Tarragona, a la muerte de Augusto el concilium provinciae decidió enviar una embajada a Tiberio para que otorgara permiso para erigir un templo a la memoria de aquél, que sirviera de ejemplo a las demás provincias (Tácito, I, 78). ¿Quizás debía ser imitado en las capitales y/o ciudades de todas las provincias? (RODÁ, 2009). Si así fuera, Sagunto sería un lugar idóneo para propagar esta devoción en el eje costero mediterráneo de la Península Ibérica.

Tampoco podemos olvidar la fuerte presencia hispana en la corte imperial, como Licinio Sura, de Tarragona, cabeza de una numerosa familia de hombres de prestigio; varios de ellos alcanzaron el consulado y el senado con los emperadores hispanos, entre los cuales Annius Verus, de Ucubi, protagonizó una brillante carrera senatorial desde Nerva hasta Trajano y fue padre de la emperatriz Faustina y abuelo de Marco Aurelio, L. Minicius Natalis, de Barcino, fue legado de la legión $V$ Macedónica en la guerra de Dacia, Pedanius Fuscus Salinator, padre e hijo, el primero de los cuales fue senador con Nerva, Trajano y Adriano. Junto a estos hay otros como: Licinius Silvanus, L. Dasumius, L. Iulius Ursus Servianus, Q. Valerius Vegetus, Herennius Severus o Curiato Materno. En algunos años los dos cónsules fueron hispanos, y además de Sura, Annio Vero padre y lulius Ursus Servianus desempeñaron este cargo en tres 
ocasiones (ROLDAN, 2001). Esta dinámica constructiva de ampliación de ciudades y de sus servicios la tenemos documentada ampliamente en la misma Italia, en Ostia se amortizan parte de las necrópolis, especialmente la de Porta Marina; además se reconstruye el templo de Hércules en Ostia, y se edifica un gran ninfeo semicircular. Otros ejemplos del siglo II d. C., donde se estaban haciendo proyectos urbanísticos semejantes al saguntino son la presencia de pórticos en las manzanas de la ciudad trajanea de Timgad (Argelia), en la urbe adrianea de Itálica y en Iuliobriga y Conimbriga (GONZALEZ, 2000).

Este gran impulso constructivo lo detectamos en Hispania por lo que se refiere a obras monumentales (circos, anfiteatros, teatros) y no sólo eso, se produce una expansión planificada en ciudades como Sagunto, lo cual conlleva también un enriquecimiento secundario de la zonas rurales dependientes de los grandes centros urbanos.

Pero en el caso del siglo II d. C. las nuevas construcciones también se realizan sobre antiguas necrópolis. Para que podamos entender la revolución que puede significar esta anulación de enterramientos debemos recordar la legislación romana sobre el tema desde el punto de vista religioso:

(Dig. 1, 8) Son lugares "sagrados» aquellos que fueron dedicados públicamente, tanto en la ciudad como en el campo. (1) Hay que saber que un lugar público puede hacerse sagrado cuando el príncipe lo dedicó, o dio poder para dedicarlo. (2) (...) Lugar sagrado es un lugar consagrado; sagrario, un lugar en el que se guardan cosas sagradas, que incluso puede estar en un edificio privado, y los que quieren desafectar de la religión este lugar suelen sacar de allí las cosas sagradas.

Como podemos comprobar, solamente la potestad imperial podría decidir en casos de tan alta jurisdicción como la religiosa, pero no sólo por lo que se refiere a enterramientos, ya que otros elementos también tenían carácter sacro y se encontraban bajo la autoridad imperial directa:

(Dig. 1, 8) (...) también en los municipios son «santas» las murallas, y que debe prohibirse que se meta nada en ellas (...) (4) Sin autorización del príncipe o del gobernador, no es lícito restaurar las murallas municipales, ni añadirles o superponerles algo.

Esta dinámica de arrasar tumbas y anular murallas se desarrolla en todo el Imperio y llevaría a que en Sagunto se obtengan tierras en zonas altamente preferentes, donde estaban las necrópolis, murallas, fosos, etc. para permitir la expansión urbanística y también para renovar los cementerios, liberando así los mejores terrenos, los más cercanos a la ciudad; planteamiento de mejora urbanística a costa de terreno sacro que 
también podemos hacer para las antiguas murallas de las ciudades (ver Dig. 1, 4, 8). Esta anulación se refiere evidentemente al monumento o espacio que acompaña al enterramiento y que podía tener cabida en el ordenamiento jurídico romano con la anulación de su carácter sagrado; no así con los difuntos propiamente dichos, que además seguían in situ, ya que en la excavación del solar de la Morería de Sagunto los únicos enterramientos destruidos lo fueron por zanjas y reformas producidas a partir del siglo IV d. C., una vez ya pasados casi 200 años de la amortización del cementerio y cuando sería más fácil devastar de una forma impune sepulcros que ya no estaban señalizados claramente desde hacía bastante tiempo, más aún si ya tenían la cobertura social del Cristianismo al tratarse de antiguos sepulcros paganos. Podríamos considerar la posibilidad de que convivieran enterramientos y viviendas, pero éste es un hecho puntual dentro de las ciudades (en Ostia Antica tenemos algunos casos, o como el del gobernador Celso en la biblioteca de Efeso - GONZALEZ, 2000), pero en el caso saguntino las tumbas desaparecen bajo nuevas construcciones, lo cual no da lugar a la hipótesis de convivencia entre ambas.

Pensemos que teóricamente solamente se permitía la ocupación del monumentum, espacio no estrictamente divinizado, mientras se deberían mantener los enterramientos pues la ley romana les confería carácter sagrado (Dig. 11, 7, 8); estos son los que actualmente se recuperan en intervenciones arqueológicas, pero cubiertos por otras construcciones. Esta actuación exigiría una intervención directa del poder imperial, aunque solamente existen datos históricos indirectos que nos den pistas de ello, como por ejemplo, cuando en las provincias los traslados de los restos humanos se podían hacer sin necesidad de autorización por parte de los pontífices (Plinio, Ep., X, 69). Dión de Prusa cuenta que la ciudad de Nicomedia había decretado mover las tumbas (Disc. XLVII, 16) y en provincias los gobernadores se arrogaban esa potestad (Plinio. Ep. X, 68). Trajano consideraba que era muy duro obligar a los provinciales a dirigirse a los pontífices si deseaban trasladar de un lugar a otro los restos de los suyos por alguna causa justa, siendo el gobernador el que, dependiendo de las razones, debía tomar la decisión (Plinio, Ep. X, 69), a diferencia de Roma:

Plinio a Trajano: (...) Nicomedia habían empezado a añadir un nuevo foro al antiguo en uno de cuyos ángulos hay un templo antiquísimo de la Gran Madre que o ha de ser reconstruido o trasladado a otro lugar (...)

Trajano a Plinio: (...) el suelo de una ciudad extranjera no necesita una consagración, como la que se hace conforme a nuestro derecho. (Plinio, Ep. X, 49-50).

Nos resta saber cuál fue el mecanismo legal que permitió llevar a delante estos actos. Hoy por hoy no existe un texto definitivo en las fuentes que nos aclare este punto, por lo cual nos limitaremos a exponer algunas posibilidades. La primera sería la ampliación 
del pomoerium de las ciudades; al quedar las necrópolis dentro del nuevo recinto sacro los enterramientos deberían ser trasladados y no se podría seguir enterrando. La posibilidad de traslado tiene dos puntos débiles, el primero es la permanencia de los enterramientos in situ, ya que sólo desaparece el monumentum, y que esta ruptura también aparece en las necrópolis que siguen funcionando como tal. La segunda posibilidad es que se mantenga el carácter sacro del terreno, eliminado los monumenta.

Pero este procedimiento necesitaría alguna operación legislativa previa, como sería reclamar los bienes de los difuntos en los casos en que no hubiese herederos para que revertieran al Estado (bona vacantia), donde el príncipe si pudiera recibir bienes sacros y después donarlos a la colectividad (CIZEK, 1983). Aquí cabría la posibilidad de que se vendieran los terrenos "expropiados" en las necrópolis que siguieran funcionando como tal para que las élites urbanas dispusieran de sitios de enterramiento en los lugares preferentes de las mismas.

Sea como sea, ninguna de las alternativas presentadas explica que los cuerpos permanezcan en zona sacra y se permita construir sobre ellos, sólo podemos pensar que la autorización para las obras incluyera la exigencia de conservar el espacio sacro de los muertos, pero aún así eso no explicaría como fueron dejados en otros recintos no sagrados, como los anfiteatros, teatros, etc. Esto nos obligaría a pensar en que no se cumplían al pie de la letra los mandatos, o que realmente se llegaron a desacralizar todos los enterramientos. Finalmente queremos introducir la reflexión sobre la dificultad de que no siempre las fuentes son exhaustivas, pues por ejemplo en el Digesto no se recoge una referencia sobre la prohibición de los Antoninos del enterramiento en zonas rurales $^{37}$, que sí aparece en la Historia Augusta: (...) unas leyes estrictísimas sobre enterramientos y sepulcros, prohibiendo incluso que los particulares construyeran tumbas en sus villas, disposición que todavía hoy se cumple (...) (HA, Marcus Aurelius, XIII, 3-6) (GOZALVES y GARCÍA, 2007: 12).

Con lo cual una orden tan trascendental, como era la de amortizar terreno sacro de las necrópolis, bien puede no estar reflejada en las fuentes conservadas. Si aceptamos cualquiera de las teorías anteriores, es muy comprensible que se facilitara los terrenos a las élites locales para construir un nuevo foro en Sagunto, reformara el circo, el teatro y el anfiteatro, además de monumentalizar vías y construir acueductos. Según este patrón podemos intentar analizar algunas obras que se construyen en este momento en Sagunto. Por un lado la construcción de un nuevo anfiteatro y de un circo no es en modo alguno sorprendente dentro del contexto de grandes obras en todo el Imperio, de la misma forma que el acondicionamiento del entorno de los mismos con puentes, calzadas, acueductos, etc. El hecho de que los Sergii pudieran sufragar un foro junto al

\footnotetext{
${ }^{37}$ Concretamente se refiere a la peste Antonina que se inicia en el año 165 d. C. (GOZALVES y GARCIA, 2007).
} 
circo entraría dentro de la lógica, quizá aprovechando parte de los terrenos obtenidos por la amortización de una necrópolis para la construcción del circo.

Respecto a los templos, dentro de la progresión que pueda apreciarse de los misterios durante los primeros años del siglo II d. C. (ALVAR y BLÁZQUEZ, 2003), quedaría perfectamente justificado un oratorio dedicado a Mitra en Sagunto, según las referencias epigráficas y los hallazgos iconográficos egiptizantes y mistéricos (CORELL y SEGUÍ, 2008). Sobre otros santuarios tampoco debemos olvidar la gran tendencia a la divinización de los emperadores, por lo que no sería sorprendente la construcción de un templo municipal de culto imperial en esta franja sacra de Sagunto, que podríamos adjudicar al Templo 1 por la semejanza formal con el de Roma, y con el municipal de culto imperial de Pompeya. Mas difícil es el caso del Templo 2; su advocación puede ser a cualquiera de las divinidades especialmente objeto de la política religiosa de la época. No conocemos completamente las características originales del templo 2 saguntino, excavado casi totalmente en 1994, como para poder afirmar tajantemente que los tres departamentos ubicados sobre el podio podrían corresponder a una cella tripartita asociable a un culto Capitolino o Isiaco ${ }^{38}$.

\section{EL TERRITORIO DURANTE EL BAJO IMPERIO}

El siguiente cambio viene matizado por unos hechos importantes en el siglo III d. C., que son las invasiones bárbaras, que más que una crisis militar posiblemente provocaron una sensación de inseguridad generalizada, ya que usualmente han de ser señalados aspectos de estabilidad y continuidad en este periodo que vincularían el siglo II d. C. con el IV d. C., lo que comportaría que durante el siglo III d. C. Hispania no sufriera el colapso total de las estructuras establecidas durante el Alto Imperio (CEPAS, 1997). Así, la mayoría de comunidades cívicas mantuvieron un papel central en la estructura administrativa de las provincias hispanas, a pesar de las considerables transformaciones que afectarían a la apariencia externa de los centros urbanos. Los nuevos enfoques de la investigación mantienen a la Península Ibérica como una región próspera unida a la estructura del imperio romano, según defienden autores como J. Arce, C. Witschel, R. Teja, A. Cepas y M. Kulikowski (WITSCHEL, 2009); a ello hay que añadir una revalorización de la situación peninsular en la antigüedad tardía (del siglo IV al VI d. C.), de tal forma que es posible constatar que una perspectiva completamente negativa en relación a la Península Ibérica en el siglo III d. C. apenas puede sostenerse en nuestros días, frente a los modelos predominantes del pasado sobre la decadencia de la vida romana desde final del siglo III d. C., con la imagen ruralizada de una región empobrecida en la mayoría de sectores de la vida social y económica (WITSCHEL, 2009). Frente a ello otros autores mantienen que el desgobierno causado en el Imperio por la anarquía militar, sin necesidad de las incursiones bárbaras, tuvo que tener importantes repercusiones en la economía y el comercio y que supuestos signos de

\footnotetext{
${ }^{38}$ Relativamente cerca aparecieron dedicatorias a Isis Pelagia y a Venus (CORELL, 2000)
} 
"continuidad" como las dedicaciones imperiales, sólo demuestran la fidelidad mostrada en un momento dado al emperador por parte de los curiales (JÁRREGA, 2008), y que ellos es aplicable a la zona entre Tarraco y Saguntum (JÁRREGA, 2011).

Los numerosos procesos de transformación ocurridos durante el siglo III d. C. cambiaron de forma considerable la imagen de Hispania, pero sin eliminar elementos estructurales fundamentales. Estos cambios se produjeron paulatinamente y a largo plazo, como las reestructuraciones de las provincias entre época severiana y la Tetrarquia. A ello hay que añadir que la mayoría de sectores económicos volverían recuperarse como mucho hacia final del siglo III, de modo que Hispania permanecería en el siglo IV d. C. como una región próspera, tal y como revelan las numerosas villas suntuosas de la época (CEPAS, 1997).

Podemos observar cómo el espacio rural se recupera rápidamente en estas fechas, pero con un matiz, ya que comprobamos que la desaparición de asentamientos en ese periodo se contrapone con la gran pujanza en villas de los siglos III y IV d. C. Esto nos puede hacer pensar que el enriquecimiento y expansión de los asentamientos rurales, que desembocarían en las conocidas como villas áulicas, se debería a una concentración de poder económico, ya que disminuye la cantidad de sitios pero la demanda de productos básicos en zonas urbanas se amplía, lo que sin duda supondría el enriquecimiento de una élite de propietarios agrarios más reducida por el éxodo de los pequeños latifundistas a las ciudades.

La pujanza en el siglo III d. C. de los grupos de presión económica surgidos en el siglo anterior, sumado al éxodo del campo que se multiplicaba en el siglo IV d. C. por un efecto similar a la "teoría del miedo" estudiada para el siglo V d. C. son en Hispania el germen de la necesidad de espacios urbanos y de necrópolis para esta nueva clase social, y que paradójicamente acabaría con el esplendor de las reformas del siglo II, ocultándolas bajo importantes transformaciones que reutilizan lugares y materiales. Dentro de la inestabilidad que caracteriza el siglo V d. C., la "teoría del miedo" (ALBA, 1998) se refiere al temor generalizado que motiva la fortificación de ciudades acompañado de la huida de los menos seguros enclaves rurales, para evitar que se reproduzcan hechos de ciudades saqueadas o arruinadas (como Conimbriga, asolada por los suevos) (ALBA, 1998). En algunos casos concretos, como el amurallamiento de Mérida, algunos autores consideran que sigue siendo válida la interpretación como "muralla del miedo" (CERRILLO, 1985).

En la zona objeto de este estudio, a nivel urbano debemos tener en cuenta que sólo contamos con dos ciudades que pudieran absorber el flujo migratorio hacia las urbes, Sagunto y Valencia. Esto, en un primer momento de miedo y de inseguridad generalizada provocada por las incursiones bárbaras (aunque hoy en día no está nada clara la incidencia de las invasiones en Hispania, lo que sí es evidente es que en el siglo III el ciclo económico de prosperidad, basado en la exportación de vino, aceite y 
garum, decae) induce al decaimiento de las explotaciones rurales y a la superpoblación urbana, con el consecuente episodio de expansión edilicia, todo ello en detrimento de los espacios públicos disponibles, como por ejemplo los pórticos de las calles ocupados, sobre todo a partir de los siglos III y IV d. C. Esta superpoblación terminaría por generar también un colapso en las infraestructuras. La abundante reutilización de materiales se asociaría a una incapacidad de suministrar materias primas en cantidad, sin olvidar una posible merma de recursos económicos por parte de los clientes. En el aspecto rural la nueva acumulación de poder en manos de grandes propietarios y la pujanza económica fruto del suministro a las vecinas ciudades superpobladas, marca un impulso renovador en algunas las villas del entorno a final del siglo III d. C., como observamos en Benicató, El Palau, Sant Gregori, L'Alter de Xilxes, Els Terrers, etc. Un indicio de cambios de posesión lo encontraríamos en algunos autores que apuntan una posible concentración de la propiedad en la zona de la Plana (JARREGA, 2011).

Dentro de este modelo del Bajo Imperio debemos tener en cuenta un factor diferenciador que, además, es un condicionante importante a la hora de consolidarlo, es el desarrollo del Cristianismo acabó por desembocar en unas importantes transformaciones generales y económicas que se vieron reflejadas en el registro arqueológico en una serie de trascendentales cambios tanto en las urbes como en prácticamente todos los asentamientos agrarios de entidad.

Así pues, podemos decir que el inicio del Cristianismo como religión oficial a finales del siglo IV d. C. alcanzó a un Imperio que se encontraba en un proceso de mutación, al salir de un proceso de enriquecimiento y ampliación entre los siglos II y III d. C. Al final del siglo IV d. C., en época de Teodosio I, hay gran cantidad de hispanos en la corte imperial y también existe un abundante comercio con Oriente en esa época, con mosaicos, joyas, sarcófagos, etc. de inspiración oriental (BLÁZQUEZ, 1988). Este fue sin duda uno de los últimos coletazos de desarrollo económico romano, posiblemente más centrado en las capitales de las diócesis y en las grandes villas áulicas, en detrimento de las decadentes urbes superpobladas y de los pequeños asentamientos rurales en vías de extinción. En este contexto, Sagunto y Valencia eran las ciudades más destacadas, donde el comercio era importante, no sólo para el autoconsumo, sino para la redistribución al entorno rural. Pero ellas mismas ya mostraban claros síntomas de deterioro, gracias a la superpoblación, detectada en la amplia compartimentación de las antiguas viviendas, la ocupación de espacios comunes (pórticos, templos, foros, termas, etc.) y un agudo fallo de los servicios públicos (colapso de cloacas, derrumbes de viviendas, aumento de vertederos incontrolados, etc.) a lo largo del siglo IV d. C.; no descartamos que la crisis política y social que ya se arrastraba en el imperio, cuyo arranque sería el asesinato de Alejandro Severo en el 235 d. C., pudiera haber colaborado en este mal funcionamiento general de las instituciones. Pero no se debe olvidar que es una situación que, en lo político, es muy corta (50 años) y en lo social es mucho más gradual .En el aspecto rural, la situación económica a finales del siglo III d. 
C. propicia la reforma y ampliación de los lugares clave para el comercio y la producción agropecuaria, como El Palau, Benicató, L'Alter de Xilxes, Santa (Alcora), etc., que muestran signos inequívocos de esta situación, sin olvidar que la desaparición de otros asentamientos agrarios podría deberse a la citada concentración de la población y de la propiedad.

\section{EL TERRITORIO EN EL PERIODO TARDO ANTIGUO}

Esta última fase de prosperidad para la Península Ibérica no alcanza el siglo $\mathrm{V} d$. C. En este caso, a diferencia del siglo III d. C., los motivos de inseguridad provocados por las incursiones bárbaras no fueron un caso puntual, sino un hecho a gran escala que afectó prácticamente todo el Imperio y que acabó repercutiendo en Hispania. Por un lado es evidente el retraimiento de la población rural con el abandono de gran parte de los asentamientos a partir de mediados del siglo IV d. C. Desconocemos el porcentaje de personas que emigraban a las ciudades o que buscaban otros asentamientos en zonas más defendibles desde el punto de vista estratégico, pero sí debemos tener en cuenta una reflexión sobre la demografía de aquel período; si justamente en el siglo III d. C. tenemos un boom poblacional especialmente en algunas ciudades, ¿cómo podemos compaginar este hecho con la gran desaparición de asentamientos rurales $\mathrm{y}$, después, en el siglo $V \mathrm{~d}$. C., con el desvanecimiento de ciudades y la disminución drástica de población en otras?

Algunos factores podrían influir en este acontecimiento, pero lamentablemente no encontramos pruebas de los mismos, aunque quizá la insalubridad provocada por el colapso de los servicios públicos, sumado a los acontecimientos bélicos y a factores económicos como la mengua del comercio de alimentos o materias primas, pudo ocasionar una drástica reducción en la cantidad de habitantes. Sea como sea, los hechos arqueológicos apuntan claramente a cuatro líneas principales de acontecimientos en este periodo:

- La desaparición de gran parte de los enclaves rurales que carecían de posibilidades efectivas de defensa ante ataques, piratería o bandolerismo; en otros se produce una gran reducción en el nivel de ocupación acompañado de un colapso de los servicios básicos.

- Concentración de la población rural en núcleos con capacidad defensiva sensible, con tendencia a la autarquía a nivel de suministros y recursos.

- Reducción de la superficie ocupada de las ciudades y tendencia al amurallamiento, donde es posible que se recuperen antiguas estructuras defensivas como sucede en Sagunto, Zaragoza, Tarragona, etc. 
- Concentración de la población en ciudades que amplían su perímetro amurallado para ocupar zonas de interés estratégico, pudiendo en parte reutilizar estructuras antiguas como circos o anfiteatros como es el caso de Valencia ${ }^{39}$, Mérida, etc.

Debemos tener en cuenta que estos sucesos venían matizados por el sistema de ocupación del territorio que se venía desarrollando desde el siglo II d. C., o sea una expansión urbana fuera del recinto amurallado primigenio, que en este caso no necesitaba ningún elemento defensivo al encontrarse en un período de paz. La posterior saturación de este espacio urbano, debido a un gran desarrollo demográfico con una pérdida de función de importantes estructuras públicas y religiosas (templos, anfiteatros, circos) y el colapso de infraestructuras por la sobreexplotación (acueductos, cloacas, calles, etc.) desembocan en una zona urbana altamente degradada y en la posterior necesidad de recuperar unos elementos defensivos que posiblemente se fosilizaron, como pueden ser las antiguas murallas, pero que logran ser puestos otra vez en funcionamiento con un coste inferior al que puede significar una nueva obra. Así podemos establecer dos modelos urbanísticos para el final del Imperio romano: el modelo "murus vetus" (Sagunto) con el reamurallamiento retraído sobre estructuras antiguas y abandonando parte de la ciudad en ruinas, y el modelo "expansionista", con el nuevo recinto defensivo ampliado para englobar zonas o edificios estratégicos (Valencia).

A partir del siglo $\mathrm{V}$ d. C. el contexto es variable para distintas zonas; a nivel urbano el caso saguntino es de clara decadencia, ya que si bien tenemos muestras de que al Grau Vell siguen llegando materiales en los siglos V y VI d. C. (ARANEGUI, 2004), éstos son prácticamente inexistentes en la excavación de la plaza de la Morería y su entorno (de ANTONIO et al., 2002, HERNÁNDEZ et al., 1993; HORTELANO, 1993 y LÓPEZ y CHINER, 1994), lo cual indica un retraimiento de la población y que este comercio también sería de redistribución en el entorno, ya que las villae que perviven en este momento en el entorno de Sagunto, y quizá más hacia el interior, seguirían demandando materiales de importación via marítima, y el Grau Vell seguía siendo un de los pocos puntos de desembarque en toda la zona de marismas de esta zona de la costa valenciana. Valencia, sin embargo, gracias en parte a su importante papel como centro episcopal, sigue siendo un substancial eje urbano (RIBERA, 2000). En el mundo rural prácticamente todos los asentamientos costeros alejados de las ciudades han desaparecido gradualmente, excepto algún elemento residual en Benicató; sin embargo prosiguen con alguna vitalidad los enclaves más hacia el interior, como San Josep (Vall d'Uixó) o Santa (Alcora), pero que acaban por desaparecer y ya no se detectan restos mediado el siglo $\mathrm{V}$ d. C. Esto implica un evidente colapso de los

\footnotetext{
${ }^{39}$ Sería interesante comprobar si al lado del circo romano de Valencia, donde apuntan las curvas de nivel (ver Lámina I!) y la muralla musulmana y visigoda realiza un importante escorzo, quizá pudiéramos encontrar alguna gran edificación, el teatro o el anfiteatro, ubicado sobre una necrópolis.
} 
yacimientos de la vía Augusta como elementos dependientes de esta ruta de comunicación y el final definitivo de los pequeños puertos costeros a favor de los grandes enclaves (Valencia, Grau Vell o Tarragona).

\section{MODELOS VISIGODOS Y MEDIEVALES}

Solamente citaremos brevemente este caso, por ser heredero de los patrones de asentamiento romanos. En el caso de los visigodos, desde épocas tempranas hasta bien entrado el siglo VII d. C. (como los ejemplos de Mérida y Sagunto) su evolución urbanística va a remolque de la romana, si bien echan a perder elementos carentes de valor estratégico (vías, acueductos, baños, villas en llano, etc.) o realizan un expolio sistemático de materiales constructivos, sin duda recuperando y adaptando elementos como murallas o templos, dentro de los esquemas expansionistas o tipo "murus veteris" que ya citamos. Gracias a ello se puede observar una importante diferencia en el desarrollo y planta de estas ciudades respecto a aquellas creaciones ex novo de época medieval, que parten sin condicionantes previos que puedan obstaculizar o favorecer el desarrollo de ciertos aspectos urbanos.

Este proceso está bien documentado en ciudades, pero sin embargo el proceso de encastillamiento que se lleva a cabo en la zona rural dificulta el análisis de este proceso de reutilización-expolio. En todos los casos debemos recordar que los visigodos eran una minoría invasora que tardó muchos años en mestizarse social y religiosamente con la población autóctona, y que en ningún caso significó un largo periodo de paz y estabilidad.

Así pues, éste es el panorama que encuentran los musulmanes al llegar a la Península, que recuerda, salvando las distancias, al que encontraron los romanos a su llegada, un poder fracturado entre la nobleza y el rey, una población latinizada sometida y una religiosidad aún no totalmente asentada. También curiosamente con los años ofrecieron un período de paz duradero que permitió recuperar las infraestructuras, como la vía Augusta o asentamientos como Spelaco, y también la demografía del periodo romano, lo que bien pudo llevar otra vez a repetir en parte los mismos esquemas de ocupación territorial de época latina, por lo que quizá pudiéramos apuntar que los musulmanes, si salvamos el paréntesis visigodo, fueron unos herederos casi directos de los modelos de asentamiento romanos, aunque con acusados cambios en la explotación del territorio en los nuevos asentamientos. 


\section{BIBLIOGRAFÍA}


AA. VV. (1911-1912): Anuari de l'Associació Catalana d'Antropologia, Etnologia y Prehistòria. Barcelona.

AA. V. (1915-1920): Anuari de l'Associació Catalana d'Antropologia, Etnologia y Prehistòria. Barcelona.

AA. VV. (1975): A Propos des Céramiques de Conimbriga. Separata de Conimbriga, 14, Facultad de Letras, Instituto de Arqueología, Coimbra.

AA. VV. (1977); Gran enciclopedia de la Región Valenciana. Valencia

AA. VV. (1981): Atlante delle forme ceramiche. Roma.

AA. VV. (1981b): Noticiario, ARSE 16. Sagunto

AA. VV. (1983): Monografía: Terra Sigillata Hispánica. Separata de Boletín del MAN, Monografías, 2, MAN, Madrid.

AA. VV. (1985); La provincia de Castellón. Tierras y gentes, Caja Ahorros Castellón.

AA. VV. (1985-2011): Fichas de Inventario Yacimientos Arqueológicos, CC-GV.

AA. VV. (1986); Burriana en su Historia I. Ayuntamiento de Burriana

AA. VV. (1988): Memorias Arqueológicas de la Comunidad Valenciana. Intervenciones rurales. GV.

AA. VV. (1990): Tecnología de la cocción cerámica desde la antigüedad a nuestros días. Asociación de Ceramología, Alicante.

AA. VV. (1998): 50 años de viaje arqueológico en Valencia. Ayuntamiento de Valencia.

AA. VV. (1999): La ciudad de Castellón de la Plana, Ayuntamiento de Castellón.

AA. VV. (2000): Conmemoración del XXX Aniversario del museo arqueológico Ayuntamiento de Burriana.

AA.VV. (2000b): Via Appia - La Villa dei Quintili, Soprintendenza archeologica di Roma. AA. VV. (2002): Artifex. La ingeniería romana en Hispania. MC. Madrid. 
AA. VV. (2005): Nuove ricerche archeologiche a Pompei ed Ercolano: atti del convegno internazionale, Roma, Pier Giovanni Guzzo, Maria Paola Guidobaldi (ed.), Soprintendenza archeologica di Pompei, Electa Napoli.

AA. VV. (2009); XXth International Congress of Roman Frontier Studies. León 2006 (Anejos de Gladius 13). Madrid, Ediciones Polifemo.

AA. VV. [CD-ROM] (1999): Memorias Arqueológicas y Paleontológicas de la Comunidad Valenciana, $n^{\circ}$ 0. GV. ISBN 84-482-2206-7

ABASCAL, J. M. (2009): Programas epigráficos en los foros romanos de Hispania, en NOGUERA CELDRAN, J. M. (ed); FORA HISPANIAE, Paisaje urbano, arquitectura, programas decorativos y culto imperial en los Foros de las ciudades hispano-romanas, MAM, Monografías 3, págs. 89-104.

ABASCAL J. M.; ALMAGRO-GORBEA, M.; CEBRIÁN, R. y HORTELANO, I, (2008): Segóbriga 2007. Resumen de las intervenciones arqueológicas, Consorcio del Parque Arqueológico de Segóbriga, Cuenca.

ADAM, J. P. (1984): La construction Romaine: matérielle et technique. Paris

AGUAROD, M. C. y MOSTALAC, A. (1998): La arqueología de Zaragoza en la Antigüedad tardía, Historia de Zaragoza 4, Zaragoza.

ALBA CALZADO, M. (1998): Consideraciones arqueológicas en torno al siglo $V$ en Mérida: repercusiones en la viviendas y en la muralla, MEA 1996, 2, págs. 361- 385.

ALBA CALZADO, M. (1999): Sobre el ámbito doméstico de época visigoda en Mérida, MEA 1997, 3, págs. 387-418.

ALBA CALZADO, M. (2001): Apuntes sobre la red de aguas (publica y privada) de Mérida en época romana, Mérida Ciudad y Patrimonio 5, págs. 59-78.

ALBA CALZADO, M. (2001b): Características del viario urbano en Emerita entre los siglos I y VII, Mérida Ciudad y Patrimonio 5, págs. 397-423.

ALBA CALZADO, M. (2002): Datos para la reconstrucción del paisaje diacrónico de Emérita: las calles porticadas desde la etapa romana hasta la visigoda, MEA 2000, 6, págs. $371-396$.

ALBIACH DESCALS, R. (2001): La topografía preurbana de la ciudad de Valencia. APL XXIV, Valencia, págs. 337-350. 
ALCALDE GONZÁLEZ, R. (2001): El ferrocarril y la articulación del territorio en la Comunidad Valenciana, en Inmaculada Aguilar y Javier Vidal (coord.), 150 años de ferrocarril en la comunidad Valenciana (1852-2002), págs. 10-29

ALEDRIS, X. (ed. 1799): Descripción de España de Xerif Aledris, conocido por El Nubiense, Imprenta Real de Madrid.

ALFOLDY, G. (1977): Los Baebii de Saguntum, Trabajos Varios 56, Servicios de Investigación Prehistórica, Diputación de Valencia.

ALFÖLDY, G. (1993): Tarraco y la Hispania romana: cultos y sociedad, en Mayer M. (ed.) Religio Deorum. Actas del coloquio internacional de epigrafía Culto y Sociedad en Occidente, Sabadell, págs. 7-26.

ALFÖLDY, G. y ABASCAL PALAZÓN, J. M. (2002): El Arco romano de Medinaceli (Soria, Hispania Citerior), Real Academia de la Historia y Universidad de Alicante, Madrid.

ALGILAGA ILA, M. A. y MELCHOR MONSERRAT, J. M. (1992): Nuevos hallazgos arqueológicos en la Plana de Burriana y su contextualización histórica, Actas del III Congreso de Historia y Filología de la Plana, Nules, págs. 20-27.

ALMAGRO GORBEA, A. (1979): Estudio fotogramétrico del teatro de Sagunto, Saguntum 14, págs.16-179.

ALMAGRO-GORBEA, M. (1980): El monumento funerario romano con friso dórico de Sagunto, SAG 15, págs. 127-135.

ALMAGRO-GORBEA, M. (1983): La topografía de Emerita Augusta, IV Congreso de Estudios Extremeños, págs. 114 - 137

ALVAR, J. y BLÁZQUEZ MARTÍNEZ, J. M. (2003): Trajano, Madrid.

AMENGUAL, J. (1987): Consenci. Correspondència amb Sant Agustí, Fundació Bernat Metge 1, Barcelona.

ANDREU PINTADO, J. (2007): En torno al ius Latii flavio en Hispania. A propósito de una nueva publicación sobre latinidad, Faventia 29/2, págs 37-46

ANDRIANI, L. M. (1838): Memoria justificativa de la defensa de Sagunto. Madrid.

ANÓNIMO (1863): Copia del informe del Anticuario de la Real Academia de la Historia acerca de los seis túmulos existentes en el lugar llamado Puchol término de Castellón de la Plana cerca del mar, AHAC. 
AQUILUÉ, X, MAR, R., NOLLA, J. M., RUIZ DE ARBULO, J. y SANMARTI, E. (1984): El fòrum roma d'Empúries (Excavacions del any 1982). Una aproximació arqueològica al procés històric de la romanització al Nord-est de la Península Ibèrica. Barcelona.

AQUILUÉ, X. y SUBÍAS, E. (1986): Sobre la fundación de la ciudad romana de Baetulo (Badalona), Protohistoria Catalana 6 Col-loqui Internacional d'Arqueologia del Puigcerdá, Puigcerdá, págs 353.359

AQUILUÉ, J. (1993): Tarraco: Guía arqueológica, Tarragona.

ARANEGUI GASCO C. y OLCINA, M. (1983): Arqueología en Sagunto ciudad, en actas I Congreso de arqueología de las ciudades, Zaragoza, págs. 113-118.

ARANEGUI GASCO, C. (1990): La arqueologia del vino, Braçal 3, Sagunto, págs. 1216

ARANEGUI GASCO, C. (1994): Datos para el conocimiento de Sagunto en el siglo II, en La ciudad y la comunidad cívica en Hispania. CSIC.-Casa de Velázquez. Madrid.

ARANEGUI GASCO, C. (2004): Sagunto: Oppidum, Emporio y Municipio Romano, Ed. Bellaterra, Barcelona.

ARANEGUI GASCO, C. (coord.) (1996): Els romans en terres valencianes. Col·lecció Politécnica, 16. Ed. Alfons el Magnànim. GV.

ARANEGUI GASCO, C. coord. (1991): Saguntum y el Mar, GV.

ARANEGUI GASCO, C. et Al. (1987): Guía de los monumentos romanos y del Castillo de Sagunto, CC, Valencia.

ARANEGUI GASCO, C., HERNÁNDEZ, E, y LÓPEZ PIÑOL, M. (1987): El foro de Saguntum: la planta arquitectónica. Los foros romanos de las provincias occidentales, Valencia, págs. 73-97.

ARANEGUI, C.; HERNÁNDEZ, E. y PASCUAL, I. (1993): El teatro romano de Sagunto. Teatros romanos de Hispania. Cuadernos de Arquitectura Romana, Mérida.

ARANEGUI, C.; RUIZ, J. M. y CARMONA, P. (2005): El humedal del puerto de ArseSaguntum. Estudio geomorfológico y sedimentológico, Saguntum 37, págs. 153 - 163.

ARASA GIL, F. (1979): Arqueologia del terme municipal de Castelló de la Plana, CPAC, 6, Castellón. 
ARASA GIL, F. (1986): La Época romana. Burriana en su Historia I, Ayuntamiento de Burriana, págs. 43-58.

ARASA GIL, F. (1996-1997): Les comarques septentrionals del litoral valencià entre els segles IV i VI, Annals de I'Institut d'Estudis Gironins. Vol. XXXVII, Girona.

ARASA GIL, F. (2002): La romanització a les comarques septentrionals del litoral valencià: poblament ibèric i importacions itàliques en els segles II-I aC, Diputación de Valencia.

ARASA GIL, F. (2004): Alqueries y su territorio en época romana, Alqueries temps de un poble. Diputación de Castellón, págs. 75-146.

ARASA GIL, F. (2006): El trazado de la Vía Augusta en tierras Valencianas, en GARCÍA PRÓSPER, E.; GUÉRIN P.; DE MADARIA, J. L. Y SÁNCHEZ, P. (eds.), Catastros, hábitats y vía romana, Generalitat Valenciana, págs. 93-130.

ARASA GIL, F. y ROSSELLÓ, V. M. (1995): Les vies romanes del territori valencià, Sèrie Publicacions de Divulgació General, Col-lecció Els Valencians i el seu territori, 7, GV, Valencia.

ARASA I GIL, F. y FLORS UREÑA, E. (2006); Un sondeig a la via Augusta entre els termes municipals de la Pobla Tornesa i Vilafamés (la Plana Alta, Castelló), APL XXVI, Valencia, págs 381-404

ARCE, J. (1988): Funus Imperatorum: Los funerales de los emperadores romanos, Alianza Ed., Madrid.

ARCE, J. (1990): Cursus publicus en la Hispania tardorromana en Simposio - la red viaria en la Hispania romana, Zaragoza, págs. 35-40.

ARCE, J. (2006): Fana, Templa, Delubra Destrui Praecipimus: El final de los templos de la Hispania Romana, AEA 79, págs. 115-124.

ARIAS BONET, G. (2002): La red viaria de la Hispania romana, Artifex, ingeniería romana en España, Catálogo, págs. 199-212, Madrid.

BALIL, A. (1960): Centuriatio. Observaciones sobre la parcelación y agrimensura romana y su conocimiento, Estudios Clásicos 30, págs. 346-359, Madrid.

BALLESTEROS, B. et al. (2009): Zonas húmedas mediterráneas y acuíferos asociados. Condicionantes hidrogeológicos del Marjal de Pego-Oliva (Alicante-Valencia), Boletín Geológico y Minero, 120 (3), págs. 459-478. 
BANHA DE LA SILVA, R. (2005): "Marcas de oleiro" em terra sigillata da Praça da Figueira (Lisboa): contribuição para o conhecimento da economia de Olisipo (séc. I a. C. - séc. II d. C.), Lisboa. Universidade do Minho.

BARRIENTOS VERA, T. (1998): Intervención arqueológica en el solar de la C/ Adriano, n 62. El Cerro del Calvario. MEA 1996, 2, págs. 27-54.

BAZZANA, A. (1987): Vestigios de centuriaciones romanas y de un camino antiguo. Burriana en su Historia I, Ayuntamiento de Burriana, págs. 61-69.

BECATTI, G. y GISMONDI, I. (1996): Topografia generale (Vol. 1), Scavi di Ostia, Ed. Poligrafico dello Stato, Roma

BEDON. R. (1999): Les villes des trois Gaules de César à Néron, Picard, Paris.

BELTRÁN DE HEREDIA, J. (2001): De Barcino a Barcinona (siglos I-VII): Los restos arqueológicos de la Plaza del Rey de Barcelona, Museo de Historia de la Ciudad, Barcelona.

BELTRÁN LLORIS, F (1990); Roma: República y Alto Imperio, en Estado Actual de la arqueología en Aragón I, (Ponencias), págs 215-262. Zaragoza.

BELTRÁN LLORIS, F. (1980): Epigrafía romana de Saguntum y su territorium, TV del SIP $n^{\circ}$ 67. Valencia.

BELTRÁN LLORIS, F. y BELTRÁN LLORIS, M. (1982): Numismática hispanoromana de la Tarraconense, Numisma 162-164, págs. 8-98. Madrid.

BELTRÁN LLORIS, M. (1990): Guía de la Cerámica Romana, Zaragoza.

BELTRÁN LLORIS, M. y FATÁS CABEZA, G. (1998): Historia de Zaragoza 2: Caesaraugusta, ciudad romana, Zaragoza.

BELTRÁN LLORIS, F (2002); Identidad cívica y adhesión al príncipe en las monedas municipales hispanas, en MARCO F., PINA F. Y REMESAL, J. (eds.): Religión y propaganda política en el mundo romano, págs. 159-163, Barcelona.

BELTRÁN VILLAGRASA, P. (1951): Hallazgos en Sagunto, AEA. Vol. XXIV. Madrid, págs. 246-247.

BELTRÁN VILLAGRASA, P. (1956): Excavaciones en Sagunto (Valencia), NAH III-IV 1954-1955. Madrid, págs. 132-133. 
BÉMONT, C. (1976): Recherches Méthodologiques sur la Céramique Sigillée- Les vases estampillés de Glanum. École Française de Rome, Bibliothèque des Écoles Françaises d'Athènes et Rome, 227, Roma.

BENDALA GALÁN, M (1976): Las necrópolis de Mérida, Emerita Augusta, Mérida, págs. $141-161$.

BENEDITO NUEZ, J.; MELCHOR MONSERRAT, J. M., y SEGUÍ MARCO, J. J. (2007); Nuevas aportaciones a la necrópolis romana del sector meridional de la ciudad de Valentia, junto a la vía Augusta, Caesaraugusta 78, Zaragoza, págs 631-644.

BENEDITO NUEZ, J.; MELCHOR MONSERRAT, J. M., y PASIES OVIEDO, T. (2012): Un nuevo fragmento de mosaico romano encontrado en la villa del Pujolet de Santa (l'Alcora, Castellón España), XCMGR, págs. 943-947.

BENEDITO NUEZ, J.; CLARAMONTE CHIVA, M. y DELAPORTE, S. (2008); Arqueología de la necrópolis andalusí del nuevo hogar "Verge del LLedó" (Castellón), BSCC LXXXIV, Castellón, págs. 463-474.

BERNI MILLET, P. (2008) Epigrafía anfórica de la Bética: nuevas perspectivas de análisis, Instrumenta 29, Universidad de Barcelona.

BERROCAL RANGEL, L. (1987): La Urbanística de Augusta Emerita (I y II), Revista de Arqueología, Madrid

BET, P. y VERTET, H. (1986): Centre de Production de Lezoux, in La terre sigillée gallo-romaine. Lieux de production du Haut Empire: implantations, produits, relations, Maison des Sciences de I'Homme, Documents D'Archéologie Française 6, Paris, págs. 138-145.

BLAEU, W. (1640): Valentia regnum; Contestani, Ptol., Edentani, Plin.; Amsterdami apud Guiljelmum Baleuw, Mapa RM.215219, Institut Cartogràfic de Catalunya.

BLÁZQUEZ MARTÍNEZ, J, M, (1988): La Hispania del Bajo Imperio. Las relaciones con Oriente, en Actas del I Congreso Peninsular de Historia Antigua, Vol. 3, págs. 177-186.

BLÁZQUEZ MARTÍNEZ, J. M. (1968): Relaciones marítimas entre Hispania y las regiones del Mediterráneo durante la República Romana, en Studi in Onore di Giuseppe Crosso II, págs. 171-191.

BOCQUET, A. y PICON, M. (1994): La Graufesenque et les autres ateliers de la Gaule du Sud: problèmes d'analyses et de techniques, in Actes du Coloque de Millau (Millau 
1994), Sociéte Française pour I 'Étude de la Céramique Antique en France, Millau, págs. $75-82$.

BONET ROSADO, H., ALBIACH DESCALS, R. y GOZALBES, M. (coord.) (2003), Romans $i$ visigots a les terres valencianes, Museu de Prehistòria y de les Cultures de València, Valencia.

BONET ROSADO, H., PEDRO MICHÓ, M. J., SÁNCHEZ MOLINA, Á. y FERRER GARCÍA, C. (coord.) (2008): Arqueología en blanco y negro: La labor del SIP: 19271950. Diputación de Valencia.

BOURGEOIS, A. y MAYET, F. (1991): Belo VI - Les Sigillées - Fouilles de Belo, Collection de La Casa de Velázquez, 34, Archéologie, 14, Madrid.

BRADFORD, J. (1947); A Technique for the Study of Centuriation, en Antiquity XXI, págs. 197 y ss. Londres.

BRAVO, G. (2007): Hispania, Ed. La esfera de los libros, Barcelona.

BRU I VIDAL, S. (08-12-1953): El mosaico romano hallado en Sagunto. Periódico Las Provincias. Valencia.

BRU I VIDAL, S. (1963): Les terres Valencianes durant l'Época Romana: L'Estel. Valencia.

BRU I VIDAL, S. (21-10-1956): Los Nuevos Hallazgos de Mosaicos romanos en Sagunto. Periódico Las Provincias. Valencia

BUXEDA I GARRIGÓS, J. y TUSET I BERTRAN, F. (1995): Revisió crítica de les bases cronològiques de la terra sigillata hispànica, Pyrenae 26, Universitat de Barcelona, págs. 171-188.

CABALlERO, L. Y MATEOS, P. (1991): Excavaciones en Santa Eulalia de Mérida, Extremadura Arqueológica II, págs. 525 - 546.

CANCELA, M. L. y MARTÍN-BUENO, M. (2008): Los julio-claudios en Bilbilis, en NOGUERA, J. M. y CONDE, E. (ed.): Escultura romana en Hispania V, Murcia, págs. 235-245,

CARCOPINO, J. (1995): La vida cotidiana en Roma en el apogeo del Imperio, Ediciones Temas de Hoy, Madrid.

CASTAGNOLI, F. (1993): Topografia Antica. Un metodo di Studio. II Italia, Universita degli Studi di Roma "La Sapienza". Roma. 
CASTILLO PASCUAL, Ma J. (1998): Opuscula Agrimensorum Veterum Hyginus et Siculus Flaccus. Universidad de La Rioja.

CATALINA, S. (1867): Oficio de traslado del Gobernador Civil de Castellón en el que se da cuenta de las noticias detalladas acerca del hallazgo del Plomo con inscripción ibérica y de los trabajos de excavación realizados en los túmulos. Adjunta copia de la Inscripción del plomo ibérico del Puch, hecha por la Comisión de Monumentos de Castellón. También informa de los restos de un templo dedicado a Venus en las lagunas de Almenara, AHAC. Manuscrito.

CAVANILLES Y CENTI, A., DELGADO Y HERNÁNDEZ, A., OLÓZAGA Y ALMANDOZ, S. de y FERNÁNDEZ- GUERRA Y ORBE, A. (1858): Minuta de oficio relativa a la Real Orden emitida Por el Ministerio de la Guerra para demoler los restos de Sagunto. La Comisión nombrada por la Real Academia de la Historia para este asunto expone los criterios por los que solicita que, en caso de que se lleve a cabo la demolición, se conserven los objetos arqueológicos que se descubran, AHAC. Manuscrito.

CEPAS, A (1997): Crisis y continuidad en la Hispania del Siglo III, CSIC, Centro de Estudios Históricos, Departamento Historia Antigua y Arqueología. Madrid.

CERRILLO MARTÍN DE CÁCERES, E. (1985): Informes. Arqueología y Agricultura Romana en la Península Ibérica, Norba. Revista de Historia.

CERRILLO MARTIN DE CACERES, E. (1995): El anfiteatro de Cáparra, Actas del Coloquio Internacional El Anfiteatro en la Hispania Romana, Mérida, págs. 311-326.

CHABRET FRAGA, A. (1888): Sagunto. Su historia y sus monumentos, Caja de Ahorros y Socorros de Sagunto, Edición Facsímile, Sagunto, 1979.

CHABRET FRAGA, A. (1897): Carta de remisión de una memoria, dibujos y un sello en lacre sobre los materiales hallados en los terrenos donde se realizan las obras para la vía del ferrocarril Calatayud-Teruel-Sagunto, AHAC. Manuscrito.

CHABRET FRAGA, A. (1897b): Informe incompleto sobre los materiales pertenecientes a la necrópolis saguntina -localizada en la parte oriental de la ciudad- hallados en las obras realizadas para la construcción del ferrocarril de Calatayud- Teruel-Sagunto, AHAC. Manuscrito.

CHABRET FRAGA, A. (1897c): La necrópolis saguntina, BRAH XXXI, págs. 458-466.

CHABRET FRAGA, A. (1897d): Plano sobre la disposición del ferrocarril y la estación del Norte en Sagunto. No se especifica la localización de la necrópolis saguntina, AHAC. Manuscrito. 
CHABRET, A. (1978): Vías romanas de la provincia de Castellón de la Plana. Caja de Ahorros de Castellón. Castellón.

CHEVAlLIER, R. (1997): Les Voies Romaines, Ed. Picard. Paris.

CHINER MARTORELL, P. y LÓPEZ PIÑOL, M. (1994): Noticia preliminar de las excavaciones de la Domus tardía del solar del Romeu (Sagunto), SAG 27, Valencia.

CHINER MARTORELL, P., LÓPEZ PIÑOL M. y GOZALBES, M. (1998): Perduraciones y contextos tardíos de los hallazgos monetarios procedentes del solar del Romeu (Sagunto, Valencia), SAG 31, págs. 233-240, Valencia.

CHOISY, A. (1873): El arte de construir en Roma. Paris.

CINCA MARTÍNEZ, J. L. (1996): La necrópolis del Cascajo y la pared sur de circo romano: dos nuevas destrucciones arqueológicas, Kalakoricos 1, págs. 45-55, Logroño.

CIZEK, E. (1983): L'Époque de Trajan. Les Belles Letres, Paris.

CLARAMONTE CHIVA, M. (2005): Aproximación al estudio de los elementos decorativos arquitectónicos, en Monográfico ARSE 39, Sagunto, págs. 83-124.

CLARAMONTE, M.; MELCHOR, J. M. y DELAPORTE, S. (2007): Estudio de los materiales cerámicos, en La excavación arqueológica del yacimiento romano del Pujolet de Santa (l'Alcora, Castellón) Arturo Oliver Foix (dir), Ayuntamiento de Alcora.

CLARAMONTE, M., BENEDITO, J., DE SANTISTEBAN, C. y MELCHOR, J. M. (2009); Ornamental materials found at Sagunto's Moorish quarter square, en IX Asmosia Conference, Tarragona.

COLINI, A. M. y COZZA, L. (1962): Ludus Magnus. Roma.

COMAS, M., LlOBET, C., PADRÓs, P., PUERTA, C. y RODRÍGuEZ, M. (1994): Observations sur les sigillées du sud de la Gaule à Baetulo (Badalone, Espagne), en Actes du Coloque de Millau (Millau 1994), Sociéte Française pour I 'Étude de la Céramique Antique en France, Millau, págs. 83-94.

CORDERO, R. y MENÉNDEZ, F. (1978), El sistema ferroviario español, en Artola, Miguel (ed.), El ferrocarril en España 1844 - 1943 Vol. 1, págs. 161-338.

CORELL VICENT, J y SEGUI MARCO, J. J. (2008): Fragmentos de inscripciones monumentales romanas de Sagunto, Sylloge Epigraphica Barcinonensis (SEBarc) VI, págs. 73-80. Barcelona. 
CORELL VICENT, J (2002): Inscripcions Romanes del País Valencia II. (Saguntum y el seu territori), Valencia.

CORELL VICENT, J. (1989); Grafito sobre vaso de cerámica hallado en Sagunto, ARSE 24, págs. 845-849.

CRISTHIE, N. y LOSEBY, S. T. (ed.) (1996): Towns in Transition: Urban Evolution in Late Antiquity and the Early Middle Ages. Aldershot: Scolar Press.

DANIEL. G. (1987): Un siglo y medio de arqueología. FCE, México.

De ANGELI, S. (1992): Templum Divi Vespasiani, Roma.

De ANTONIO, J. M., ANTONI, C. y HERNÁNDEZ, F. J. (2002): Notícia preliminar de les excavacions de la domus romana del solar del Cinema Marvi (Sagunt), ARSE 36, Sagunto págs. 96-116.

DE LABORDE, A. (1811): Voyage Pittoresque et historique de l'Espagne, Paris

De MARIA, P. R. (1935): El repartiment de Burriana y Vila-real, Valencia.

De VILLUGA, P. (1546): Repertorio de todos los caminos de España hasta ahora nunca visto, en el que hallará cualquier viaje que quiera andar muy provechoso para todos los caminantes, Edición Facsímil 1998. Vicent García Ed.

DELGADO Y HERNÁNDEZ, A. (1859): Informe sobre el viaje literario que esa institución le encomienda para comprobar el estado en el que se encuentran el teatro y el castillo de Murviedro, AHAC. Manuscrito.

DELGADO Y HERNÁNDEZ, A. (1877): Antigüedades de Murviedro, BRAH, Tomo 1 cuaderno $V$, Madrid.

DESBAT, A., PICON, M. y DJELLID, A. (2000): Le début des importations de sigillées à Lyon, in Rei Cretariae Romane Fautorum Acta, 36, R. C. R. F., Abingdon, págs. 513 523.

DÍAZ-ANDRĖU, M., MORA RODRIGUEZ, G. y CORTADELLA MORRAL, J. (coords.) (2009): Diccionario histórico de la arqueología española, Ed. Marcial Pons, Madrid.

DOMíNGUEZ, J. A. (1991): La cerámica de paredes finas, Universidad de Zaragoza.

DOÑATE SEBASTIA, J. M. (1972): Datos para la Historia de Villarreal, Ayuntamiento de Vila-real 
DOSI, A. y SCHNELL, F. (1986b): Pasti i vasellame di tavola, Ed. Quasar, Roma

DUPRÉ, X. Y CARRETÉ, J. M. (1993), La Antigua Audiencia. Un acceso al foro provincial de Tarraco, AEA, 165, Madrid

DUPRÉ, X. y REMOLÀ, J. A. (2002): A propósito de la gestión de los residuos urbanos en Hispania, Romula, 1, Sevilla.

ELADIO GRANGEL, E. y PILAR ULLOA. P. (1996); "Ildum". Mansio romana junto a la vía Augusta (Vilanova d'Alcolea, Castellón), CPAC 17, págs. 349-366.

ENRÍQUEZ, J. J., ÁLVAREZ, J. M., CERRILLO, E., RAMOS, F., et al. (1994): Conjunto Arqueológico de Mérida, Salamanca.

ESPINOSA A., CASTILLO R. y SÁEZ F. (2005): Evolución de los puertos y fondeaderos en las costas meridionales de la Comunidad Valenciana durante la época romana, sus precedentes ibéricos y su evolución en la alta Edad Media. En A. GALLINA ZEVI, R. TURCHETTI (a cura di), Le strutture dei porti e degli approdi antichi, Anciennes routes maritimes Mediterranéennes (ANSER). II seminario, Roma-Ostia antica, 16-17 aprile 2004. Roma, págs.23-44.

ESTEVE GÁlVEZ, F. (1956): La Villa romana de Benicató, en Revista Penyagolosa 2, Castellón.

ESTEVE GALVEZ, F. (1986): L'amollonament de la via romana al Pla de l'Arc, Estudis Castellonencs 3, Diputación de Castellón, págs. 243-274.

ETTLINGER, E., HEDINGER; B., HOFFMANN, B., KENRICK; P., PUCCl, G., ROTHRUBI, K., SCHNEIDER, G., SHNURBEIN, S. V., WELLS, C. M. y ZABEHLICKYSCHEFFWNEGGER, S. (1990): Conspectus Formarum Terrae Sigillatae Italico Modo Confectae. Dr. Rudolf Habelt GMBH, Römische-Germanische Komission des Deutschen Archaeölogischen Instituts zu Frankfurt A. M., Materialen zu römischegermanische Keramik, 10, Bonn.

FALOMIR VENTURA, C. (2005): Vidrio romano: El solar de la Plaza de la Morería de Sagunto, en Monográfico ARSE 39, Sagunto, págs. 125-144.

FEIJOÓ MARTÍNEZ, S. (2000): Generación y transformación del espacio urbano romano de Augusta Emerita al exterior de la muralla. MEA 1998 4, págs. 571-581.

FELIP SEMPERE, V. (2000): Recull per a una historia de Nules. Ayuntamiento de Nules. 
FELIP SEMPERE, V. y VICENT CAVALLER, J. A. (1998): Ibers i Romans al Camp de Nules (Mascarell, Moncofa, Nules i La Vilavella) (reed.), Ayuntamiento de Nules.

FERNÁNDEZ CASTRO, M. C. (1981): Villa Romana y Basílica cristiana en Hispania, en La religión romana en Hispania, CSIC, Madrid, págs. 383-389.

FERNÁNDEZ IZQUIERDO, A. (1980): Estudio de los restos arqueológicos submarinos en las costas de Castellón, CPAC, 7, Castellón.

FERNÁNDEZ IZQUIERDO, A. (1991): Los contactos comerciales en la antigüedad, a través del material arqueológico submarino, Burriana en su Historia II, Ayuntamiento de Burriana, págs. 29-46.

FERNÁNDEZ UBIÑA, J. (1981): Comportamientos y alternativas cristianas en una época de crisis: el testimonio de Cipriano, Memorias de Historia Antigua, CSIC, Madrid

FERNÁNDEZ VEGA, P. A. (1999): La casa romana, Ed. Akal, Madrid.

FERNÁNDEZ-GUERRA Y ORBE, A. (1867): Minuta de informe en el que se analiza la etimología de la palabra Murviedro $v$ el momento en el que se incorporó como nombre de esta villa valenciana, AHAC. Manuscrito.

FERRER, J. J. (1992): Roma y la nueva sociedad. La romanización, Historia de Castellón I, Levante de Castellón, págs. 121 - 128

FLETCHER VALLS, D. y ALCÁCER GRAU, J. (1955): Avance a una arqueología romana de la provincia de Castellón, BSCC, XXXI, Castellón.

FLETCHER VALLS, D. y ALCACER GRAU, J. (1956): Avance a una arqueología romana de la provincia de Castellón, BSCC, XXXII, págs. 135-162.

FLÓREZ I SANTASUSANA M. y PALET I MARTÍNEZ, J. M. (2011): Asentamientos rurales y estructuración de la Layetania interior (Barcelona): romanización e impacto de los programas de organización territorial, en Corsi, C. y Vermeulen F. (ed.) Changing Landscapes The impact of Roman towns in the Western Mediterranean, Ricerche series maior 1, Universidade de Evora, págs. 141-166

FORNER TIGELL, V. (1933): Una colonia fenicia en el término de Burriana, BSCC XIV, Castellón.

FRAZER, A. (1966): The iconography of the imperor Maxentius buildings in Via Appia, Art Bulletin XLVIII, 385-392. 
FUENTES, Á. (1999): La ciudad en la antigüedad tardía a la luz de los textos arqueológicos, en Complutum y las ciudades hispanas en la Antigüedad Tardía, Alcalá de Henares, págs. 73-86.

GARCÍA MORENO, L. A. (1972): Las colonias de Comerciantes Orientales en la Península Ibérica, Habis 3, págs. 127-154.

GARCÍA MORENO, L. A. (1977-1978): La cristianización de la topografía de las ciudades de la Península Ibérica durante la Antigüedad Tardía, AEA 50-51, págs. 311 $-321$.

GARCÍA MORENO, L. A. (1986): Las transformaciones de la topografía de las ciudades en Lusitania en la antigüedad tardía, Revista de Estudios Extremeños.

GARCÍA Y BELLIDO, A. (1963); El lienzo megalítico del Artemision de Saguntum, BRAH 153, Págs. 301-305. Madrid.

GARCÍA PRÓSPER, E.; GUÉRIN, P.; DE MADARIA J. L. Y SÁNCHEZ, P. (2006): Campaña de prospección en la centuriación romana de Sagunto, en GARCíA PRÓSPER, E.; GUÉRIN P.; DE MADARIA, J. L. Y SÁNCHEZ, P. (eds.), Catastros, hábitats y vía romana, Generalitat Valenciana, págs. 247-298.

GARZA DEL BONO, P. de la (1877): Informe sobre varias inscripciones romanas que se encuentran en el casco urbano de Linares, algunas conocidas de... También se informa sobre su viaje a Sagunto del que hace algunas observaciones acerca de su teatro, de inscripciones que se hallan en alrededores sobre el trazado de la muralla romana y musulmana, AHAC. Manuscrito.

GAYANGOS, P. de, (1850): Memoria sobre la Crónica del Moro Rasis, Madrid.

GENIN, M. y VERNHET, A., dir. (2002): Céramiques de La Graufesenque et autres productions d'époque romaine - Nouvelles Recherches - Hommages à Bettina Hoffmann. Éd. Monique Mergoil, Archéologie et Histoire Romaine, Millau.

GIOVANNI GUZZO, P. y GUIDOBALDI, M. P. (2003): Nuove ricerche archeologique a Pompei ed Ercolano. Electa Napoli.

GIUNTOLI, E. (1989) Arte e historia de Pompeya, Ed. Bonechi, Florencia.

GODOY FERNÁNDEZ, C. (1989); Arquitectura cristiana y liturgia: reflexiones entorno a la interpretación funcional de los espacios, en Espacio, Tiempo y Forma, Serie I Prehistoria y Arqueología, $T$ 2. Barcelona, págs. 355-387. 
GÓMEZ ROS, J., FALCÓ FUERTES, V., ROVIRA GOMAR, M. L., MARTÍNEZ MARTÍNEZ, M. T., PALOMAR MACIÁN, V., RIVAS HUESA, L, (1989): La villa romana de Uxó (La Vall d'Uixó, Castelló): Noticia preliminar, en Actas del XIX CNA vol. 1, Castellón, págs. 757-768.

GÓMEZ SERRANO N. P. (1961): Aqüeducte del Corral dels Xurros, ARSE V, Sagunto.

GONZÁLEZ, J. (ed) (2000): Trajano emperador de Roma, “L’Erma” di Brestchneider, Roma.

GONZÁLEZ SIMANCAS, M. (1923): Excavaciones de Sagunto. Memoria presentada a la Junta Superior, Madrid.

GONZÁlEZ SIMANCAS, M. (1927): Excavaciones de Sagunto. Memoria de los trabajos realizados durante los años 1923-1922, Madrid.

GONZÁLEZ SIMANCAS, M. (1933): Excavaciones de Sagunto. Memoria de los trabajos realizados en dichas excavaciones, Madrid.

GONZÁLEZ VILLAESCUSA, R. (2001): El mundo funerario romano en el País Valenciano: monumentos funerarios y sepulturas entre los siglos I a. C.-VII d. C., Instituto Alicantino de Cultura "Juan Gil-Albert".

GONZALEZ VILLAESCUSA, R. (2002): Las formas de los paisajes mediterráneos, (Ensayos sobre las formas, funciones y epistemología parcelarias: estudios comparativos en medios mediterráneos entre la antigüedad y época moderna), Universidad de Jaén.

GONZÁLEZ VILLAESCUSA, R. (2007): Ce que la morphologie peut apporter à la connaissance de la centuriation d'llici (Elche, Espagne), Agri centuriati 4, págs. 29-42.

GONZÁLEZ VILLAESCUSA, R. (2006): Bonificación de zonas palustres en el ager saguntinus, en GARCÍA PRÓSPER, E.; GUÉRIN P.; DE MADARIA, J. L. Y SÁNCHEZ, P. (eds.), Catastros, hábitats y vía romana, Generalitat Valenciana, págs. 215-246.

GOUDINEAU, C. (1968): La céramique arétine lisse - Fouilles de l'École Française à Bolsena (Poggio Moscini), 1962-67, Mélanges de l'École Française de Rome 4, Paris.

GOZALBES CRAVIOTO, E. y GARCÍA GARCÍA, I. (2007): La primera peste de los Antoninos (165-170). Una epidemia en la Roma Imperial, Asclepio - Revista de Historia de la Medicina y de la Ciencia LIX, nº 1, enero-junio, Madrid, págs. 7-22.

GRANADOS, O. (1991): Estructura urbana de la ciutat romana, Historia de Barcelona, Vol. I (La ciudad antigua), Barcelona. 
GROS, P. (1996): L'Architecture Romaine I y II. Paris

GROS, P. y TORELLI, M. (1992): Storia dell'urbanística-ll mondo romano. Editori Laterza, Roma y Bari.

GROSSE, R. (1947): Las fuentes de época visigoda y bizantina, Fontes Hispaniae Antiquae IX, Barcelona

GUICHARD, P. y MESADO, N. (1976): Un menut poble del País Valencià durant l'època musulmana: Borriana, Col-lecció Papers 1, Ayuntamiento de Burriana.

GUITART, J. (1976), Baetulo. Topografía arqueológica, urbanismo e historia, Monografías Badaloneas 1, Barcelona.

GUSI JENER, F. (1991): La Plana i el Grau de Castelló, Apunts d'arqueologia municipal, Castelló Festa Plena, Castellón.

GUSI JENER, F. coord. (2000): Servicio de Investigaciones Arqueológicas y Prehistóricas, XXV Aniversario 1975-2000, Diputación de Castelló, Castellón.

GUSI, F. y OLARIA, C. (1977): La villa romana de Benicató (Nules, Castellón), CPAC, 4, Castellón, p. 101-144.

HATT, J. J. (1967): Reflexions de methode sur les foullies d'oficines ceramiques, Revue Archeologique du Centre, 24, Paris, págs. 323-327.

HAUSCHILD, Th. (1994): El templo romano de Evora: nuevas investigaciones; La ciudad en el mundo romano, Tarragona, págs. 197-200.

HAYES, J. (1980): A supplement to Late Roman Pottery, Londres.

HERNÁNDEZ HERVÁS, E. (1989): El teatro romano de Sagunto, Generalitat Valenciana, Valencia.

HERNÁNDEZ HERVAS, E. (1990): C/ Obispo Miedes (Sagunto), en EASCV 19841988. I Intervenciones Urbanas, GV, Valencia, págs. 124-126.

HERNÁNDEZ HERVAS, E. (1998): Museu Arqueològic de Sagunt. Patrimoni d'una ciutat, GV, Valencia.

HERNÁNDEZ HERVAS, E. y SÁNCHEZ, P. (1999): Seguimiento arqueológico del colector de la Glorieta (Sagunto), ARSE 32-33, págs. 83-108. 
HERNÁNDEZ HERVAS, E., LÓPEZ PIÑOL, M. y PASCUAL BUYE, I. (1996): La implantación del circo en el área suburbana de Saguntum, SAG 29, Valencia, págs. 221-230.

HIDALGO PRIETO, R. (1999): La incorporación del esquema palacio-circo a la imagen de la Corduba bajoimperial, Ciudades Privilegiadas en el Occidente Romano: Naturaleza y Evolución, Organización Jurídica y Modelos Urbanos, Sevilla, págs. 379396.

HIDALGO PRIETO, R. (2003): En torno a la imagen urbana de Itálica, Romula 2, Universidad Pablo de Olavide, Sevilla págs. 89 - 126

HORTELANO UCEDA, I. (1993): Los niveles romanos de la Iglesia de San Salvador (Sagunto). SAG 26, Valencia, págs. 253-258.

HUICI MIRANDA, A. (1970): Historia musulmana de Valencia y su región: novedades y rectificaciones, Valencia.

HUMPHREY, J. H. (1986): Roman Circuses. Arenas for Chariot Racing, Londres.

JÁRREGA, R. (1991): Cerámicas finas tardorromanas y del mediterráneo oriental en España. Estado de la cuestión, Anejos del AEA XI, Madrid.

JÁRREGA, R. (1996): El yacimiento romano de El Campillo (Altura). Nuevos datos para el estudio de la romanización del Alto Palancia (Castellón), CPAC 17, págs 367-381.

JÁRREGA, R. (1998): El poblamiento romano en la comarca del Alto Palancia. Estado actual de nuestros conocimientos, CPAC 19, págs. 349-369.

JÁRREGA, R. (2000): El Alto Palancia en la época romana. Colección Universitaria. Geografía e Historia, Diputación de Castellón.

JÁRREGA, R. (2000b): La vía romana de Saguntum a Caesaraugusta en la comarca del Alto Palancia: estudio arqueológico. Millars. Espai i Història XXIV págs. 35 - 58

JÁRREGA, R. (2008): La crisi del segle III a l'àrea compresa entre Tarraco i Saguntum: aproximació a partir de les dades arqueològiques, en El camp al segle III. De Septimi Sever a la tetrarquia. Estudis sobre el Mon rural d'època romana 3, Girona.

JÁRREGA, R. (2011): La Plana romana, Publicaciones de la Universitat Jaume I, Diputación de Castellón.

JIMÉNEZ MARTíN, A. (1976): Los acueductos de Mérida, Actas del simposio internacional conmemorativo del bimilenario de Mérida, págs. 111 - 125. 
JIMÉNEZ SALVADOR, J. L. (1989): El monumento funerario de los Sergii en Sagunto. En Homenaje A. Chabret 1888-1988, Valencia, págs. 207-220.

JIMÉNEZ SALVADOR, J. L. (1992): El monumento funerario del Colegio Romeu en Sagunto. Homenaje a E. Pla Ballester, TV del SIP 89, Valencia, págs. 539-554.

JUAN TOVAR, L. C. (1990): El alfar y su contexto: las vías de comunicación, en Simposio la red viaria en la Hispania romana, págs. 293-299.

JUNG, C. (2006): Organización y dinámica de los paisajes históricos del Tricastin, en GARCÍA, E.; GUÉRIN P.; DE MADARIA, J. L. Y SÁNCHEZ, P. (eds.), Catastros, hábitats y vía romana, Generalitat Valenciana, págs. 29-46.

KEAY, S., CREIGHTON, J. y REMESAL RODRÍGUEZ, J. (2001): Celti (Peñaflor) - La Arqueología de una Ciudad Hispanorromana en la Baetica: Prospecciones y Excavaciones 1987-1992. Junta de Andalucía, Consejería de Cultura, Monografías Arqueológicas 12, Sevilla.

LAMBOGLIA, N. (1952): Per una clasificazione preliminare della ceramica campana, Bordighera.

LANCEL, S. (1994). Cartago. Editorial Crítica.

LEDO CABALLERO, A. C. (2005): La calzada ARSE/SAGUNTUM-CELTIBERIA. Estudio Histórico-Arqueológico. Real Academia de la Cultura Valenciana Sección de Prehistoria y Arqueología. Serie arqueológica 21, Valencia

LEVEAU, P.; TRÉMENT, F.; WALSH, K. y BARKER, G. (eds.) (1999); Environmental Reconstruction in Mediterranean Landscape Archaeology, The Archaeology of Mediterranean Landscapes 2, Oxbow Books, Oxford.

LLINAS, J y SABRERA (1993): La Vil-la romana de la Vinya d'en Crispi (Guissona, La Segarra). Revista d'Arqueologia de Ponent, 3, págs. 323-331, Lérida.

LLOBREGAT CONESA, E. (1983): Relectura de Ravennate: dos calzadas, una mansión inexistente y otros datos de la geografía antigua del país valenciano, Lucentum Anales de la universidad de Alicante. Prehistoria, arqueología e historia antigua 2, págs. 225-242.

LLORENS OTERO, J. M.; MELCHOR MONSERRAT, J. M.; BENEDITO NUEZ, J. y FERRER CASTELLÓ, J. L. (1999); Paradigma de la excavación urbana en Valencia (La excavación del Pont de Fusta), en Actas del XXIV CNA vol 5, Cartagena, págs. 89-94. 
LLORENS OTERO, J. M. (2005): Aproximación al estudio de los materiales óseos, en Monográfico ARSE 39, Sagunto, págs. 183-208.

LLORENS, M. del M. Y RIPOLLÉS ALEGRE, P. P. (1998): El deposito monetal de la Domus A de Romeu: nuevas aportaciones de monedas de bronce en Saguntum durante el siglo III d. C., SAG 28, págs. 217-225.

LÓPEZ BRAVO, F. y DELAPORTE. S. (2005): Estudio preliminar del mobiliario metálico de época romana del solar de la Morería de Sagunto, en Monográfico ARSE 39, Sagunto, págs. 145-182.

LÓPEZ GÓMEZ, A. (1975): Posibles centuriaciones en Castellón de la Plana, Estudios sobre centuriaciones romanas en España, Madrid, págs. 129-136.

LÓPEZ PIÑOL, M, y CHINER MARTORELL, P. (1994): Noticia preliminar de las excavaciones de la Domus tardía del solar del Romeu (Sagunto). SAG 27, Valencia.

LÓPEZ PIÑOL, M. (1991): El nivel de abandono del Grau Vell. Las sigillatas de producción africana, Saguntum y el mar, Valencia, págs. 103-106.

LÓPEZ PIÑOL, M. (1991b): Terra Sigillata itálica, gálica e hispánica. Saguntum y el mar, Valencia, págs. 98-102.

LÓPEZ QUIROGA, J. y MARTÍNEZ TEJERA A. M. (2006): El destino de los templos paganos en Hispania durante la antigüedad tardía, $A E A L X X I X$, págs. 125-153, Madrid.

LUGLI. G. (1939); Saggi di esplorazione archeologica mezzo della fotografia aerea, Roma.

MACIAS SOLÉ, J. M. (2000): Tarraco en la Antigüedad Tardía: un proceso simultaneo de transformación urbana e ideológica, en Los orígenes del Cristianismo en Valencia y su entorno, Valencia, págs. 259-271

MADOZ, P. (1848): Diccionario Geográfico-Estadístico-Histórico de España y sus posesiones de Ultramar, T. XI, pág. 777.

MAGALLON, M. A. (1990): Organización de la red viaria romana en el valle medio del Ebro en Simposio - red viaria en Hispania romana, Zaragoza, págs. 301-315.

MAR, R. (1996): Santuarios e inversión inmobiliaria en la urbanística ostiense del siglo II. Roman Ostia revisited. Archeological and Historical Papers in Memory of Russell Meiggs, Anna Gallina-Amanda Claridge (Ed). British School at Rome, págs. 115-164. 
MAR, R. Y GUIDI-SÁNCHEZ, J. J. (2010): Formación y usos del espacio urbano Tardoantiguo en Tarraco, Espacios Urbanos en el Occidente Mediterráneo (s. VI-VIII), Toledo, págs. 173-182.

MARIN RUBIO, E. (2005): Los materiales ibéricos del solar de la Plaza de la Morería, en Monográfico ARSE 39, Sagunto, págs. 63-82.

MÁRQUEZ PÉREZ, J. (1998): Nuevos datos sobre la dispersión de las áreas funerarias de Emerita Augusta, MEA 1994-95, 1, págs. 291-301.

MÁRQUEZ PÉREZ, J. (2000): Aportaciones al estudio del mundo funerario en Emerita Augusta. MEA 1998, 4, págs. 525-547.

MARTÍN, F. (1994); Las constituciones imperiales en Hispania, en Roma y las Provincias: realidad administrativa. Ed. Clásicas. Madrid

MATEOS CRUZ, P. (1995): Proyecto Arqueología urbana de Mérida: desarrollo y primeros resultados. Extremadura Arqueológica, IV, págs. 191- 215.

MATEOS CRUZ, P. (1999): Santa Eulalia de Mérida: Arqueología y urbanismo, Anejos de $A E A X I X$, Madrid.

MATEOS CRUZ, P. (ed.) (2006): El "Foro Provincial” de Augusta Emerita: Un conjunto monumental de culto imperial, Anejos AEA XLII, Madrid.

MATEOS CRUZ, P. y ALBA, M. (2000): De Emerita Augusta a Marida. Visigodos y Omeyas. Anejos AEA XXXIII, Madrid.

MATEOS CRUZ, P. y MÁRQUEZ PÉREZ, J. (1999): Nuevas estructuras urbanas relacionadas con el Teatro Romano de Mérida. Pórtico de acceso. MEA 1997, 3.

MATEU BELLES, J. F. y PALOMAR ABASCAL, J. M. (1990): Morvedre en una imatge de 1563, Les vistes valencianes de'Anthonie Van Den Wijngaerde, Valencia, págs. 149220

MAYER, M. y RODÁ, I. (1991): El comercio del mármol en el Mediterráneo y su reflejo en ciudad romana de Sagunto. Saguntum y el mar, Valencia, págs. 37-43.

MAYET, F. (1984): Les Céramiques Sigillées Hispaniques. Contribution à I'histoire économique de la Péninsule Ibérique sous l'Empire Romain, Paris, Centre Pierre Paris.

MAYORAL HERRERA, V., CHAPA BRUNET, T., URIARTE GONZALEZ, A. y CABRERA DIEZ, A. (2006): Escuchando el ruido de fondo: Estrategias para el estudio 
de los paisajes agrarios tardoibéricos en la región del Guadiana Menor, CAE 26, Teruel, págs. 87-114.

MELCHOR MONSERRAT, J. M. (1994): Prospecciones arqueológicas en el Palau/Tirao (Burriana): la cerámica, Actas del IV Congreso de Historia y Filología de la Plana, Nules.

MELCHOR MONSERRAT, J. M. (1995): Aproximación a la historia de la arqueología en Castellón, Actas Congreso de Historiografía de la Arqueología en España (siglos XVIII a XX), Málaga. págs. 497-506.

MELCHOR MONSERRAT, J. M. (2005): Breve Historia de Burriana. Ayuntamiento de Burriana.

MELCHOR MONSERRAT, J. M. (2005b): Intervenciones arqueológicas en la Ronda de Burriana. Primeras aportaciones, en actas del VII Congreso de Historia de la Plana. Ayuntamiento de Nules.

MELCHOR MONSERRAT, J. M. (2007): Dos siglos de destrucción de patrimonio histórico de Sagunto (1807-2007), ARSE 41. Sagunto.

MELCHOR MONSERRAT, J. M., BENEDITO NUEZ, J. (2000): Campaña de excavaciones arqueológicas en los yacimientos de El Palau (Burriana, Castellón), CPAC 21, Castellón, págs. 303-319.

MELCHOR MONSERRAT, J. M., BENEDITO NUEZ, J. (2001): Un edificio termal de época romana en el yacimiento de El Palau (Burriana, Castellón). Actas del XXVI CNA. Zaragoza.

MELCHOR MONSERRAT, J. M., BENEDITO NUEZ, J. (dir.)(2005): Monográfico ARSE 39 , Sagunto.

MELCHOR MONSERRAT, J. M. Y BENEDITO NUEZ, J. (2005) Segunda campaña de Intervenciones arqueológicas en el edificio termal romano del Palau (BurrianaCastellón), actas del XXXII CNA. Bolskan 20, págs. 237-242. Huesca.

MELCHOR MONSERRAT, J. M., BENEDITO NUEZ, J. (2007): La excavación arqueológica, en La excavación arqueológica del yacimiento romano del Pujolet de Santa (l'Alcora, Castellón) Arturo Oliver Foix (dir), Ayuntamiento de Alcora.

MELCHOR MONSERRAT, J. M. y BENEDITO NUEZ, J. (2009); Nuevas aportaciones arqueológicas al conocimiento la Saguntum visigoda, en I Congreso Internacional "Espacios Urbanos en el Occidente Mediterráneo" entre los siglos VI-VIII, Toledo 
MELCHOR MONSERRAT, J. M., et al. (2004): El Monumento funerario del "Solar de la Morería”. Avance arqueológico y antropológico. ARSE 38, Sagunto.

MELCHOR MONSERRAT, J. M., SEGUÍ MARCO, J. J. y BENEDITO NUEZ, J. (2000): Nuevas inscripciones funerarias de Valentia, Hispania Antiqua, XXIV, Valladolid.

MELCHOR MONSERRAT, J. M., SEGUÍ, J. J. y BENEDITO NUEZ, J. (2004): Un relieve de ambiente nilótico hallado en la excavación de la Plaza de la Morería, Opulentissima Saguntum, Sagunto.

MELCHOR MONSERRRAT, J. M., CLARAMONTE CHIVA M. y BENEDITO NUEZ, J. (2008): La excavación arqueológica del yacimiento ibero-romano de Els Terrers (Sagunto-Faura), ARSE 42. Sagunto.

MELCHOR MONSERRRAT, J. M., y BENEDITO NUEZ, J. (2009): El estudio de la cerámica de paredes finas de la excavación arqueológica de la Plaza de la Morería, ARSE 43. Sagunto.

MERCADAL, J. G. (1962): Viajes de extranjeros por España y Portugal. Ed. Aguilar, Madrid.

MESADO OLIVER, N. (1969): Los yacimientos de Burriana, APL XII, Valencia.

MESADO OLIVER, N. (1974): Vinarragell (Burriana, Castellón), TV del SIP 46. Diputación Provincial. Valencia.

MESADO OLIVER, N. (1991): El Campo y su patrimonio cultural. Burriana en su Historia II, Burriana, Ayuntamiento de Burriana, págs. 153-231.

MESADO OLIVER, N. (2004): Alqueries y su entorno en época prerromana, Alqueries temps de un poble. Diputación de Castellón, págs. 19-76.

MESADO OLIVER, N. et al. (1989) Sant Gregori, Burriana, en Excavacions d'urgència a la Comunitat Valenciana. Intervencions rurals. GV, Valencia.

MESADO OLIVER, N., GIL I CABRERA, J. L. y RUFINO GUINOT, A. (1991): Museo Histórico Municipal de Burriana. Ayuntamiento de Burriana.

MEZQUÍRIZ IRUJO, M. A. (1983): Tipología de la Terra Sigillata Hispánica, en Terra Sigillata Hispánica-Monografías Arqueológicas, Separata del Boletín del MAN I, 2, Madrid, págs. 123-131. 
MEZQUÍRIZ, M. A. (1985): Terra Sigillata Ispanica, en Enciclopedia dell'Arte Antica Classica e Orientale, II, Ceramica fine romana nel bacino Mediterraneo (Tardo Ellenismo e Primo Imperio), Instituto della Enciclopedia Italiana, Roma, págs. 97-174.

MOLANO, J. y ALVARADO, M. (1997): Avance de las excavaciones en la necrópolis oriental en Emerita Augusta: el sitio del Disco (1988-1990), XXIII CNA, Teruel, págs. 113.

MORA, G. y DÍAZ-ANDRÈU, M. (coords.), (1997): La cristalización del pasado: génesis y desarrollo del marco institucional de la Arqueología en España, Málaga.

MOREL, J. P. (1981): La ceramique Campanienne. Paris.

MORENO LÓPEZ, E. (1858): Oficio de traslado del Ministerio de la Guerra al Ministerio de Fomento en la que se comunica la Real Orden por la que se concede a la Real Academia de la Historia el derecho de actuar en el circo de Sagunto y de recoger todos los objetos arqueológicos de la zona, AHAC.

MOROTE BARBERA, J. G. (1979): El trazado de la vía Augusta desde Tarracone a Carthagine Spartaria. Una aproximación a su estudio, SAG 14, Valencia

MOROTE BARBERÁ, J. G. (2002): La vía Augusta y otras calzadas en la Comunidad Valenciana, Valencia.

MOROTE, J. G. y MELCHOR, J. M. (2008): Época Paleocristiana y visigoda, en Catalogo Espais de Llum (Burriana, Vila-real, Castelló 2008-09). GV.

MUÑOZ CATALA, A. (1972): Algunas observaciones sobre las vías romanas de la provincia de Castellón, APL XIII, págs.149-160.

NIETO PRIETO, J. (1986): El Pecio Culip IV: Observaciones sobre la Organización de los Talleres de Terra Sigillata de La Graufesenque, en Archeonautica, 6, CNRS, Paris, págs. 81-119.

NOGUERA CELDRAN, J. M. (ed) (2009): FORA HISPANIAE, Paisaje urbano, arquitectura, programas decorativos y culto imperial en los Foros de las ciudades hispanorromanas, MAM, Monografías 3. Murcia.

NOGUERA CELDRAN, J. M. (1995-1996): Instalaciones portuarias romanas: representaciones iconográficas y testimonio histórico. ANMURCIA 11.12, Murcia, págs 219-235.

NOLLA, J. M. y CASAS, J. (1984): Carta arqueológica de les comarques de Girona. El poblament d'epoca romana al Nord-est de Catalunya. Gírona. 
OLÀRIA I PUYOLES, C. (1989): Benicató: Nules, la Plana Baixa, en Memòries arqueològiques a la Comunitat Valenciana: 1984-1985, GV, págs.123-124.

OLCINA, M. (1987): La necrópolis romana, en Guía de los monumentos romanos y del Castillo de Sagunto, Valencia, págs. 109-112.

OLCINA, M. (1991): El descubrimiento del mosaico de Baco en Sagunto, I Congreso Internacional de Historiografía de la Arqueología y de la Historia Antigua en España (Siglos XVIII-XX), Madrid, págs. $49-55$.

OLESTI I VILA, O. (2000); Integració i transformació de les comunitats iberiques del maresme durant el s. II-I aC: un model de romanització per a la Catalunya litoral $\mathrm{i}$ prelitoral, Empuries 52, págs. 55-86

OREJAS, A. (1995); Del "marco geográfico" a la Arqueología del paisaje. La aportación de la fotografía aérea, Monografías 15, CSIC, Madrid.

OREJAS, A.; RUIZ DEL ARBOL, M. y LOPEZ, O. (2002); Los registros del paisaje en la investigación arqueológica, $A E A$ 75, Madrid, págs. 287-311,

ORLANDIS, J. (1987): El Primado Romano en Hispania durante la Antigüedad Tardía, Revista Historia, Instituciones y Documentos, Sevilla.

OSWALD, F. (1931): Index of Potters Stamps on terra sigillata (Samian Ware). Margidunum.

OXÉ, A., COMFORT, H. y KENRICK, P. (2000): Corpus Vasorum Arretinorum (2 ${ }^{\mathrm{a}}$ Ed., revisada y ampliada). Dr. Rudolf Habelt GMBH, Bonn.

PADRÓ, J. (1985): Baetulo. Arqueología urbana 1975-1985, Monografíes badalonínes, 7, Badalona.

PADRÓ, J. (2000): Excavacions arqueològiques a Júlia Líbica (Llívia, la Cerdanya), Patronat Francesc Eiximenis, Institut d'Estudis Ceretans, Girona

PALET, J. Ma; GURT, J. Mª y ARIÑO E. (2004): El pasado presente: arqueología de los paisajes en la Hispania romana, Ed. Universidad Salamanca.

PALET MARTíNEZ, J.M.; FIZ FERNÁNDEZ, J. I. y ORENGO ROMEU, H. A. (2009): Centuriació i estructuració de l'ager de la colònia Barcino: anàlisi arqueomorfològica $\mathrm{i}$ modelació del paisatge, QUARHIS, Epoca II, $n^{\circ} 5$, págs. 106-123

PALET MARTíneZ, J. M.; ORENGO ROMEU, H. A. Y RIERA MORA, S. (2011): Centuriación del territorio y modelación del paisaje en los llanos litorales de Barcino 
(Barcelona) y Tarraco (Tarragona): una investigación interdisciplinar a través de la integración de datos arqueomorfológicos y paleoambientales, en Sistemi centuriali e opere di assetto agrario tra età romana e primo medioevo aspetti metodologici, ricostruttivi e interpretativi, Agri Centuriati 7-2010, Roma, págs. 113-130.

PALMA GARCÍA, F. (2006): La muralla romana: ampliaciones a su conocimiento y un debate cronológico, MEA 2004, 7.

PALOL, P. de (1967): Arqueología cristiana de la España Romana (siglos IV al VI), CSIC, Instituto Enrique Florez, Madrid-Valladolid

PALOS Y NAVARRO, E. (1804): Informe descriptivo de las ruinas romanas de la antigua ciudad de Sagunto, AHAC.

PASCUAL BUYE, I. (1989): La cerámica de cocina de Sagunto, Homenaje a Chabret, Valencia, págs. 93-142.

PASCUAL BUYÉ, I. (1991): Una torre defensiva romana bajo la C/ Muralla (Sagunto, Valencia), ARSE 26, págs. 123-132.

PASCUAL BUYÉ, I. (1998): Últimas investigaciones sobre el Circo Romano de Sagunto, Braçal, 17-18, págs.197-211.

PASCUAL BUYE, I. (1999): Cami Reial de Sagunt, Memorias Arqueológicas y Paleontológicas de la Comunidad Valenciana 0, GV, Valencia.

PASCUAL-AHUIR GINER, Ma del M. (2005): Estudio preliminar de los hallazgos monetarios de la plaza de la Morería en Sagunto, en Monográfico ARSE 39, Sagunto, págs. 35-56.

PASSELAC, M. y VERNHET, A. (1993): Céramique sigillée sud-gauloise, a Dictionnaire des Céramiques Antiques (Vllème $s$. av. né. - Vllème s. de né.) en Méditerranée nordoccidentale (Provence, Languedoc, Ampurdan), Lattara 6, págs. 569-580.

PASTOR DE AROZENA, B. (1998): Retórica imperial: el rapto en la legislación de Constantino, Faventia 20/1, págs. 75-81.

PEACOCK, D. P. S. y WILLIAMS, D. F. (1986): Amphorae and the Roman Economy, Longman Archaeology, Londres y Nueva York.

PEACOCK, P. S. (1982): Pottery in the Roman World: an ethnoarchaeological approach, Logman, Londres y Nueva York.

PÉREZ, A. (1984): La ciutat d'llerda. Lérida. 
PERIS Y FUENTES, J. (1922): Escarceos arqueológicos. Castellón y sus cercanías. BSCC III, Castellón, págs. 218 - 223.

PERIS Y FUENTES, M. (s/a): Burriana. Monografía histórica, original mecanografiado conservado en el Museo Arqueológico de Burriana.

PERNA, R. (2005): Citta antiche in Italia. Urbs Salvia. L'Erma di Bretscheneider.

PICON, M. (2002): Les modes de cuisson, les pátes et les vernis de la Graufesenque: une mise au point, en Céramiques de La Graufesenque et autres productions d'époque romaine - Hommages à Bettina Hoffmann, Éd. Monique Mergoil, Archéologie et Histoire Romaine 7, Millau, págs. 139-163.

PINGARRON SECO, E. (1981): Rastreo de una "centuriato" en la zona sur de la huerta de Valencia, Cuadernos de Geografía 29, Valencia, págs. 161-176.

PINON, P. (1990): Approche typologique des modes de réutilisation des amphithéâtres de la fin de l'Antique au XIX siècle, en Spectacula I, Lattes.

PIQUERAS HABA, J. y SANCHIS DEUSA, C. (1992): L'Organització històrica del territori Valencià, Conselleria d'Obres Publiques, Urbanisme i Transport, Valencia.

PISANI SARTORIO, G. (1988): Mezzi di trasporto e traffico, en Vita e Costumi dei romani antichi, Museo della civilta, Roma.

POLAK, M. (1994): Quelques aspects de l'évolution de la sigillée lisse de La Graufesenque, in Actes du Coloque de Millau (Millau 1994), Sociéte Française pour I 'Étude de la Céramique Antique en France, Millau, págs. 63-75.

POLO CERDÁ, M. y GARCÍA PROSPER, E. (2005): Estudio bioantropológico de restos óseos hallados en el interior de la cloaca de la vía romana del "solar de la Morería" de Sagunto, Monográfico ARSE 39, Sagunto, págs. 209-229.

POLO CERDÁ, M.; GARCÍA PROSPER, E. y SANCHIS SERRA, A. (2005): Estudio bioarqueológico de cremaciones del monumento funerario romano del "solar de la Morería" Sagunto, Monográfico ARSE 39, Sagunto, págs. 228-268.

PONS PUJOL, LL. (2004): La annona militaris en la Tingitana: observaciones sobre la organización y el abastecimiento del dispositivo militar romano, Africa romana 6, L’Africa romana XV, Tozeur 2002, Roma, págs. 1663-1680.

PORCAR RIPOLLÉS, J. B. (1933): Les cultures de la platja de Castelló, BSCC, XIV, Castellón. 
PORCAR RIPOLLÉS, J. B. (1935): Construcción romana de la Senda de la Palla, BSCC, XVI, Castellón.

PORTACELLI, M. (1993). La rehabilitación del teatro romano de Sagunto. Teatros romanos de Hispania. Cuadernos de Arquitectura Romana, Mérida.

POVEDA NAVARRO, A. M. (1999): Las Producciones de Terra Sigillata Hispánica y su comercialización en el Sureste de Hispania, en Terra Sigillata Hispánica: Centros de fabricación y producciones altoimperiales- Homenaje a $M^{a}$ Ángeles Mezquíriz, Universidad de Málaga, págs. 209-230.

PRIETO, A. (1998); Las transformaciones económicas de la Hispania Citerior durante la época republicana, Italia e Hispania en la crisis de la República Romana, Madrid, págs. 87-98.

PREVOSTI I MONCLUS, M. (1981): Cronologia i poblament a l'area rural d'lluro, Mataró.

PREVOSTI I MONCLUS, M. (1981): Cronologia i poblament a l'area rural de Baetulo, Monografies badalonines, 3. Barcelona.

PREVOSTI I MONCLÚS, M. y CLARIANA I ROIG, J. F (1988): Torre Llauder. Mataró vil·la romana (Guíes de jaciments arqueologícs), Barcelona.

PREVOSTI, M. y GUITART I DURAN J. (dir.) (2010): Ager Tarraconensis 1 y 2 Institut Català d'Arqueologia Clàssica, Tarragona.

PUCCI, G. (1985): Terra Sigillata Italica, Enciclopedia dell'Arte Antica Classica e Orientale, II, Ceramica fine romana nel bacino Mediterraneo (Tardo Ellenismo e Primo Imperio), Instituto della Enciclopedia Italiana, Roma, págs. 359- 406.

PURCELL, N. (1995): The Roman Villa and the landscape of production. Urban Society in Roman Italy (T.J. Cornell y K. Lomas, eds.), Londres, págs. 151-179.

RABANAL ALONSO, M. A. (1985): Fuentes literarias del País Valenciano en la Antigüedad, ARQUEOLOGÍA DEL PAÍS VALENCIANO: Panorama y perspectivas, Anejo de la revista Lucentum, Universidad de Alicante.

RACÓN MARQUES, S. y SÁNCHEZ MONTÉS, A. (2000): Complutum. Tradición y cambio en la Antigüedad Tardía, en Los orígenes del Cristianismo en Valencia y su entorno, Valencia, págs. 235-242.

RAMALLO ASENSIO, S. F. (2000): La Porticus Post Scaenam en la arquitectura teatral romana. Introducción al tema, anales de la Universidad de Murcia 16, págs. 87-120. 
REAL ACADEMIA DE LA HISTORIA (1864): Minuta de oficio en la que se informa del hallazgo de seis túmulos en el Puch, en uno de los cuales, se encontró una lámina de Plomo con Inscripción ibérica, AHAC.

REAL ACADEMIA DE LA HISTORIA (1867): Minuta de oficio en la que se comunica el dictamen acerca del cambio de nombre de Murviedro por el antiguo de Sagunto, AHAC.

REIS, M. P. (2010): Tanques, fontes e espelhos de água nos fora lusitanos, en T. Nogales Basarrate (Ed.) Cidade e foro na Lusitânia Romana, Studia Lusitana 4, Junta de Extremadura, págs. 285-314.

REMESAL RODRÍGUEZ J. (1995): El sistema annonario como base de la evolución económica del Imperio romano, en T. HACKENS, M. MIRÓ, Le commerce maritime romain en Méditerranée occidentale. Barcelone 1988, PACT. 27, págs. 355-367.

REMESAL RODRÍGUEZ, J. (2002): Aspectos legales del mundo funerario romano, en Espacios y Usos Funerarios en el Occidente Romano, Seminario de Arqueología de la Universidad de Córdoba.

REMOLÀ VALLVERDÚ, J. A. (2004): Tarraco quanta fuit ipsa ruina docet, Simulacra Romae, Tarragona.

REMOLÀ VALLVERDÚ, J. A. y RUIZ DE ARBULO BAYONA, J. (2002): L'aigua a la colònia Tarraco, Empúries 53, págs. 29-37.

REMOLÀ, J. A. (2003): Arquitectura funeraria, en Capitales Provinciales de Hispania 3 (Tarragona), "L'Erma” di Bretschneider, Roma.

REVILLA CALVO, V. (1995): Producción artesanal, viticultura y propiedad rural en la Hispania Tarraconensis, en Gerión, $n^{\circ} 13$, Servicio de Publicaciones, Universidad Complutense. Madrid.

REVILLA CALVO, V. (1995b): Producción cerámica, viticultura y propiedad rural en Hispania Tarraconensis (siglos I a. C. - III d. C.), Cuadernos de Arqueología, 8, CEIPAC Biblioteca, Barcelona.

REVILLA CALVO, V. (1998): La villa de Casa Blanca (Tortosa, Tarragona): evolución y arquitectura de un asentamiento rural de los siglos I al V dC, CPAC 19, págs. 395-416.

REVILLA CALVO, V. (2004): Economia i poblament romà al curs inferior de l'Ebre: la vil·la de Casa Blanca (Tortosa). Diputació Provincial de Tarragona.

REVILLA CALVO, V. (2004): El poblamiento rural en el noreste de Hispania entre los siglos II a. C. y I d. C.: Organización y dinámicas culturales y socioeconómicas, en 
Pierre Moret y Teresa Chapa (Ed.) Torres, Atalayas y Casas Fortificadas: Explotación y control del territorio en Hispania (s. III a. de C. - s. I d. de C.), Universidad de Jaén.

REVILLA CALVO, V. y REMESAL RODRÍGUEZ, J. (2004): Ánforas y epigrafía anfórica en Hispania Tarraconensis, Epigrafía Anfórica. Proyecto Amphorae. Col-lecció Instrumenta, 17, CEIPAC Biblioteca, Barcelona, págs. 159-196.

REVILLA, V. y CELA, X. (2006): La transformación material e ideológica de una ciudad en Hispania: Iluro (Mataró) entre los siglos I y VII d. C., AEA 79, págs. 89-114

RIBERA LACOMBA, A. (2000): La ciudad de Valencia en época visigoda, Los orígenes del Cristianismo en Valencia y su entorno, Valencia, págs. 151-164.

RIBERA I LACOMBA, A (2001): El circo romano de Valencia (Hispania Tarraconensis), en NOGALES, T. y SÁNCHEZ-PALENCIA, F. J., Congreso internacional el circo en Hispania romana. Ministerio de Educación, Cultura y Deporte, Mérida, págs. 175-195

RIBERA LACOMBA, A. et al. (1989): Guía Arqueológica de Valencia. GV.

RIBERA LACOMBA, A. y ROSELLO MESQUIDA, R. (1999): La Almoina: el nacimiento de la Valentia cristiana, Cuadernos Difusión Arqueológica 5, Valencia.

RIPOLL, E. (1974): Empúries. Descripció de les ruïnes i Museu monogràfic, Barcelona.

RIPOLLES ADELANTADO, E. (1990): Cami Vell del Mar (Sagunto), EASCV 19841988, II Intervenciones Rurales, GV, Valencia, págs. 189-191.

RIPOLLES ALEGRE, P. P. (2007): Las excavaciones del Arzobispo Antonio Despuig en Sagunto (siglo XVIII), según un manuscrito del British Museum, Revista ARSE 41, 217 230, Sagunto.

RIPOLLÉS, P. P. y LLORENS, Ma . del M. (2002): Arse-Saguntum. Historia Monetaria de la ciudad y su territorio, Sagunto.

ROCA ROUMENS, M. y FERNÁNDEZ GARCÍA, Ma I. coord. (1999): Terra Sigillata Hispánica. Centros de fabricación y producciones altoimperiales. Universidad Málaga.

ROCA Y ALCAIDE, F. (1932): La Historia de Burriana, Castellón.

ROCA, F. (1964): Memoria que presenta la Junta Directiva del Centro Arqueológico Saguntino con motivo de unas prospecciones llevadas a cabo en un antiguo monumento romano de nuestra ciudad, ARSE 7, págs. 1-5.

ROCA, F. (1976): Sobre unos silos de Época Romana en Sagunto, ARSE 14. 
ROCA, F. (1977): ¿Nueva villa romana en Sagunto? ARSE 15, págs. 24-25.

RODA DE LIANZA, I. (2009) Espacios de representación en los foros de Hispania, en NOGUERA CELDRAN, J. M. (ed); FORA HISPANIAE, Paisaje urbano, arquitectura, programas decorativos y culto imperial en los Foros de las ciudades hispanorromanas, MAM, Monografías 3. Murcia, págs. 69-88.

RODRÍGUEZ NEILA, J. R. (1991): Espacios de uso funerarios como indicadores de medidas en las necrópolis romana, Conimbriga 30, págs. 59-94.

RODRÍGUEZ NEILA, J. R. (1992): Algunas observaciones sobre los acotados funerarios romanos, In memoriam J. Cabrera Moreno, págs. 437 - 448.

ROLDÁN GÓMEZ, L. (1992): Técnicas constructivas romanas en Carteia (San Roque, Cádiz), Monografías arquitectura romana 1, UAM, Departamento Prehistoria y Arqueología.

ROLDÁN GÓMEZ, L. (1993): Técnicas constructivas romanas en Itálica (Santiponce, Sevilla), Monografías arquitectura romana 2, UAM, Departamento Prehistoria y Arqueología.

ROLDÁN HERVÁS, J. M. (1976): Itineraria Hispana. Fuentes antiguas para el estudio de las vías romanas en la Península Ibérica. Universidades de Valladolid y de Granada.

ROLDÁN HERVÁS, J. M. (2001): Historia Antigua de España I, UNED, Madrid.

ROMEO MARUGÁN, F. (1997): El impacto de Roma en los sistemas defensivos ibéricos del valle medio del Ebro, en El Mediterráneo: hechos de relevancia histórico militar y sus repercusiones en España. $V$ Jornadas Nacionales de Historia Militar, Sevilla, págs. 115-140.

ROSSELLÓ VERGER, V. y ARASA GIL, F. (1992): Les vies romanes al País Valencià, II-lusions i certeses, Estudis d'Arqueologia Ibèrica $i$ Romana, Homenatge a Enric Pla Ballester, SIP, Valencia.

ROURE, A., CASTANYER, P., NOLLA, J. M., KEAY, S. T. y TARRÚS, J. (1988): La vil·la romana de Vilauba (Camás), Girona.

RUIZ, M. (2006): Paisajes agrarios del NE de Lusitania, CAE 26, Teruel, págs. 115-142.

J. RUIZ DE ARBULO, J.; R. CEBRIÁN y HORTELANO, I. (2009): El circo romano de Segóbriga (Saelices, Cuenca). Arquitectura, estratigrafía y función, Museo de Segóbriga, Cuenca. 
SAEZ, P.; ORDOÑEZ, S. y GARCIA-DILS, S. (2006): Paisaje agrario y territorio en la campiña occidental de la Bética, CAE 26, Teruel, págs. 143-170.

SAN NICOLÁS PEDRAZ, Ma P. (2007): El mosaico de las sandalias del Pujolet de Santa, en La excavación arqueológica del yacimiento romano del Pujolet de Santa (l’Alcora, Castellón) Arturo Oliver Foix (dir), Ayuntamiento de Alcora.

SANCHIS GUARNER, M. (1983 reed.): La ciutat de València: síntesi d'història i de geografia urbana, Ayuntamiento de Valencia.

SANMARTI, J. (1984): Els edificis sepulcrals dels Països Catalans, Aragó i Múrcia, Fonaments 4, págs. 87-165.

SARTHOU CARRERES, C. (1913 circa): La Provincia de Castellón, en CARRERES CANDI, C. (ed.): Geografía general del Reino de Valencia, Castellón.

SCHULTEN, A. y MALUQUER DE MOTES, J. (1987): Hispania Antigua según Pomponio Mela, Plinio el Viejo y Claudio Ptolomeo, Fontes Hispania Antiquae VII, Barcelona.

SEGUÍ, J. J.; MELCHOR, J. M. y BENEDITO, J. (2003); Noticia de piezas singulares aparecidas en la Valencia romana, Bolskan 20, Huesca, págs. 233-236.

SEGUÍ MARCO, J. J., MELCHOR MONSERRAT, J. M., BENEDITO NUEZ, J. y PASCUAL AHUIR, M. M. (2003): Avance del hallazgo de un tramo de calzada y un relieve nilótico en Sagunto, Opulentissima Sagunto. Fundación Bancaixa.

SGARLATA, M. (2003): S. Giovanni a Siracusa, Volumen 8 de Catacombe di Roma e d'Italia, Pontificia commissione di archeologia sacra, Roma

SILLIERES, P. (1983): Ornières et voies romaines, en Les voies romaines en Gaule et dans le monde romain occidental, Caesarodunum 18, págs. 37-45. Paris.

SMITH, W. (1867): Dictionary of Greek and Roman Biography and Mythology, Oxford.

STENICO, A. (1960): La Ceramica Arretina I-museo Archeologico di Arezzo, Rasinius I, Cisalpino.

STENICO, A. (1966): La Ceramica Arretina II - Collezione Diverse, Punzioni, Modelli, Calchi, etc., Cisalpino.

SUTHERLAND, C. H. V. (1984): The Roman Imperial Coinage, London. 
TARRADELL MATEU, M. (1962): La ciudad romana de Valencia: Estudios varios, Universidad de Valencia Laboratorio de Arqueología, Valencia.

TORELLI, M. (1999): Paestum romana, Paestum Ingeneria per la Cultura, Salerno.

TOYNBEE, J. M. C. (1996): Death and Burial in the roman World (2 Ed.). John's Hopkins University Press, Baltimore.

ULLOA, P. (2006): Excavaciones en la vía Augusta en Vall d'Alba (Castellón). en GARCÍA PRÓSPER, E.; GUÉRIN P.; DE MADARIA, J. L. Y SÁNCHEZ, P. (eds.), Catastros, hábitats y vía romana, Generalitat Valenciana, Valencia.

UTRILLA, T. (1962): Sobre los orígenes de Burriana. Investigaciones en la partida de la regenta I, RBA 65, Burriana, pág. 08-09.

UTRILLA, T. (1963): Sobre los orígenes de Burriana. Investigaciones en la partida de la regenta II, RBA 66, Burriana, págs. 10-12.

UTRILLA, T. (1963b): Sobre los orígenes de Burriana. Investigaciones en la partida de la regenta III, $R B A, 67$, Burriana, págs. 13-15.

UTRILLA, T. (1964): Sobre los orígenes de Burriana. Investigaciones en la partida de Torre de Onda, RBA 78, Burriana, págs. 10-12.

UTRILLA, T. (1964a): Sobre los orígenes de Burriana. Investigaciones en la Partida del Palau II. RBA 75, Burriana, págs. 8-9.

UTRILLA, T. (1964b): Sobre los orígenes de Burriana. Investigaciones en la Partida del Palau III. RBA 78, Burriana, págs. 12-13.

UTRILLA, T. (1965): Sobre los orígenes de Burriana. Investigaciones en la Partida del Palau VI y VII (sic). RBA 80 y 82, Burriana, págs. 10-11.

UTRILLA, T. (1966): Sobre los orígenes de Burriana. Investigaciones en la Partida de Torre d'Onda. RBA 87, Burriana, págs. 13-15.

VALL PLA, M. A. (1961): Mosaicos romanos de Sagunto. APL XI, Valencia, págs. 141176.

VALOR ABAD, J. P. (2009); El convent de Sant Francesc, plaza cronista Chabret (Sagunto). Un avance sobre la intervención arqueológica de urgencia 2005, SAG 41, págs. 237-249. 
VAQUERIZO, D. V., ed. (2001): Funus Cordobensium- Costumbres Funerarias en la Córdoba Romana. Seminario de Arqueología - Universidad de Córdoba.

VAQUERIZO, D. V., ed. (2002): Espacios y Usos Funerarios en el Occidente Romano, Congreso Internacional en la Facultad de Filosofía y Letras de la Universidad de Córdoba. Seminario de Arqueología - Universidad de Córdoba.

VENTURA VILLANUEVA, A. (1996): Recuperación de la Córdoba romana: los edificios de espectáculos, en Ciudades Modernas superpuestas a la Antiguas, Mérida.

VENTURA VILLANUEVA, A. (2003): Edificios de Espectáculos, en Capitales Provinciales de Hispania 1 (Córdoba), "L’Erma” di Bretschneider, Roma.

VERNHET, A. (1986): L'essor des ateliers entre 30 et 120 ap. J.C., en La terre sigillée gallo-romaine. Lieux de production du Haut Empire: implantations, produits, relations, Maison des Sciences de I'Homme, Documents D'Archéologie Française, 6, Paris, págs. 39-41.

VERSLUYS, M. J. y SEGUI MARCO, J. J. (2008); A newly discovered relief from Saguntum, Madrider Mitteilungen 49, Madrid, págs. 341-353.

VICENT CAVALLER, J. A. (1979): Excavacions al santuari hispano-roma de Santa Bárbara (La Vilavella de Nules, Plana Baixa), CPAC 19, Diputación de Castellón, págs. 181-221.

VICENT, J. M. (1991); Fundamentos teóricos y metodológicos para un programa de investigación arqueo-geográfica, en LOPEZ GARCIA, P. (ed.) (1991); El cambio cultural del IV al II milenio a. C. en la comarca del NW de Murcia, págs. 29-117, Madrid.

VICIANA, R. M. (1574): Crónica de la ínclita y coronada ciudad y Reino de Valencia, Ed. Gredos, Madrid, 1979.

VILLALMANZO, J (1987): Las salinas del siglo XVI, en Burriana en su Historia I, págs. 141-149. Ayuntamiento de Burriana.

VIVES, A. (1926): La moneda hispánica, Madrid.

VIZCAíNO, D. (2001): Informe preliminar de las zanjas de la Plaza Mayor de Sagunto. Primeras conclusiones (seguimiento arqueológico), ARSE 35, Sagunto, págs 117-124.

YEGÜL, F. (1992): Baths and Bathingin Classical Antiquity, New York. 
WELLS, C. M. (1990): A note on the term "pre-sigillata", in Conspectus Formarum Terrae Sigillatae Italico Modo Confectae, Dr. Rudolf Habelt GMBH, Materialen zu romische-remanische Keramik, 10, Bonn, pág. 4.

WILKINSON, T. J. (1982); Definition of Ancient Manured Zones by Means of extensive Shred-sampling Techniques, Journal of Field Archeology 9, Boston.

WILKINSON, T. J. (1989); Extensive shred scatters and land-use intensity: some recent results, Journal of Field Archeology 16, Boston.

WITSCHEL, C. (2009); La crisis del siglo III en Hispania: algunas reflexiones, en ANDRĖU, J., CABRERO, J. y RODÁ, I. (ed.) (2009); Hispaniae, Las provincias hispanas en el mundo romano, Documenta 11, ICAC, Tarragona, págs. 473-503. 


\section{AUTORES CLÁSICOS CITADOS EN EL TEXTO}

AA. VV. (1989) Historia Augusta. Ed. Akal. Madrid.

AA. VV. (1975): El Digesto de Justiniano. Ed. Aranzadi, Pamplona.

TÁCITO (1991): Anales, Ed. Gredos, Madrid.

DION DE PRUSA (2000): Discursos, Ed. Gredos, Madrid.

ESTRABÓN (1998): Geografía, Ed. Gredos, Madrid.

FRONTINO (1985): Los acueductos de Roma, Colección Hispánica de artes griegas y latinas, CSIC, Madrid.

CIPRIANO DE CARTAGO (1998): Cartas, Ed. Gredos, Madrid.

LIVIO (1993): Ab Urbe Condita, Ed. Gredos, Madrid.

LUCRECIO (1962): De Rerum Natura, Barcelona.

PLINIO EL JOVEN (2005), Epístolas, Ed. Gredos, Madrid.

PTOLOMEO (1959): Geographia, Librería General V. Suárez, Madrid.

SUETONIO (1992): Vida de los doce césares, Ed. Gredos, Madrid.

VARRÓN (1998): La lengua latina, Ed. Gredos, Madrid.

VITRUVIO (2009): Los diez libros de Arquitectura, Ed. Alianza. Madrid. 


\section{ABREVIATURAS UTILIZADAS EN LA BIBLIOGRAFÍA}

\section{$A E A=$ Archivo Español de Arqueología}

AHAC = Portal web: Antigua. Historia y Arqueología de las civilizaciones (Cervantes Digital). Archivo de la real Academia de la Historia.

ANMURCIA = Anales de Prehistoria y Arqueologia de la Universidad de Murcia

$\mathrm{APL}=$ Archivo de Prehistoria Levantina

ARSE - Revista del Centro Arqueológico Saguntino

$B R A H=$ Boletín de la Real Academia de Historia

$B S C C=$ Boletín de la Sociedad Castellonenca de Cultura

$B V=$ Biblioteca Valencia

$B D V=$ Biblioteca Digital Valenciana

$C A E=$ Congreso de Arqueología Espacial

$C A S=$ Centro Arqueológico Saguntino

$\mathrm{CC}=$ Conselleria de Cultura y Deporte

CNA = Congreso Nacional de Arqueología

$\mathrm{CPAC}=$ Cuadernos de Prehistoria y Arqueología Castellonenses

CSIC = Consejo Superior de Investigaciones Científicas

EASCV = Excavaciones Arqueológicas de Salvamento a la Comunidad Valenciana

Ed. $=$ Editorial

$F C E=$ Editorial Fondo de Cultura Económica

FCG $=$ Fundação Calouste Gulbenkian

$\mathrm{GC}=$ Generalitat de Catalunya

$\mathrm{GV}=$ Generalitat Valenciana

MAM = Museo Arqueológico de Murcia

$M C=$ Ministerio de Cultura

$\mathrm{MEA}=$ Revista Mérida Excavaciones Arqueológicas

RACV = Real Academia de Cultura Valenciana

$R B A=$ Revista Buris-ana

SAG = Saguntum. Revista del Laboratorio de Arqueología de la Universidad de Valencia.

SIAP = Servicio de Investigaciones Arqueológicas y Prehistóricas de la Diputación de Castellón TV del SIP = Serie de Trabajos Varios del SIP

$U A M=$ Universidad Autónoma de Madrid

USMA = Ufficio Storico Ministero del Aire di Italia 


\section{IMÁGENES MATERIALES}




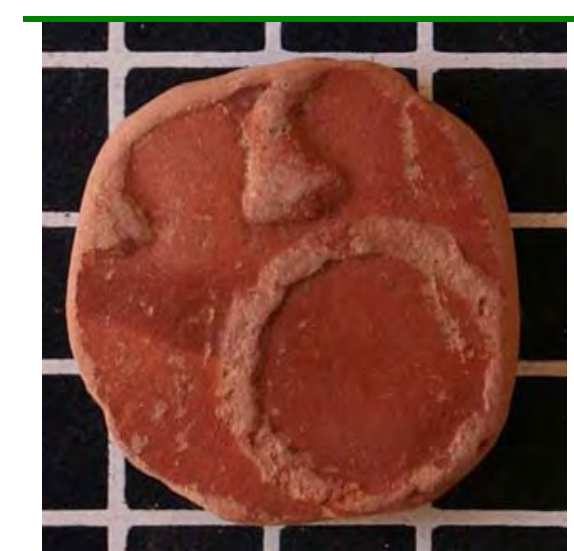

IMAGEN 1- EL PALAU

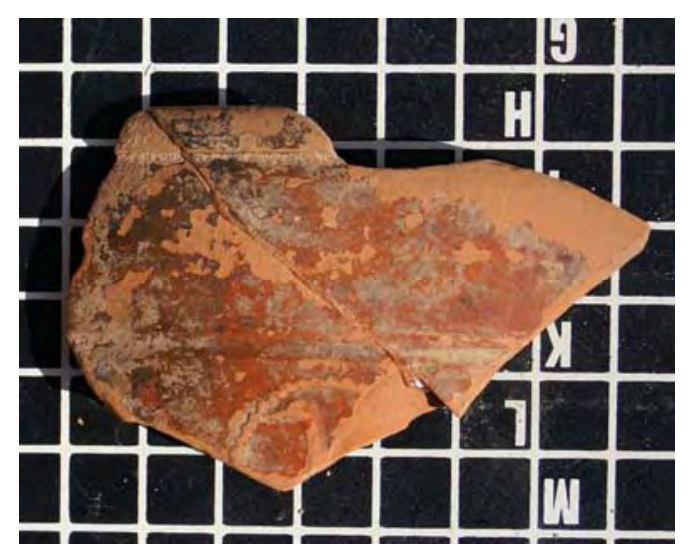

IMAGEN 3- EL PALAU

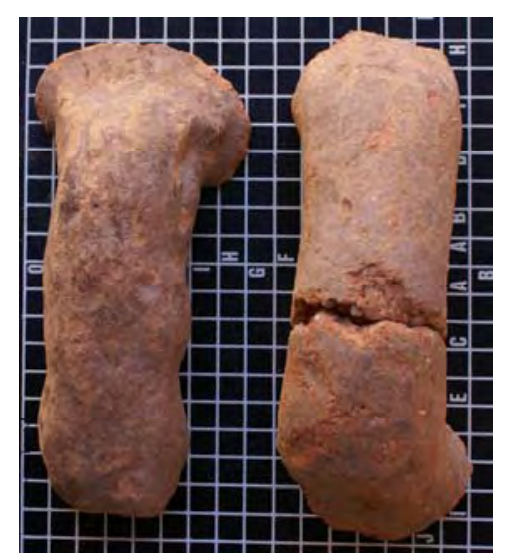

IMAGEN 5- EL PALAU

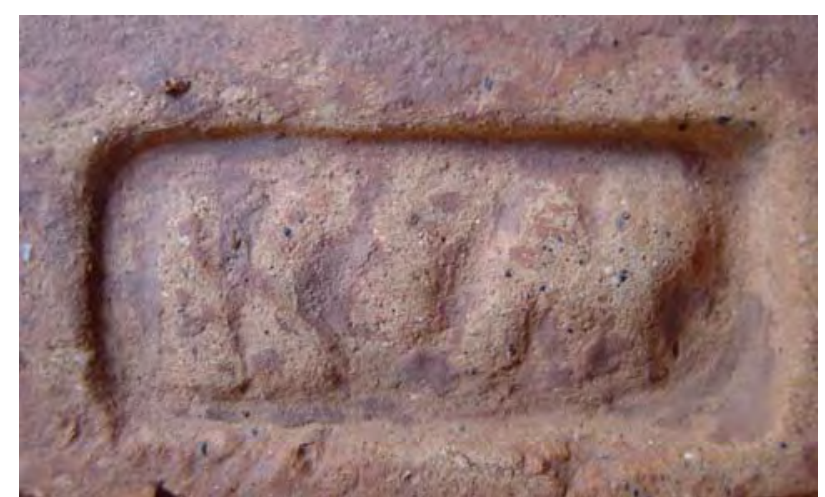

IMAGEN 7- EL PALAU

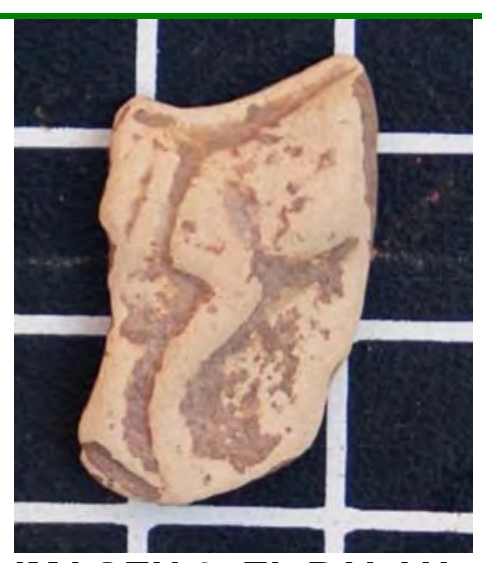

IMAGEN 2- EL PALAU

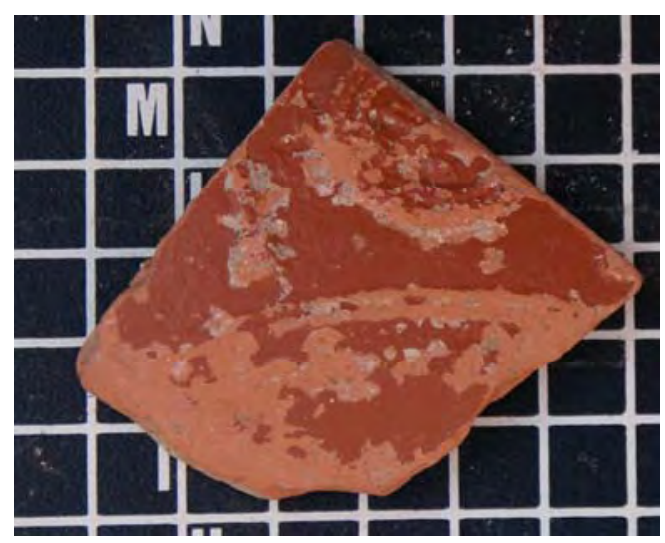

IMAGEN 4- EL PALAU

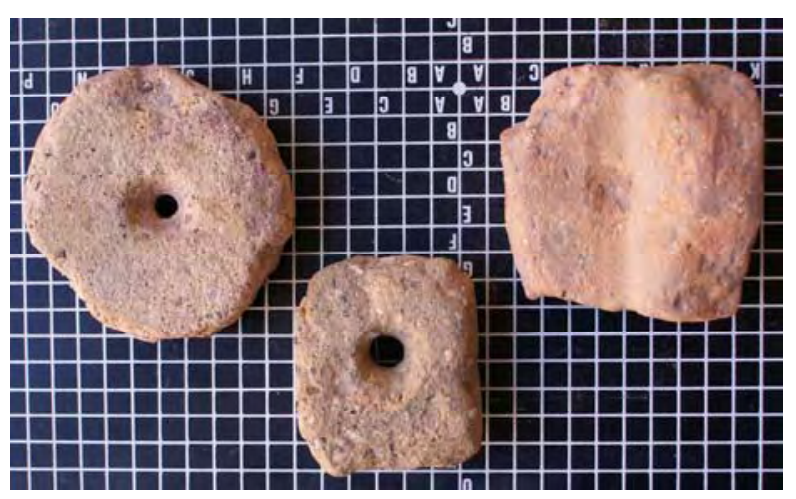

IMAGEN 6- EL PALAU

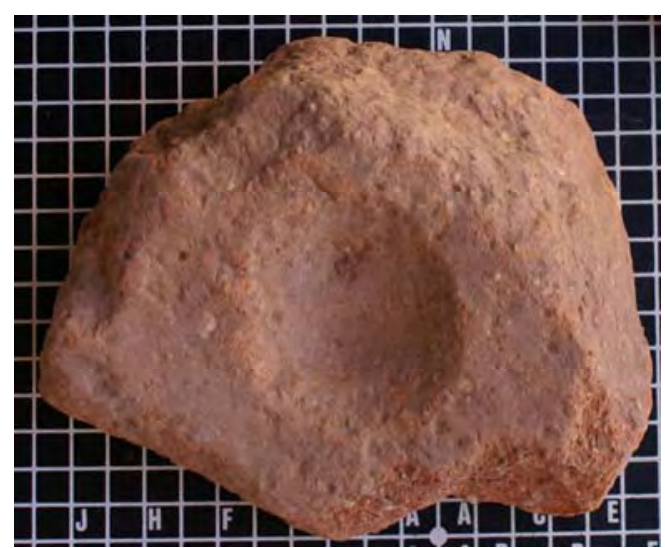

IMAGEN 8- EL PALAU 


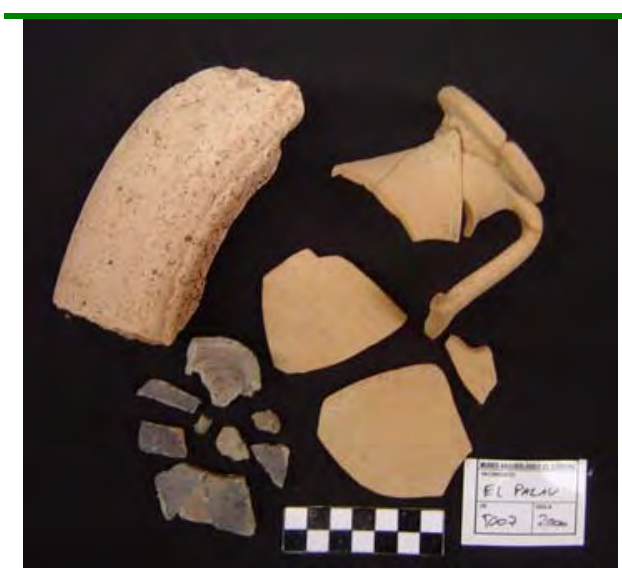

IMAGEN 9- EL PALAU
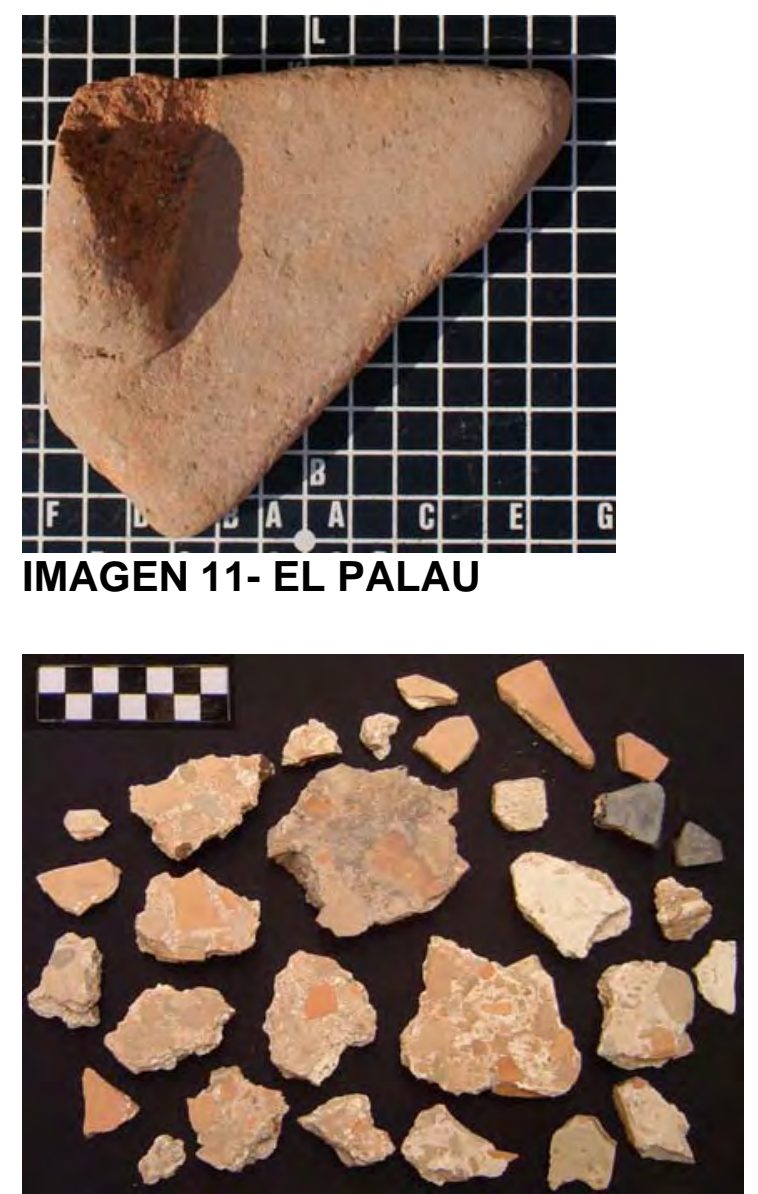

IMAGEN 13 - VINARRAGELL

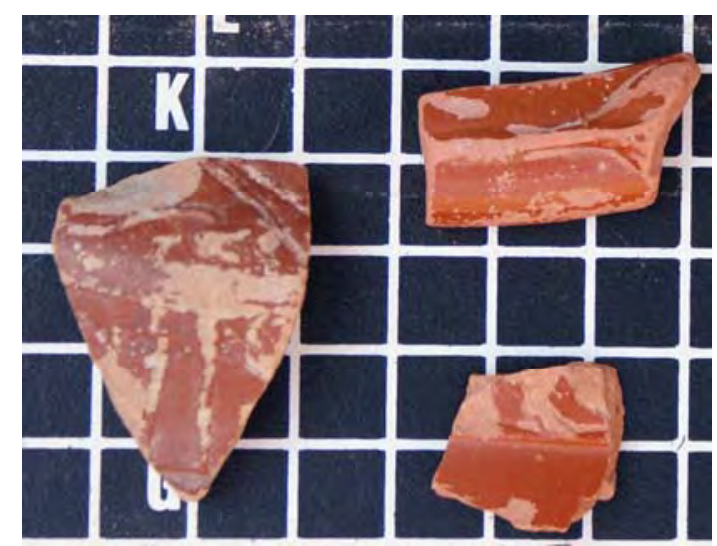

IMAGEN 15 - TORRE D'ONDA

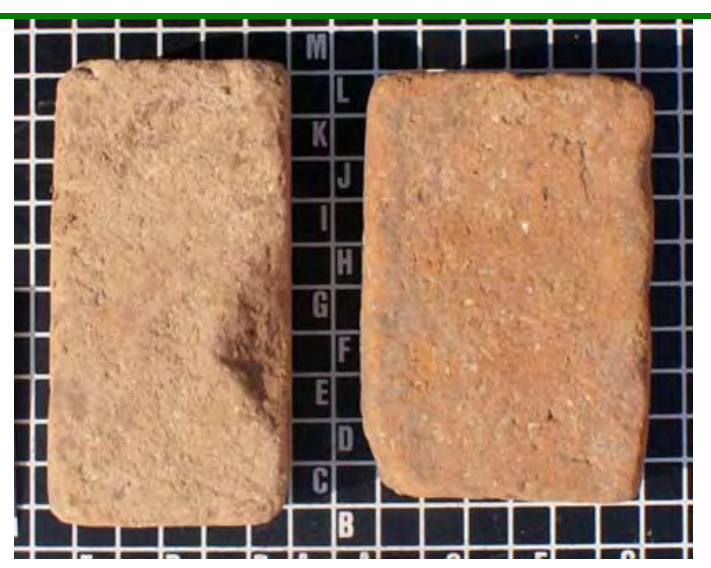

IMAGEN 10- EL PALAU

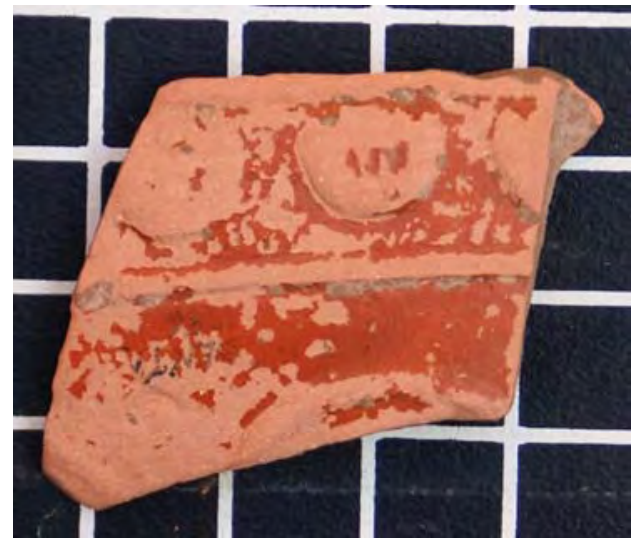

IMAGEN 12 - LA REGENTA

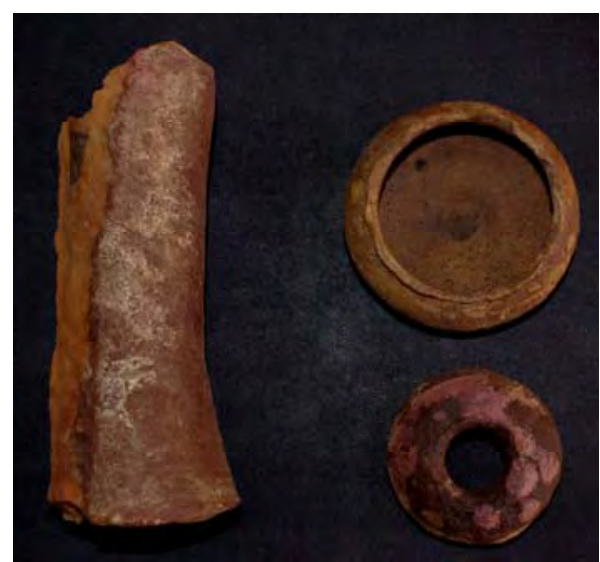

IMAGEN 14 - ELS ESTANYS

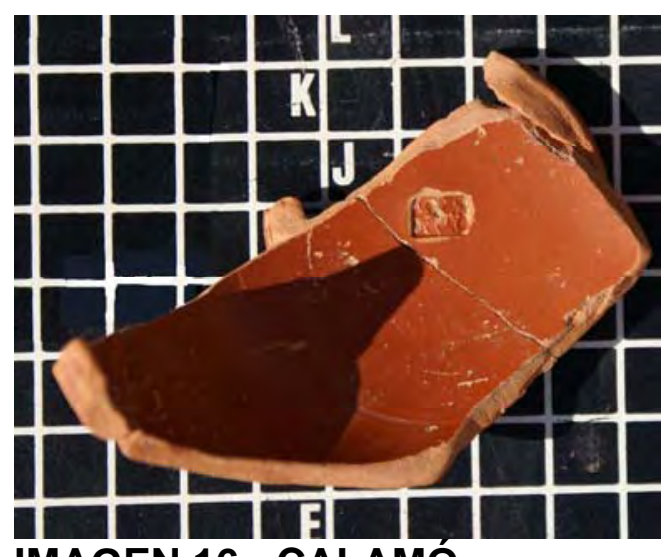

IMAGEN 16 - CALAMÓ 

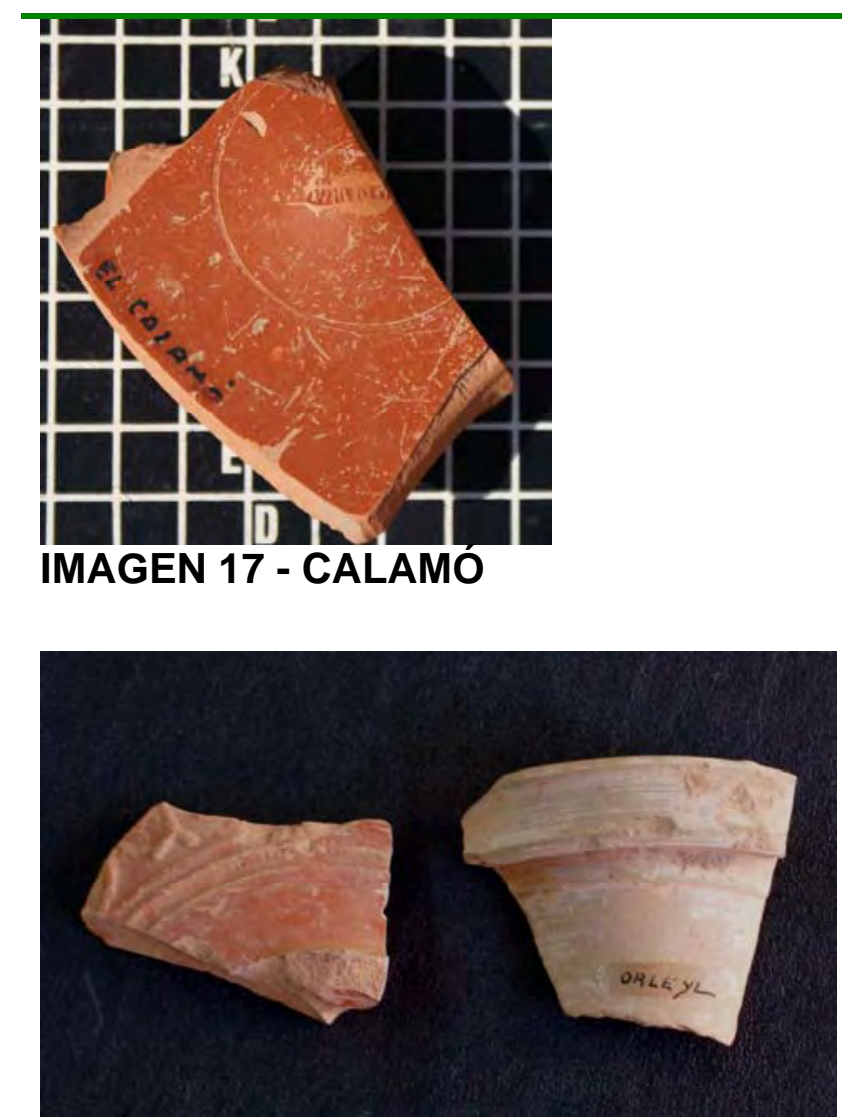

IMAGEN 19 - ORLEYL

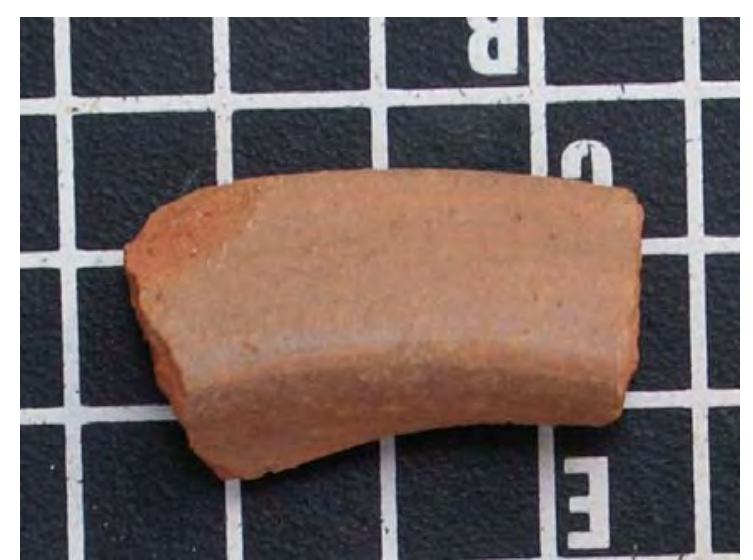

IMAGEN 21 - MORERIA (SAGUNTO)

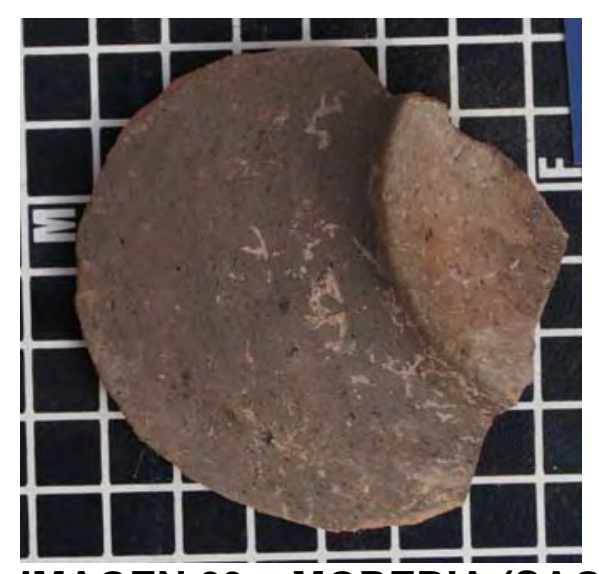

IMAGEN 23 - MORERIA (SAGUNTO)
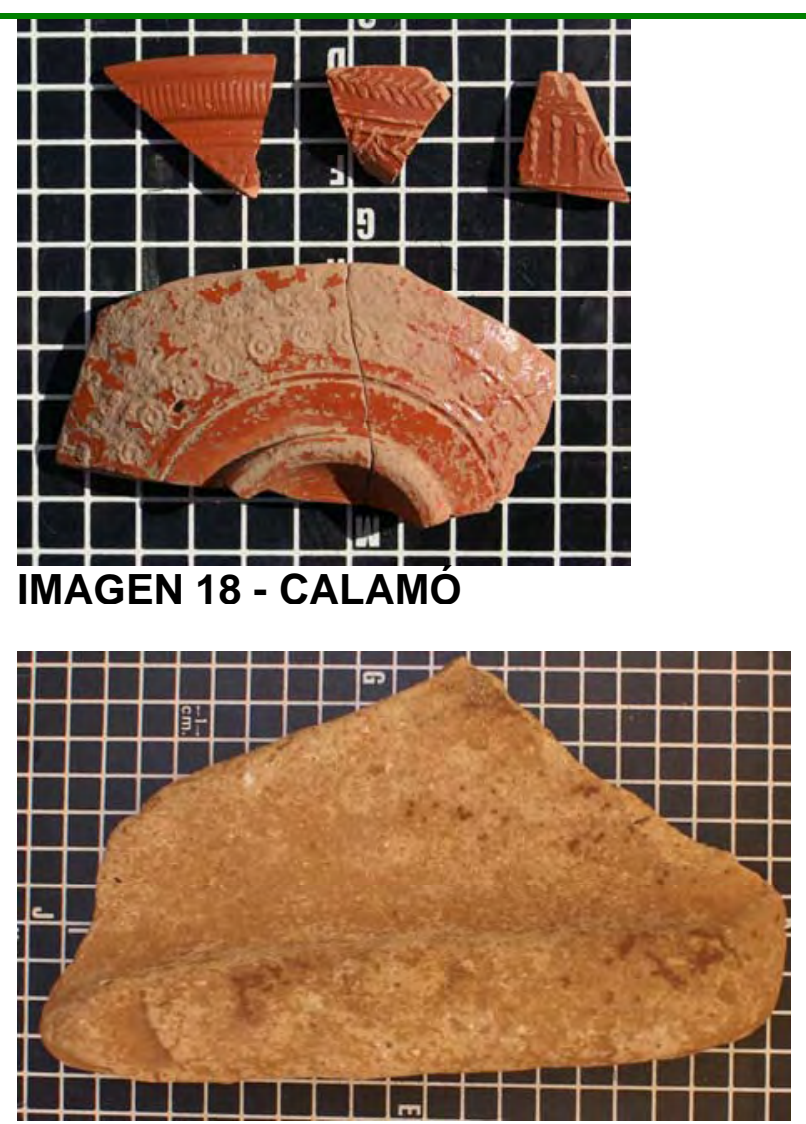

IMAGEN 20 - LA SANG (BURRIANA)

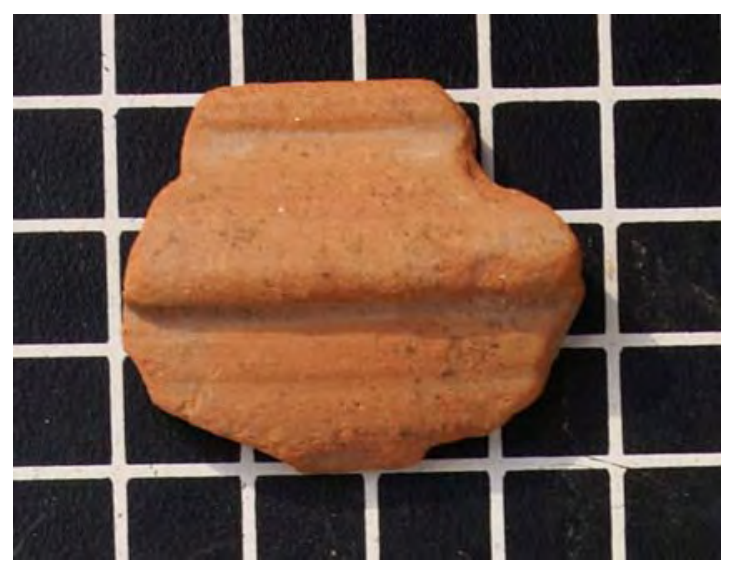

IMAGEN 22 - MORERIA (SAGUNTO)

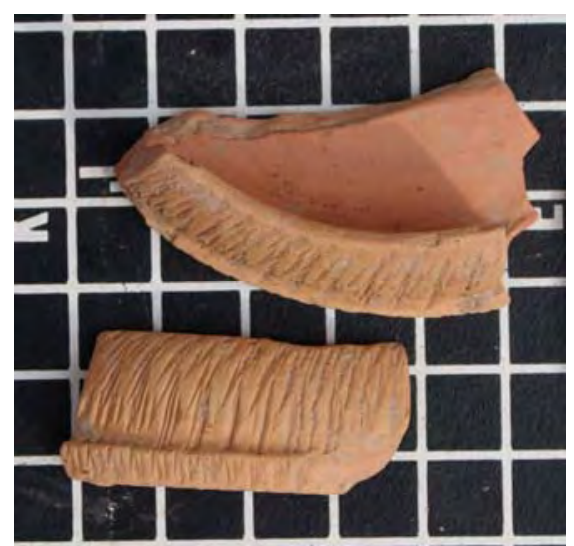

IMAGEN 24 - MORERIA (SAGUNTO) 


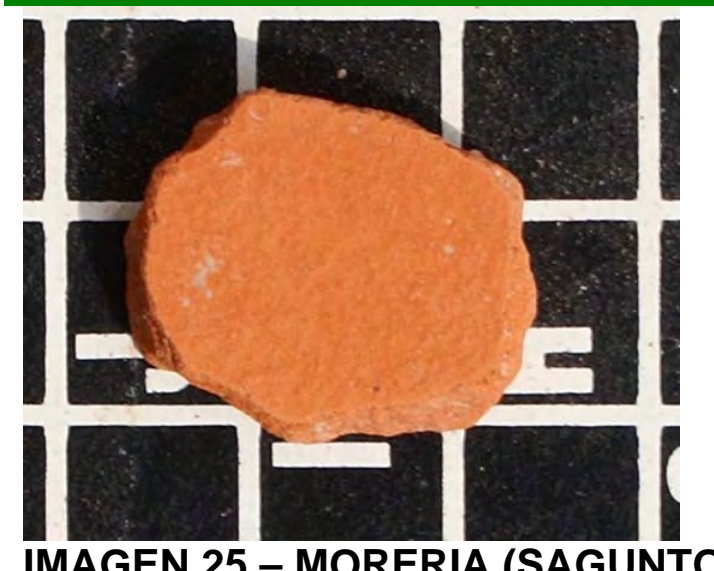

IMAGEN 25 - MORERIA (SAGUNTO)

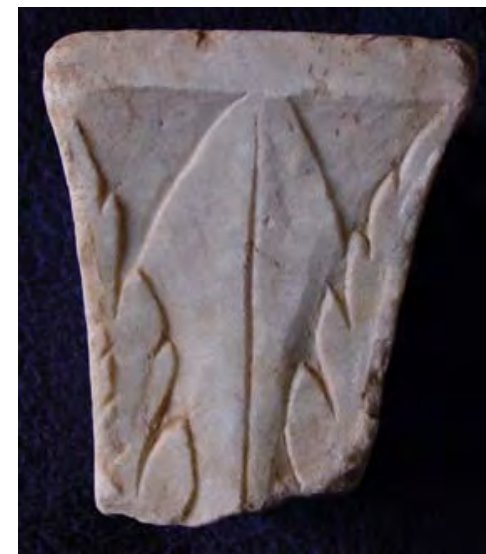

IMAGEN 27 - MORERIA (SAGUNTO)

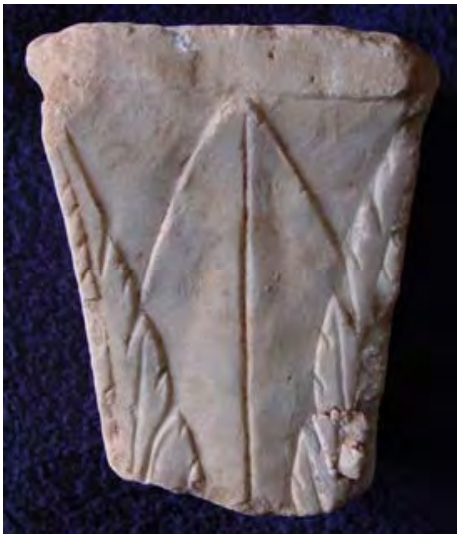

IMAGEN 29 - MORERIA (SAGUNTO)

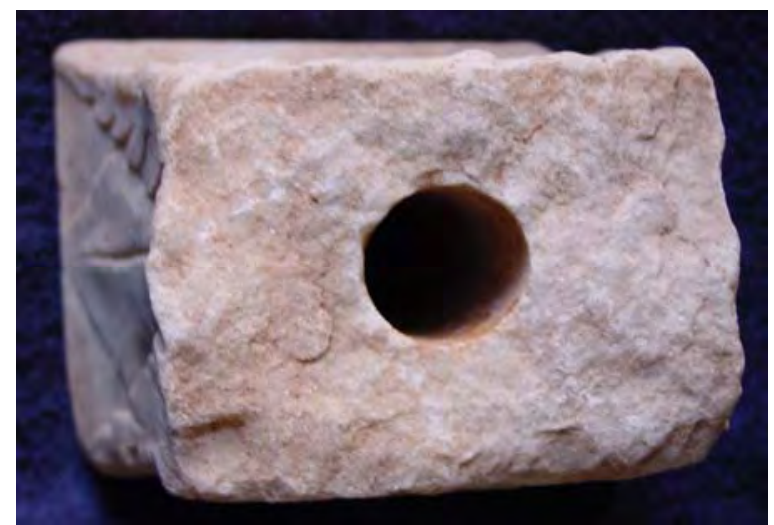

IMAGEN 31 - MORERIA (SAGUNTO)

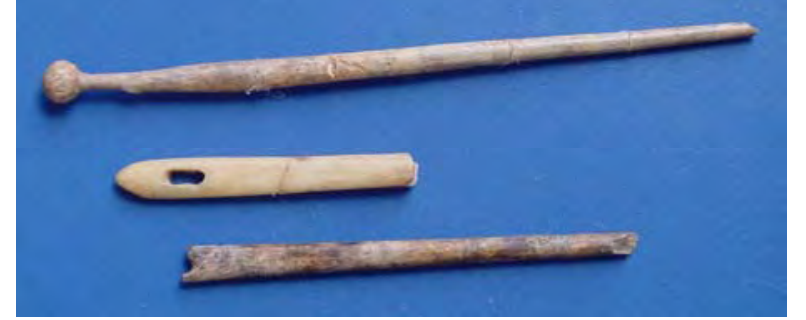

IMAGEN 26 - MORERIA (SAGUNTO)

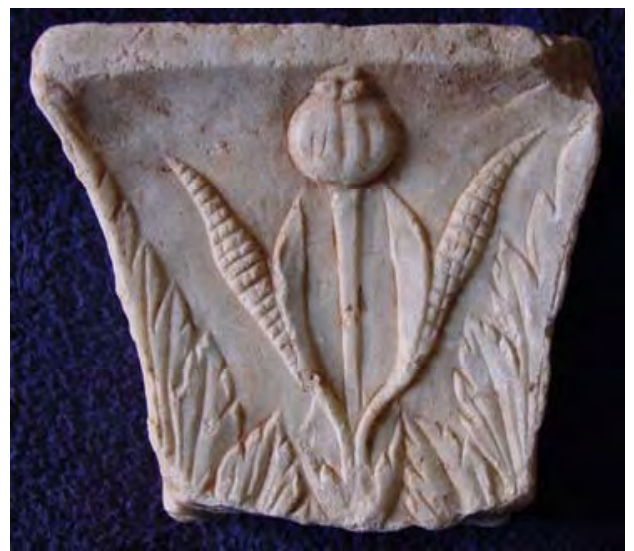

IMAGEN 28 - MORERIA (SAGUNTO)

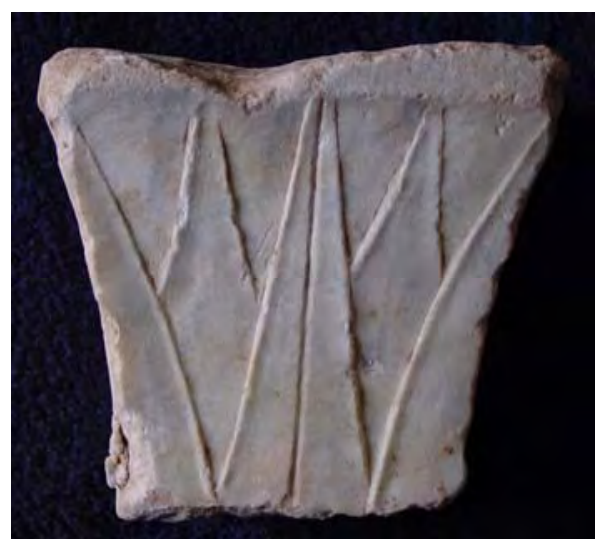

IMAGEN 30 - MORERIA (SAGUNTO)

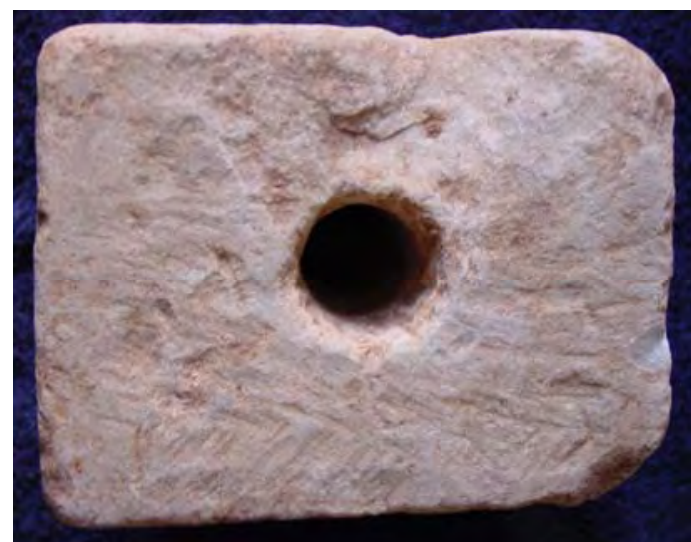

IMAGEN 32 - MORERIA (SAGUNTO) 


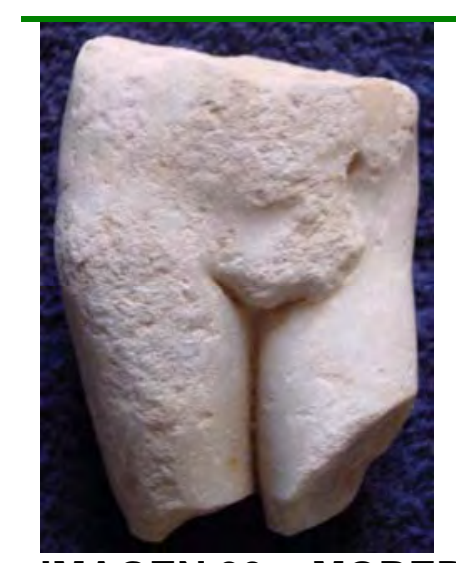

IMAGEN 33 - MORERIA (SAGUNTO)

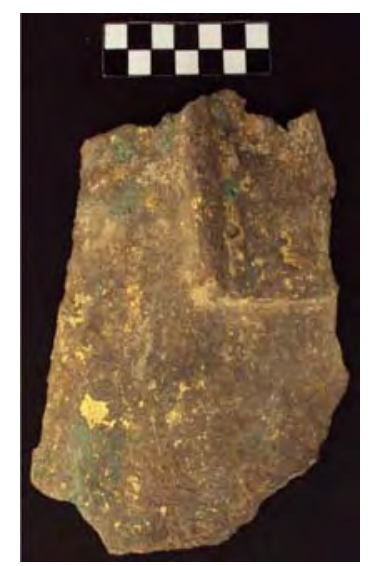

IMAGEN 35 - MORERIA (SAGUNTO)

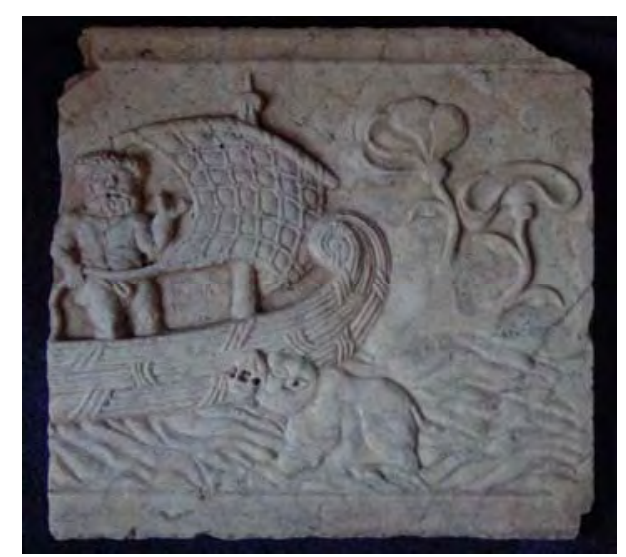

IMAGEN 37 - MORERIA (SAGUNTO)

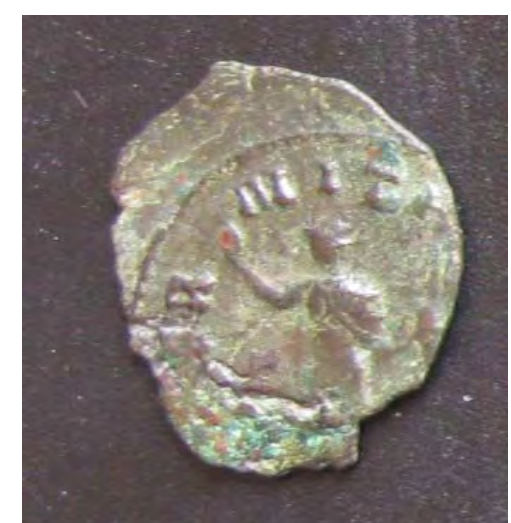

IMAGEN 39 - MORERIA (SAGUNTO)

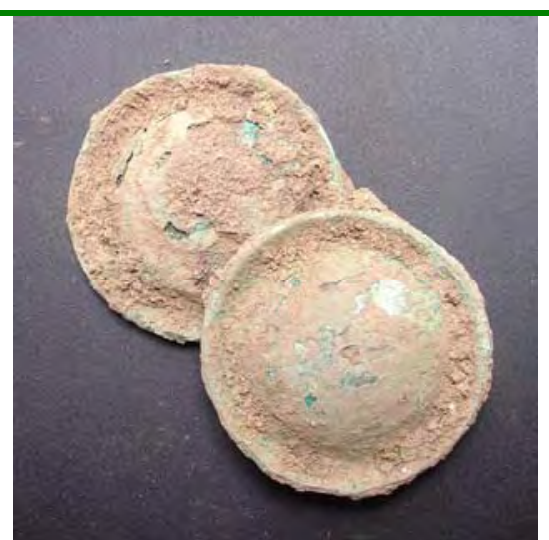

IMAGEN 34 - MORERIA (SAGUNTO)

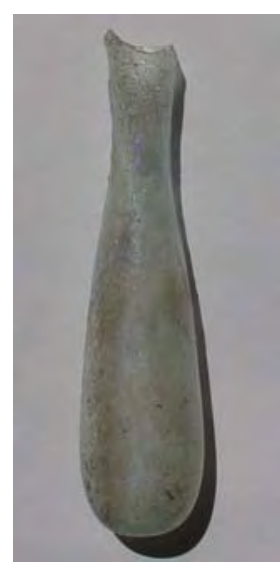

IMAGEN 36 - MORERIA (SAGUNTO)

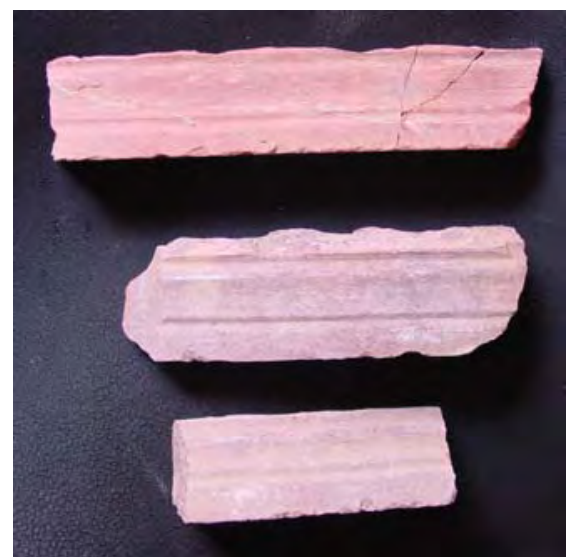

IMAGEN 38 - MORERIA (SAGUNTO)

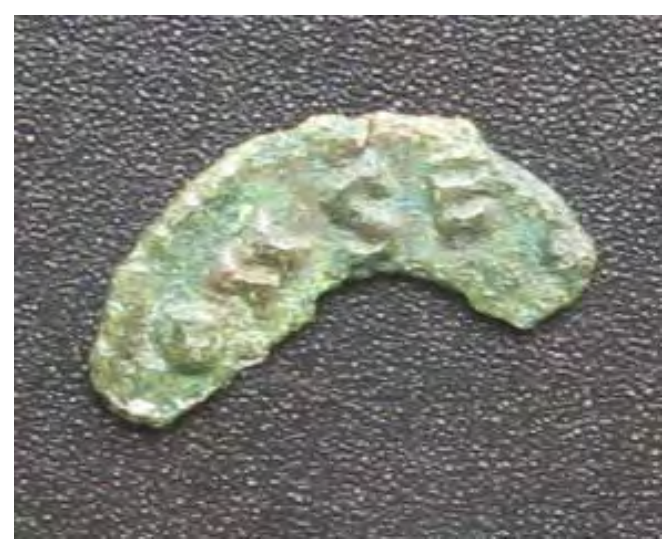

IMAGEN 40 - MORERIA (SAGUNTO) 


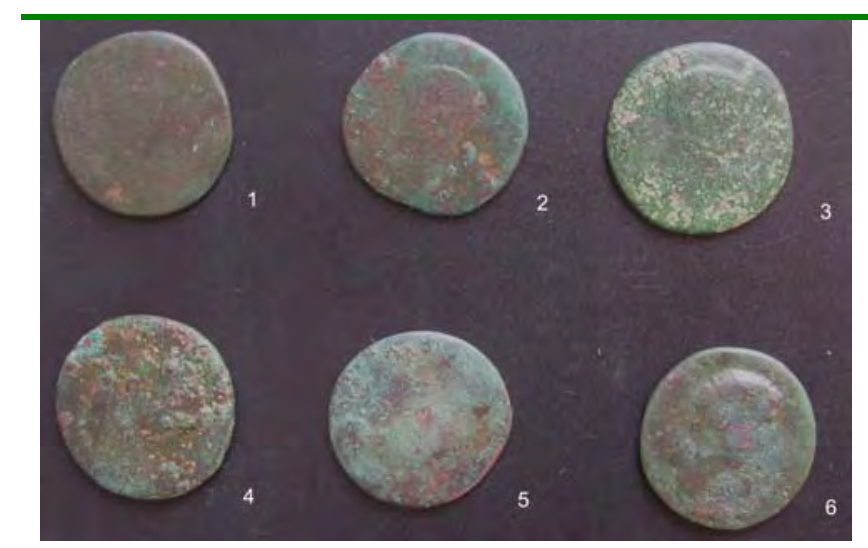

IMAGEN 41 - MORERIA (SAGUNTO)

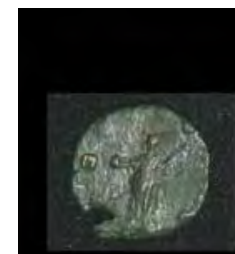

1056 $1056(L)$ $1056(C)$

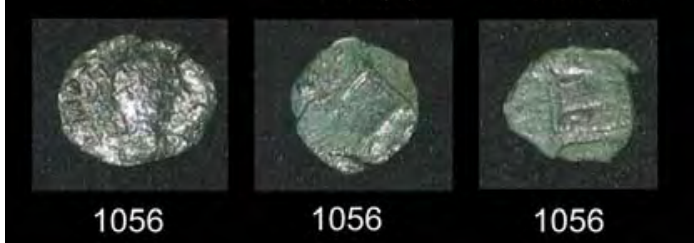

IMAGEN 43 - MORERIA (SAGUNTO)

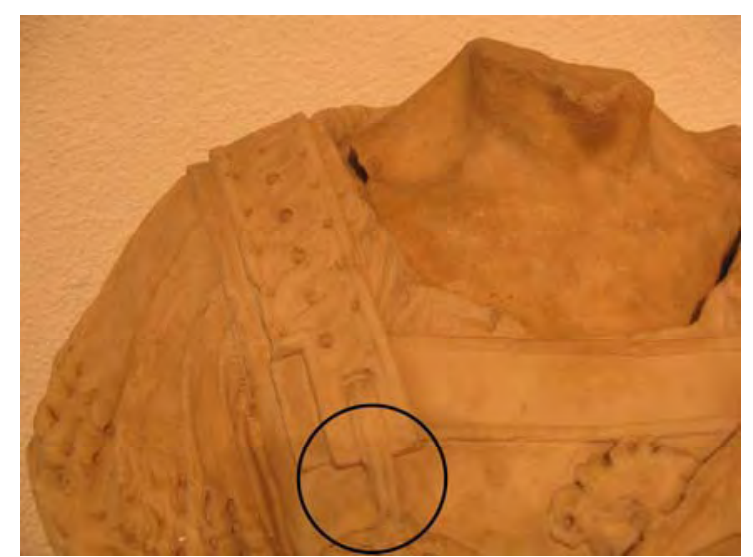

IMAGEN 45- MUSEO VALLADOLID

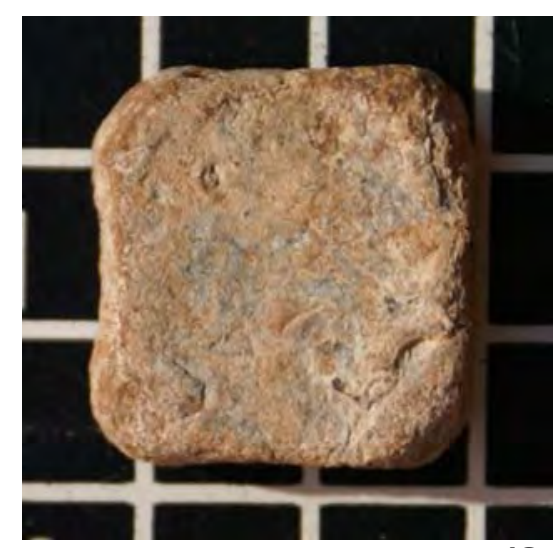

IMAGEN 47 - MORERIA (SAGUNTO)

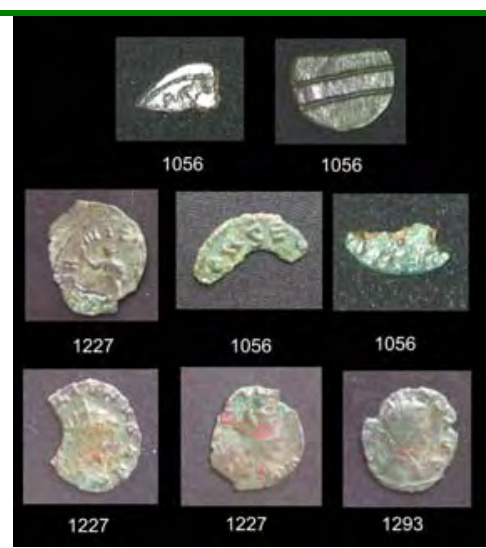

IMAGEN 42 - MORERIA (SAGUNTO)

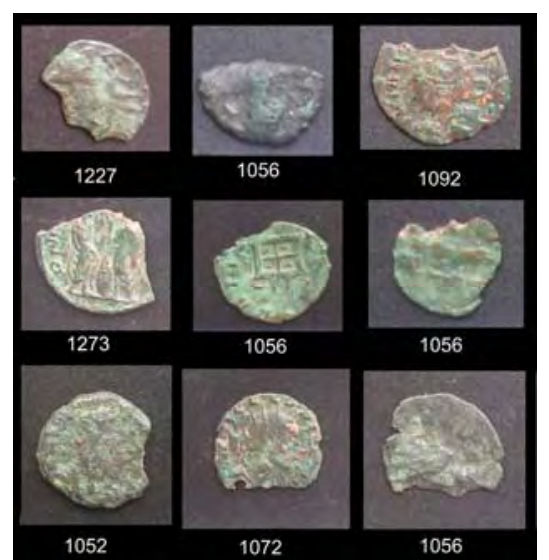

IMAGEN 44 - MORERIA (SAGUNTO)

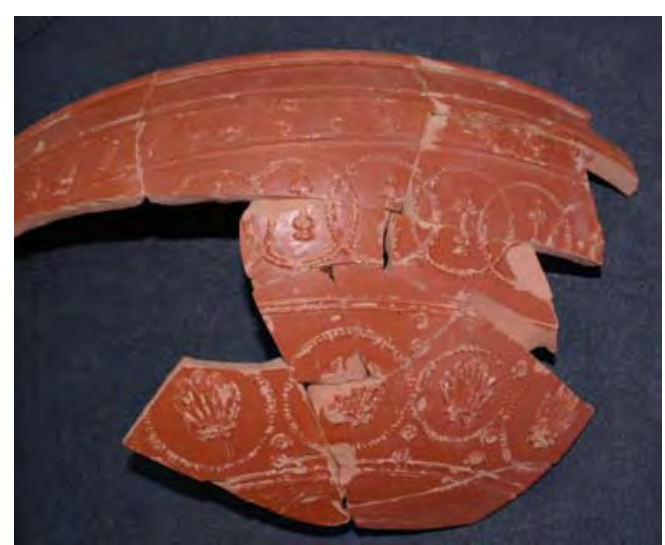

IMAGEN 46 - MORERIA (SAGUNTO)

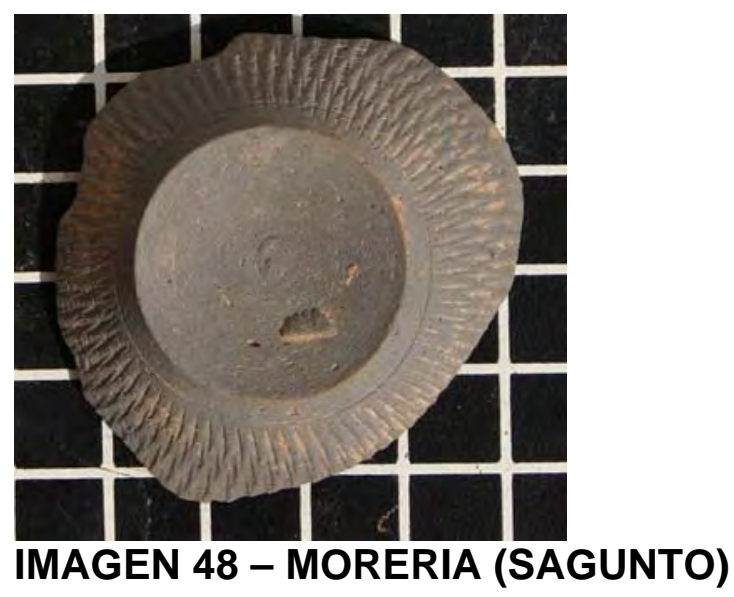




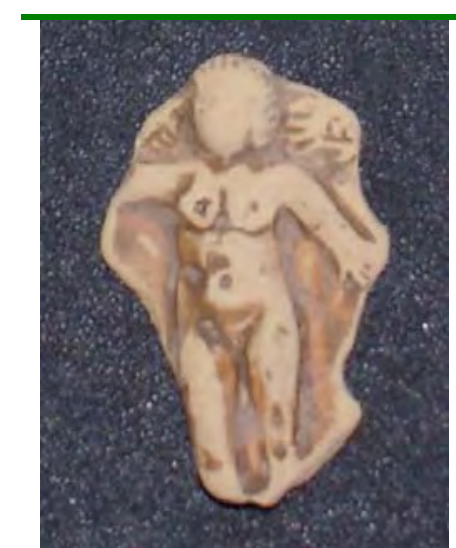

IMAGEN 49 - MORERIA (SAGUNTO)

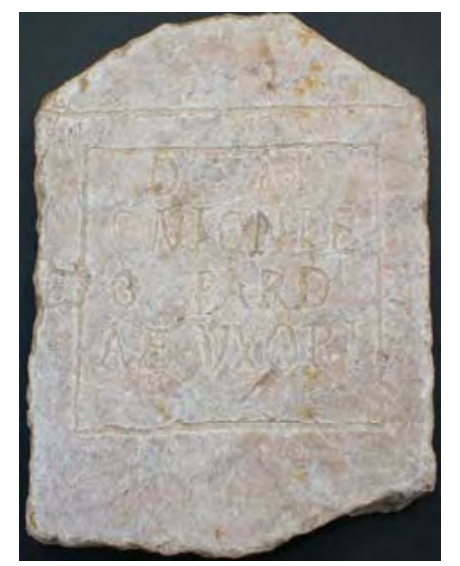

IMAGEN 51 - LES ALQUERIES

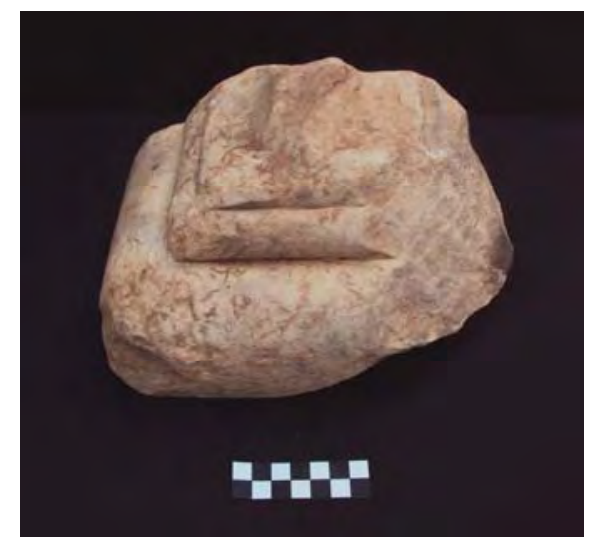

IMAGEN 53 - SAN GREGORI

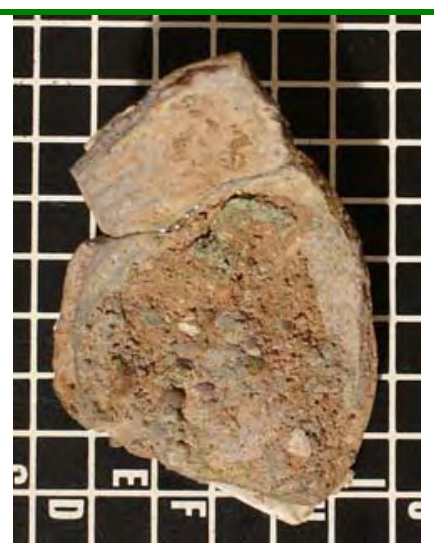

IMAGEN 50 - MORERIA (SAGUNTO)

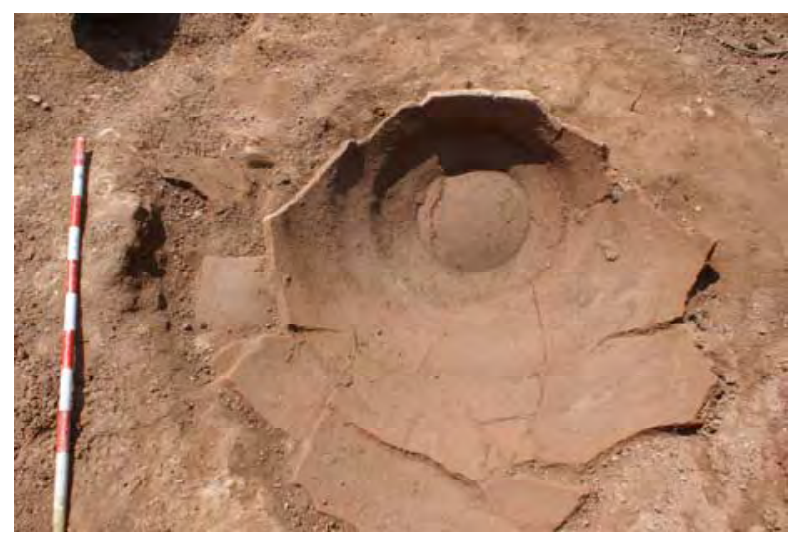

IMAGEN 52 - SAN GREGORI

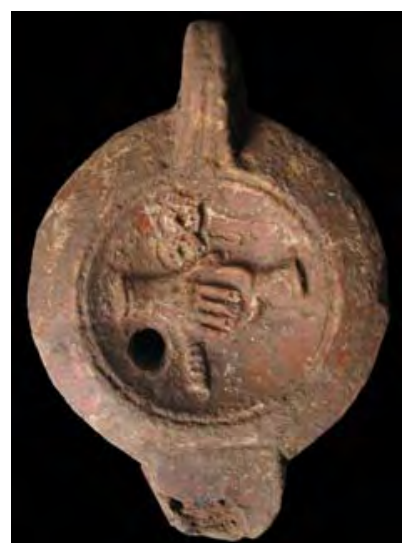

IMAGEN 54 - SAN GREGORI

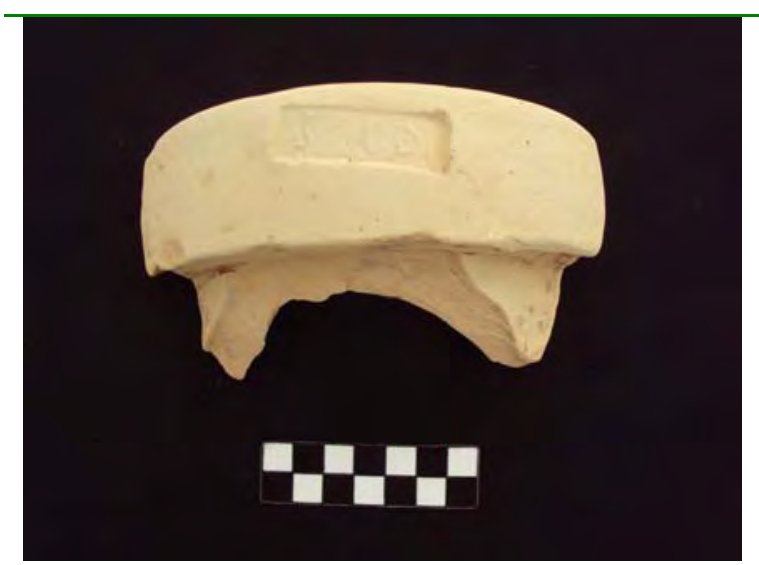

IMAGEN 55 - TORRE D'ONDA

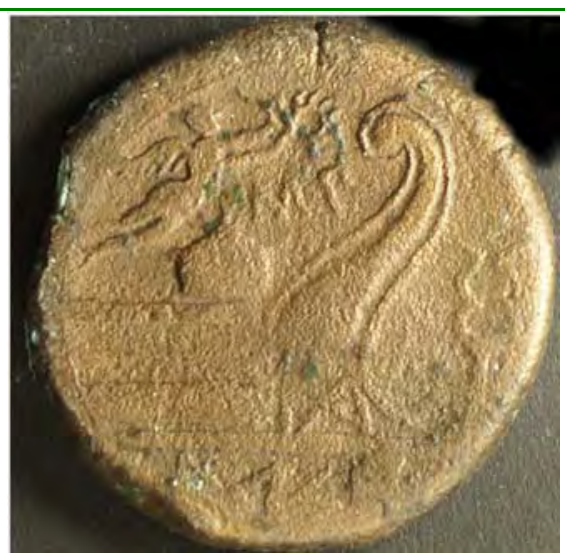

IMAGEN 56 - TORRE D'ONDA 


\section{DIBUJOS Y GRABADOS}




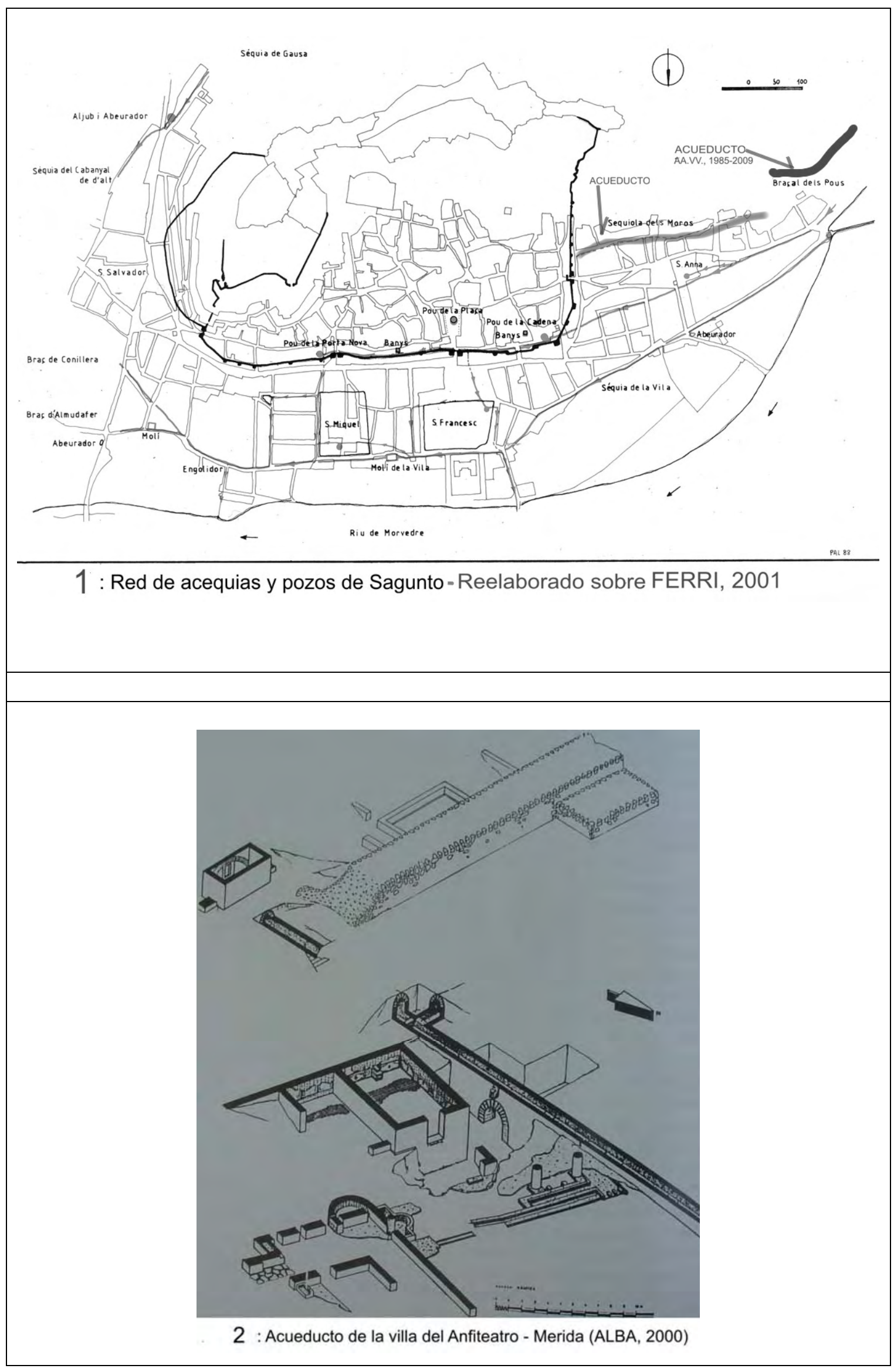




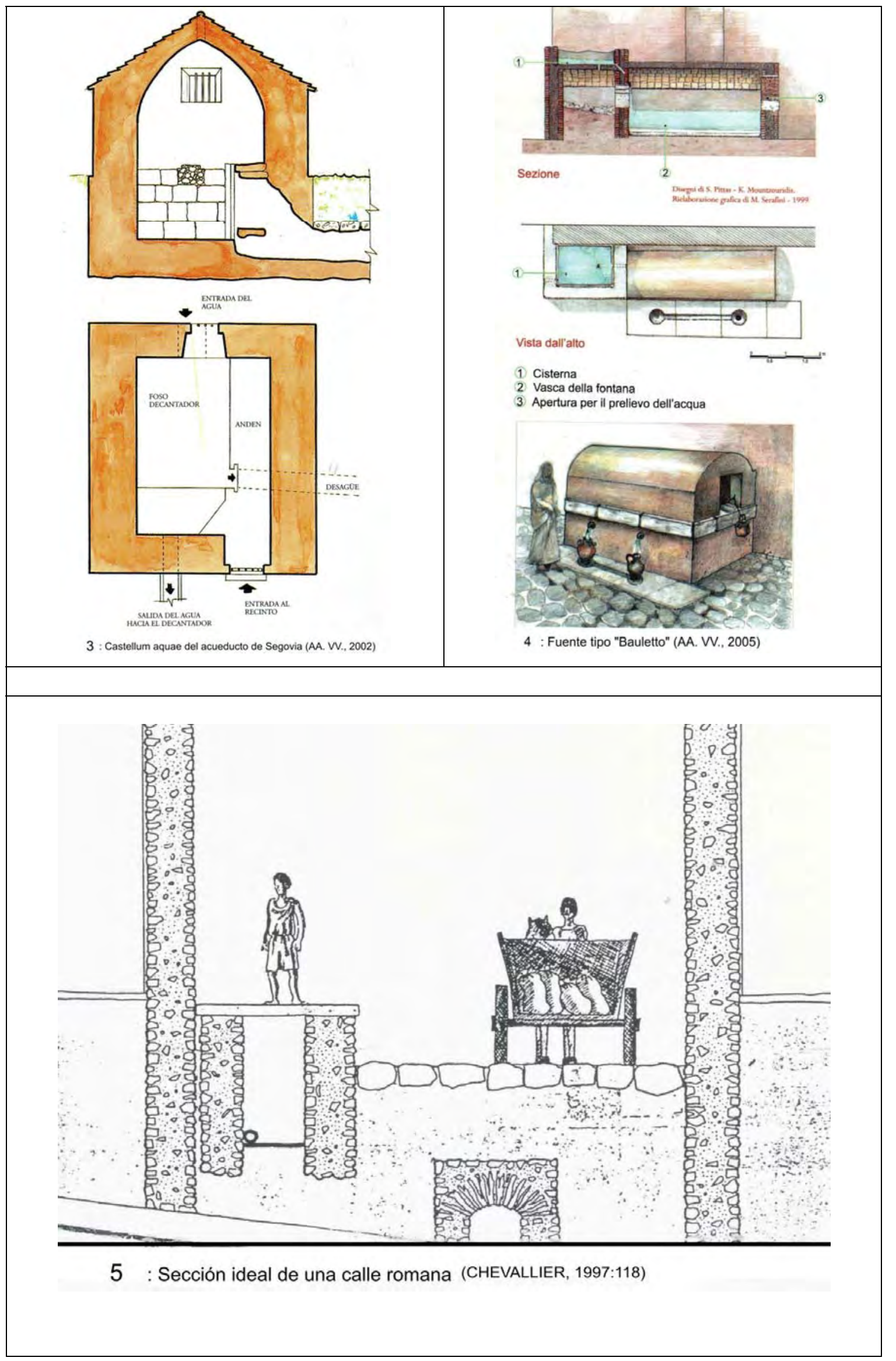




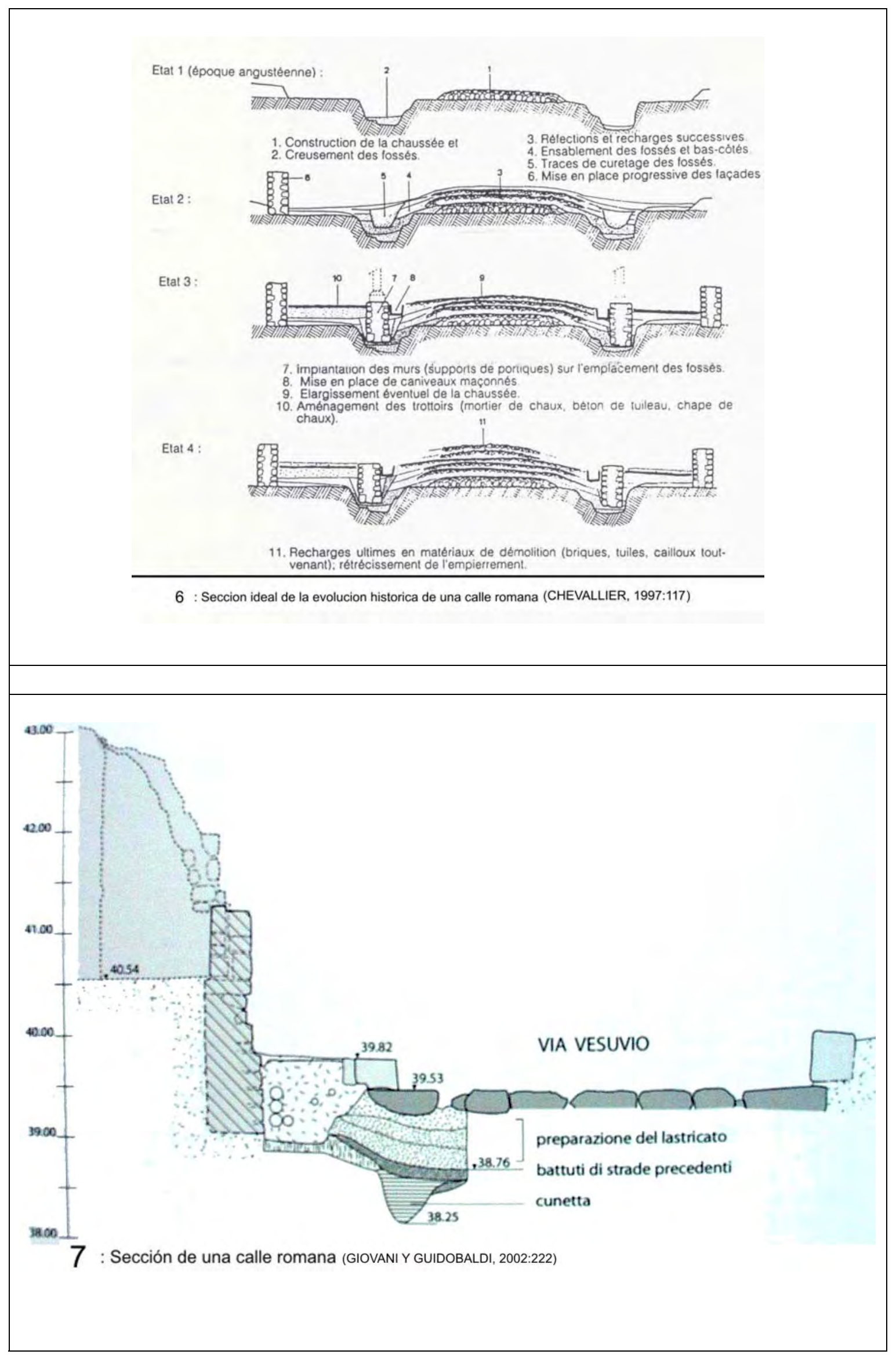




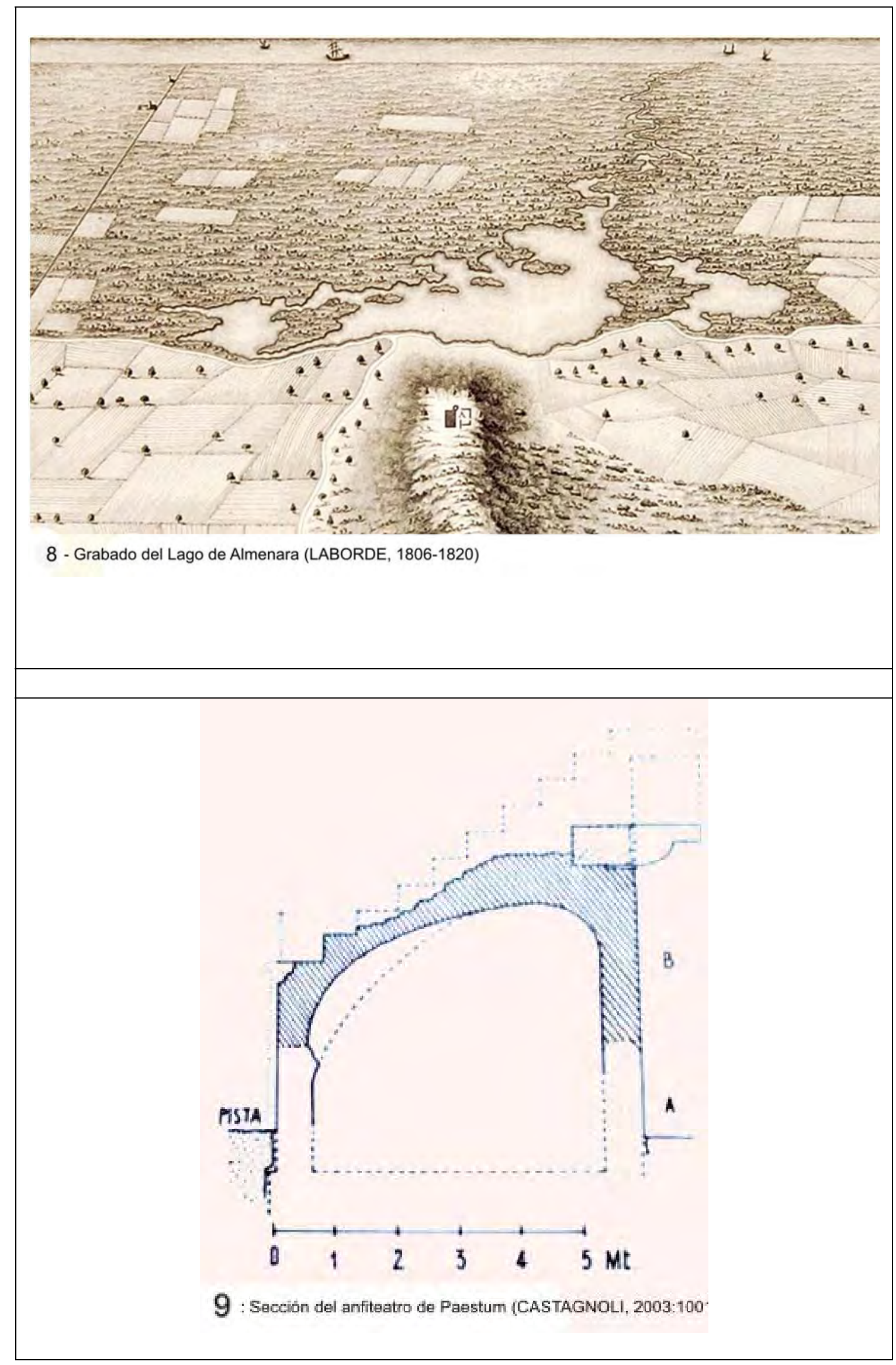




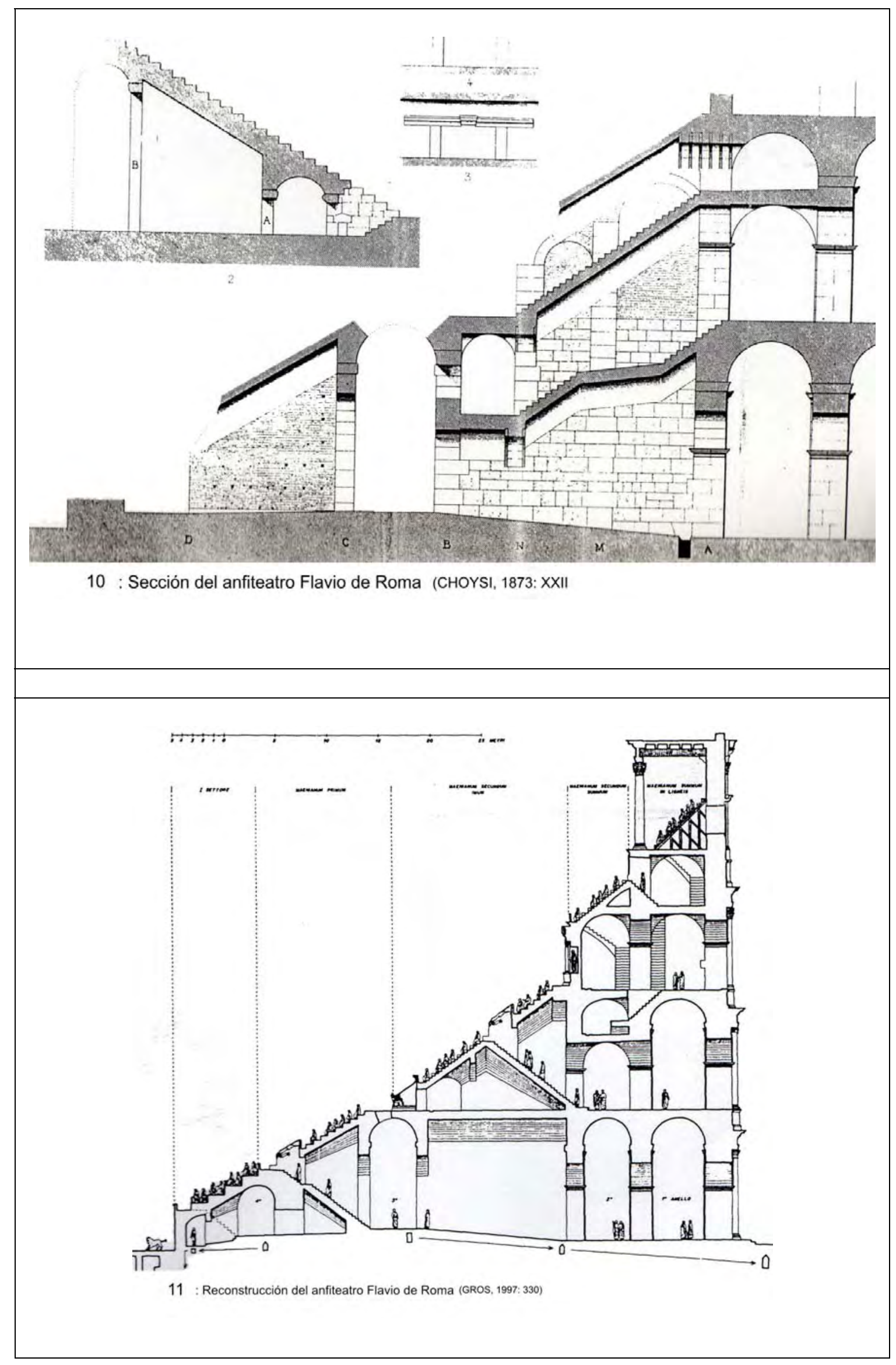




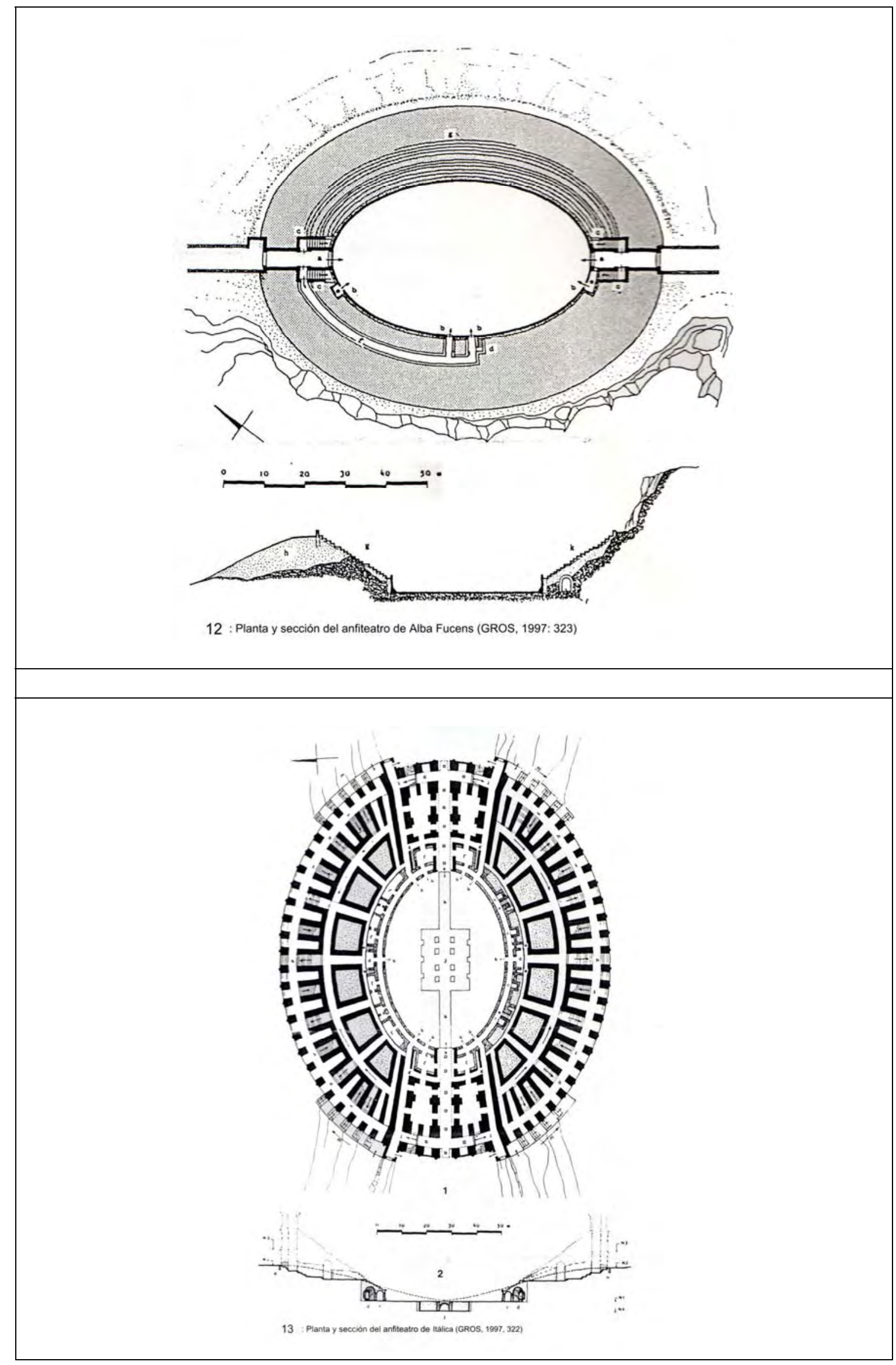




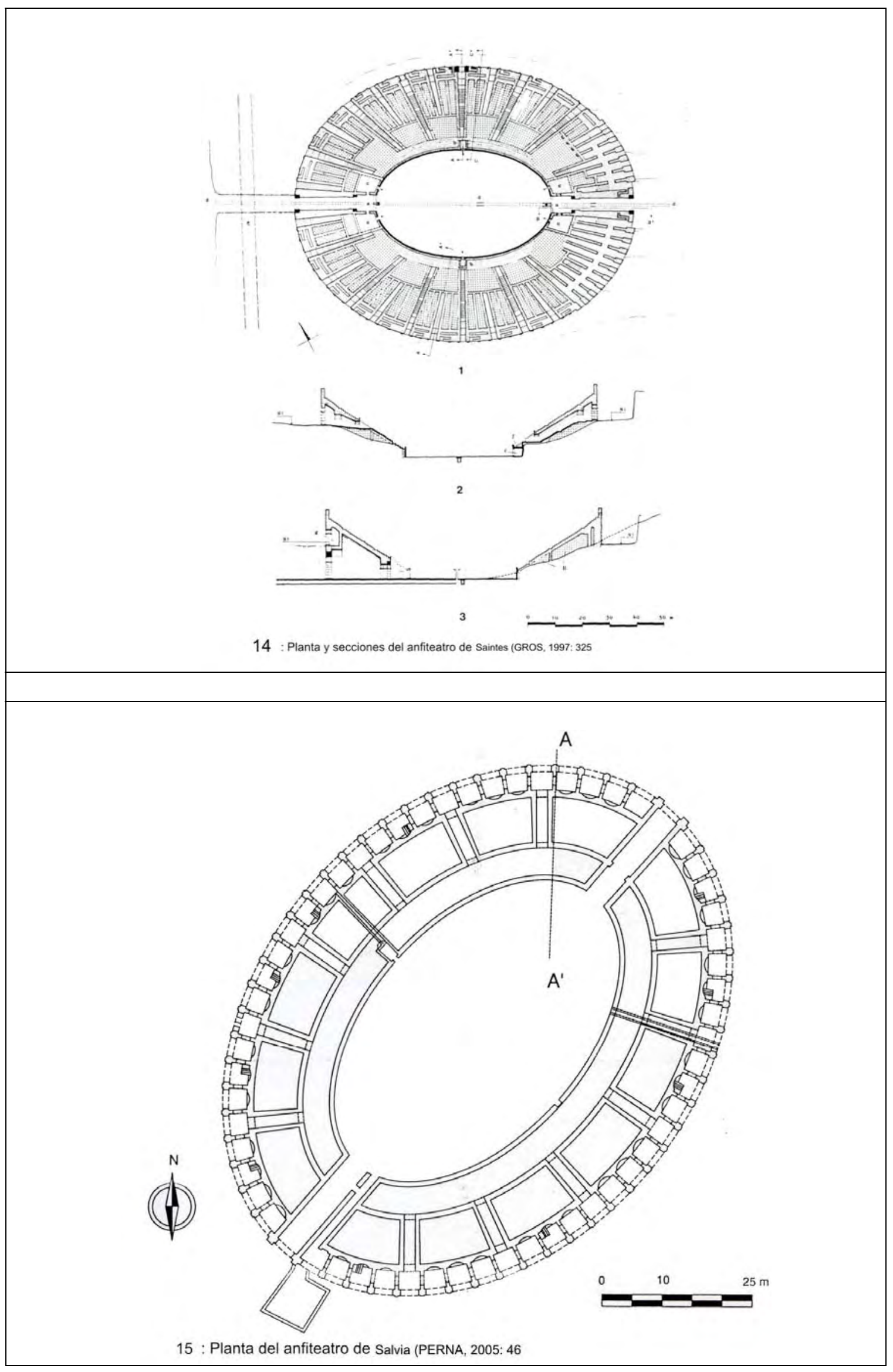




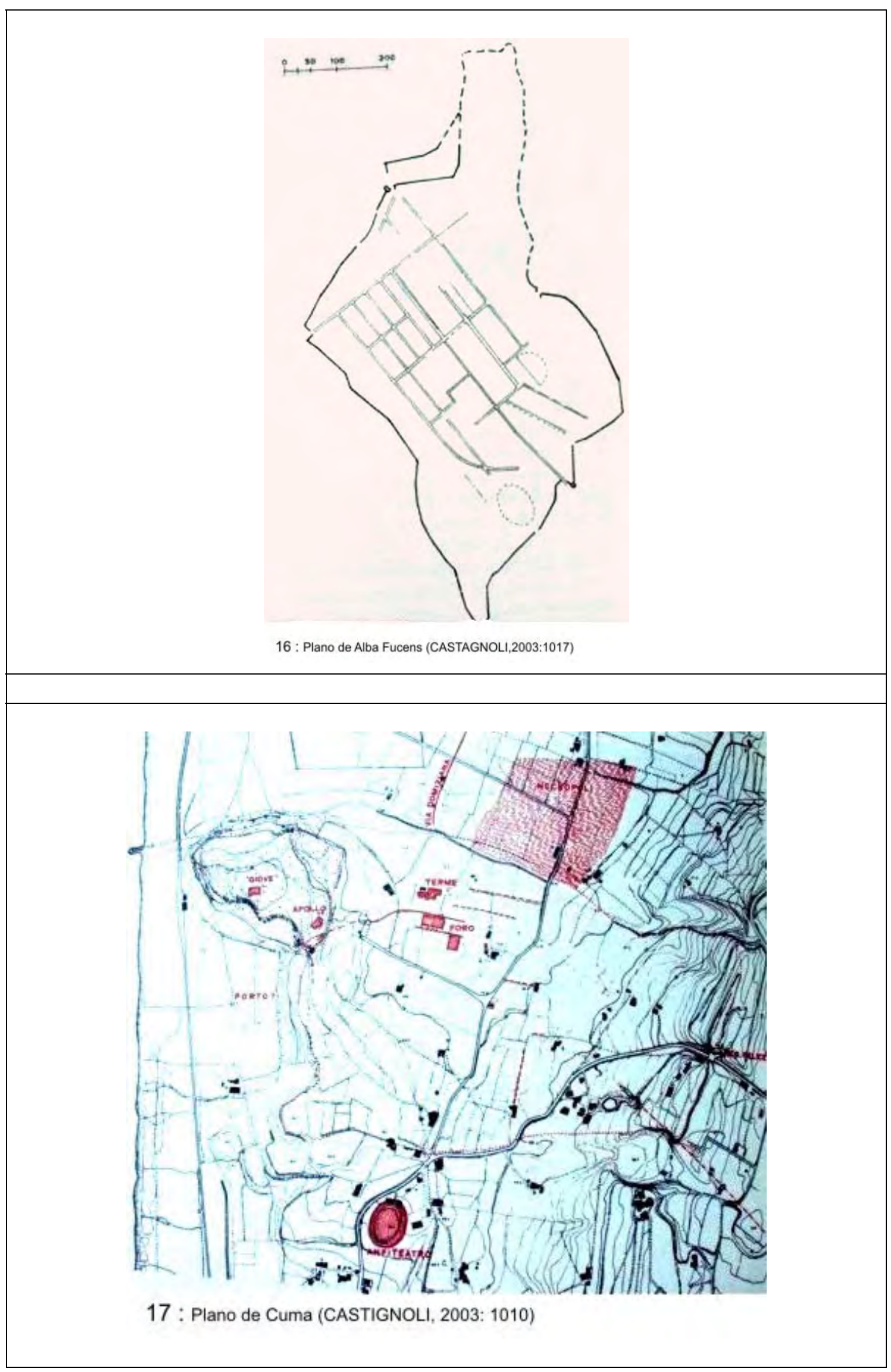




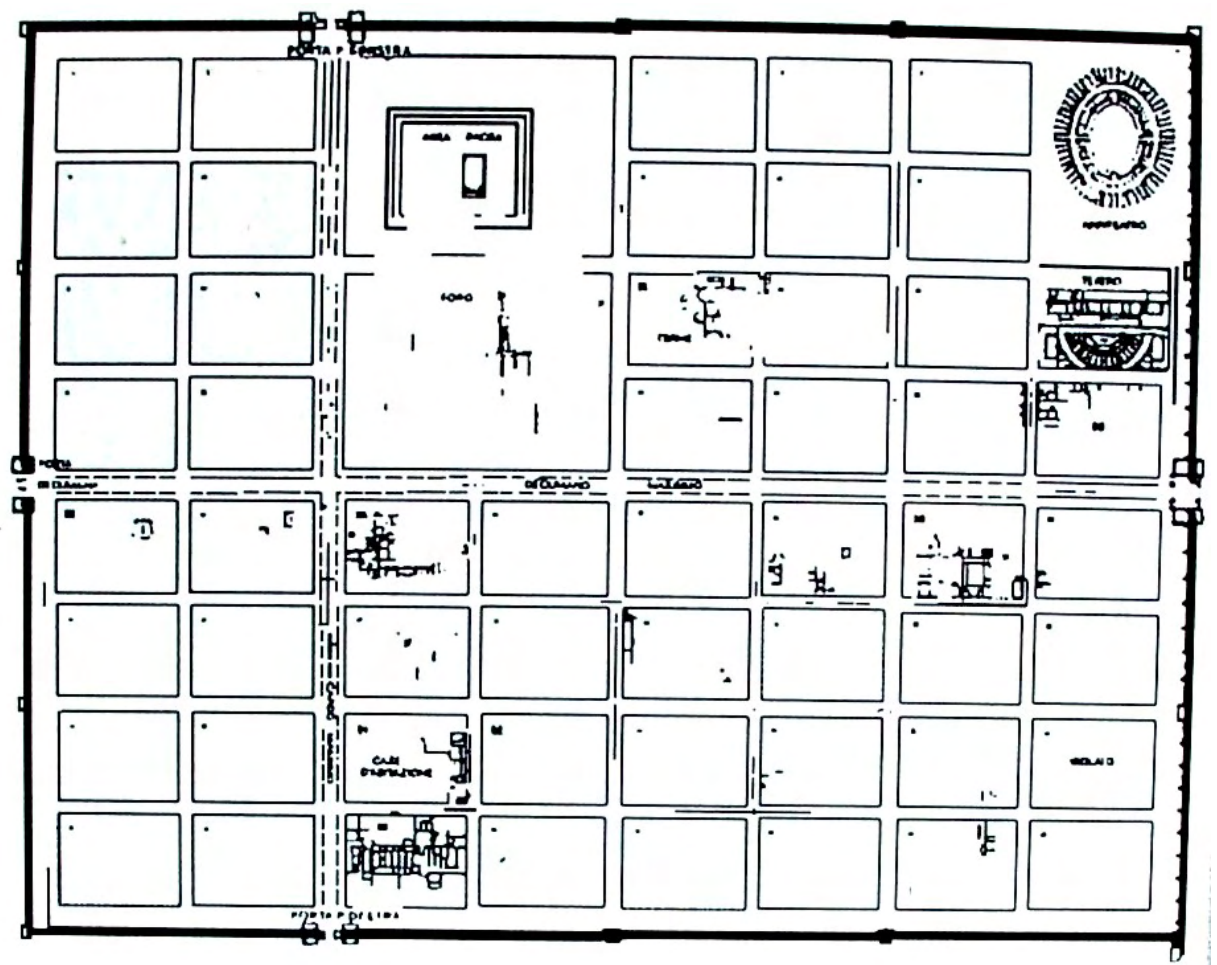

18 : Plano de Aosta (VENTURA, 1996: 48)

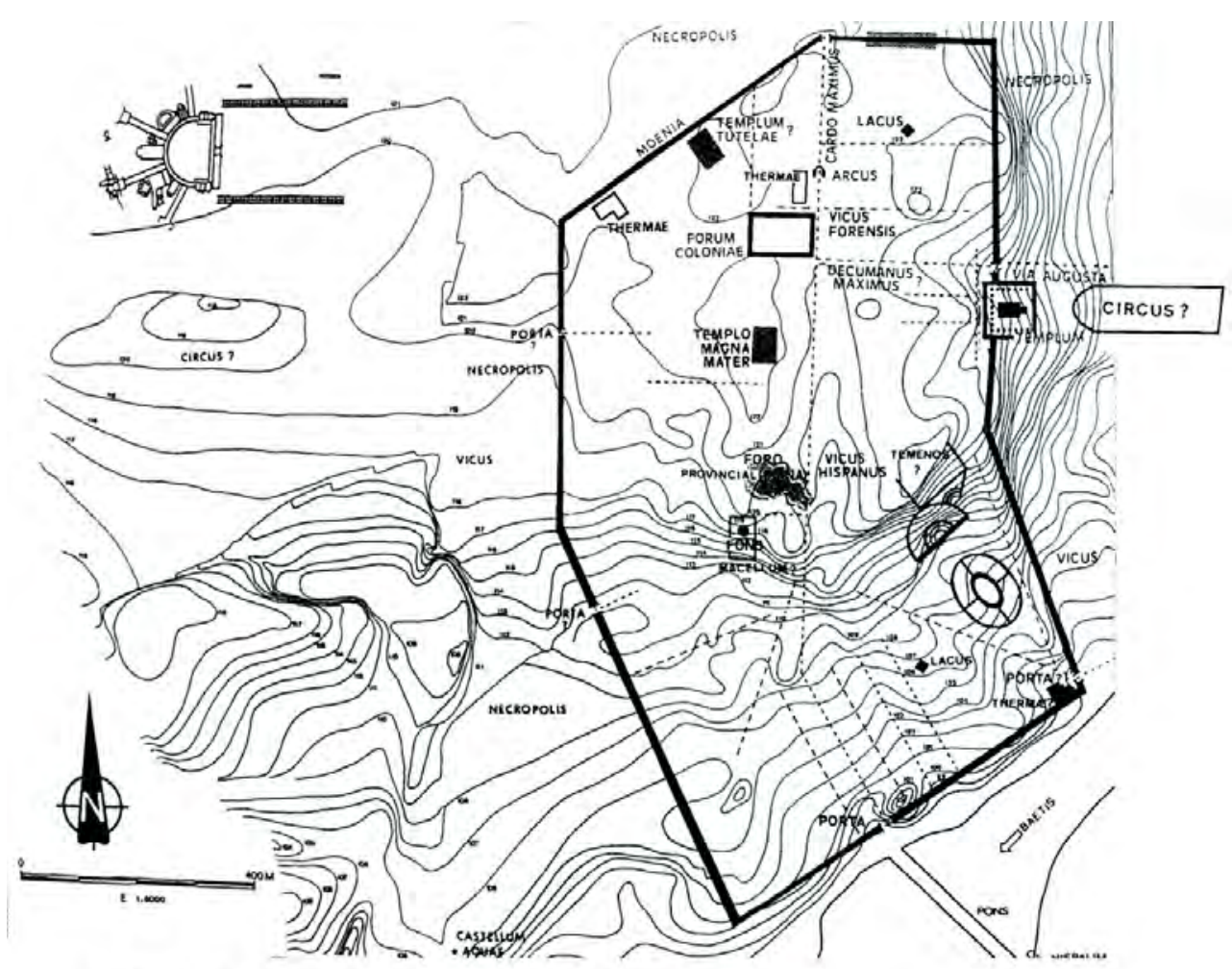

19 : Plano de Corduba (VENTURA, 1996: 49) 


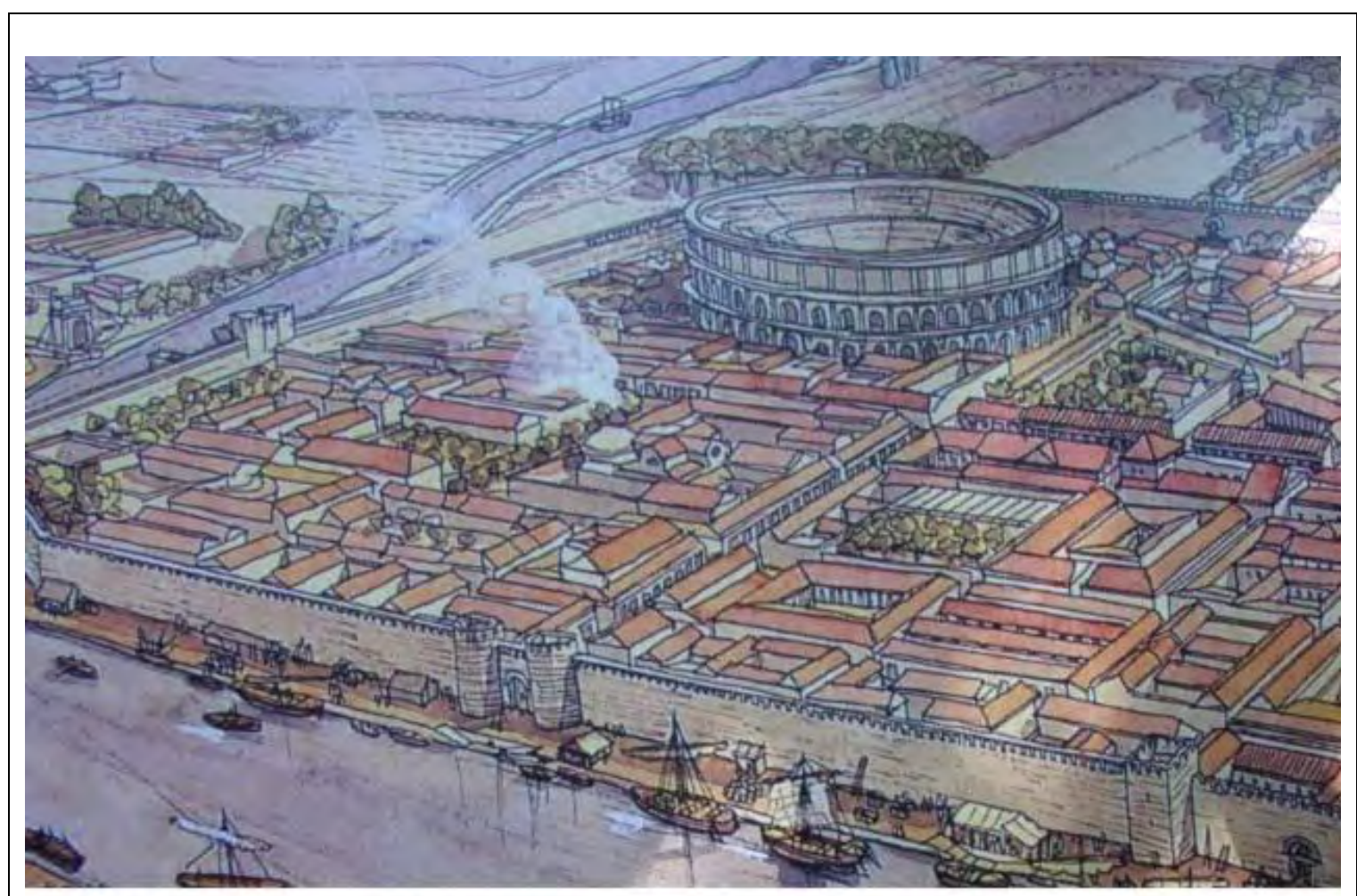

20 : Restitución de la ciudad de Aquilieia (Sitio arqueológico de Classe)

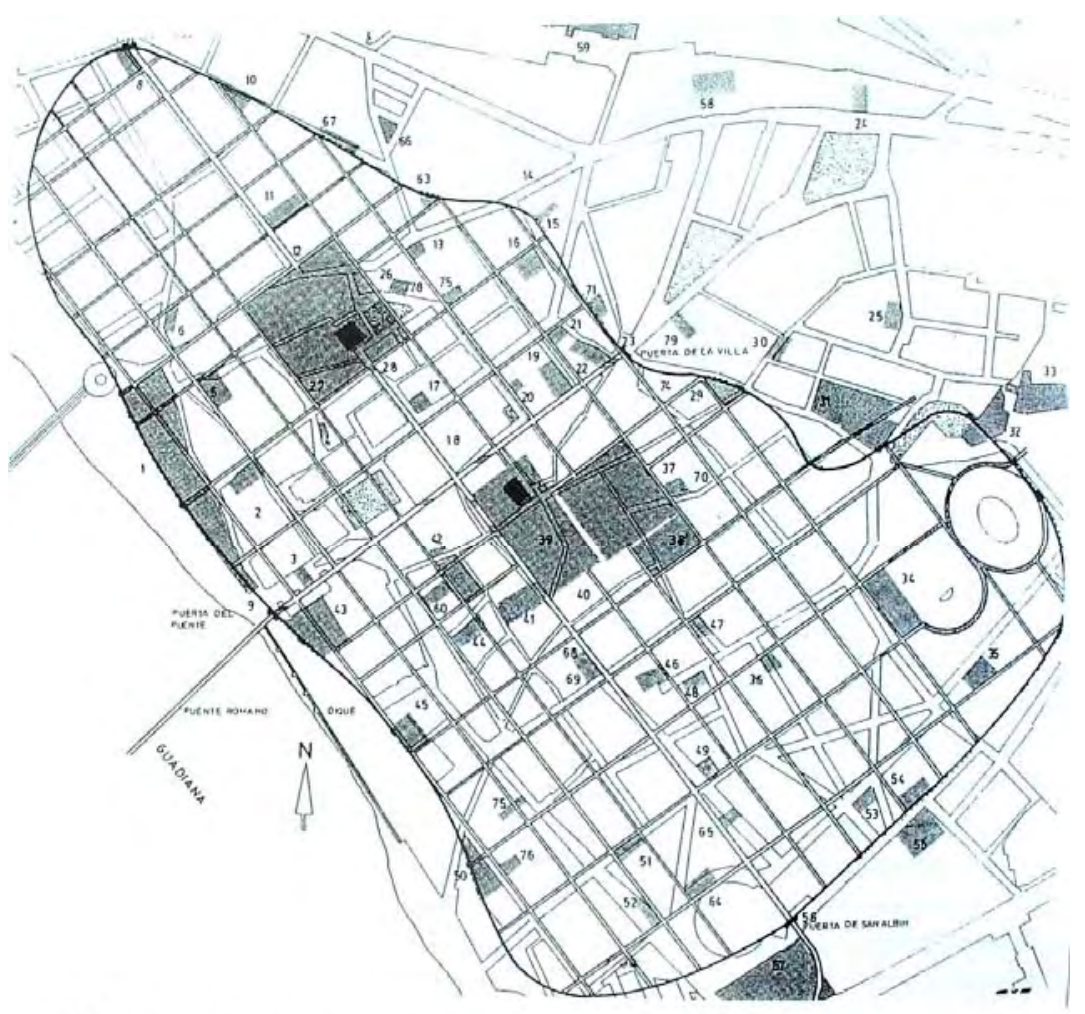

21: Plano de Emerita Augusta (ALBA, 2001: 399) 


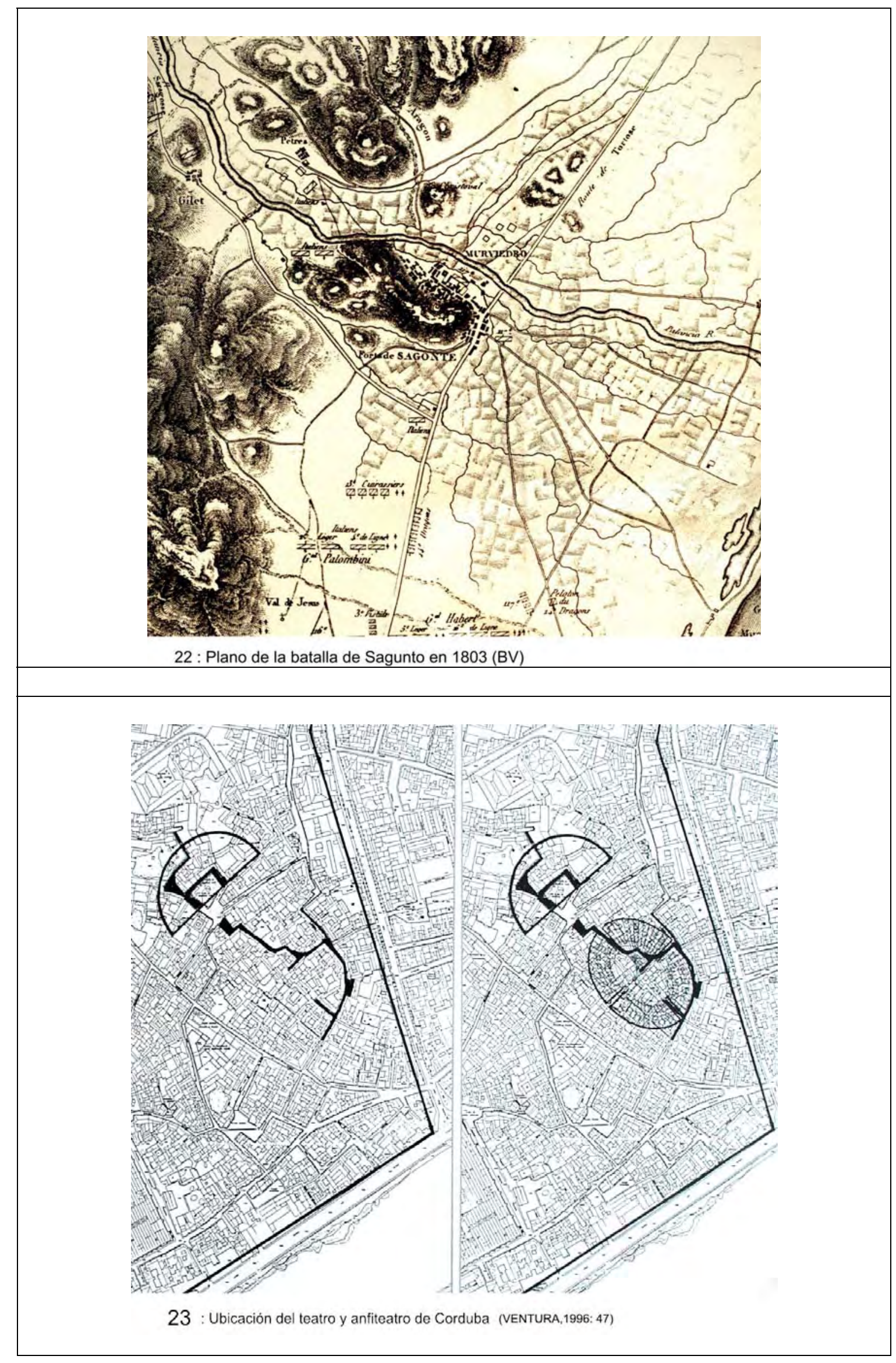




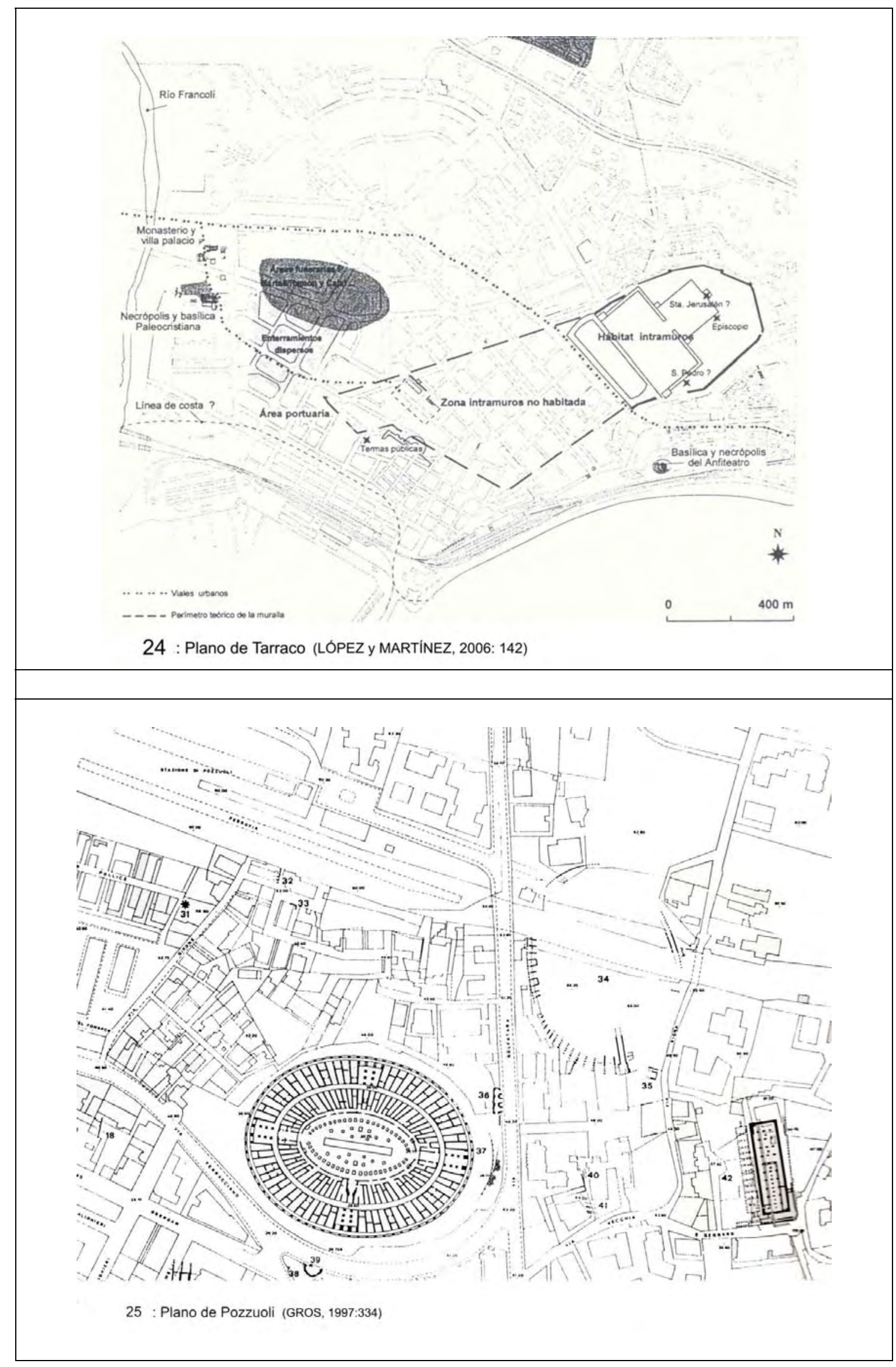




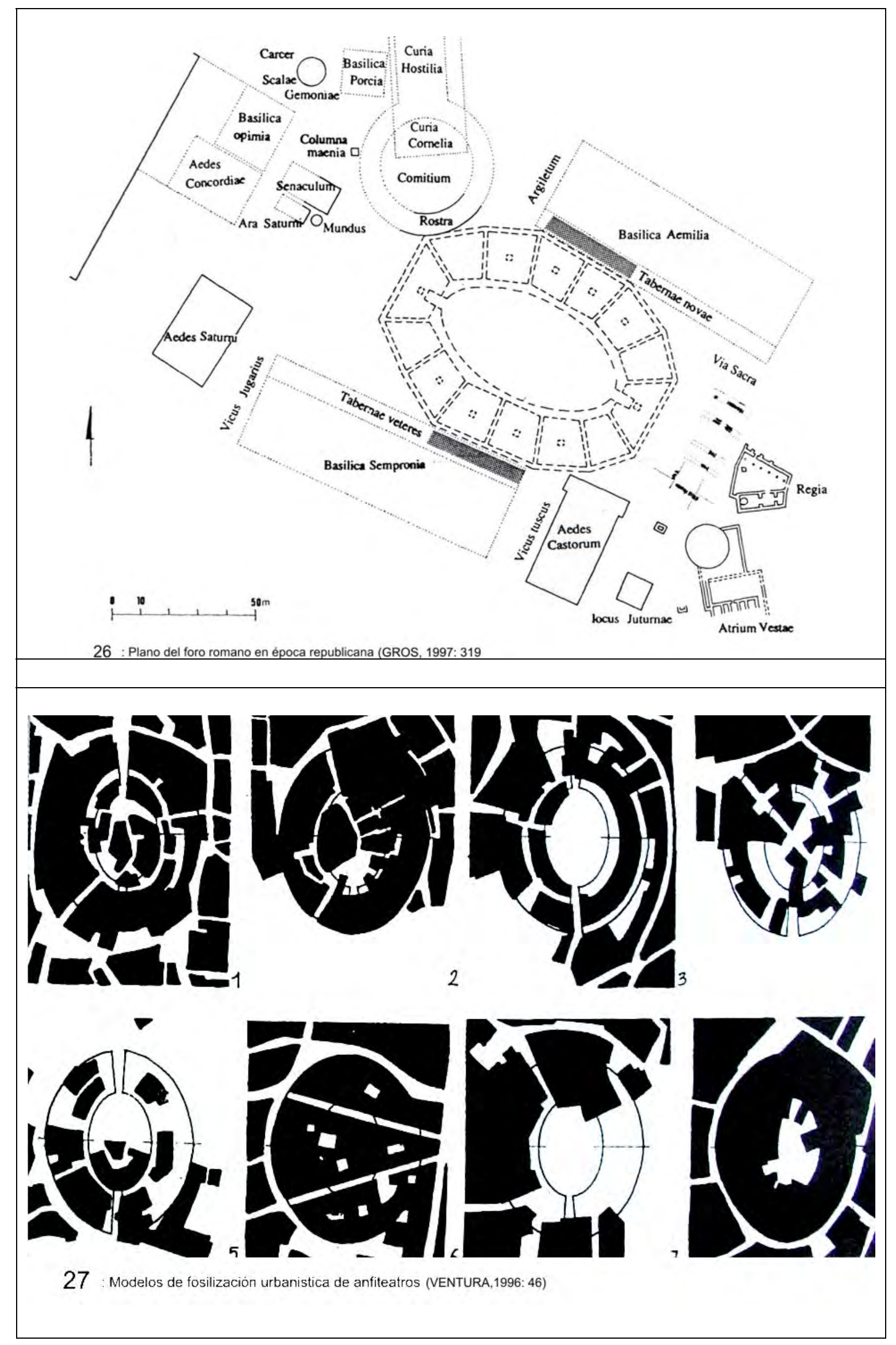




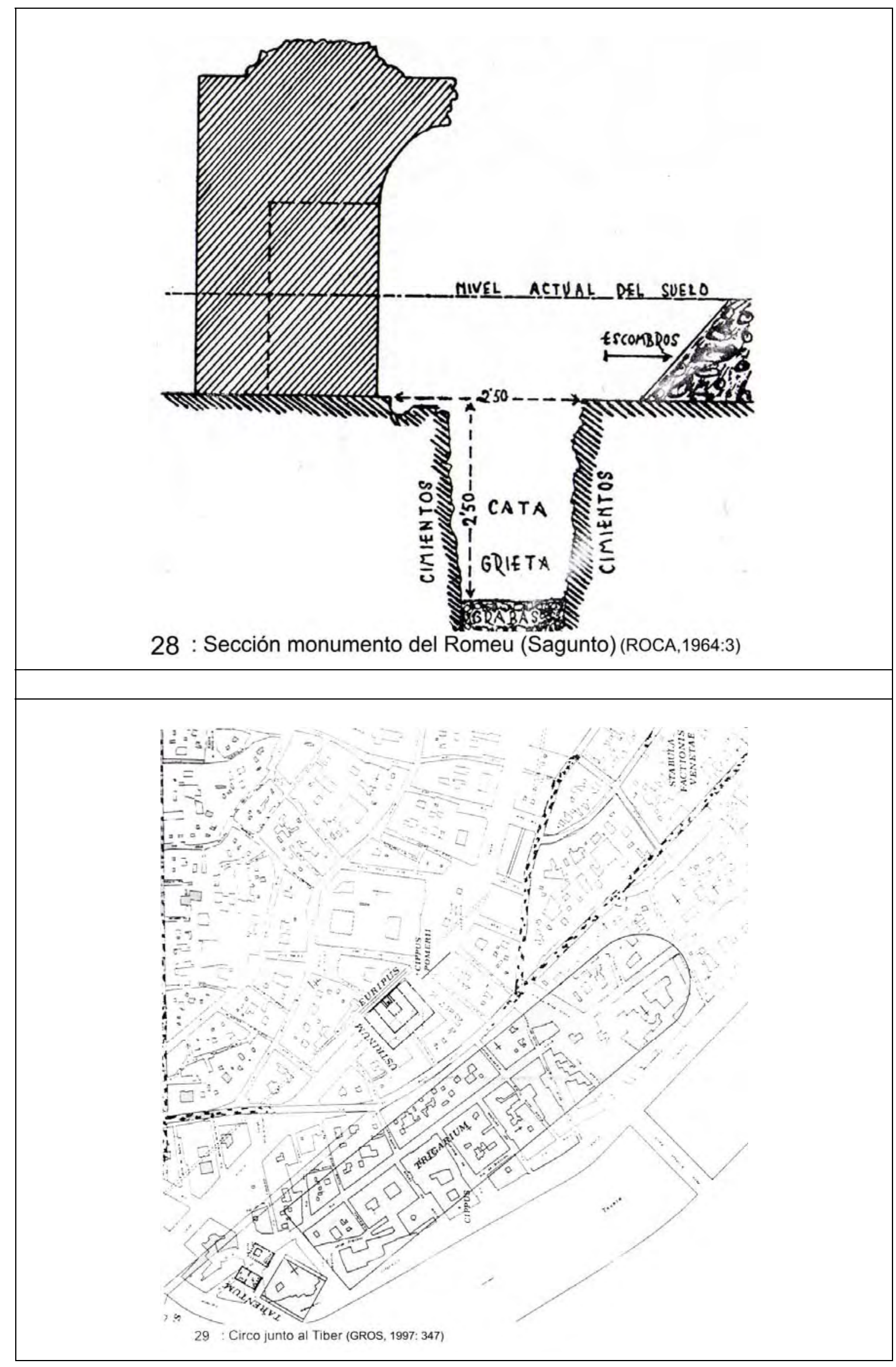




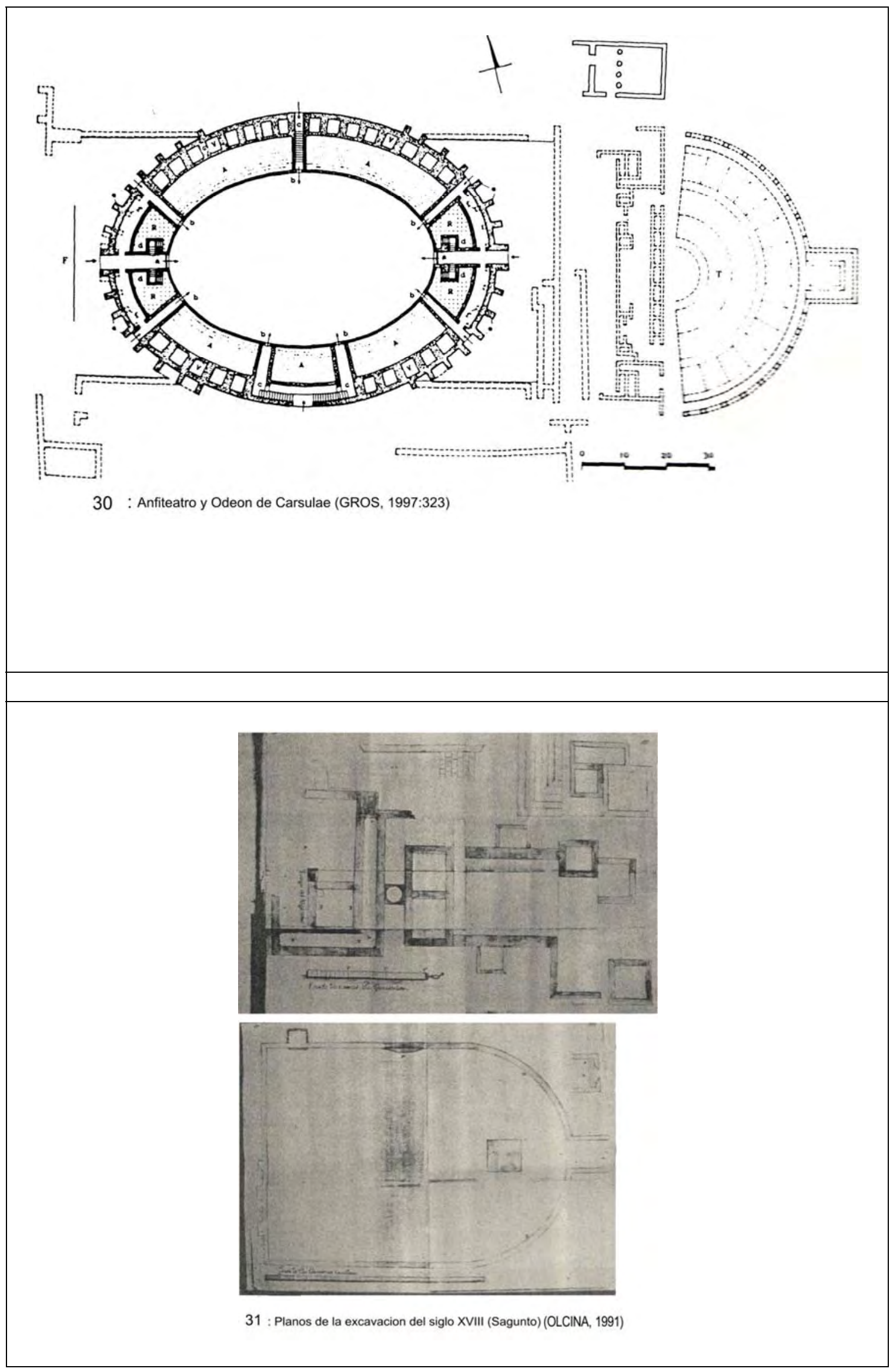




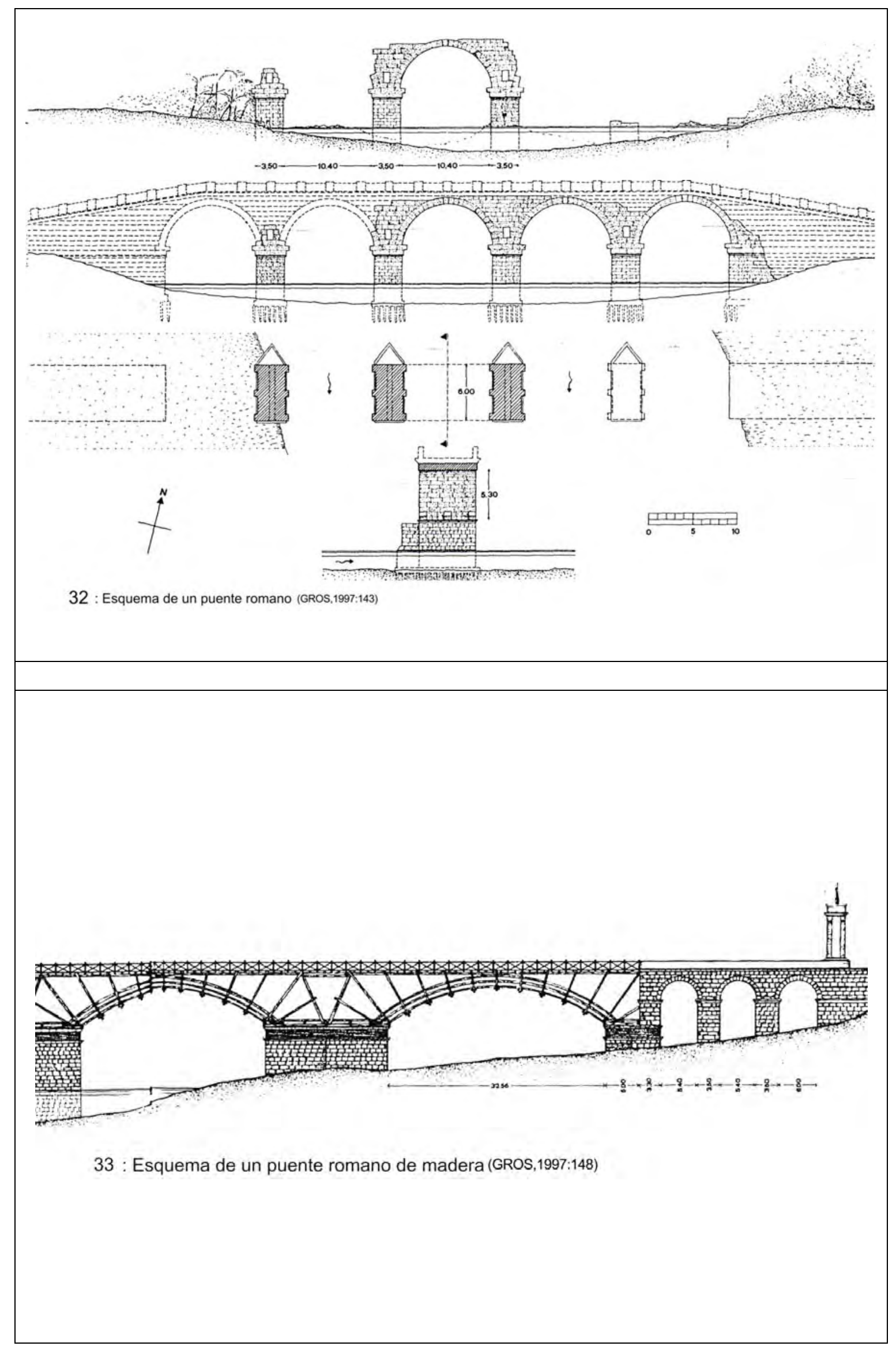




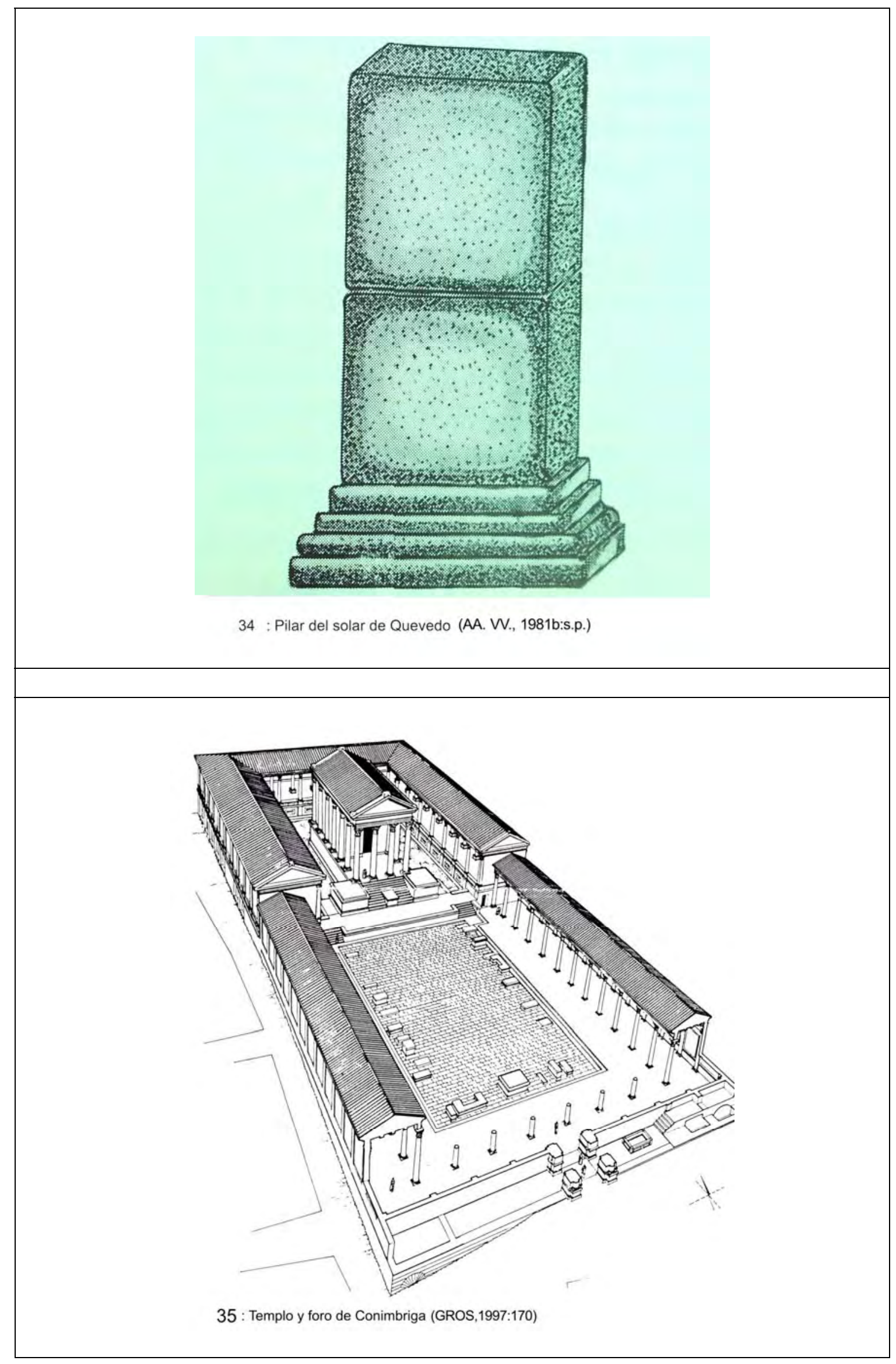




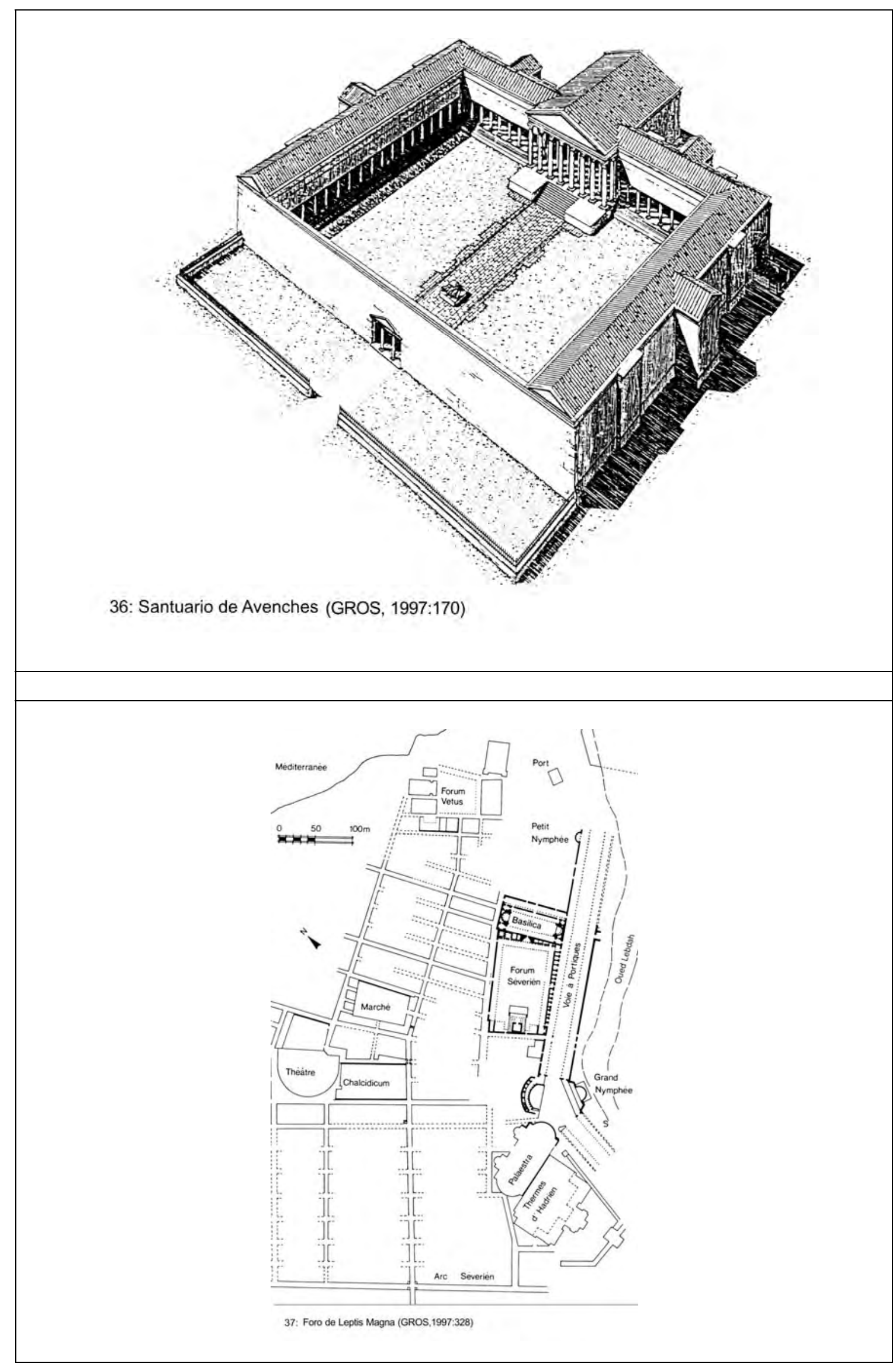




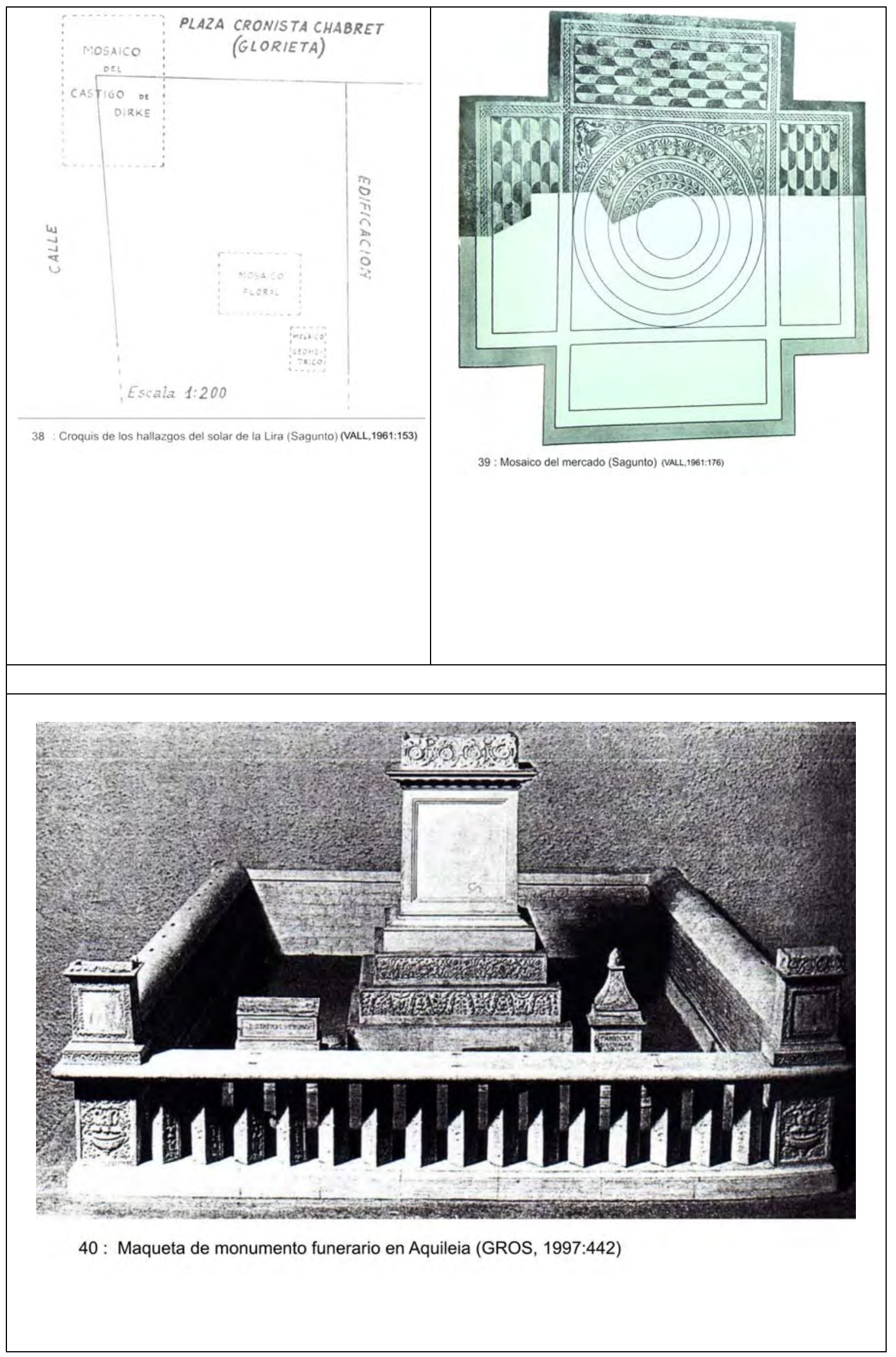




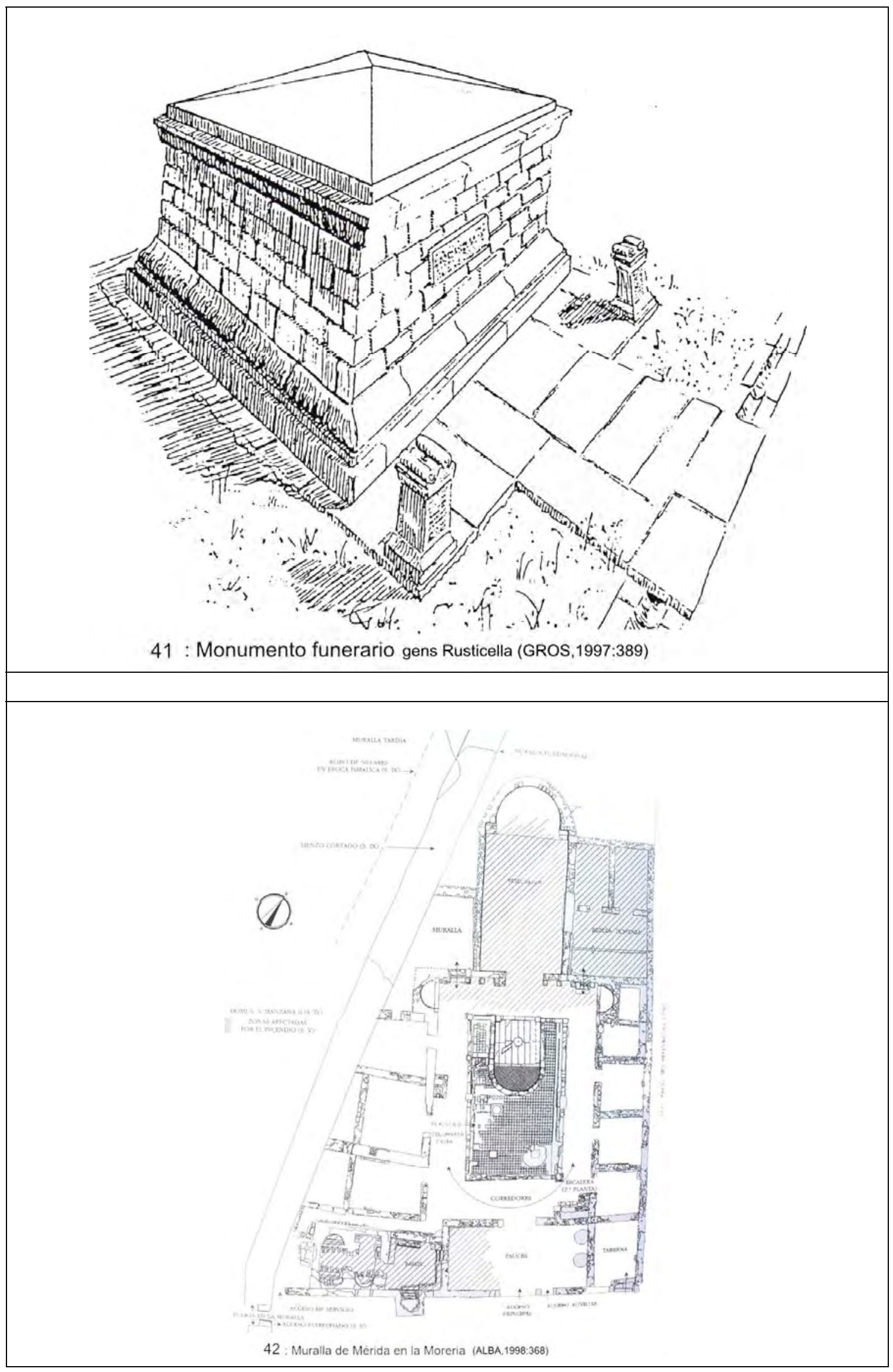




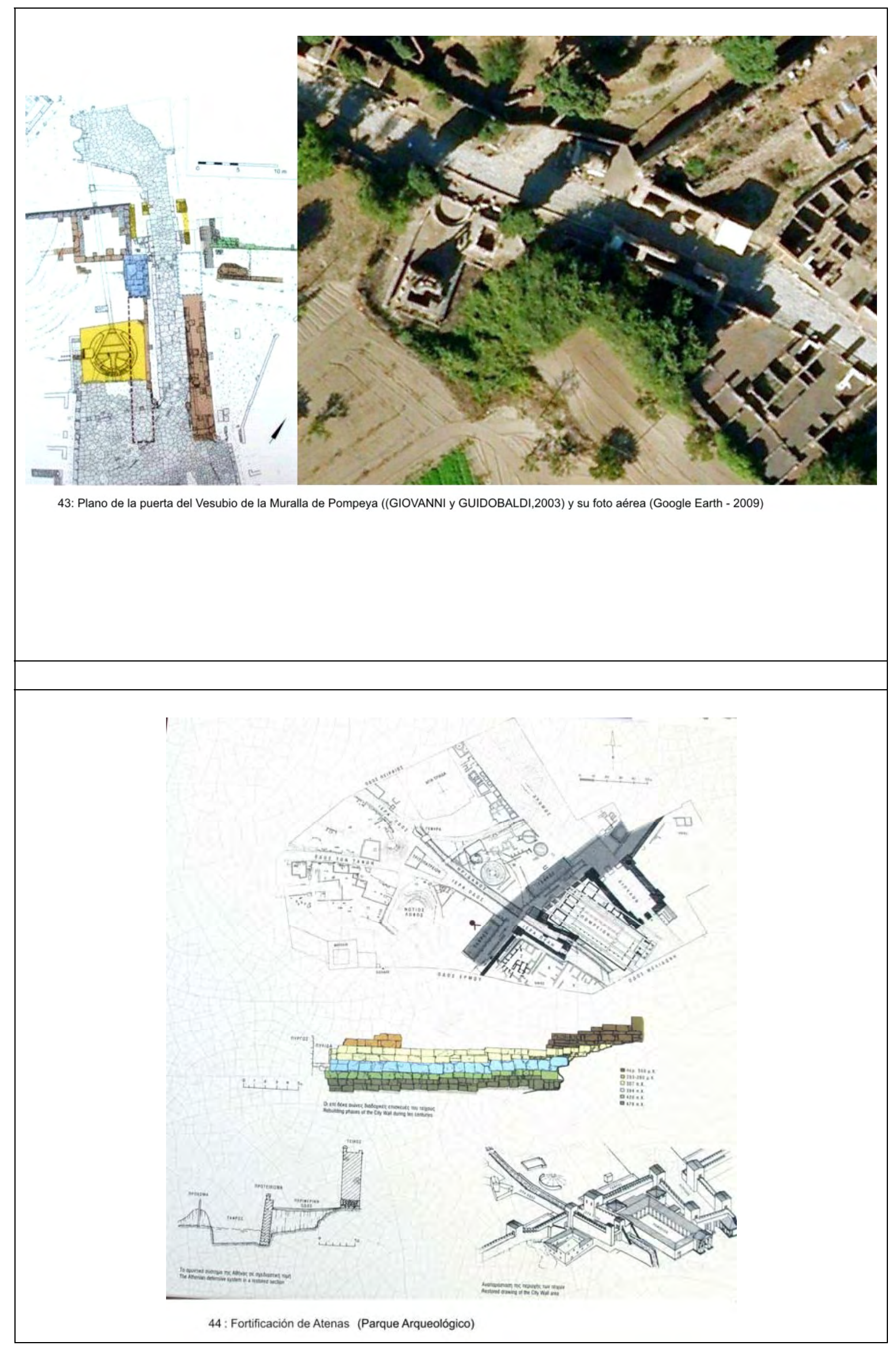




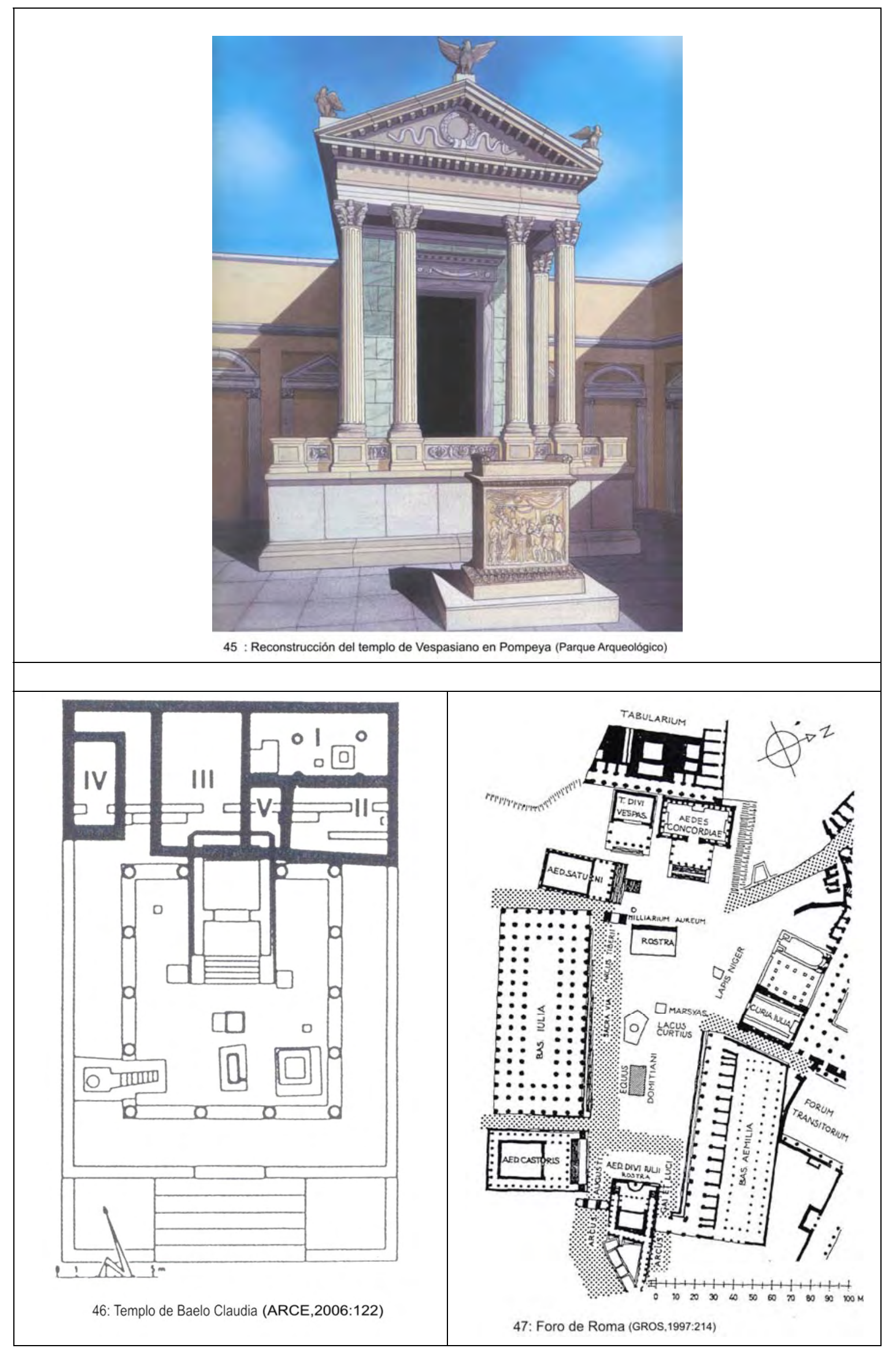




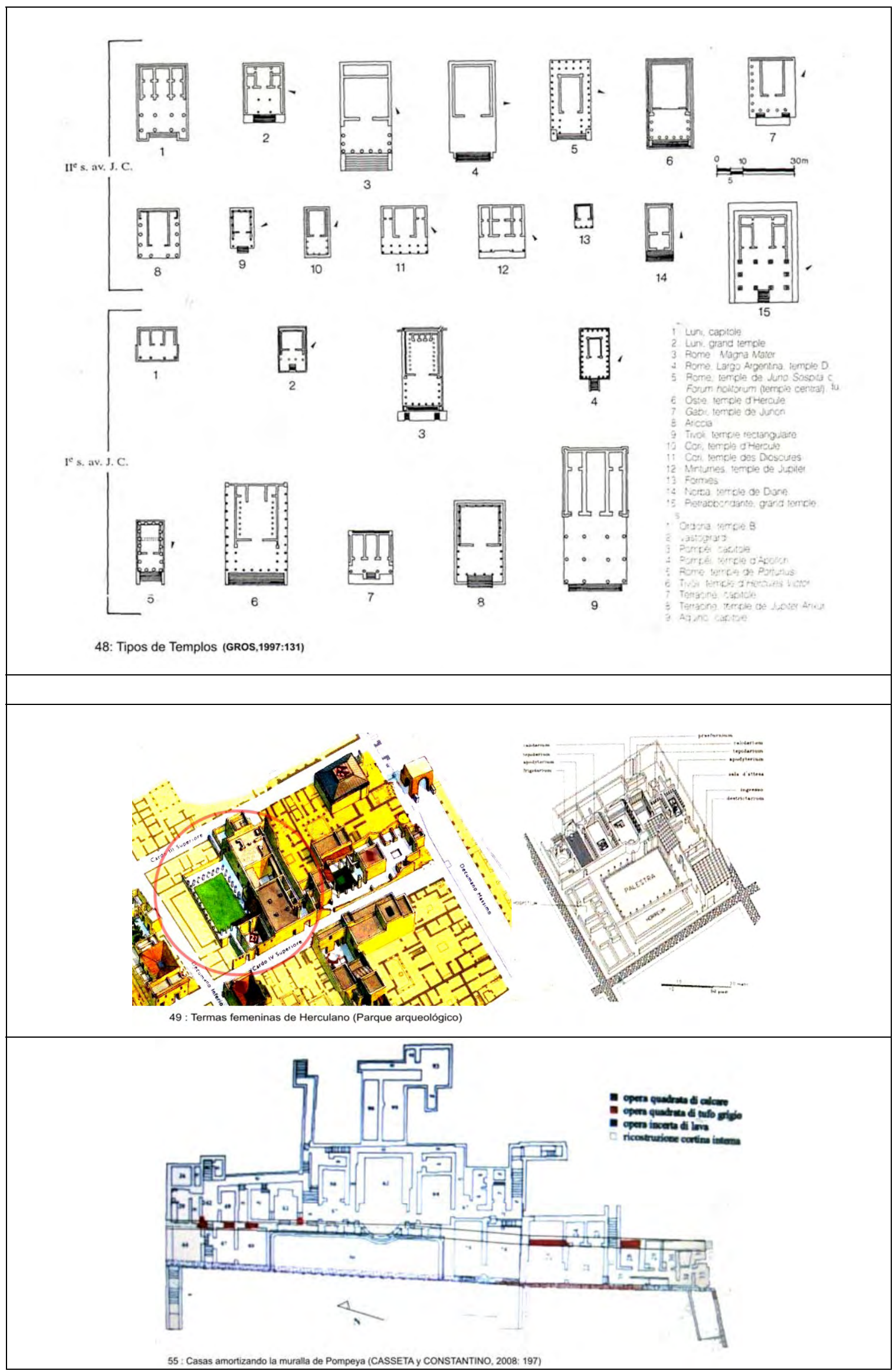




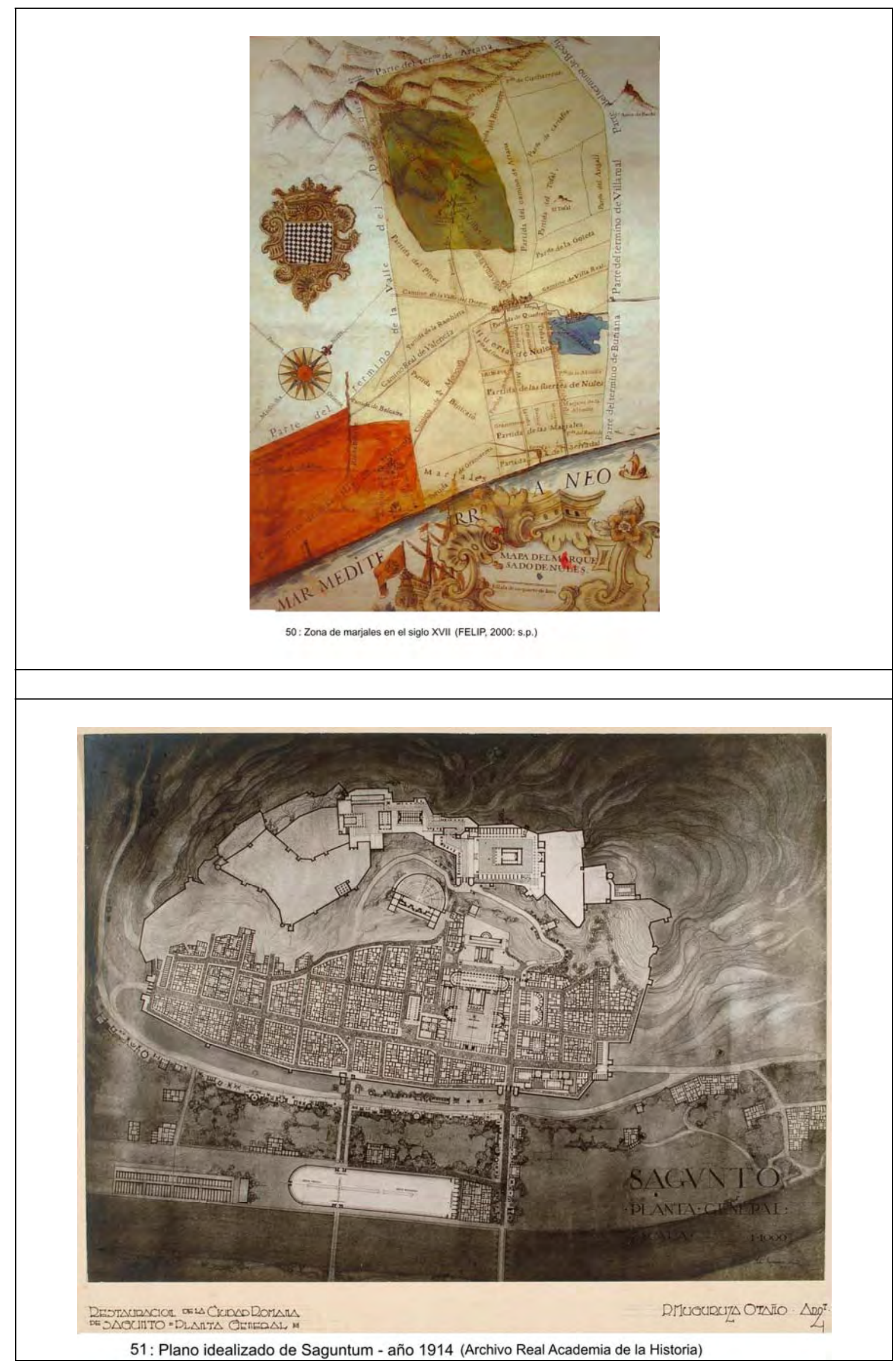




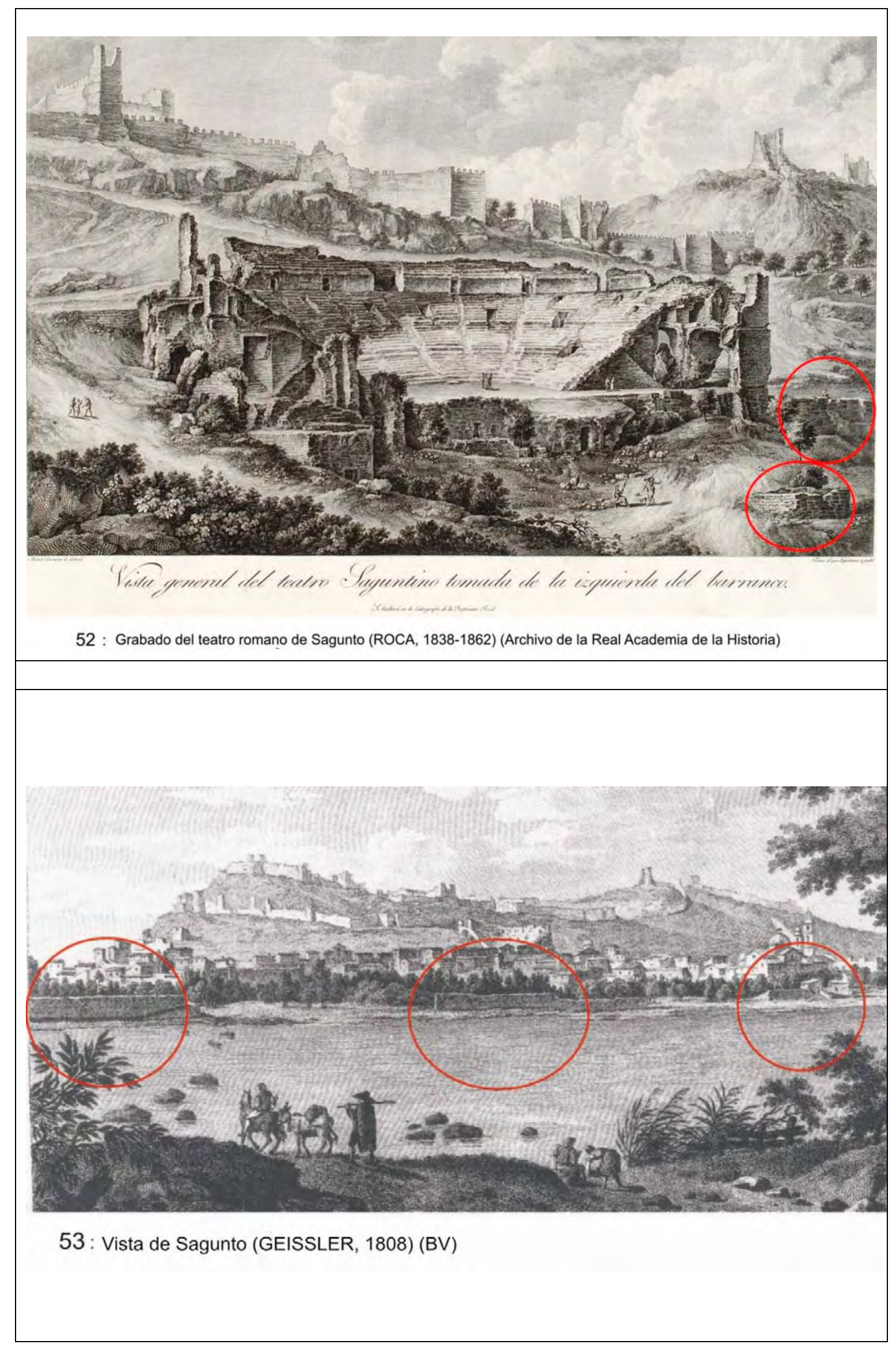




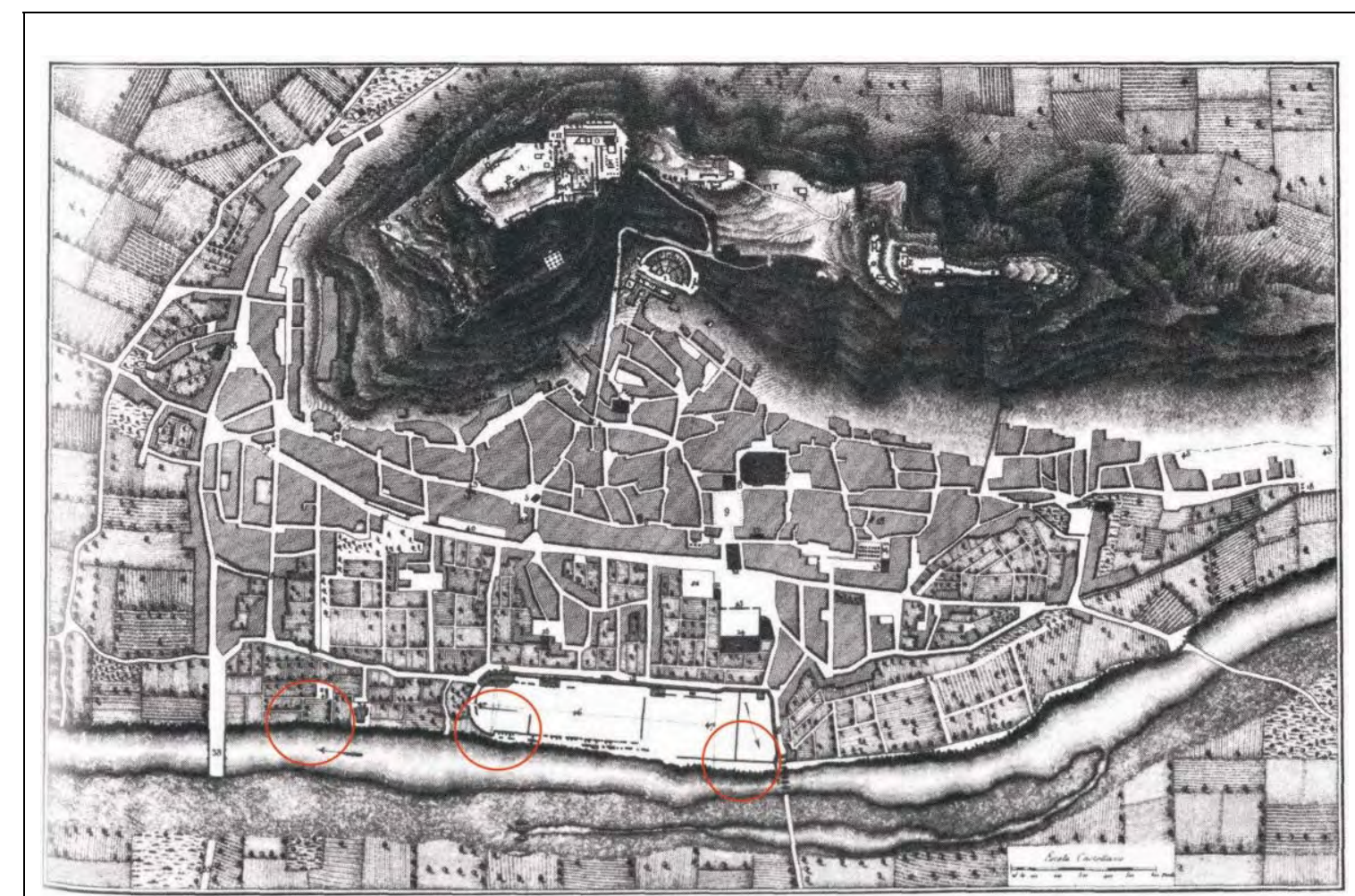

54 : Plano de Laborde año 1808 (BV)

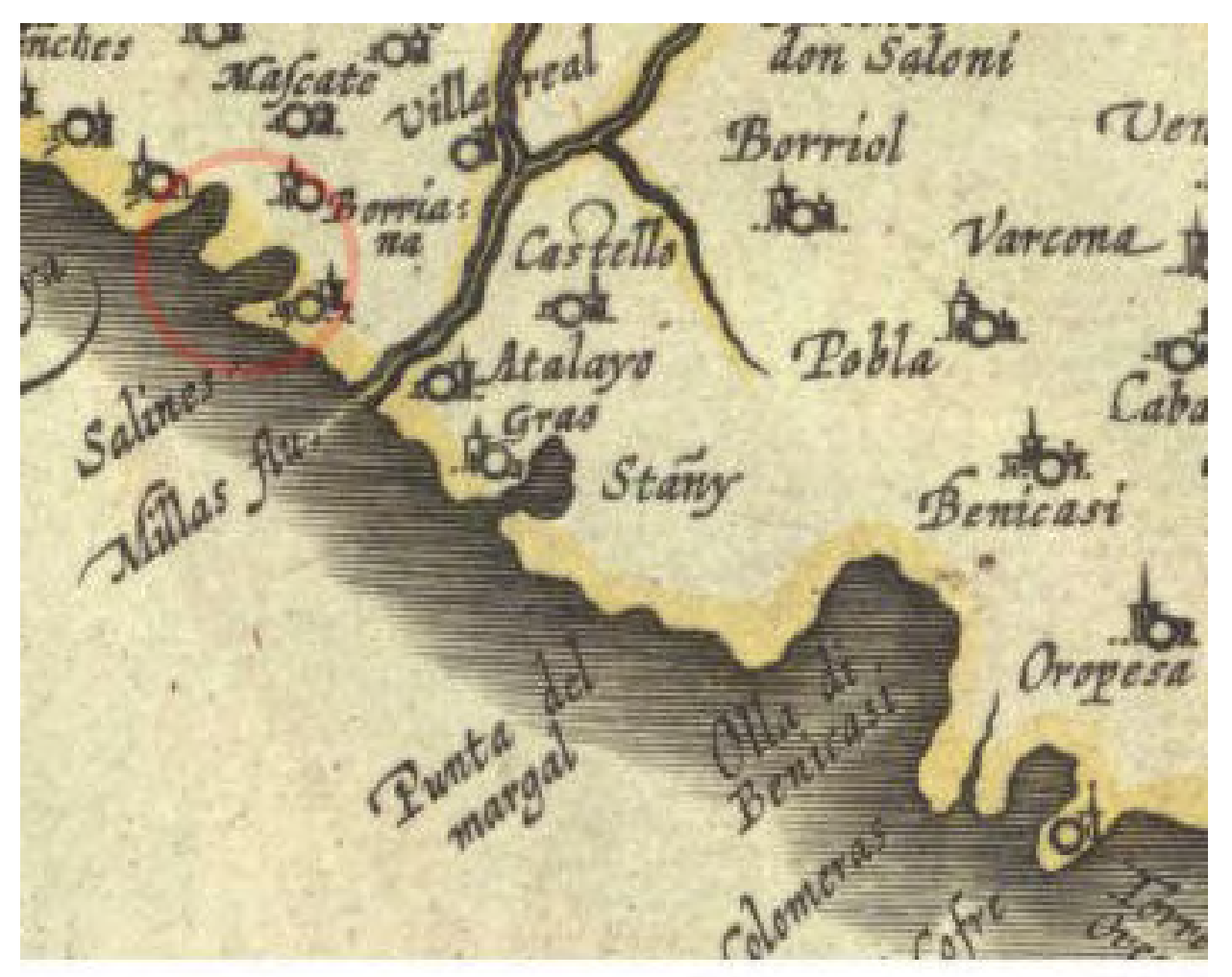

56 : Plano de la costa de Burriana (BLAEU, 1630) 
FOTOS 


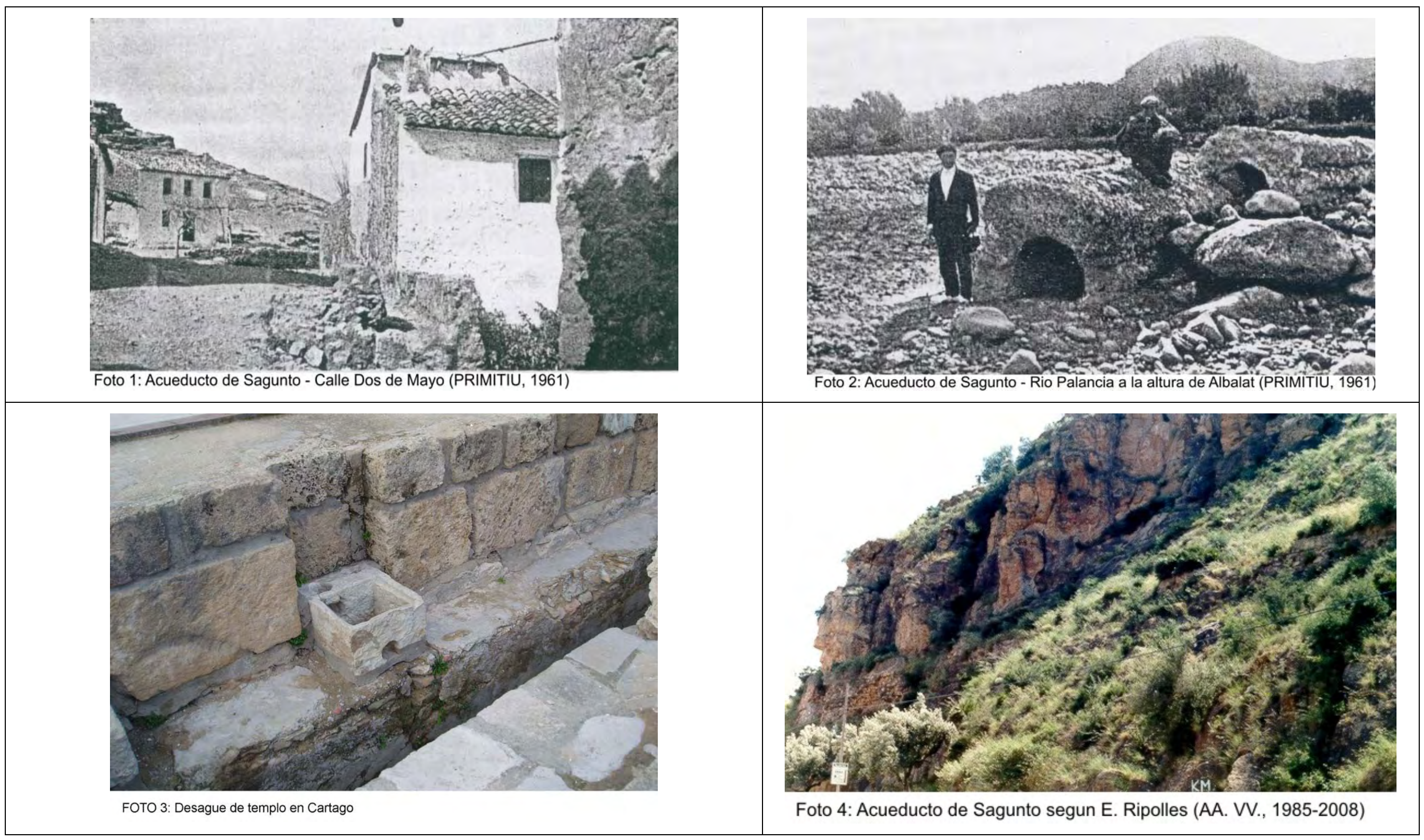




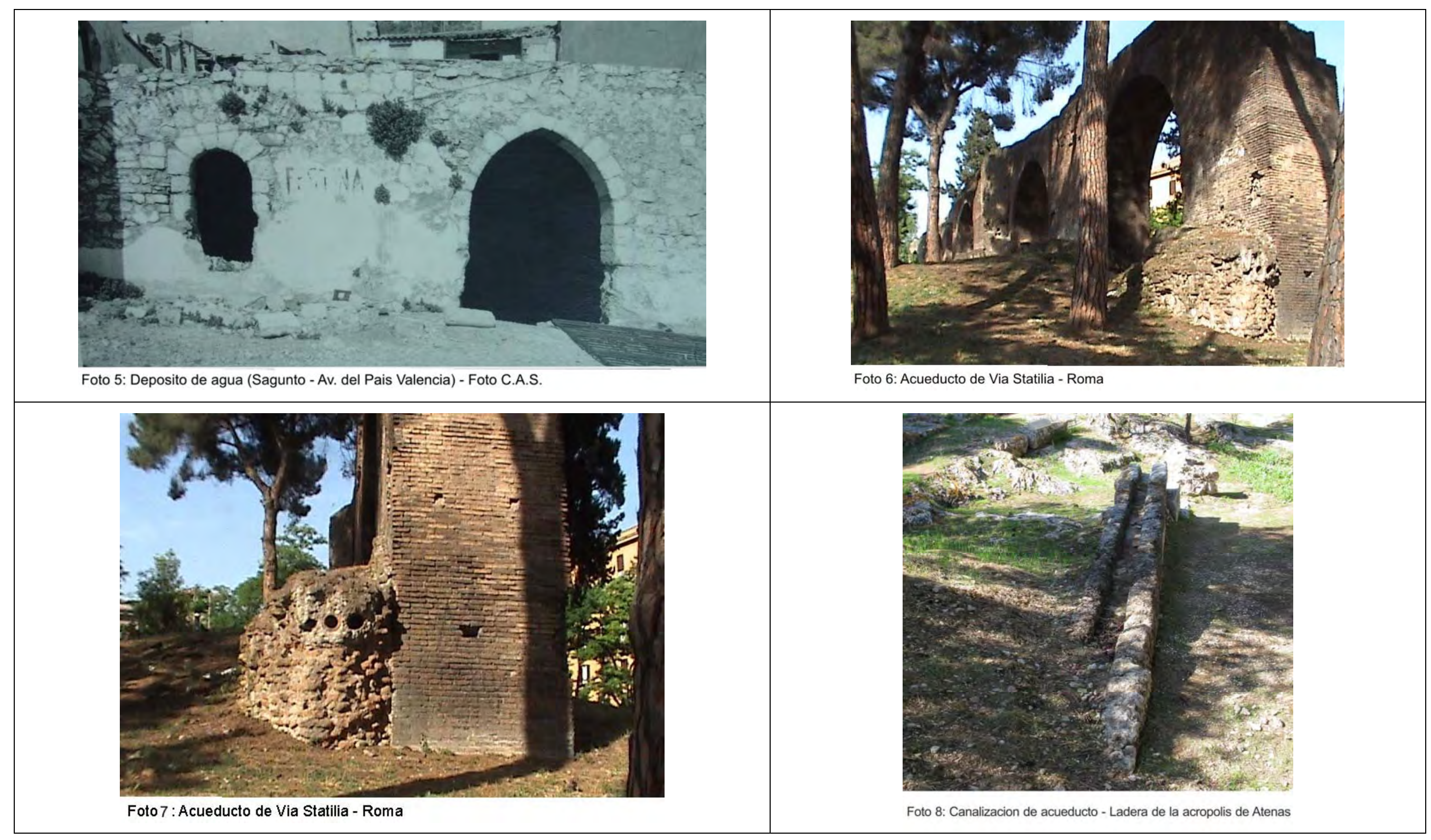




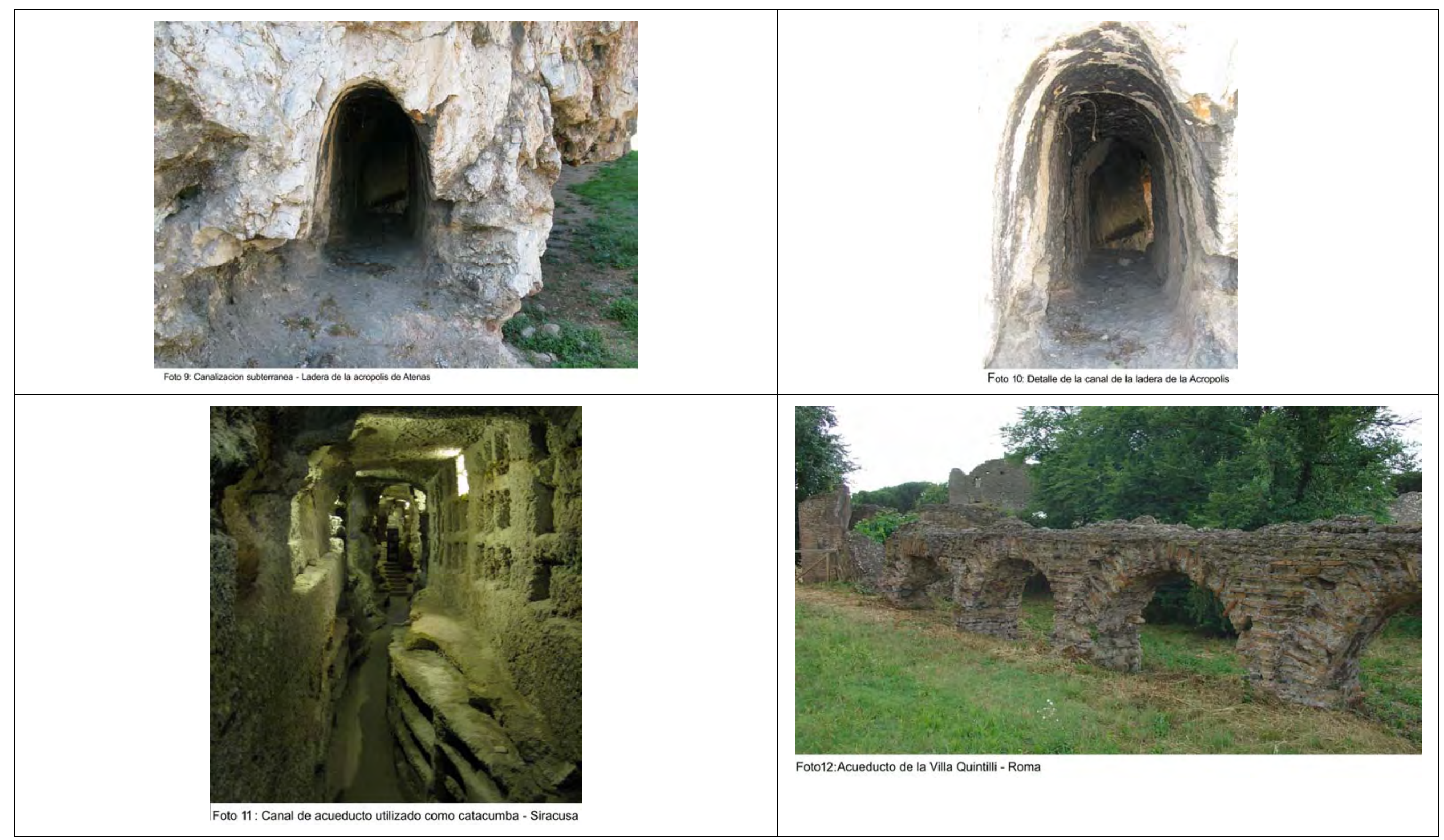




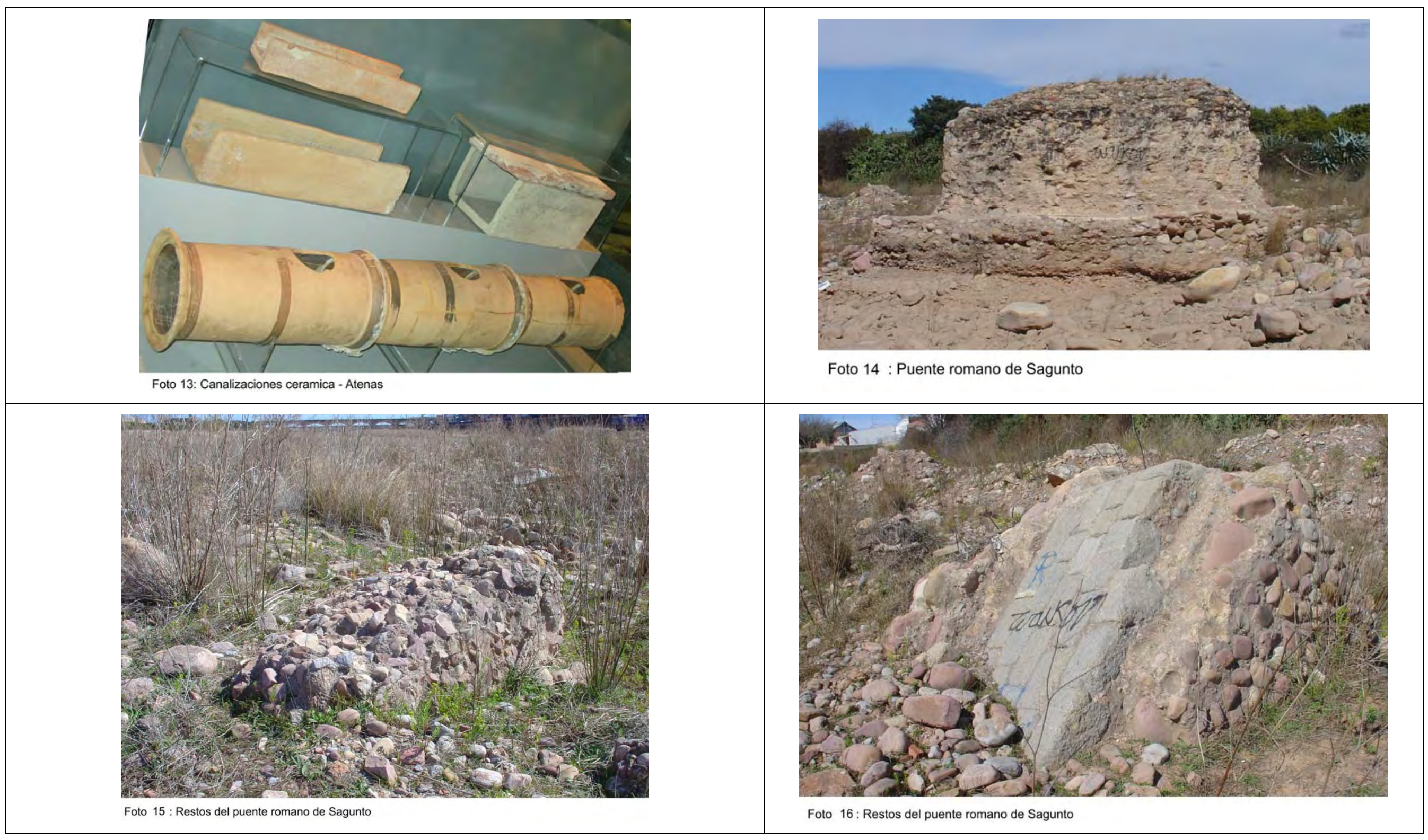




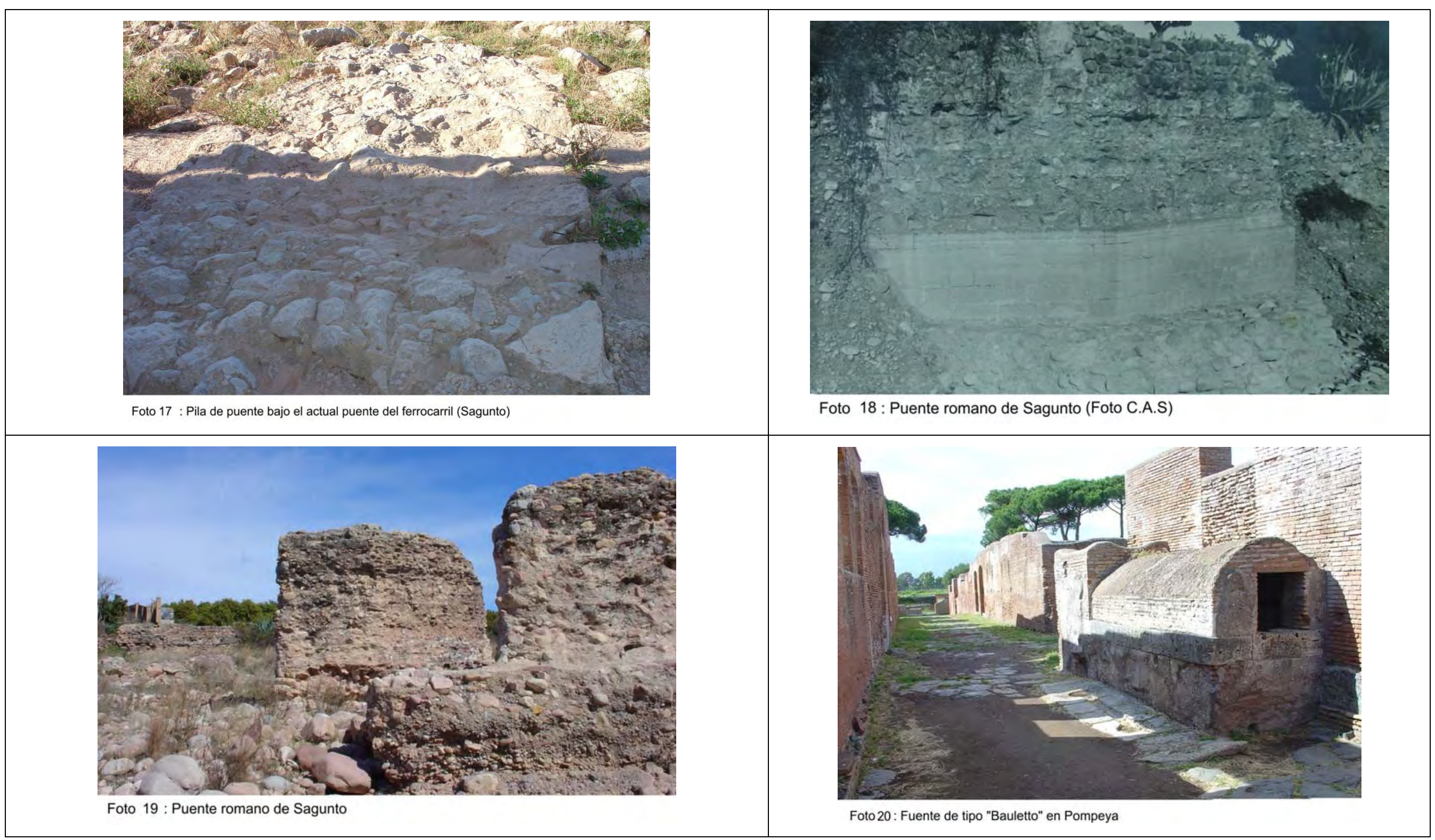




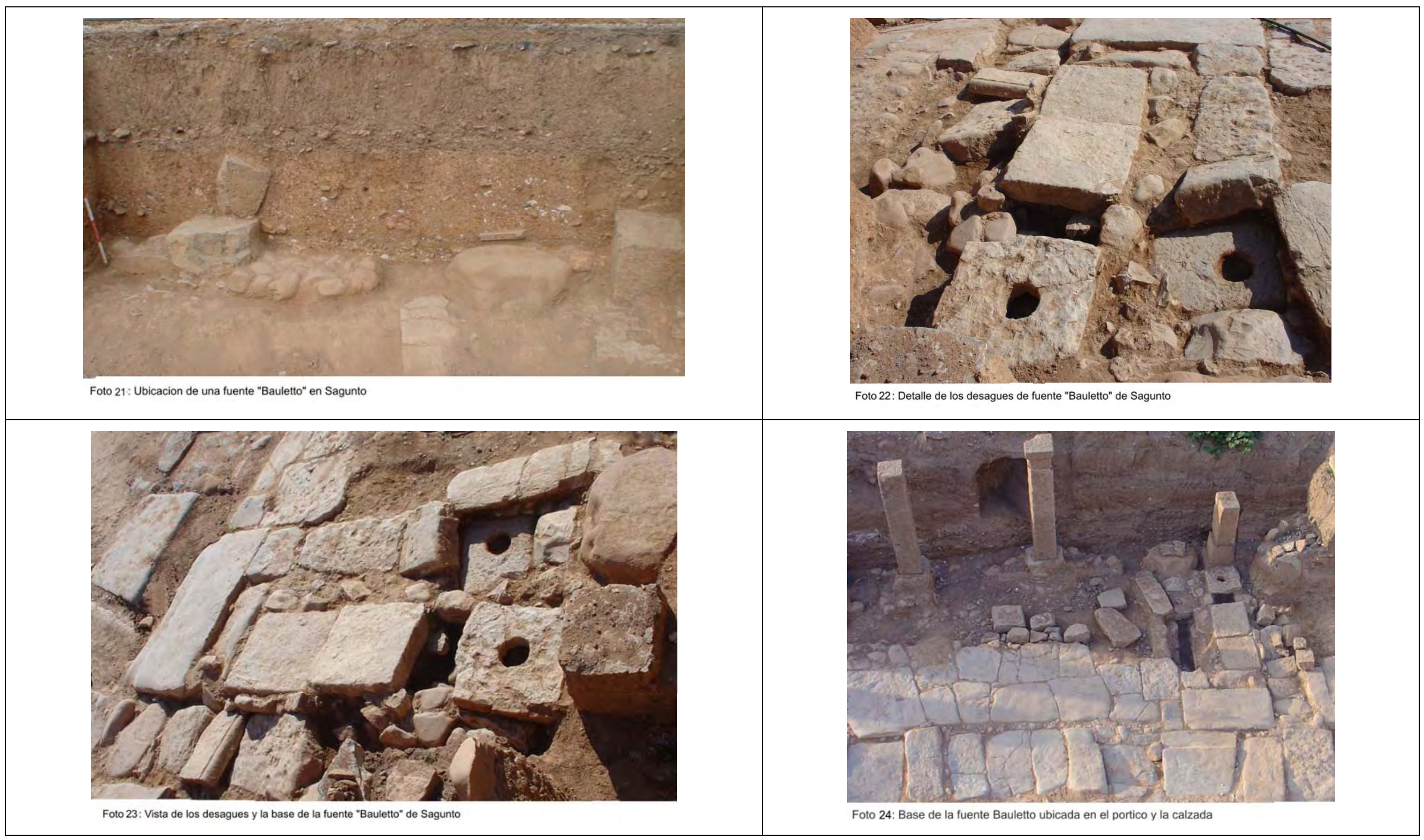




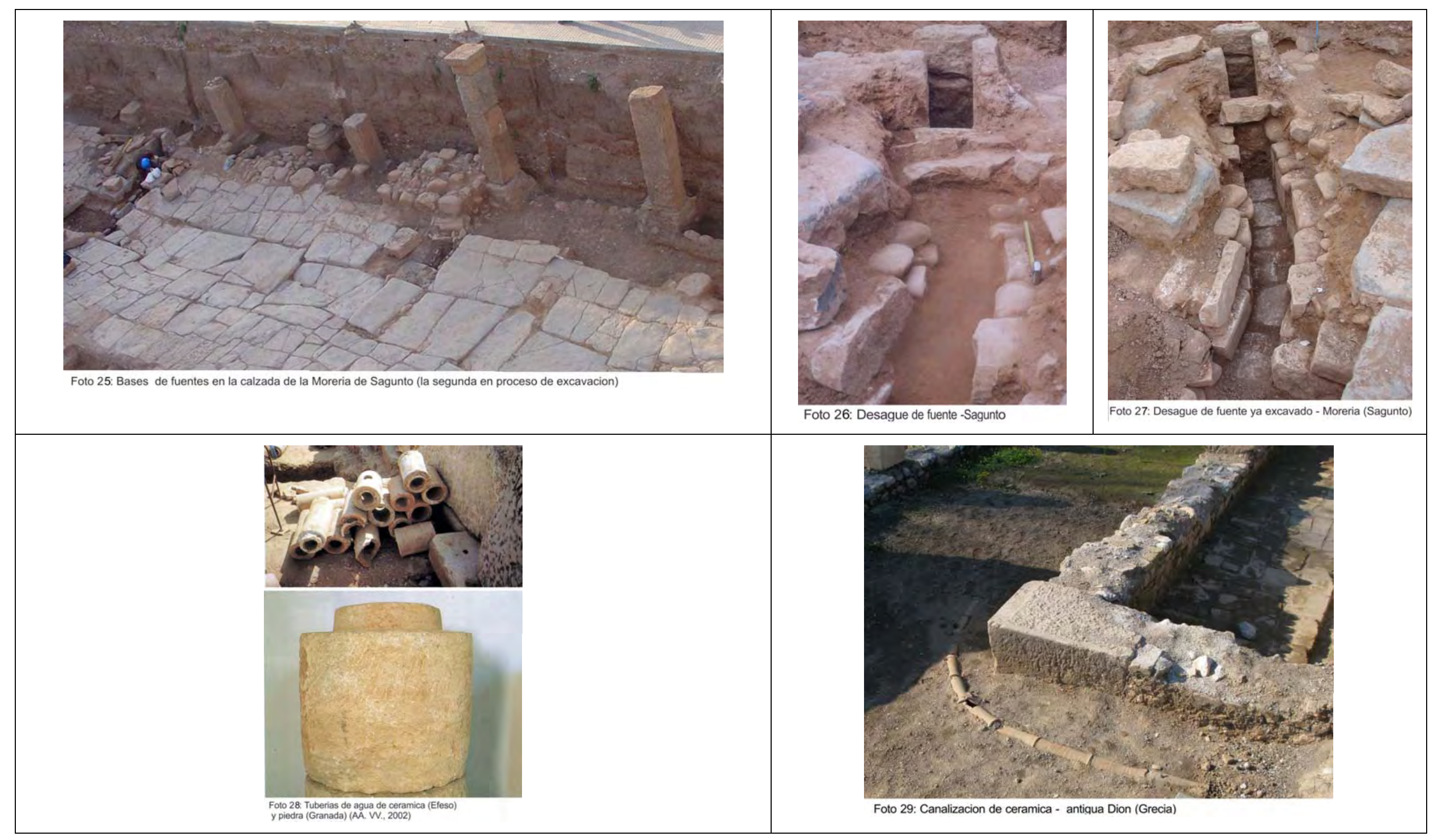




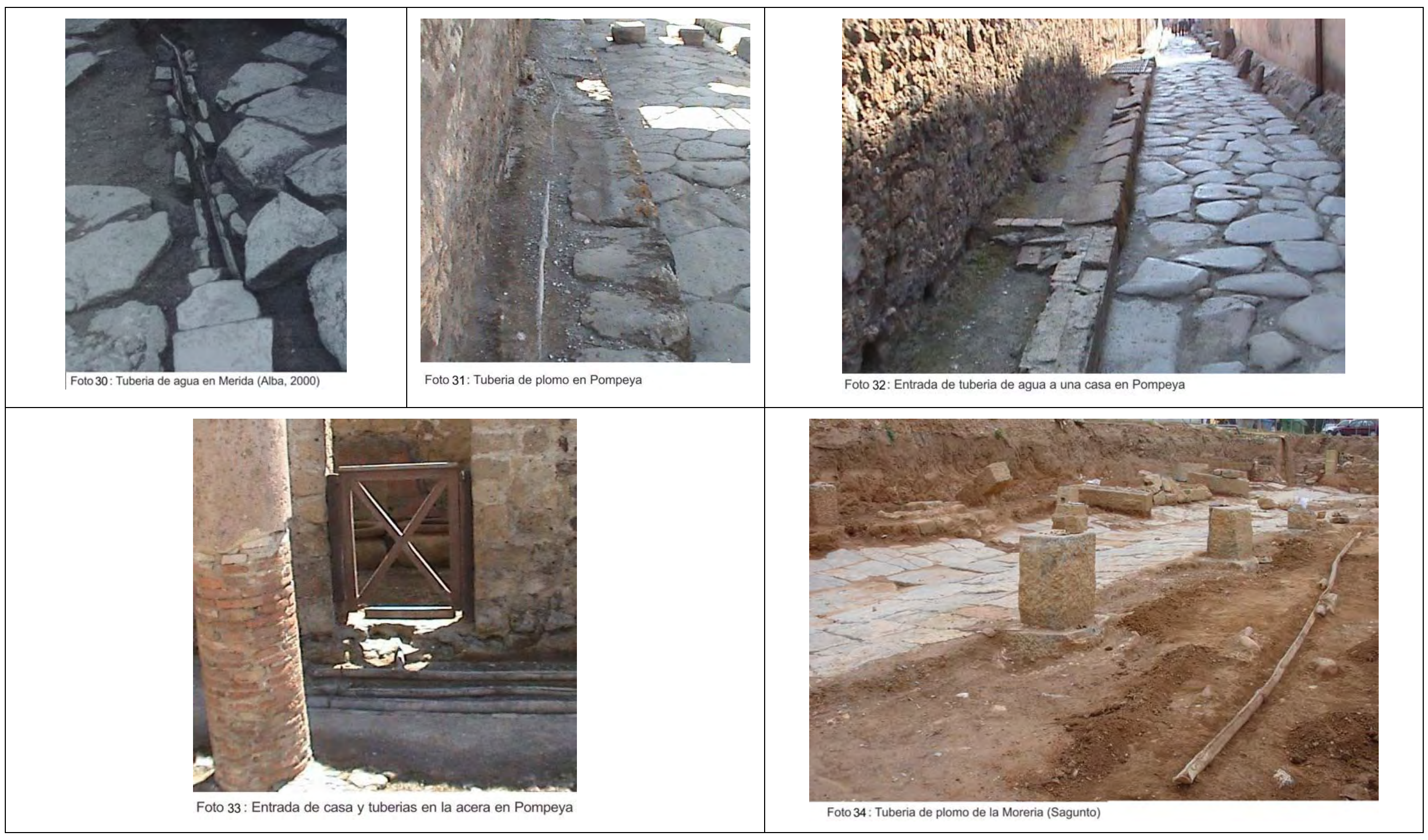




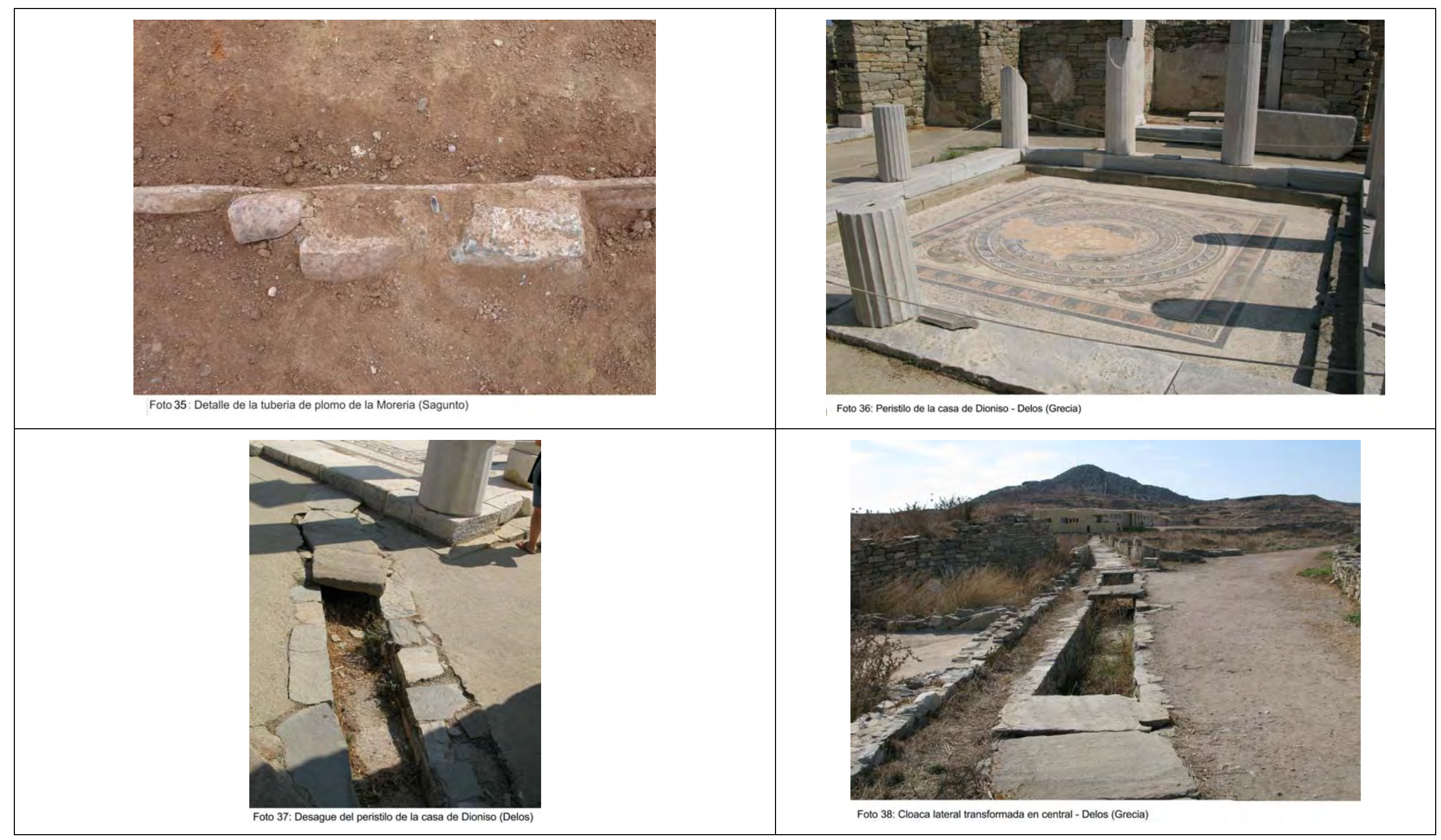




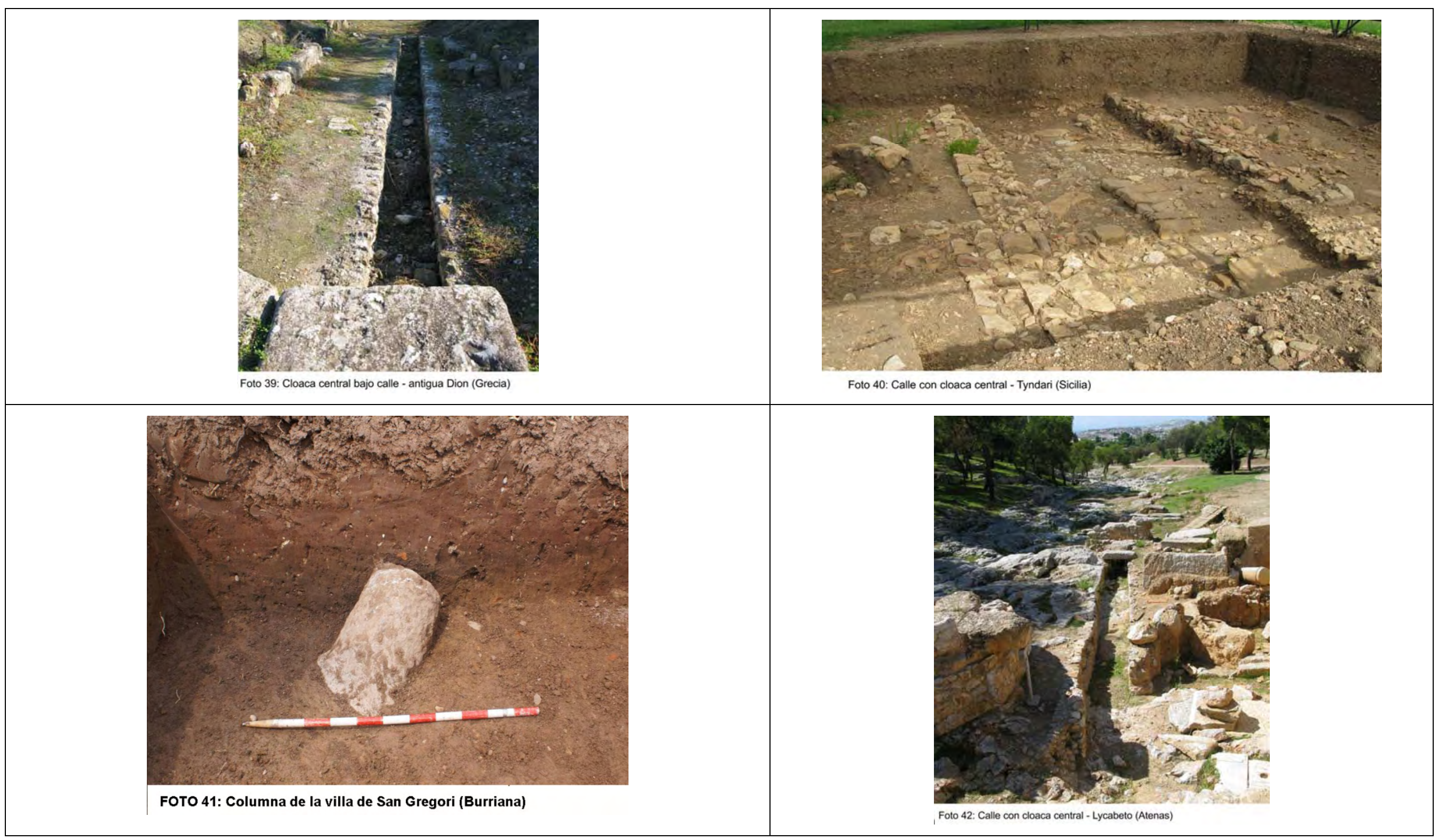




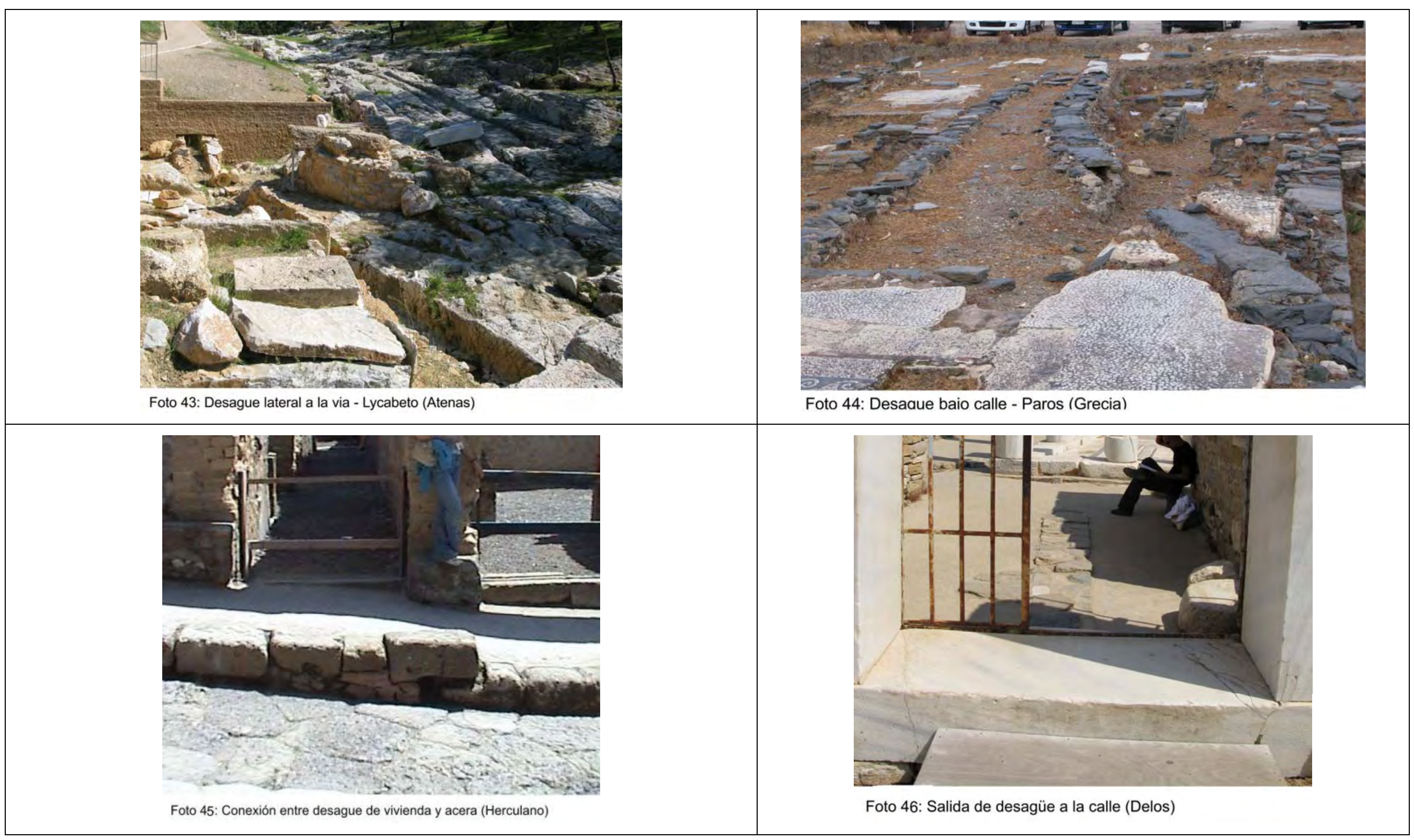




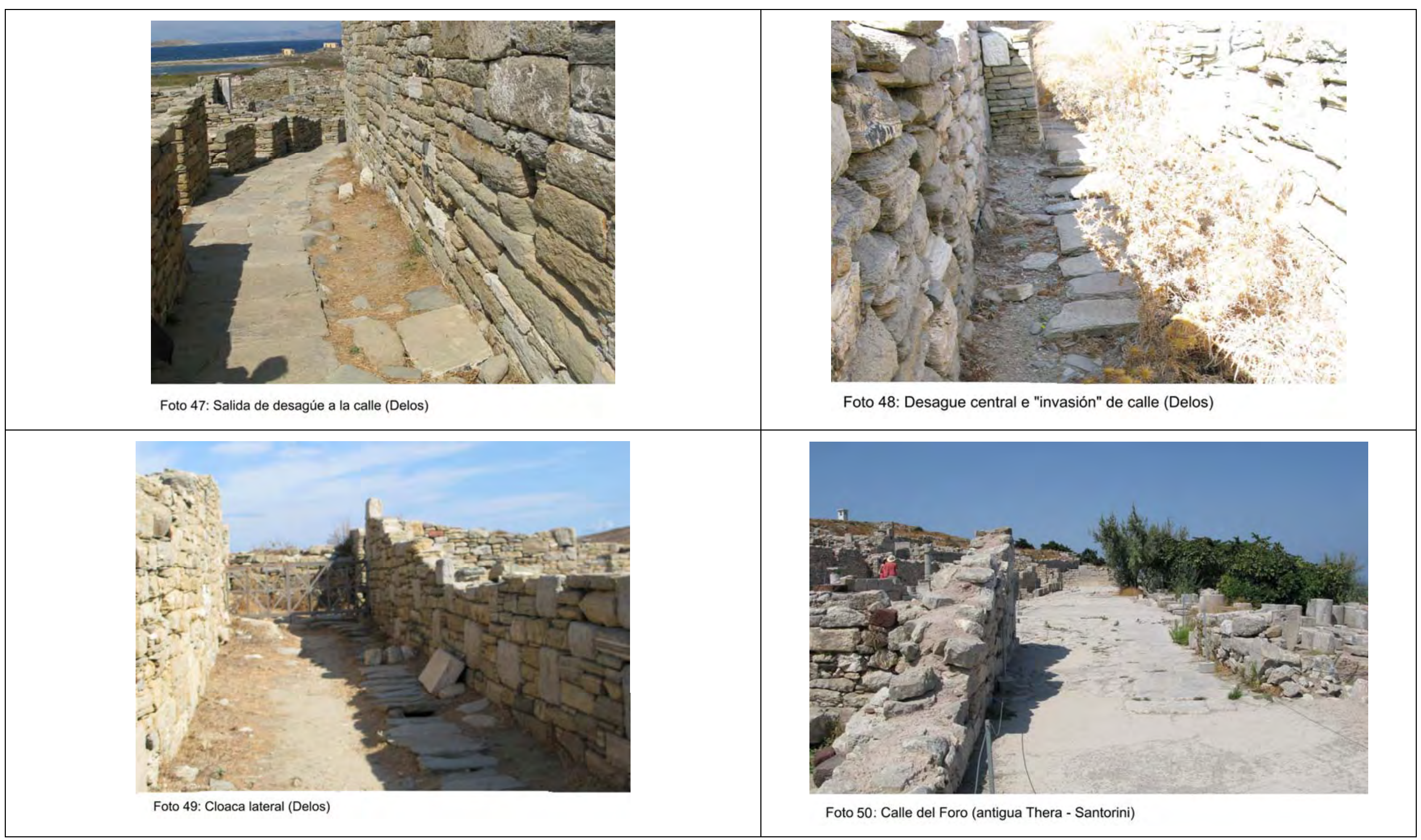




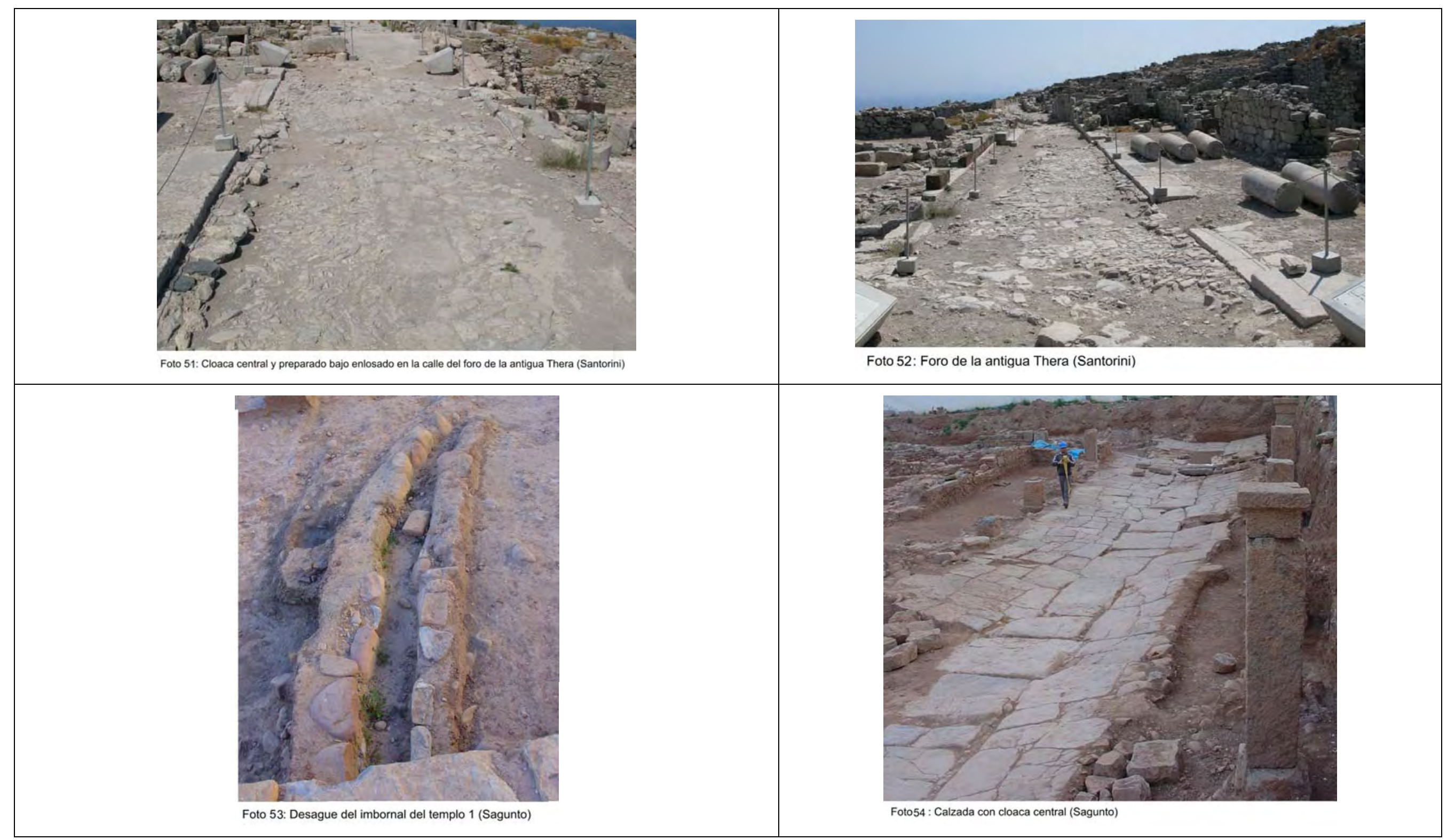




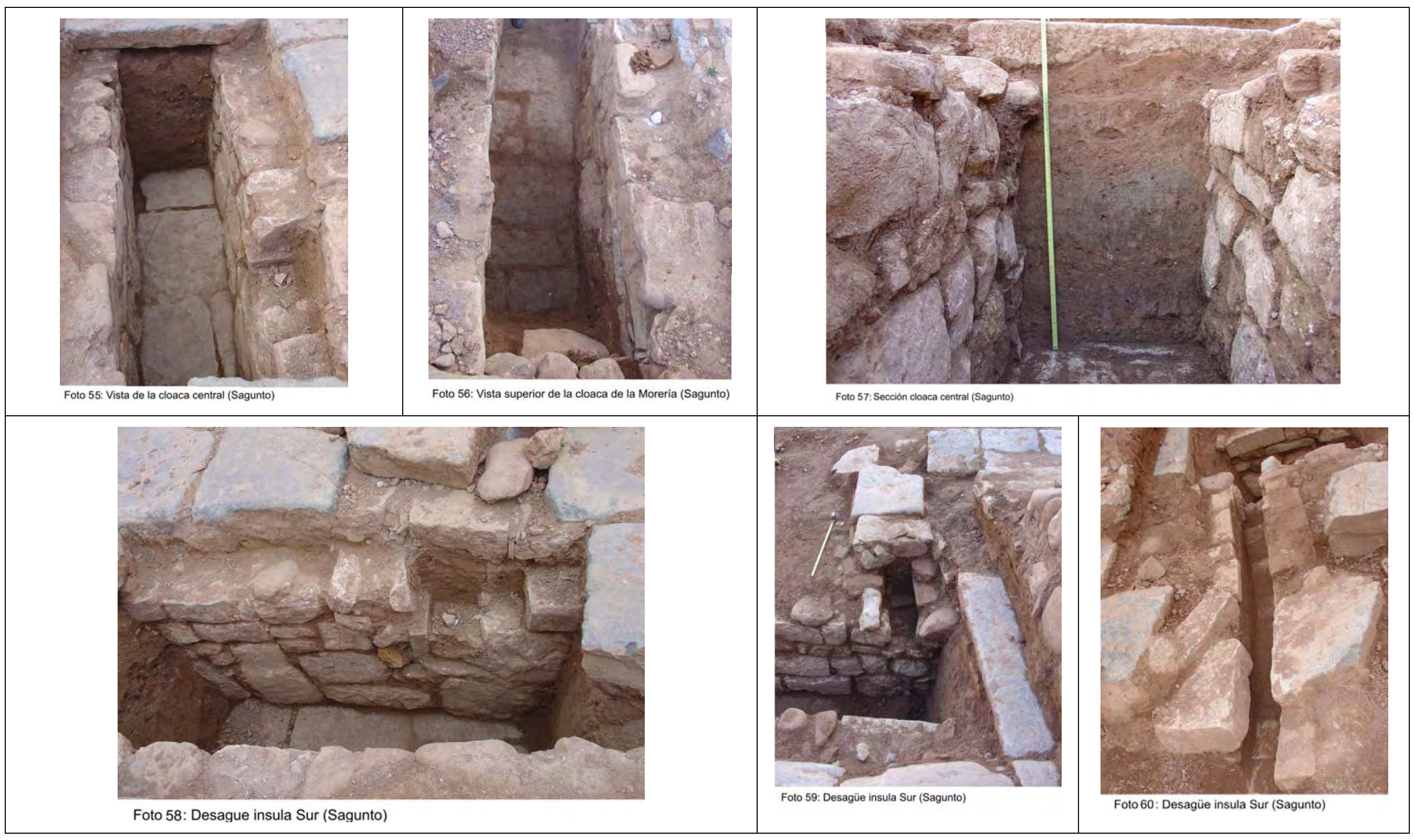




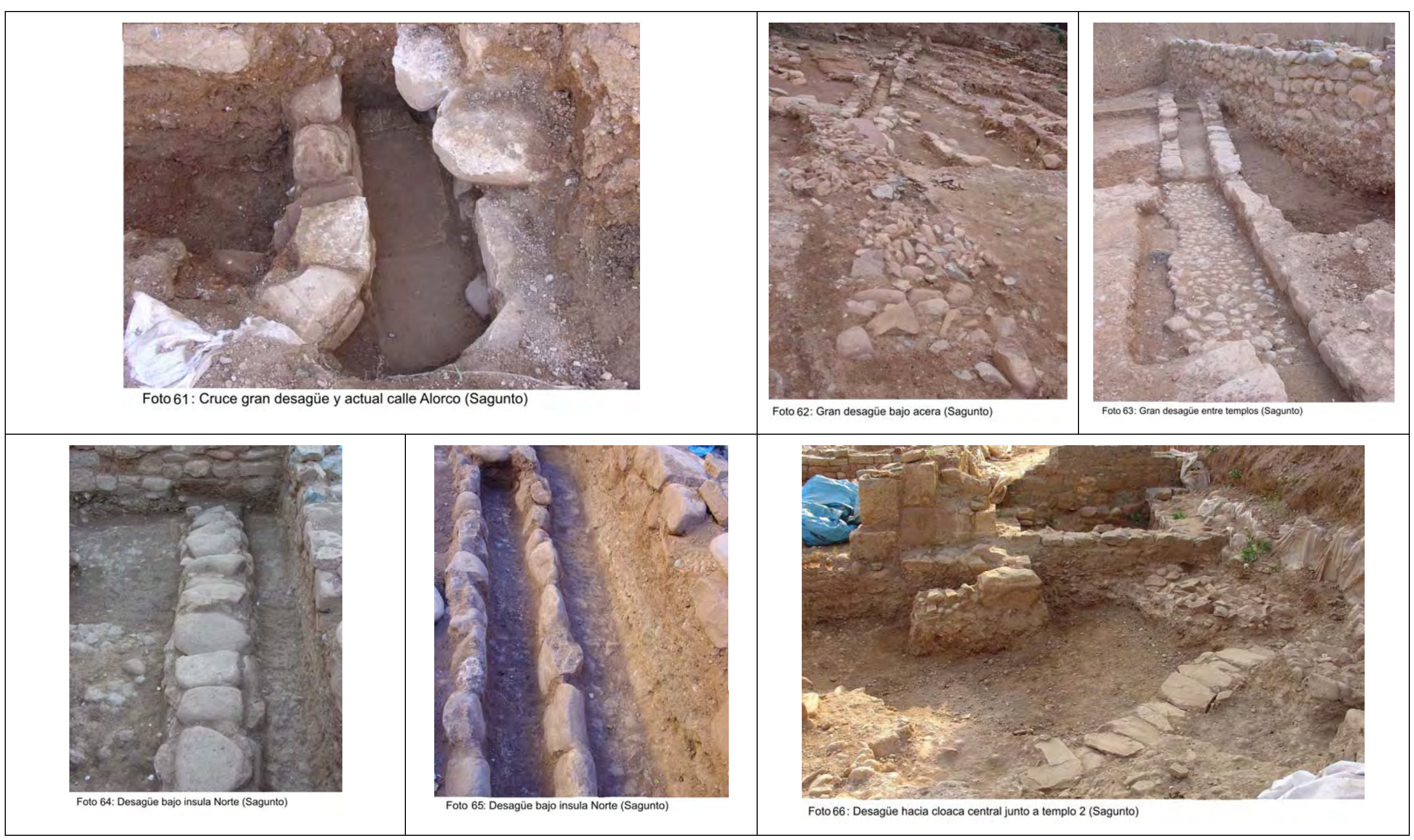




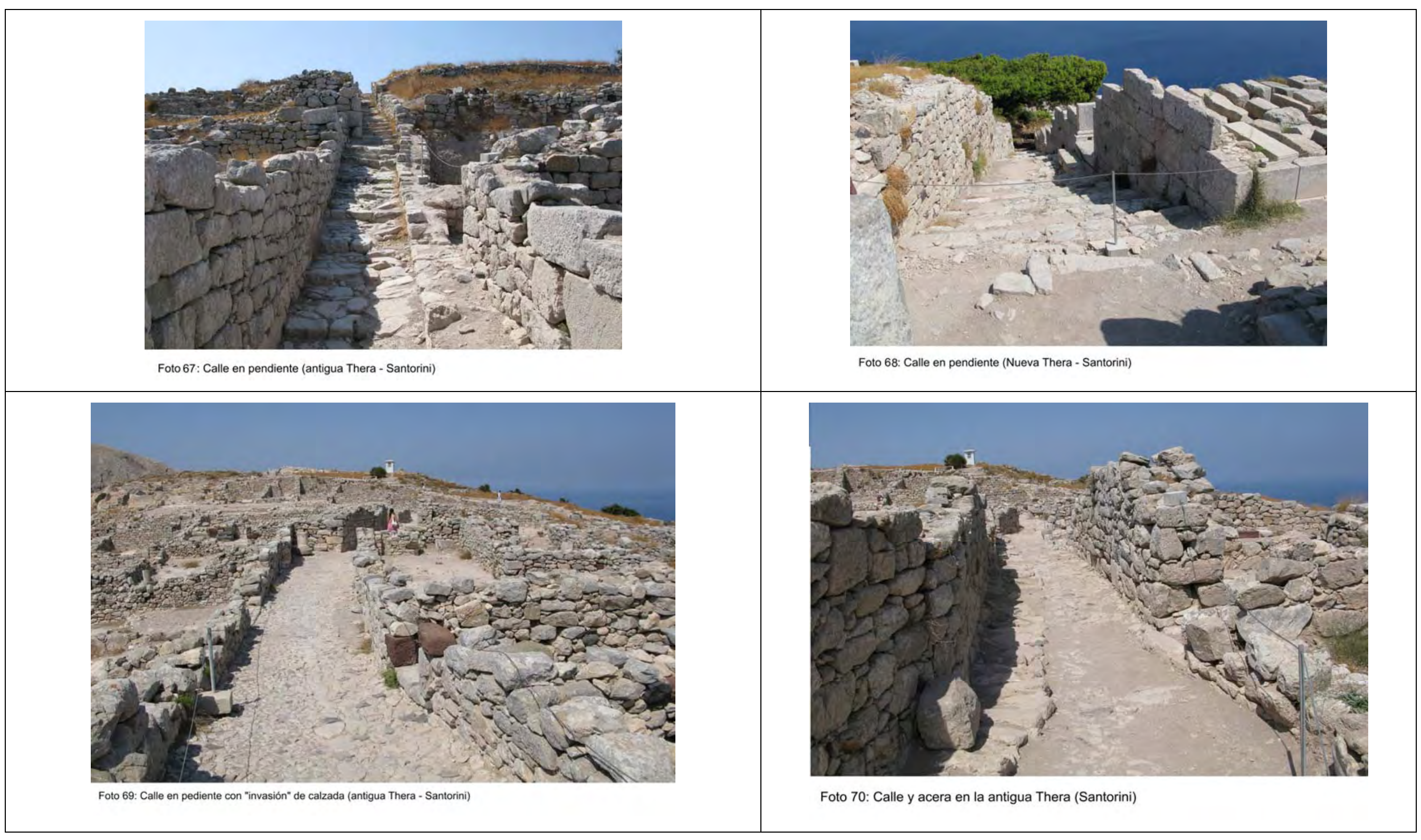




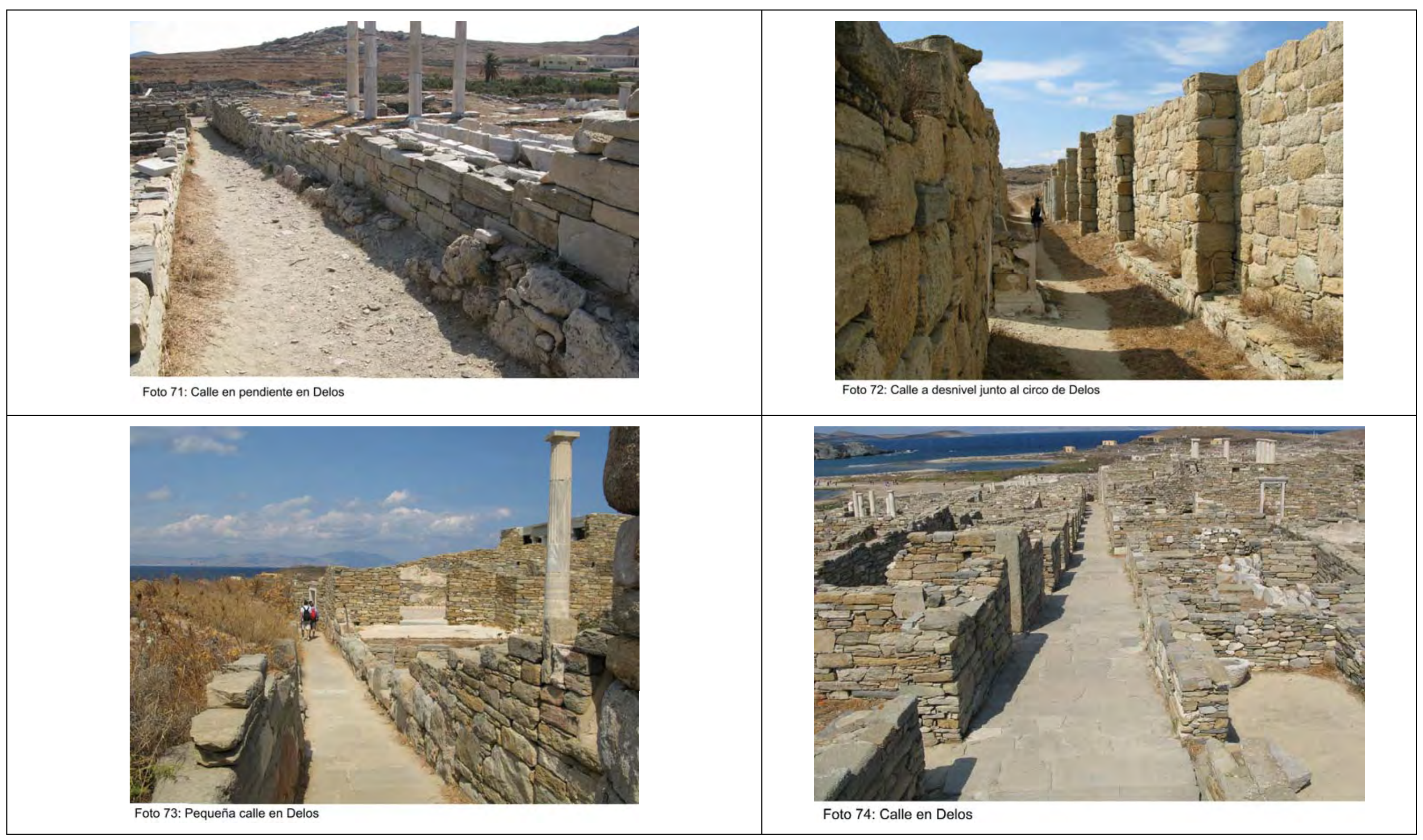




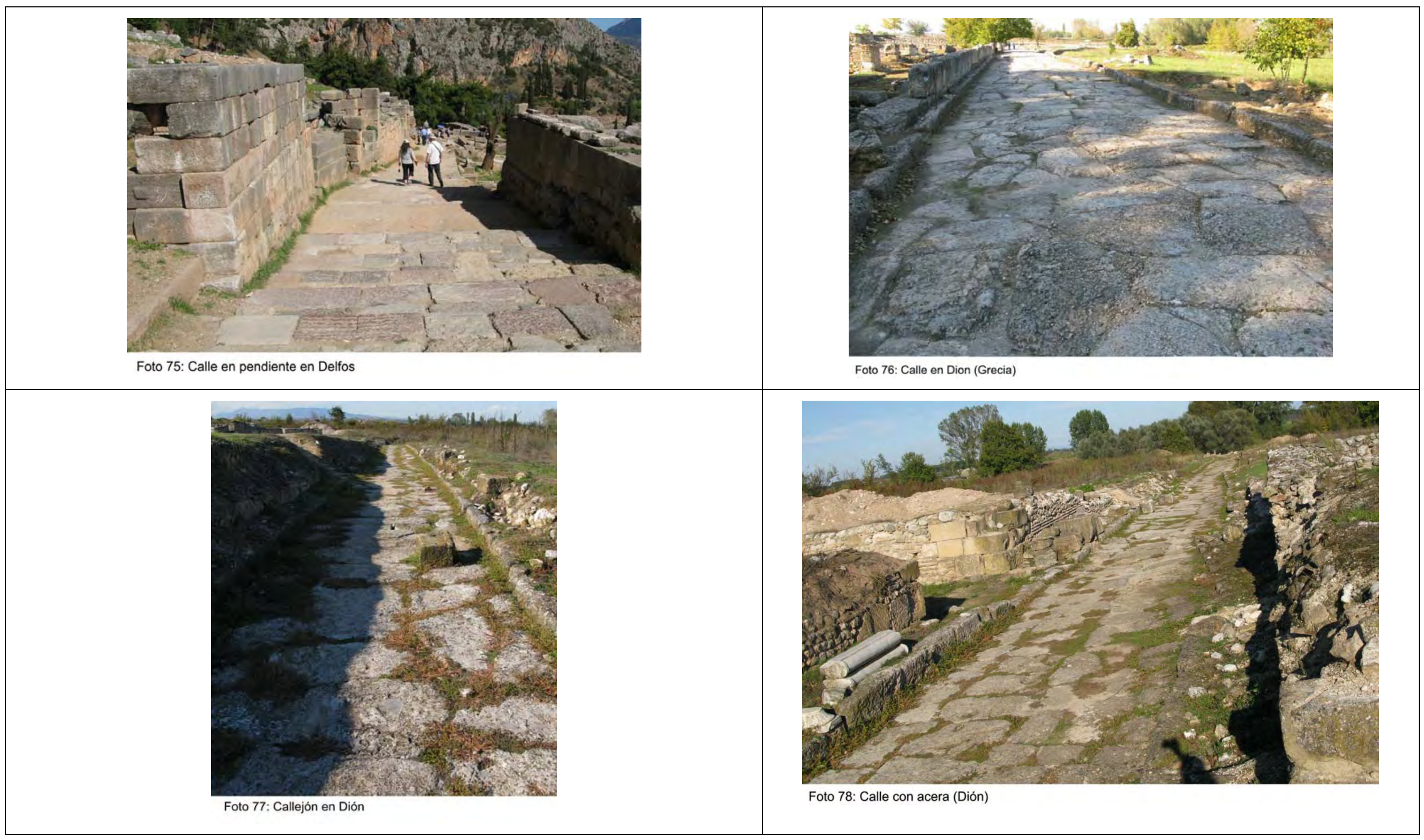




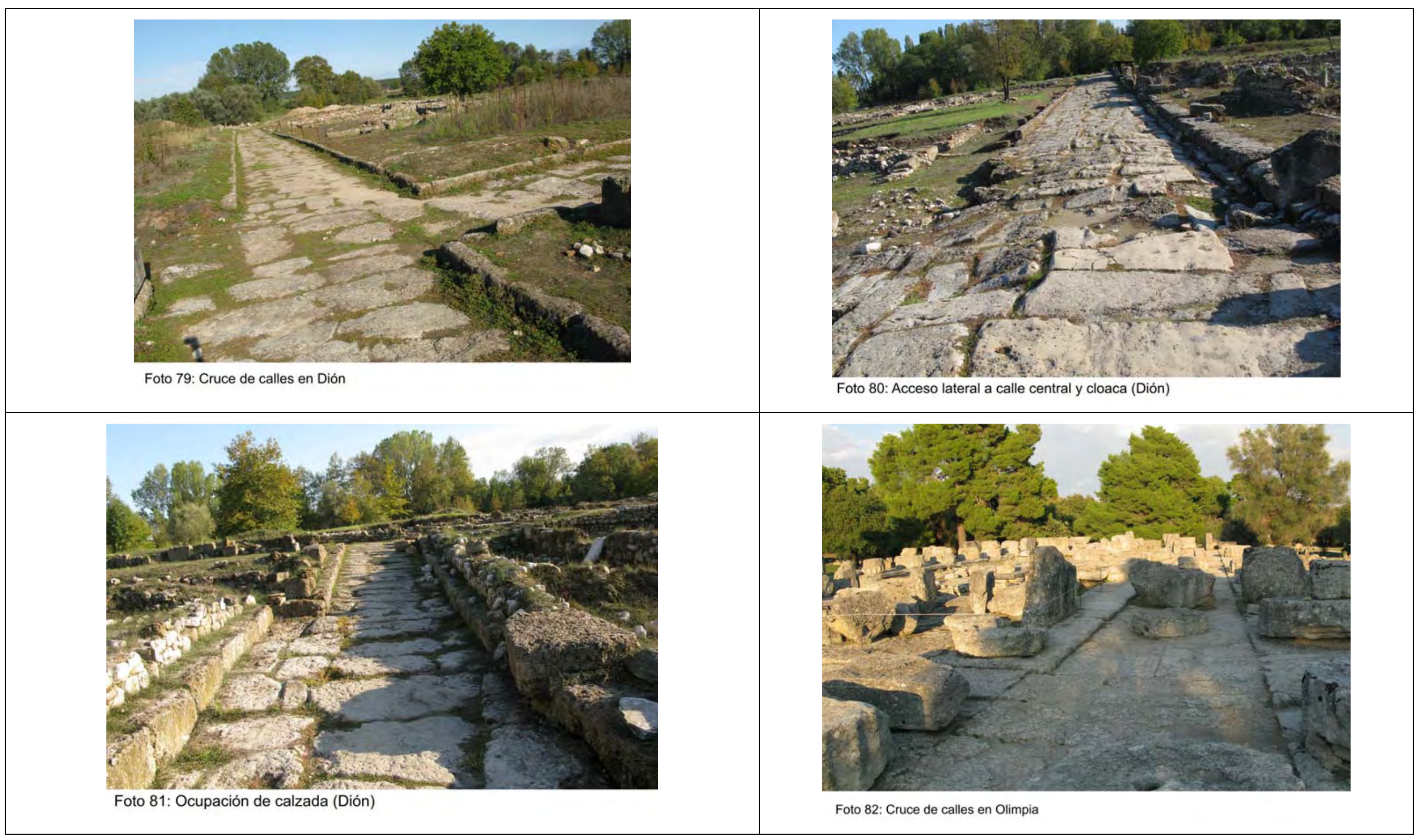




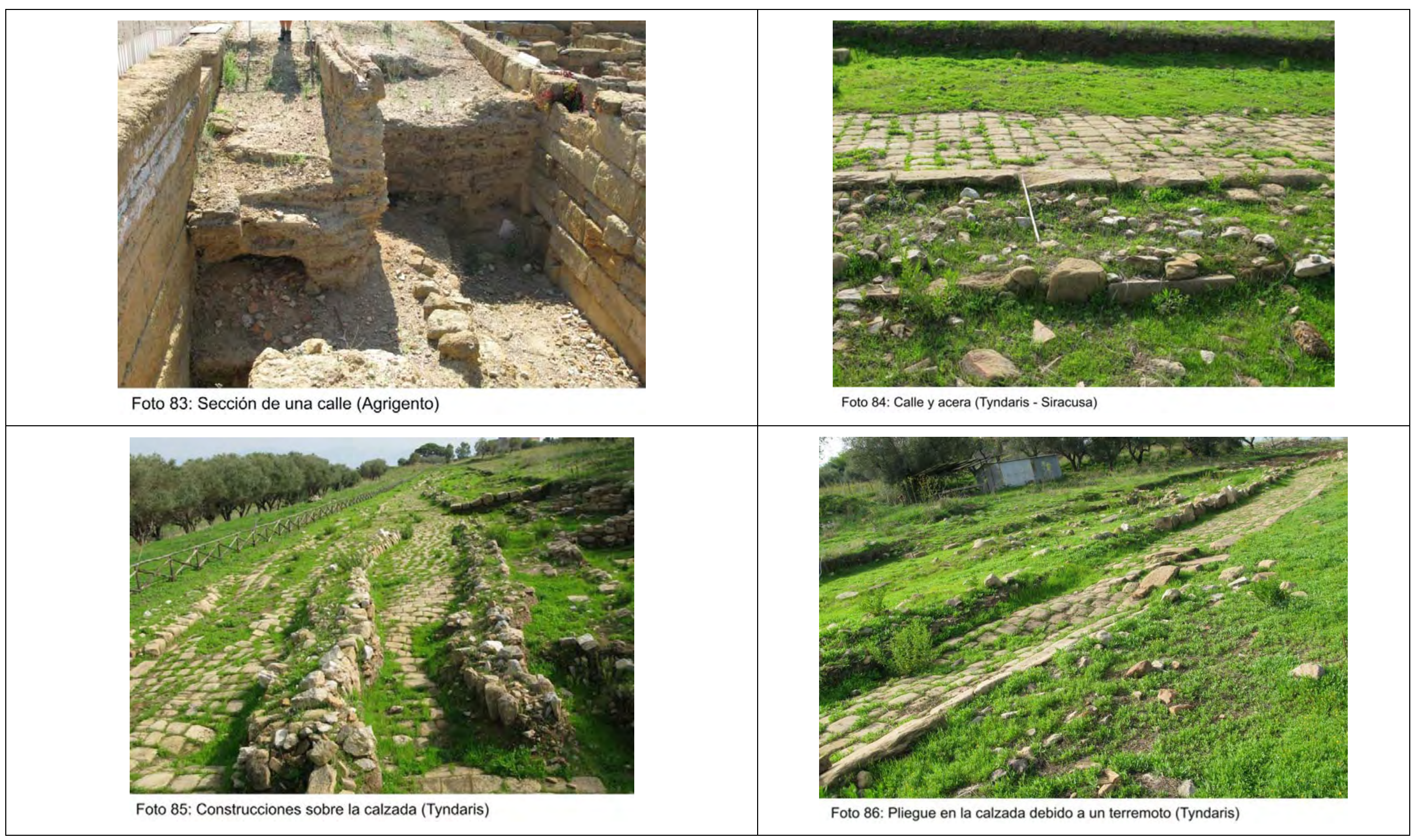




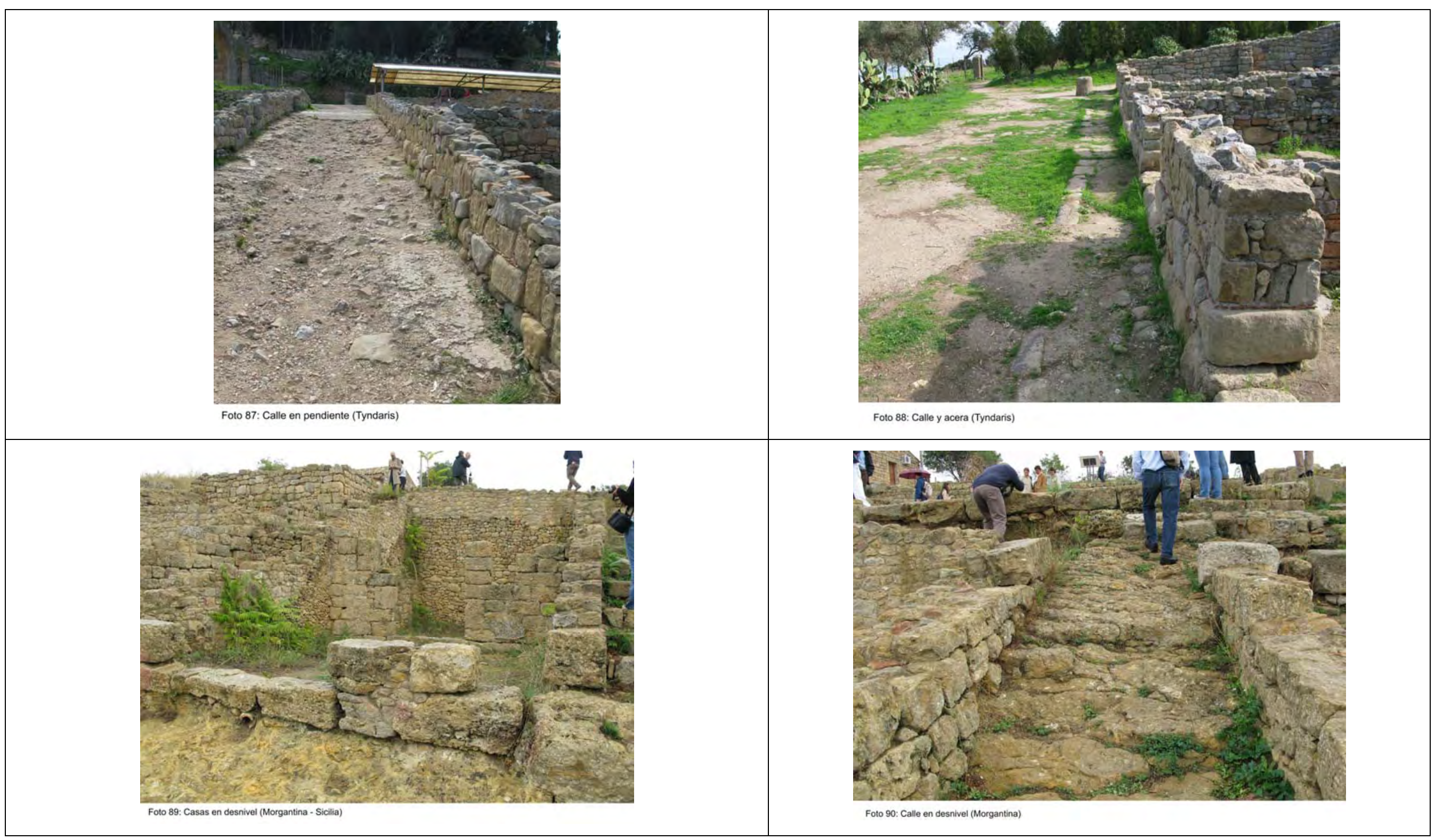




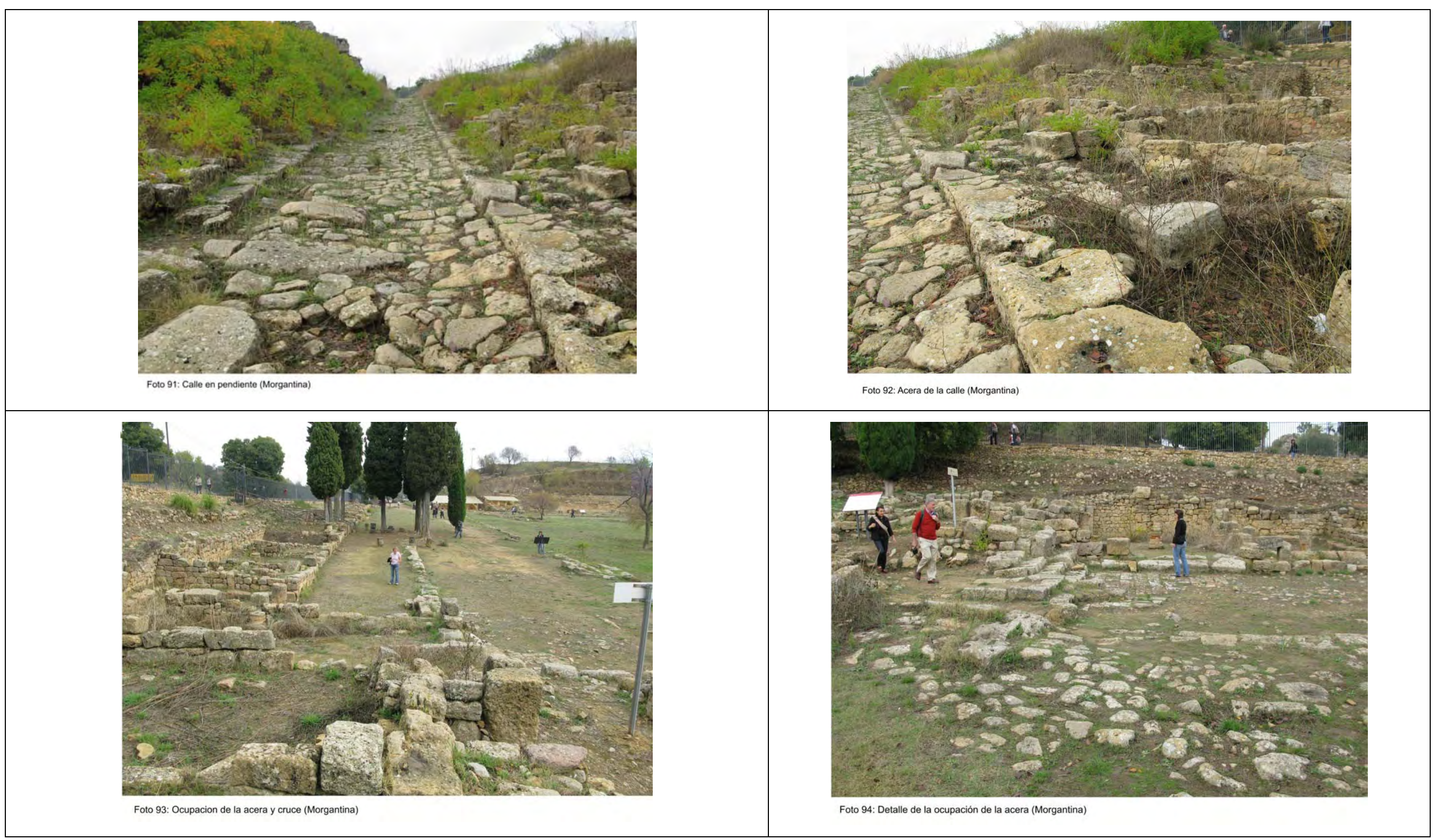




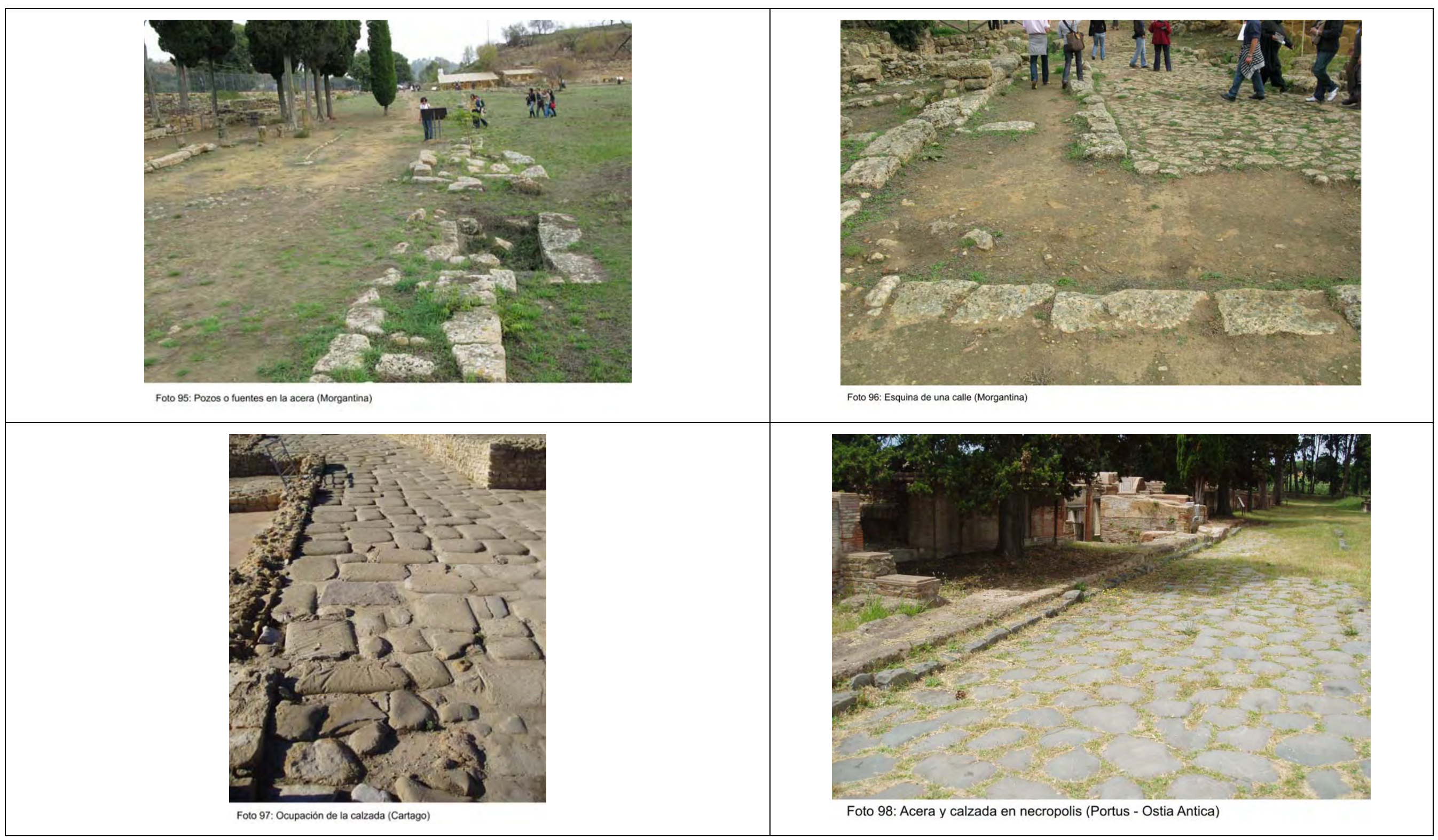




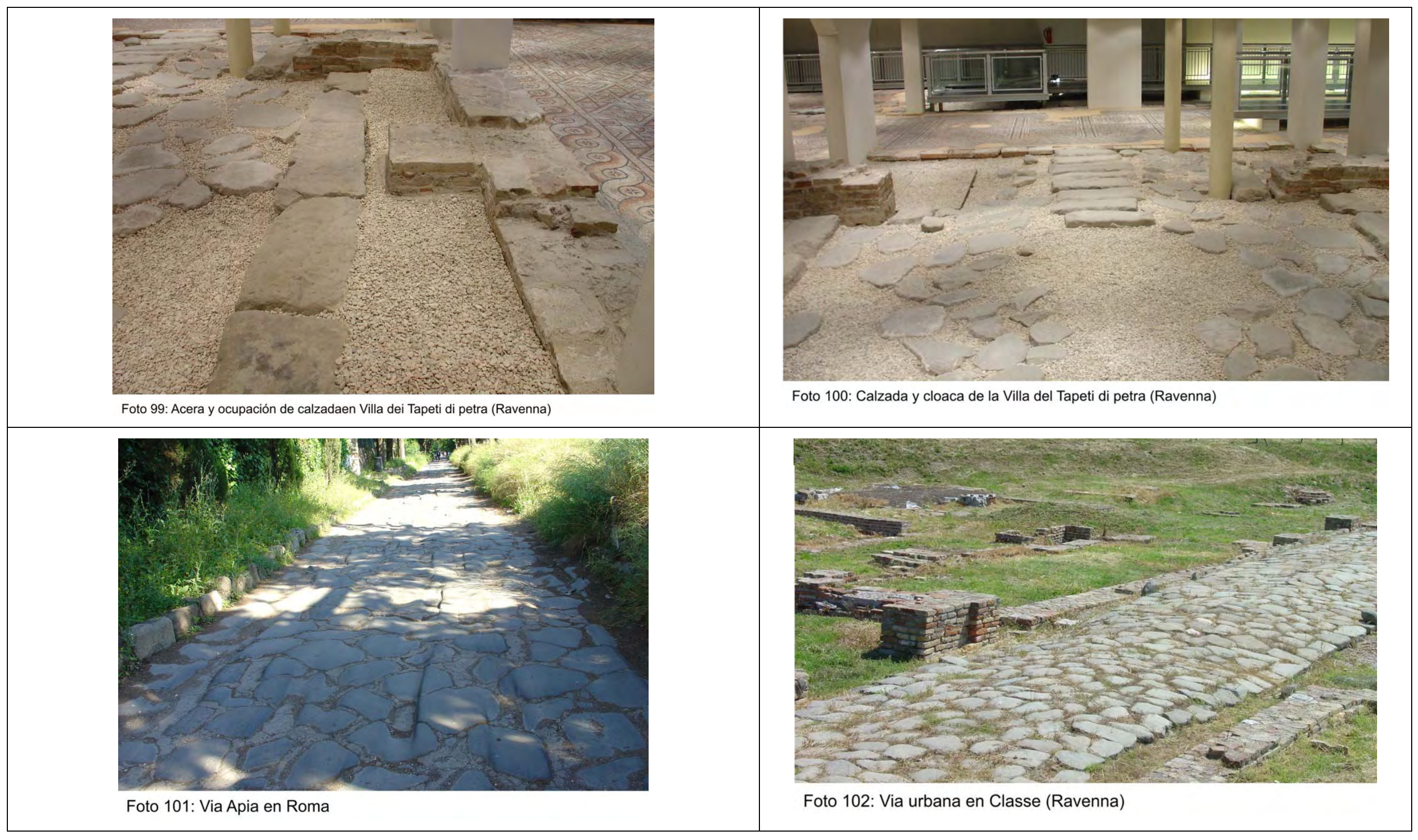




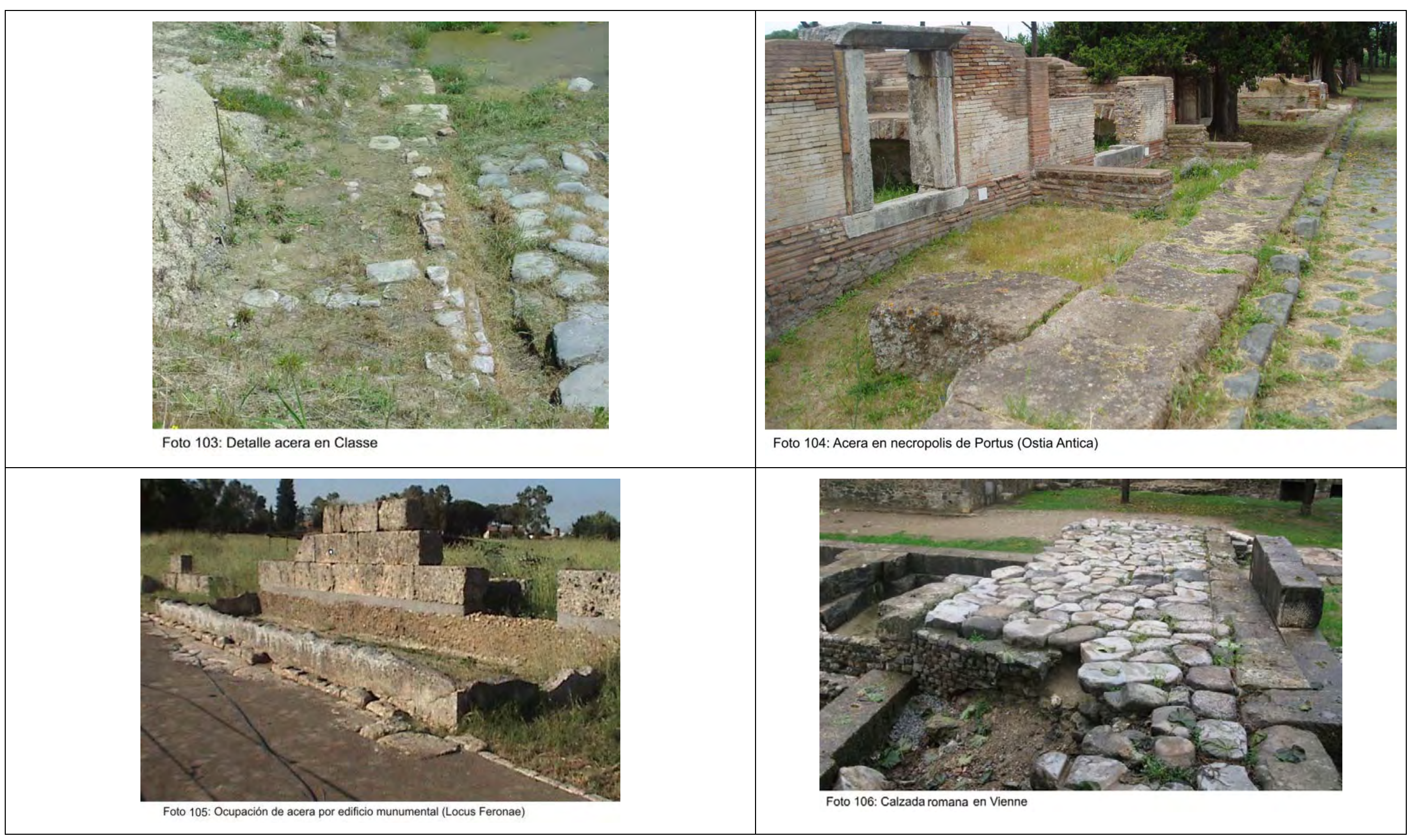




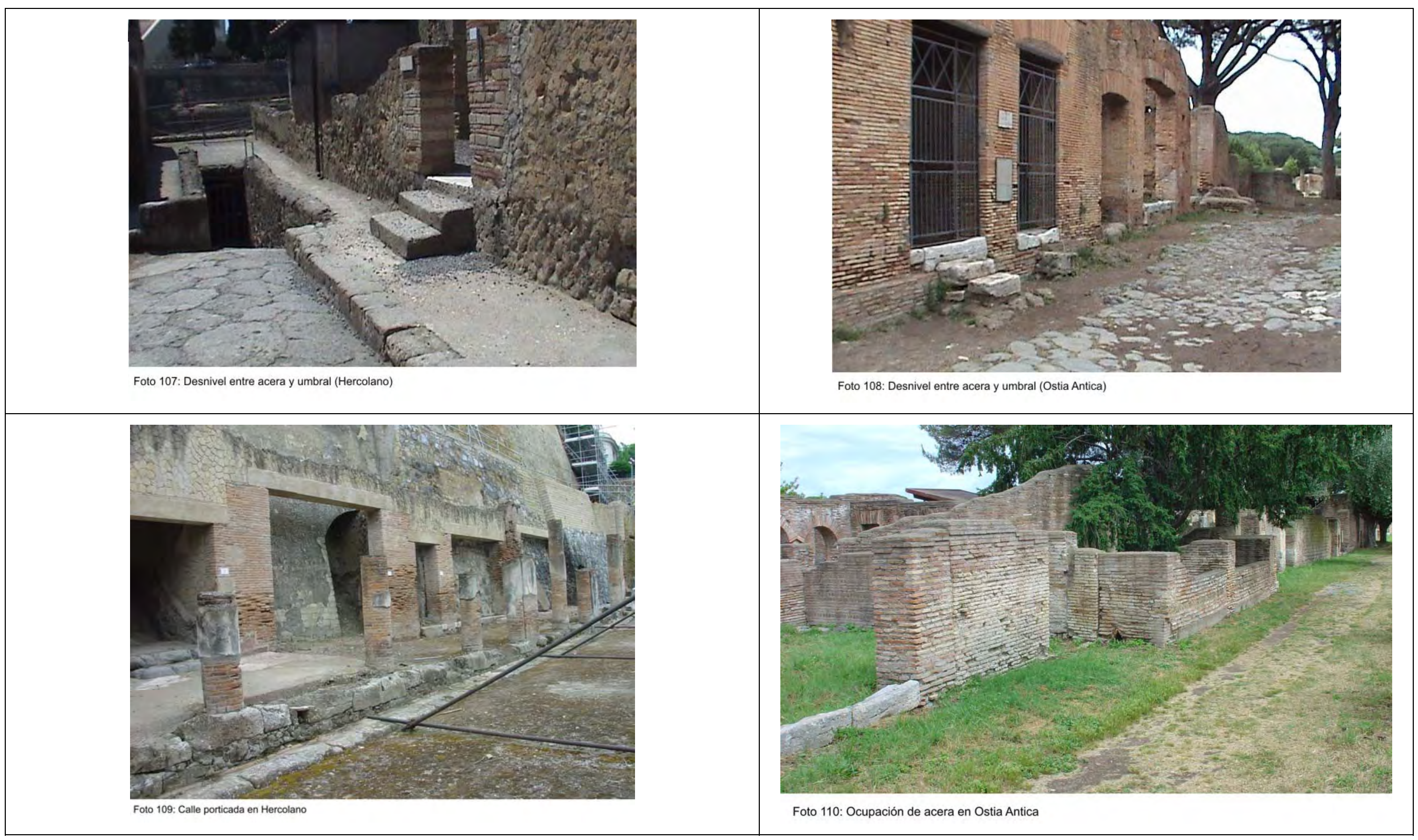




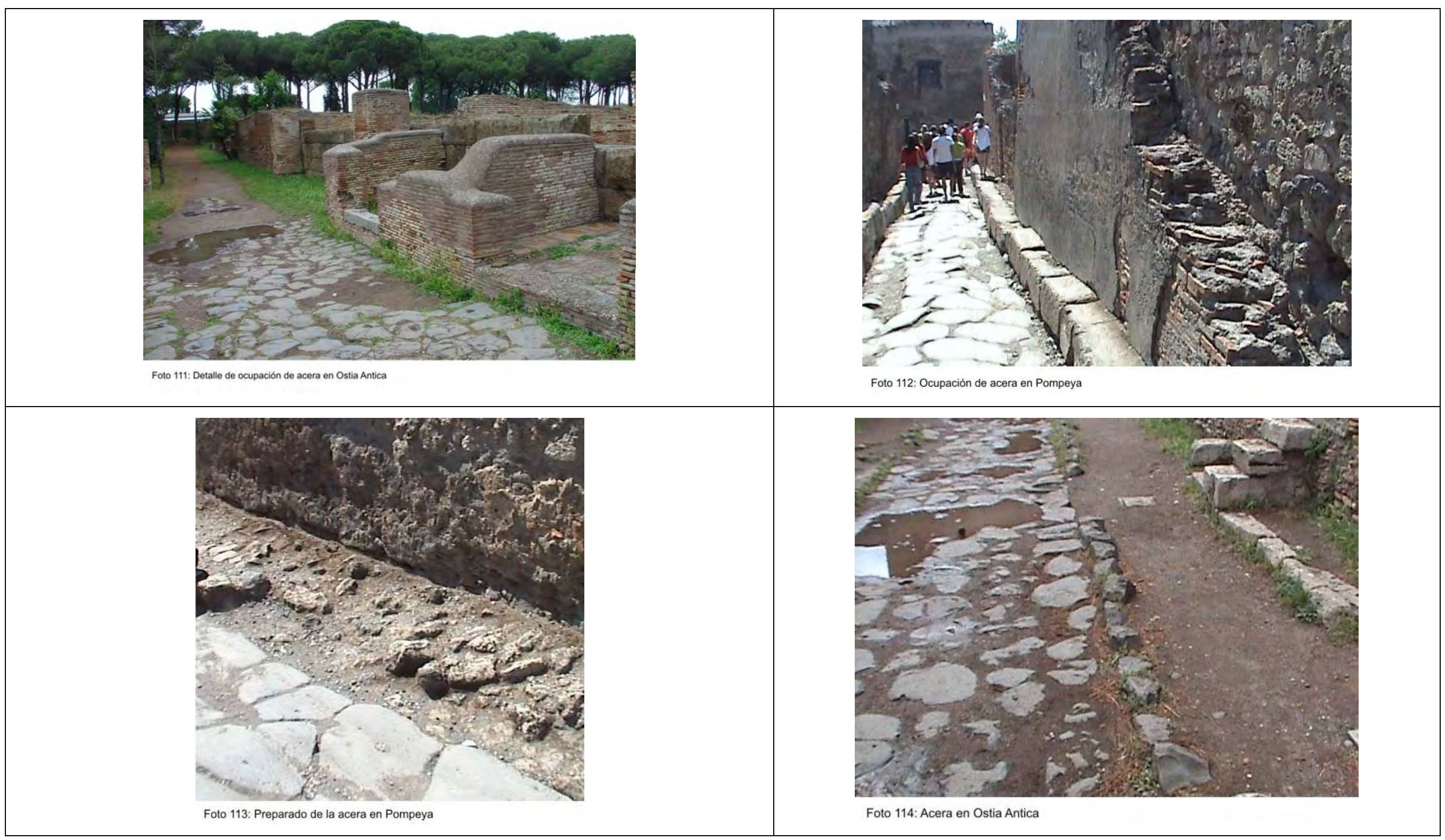




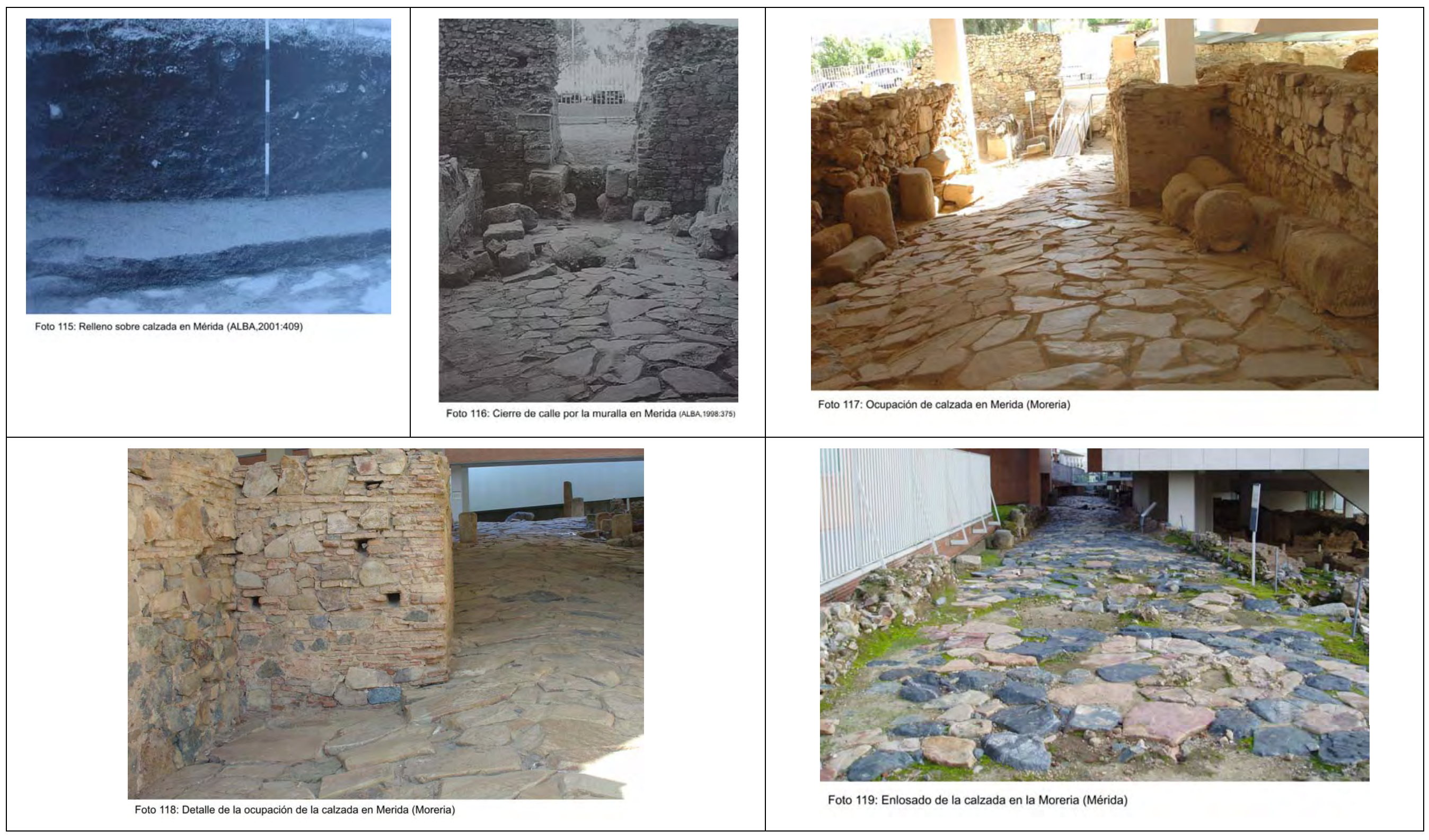




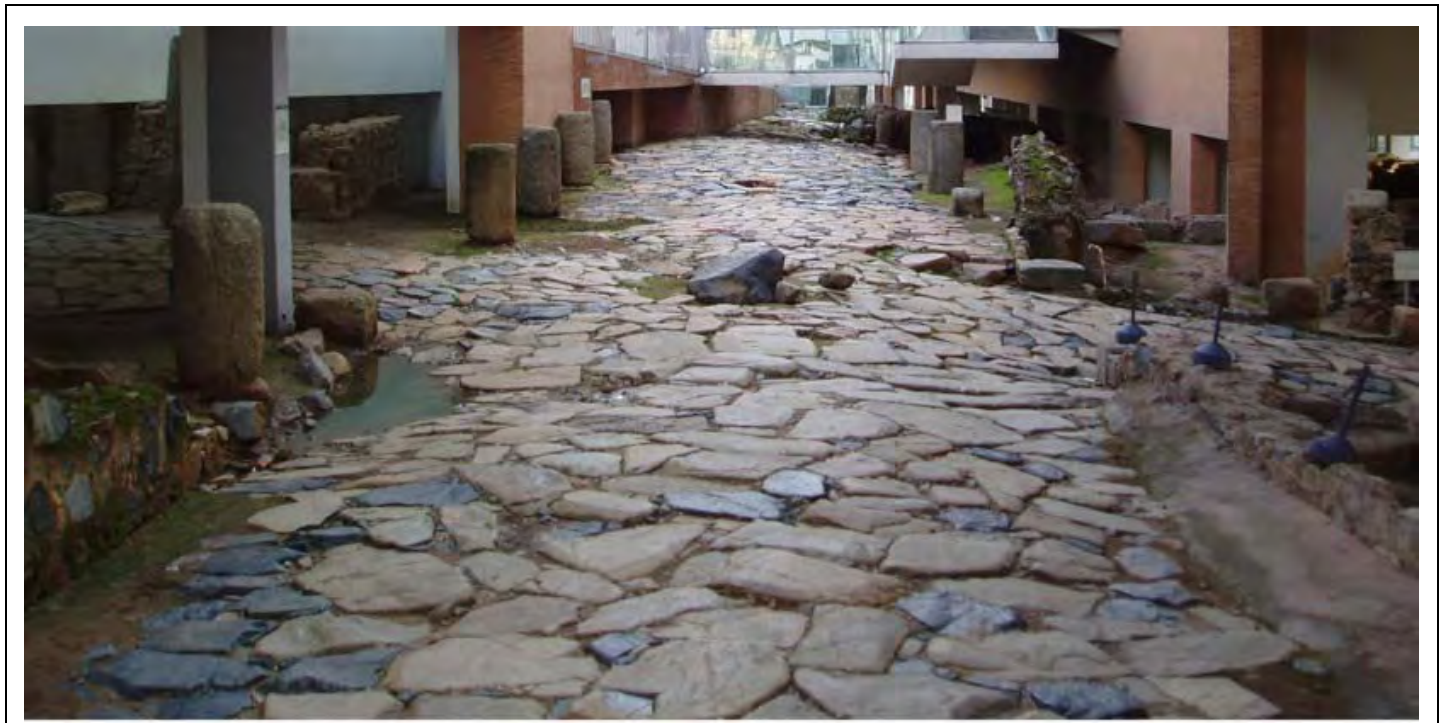

Foto 120: Cruce de calles en Mérida (Moreria)

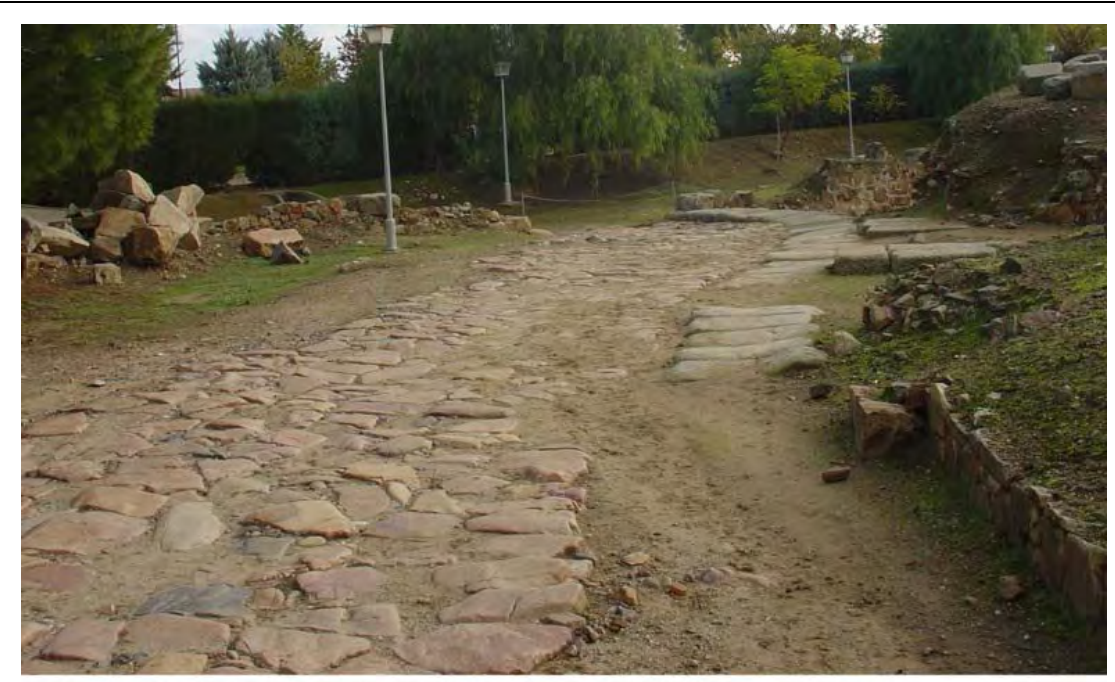

Foto 122: Calzada perimetral al anfiteatro (Mérida)

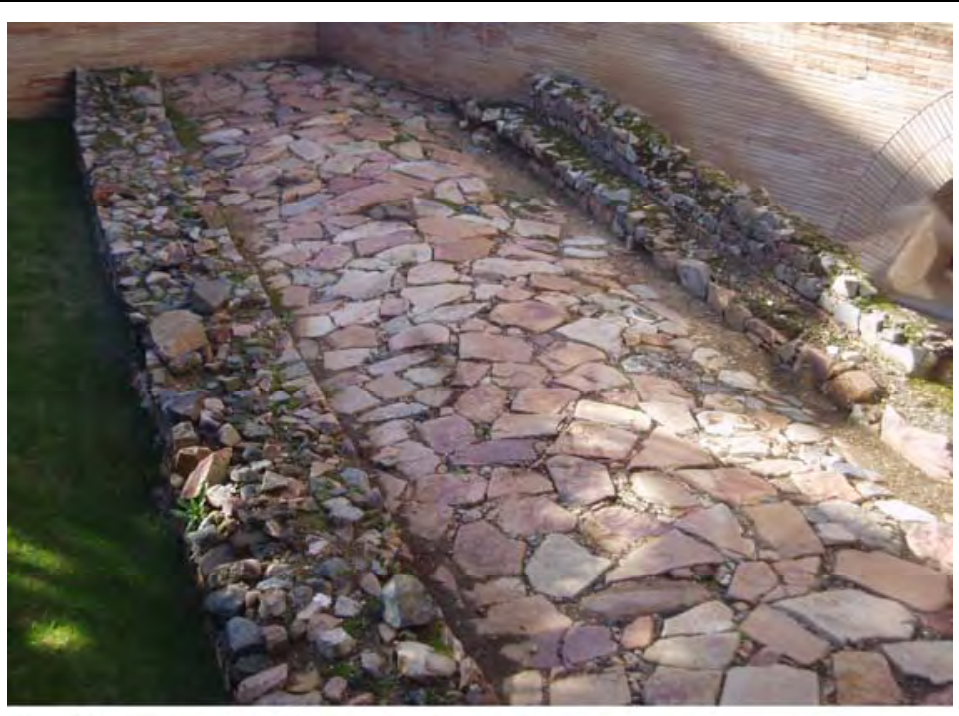

Foto 121: Calzada y acera en Mérida (zona casa del Anfiteatro)

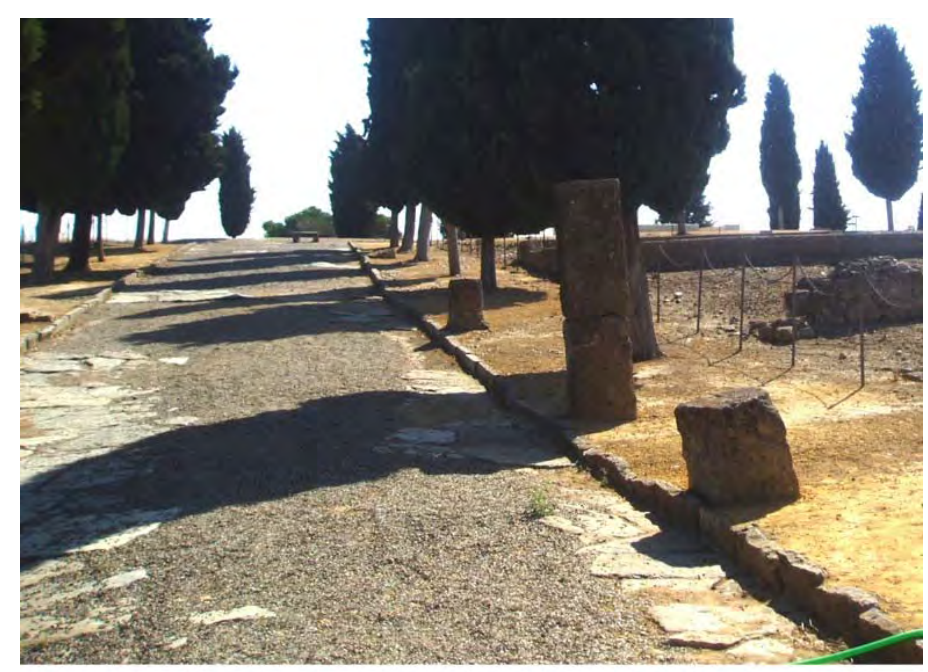

Foto 123: Calzada porticada con pilares de piedra (Itálica) 


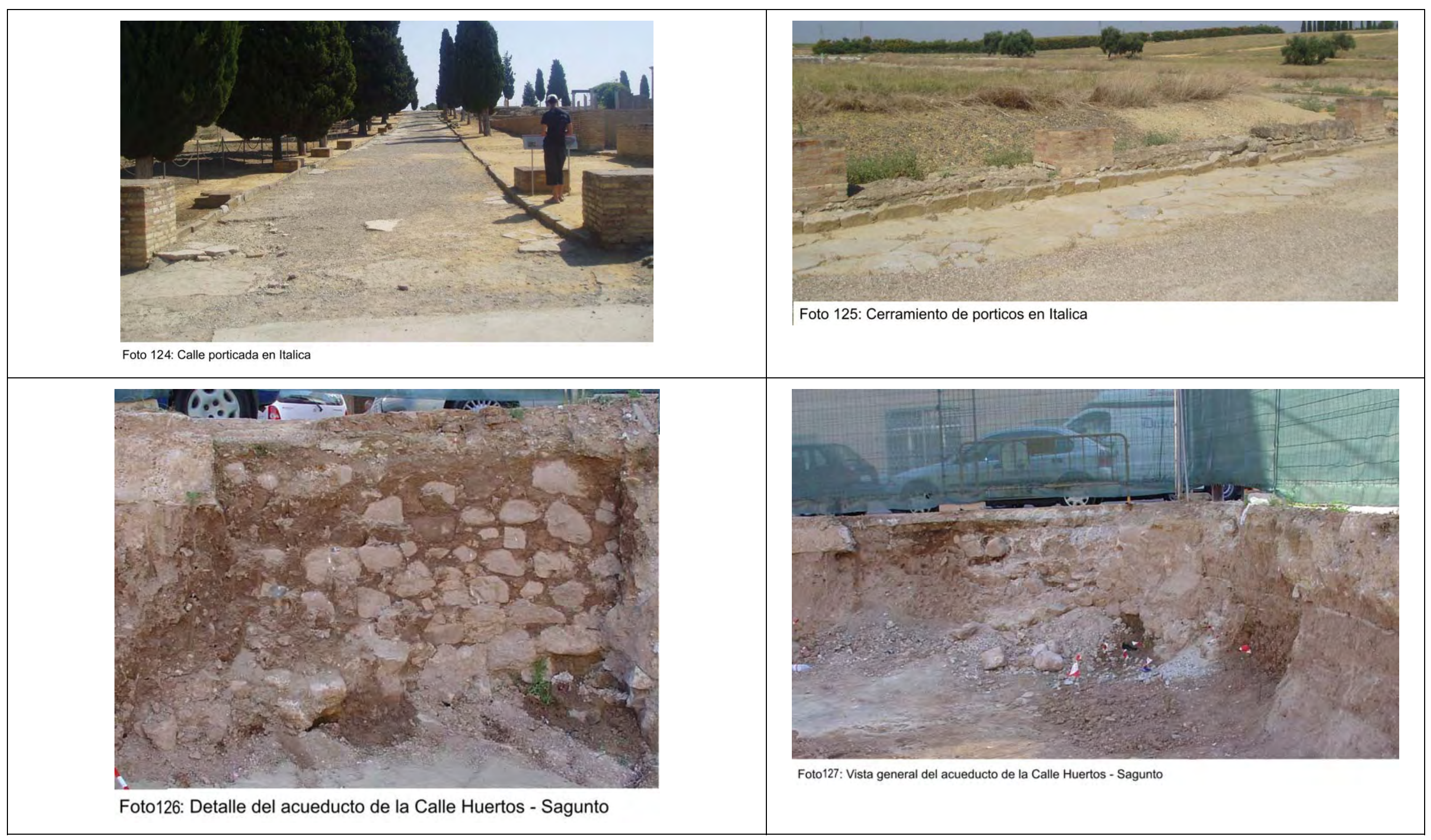



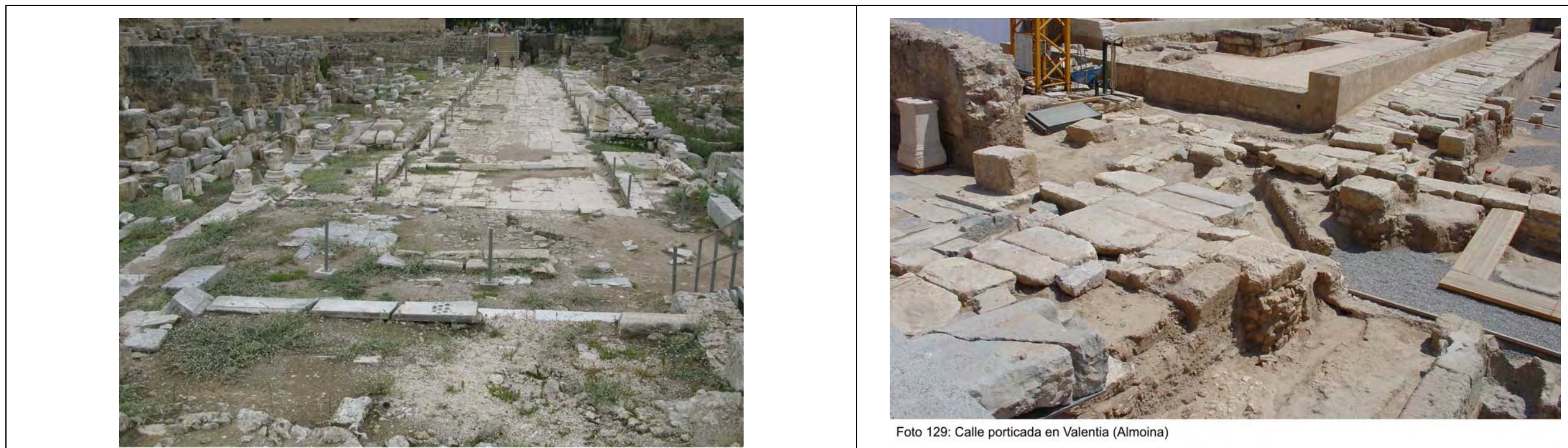

Foto 128: Calle romana en Corinto

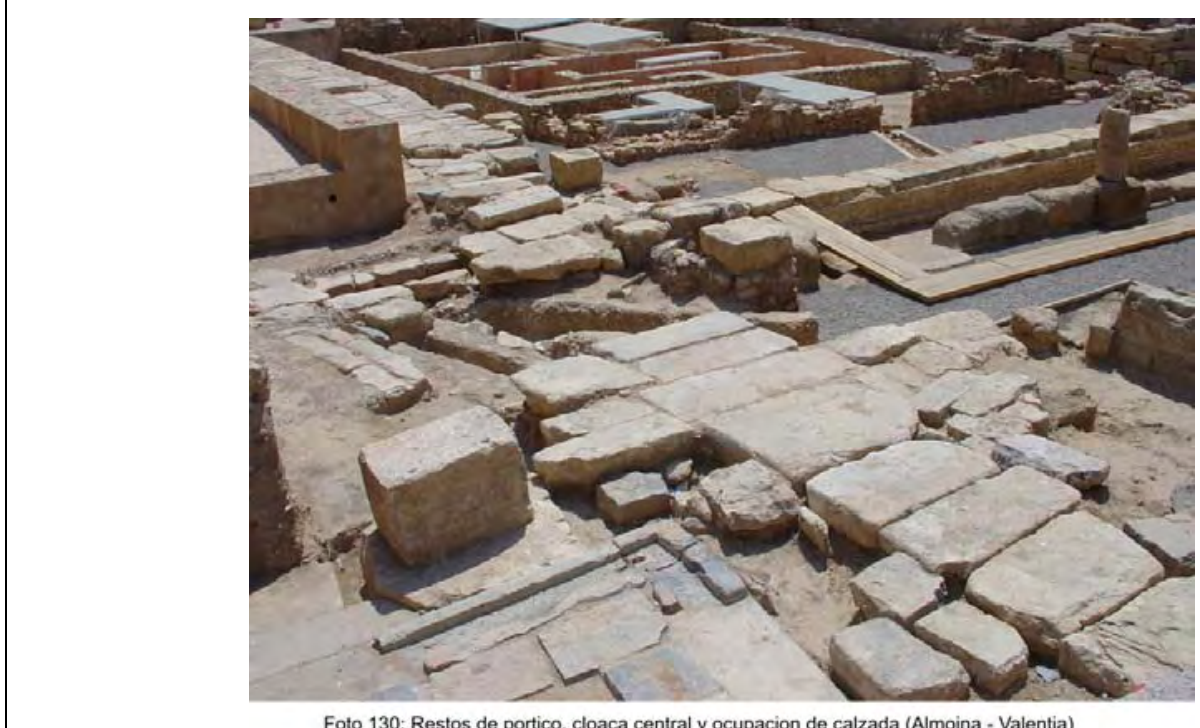

Foto 129: Calle porticada en Valentia (Almoina)

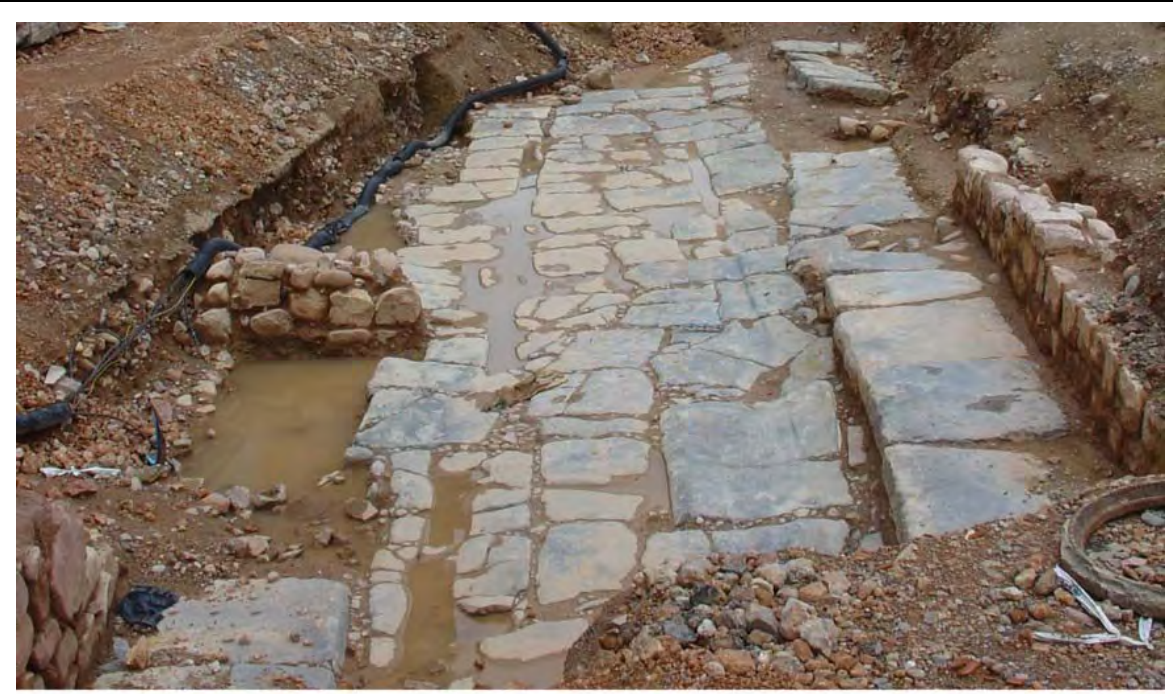

Foto 131: Carriladas y ocupación de calzada en Sagunto (Av. del País Valencià) 


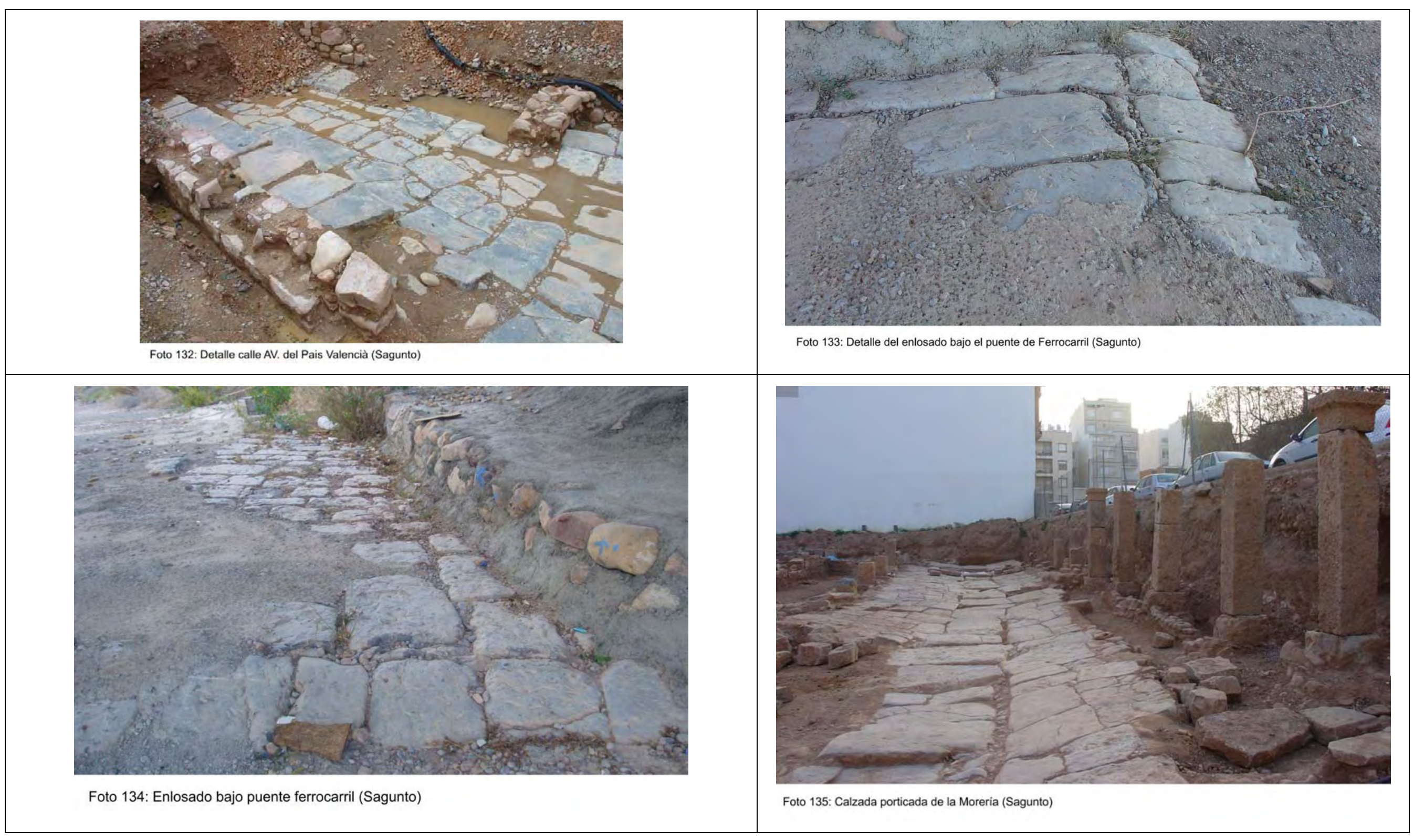




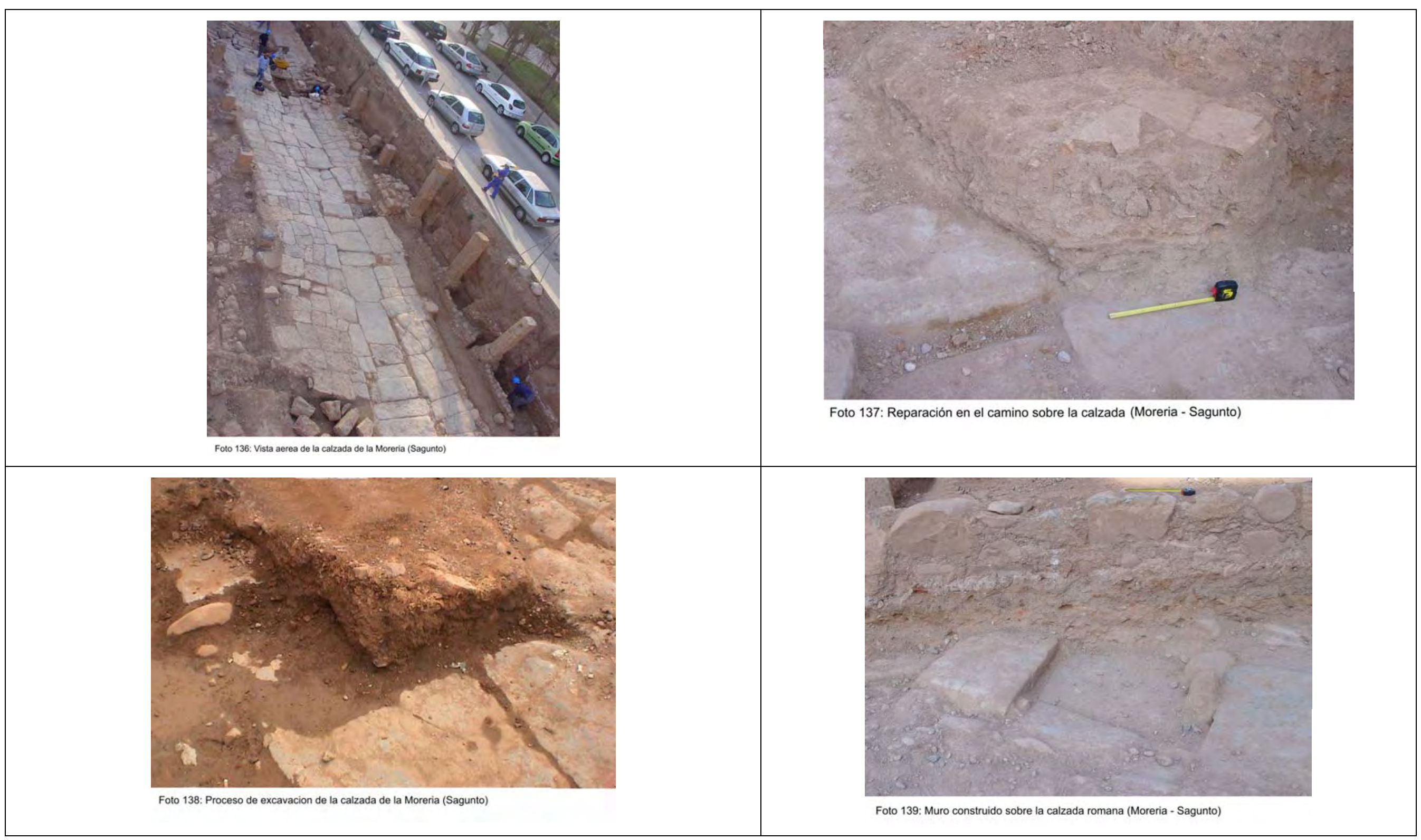




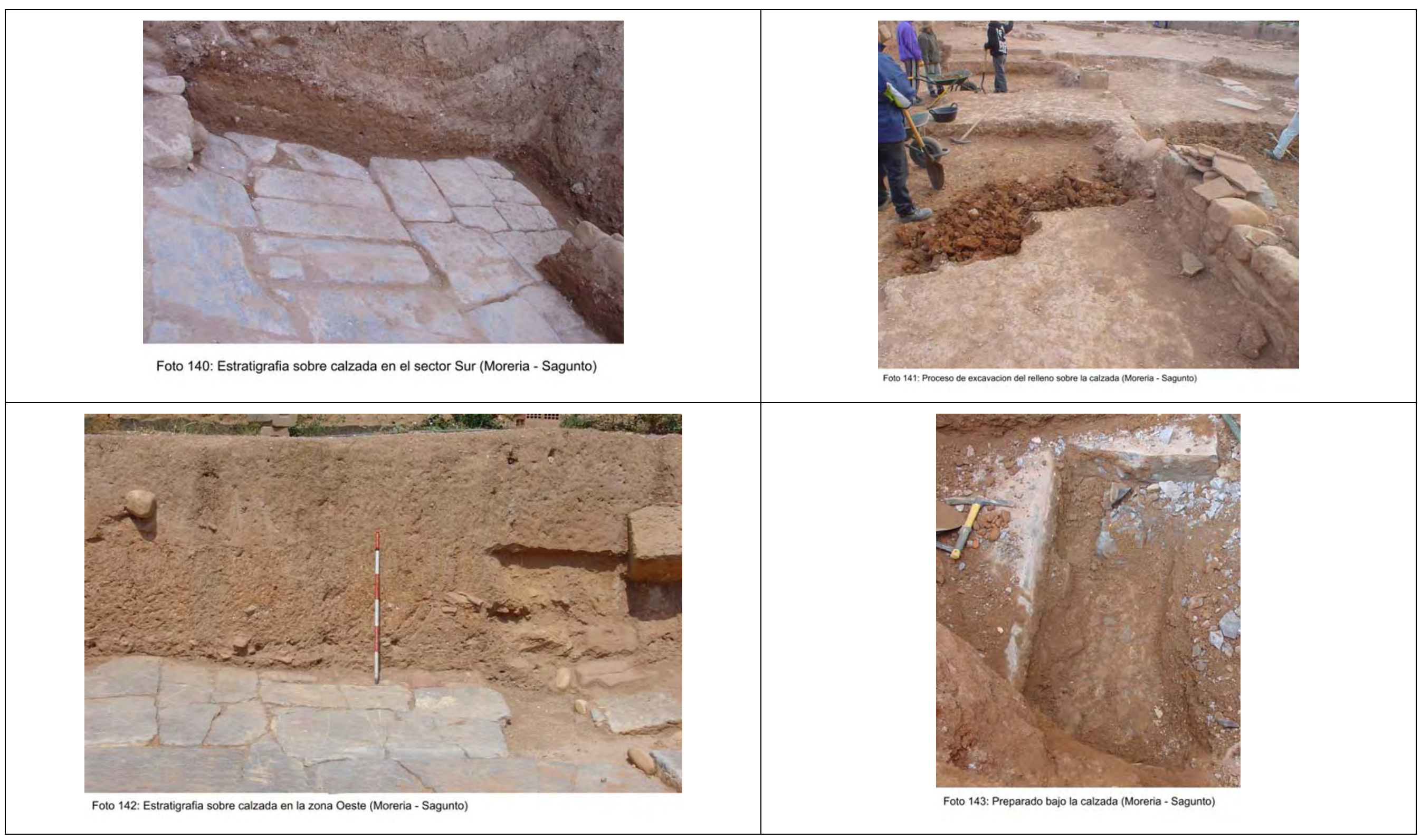




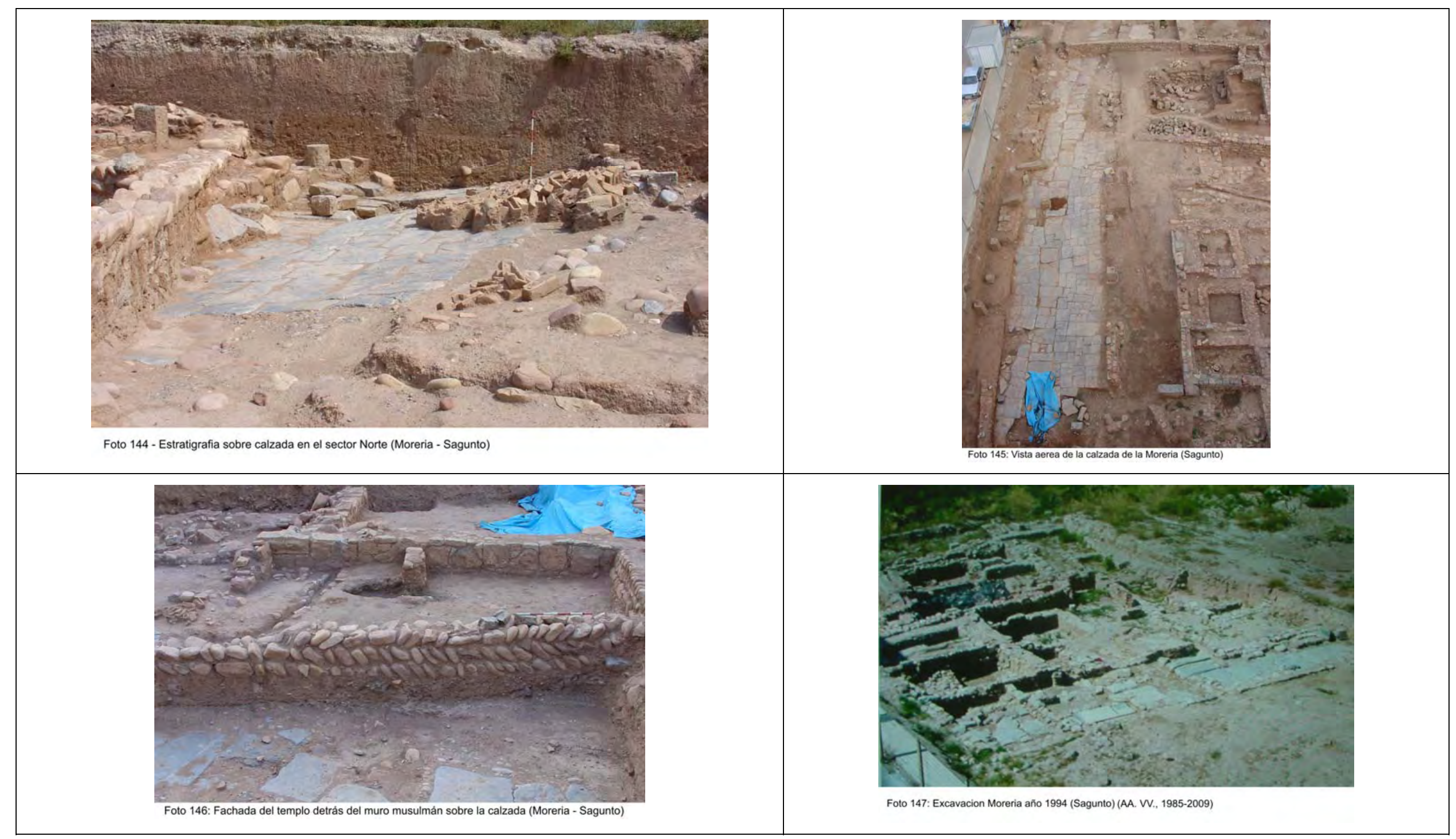




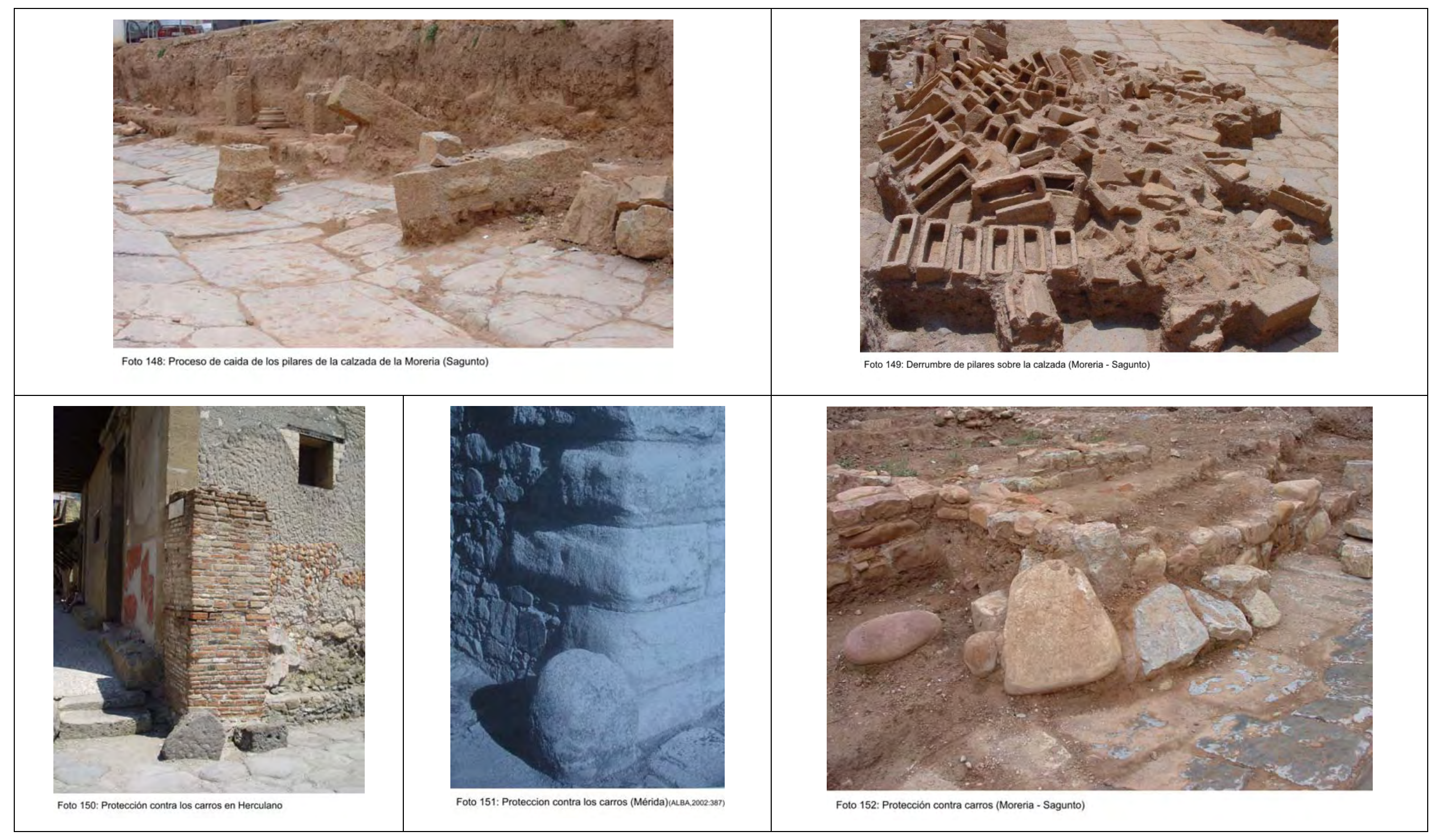




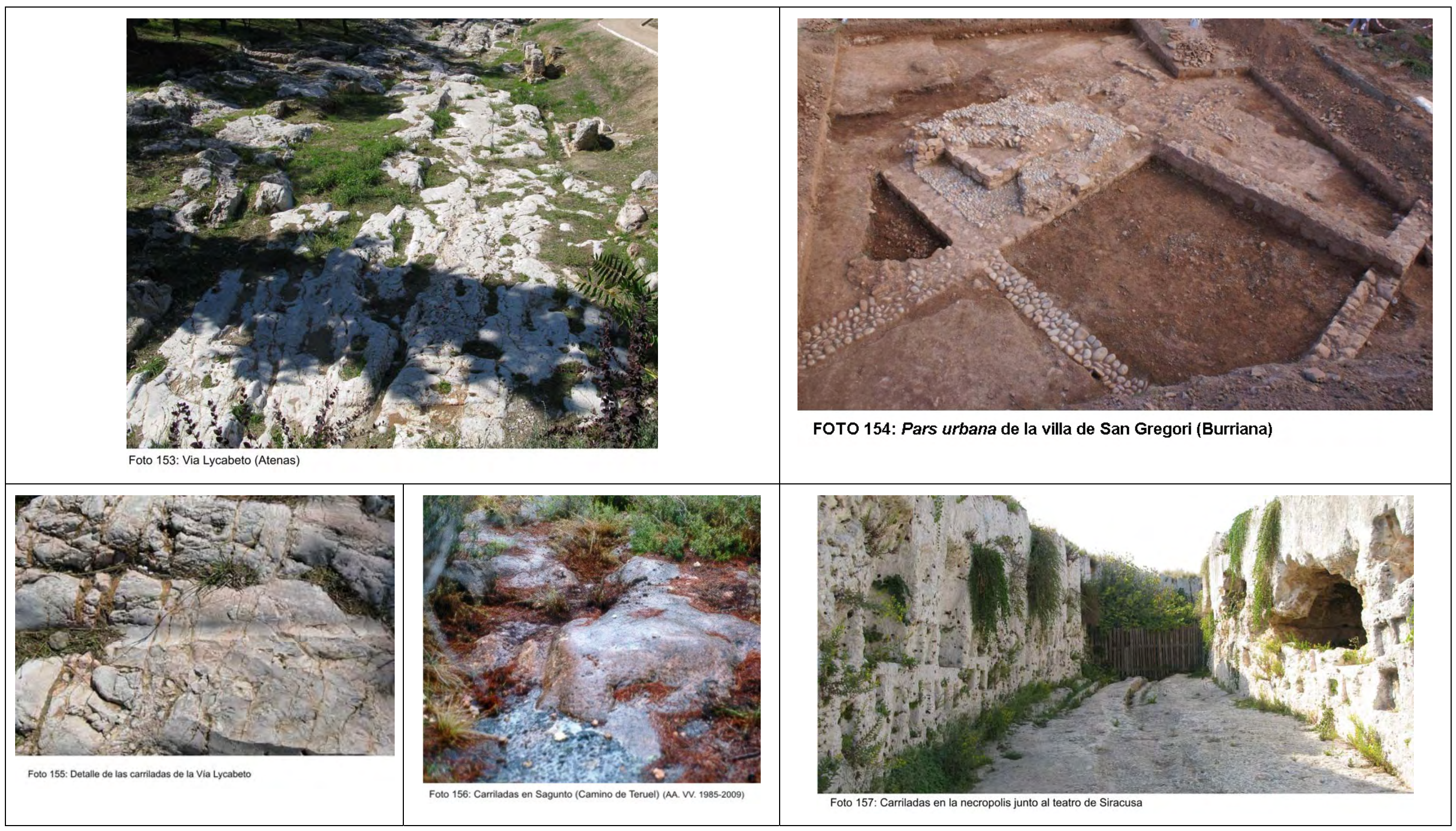




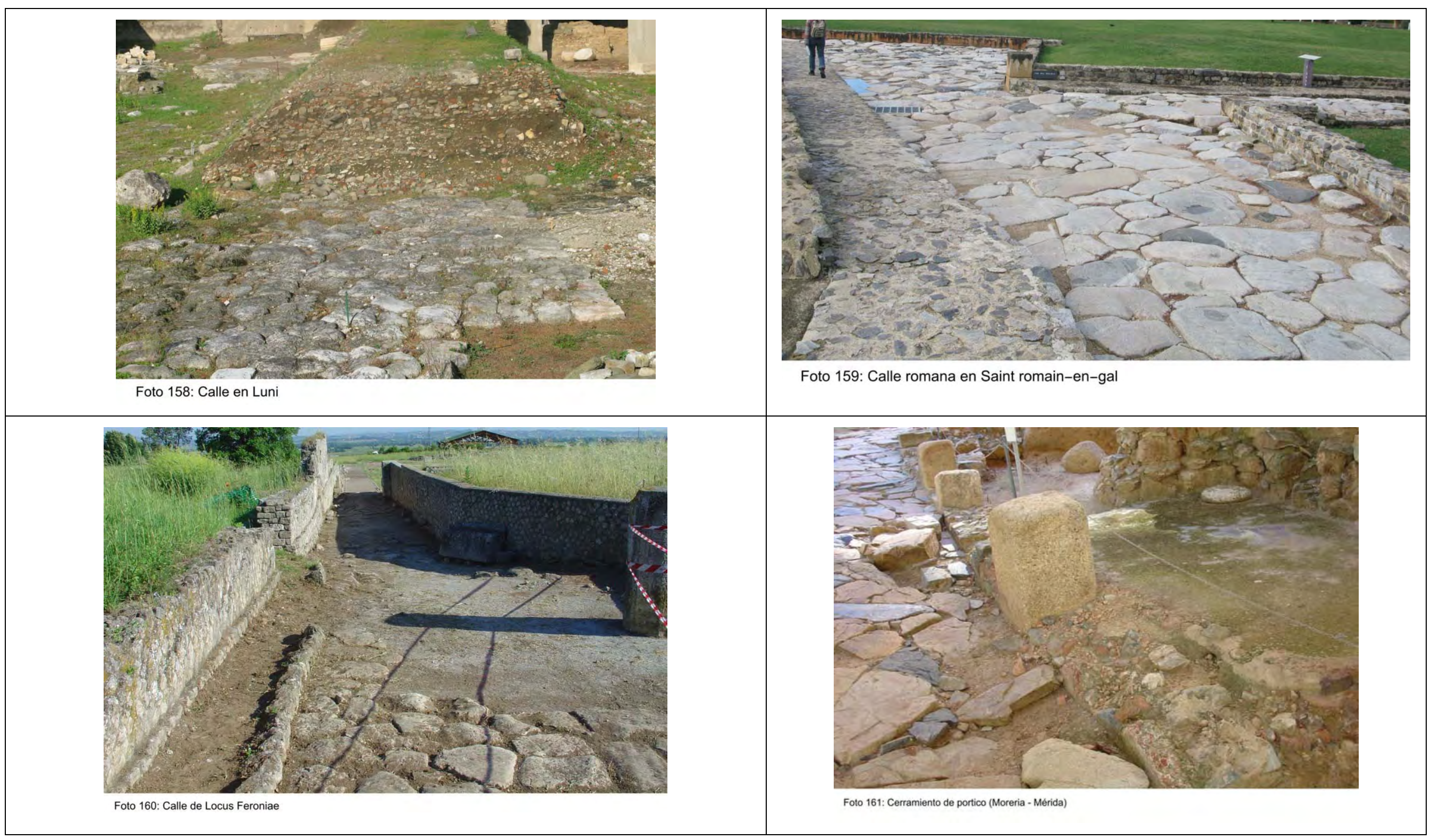




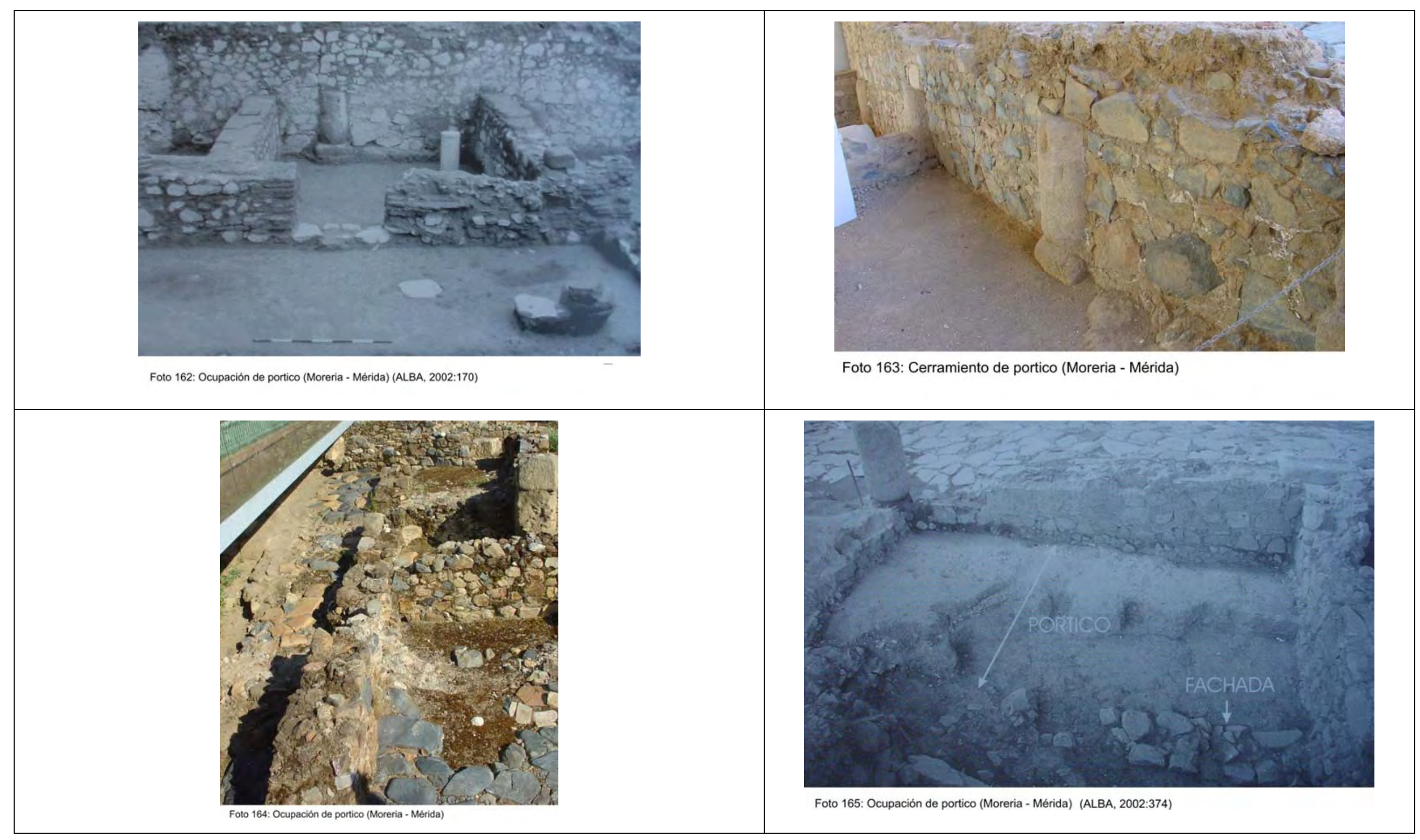




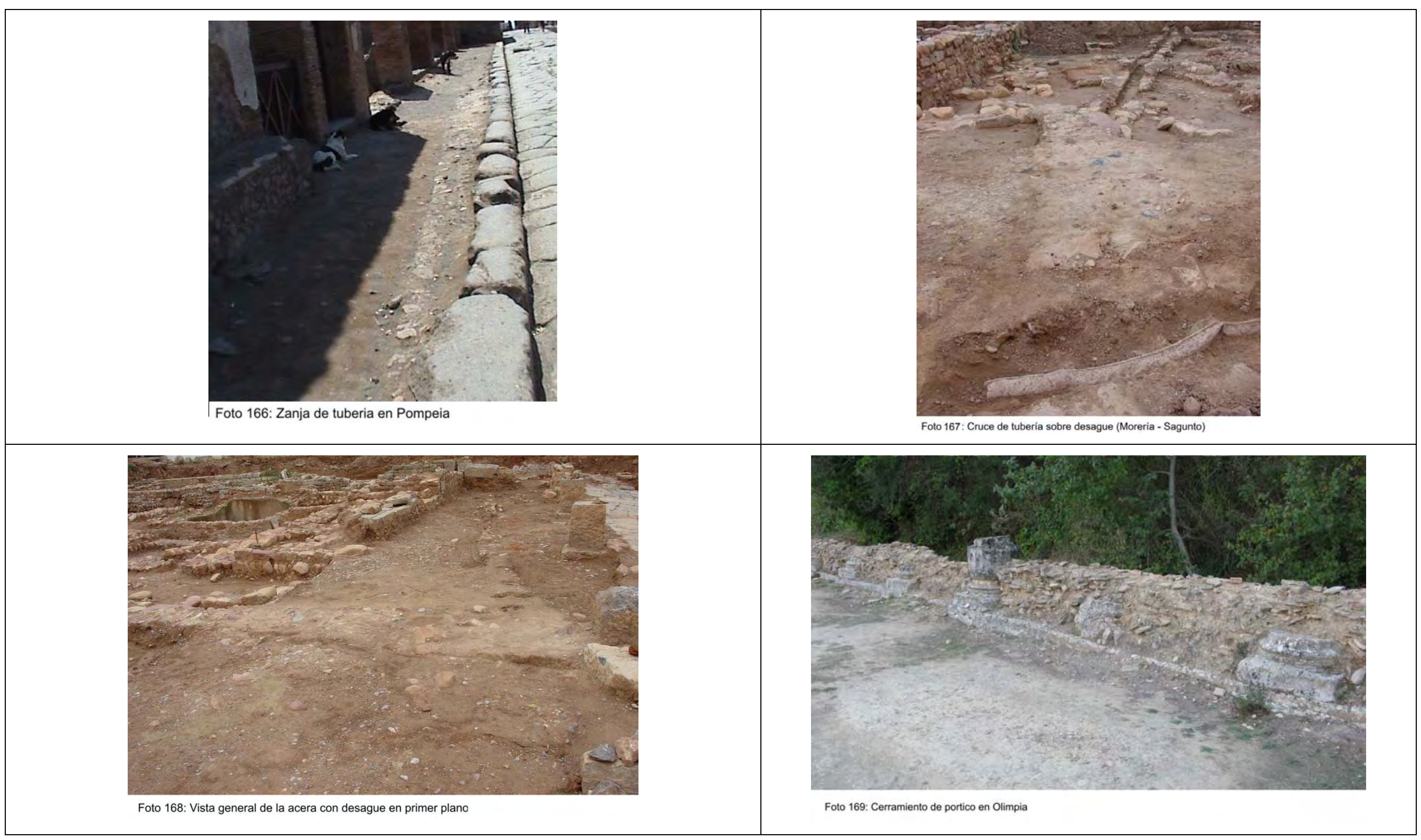




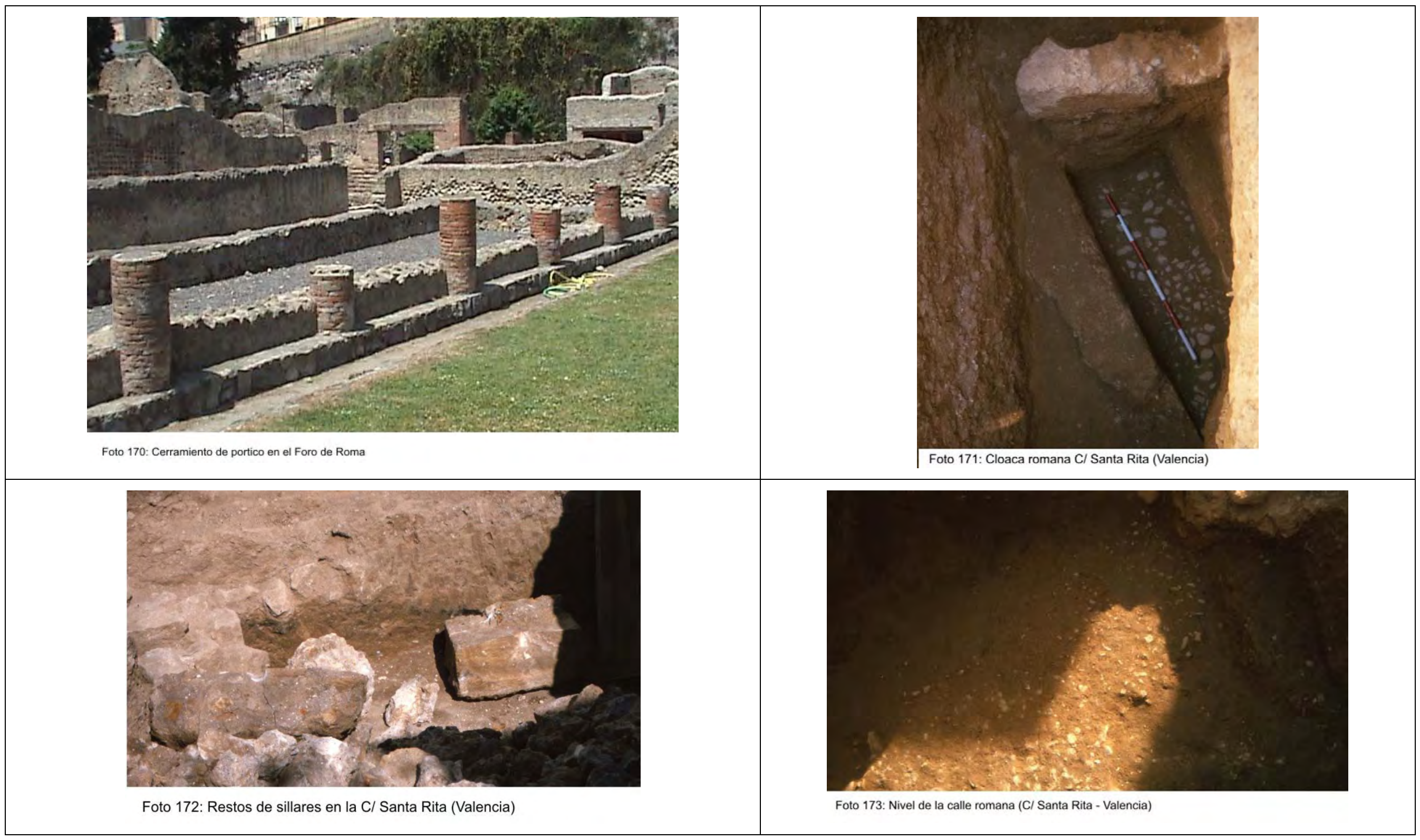




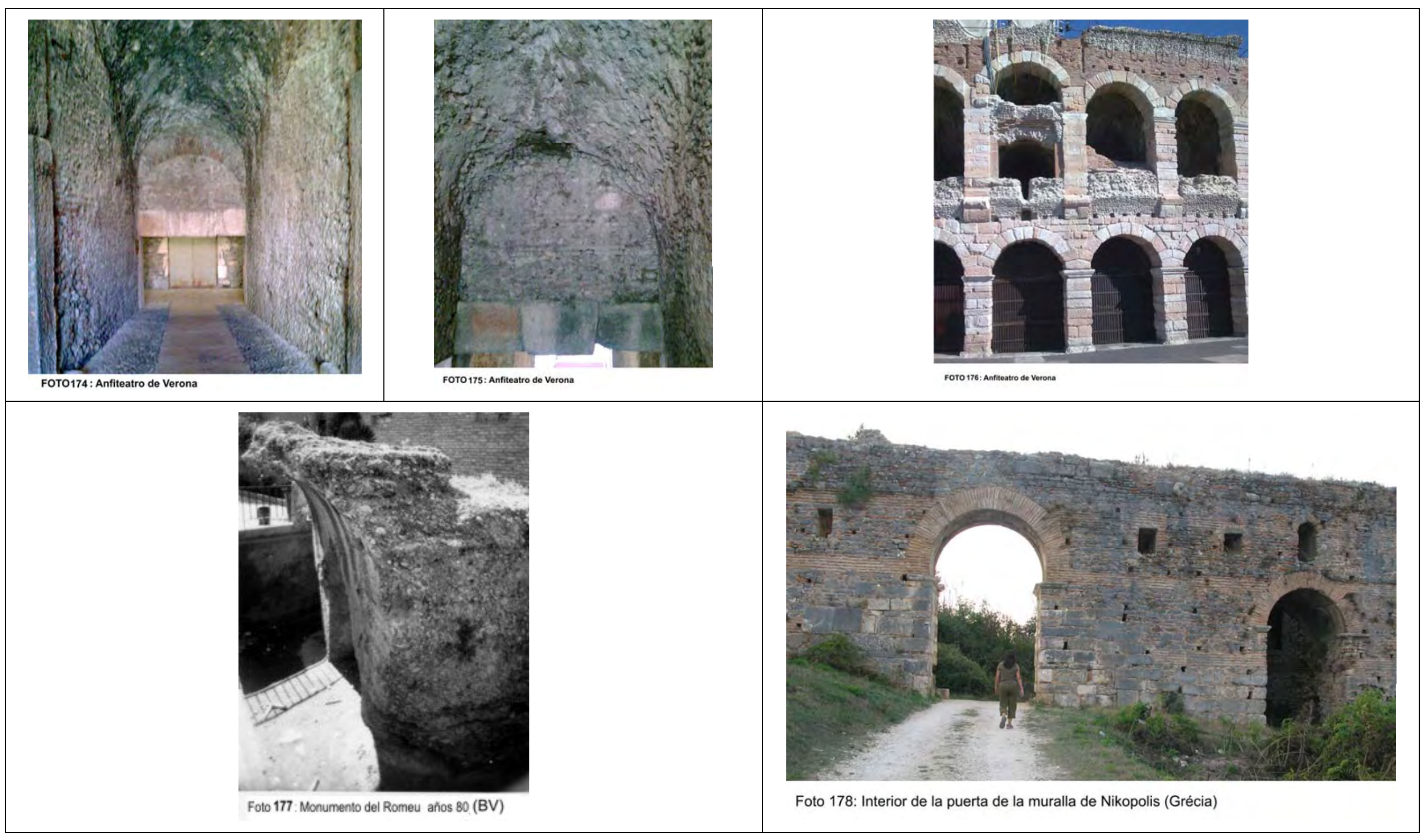




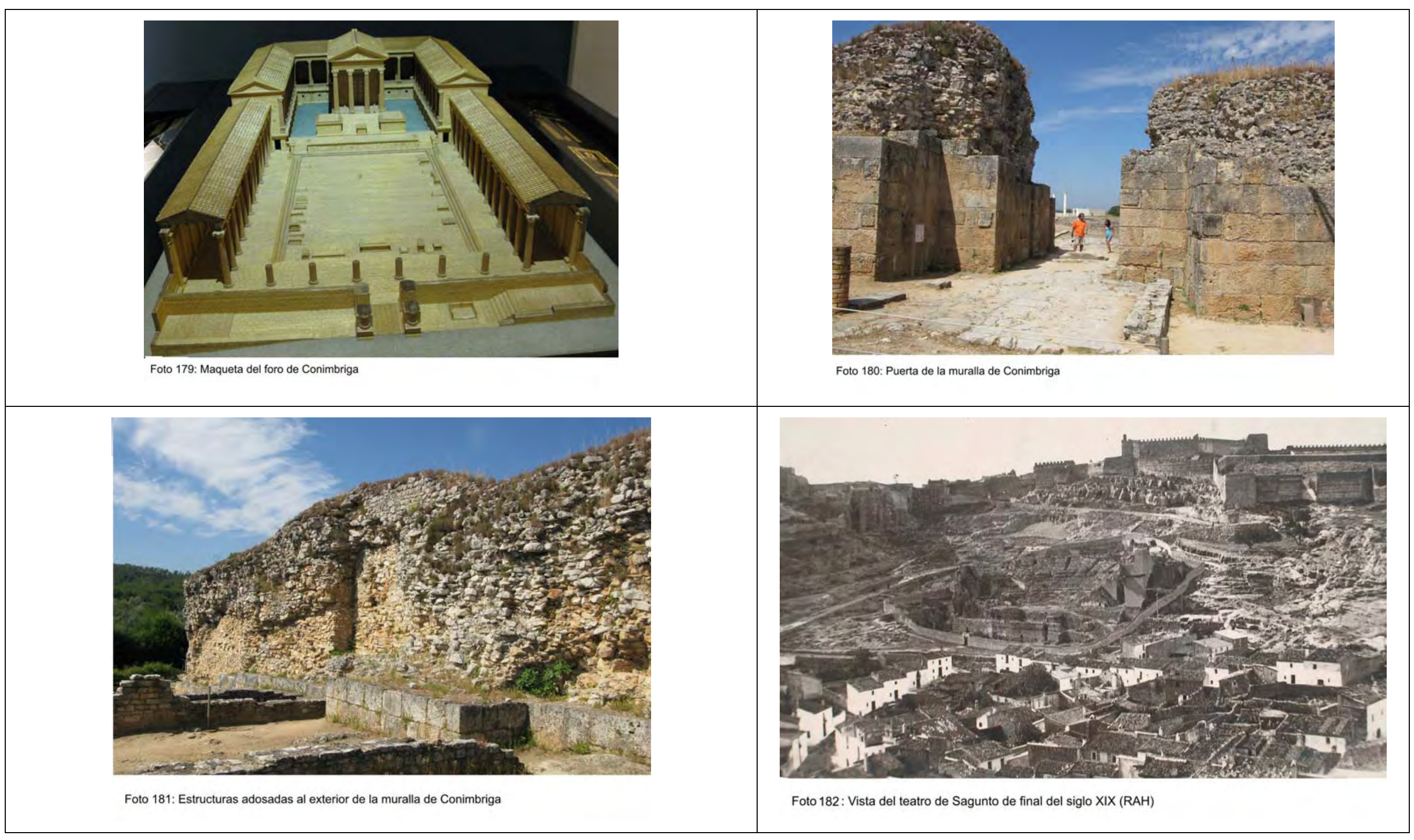




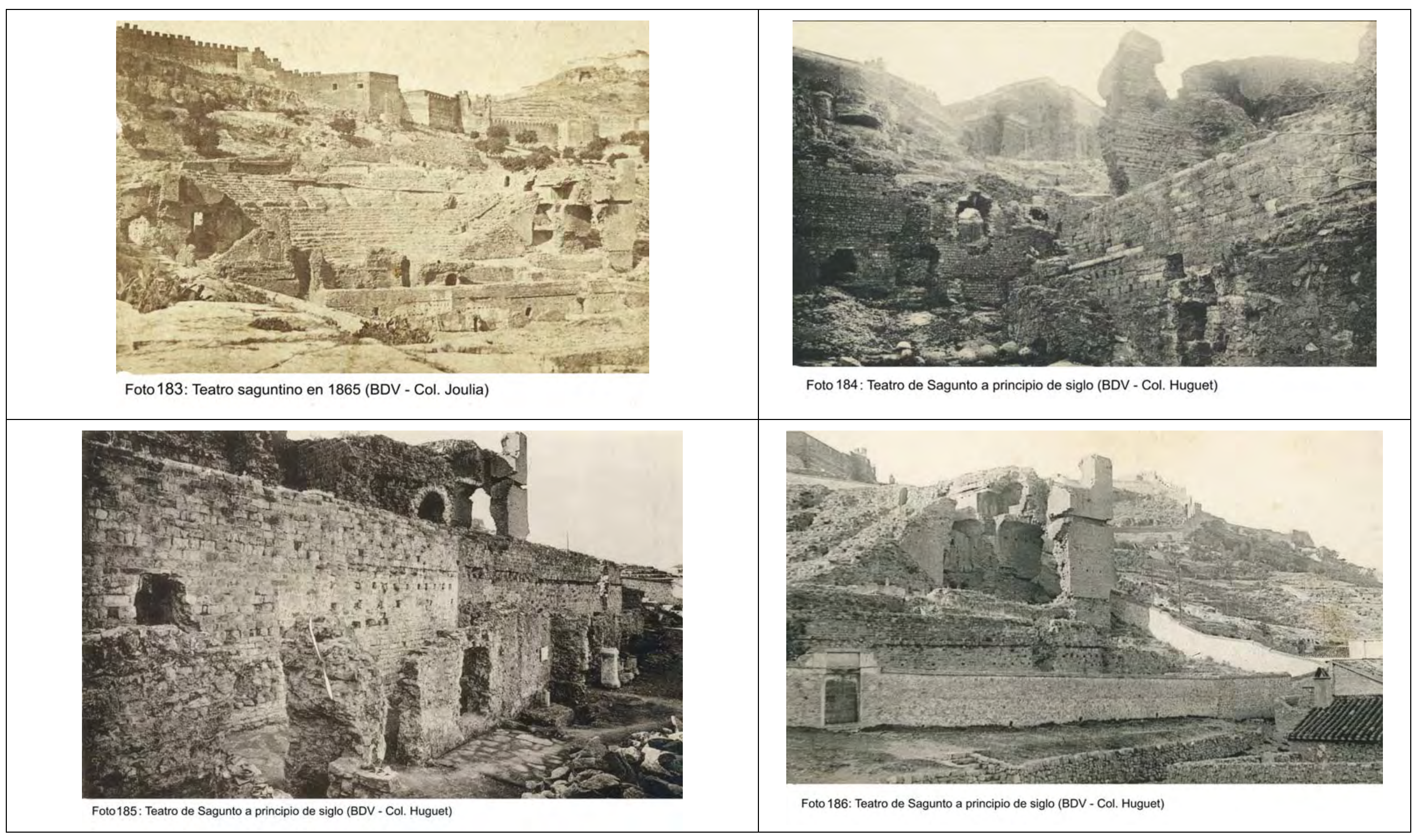




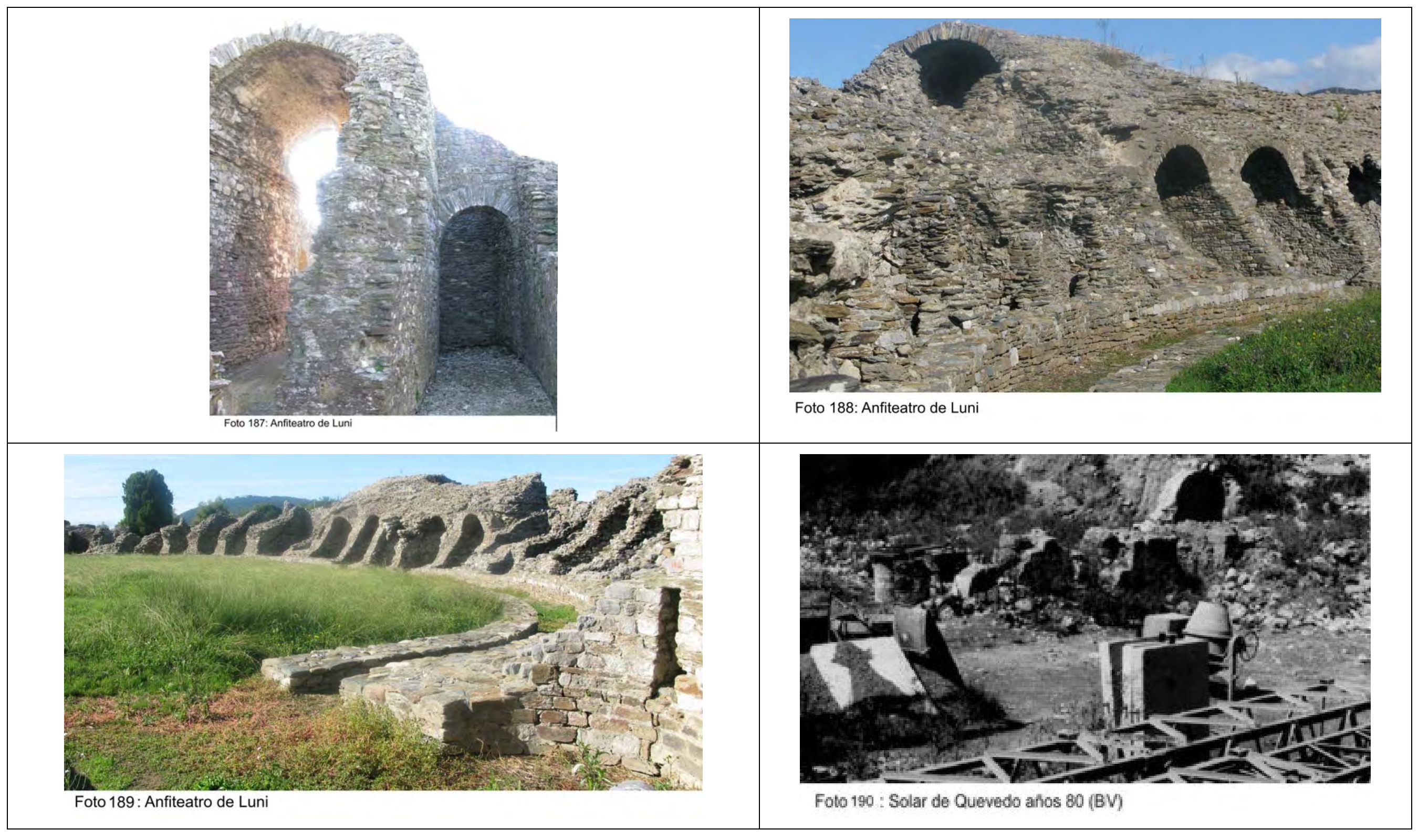




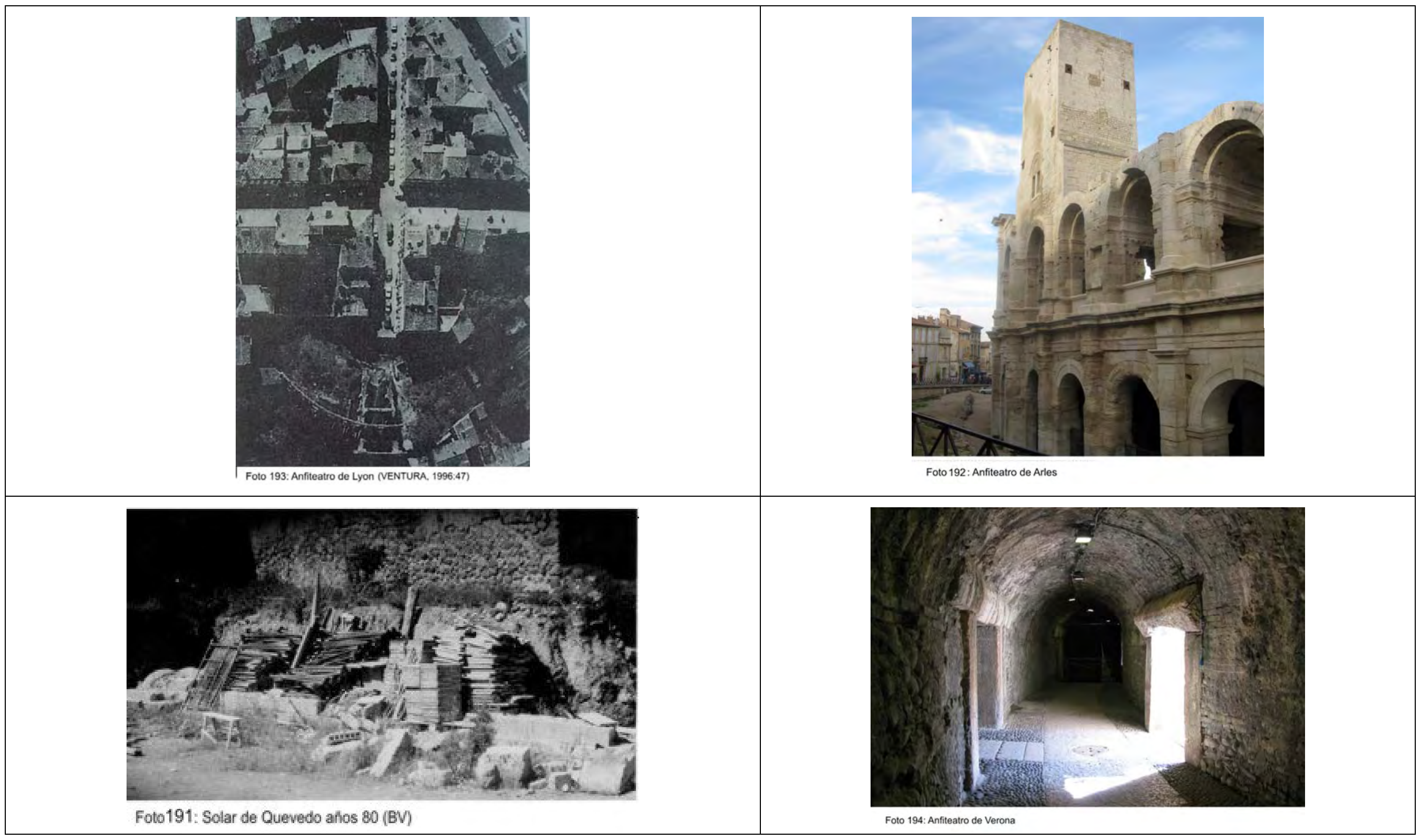




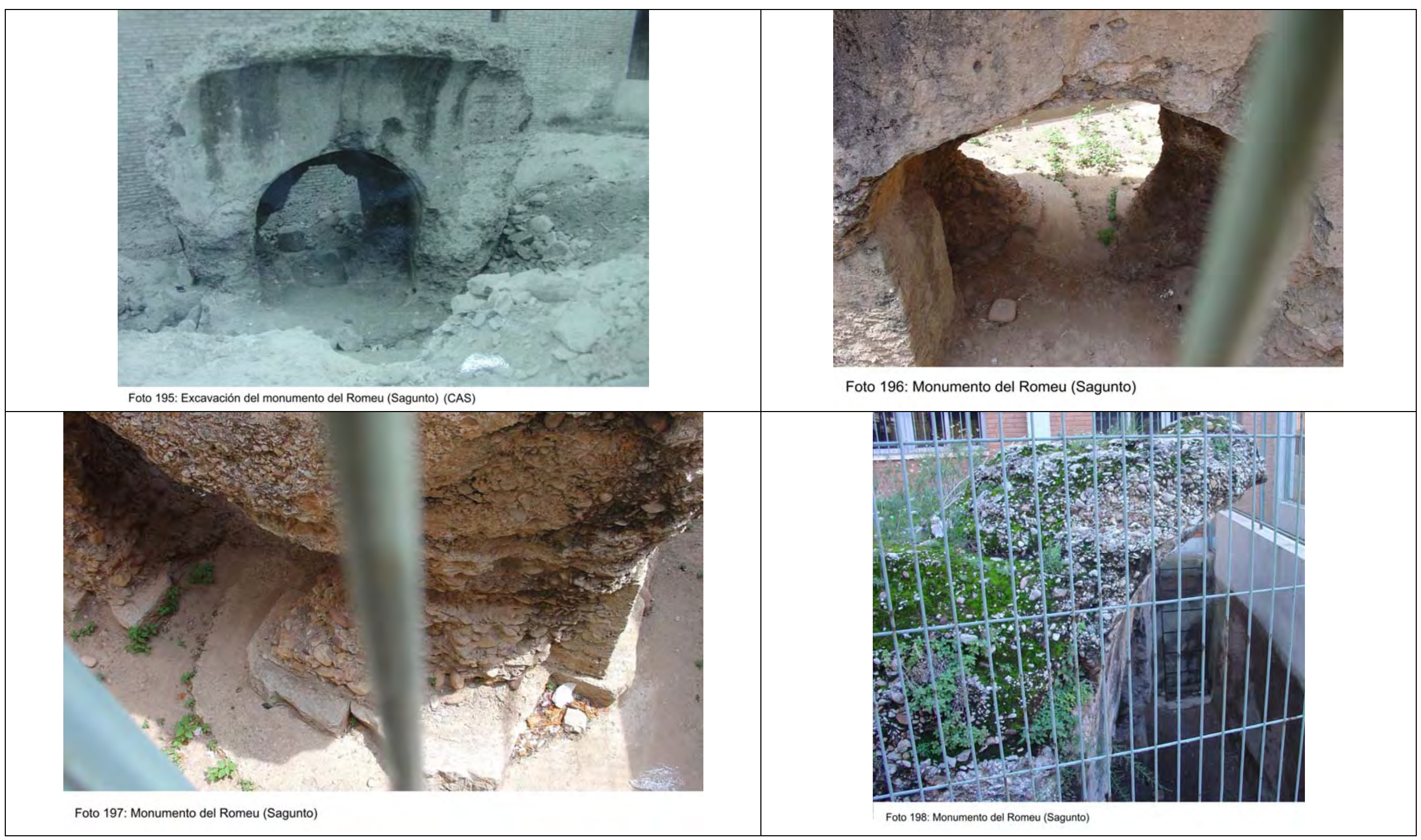




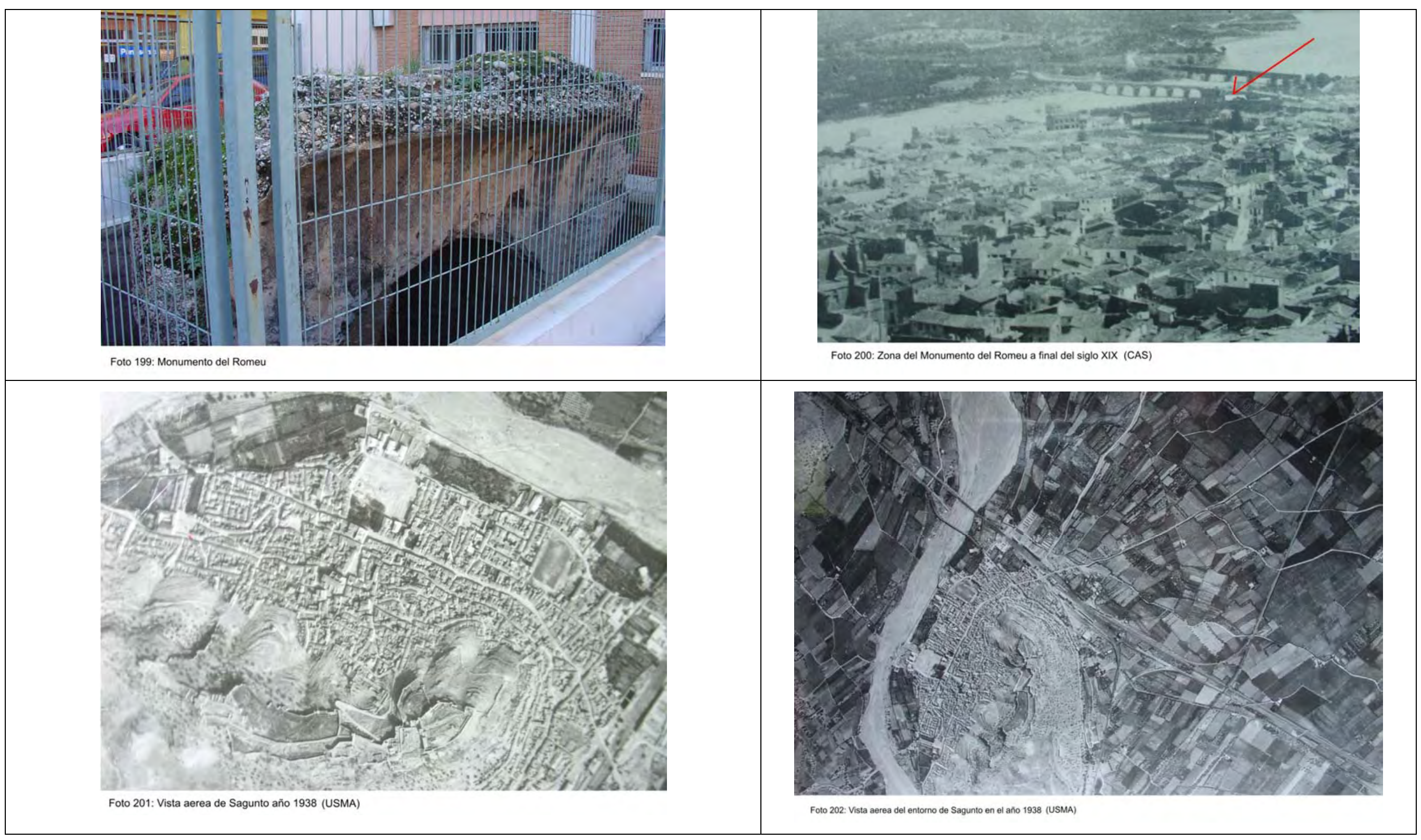




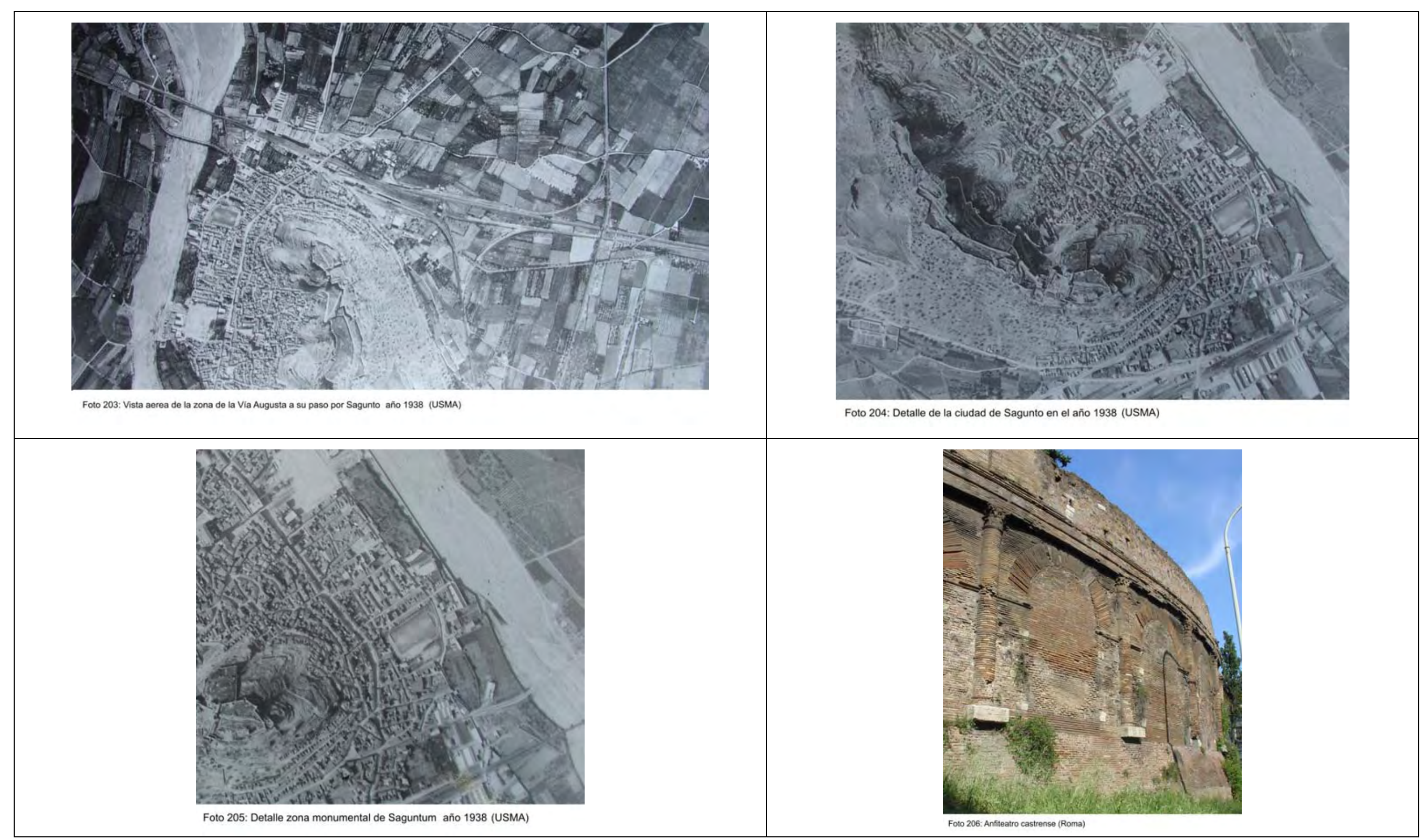




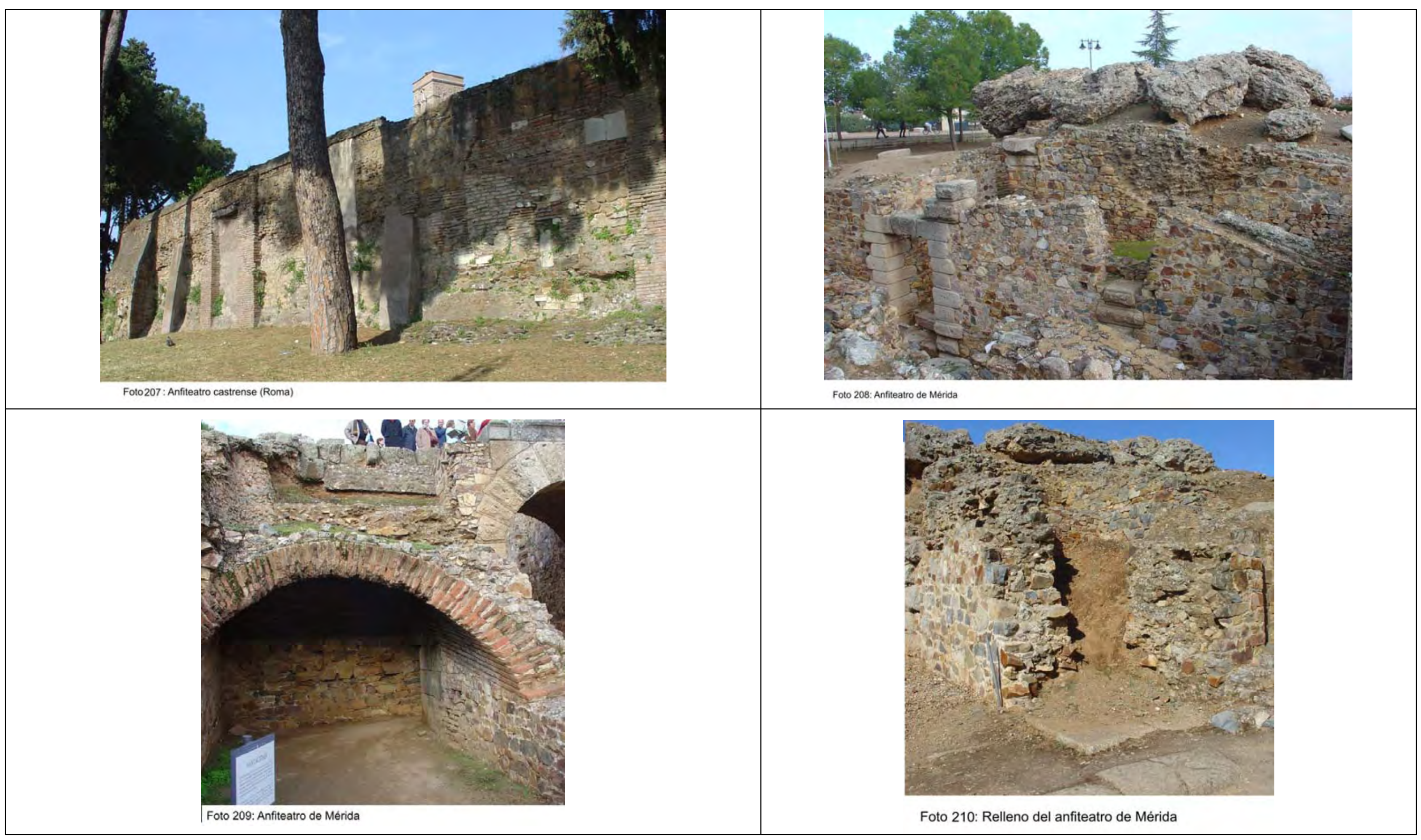




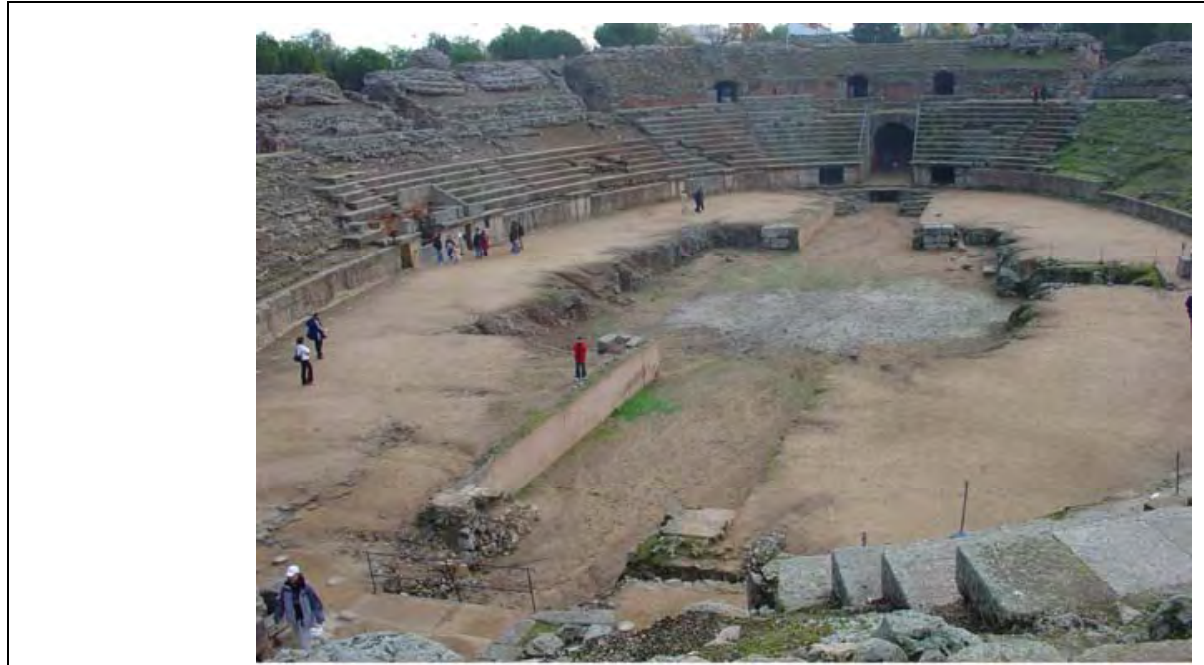

Foto 211: Anfiteatro de Mérida

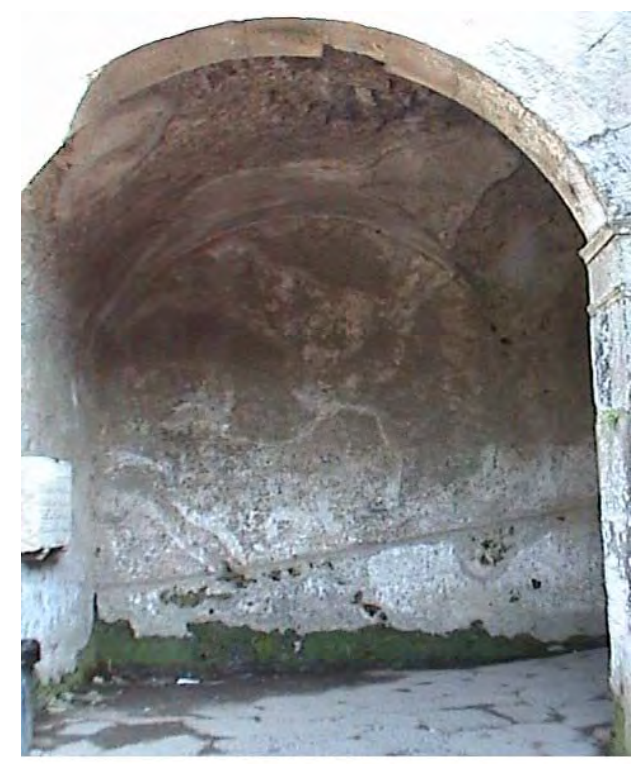

Foto 213: Anfiteatro de Pompey

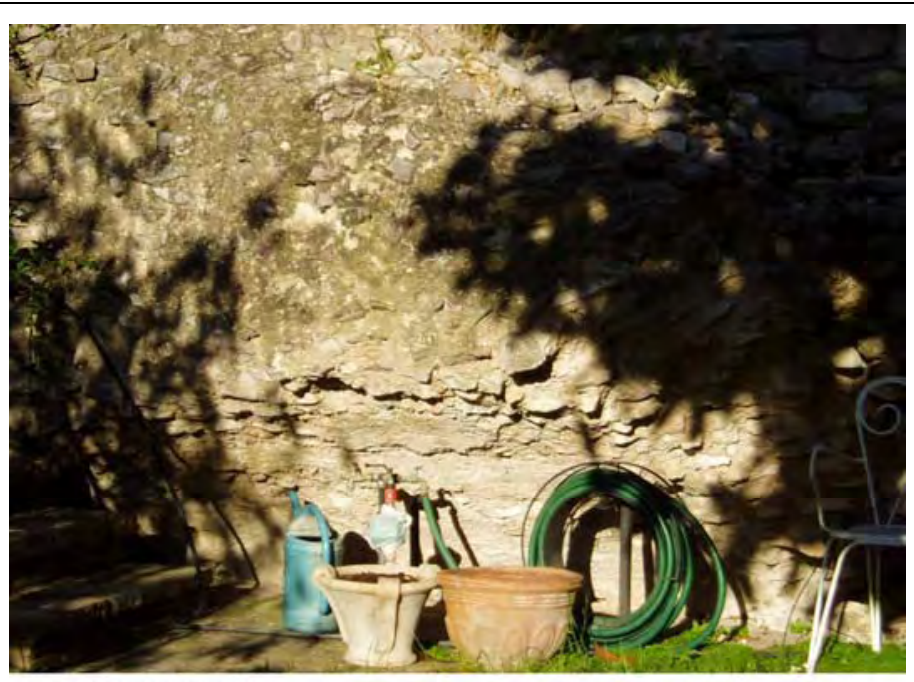

Foto 212: Anfiteatro de Asis

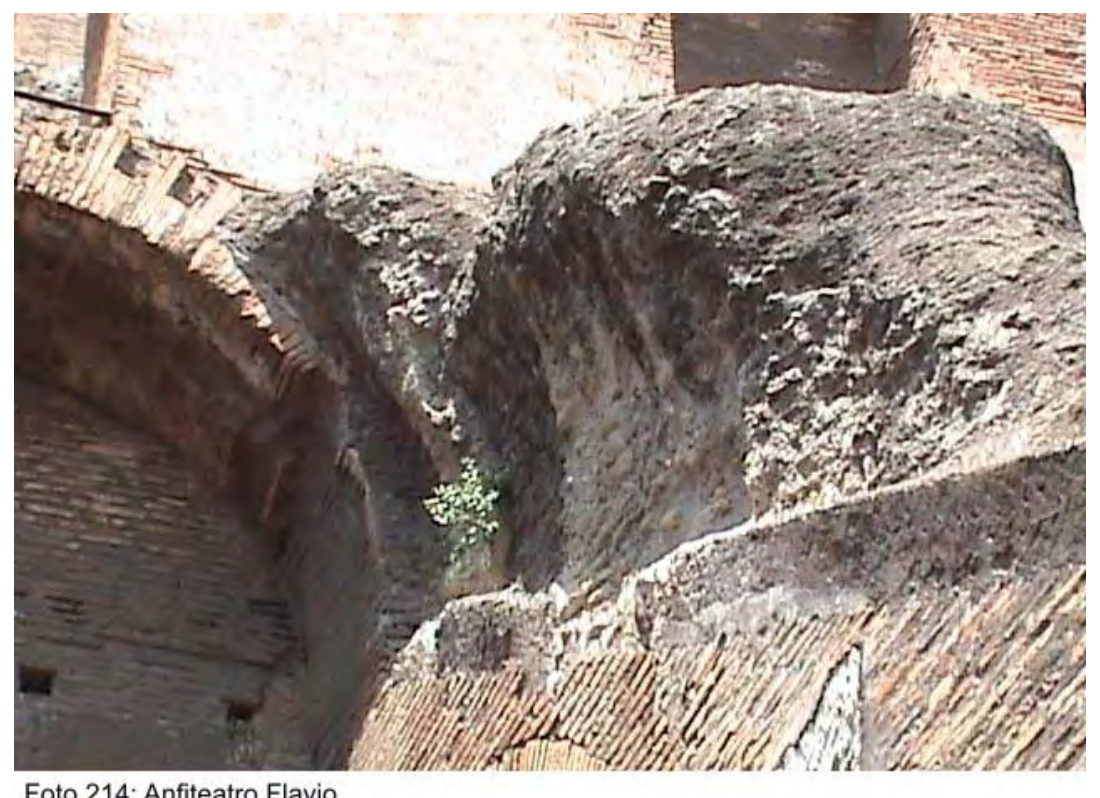




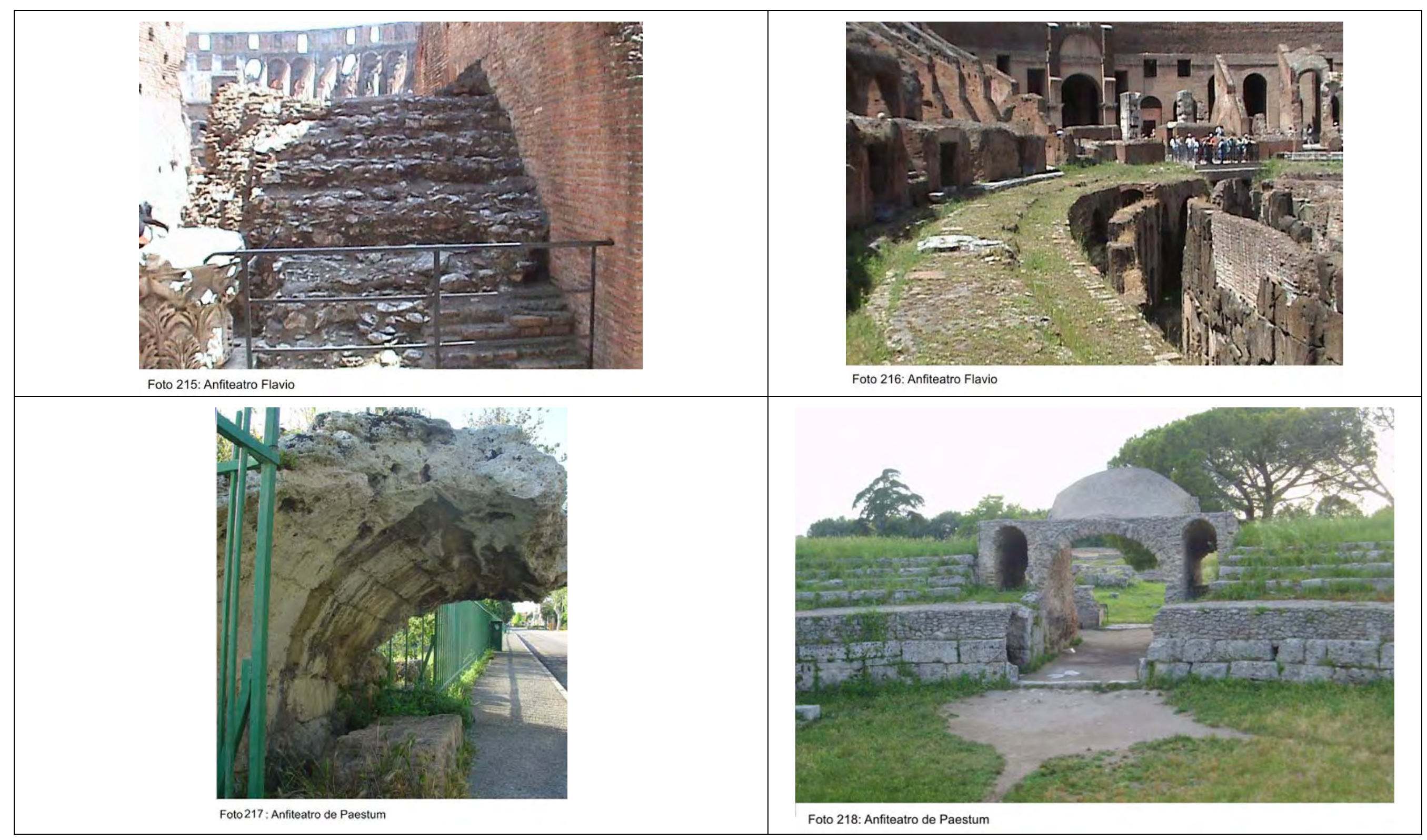




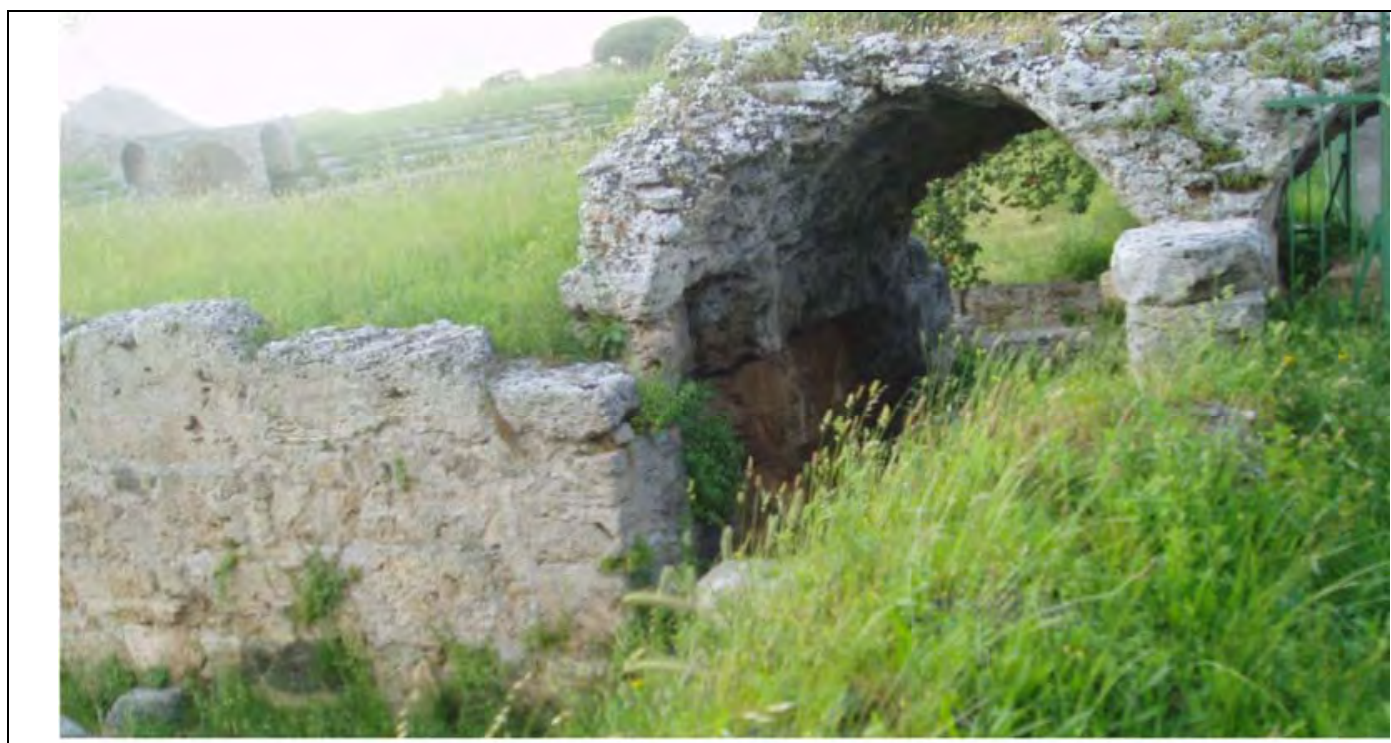

Foto 219: Anfiteatro de Faestum

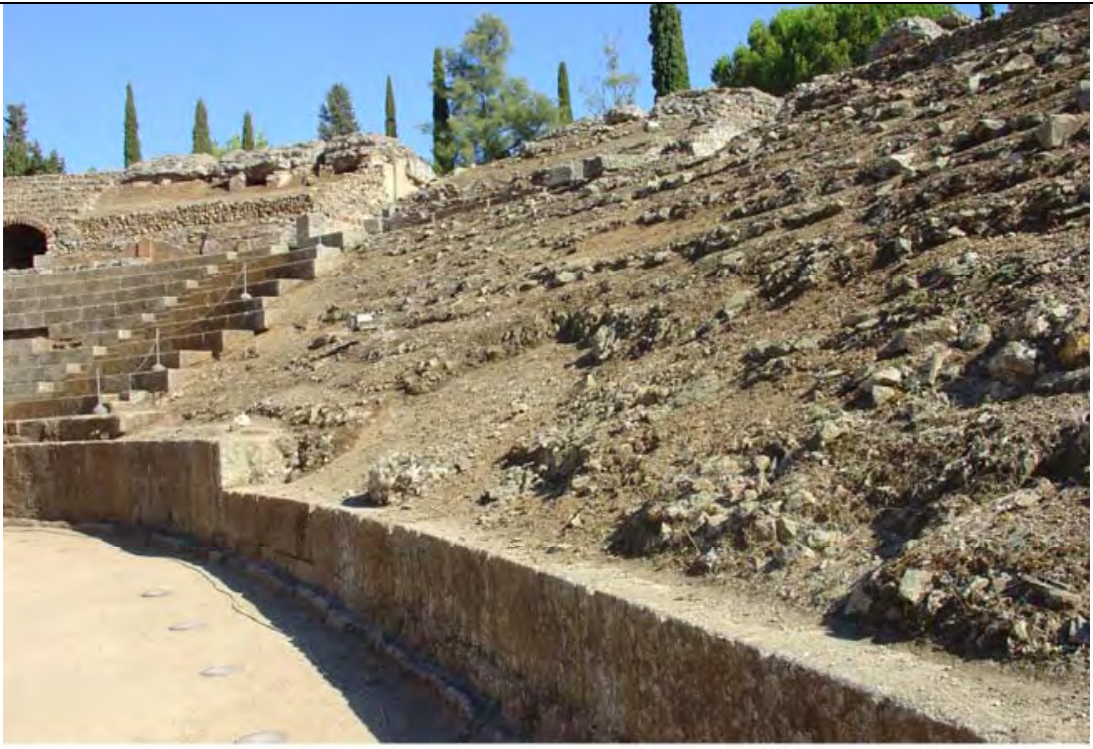

Foto 220: Anfiteatro de Merida
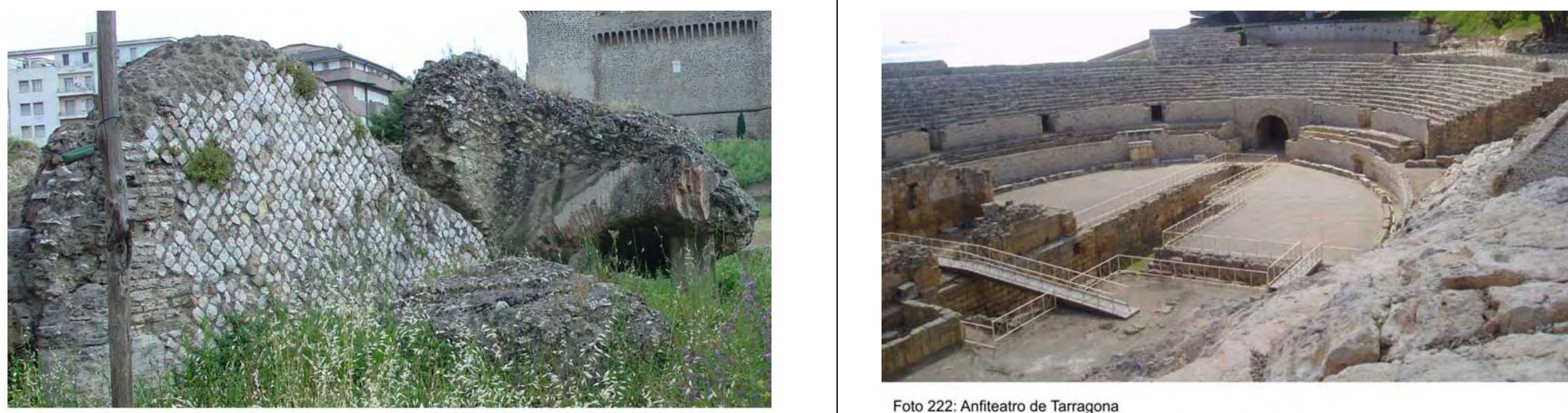

Foto 221: Anfiteatro de Tivoli

Foto 222: Anfiteatro de Tarragona 


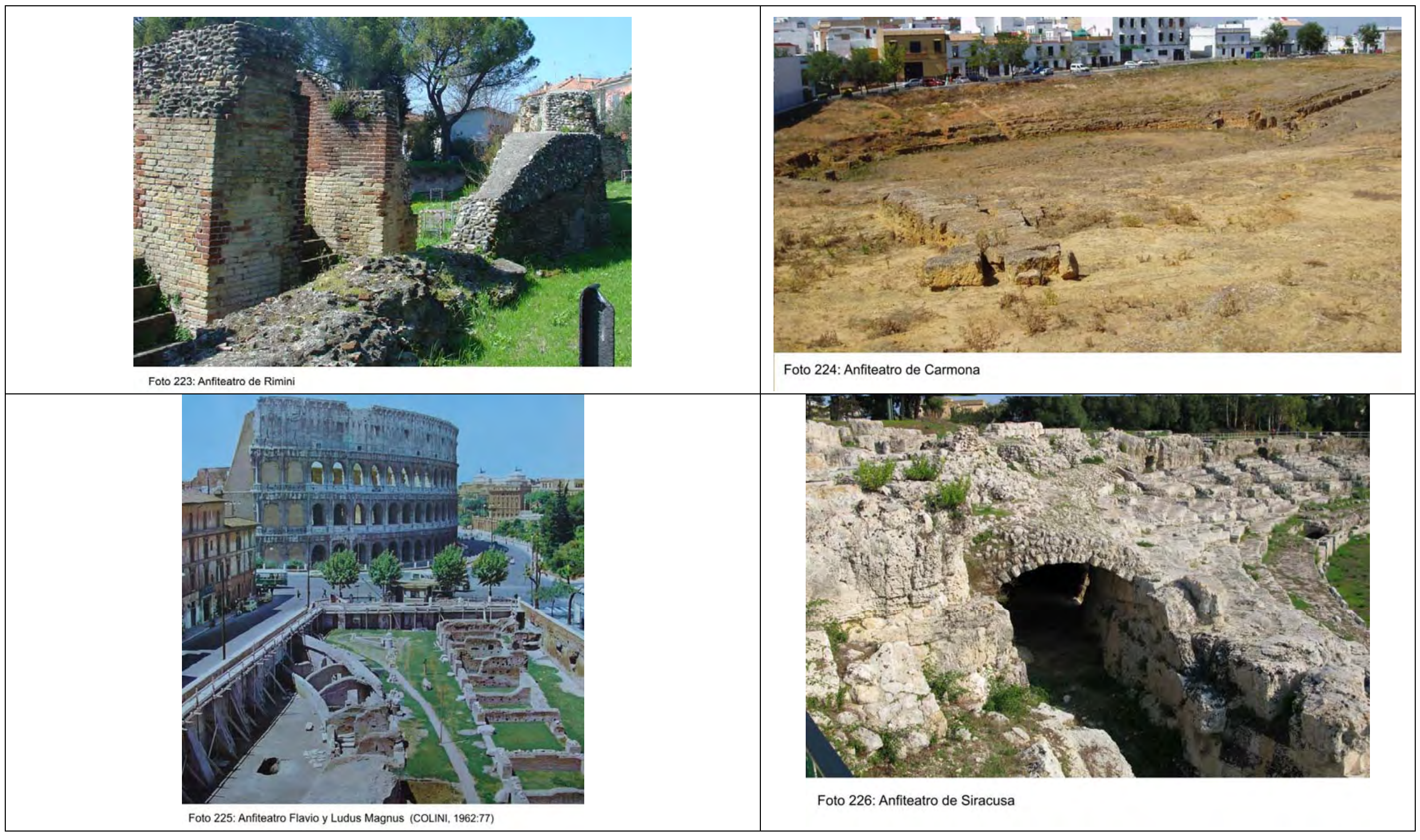




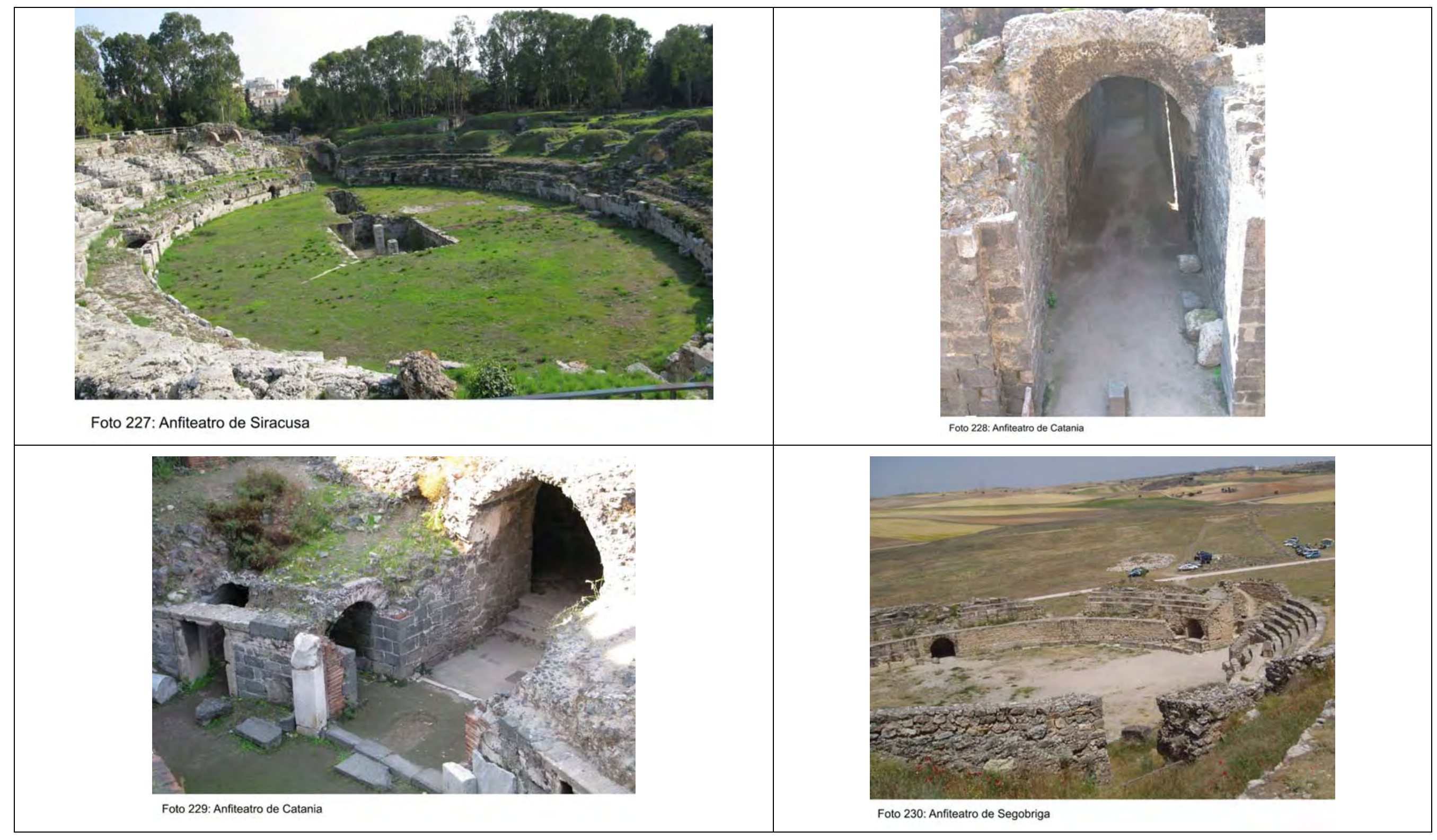




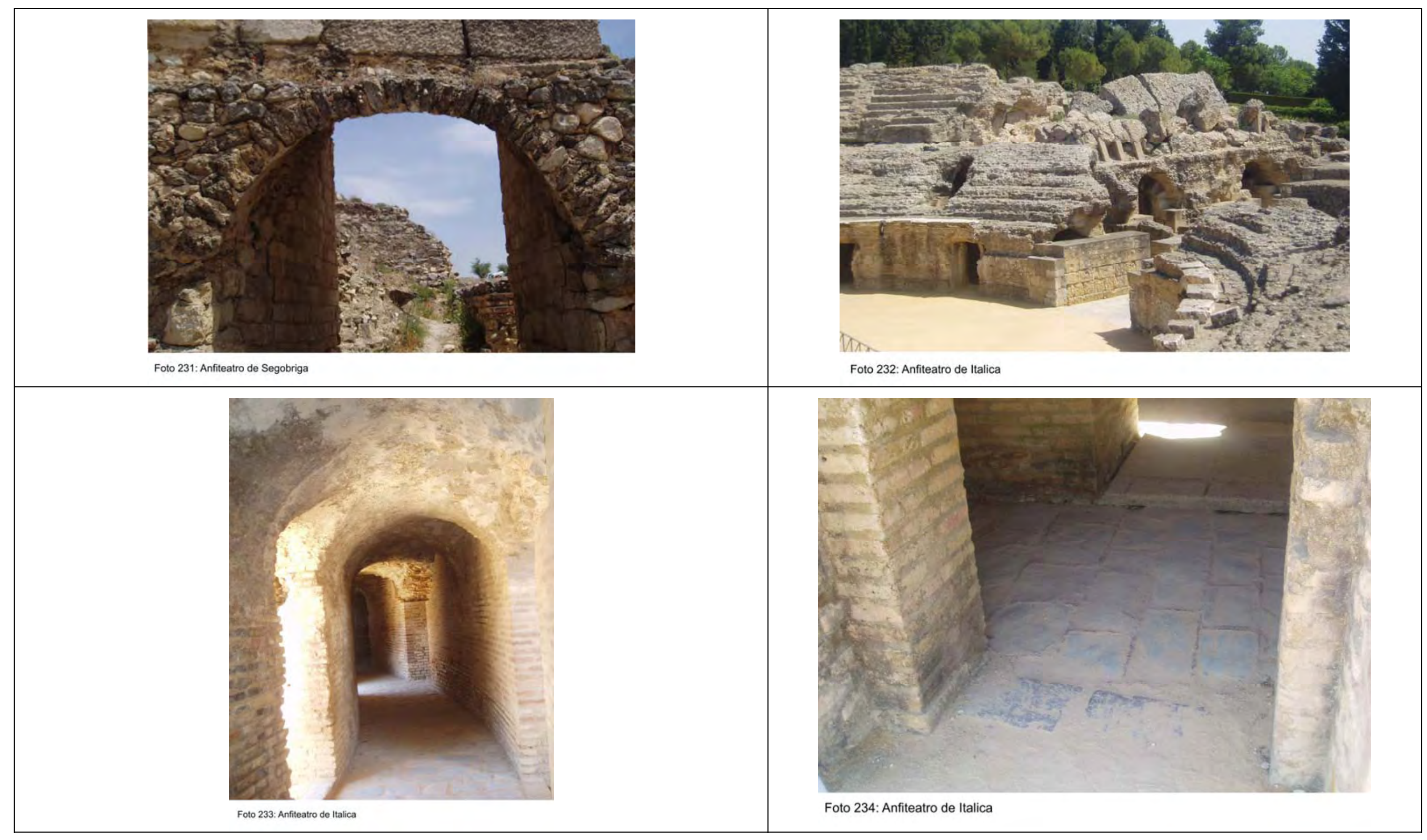




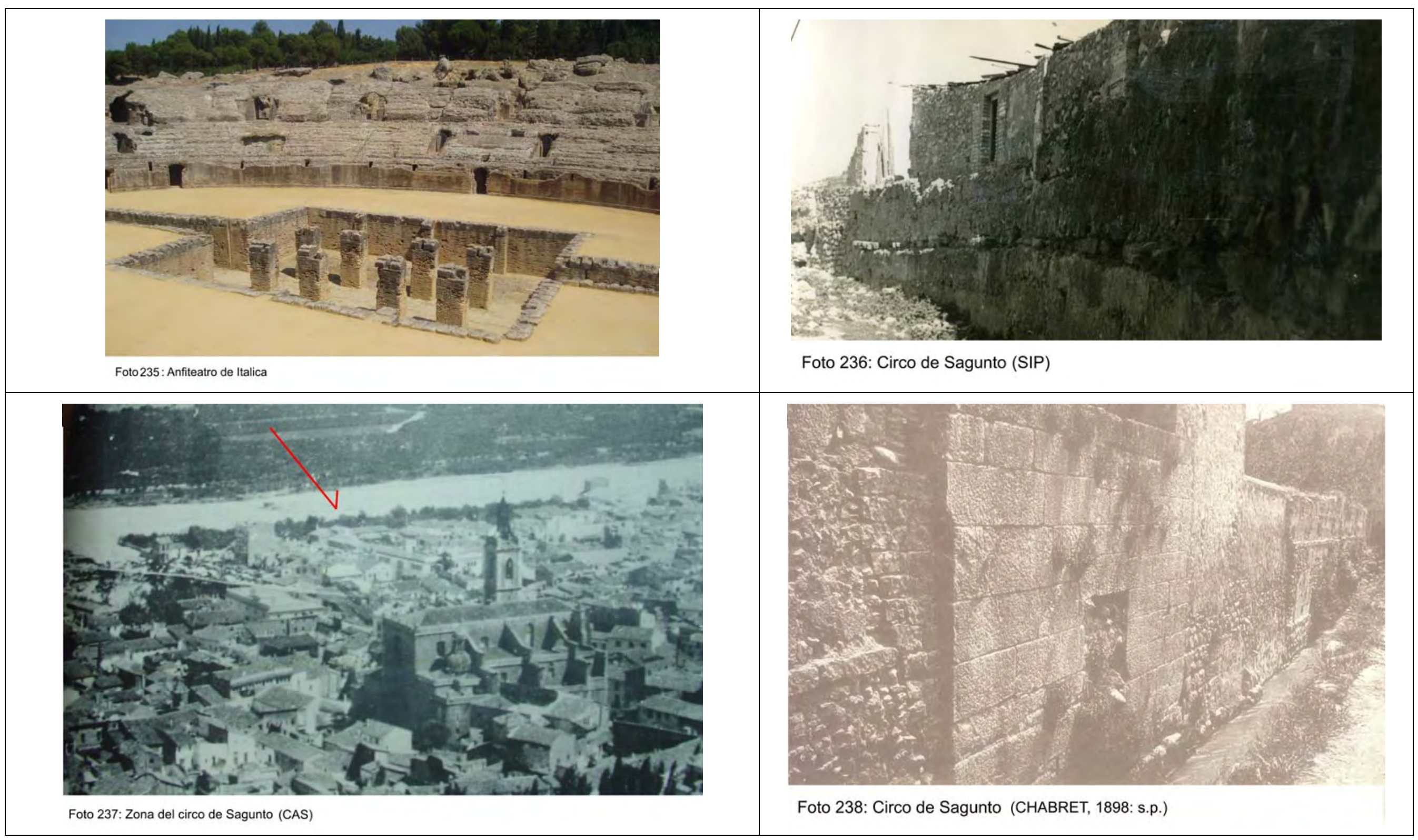




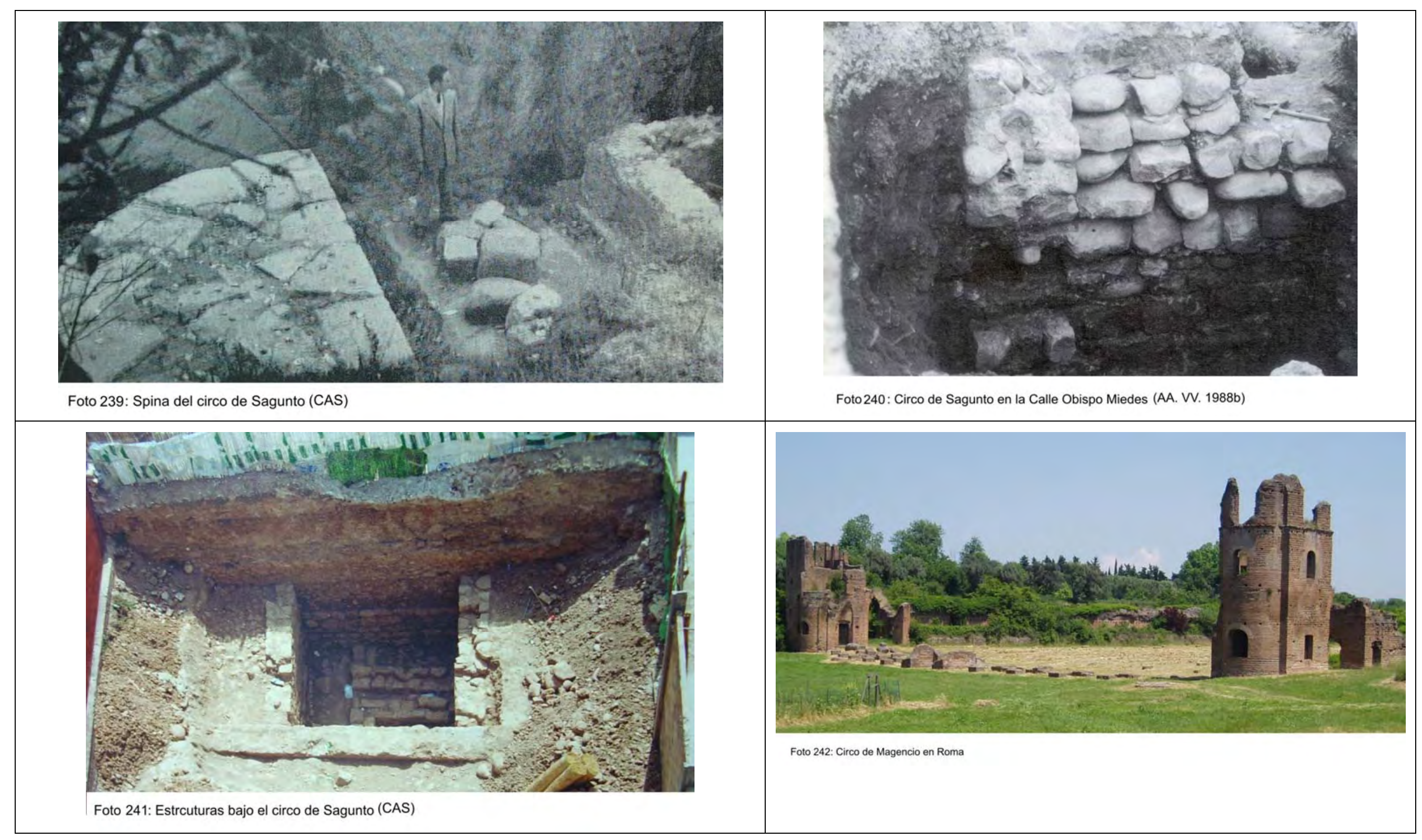




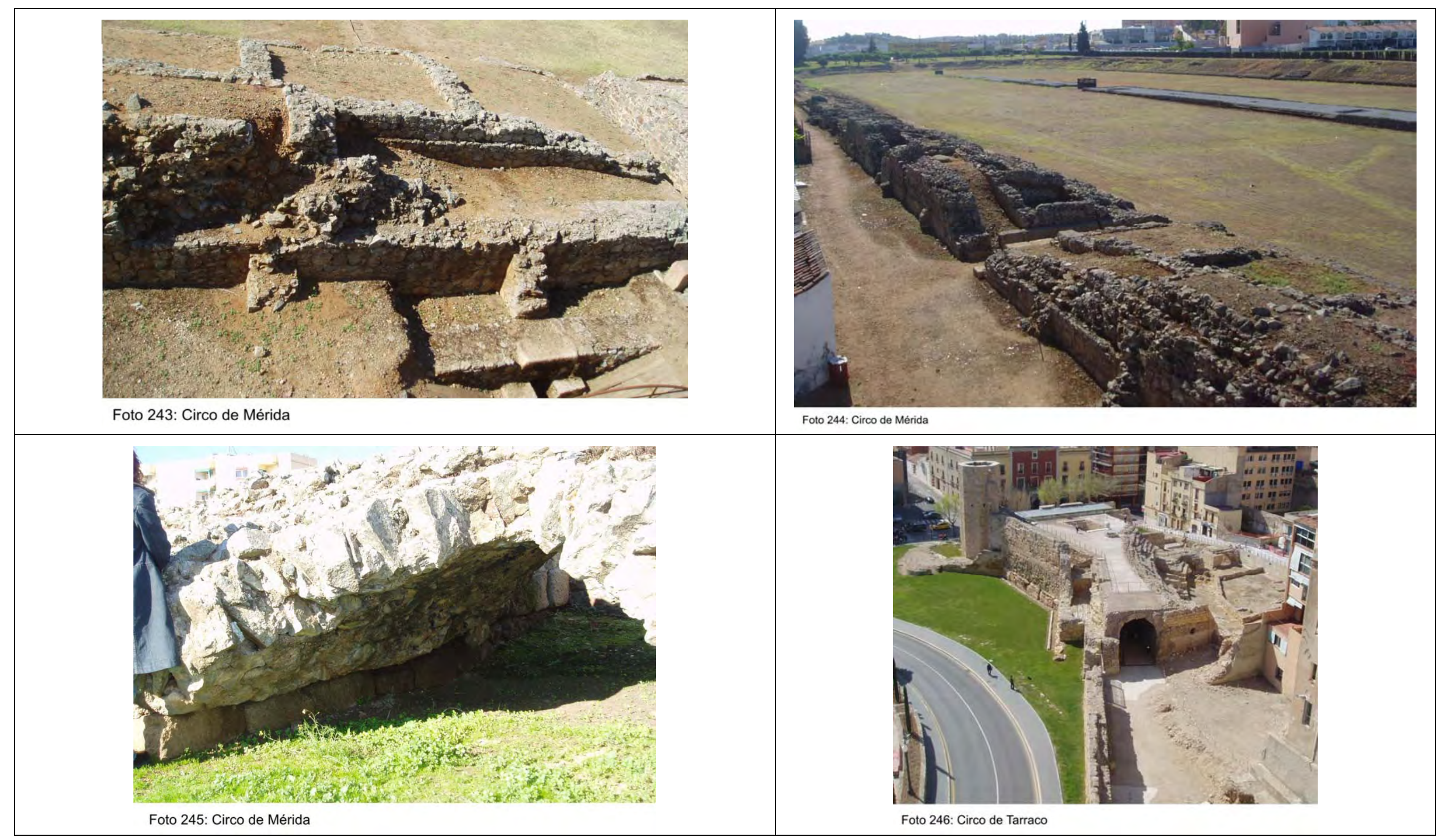




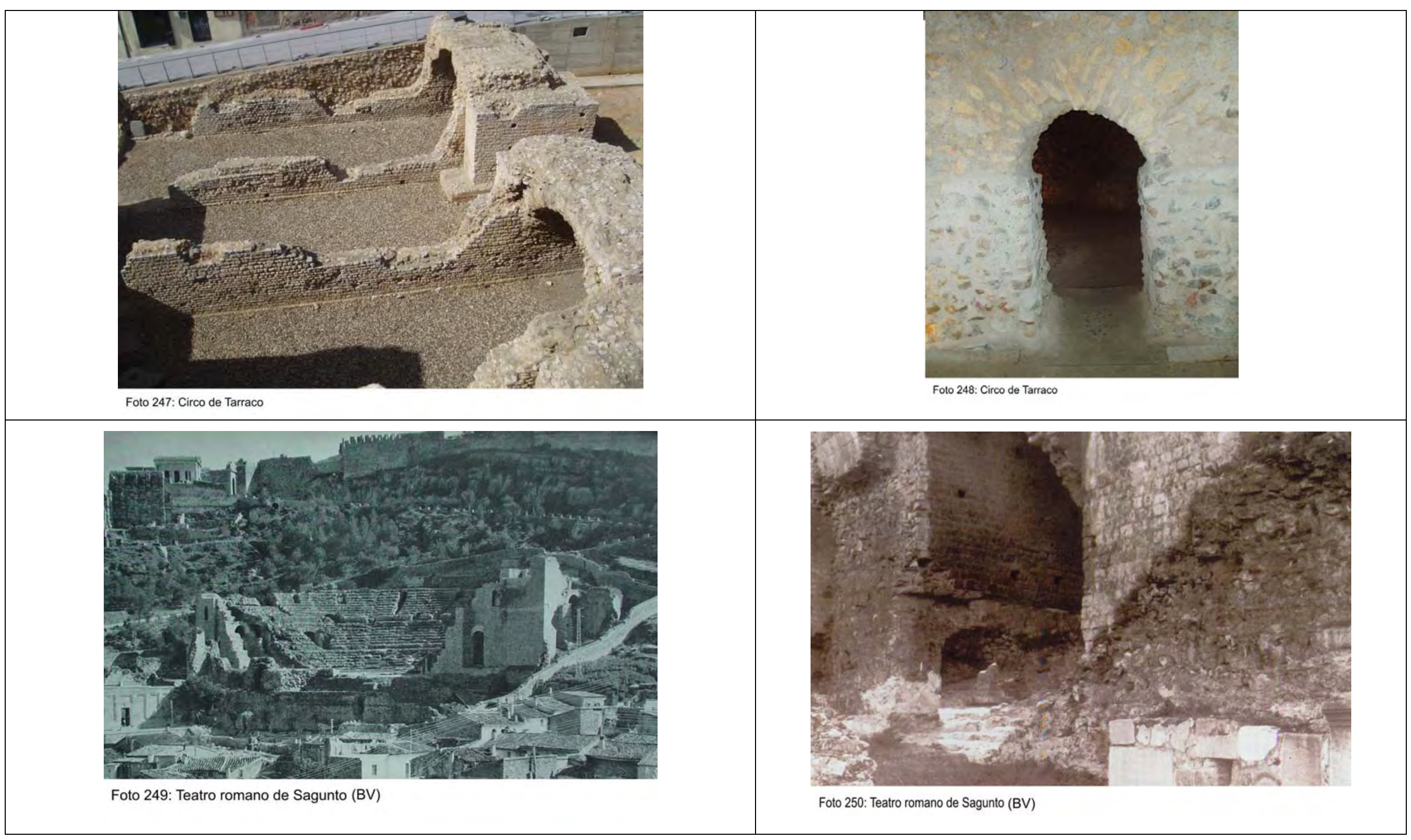




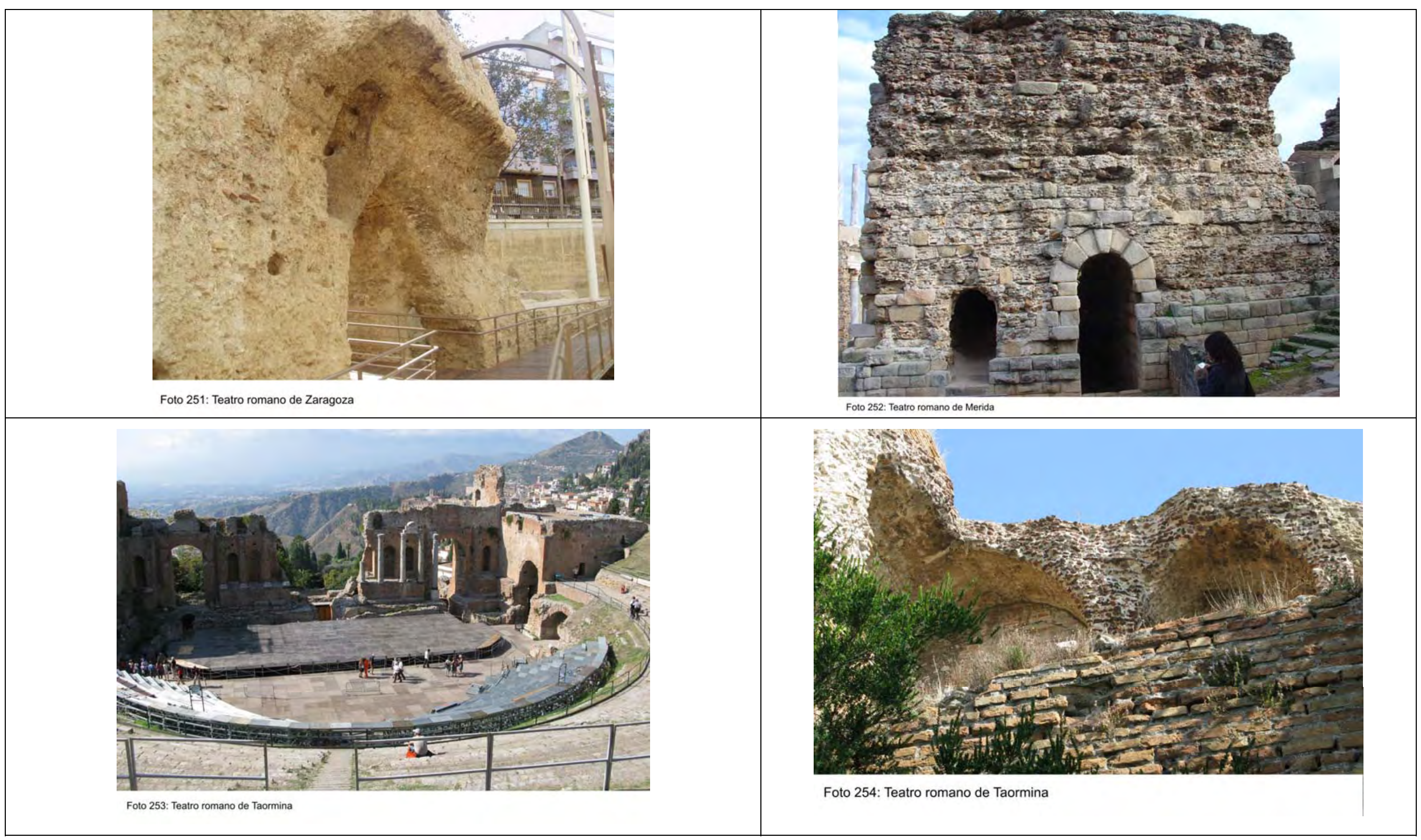




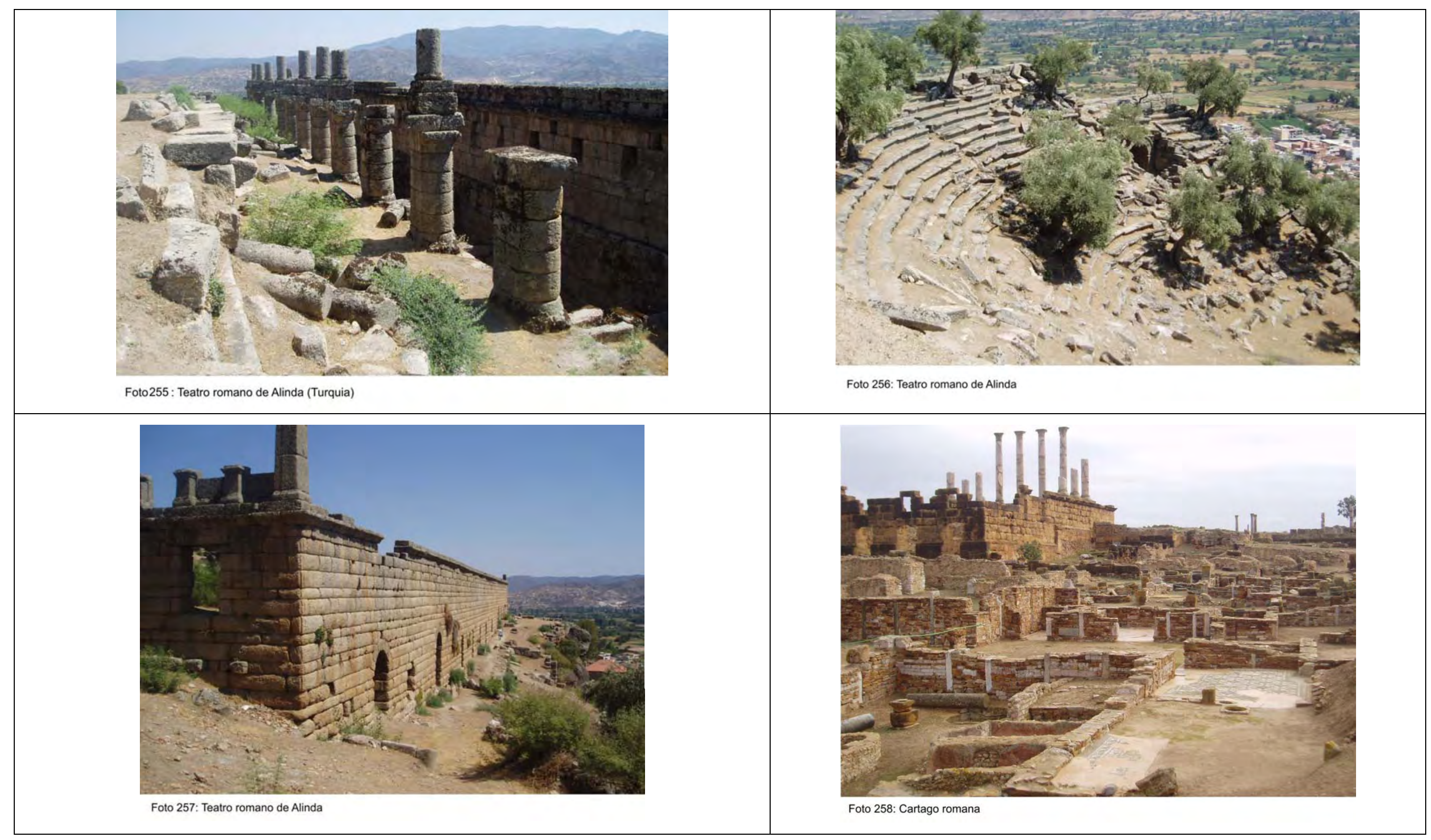




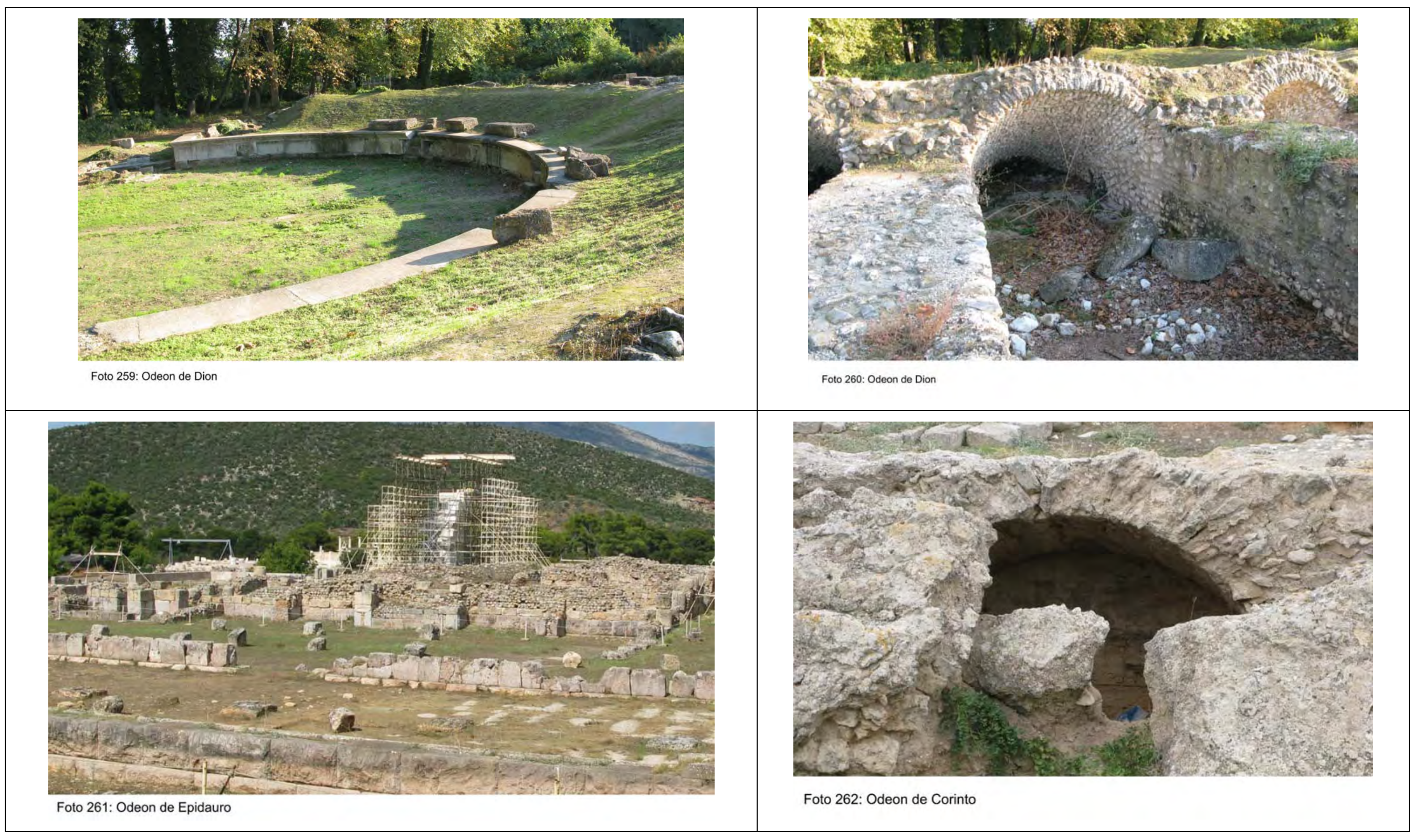




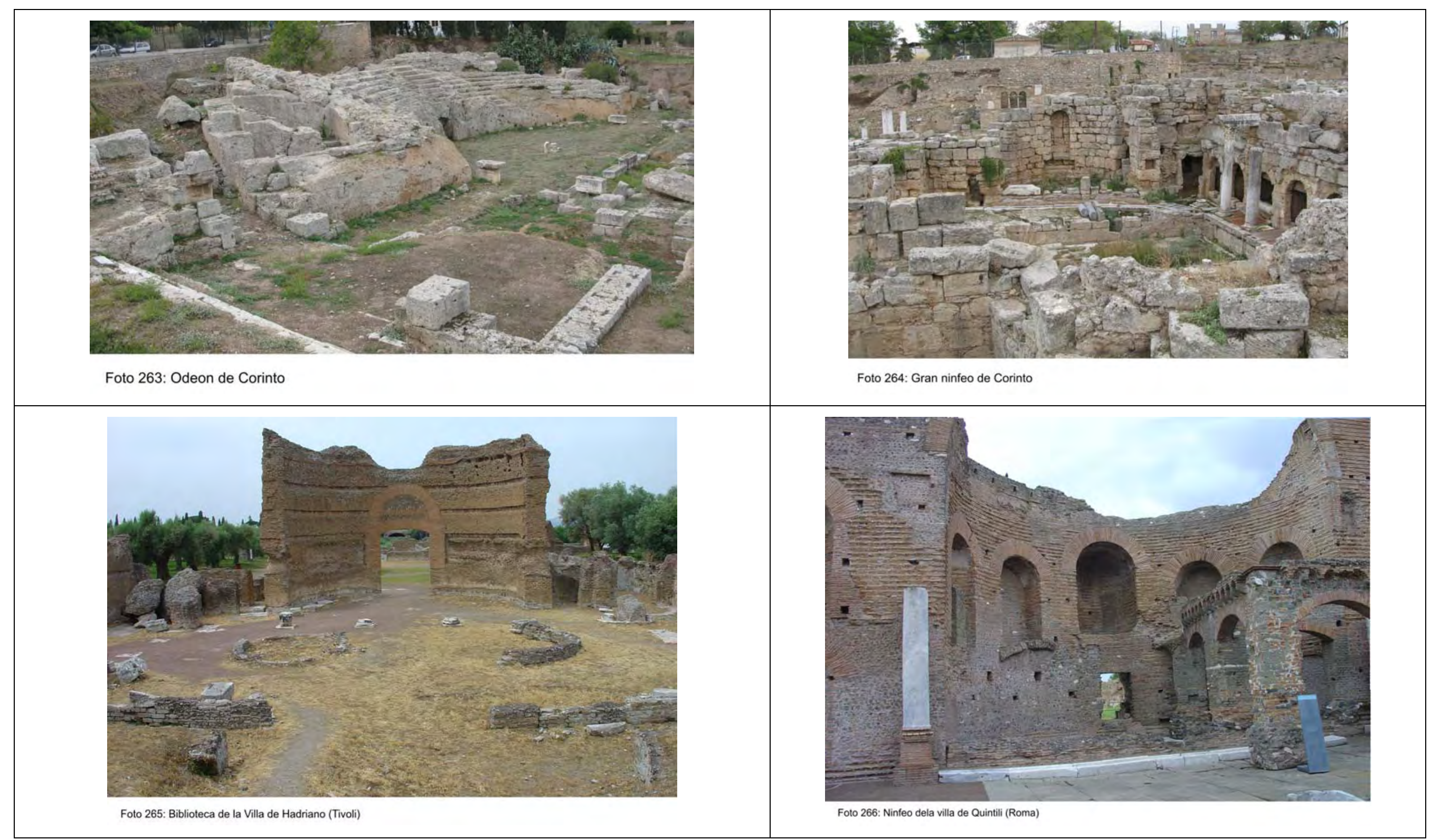




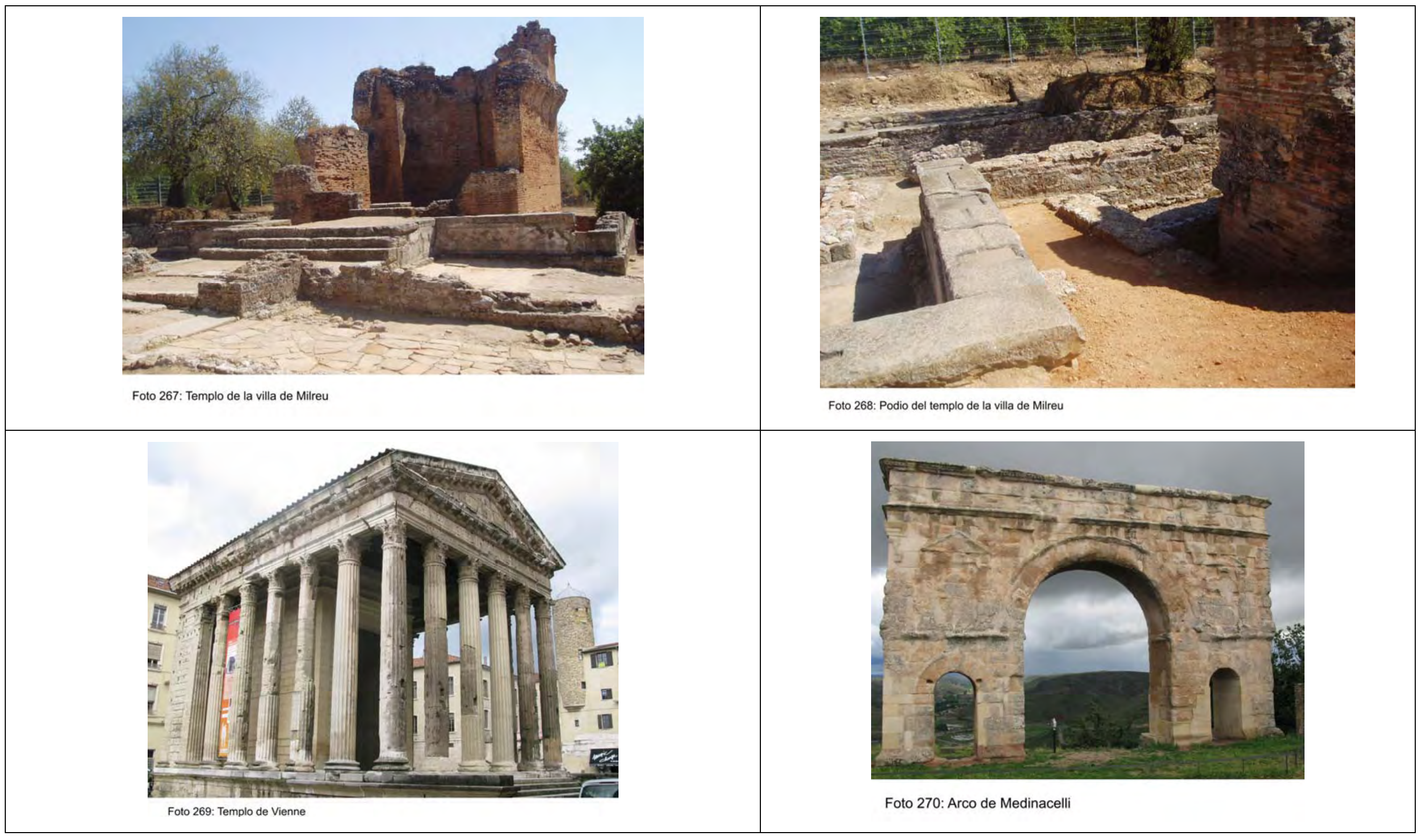




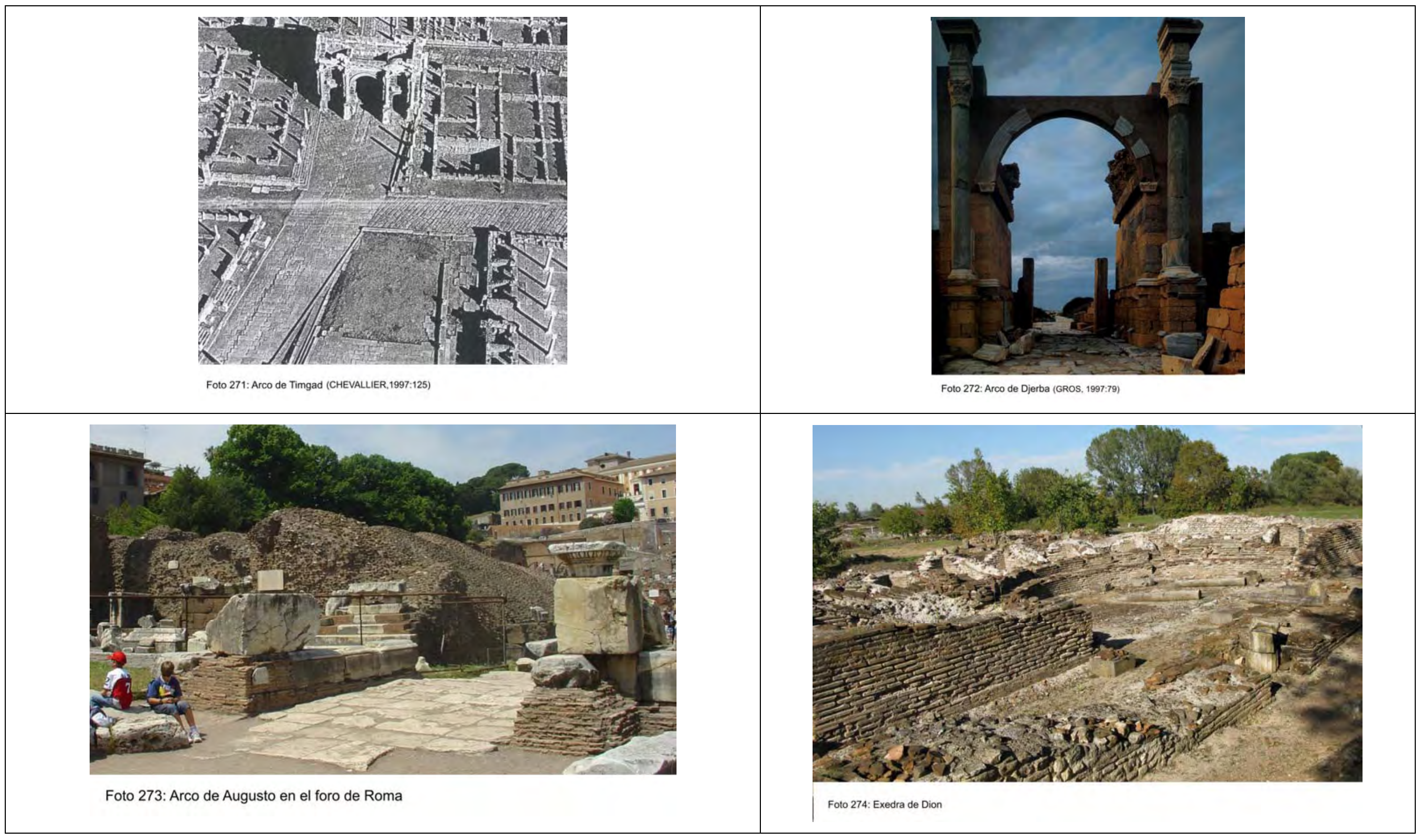




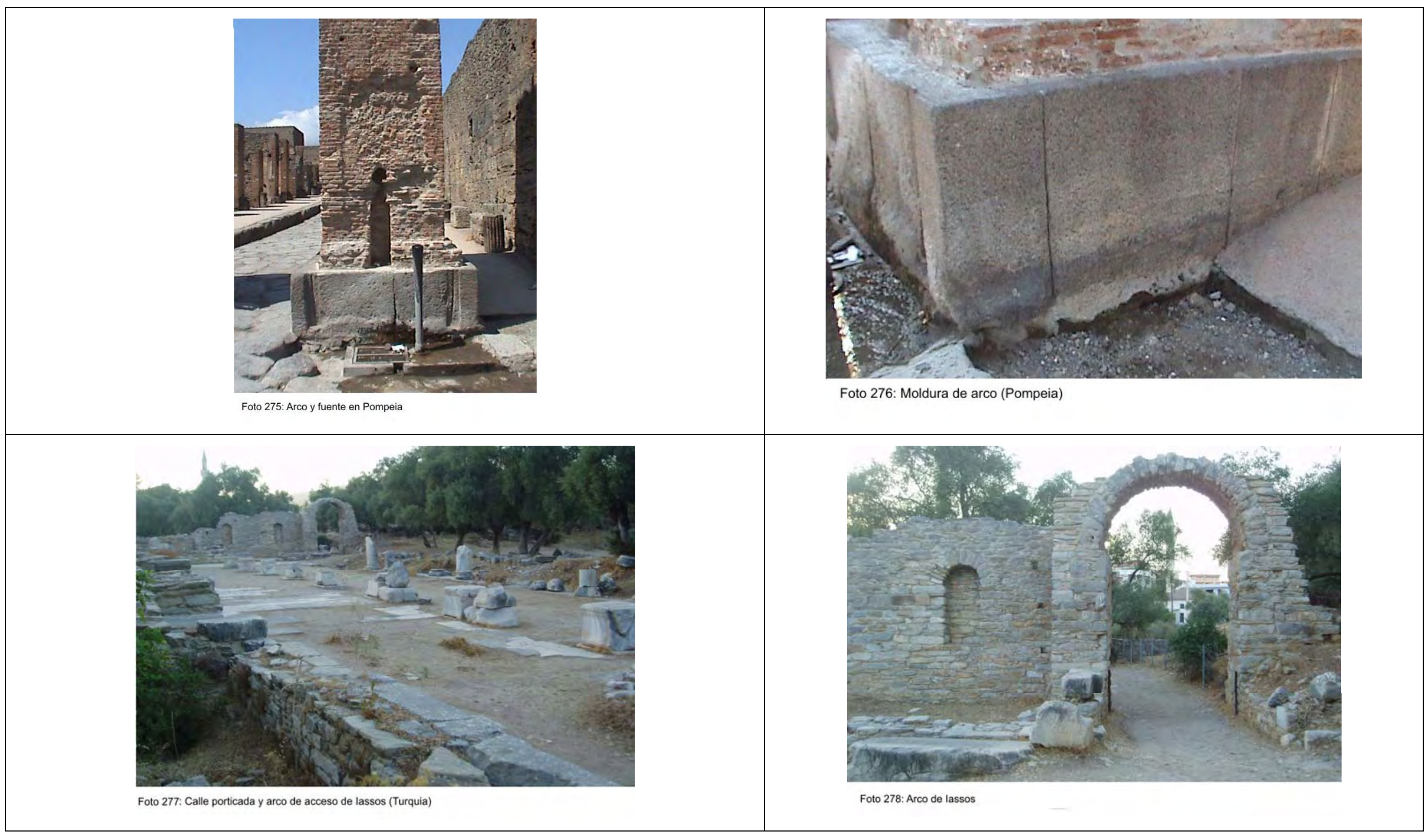




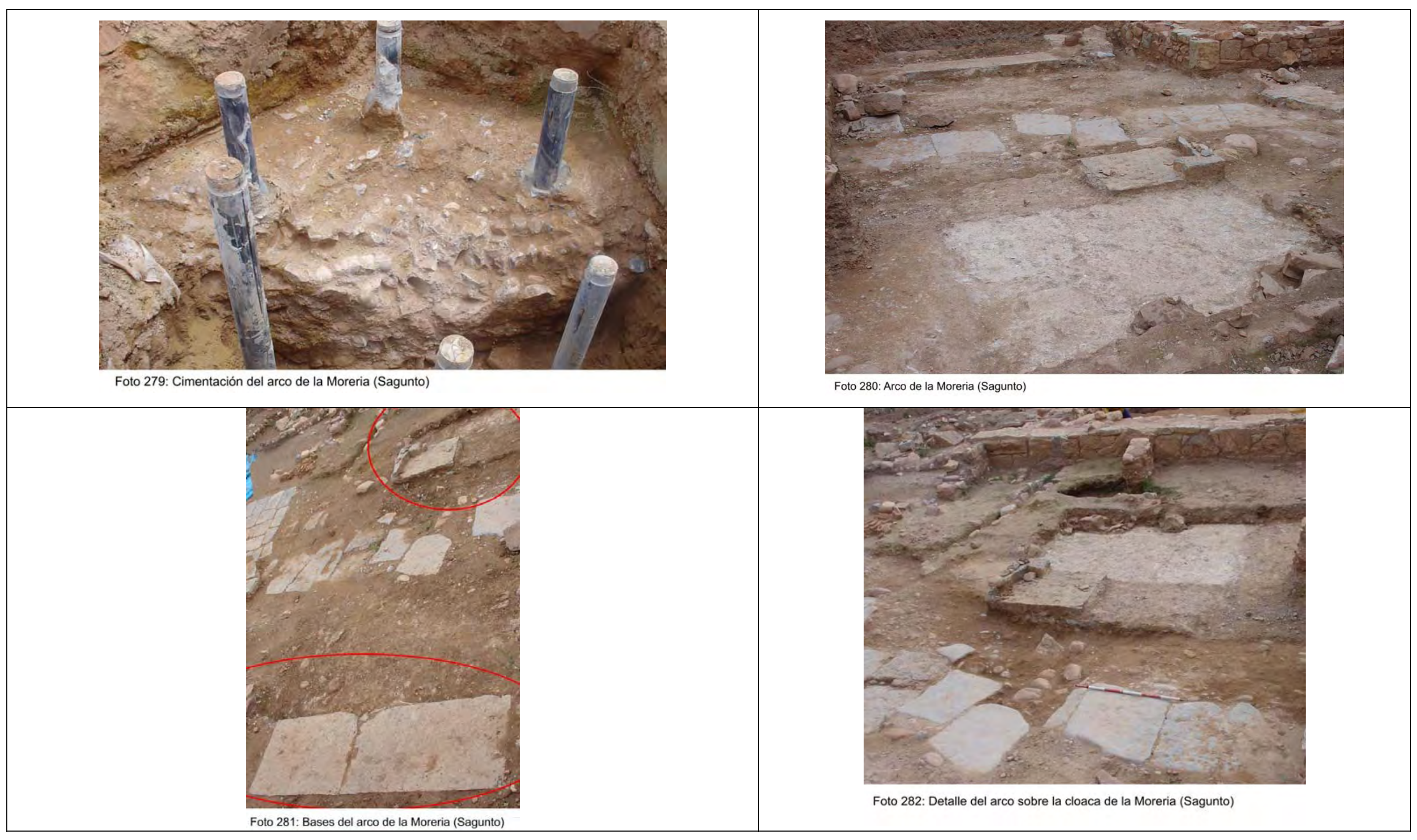




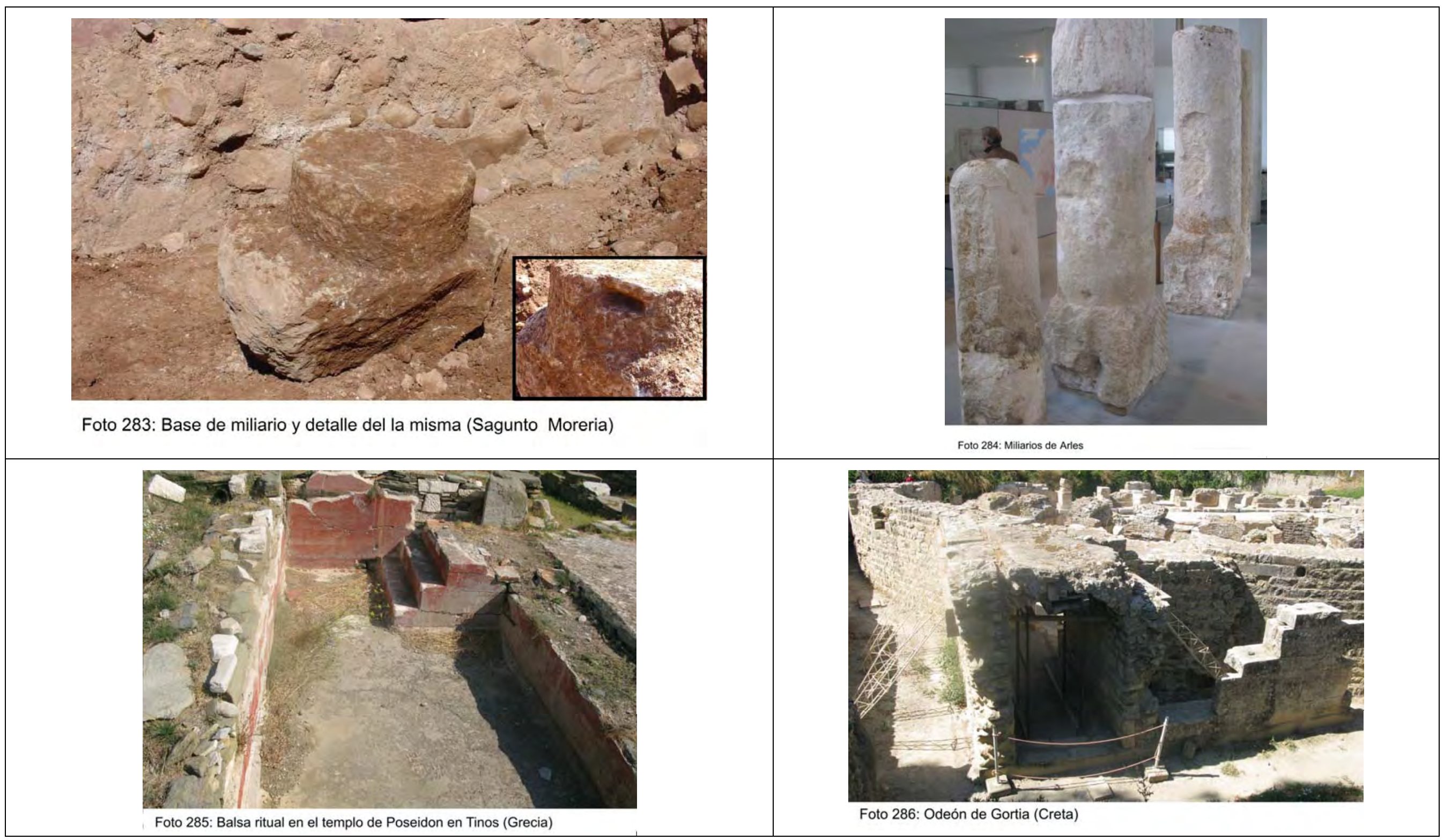




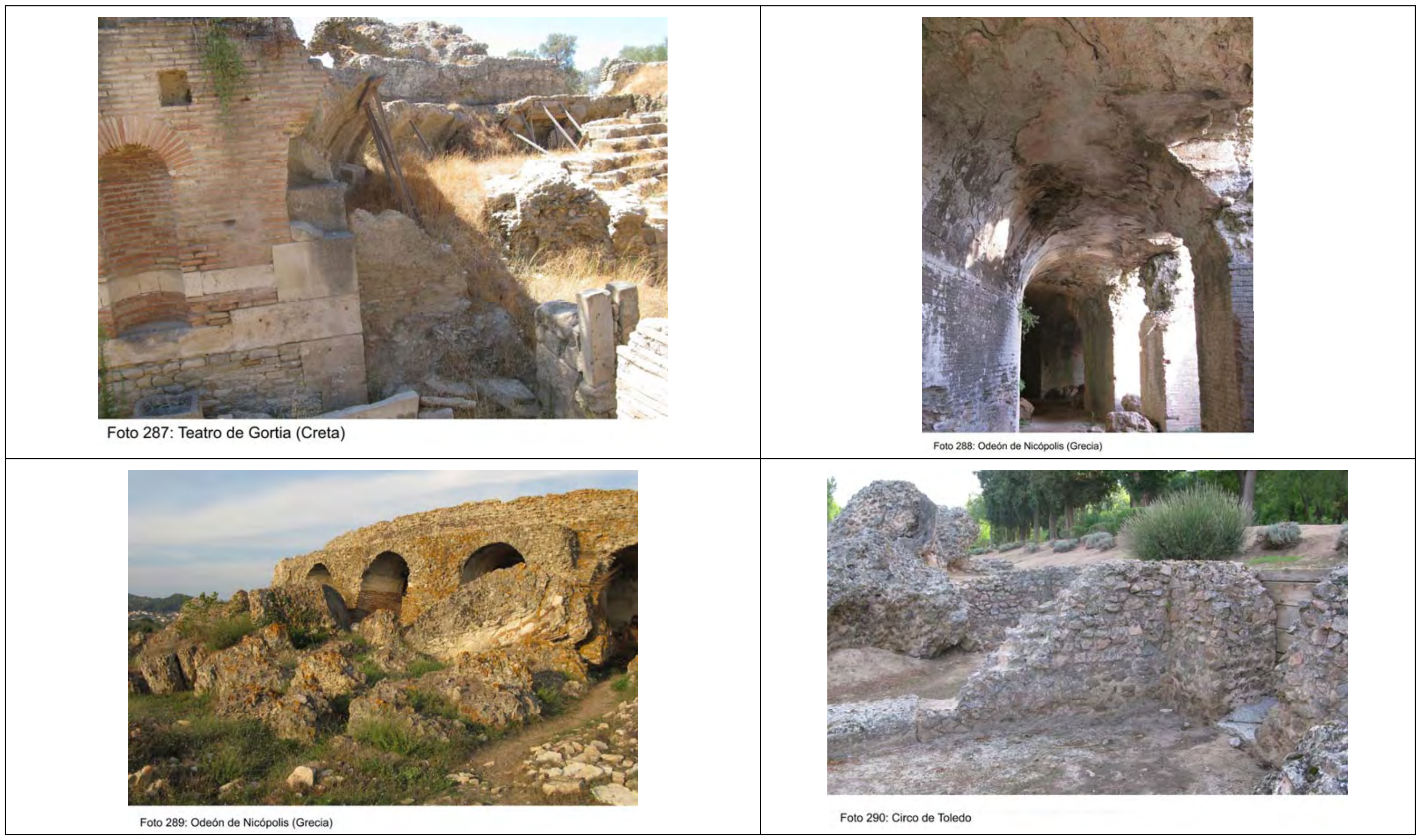




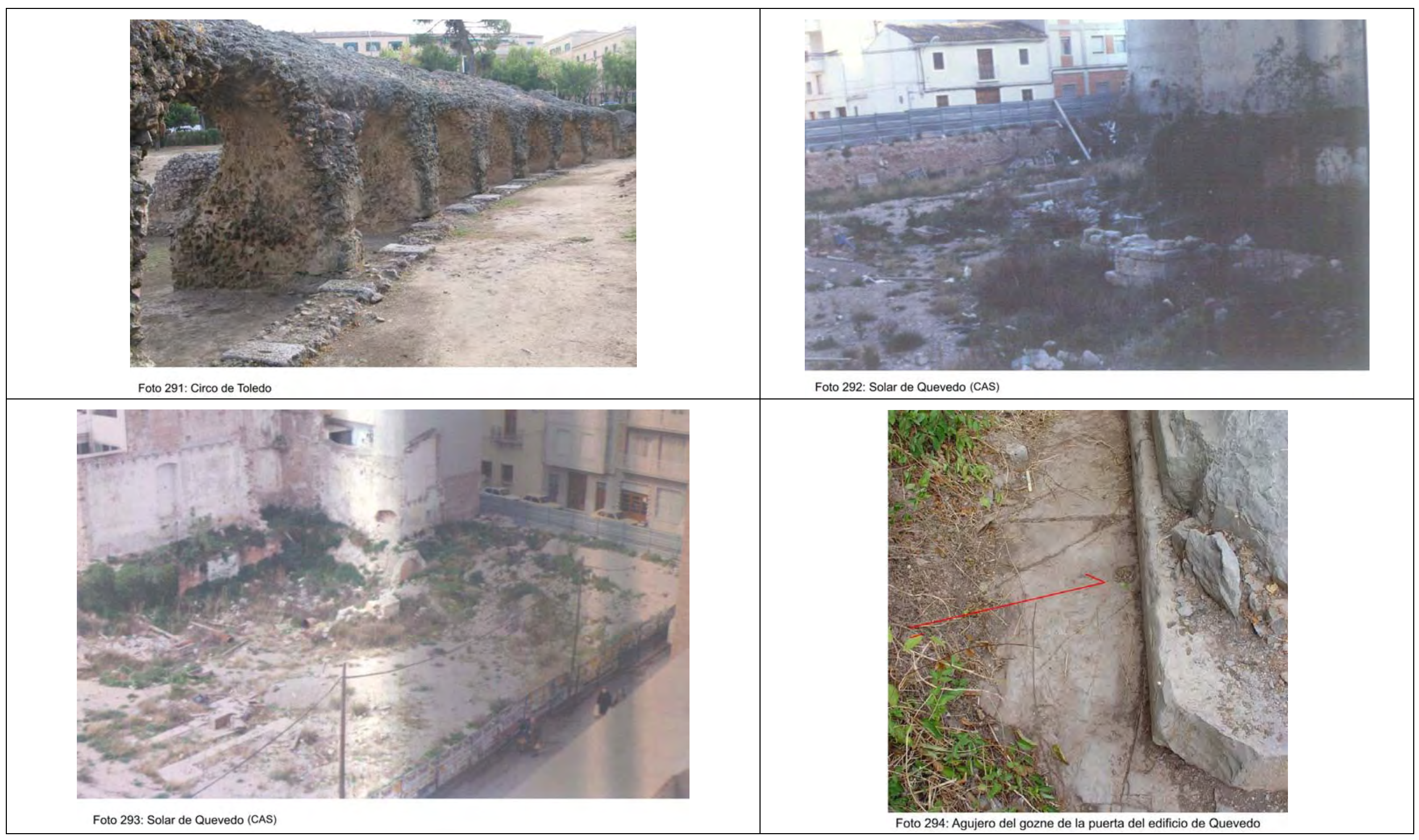




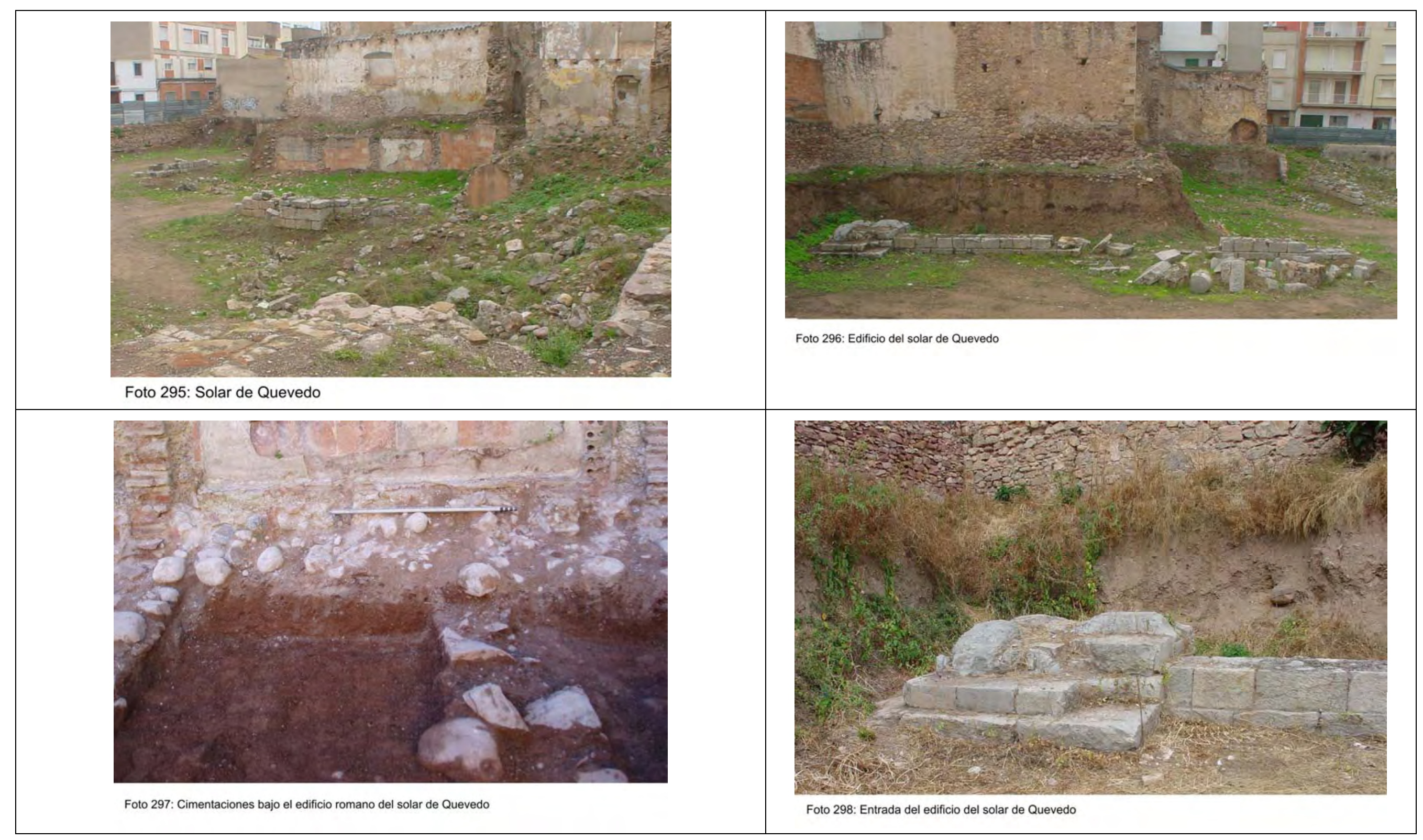




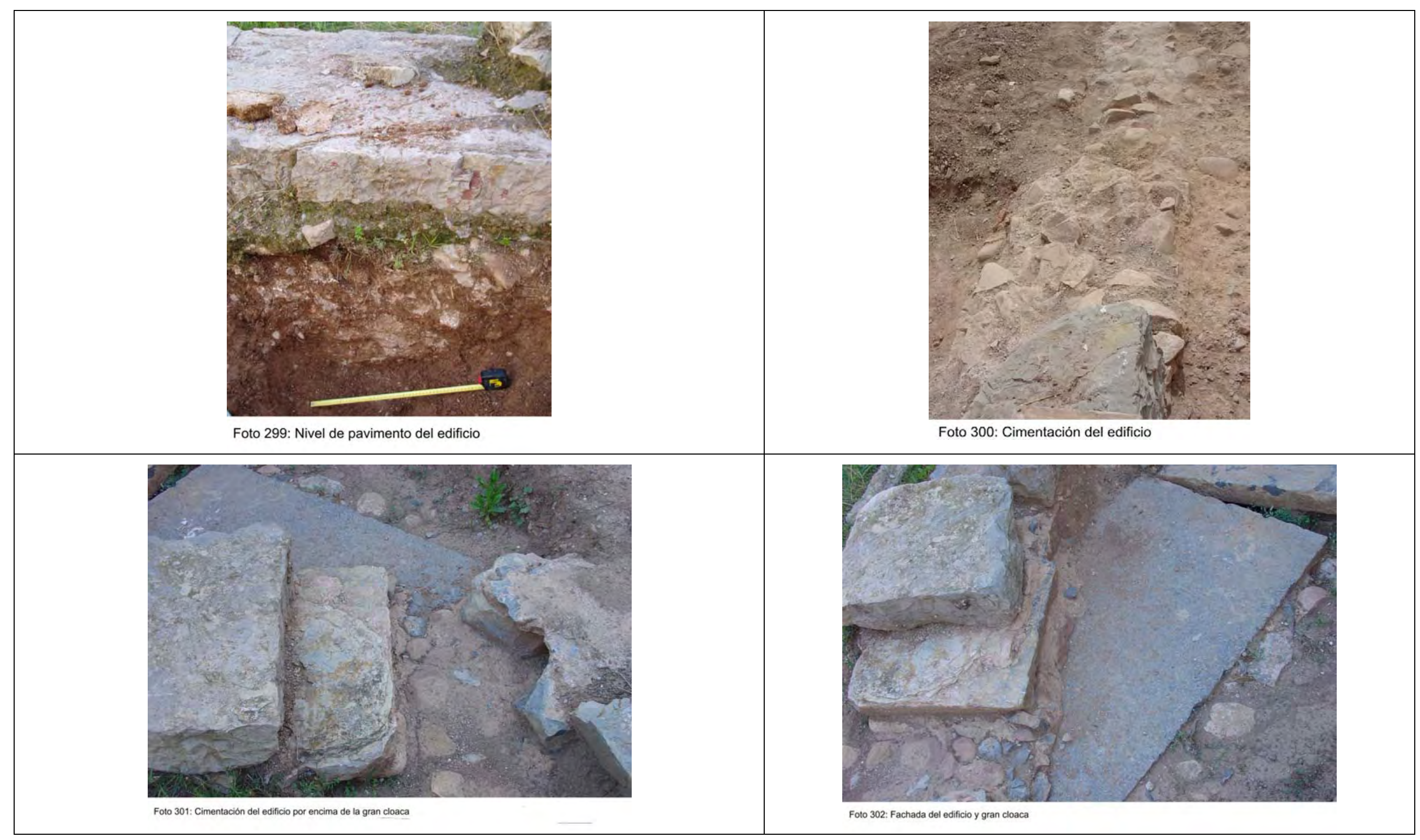




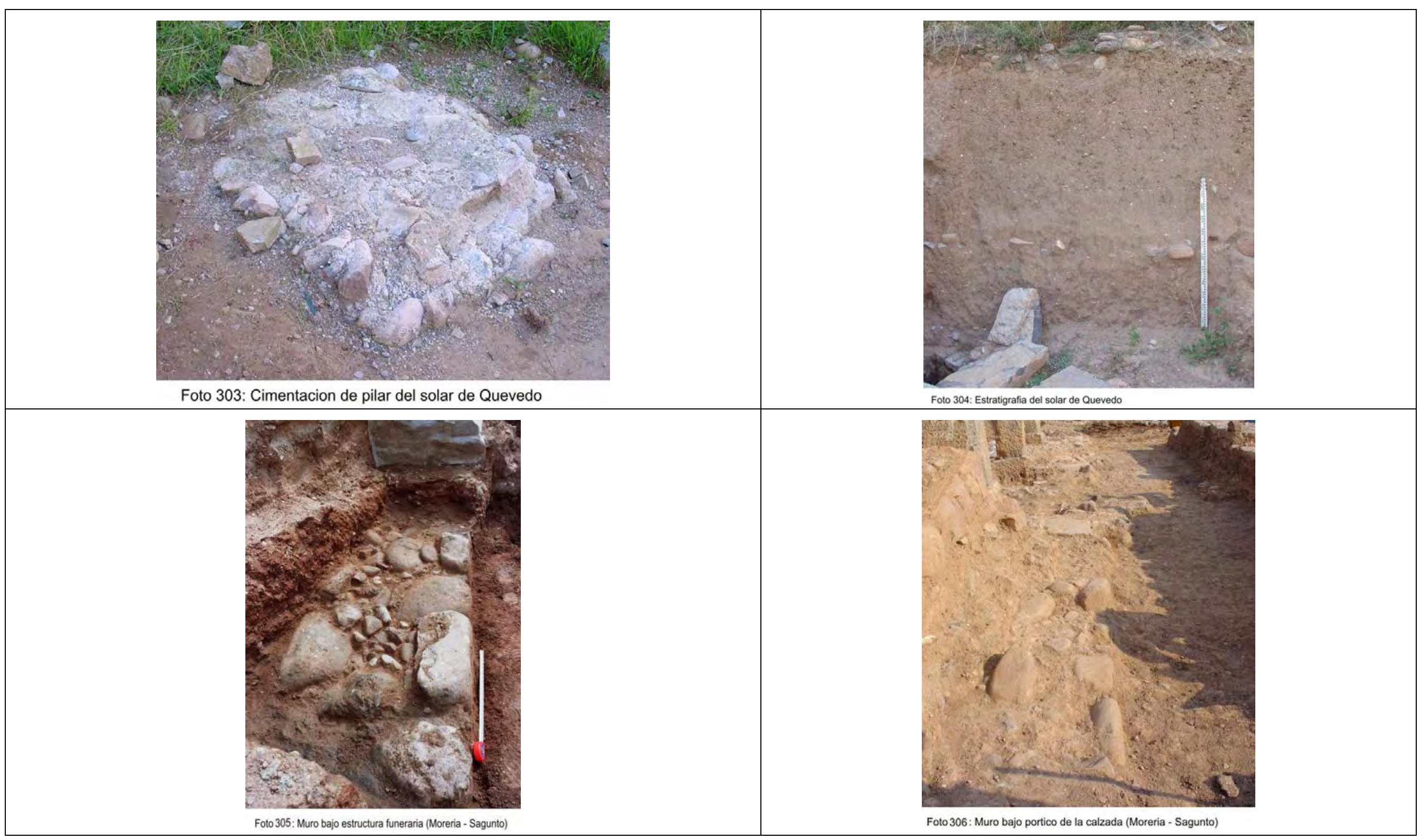




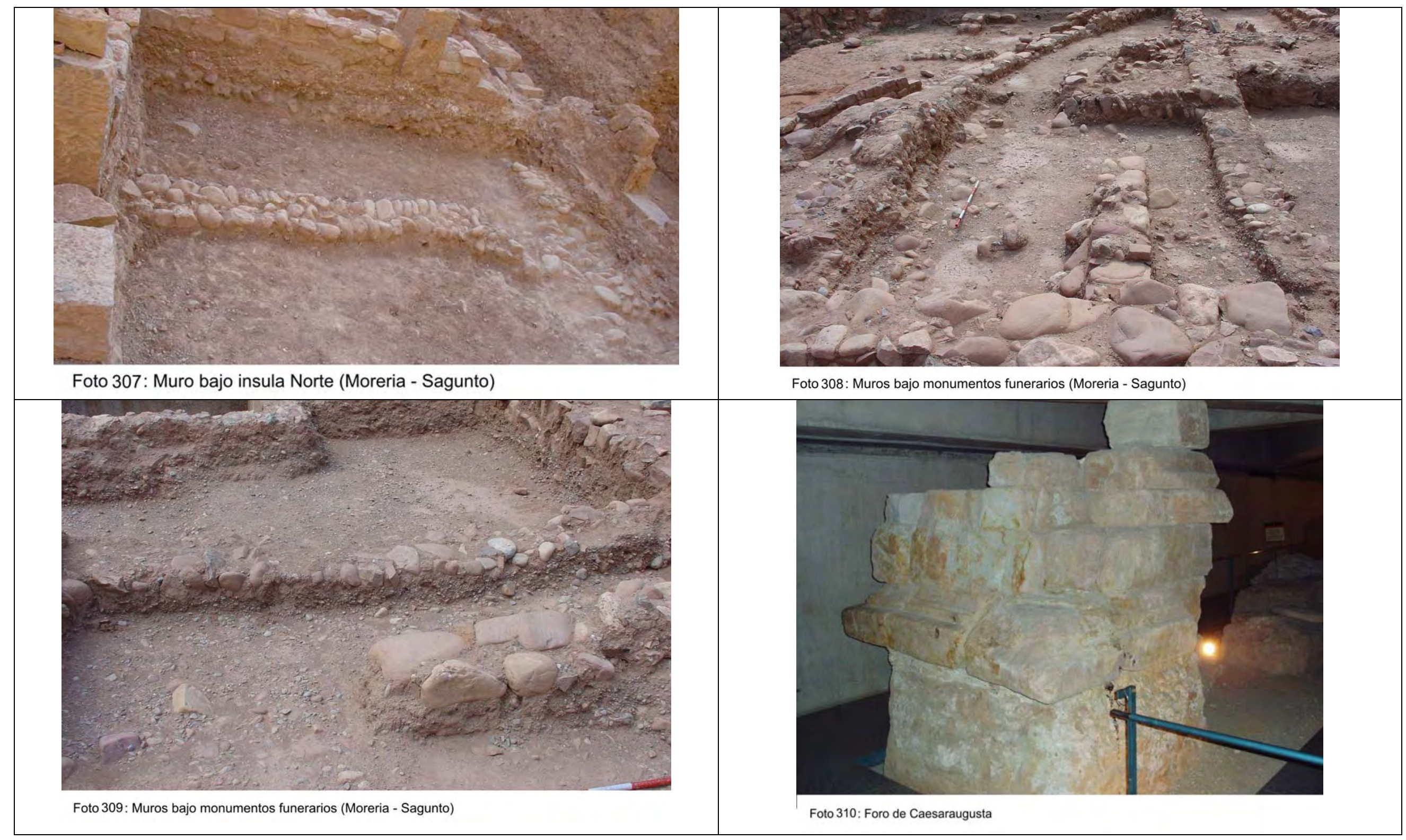




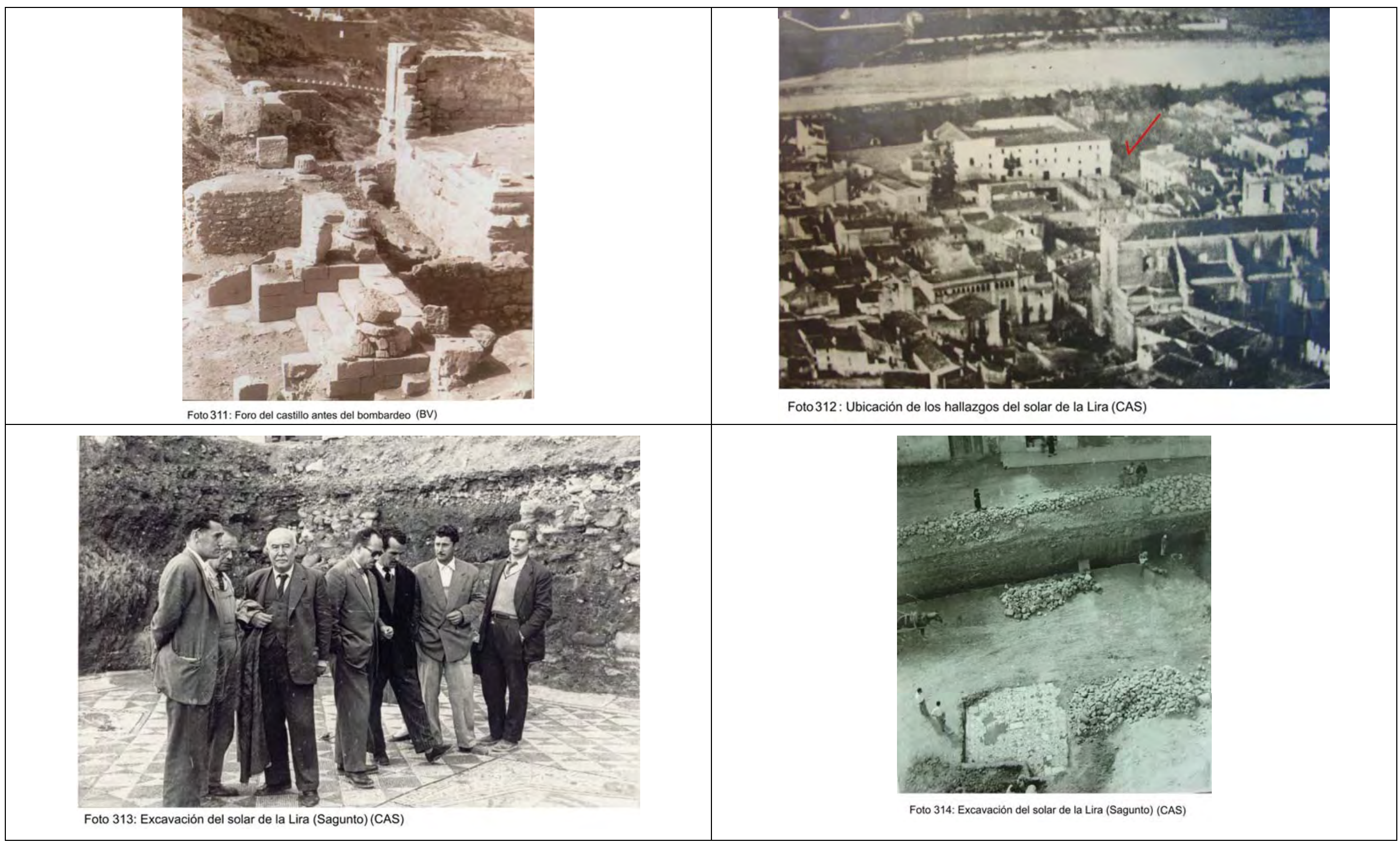




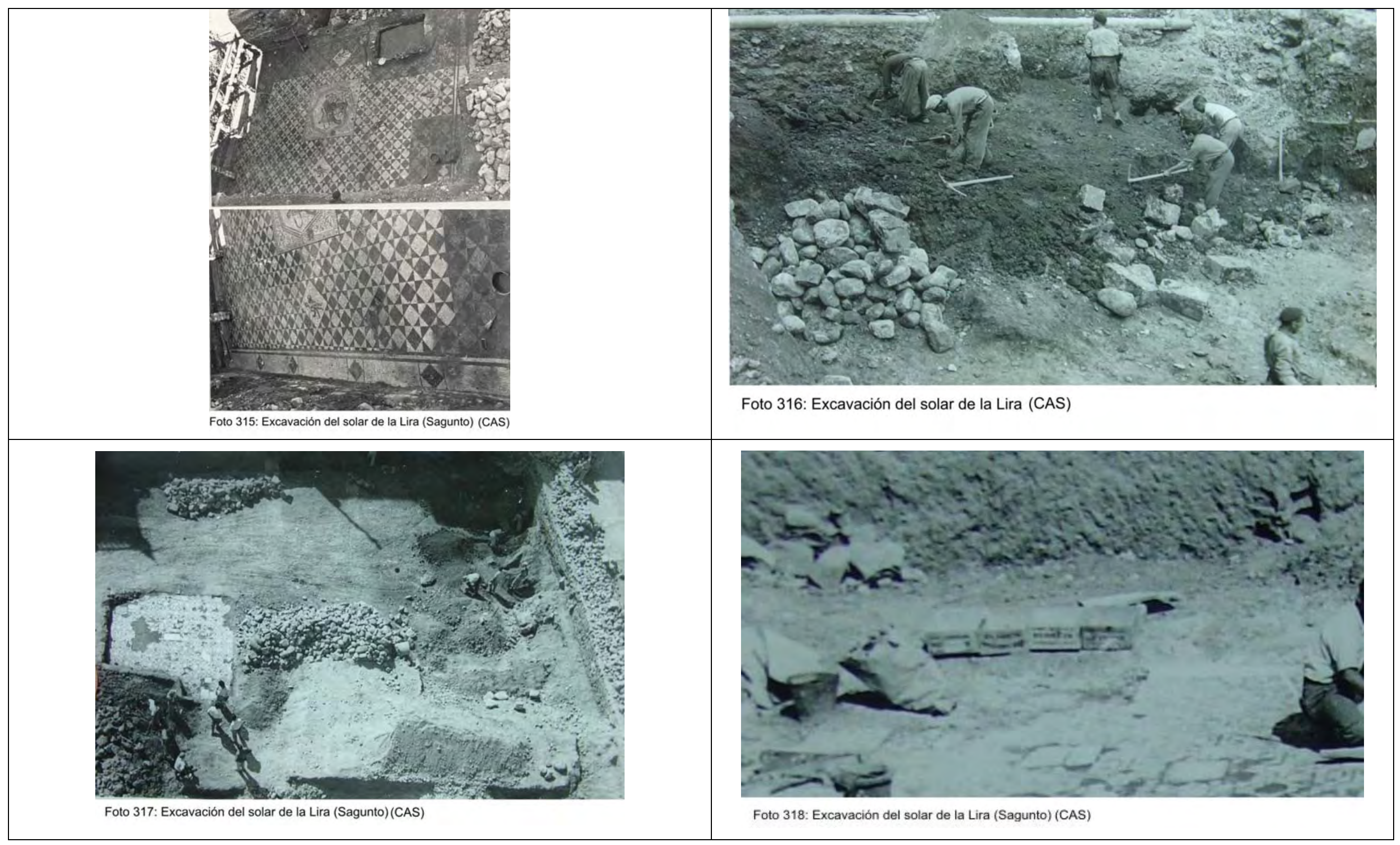




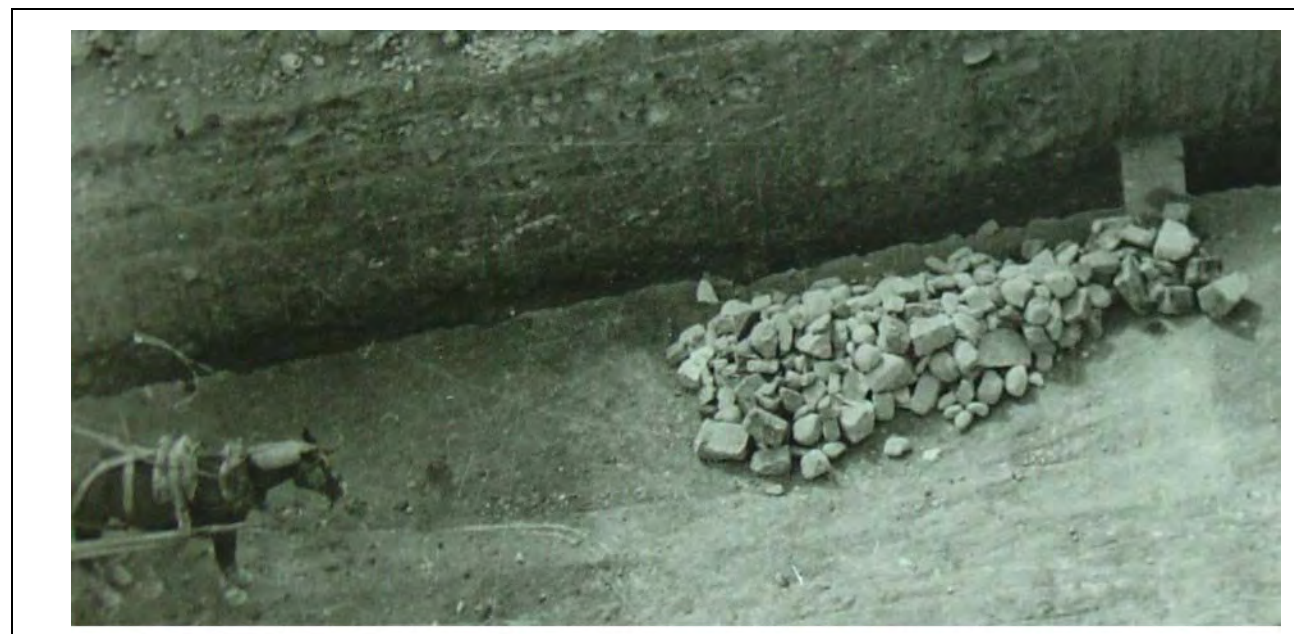

Foto 319: Excavación del solar de la Lira (Sagunto) (CAS)

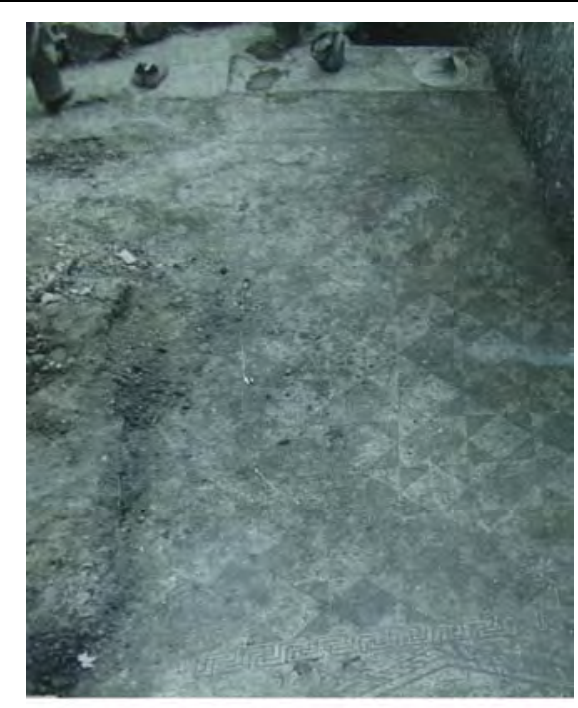

Foto 320: Excavación del solar de la Lira (Sagunto) (CAS)

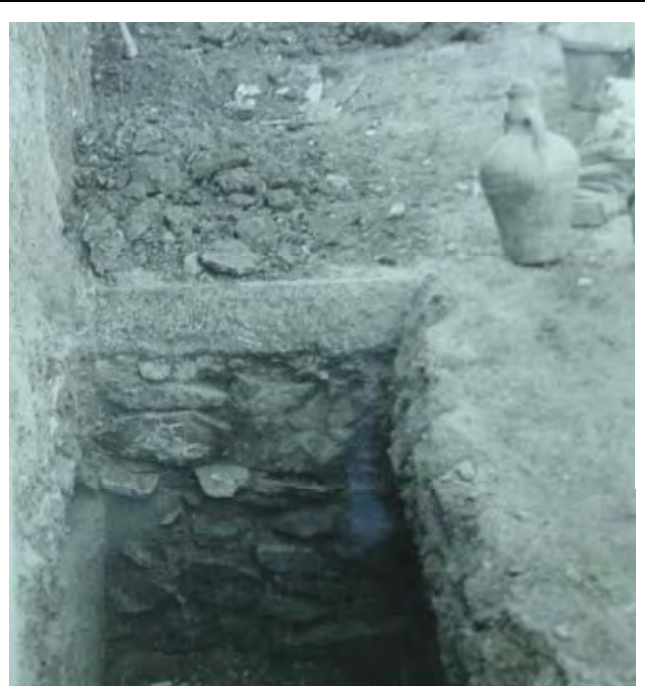

Foto 321: Excavación del solar de la Lira (Sagunto) (CAS)
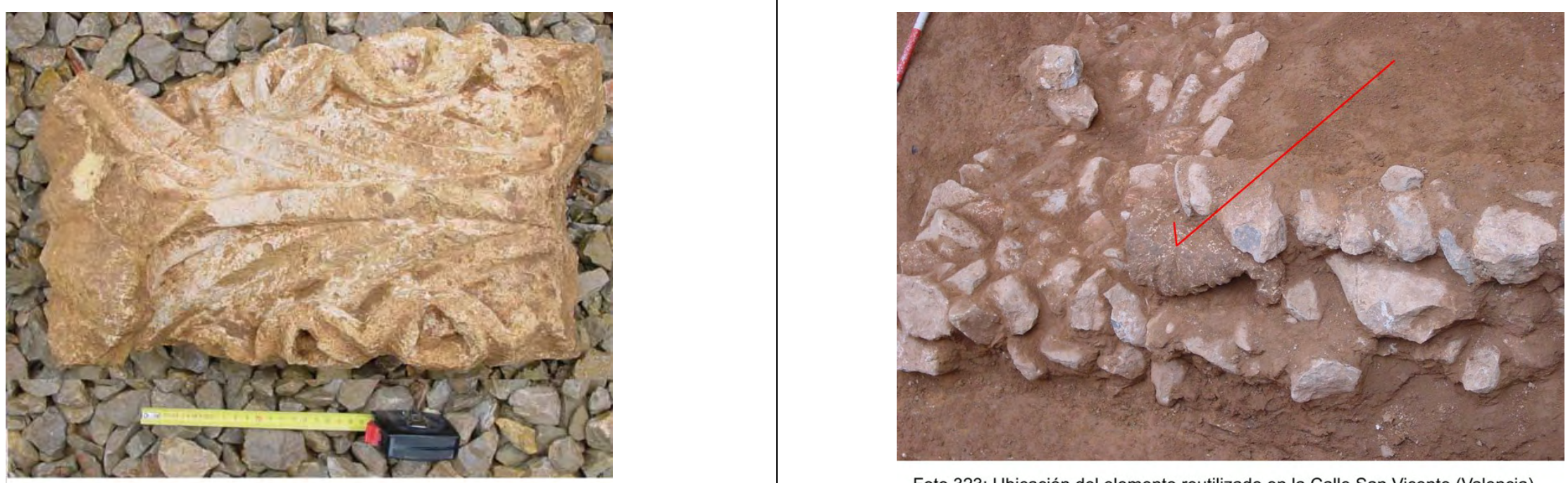

Foto 322: Elemento reutilizado en monumento funerario (C/San Vicente - Valencia) 


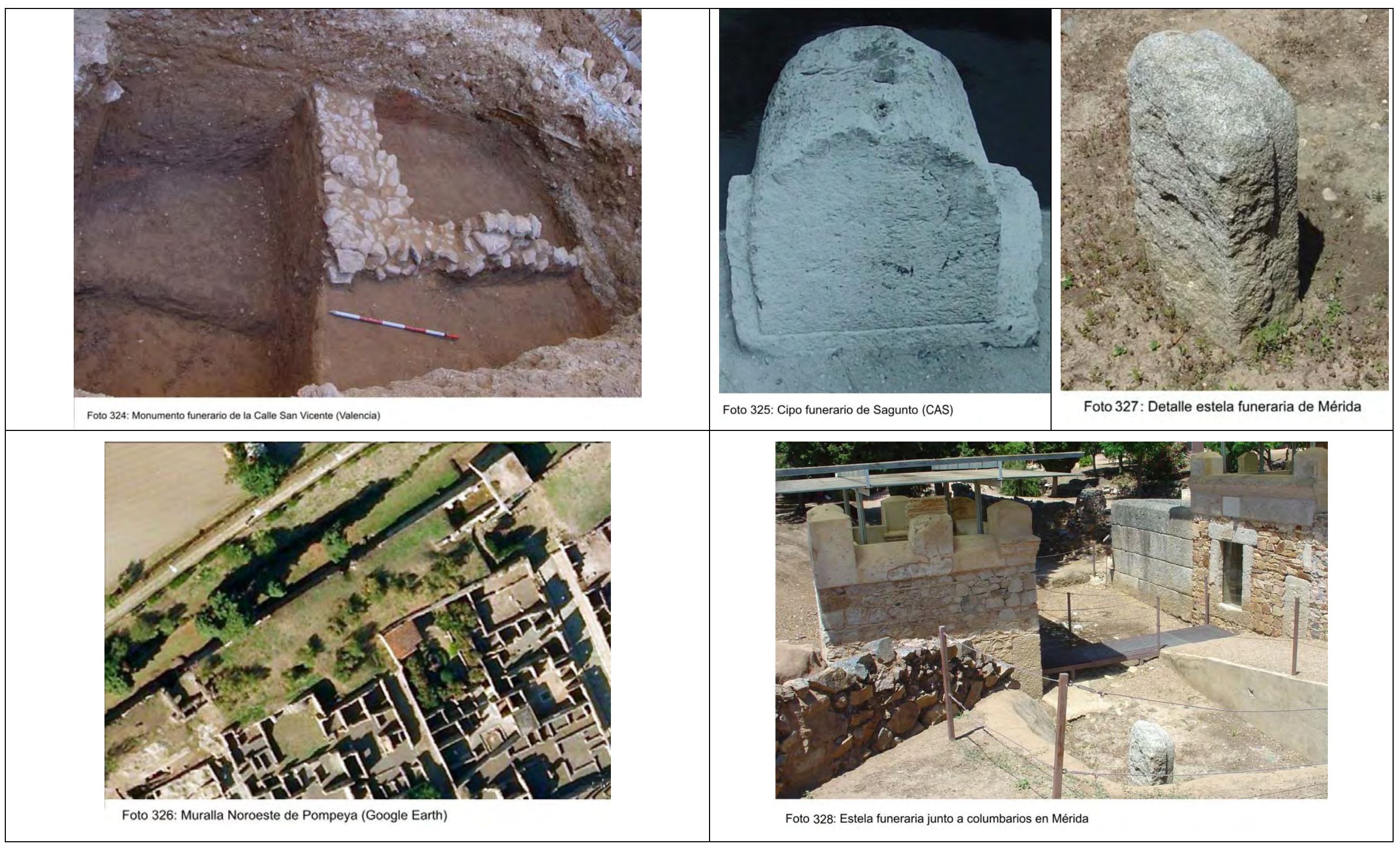




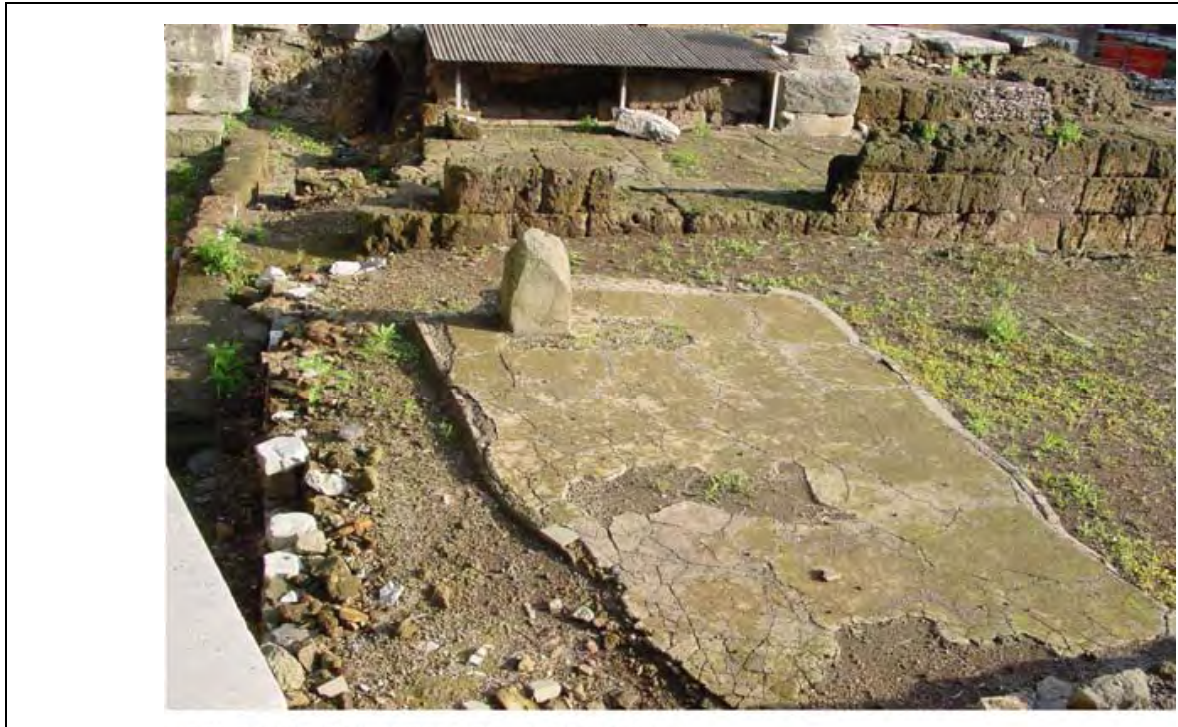

Foto 329: Estela funeraria y pavimento en Roma

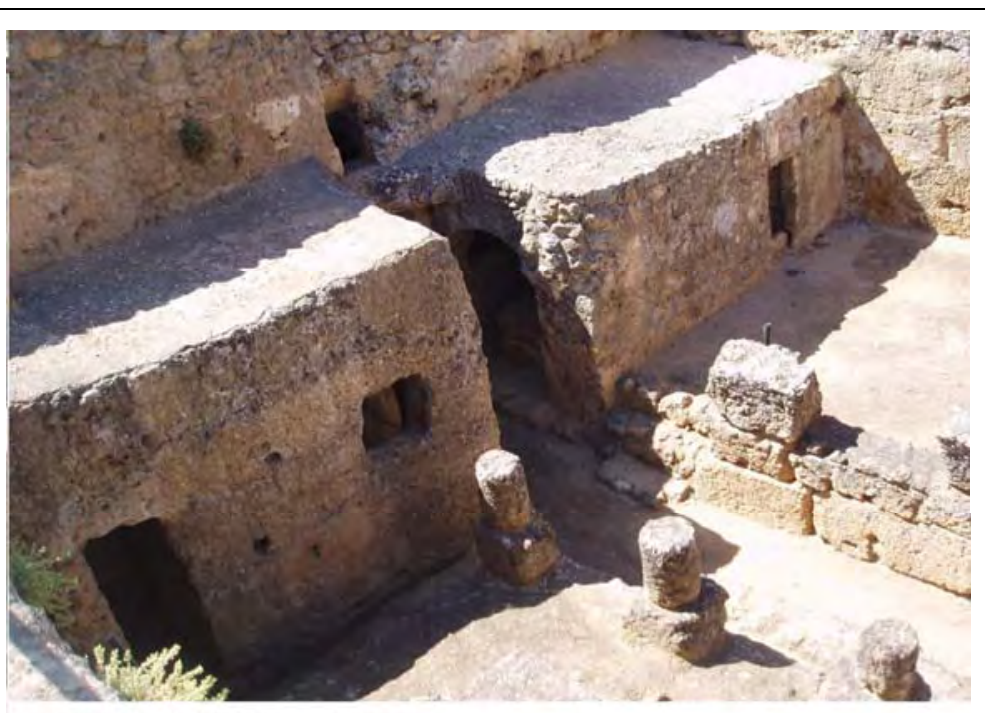

Foto 331: Tumba del elefante en Carmona

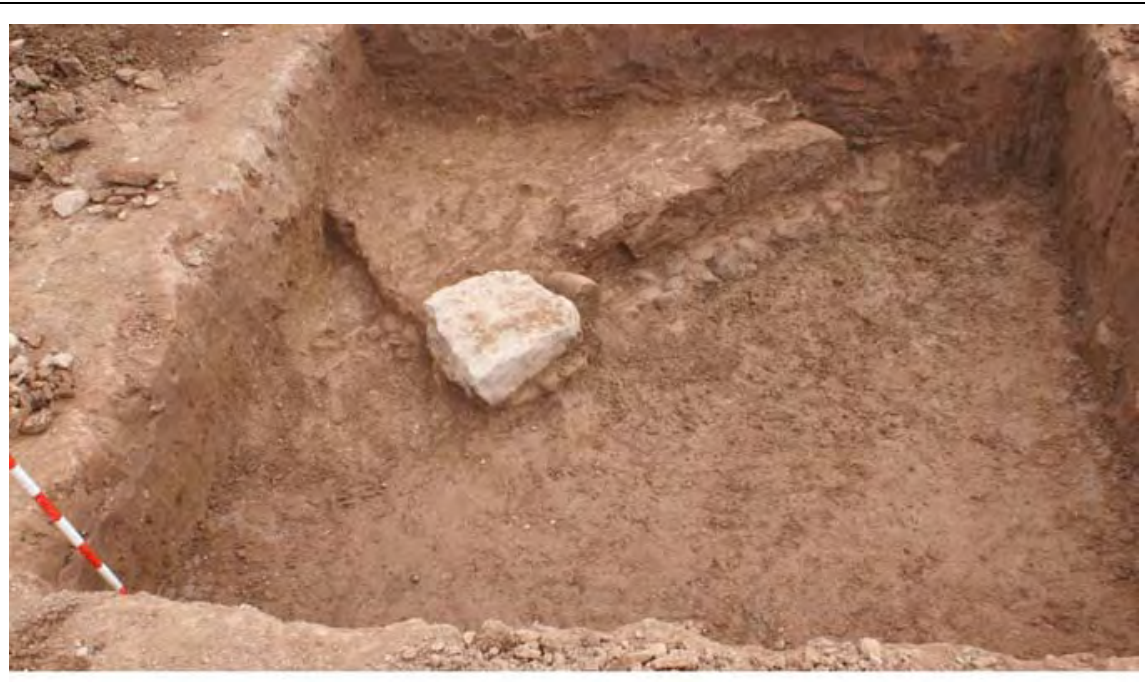

Foto 330: Limite de la pars urbana de San Gregori

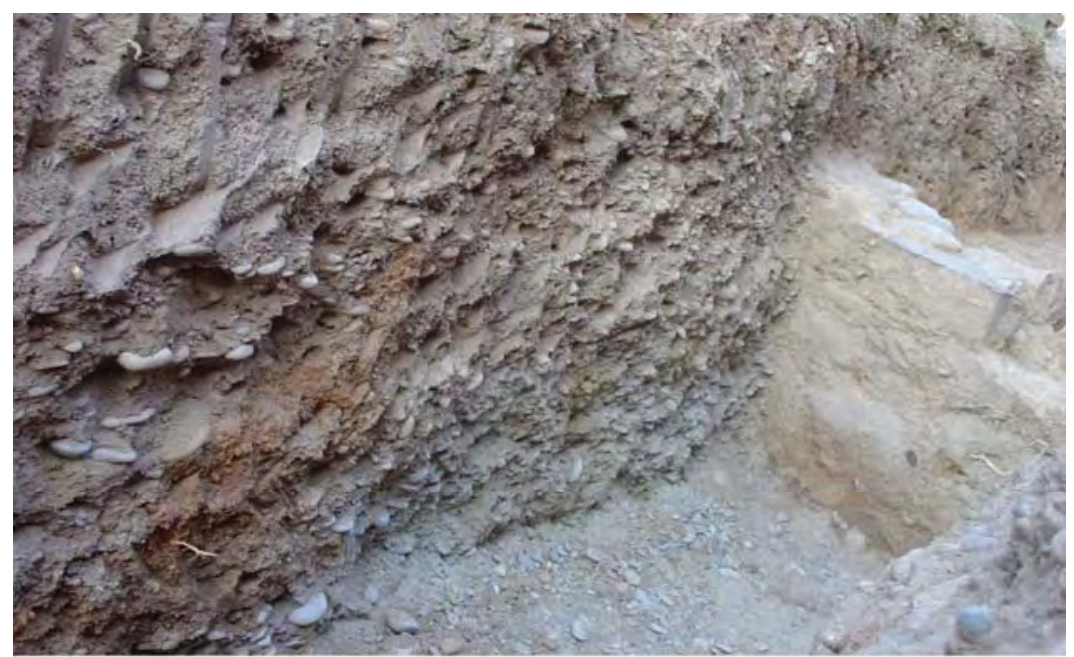

Foto 332: Relleno en el borde externo del yacimiento de Torre d'Onda 


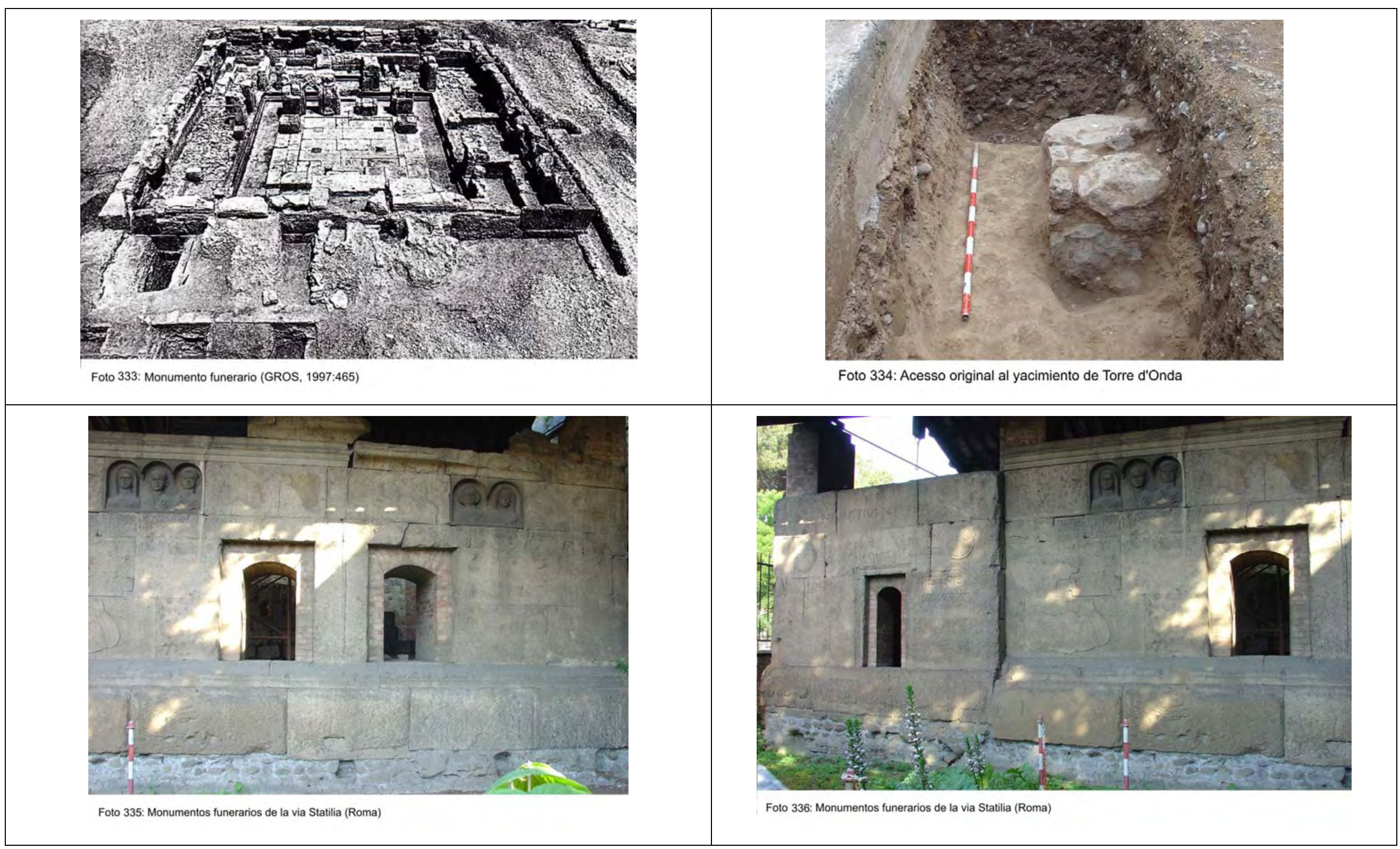




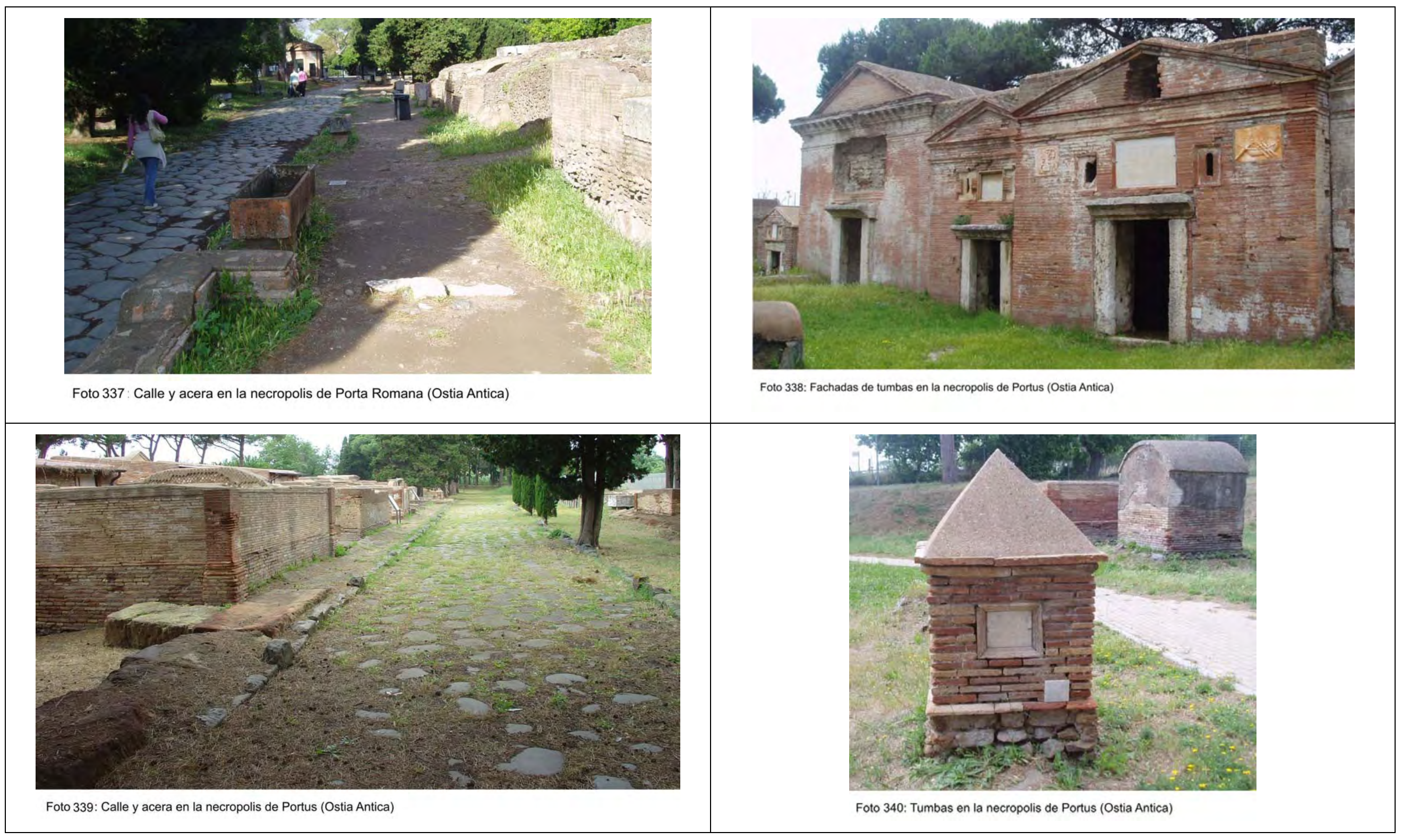




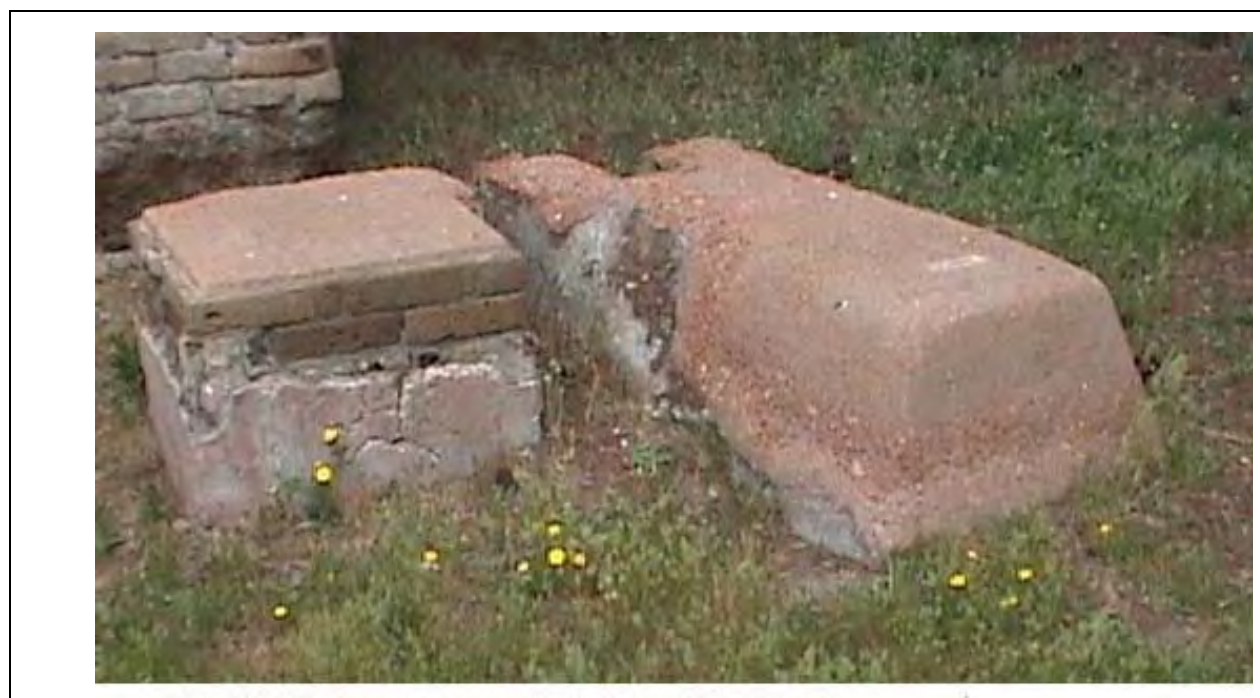

Foto 341: Tumbas en la necropolis de Portus (Ostia Antica)
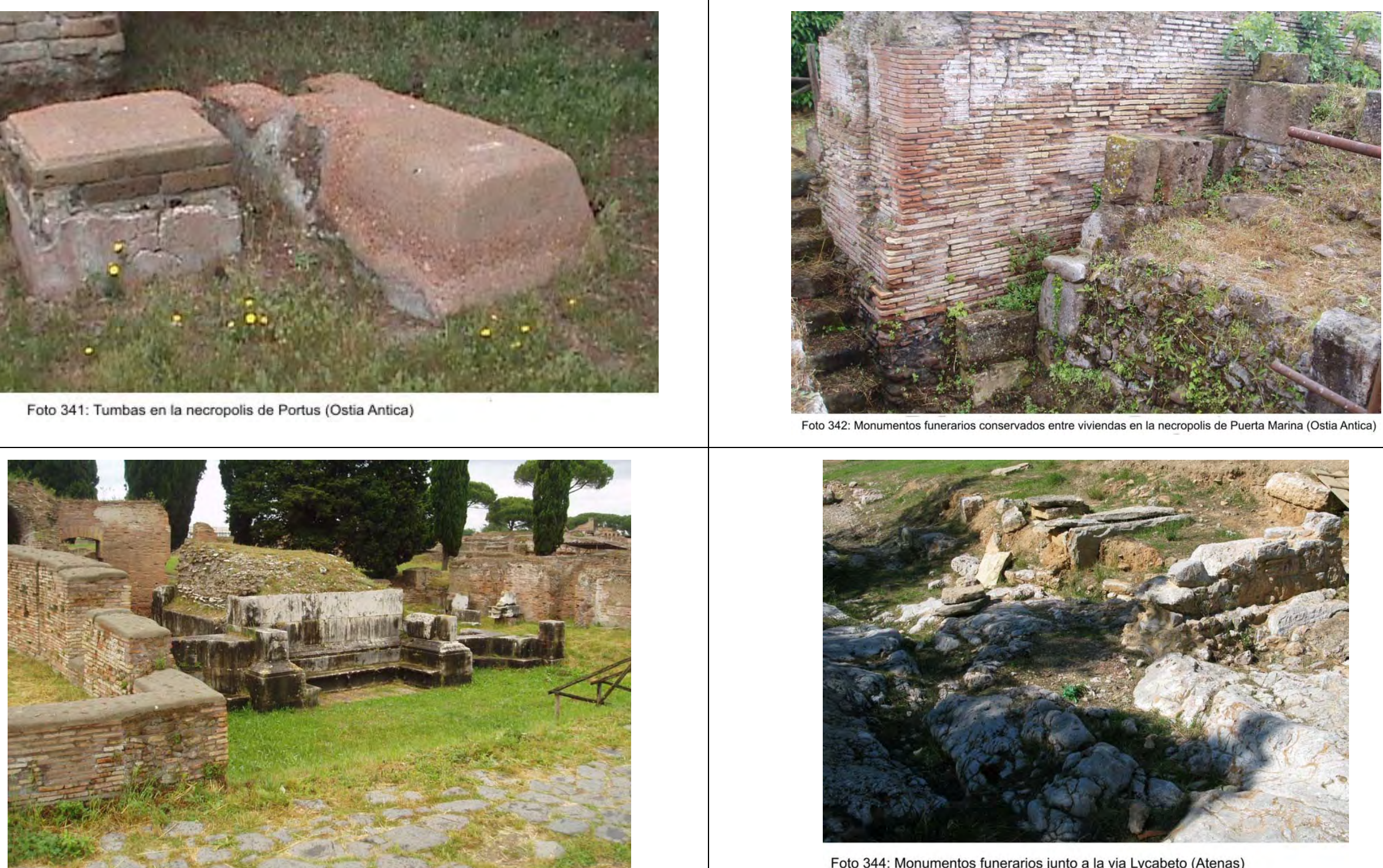

Foto 343: Monumento funerario conservado entre viviendas en Porta Marina (Ostia Antica)

Foto 344: Monumentos funerarios junto a la via Lycabeto (Atenas) 


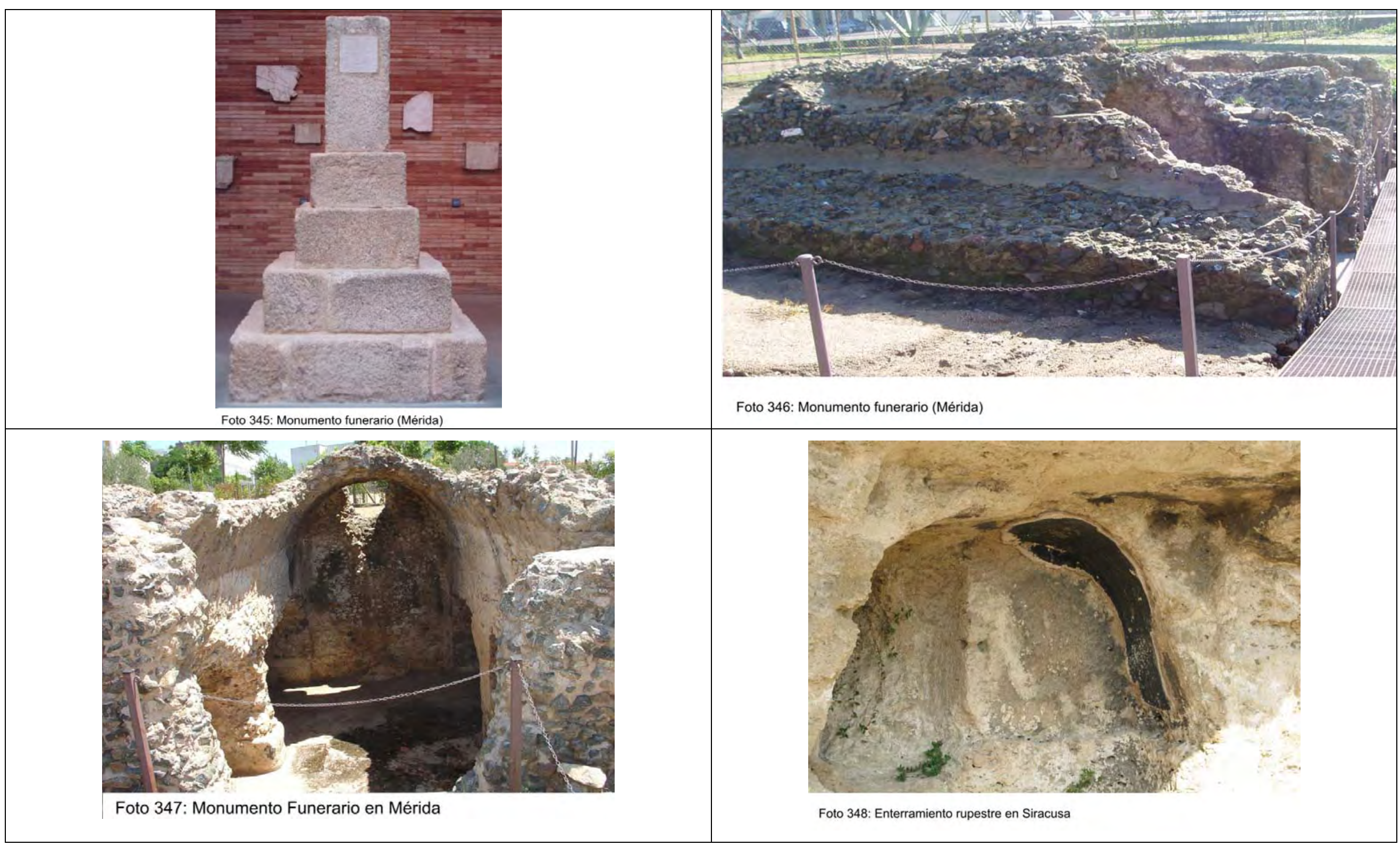




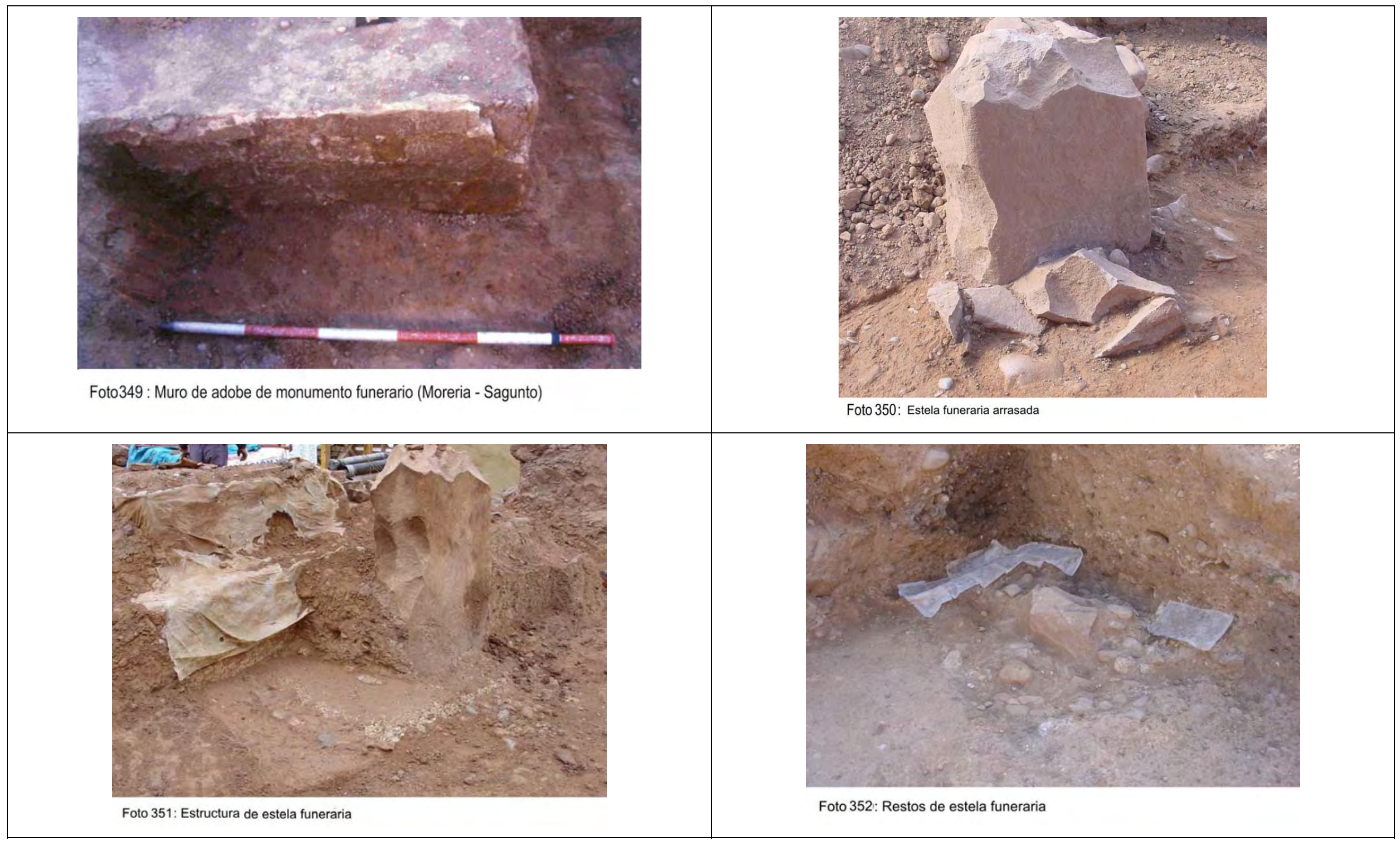




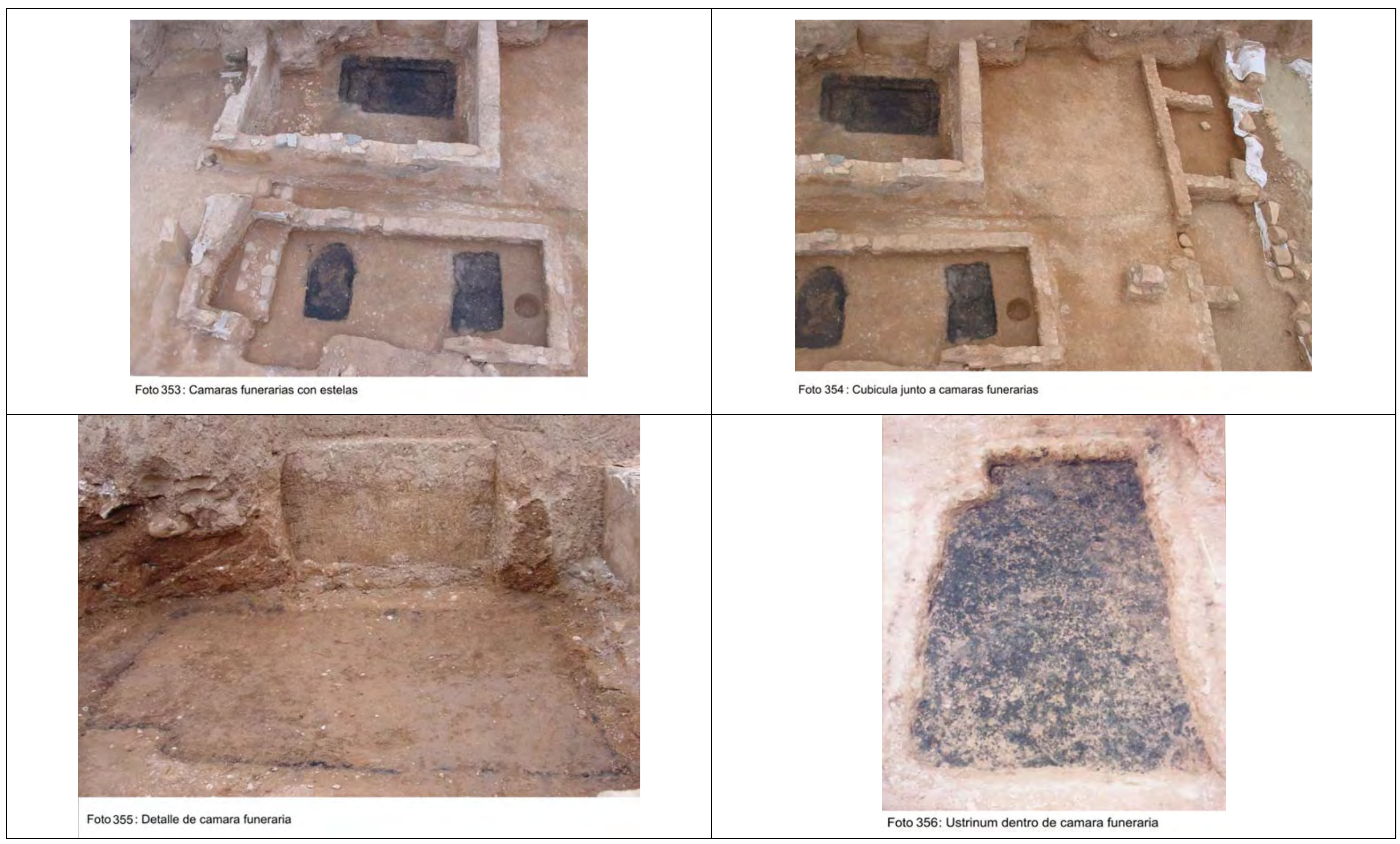




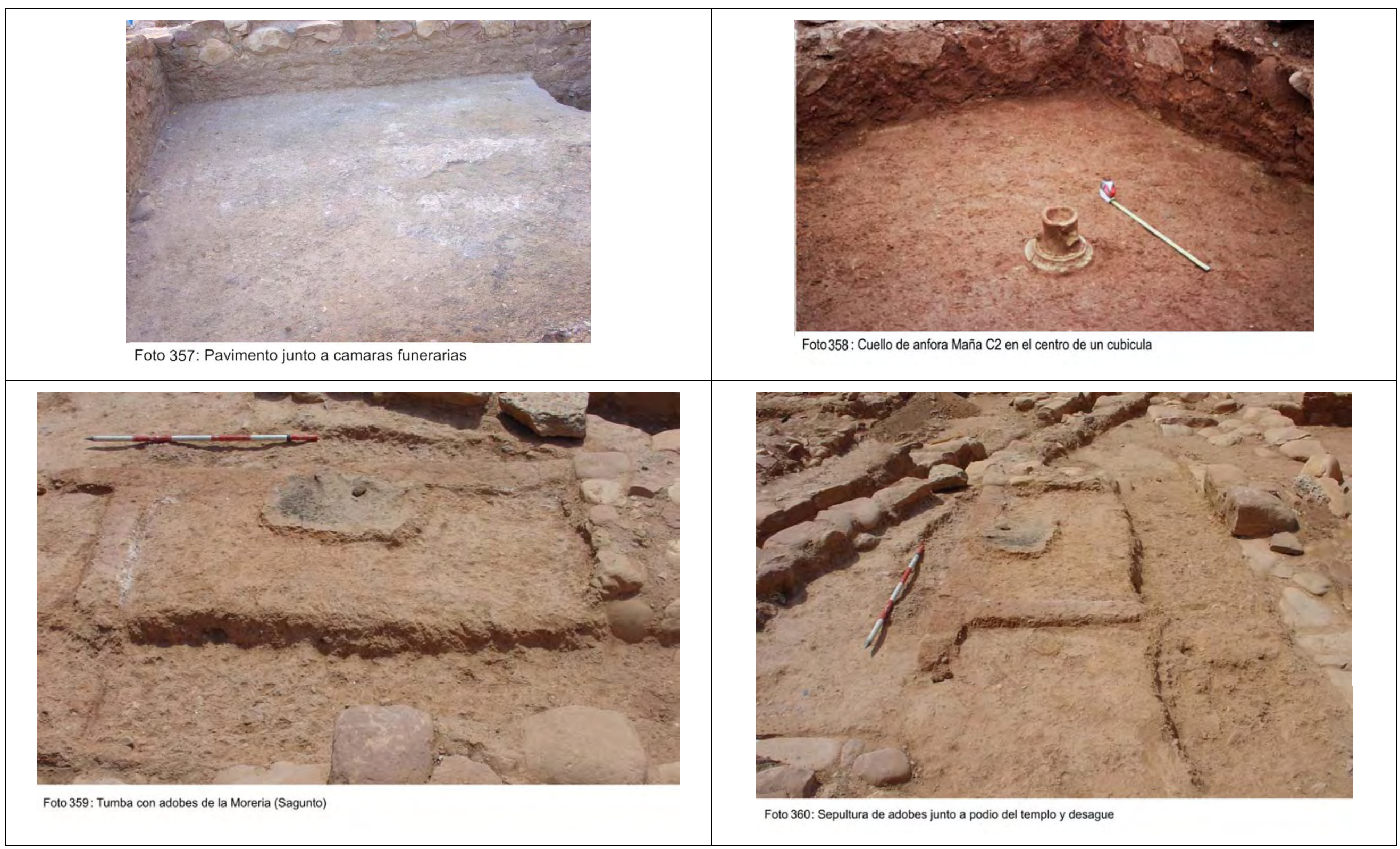




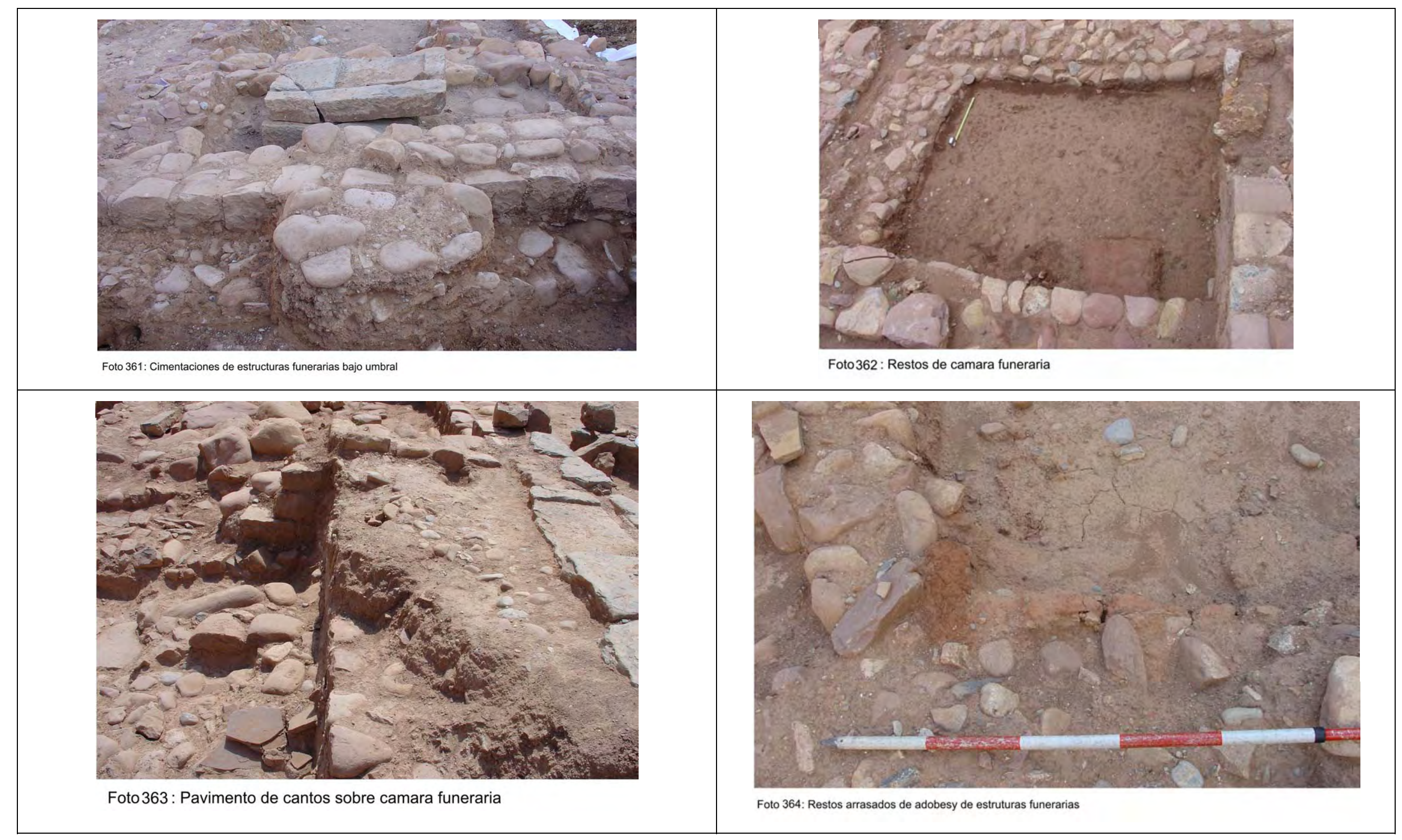




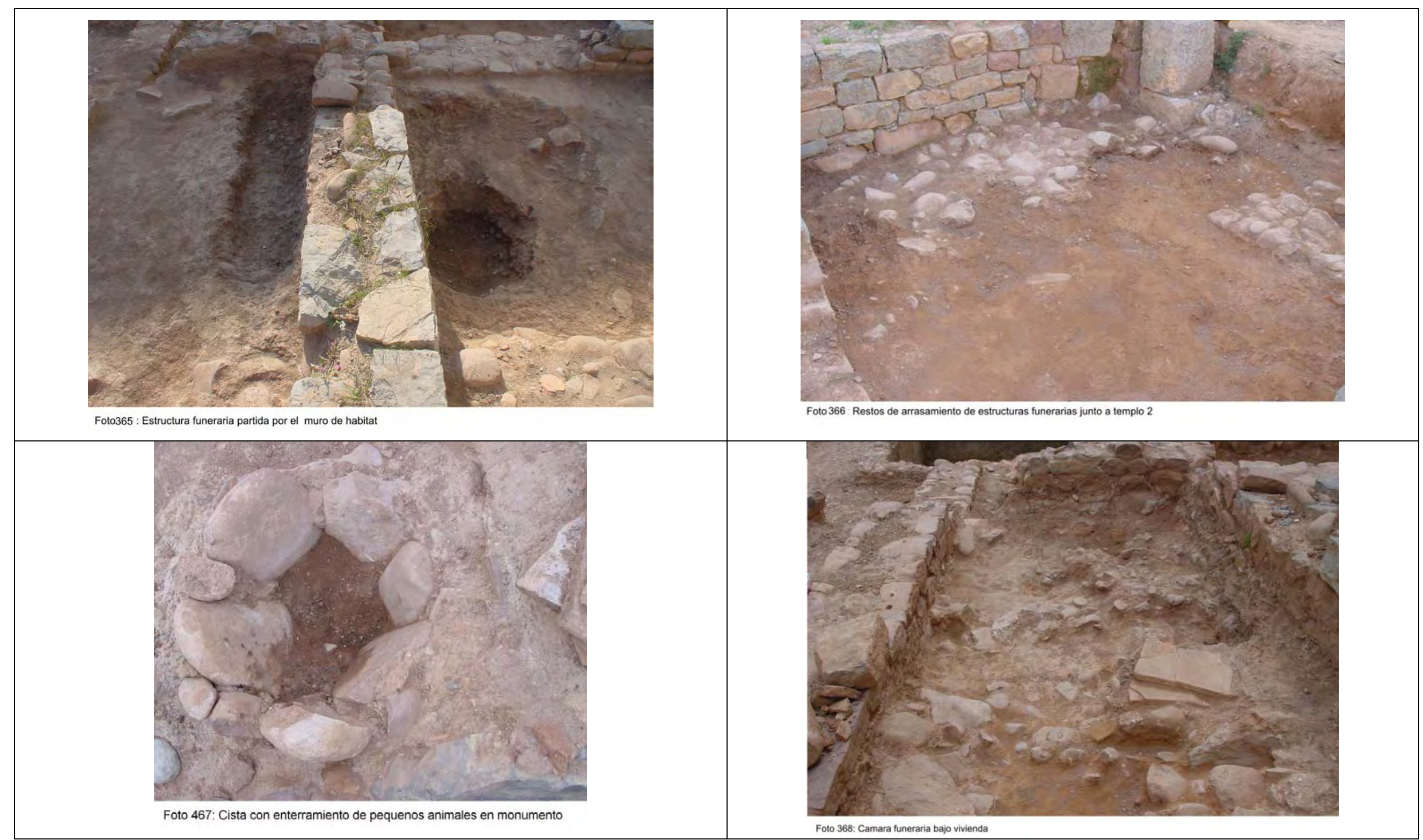




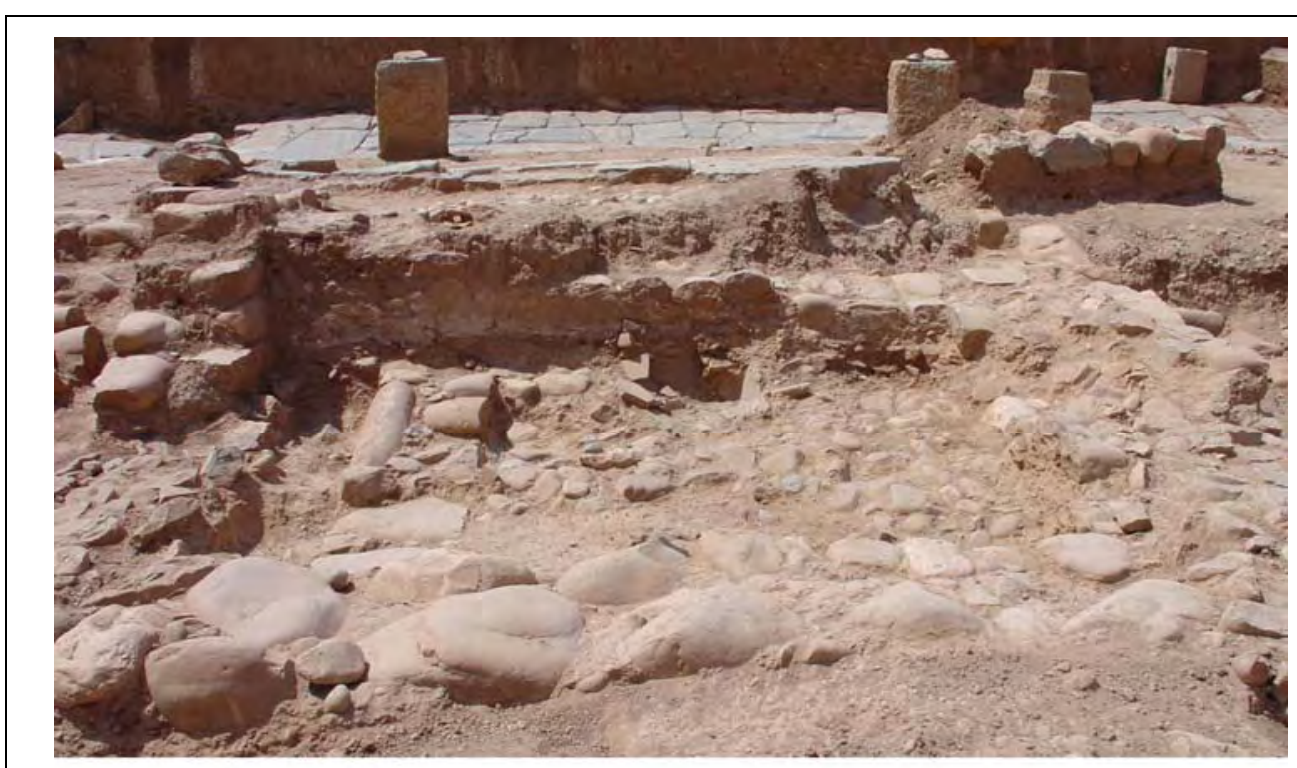

Foto 369: Camara funeraria bajo vivienda

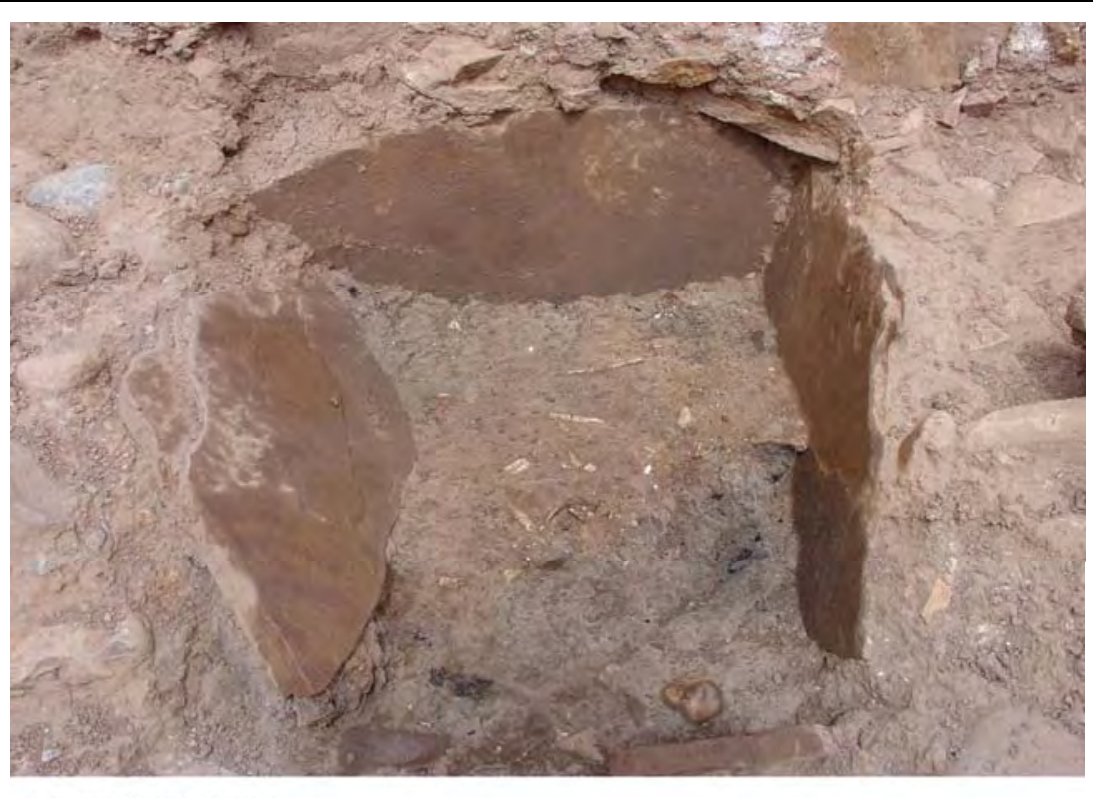

Foto 370: Deposito funerario

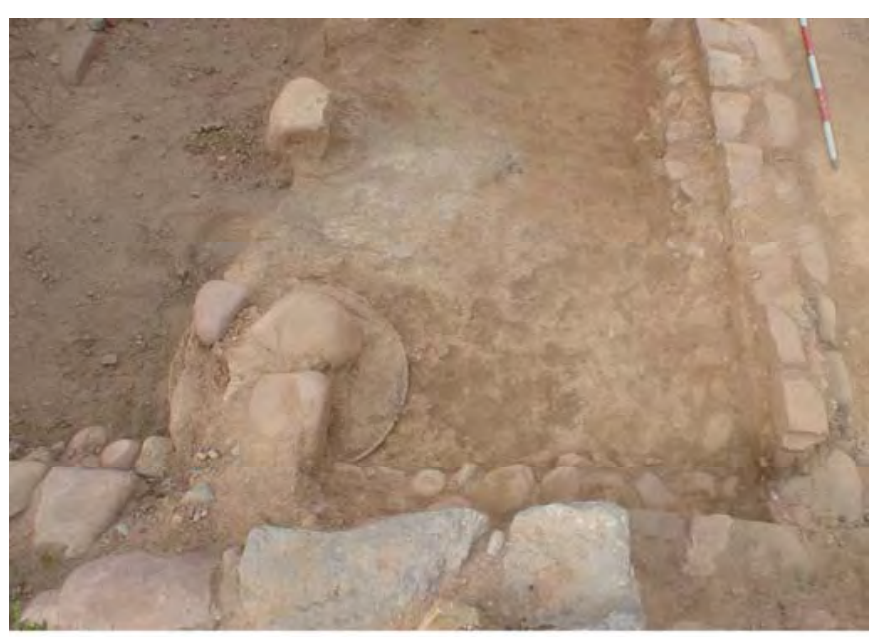

Foto 371: Camara funeraria (la Moreria - Sagunto)

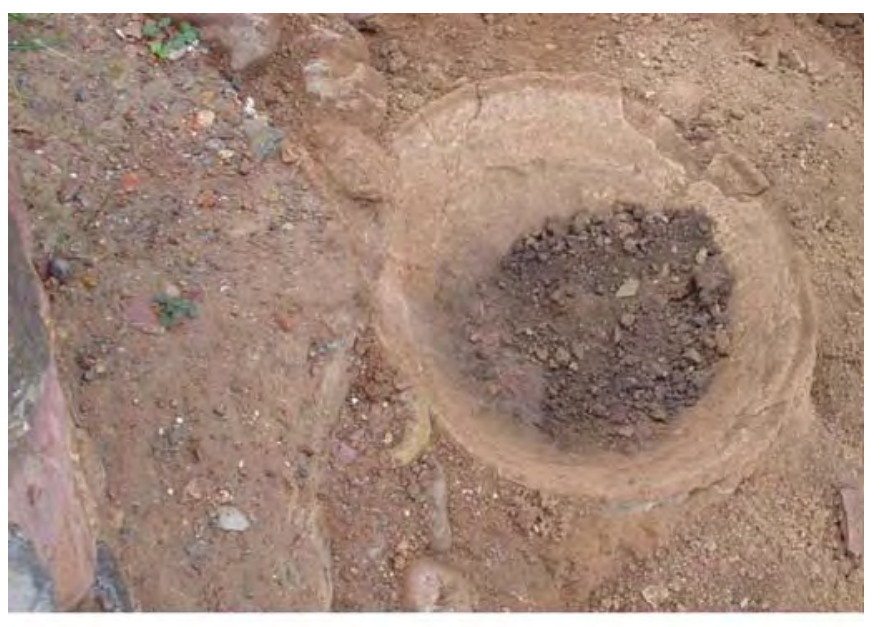

Foto 372: Proceso de excavación de la camara funeraria (la Moreria - Sagunto) 


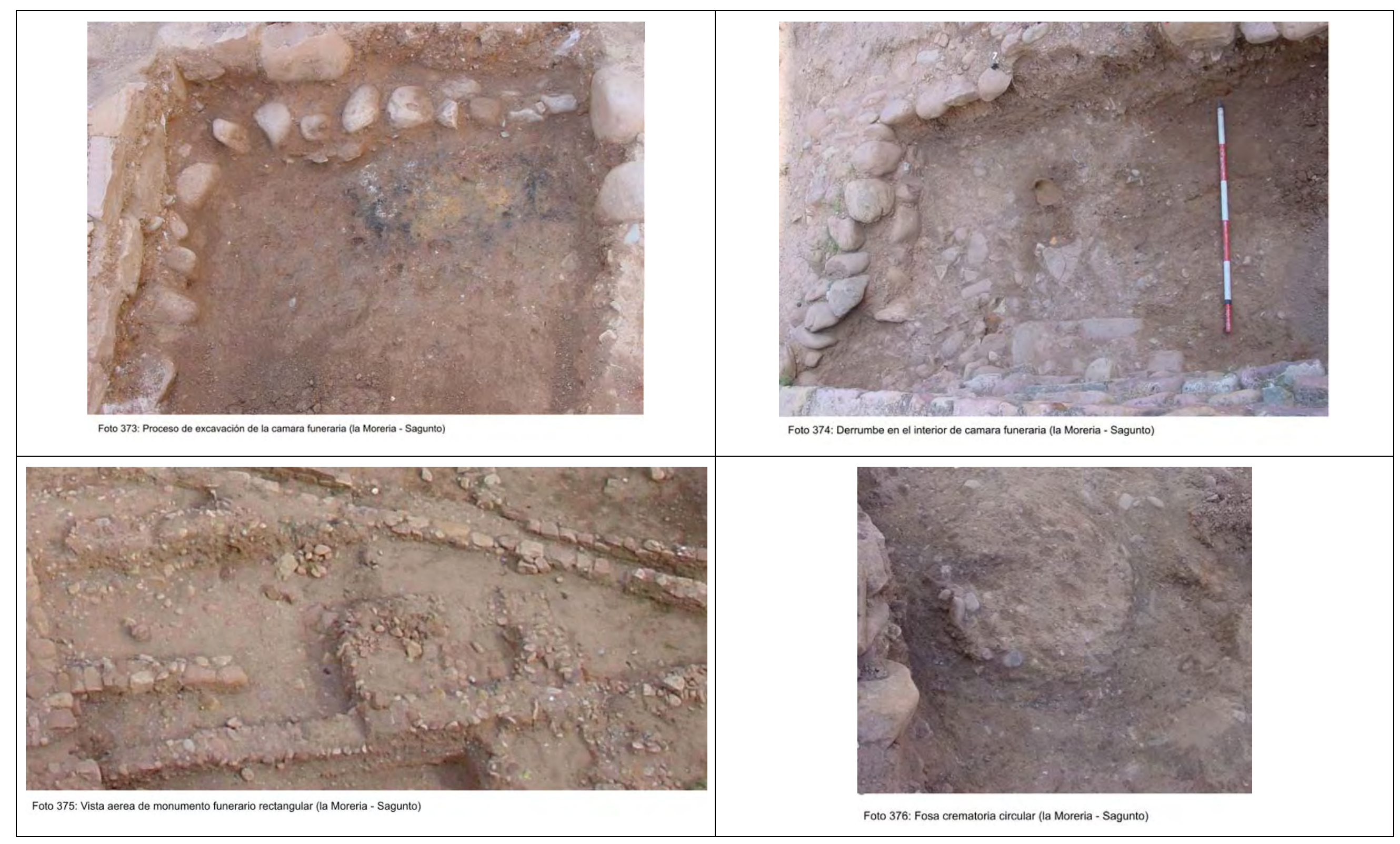




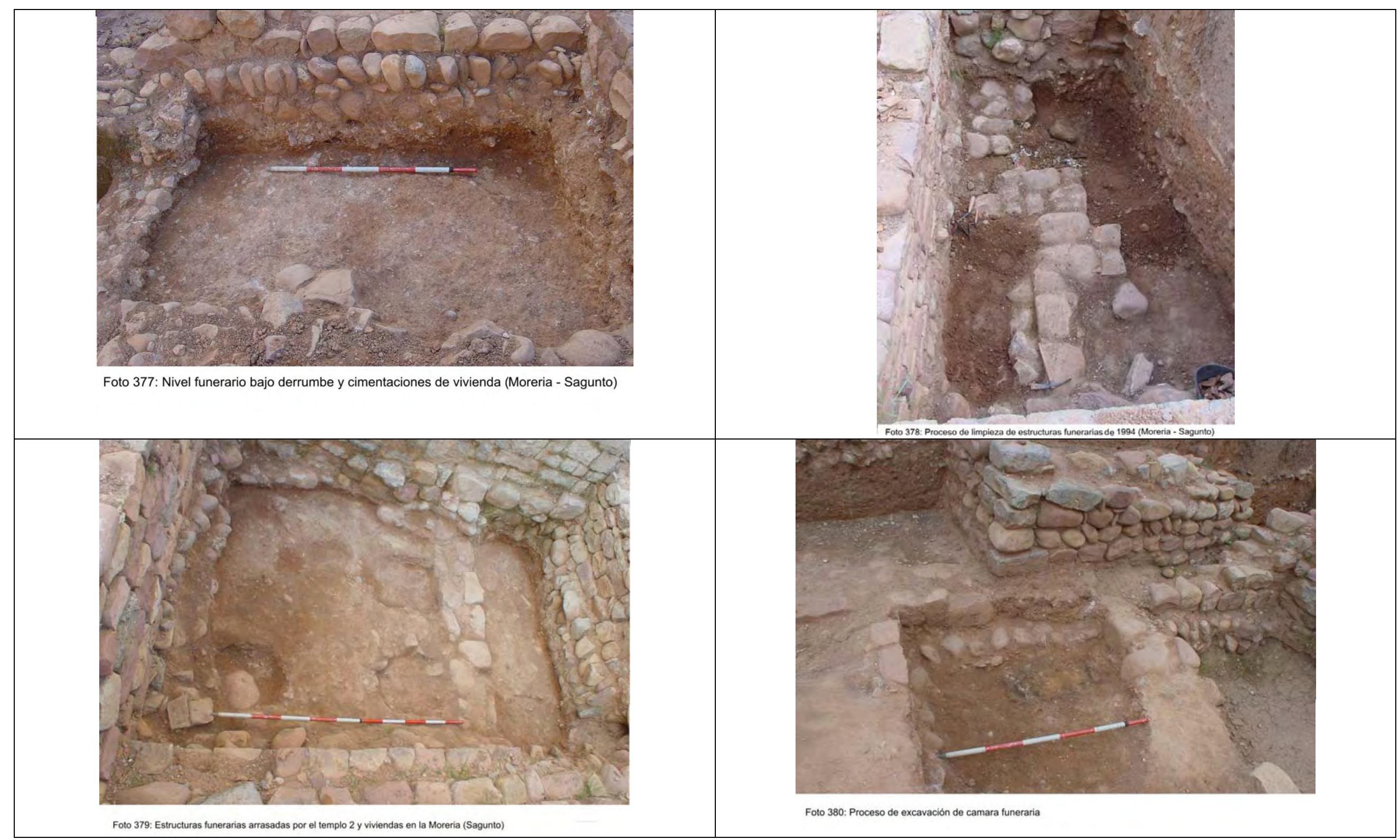




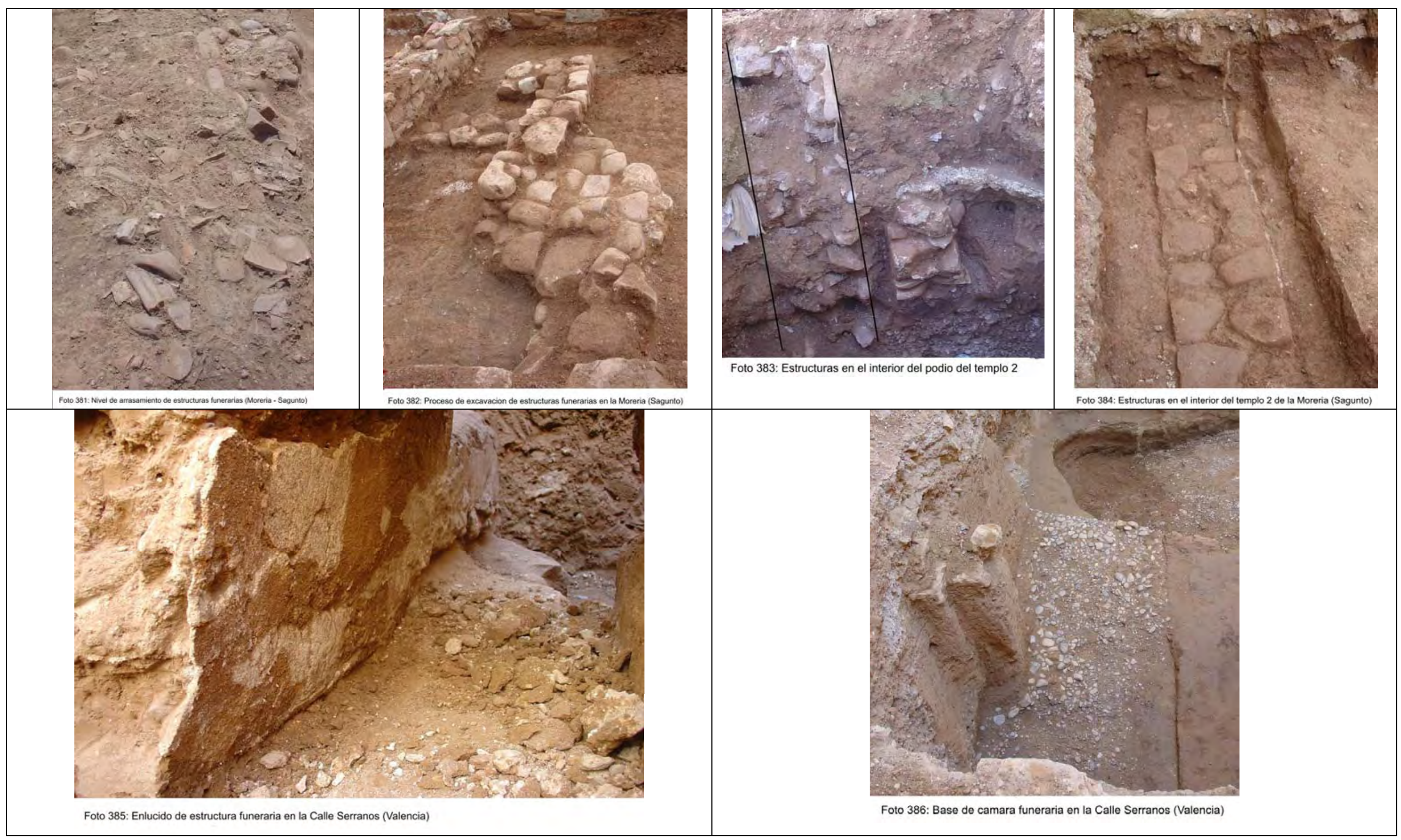




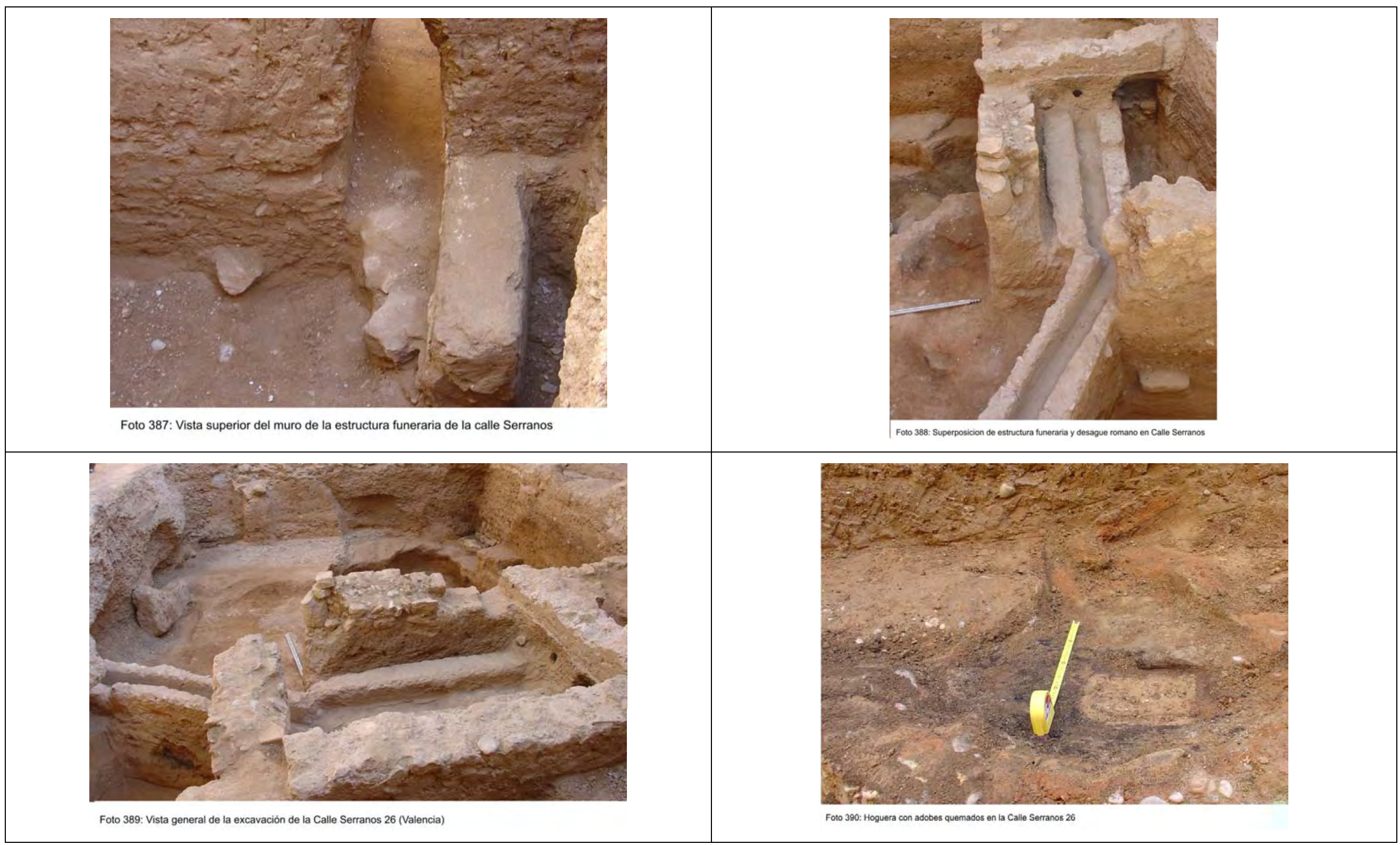




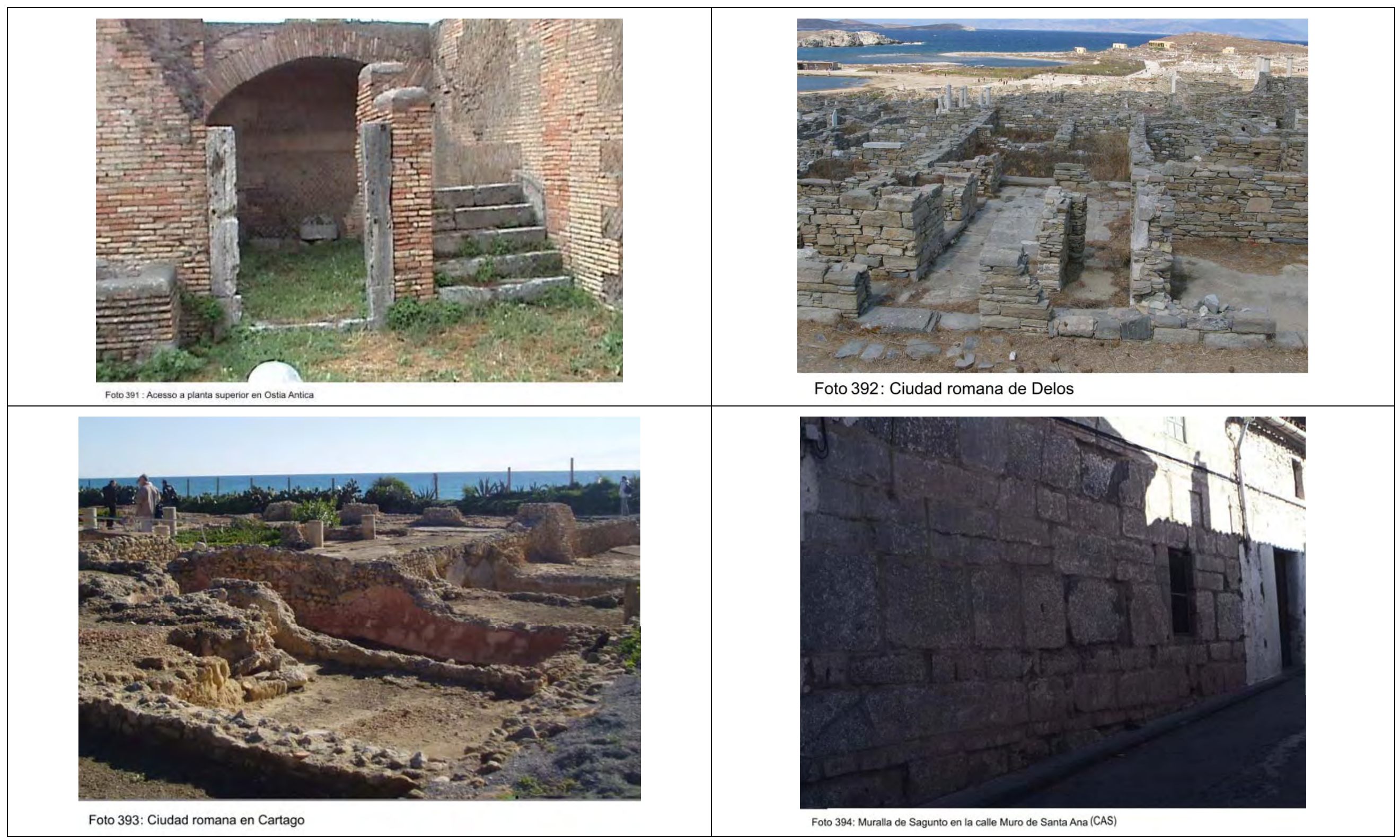




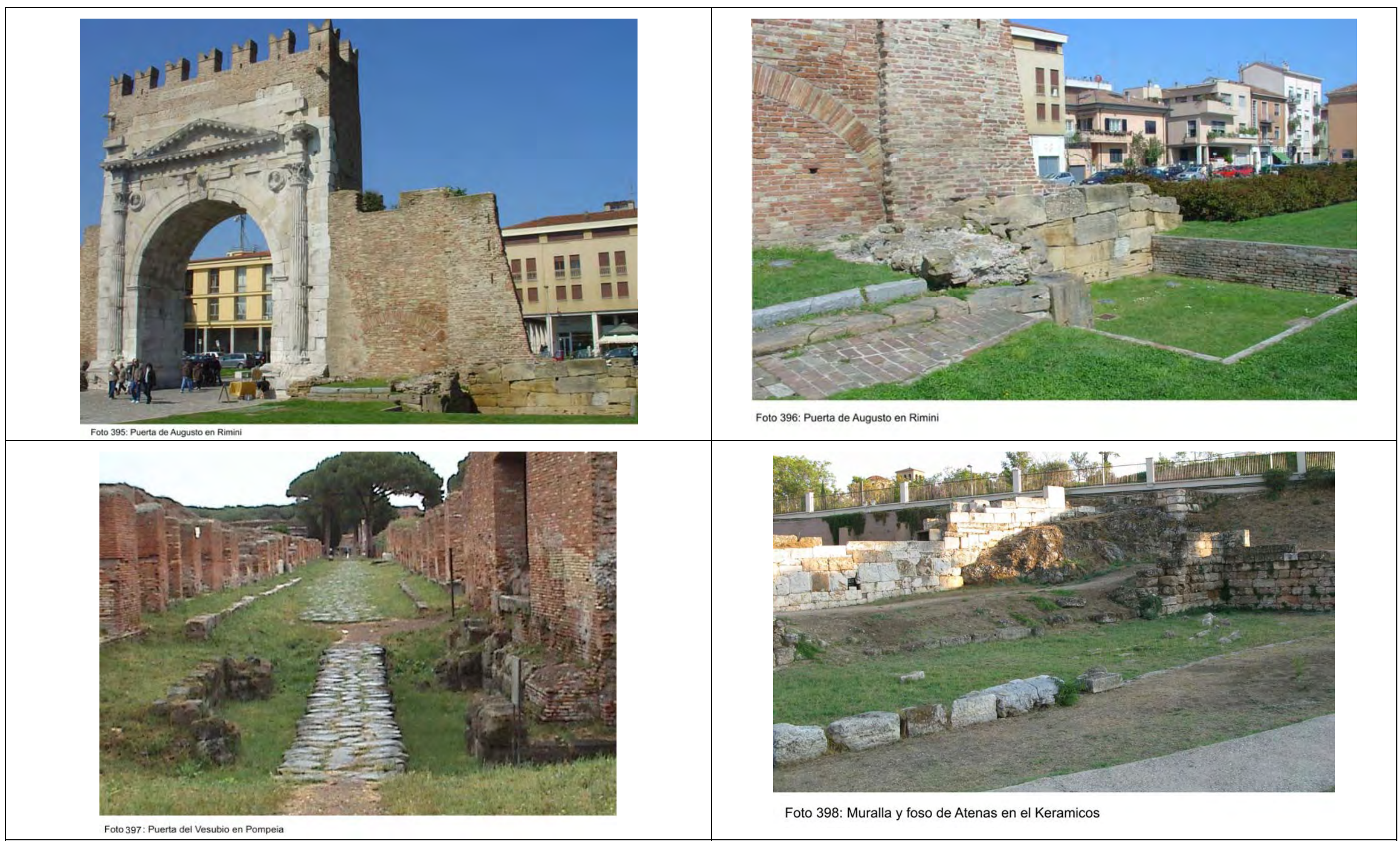




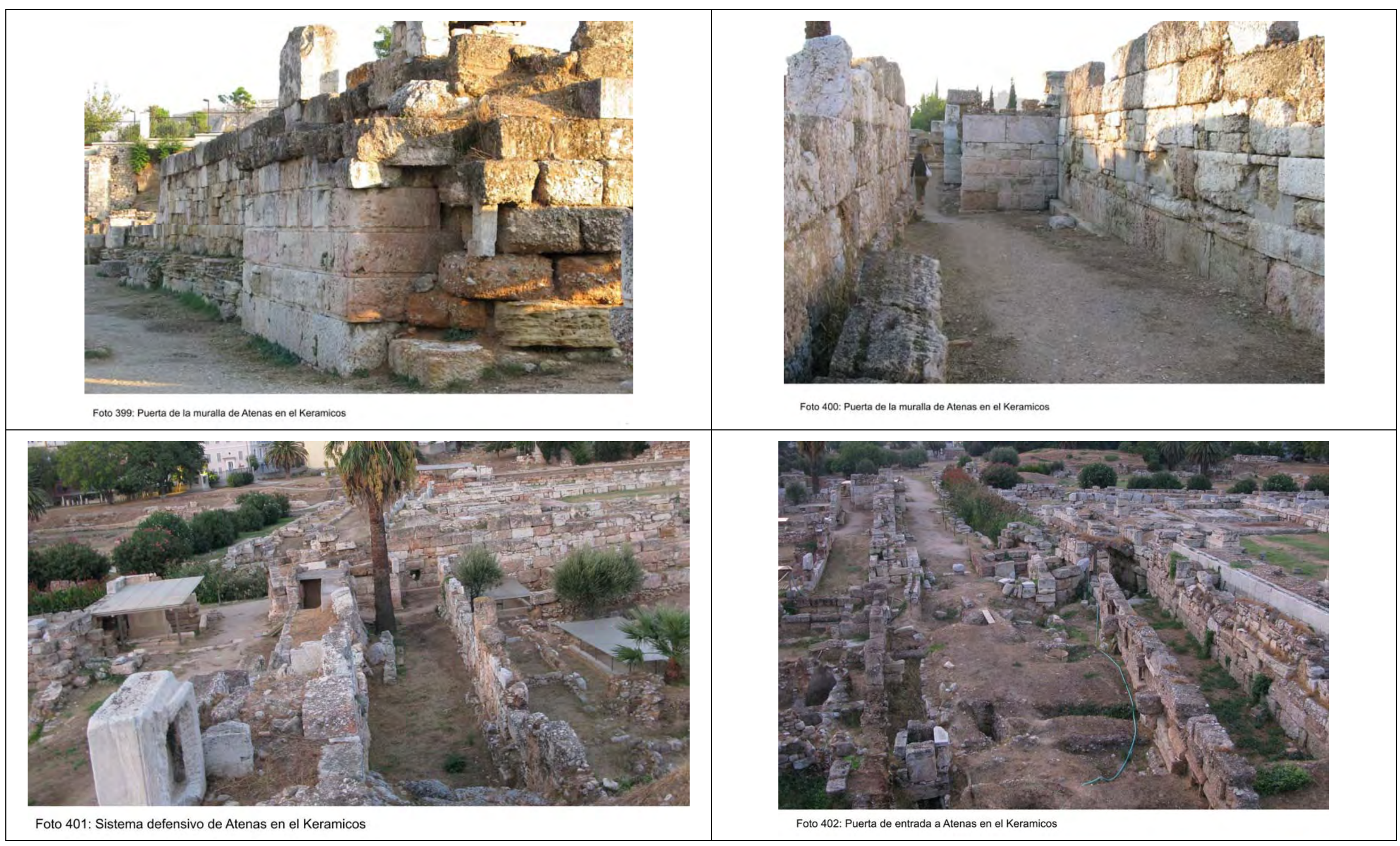




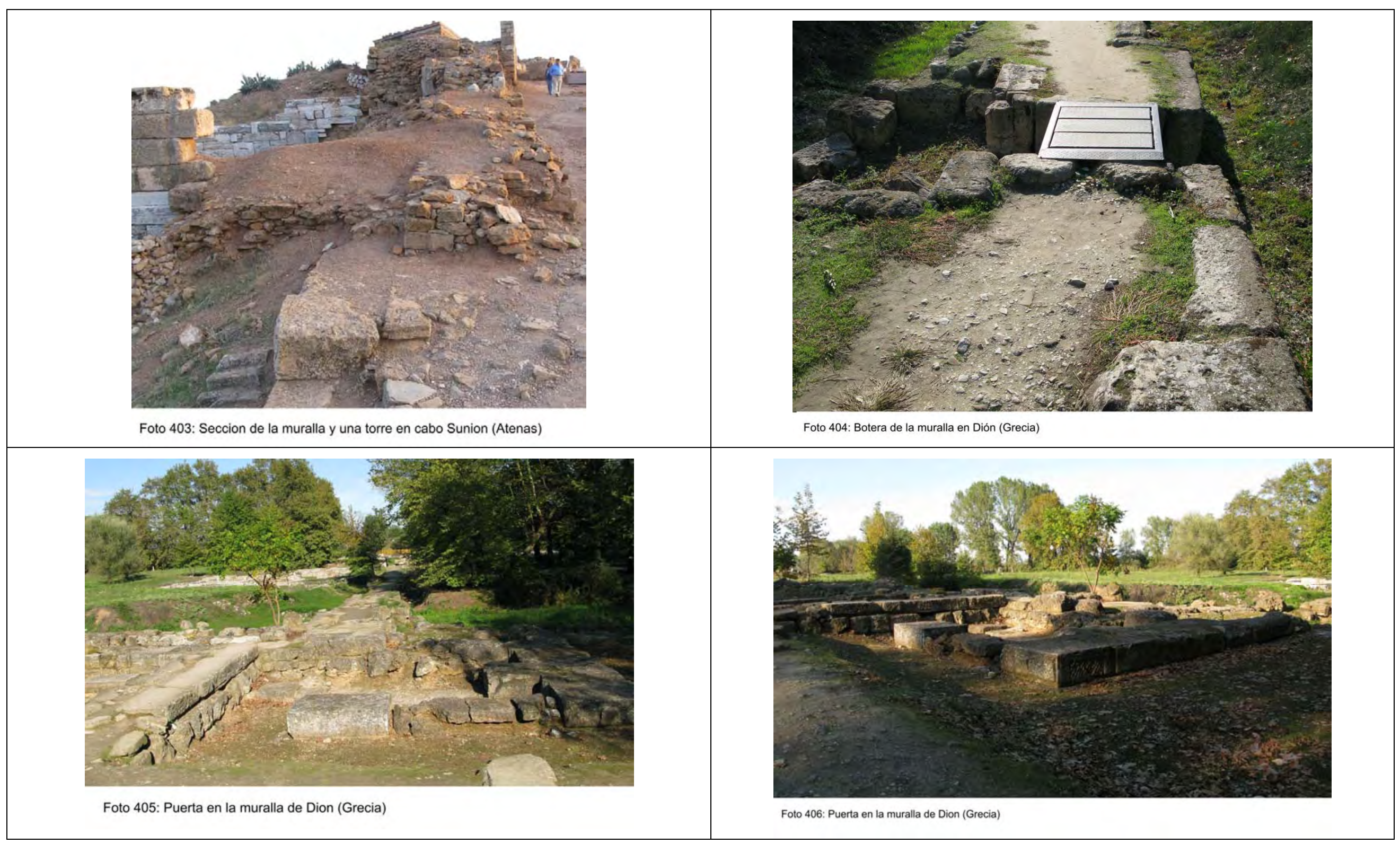




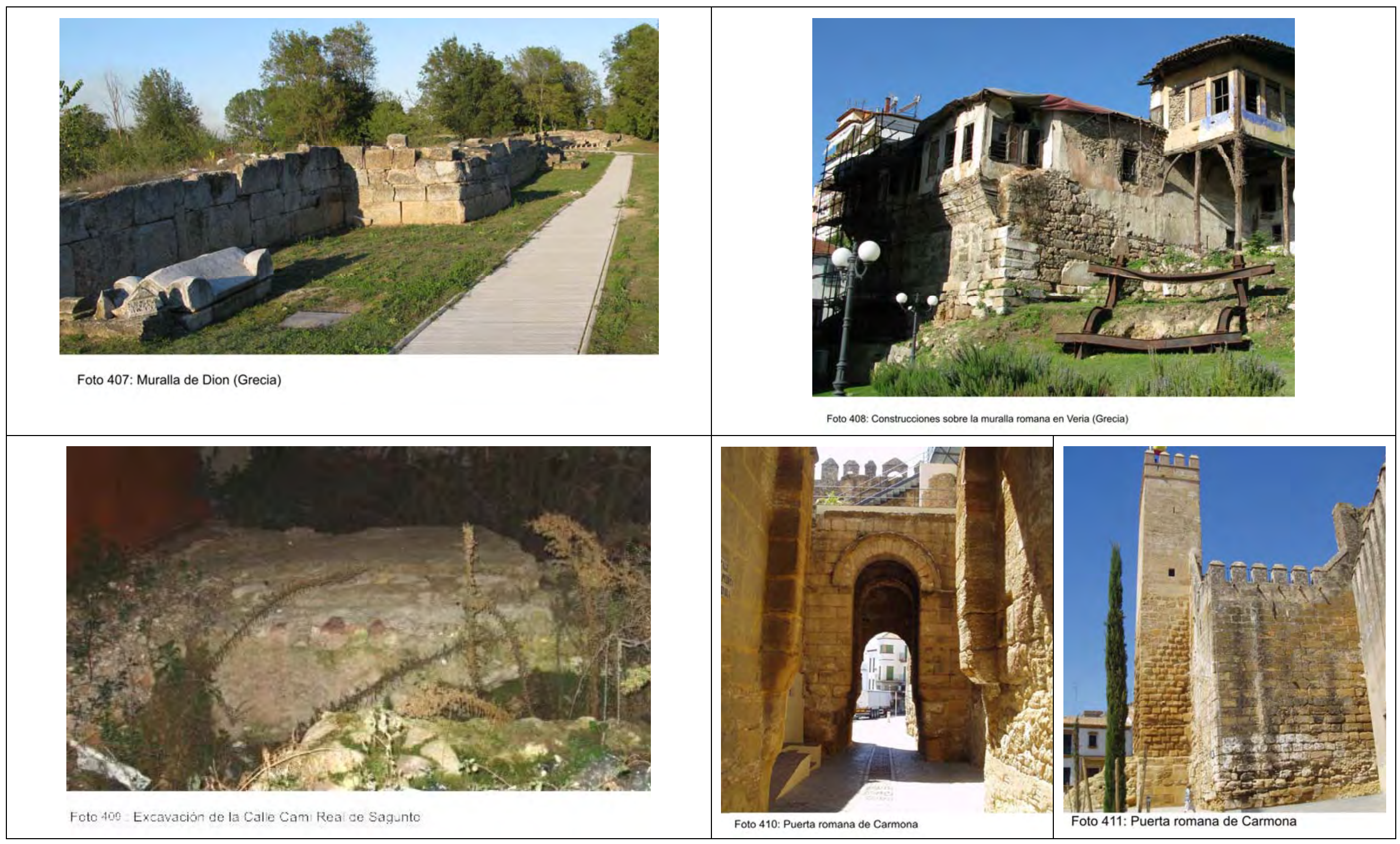




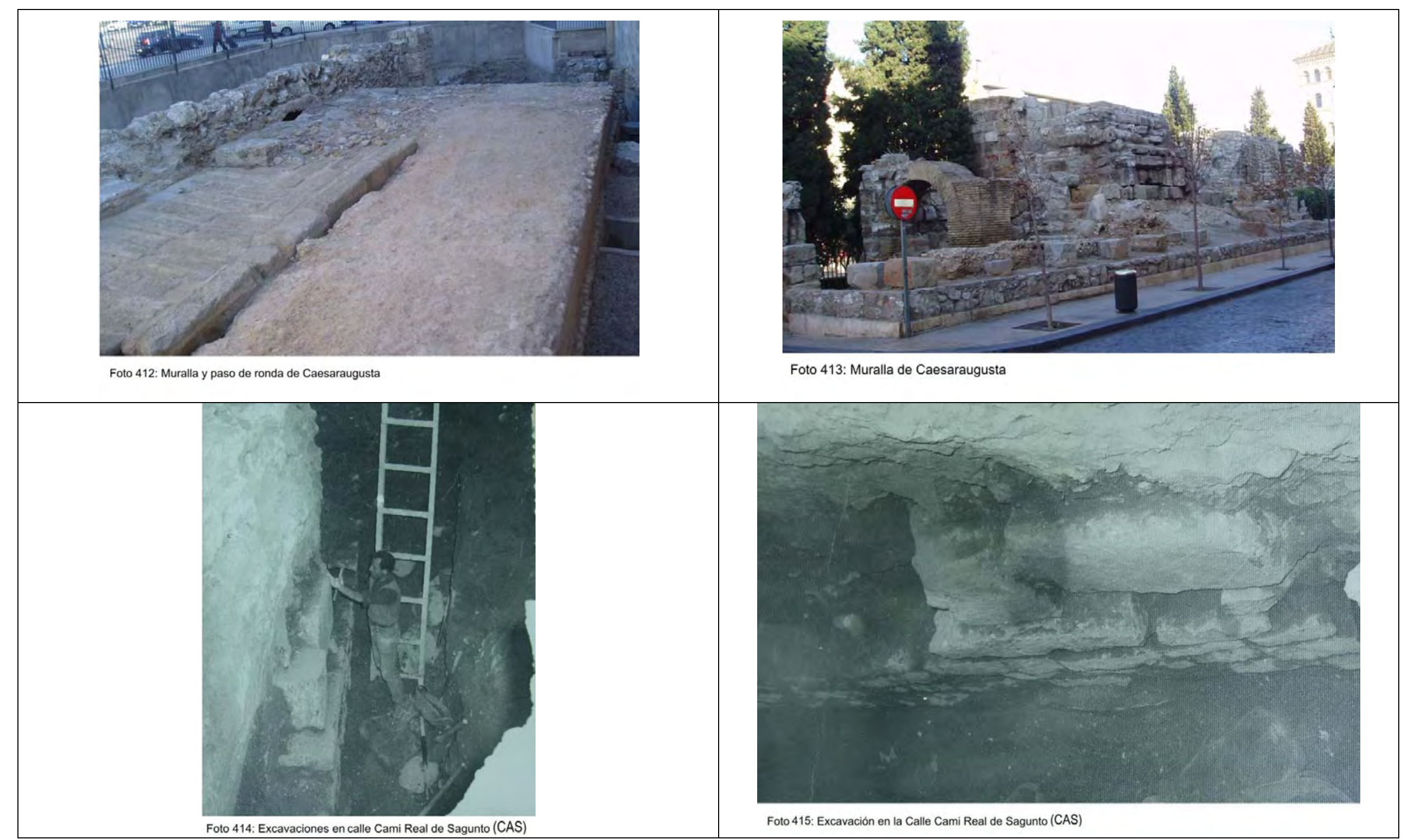




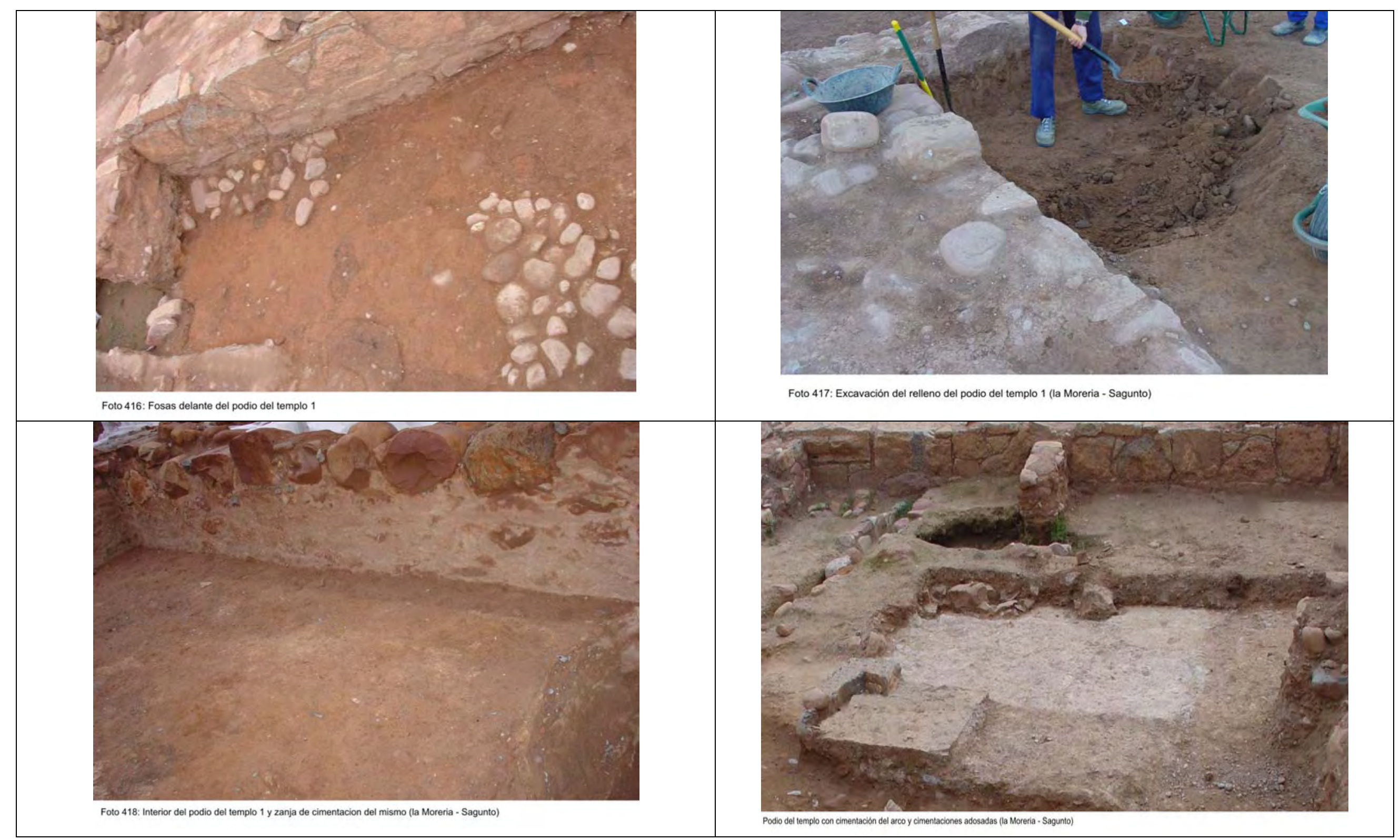




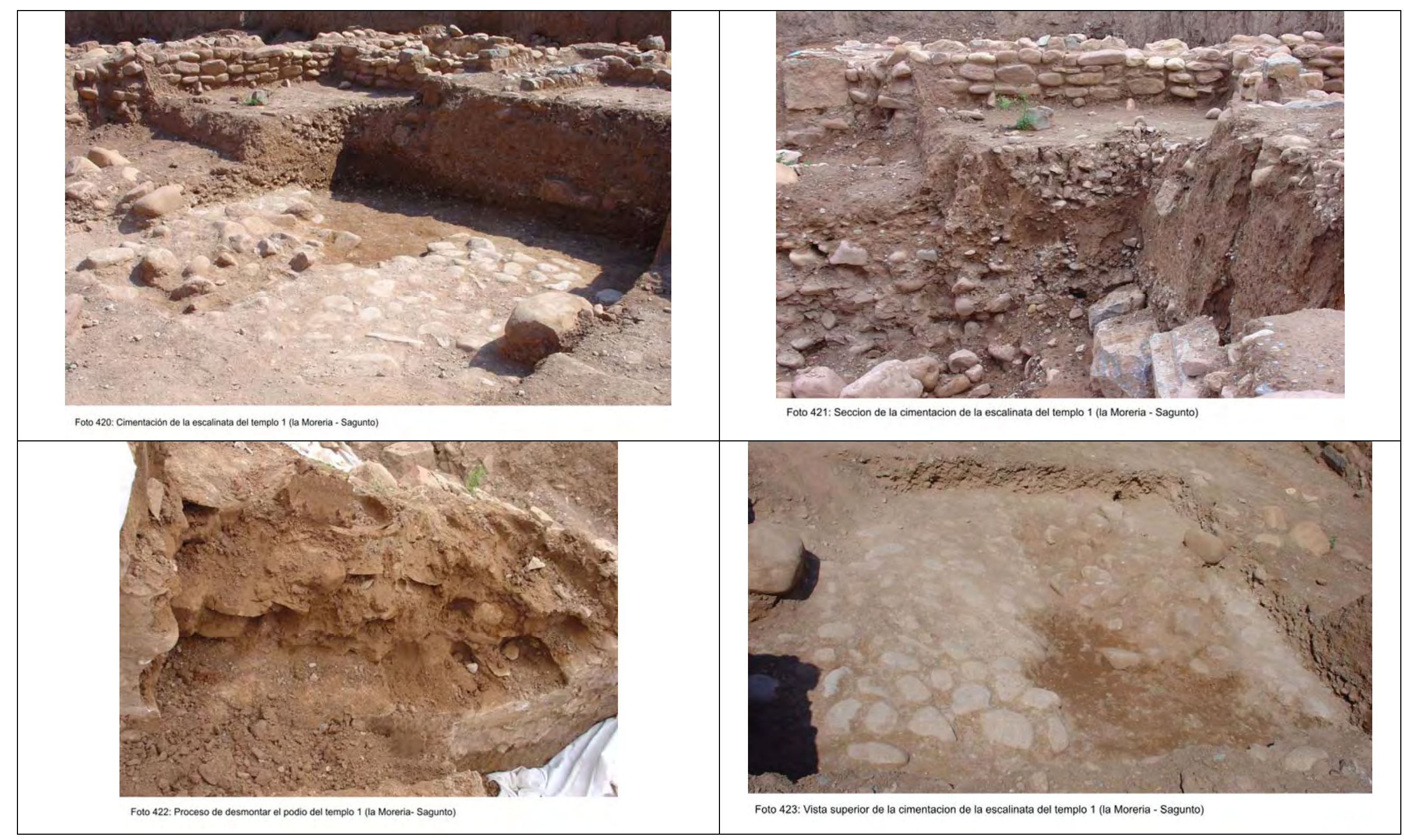




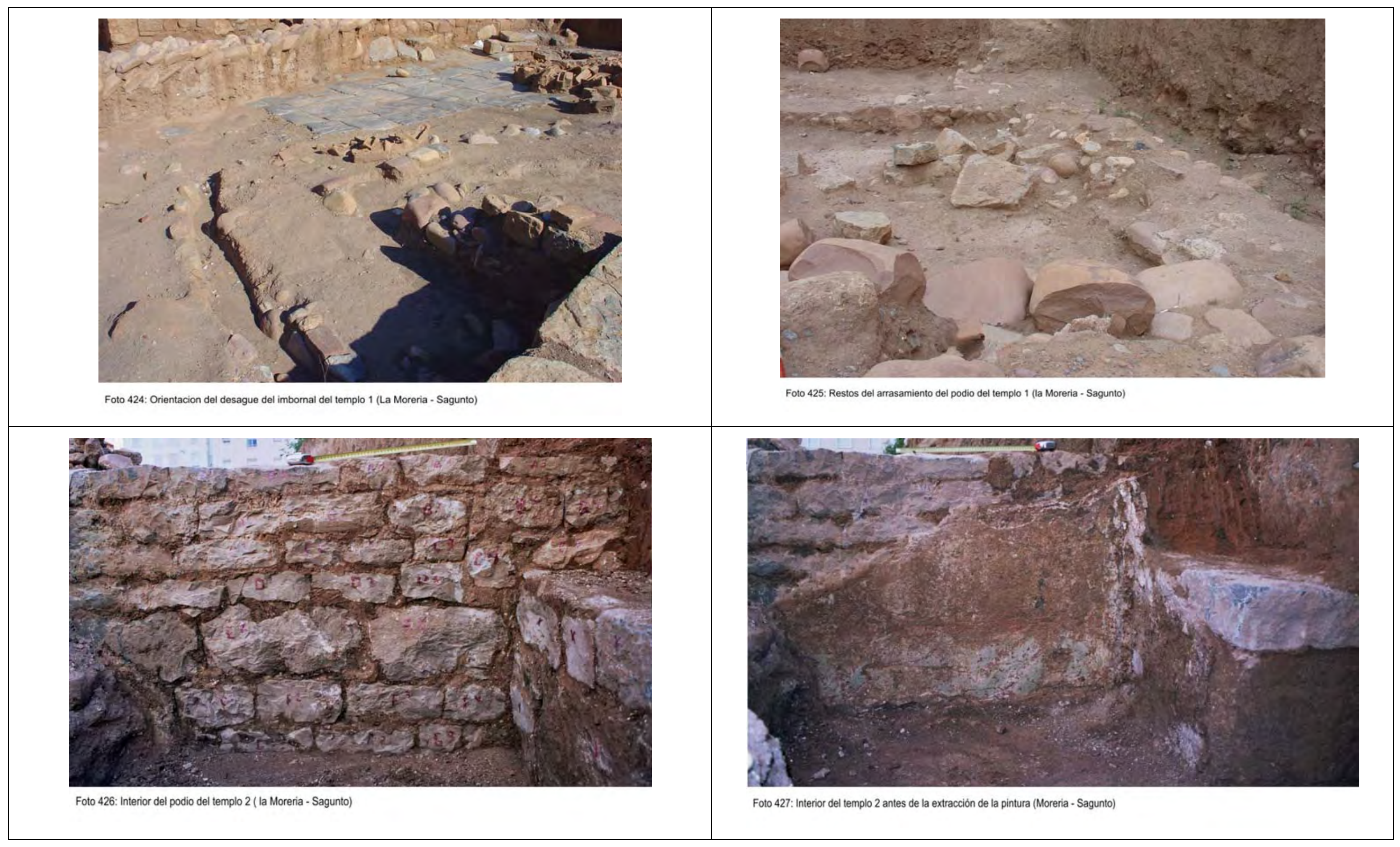




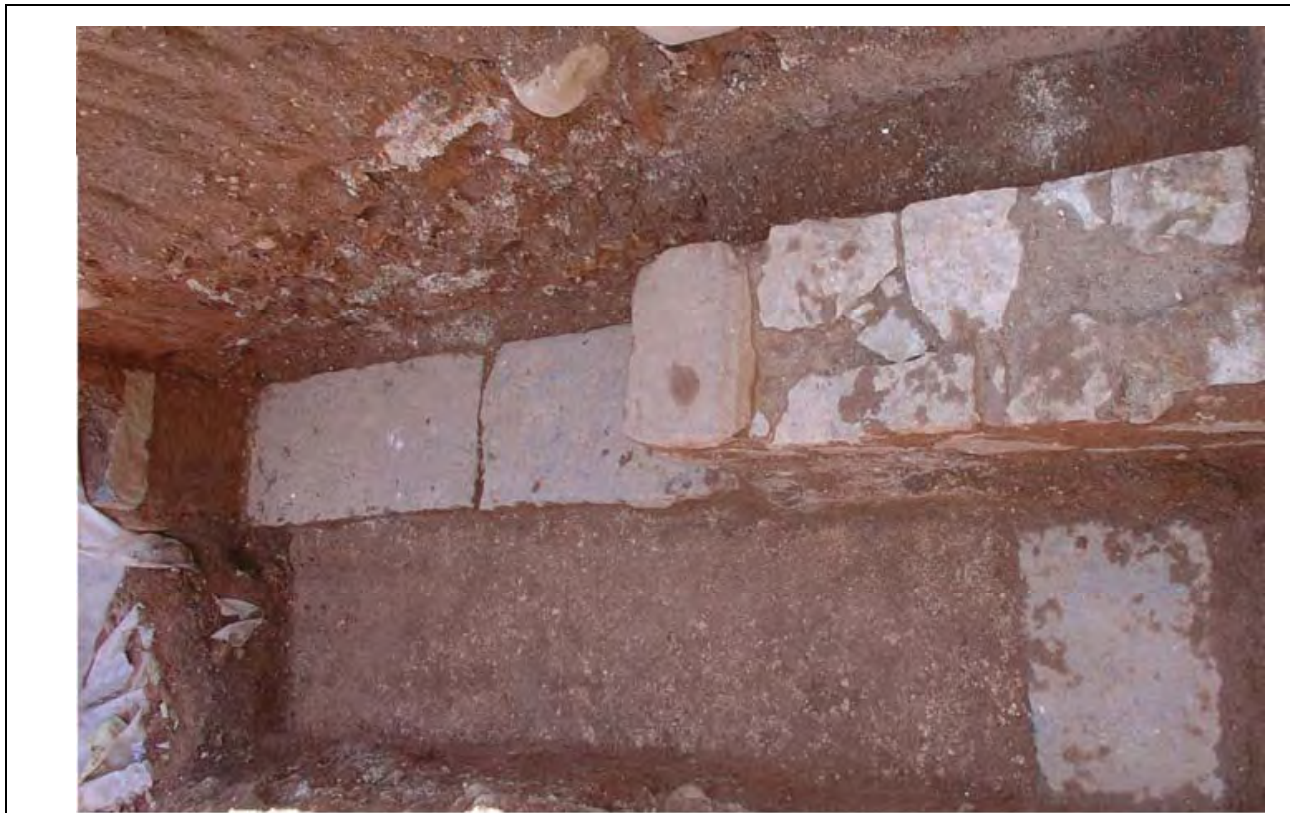

Foto 428: Umbral en el interio del templo 2 (Moreria - Sagunto)

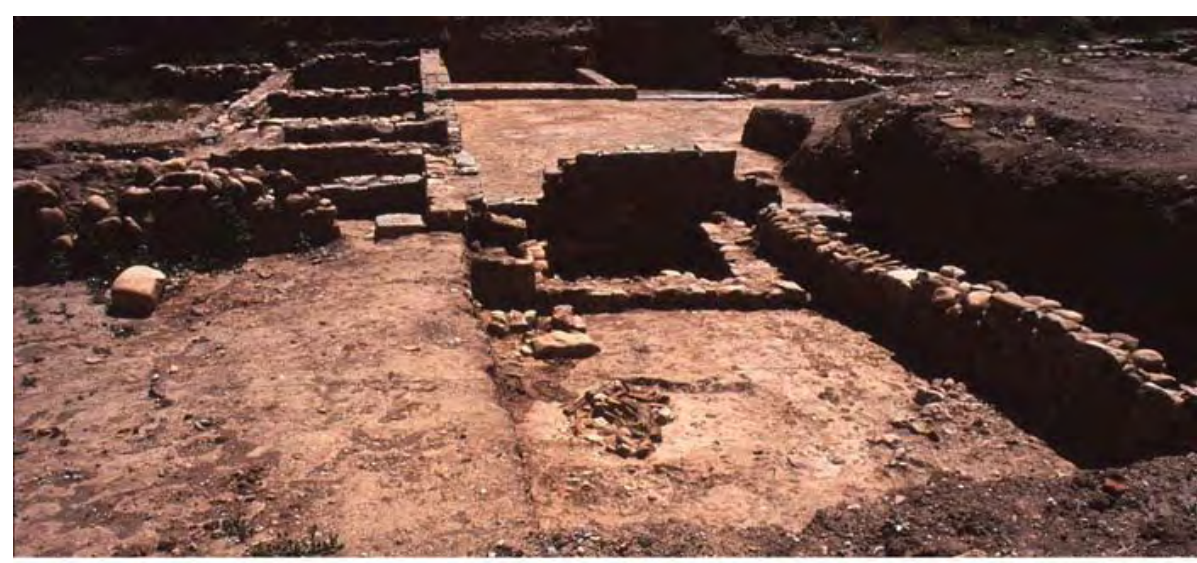

Foto 430: Moreria año 1994 (CAS)

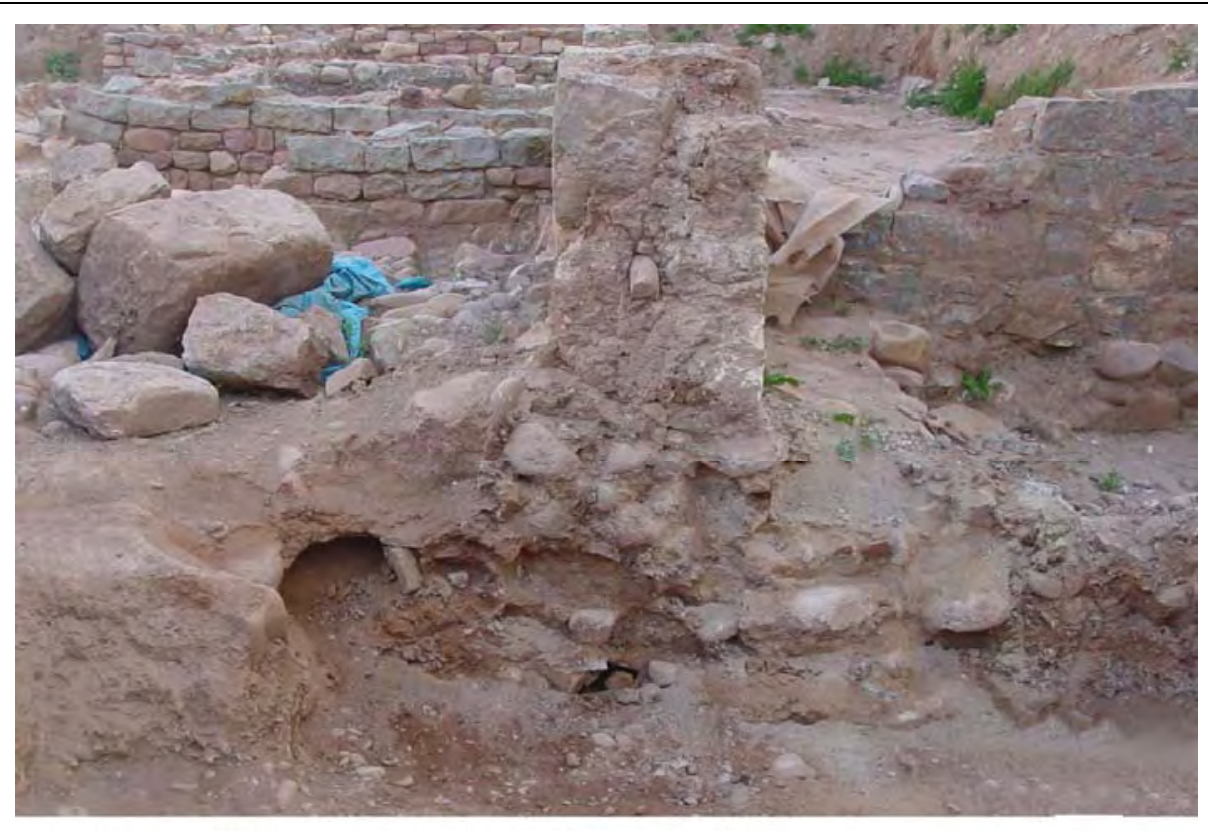

Foto 431: Proceso de desmontar el muro del templo 2 (Moreria - Sagunto)

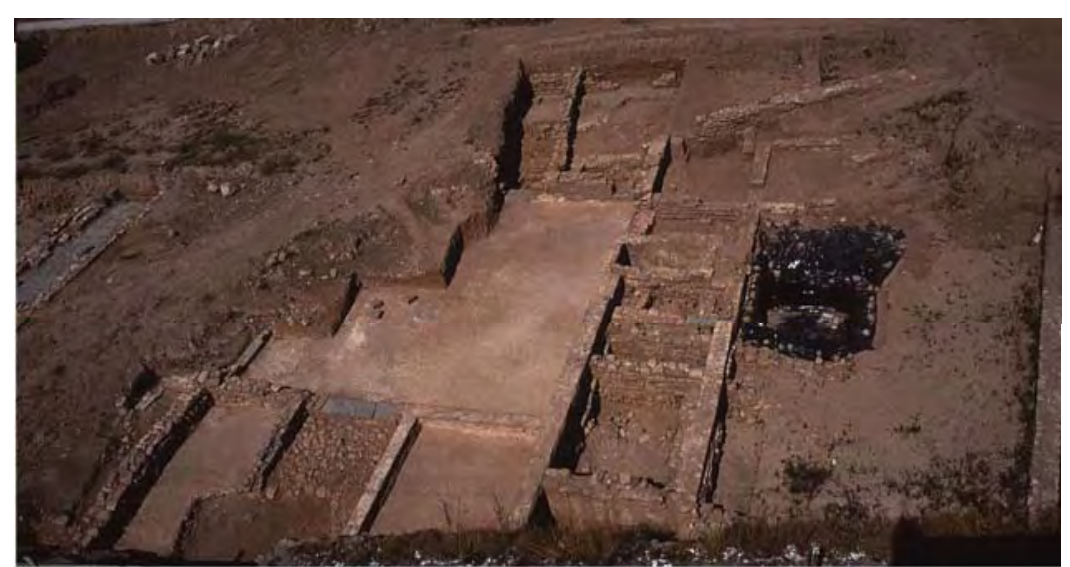

Foto 429: Moreria año 1994 (CAS) 


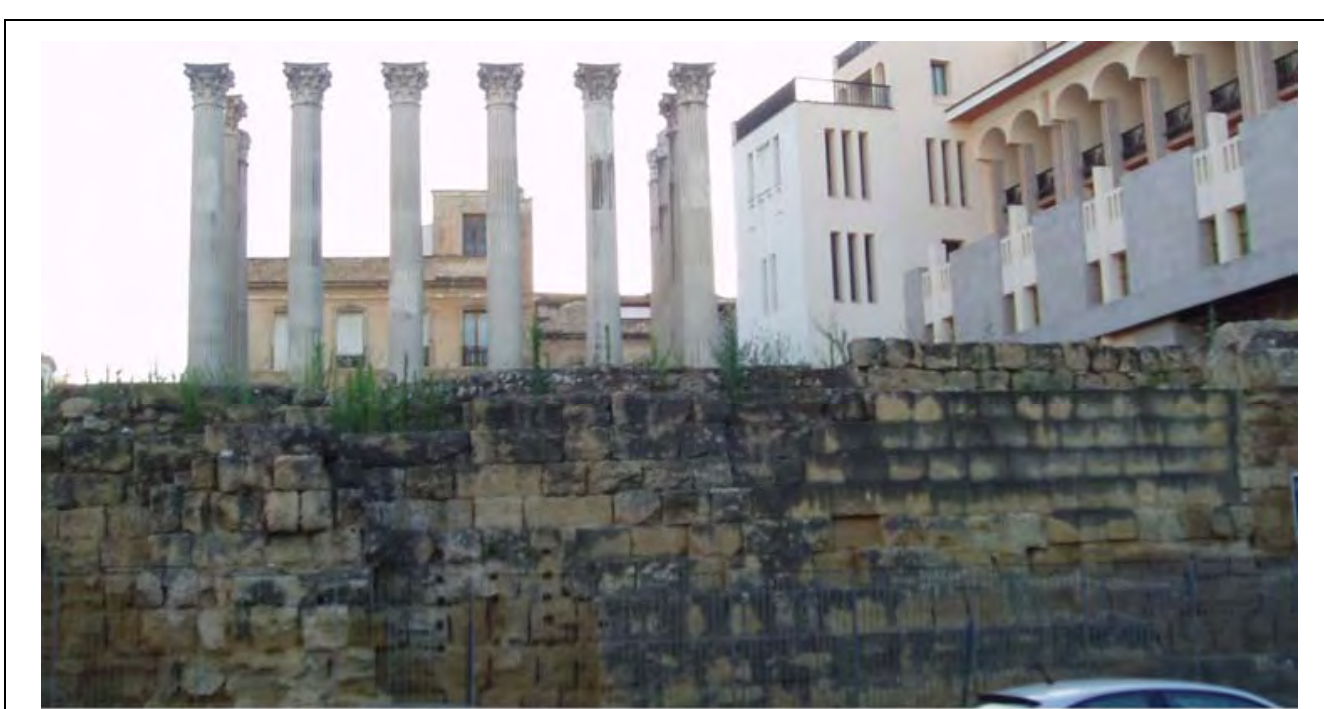

Foto 432: Templo de Cordoba

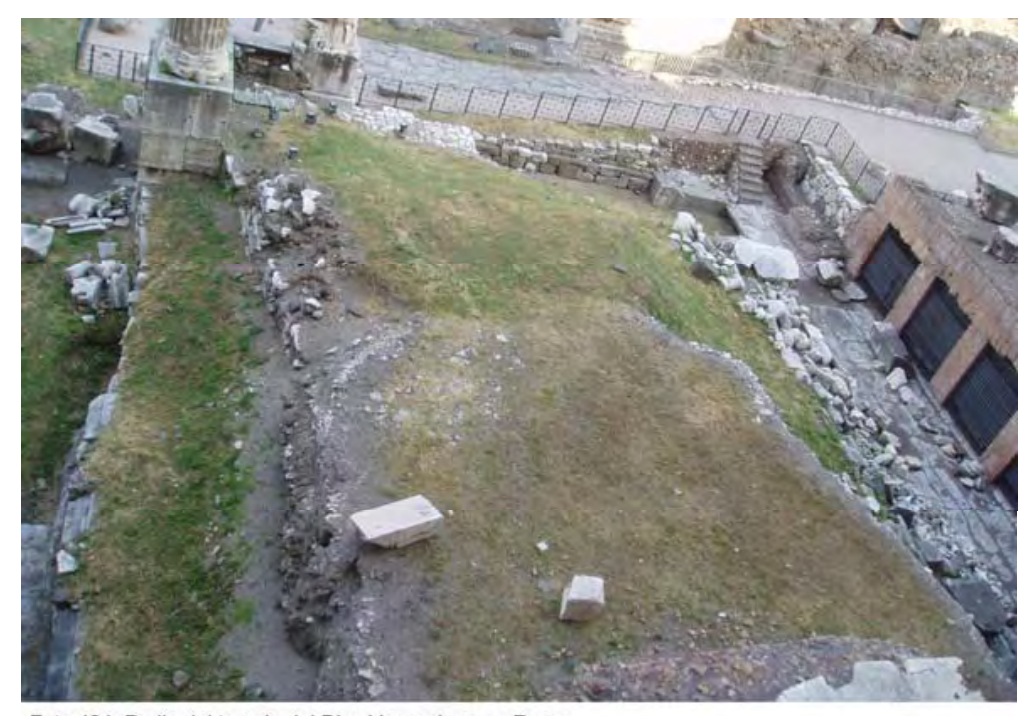

Foto 434: Podio del templo del Divo Vespasiano en Roma

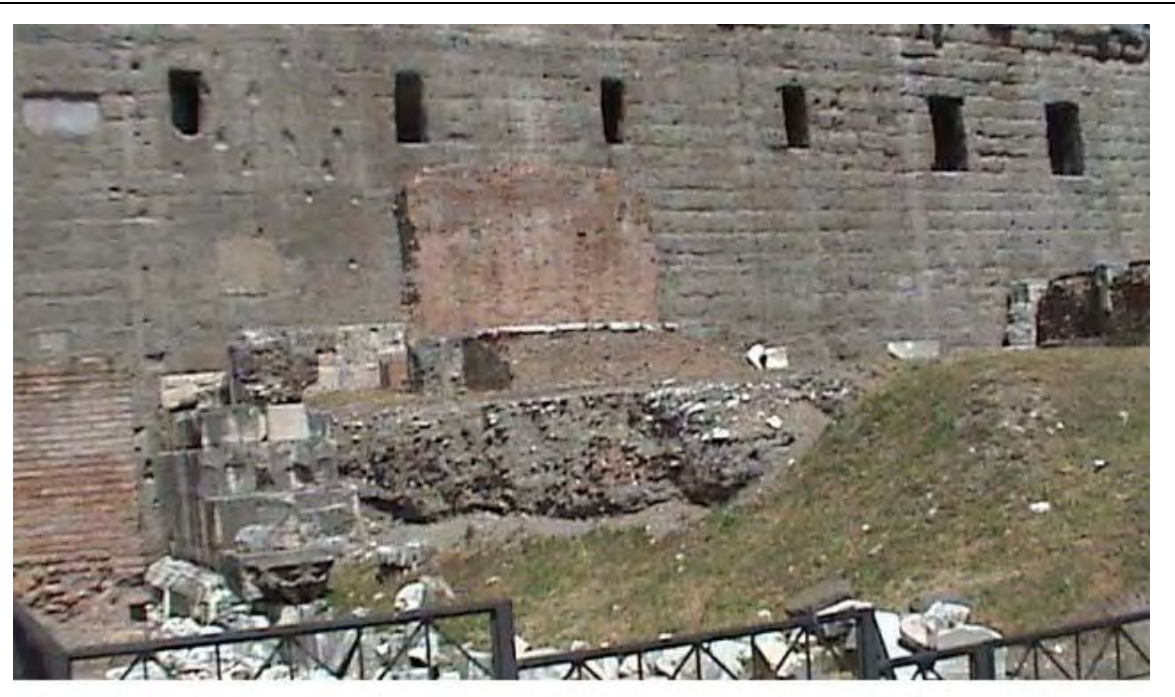

Foto 433: Templo del Divo Vespasiano en Roma

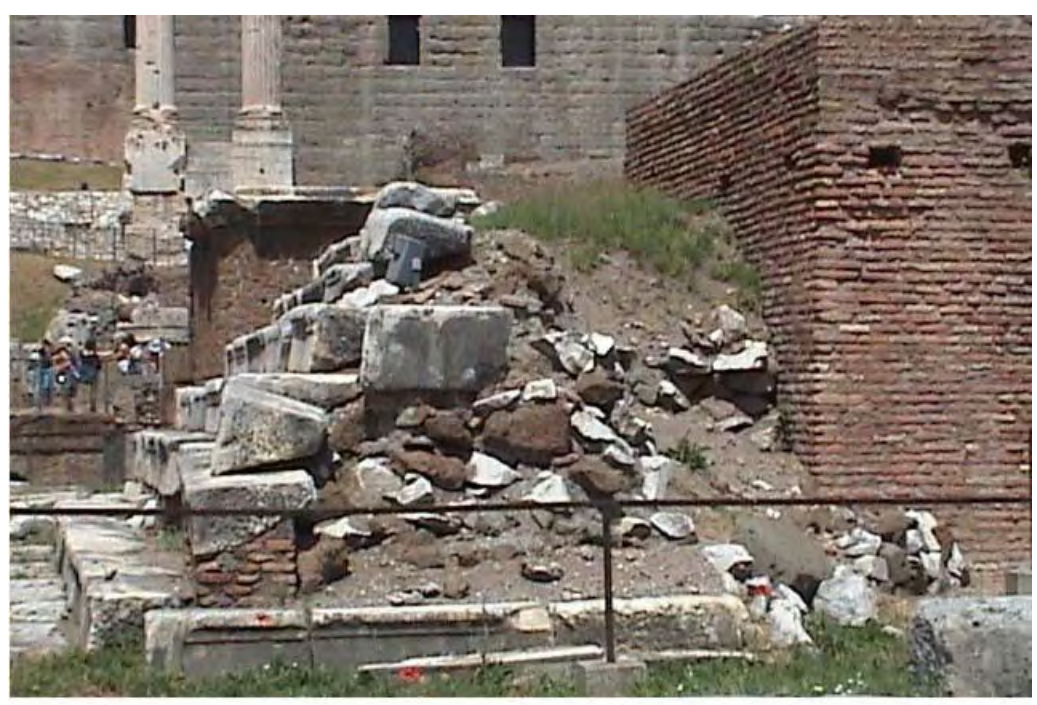

Foto 435: Escalinata junto a la Via Sacra en el foro romano (Columna de Focas) 


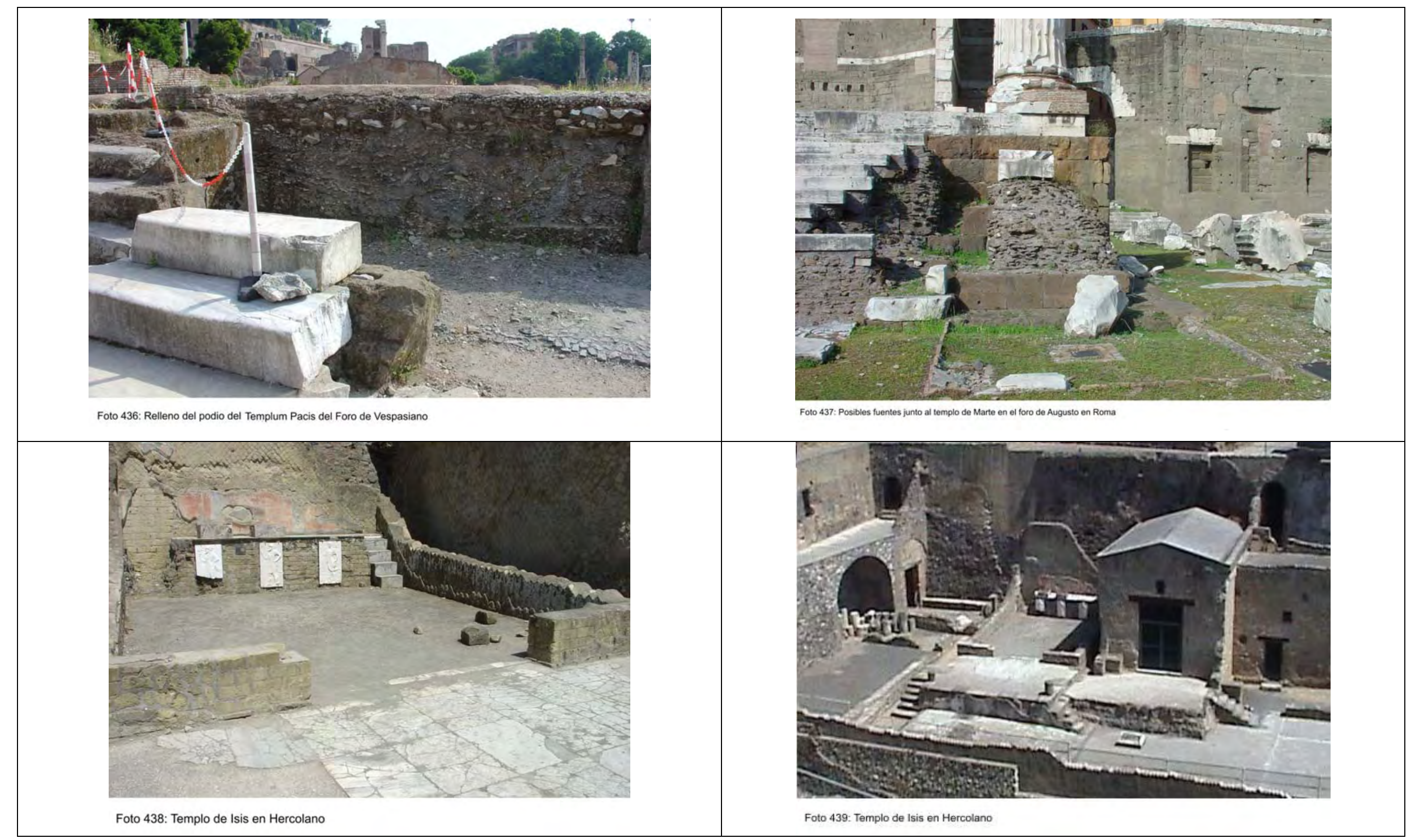




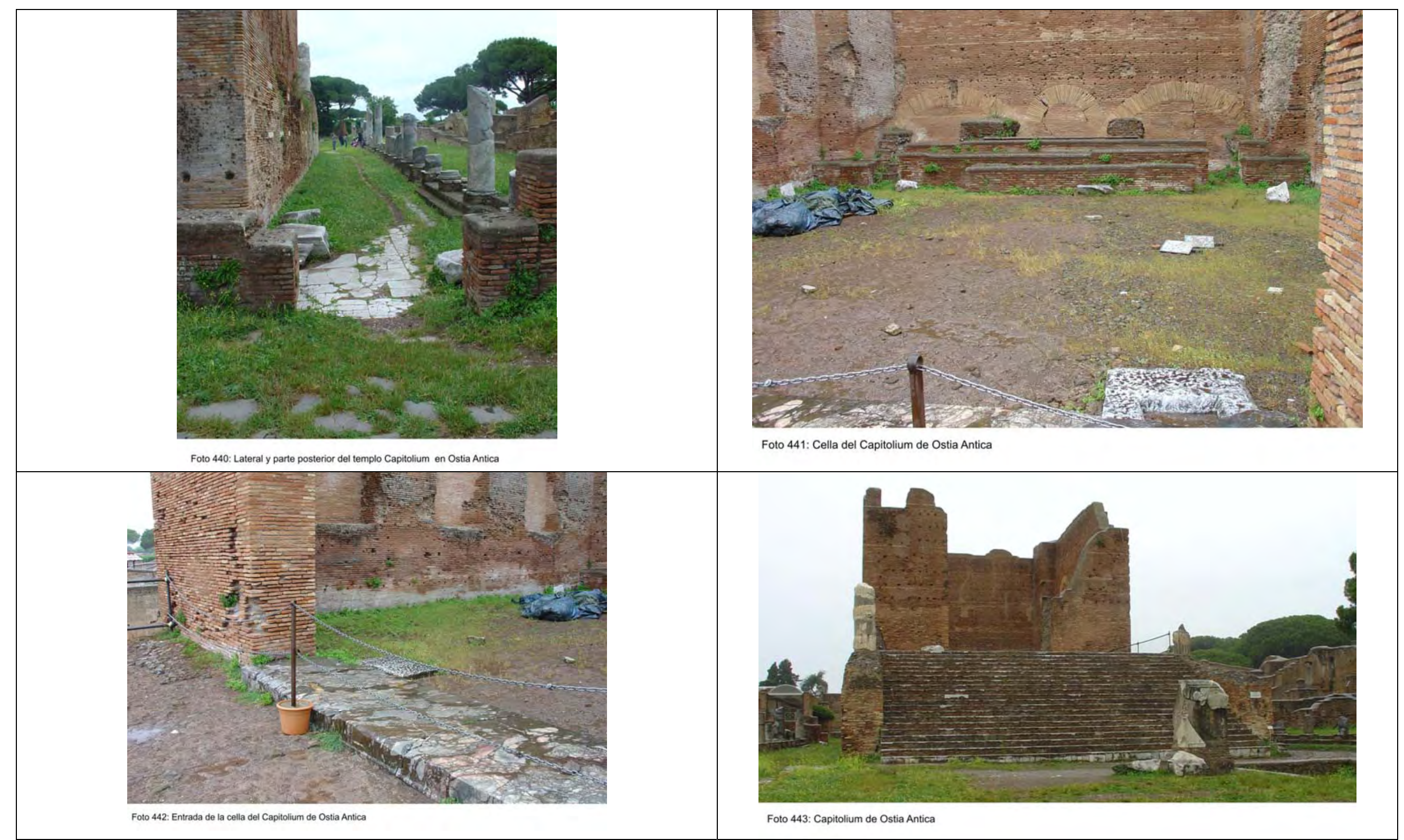




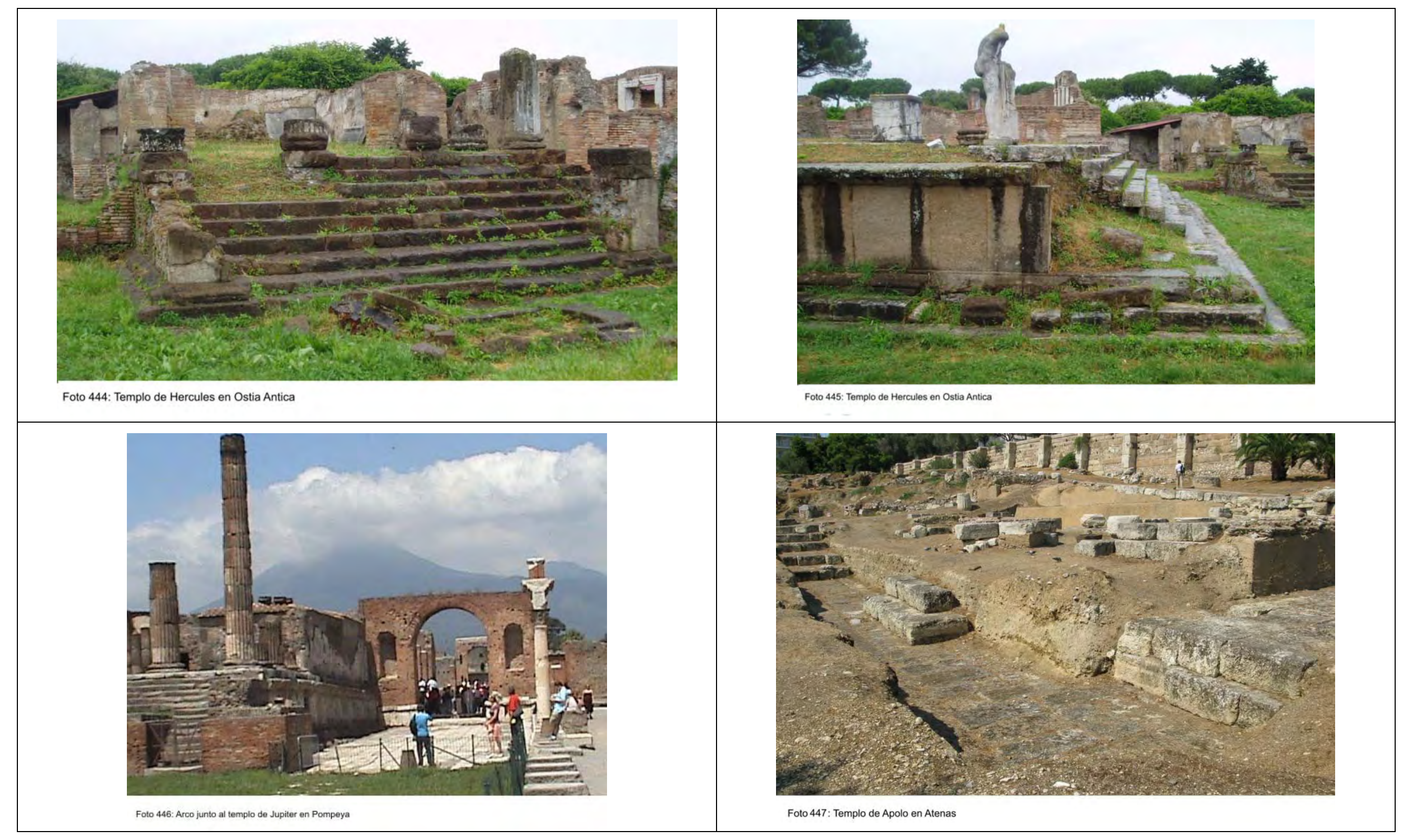




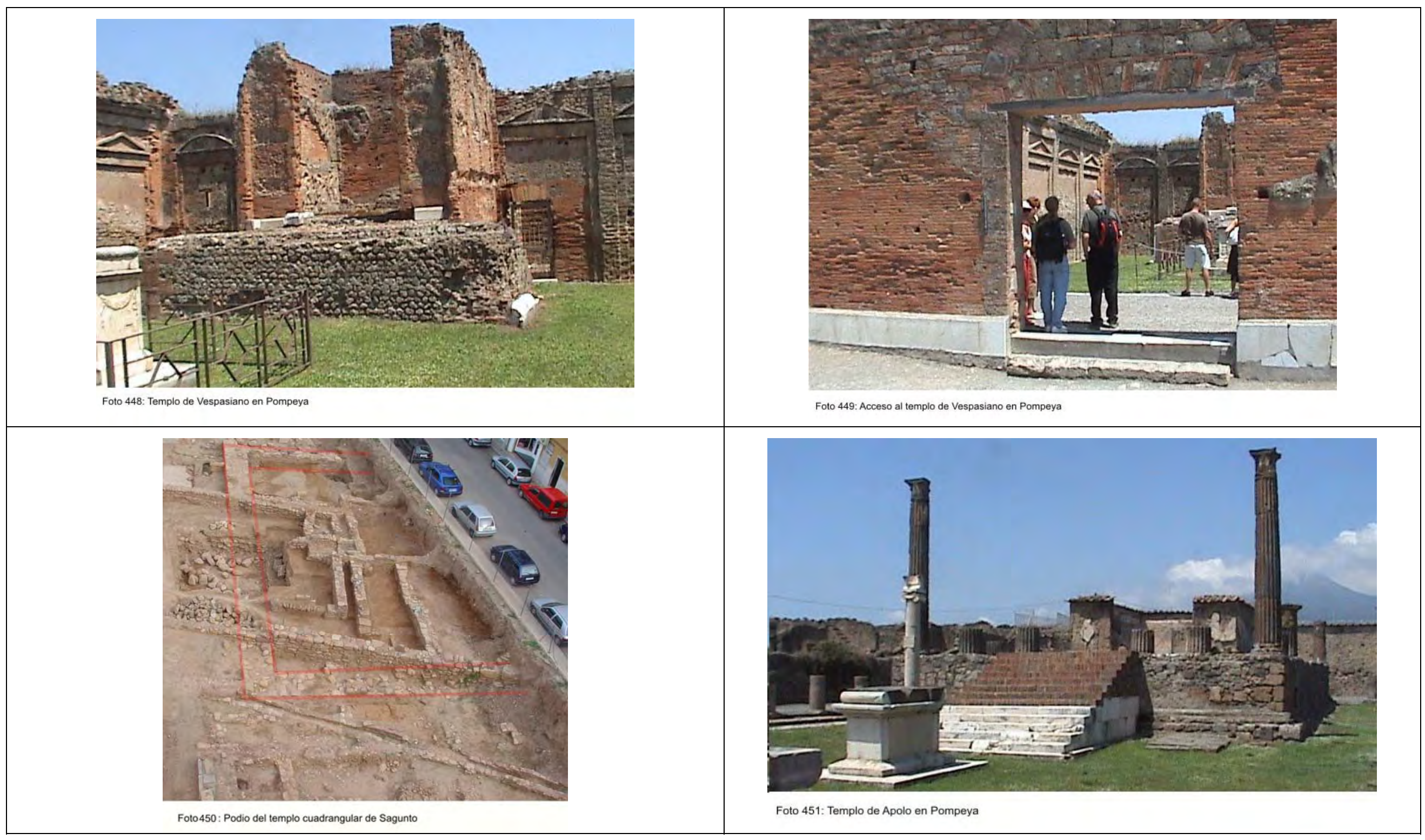




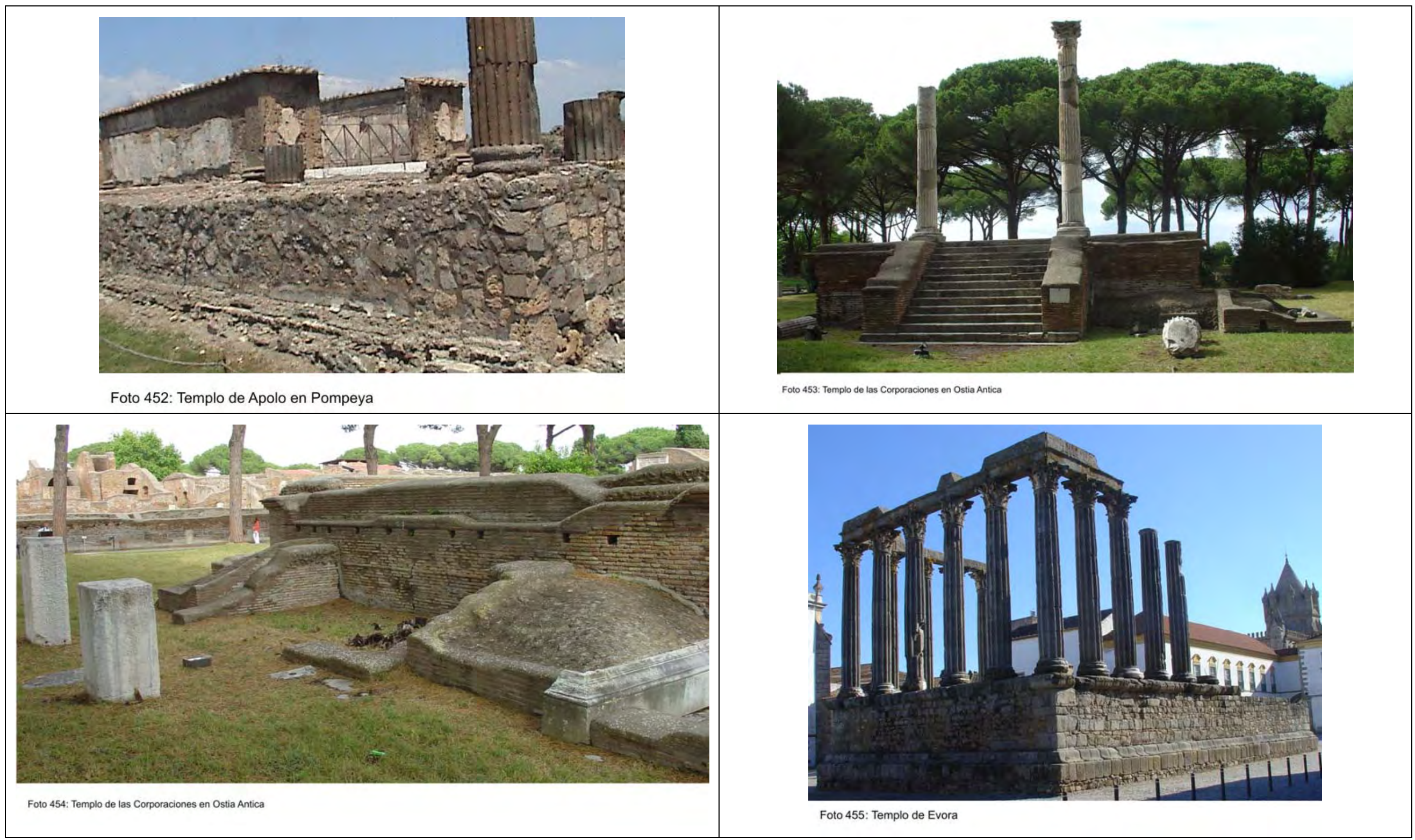




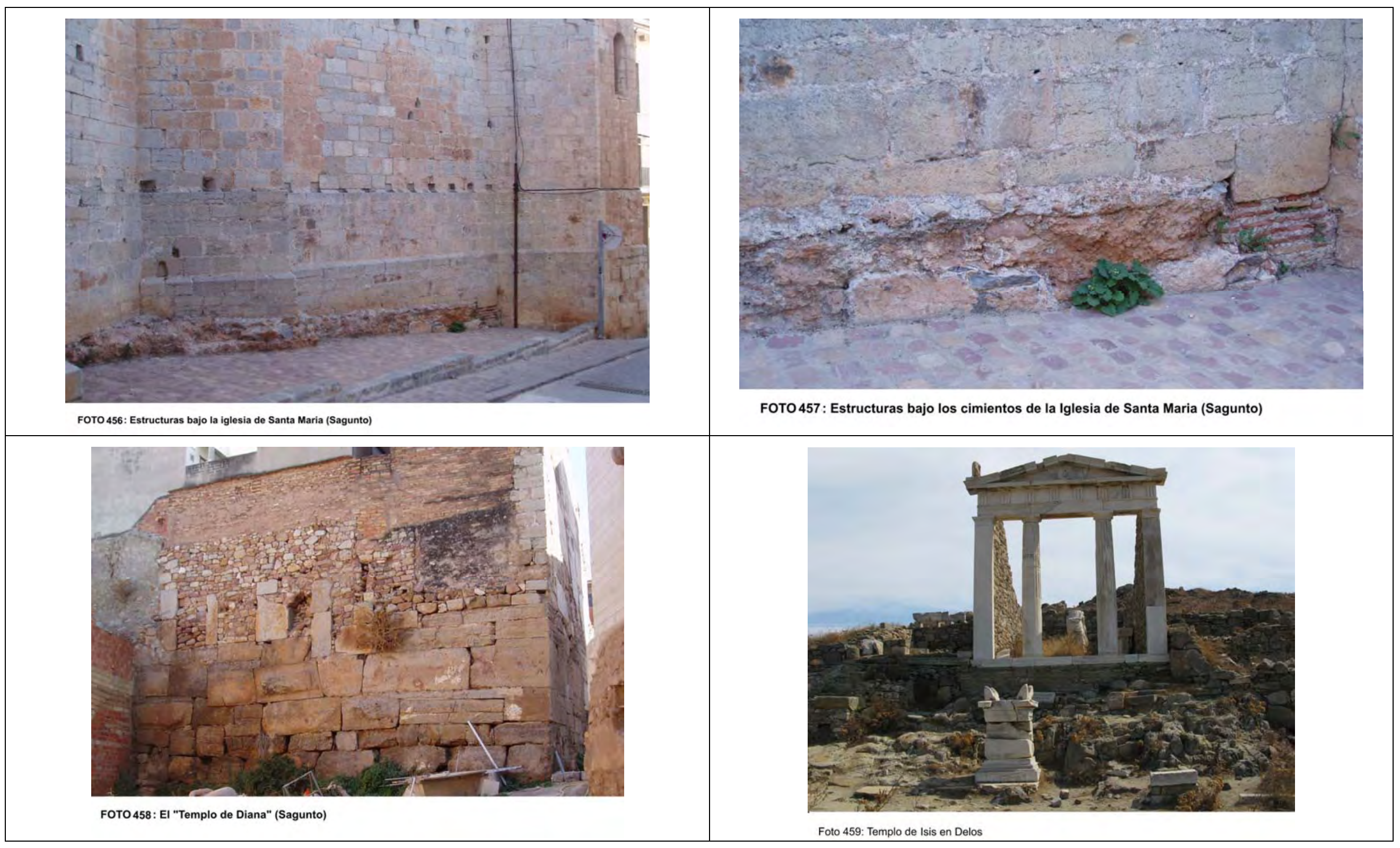




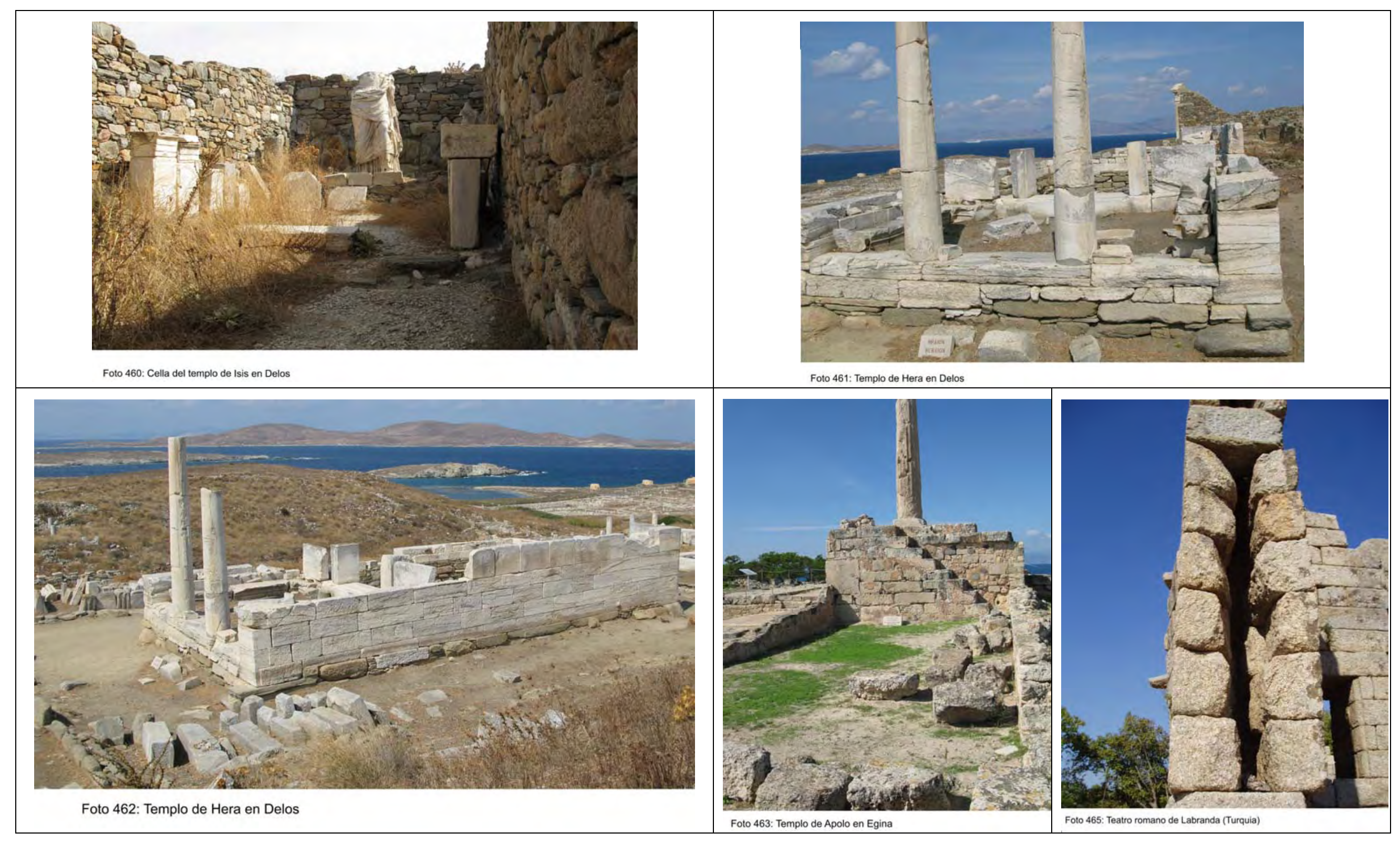




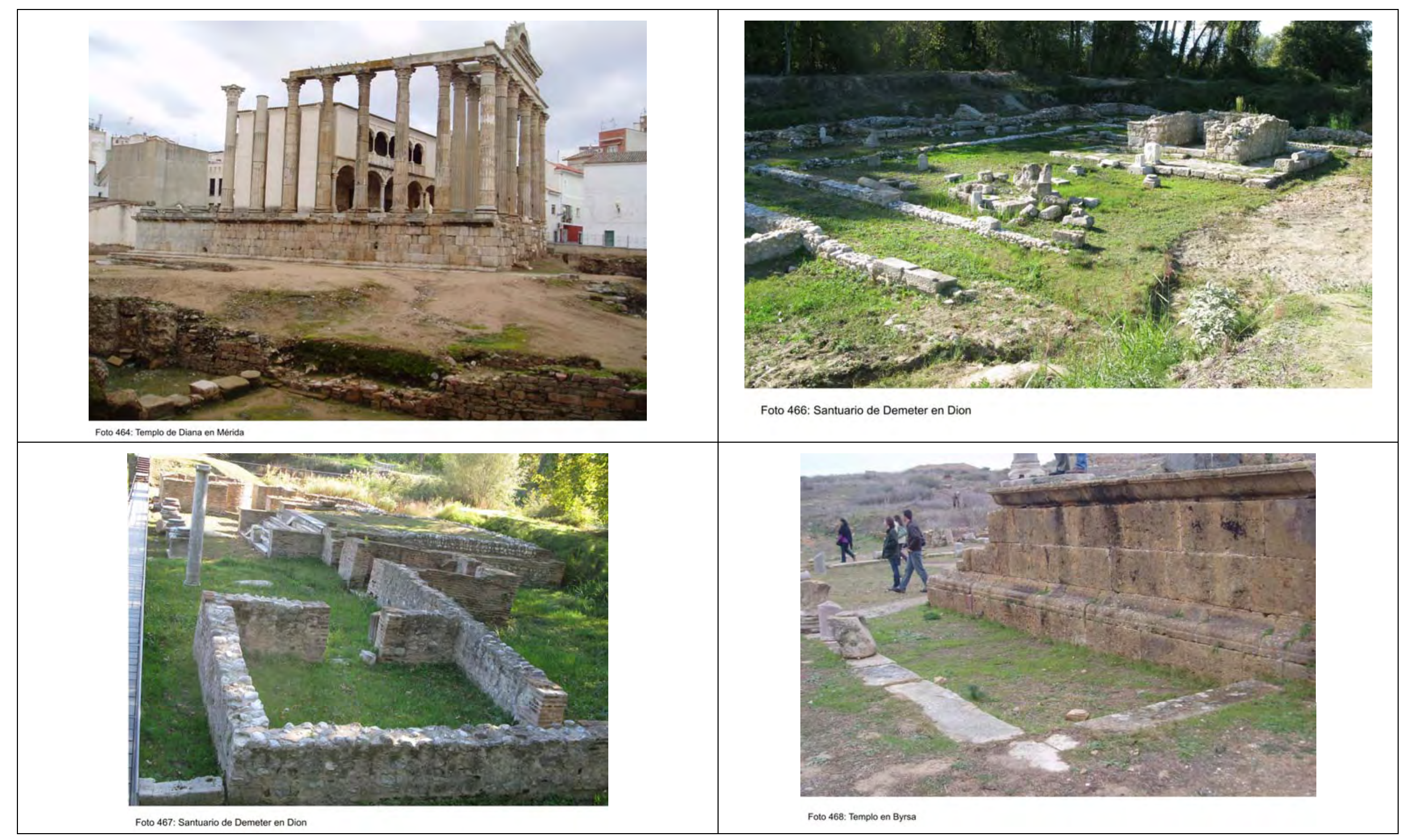




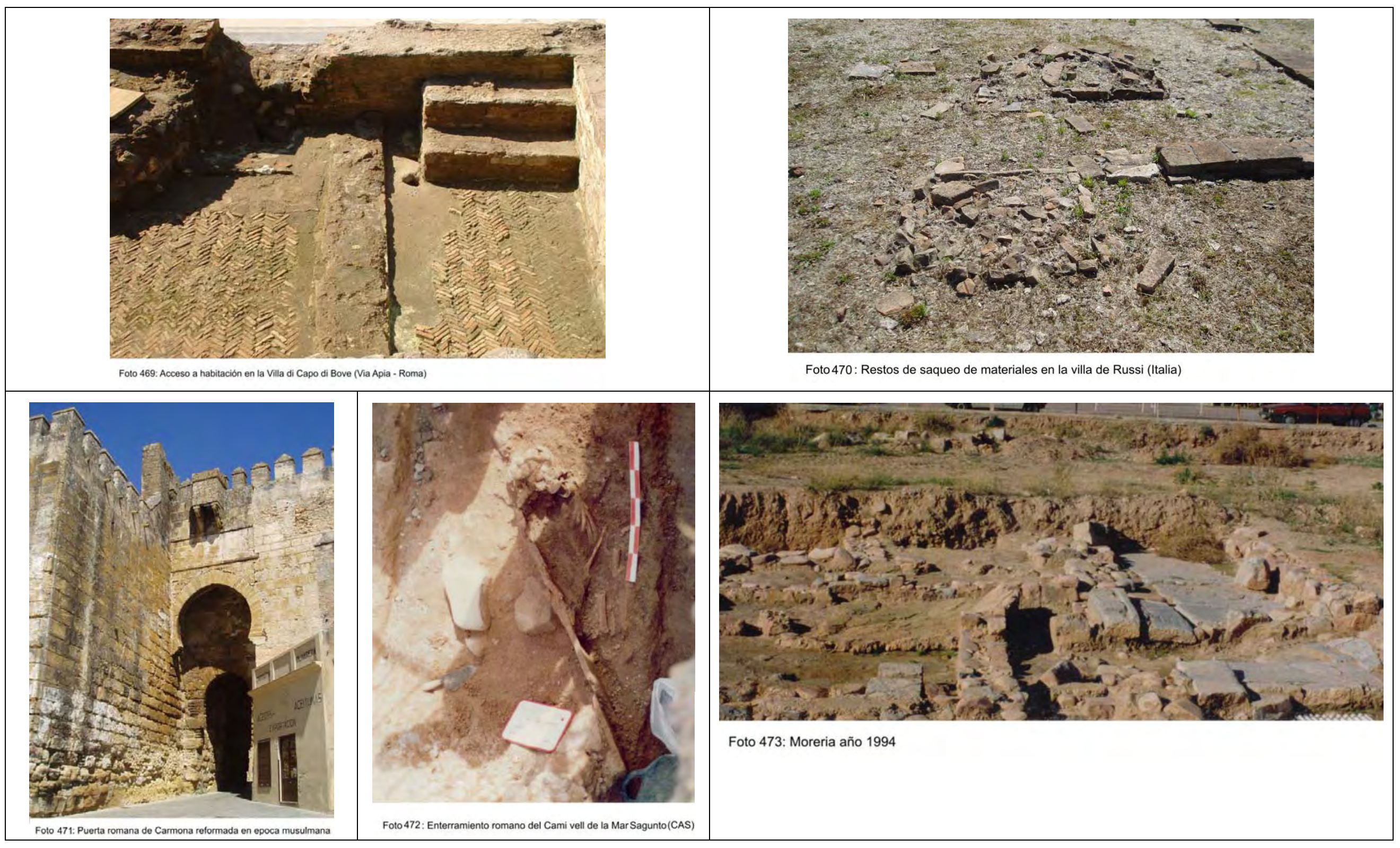




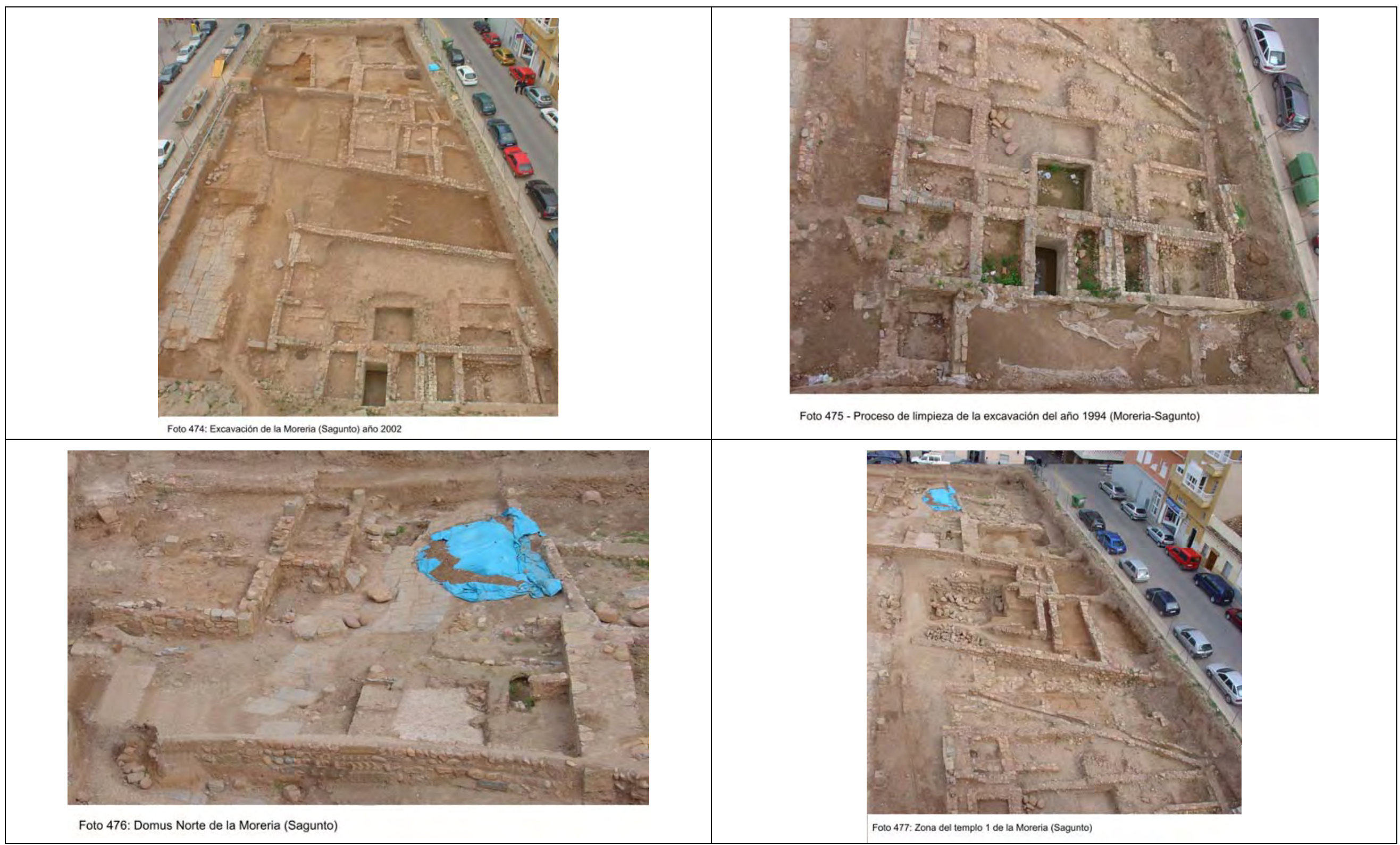




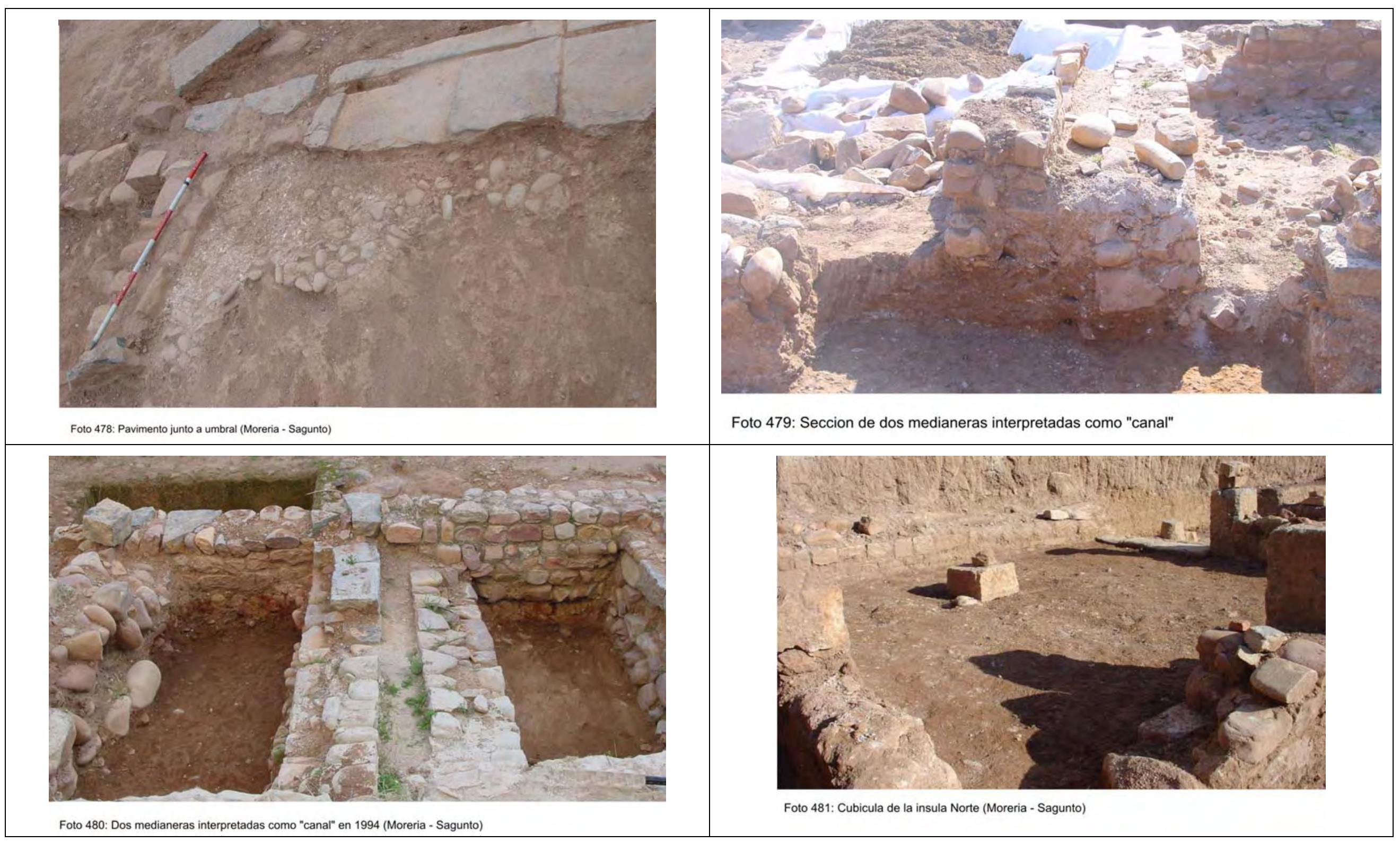




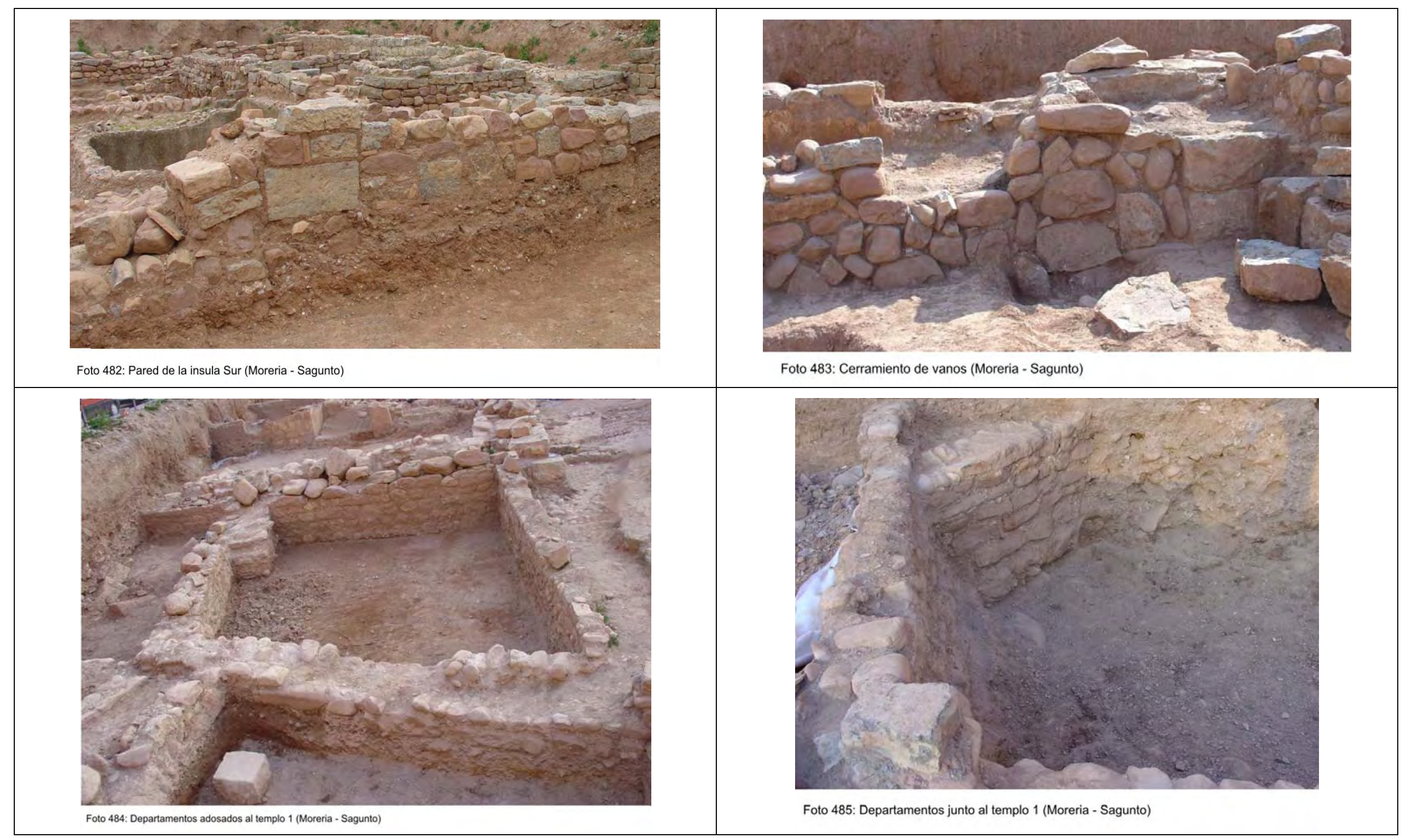




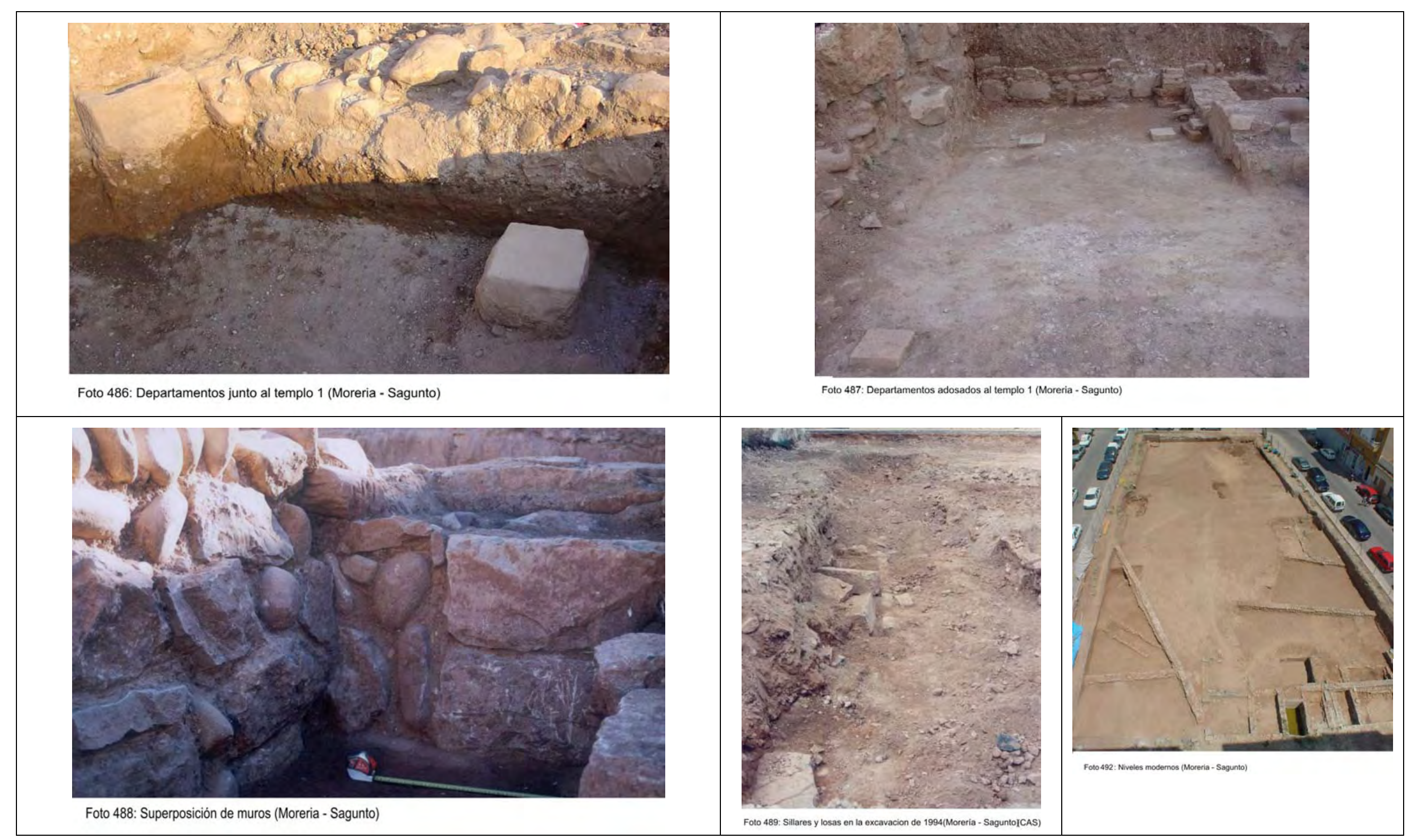




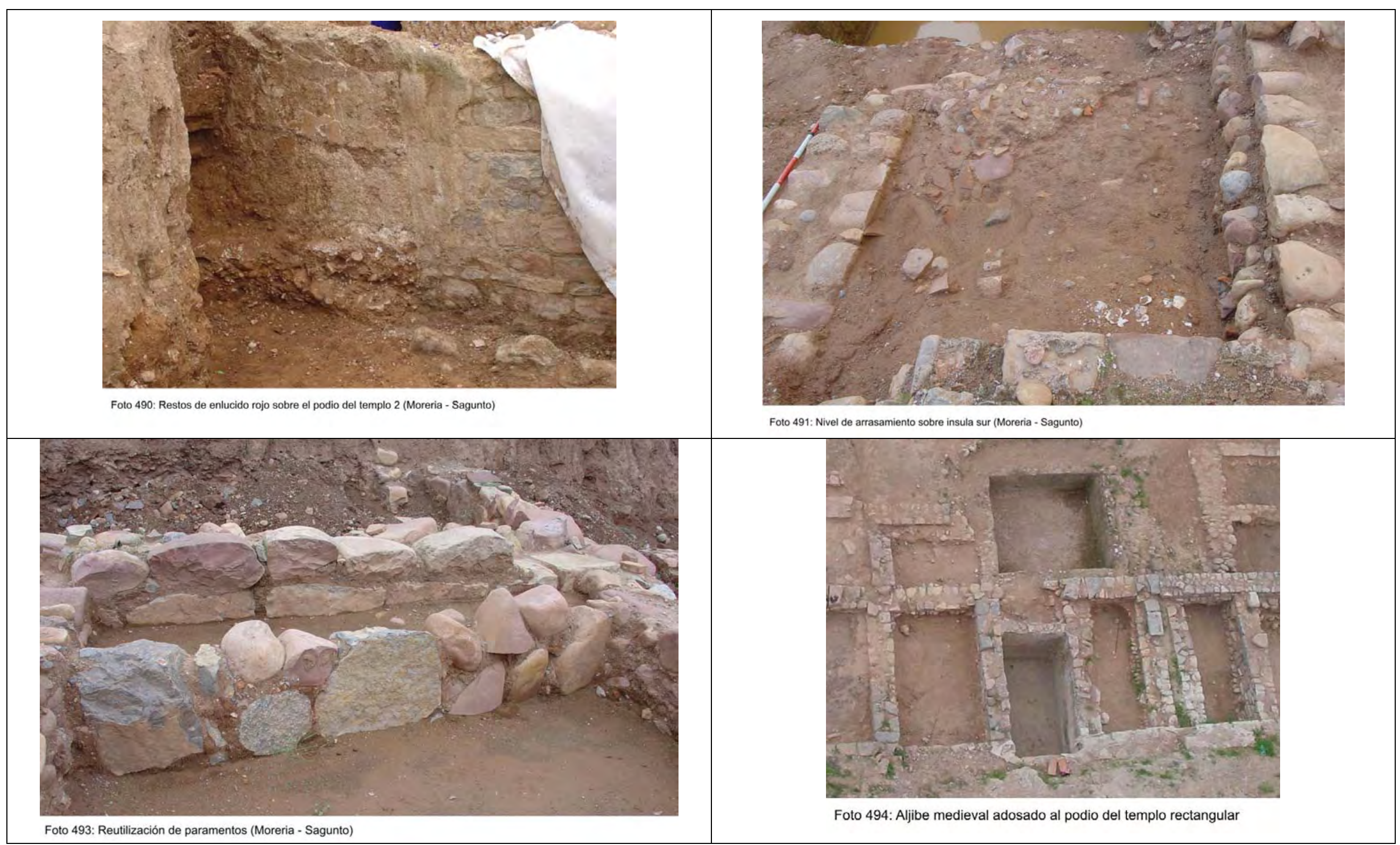




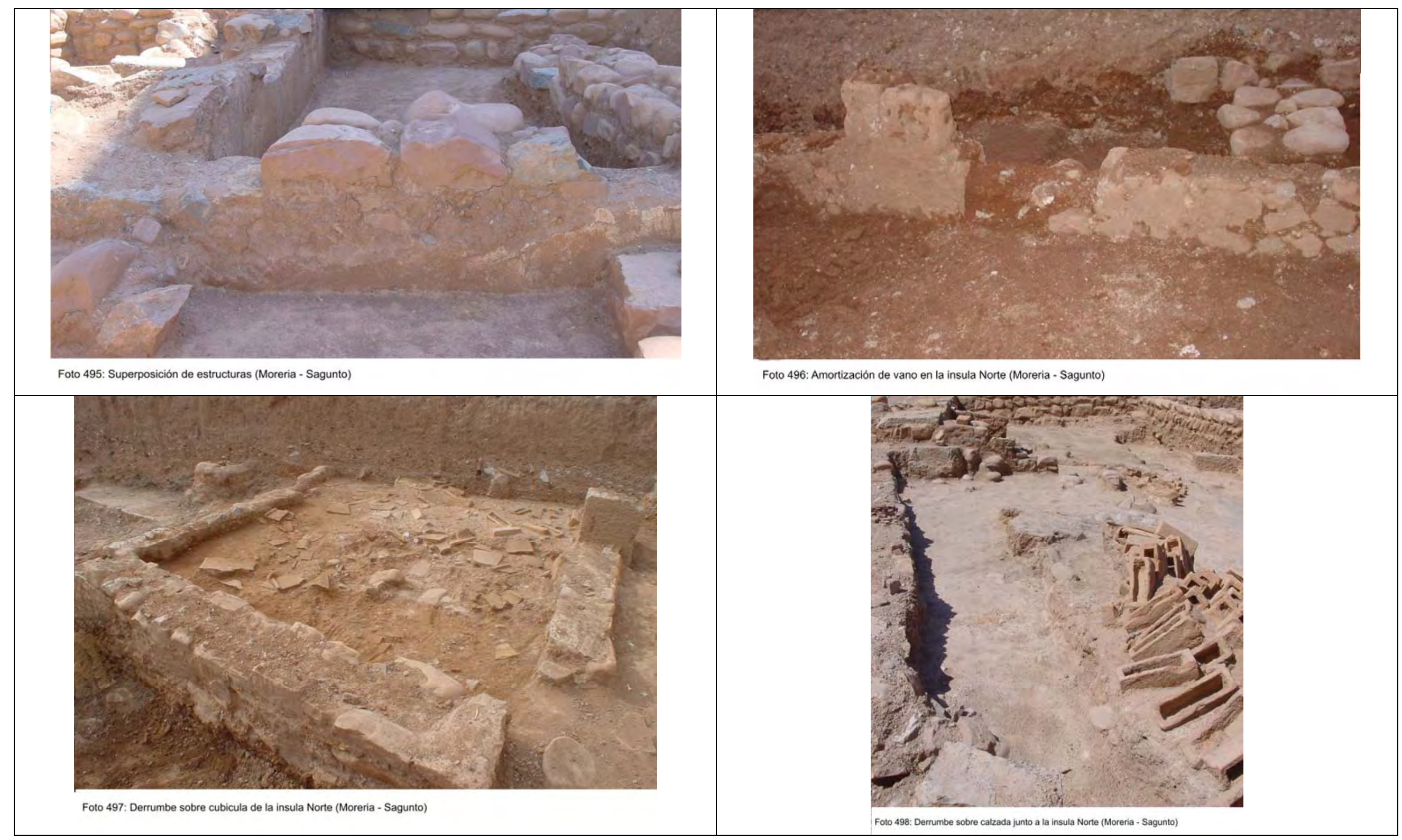




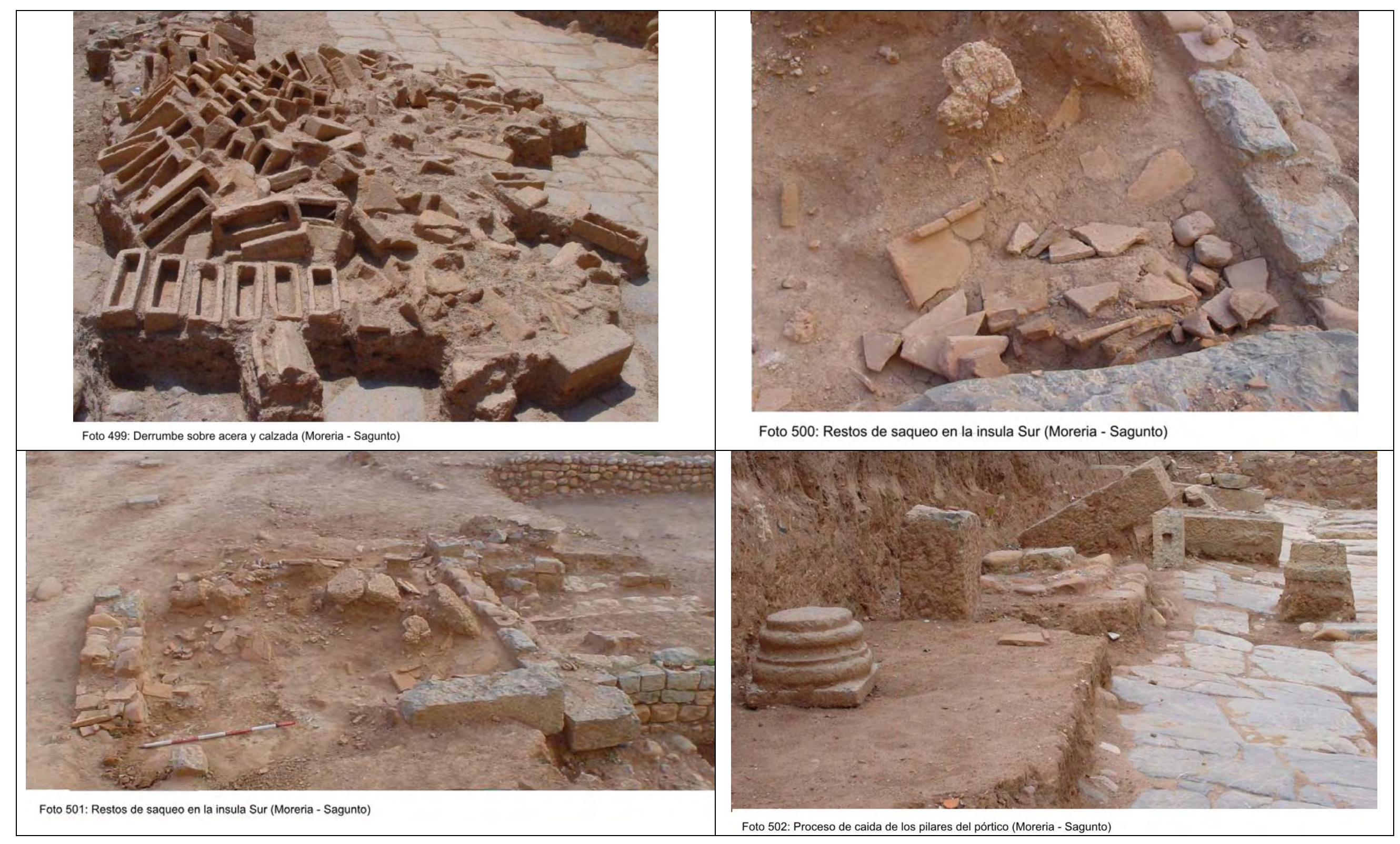



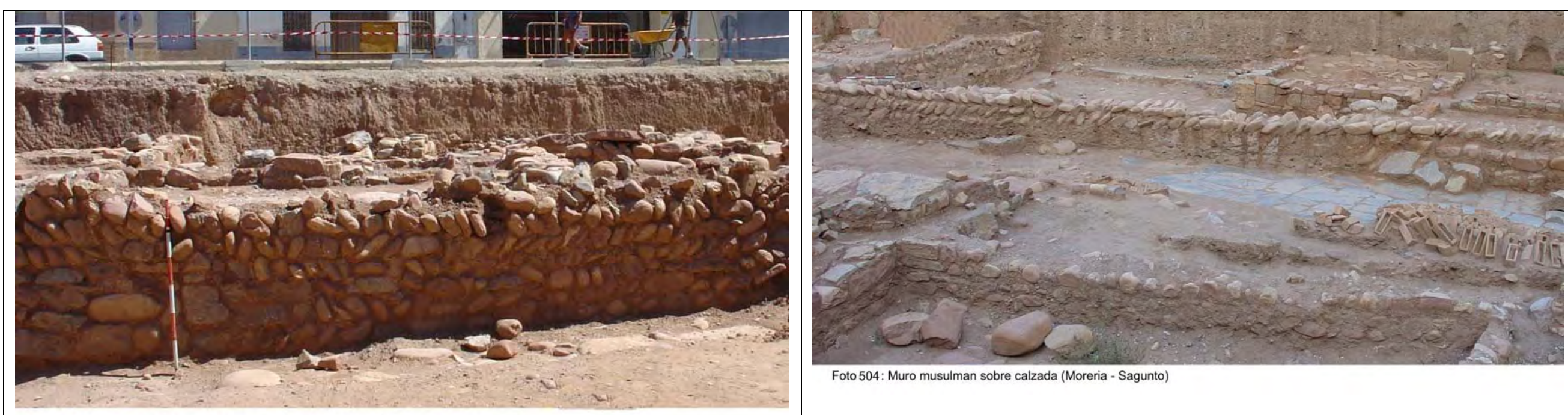

Foto 503: Muro musulman sobre podio del templo (Moreria - Sagunto)

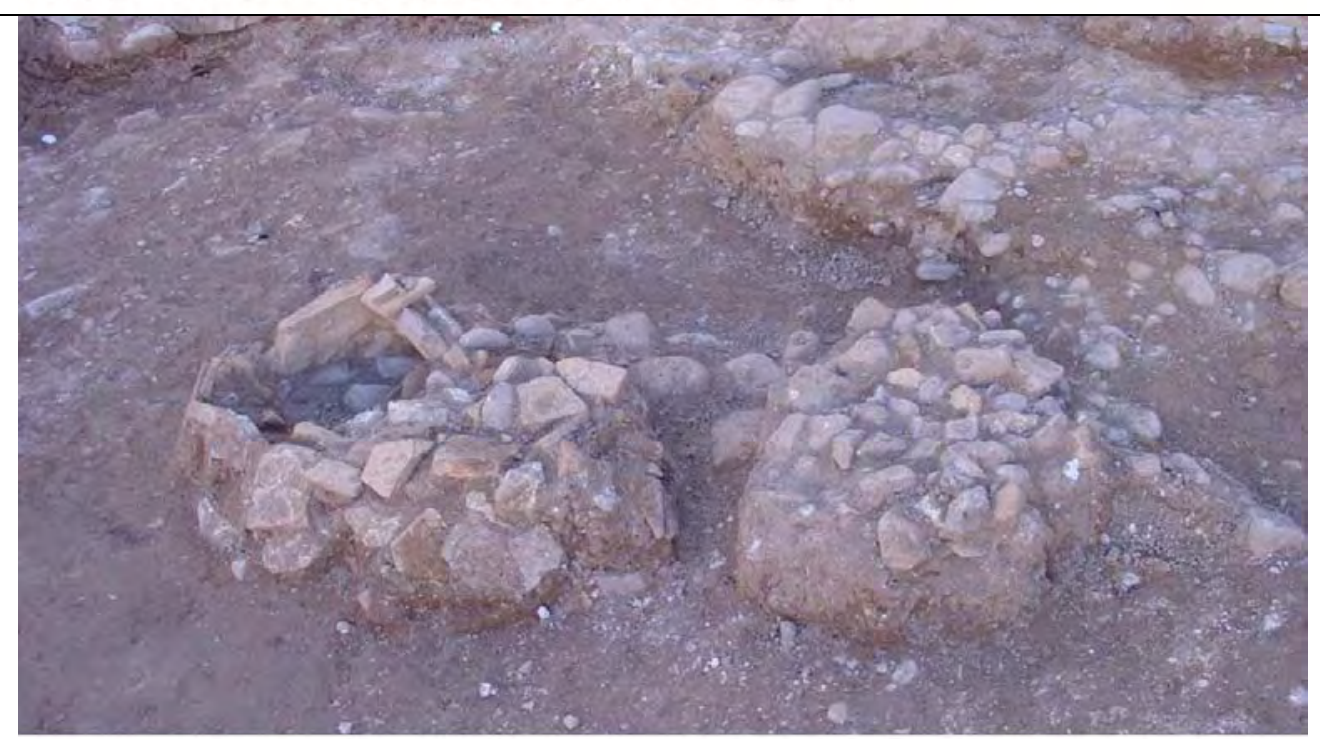

Foto 505: Restos de saqueo junto a templo 2 (Moreria - Sagunto)

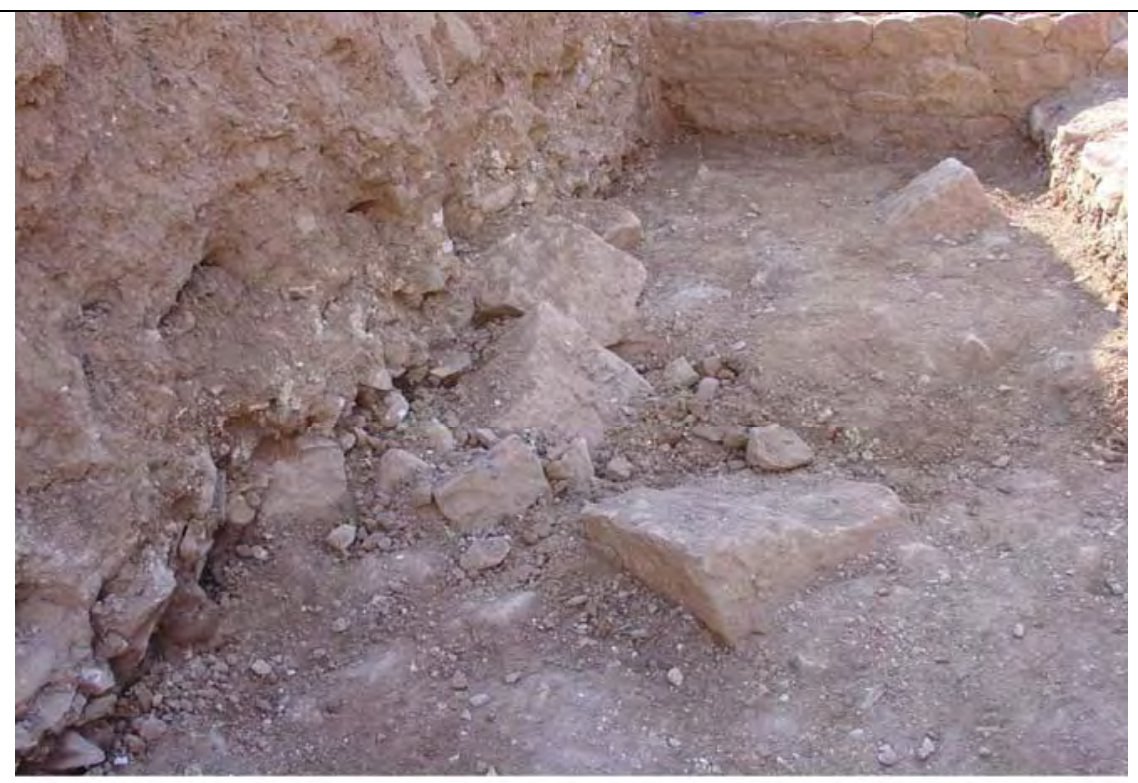

Foto 506: Restos del arrasamiento del templo 1 (Moreria - Sagunto) 


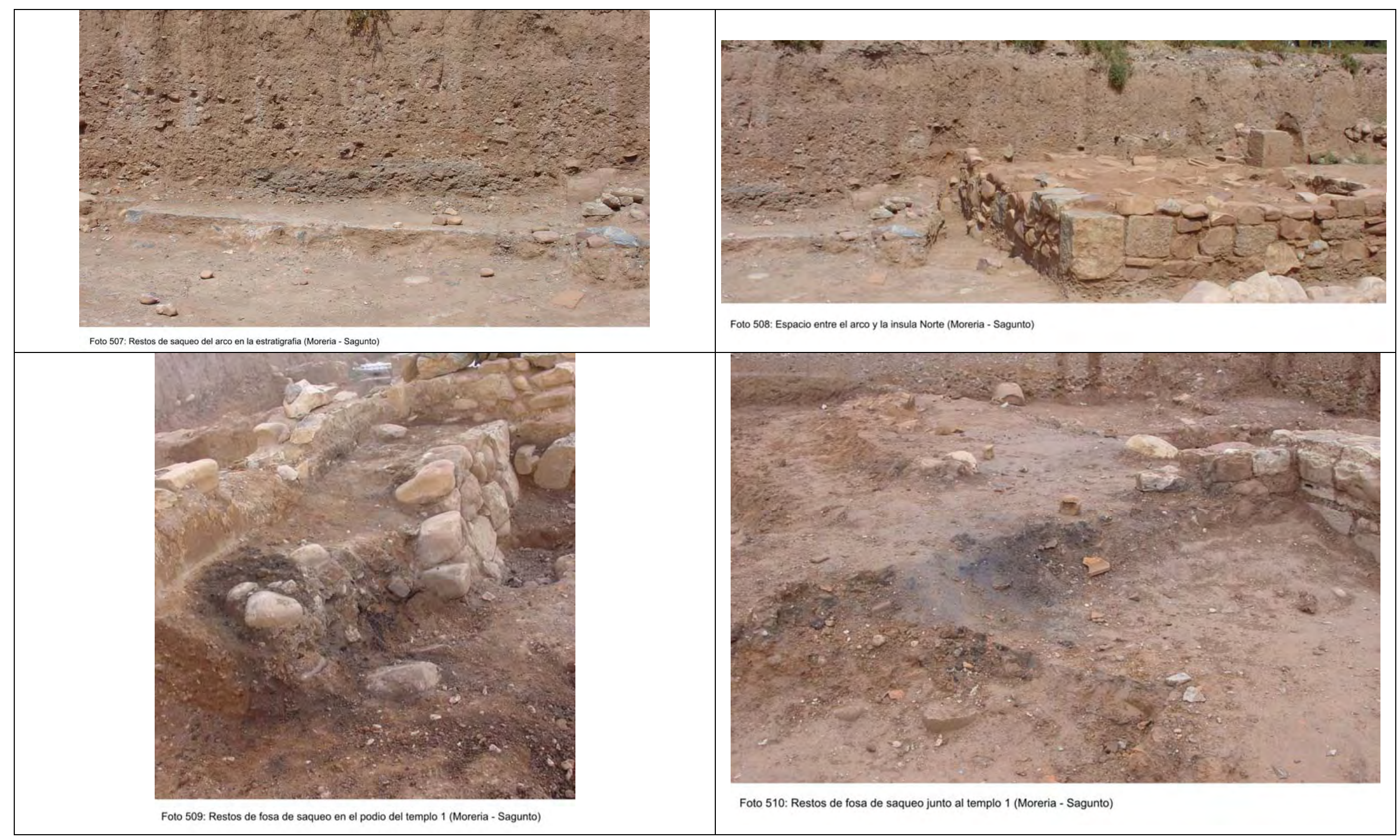




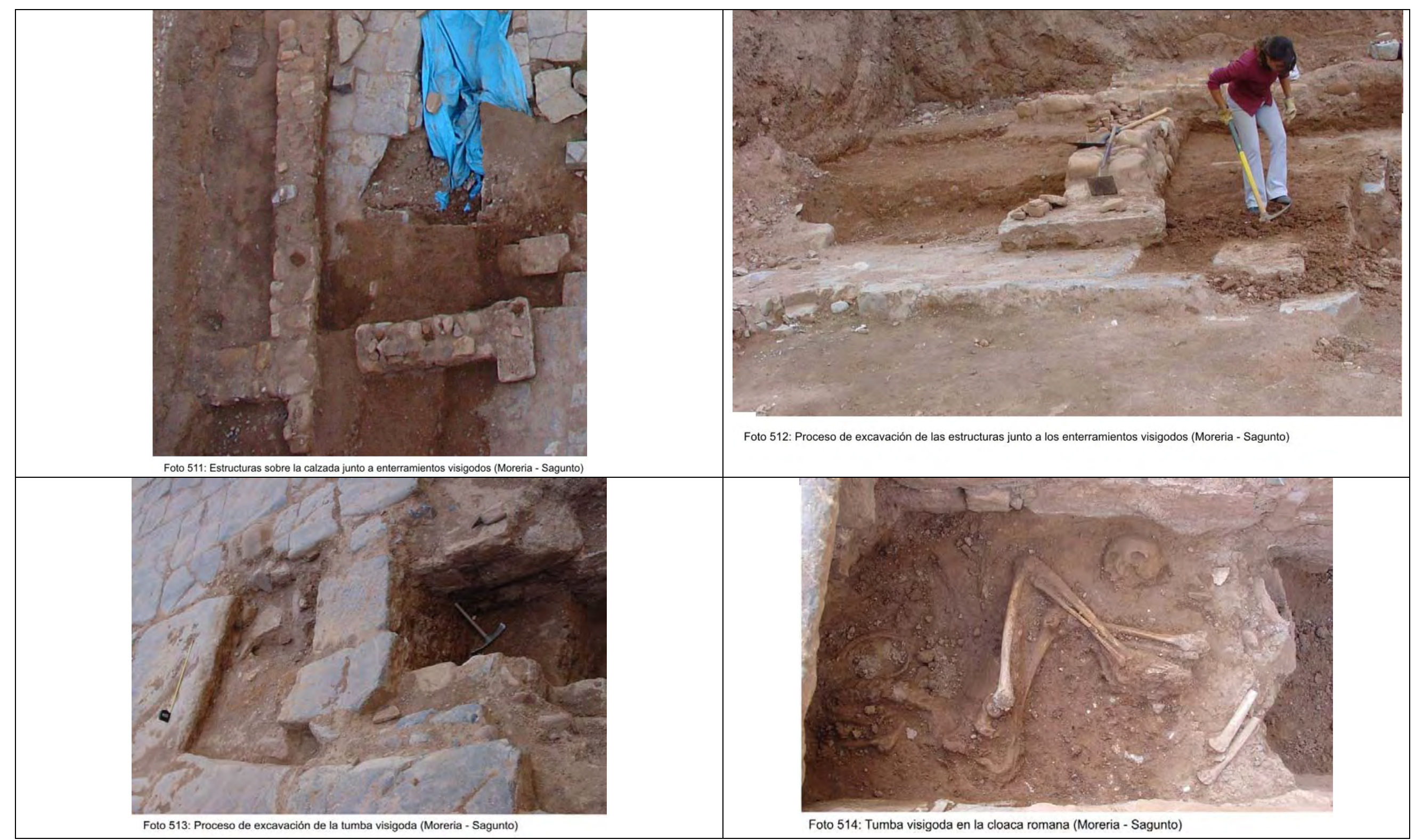




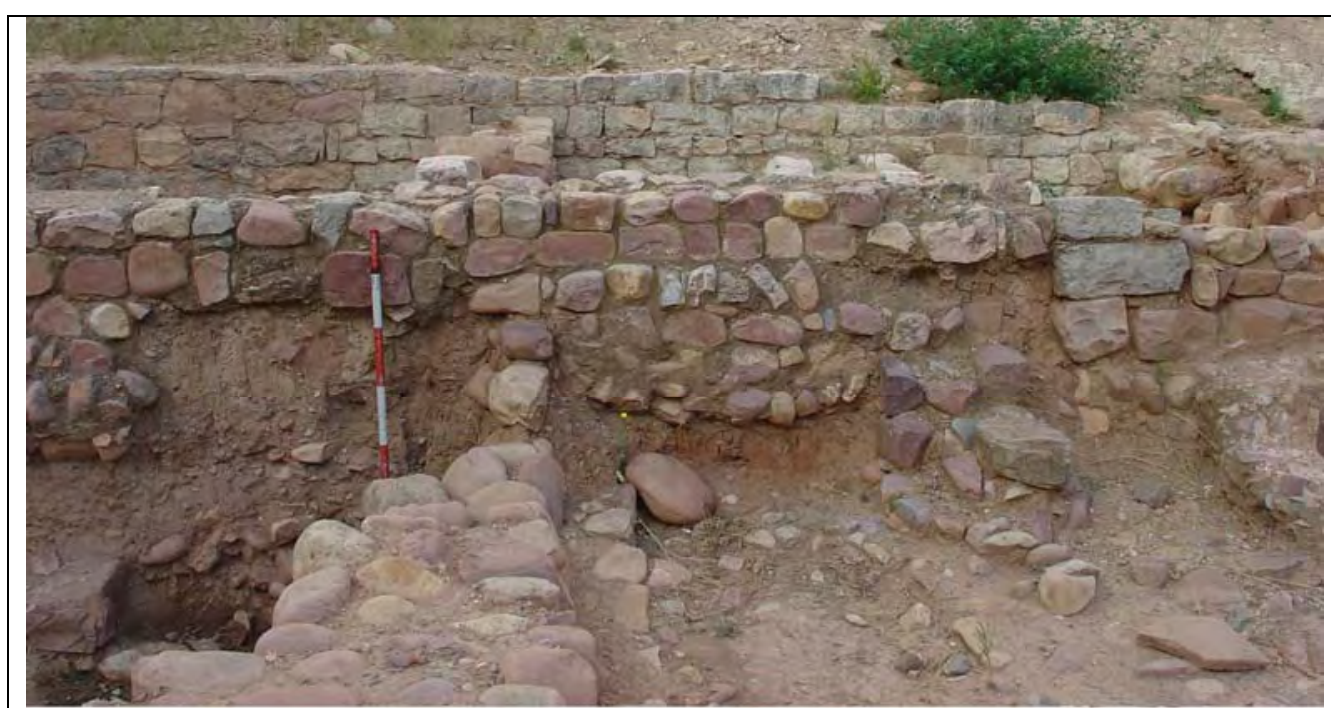

Foto 515: Superposición de estructuras medievales junto al templo 2 (Moreria - Sagunto)

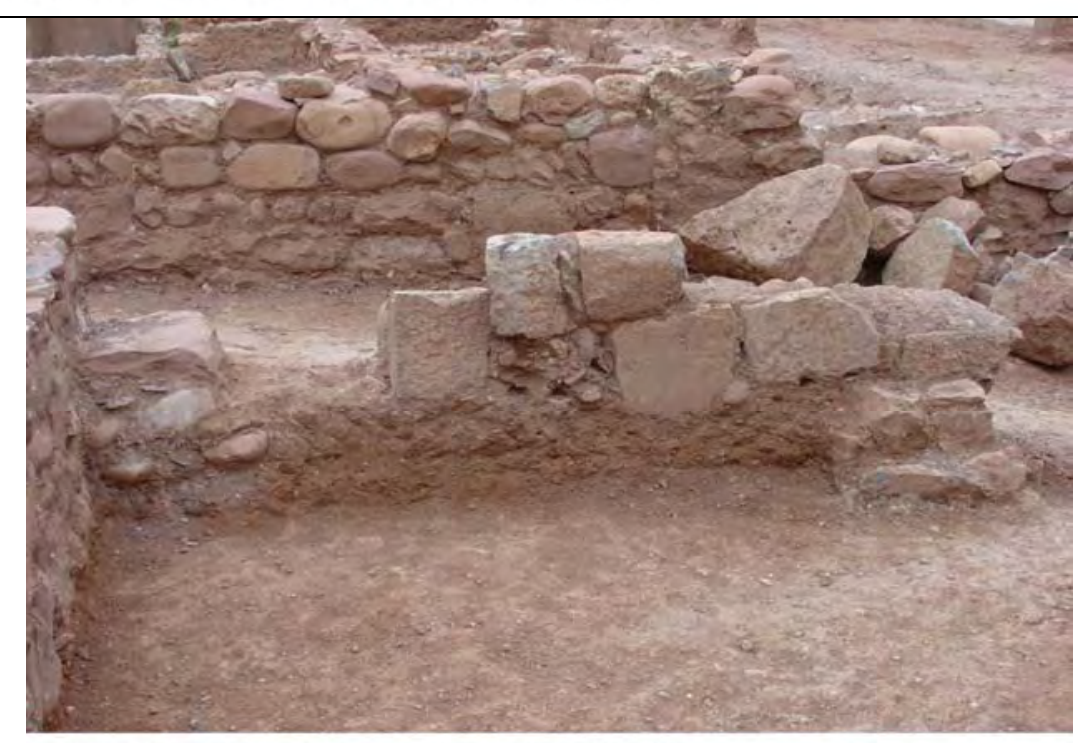

Foto 517: Reutilizacion de elementos arquitectonicos (Moreria - Sagunto)

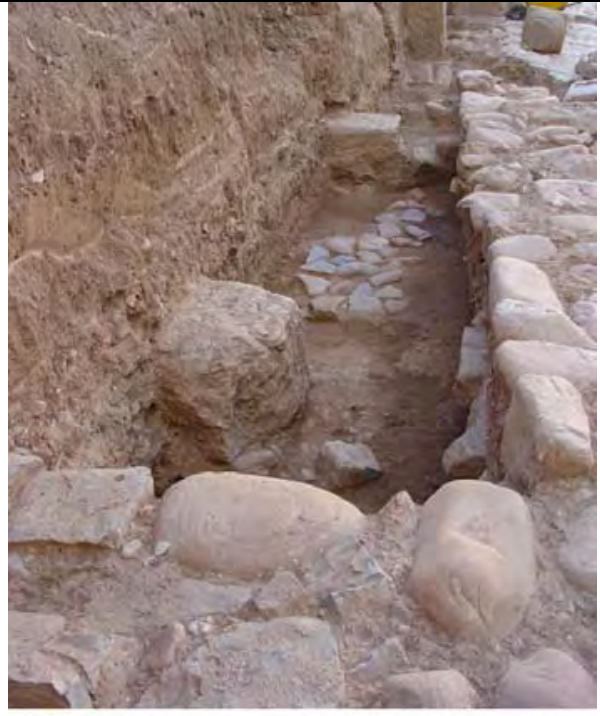

Foto 516: Interior del edificio construido sobre la acera (Moreria - Sagunto)

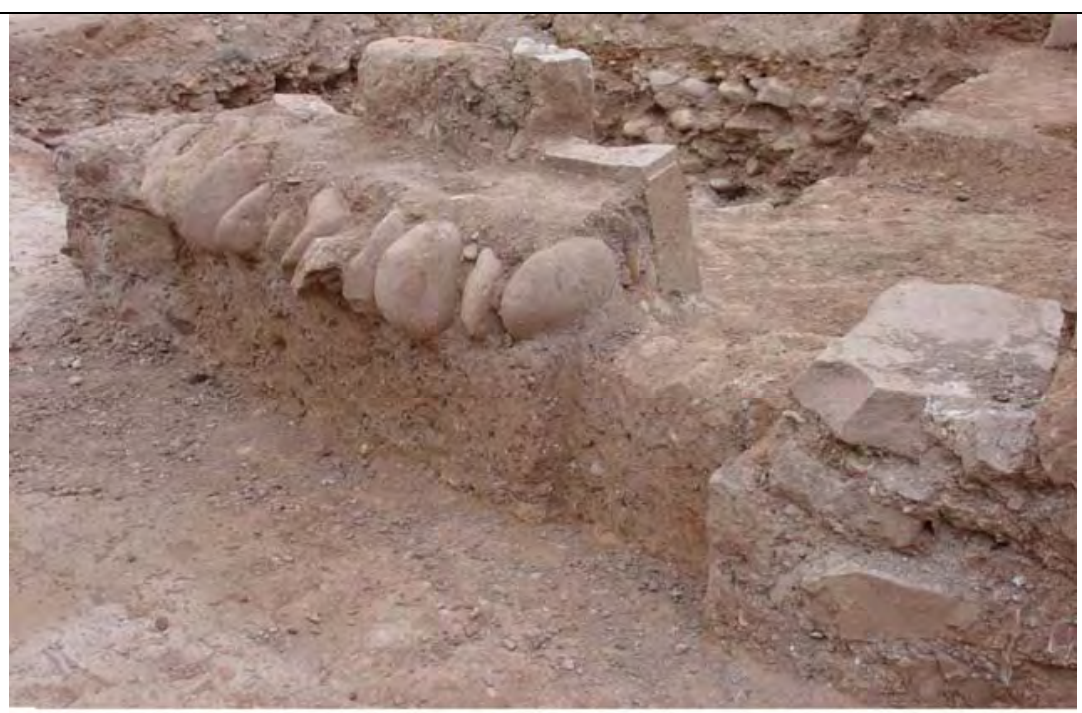

Foto 518: Cerramiento de portico en el interior del podio del templo 1 (Moreria - Sagunto) 


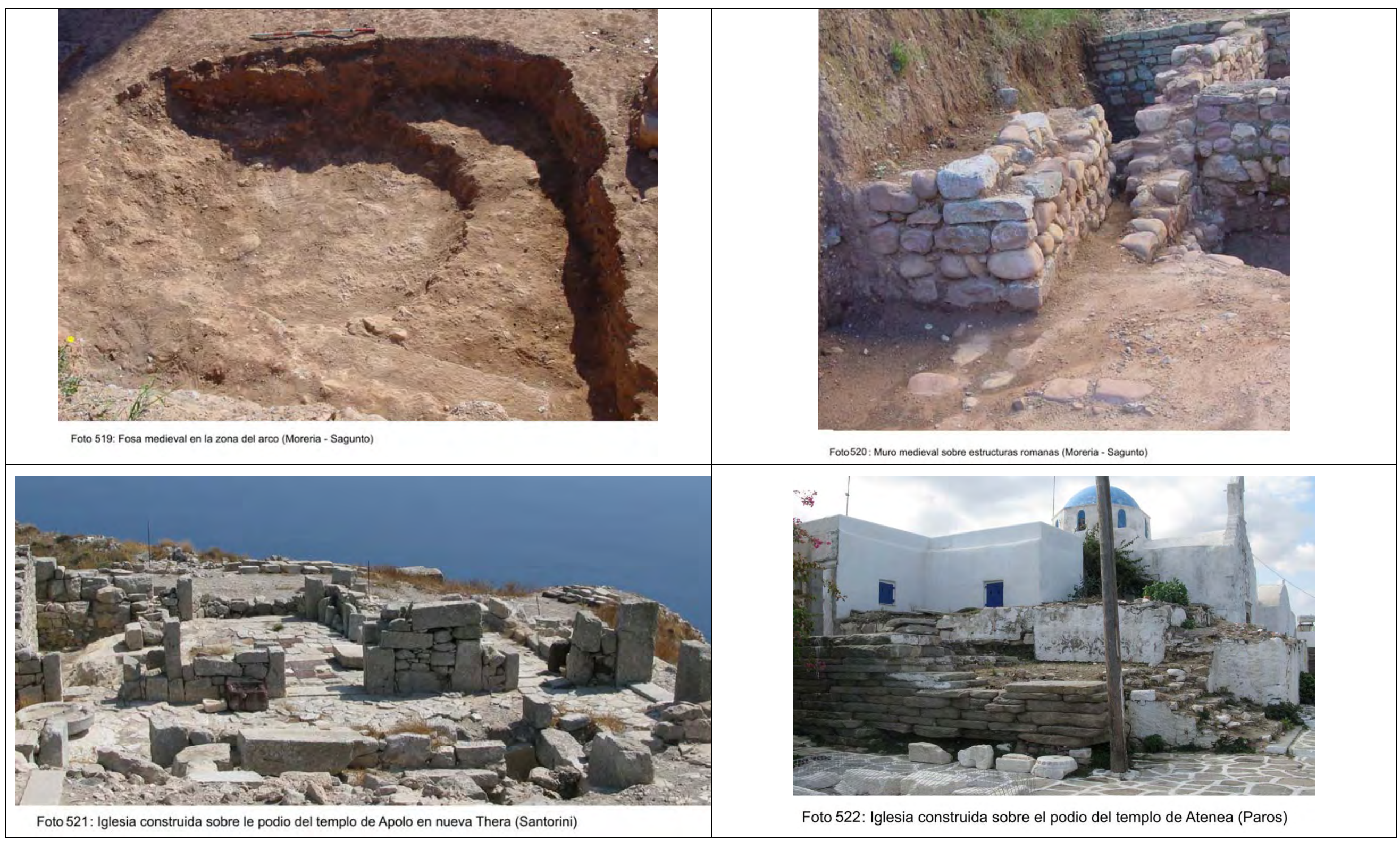




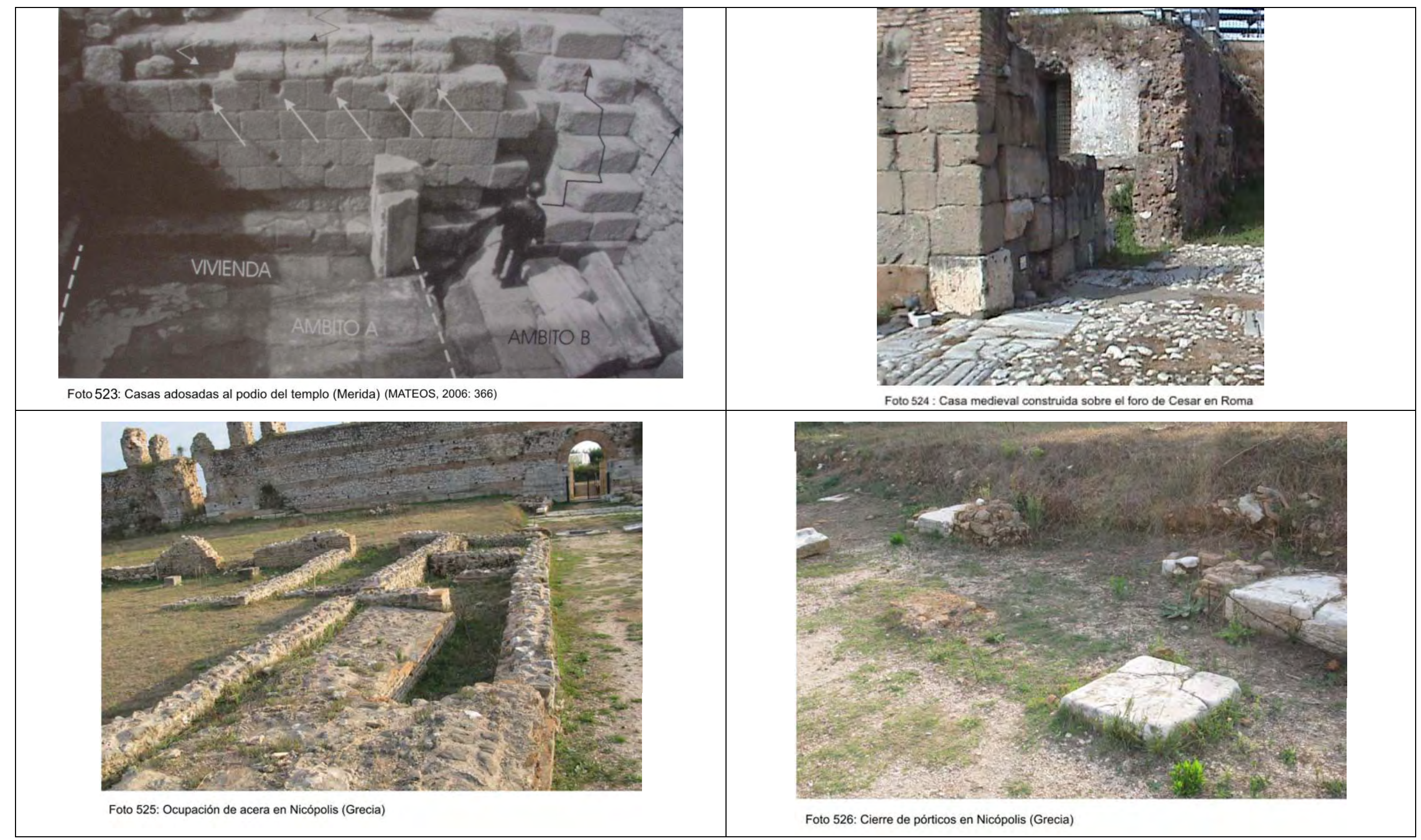




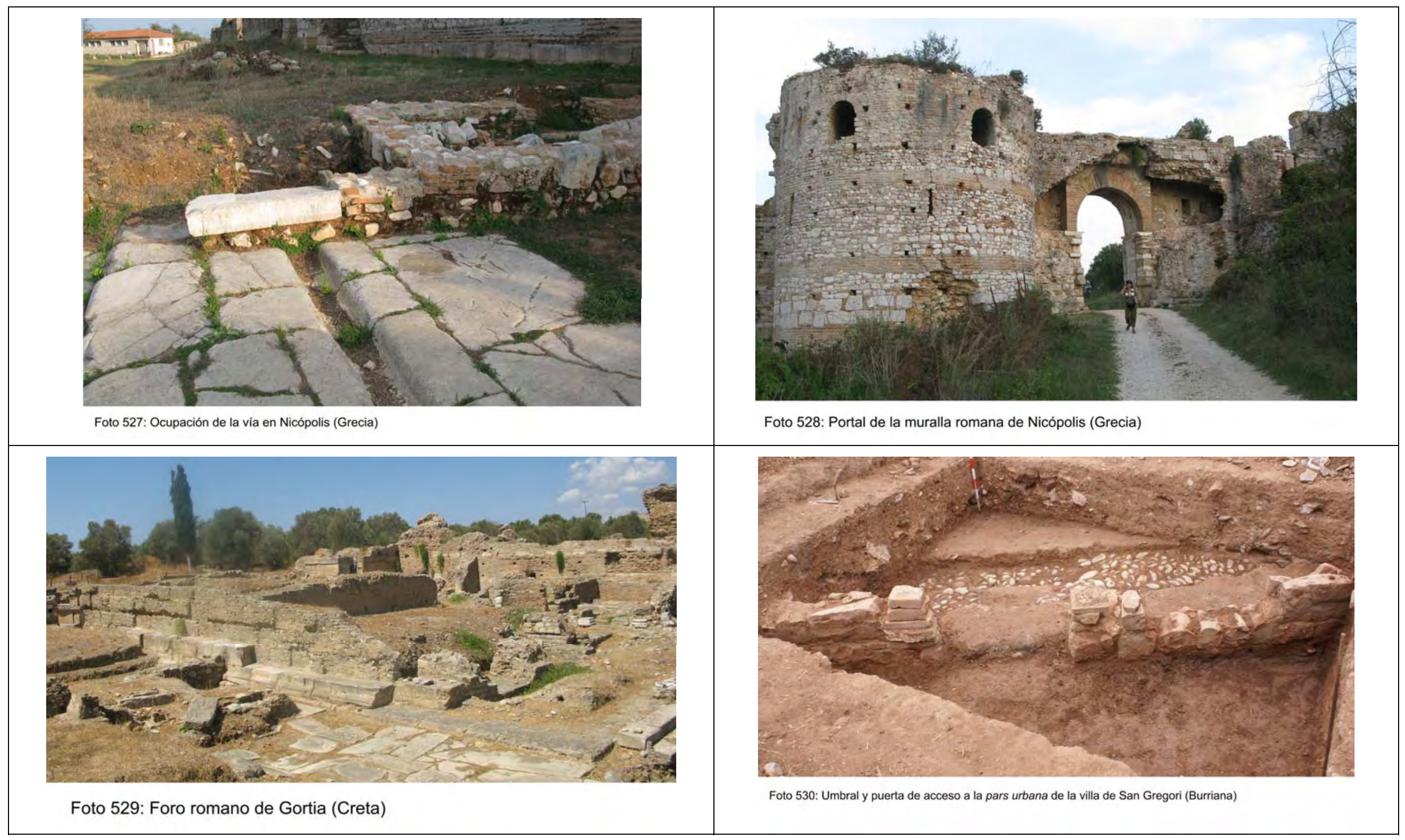




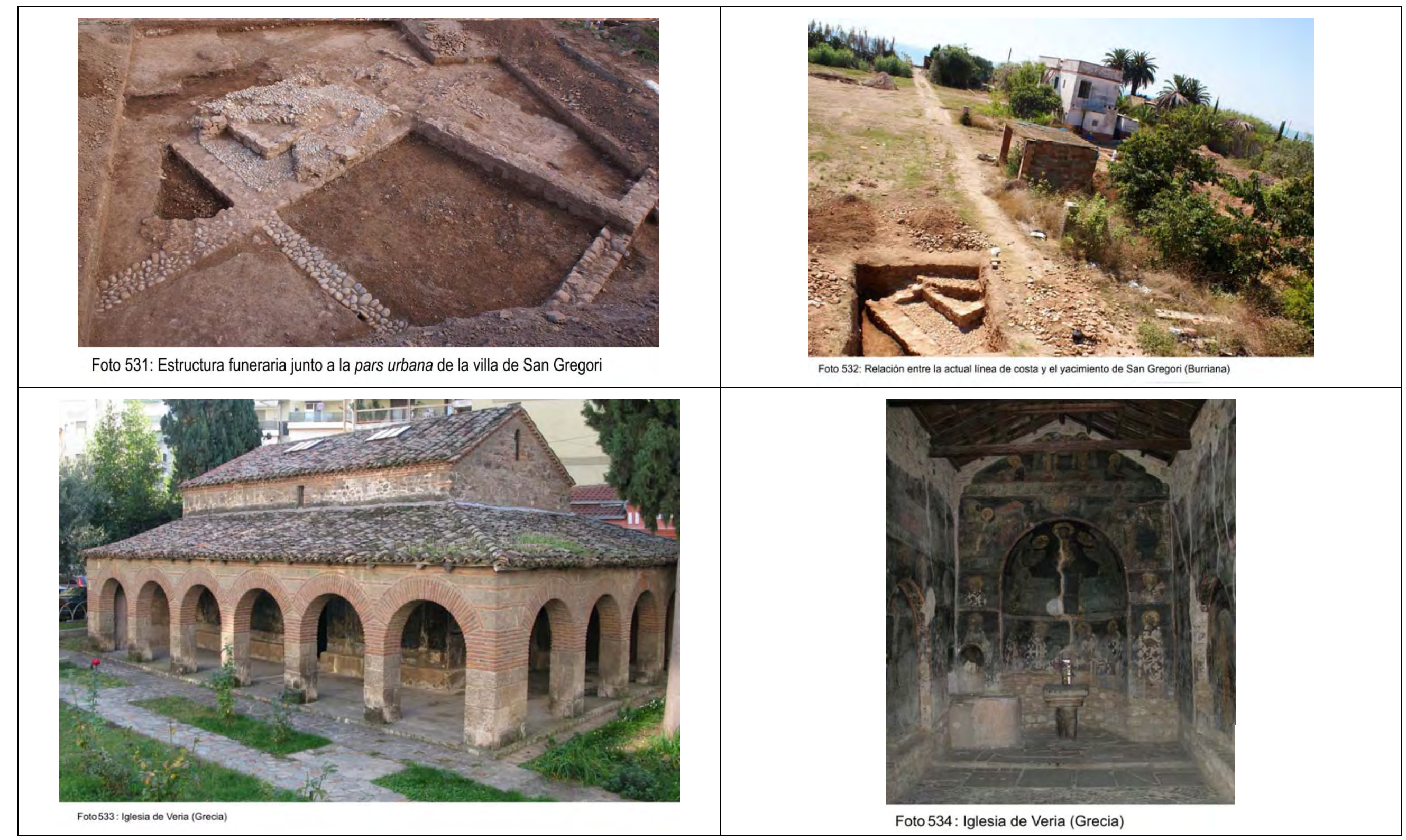




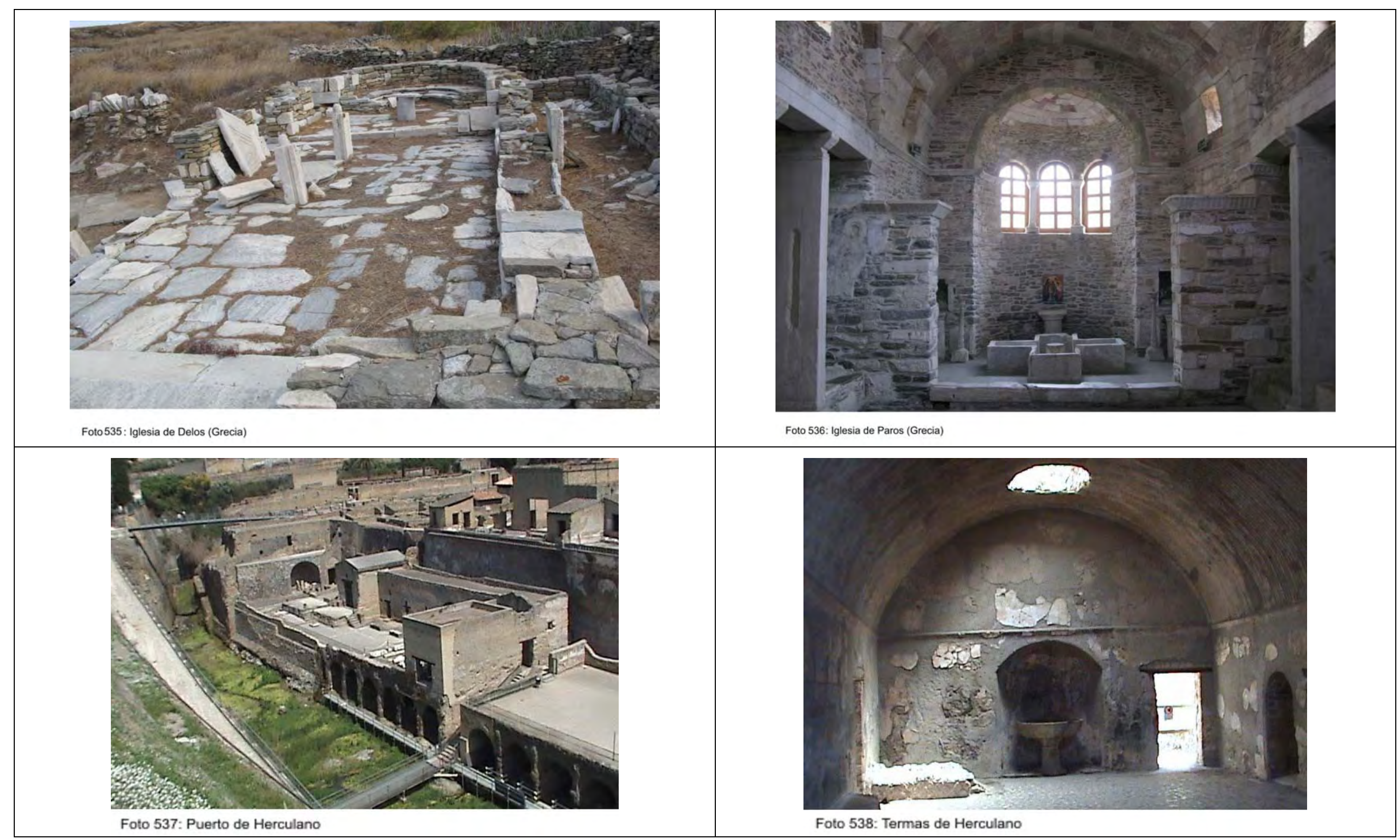




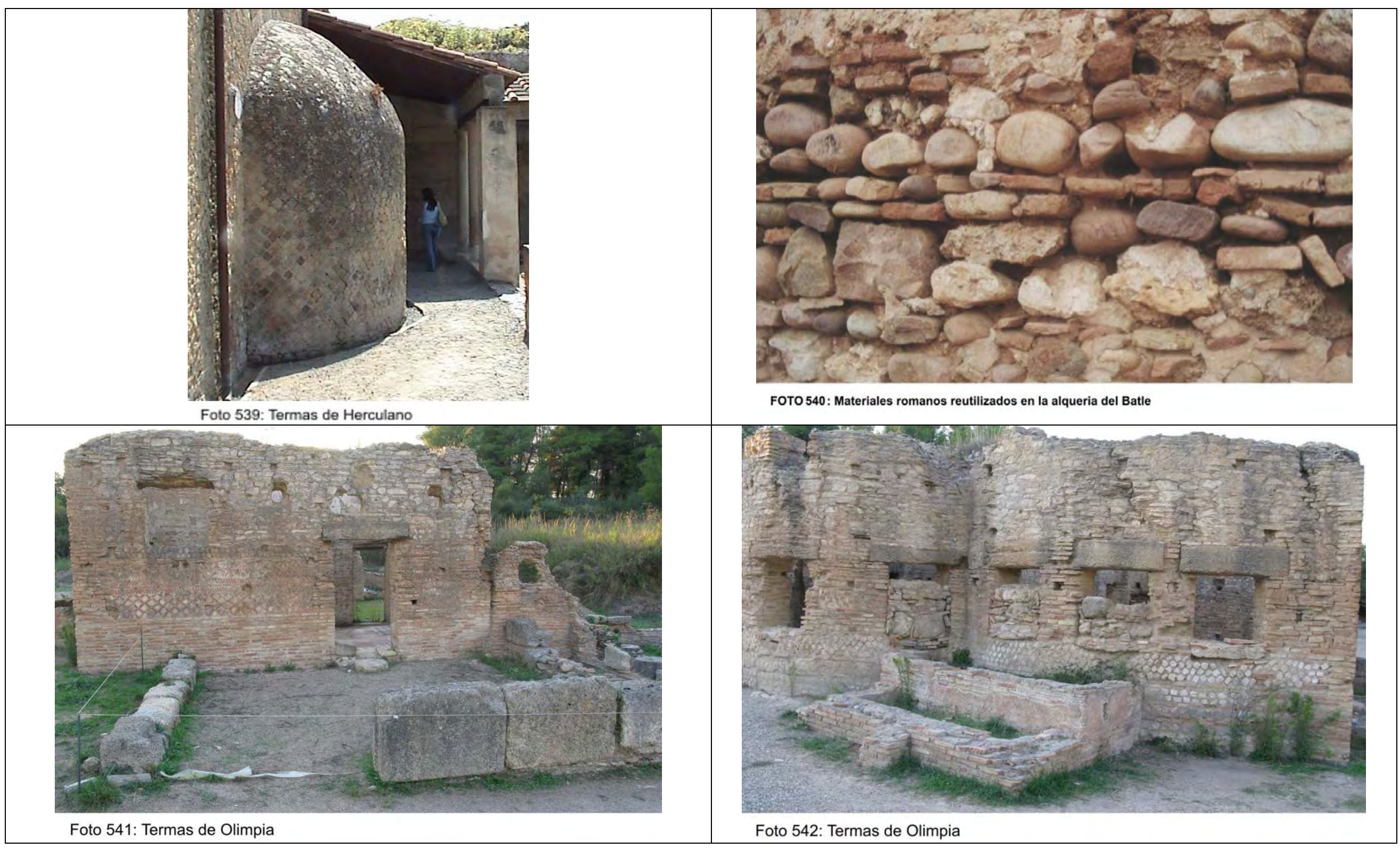




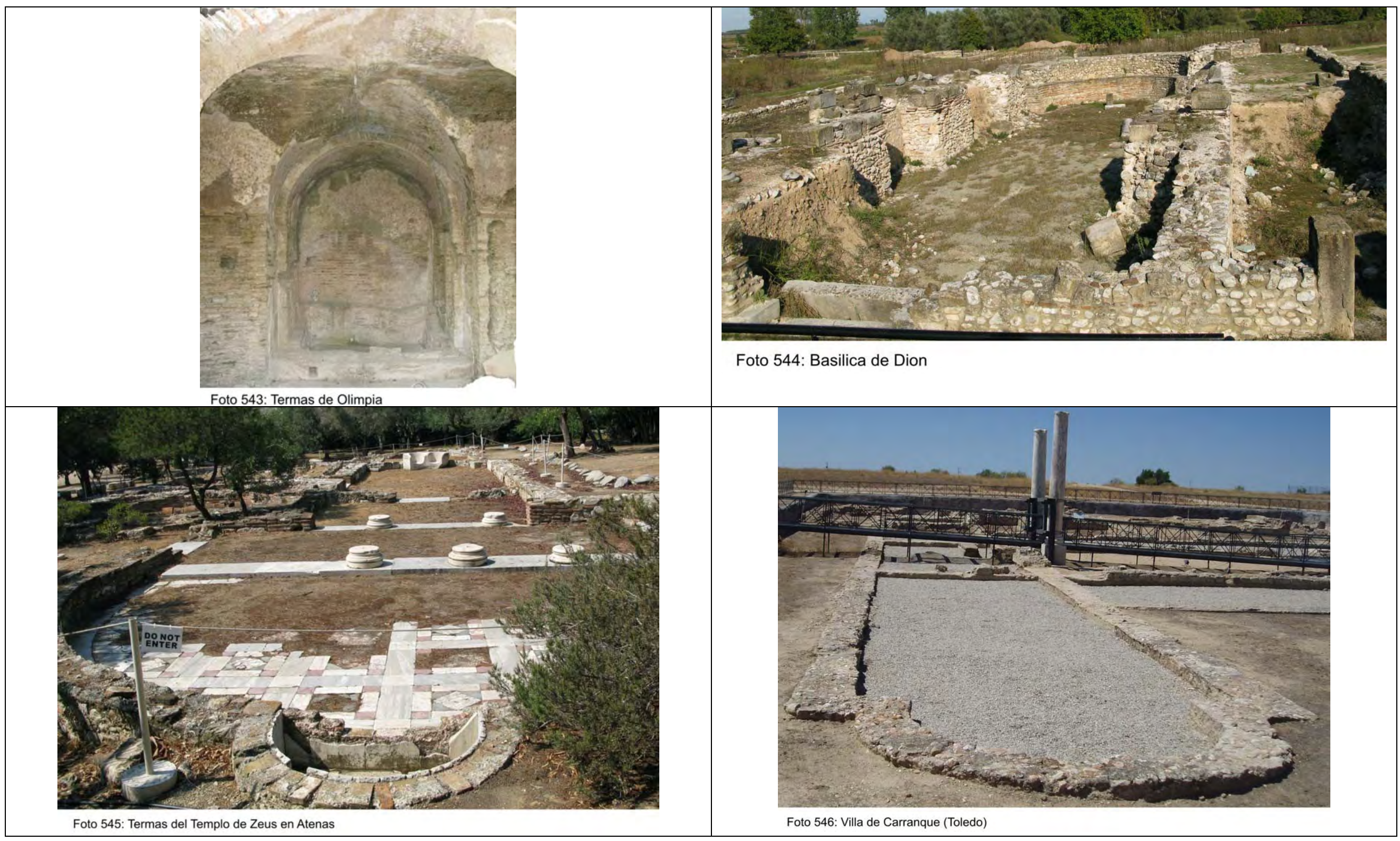




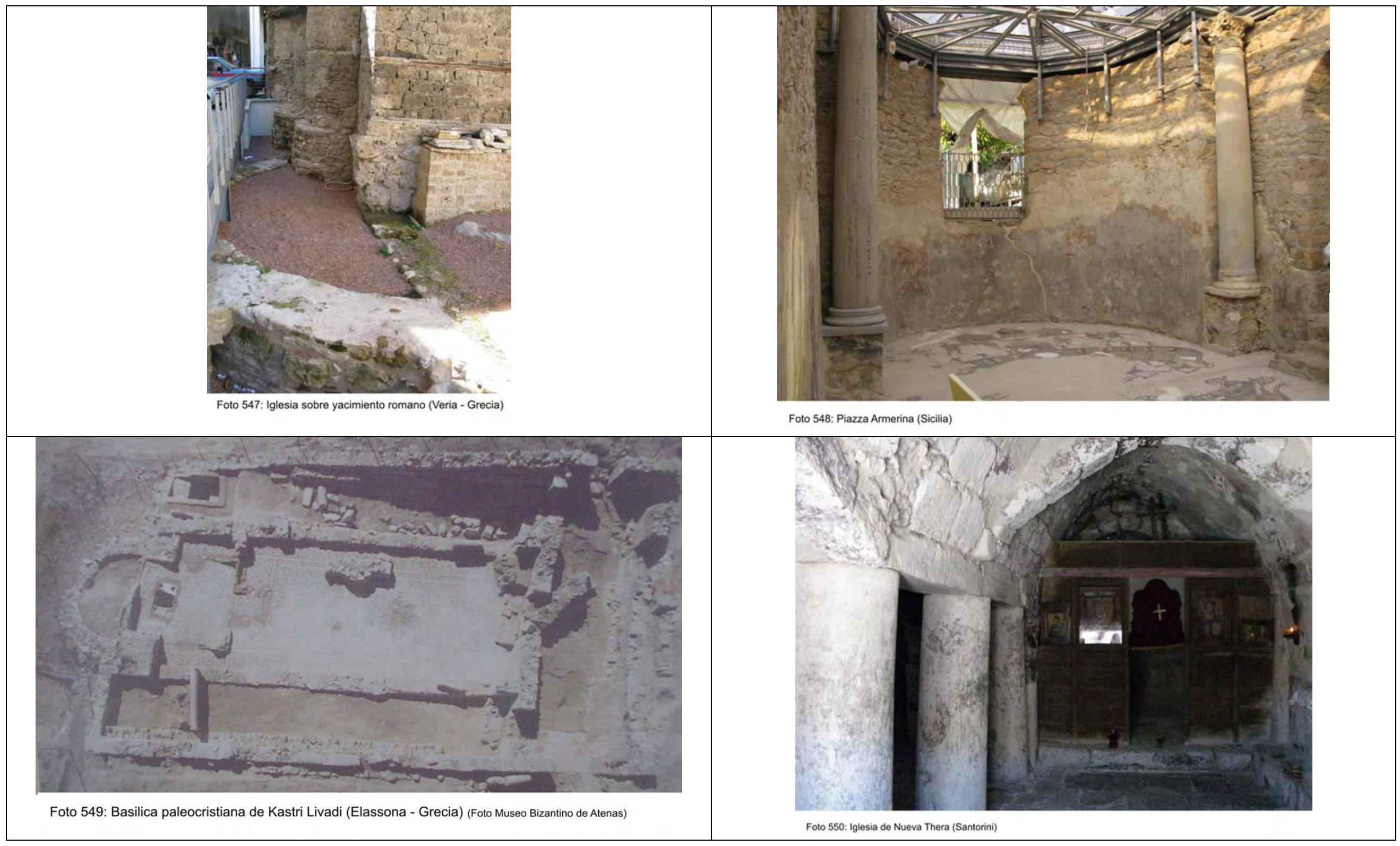




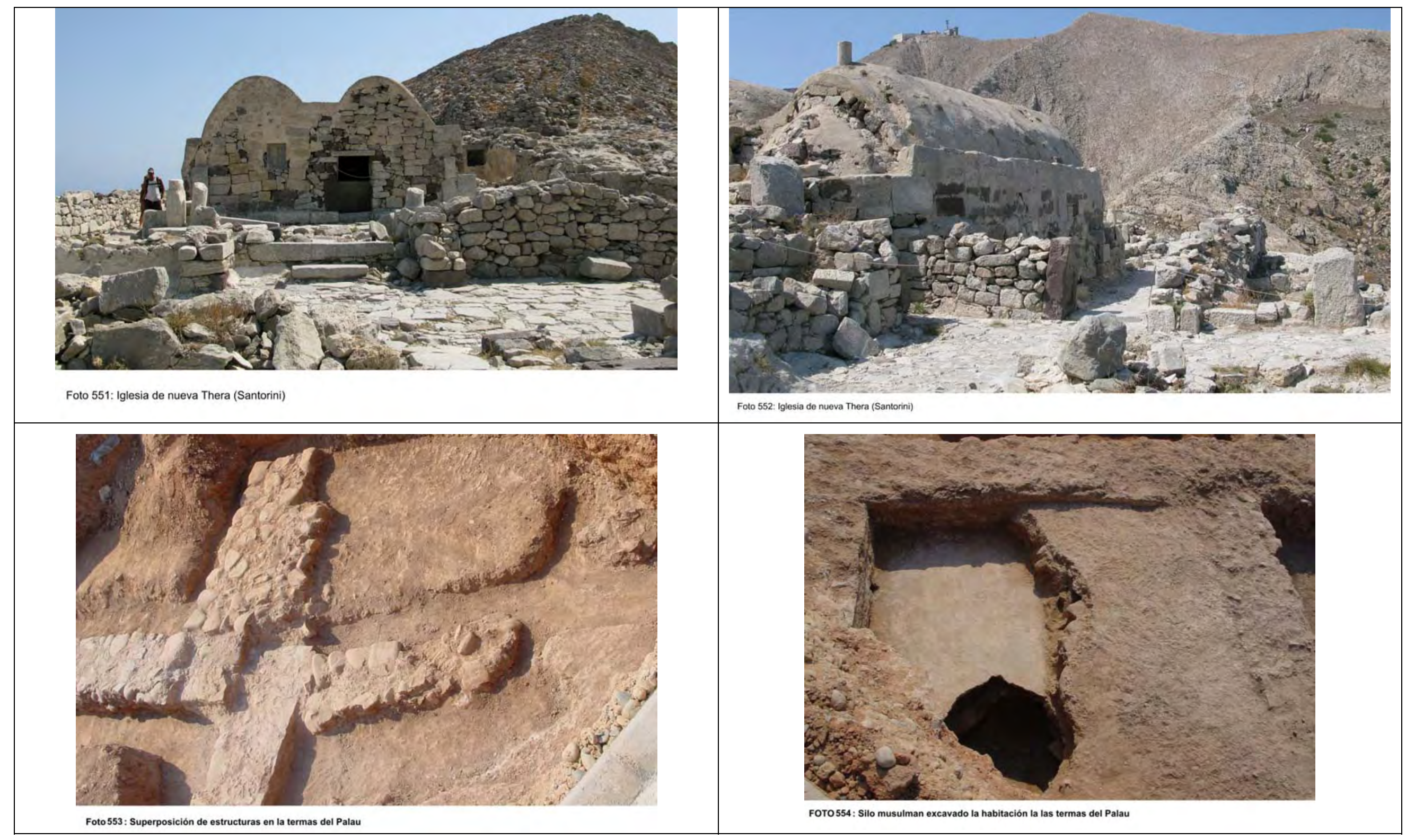




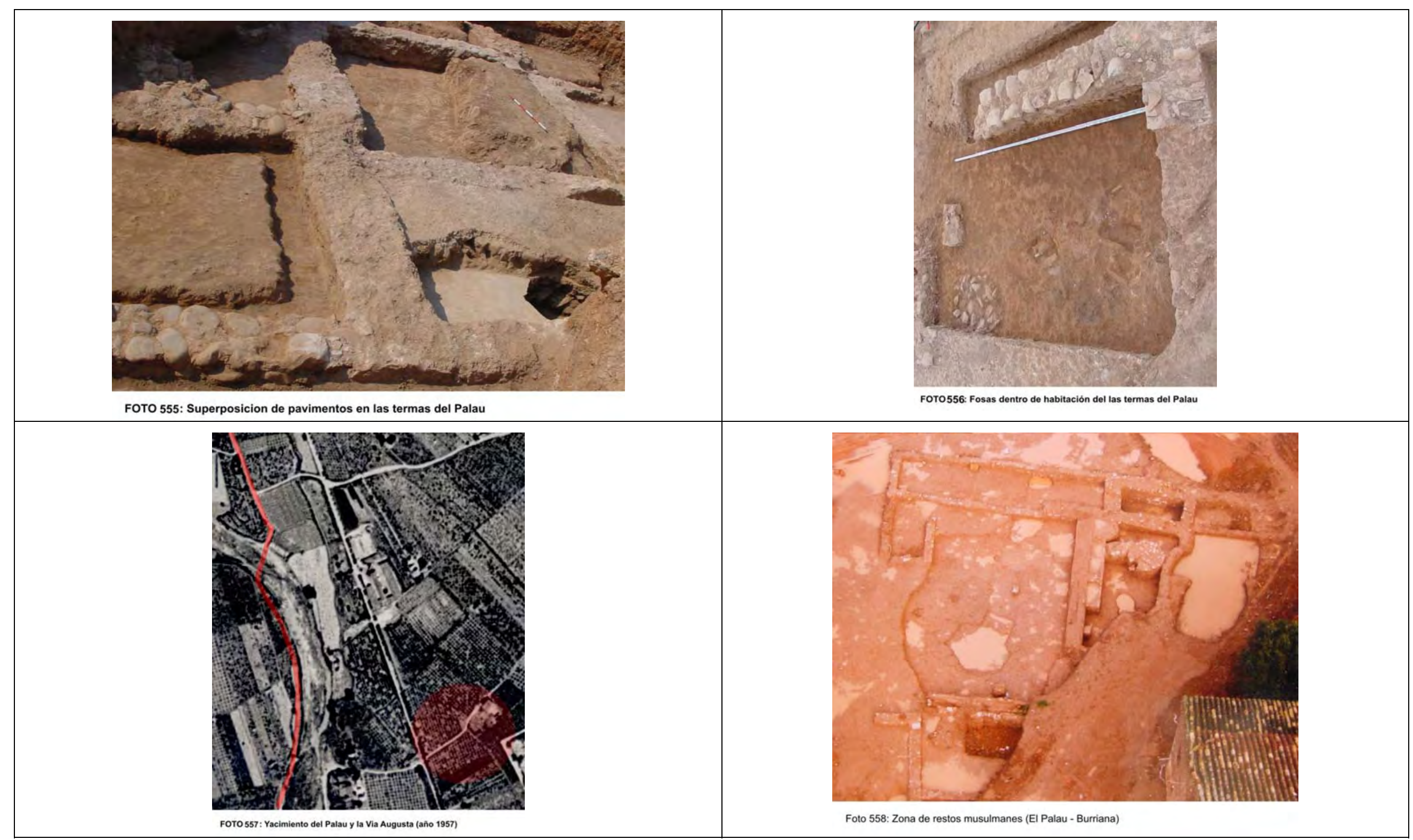




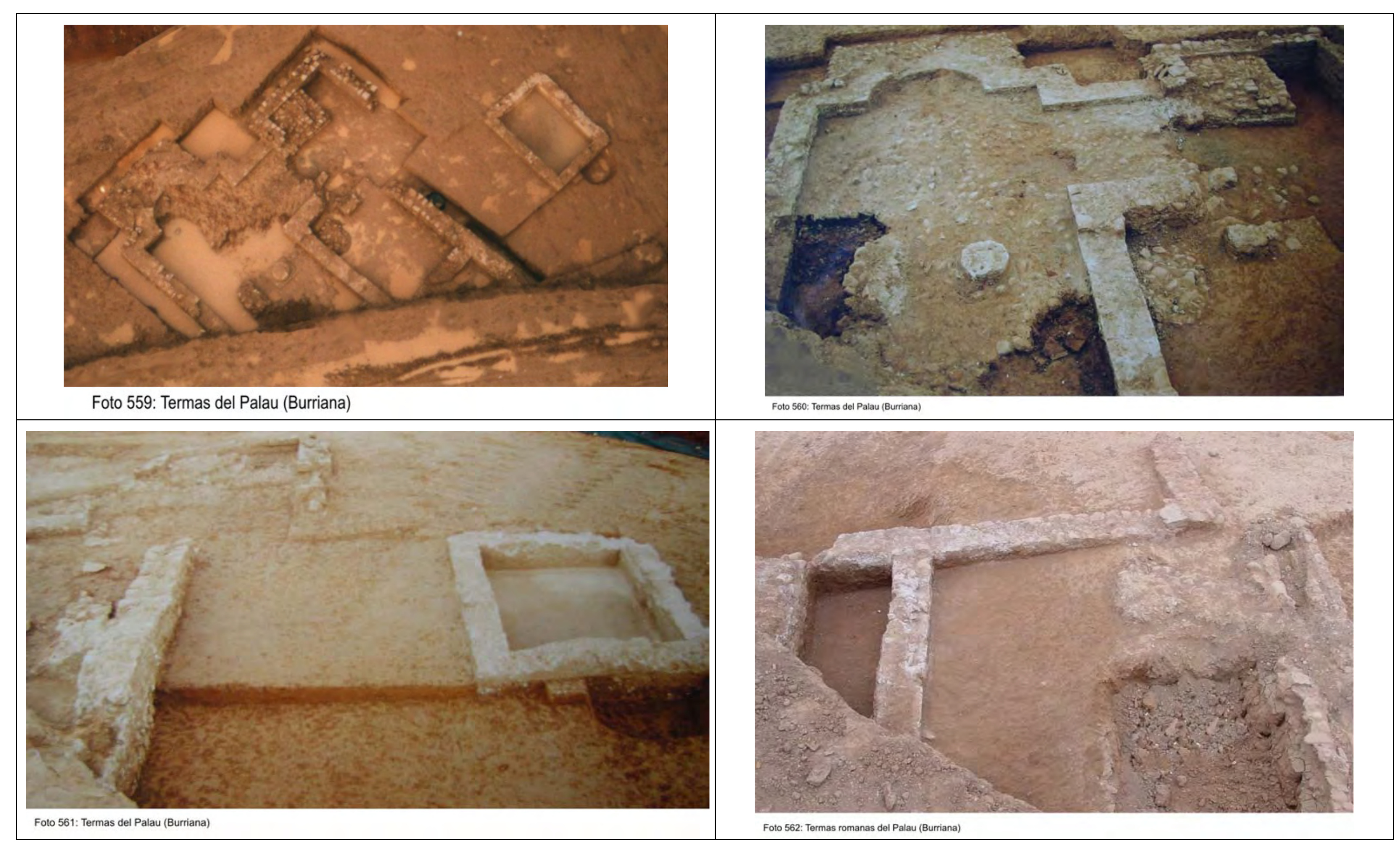




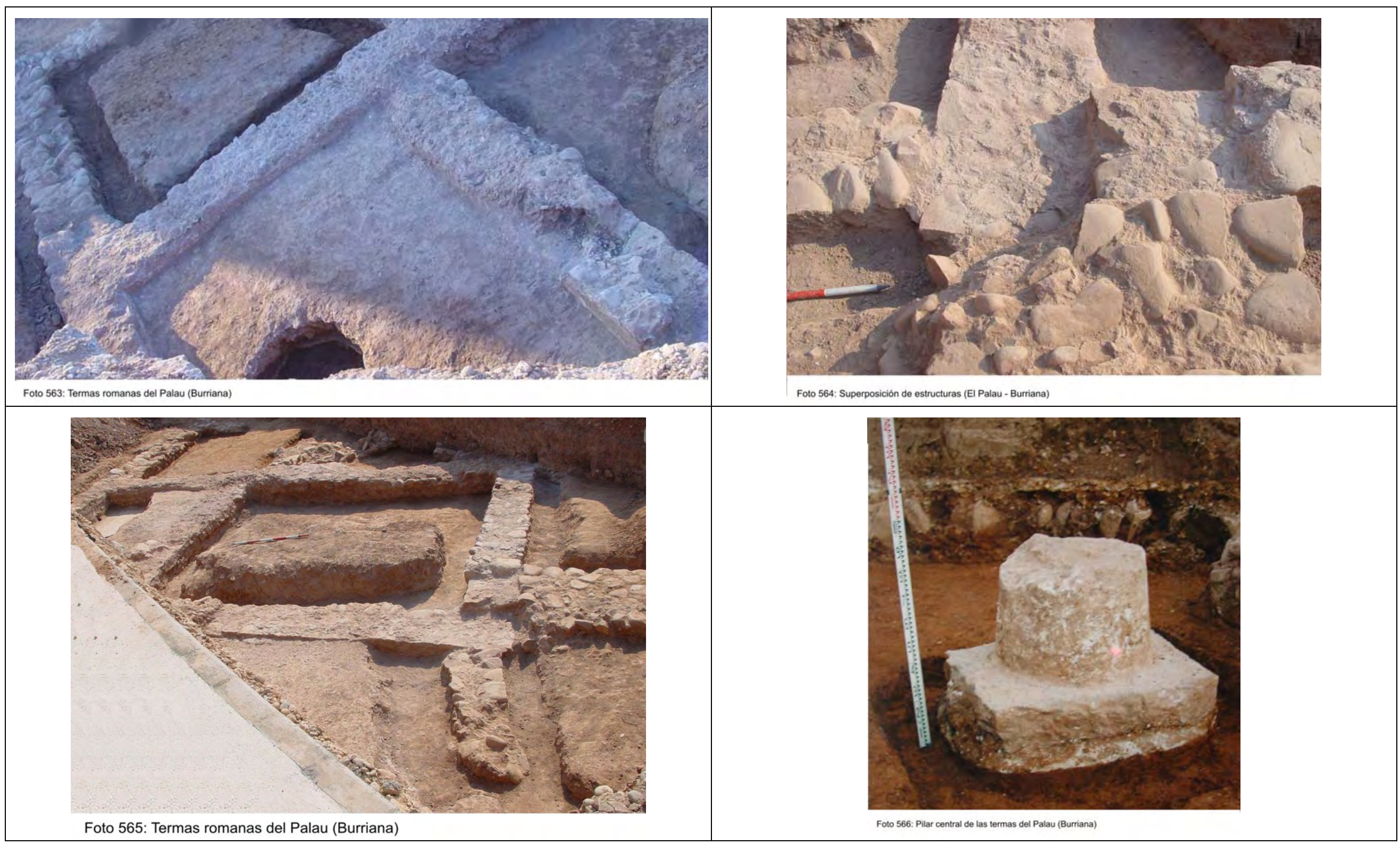




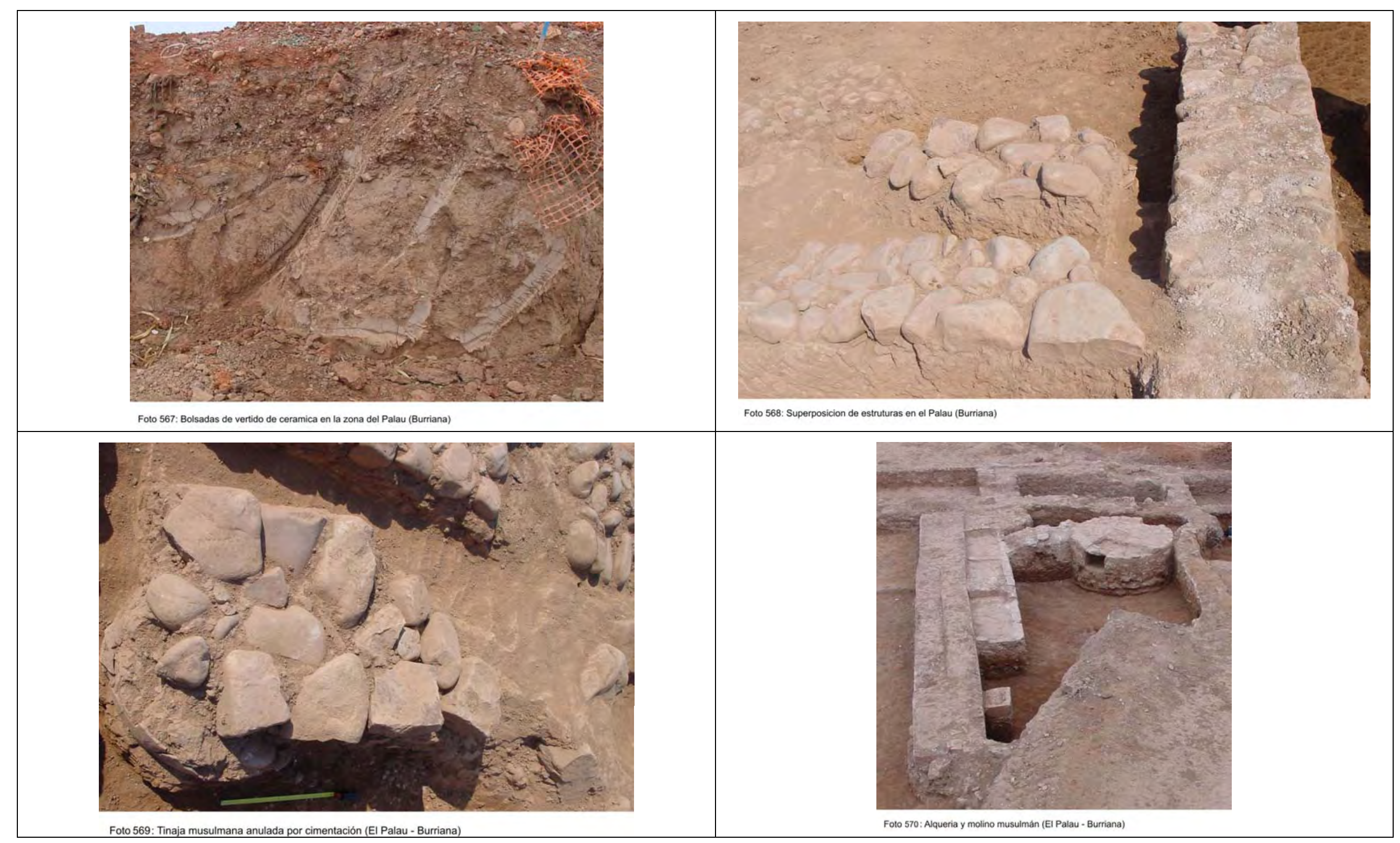




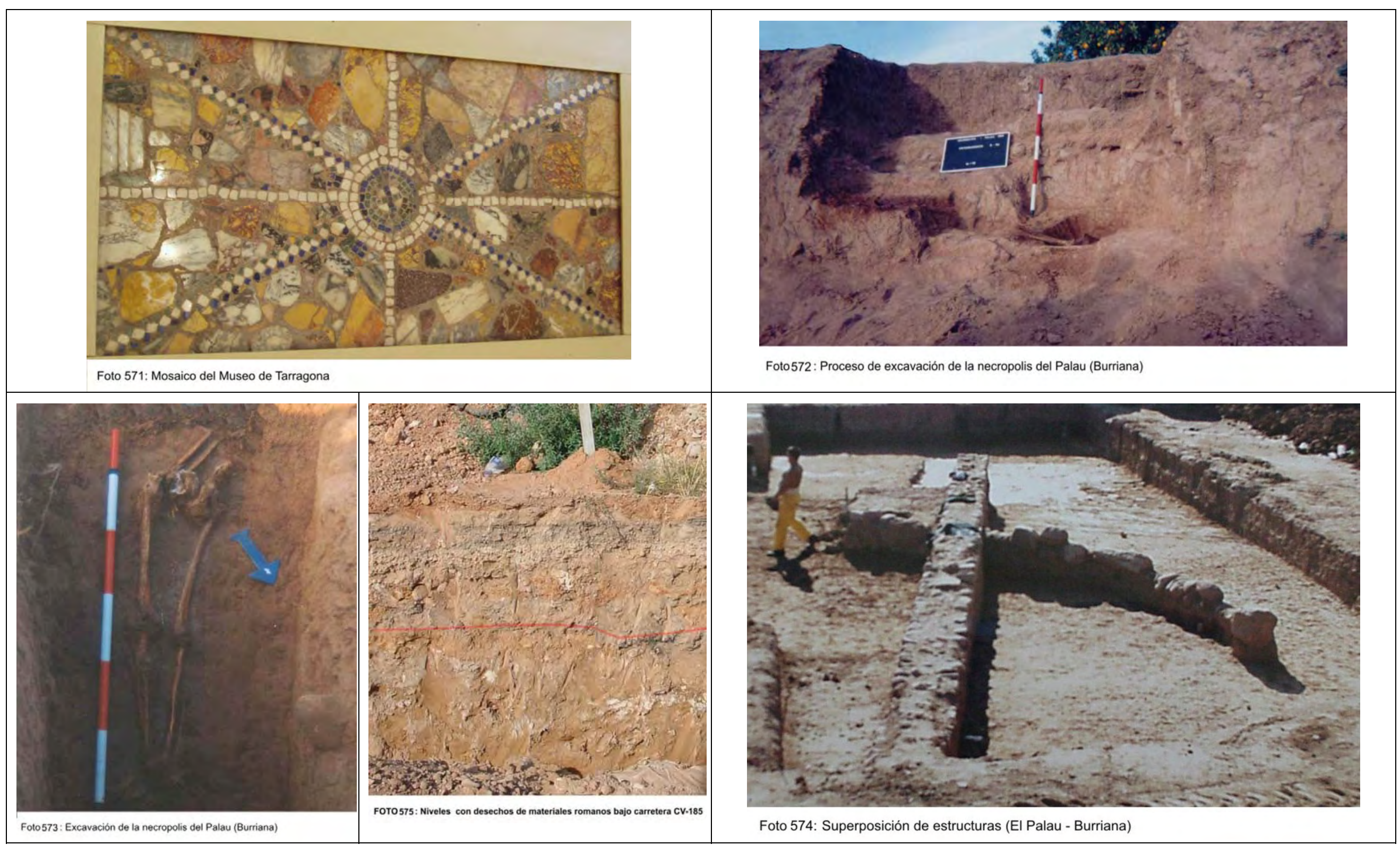




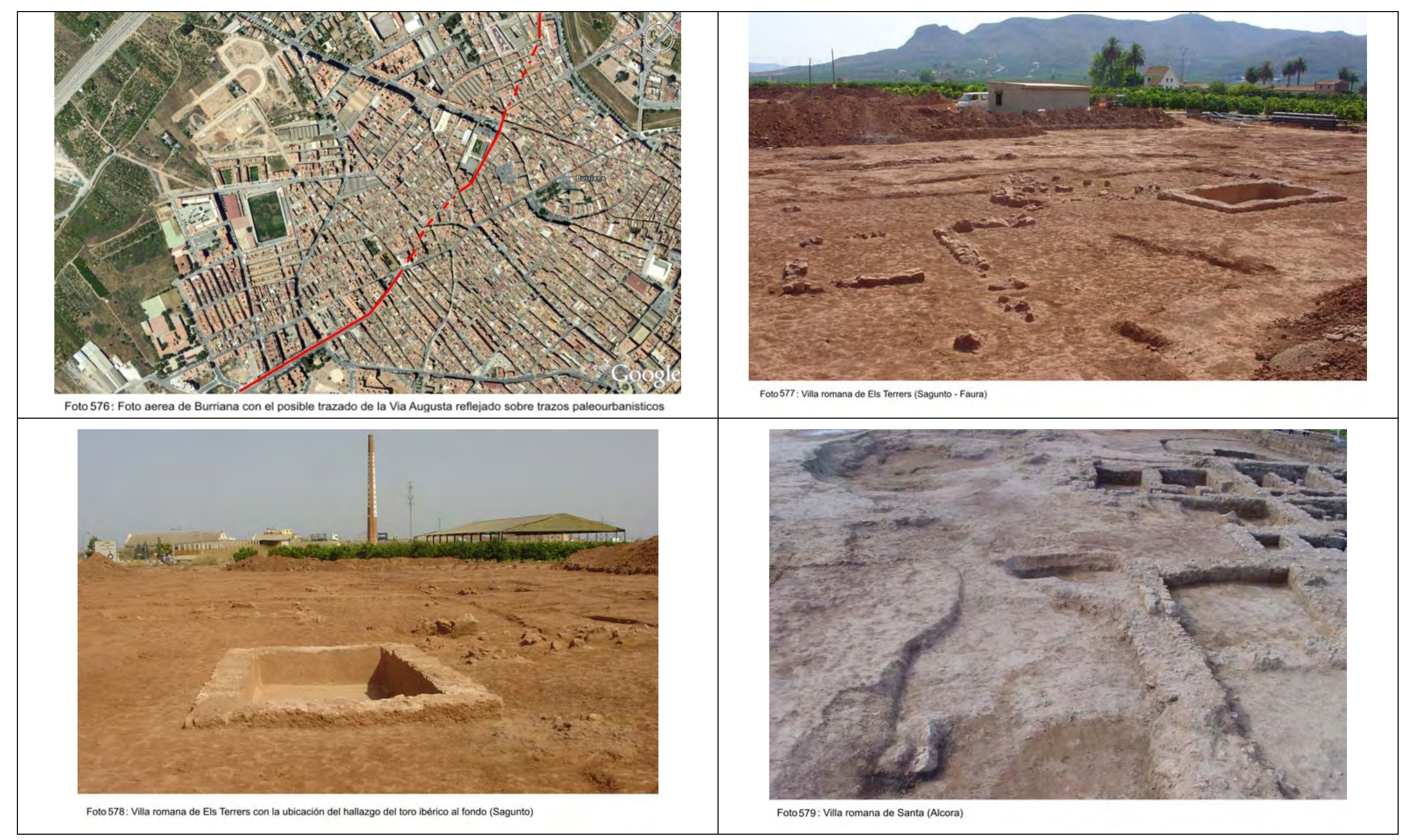



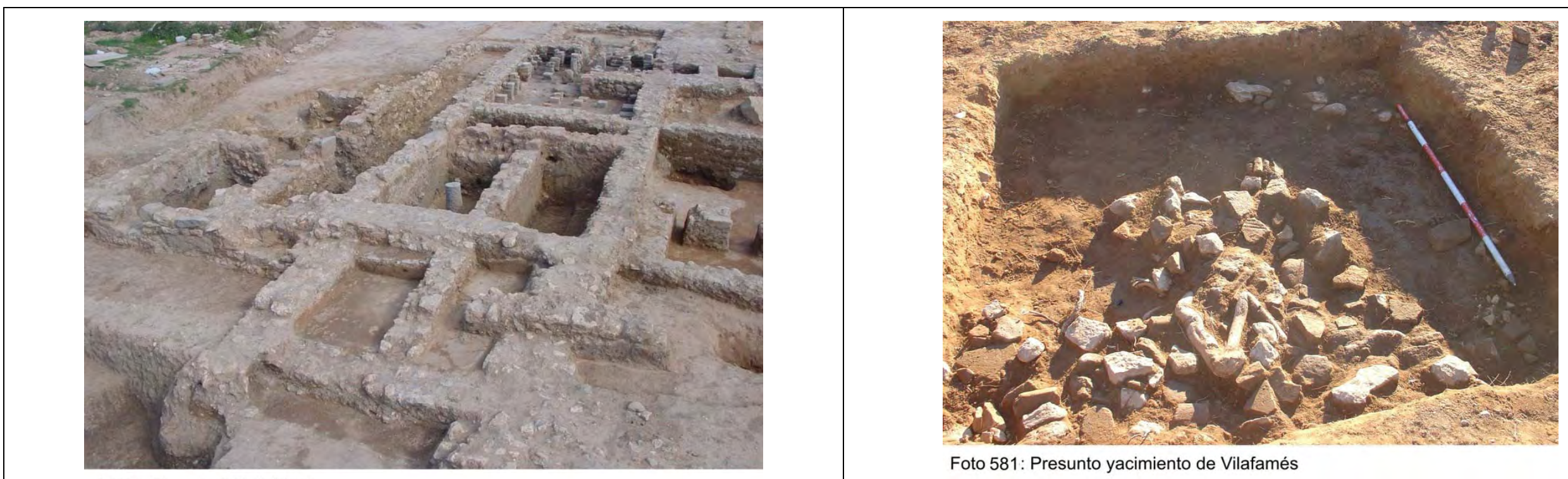

Foto 580: Villa romana de Santa (Alcora)

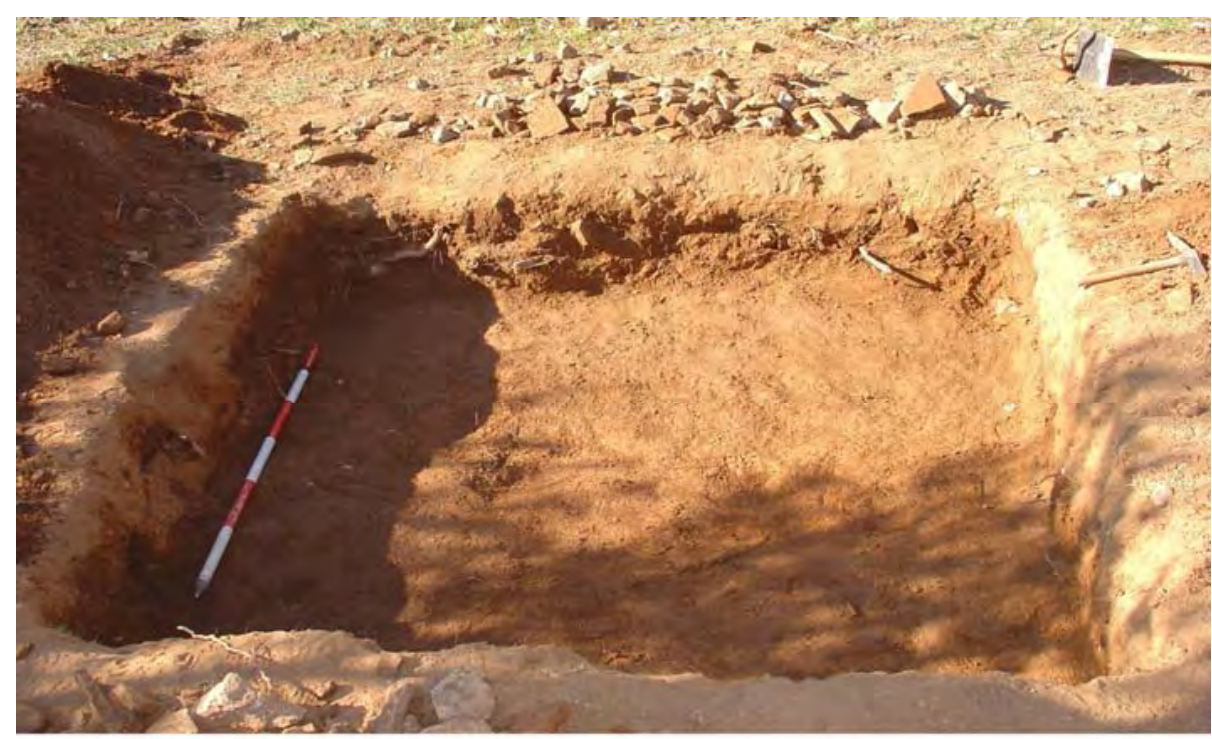

Foto 581: Presunto yacimiento de Vilafamés

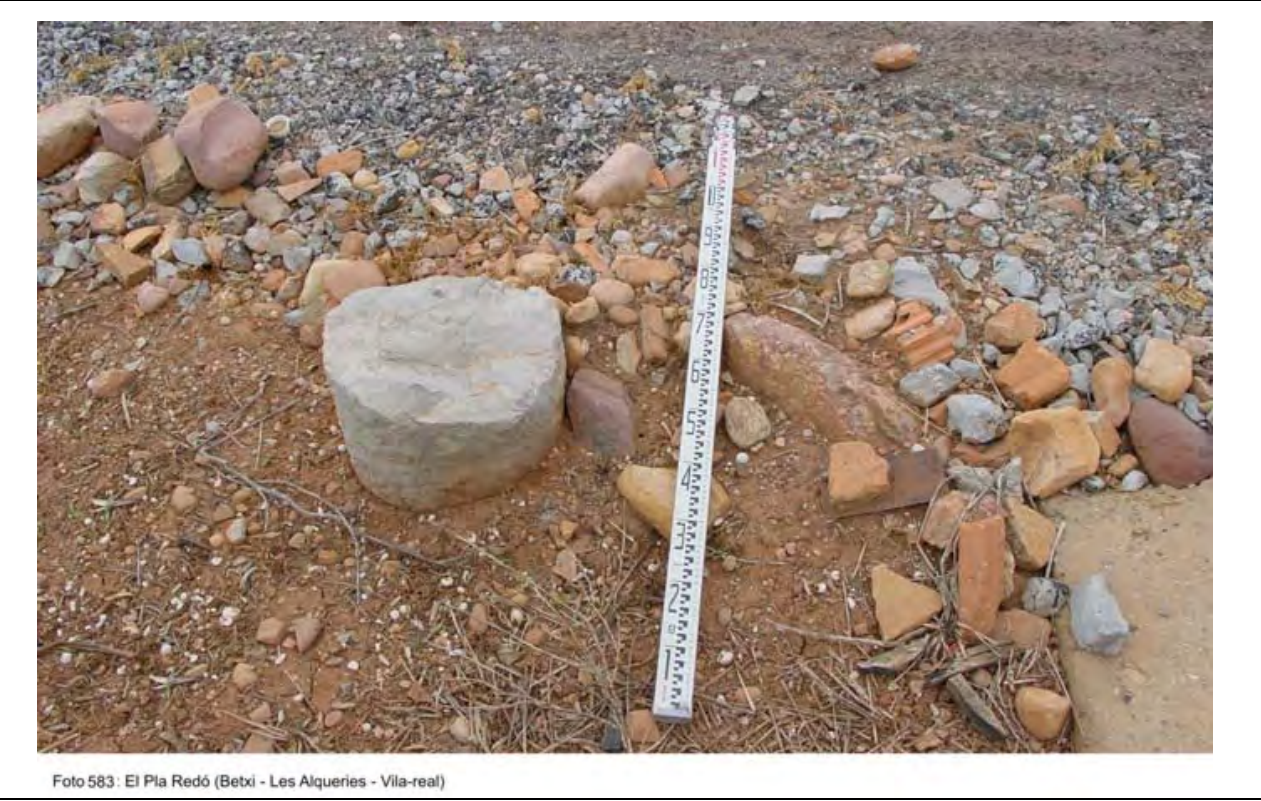




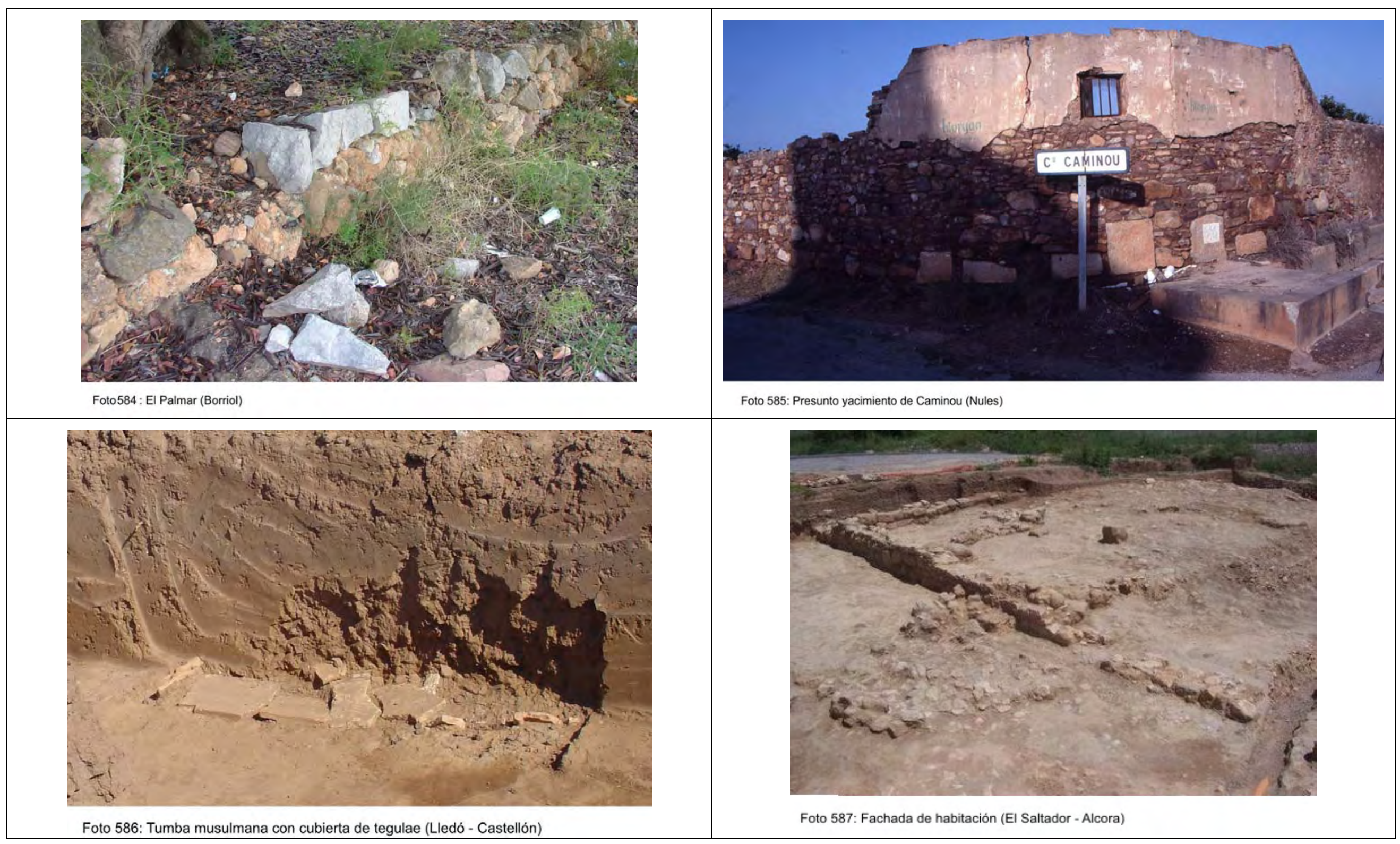




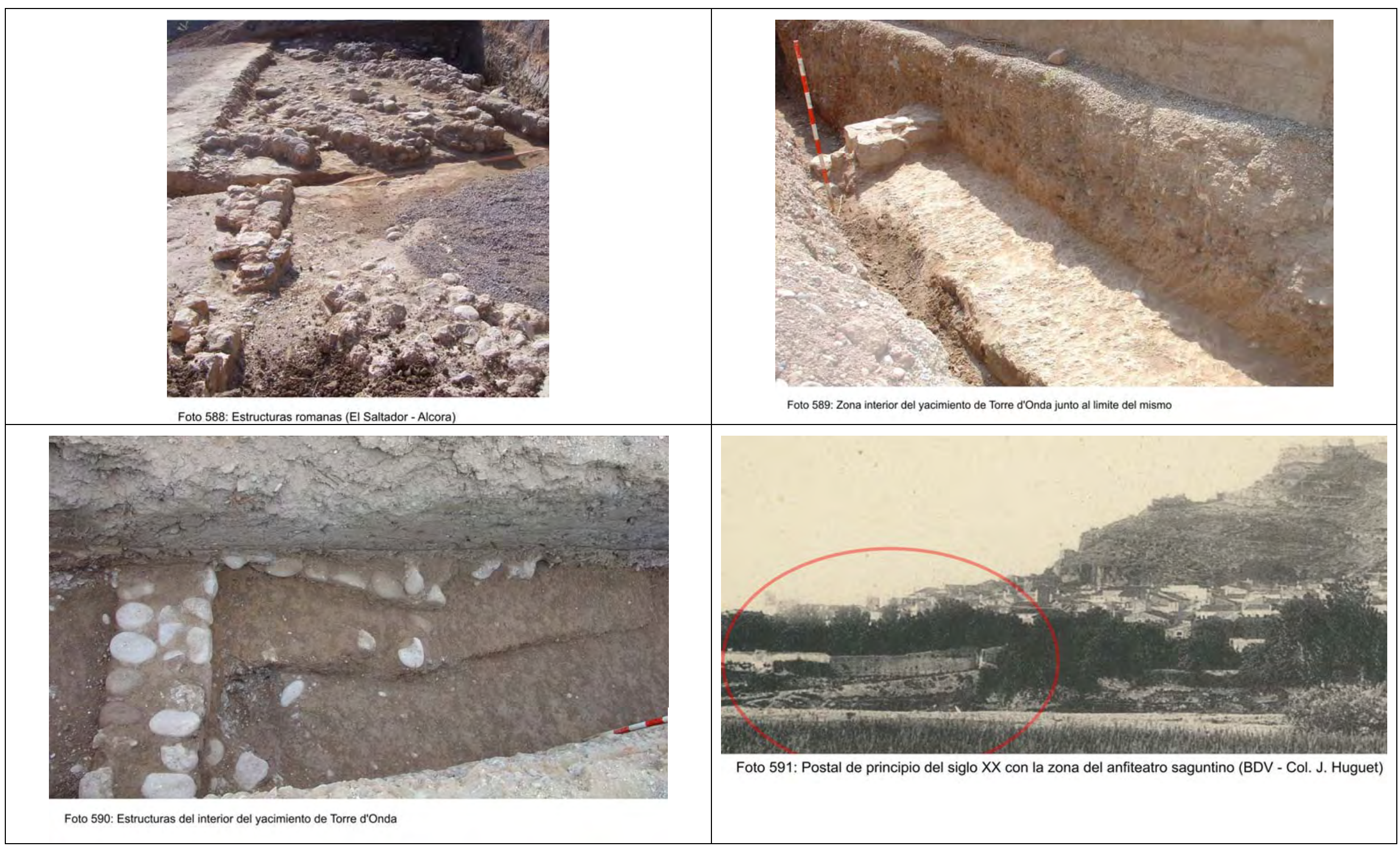




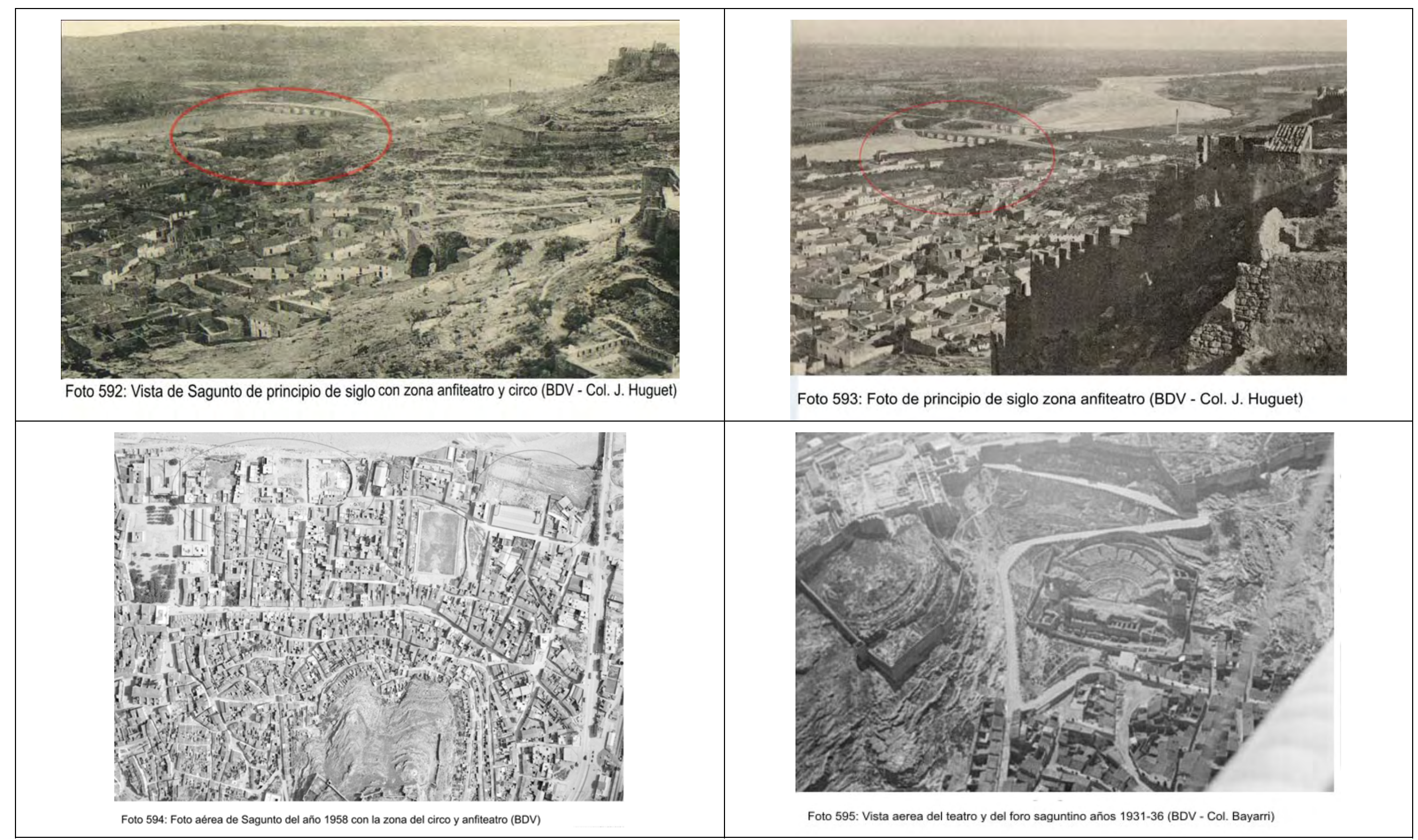




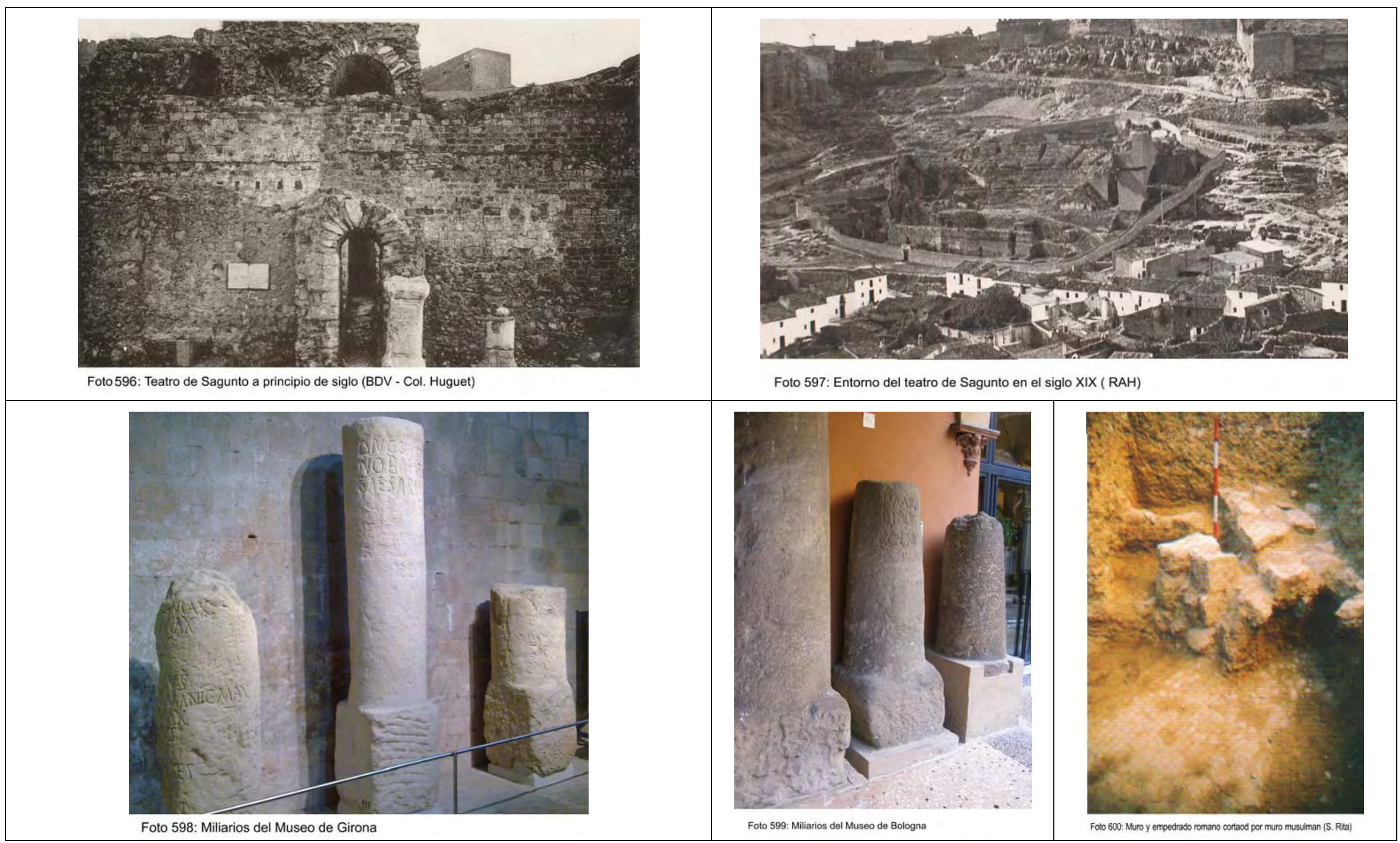




\section{B}

\section{A}

wer.

$\frac{7 y=}{4}$

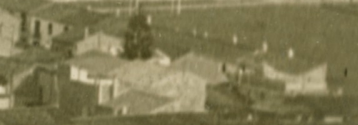

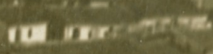

Foto 601: Sagunto a final del siglo XX (zona del anfiteatro) 

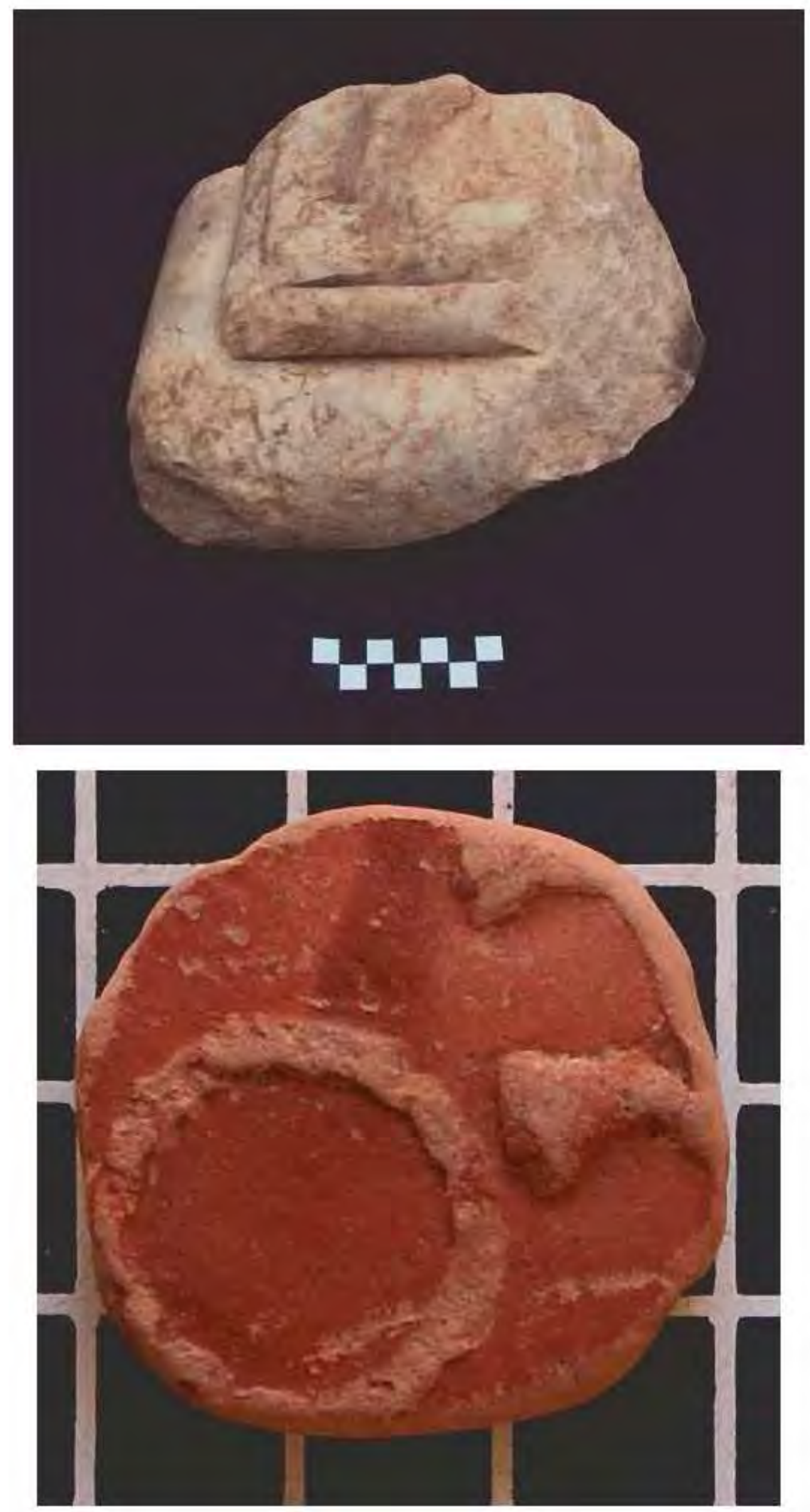


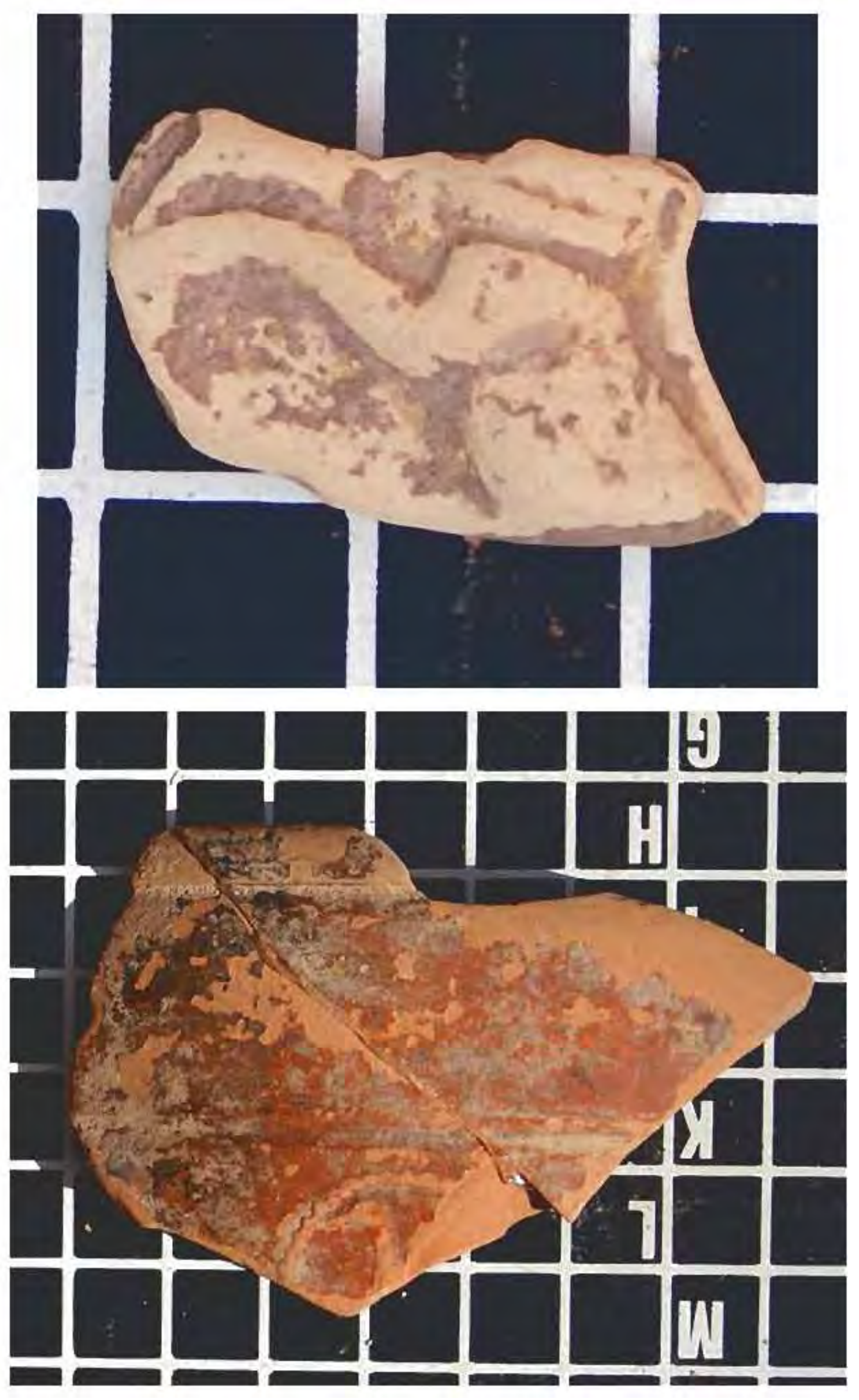



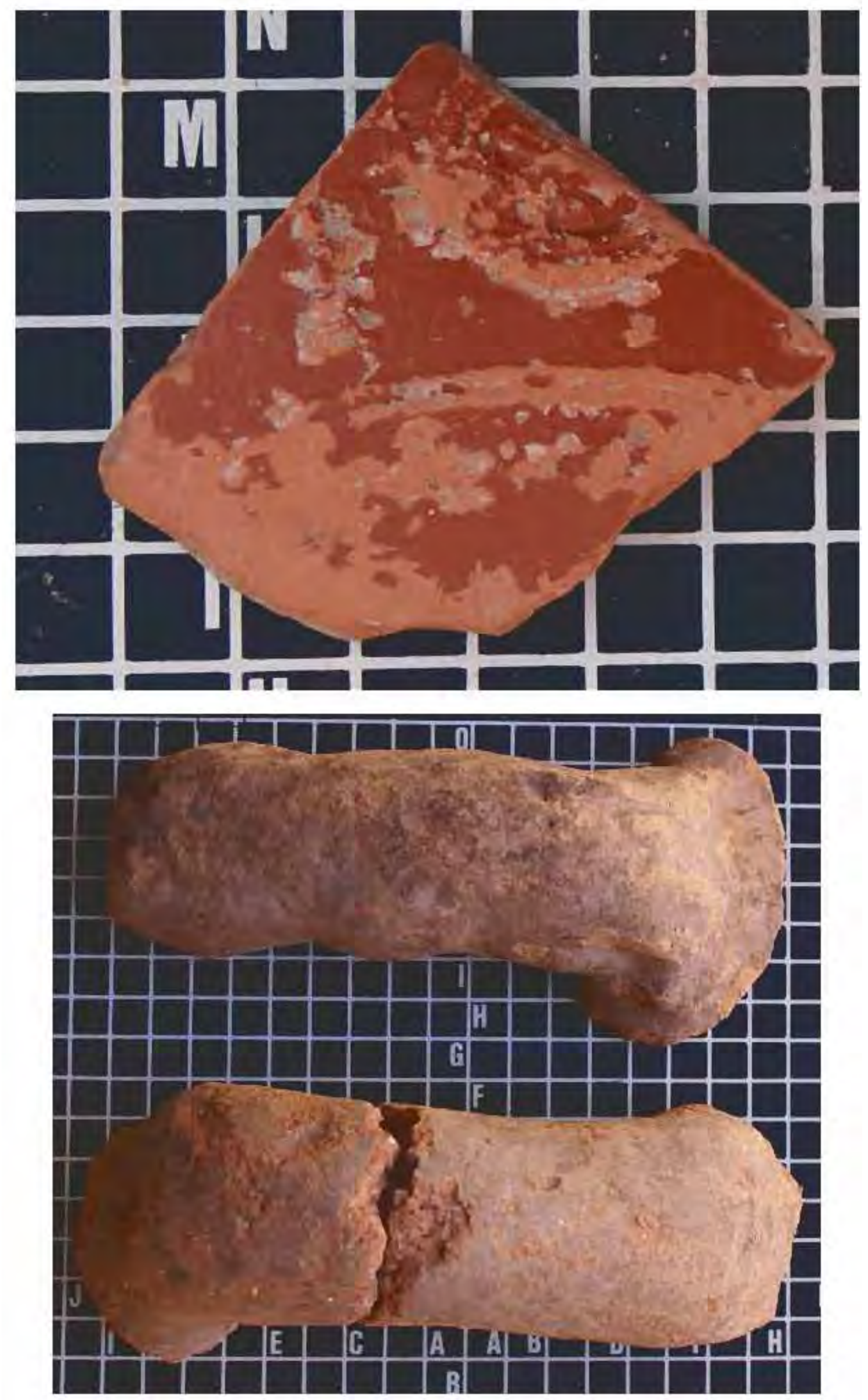

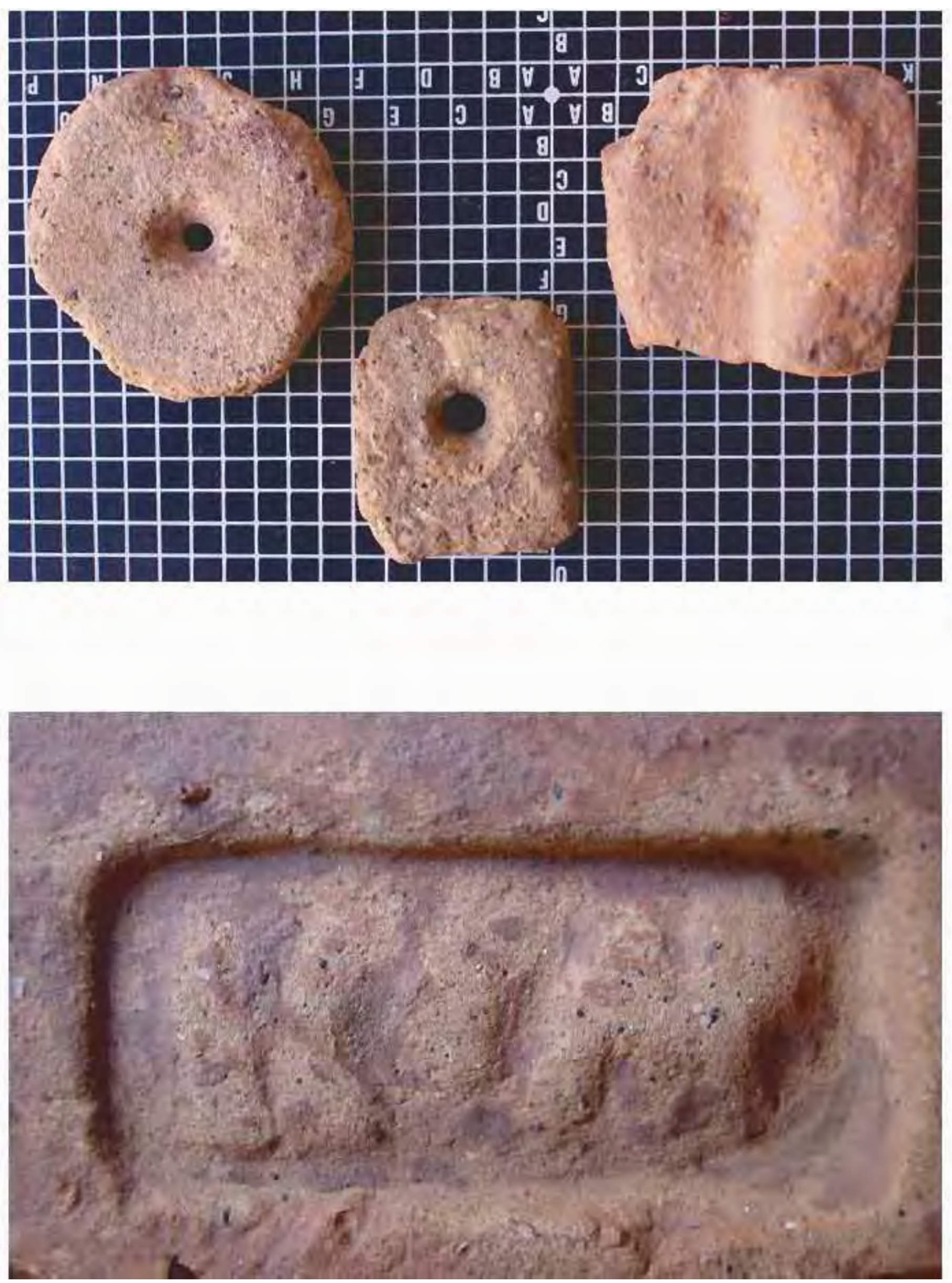

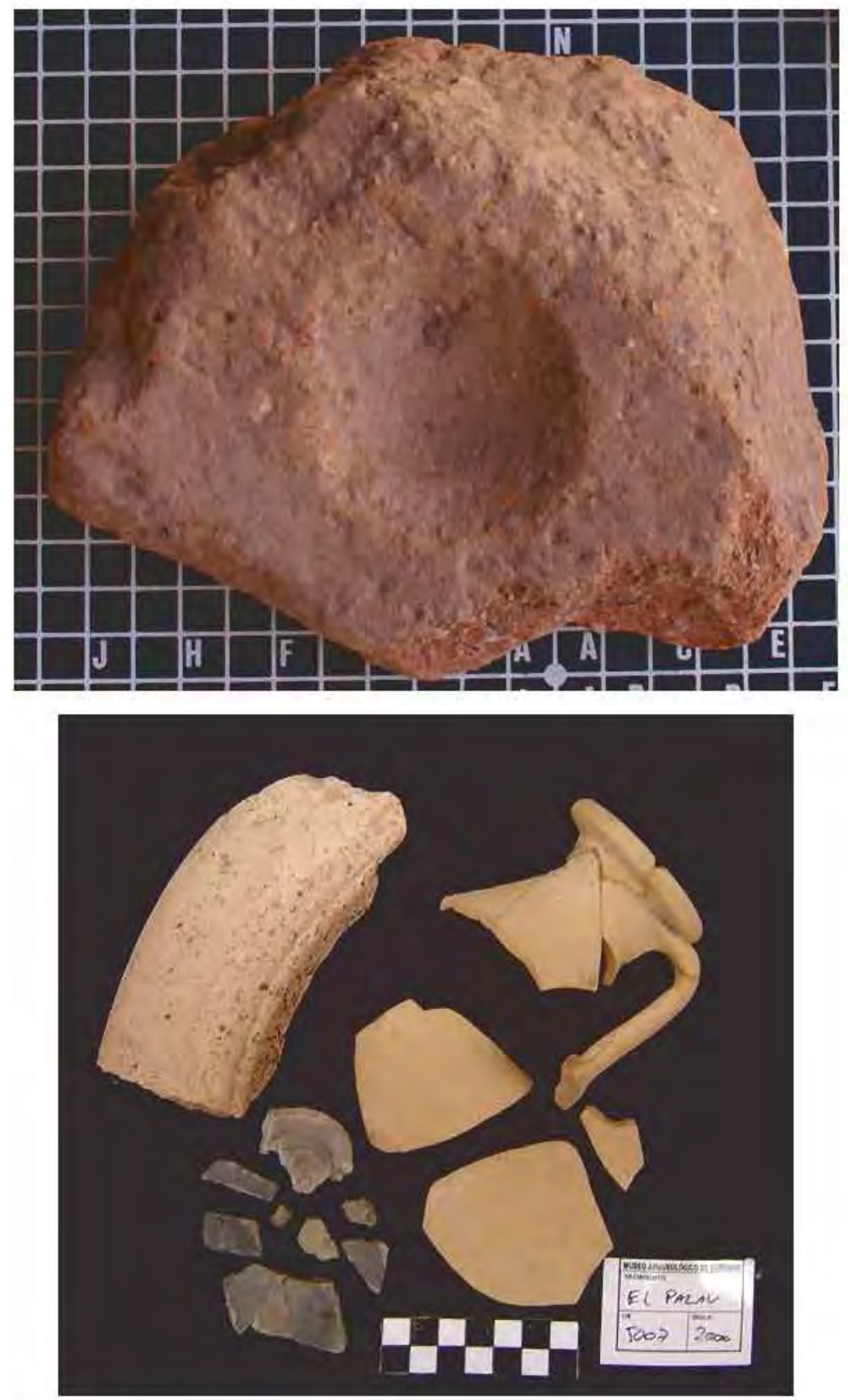

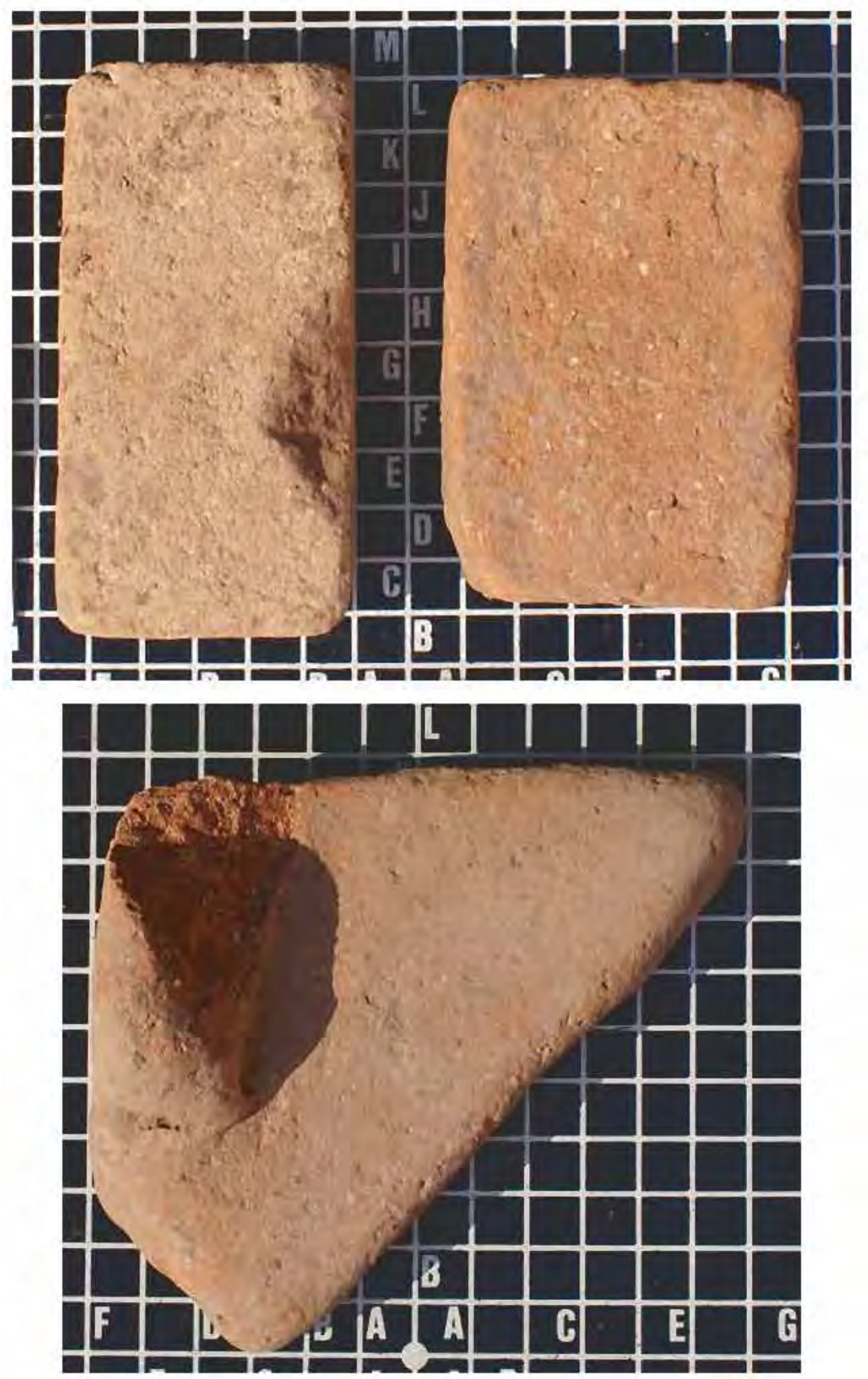

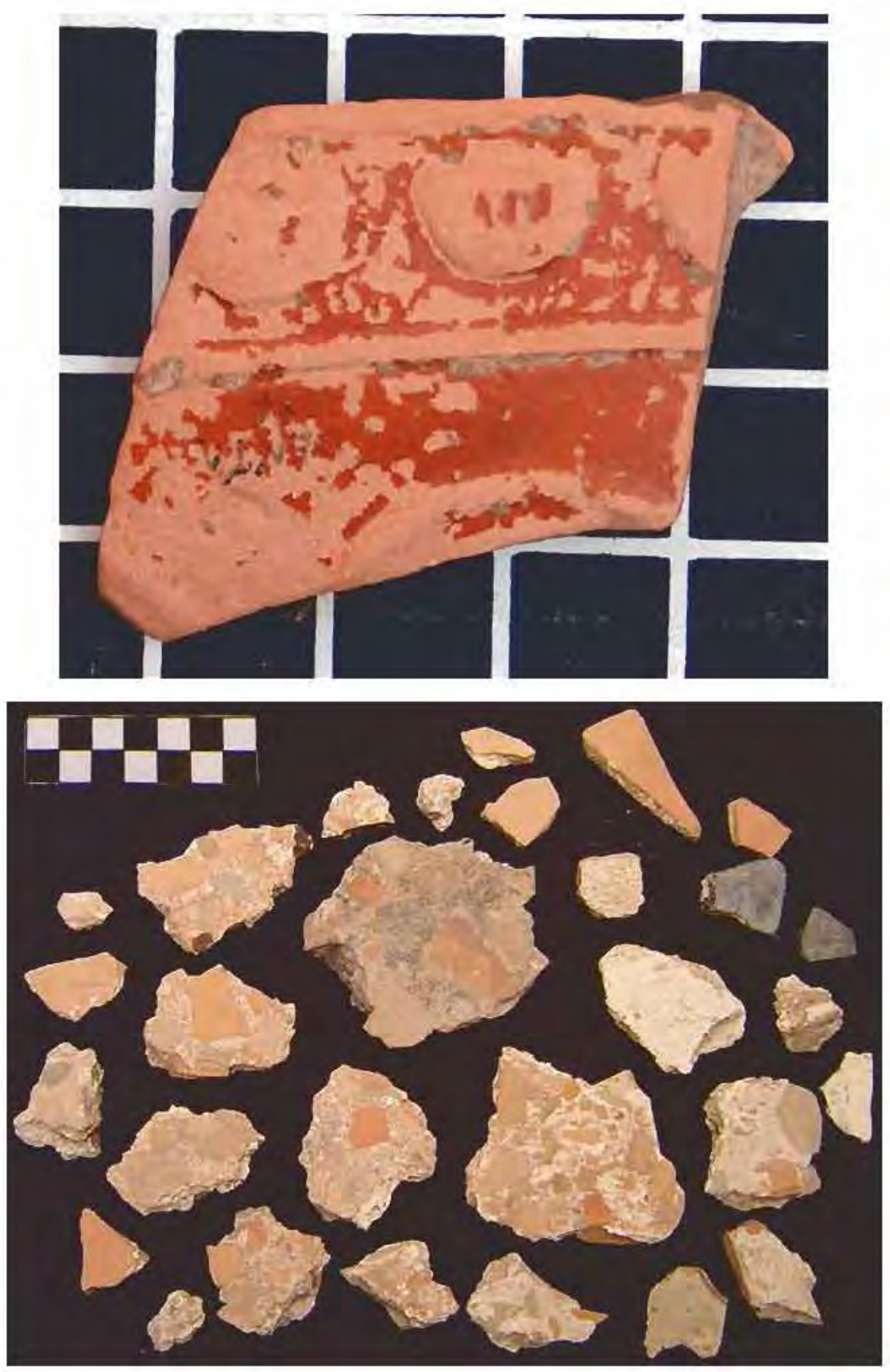


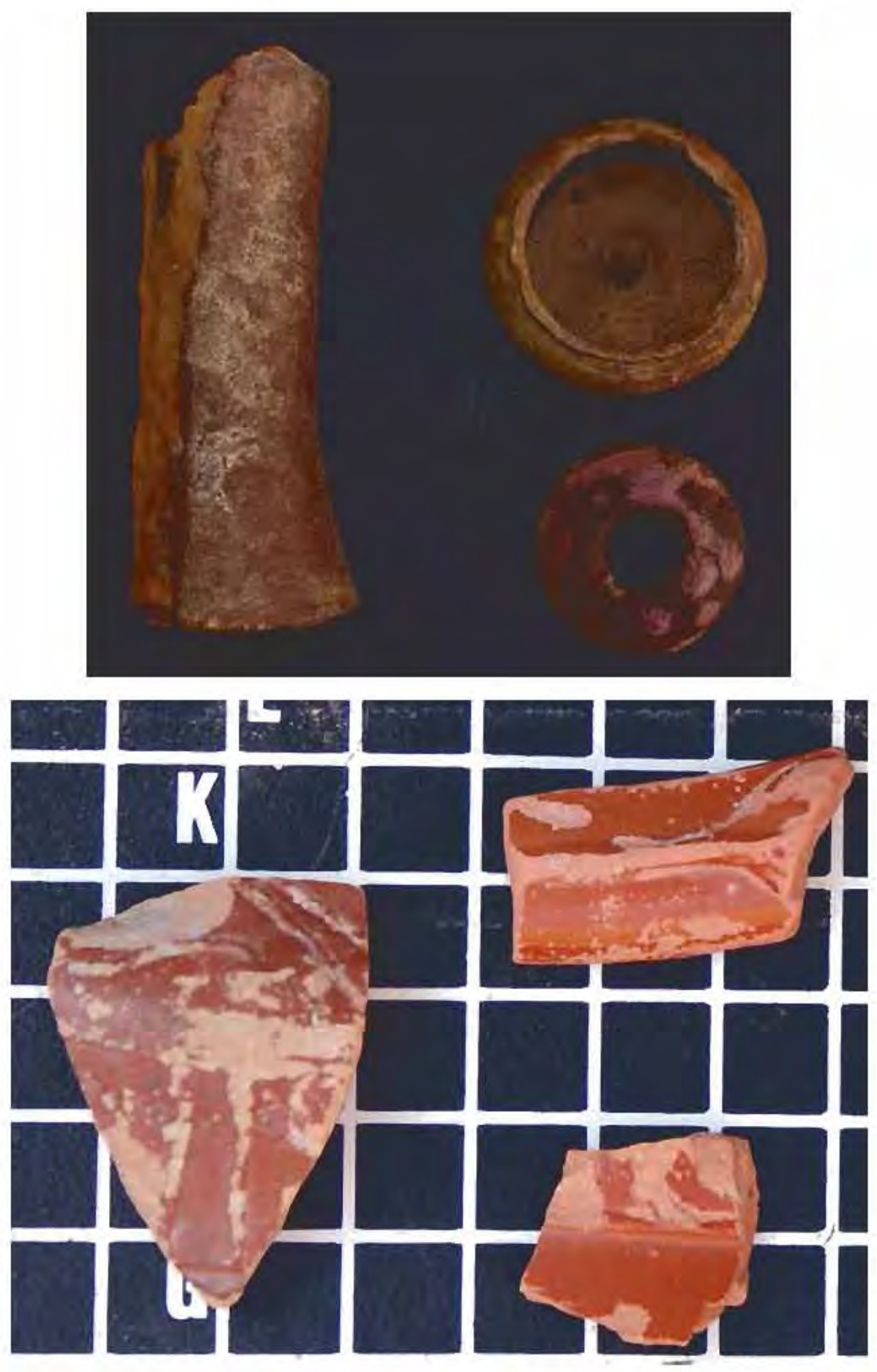




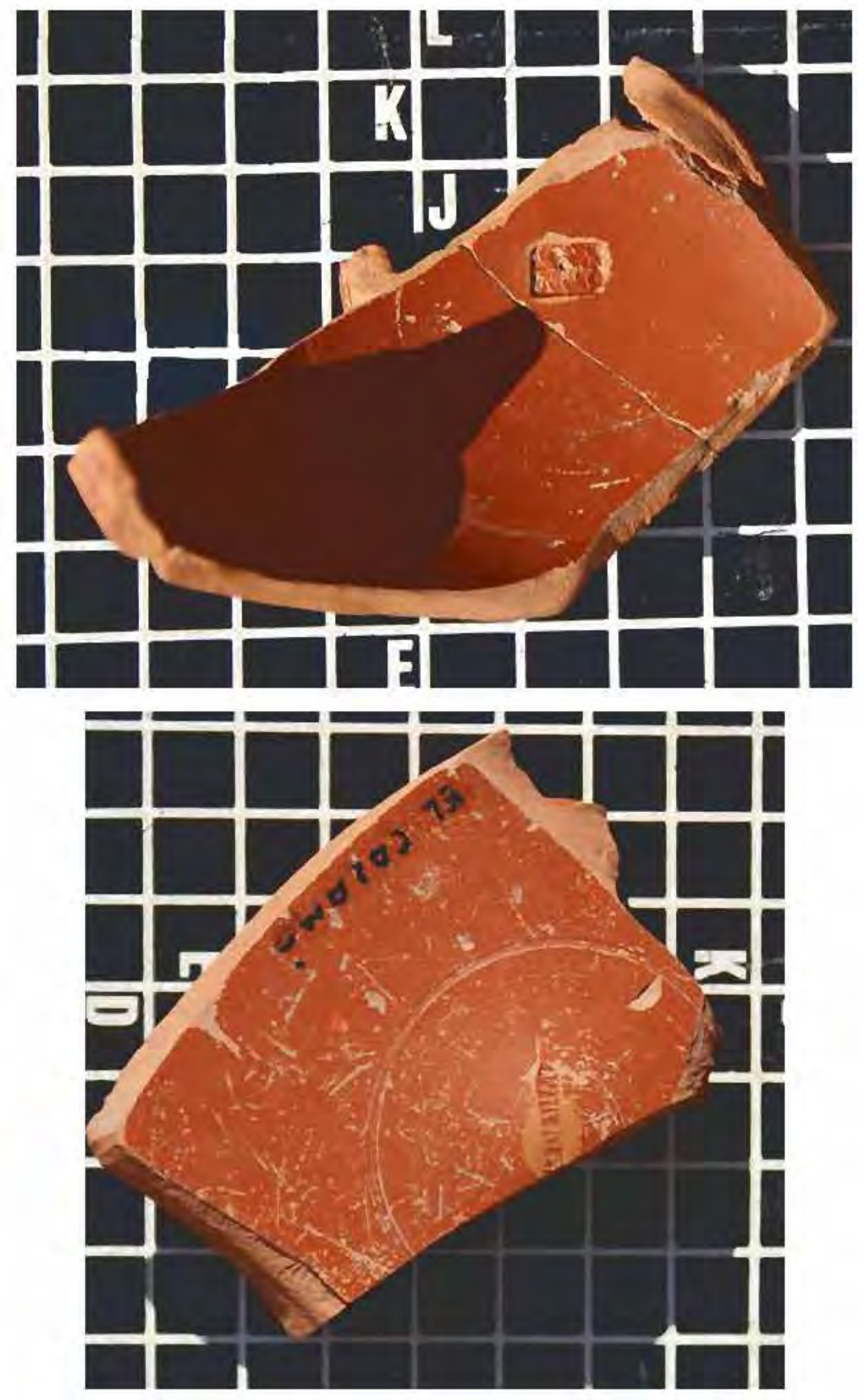



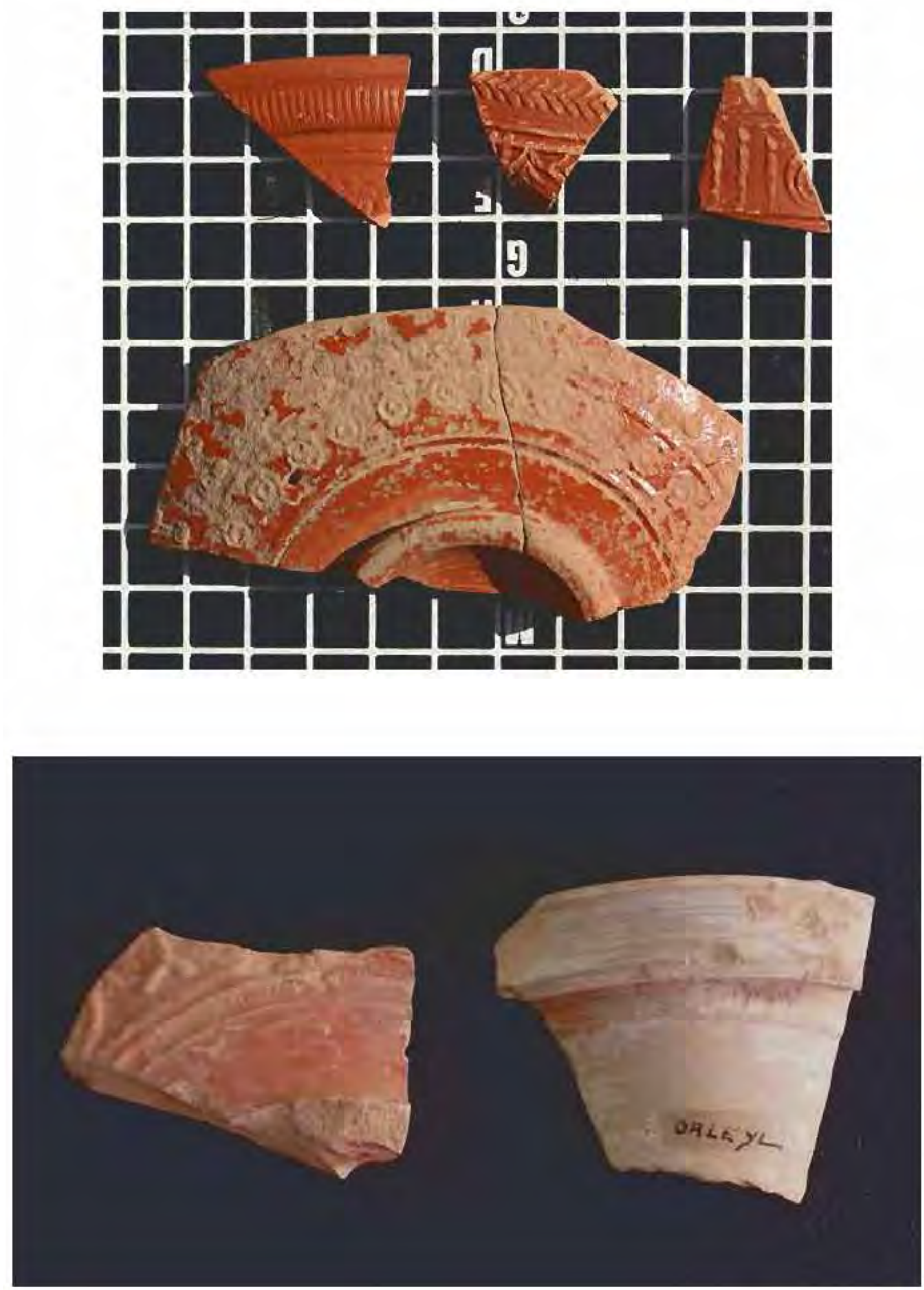

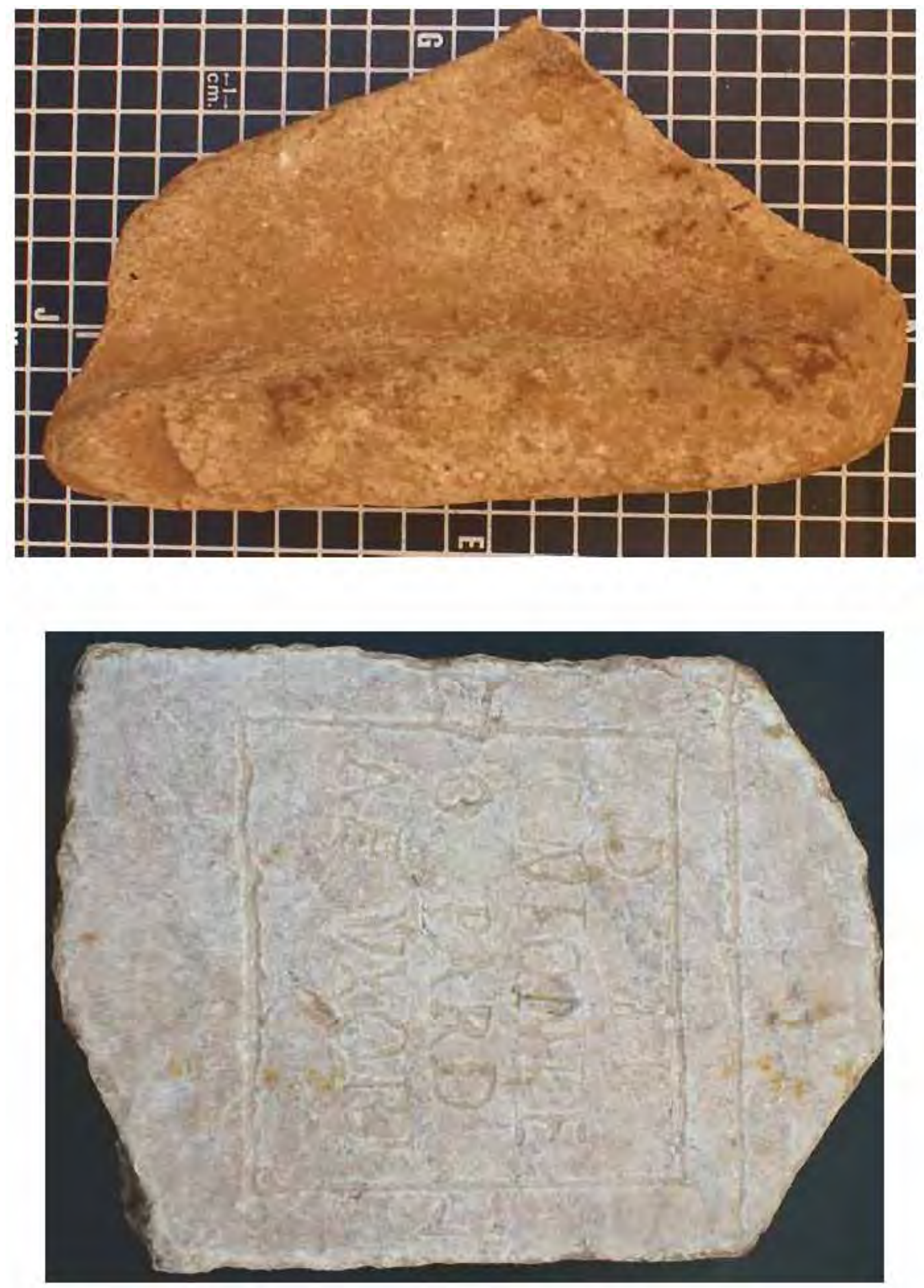


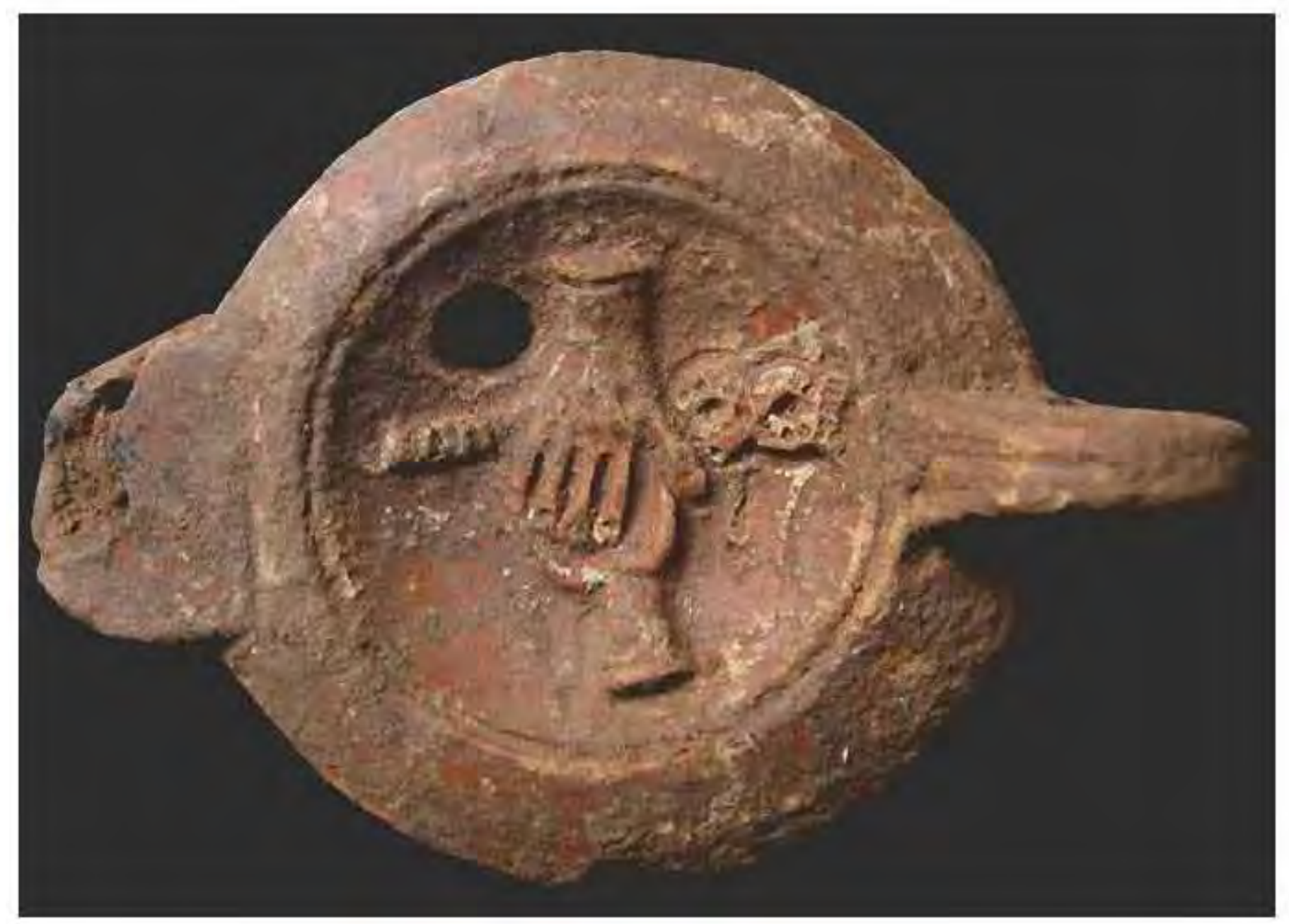




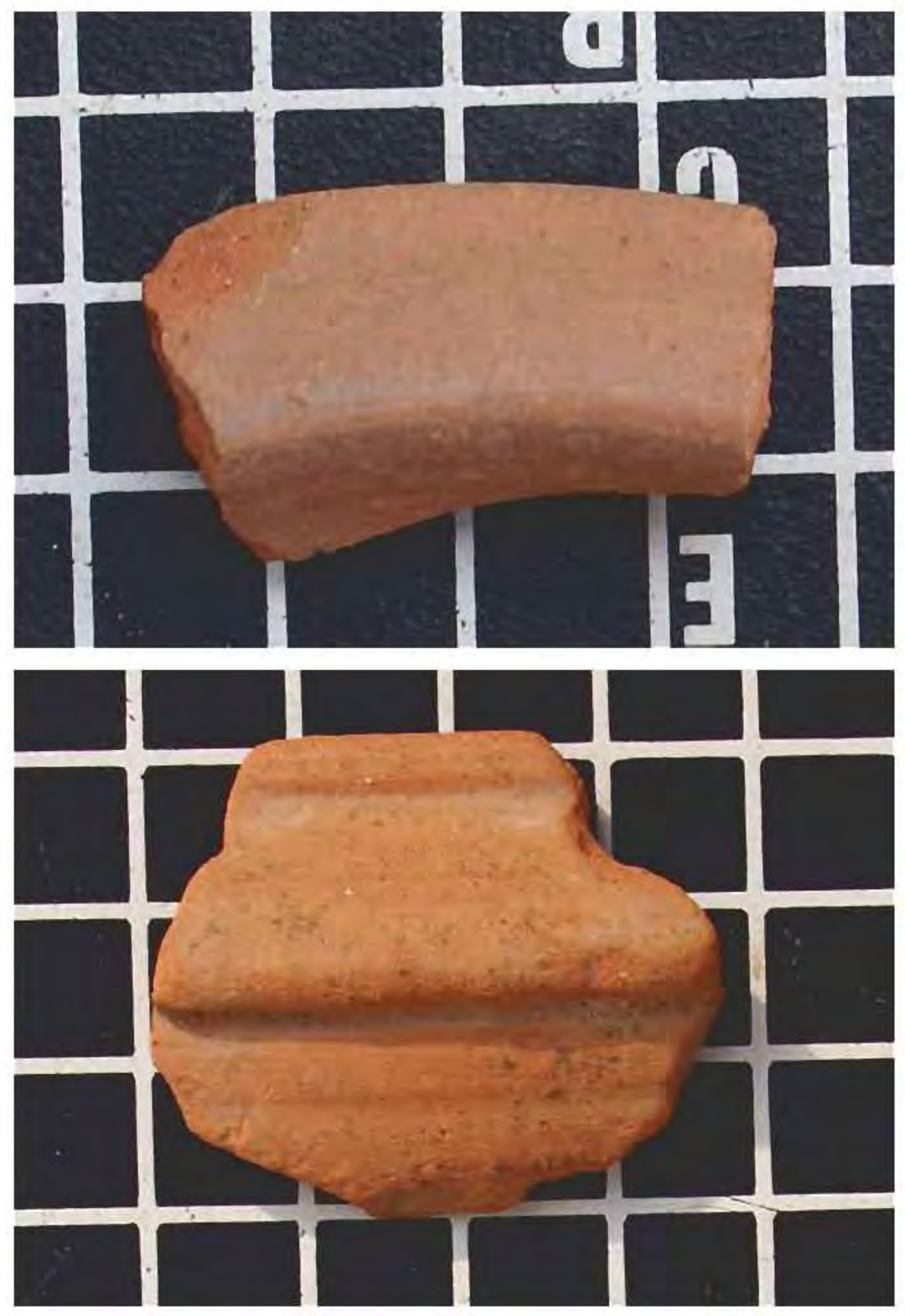




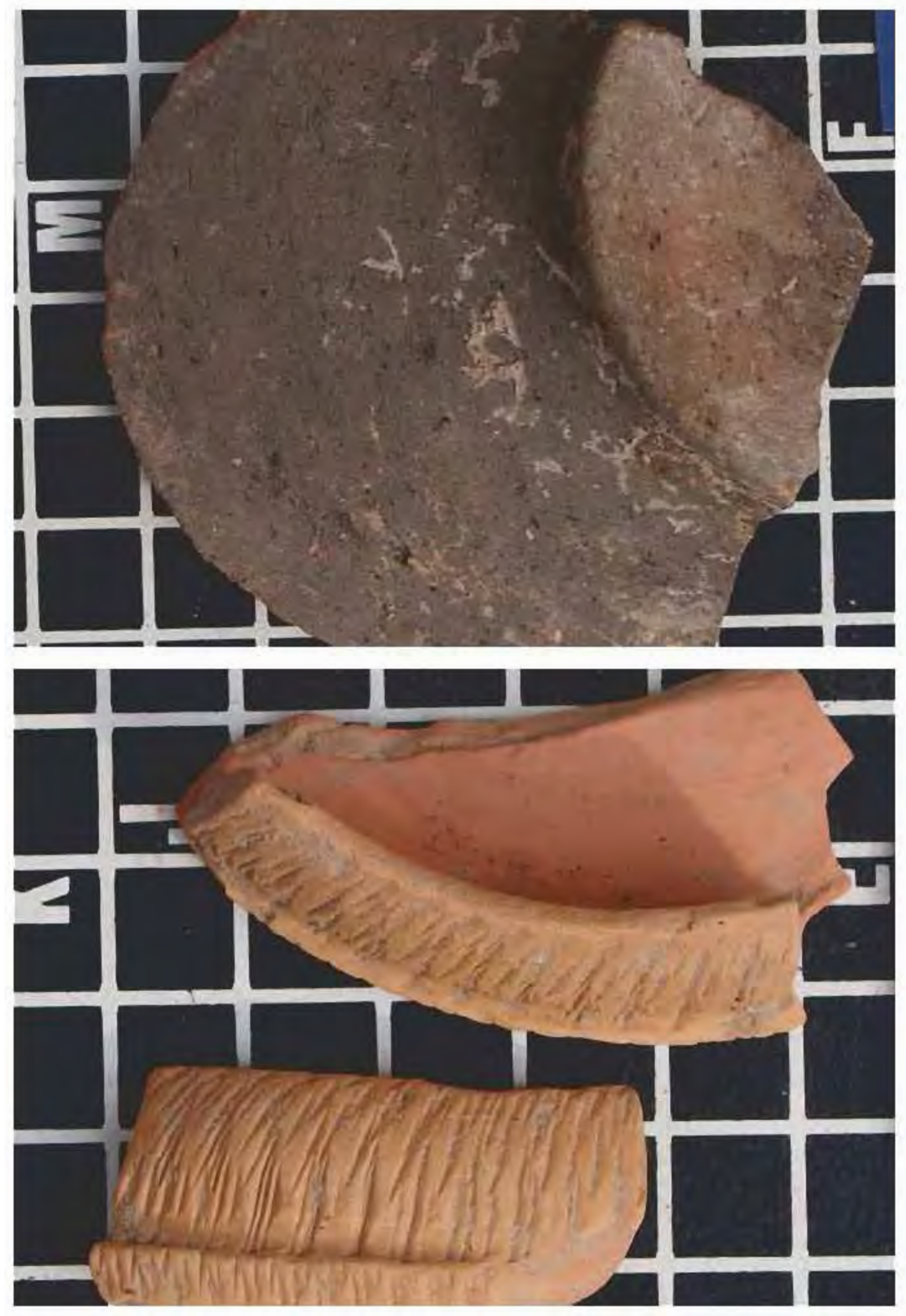



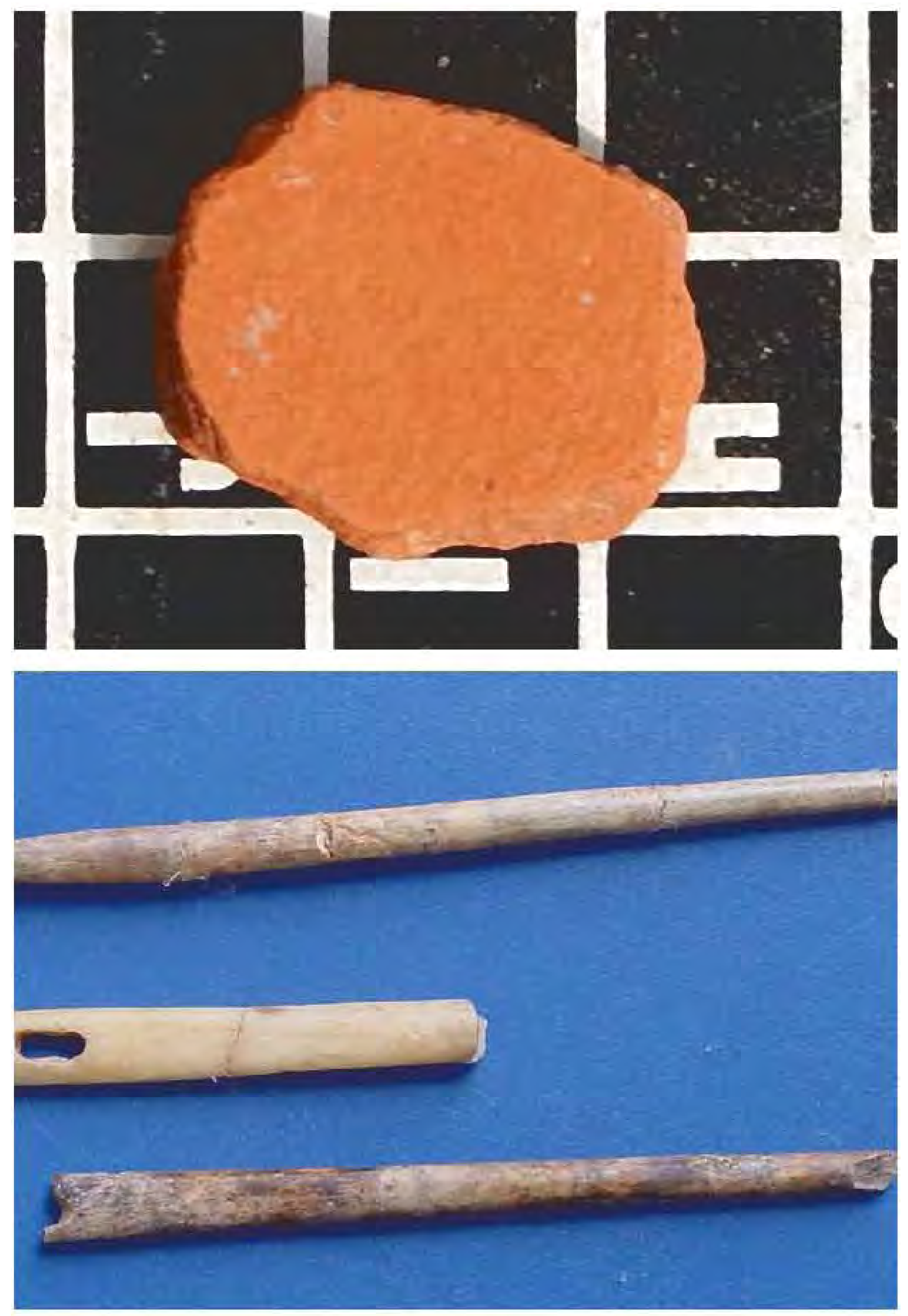

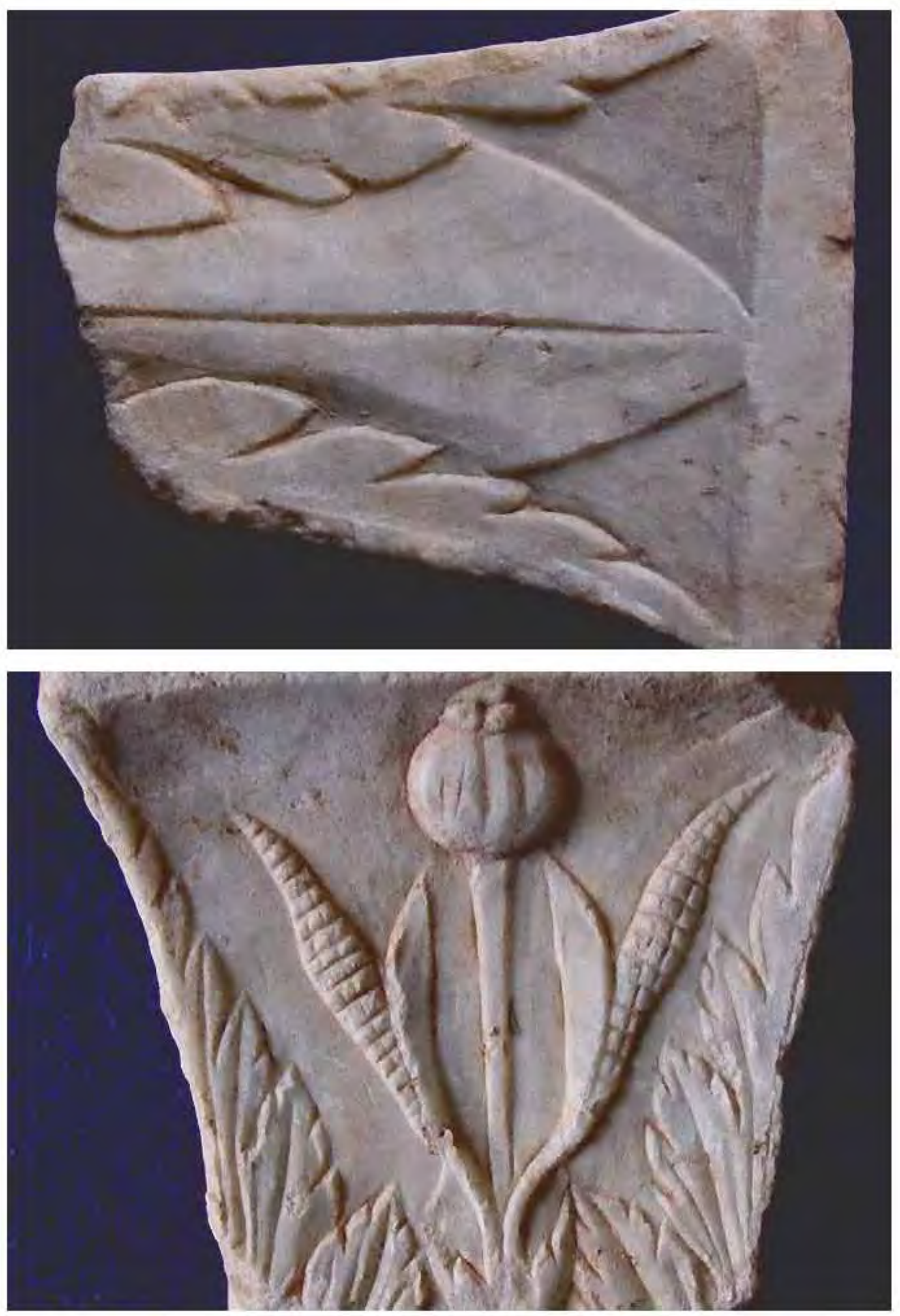

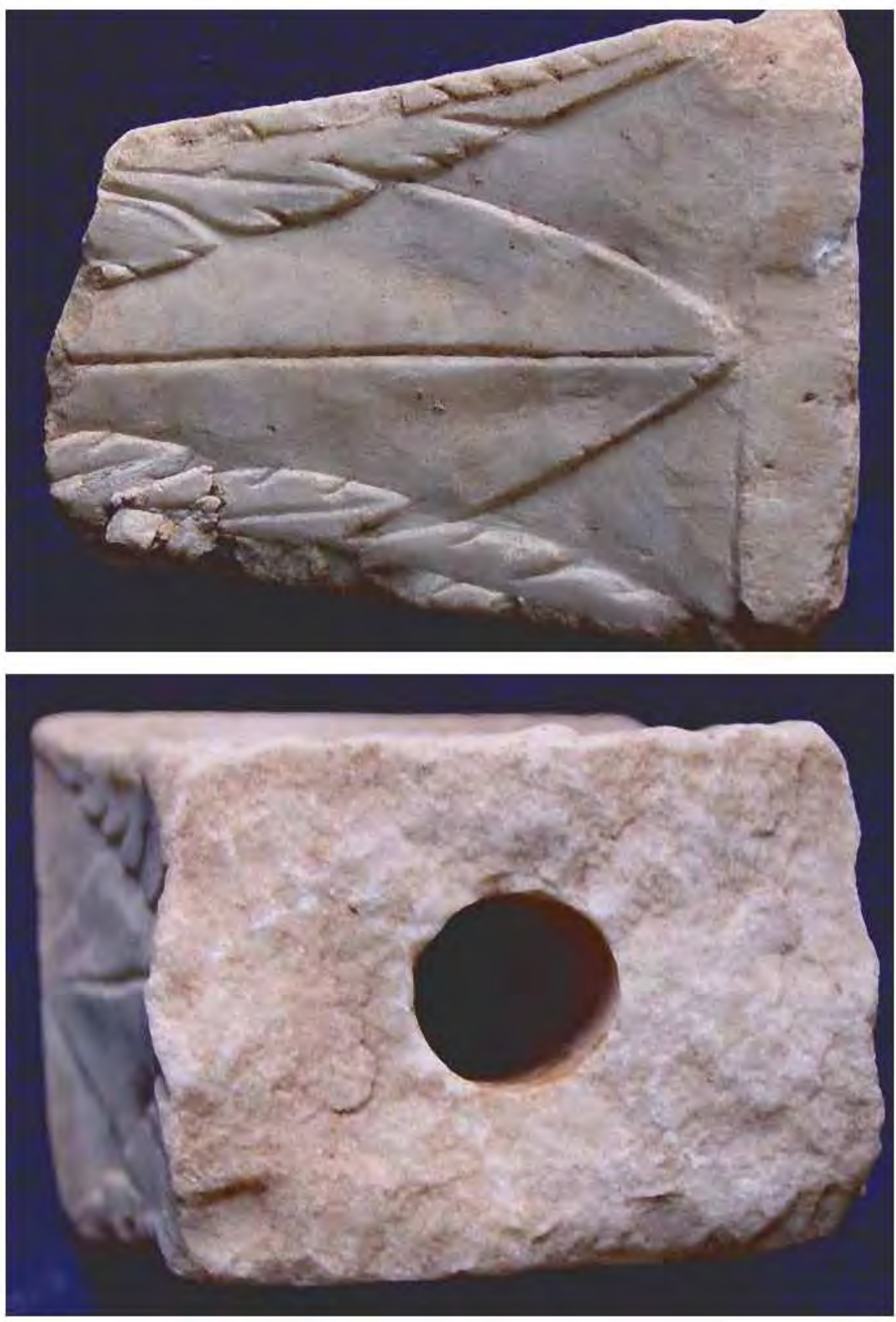

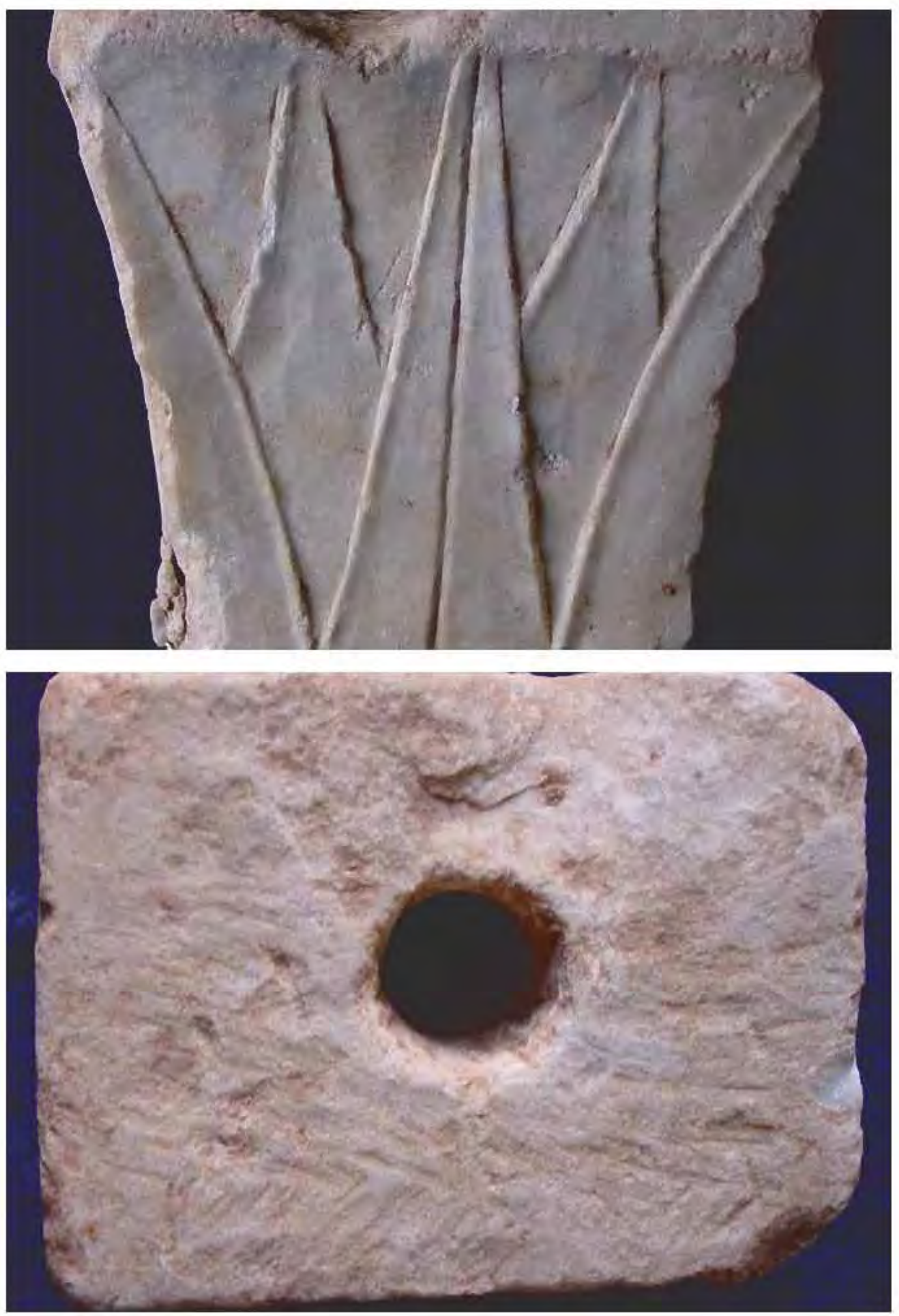

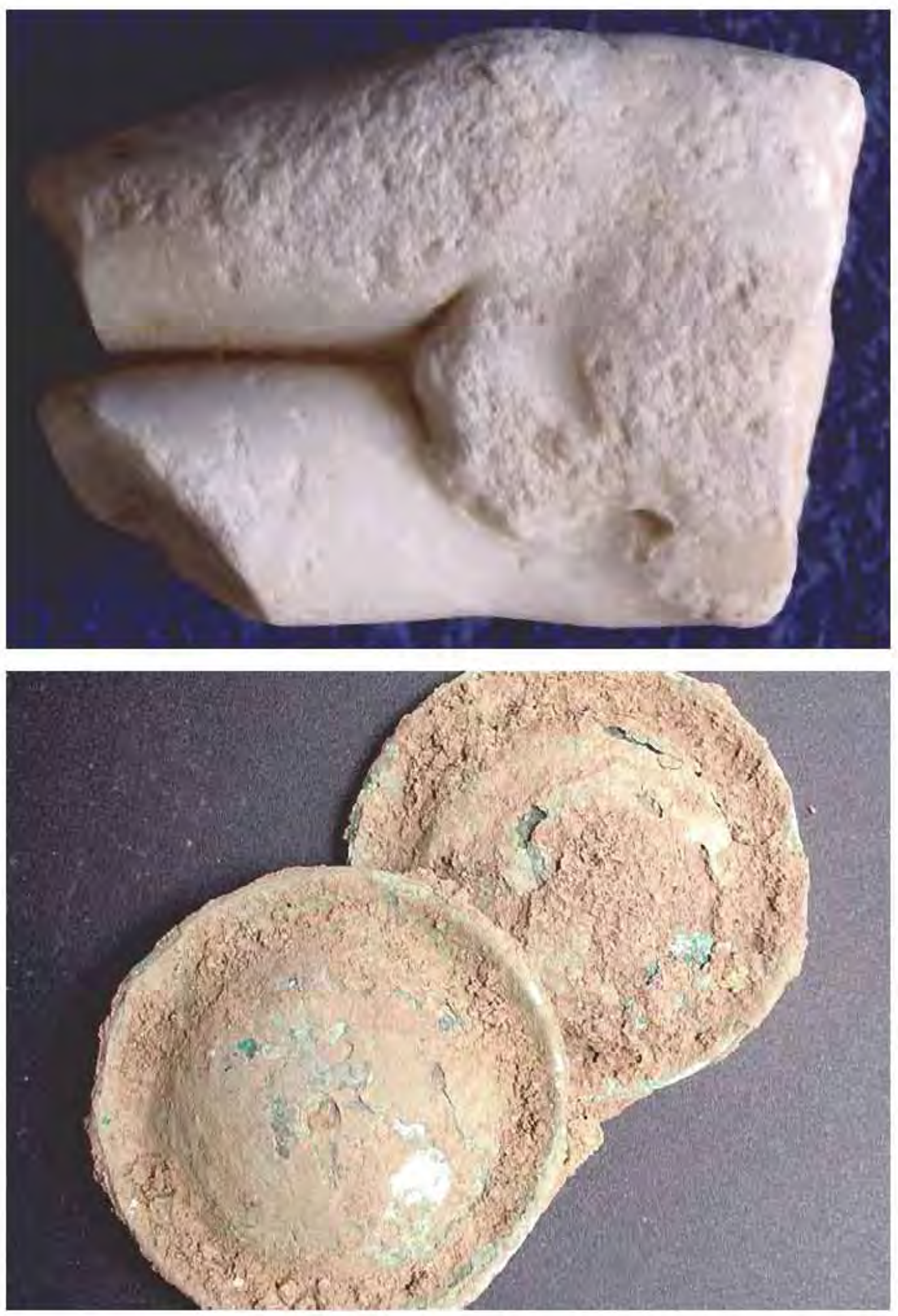

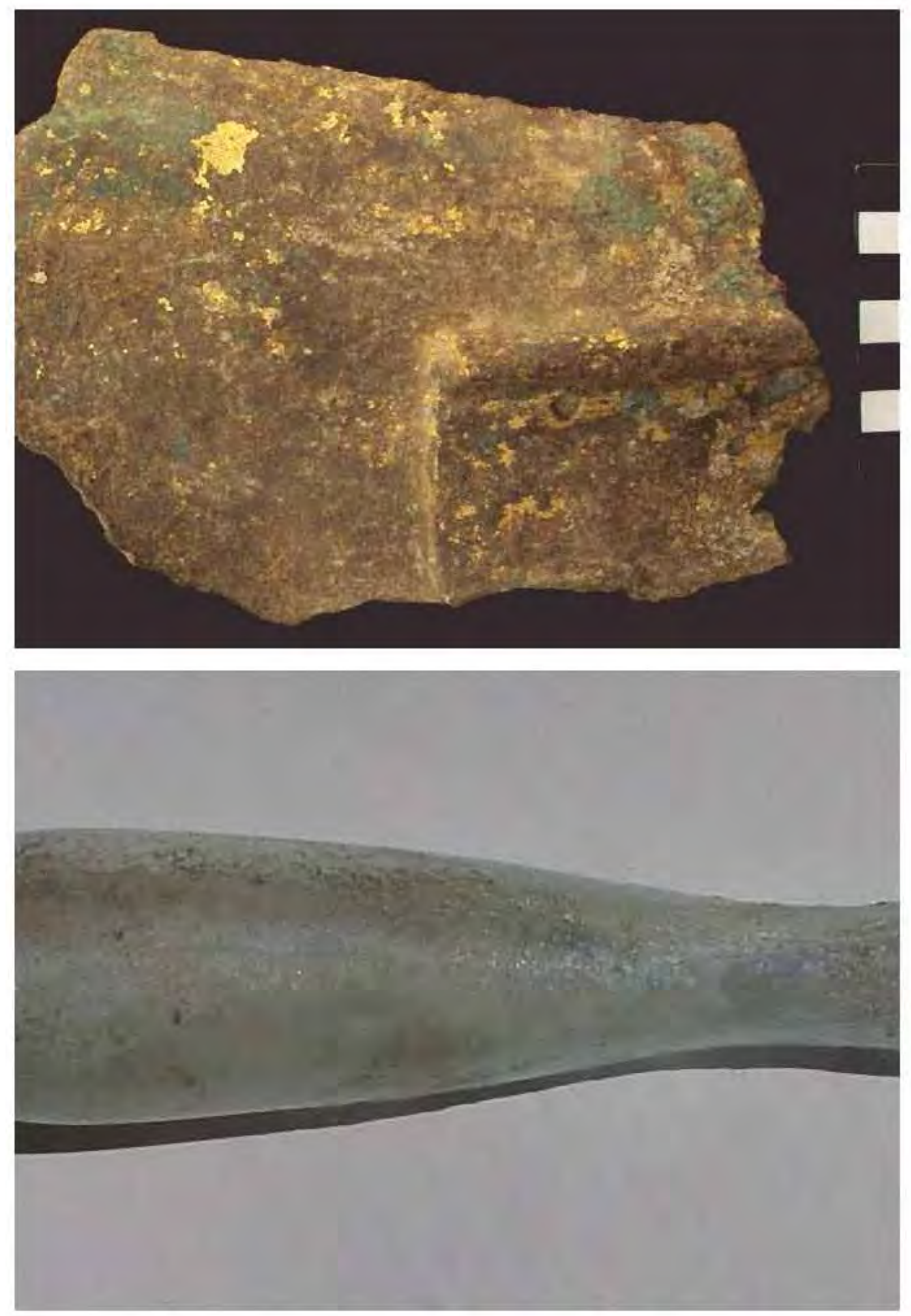

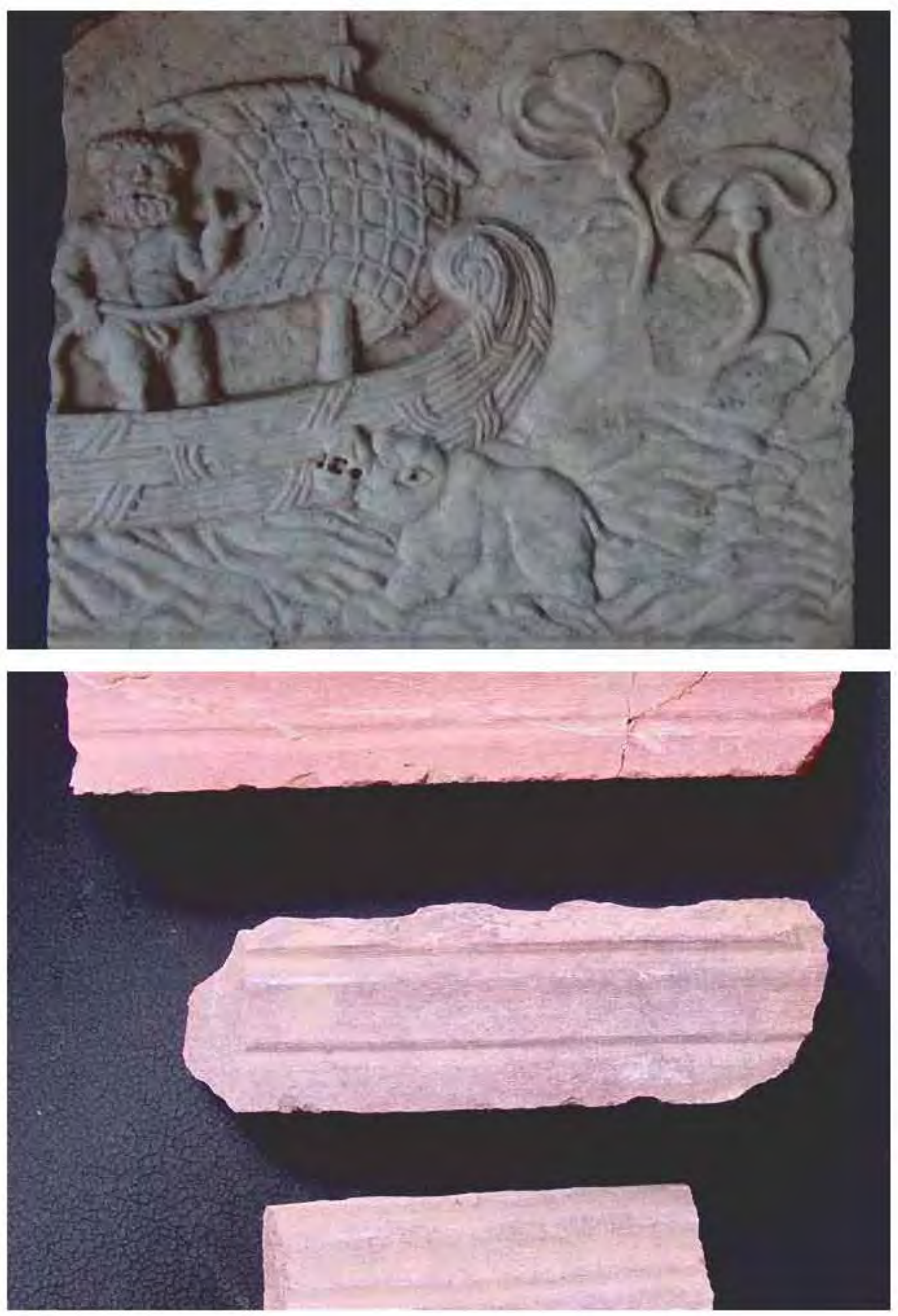

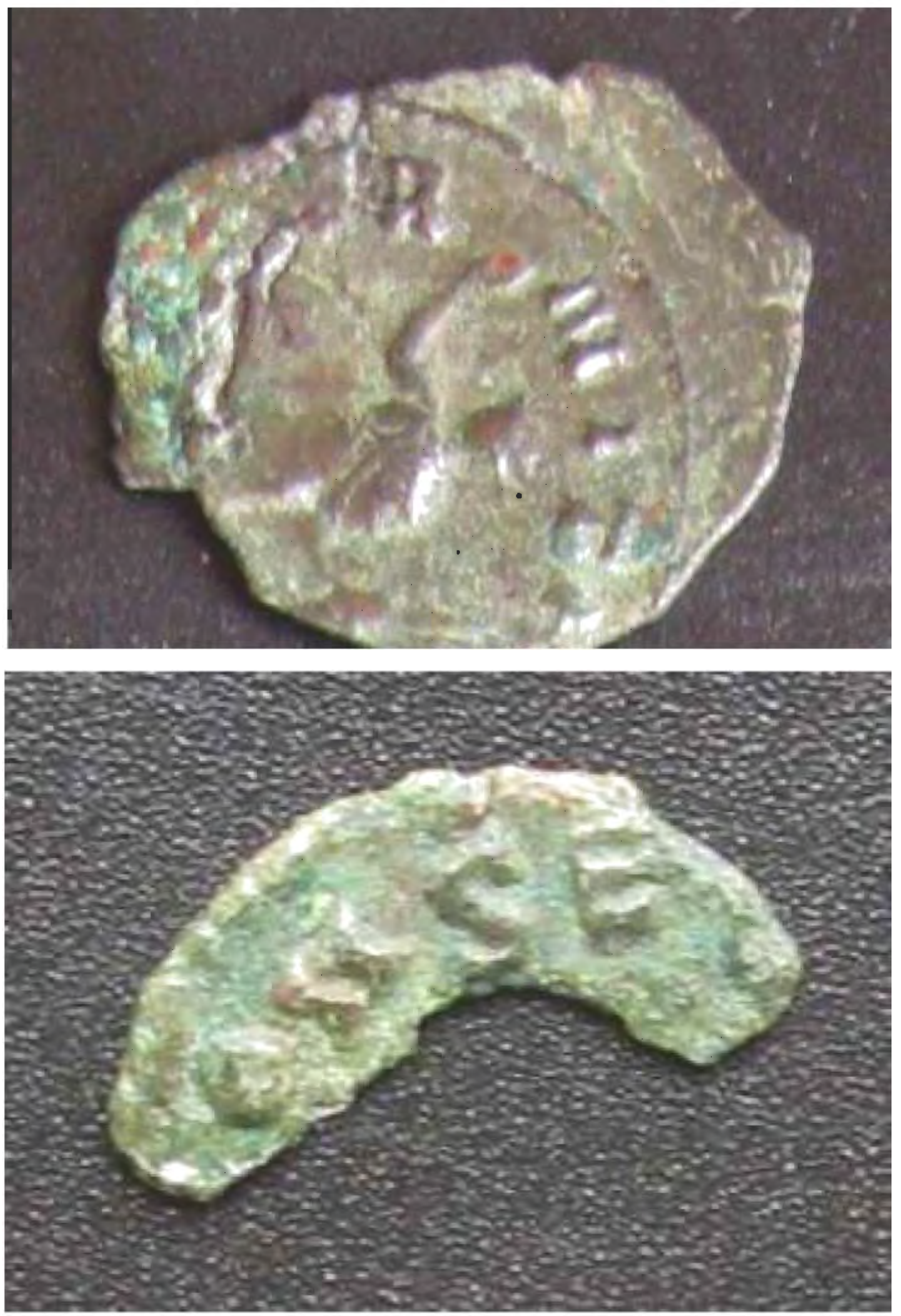

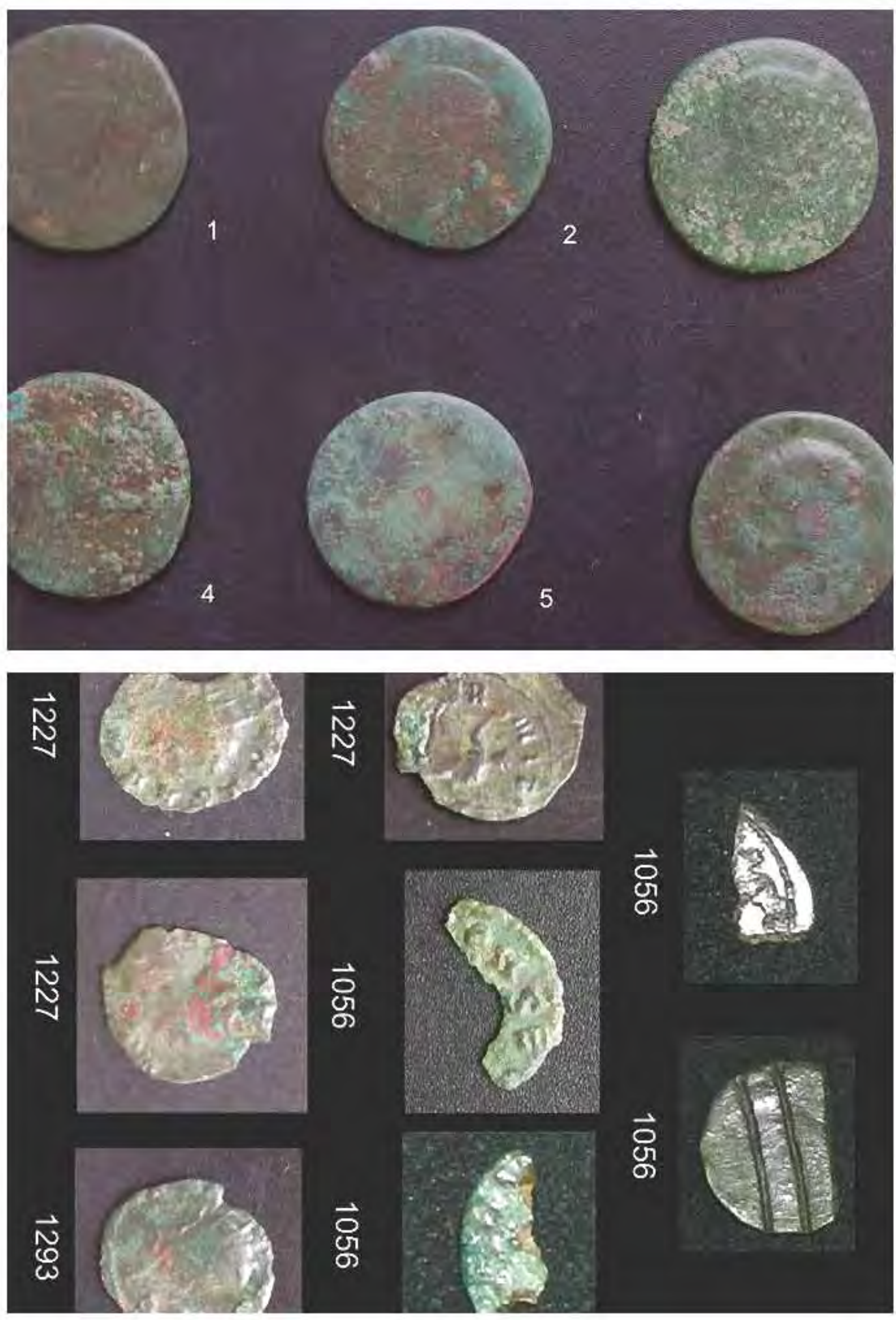


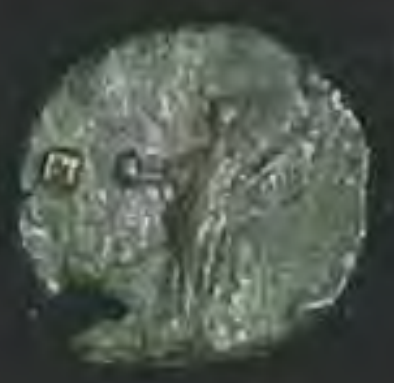

1056

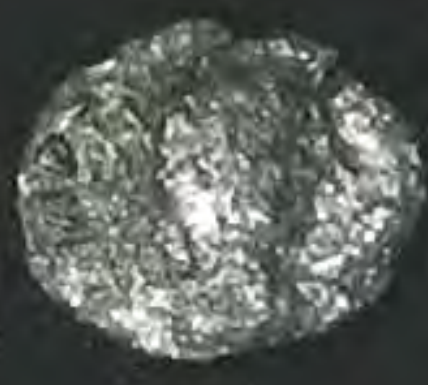

1056

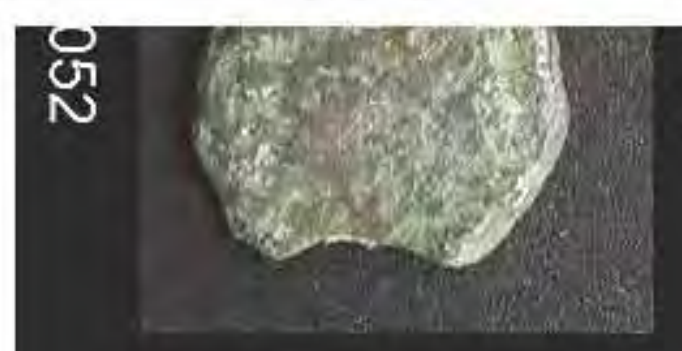

W

\section{6 (L)}

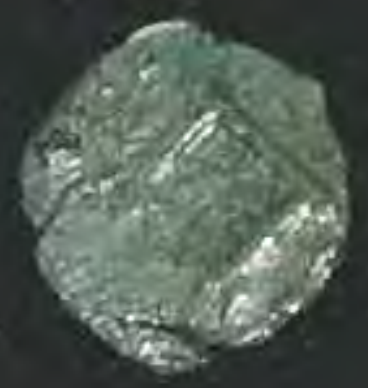

1056

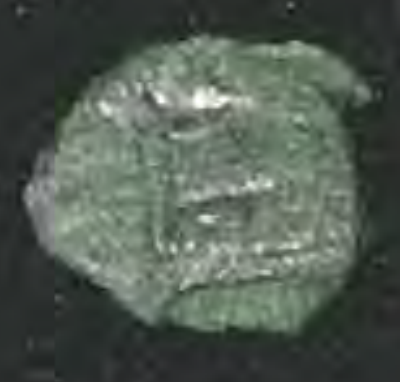

1056 (C)

\section{6}
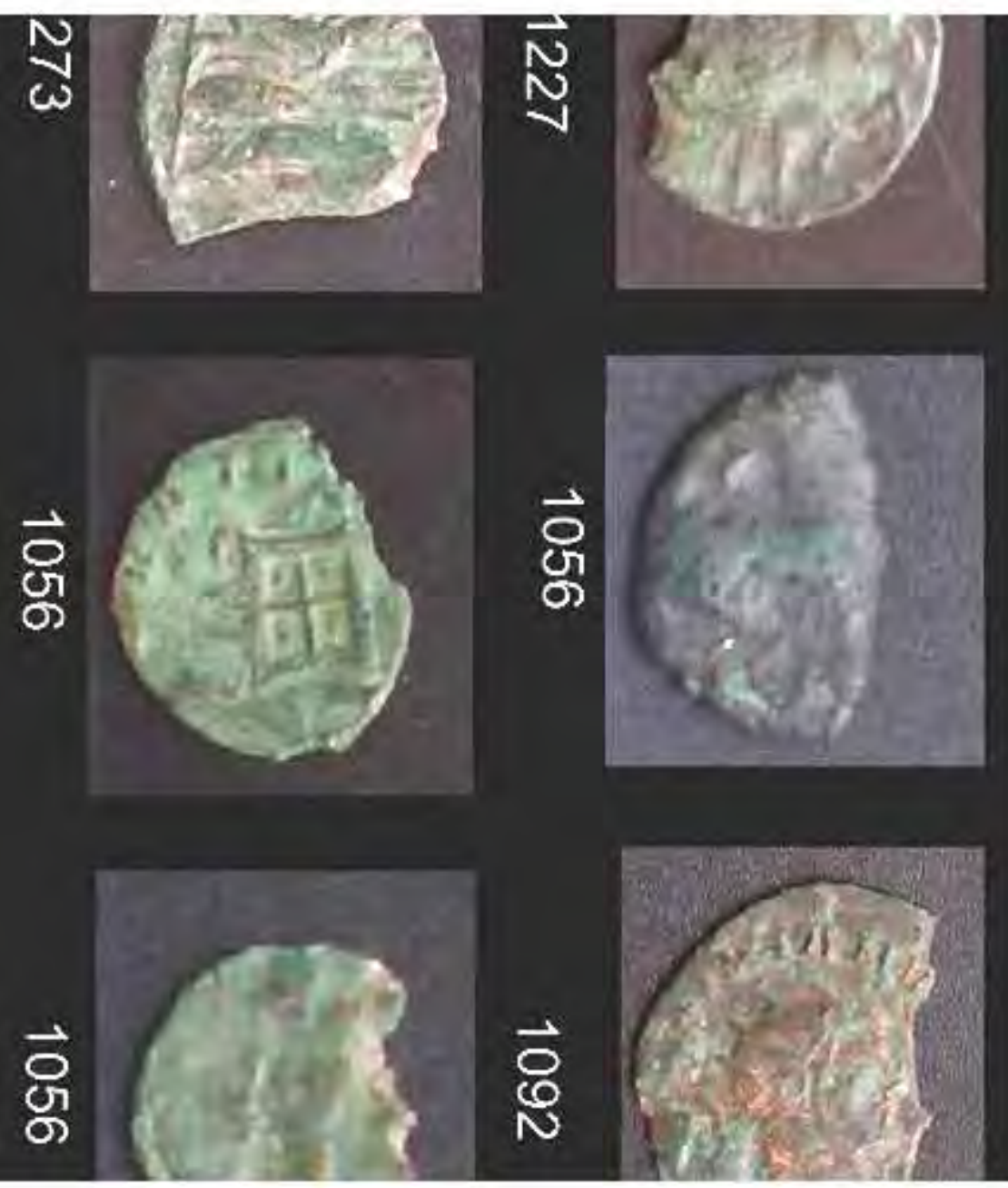

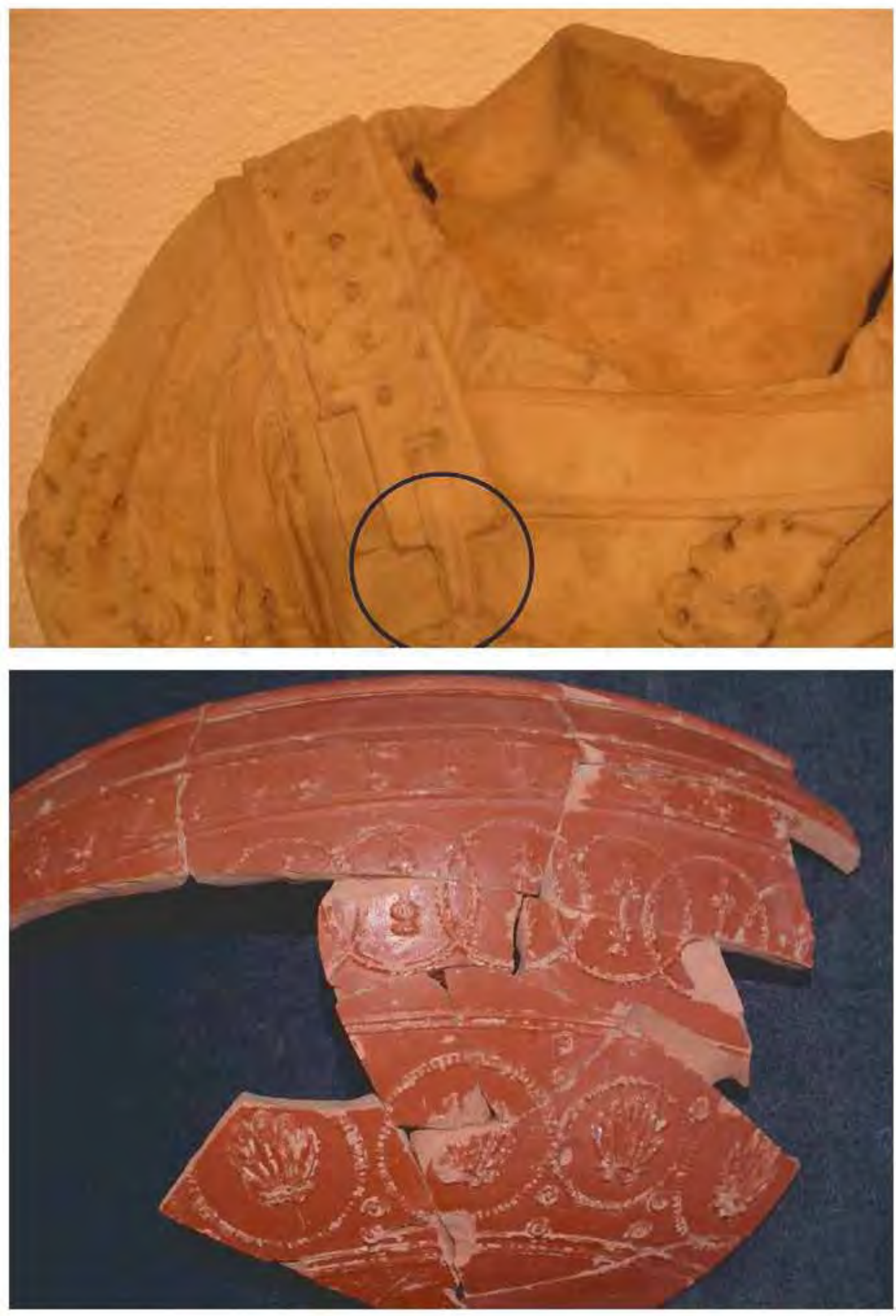

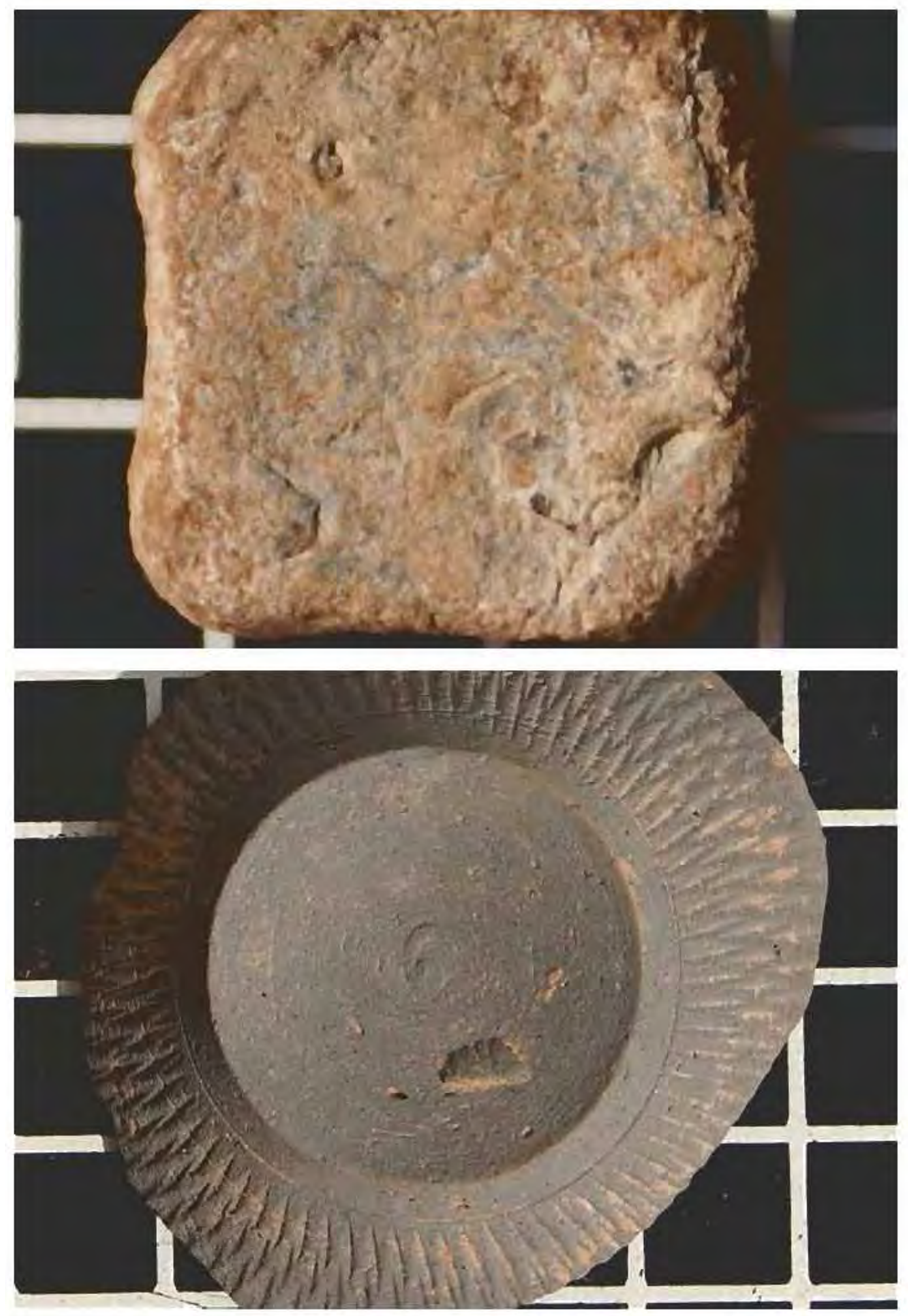

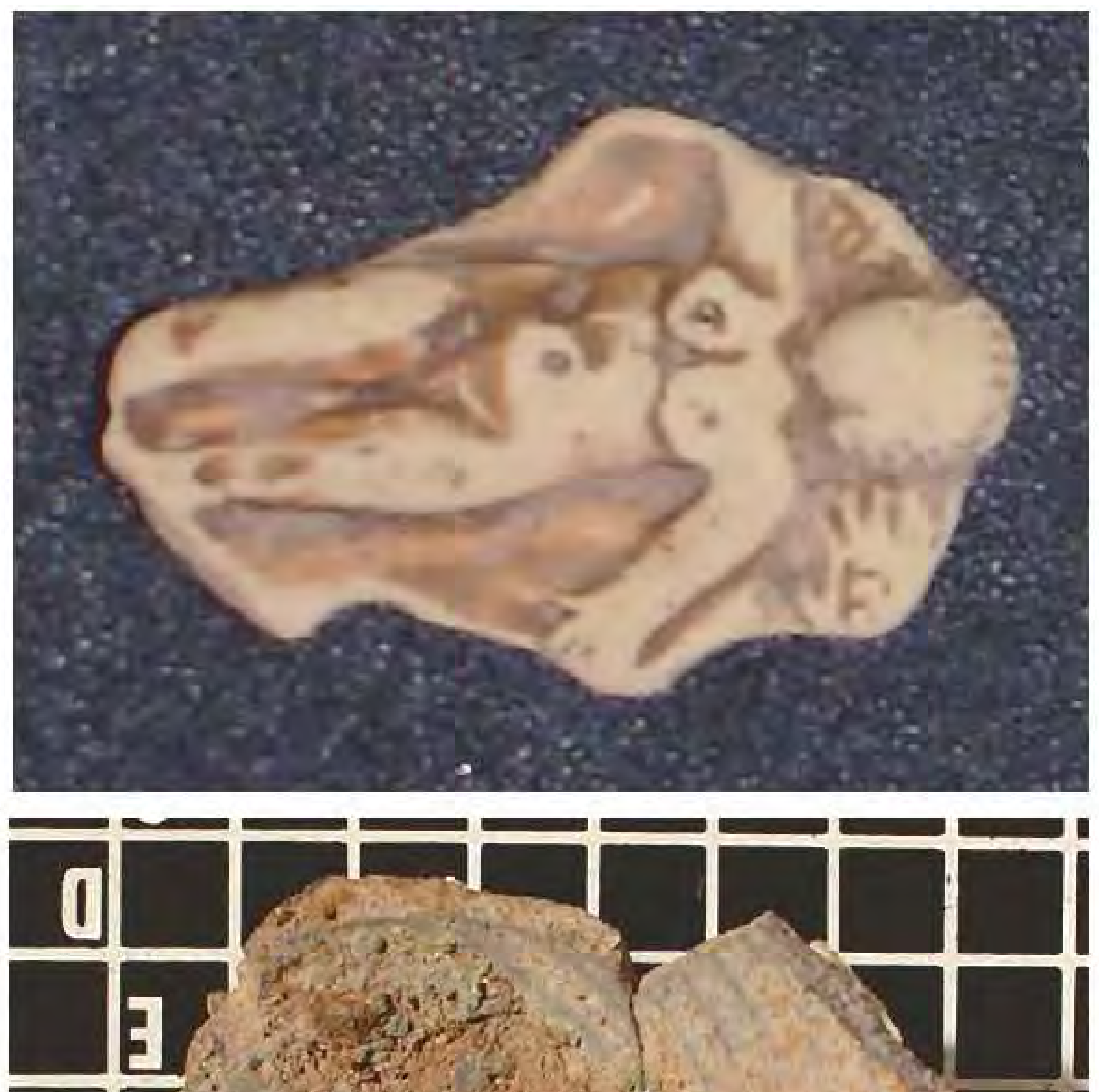

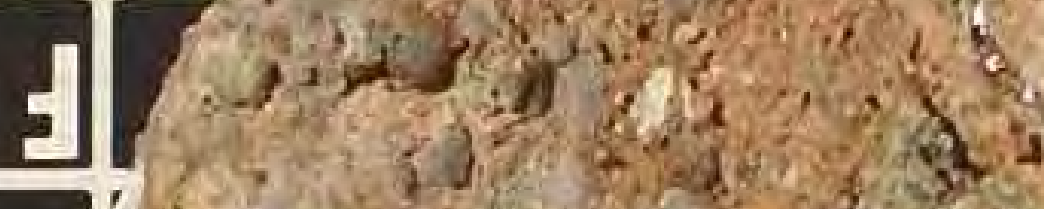
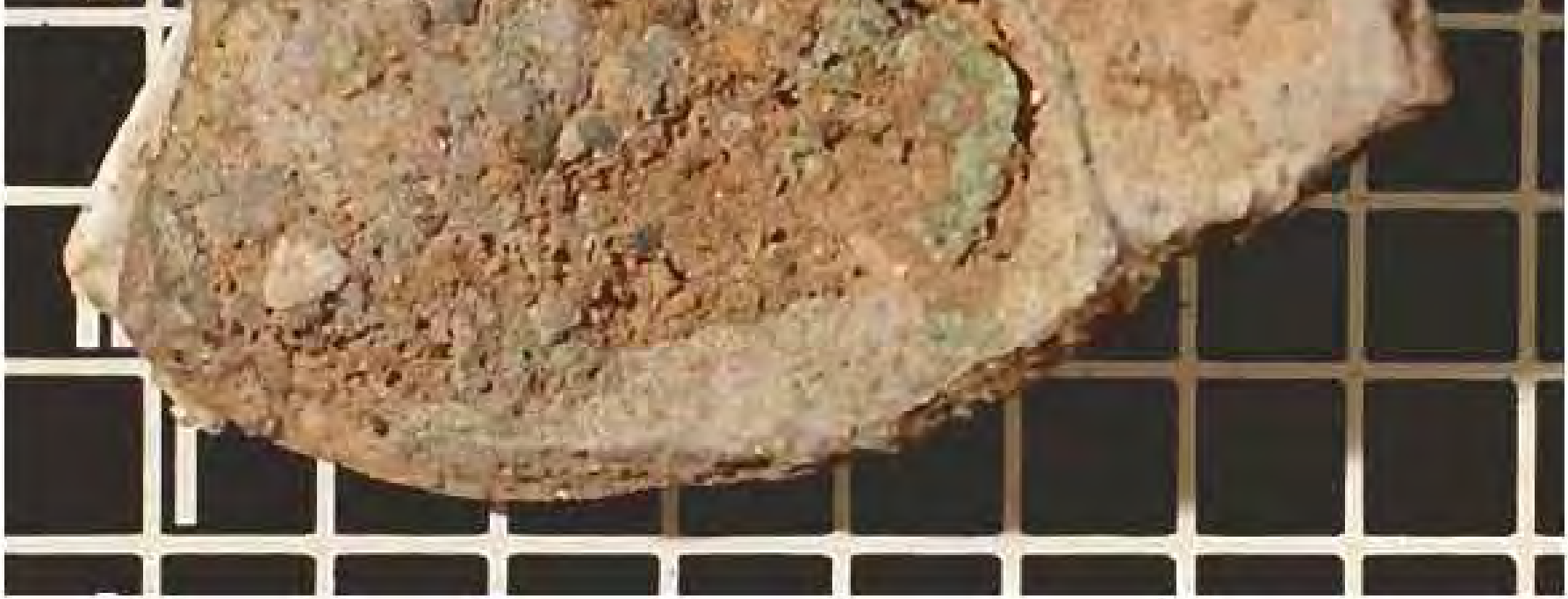
PLANOS 


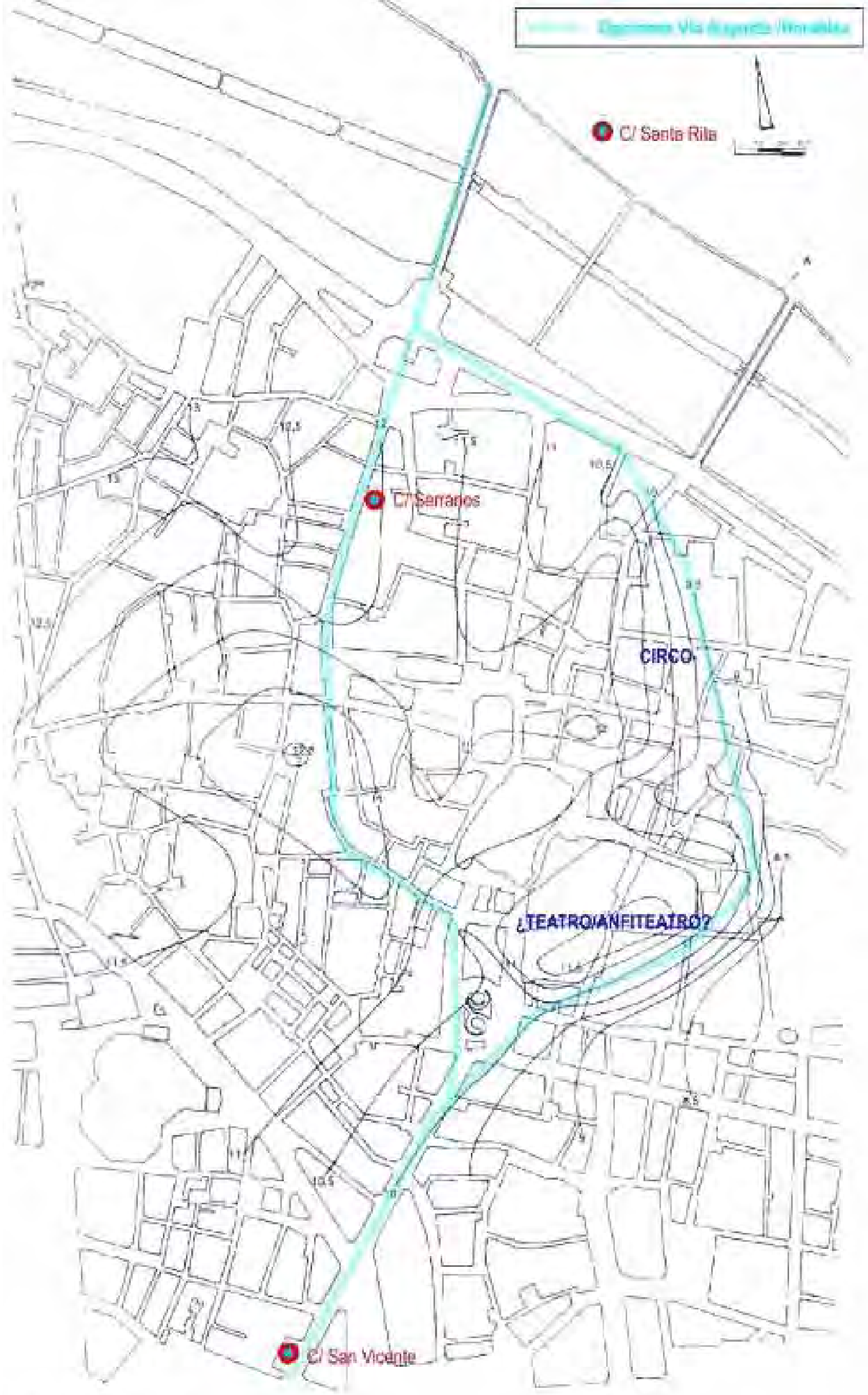



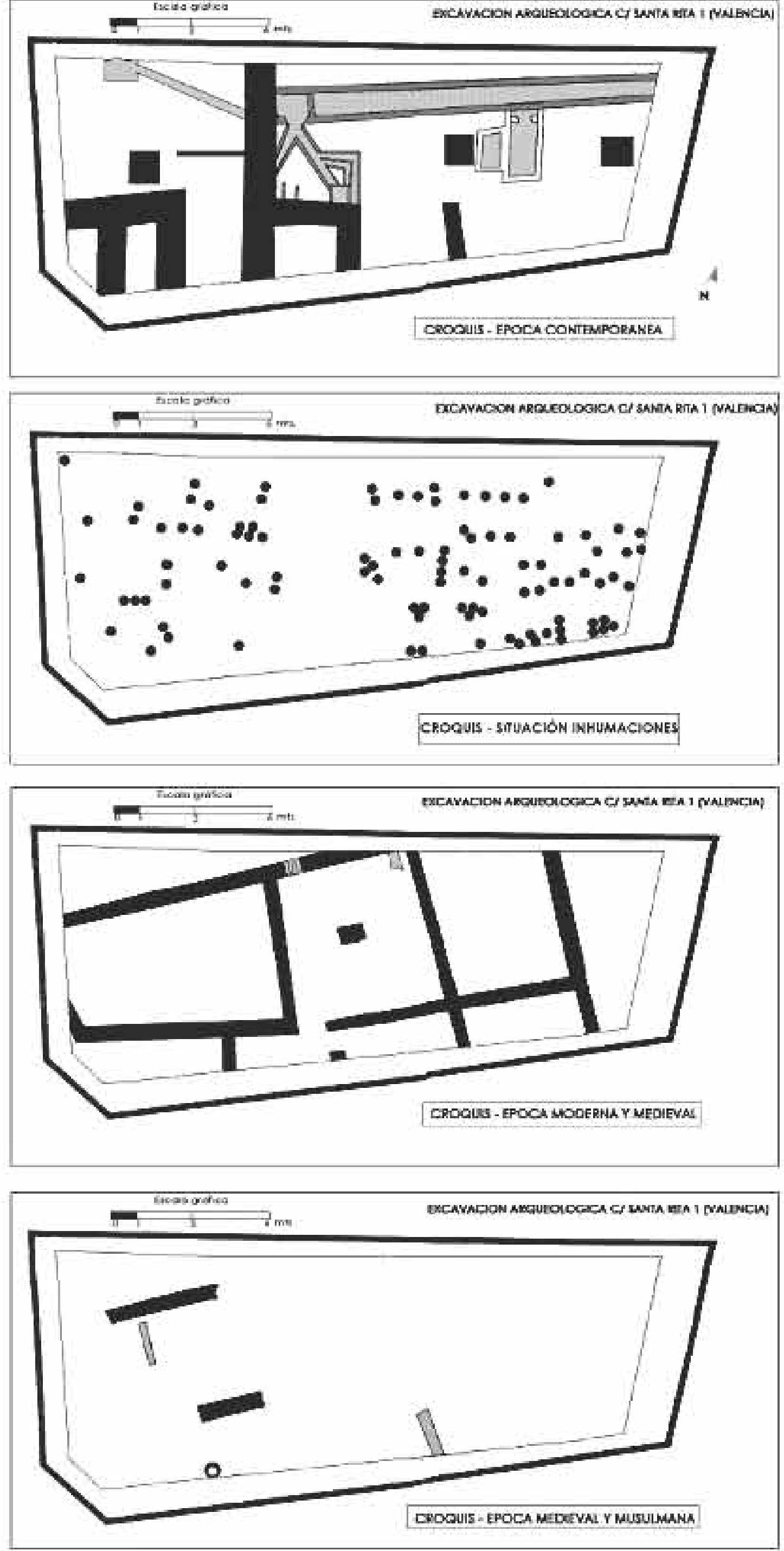

LAMINA II 


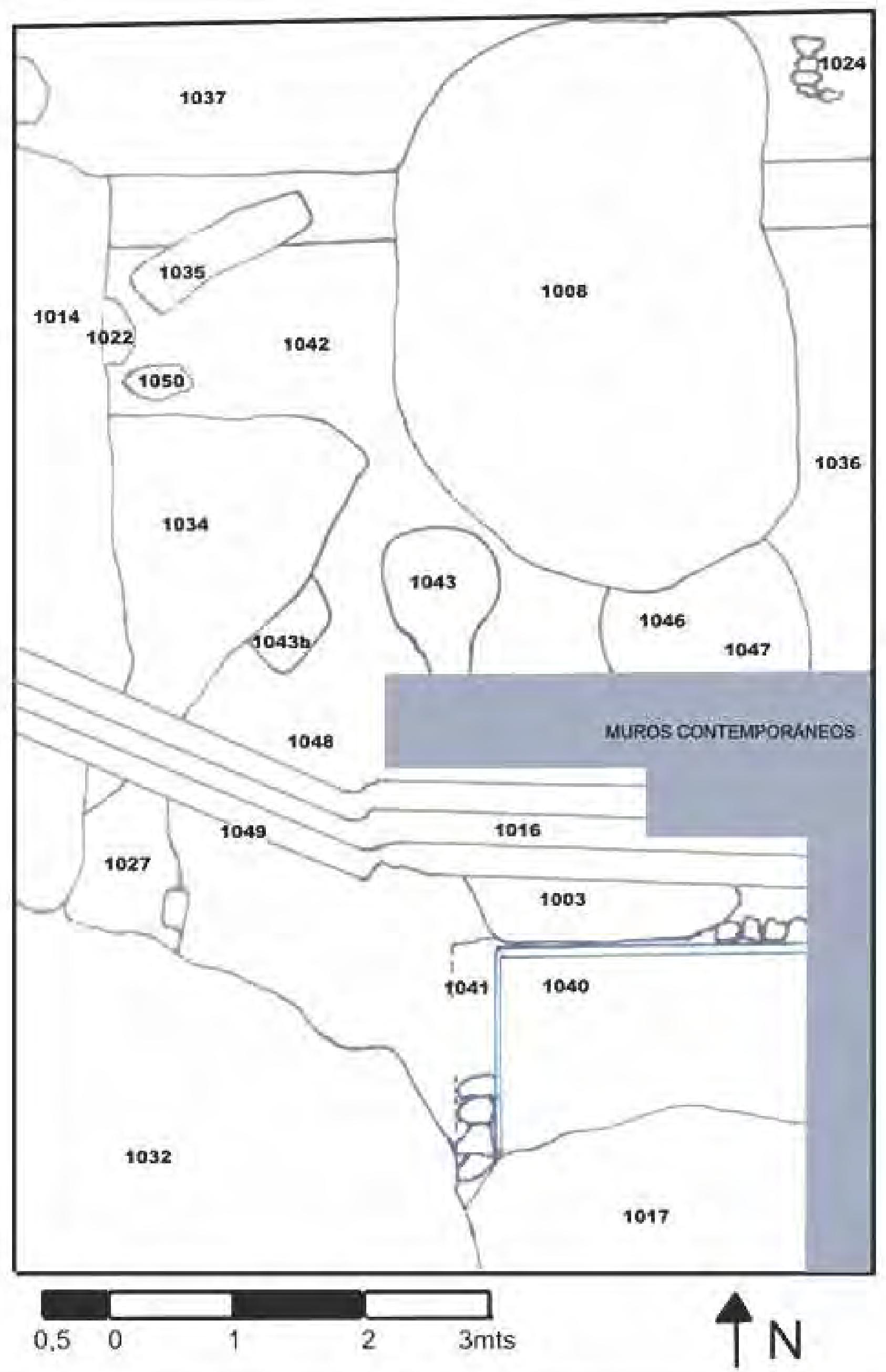

EXCAVACION ARQUEOLOGICA CALLE SERRANOS, 26 - VALENCIA 


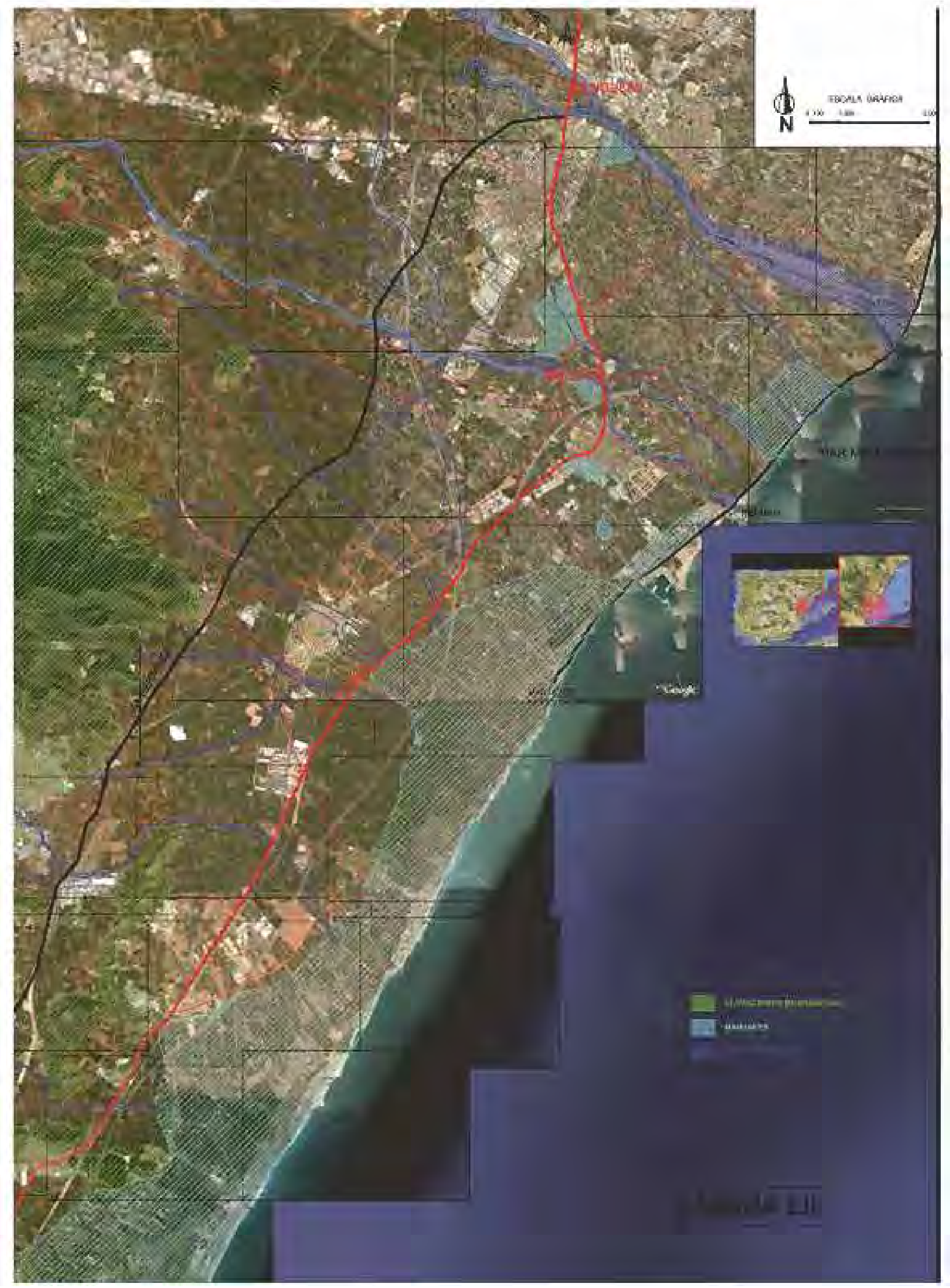




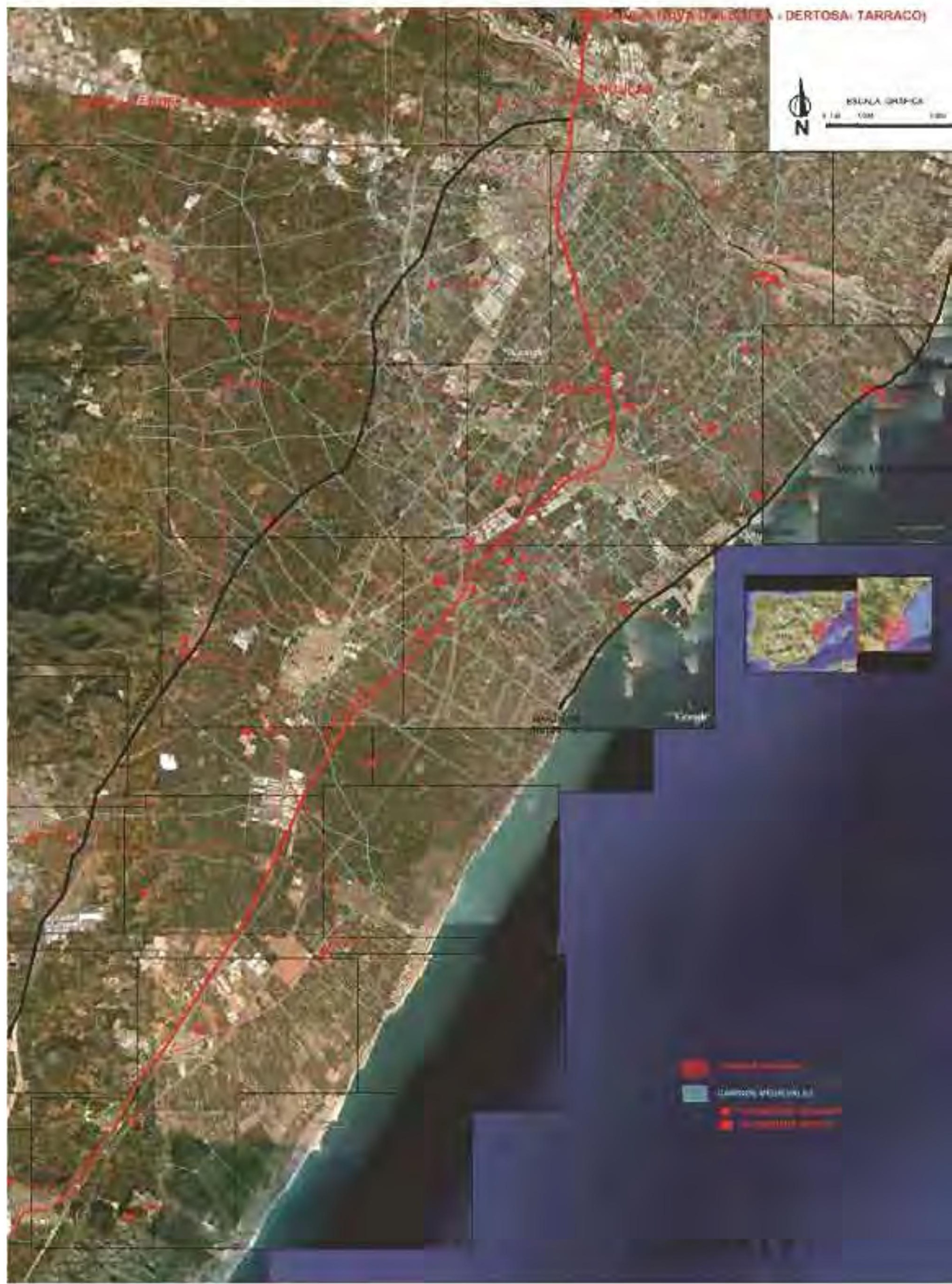




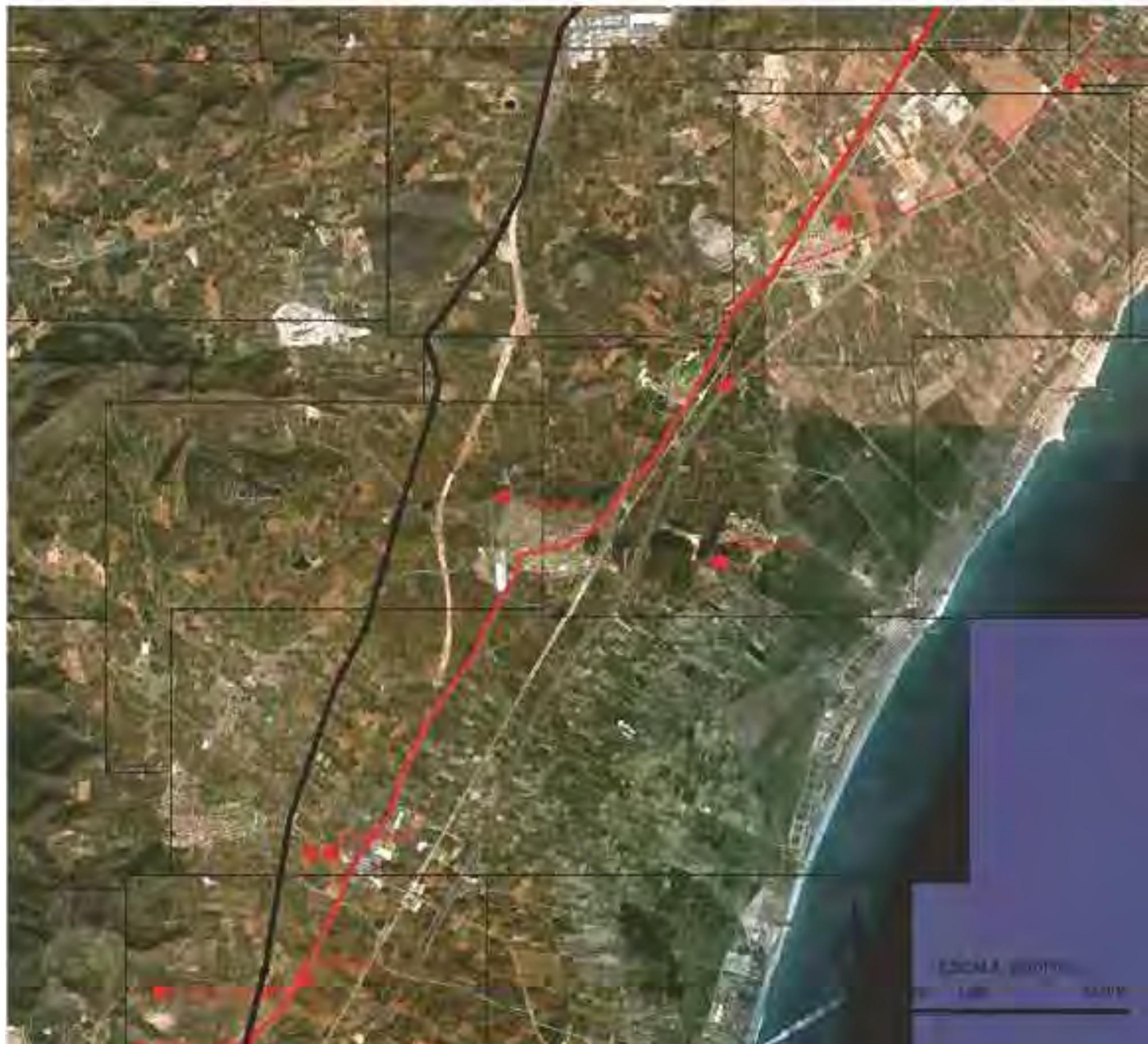

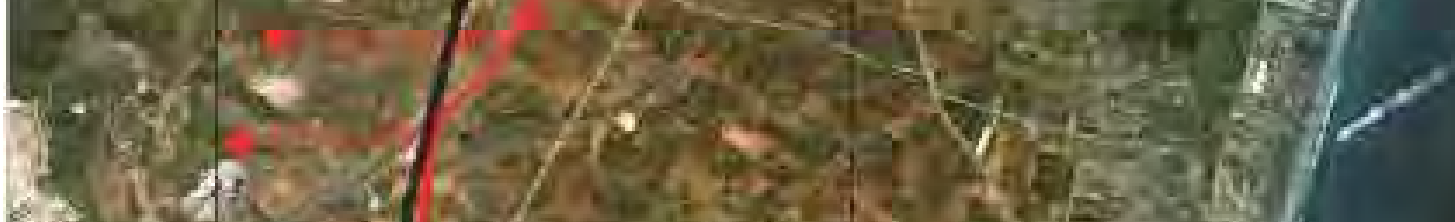

$7+48-1=2 x+3=0$

x. $4(x+2)$

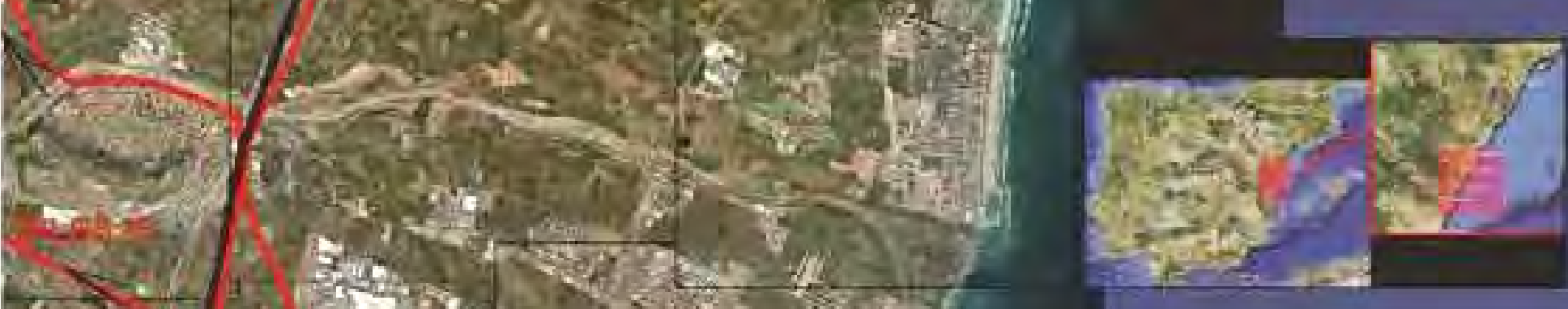

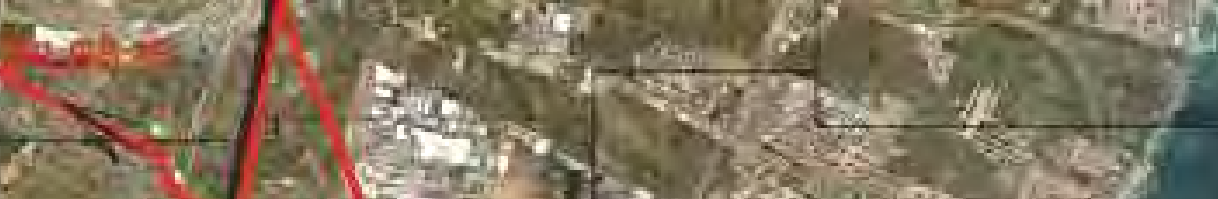

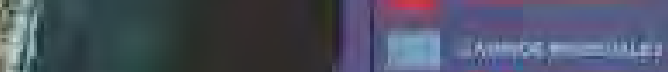

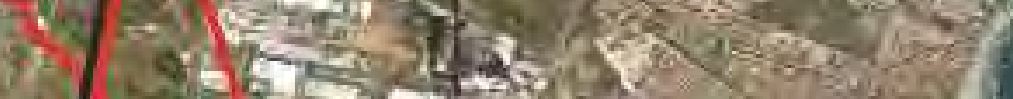

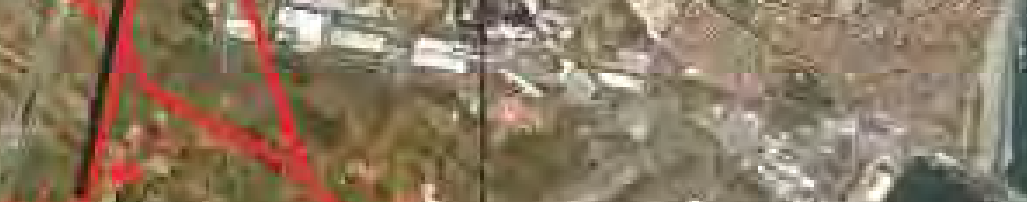

LAMINA LVT 


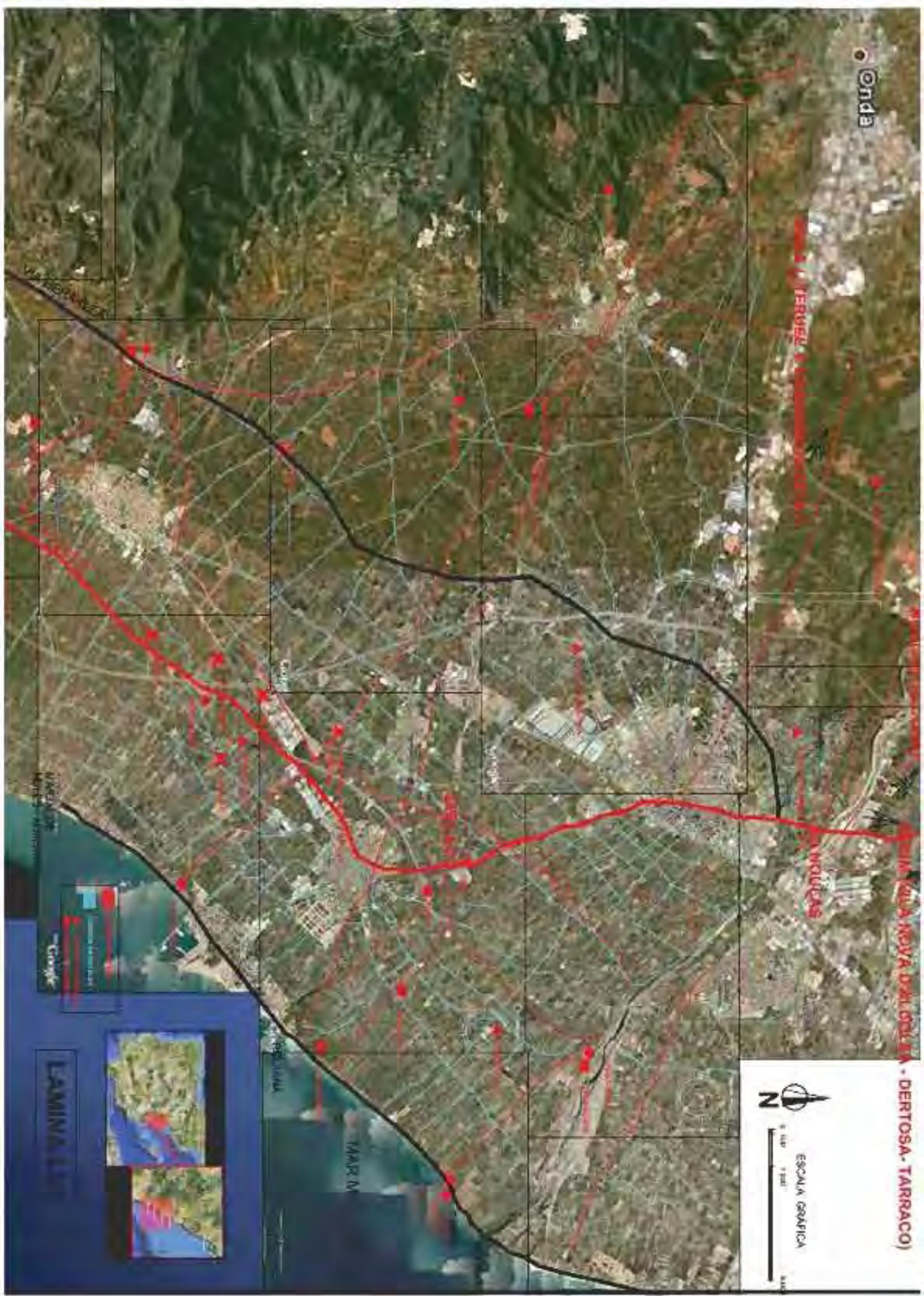




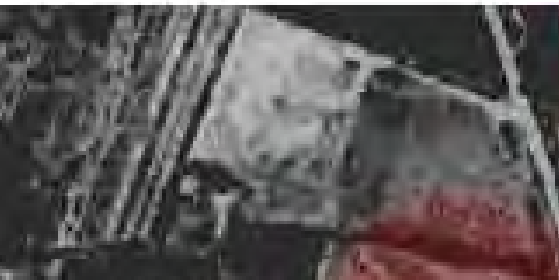

Necrópolis iberica
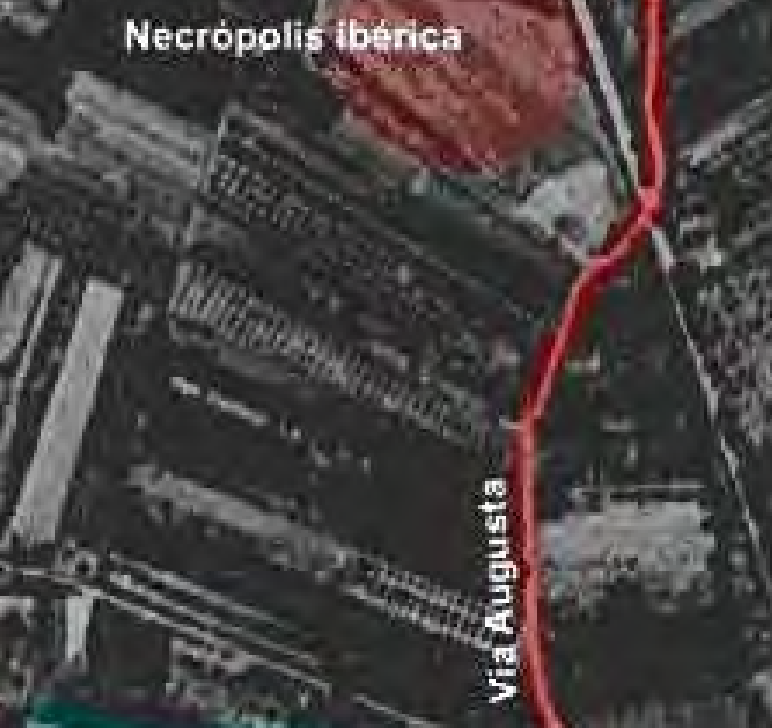

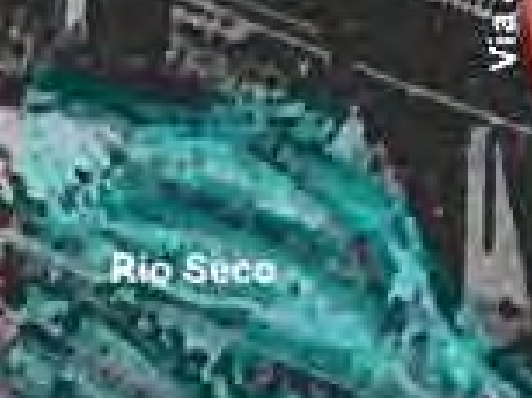

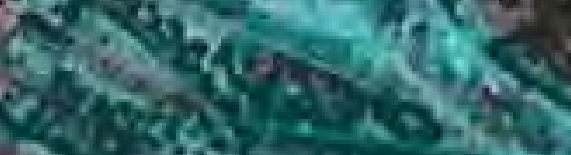

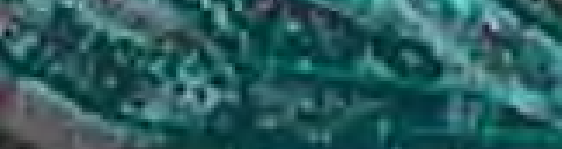

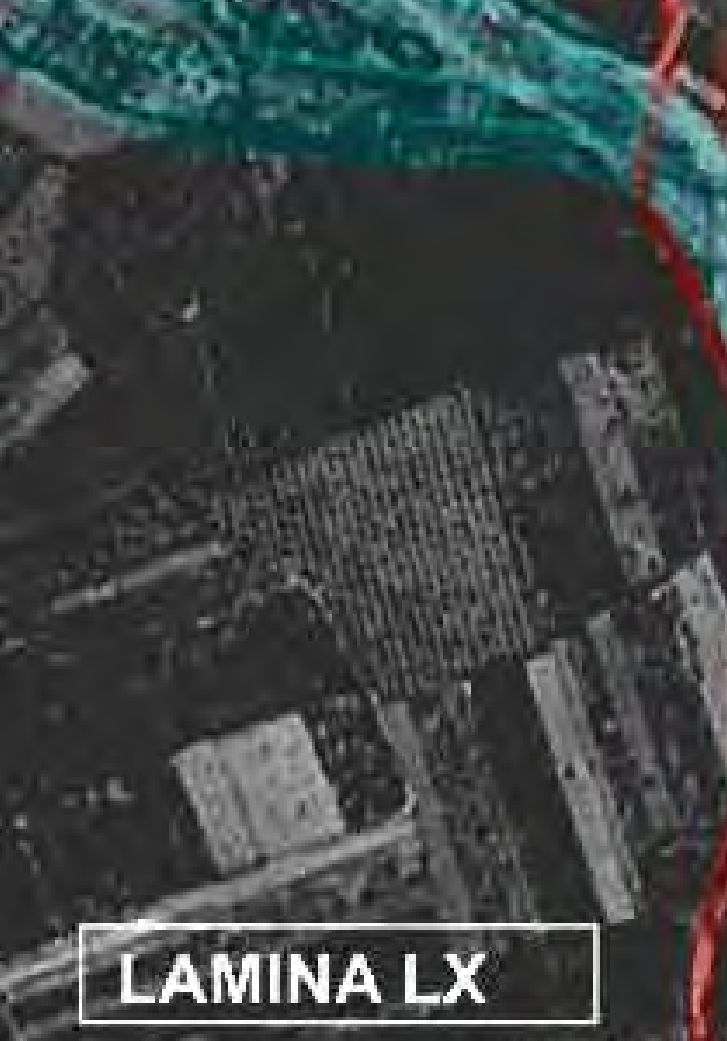

LAMINA LX

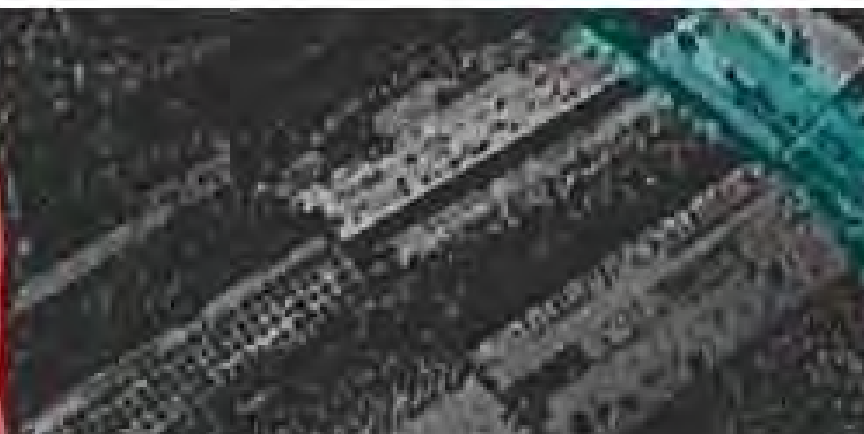




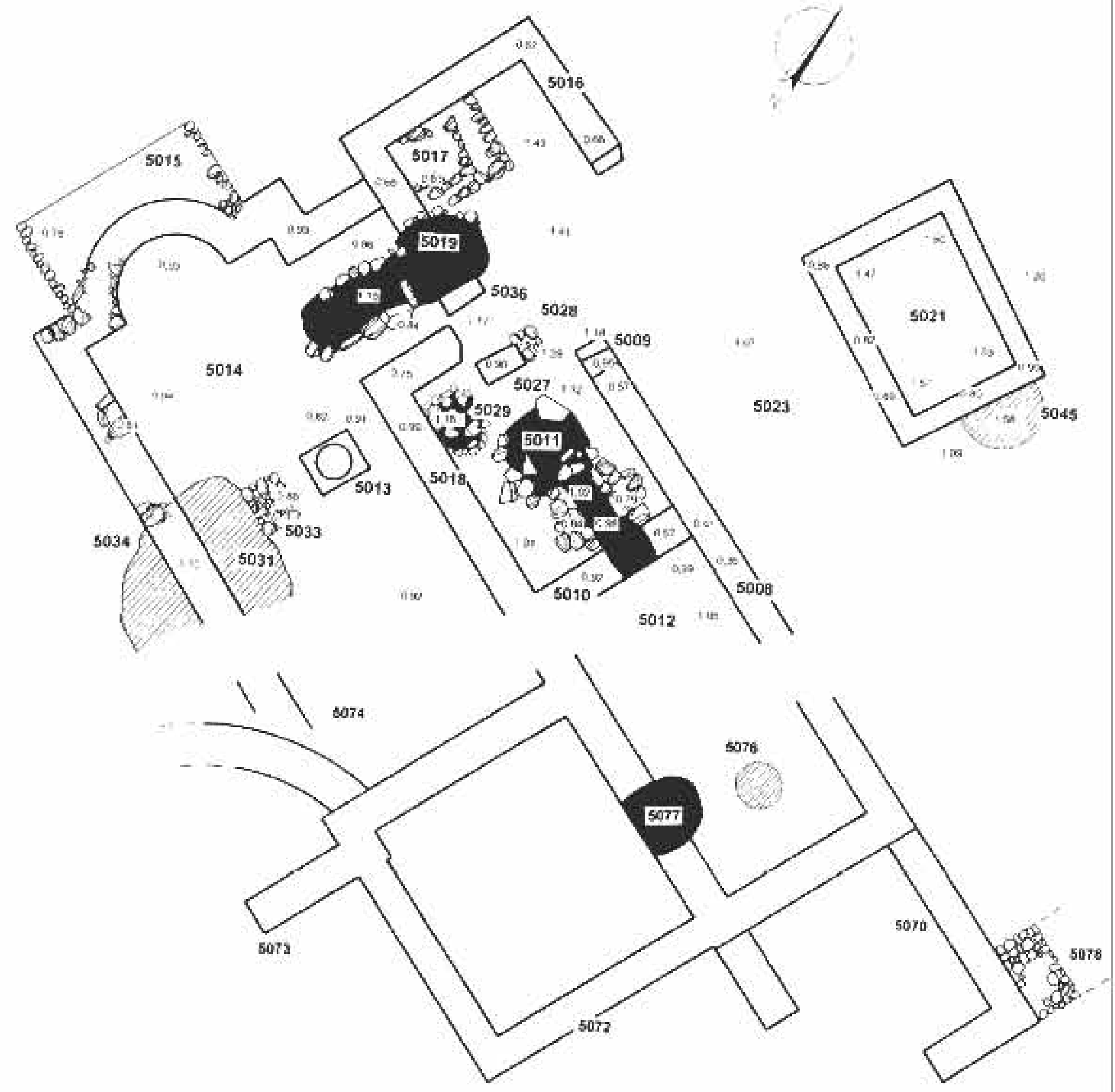

ESCALAGRAFICA

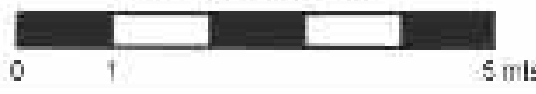


SECCIONES SONDEO S GRAO DE CASTELLION - PT JOL DE GASSET

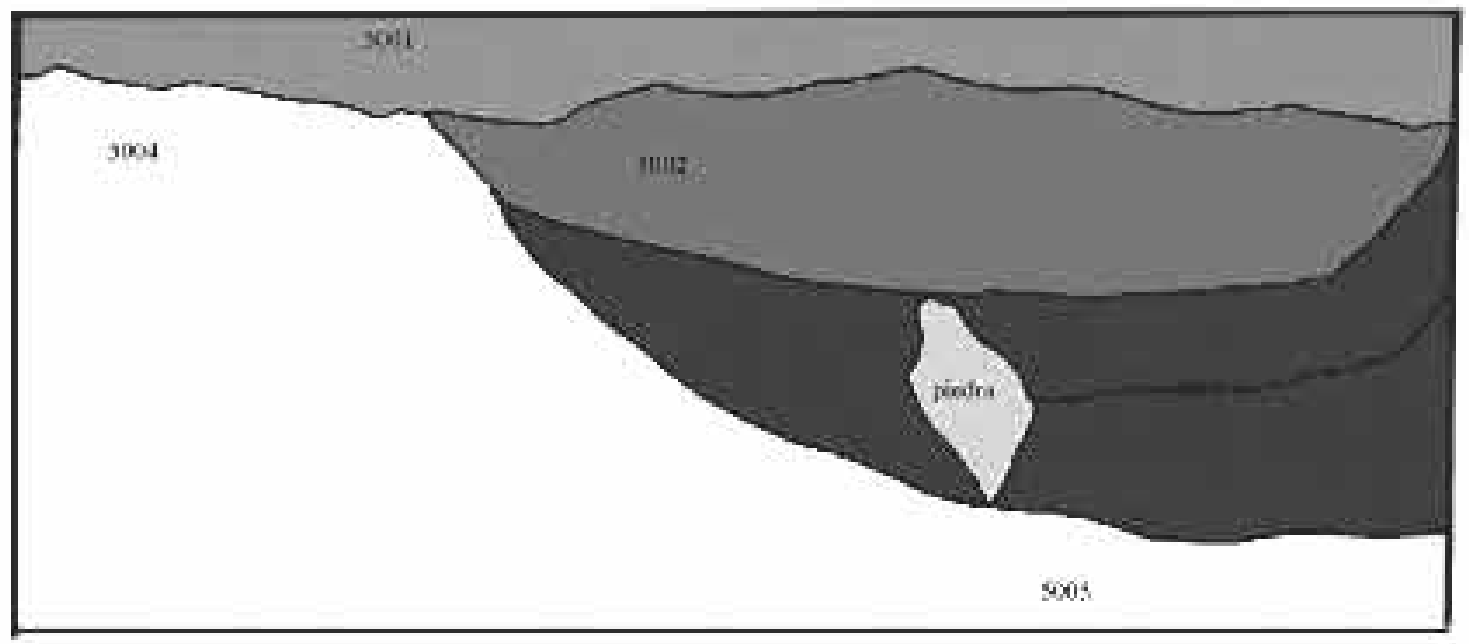

LADO ESTE
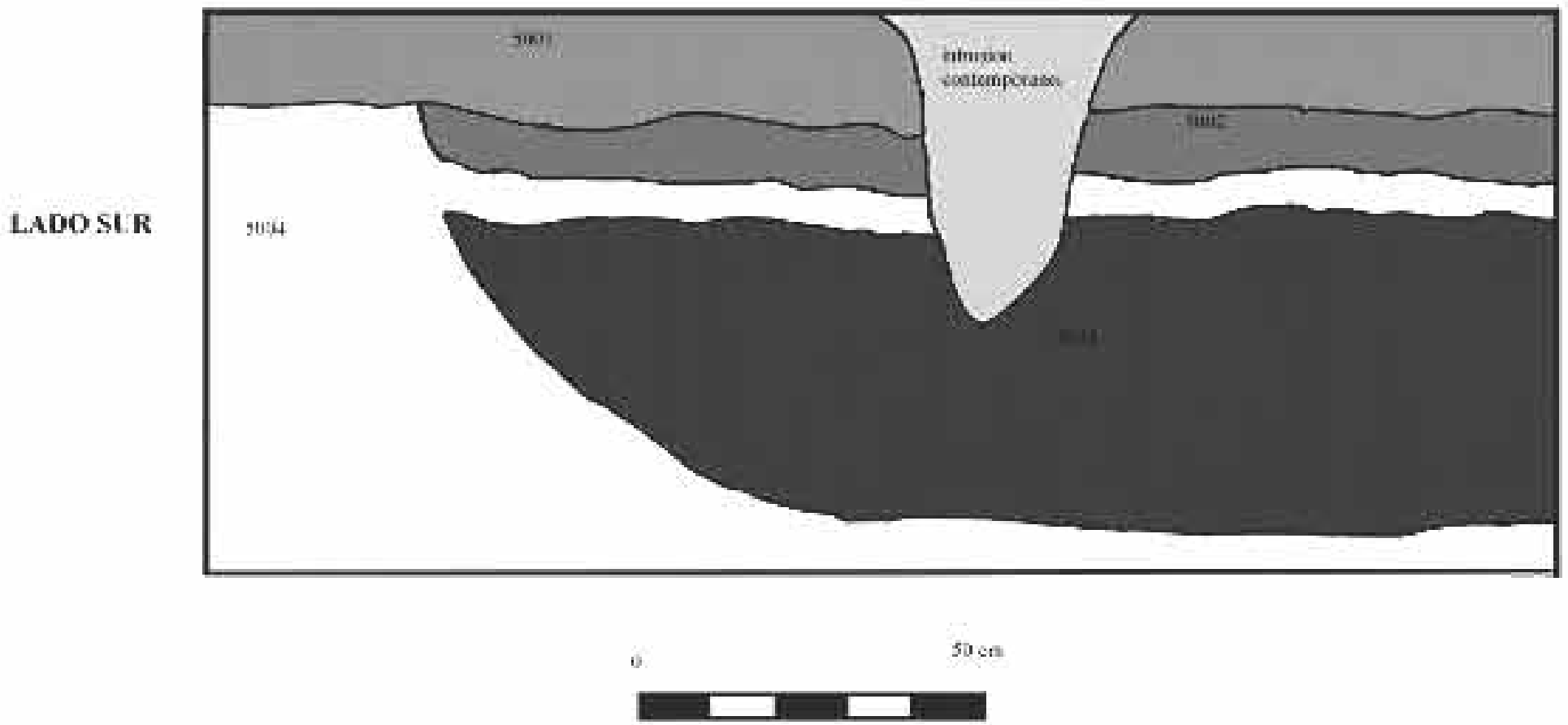


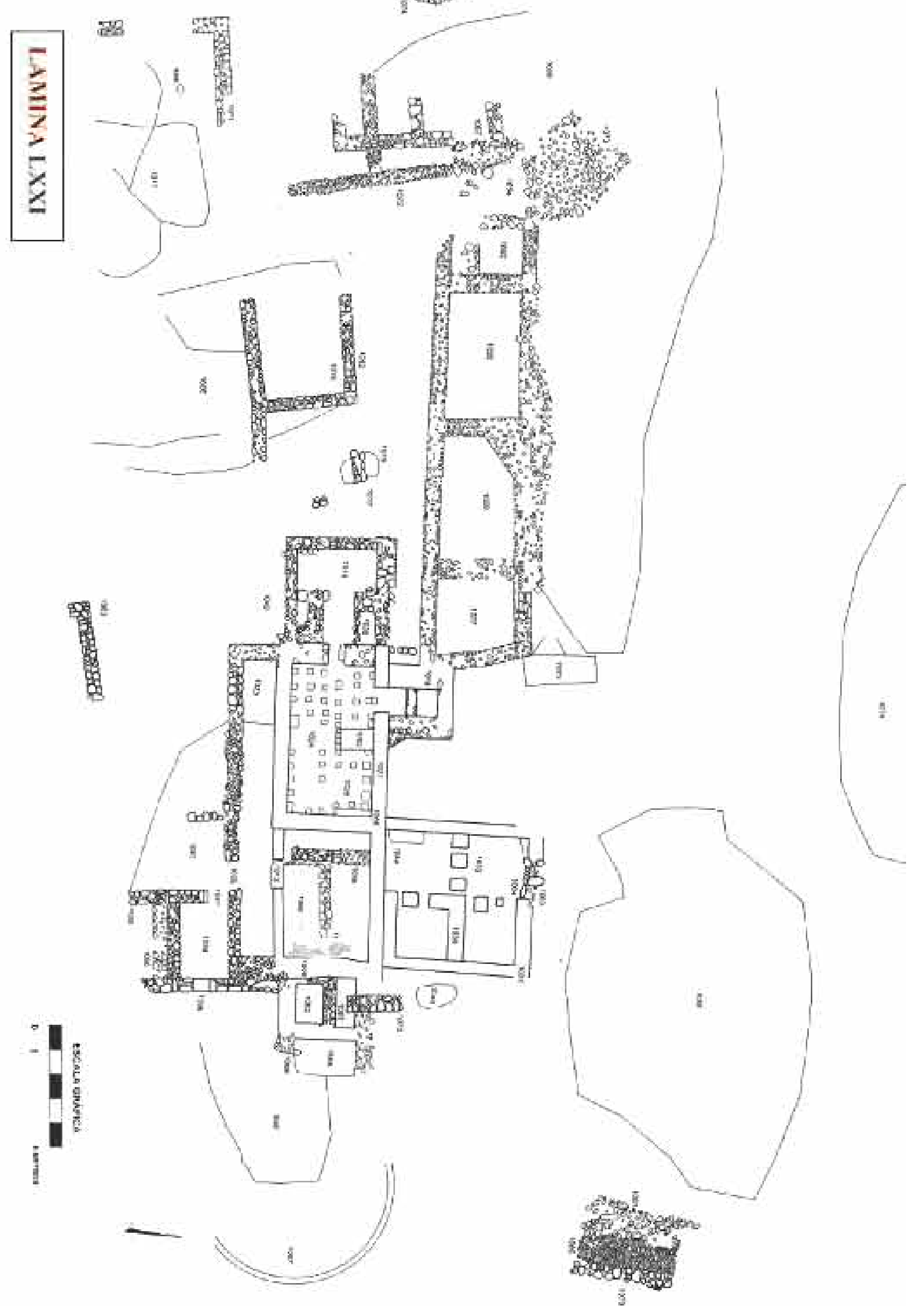




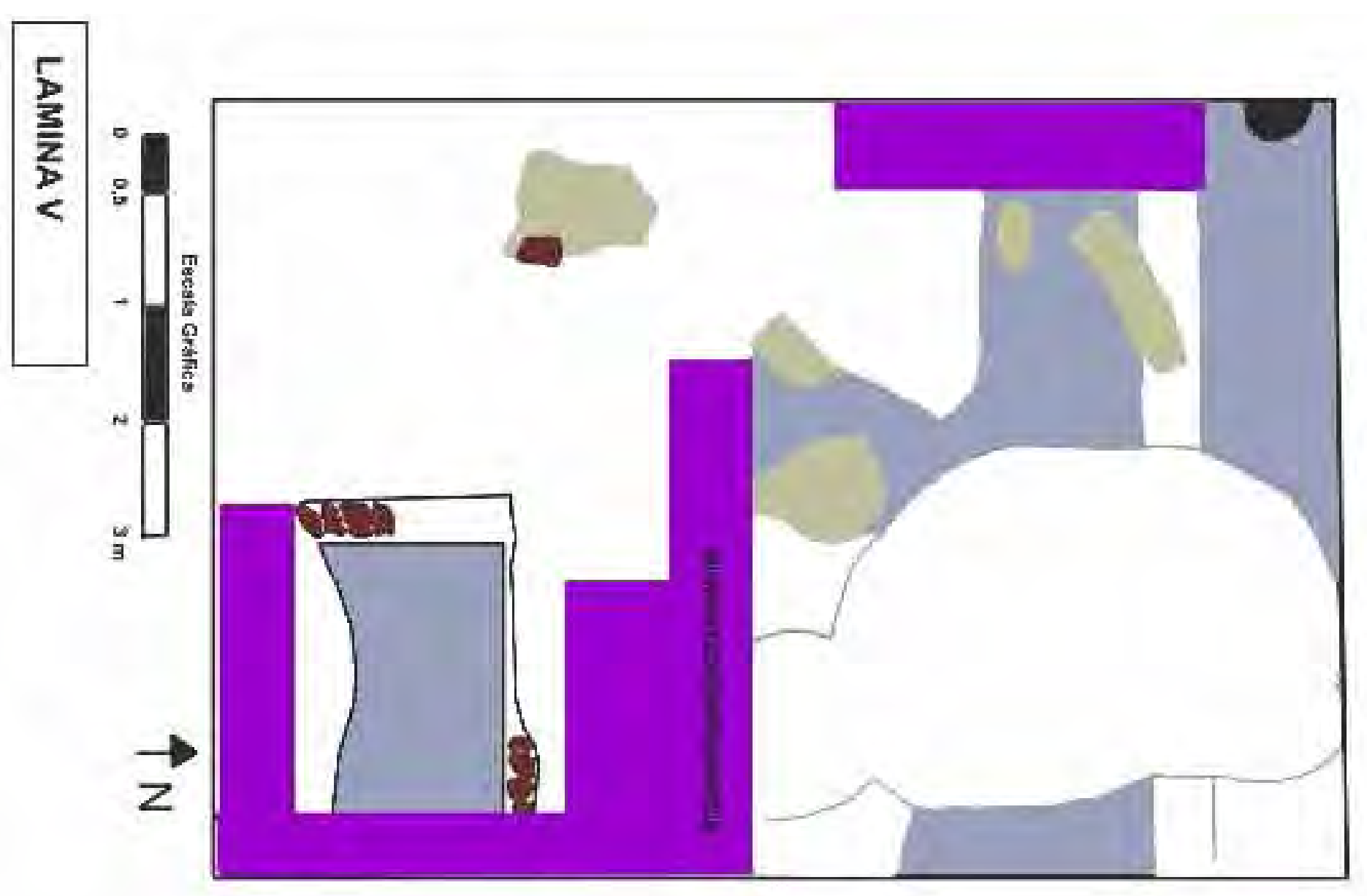

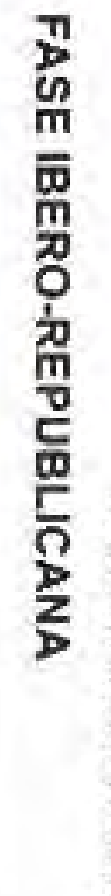

2

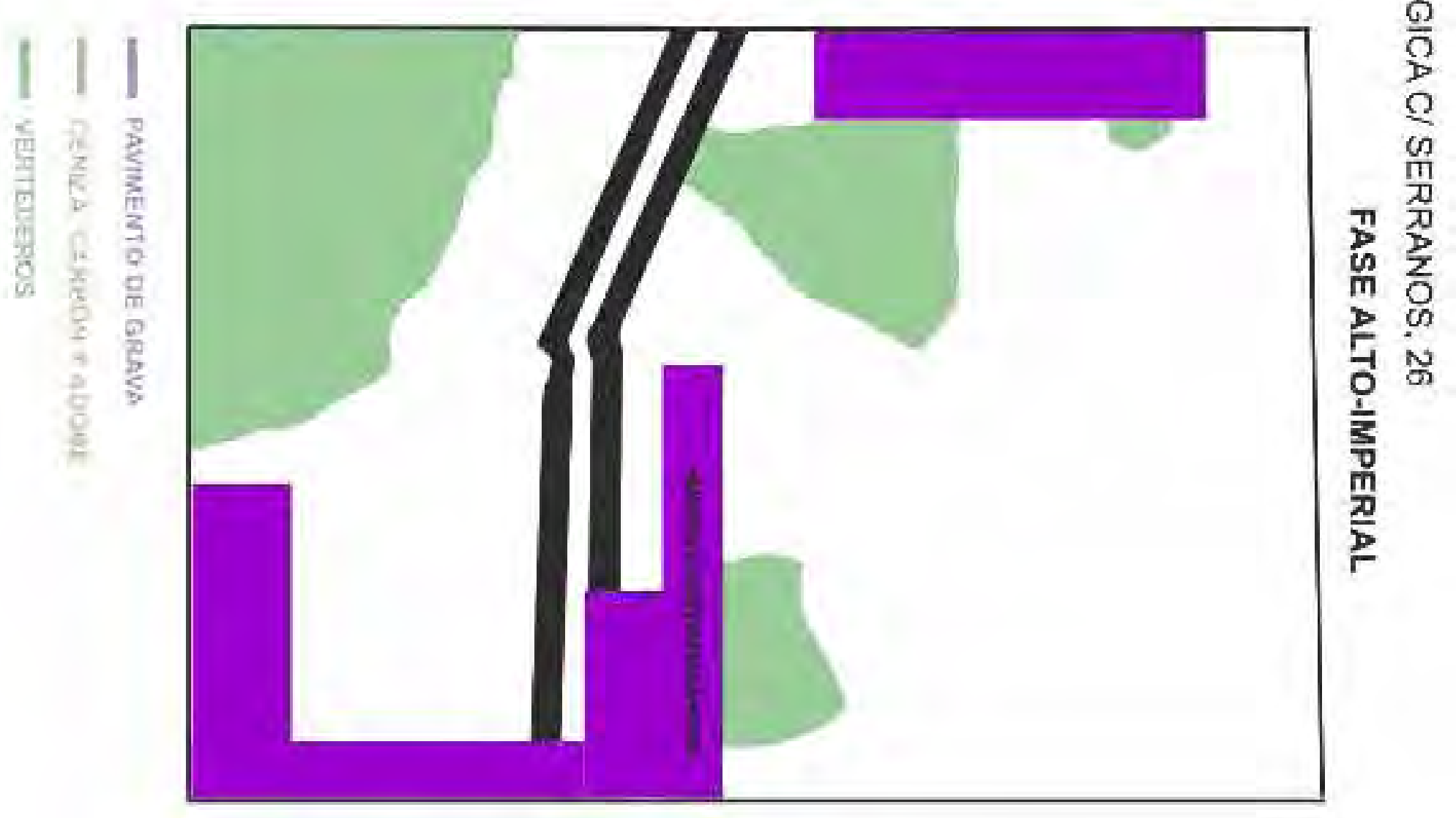



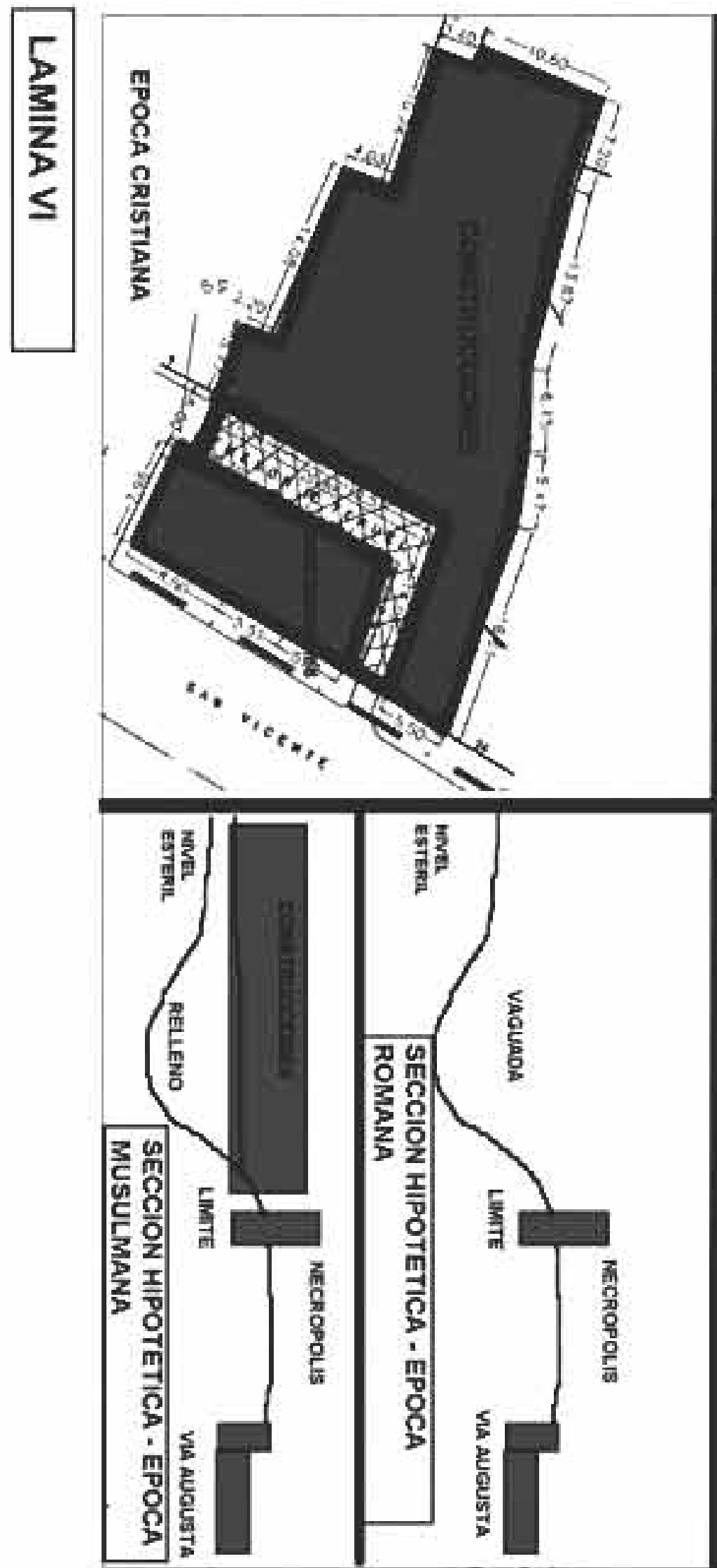
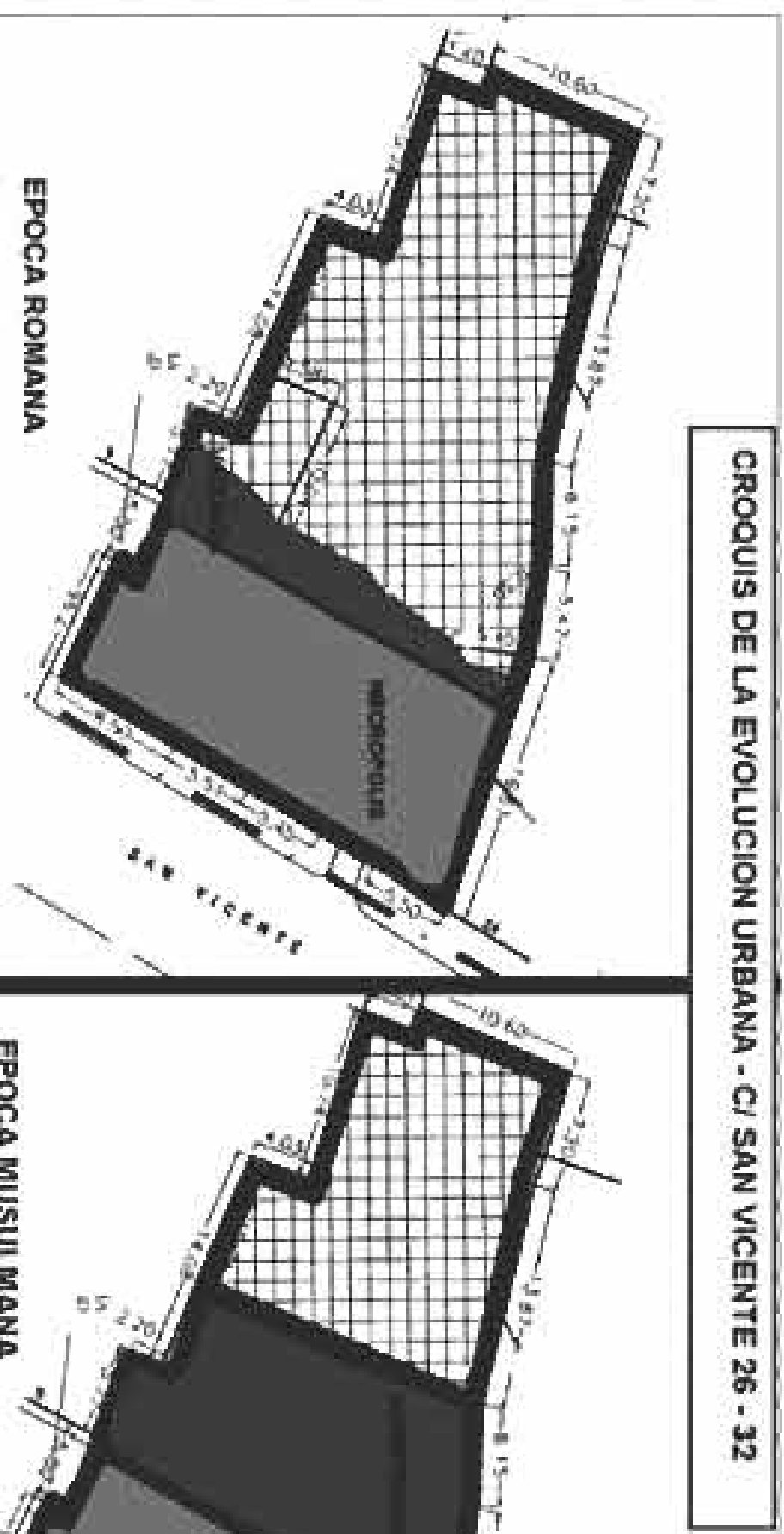


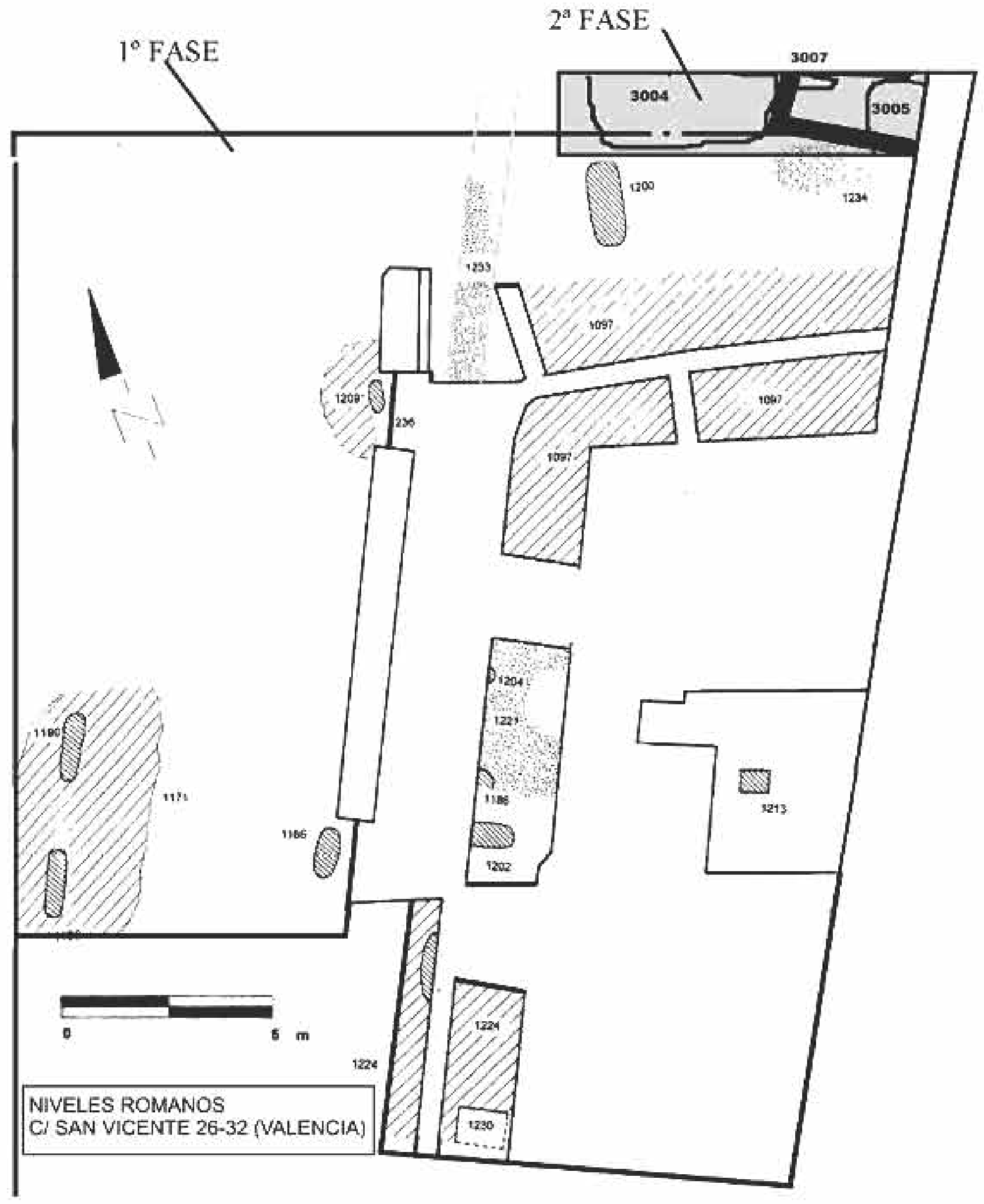

\section{LAMINA VII}



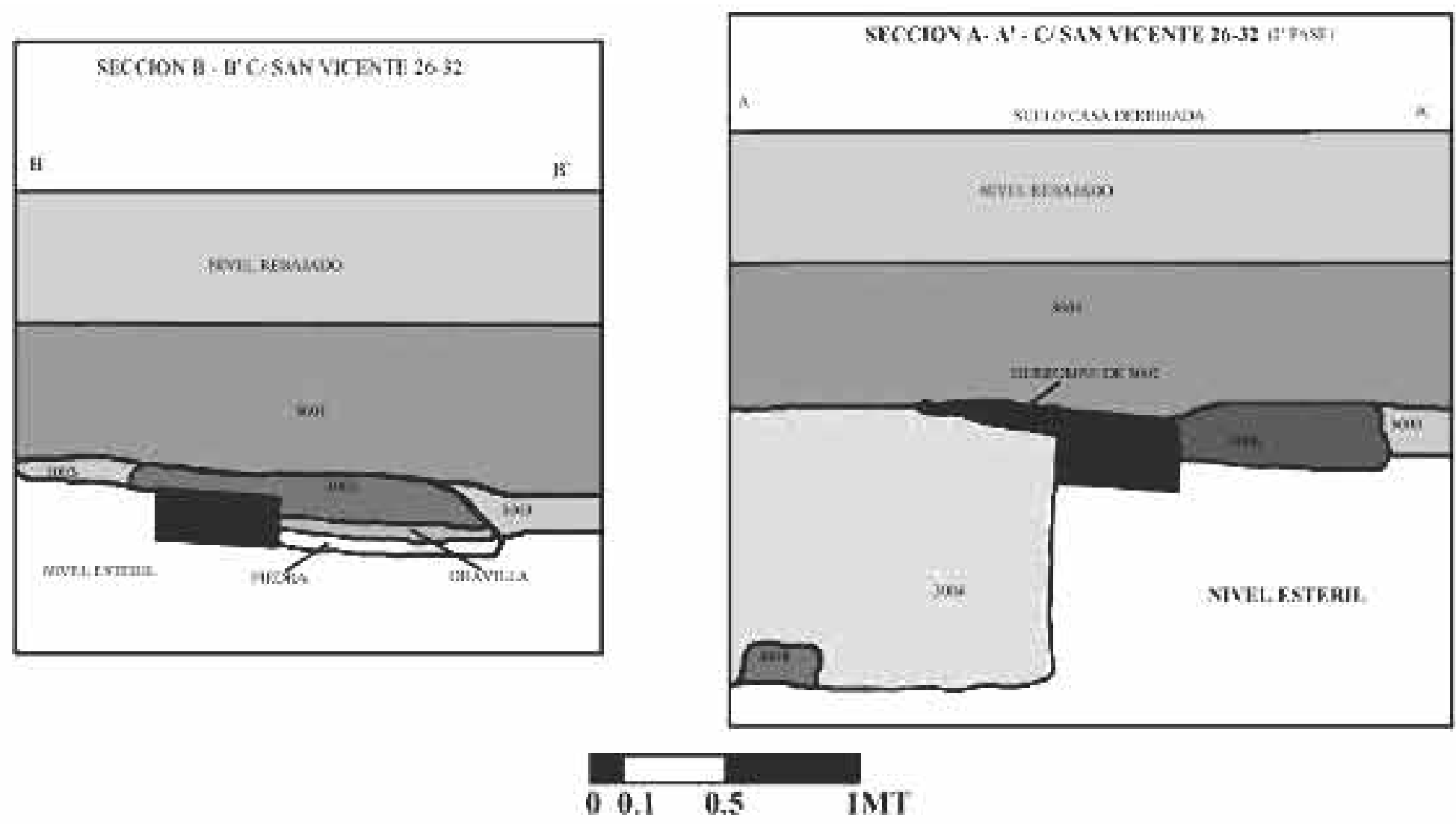

A

MI KOS PANTAILA

$\cdot A^{\prime}$

B'
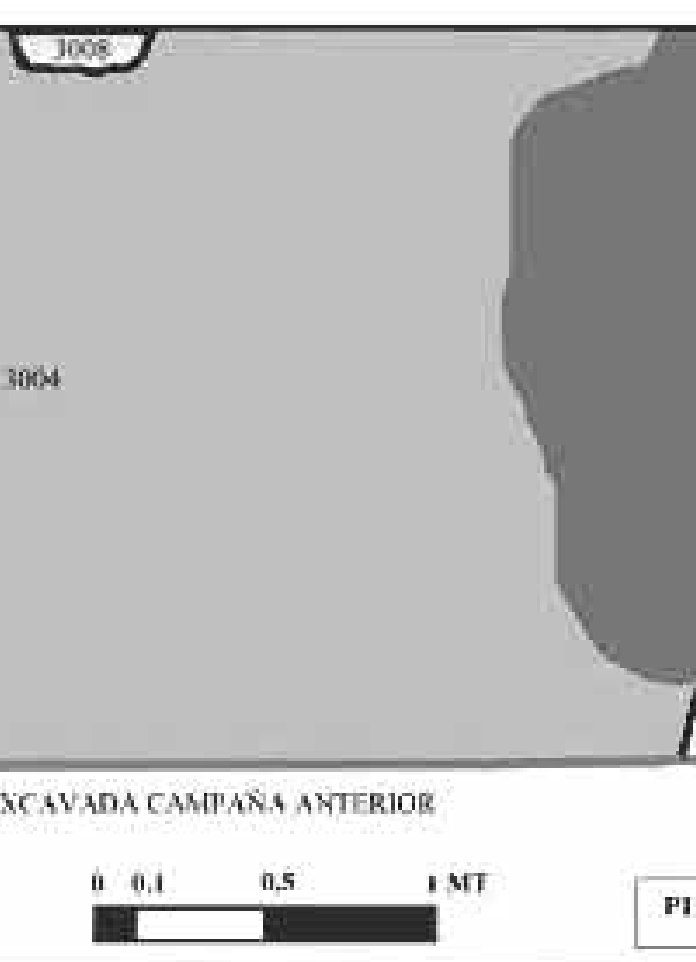

\section{LAMINA VIII}




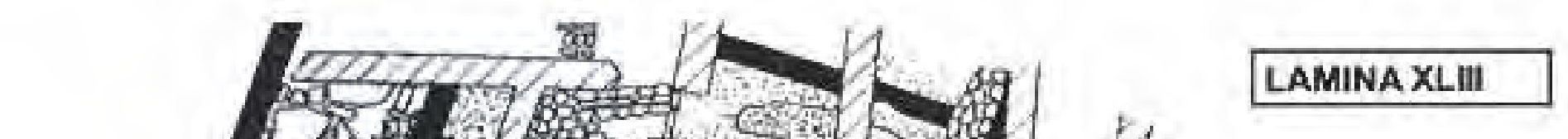




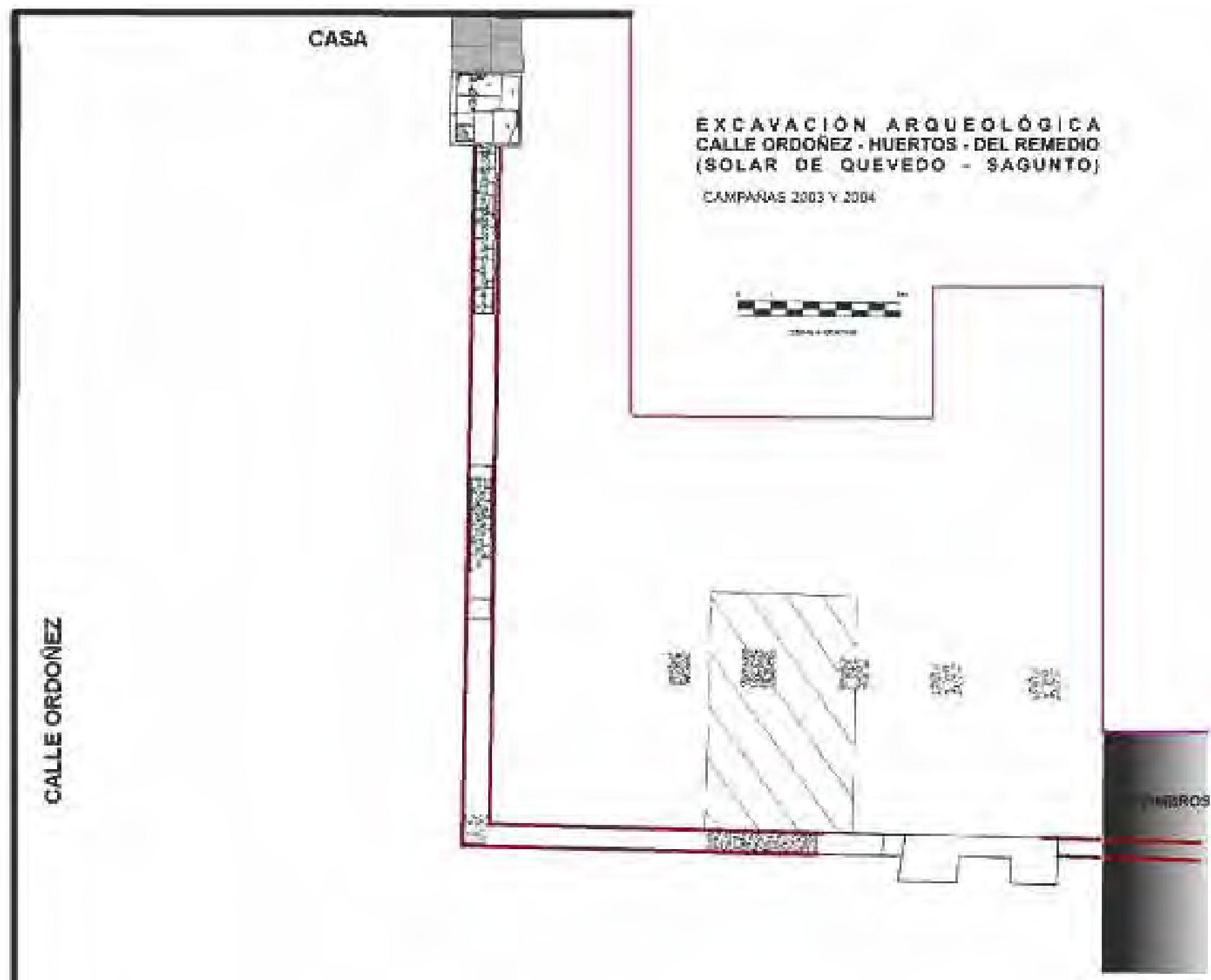




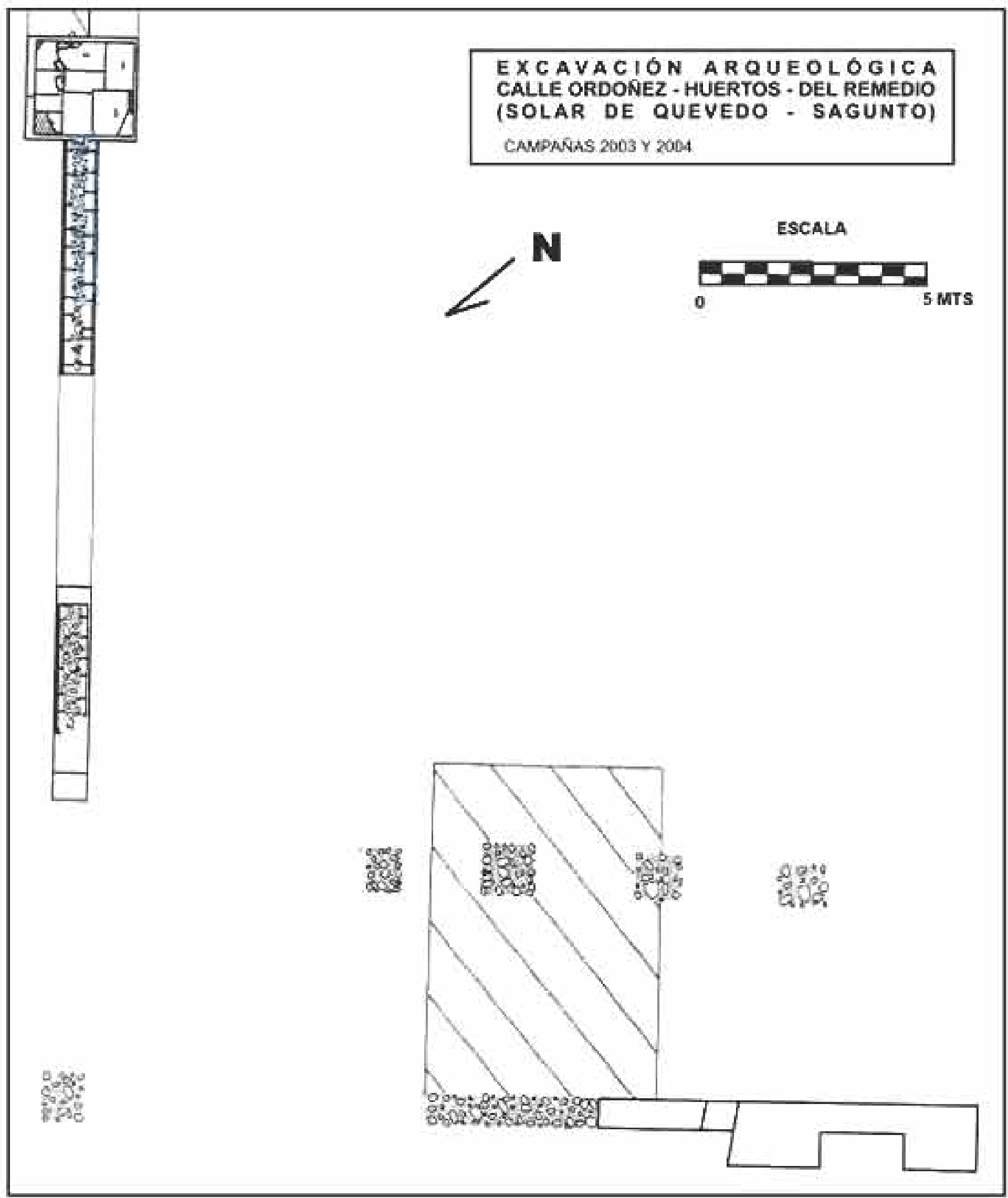

LAMINA XLVII 


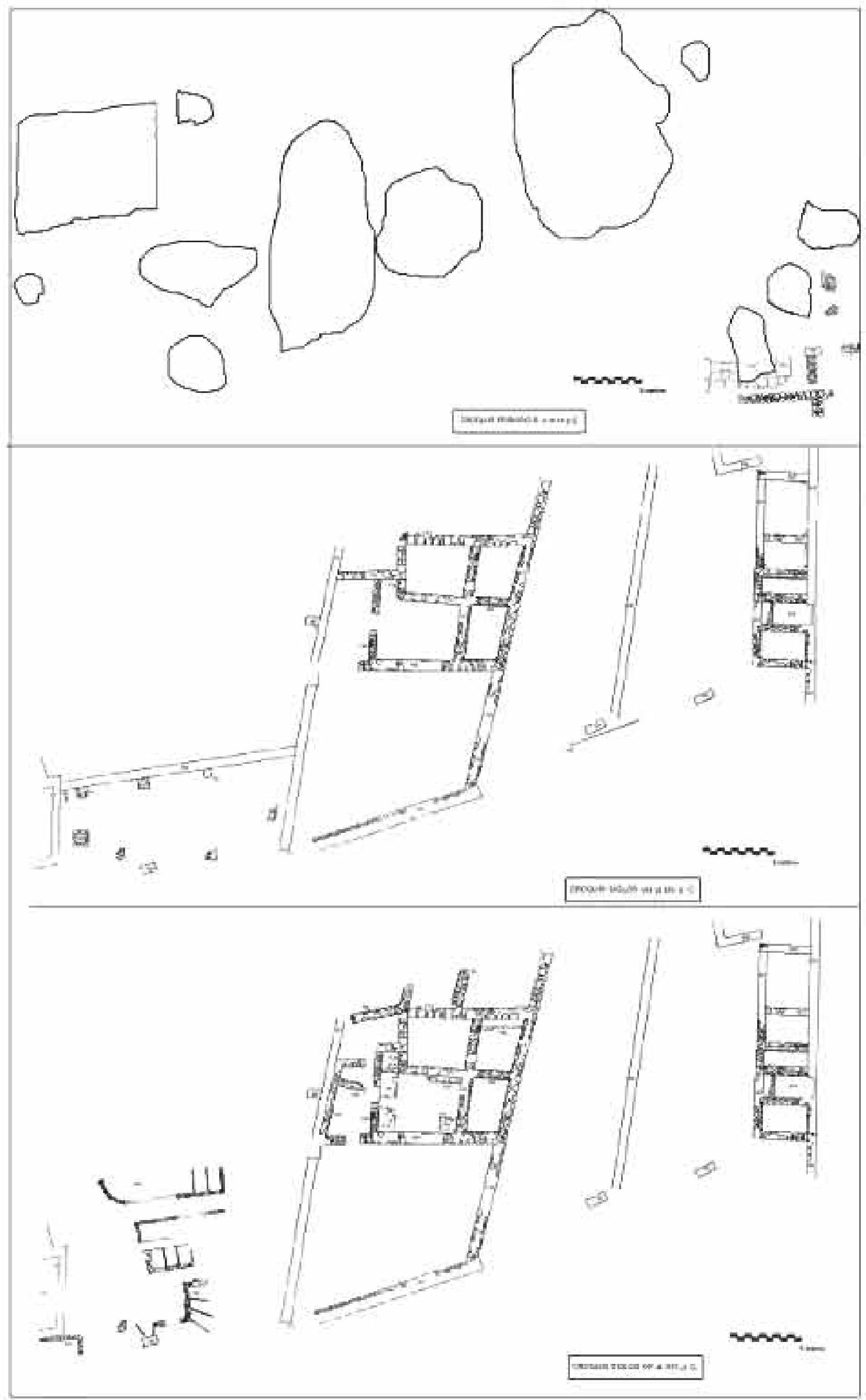




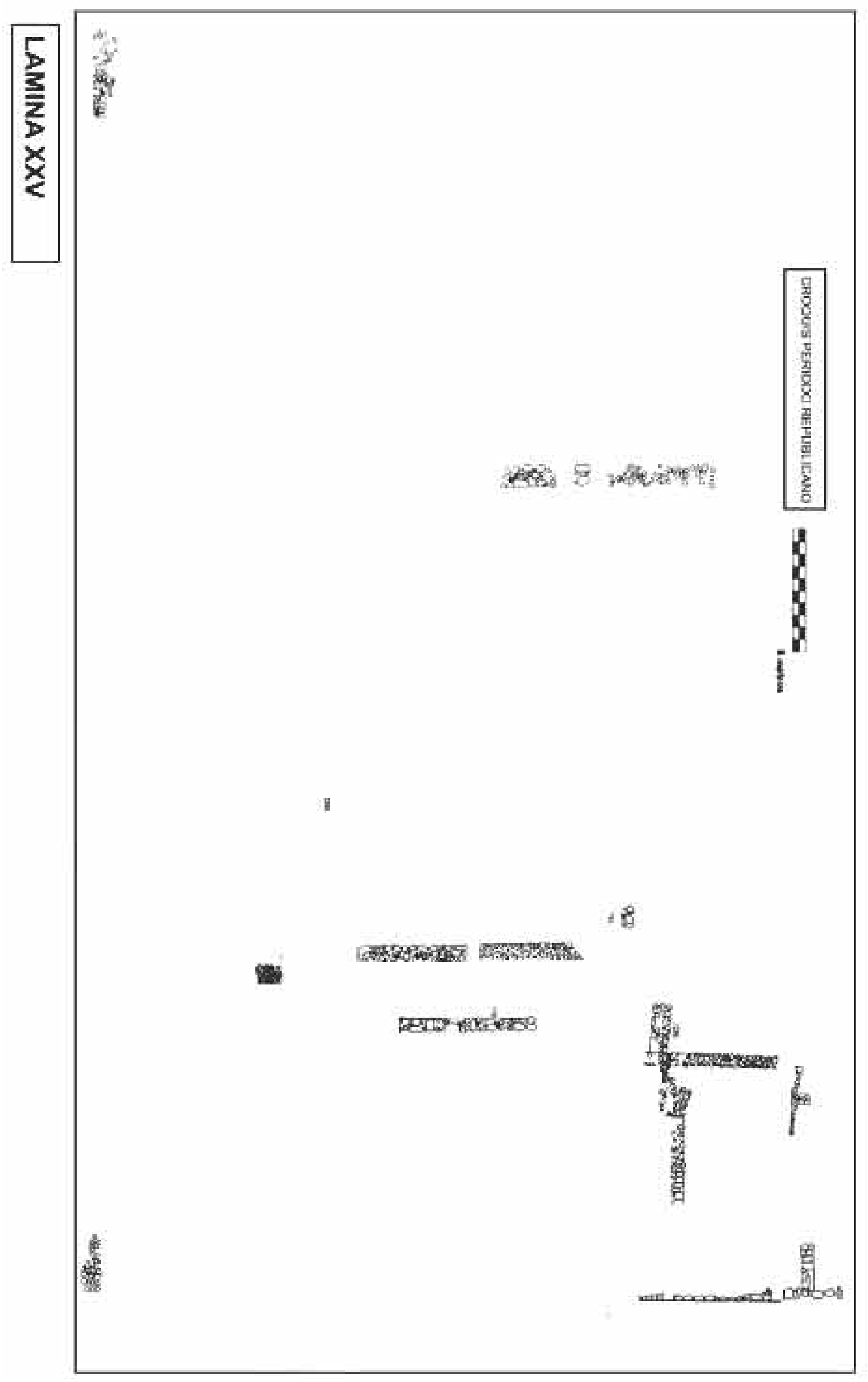




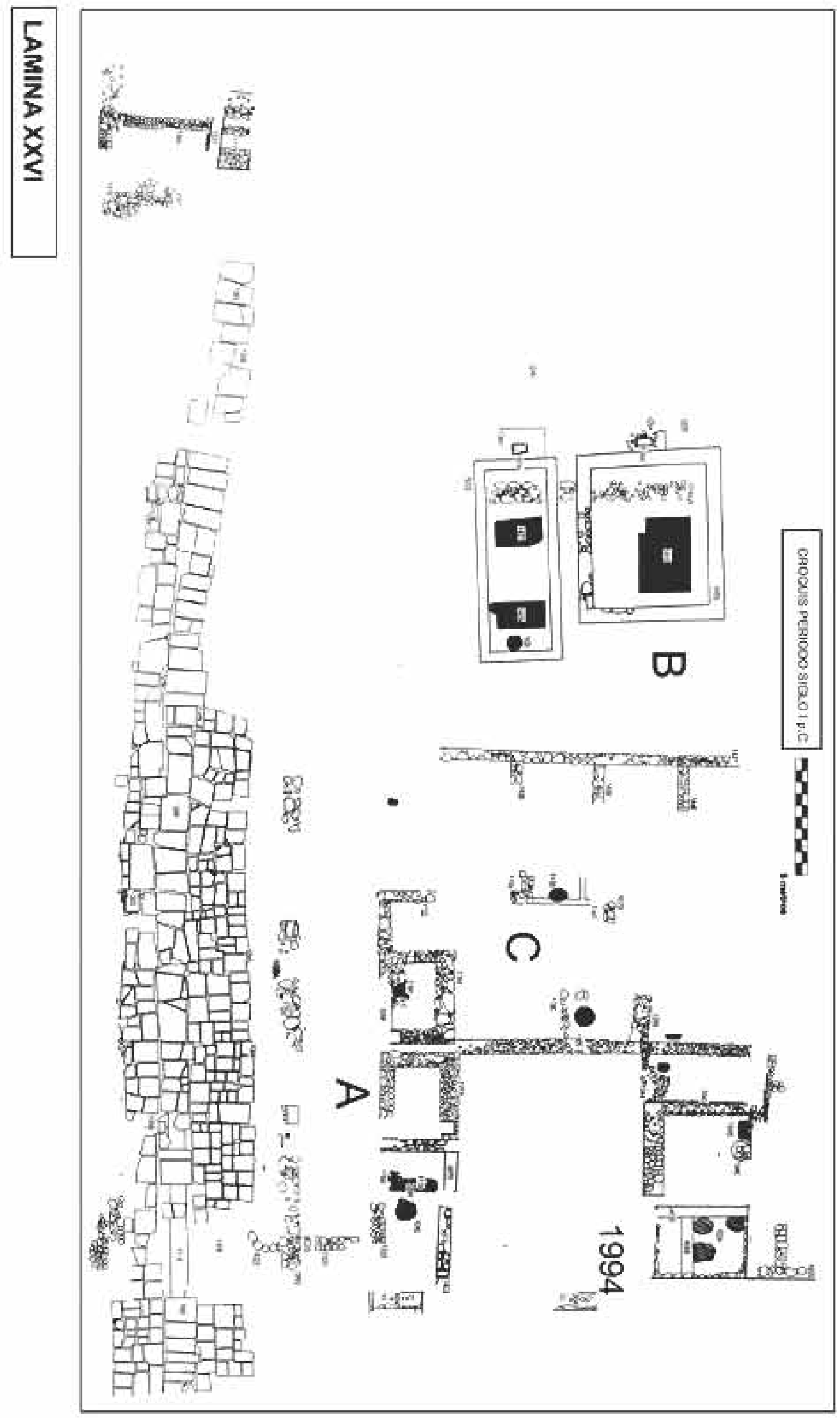




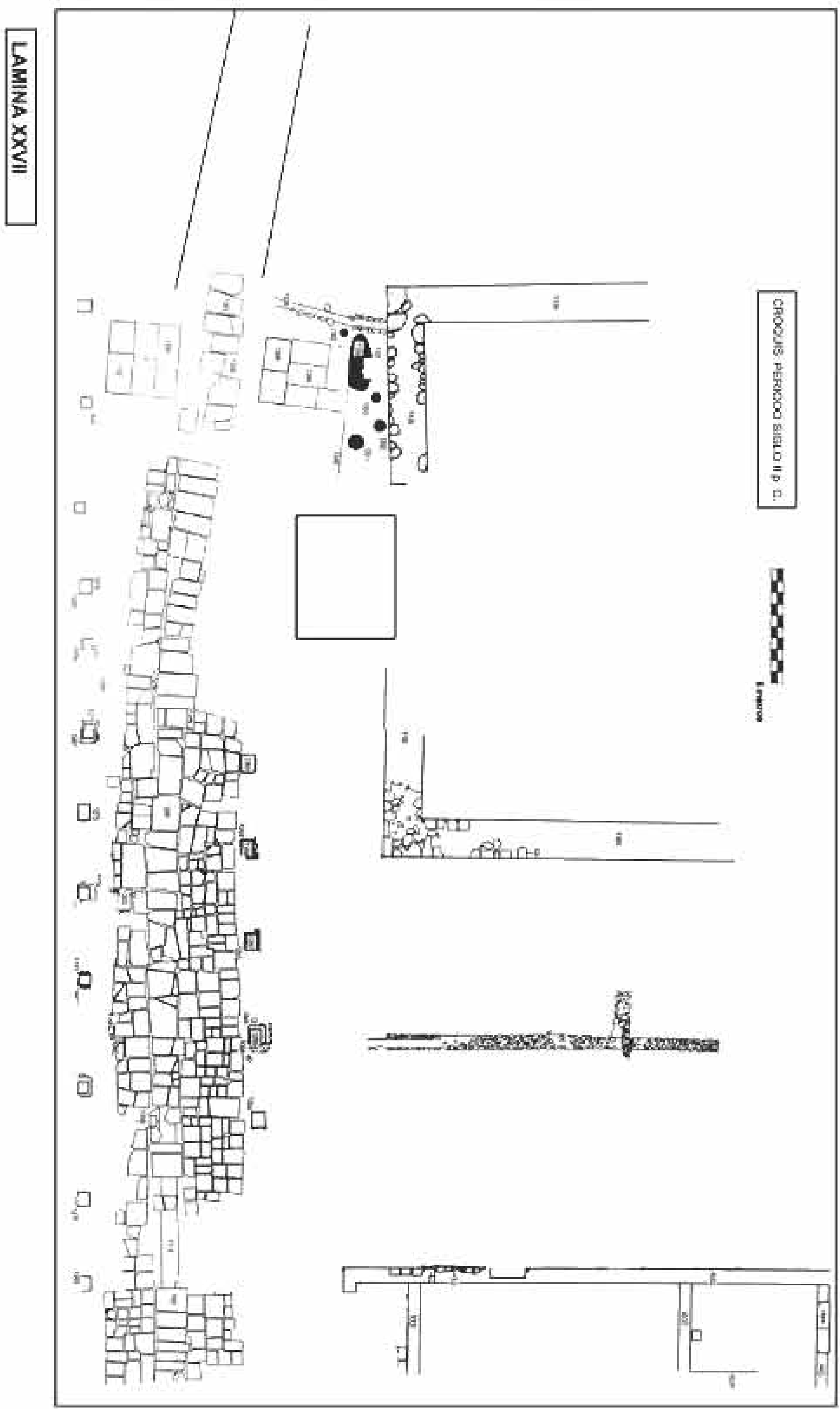




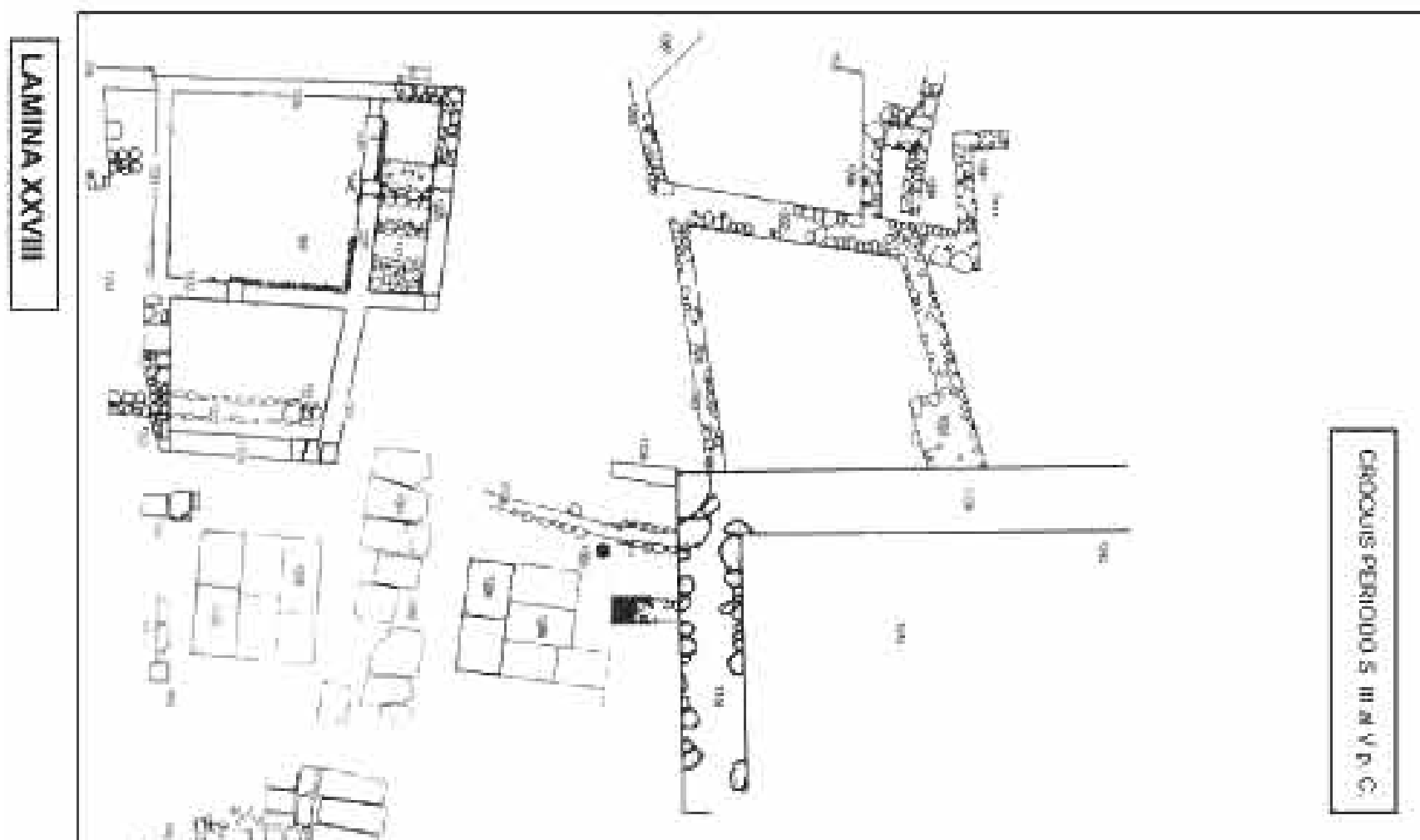

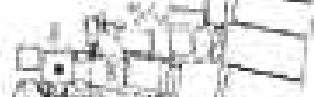

(Y). in
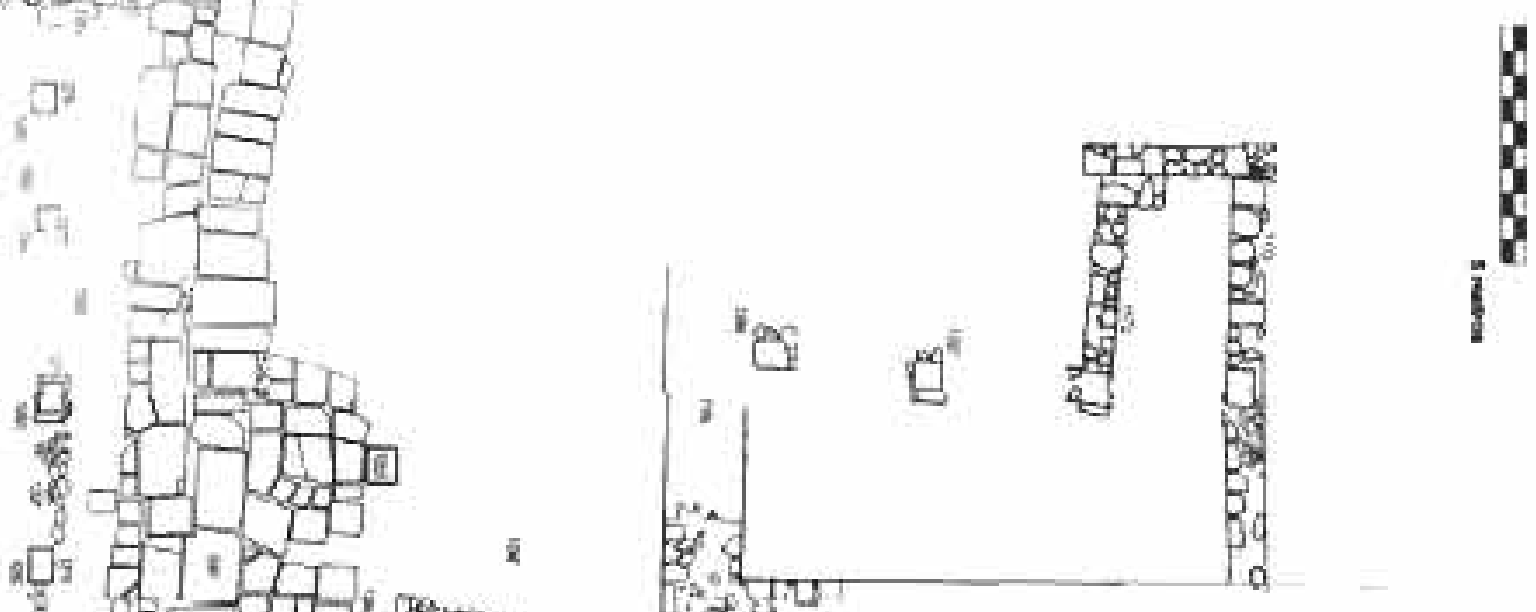

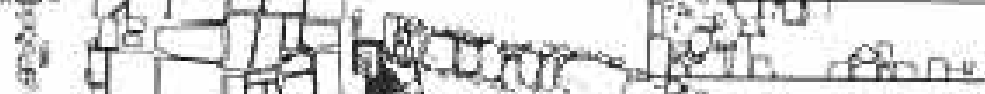

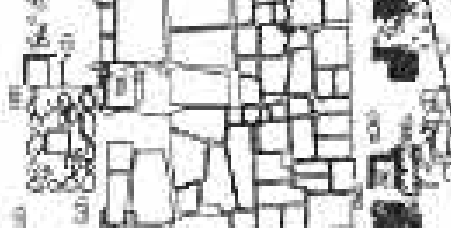

34

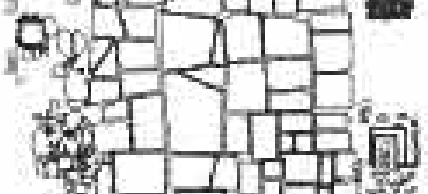

$=20 \frac{112}{2}$
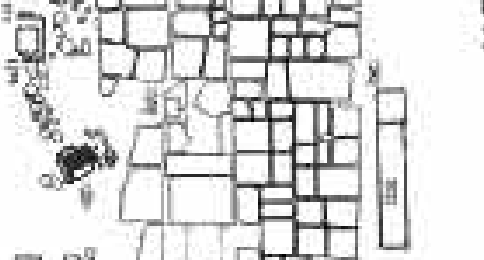

प.

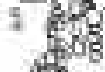

v
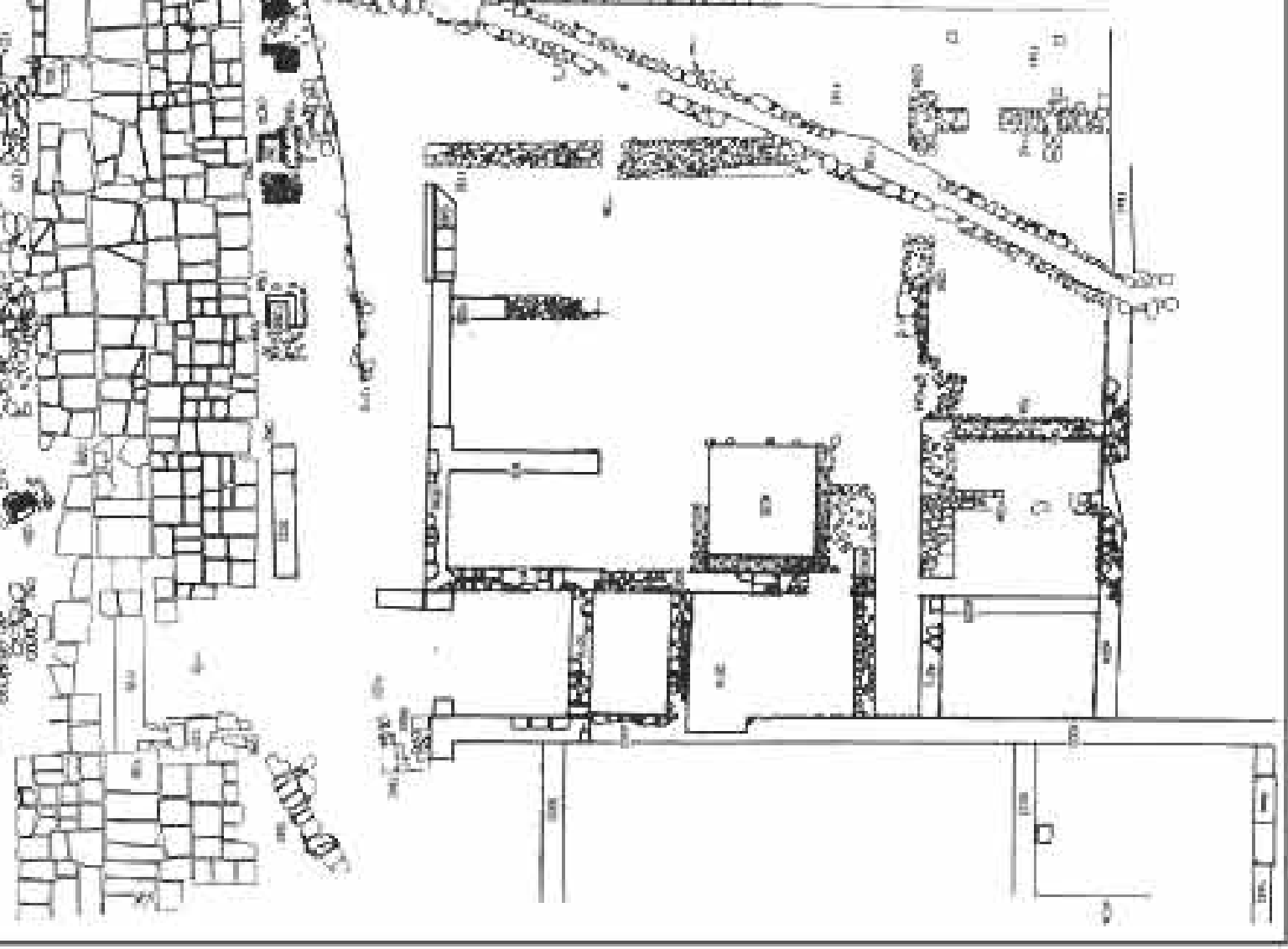


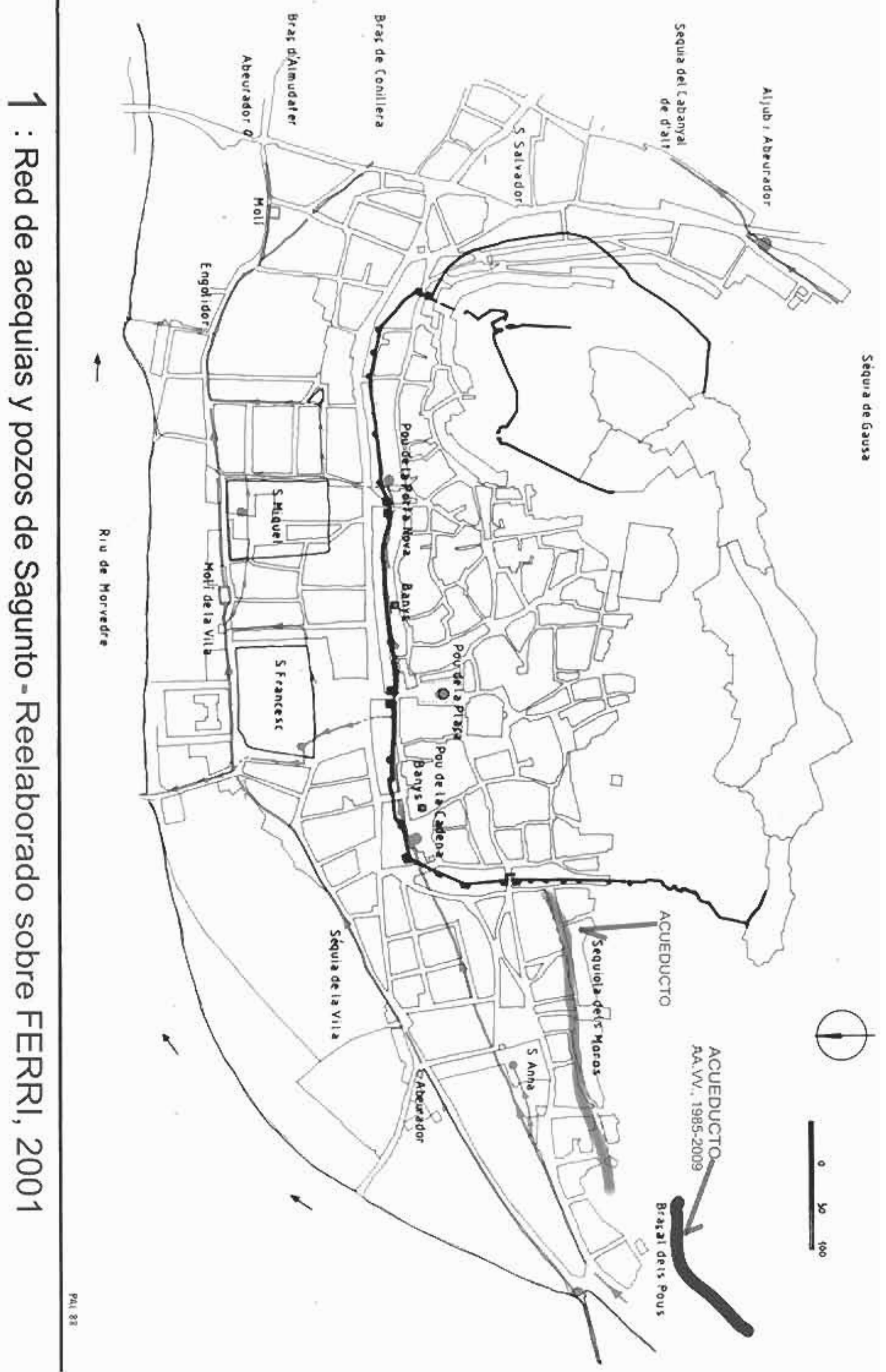



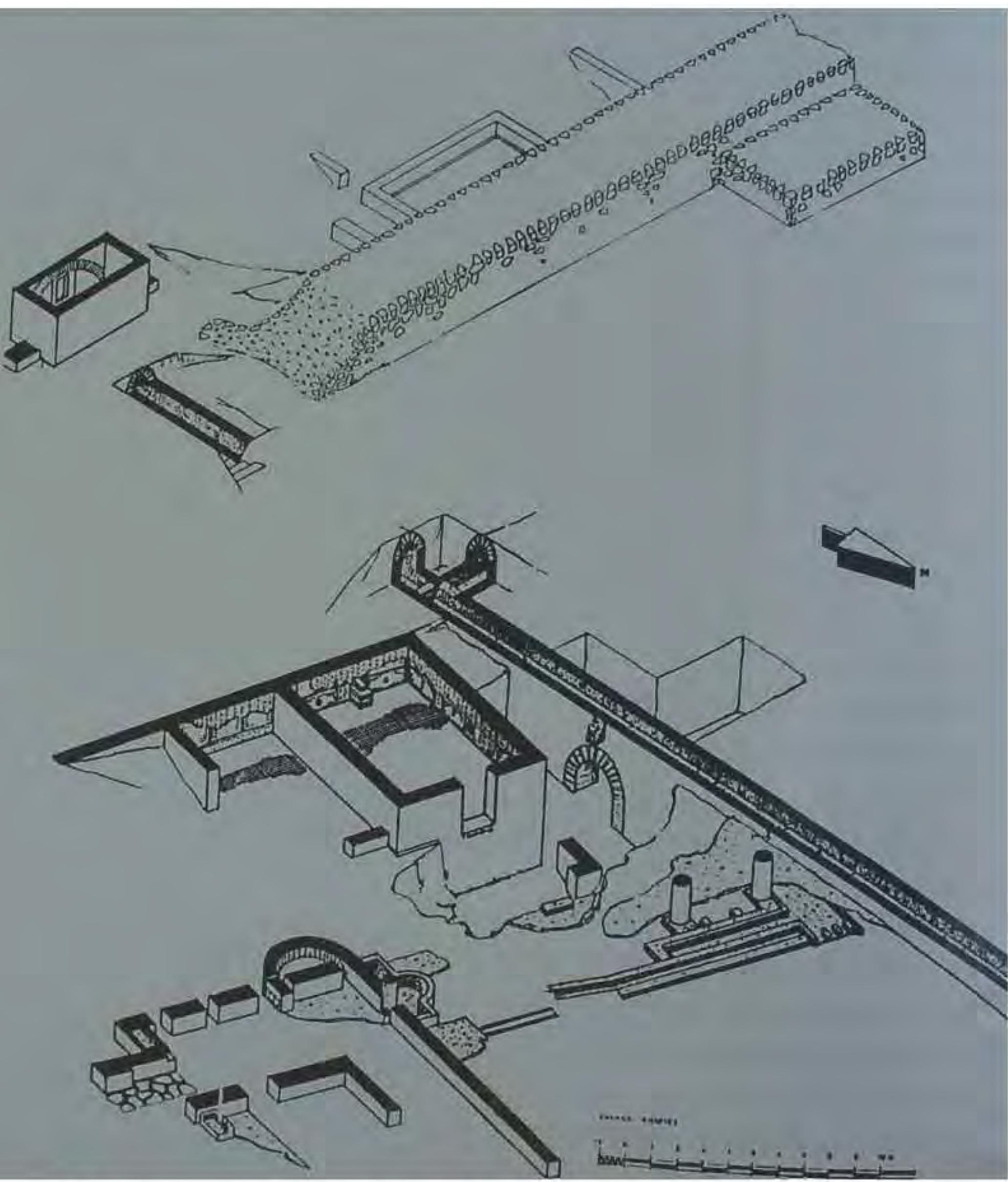

2 : Acueducto de la villa del Anfiteatro - Merida (ALBA, 2000) 

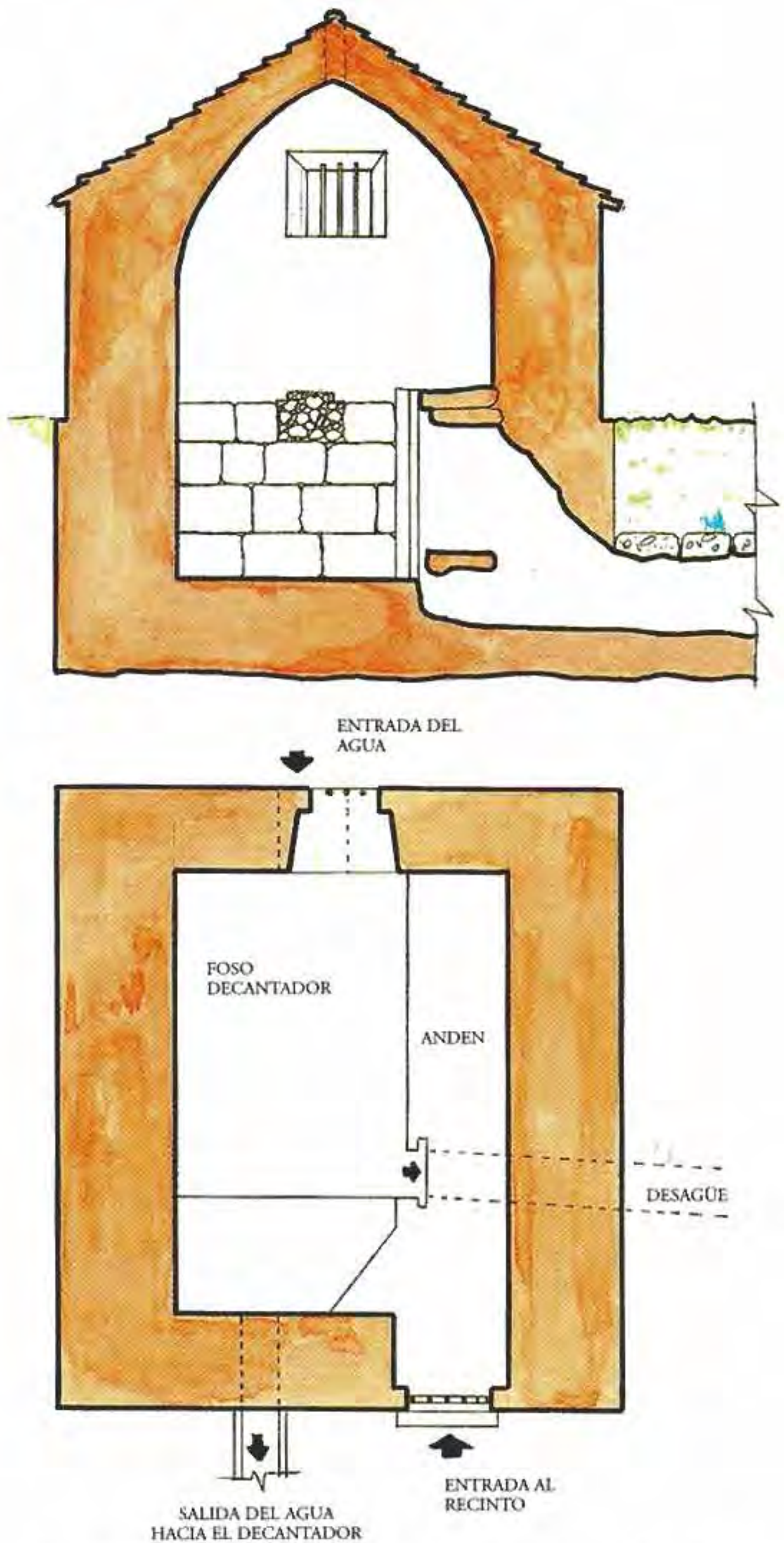

3 : Castellum aquae del acueducto de Segovia (AA. W.., 2002) 


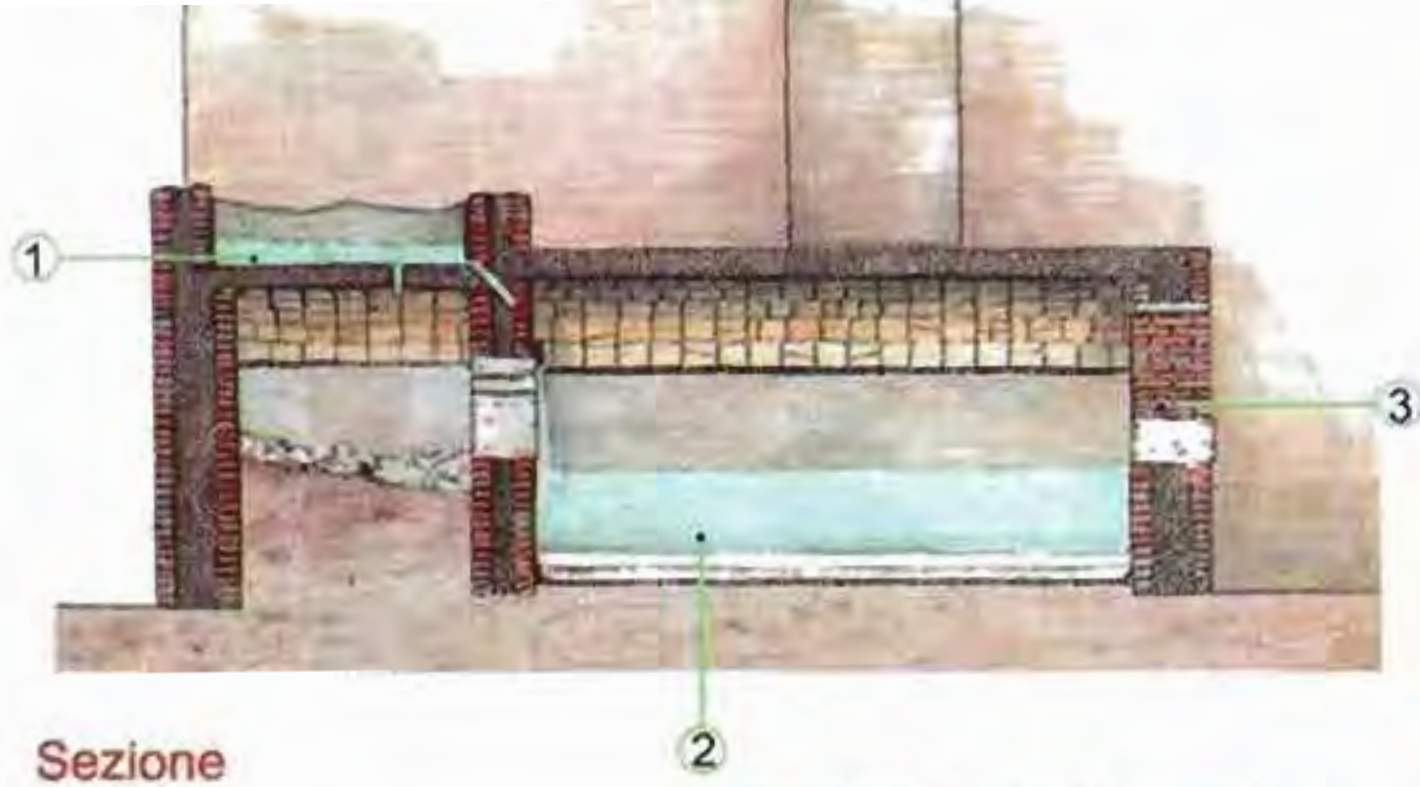

Disegni di S. Pritas - K, Mounteguridis.

Rielahorazione grafica dil M. Serafini - 1999

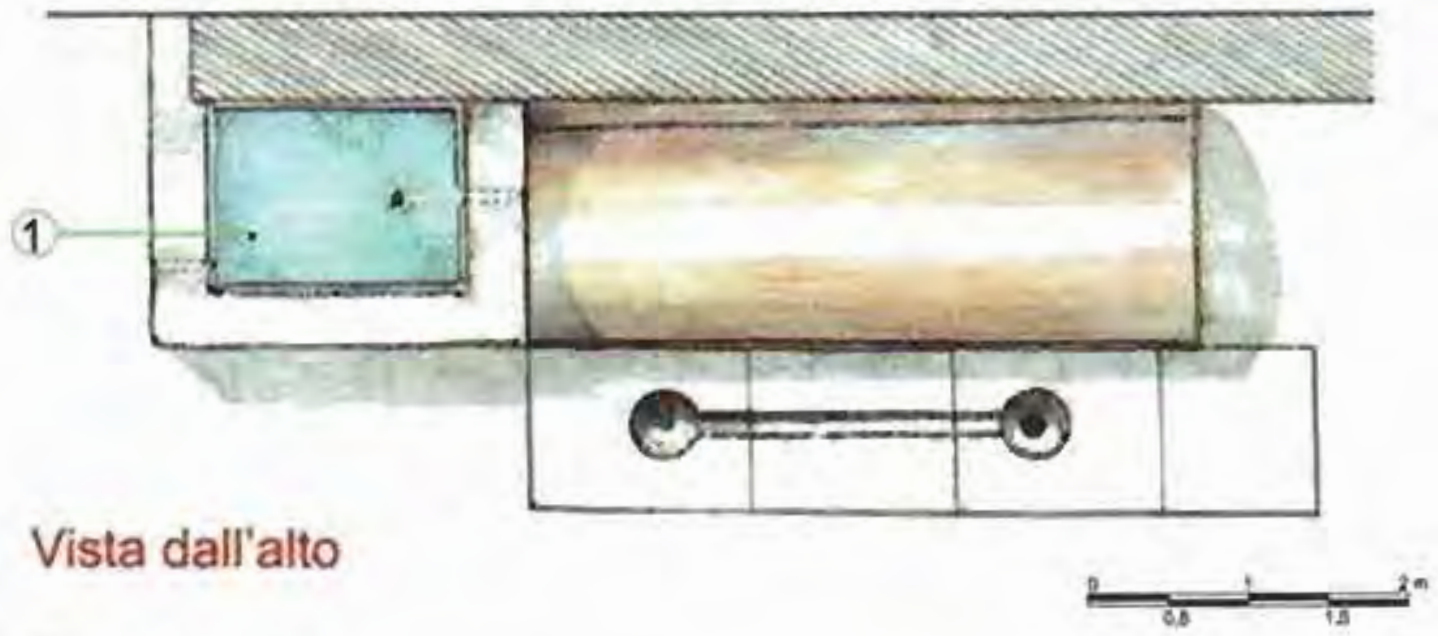

(1) Cisterna

(2) Vasca della fontana

3 Apertura per il prelievo dell'acqua

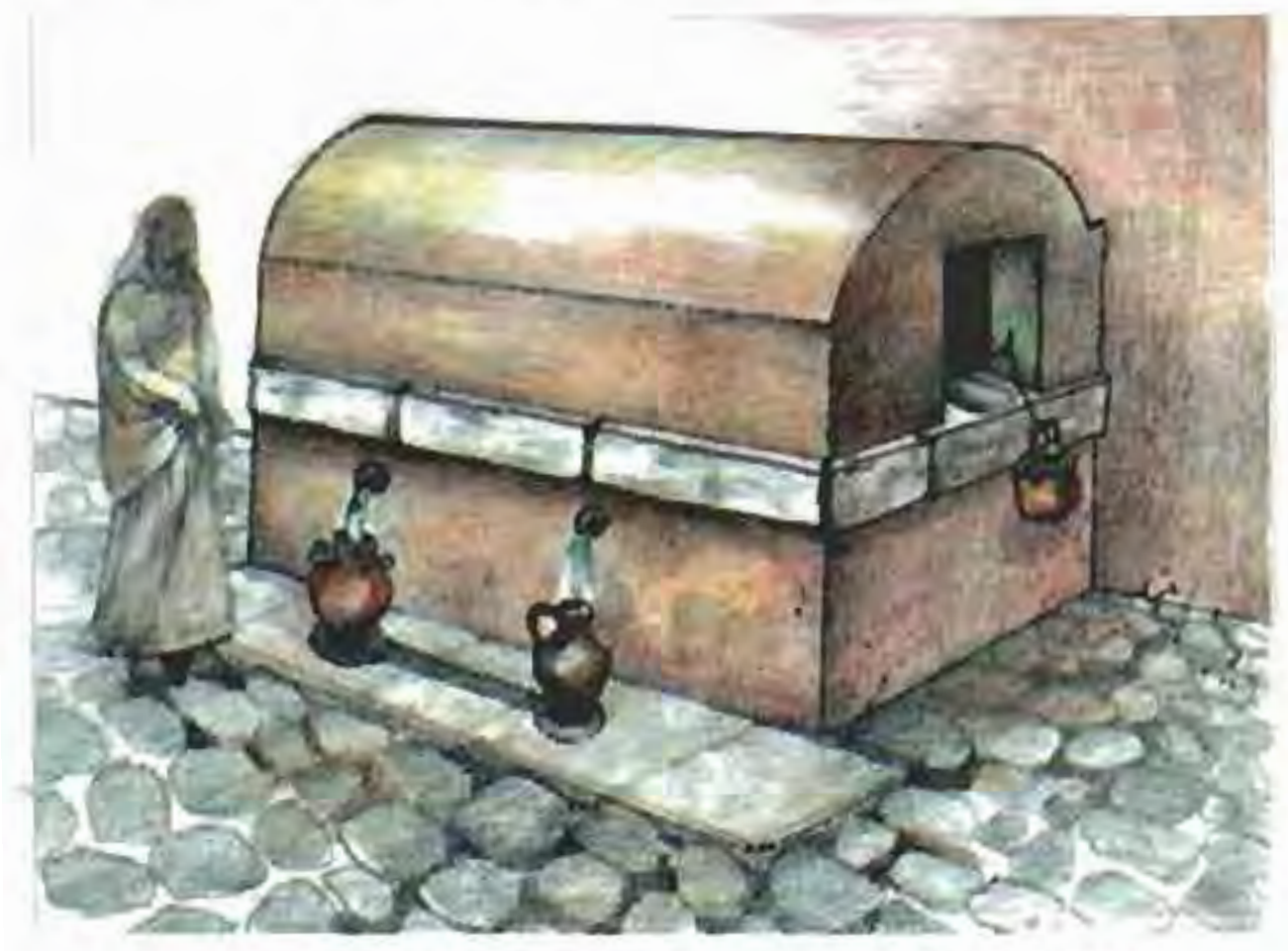

4 : Fuente tipo "Bauletto" (AA. VV., 2005) 


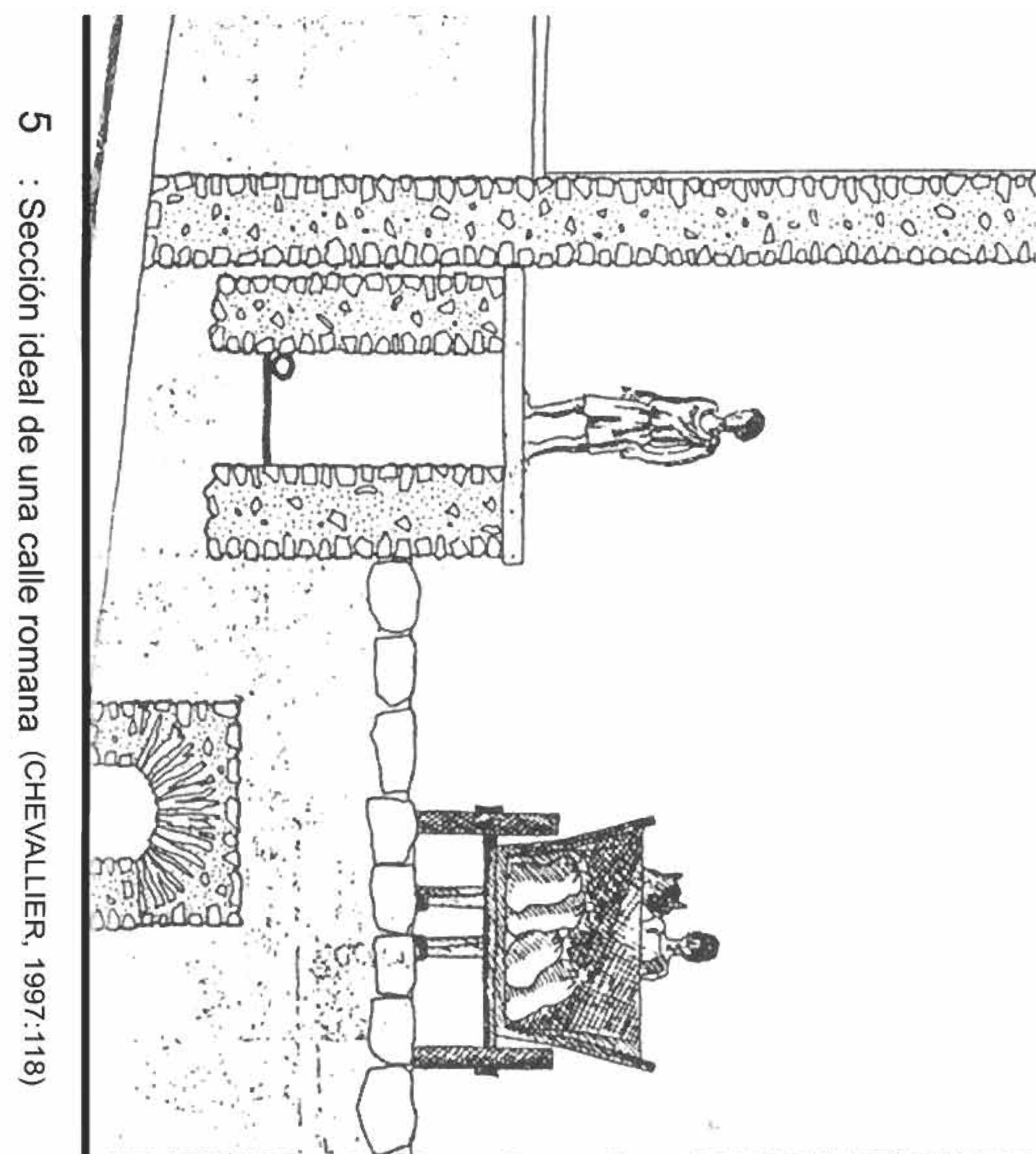

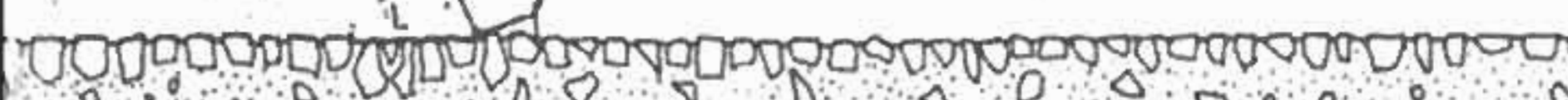

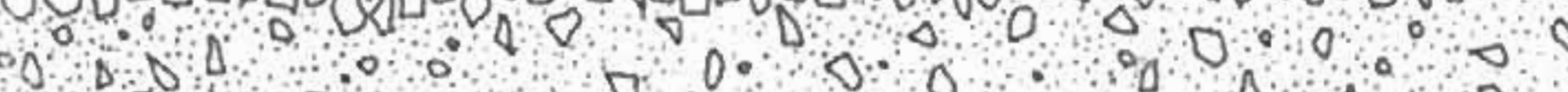

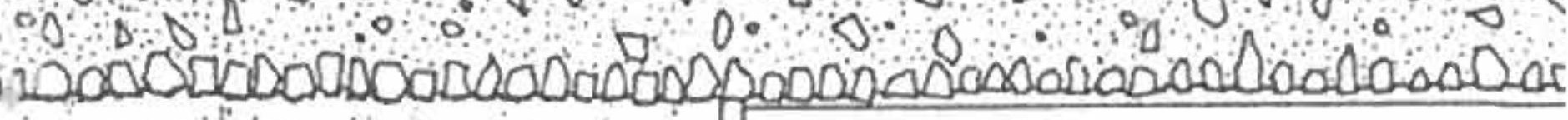

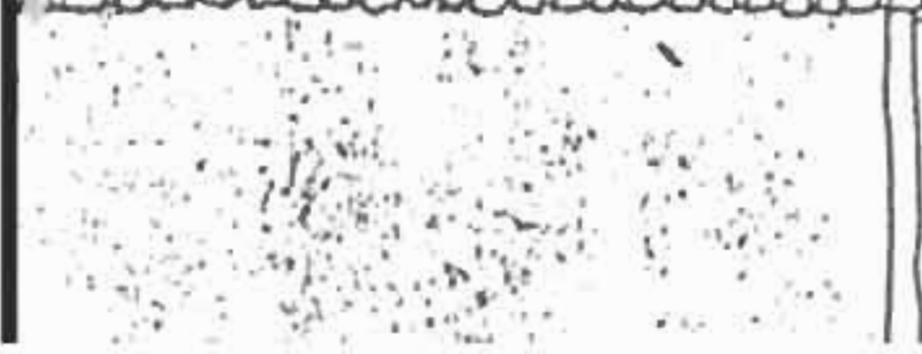




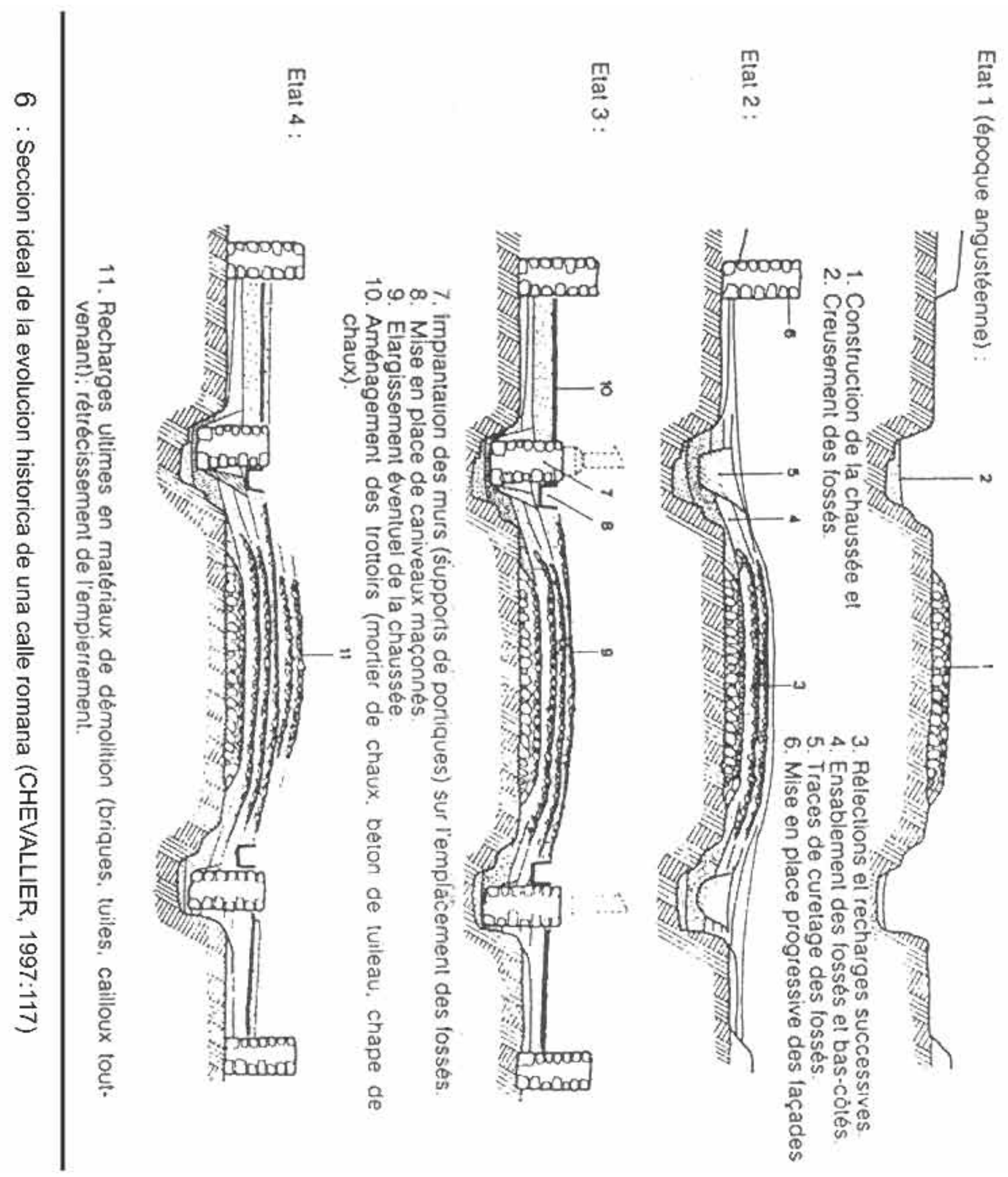




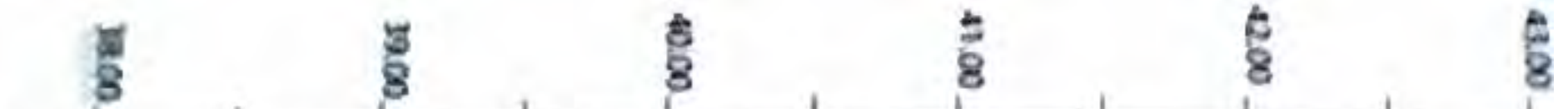

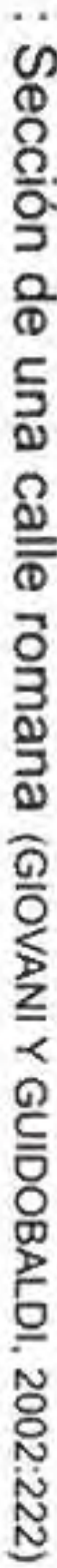

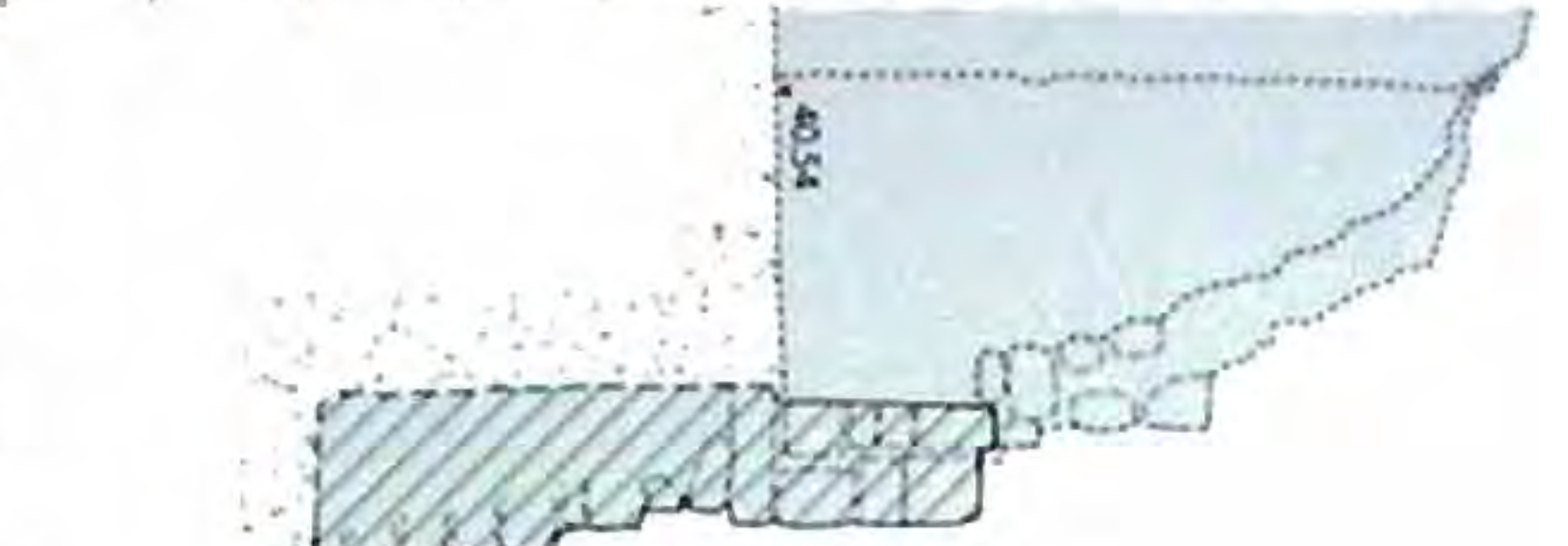




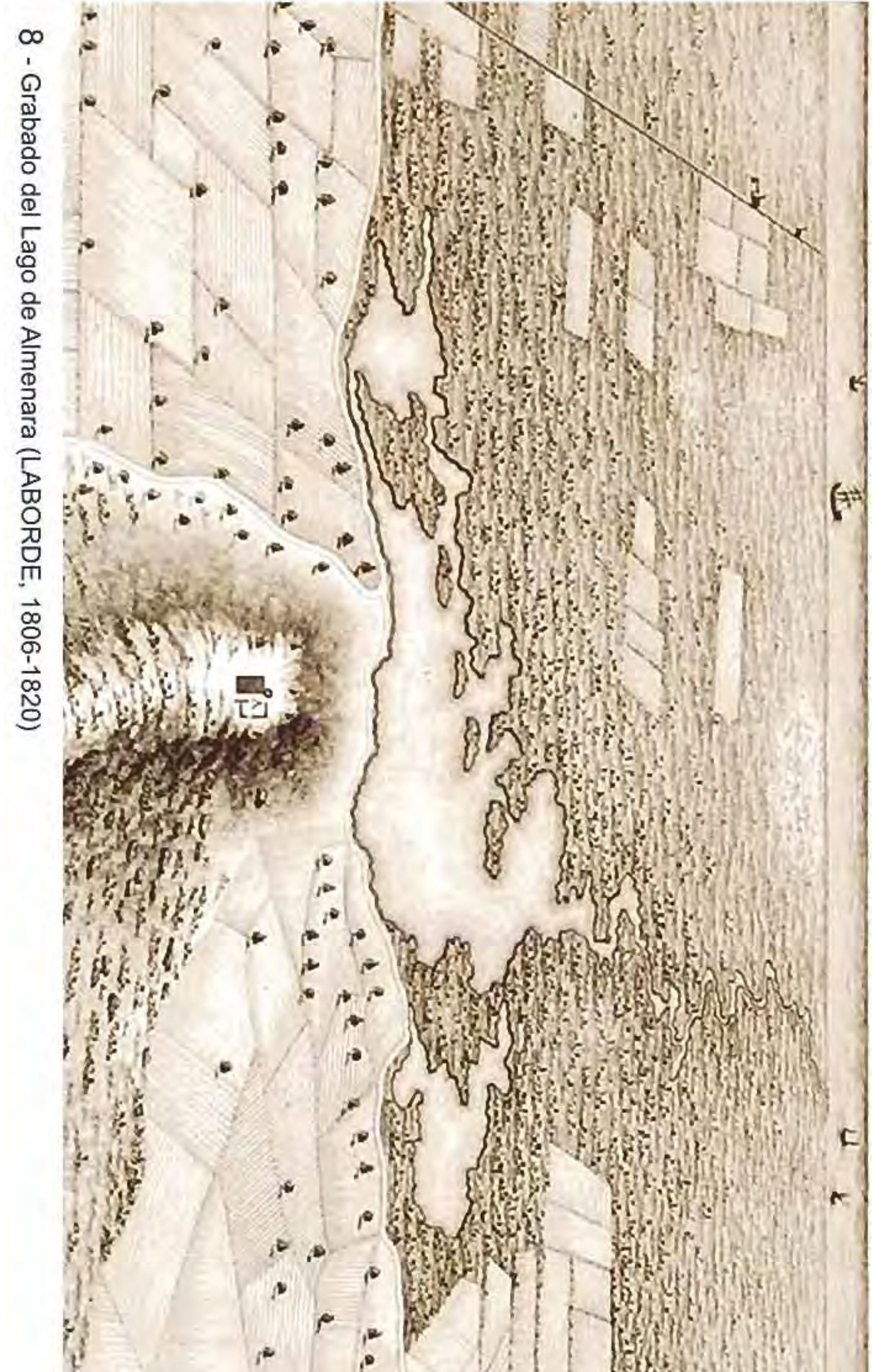




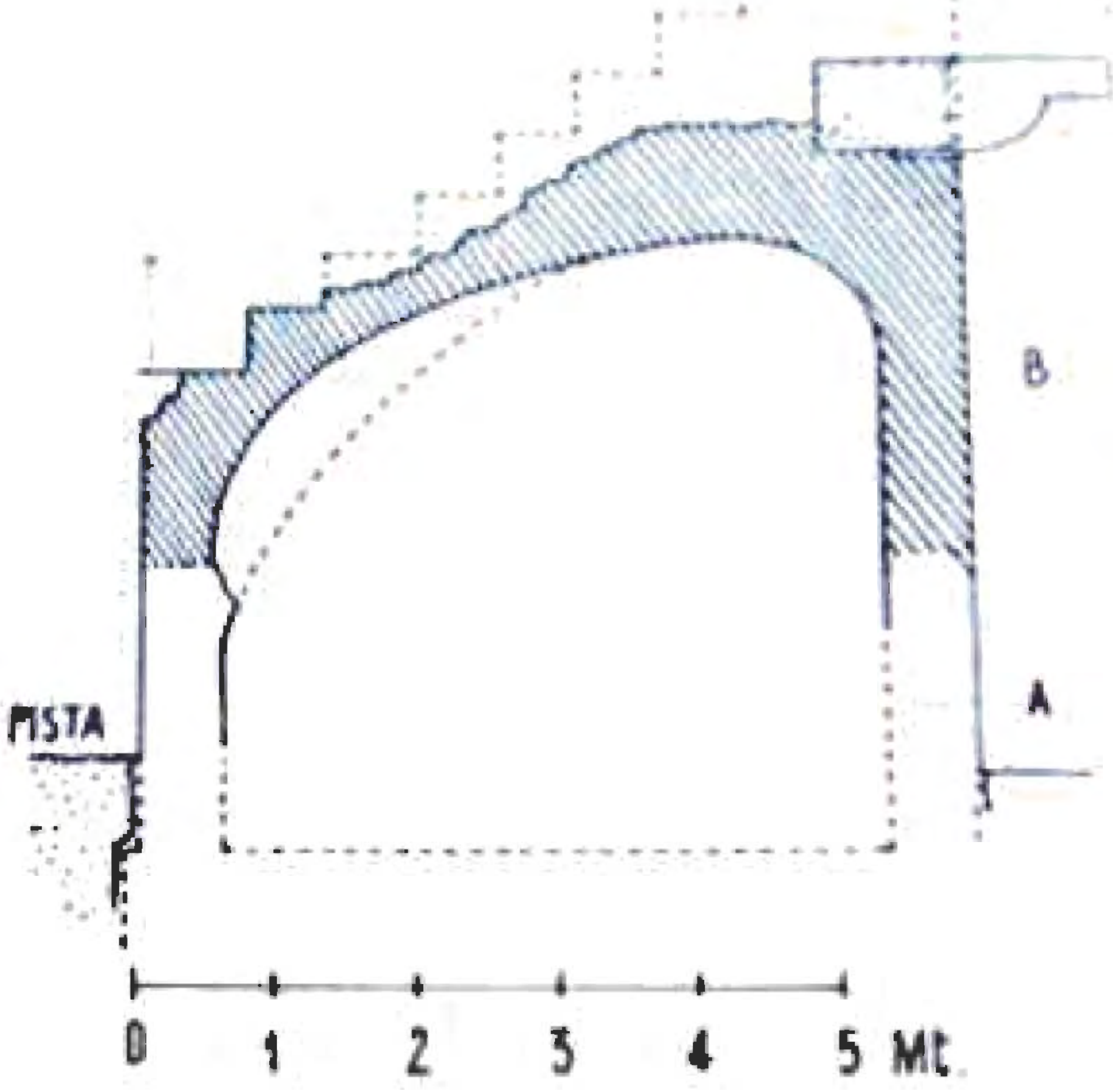

9 : Sección del anfiteatro de Paestum (CASTAGNOLI, 2003:100 


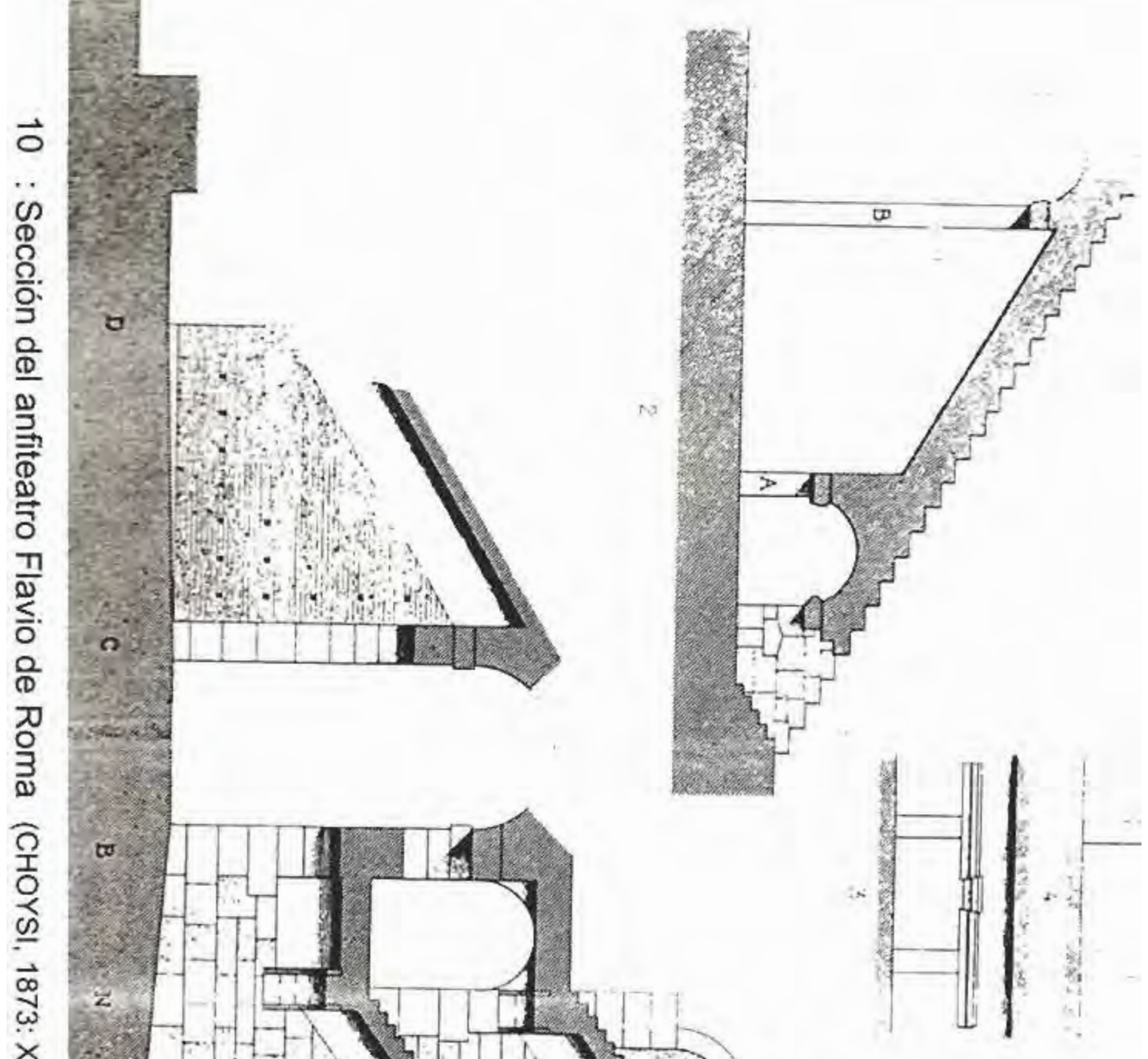




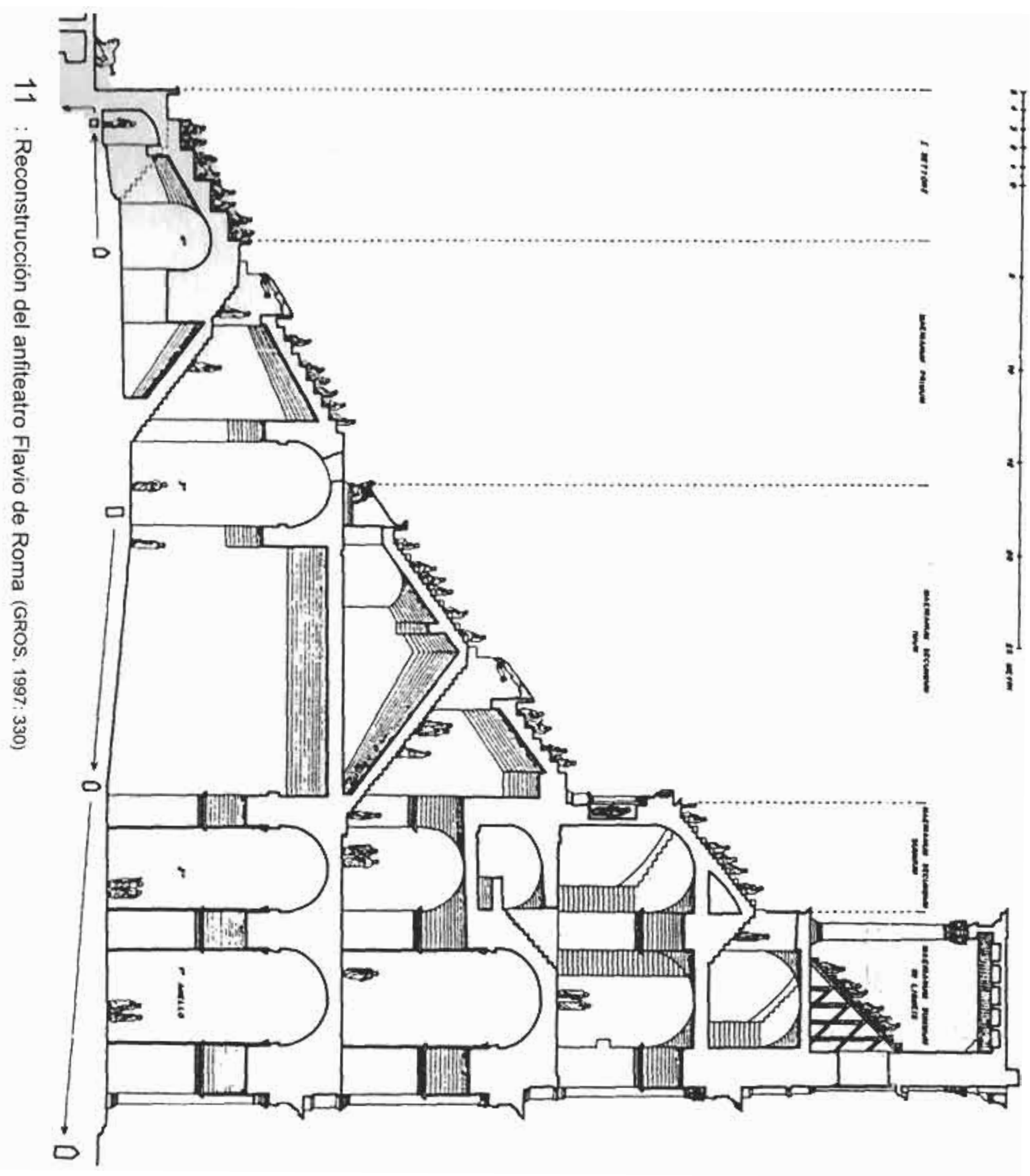




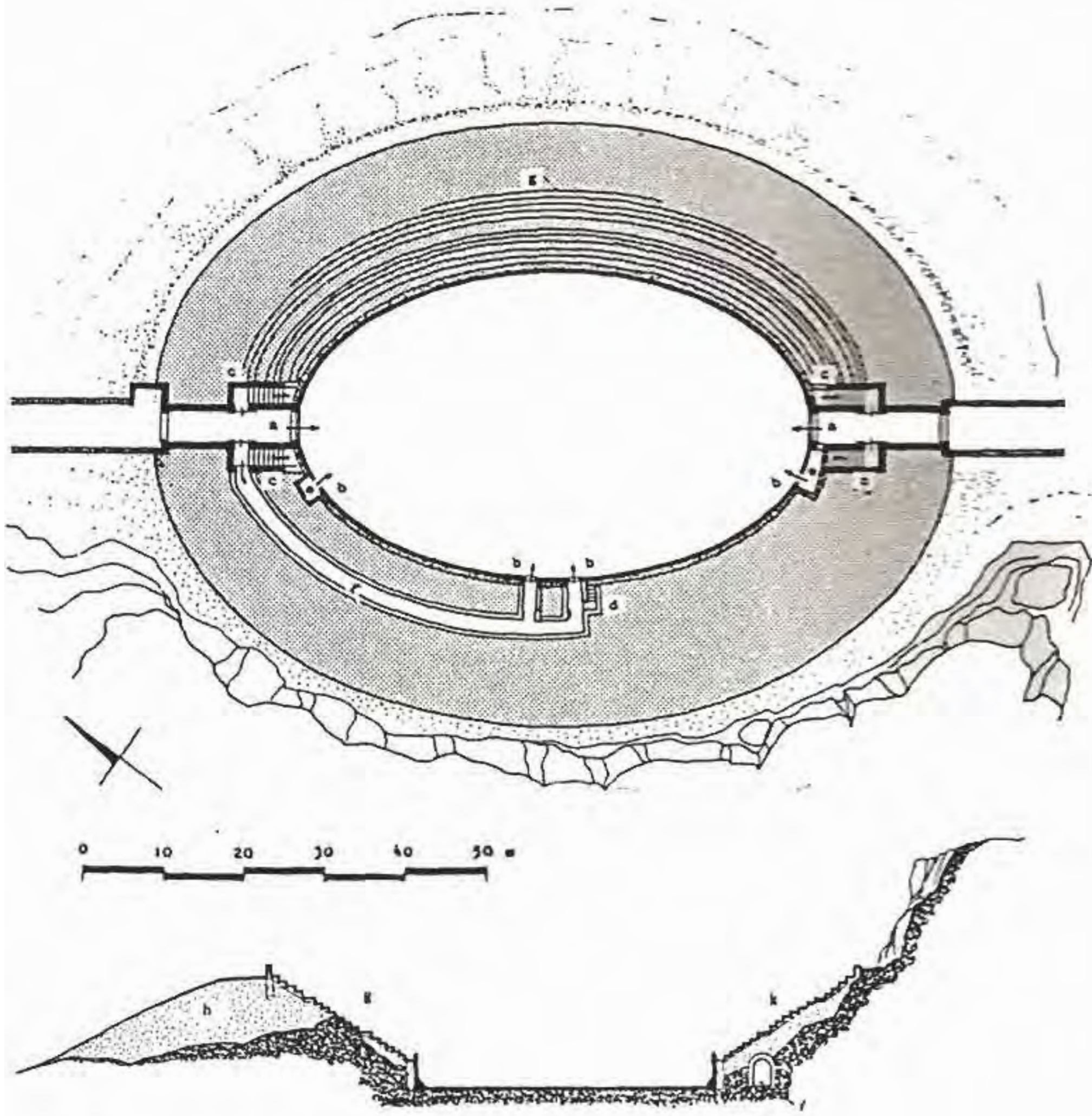

12 : Planta y sección del anfiteatro de Alba Fucens (GROS, 1997: 323) 

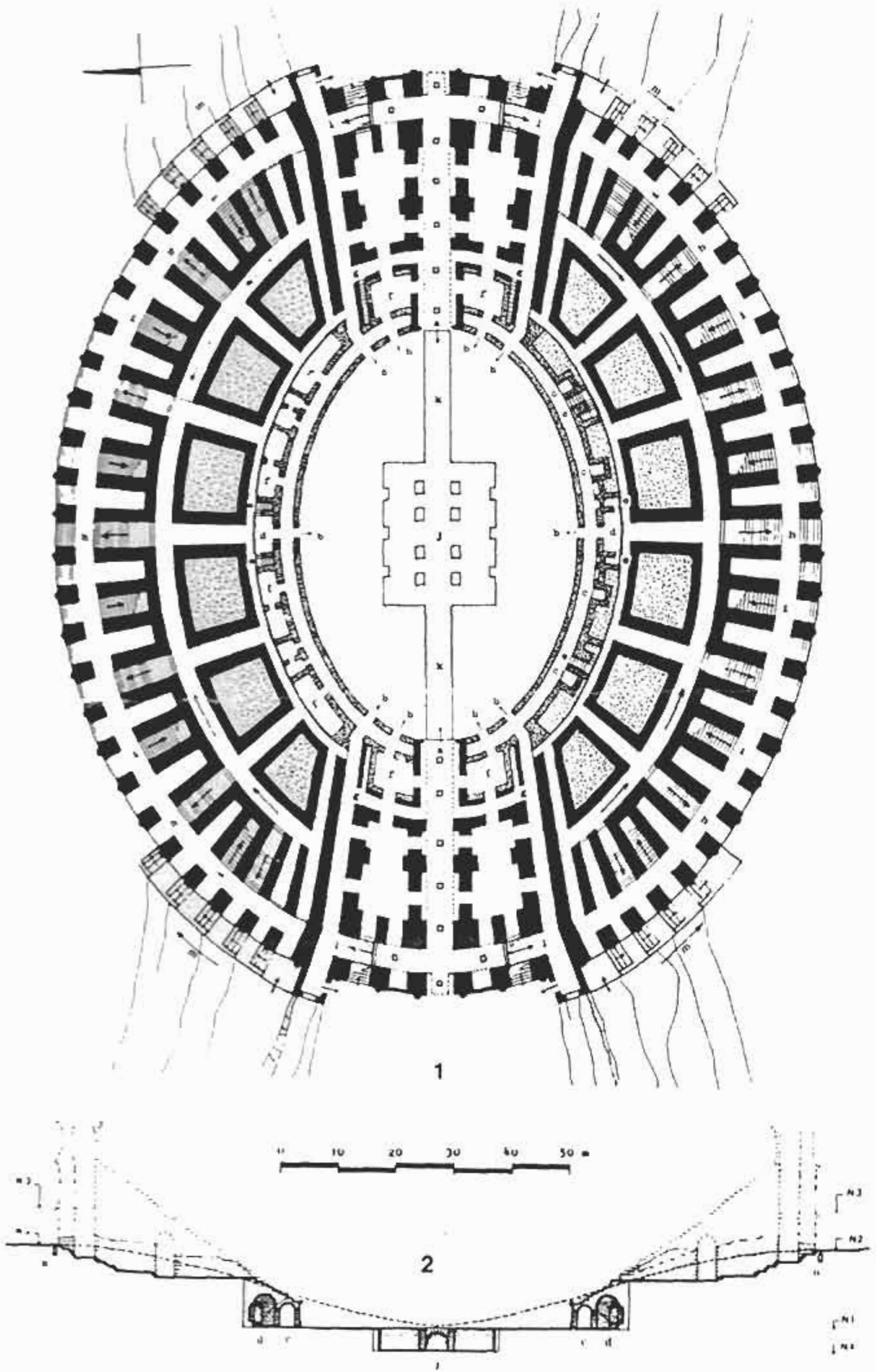


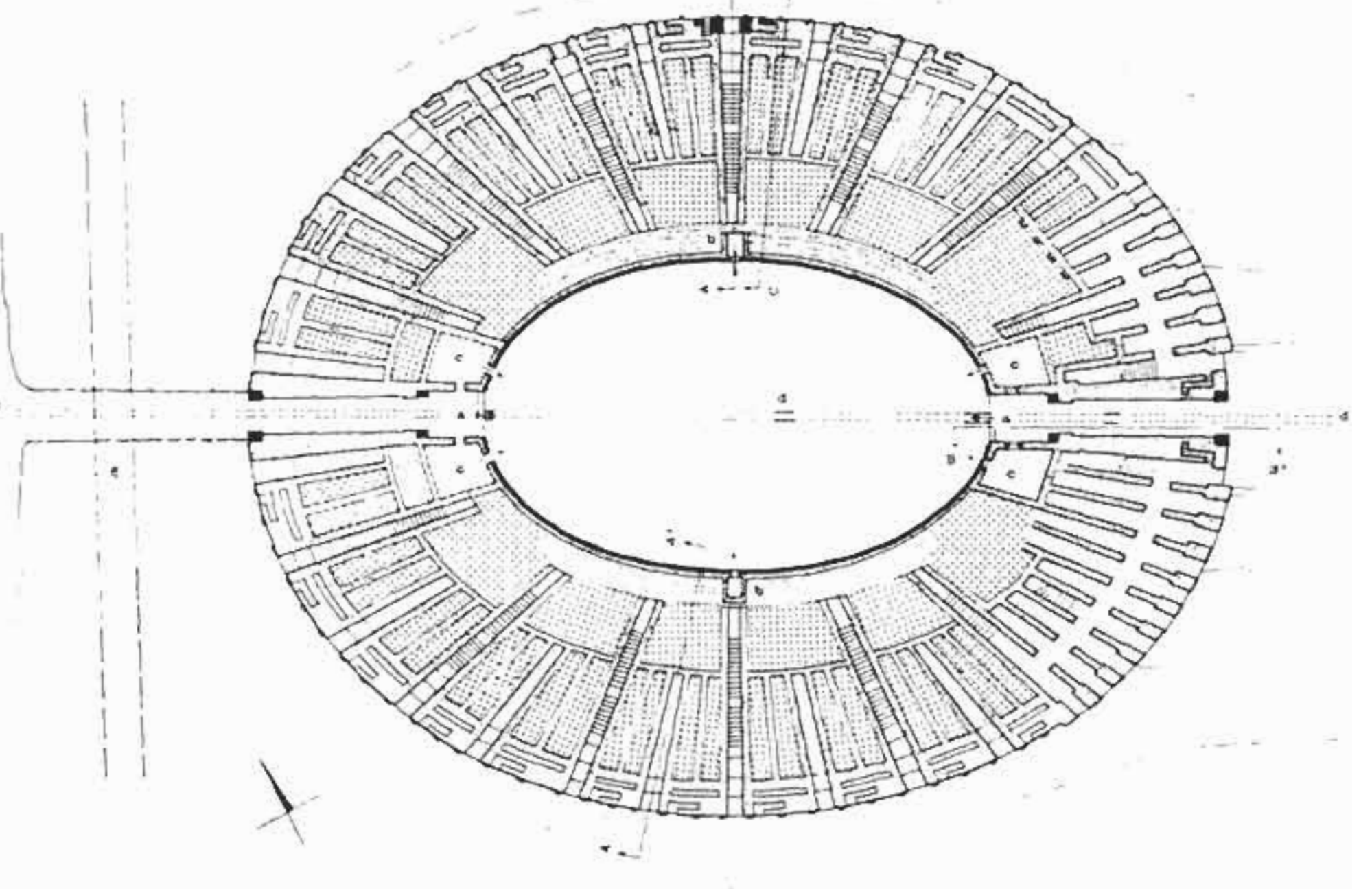

1

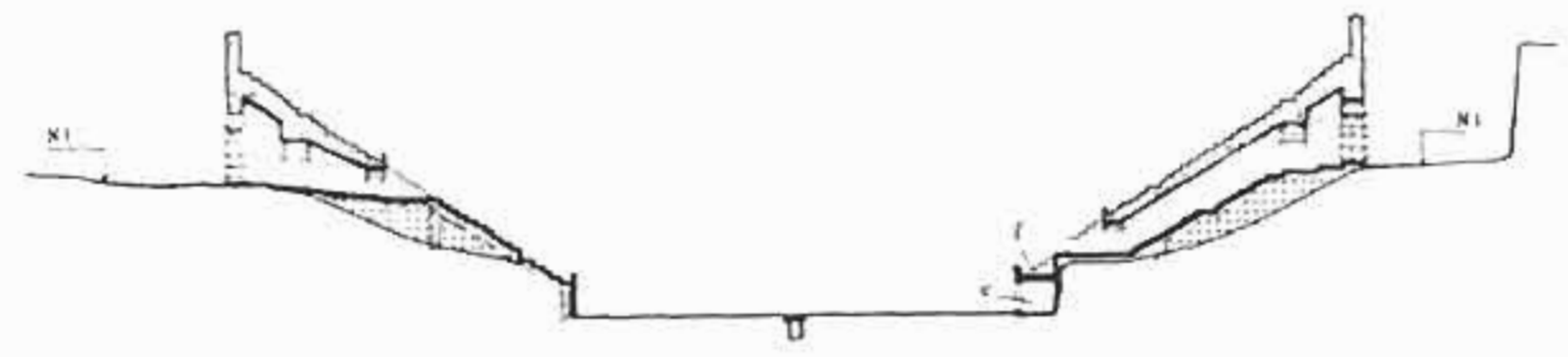

2
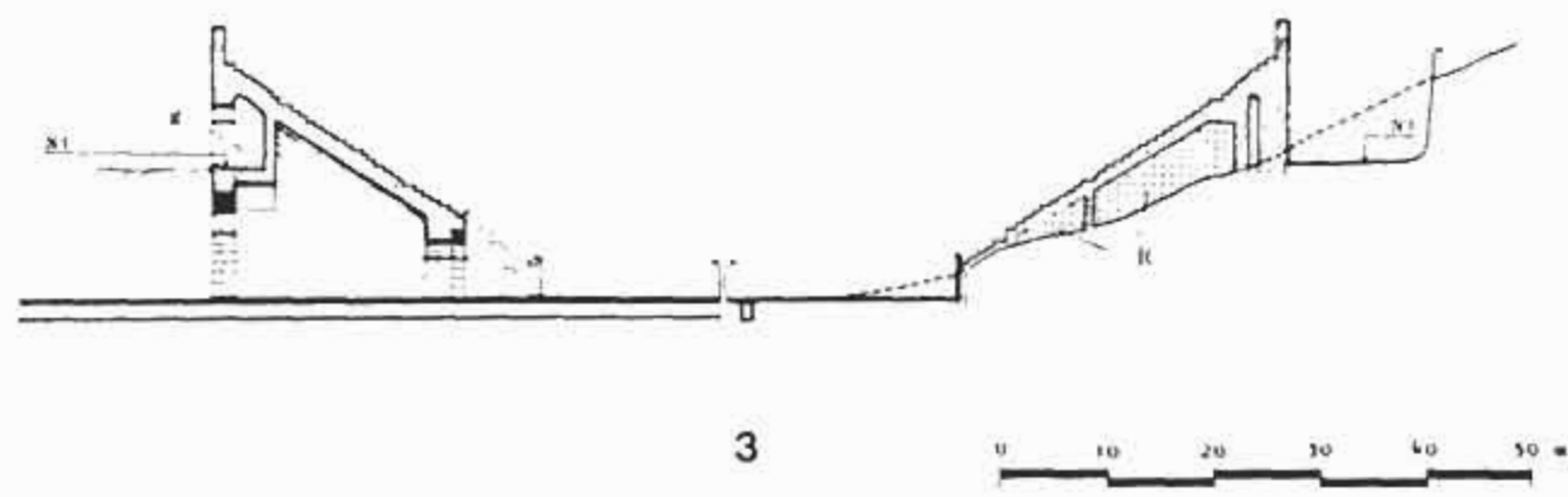

14 : Planta y secciones del anfiteatro de Saintes (GROS, 1997: 325 


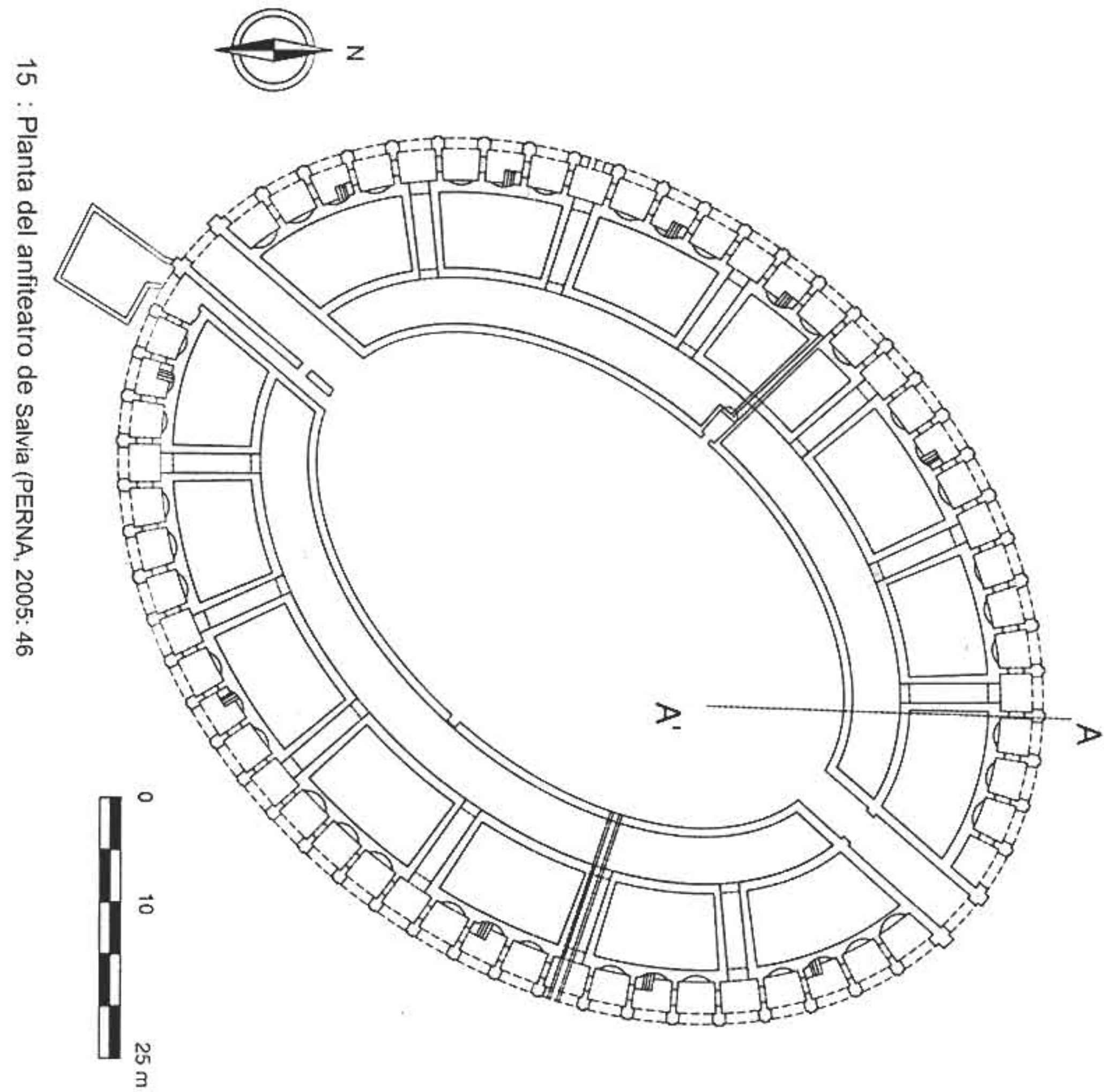




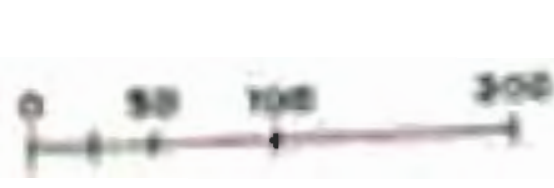

$\ldots \pi$

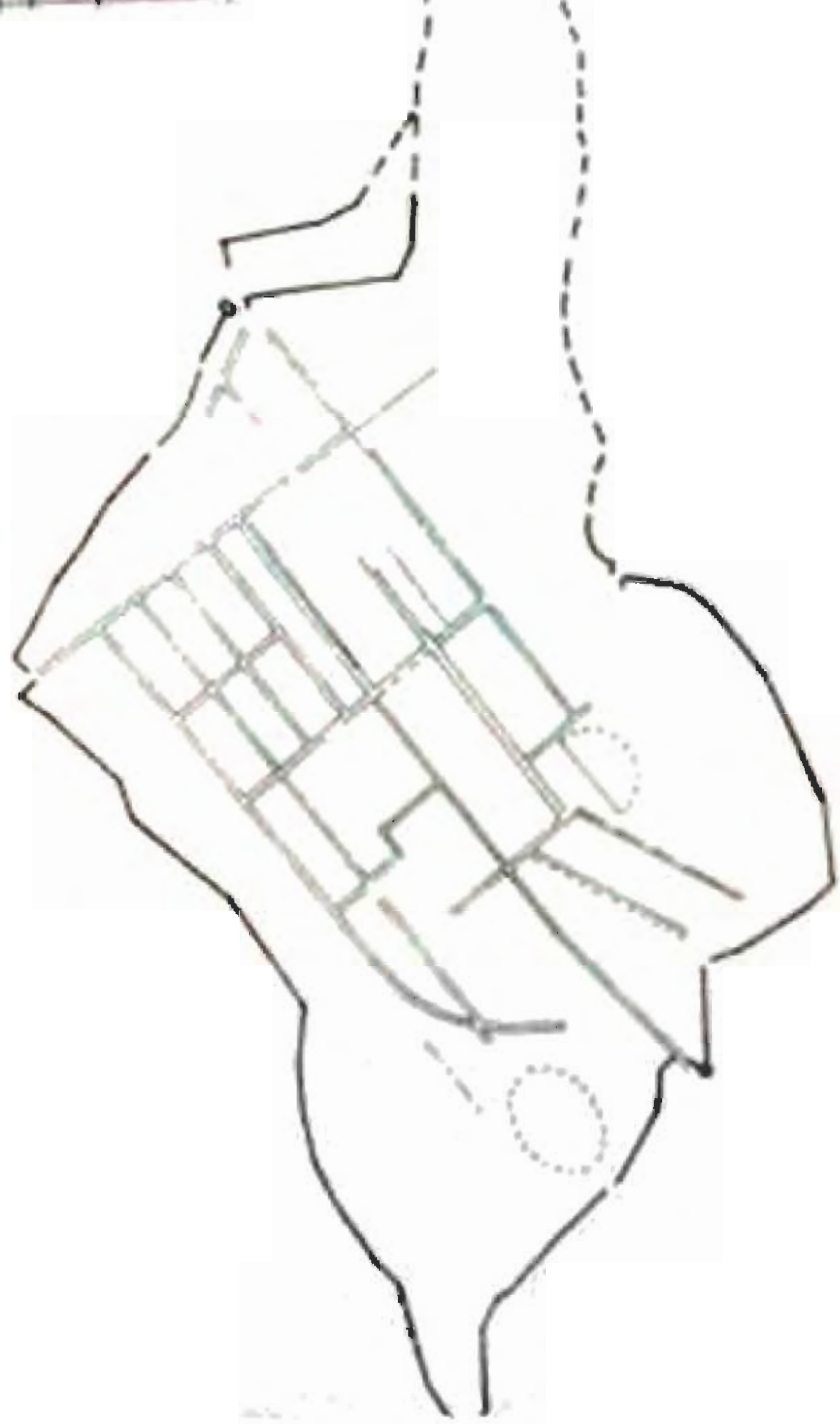

16 : Plano de Alba Fucens (CASTAGNOLI,2003:1017) 


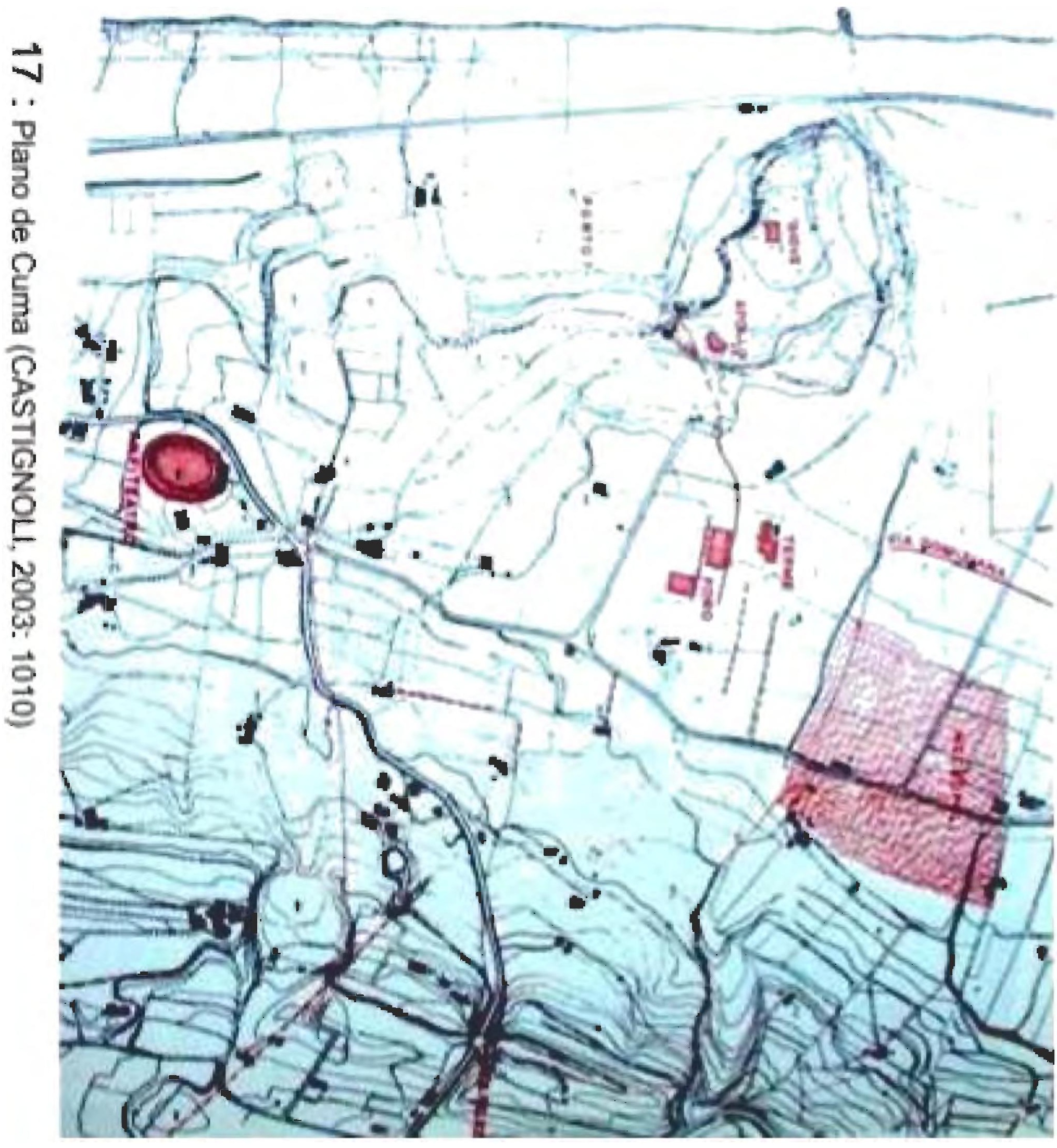




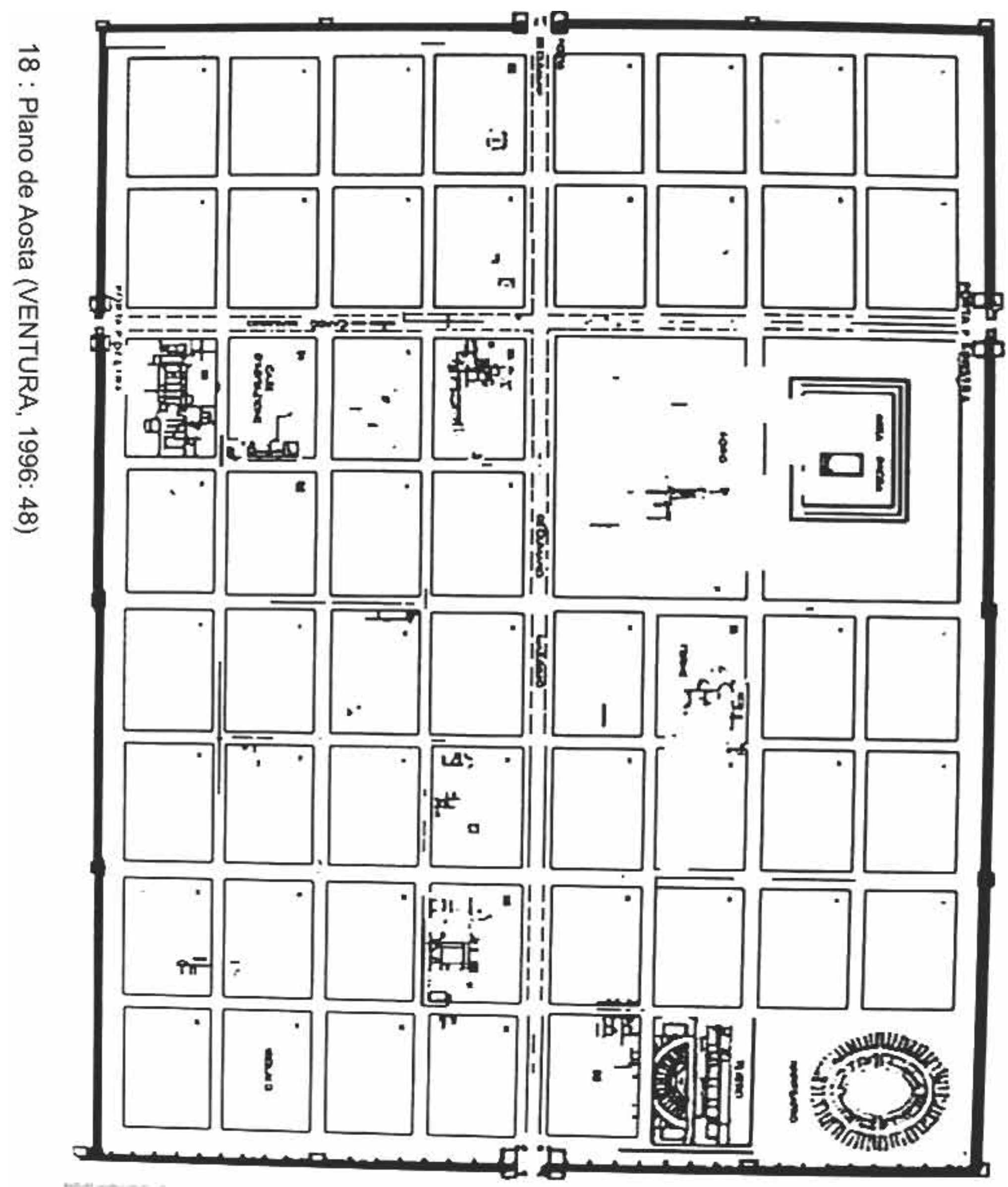




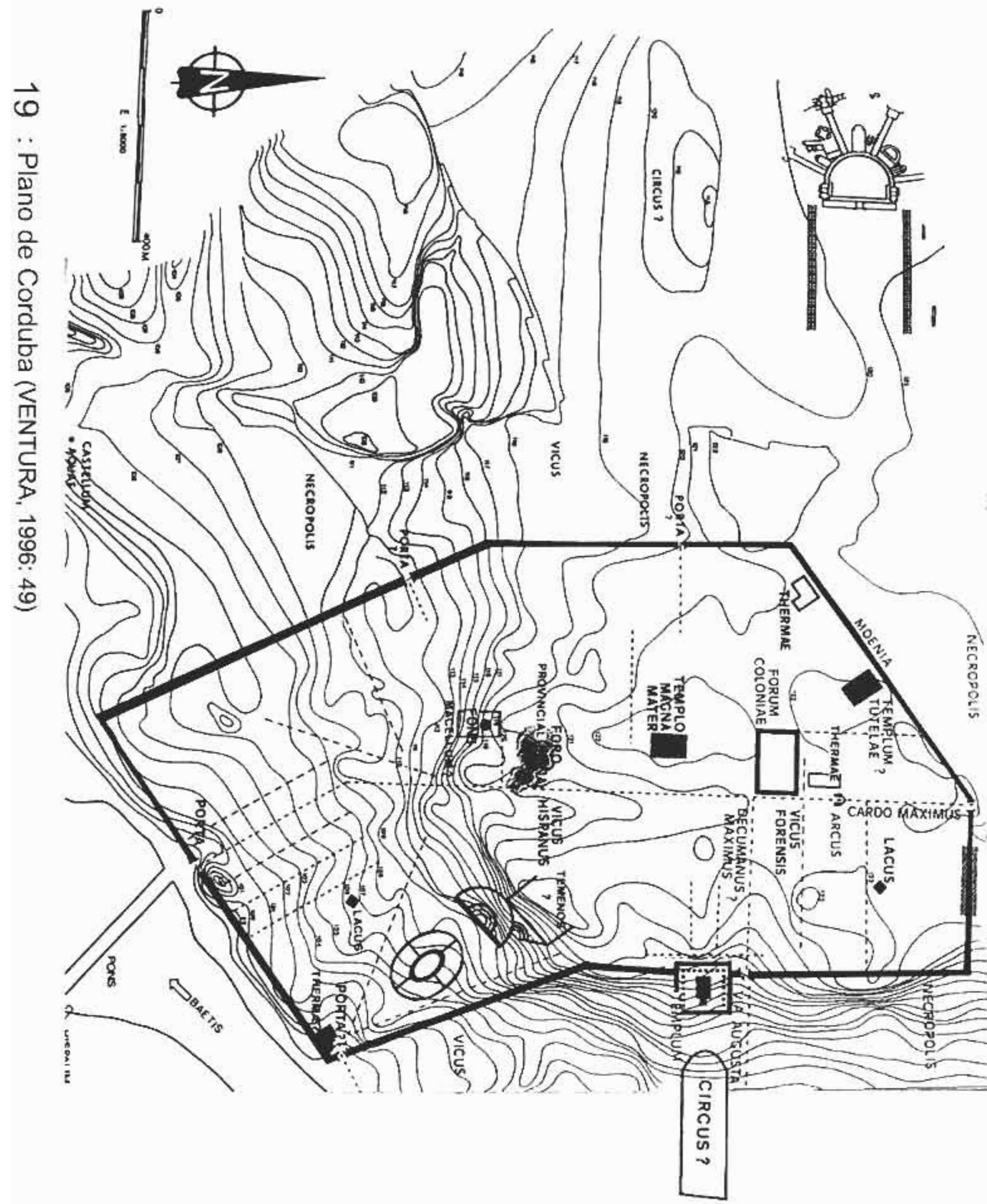




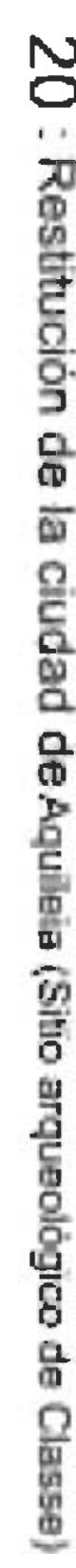

VI 12
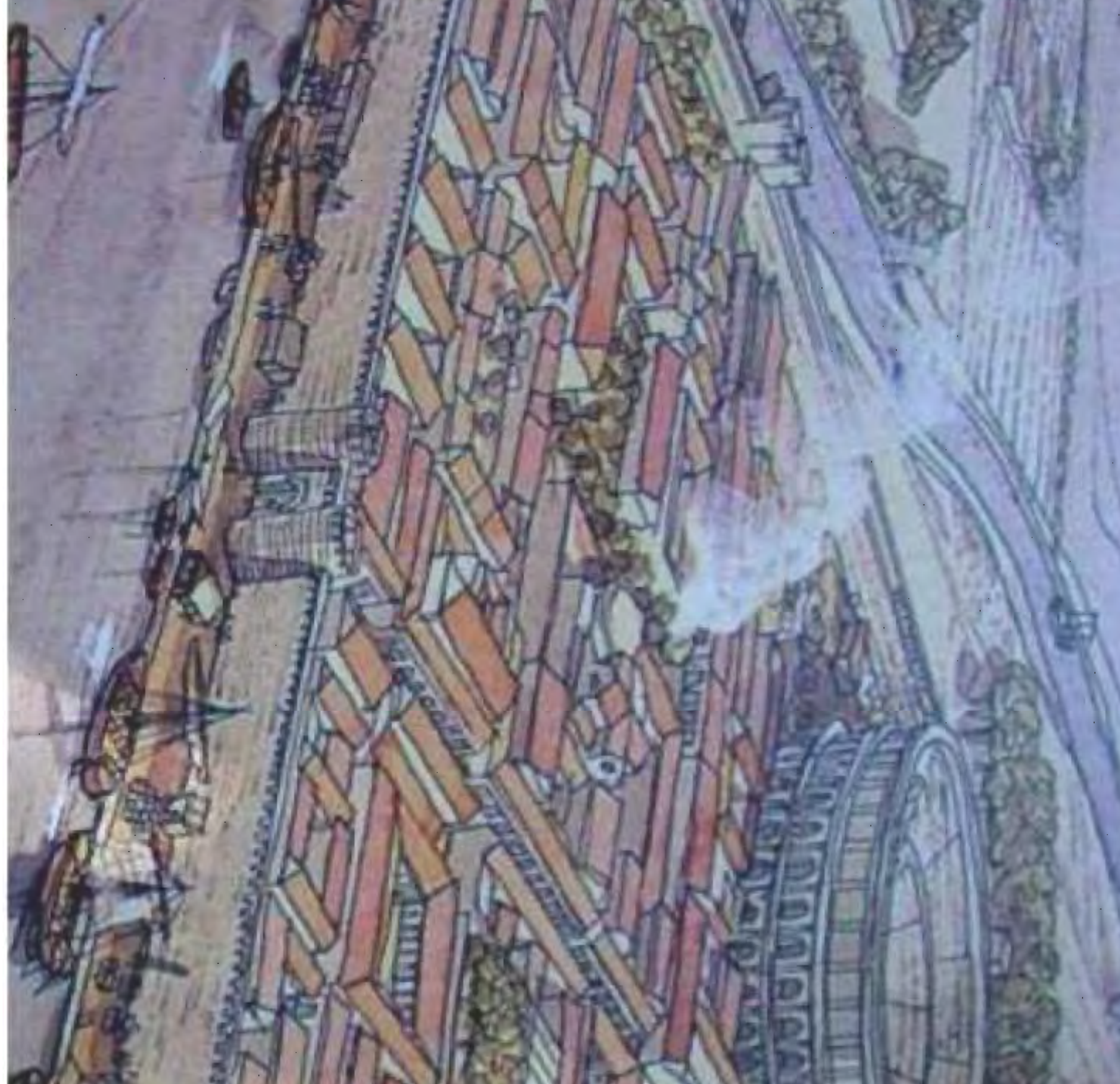

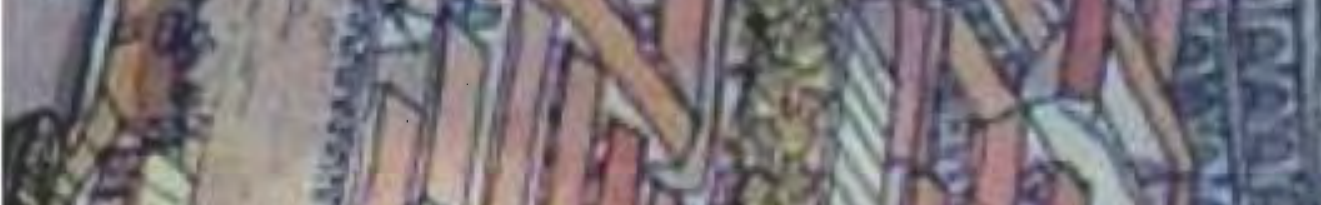

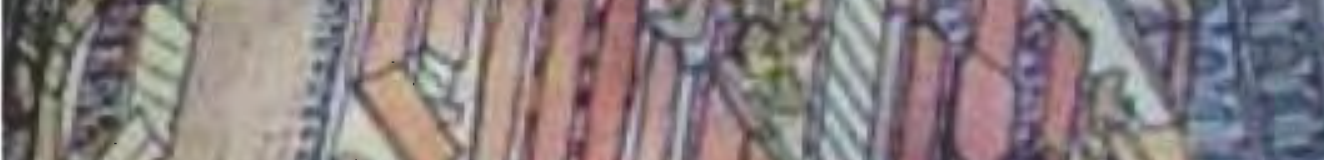

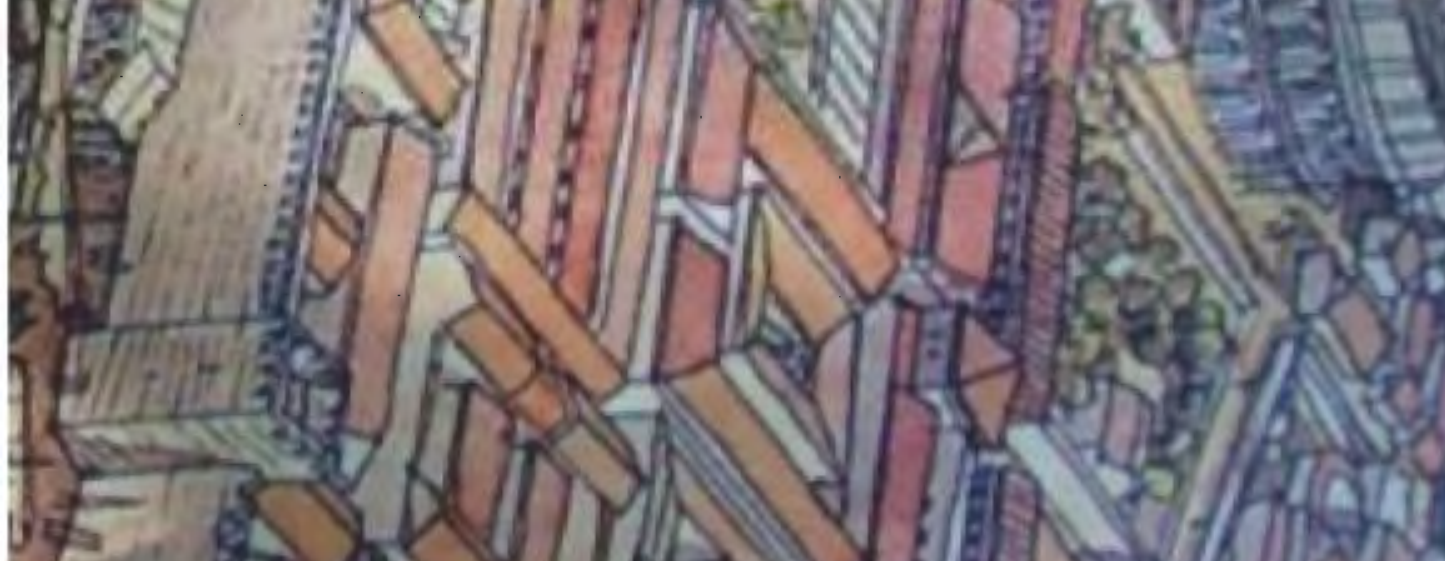

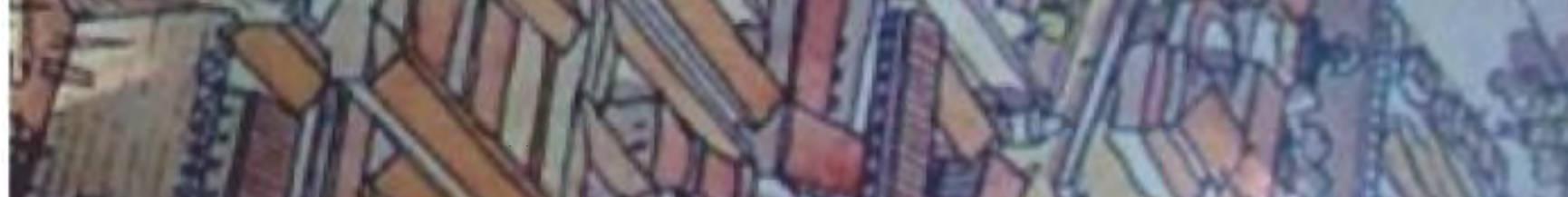




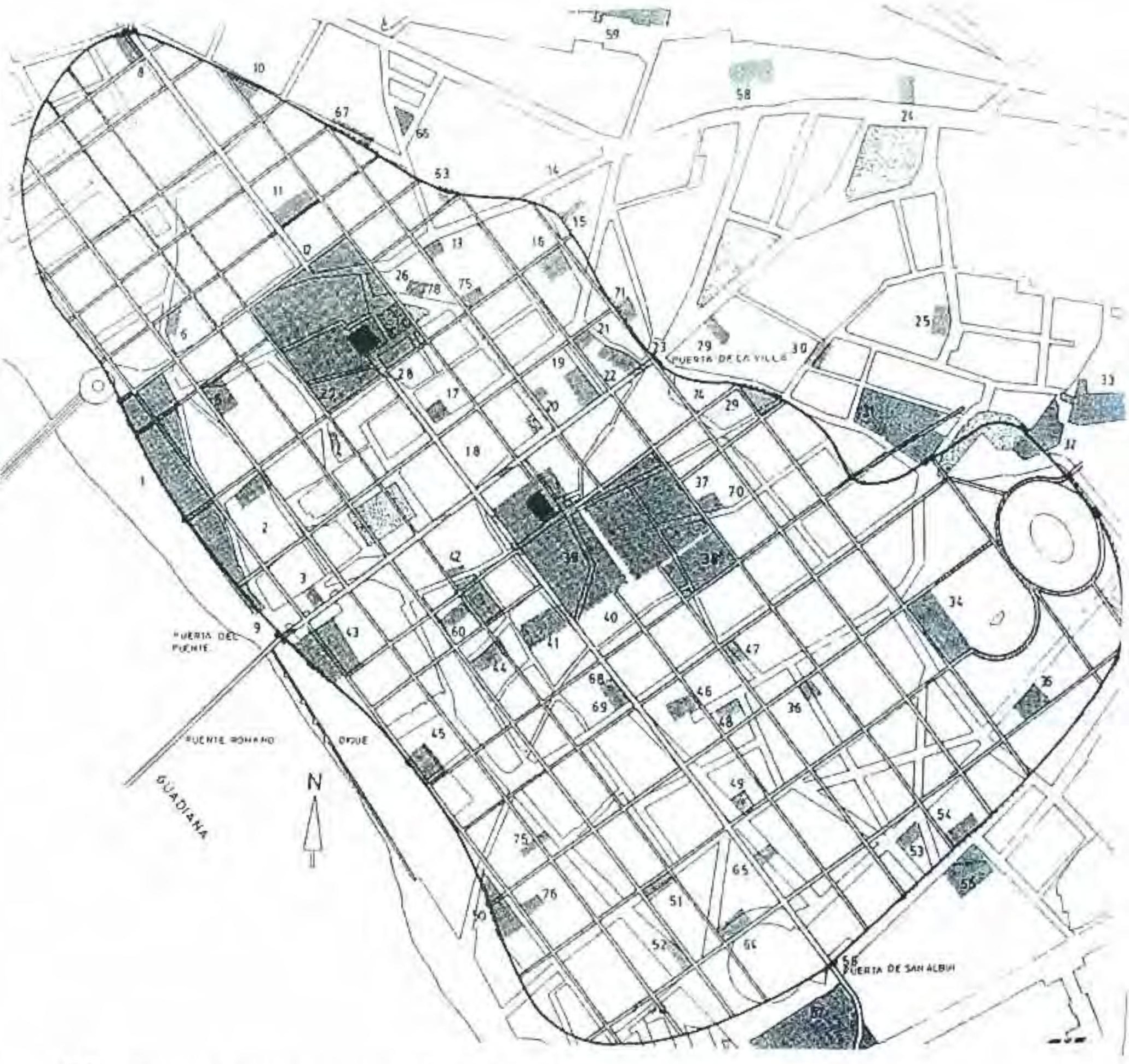

21 : Plano de Emerita Augusta (ALBA, 2001: 399) 


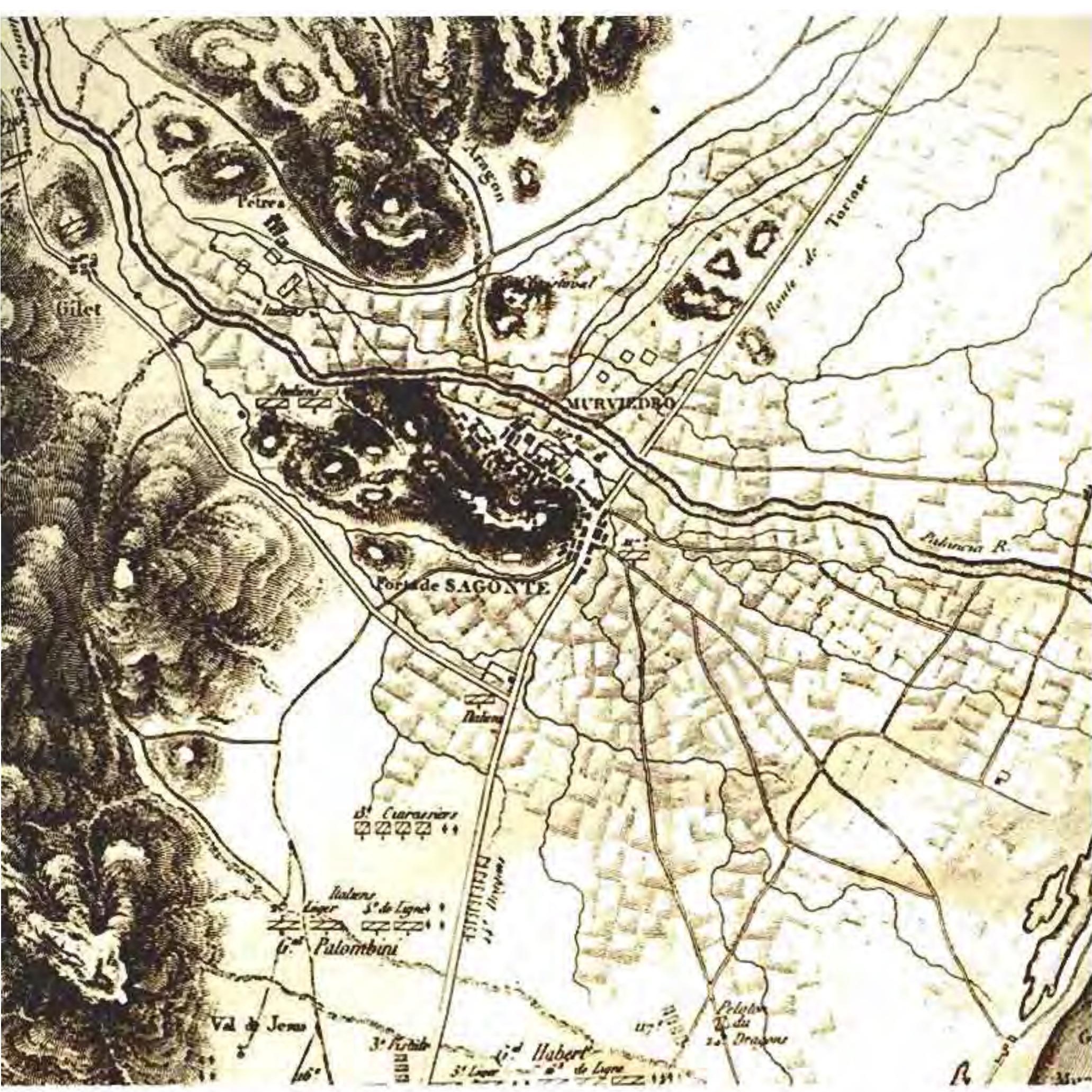

22 : Plano de la batalla de Sagunto en 1803 (BV) 

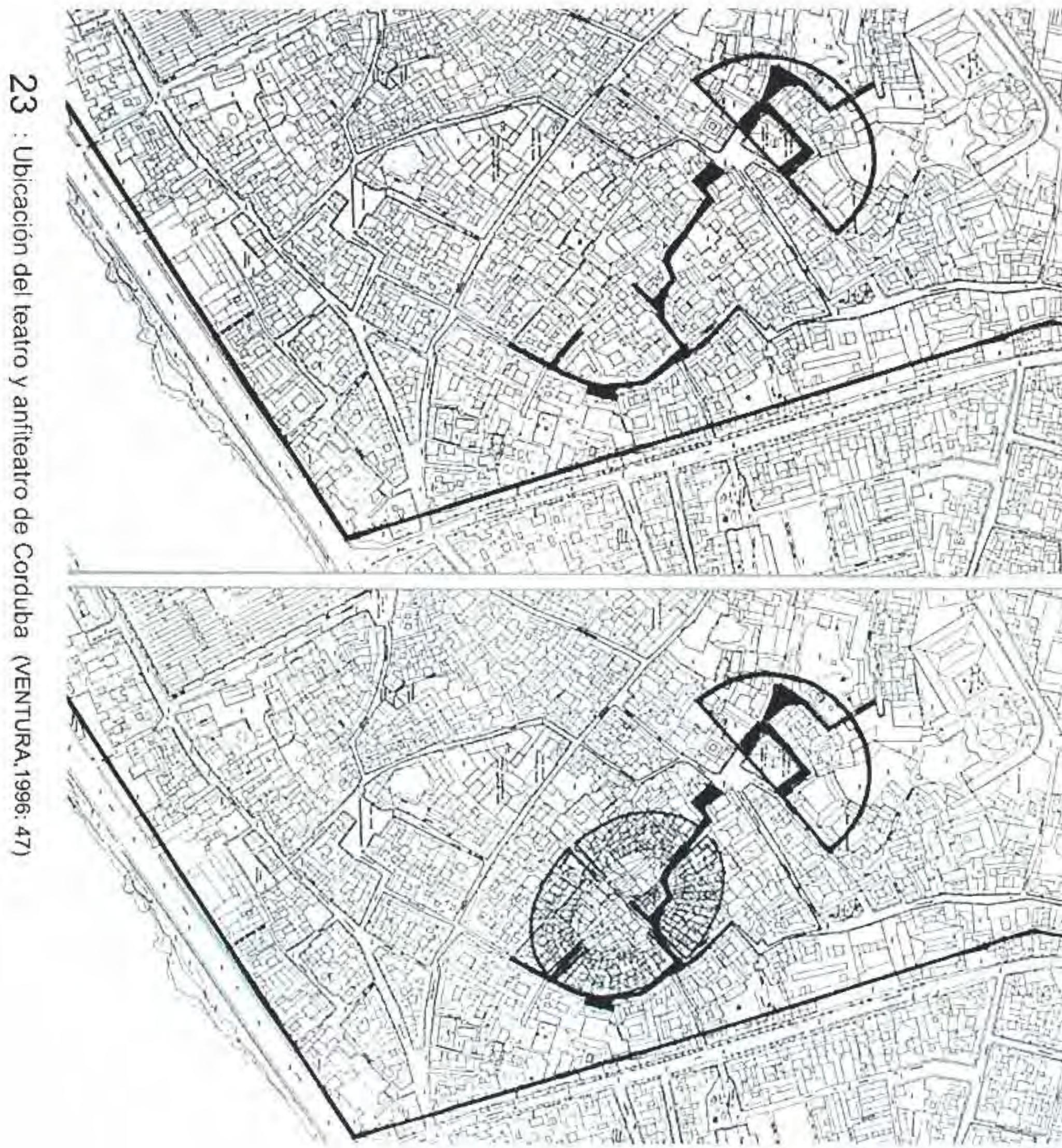


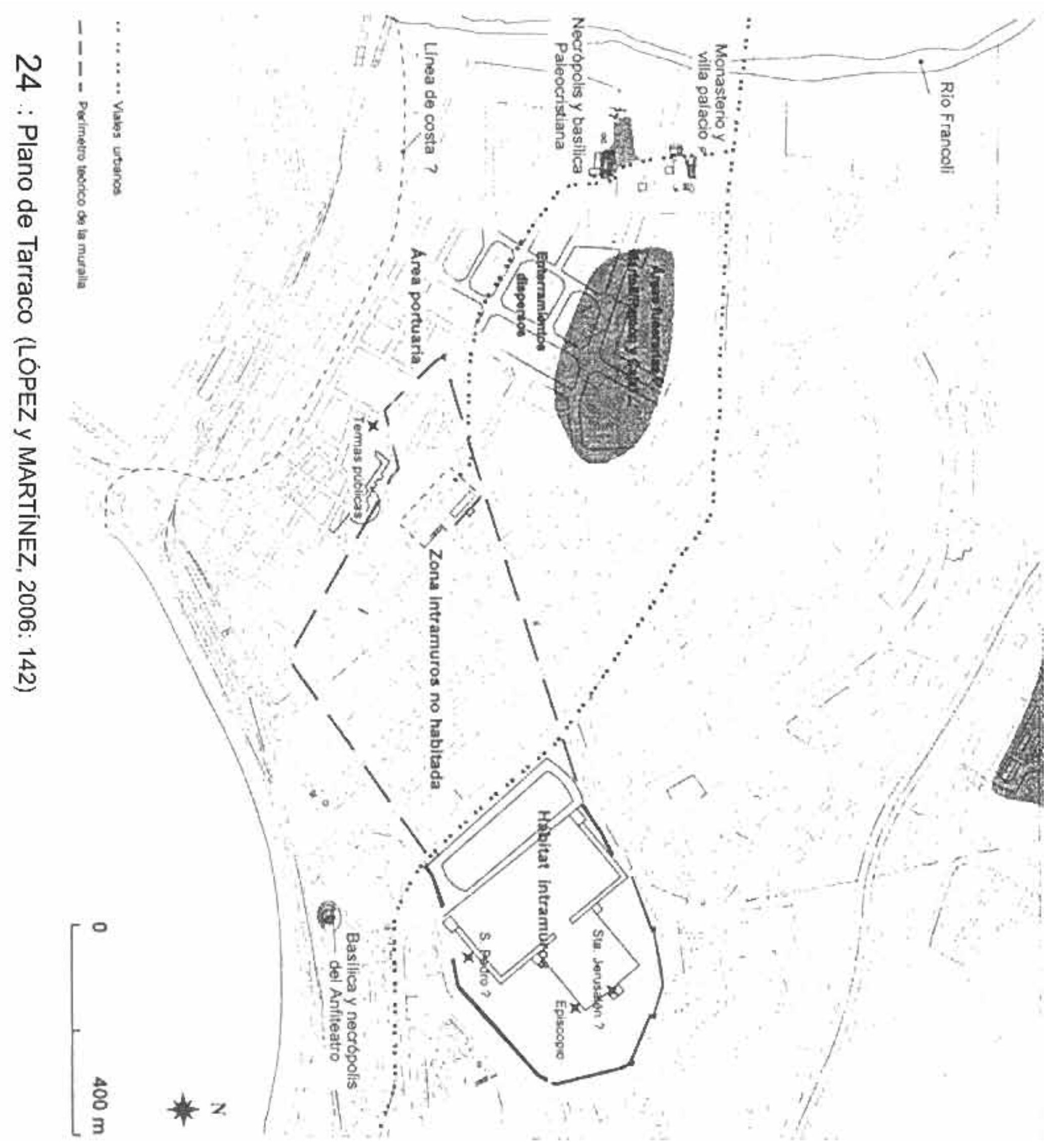




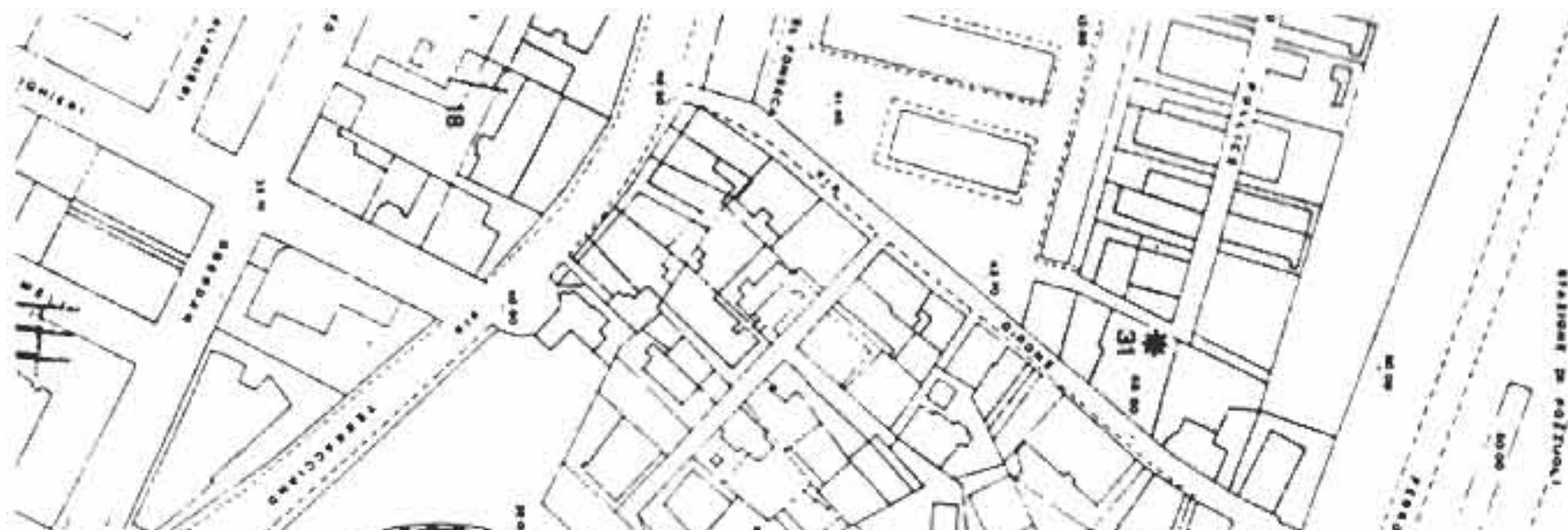
\% C.
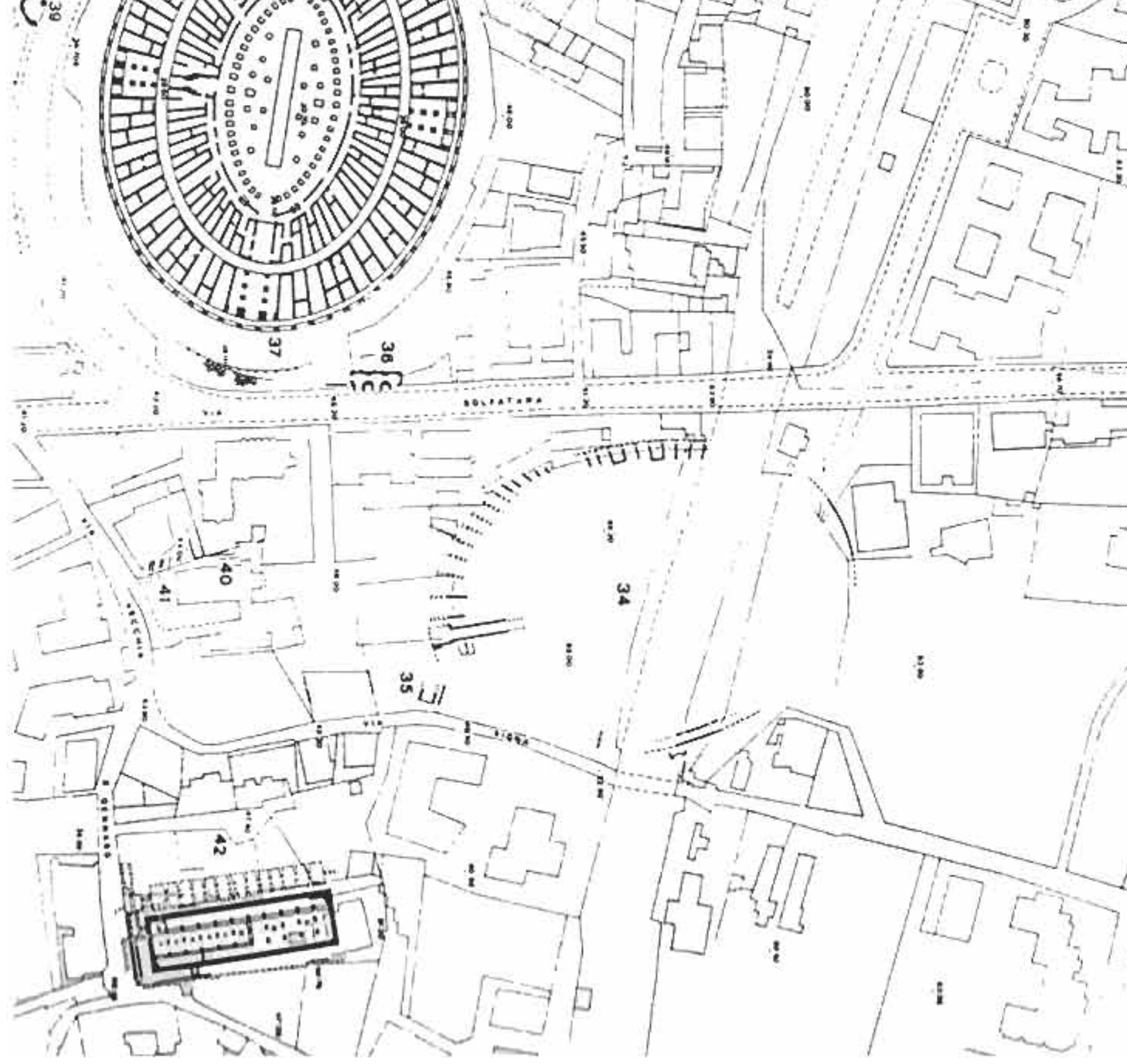


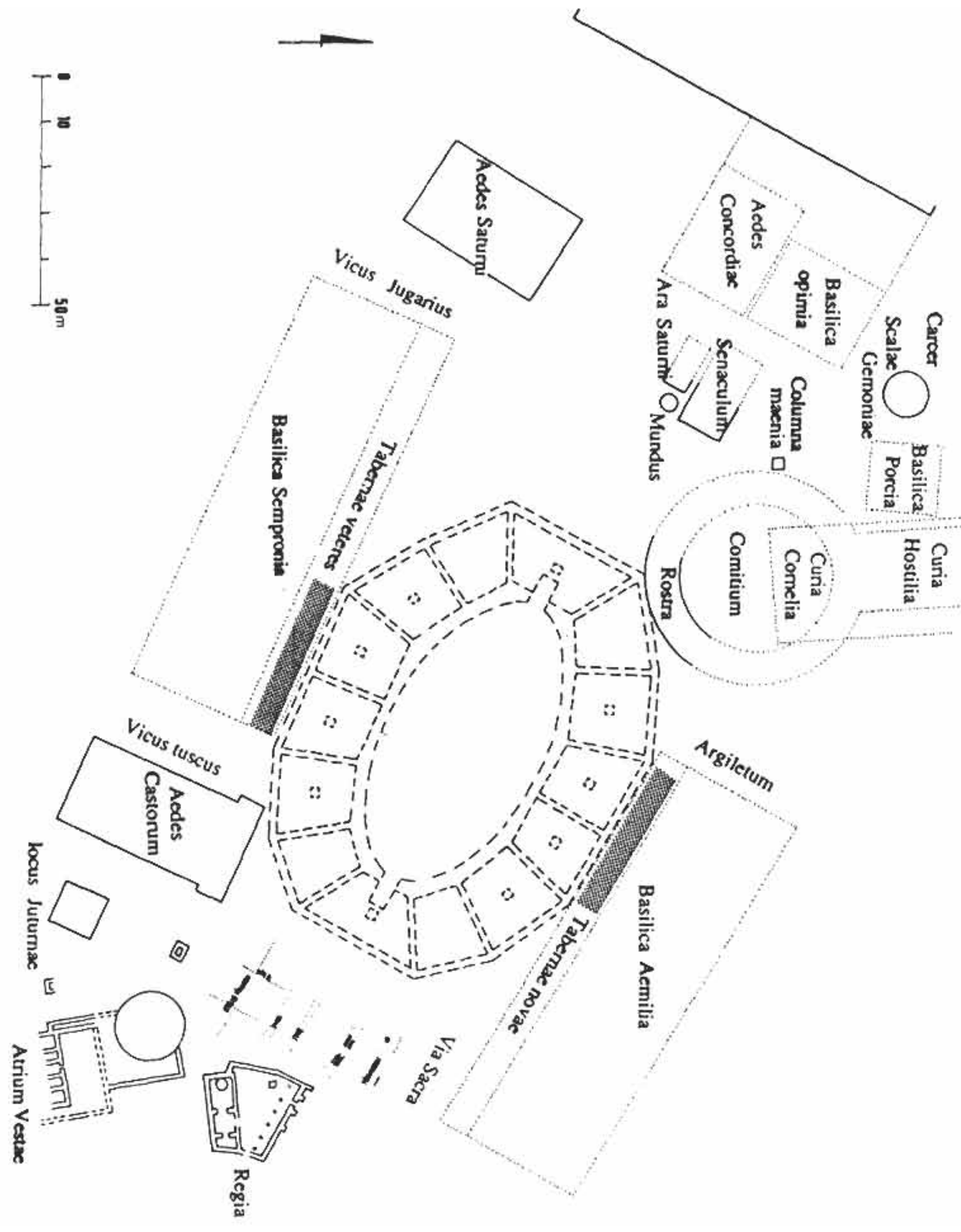




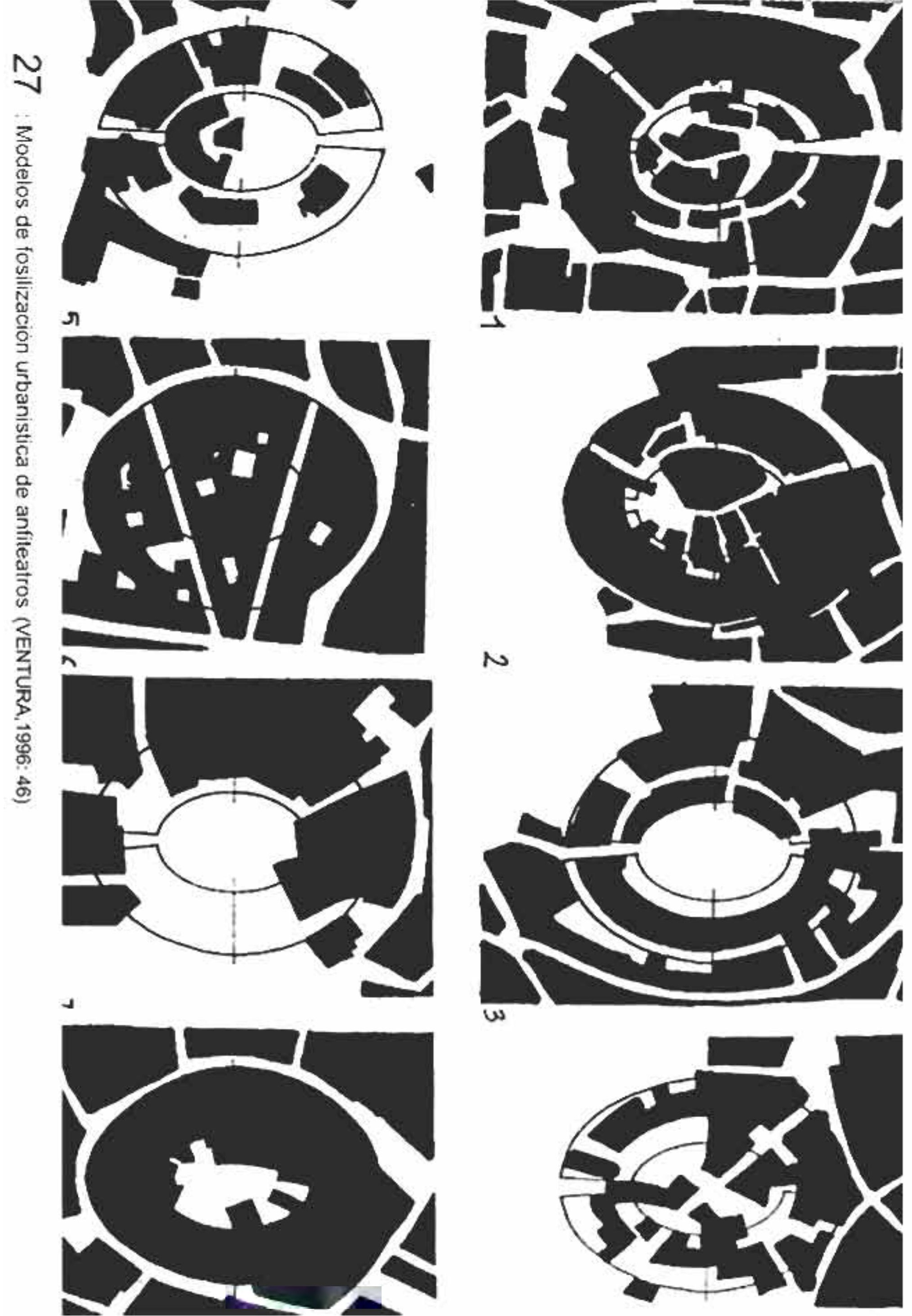




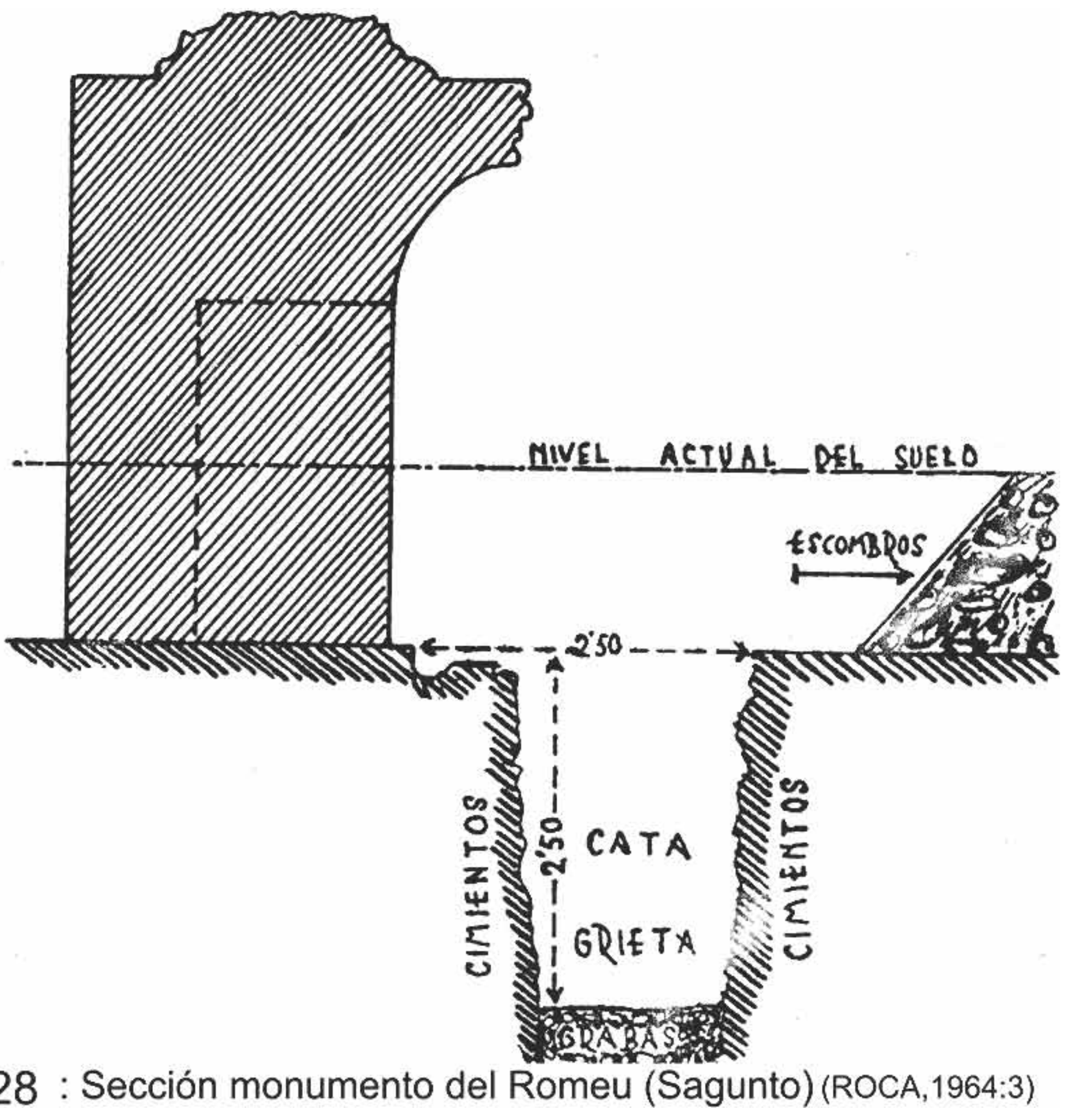


$\frac{1}{=0}=0$

$=0$

(1)

an $\quad 100$

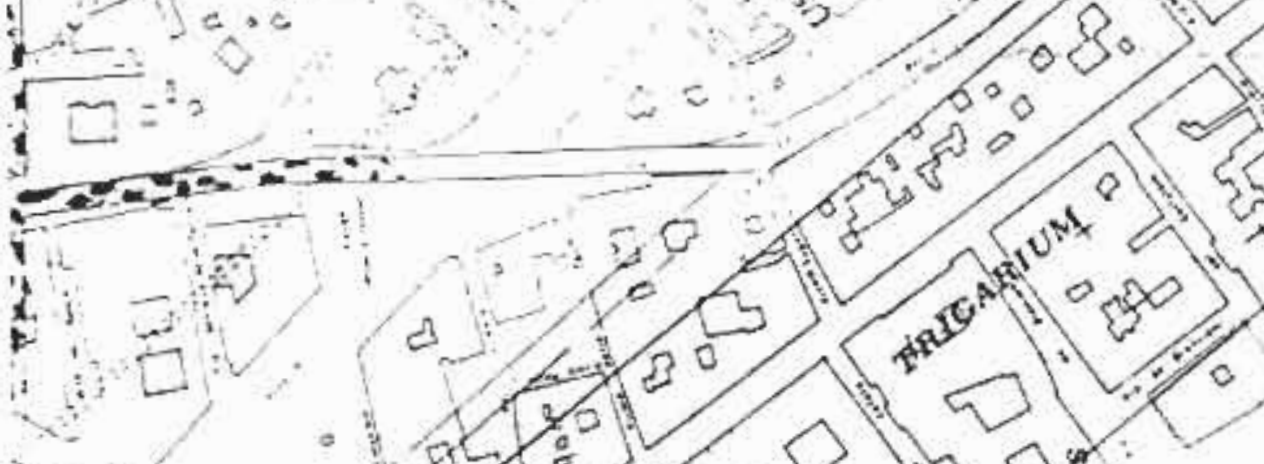




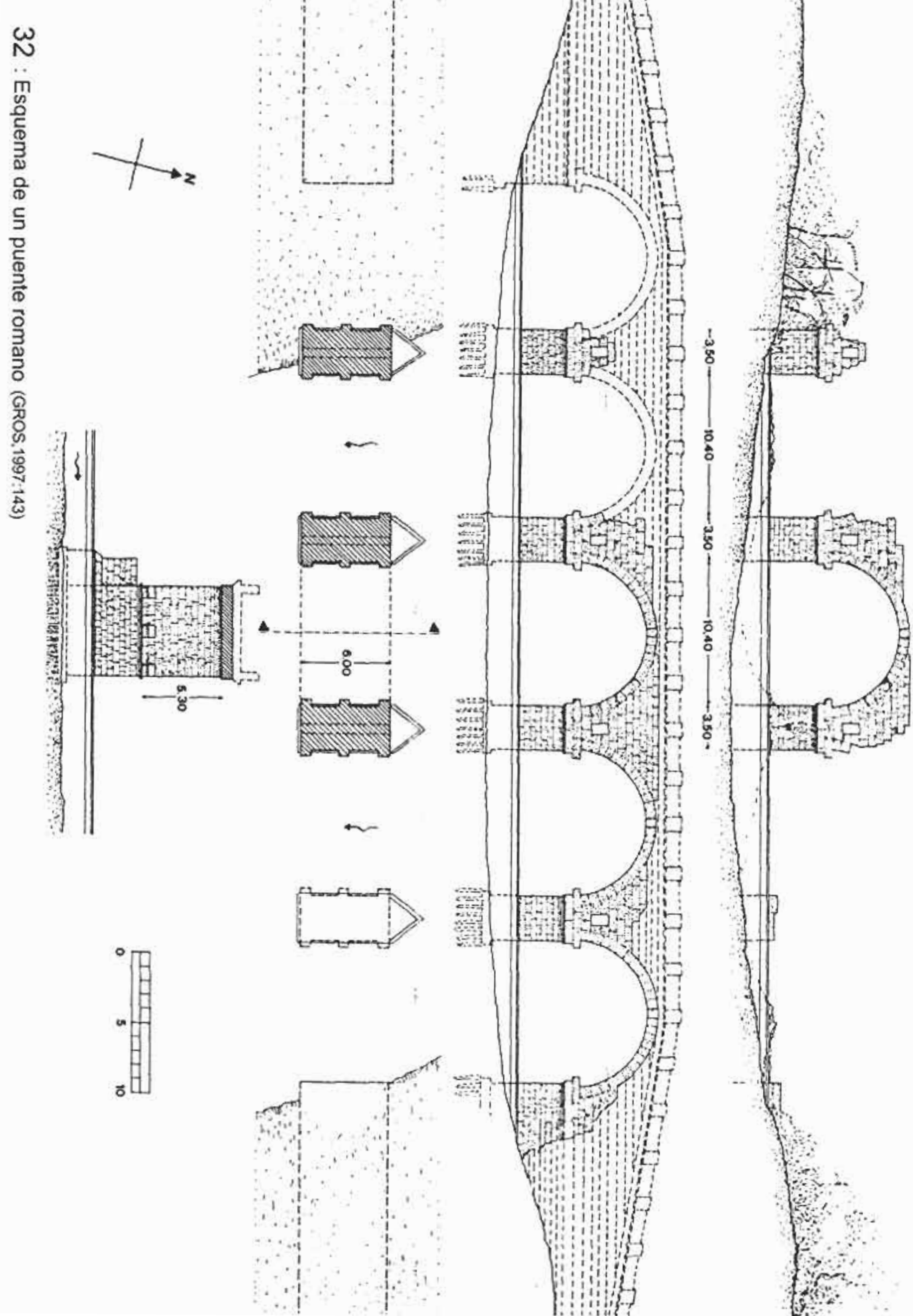




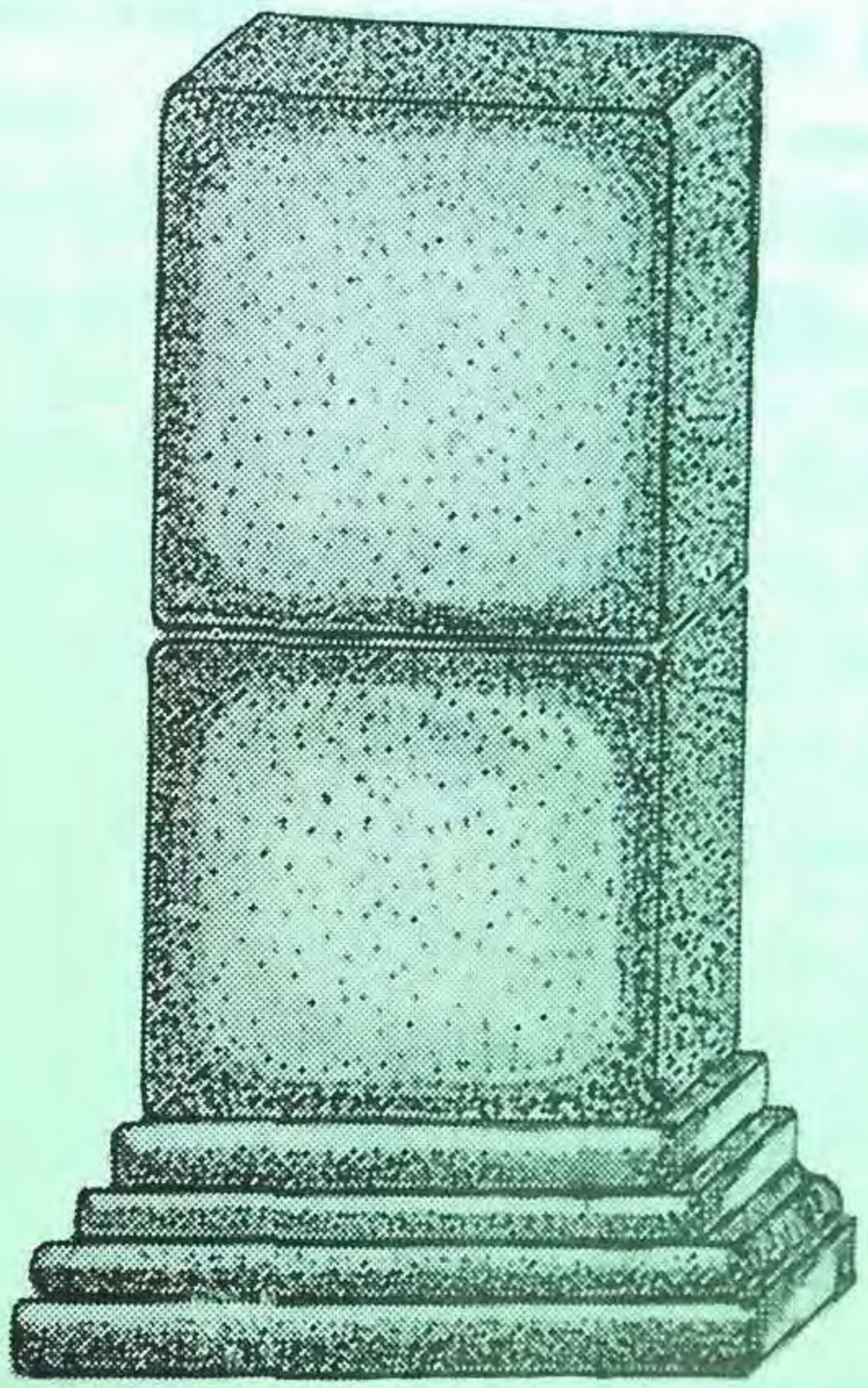

34 : Pilar del solar de Quevedo (AA. W.., 1981b.s.p.) 


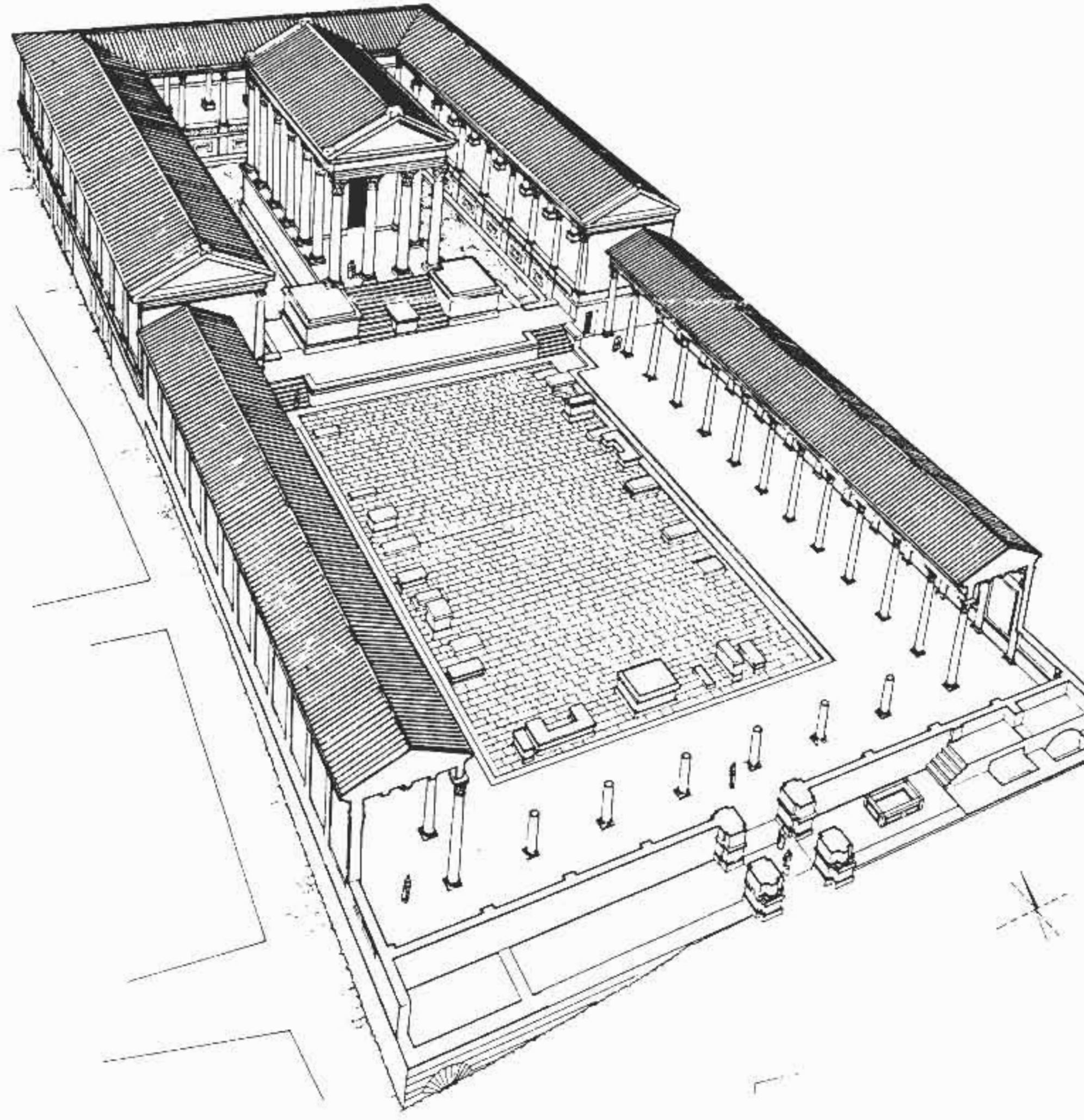

35 : Templo y foro de Conimbriga (GROS,1997:170) 


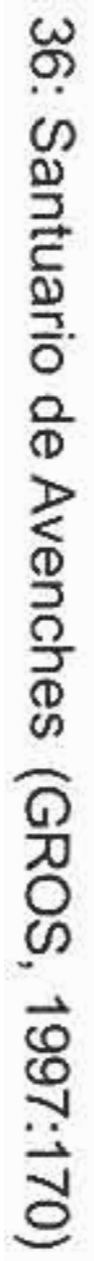

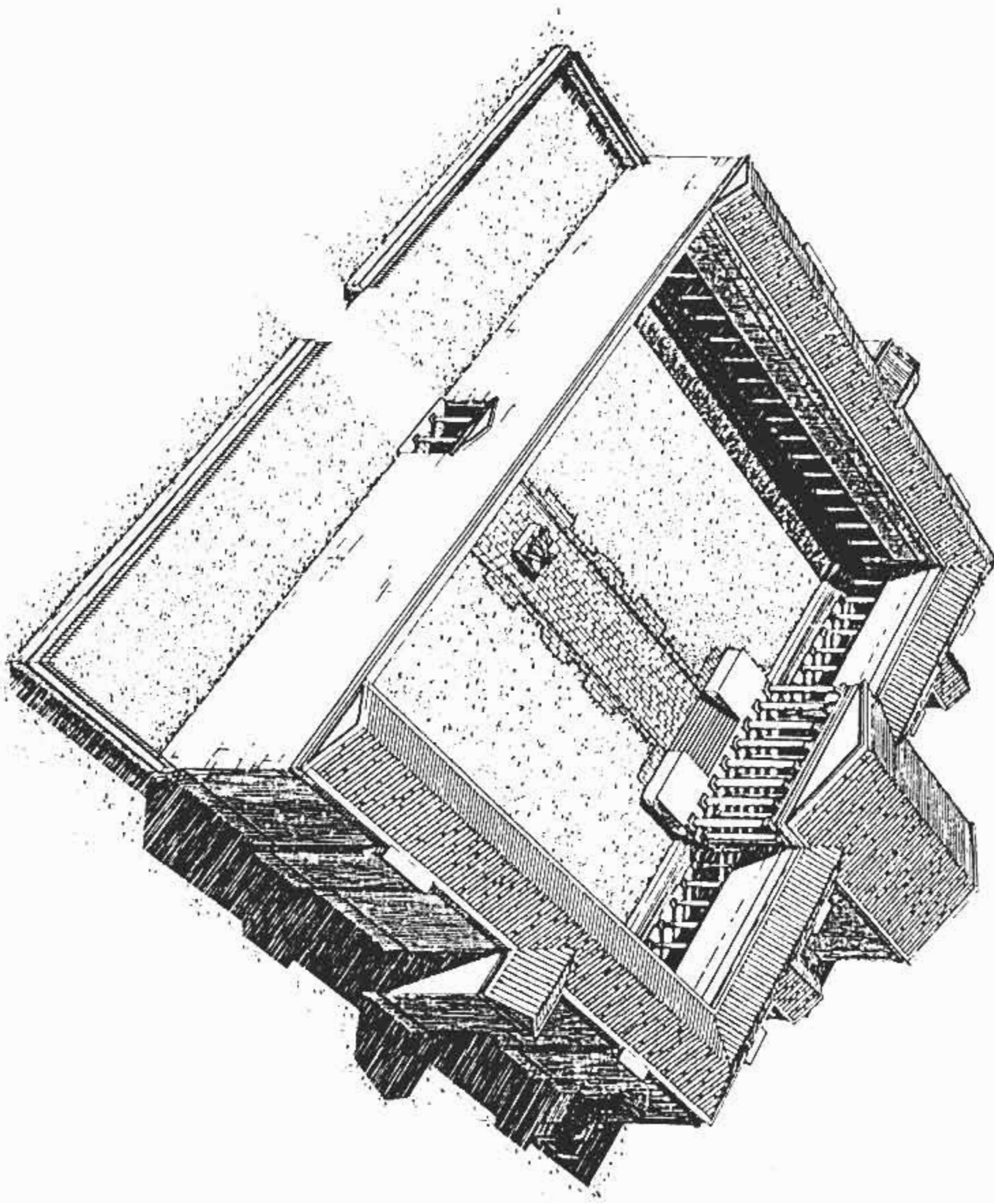




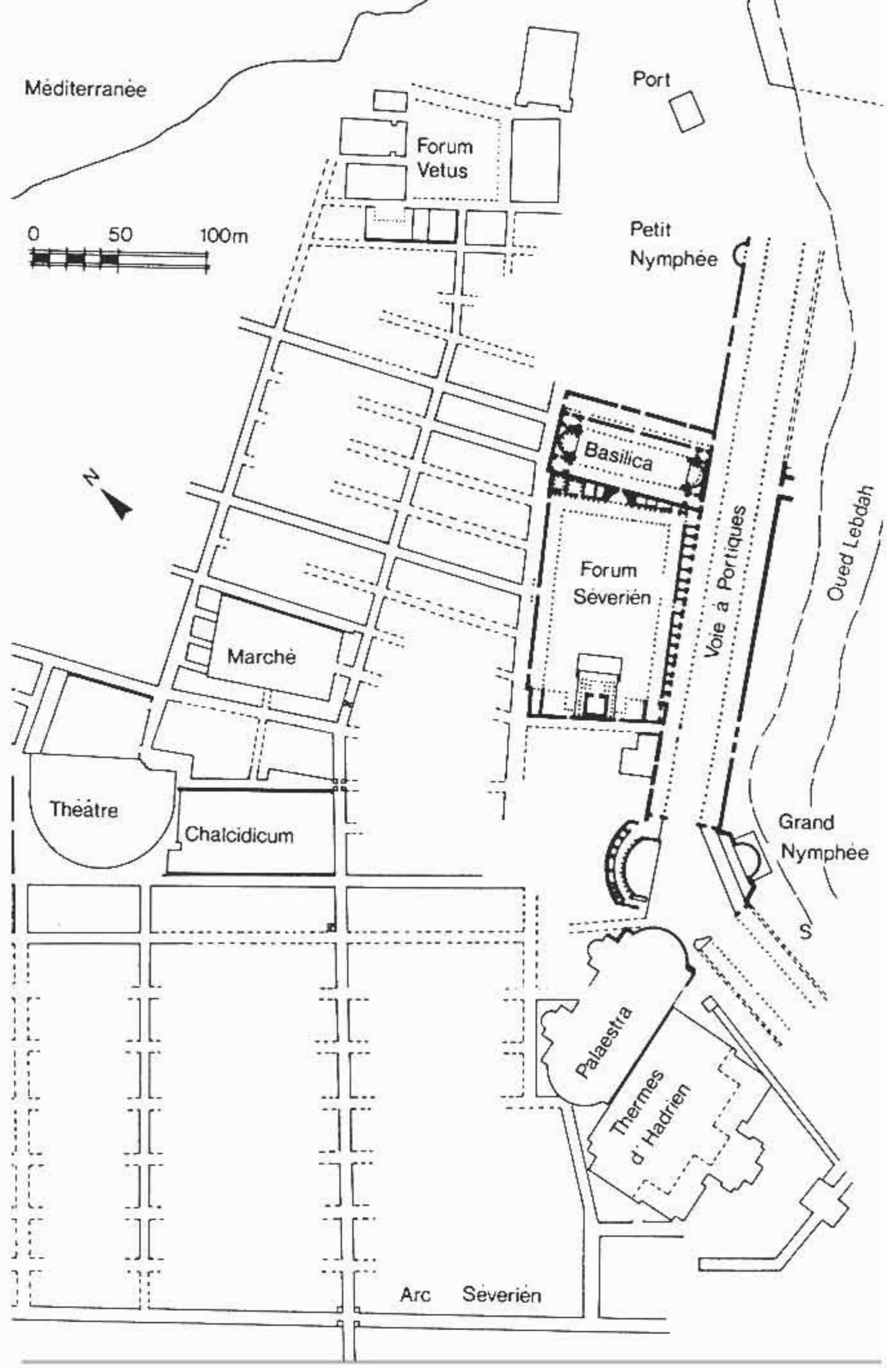




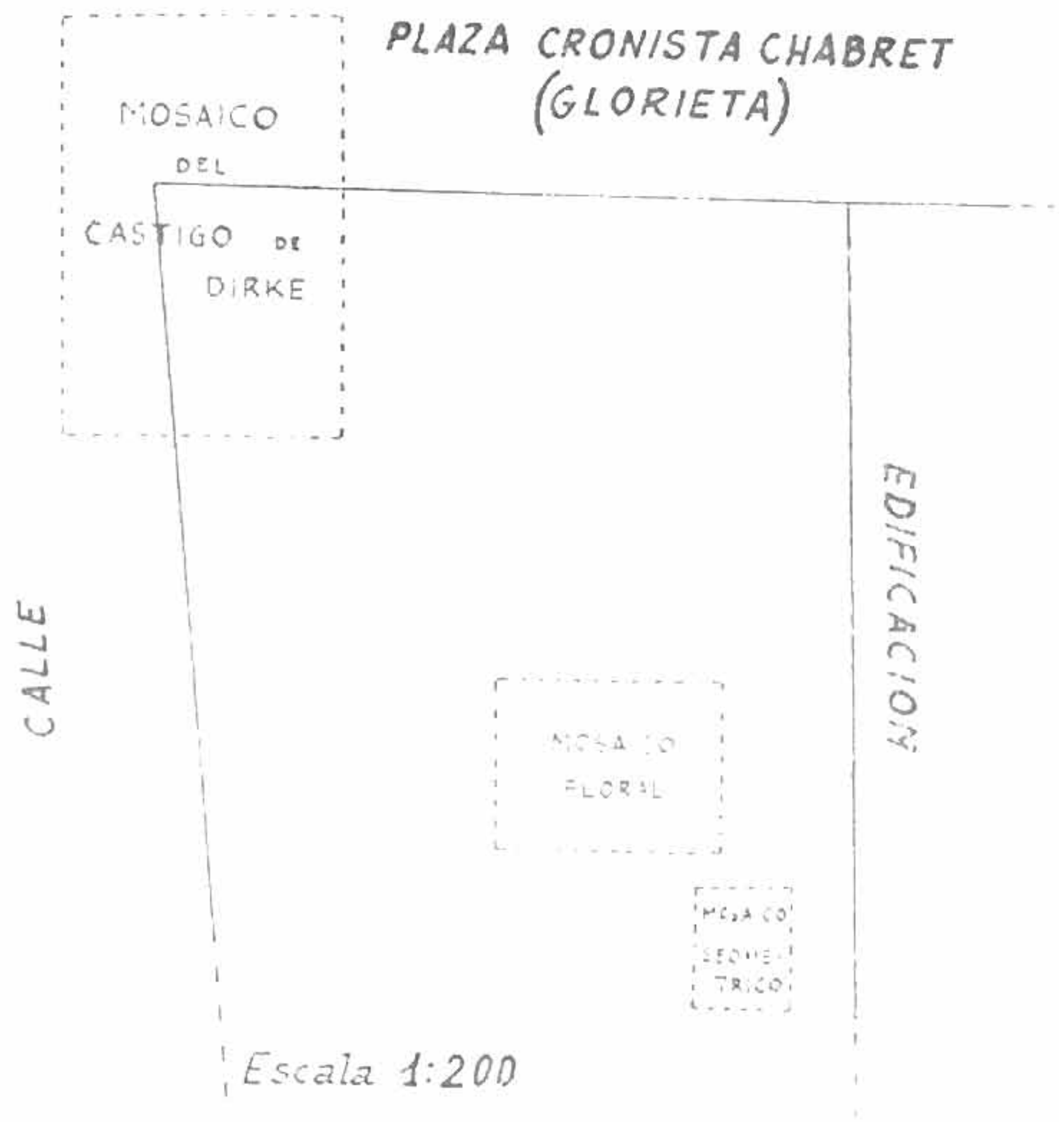

38 : Croquis de los hallazgos del solar de la Lira (Sagunto) (VALL,1961:153) 


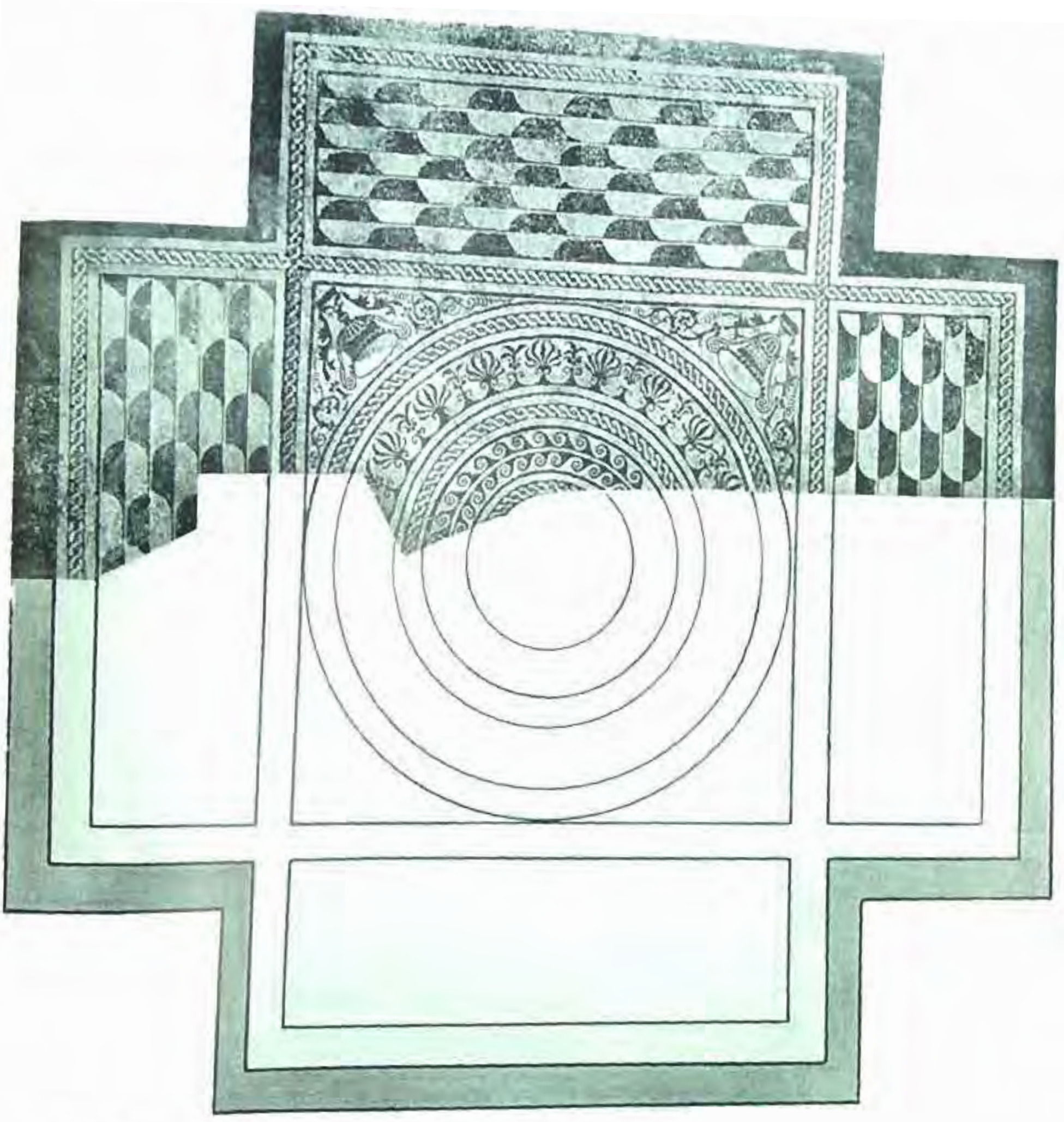

39: Mosaico del mercado (Sagunto) (VALL.1961:176) 


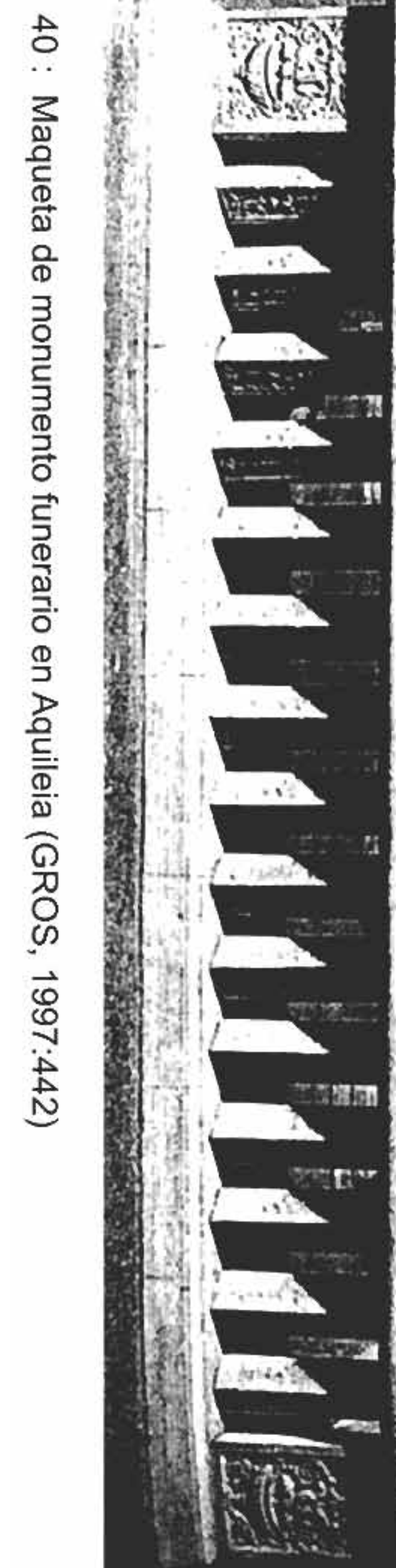

行

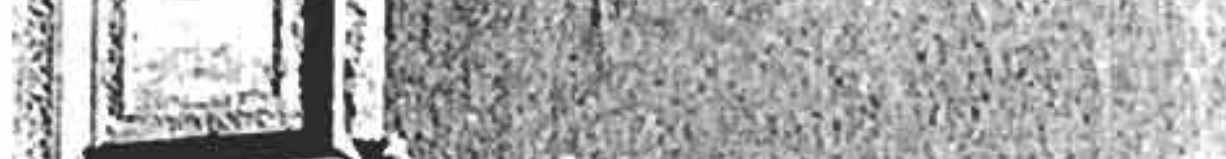

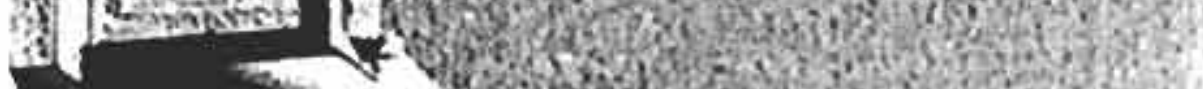
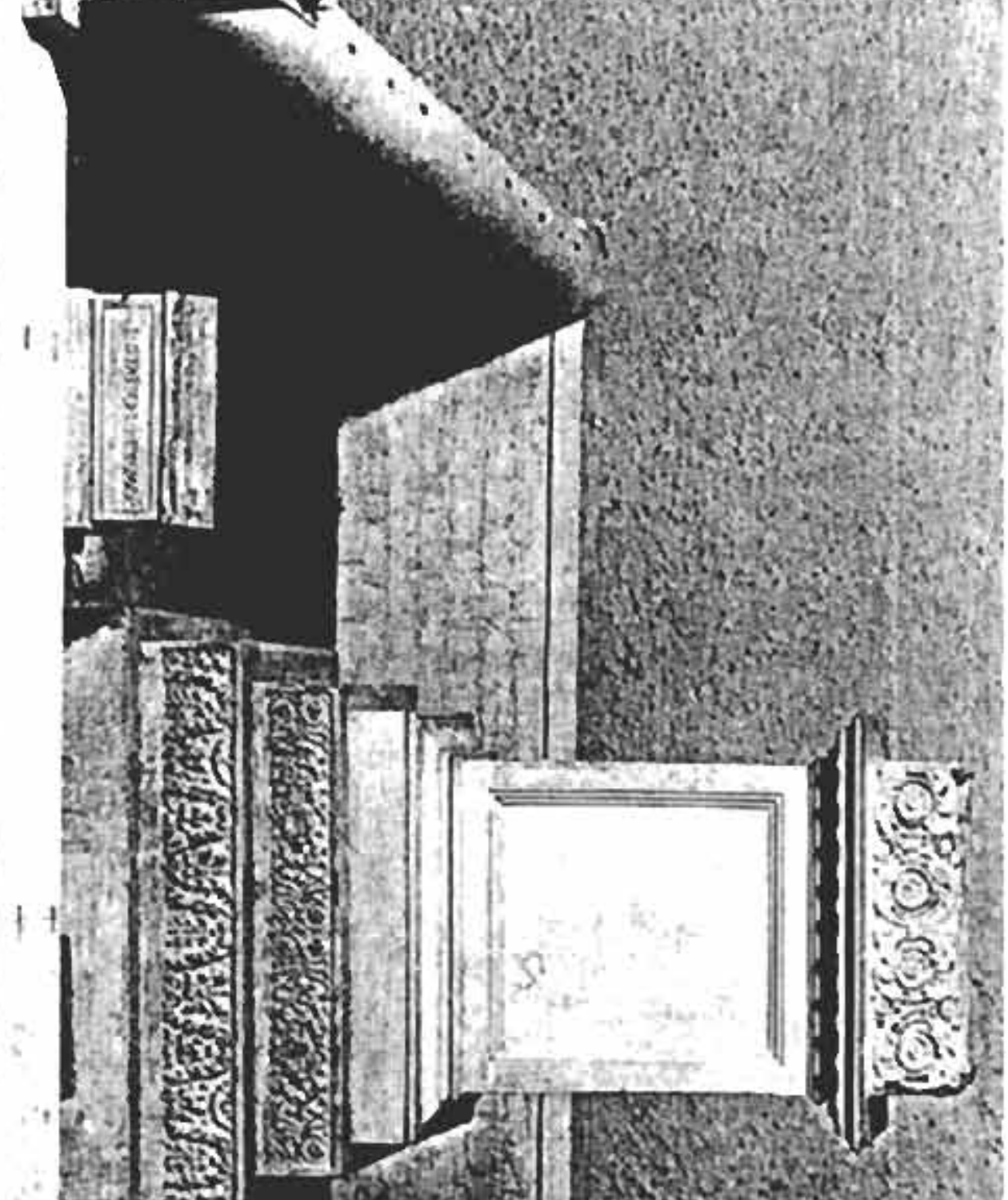

\section{An 1 was}

teris ore

Q

in
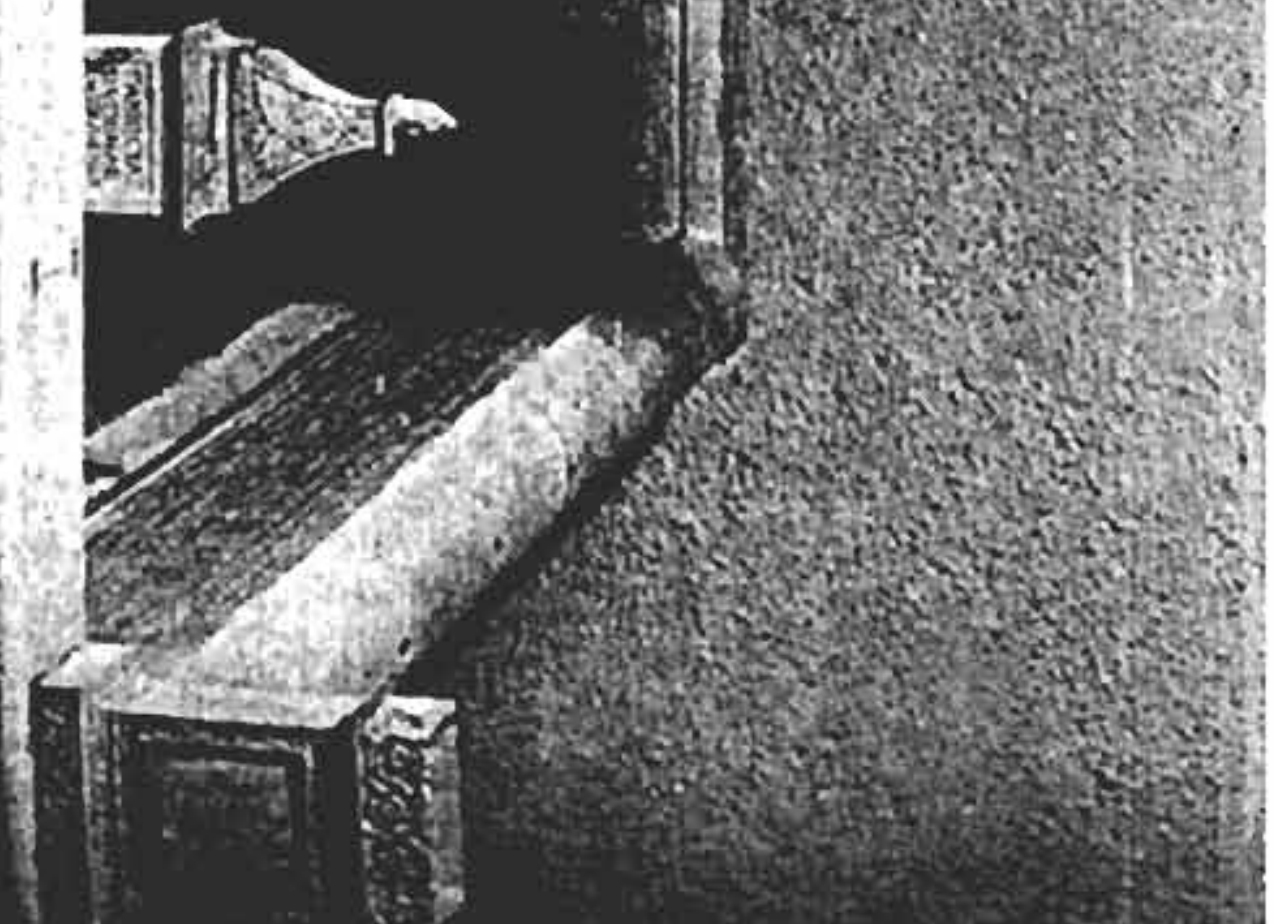


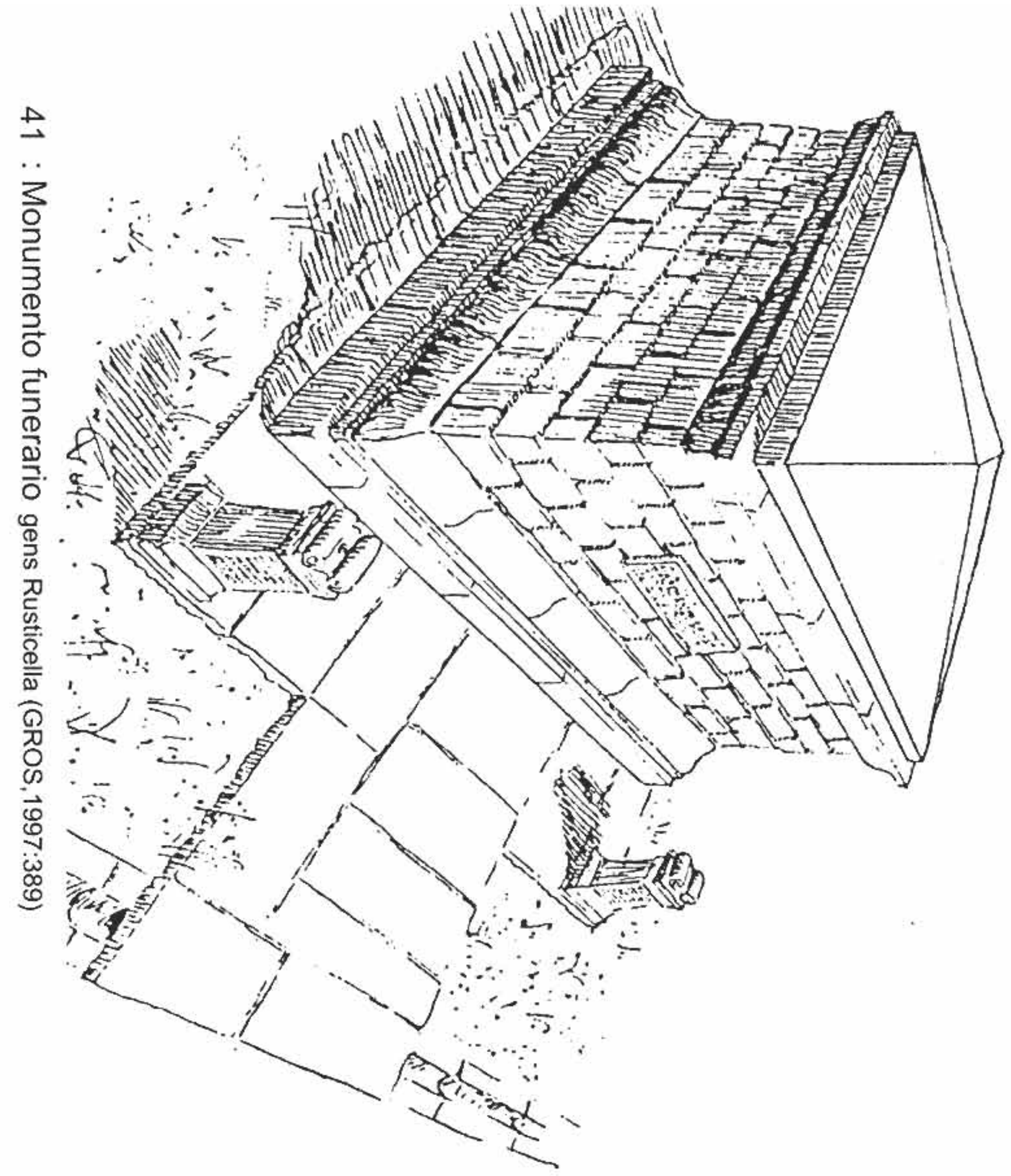




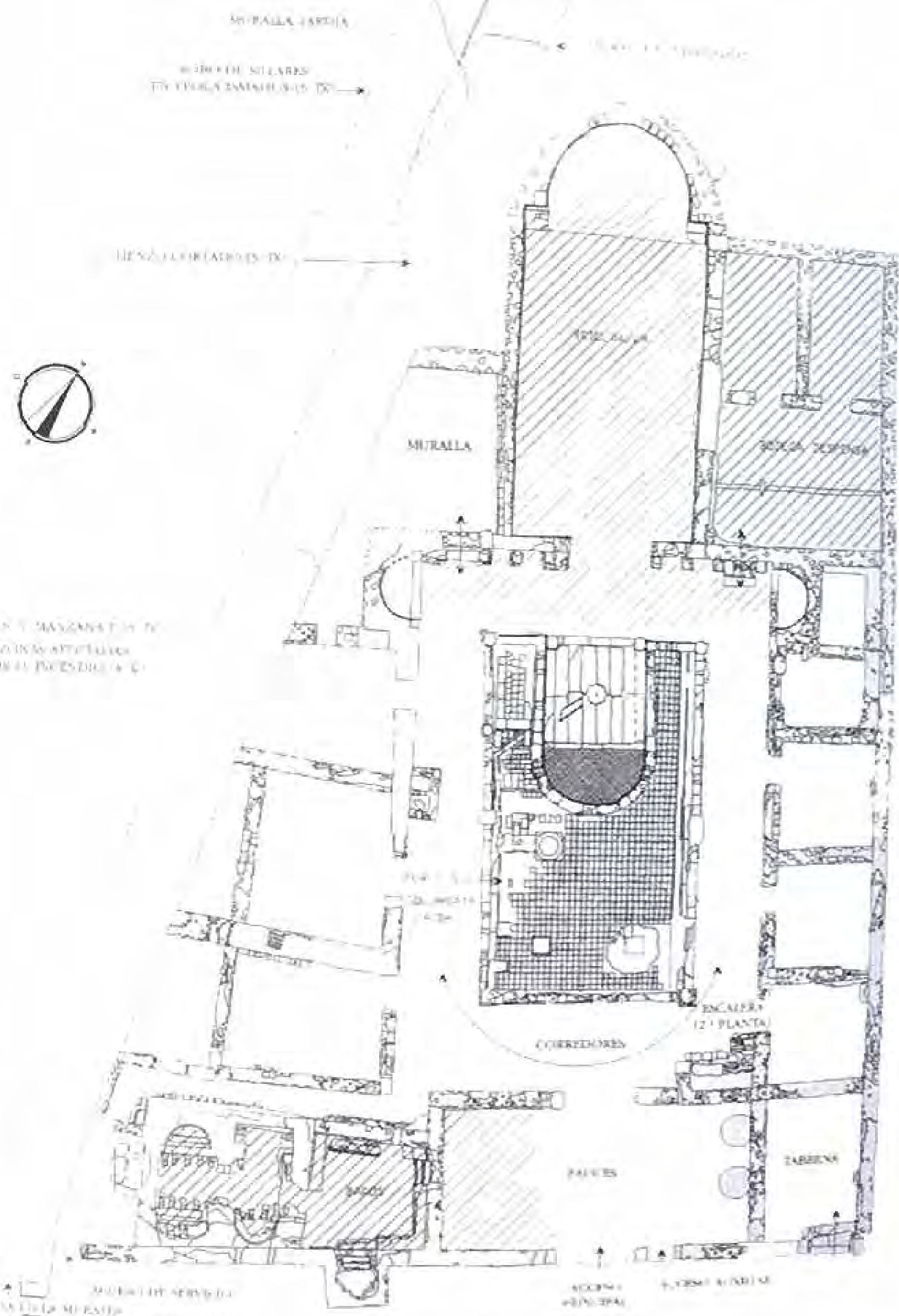

42. Muralla de Mèrida en la Moreria (ALBA.1998:368) 


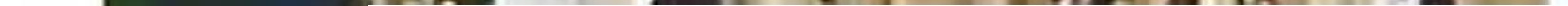




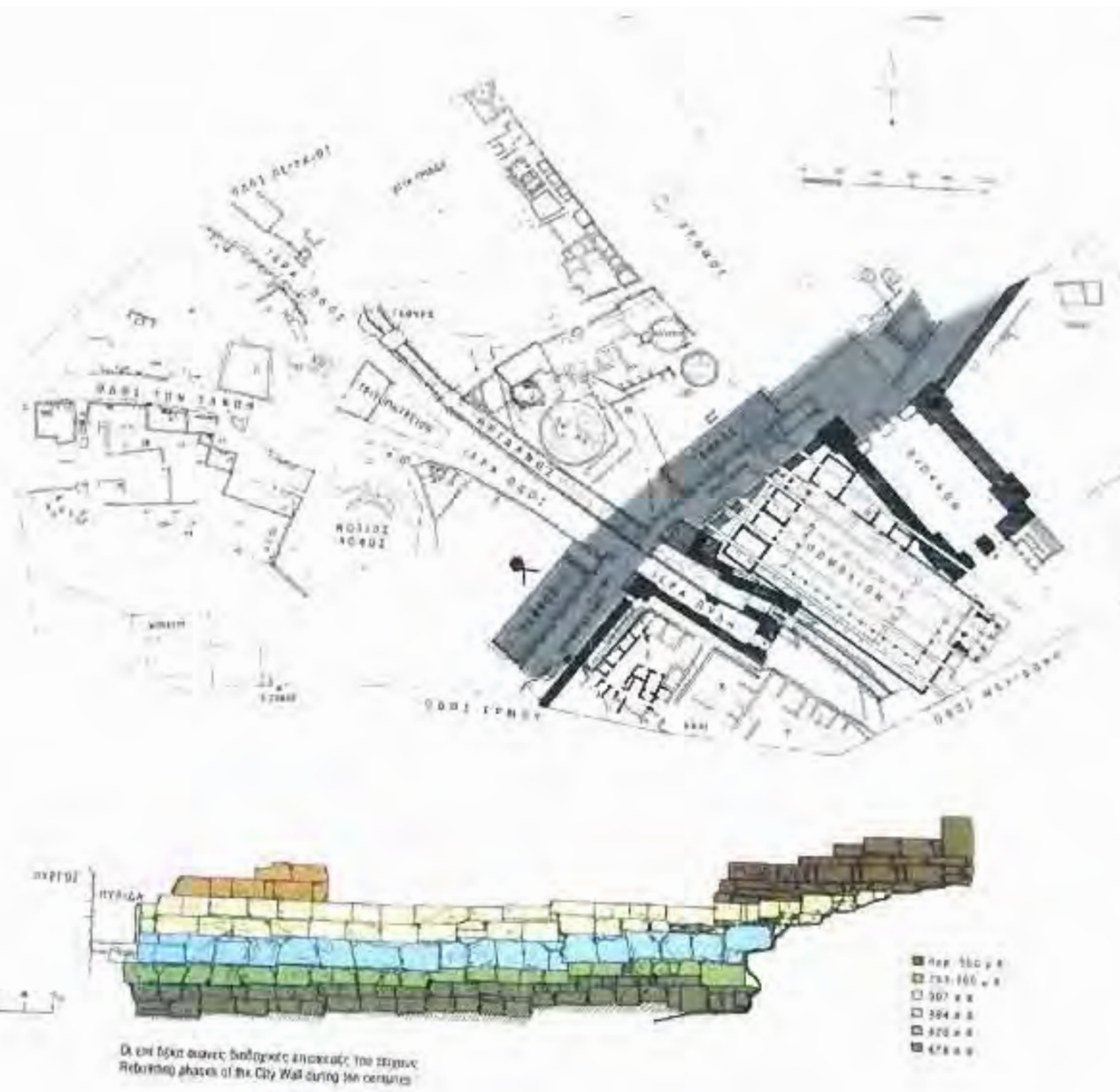

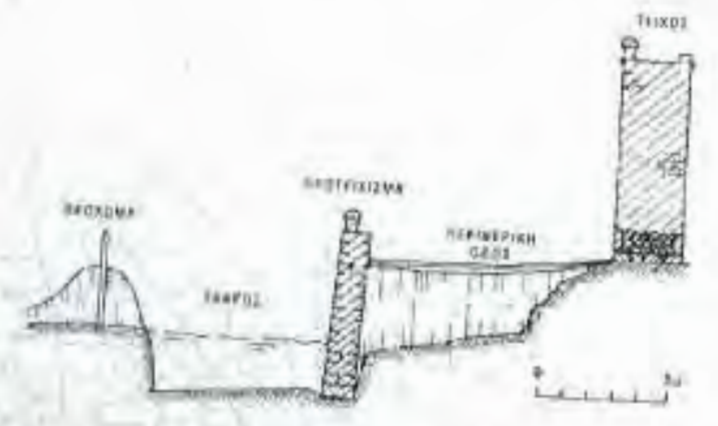

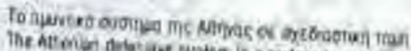

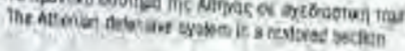

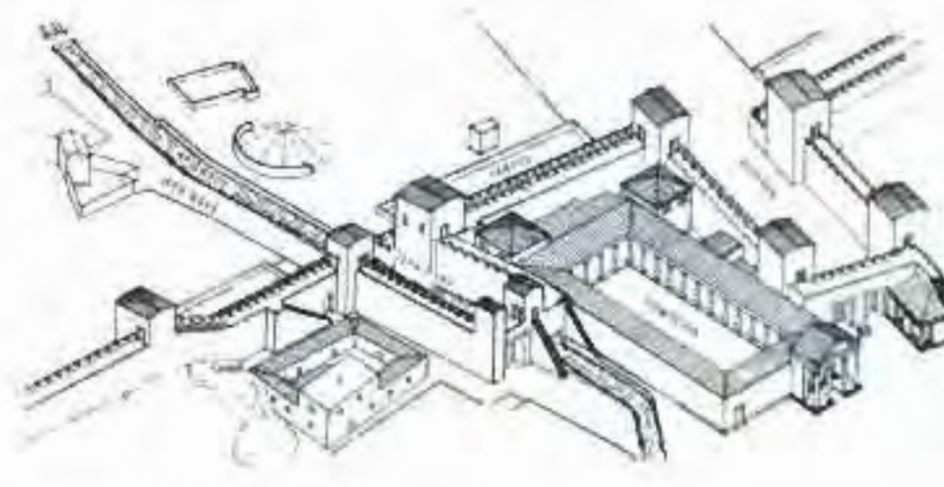

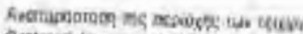
Restowet danuag al he Oto Wal ves

44 : Fortificación de Atenas (Parque Arqueológico) 


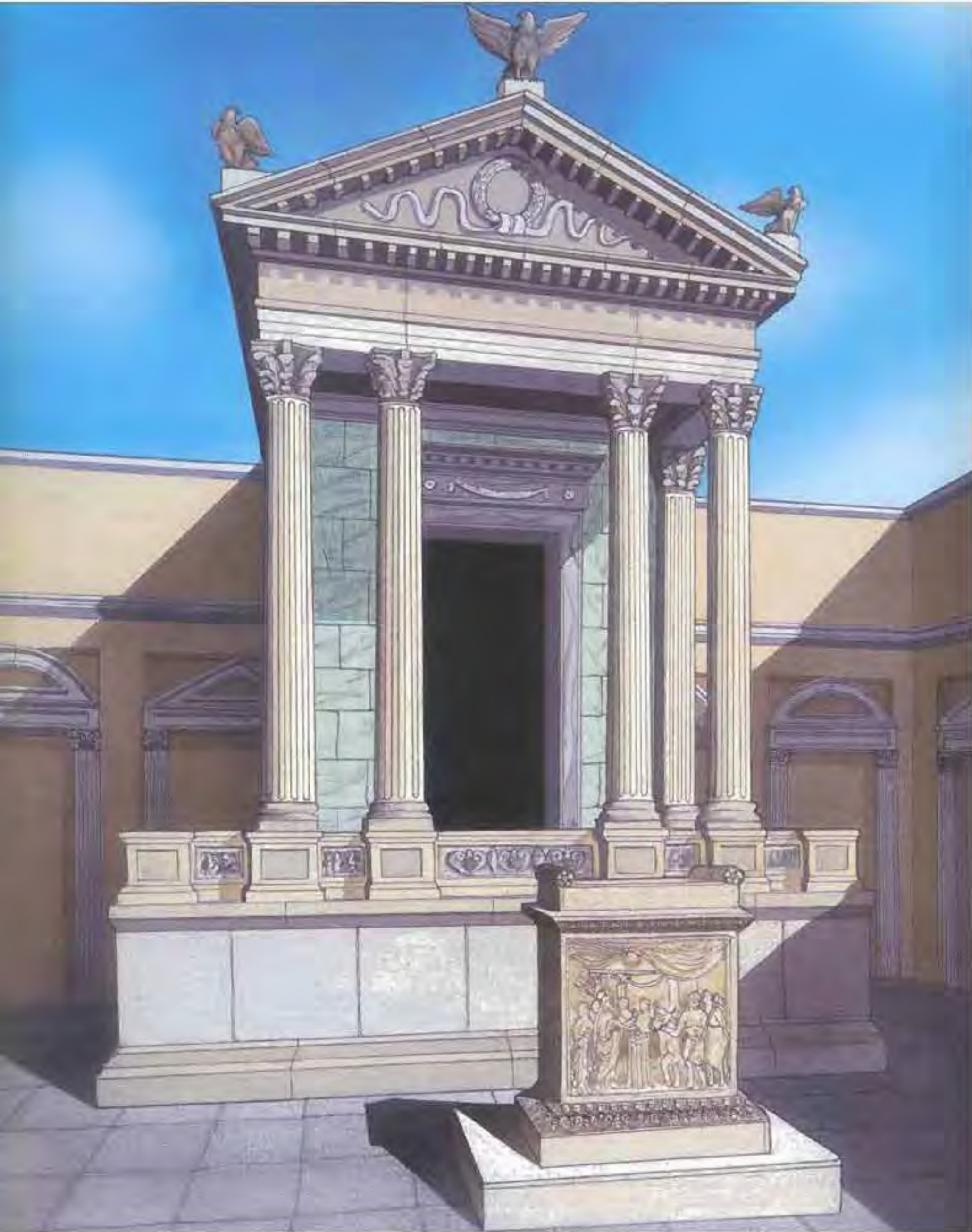

45 : Reconstrucción del templo de Vespasiano en Pompeya (Parque Arqueológico) 


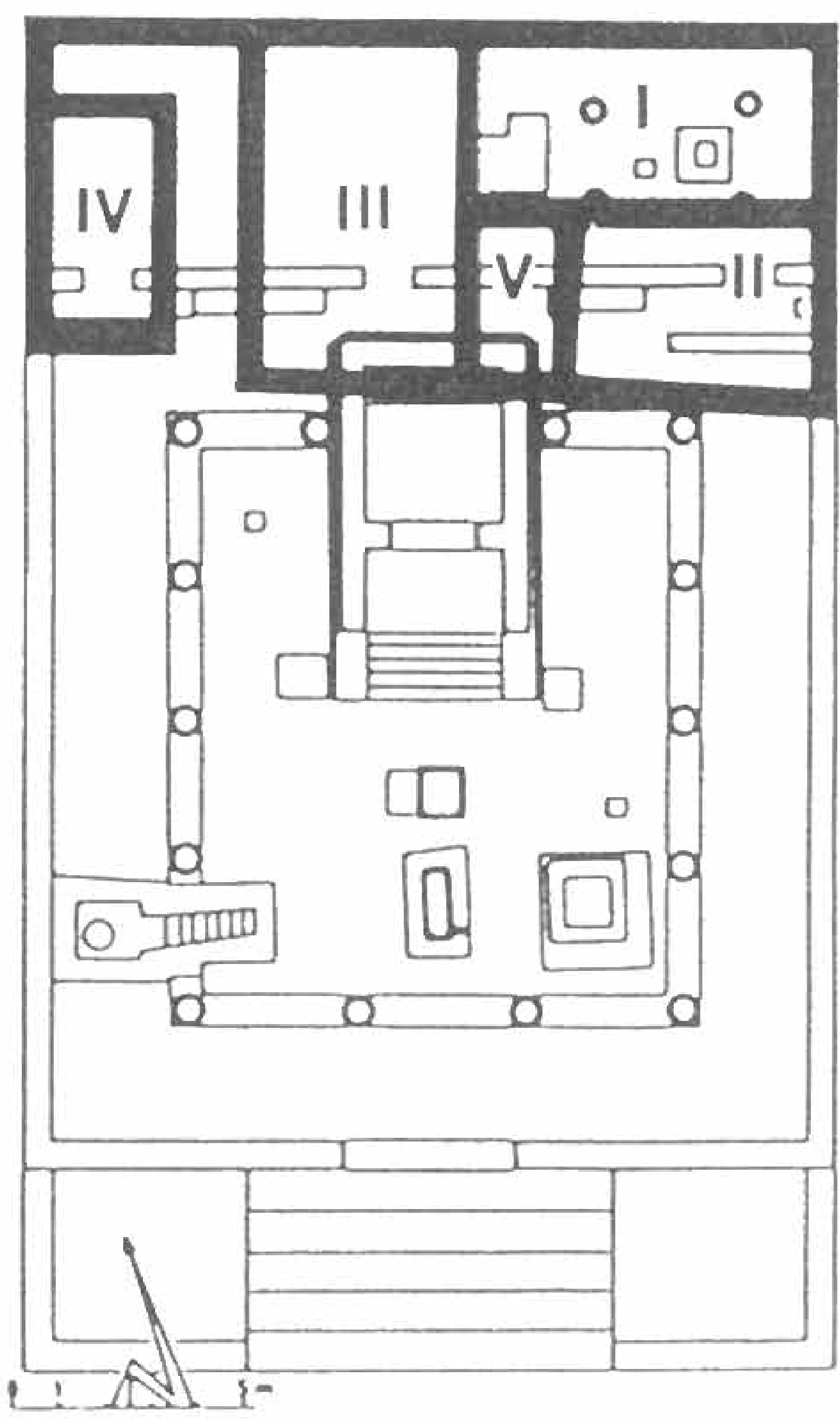

46: Templo de Baelo Claudia (ARCE,2006:122) 


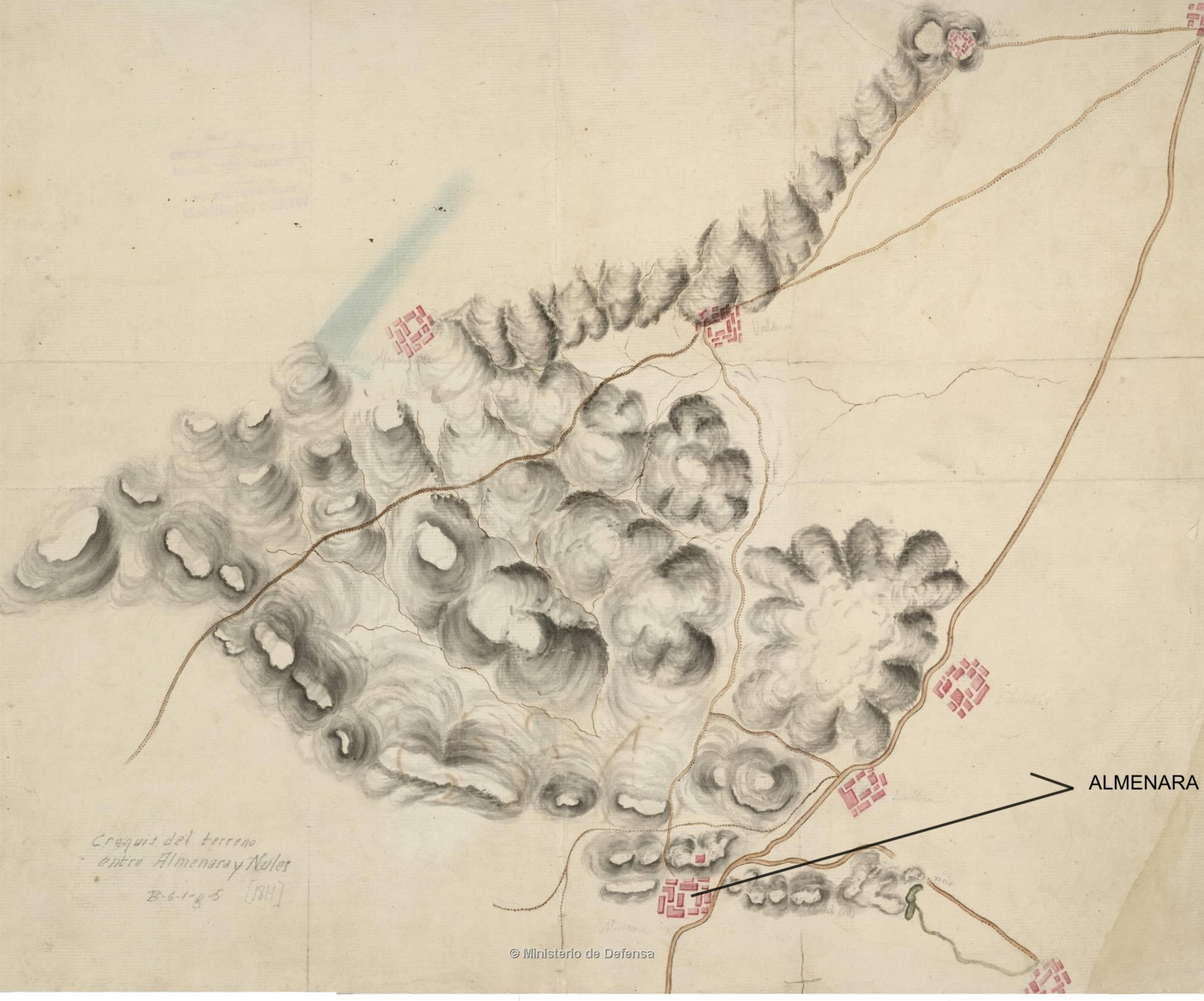

57: Plano del año 1813 (Ministerio de Defensa de España- SG-Ar.G- T.2-C2.1) 


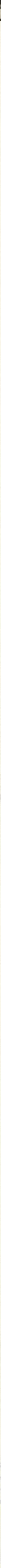

58:Plano años 1813-15 (Ministerio de Defensa España SG Ar.G-T.3-C.2-2) 
LAMINAS, GRAFICOS Y TABLAS 


\section{LAMINA I}
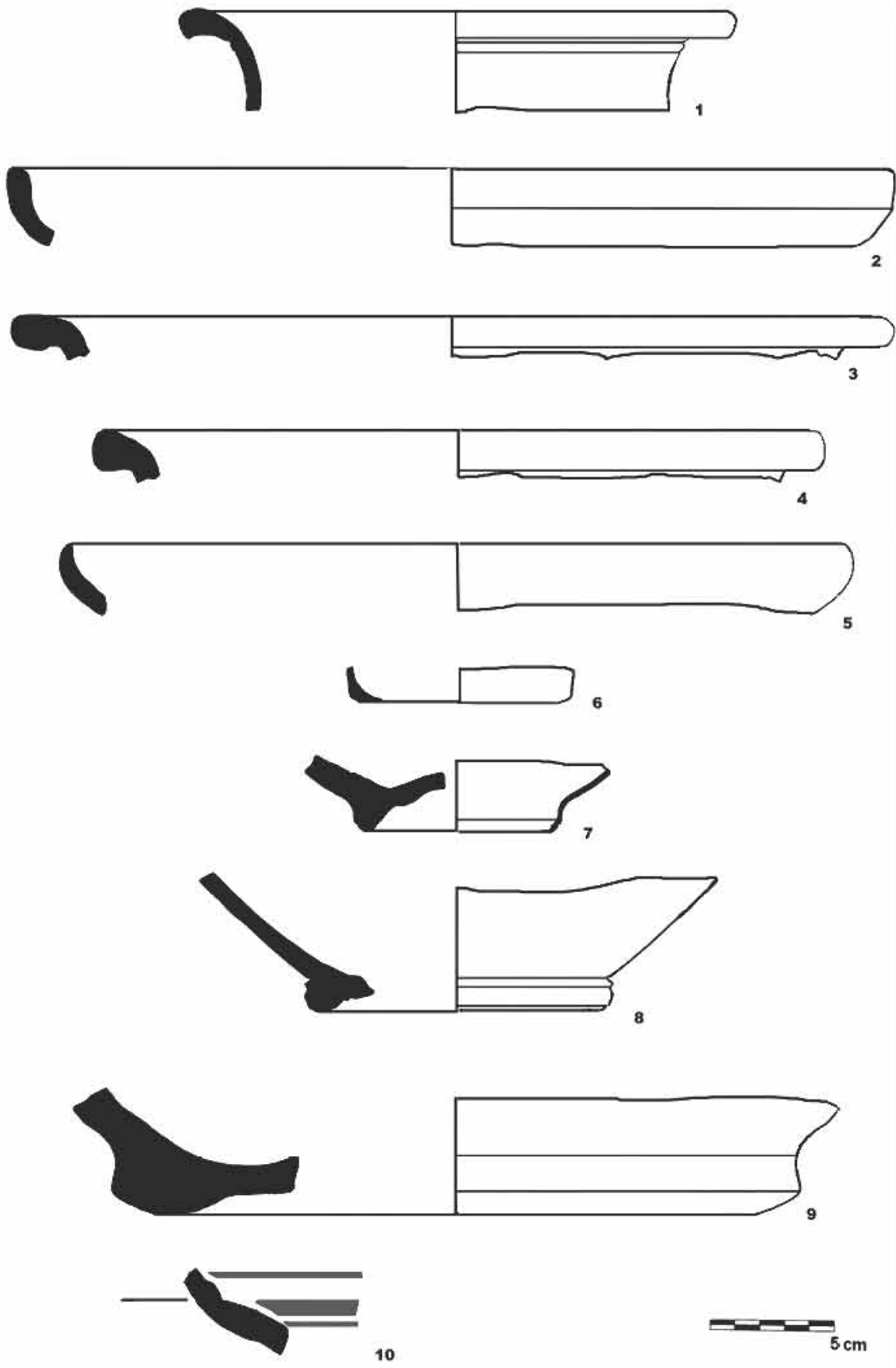


\section{Materiales del yacimiento del Pujol de Gasset (Castellón)}

1. Borde exvasado de cerámica de cocina. Época musulmana. (UE 5002)

2. Borde reentrante de gran plato. Época Ibérica (UE 5002)

3. Borde plano. Época ibérica. (UE 5002)

4. Borde exvasado cuadrangular de cerámica reductora de cocina. Época ibérica (UE 5002)

5. Borde de cuenco de Campaniense A. Posible Lamboglia 25. (UE 5002)

6. Base de cubilete de paredes finas. (UE 5002)

7. Base con pie moldurado destacado. Época ibérica (UE 5002).

8. Base con pie moldurado. Época ibérica. (UE 5002).

9. Base en codo de cerámica beige y gris. Época ibérica (UE 5001).

10. Carena decorada con franjas y filetes vinosos e incisión externa. Época ibérica (UE 5001). 
LAMINA ॥

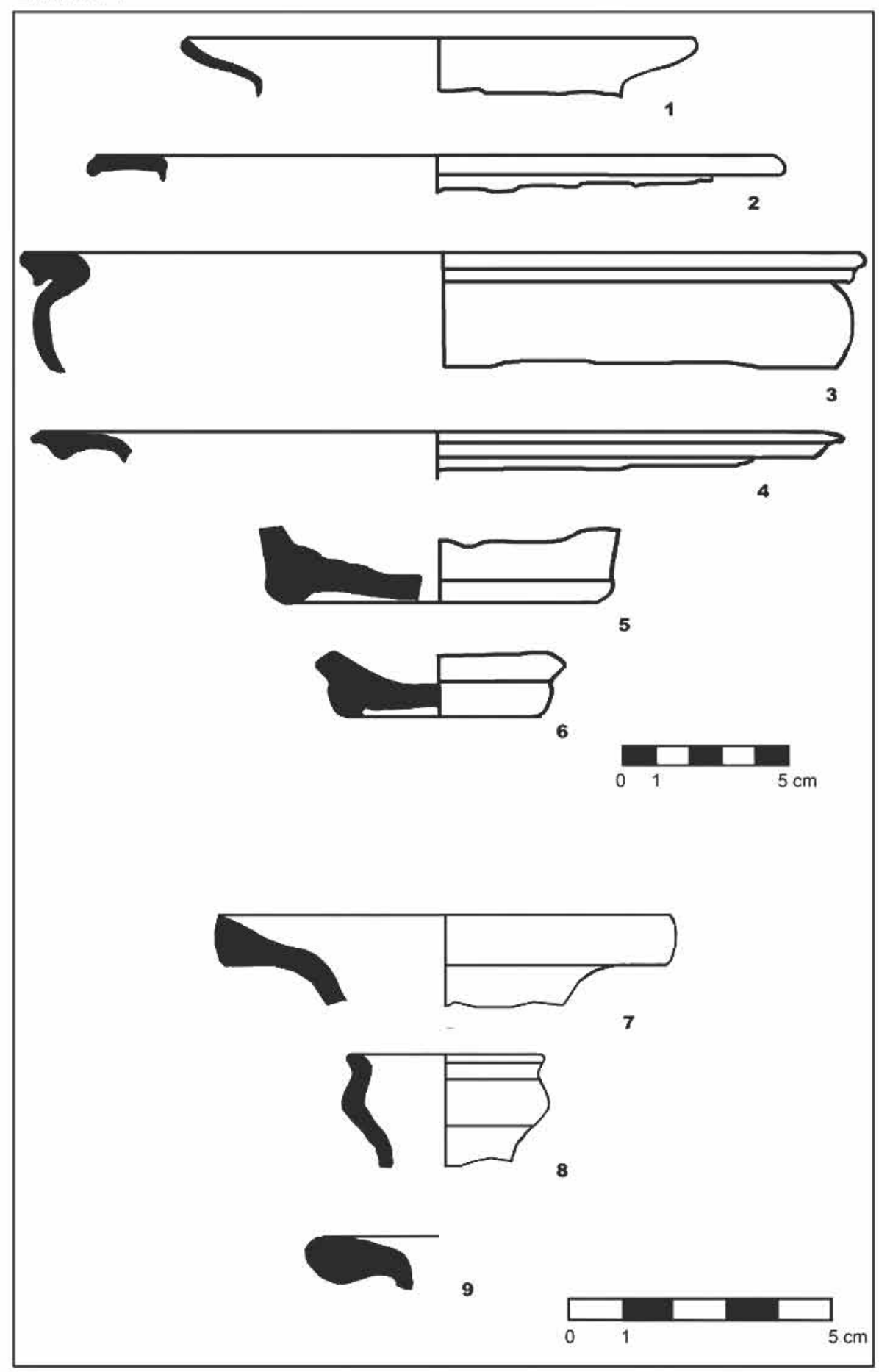




\section{LAMINA II}

Materiales del yacimiento de la "Necrópolis de Les Alqueries" (Castellón)

1. Borde exvasado de cerámica común romana.

2. Borde de ala plana de cerámica común romana.

3. Borde moldurado de cerámica común romana.

4. Borde plano moldurado de cerámica común romana.

5. Base con pie de cerámica común romana.

6. Base con pie en codo de cerámica común romana.

Materiales del yacimiento del "Camí Corrent/Cap de Terme" (Burriana)

7. Borde cuadrangular de botella romana.

8. Borde recto de botella romana.

9. Borde exvasado de cerámica común romana. 

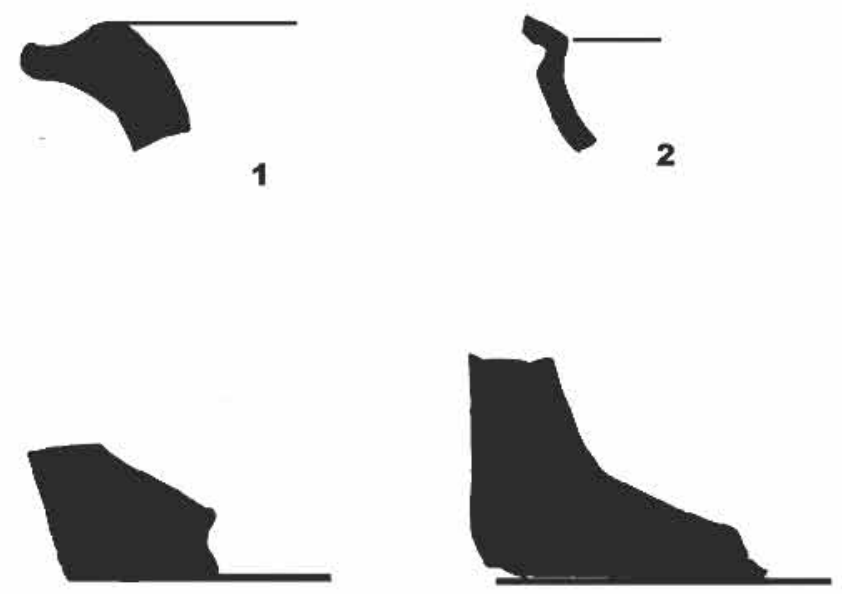

3
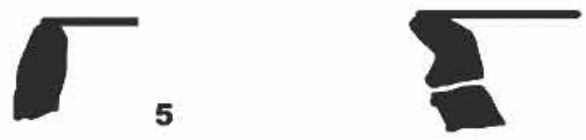

6
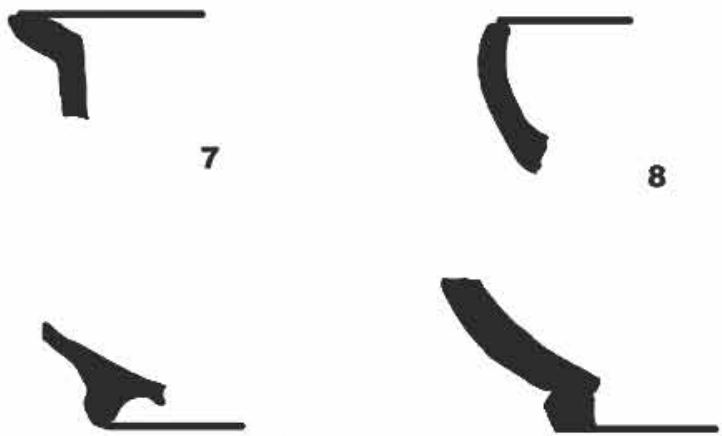

9

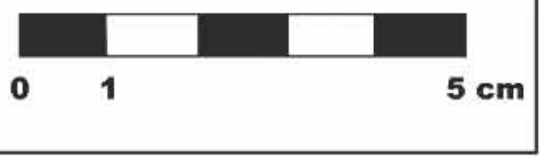




\section{Materiales del yacimiento de la Regenta (Burriana)}

\begin{tabular}{|ll|}
\hline 1. & Borde de cabeza de ánade. Época ibérica. (Sondeo 1) \\
2. & Fragmento carenado de TSS. (Sondeo 1) \\
3. & Fragmento de tegula. (Sondeo 2) \\
4. & Fragmento de tegula. (Sondeo 2) \\
5. & Borde recto de cuenco de cerámica común romana. (Sondeo 2) \\
6. & Borde recto de cuenco con perforación de cerámica común romana. (Sondeo 2) \\
7. & Borde en ala de botella de cerámica común romana. (Sondeo 3) \\
8. & Borde recto reentrante de cuenco de cerámica común romana. (Sondeo 3) \\
9. & Base con pie destacado de cerámica común romana. (Sondeo 3) \\
10. & Base con pie anillado de cerámica común romana. (Sondeo 3) \\
\hline
\end{tabular}




\section{Materiales del yacimiento de Carabona (Burriana)}

\begin{tabular}{|ll|}
\hline 1. & Pondus. \\
2. & Borde de urna de cerámica ibérica. \\
3. & Borde de urna de cerámica ibérica. \\
4. & Borde de urna de cerámica ibérica. \\
5. & Base con umbo de cerámica ibérica. \\
6. & Base con pie de cerámica ibérica. \\
7. & Asa bífida de urna ibérica. \\
\hline
\end{tabular}




\section{LAMINA V}

Materiales del yacimiento de Carabona (Burriana)

1. Borde de copa caliciforme de cerámica ibérica.

2. Base en codo de cerámica ibérica.

3. Borde de urna de cerámica ibérica.

4. Borde de urna de cerámica ibérica.

5. Borde de urna de cerámica ibérica.

6. Borde de tinaja de cerámica ibérica con asas bífidas. 

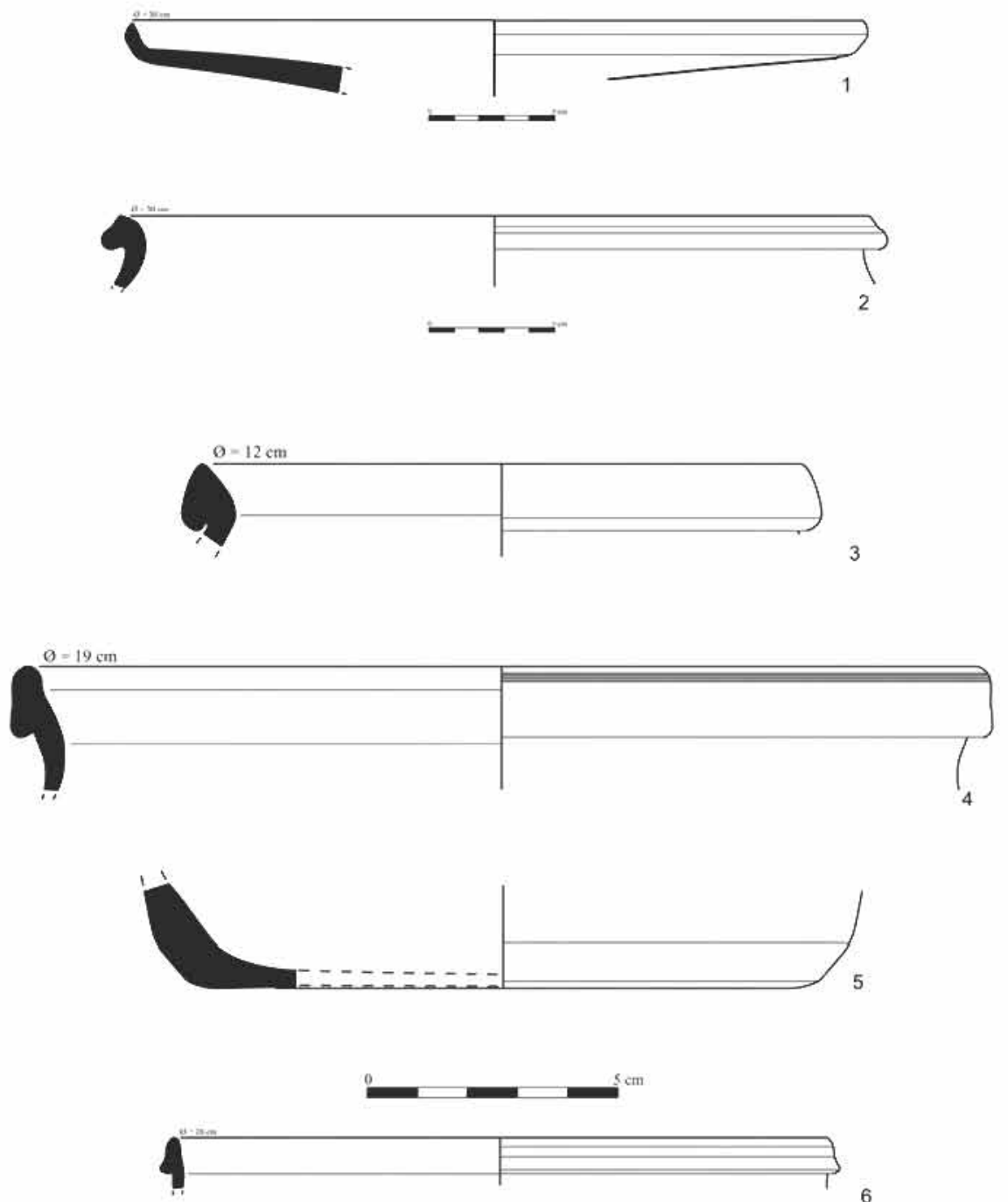


\section{Materiales del yacimiento de Torre d'Onda (Burriana)}

\begin{tabular}{|ll}
\hline 1. & Campaniense B forma Morel 2286a 1 (UE 1014) \\
2. & Borde de cabeza de ánade de cerámica Ibérica (UE 1014) \\
3. & Borde engrosado de cerámica reductora ¿Itálica? (UE 1014) \\
4. & Borde moldurado de cerámica reductora ¿Itálica? (UE 1014) \\
5. & Base plana de cerámica a mano reductora ¿Hierro? (UE 1016) \\
6. & Borde moldurado de cerámica reductora ¿Itálica? (UE 1014) \\
7. & Borde recto de cerámica a mano reductora ¿Hierro? (UE 1016) \\
\hline
\end{tabular}



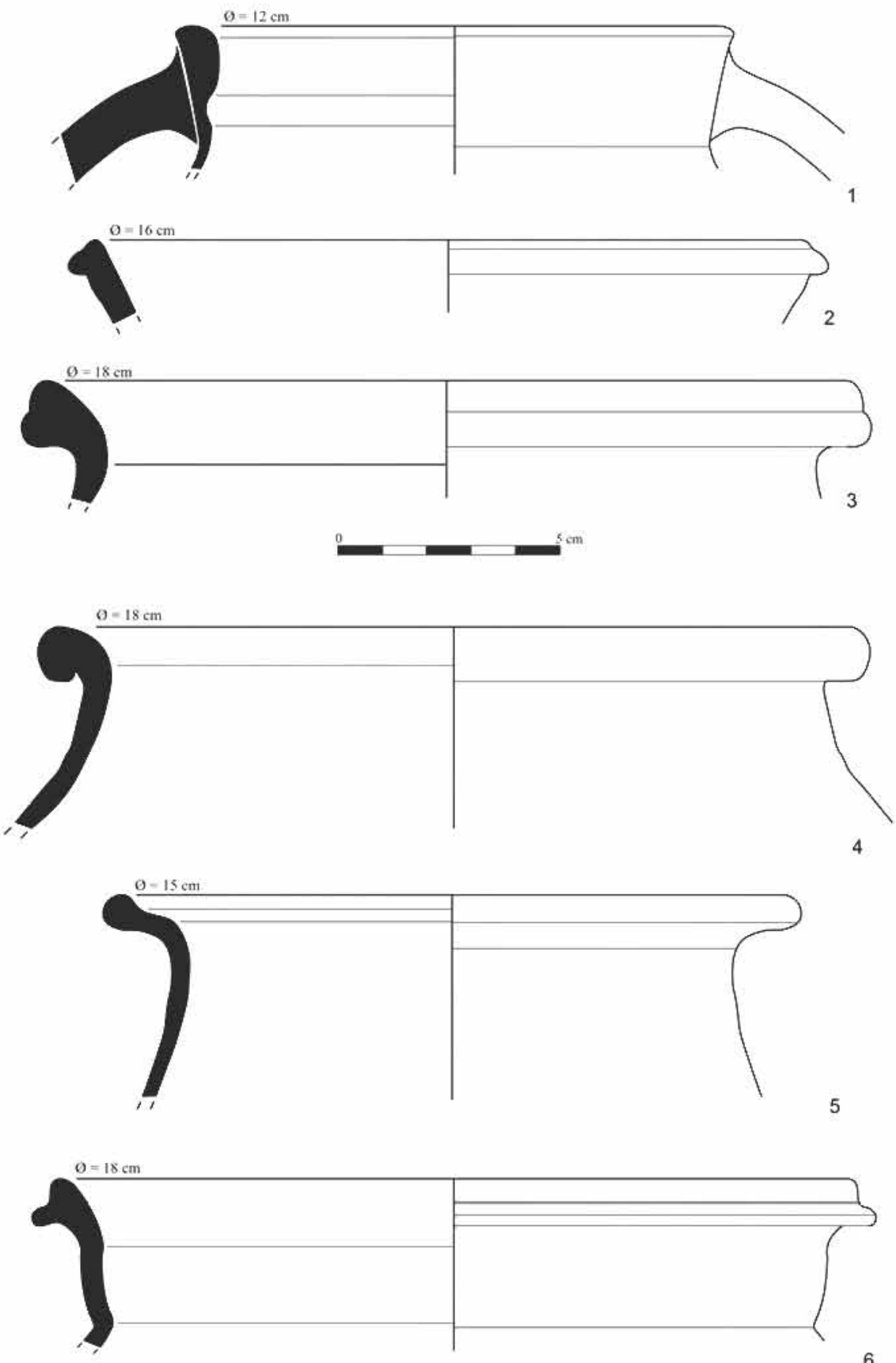


\section{Materiales del yacimiento de Torre d'Onda (Burriana)}

1. Borde recto con asa de cerámica ibérica (UE1014)

2. Borde recto subtriangular de cerámica Ibérica (UE1014)

3. Borde de cabeza de ánade de cerámica Ibérica (UE 1014)

4. Borde exvasado engrosado de cerámica Ibérica (UE 1014)

5. Borde plano moldurado de cerámica lbérica (UE 1014)

6. Borde de cabeza de ánade de cerámica Ibérica (UE 1014) 

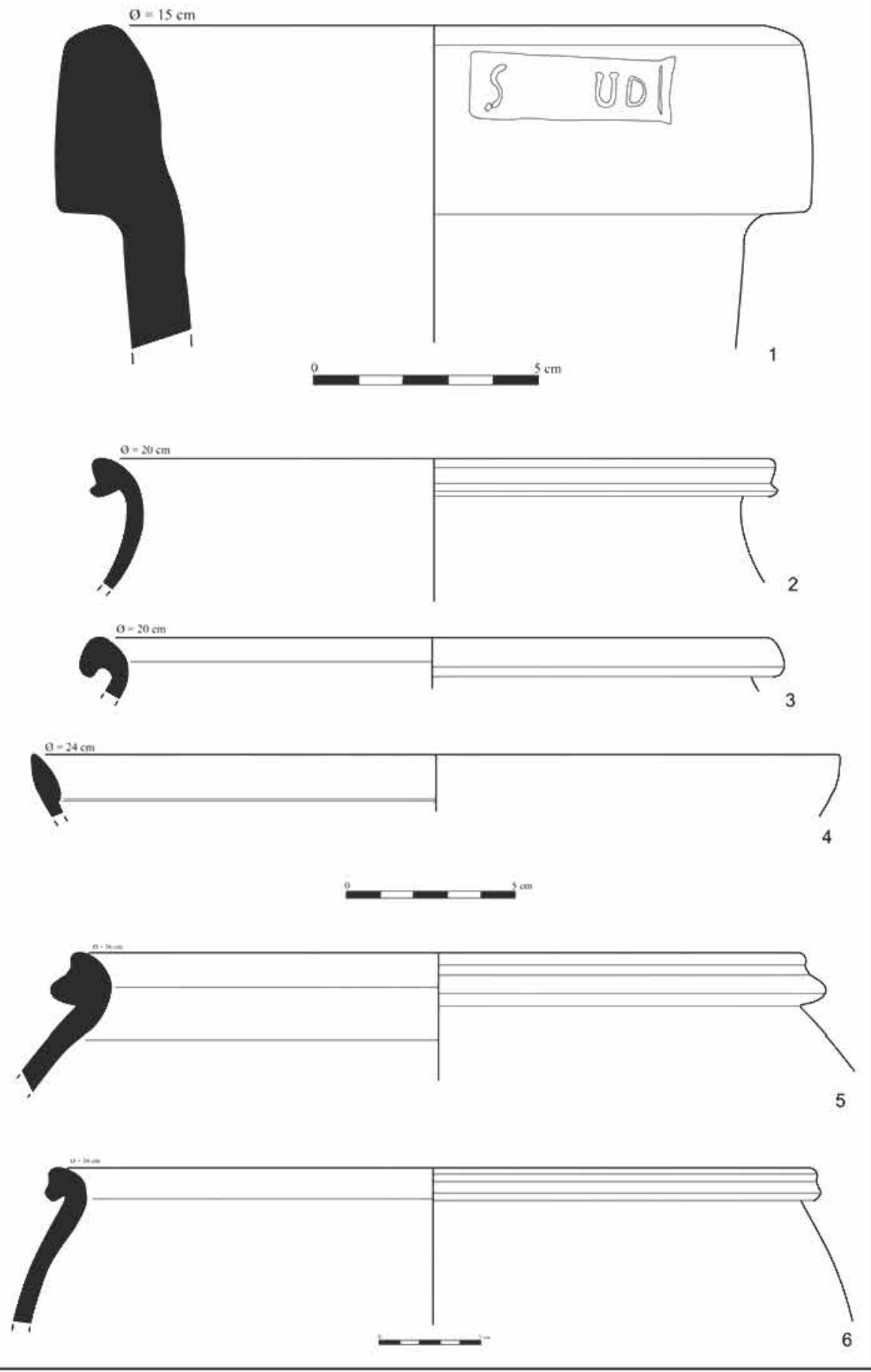


\section{Materiales del yacimiento de Torre d'Onda (Burriana)}

1. Borde recto de ánfora romana, posible Dressel 1B s. I a. C. (UE 1014)

2. Borde de cabeza de ánade de cerámica Ibérica (UE 1014)

3. Borde exvasado engrosado de cerámica Ibérica (UE 1014)

4. Borde Lamboglia 10 A (UE 1016)

5. Borde de cabeza de ánade de cerámica lbérica (UE 1014)

6. Borde de cabeza de ánade de cerámica Ibérica (UE 1014) 

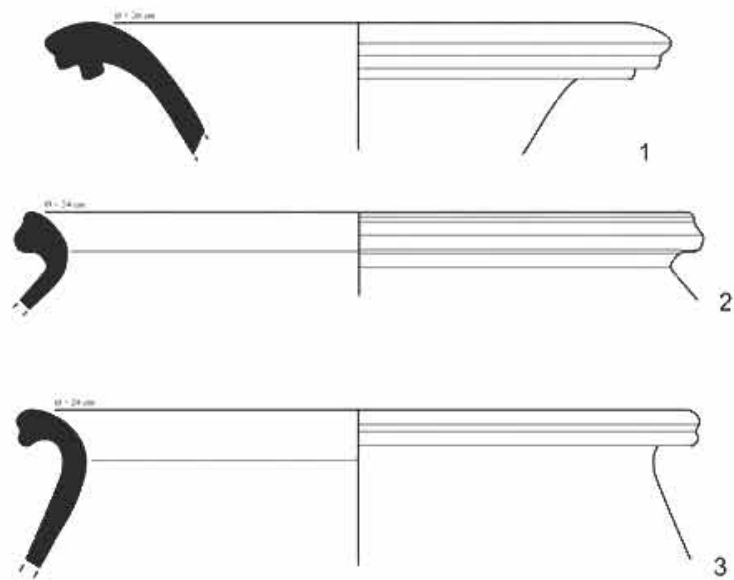

$-1-$
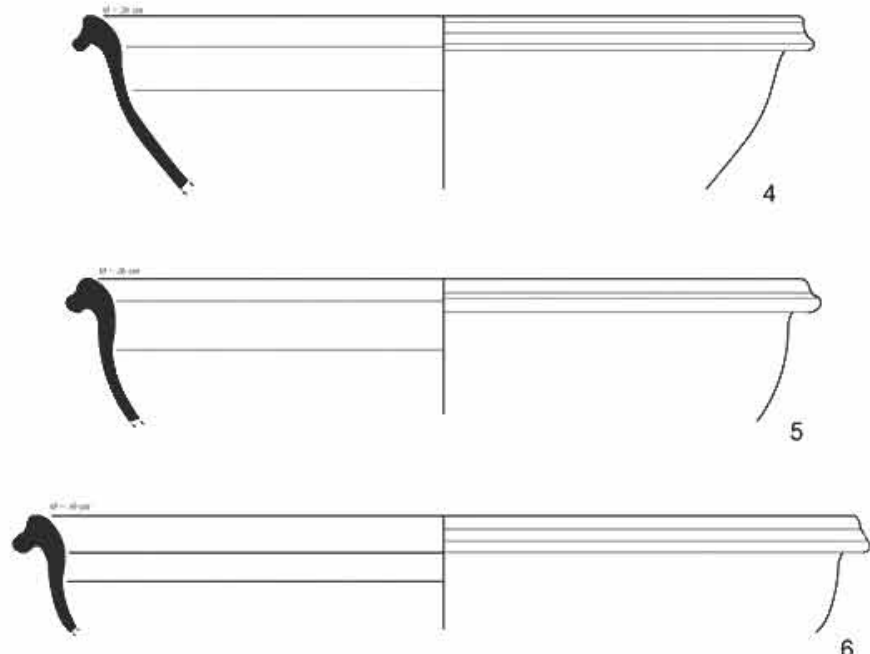

Muela de piedra

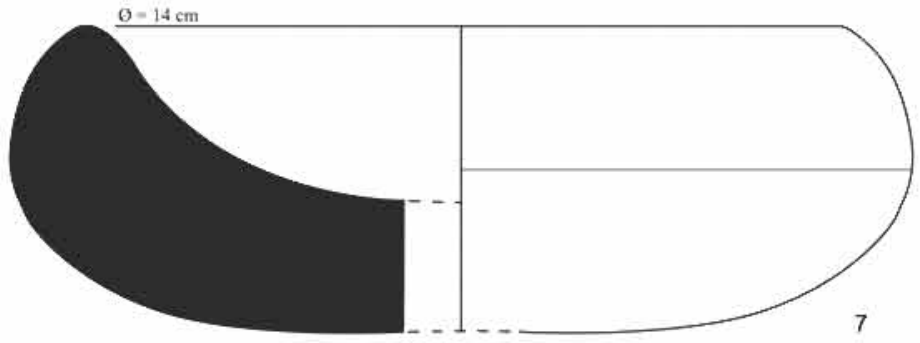




\section{Materiales del yacimiento de Torre d'Onda (Burriana)}

1. Borde exvasado moldurado de cerámica Ibérica (UE 1014)

2. Borde de cabeza de ánade de cerámica Ibérica (UE 1014)

3. Borde de cabeza de ánade de cerámica Ibérica (UE 1014)

4. Borde de cabeza de ánade de cerámica Ibérica (UE 1014)

5. Borde de cabeza de ánade de cerámica Ibérica (UE 1014)

6. Borde de cabeza de ánade de cerámica Ibérica (UE 1014)

7. Molino de piedra (UE 1014) 


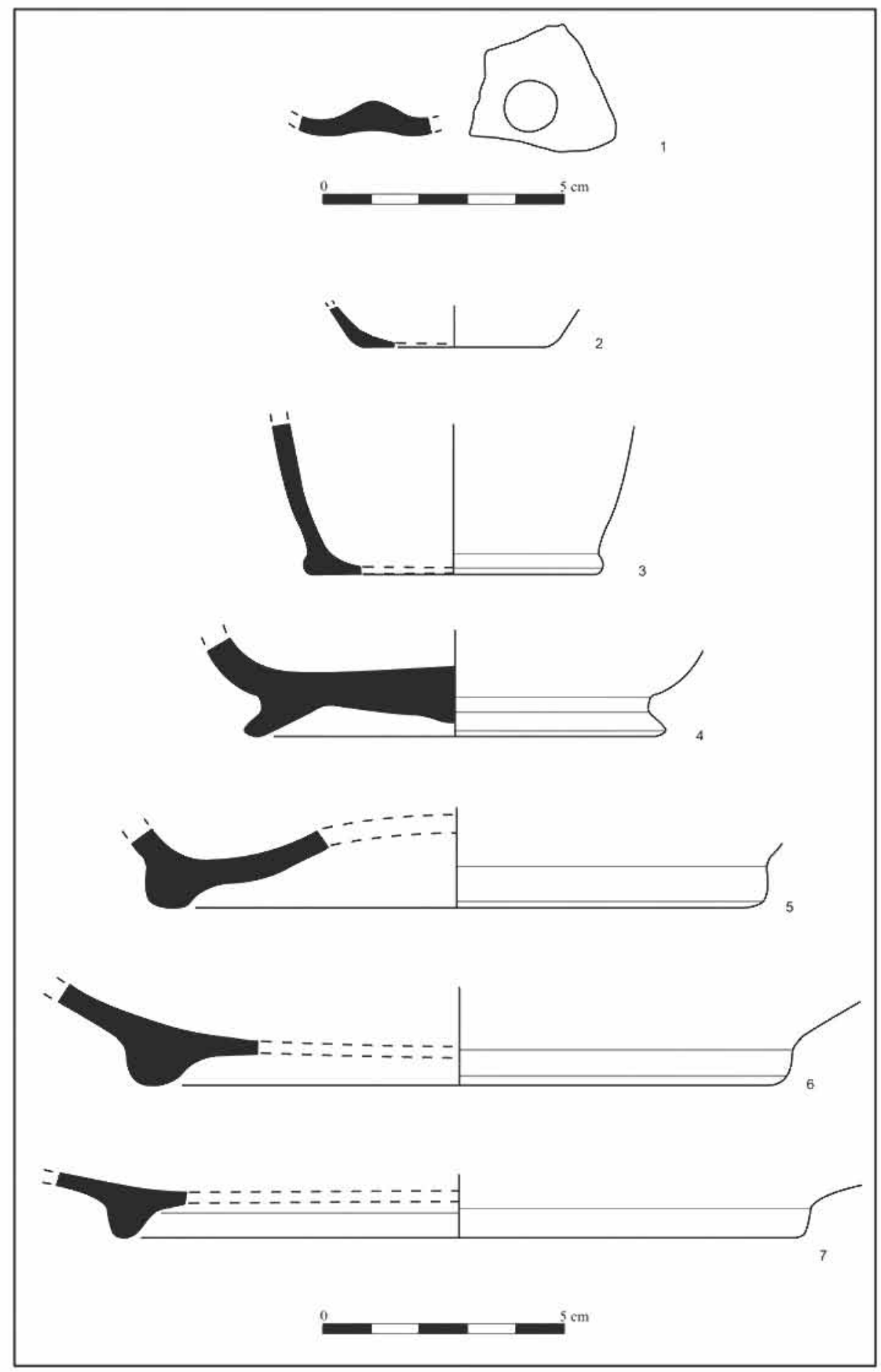




\section{Materiales del yacimiento de Torre d'Onda (Burriana)}

1. Base con umbo de cerámica Ibérica (UE 1014)

2. Base plana de posible Mayet XXIII de paredes finas (UE 1014)

3. Base plana de posible Mayet $V$ de paredes finas (UE 1014)

4. Base posible Morel 2323h 1 Campaniense B (UE 1014)

5. Base con pie de cerámica Ibérica (UE 1014)

6. Base con pie de cerámica Ibérica (UE 1014)

7. Base con pie de cerámica Ibérica (UE 1014) 


\section{LAMINA XI}

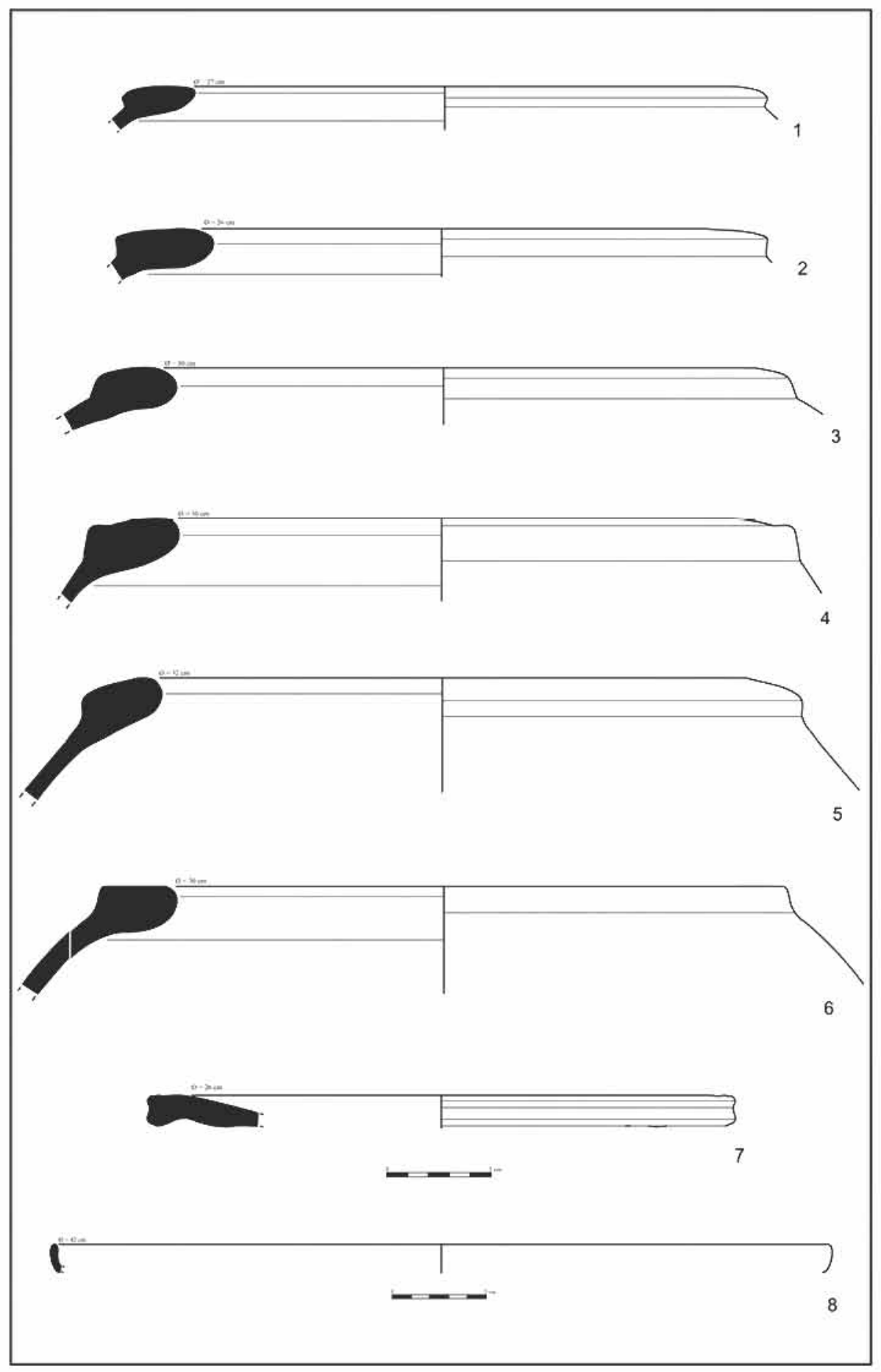




\section{Materiales del yacimiento de Torre d'Onda (Burriana)}

1. Borde reentrante engrosado de ánfora Ibérica (UE 1015)

2. Borde reentrante engrosado de ánfora Ibérica (UE 1015)

3. Borde reentrante engrosado de ánfora Ibérica (UE 1015)

4. Borde reentrante engrosado de ánfora Ibérica (UE 1015)

5. Borde reentrante engrosado de ánfora Ibérica (UE 1014)

6. Borde reentrante engrosado de ánfora Ibérica (UE 1014)

7. Borde reentrante engrosado de ánfora Ibérica (UE 1014)

8. Borde plano moldurado de cerámica Ibérica (UE 1014)

9. Borde de posible Morel 2252e 1 Campaniense B (UE 1014) 

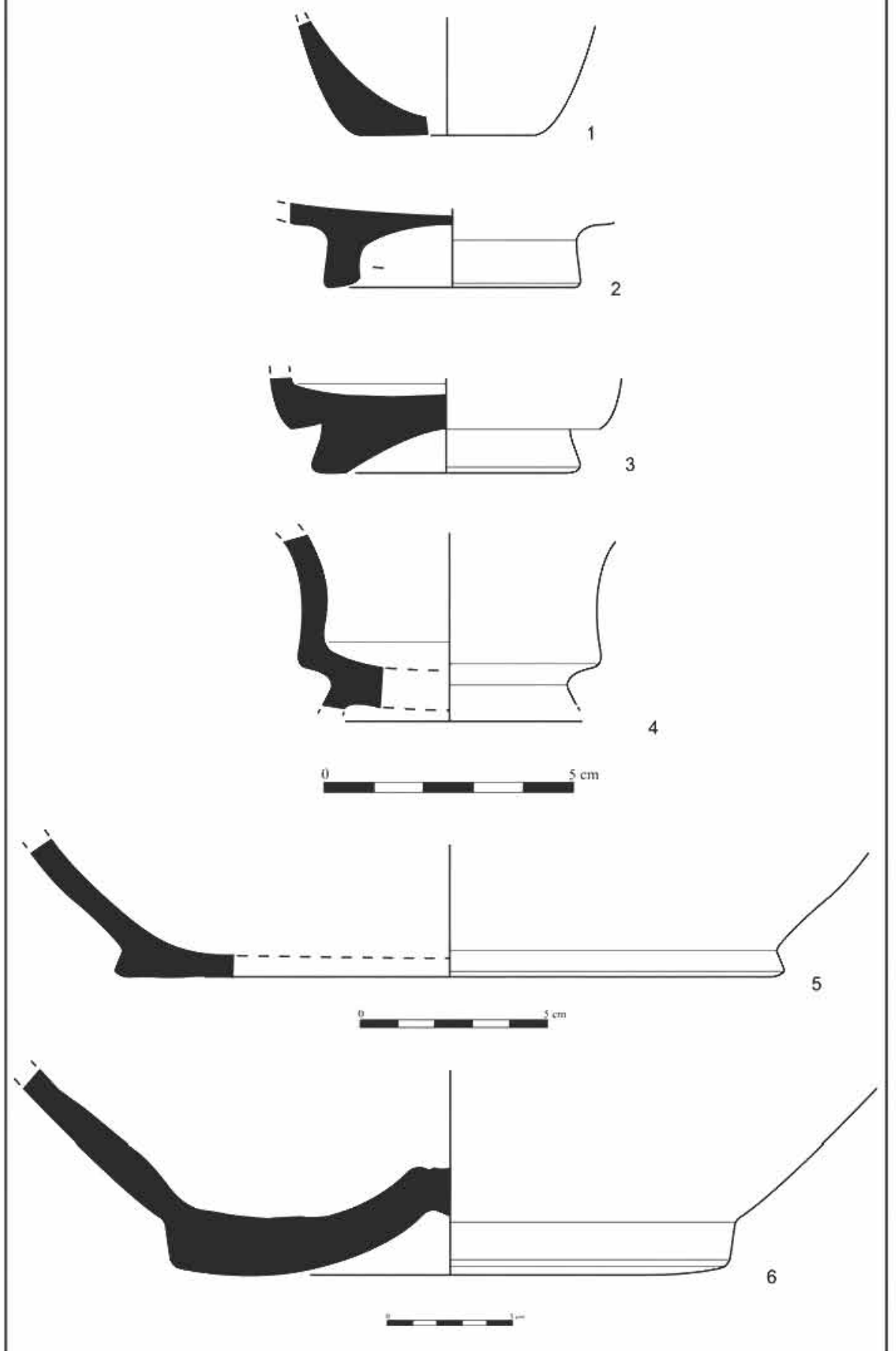

$$
\mathrm{cm}
$$


Materiales del yacimiento de Torre d'Onda (Burriana)

1. Base de posible Mayet IV de paredes finas (UE 1014)

2. Base patera de Campaniense B (UE 1014)

3. Base de posible Morel 1222a 1 de Campaniense B (UE 1014)

4. Base de Morel 1222a 1 de Campaniense B (UE 1014)

5. Base con codo de cerámica Ibérica (UE 1014)

6. Base con umbo de cerámica Ibérica (UE 1014) 


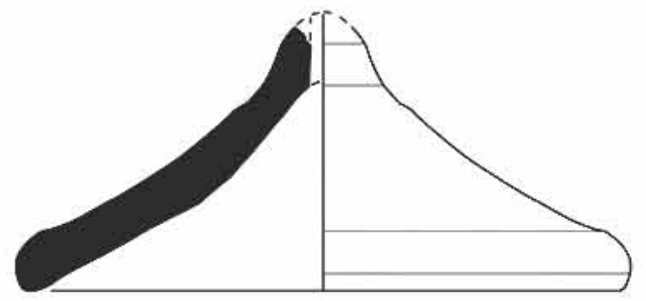

1
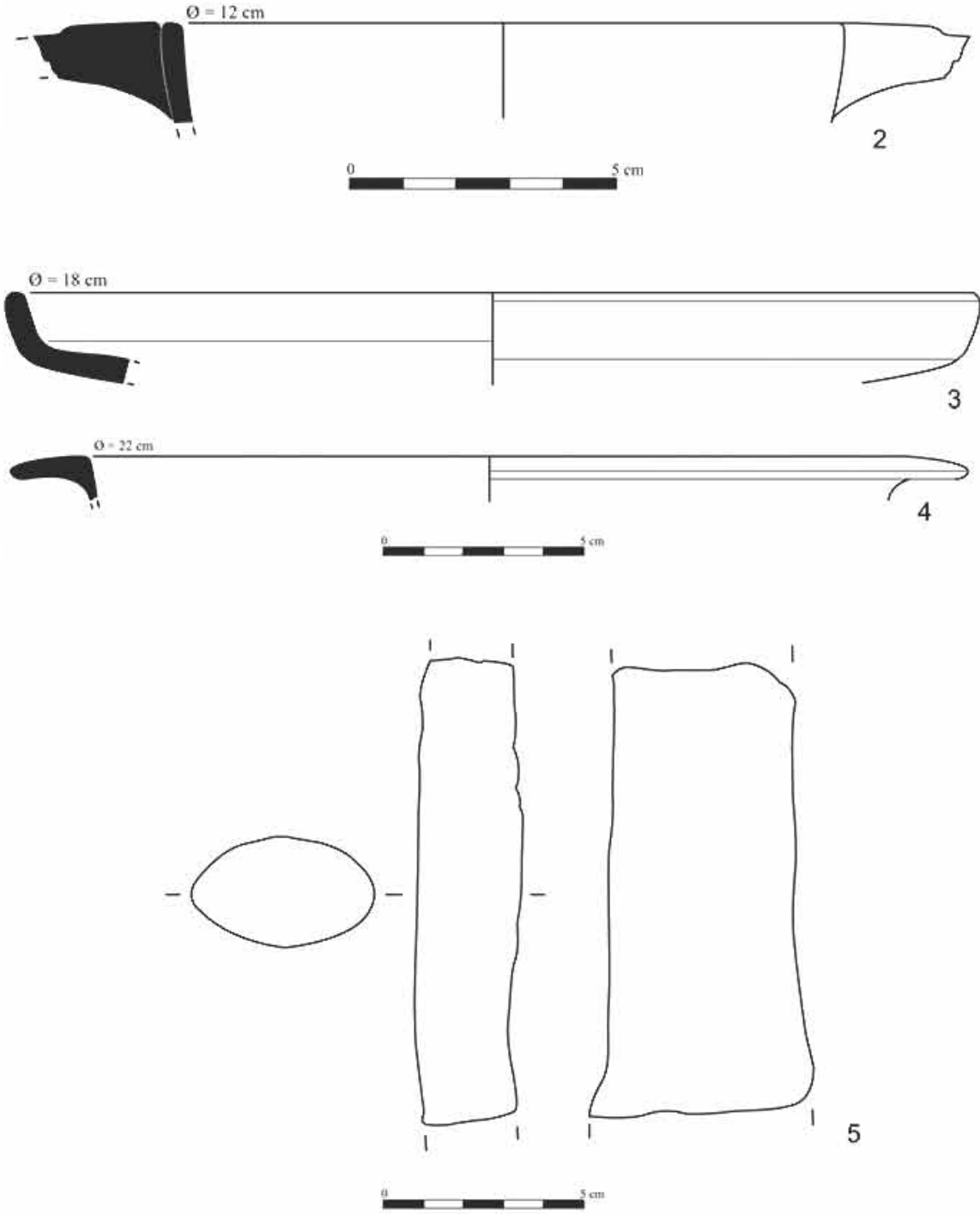


\section{Materiales del yacimiento de Torre d'Onda (Burriana)}

1. Borde exvasado de tapadera de cerámica Ibérica (UE 1014)

2. Borde recto con asa de cerámica Ibérica (UE 1014)

3. Borde de Morel 2266a 1 de Campaniense B (UE 1014)

4. Borde plano de cerámica ibérica (UE 1014)

5. Asa de sección elipsoidal de ánfora de la Campania (UE 1014) 


$$
\begin{aligned}
& 19 \\
& 0
\end{aligned}
$$


Materiales del yacimiento de Torre d'Onda (Burriana)
1. Asa anular geminada de cerámica Ibérica
2. Asa anular geminada de cerámica Ibérica
3. Asa anular geminada de cerámica Ibérica
4. Carena de ánfora de la Campania
5. Carena de ánfora romana con asa de sección cilíndrica 



\section{LAMINA XV}

\section{Materiales del yacimiento de Torre d'Onda (Burriana)}

1. Pivote de ánfora romana (UE 1014)

2. Pivote de ánfora romana (UE 1014)

3. Pivote de ánfora romana (UE 1014)

4. Borde recto subtriangular de ánfora romana (UE 1014)

5. Borde recto engrosado de ánfora romana, posiblePascual 1 s. I a.C. / I d.C. (UE 1014)

6. Borde recto engrosado de ánfora romana (UE 1014) 

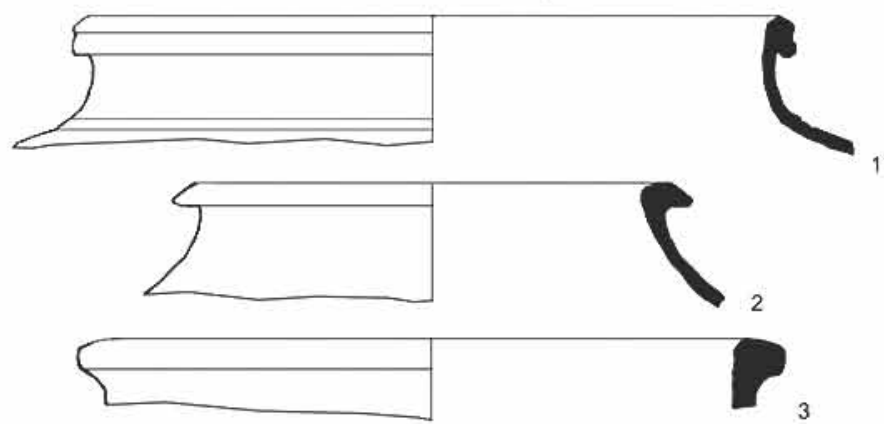

3
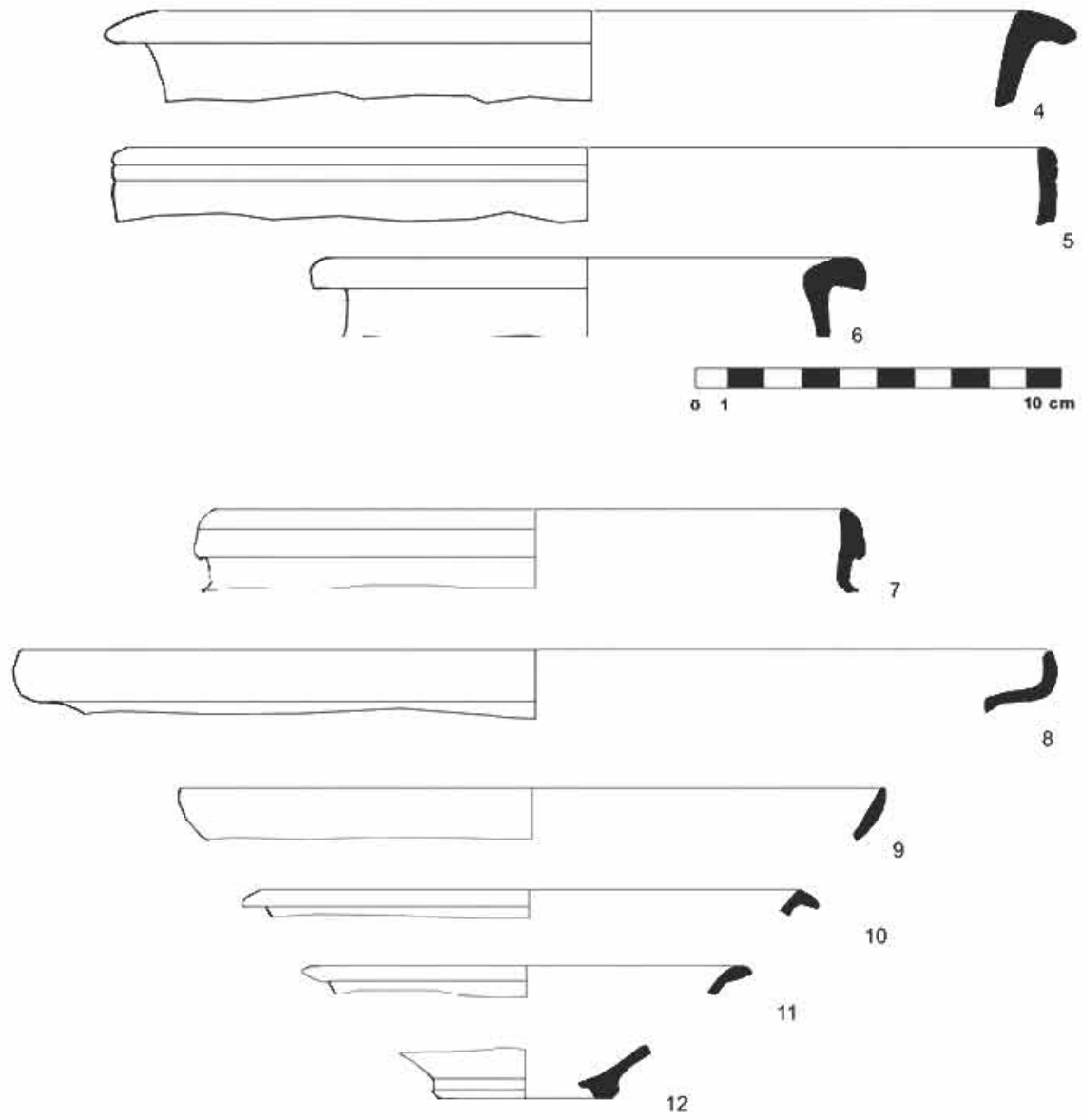


\section{Materiales del yacimiento de Torre d'Onda (Burriana)}

1. Borde de cabeza de ánade de cerámica reductora Ibérica (UE 1014)

2. Borde exvasado de cerámica reductora Ibérica (UE 1014)

3. Borde recto engrosado de cerámica reductora Ibérica (UE 1014)

4. Borde plano exvasado de cerámica Ibérica (UE 1014)

5. Borde recto de cerámica reductora Itálica (UE 1014)

6. Borde plano engrosado de cerámica reductora Itálica (UE 1014)

7. Borde recto subtriangular de cerámica reductora ¿Itálica? (UE 1014)

8. $\quad$ Borde de Morel 2552e de Campaniense B (UE 1014)

9. $\quad$ Borde posible Morel 2173a de Campaniense B (UE 1014)

10. Borde plano exvasado de cerámica Ibérica (UE 1014)

11. Borde almendrado exvasado de cerámica Ibérica (UE 1014)

12. Base con pie destacado de cerámica Ibérica (UE 1014) 


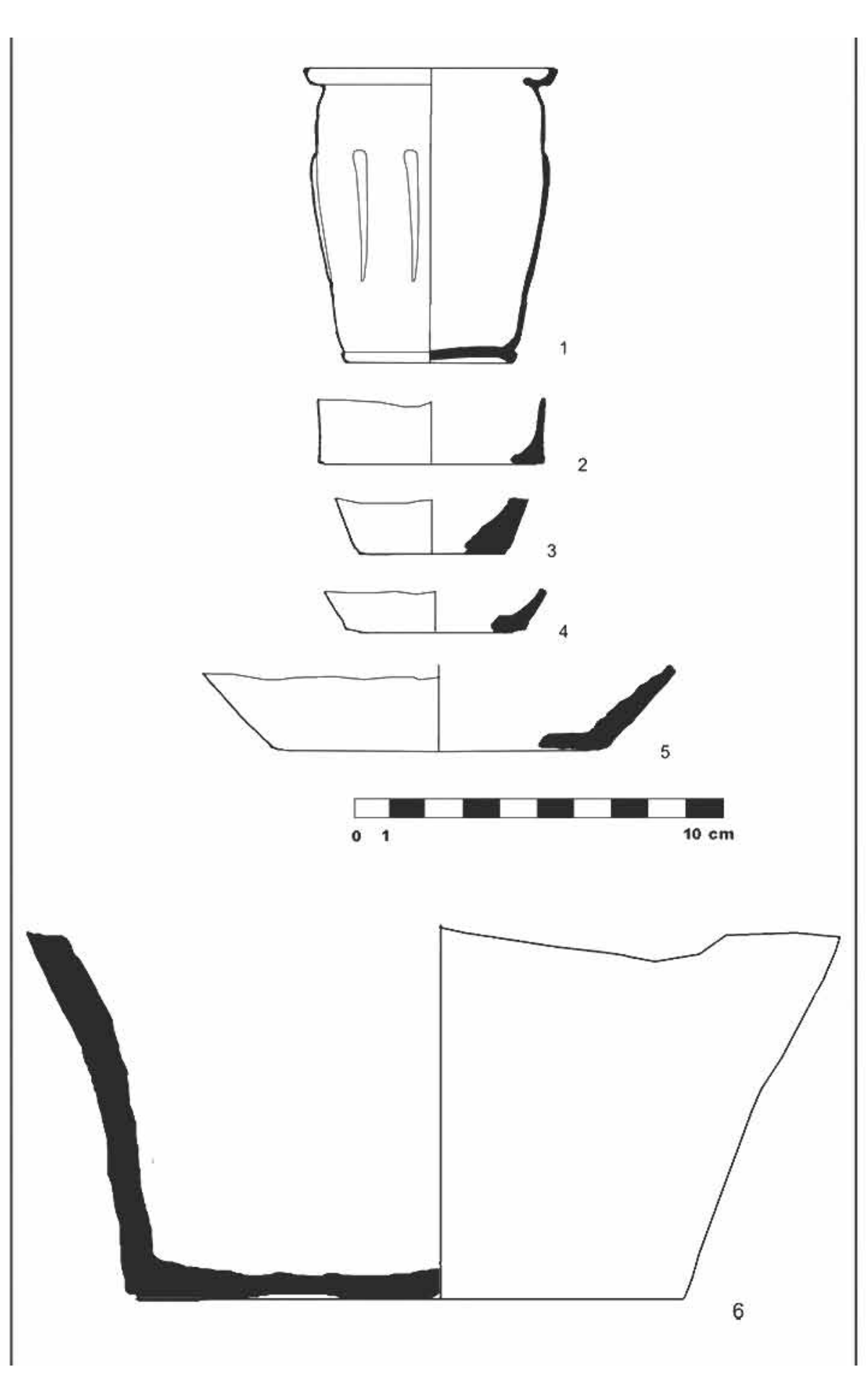




\section{Materiales del yacimiento de Torre d'Onda (Burriana)}

1. Base plana y borde de Mayet III de paredes finas de cerámica reductora (UE 1014)

2. Base plana de cerámica Itálica (UE 1014)

3. Base plana de cerámica Itálica (UE 1014)

4. Base plana de cerámica reductora ¿Itálica? (UE 1014)

5. Base plana de cerámica reductora ¿Itálica? (UE 1014)

6. Gran base plana de cerámica a mano ¿Hierro/lbérico Antiguo? (UE 1016) 


\section{LAMINA XVIII}

\section{Materiales del yacimiento del Tirao / Palau (Burriana)}

\begin{tabular}{|ll|}
\hline 1. & Base de TSS con sigilla. (El Tirao) \\
2. & Base con pie de TSI. (EI Tirao) \\
3. & Base con pie TSS. (EI Tirao) \\
4. & Base con pie del Taller de las tres palmetas radiales. (EI Tirao) \\
5. & Forma Drag. $29 b$ de TSS decorada (El Tirao) \\
6. & Fichas recortadas en TSH. (UE 2004) \\
7. & Borde almendrado de ánfora (UE 4002). \\
\hline
\end{tabular}



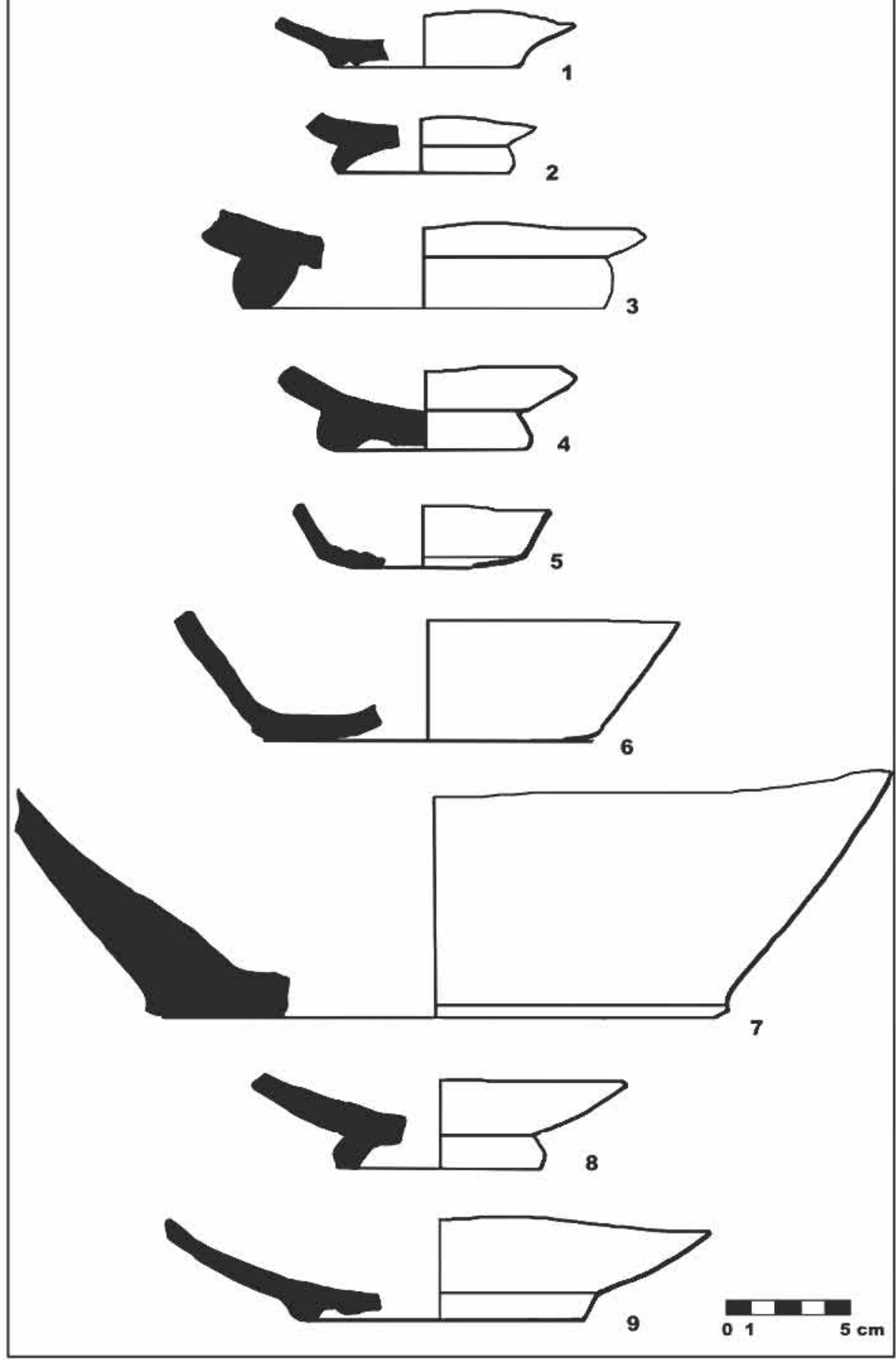


\section{LAMINA XIX}

\section{Materiales del yacimiento del Palau (Burriana)}

\begin{tabular}{|ll|}
\hline 1. & Base con pie anillado de cerámica común romana. (UE 4002) \\
2. & Base con pie de cerámica común romana. (UE 4002) \\
3. & Base con pie de cerámica común romana. (UE 4002) \\
4. & Base con pie de cerámica común romana. (UE 4002) \\
5. & Carena recta. Posible imitación de cerámica africana de cocina. (UE 4002) \\
6. & Base plana con umbo de cerámica común romana. (UE 4002) \\
7. & Base con pie en codo. Posible ánfora (UE 4002). \\
8. & Base con pie destacado de cerámica común romana. (UE 1022). \\
9. & Base con pie anillado de cerámica común romana. (UE 1026). \\
\hline
\end{tabular}



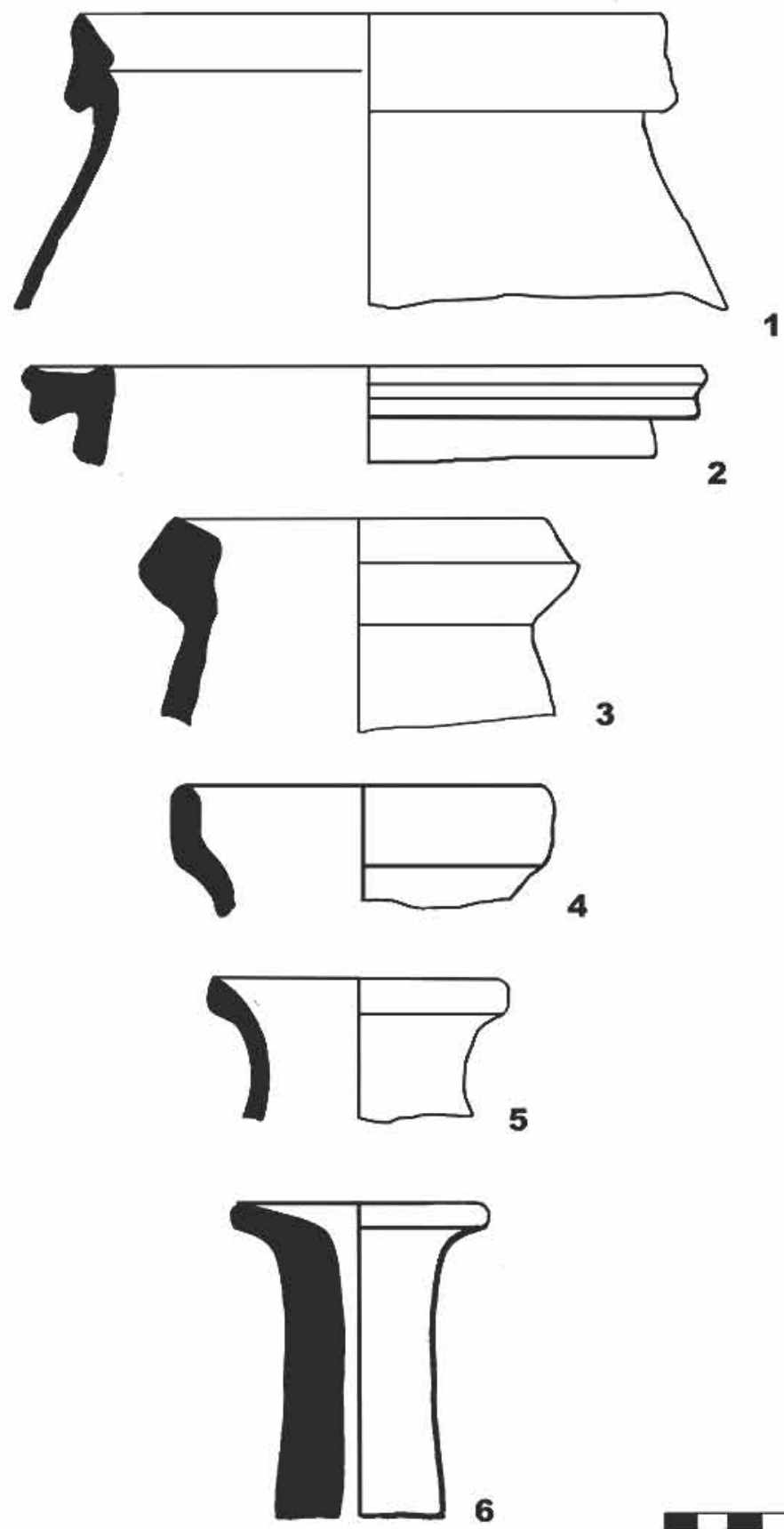


\section{Materiales del yacimiento del Palau (Burriana)}

\begin{tabular}{|ll|}
\hline 1. & Borde plano de cerámica común romana. (UE 4002) \\
2. & Forma Lamboglia 10B cerámica común romana. (UE 4002) \\
3. & Forma Lamboglia 10A cerámica común romana. (UE 4002) \\
4. & Borde recto de cerámica común romana. (UE 4002) \\
5. & Borde recto de cerámica común romana (UE 2004) \\
6. & Borde recto de cerámica común romana. (UE 2004) \\
7. & Borde recto cerámica común romana (UE 1026). \\
8. & Borde recto de cerámica común romana (UE 1022). \\
\hline
\end{tabular}



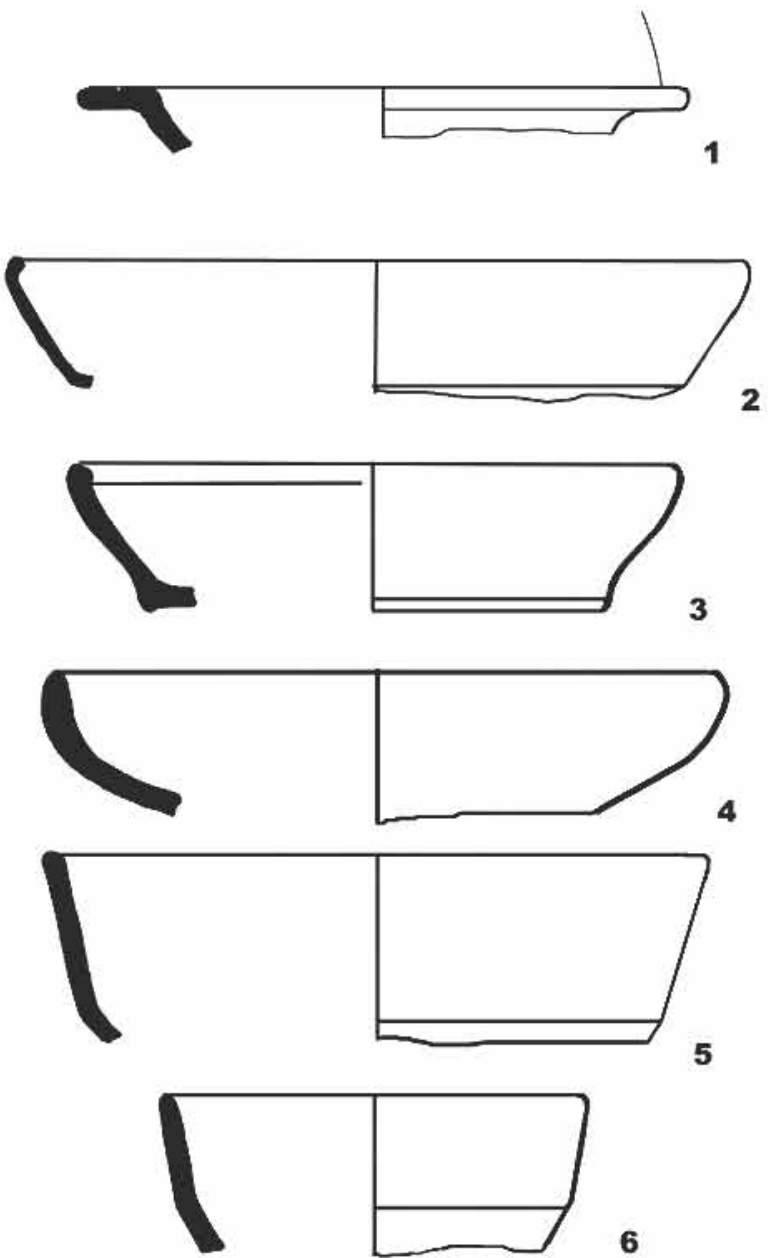

6

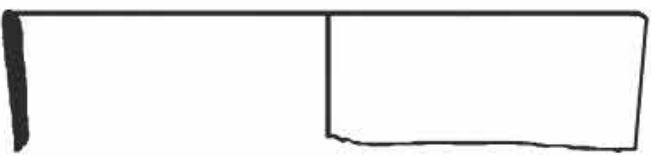

7
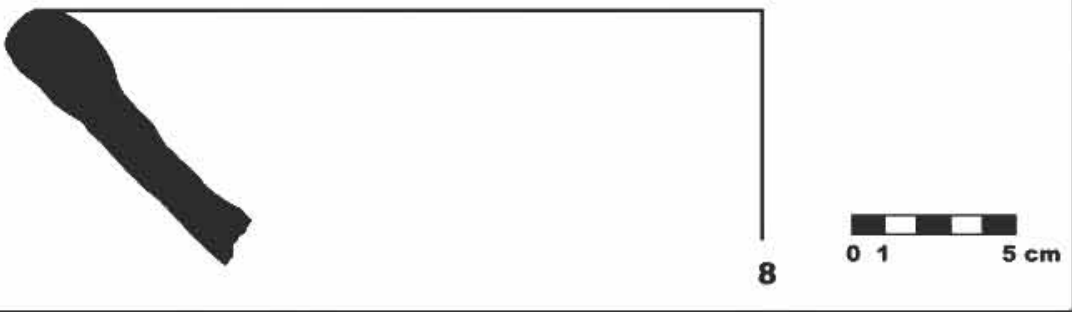


\section{LAMINA XXI}

Materiales del yacimiento del Palau (Burriana)

1. Borde subtriangular de olla de cerámica común romana. (UE 4002)

2. Borde moldurado de ollita de cerámica común romana (UE 4002)

3. Borde cuadrangular de botella de cerámica común romana. (UE 4002)

4. Borde recto de botella de cerámica común romana (UE 4002)

5. Borde exvasado de botella de cerámica común romana (UE 4002)

6. Parte superior de tubuli. (UE 4002) 

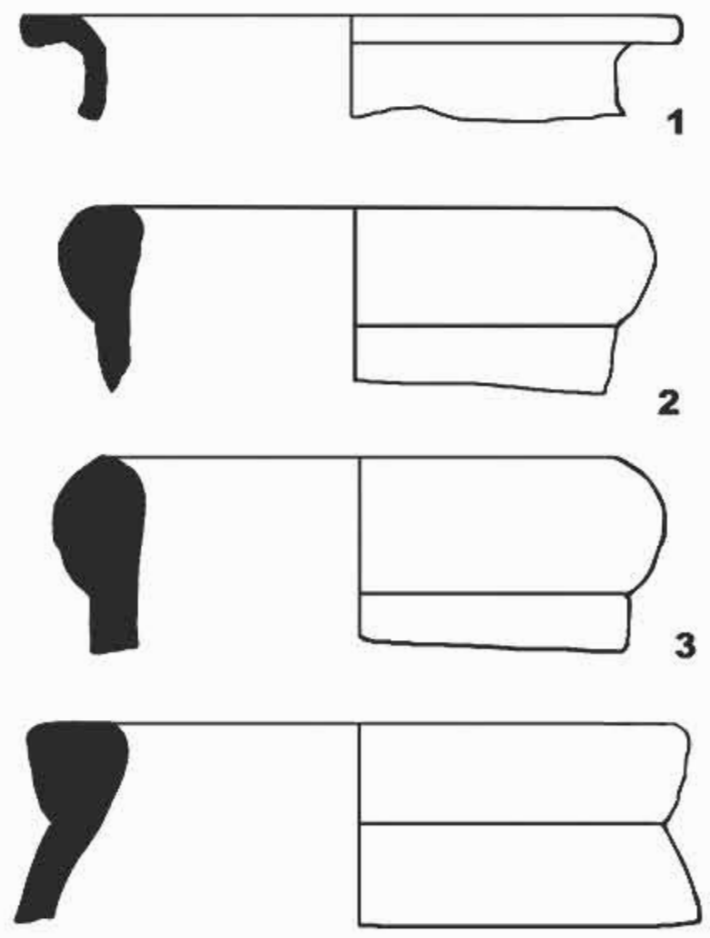

4
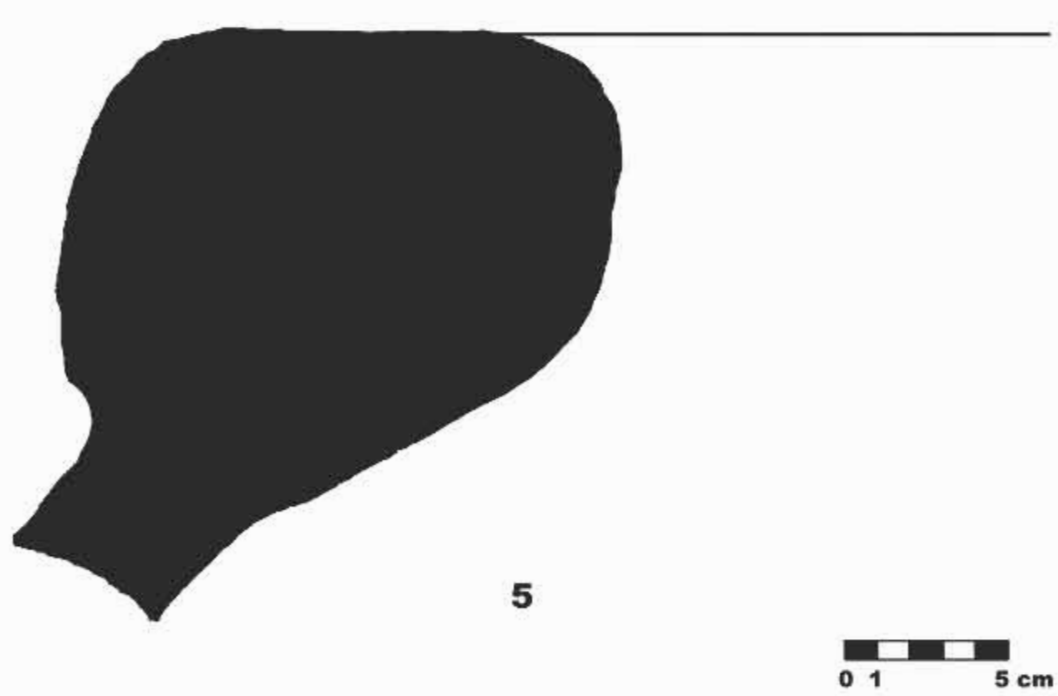


\section{LAMINA XXII}

Materiales del yacimiento del Palau (Burriana)

1. Borde rectangular de olla de cerámica común romana. (UE 4002)

2. Borde almendrado de ánfora romana (UE 2002)

3. Borde almendrado de ánfora romana. (UE 4002)

4. Borde cuadrangular de ánfora romana (UE 4002)

5. Borde cuadrangular de dolia tipo Garoupe B (UE 4002) 

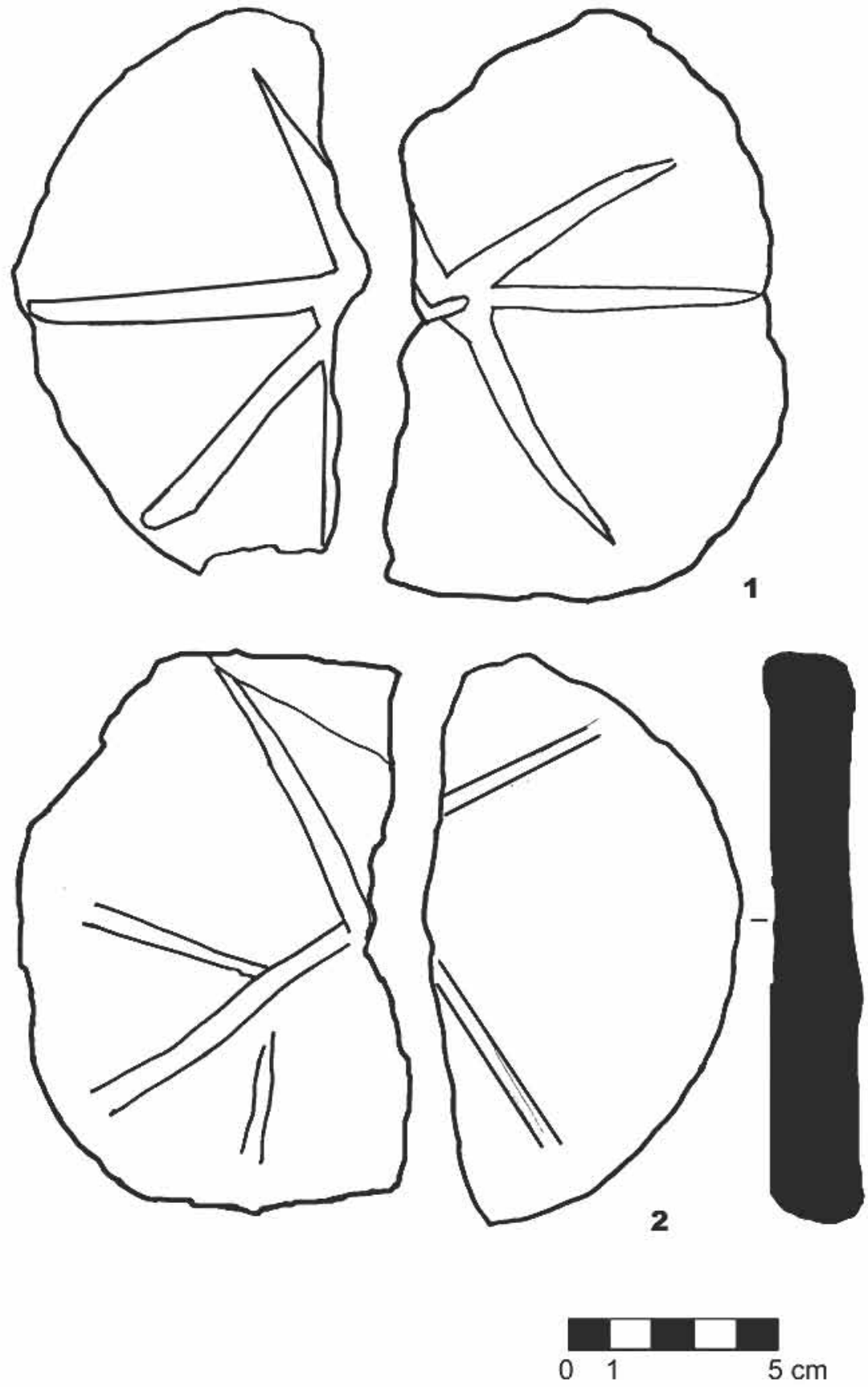


\section{LAMINA XXIII}

Materiales del yacimiento del Palau (Burriana)
1. Ladrillo de pilae. (UE 1002)
2. Ladrillo de pilae. (UE 1002) 

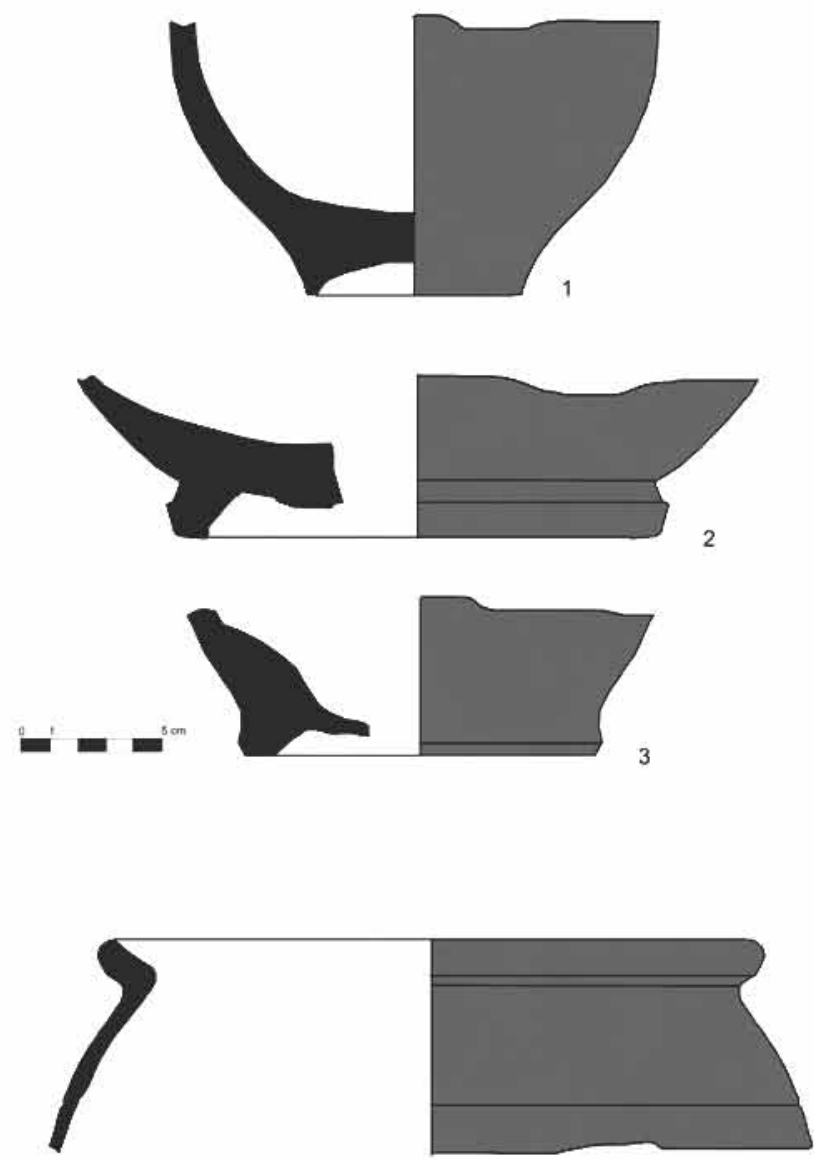

4
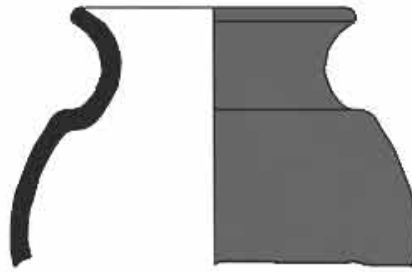

5

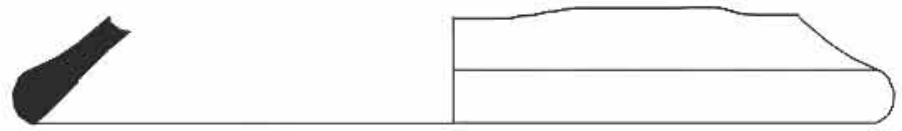




\section{LAMINA XXIV}

\section{Materiales del yacimiento del Palau (Burriana)}

1. Base de cerámica reductora romana. (UE 5030)

2. Base con pie destacado de cerámica reductora romana (UE 5030)

3. Base de cerámica reductora romana (UE 5030)

4. Borde exvasado de cerámica reductora romana (UE 5065)

5. Borde exvasado de cerámica reductora romana (UE 2003)

6. Borde de plato forma Ostia I, 261 (Prospección) 

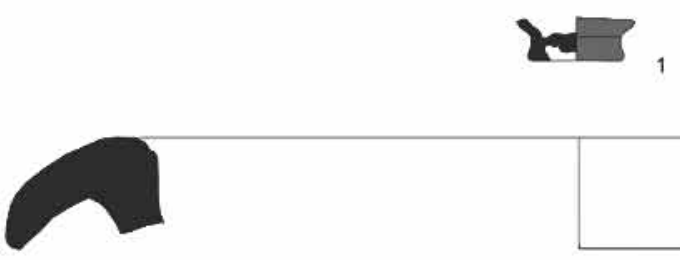

3
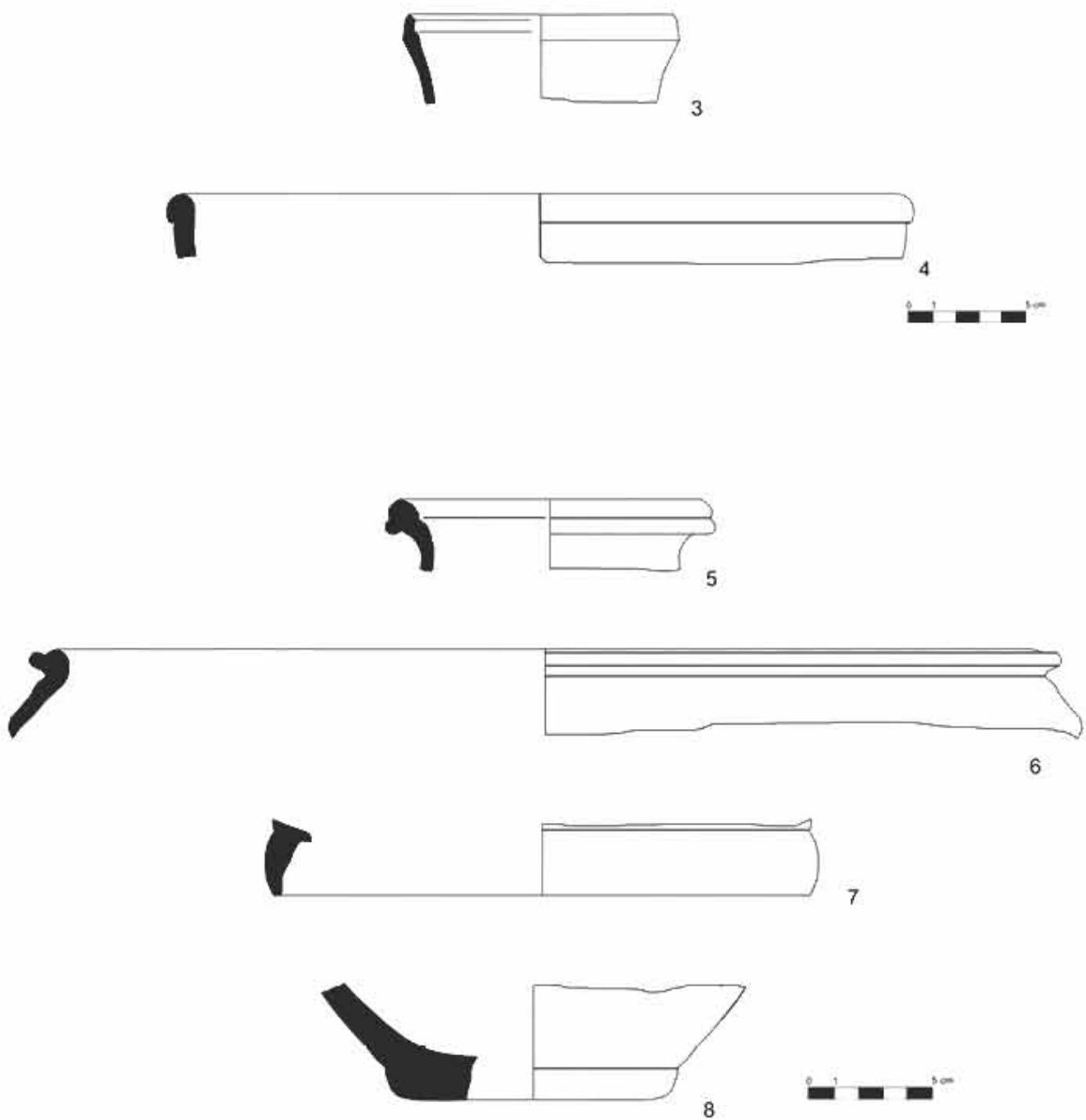


\section{LAMINA XXV}

\section{Materiales del yacimiento del Palau (Burriana)}

1. Base de cerámica reductora romana (UE 5007)

2. Borde de mortero forma Dramont 2 D2 (UE 5007)

3. Borde de botella de cerámica común romana (UE 8018)

4. $\quad$ Borde de posible Drag. 37 de TSH (UE 8018)

5. Borde moldurado de cerámica común romana (UE 5020)

6. Borde de tipo cabeza de ánade de cerámica común ibérica (UE 2004)

7. Base con pie destacado de cerámica común ibérica (UE 2004)

8. Base de mortero de cerámica común romana (UE 5020) 


\section{Materiales del yacimiento del Palau (Burriana)}

1. Base de TSS (UE 2003)

2. Base de TSH (UE 5005)

3. Borde de Hayes 16 de TSCA (UE 5005)

4. Pivote de ánfora romana (UE 2004)

Materiales del yacimiento de Torre d'Onda (Burriana)

5. Forma Lamboglia 1 de Campaniense C (año 1988)

Materiales del yacimiento del Alter (Xilxes)

6. Forma Lamboglia 10A (Superficie)

7. Forma Hayes 99b de TSCA/D (Superficie)

Material del yacimiento de Benicató (Nules)

8. Forma Drag. 15/17 de TSI (Superficie) 


\section{LAMINA XXVIII}

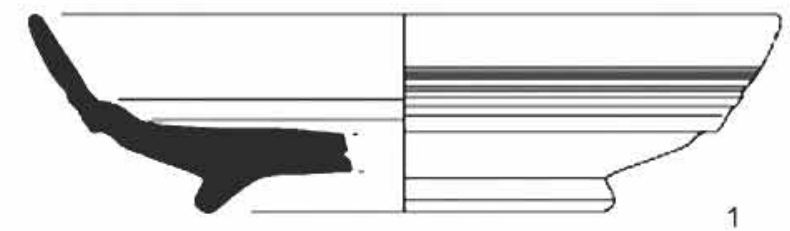

1
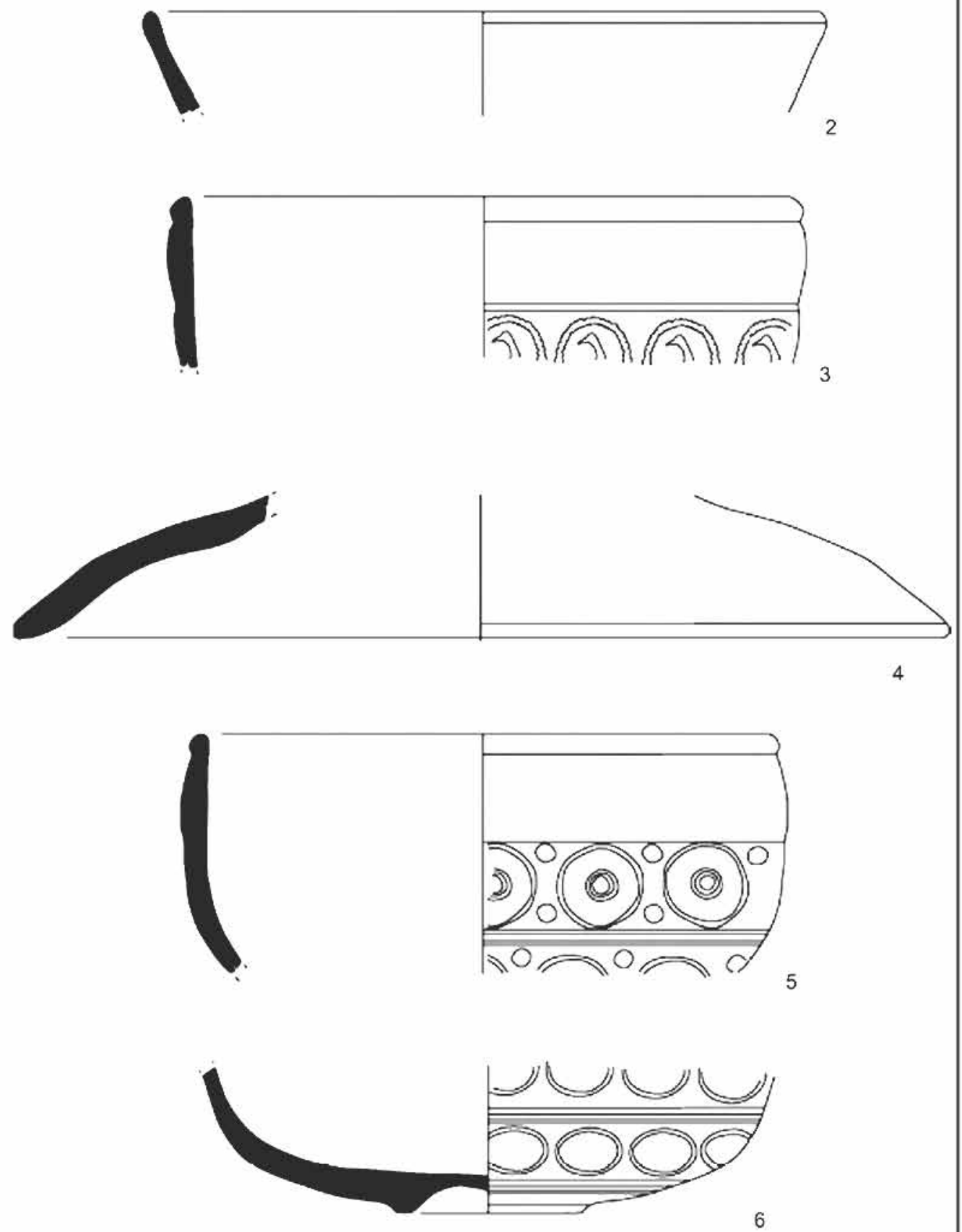


\section{LAMINA XXVII}

\section{Materiales del yacimiento del Palau (Burriana)}

1. Forma Drag. $15 / 17$ de TSI (UE 2004)

2. Forma Drag. 18 de TSH (UE 2003)

3. Forma Drag. 37 de TSS decorada (UE 4002)

4. Plato tapadera de forma itálica (UE 2003)

5. Forma Drag. 37 de TSH decorada (UE 5065)

6. Forma Drag. 37 de TSH decorada (UE 2004) 

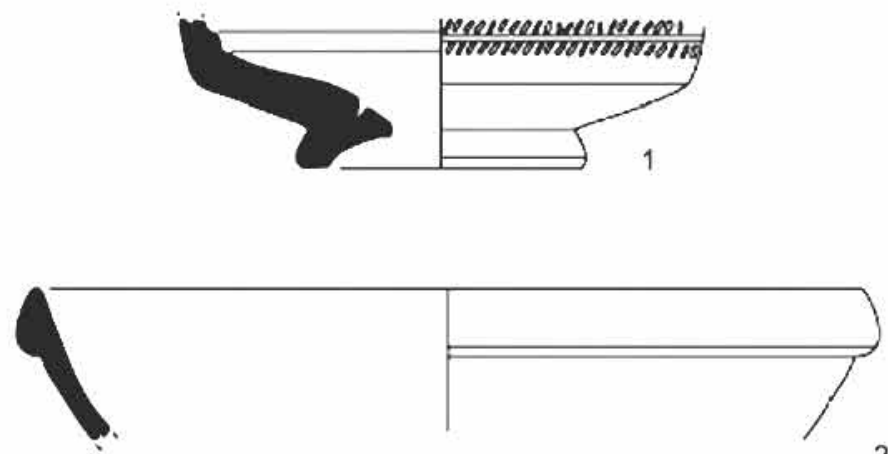

2
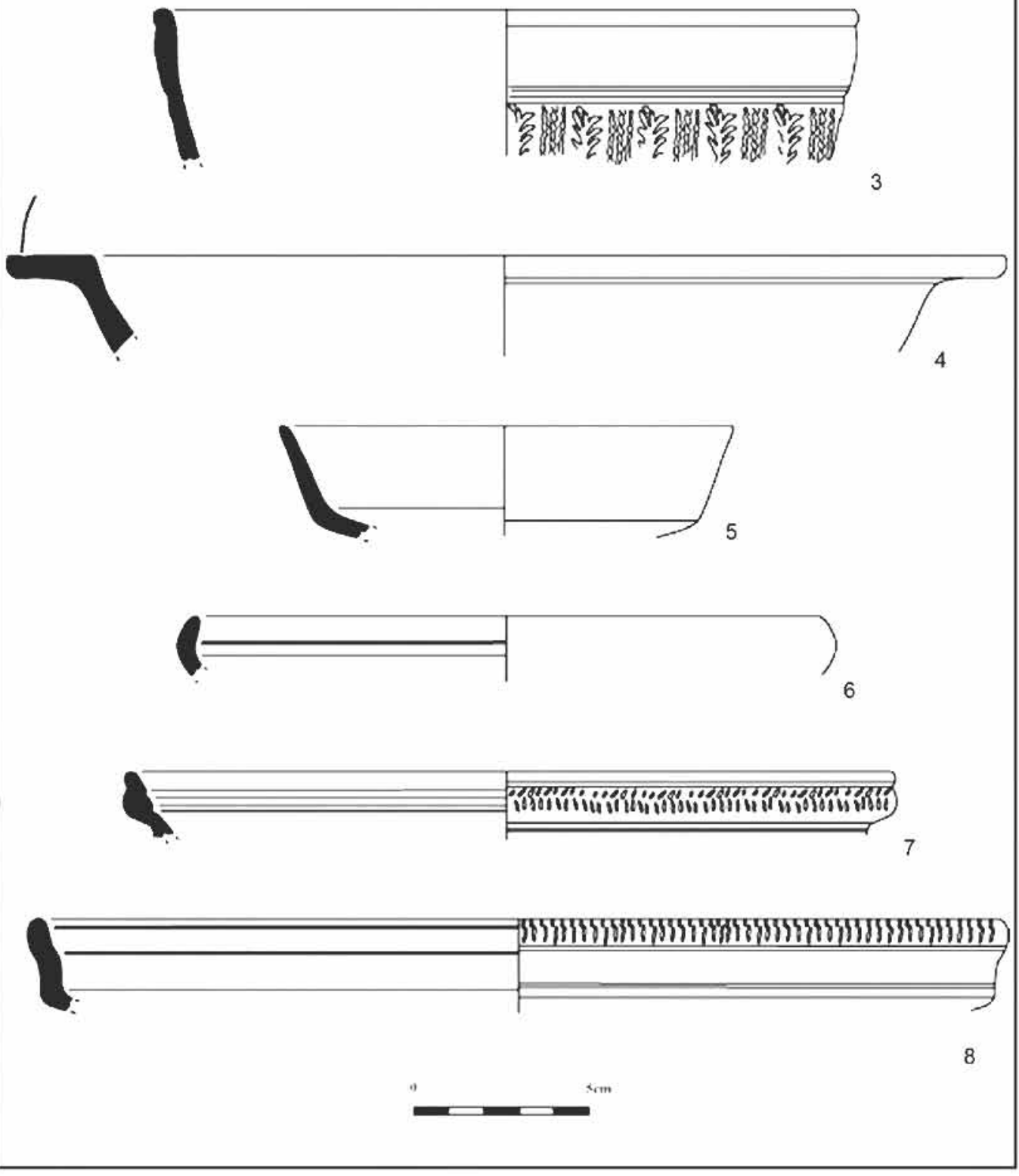


\section{Materiales del yacimiento del Alter (Xilxes)}

1. Base con pie de posible Drag. 18b de TSH. (Superficie)

2. Forma posible Hayes 94 de TSCD (Superficie)

3. Forma Lamboglia 10A (Superficie)

Materiales del yacimiento del Castellar (Xilxes)

4. Forma Hayes 99b de TSCD (Superficie)

5. Forma Drag. 29b de TSS decorada (Superficie)

Materiales del Templet de Santa Barbara (La Vilavella)

6. Forma Drag. 18 de TSS (Superficie)

Materiales del yacimiento de Benicató (Nules)

7. Forma Hayes 26 de TSCA (Superficie)

8. Forma Drag. $15 / 17$ de TSI (Superficie) 


\section{LAMINA XXXI}

Materiales del yacimiento del Calamó (Burriana)

1. Forma Hayes 9A de TSCA. (Superficie)

2. Base de TSH decorada (Superficie)

3. Forma Drag. 29 de TSS decorada (Superficie)

Materiales del yacimiento de Sant Josep (La Vall d'Uixó)

4. Forma Hayes 91A de TSCD (Superficie)

5. Forma Hayes 61A de TSCD (Superficie)

Materiales del yacimiento de Orleyl (La Vall d'Uixó)

6. Forma Drag. 35/36 de TSS decorada (Orleyl II P-1) 

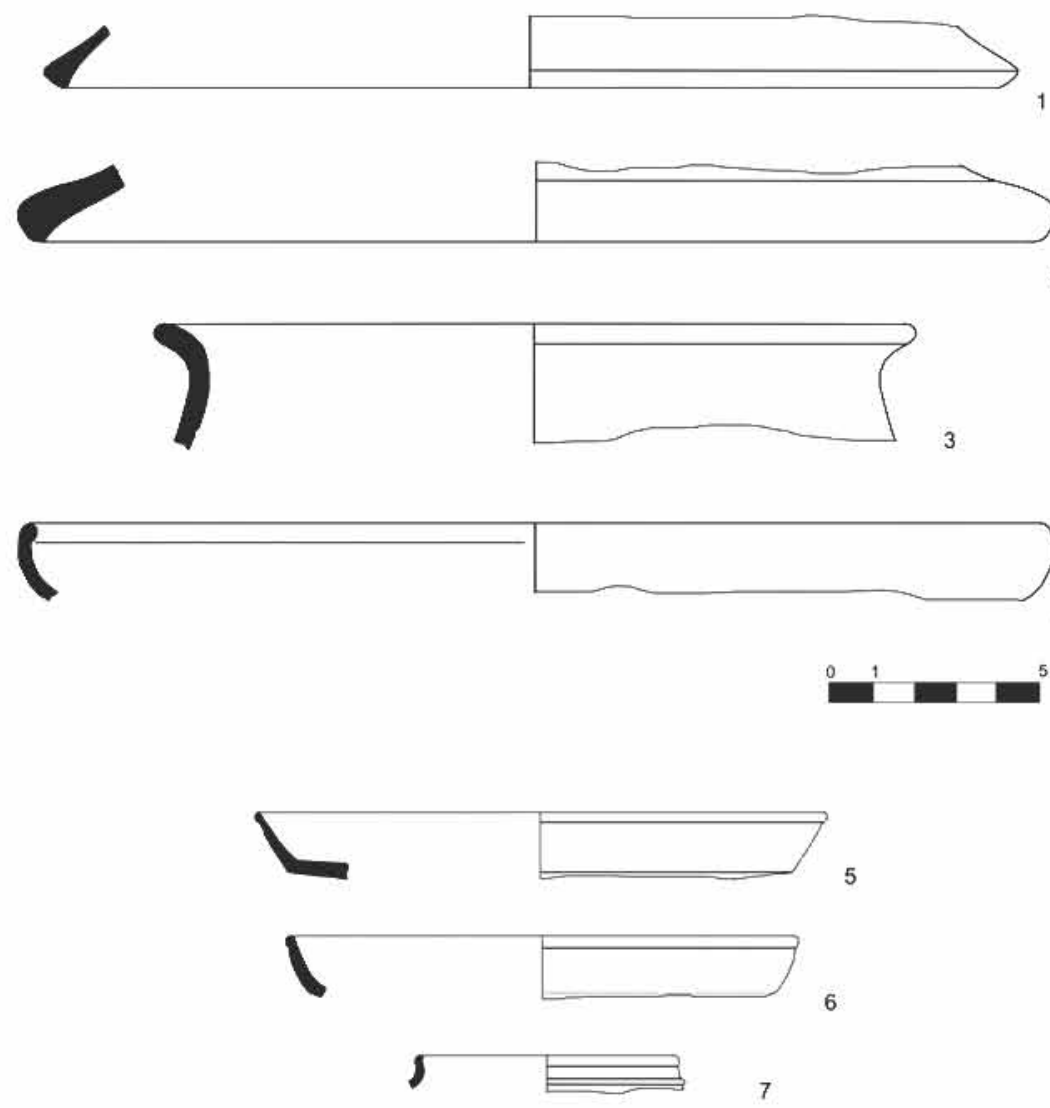

I
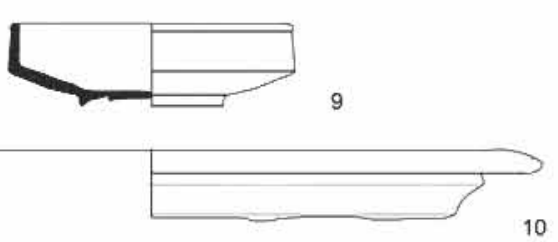

10
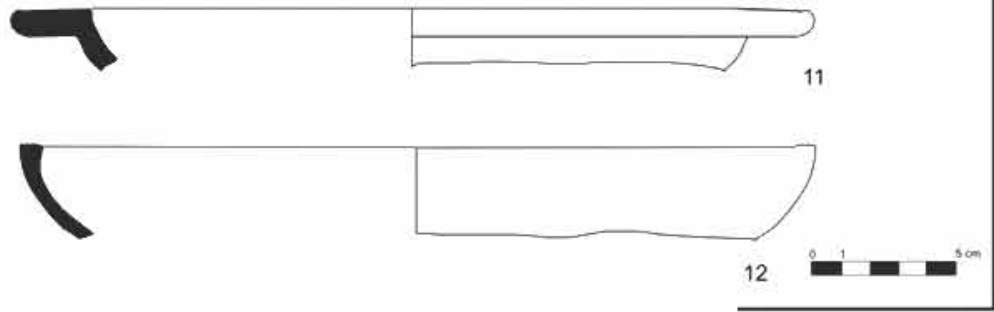


\section{LAMINA XXXII}

Materiales del yacimiento de Virrangues (Burriana)

1. Forma Ostia II, 302.

Materiales del yacimiento del Regall (Burriana)

2. Forma Ostia I, 261.

Materiales del yacimiento de la Punta del Cid (Almenara)

3. Borde exvasado de cerámica reductora visigoda.

Materiales del yacimiento del Solaig (Bechí)

4. Forma Drag. 18A de TSS (Superficie)

5. Forma Drag. 18A de TSS (Superficie)

6. Forma Drag. 15/17 de TSI (Superficie)

7. Borde recto de TSCA (Superficie)

\section{Materiales del yacimiento del Alter (Chilches)}

8. Borde recto de TSCA. (Superficie)

9. Imitación forma Lamboglia 23 de TSCA (Superficie)

10. Imitación forma Lamboglia 22A de TSCA (Superficie)

11. Imitación forma Lamboglia 17 de TSCA (Superficie) 


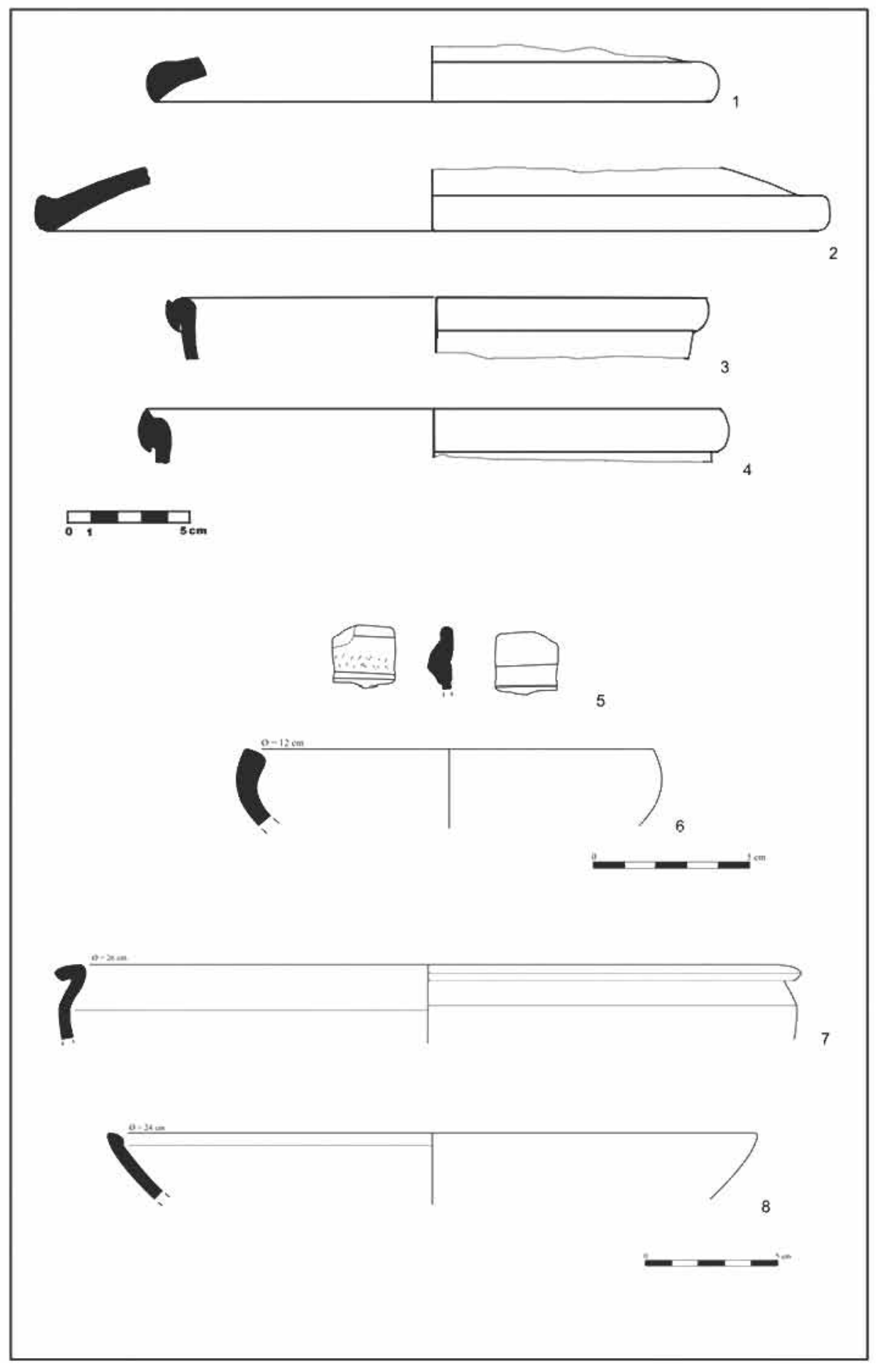




\section{Materiales del yacimiento del solar de Quevedo (Sagunto)}

\begin{tabular}{|ll|}
\hline 1. & Plato tapadera de cerámica africana. Forma Ostia I, 261 (UE 1001) \\
2. & Plato tapadera de cerámica africana. Forma Ostia I, 261 (UE 1001) \\
3. & Borde de cazuela de cerámica africana. Forma Ostia III, 324 (UE 1001) \\
4. & Borde de cazuela de cerámica africana. Forma Ostia III, 324(UE 1001) \\
5. & Borde de TSCA forma Lamboglia 9A. (UE 3005). \\
6. & Borde recto de cuenco de cerámica común romana. (UE 3005) \\
7. & Borde exvasado. Cronología ibérica. (UE 3006) \\
8. & Borde forma Lamboglia 10A. (UE 3001) \\
\hline
\end{tabular}



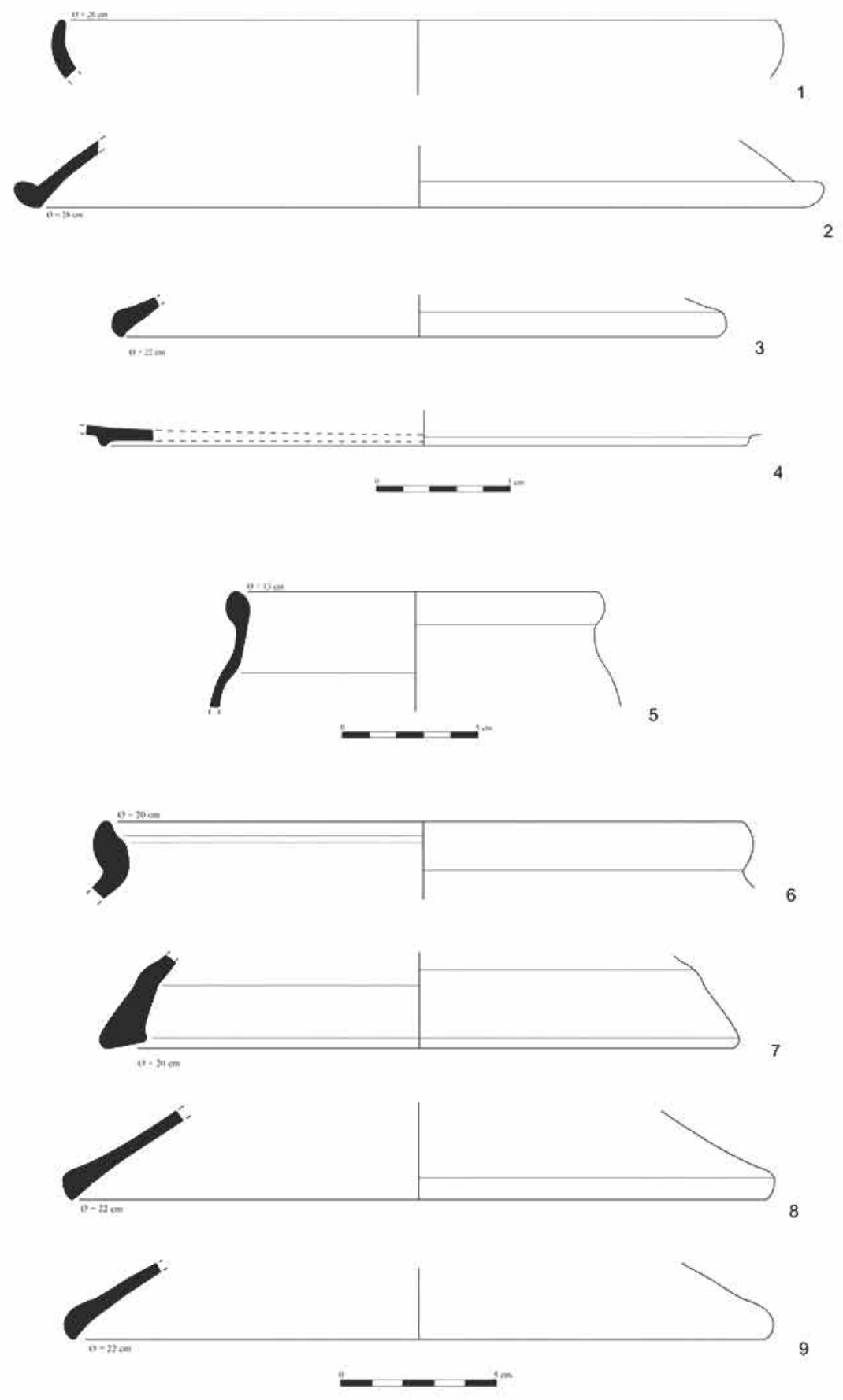


\section{Materiales del yacimiento del solar de Quevedo (Sagunto)}

1. Borde TSCA forma Hayes 17. (UE 3005)

2. Borde forma Ostia I, 262. (UE 3005).

3. Borde forma Ostia I, 261 (UE 3005).

4. Base de TSCA. Cronología s. I / II p. C. (UE 3005).

5. Borde de urna de cerámica ibérica. (UE 3006)

6. Borde de cerámica reductora romana. (UE 3006).

7. Pie de urna de cerámica común romana. (UE 3006)

8. Borde forma Ostia I, 261. (UE 3006)

9. Borde forma Ostia I, 261. (UE 3006) 


\section{Materiales del yacimiento del solar de Quevedo (Sagunto)}

1. Borde forma Ostia I, 261. (UE 3002)

2. Borde forma Ostia I, 262. (UE 3001). Posible imitación de cerámica reductora

3. Borde forma Ostia I, 261. (UE 3001)

4. Borde forma Ostia I, 261. (UE 3001)

5. Borde forma Ostia III, 108. (UE 3001)

6. Borde forma Ostia III, 267A. (UE 3001)

7. Borde forma Ostia III, 267A. (UE 3001) 

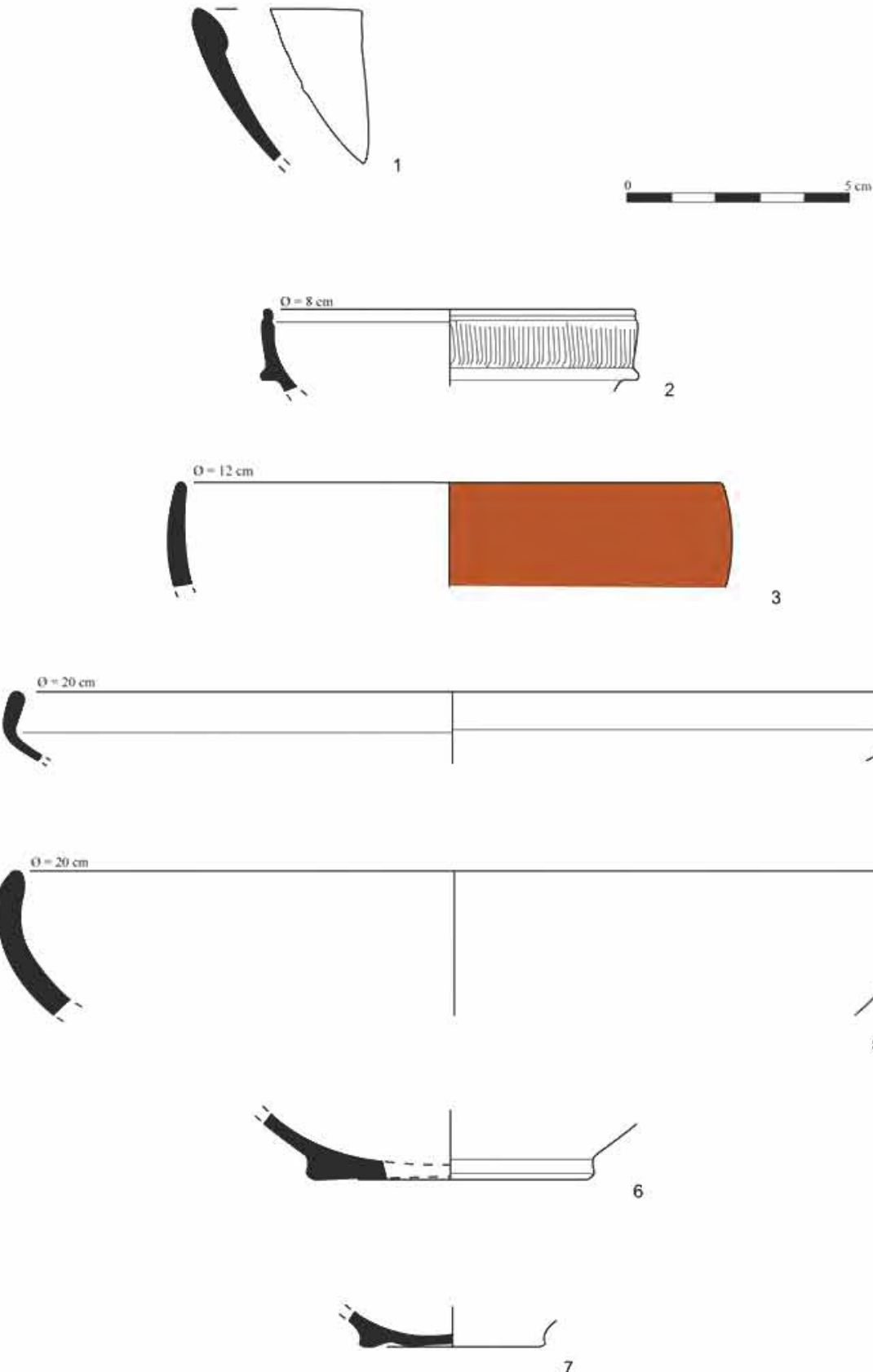


\section{Materiales del yacimiento del solar de Quevedo (Sagunto)}

1. Borde forma Lamboglia 10A. (UE 3001)

2. Borde de TSS forma Drag. 24/25. (UE 3001)

3. Borde de TSH posible forma Mesquíriz 50. Cronología s. I / II p. C. (UE 3001)

4. Borde recto de plato de cerámica común romana. (UE 3001)

5. Borde de TSCA forma Hayes 17. (UE 3001)

6. Base en codo de cerámica común romana (UE 3001)

7. Base con pie indicado de cerámica común romana (UE 3001) 


$$
-0
$$


Materiales del yacimiento del solar de Quevedo (Sagunto)

1. Borde de cerámica común romana. Cronología alto imperial. (UE 3002)

2. Borde recto de patera. Cronología ¿visigoda? (UE 3001)

3. Ánfora similar a las de Ágora de Atenas. Cronología $1^{\mathrm{a}}$ mitad s. III p. C. (UE 3006)

4. Base plana de cerámica norte-africana. (UE 3006)

5. Base en codo de cerámica común romana. (UE 3006)

6. Base con pie indicado de cerámica común romana. (UE 3006) 


\section{LAMINA XXXVIII}

\section{Materiales del yacimiento del solar de Quevedo (Sagunto)}

1. Borde exvasado de cerámica común ibérica. (UE 3004)

2. Borde de ánfora Keay XLV. (UE 3002)

3. Borde recto. Cronología ¿ibérica? (UE 3003)

4. Borde moldurado de cerámica común romana (UE 3003)

5. Borde imitación forma Luni I. (UE 3003)

6. Base de copa de cerámica común romana. (UE 3002)

7. Borde forma Lamboglia 10A. (UE 3004)

8. Base de TSCA. (UE 3003)

9. Borde forma Lamboglia 10B (UE 3004)

10. Borde TSI clásica posible Goudineau 21. (UE 3004) 

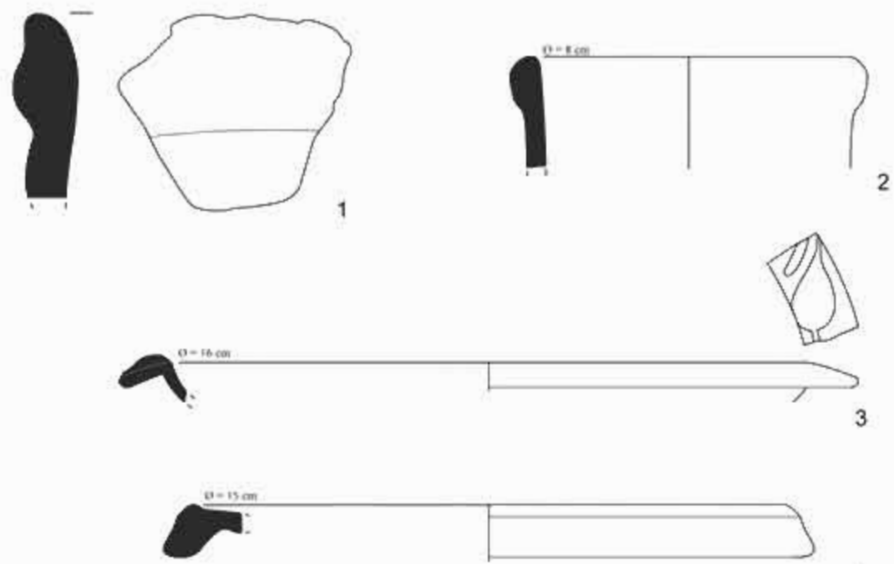

4
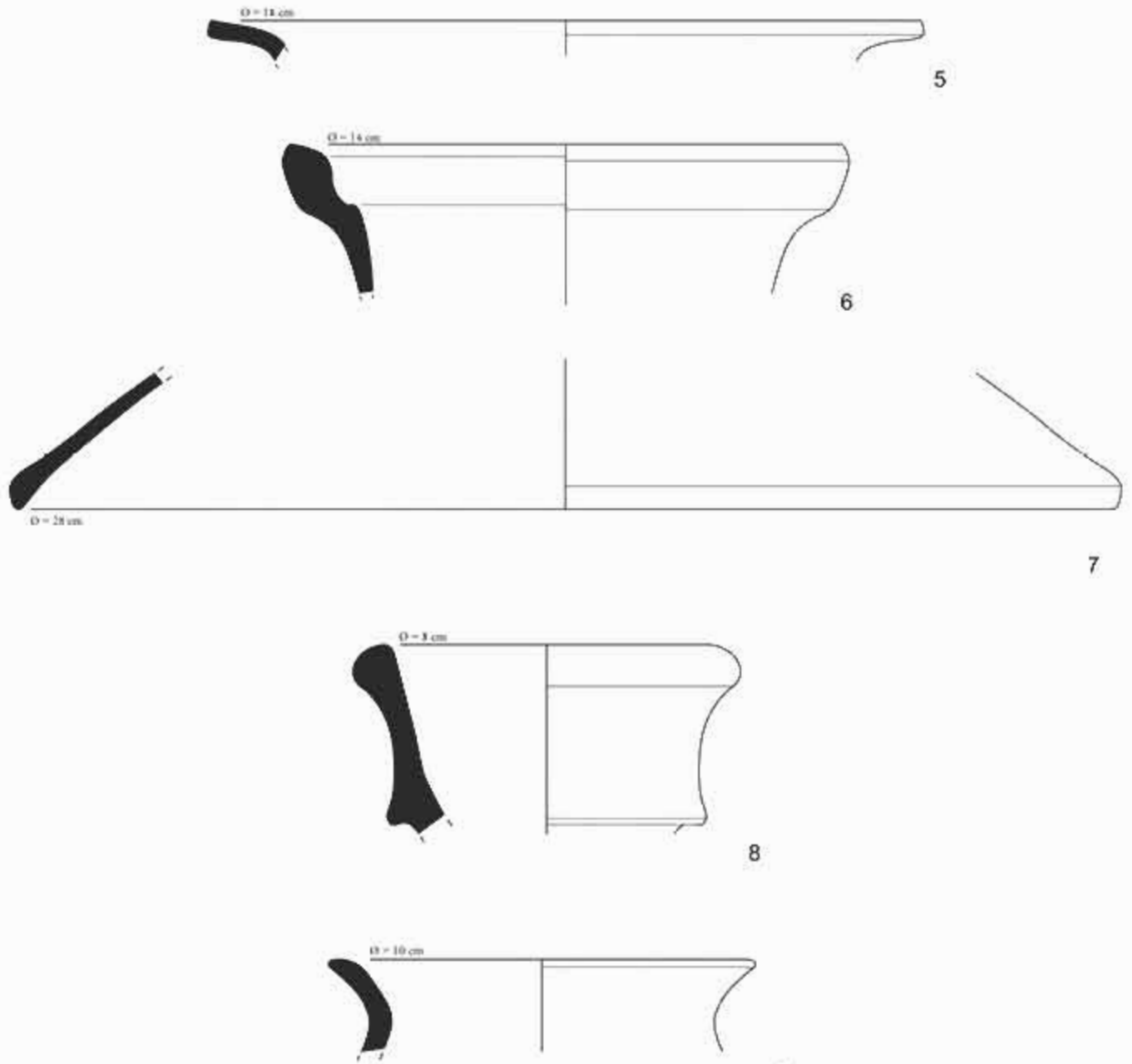


\section{Materiales del yacimiento del solar de Quevedo (Sagunto)}

1. Borde de ánfora púnica tipo Maña. (UE 3004)

2. Borde almendrado de ánfora romana. (UE 3004)

3. Borde de TSS forma Drag. 35. (U. E. 3004)

4. Base de copa de cerámica común romana. (UE 3004)

5. Borde de Kalathos. Cronología ibérica. (UE 3004)

6. Borde moldurado de cerámica común romana. (UE 3004)

7. Borde forma Ostia II, 302. (UE 3004)

8. Borde cuadrangular de cerámica común romana. (UE 3004)

9. Borde de cerámica reductora romana. (UE 3004) 
LAMINA XL
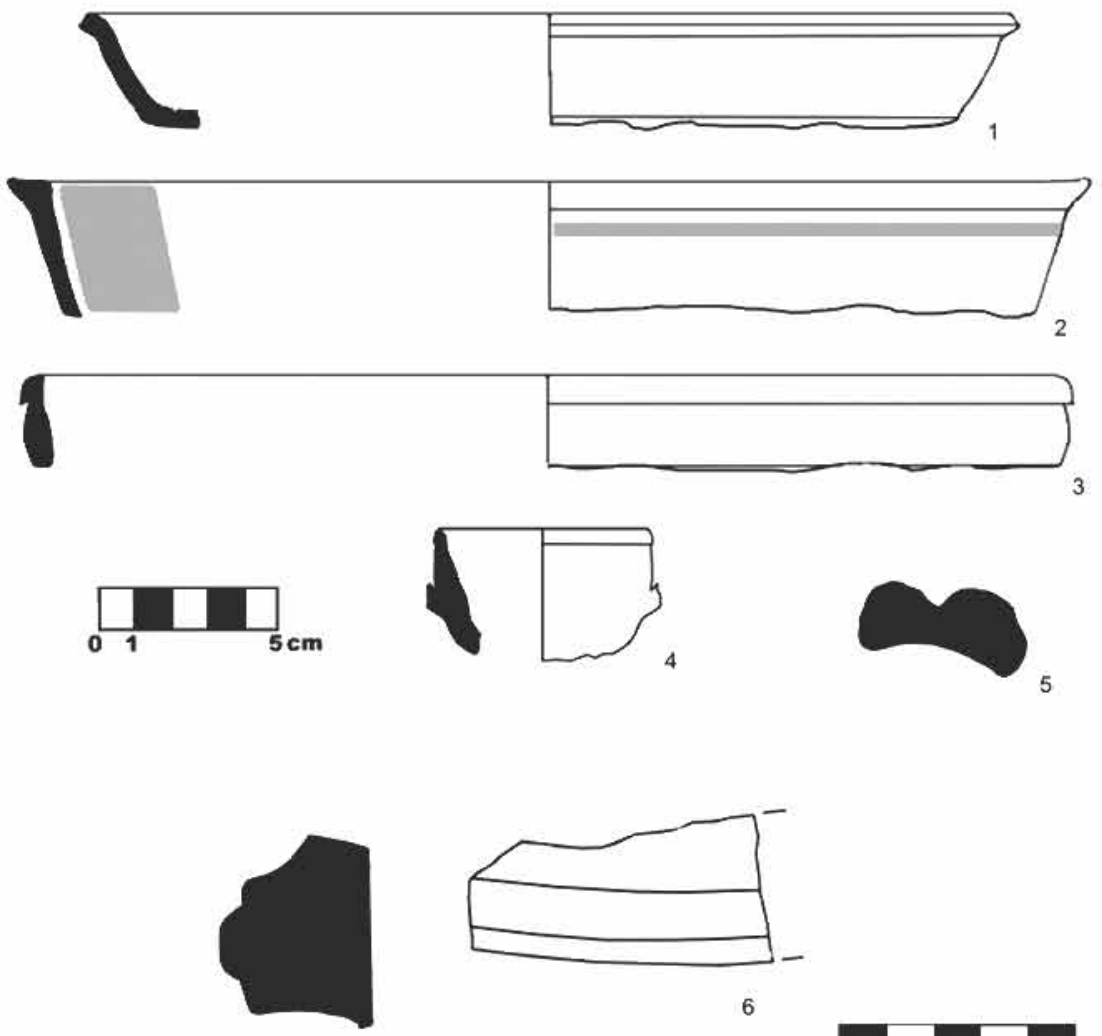

6
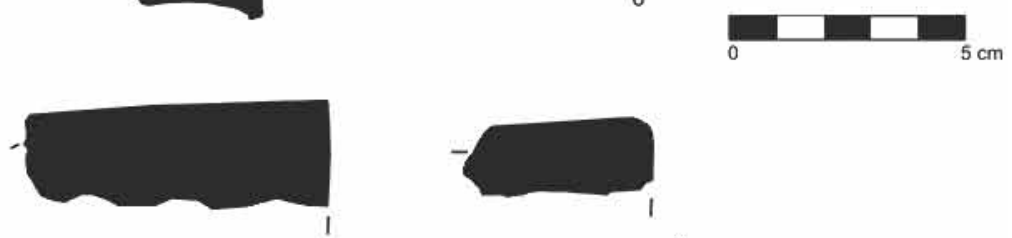

8
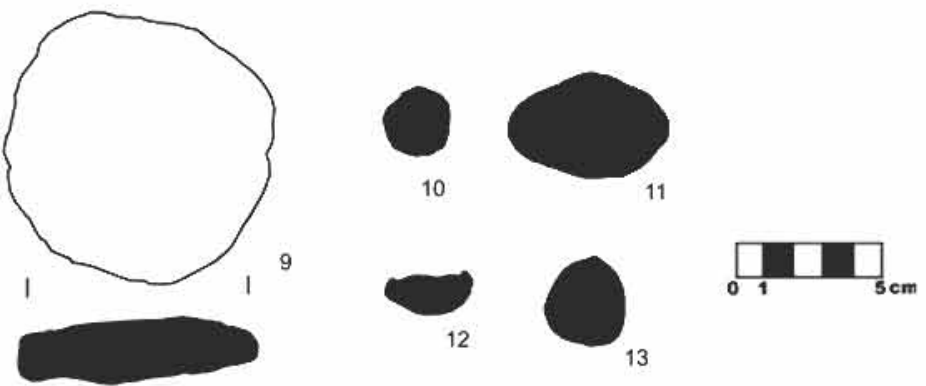


\section{Materiales del yacimiento del solar de Quevedo (Sagunto)}

1. Borde T.S. I, forma Goudineau 43. (UE 3004)

2. Borde plano de cerámica ibérica decorada. (UE 3004)

3. Borde de T. S. I., posible forma Drag. 29. (UE 3004)

4. Borde de botella con arranque de asa de cerámica común romana. (UE 3004)

5. Asa de sección plana con canaleta central de cerámica común romana. (UE 3004)

6. Moldura de mármol blanco. (UE 3004)

7. Moldura de mármol blanco. (UE 3004)

8. Moldura de mármol blanco. (UE 3004)

9. Tapadera circular recortada sobre fragmento de ánfora de la Campania. (UE 3004)

10. Asa de sección cilíndrica de cerámica común romana. (UE 3004)

11. Asa de sección elipsoidal de cerámica común romana. (UE 3004)

12. Asa de sección elipsoidal de cerámica común romana. (UE 3004)

13. Asa de sección circular de cerámica común romana. (UE 3004) 

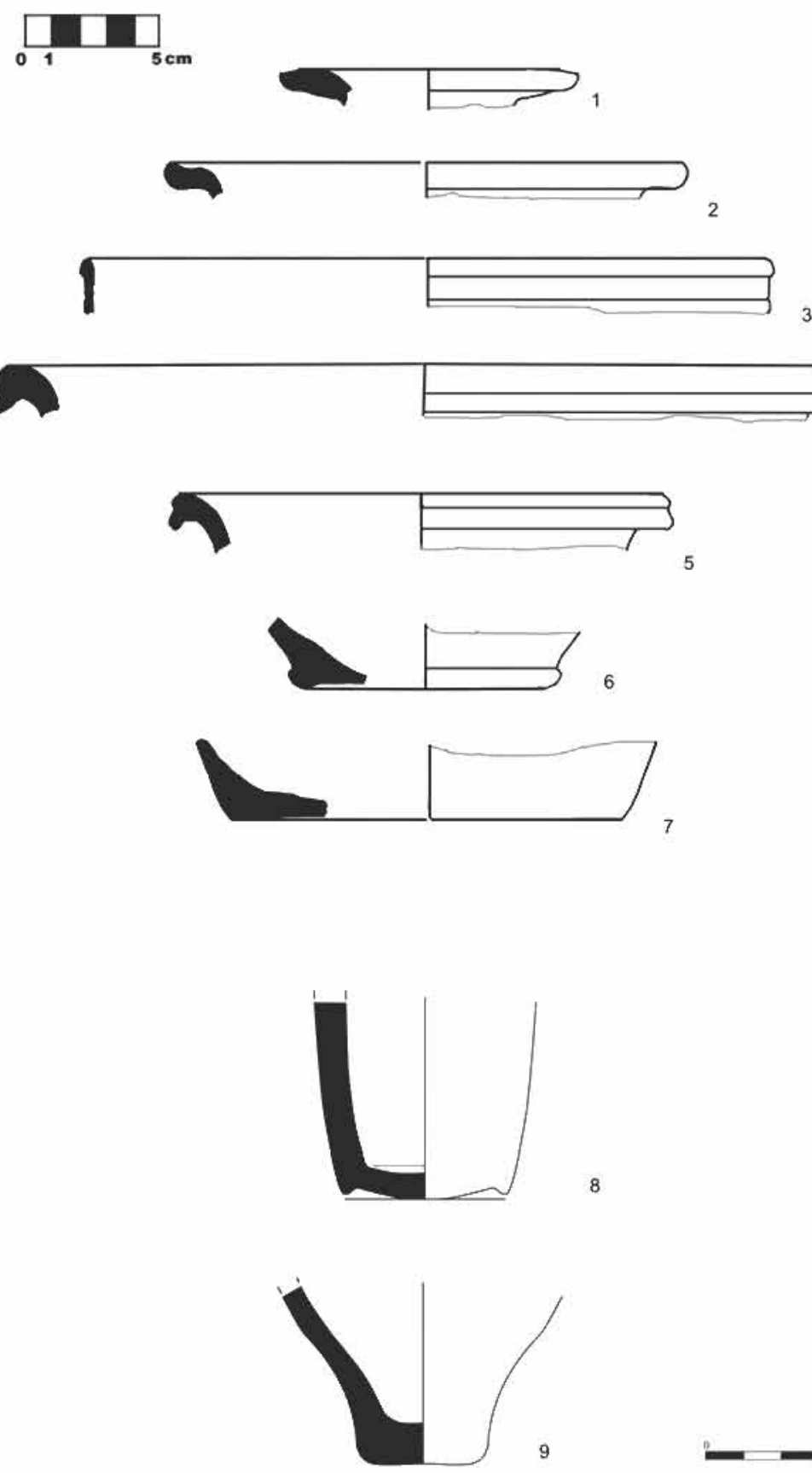


\section{Materiales del yacimiento del solar de Quevedo (Sagunto)}

1. Borde exvasado de botella posiblemente norte-africana (UE 1012)

2. Borde exvasado moldurado de cerámica romana. (UE 1012)

3. Borde decorado, posible forma Drag.17. (UE 1012)

4. Borde de cabeza de ánade de cerámica ibérica. (UE 1012)

5. Borde de cabeza de ánade de cerámica ibérica. (UE 1012)

6. Base con umbo y pie en codo de cerámica ibérica. (UE 1012)

7. Base plana de cerámica de cocina de cerámica romana. (UE 1012)

8. Pivote de ánfora posible Africana I. (UE 3004)

9. Fragmento de pivote de ánfora romana. (UE 3004) 

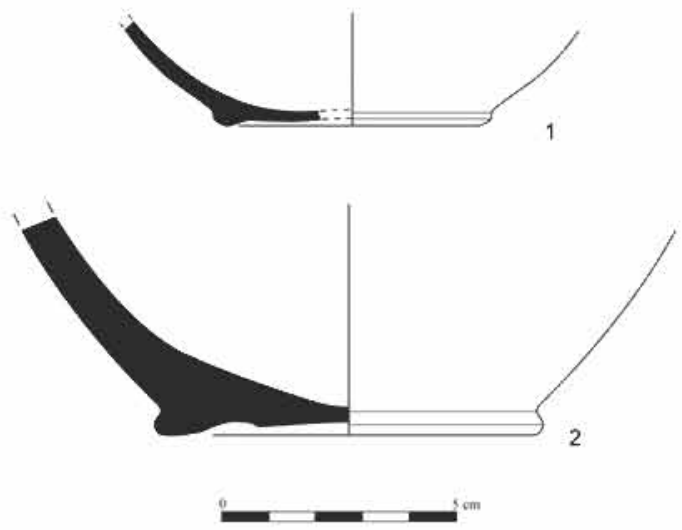

1
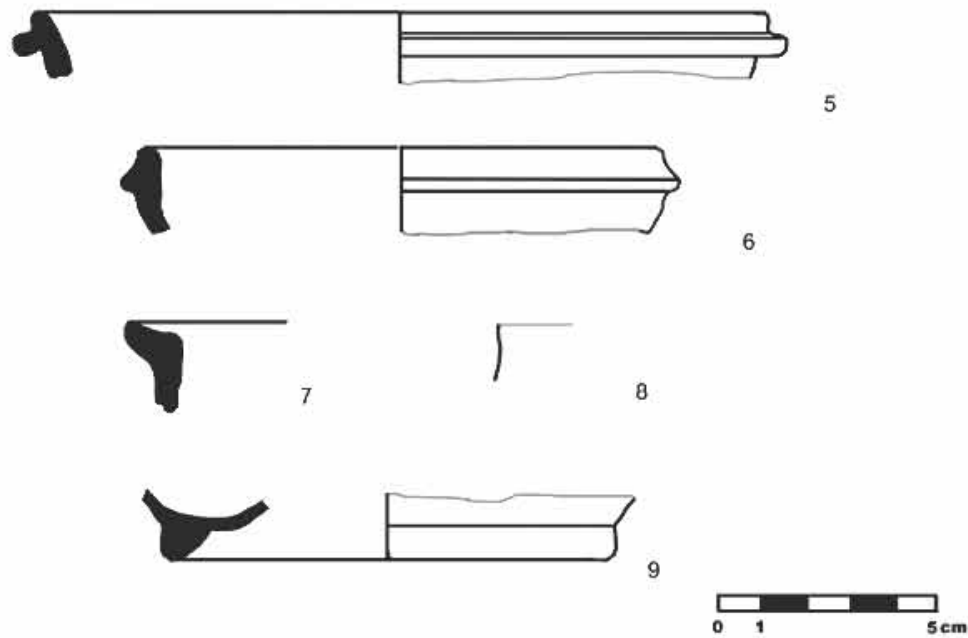


\section{LAMINA XLII}

\section{Materiales del yacimiento del solar de Quevedo (Sagunto)}

1. Base con pie de cerámica común romana. (UE 3004)

2. Base plana de ánfora. Cronología romana. (UE 3004)

3. Borde de cerámica ibérica. (UE 3007)

4. $\quad$ Borde plato tapadera. Forma Ostia II, 302 (UE 1012)

5. Borde de moldurado de cerámica común romana (UE 1001)

6. Borde recto con moldura destacada de cerámica común romana (UE 1001)

7. Borde plano moldurado de cerámica común romana (UE 1001)

8. Borde exvasado de vidrio. Cronología romana (UE 2003)

9. Base con pie destacado y umbo de cerámica itálica (UE 1001) 

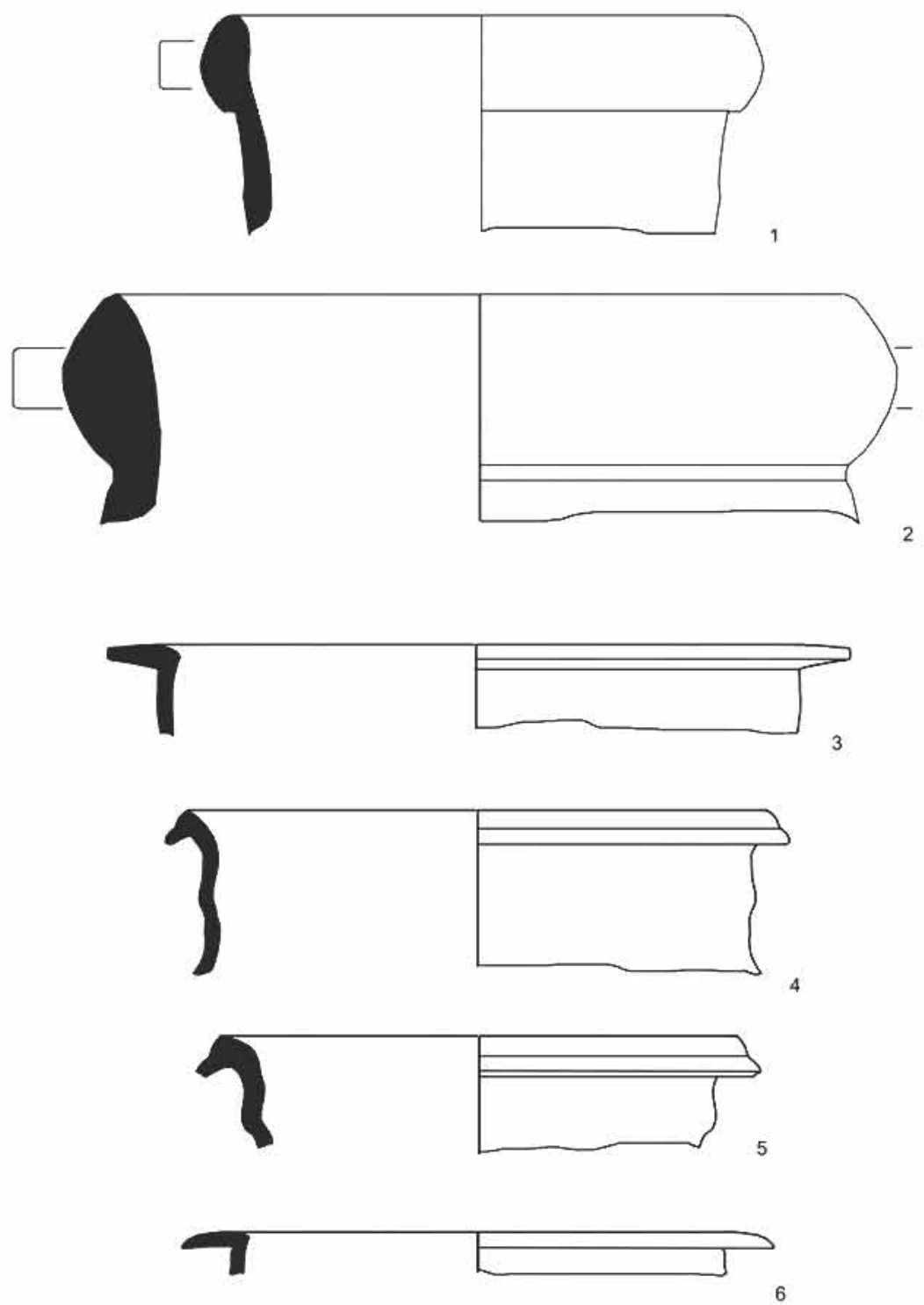


\section{Materiales del yacimiento de la Plaza de la Morería (Sagunto)}

1. Borde de ánfora con estampilla MPM, posible Dressel 2-4 (UE 1086)

2. Borde de ánfora con estampilla MB, posible Dressel 6a (UE 1086)

3. Borde plano de Kalathos de cerámica ibérica (UE 1349)

4. Borde de tipo cabeza de ánade de cerámica ibérica (UE 1336)

5. Borde de tipo cabeza de ánade de cerámica ibérica (UE 1336)

6. Borde plano de Kalathos de cerámica ibérica (UE 1336) 


\section{Materiales del yacimiento de la Plaza de la Morería (Sagunto)}

\begin{tabular}{ll}
\hline 1. & Forma Hayes 33 de TSCA. (UE 1056) \\
2. & Borde moldurado cerámica común romana (UE 1153) \\
3. & Forma Drag. 18b de TSS. (UE 1123) \\
4. & Imitación forma Lamboglia $17 b$ de cerámica común romana (UE 1131) \\
5. & Forma Mezquiriz 17 de TSH (UE 1101$)$ \\
6. & Forma Hayes 26 de TSCA (UE 1106) \\
7. & Borde de mortero forma Dramont D2 de $2^{a} 1 / 2$ S. I a la $1^{\text {a } 1 / 2 ~ S . ~ I I ~ d . ~ C . ~(U E ~ 1052) ~}$ \\
8. & Borde de ánfora africana con estampilla DP (UE 1110)
\end{tabular}




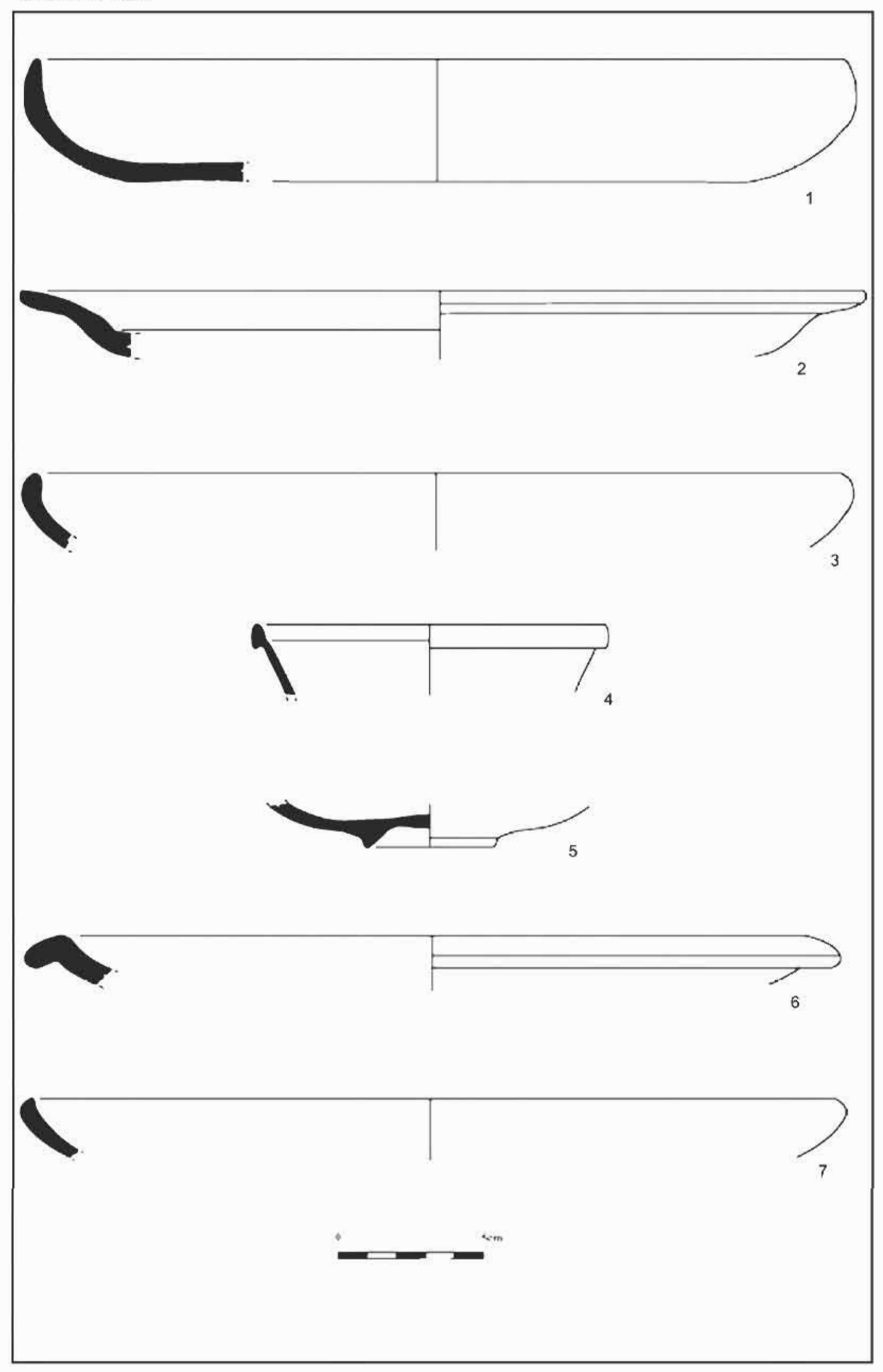




\section{Materiales del yacimiento de la Plaza de la Morería (Sagunto)}

1. Forma Torre Llauder 6.7 de cerámica con engobe rojo pompeyano. (UE 1146)

2. Forma Atlante Tav. XXX, 4 de TSH (UE 1106)

3. Forma Atlante Tav. XL, 3 de TSH. (UE 1106)

4. Forma Ettingler, 14-1 de TSI (UE 1133)

5. Base con pie de TSH (UE 1133)

6. Forma Atlante Tav. XXV, 6 de TSCA/D (UE 1114)

7. Forma Atlante Tav. XVI, 6 de TSCA. (UE 1365) 


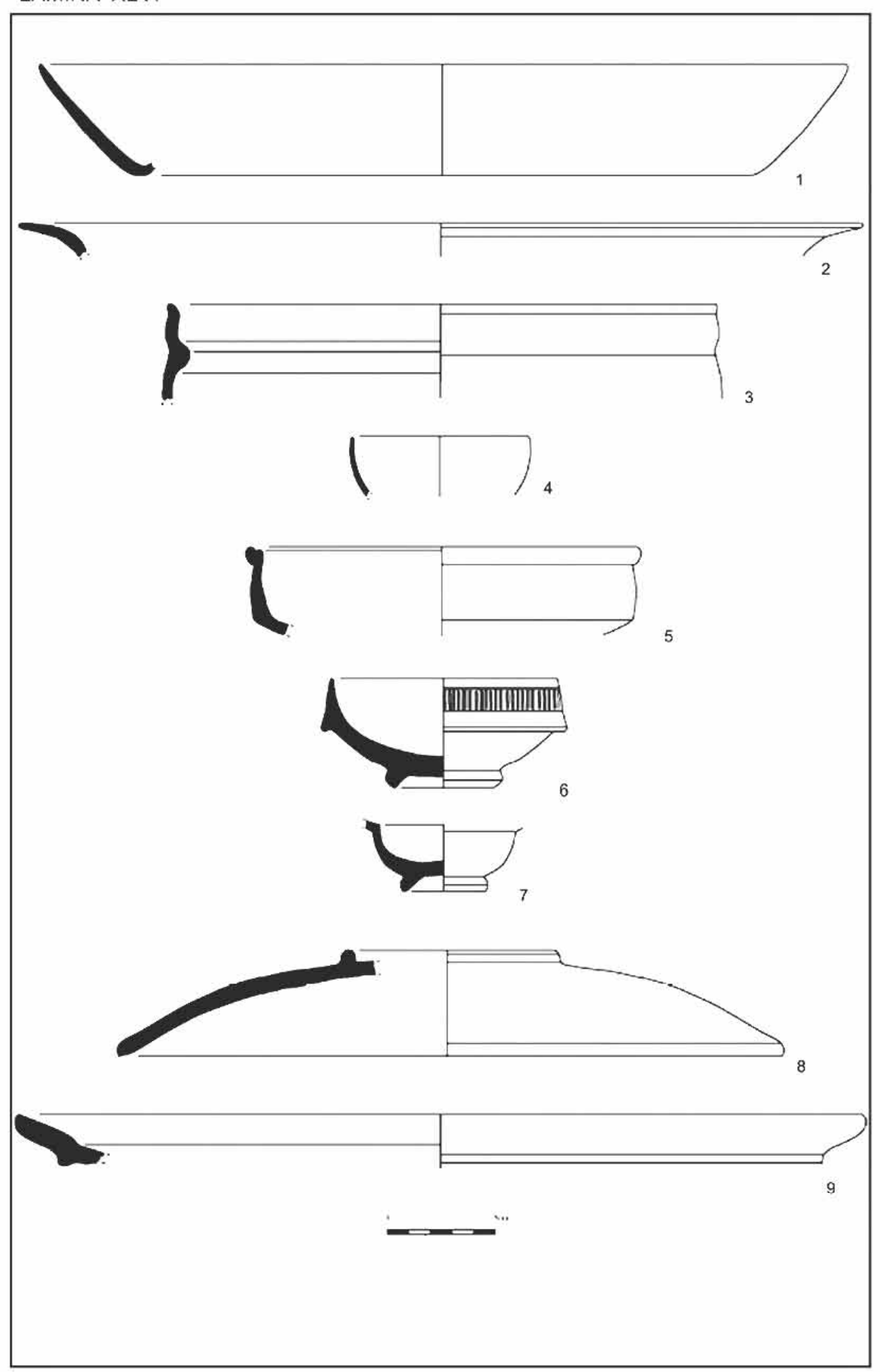




\section{Materiales del yacimiento de la Plaza de la Morería (Sagunto)}

1. Forma Atlante Tav. XVII, 18 de TSCA (UE 1310)

2. Forma Atlante Tav. XXVI, 3 de TSCA. (UE 1088)

3. Forma Hayes 194 de cerámica africana de cocina (UE 1349)

4. Forma Conspectus 36.3.1 de TSI (UE 1016)

5. Forma Hayes 197 de cerámica africana de cocina. (UE 1242)

6. Forma Dragendorff $24 / 25$ de TSH (UE 1061)

7. Forma Dragendorff 27 de TSH (UE 1404)

8. Forma Atlante Tav. XL, 3 de TSH. (UE 1106)

9. Forma Hayes 196 de cerámica africana de cocina (UE 1379)

10. Forma similar a Ostia I, 263 de cerámica africana de cocina (UE 1310) 

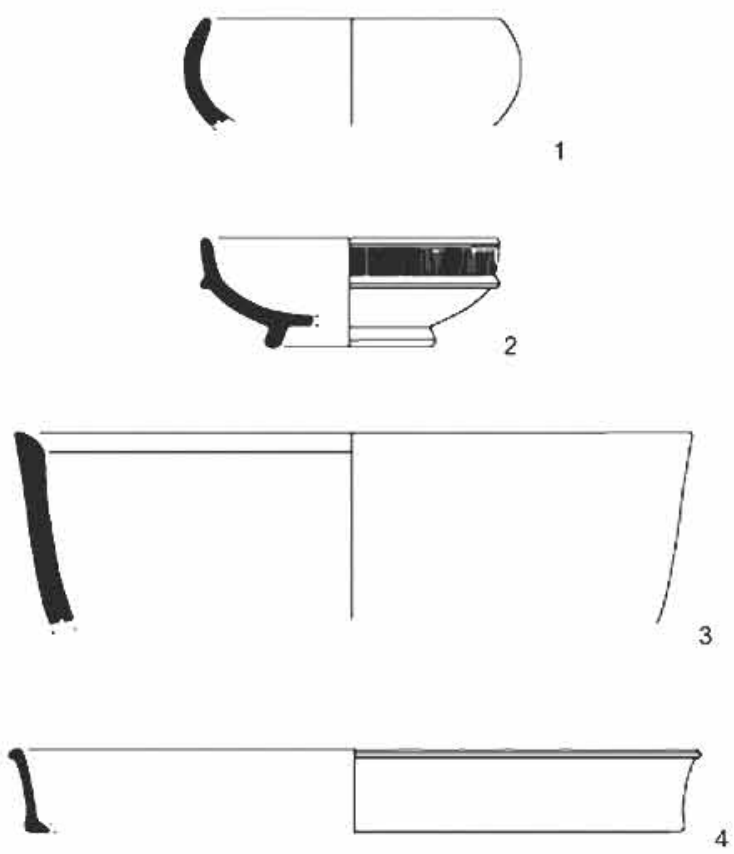

5
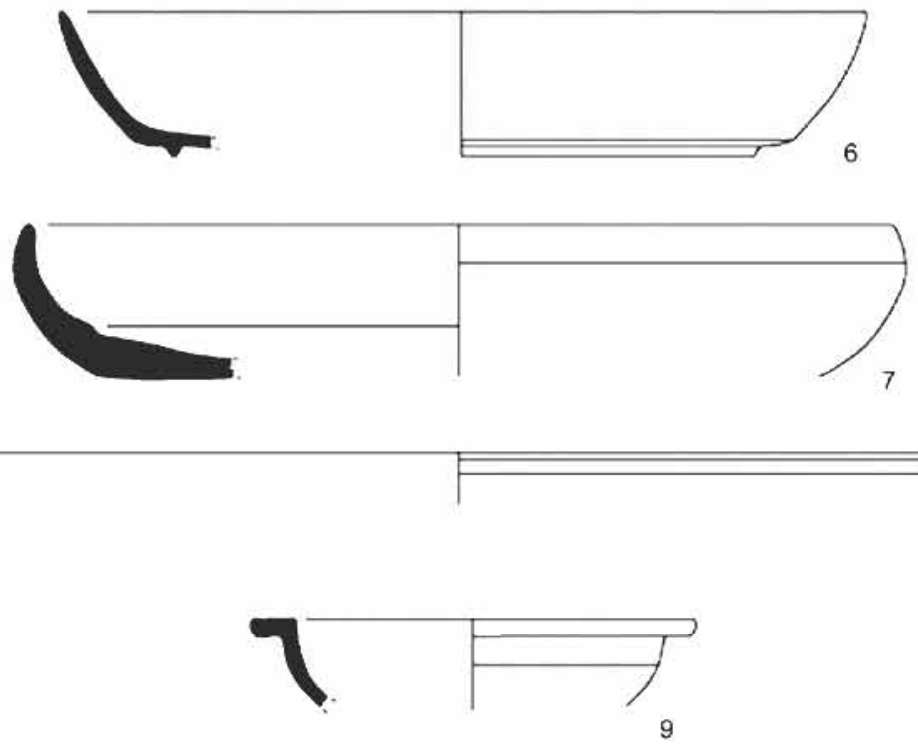


\section{LAMINA XLVII}

\section{Materiales del yacimiento de la Plaza de la Morería (Sagunto)}

1. Forma Atlante Tav. XXVIII, 3 de TSH (U.E. 1056)

2. Forma Drag. 24/25b de TSS. (U.E. 1056)

3. Forma Hayes $14 \mathrm{~b}$ de TSCA (U.E. 1056)

4. Forma Drag. $14 / 17$ de TSI. (U.E. 1056)

5. Forma Atlante Tav. XVII, 18 de TSCA (U.E. 1056)

6. Forma Atlante Tav. XVII, 18 de TSCA. (U.E. 1052)

7. Forma Atlante Tav. XXIV, 5 de TSCA/D (U.E. 1052)

8. Forma Atlante Tav. XXVI, 9 de TSCA/D. (U.E. 1052)

9. Forma Atlante Tav. LI, 10 de TSCD (U.E. 1056) 


\section{Materiales del yacimiento de la Plaza de la Morería (Sagunto)}

1. Forma Atlante Tav. XXIV, 3 de TSCA (UE 1052)

2. Forma Lamboglia 10B de TSCA. (UE 1052)

3. Forma Drag. 46 de TSS (UE 1060)

4. Forma Ostia III, 267 de cerámica africana de cocina. (UE 1103)

5. Forma Hayes 8A de TSCA (UE 1103)

6. Forma Ettingler 36-1 de TSI (UE 1103)

7. Forma Drag. 18b de TSS (UE 1086)

8. Forma Drag. 29 de TSS (UE 1072) 


\section{LAMINA XLIX}
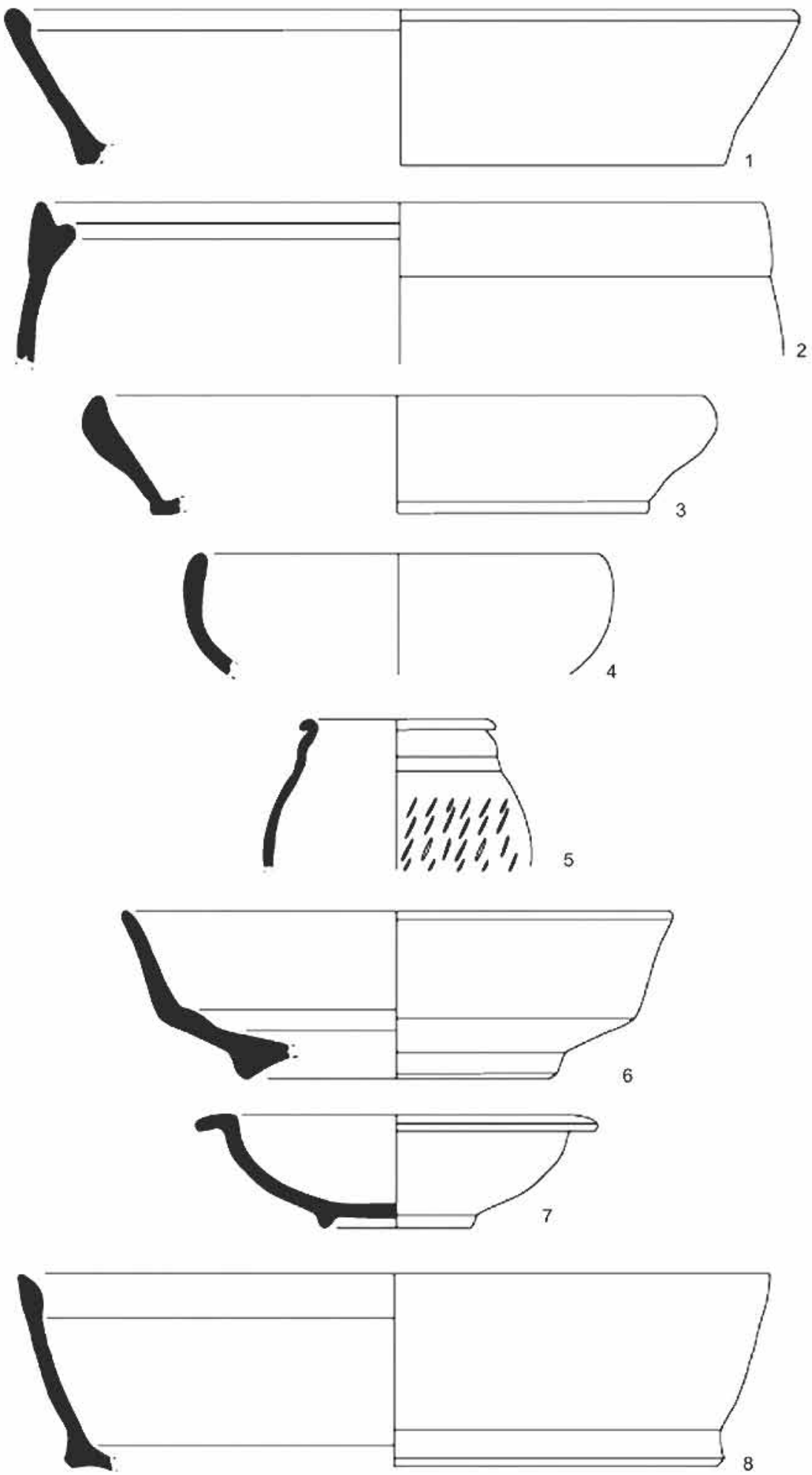

12 
Materiales del yacimiento de la Plaza de la Morería (Sagunto)

1. Forma Lamboglia $10 \mathrm{~B}$ de cerámica africana de cocina (UE 1056)

2. Forma Atlante Tav. CVIII, 16 de cerámica africana de cocina. (UE 1056)

3. Forma Lamboglia 10A de TSCA (UE 1056)

4. Forma Atlante Tav. XXIV, 3 de TSCA/D. (UE 1056)

5. Borde de cerámica de paredes finas de la Tarraconense. (UE 1056)

6. Forma Drag. 18 de TSH (UE 1047)

7. Forma Hayes $6 c$ de TSCA (UE 1131)

8. Forma Lamboglia 10A de TSCA (UE 1056) 
LAMINA L

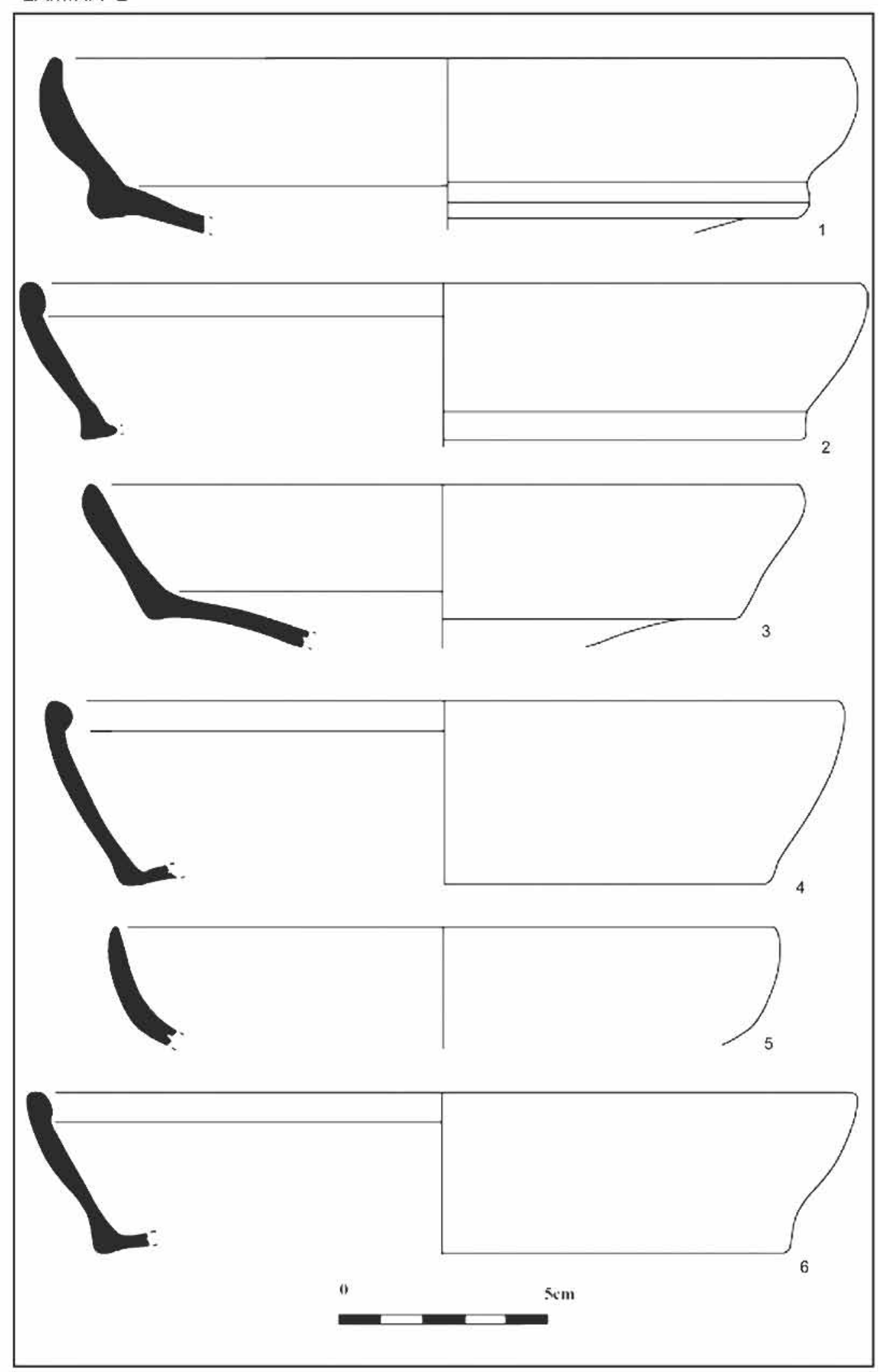




\section{LAMINA L}

\section{Materiales del yacimiento de la Plaza de la Morería (Sagunto)}

1. Forma Lamboglia 10B de cerámica africana de cocina (UE 1310)

2. Forma Lamboglia 10A de TSCA (UE 1310)

3. Forma Lamboglia 10B de cerámica africana de cocina (UE 1135)

4. Forma Lamboglia $10 \mathrm{~A}$ de cerámica africana de cocina (UE 1088)

5. Forma Lamboglia 8 de TSCA2. (UE 1113)

6. Forma Lamboglia 10A de cerámica africana de cocina (UE 1319) 


\section{Materiales del yacimiento de la Plaza de la Morería (Sagunto)}

1. Tapadera de cerámica común romana, (UE 1123)

2. Borde de cerámica común romana, imitación de forma Hayes 6c. (UE 1056)

3. Forma Ettingler 36-1 de TSI (UE 1111)

4. $\quad$ Forma Ettlinger 4-1 de TSS. (UE 1100)

5. Forma Drag. 27 de TSI. (UE 1100)

6. Forma Drag. 29 de TSH. (UE 1131)

7. Forma Ettlinger 36-1 de TSS (UE 1131). 

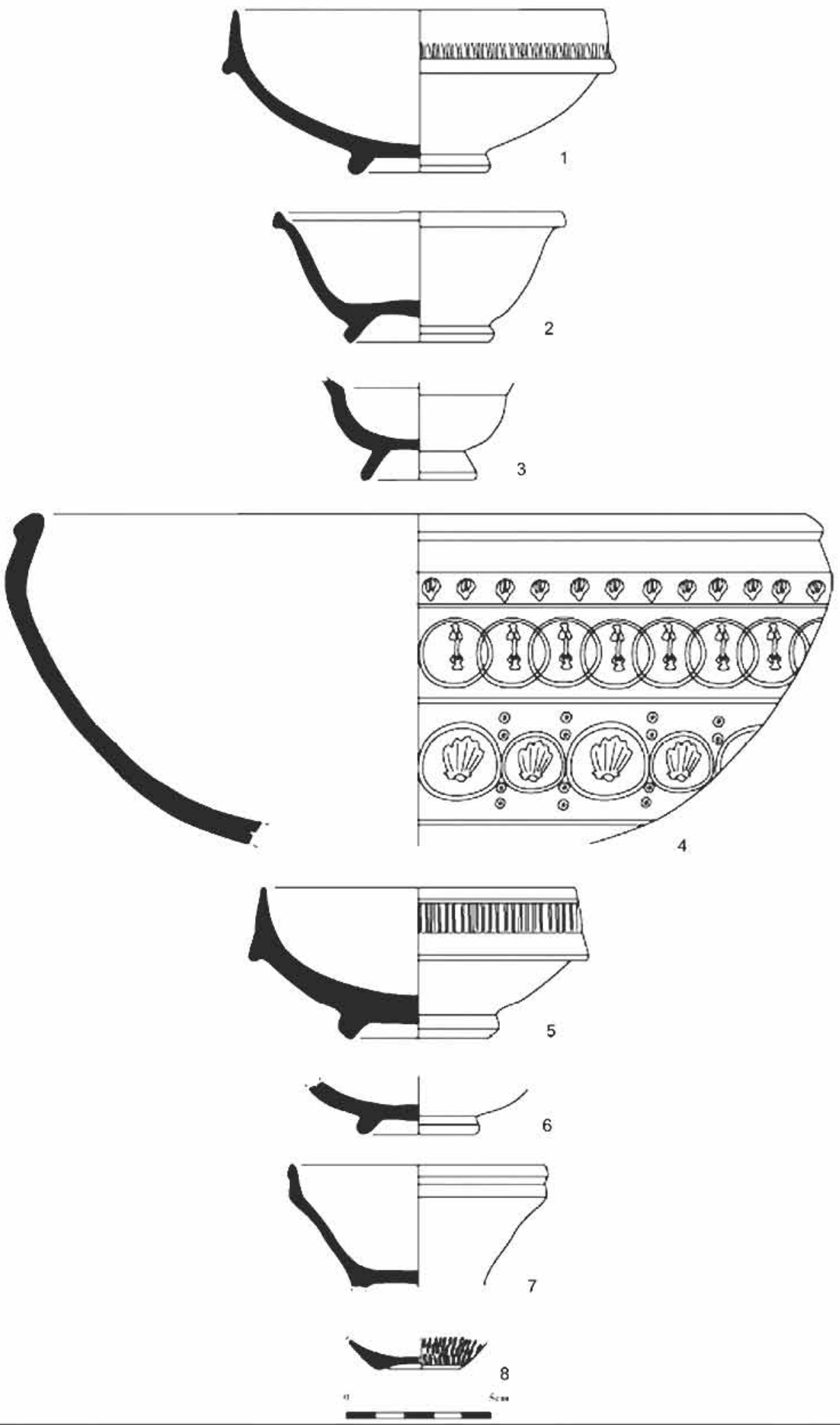


\section{LAMINA LII}

\section{Materiales del yacimiento de la Plaza de la Morería (Sagunto)}

1. Forma Dragendorff $24 / 25 b$ de TSS. (U.E. 1111)

2. Forma Loeschke serv. 1, Haltern 7 de TSS. (UE 1123)

3. Forma Drag. 27 de TSH. (UE 1131)

4. Forma Drag. 37b decorada (sobre acequia). (UE 4002)

5. Forma Drag. 24/25b de TSI. (UE 1111)

6. Base con pie de TSS. (UE 1111)

7. Forma Ettlinger 25-1 de TSI (cubicula templo).

8. Base de cerámica reductora de paredes finas decorada a ruedecilla (cubicula templo). 


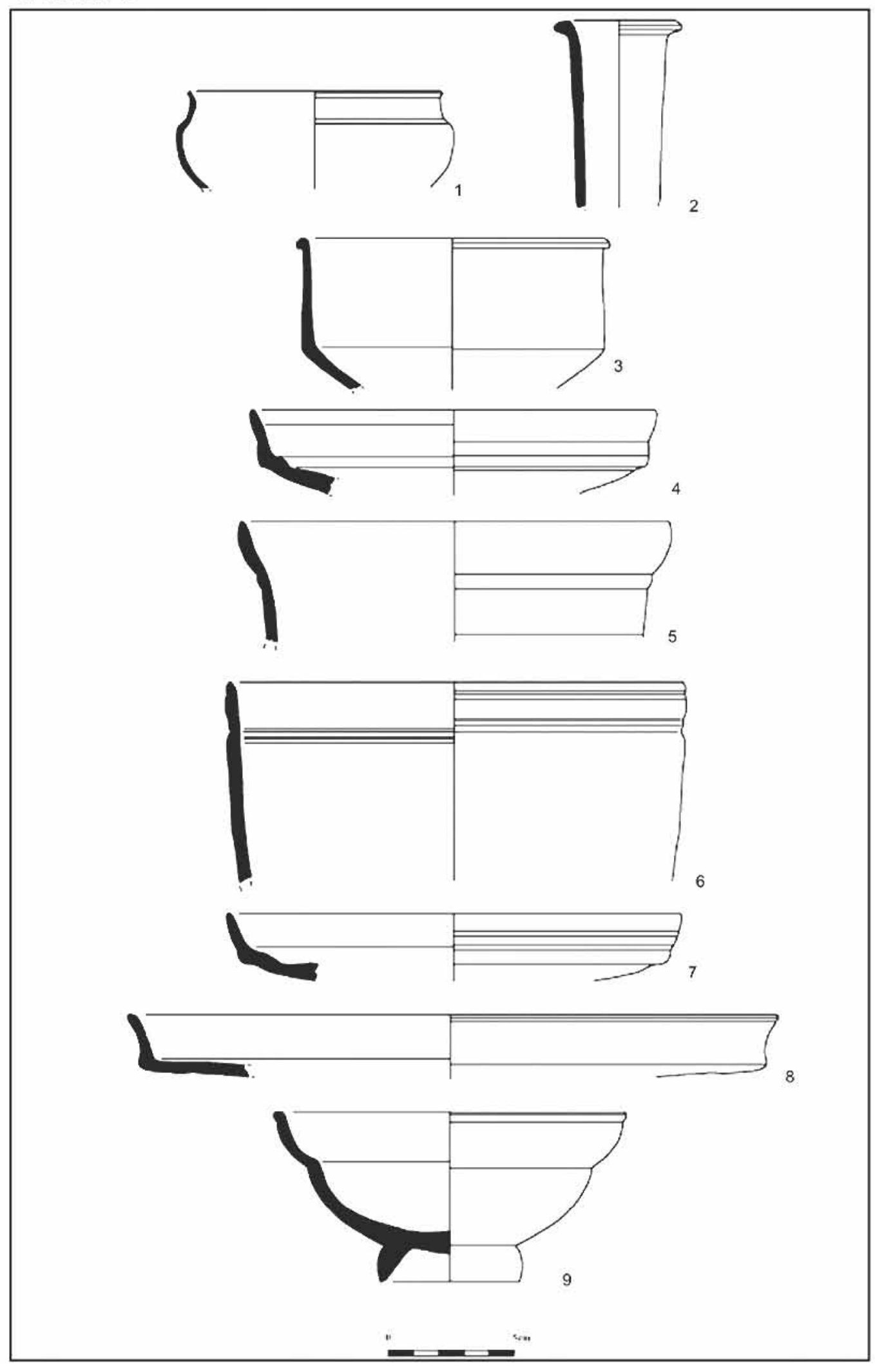




\section{Materiales del yacimiento de la Plaza de la Morería (Sagunto)}

1. Borde de caliciforme de cerámica de paredes finas romana. (UE 1339)

2. Borde de ungüentario de cerámica común romana (UE 1375)

3. Forma Ritterling 1913, 9b de TSS. (UE 1375)

4. Forma Drag. 15/17 de TSS (UE 1375)

5. Forma Ettingler R5-2 de TSI (UE 1111)

6. Forma Ettingler 26-2 de TSI. (UE 1111)

7. Forma Drag. $15 / 17$ de TSS (UE 1131)

8. Forma Ettingler $20-4$ de TSI (UE 1111)

9. $\quad$ Forma Drag. 27 de TSS (UE 1111) 

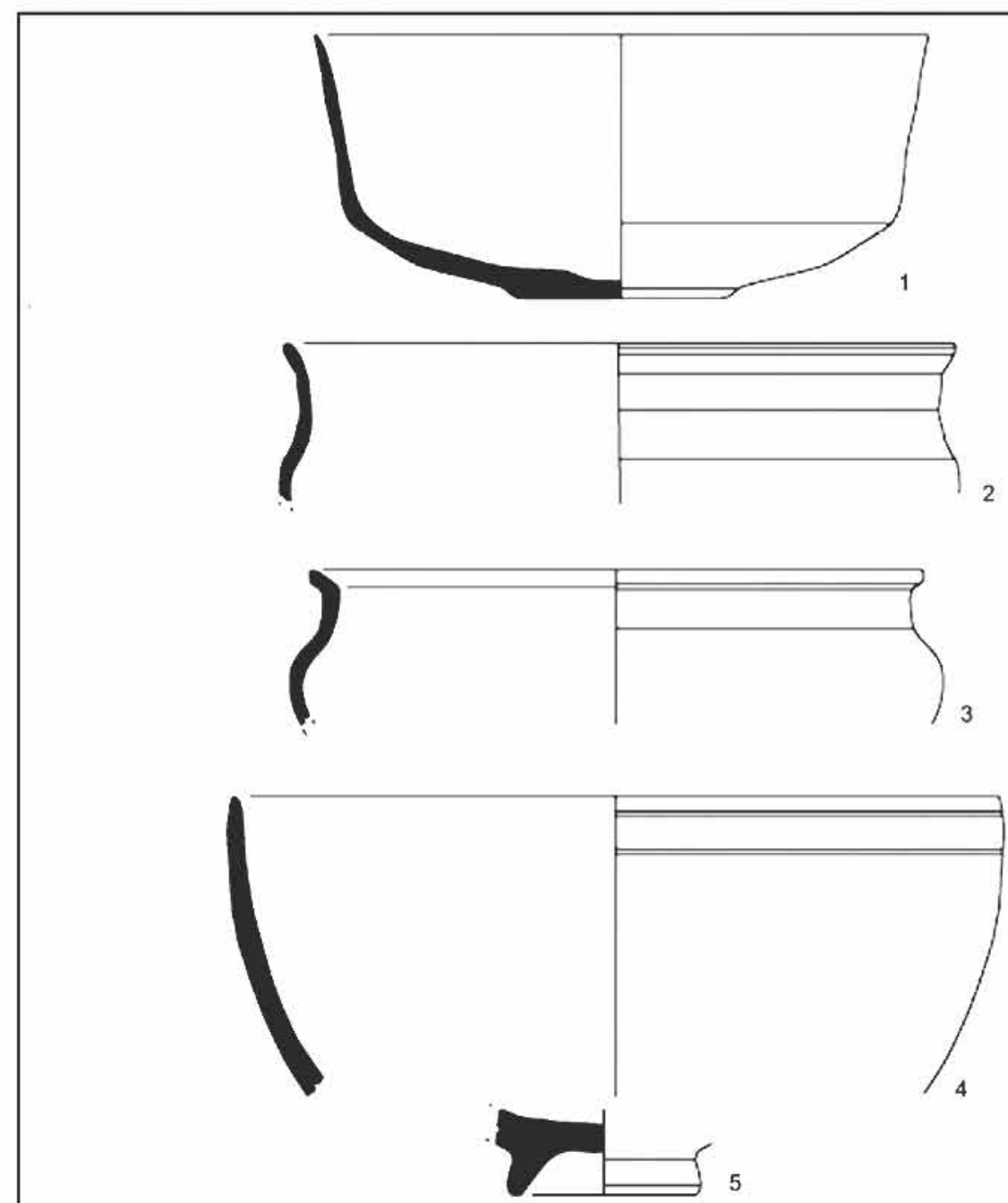

100000000000000000001000000 Distitiso

$08,393831394383883833837,3888$

030101030000010000312000030100000

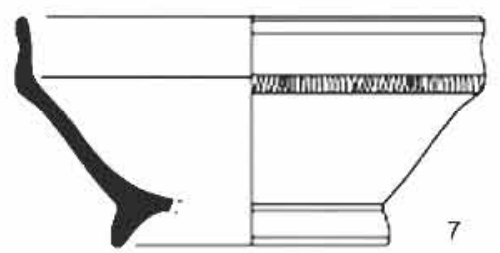




\section{Materiales del yacimiento de la Plaza de la Morería (Sagunto)}

1. Forma Mayet XXXIV de cerámica paredes finas del Noroeste peninsular. (U. 1119)

2. Borde de cerámica reductora de paredes finas romana. (UE 1092)

3. Borde de cerámica reductora de paredes finas romana. (UE 1092)

4. Forma Ettigler, 36-3 de TSI (UE 1018)

5. Base con pie de TSH (UE 1360)

6. Forma Hayes 8b de TSCA (UE 1177)

7. Forma Ettingler $17-1$ de TSI (UE 1147) 

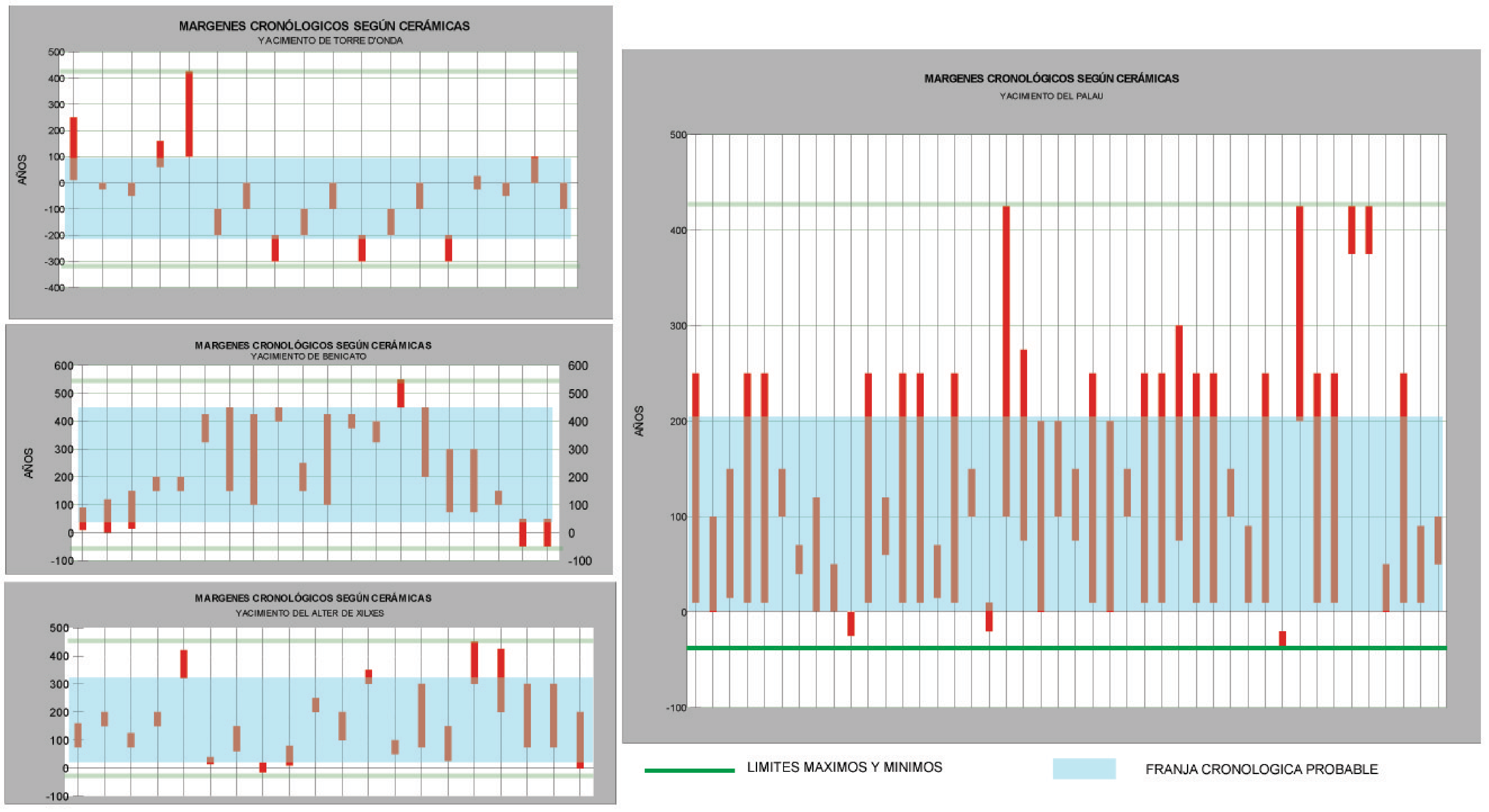


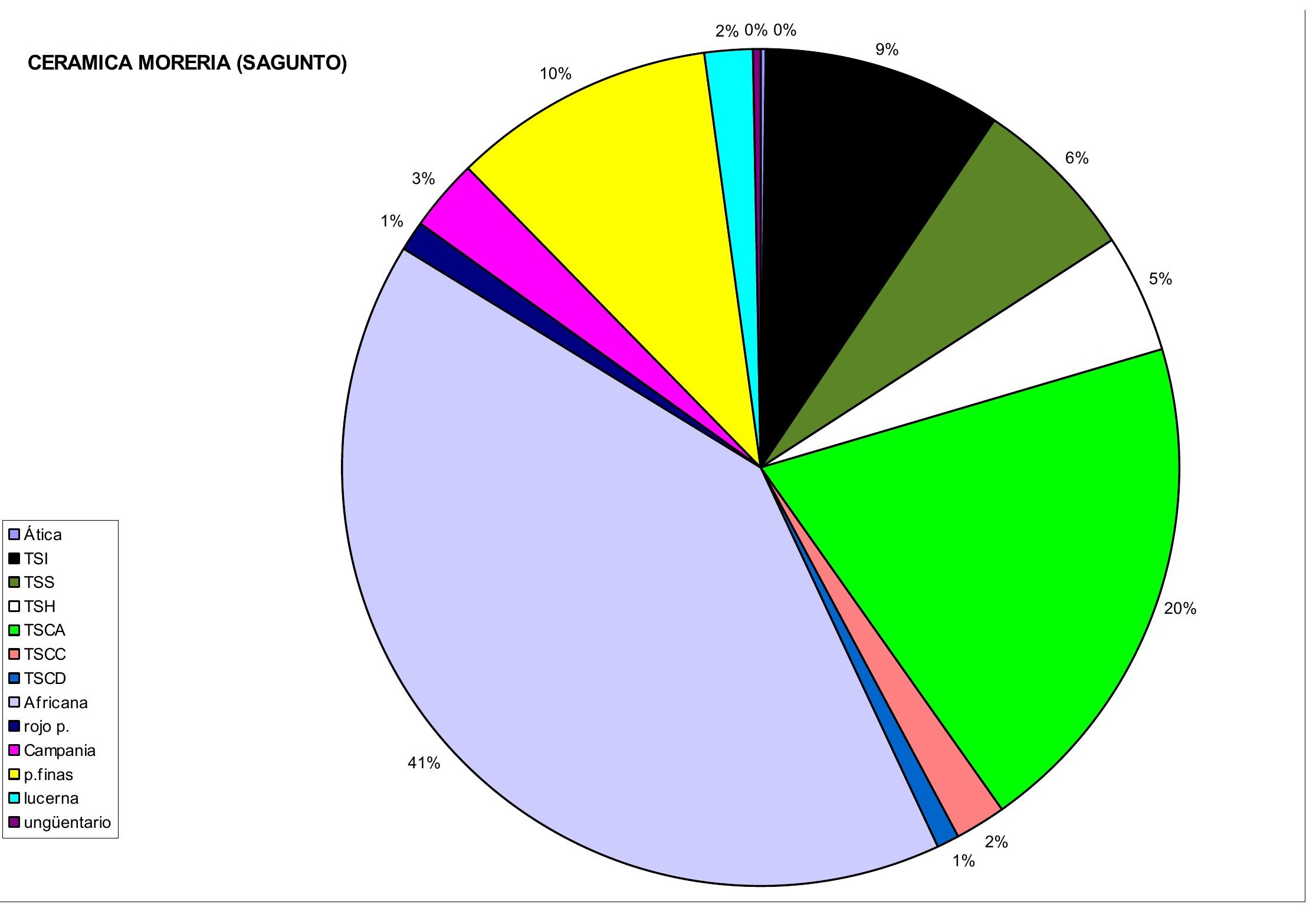


FRAGMENTOS CERAMICOS - MORERIA (SAGUNTO)

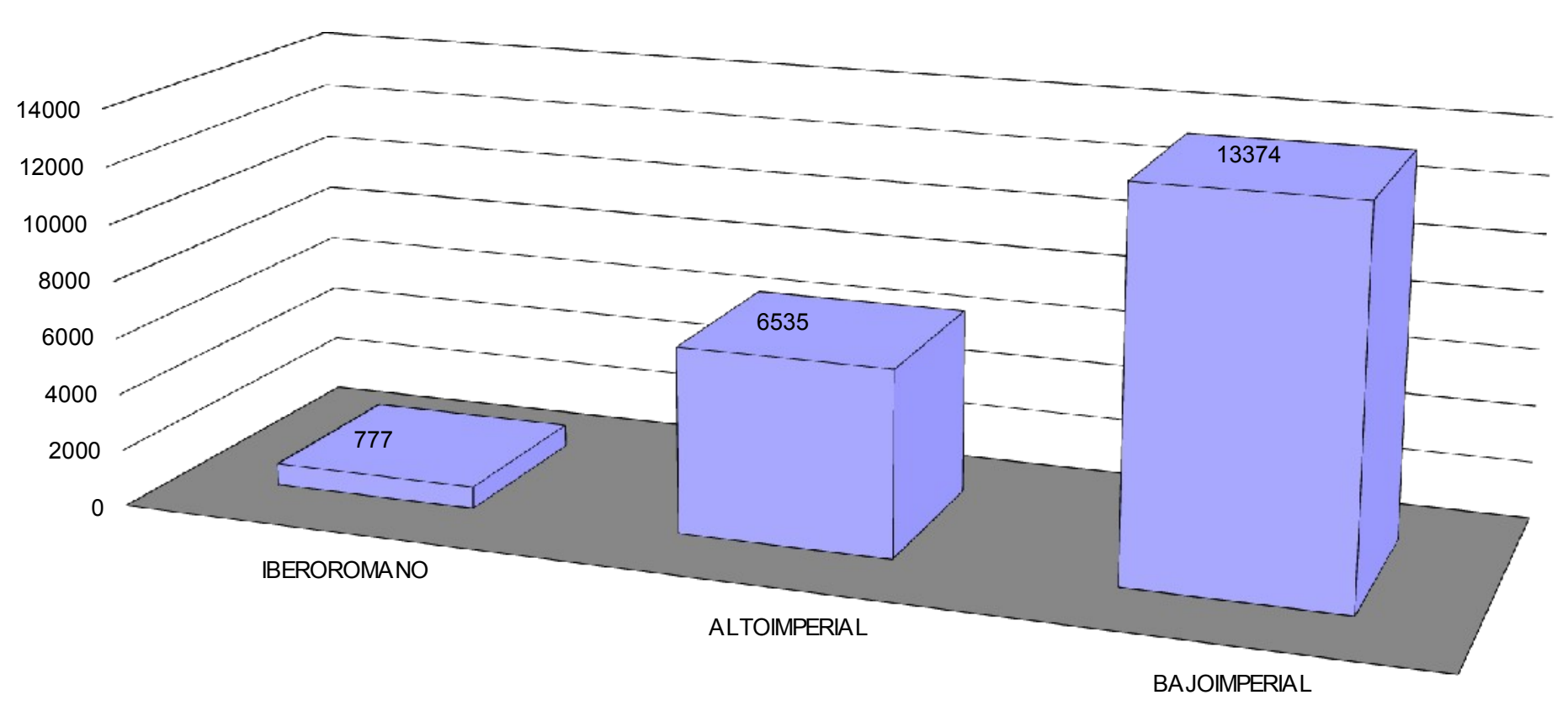




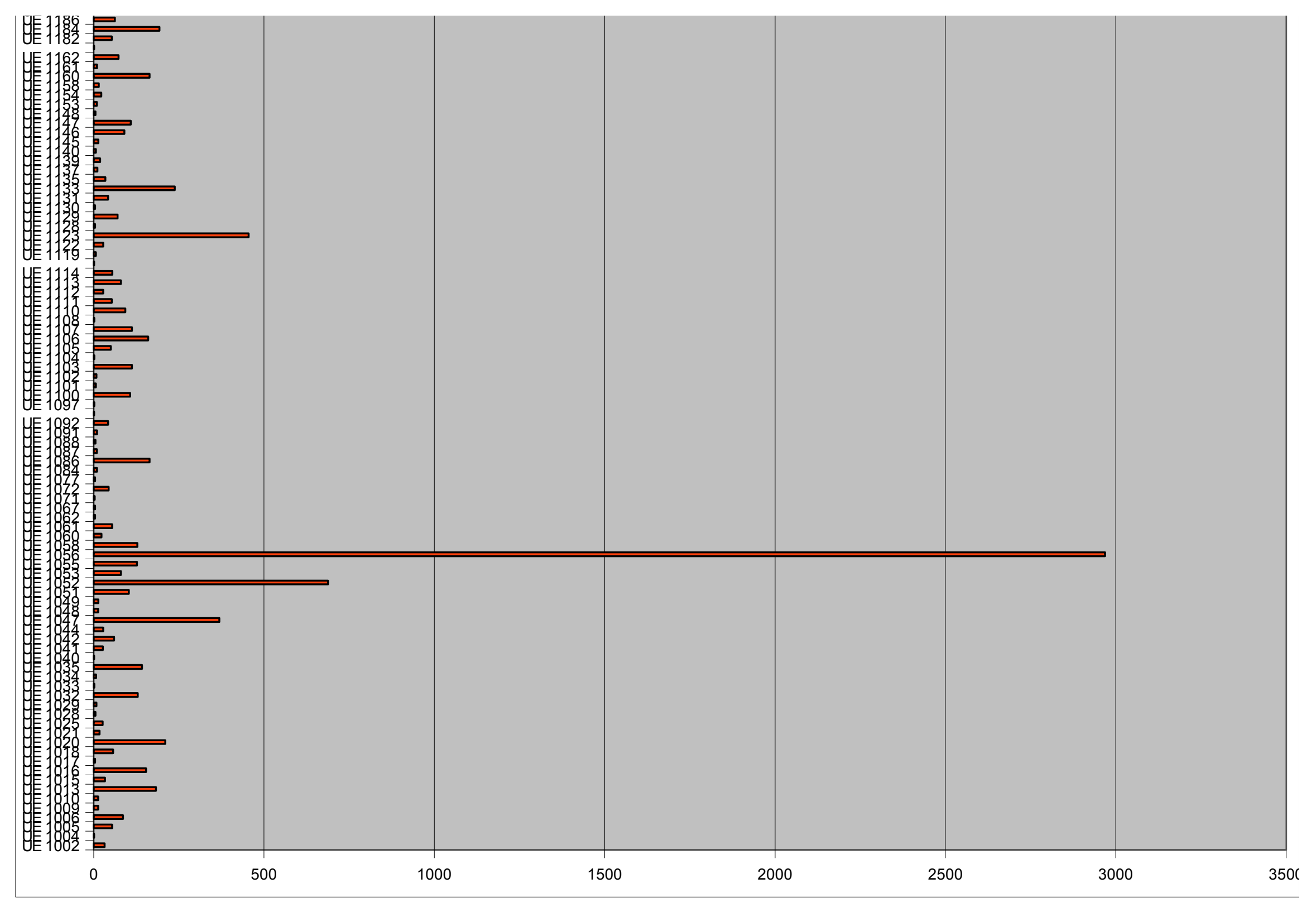


MARGENES EN DATACIONES CERÁMICAS

YACIMIENTO DEL SOLAR DE QUEVEDO

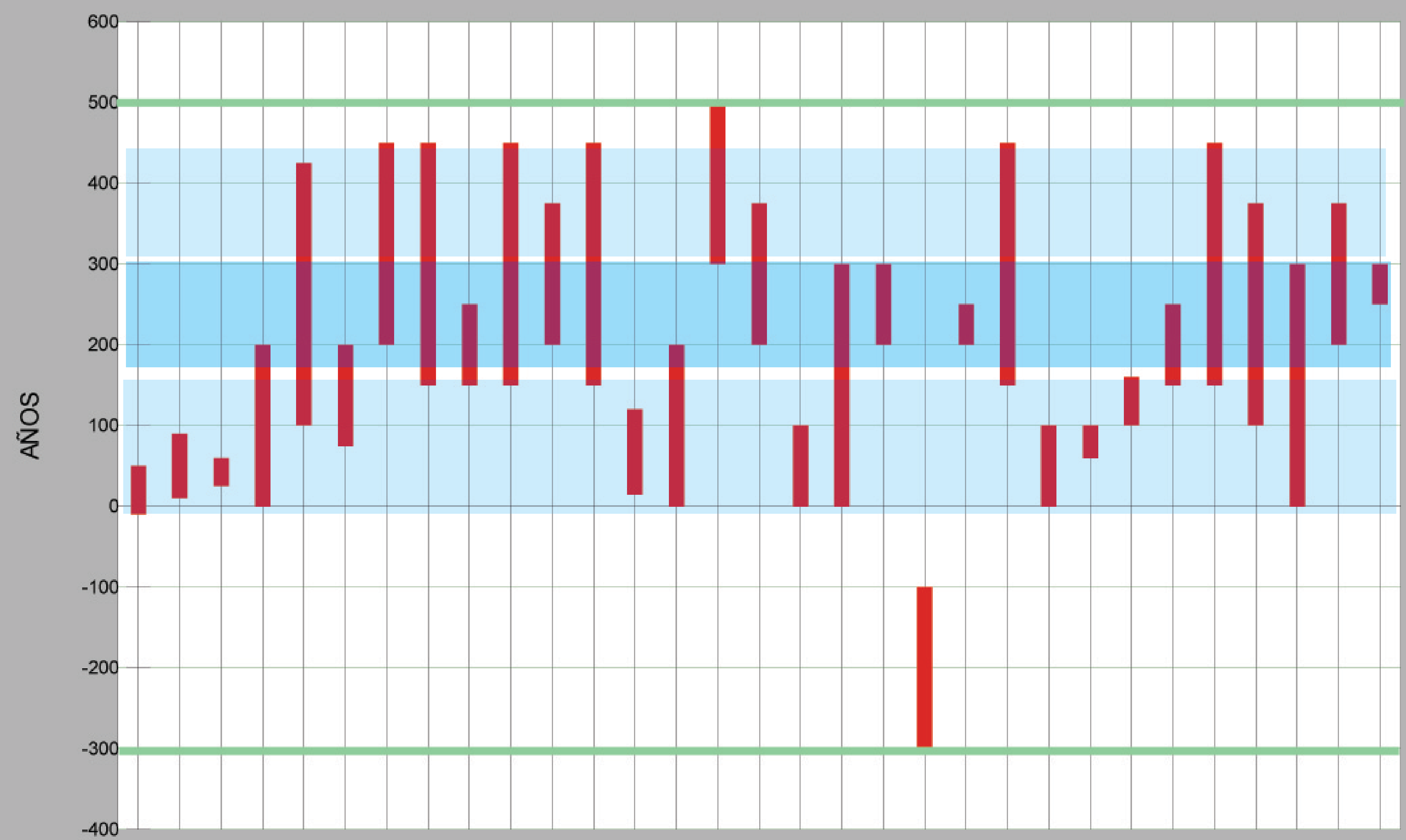


600

500

400

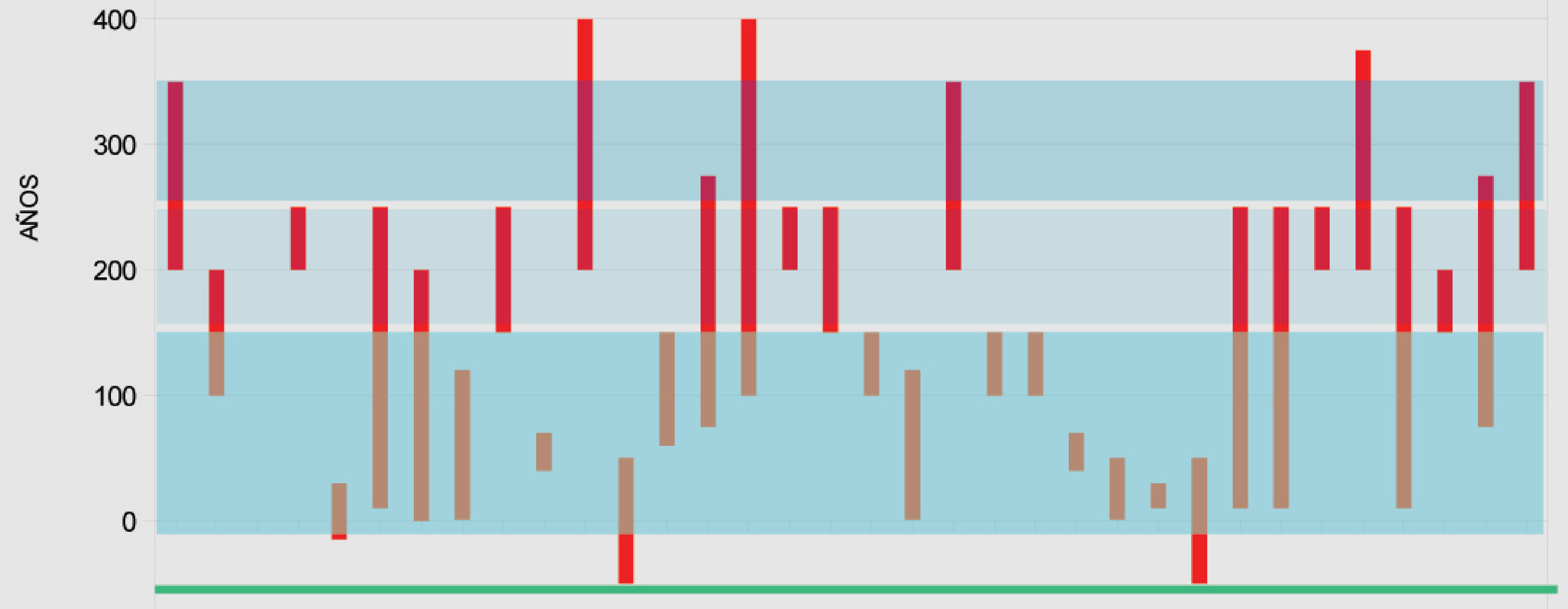




\section{CERAMICAS - SOLAR DE QUEVEDO (SAGUNTO)}

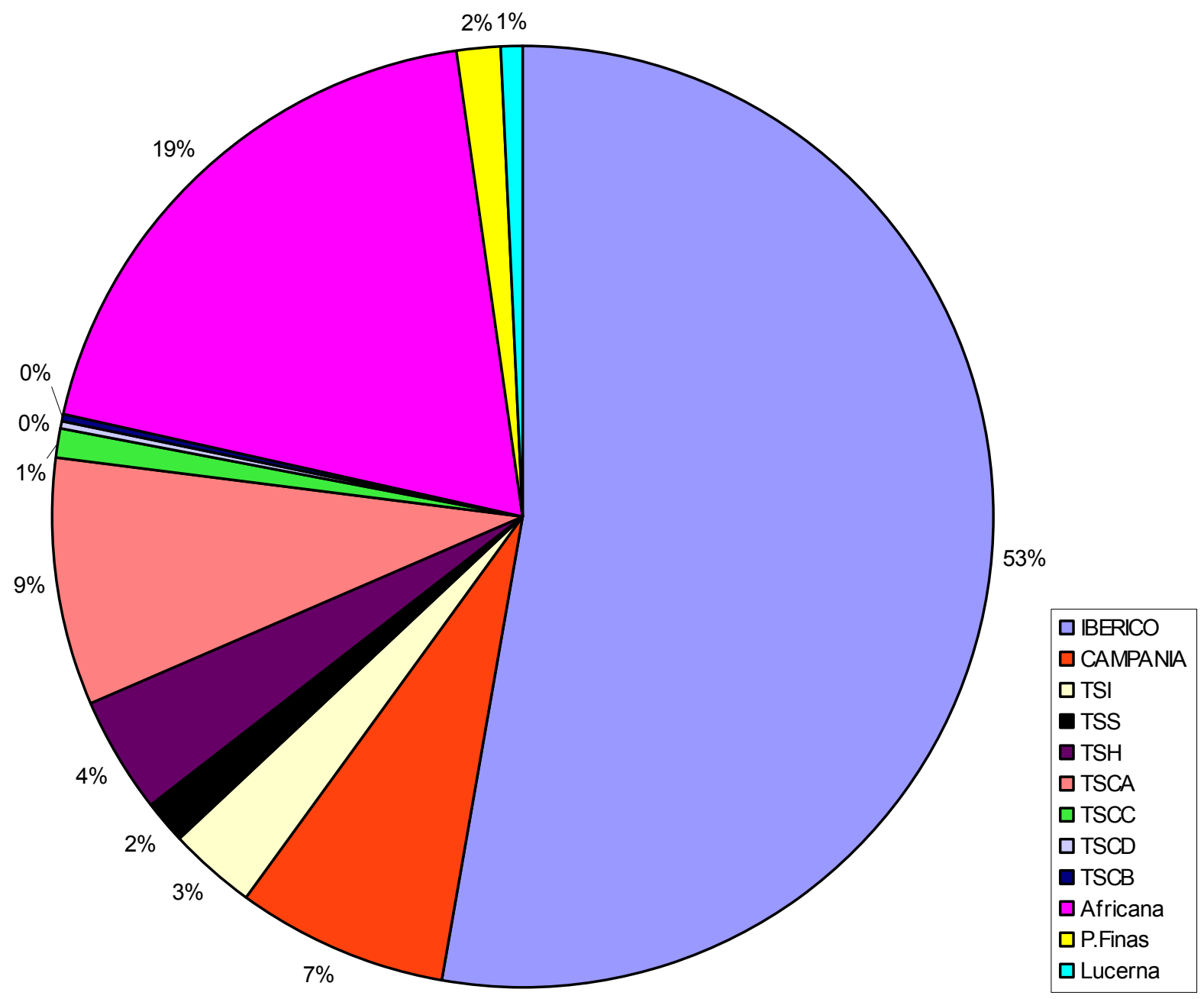

CERAMICAS POR PERIODOS - SOLAR DE QUEVEDO (SAGUNTO)

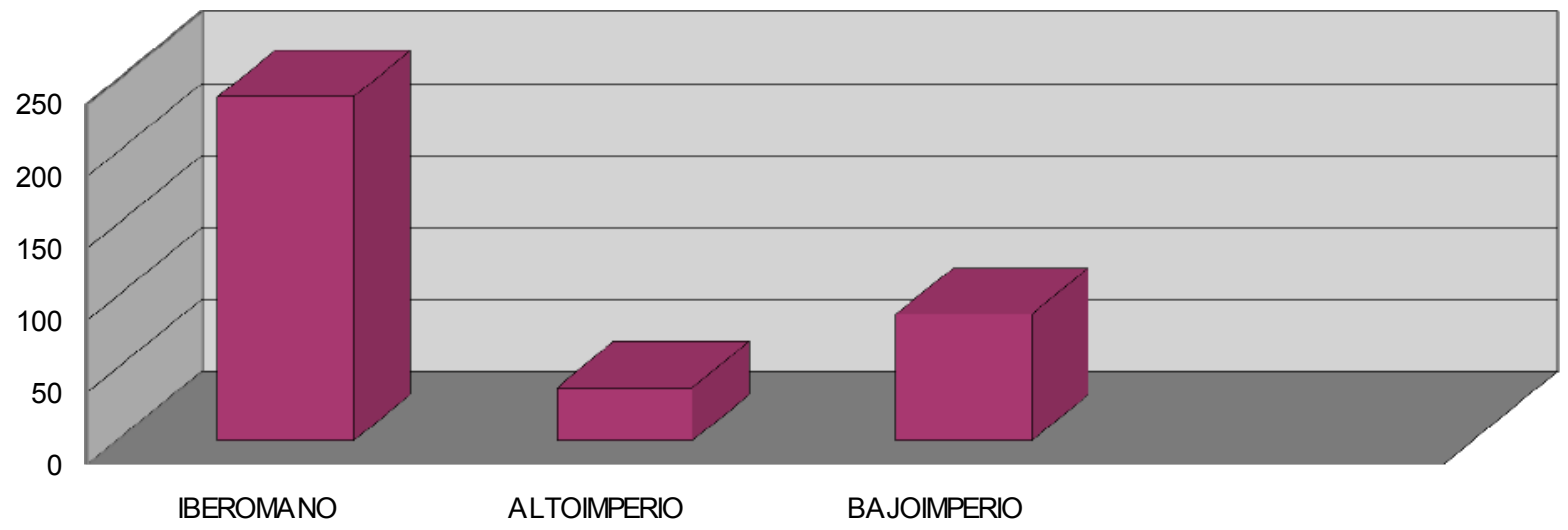




\section{FRAGMENTOS CERAMICOS - EL PALAU}

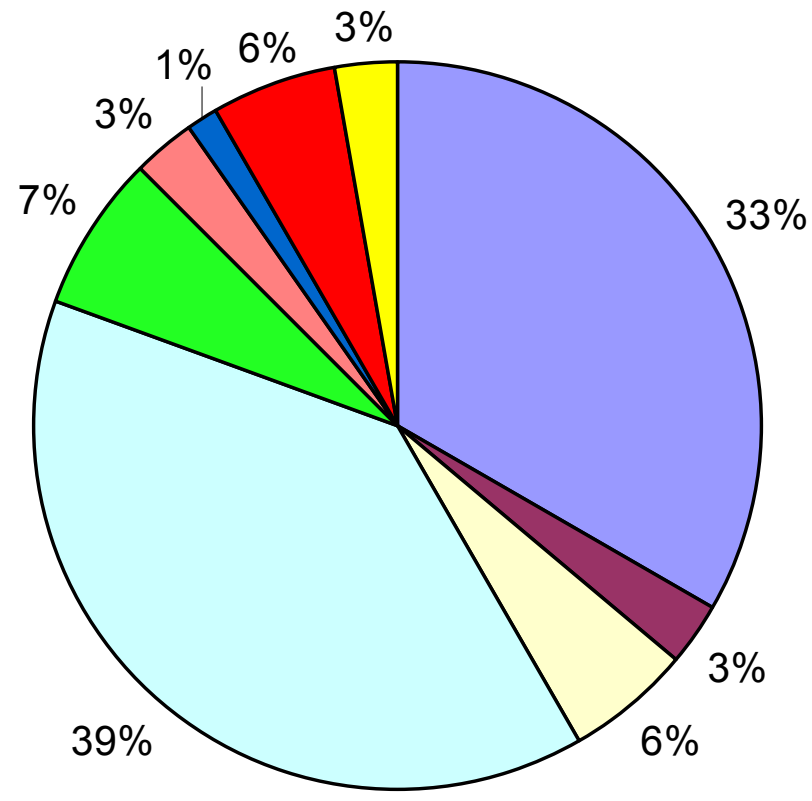

\section{$\square$ IBERO $\square$ CAMPANIA $\square$ TSI $\square$ TSS $\square$ TSH \\ $\square$ TSCA $\square$ TSCC $\square$ Africana $\square$ lucerna}

\section{CERAMICAS - EL PALAU}




\section{MONEDAS EN LAS PRINCIPALES UES}

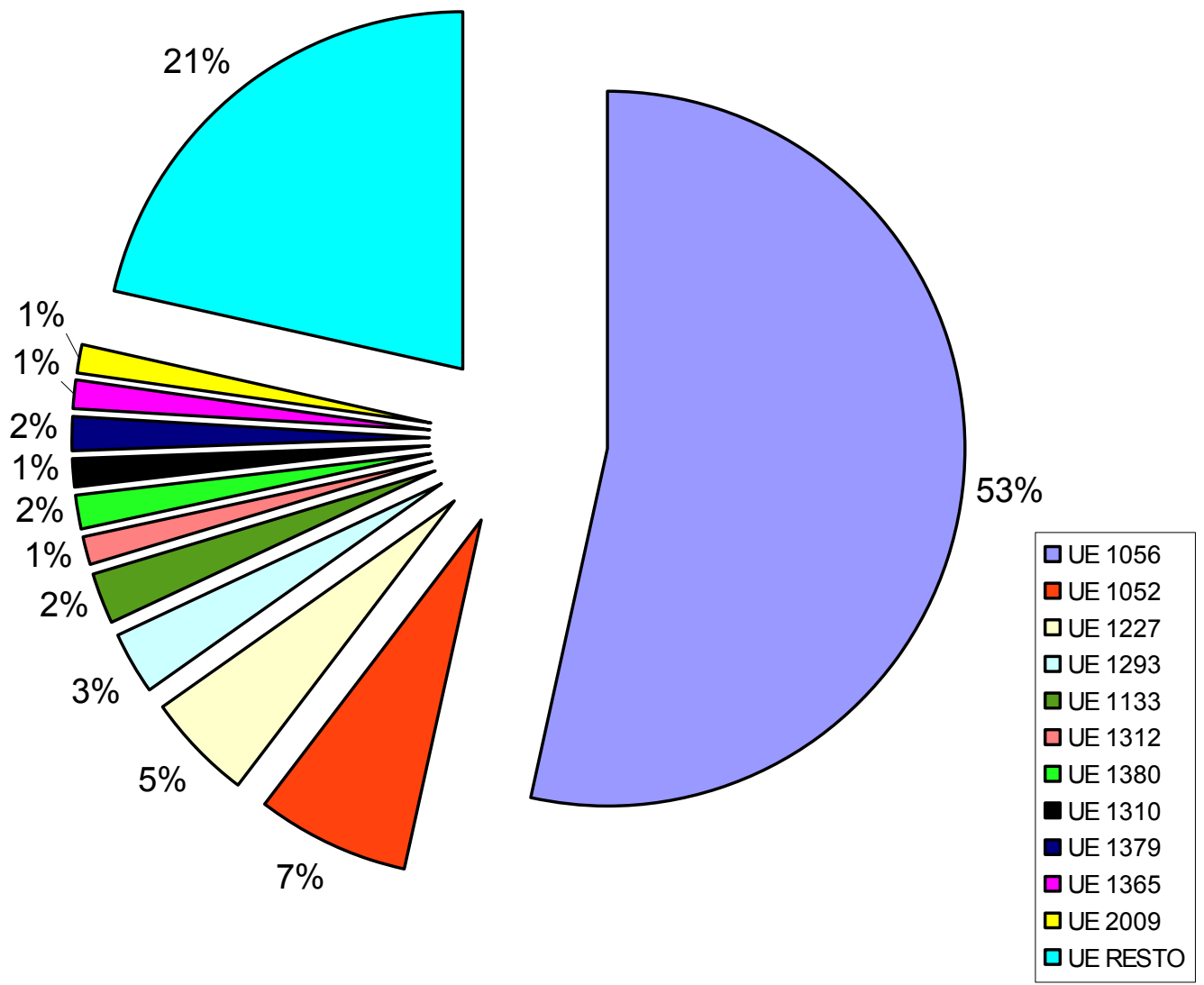

\section{MONEDAS POR PERIODOS}

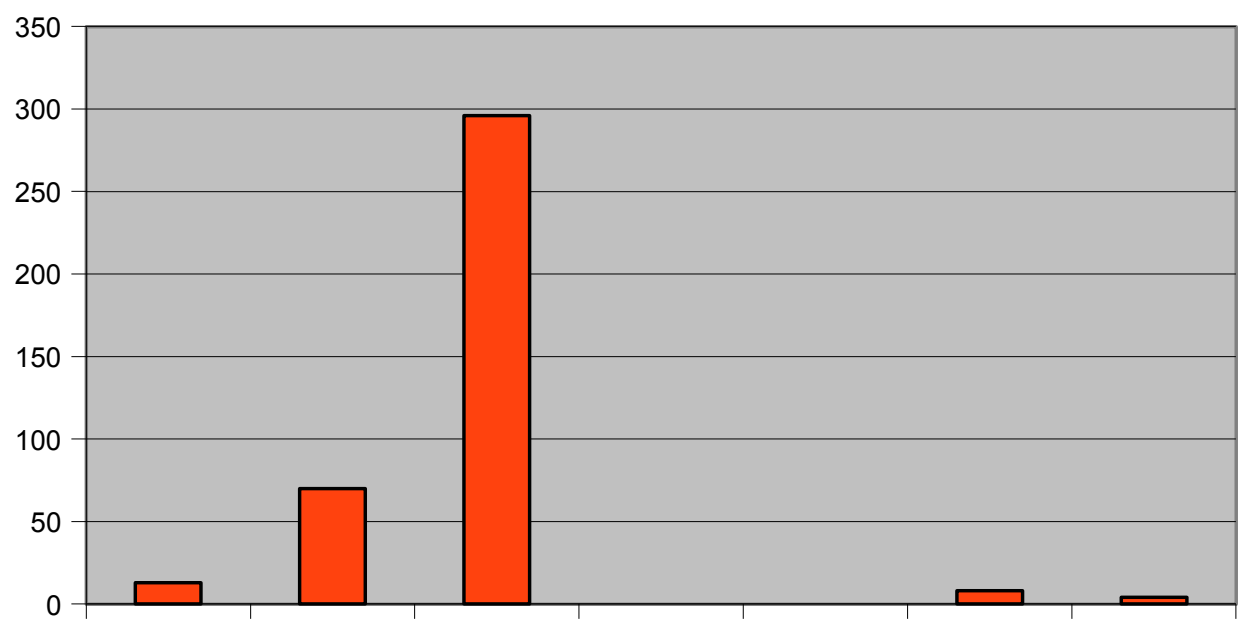

IBERO- ALTOIMPERI BAJOIMPERI VISIGODA MUSULMAN MEDIEVAL MODERNA ROMANA O 


\section{LISTADO DE MARCAS Y GRAFITOS (BURRIANA)}

\begin{tabular}{|c|c|c|c|c|c|c|c|c|}
\hline № & U.E. & $\begin{array}{c}\text { LECTUR } \\
\text { A }\end{array}$ & $\begin{array}{c}\text { OTRA } \\
\text { LECTUR } \\
\text { A }\end{array}$ & FORMA & INTERPRETACIÓN & DIBUJO & FOTO & COMENTARIOS \\
\hline 1 & 2003 & {$[i] \mathrm{OV}[i]$} & & $\begin{array}{l}\text { Base con pie } \\
\text { de TSSG } \\
\text { Grafito post- } \\
\text { cocción }\end{array}$ & Demasiado genérico & & & $\underline{\text { El Palau }}$ \\
\hline 2 & 2003 & Geométrico & & $\begin{array}{l}\text { Imbrice } \\
\text { Grafito } \\
\text { ante } \\
\text { cocción }\end{array}$ & Motivo Cruciforme & & & $\underline{\text { El Palau }}$ \\
\hline 3 & 2003 & {$[i] \mathrm{ICM}$} & {$[i] \mathrm{TCM}$} & $\begin{array}{l}\text { Base de } \\
\text { TSSG }\end{array}$ & $\begin{array}{l}\text { Of.DIVICVS ó PATRICIVS, } \\
\text { en Lezoux. Del 100-150 d. C. } \\
\text { (Hofmann 1971) ó 115-160 } \\
\text { (Oswald 1931). } \\
\text { ó } \\
\text { Of. MEDDICVS Eincheville } \\
\text { Boucheporn. Del 100-115 d. C. } \\
\text { (Oswald 1931) } \\
\text { ó } \\
\text { Of. RVSTICVS Graufesenque } \\
\text { 40-70 d. C. (Hofmann 1971) }\end{array}$ & & & $\begin{array}{l}\text { El Palau } \\
\text { Paraleleos: } \\
\text { DIVICM } \\
\text { MEDDICM } \\
\text { PATRICM } \\
\text { RVSTICM }\end{array}$ \\
\hline 4 & 2004 & {$[\dot{i}] \mathrm{OII}[\mathbf{i}]$} & $\begin{array}{c}{[.] \mathrm{OIN}[.]} \\
{[.] \mathrm{OIM}[.]} \\
{[.] \mathrm{HO}[.]} \\
{[.] \mathrm{HC}[.]} \\
{[.] \mathrm{IIO}[.]} \\
{[.] \mathrm{IIC}[.]}\end{array}$ & $\begin{array}{l}\text { Dolia. } \\
\text { Grafito post- } \\
\text { cocción }\end{array}$ & Demasiado genérico & & & $\underline{\text { El Palau }}$ \\
\hline
\end{tabular}




\section{LISTADO DE MARCAS Y GRAFITOS (BURRIANA)}

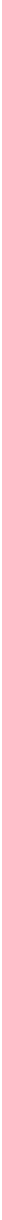


LISTADO DE MARCAS Y GRAFITOS (BURRIANA)

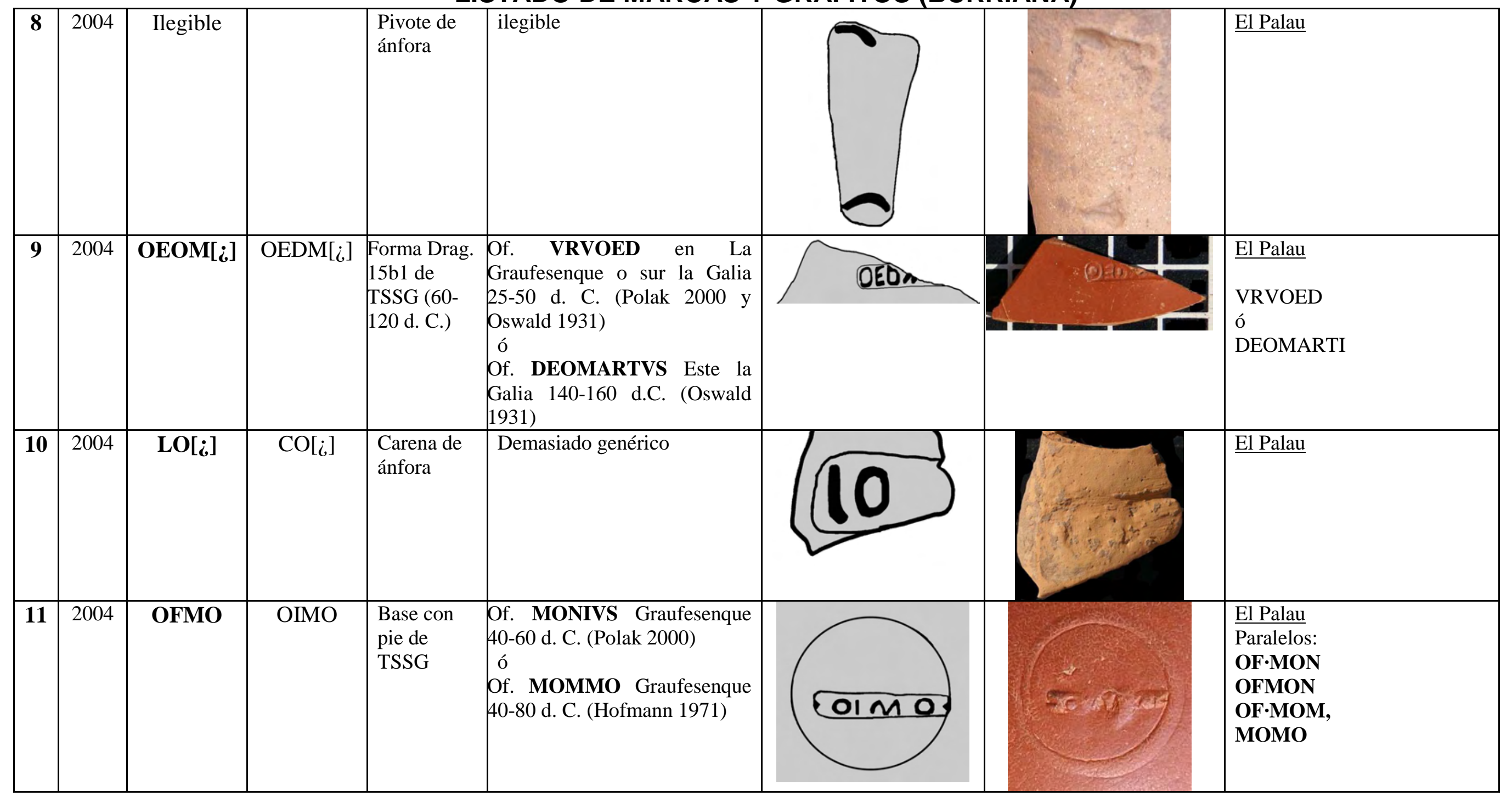




\section{PLAZA DE LA MORERIA (SAGUNTO)}

1002

1006

1006

1006

1016

1016

1016

1016

1016

1018

1018

1020

1020

1047

1047

1047

1047

1047

1047

1047

1052

1052

1052

1052

1052

1052

1052

1052

1052

1052

1052

1052

1052

1052

1052

1052

1052

1052

1052

1052

1052

1052

1056

1056

1056

1056

1056

1056

1056

1056
Ettlinger 34-1 Goudineau 38b; Pucci 37, 3 a $6 \quad 30$ d. C. al 90 d. C. Lamboglia 10 A, Hayes 23B

(2) Bordes rectos

(3) Bases planas

Lamboglia 8, Hayes 17

Conspectus 36.3.1

(40) Fragmentos informes

(4) Bordes rectos

Borde recto

Ettingler 36-3

Lamboglia 10 A, Hayes 23B

Hayes $14 b$, Lamboglia $3 b$

Base con pie

Drag. 18

(3) Lamboglia $10 \mathrm{~A}$, Hayes 23B

(3) Fragmentos informes

Base plana

Imitación Lamboglia $1 \mathrm{~b}$, Hayes $8 \mathrm{~b}$

Lamboglia $10 \mathrm{~B}$, Hayes $23 \mathrm{~A}$

Lamboglia 40, Hayes 31

Lamboglia 8, Hayes 17

Borde de Dramont 2

Drag. 15/17

Atlante Tavola XXVI, 9

(2) Drag. 37b

Hayes 6c, Lamboglia 23b

Drag. 24/25b

Ettlinger 3-2, Goudineau 43; Pucci 19, 13

Ettingler, 36-3

(3) Base con pie

(2) Base con pie

(10) Fragmentos informes

(2) Atlante Tavola XVII, 18

Atlante Tavola XXVI, 15

(7) Fragmentos decorados

Borde recto

(2) Lamboglia 10B, Hayes 23A

Atlante Tavola XXIV, 5

Atlante Tavola XXIV, 3

Atlante Tavola XXIV, 4

Lamboglia 1b, Hayes 8b

Atlante Tavola XXVI, 9

Atlante Tavola XXIV, 4

Lamboglia 23b, Hayes $6 c$

(2) Atlante Tavola LI, 10

Atlante Tavola XVII, 18

Ettlinger 18-2; Goudineau 36a; Pucci 10, 3-8

Borde recto

(2) Fragmentos decorados

Drag. $15 / 17$ s. II d. C. al inicio V d. C.

75 al 300 d. C. (genérica)

75 al 300 d. C. (genérica)

200 al 300 d. C.

s. I d. C.

50 a. C. al 50 d. C. (genérica)

50 a. C. al 50 d. C. (genérica)

75 al 300 d. C. (genérica)

10 al $30 \mathrm{~d}$. C.

s. II d. C. al inicio V d. C.

150 d. C. al 200 d. C.

300 a. C. al 225 a. C.

15 d. C. al 150 d. C.

s. II d. C. al inicio V d. C.

10 d. C. al 250 d. C. (genérica)

200 al $450 \mathrm{~d}$. C. (genérica)

150 d. C. al 200 d. C.

Final I d. C al final III d. C.

200 d. C. al 250 d. C.

150 d. C. al 250 d. C.

Fase 4 - Antoniniana

1 d. C. al 120 d. C.

$1^{\mathrm{a}} \mathrm{1} / 2$ III a la $1^{\mathrm{a}} \frac{1}{1 / 2}$ s. IV d. C.

100 d. C. al 150 d. C.

100 d. C. al 200 d. C.

40 d. C. al 70 d. C.

$1 \mathrm{~d}$. C. al $50 \mathrm{~d}$. C.

$10 \mathrm{~d}$. C. al $30 \mathrm{~d}$. C.

50 a. C. al 50 d. C. (genérica)

10 d. C. al 250 d. C. (genérica)

10 d. C. al 250 d. C. (genérica)

$1^{\text {a }} 1 / 2$ mitad s. III d. C.

$1^{a} 1 / 2$ s. III-final s. IV d.C.

10 d. C. al 250 d. C. (genérica)

100 al 250 d. C. (genérica)

Final I d. C al final III d. C

$1^{a} 1 / 2$ S. III

$1^{a} 1 / 2$ S. III

$1^{a} 1 / 2$ s. III

150 d. C. al 200 d. C.

$1^{\mathrm{a}} 1 / 2$ s. III $-1^{\mathrm{a}} 1 / 2$ IV d. C.

$1^{\mathrm{a}} \mathrm{a} / 2 \mathrm{~s}$. III

100 d. C. al 200 d. C.

final $\mathrm{V}$ a inicio s. VI d. C.

$1^{\mathrm{a}} \mathrm{1} / 2$ s. III d. C.

15 a. C. al 30 d. C.

10 d. C. al 250 d. C. (genérica)

0 d. C. al 200 d. C. (genérica)

1 d. C. al 120 d. C.
TSS

Africana

TSCA

TSCA

TSCA

TSI

TSI

TSI

TSCA

TSI

Africana

TSCA

Palmetas radiales

TSH

Africana

TSS

TSCC

TSCA

Africana

TSCA

TSCA

Mortero

TSS

TSCC

TSH

TSH

TSS

TSS

TSI

TSI

TSS

TSS

TSCA2

TSCC

TSS

¿TSCB?

Africana

TSCA/D

TSCA/D

TSCA/D

TSCA

TSCC

TSCA/D

Común

TSCD

TSCA

TSI

TSS

TSH

TSS 
150 d. C. al 200 d. C.

TSCA

s. III al IV d. C.

TSH

(3) Fragmentos decorados

50 a. C. al 50 d. C. (genérica)

TSI

1056

1056

1056

1056

1061

1072

1072

1072

1072

1086

1086

1086

1086

1086

1086

1087

1088

1088

1092

1096

1100

1100

1100

1100

1100

1101

1101

1101

1102

1103

1103

1103

1103

1103

1103

1103

1103

1103

1106

1106

1106

1106

1110

1110

1110

1111

1111

1111

1111

1111

1111

(2) Ostia II, 306

Lamboglia $10 \mathrm{~B}$, Hayes $23 \mathrm{~A}$

(2) Lamboglia 10 A, Hayes 23B

Hayes 33

Drag 24/25

Ettlinger 3-2, Goudineau 43; Pucci 19, 13

Lamboglia 10 b, Hayes 23 A

Atlante Tavola XVII, 18

Drag. 29

Ettlinger 18-2 Goudineau 36a; Pucci 10, 3-8

Fragmento decorado

Drag. 18b, Goudineau 43; Pucci 19, 13

Drag. $24 / 25 b$

Drag 27

Ritterling 1913, 9b

$1^{\circ} 1 / 3$ s. I d. C a la $1 / 2$ s. II d. C.

Final I d. C al final III d. C.

s. II d. C. al inicio V d. C.

200 d. C. al 250 d. C.

15 d. C. al 120 d. C.

10 d. C. al 50 d. C.

Final I d. C al final III d. C.

$1^{\mathrm{a}} \mathrm{1} / 2 \mathrm{~s}$. III d. C.

10 d. C. al 90 d. C.

15 a. C. al $30 \mathrm{~d}$. C.

75 al 300 d. C. (genérica)

10 d. C. al 50 d. C.

40 d. C. al 70 d. C.

10 d. C. al 120 d. C.

15 d. C. al 70 d. C.

Africana

Fragmento decorado

Lamboglia 10 A, Hayes 23B

Atlante Tavola XXVI, 9

Lamboglia 10 A, Hayes 23B

Drag 15/17

(2) Hayes 200

Lamboglia 10 A, Hayes 23B

Lamboglia 40, Hayes 31

Ettlinger 4-1; Pucci 6, 1

Drag. 27, Halt 11 (serv. 3) Goudineau 32b

Lamboglia $10 \mathrm{~A}$, Hayes 23B

Ettlinger 18-2; Goudineau 36a; Pucci 10, 3-8

Mezquiriz 17

Lamboglia 10 A, Hayes 23B

Ostia III, 267

Atlante Tavola XXVI, 1

Atlante Tavola LI, 10

Drag. 19

Drag. 24/25b

Fragmento decorado

Lamboglia 14, Hayes140 decorado

Lamboglia 10 A, Hayes 23B

Posible Ettlinger 36-1, Goud 21; Pucci 31,1 y 2

(3) Atlante Tavola XL, 3

Atlante Tavola XXX, 4

Hayes 200

Hayes 26

Ostia III, 332

Ostia I, 261

Ánfora Keay 5bis (Estampilla DP)

Drag. 27

(3) Fragmento decorado

Posible Ettlinger 36-1, Goud 21; Pucci 31,1 y 2

Lamboglia 1963, 40, Hayes 31

(2) Ettlinger 34-1 Goud. 38b; Pucci 37,3 a 6

Ettlinger 26-2; Pucci 29, 2-4

Ettingler R5-2

Drag. $24 / 25 b$

50 a. C. al 50 d. C. (genérica)

s. II d. C. al inicio V d. C.

$1^{a} 1 / 2$ III al la $1^{a} 1 / 2$ s. IV d. C.

s. II d. C. al inicio V d. C.

1 d. C. al 120 d. C.

$1^{\mathrm{a}} 1 / 2 \mathrm{~s}$. II a s. IV d. C.

s. II d. C. al inicio V d. C.

$1^{\mathrm{a}} 1 / 2 \mathrm{~s}$. III al s. IV d. C.

40 a. C. al 10 a. C.

Africana

Africana

TSCA

TSH

TSS

Africana

TSCA

TSS

TSI

1 d. C. al 30 d. C.

s. II d. C. al inicio V d. C.

15 a. C. al 30 d. C.

s. I al II d. C.

TSCA

TSS

TSS

TSS

TSS

TSI

Africana

TSCA

Africana

TSS

TSCA

Africana

¿TSCC?

TSI

TSI

Africana

s. II d. C. al inicio V d. C.

TSI

TSH

$1^{\mathrm{a}} \mathrm{1} / 2 \mathrm{~s}$. II al inicio $\mathrm{s}$. $\mathrm{V} \mathrm{d}$. C.

Africana

$1^{\mathrm{a}} \quad 1 / 2$ s. III-final s. IV d. C.

Africana

final $\mathrm{V}$ a inicio s. VI d. C.

1 d. C. al 50 d. C.

TSCC

TSCD

40 d. C. al 70 d. C.

TSS

$0 \mathrm{~d}$. C. al $200 \mathrm{~d}$. C. (genérica)

TSS

125 d. C. al 225 d. C.

TSH

s. II d. C. al inicio V d. C.

TSCA

30 a. C. al 1 a. C.

Africana

TSI

S. III al IV d. C.

S. II al III d. C.

TSCA

$1^{\mathrm{a}} 1 / 2$ s. II a s. IV d. C.

TSH

150 d. C. al 200 d. C.

TSCA

$1^{\mathrm{a}} 1 / 4 \mathrm{~s}$. II al final s. V d. C.

TSCA

Africana

Final s. IV al inicio s. V d. C. Africana

siglo III d. C.

Africana

10 d. C. al 120 d. C.

TSS

50 a. C. al 50 d. C. (genérica) TSI

30 a. C. al 1 a. C.

200 d. C. al 250 d. C.

TSI

30 d. C. al 90 d. C.

TSCA

1 d. C. al 50 d. C.

TSI

TSI

10 a. C. al 15 d. C.

TSI

40 d. C. al 70 d. C.

TSS 
Ettlinger 20-4; Goudineau 39c; Pucci 10

40 d. C. al 80 d. C.

TSI

Lamboglia 8, Hayes 17

Atlante Tavola XXV, 6

Atlante Tavola XVI, 6

Lamboglia 8, Hayes 17

Similar a Mayet XXXIV

Imitación plato Celsa 79/80 Forma 7

Drag. 15/17

Atlante Tavola LI, 10

Vernhet 1976-Ve F1, Drag. 46

Base con pie

(3) Fragmentos decorados

Ettlinger 3-2, Goudineau 43; Pucci 19, 13

Lamboglia 10B, Hayes 23 A

Drag. $18 \mathrm{~b}$

Loeschke serv. 1, Haltern 7

Posible Drag. 27

Posible Ettlinger 36-1, Goud 21; Pucci 31, 1 y 2

Drag. 29

Drag. 15 al17

Hayes 6c, Lamboglia 23b

Drag. $17 \mathrm{~b}$

Hayes 6c, Lamboglia 23b

Ettlinger 14-1, Goud 13,16,18,24; Pucci 20y 21

Drag. 27, Halt 11 (serv. 3) Goudineau 32b

(3) Lamboglia $10 \mathrm{~B}$, Hayes $23 \mathrm{~A}$

Lamboglia 10A, Hayes 23B

Atlante Tavola LI, 10

Torre Llauder 67

(2) Lamboglia 10 A, Hayes 23B

Ettingler 17-1

Fragmento decorado

Lamboglia 1b, Hayes $8 b$

Fragmento decorado

Fragmento decorado

Ritterling $9 \mathrm{~b}$

(2) Fragmentos decorado

Base

Drag. 18

Fragmento decorado

Hayes 197, Ostia III, 267

Fragmento decorado

Similar a Ostia I, 263

(2) Lamboglia 10 A, Hayes 23B

Lamboglia $10 \mathrm{~B}$, Hayes $23 \mathrm{~A}$

Lamboglia 1963, 40, Hayes 31

Lamboglia 10 A, Hayes 23B

Fragmento decorado

Ostia II, 306

Fragmento decorado

Lamboglia 10 B, Hayes 23 A

Ettlinger 18-2; Goud. 36a; Pucci 10, 3-8

Hayes 182, Carandini 1969, 61

Ostia II, 303; Hayes 194, Lamboglia 10

(2) Fragmentos decorados

Torre Llauder 67
150 d. C. al 250 d. C.

$1^{\mathrm{a}} 1 / 2 \mathrm{~s}$. III d. C.

$2^{a} 1 / 2$ s. II a la $1^{a} 1 / 2$ s. III d. C.

150 d. C. al 250 d. C.

Siglo I d. C.

I a. C. al I d. C.

1 d. C. al 120 d. C.

final $\mathrm{V}$ al inicio s. VI d. C.

90 d. C. al 150 d. C.

10 d. C. al 250 d. C. (genérica)

10 d. C. al 250 d. C. (genérica)

10 d. C. al 50 d. C.

Final I d. C al final III d. C.

60 d. C. al 150 d. C.

1 d. C. al 20 d. C.

100 d. C. al 150 d. C.

30 a. C. al 1 a. C.

10 d. C. al 90 d. C.

1 d. C. al 120 d. C.

100 d. C. al 200 d. C.

15 d. C. al 60 d. C.

100 d. C. al 200 d. C.

15 a. C. al 1 a. C.

1 d. C. al 30 d. C.

Final I d. C al final III d. C.

s. II d. C. al inicio V d. C.

final $\mathrm{V}$ al inicio s. VI d. C.

I a. C. al I d. C.

s. II d. C. al inicio V d. C.

15 a. C. al 15 d. C.

50 a. C. al 50 d. C. (genérica)

150 d. C. al 200 d. C.

50 a. C. al 50 d. C. (genérica)

0 d. C. al 200 d. C. (genérica)

15 d. C. al 70 d. C.

50 a. C. al 50 d. C. (genérica)

0 d. C. al 200 d. C. (genérica)

15 d. C. al 150 d. C.

50 a. C. al 50 d. C. (genérica)

$1^{\mathrm{a}} \mathrm{1} / 2 \mathrm{~s}$. II al inicio $\mathrm{s}$. V d. C.

50 a. C. al 50 d. C. (genérica)

III-IV d. C.

s. II d. C. al inicio V d. C.

Final I d. C al final III d. C.

200 d. C. al 250 d. C.

s. II d. C. al inicio V d. C.

$10 \mathrm{~d}$. C. al $250 \mathrm{~d}$. C. (genérica)

$1^{\circ} 1 / 3 \mathrm{~s}$. I d. C al $1 / 2$ s. II d. C.

50 a. C. al 50 d. C. (genérica)

Final I d. C al final III d. C.

15 a. C. al 30 d. C.

$1^{\mathrm{a}} \mathrm{a} / \mathrm{2}$ s. III a s. IV d. C.

$1^{\circ} 1 / 3 \mathrm{~s}$. I al la $1^{\mathrm{a}}{ }^{1 / 2} \mathrm{~s}$. II d. C.

50 a. C. al 50 d. C. (genérica)

I a. C. al I d. C.
TSCA2

TSCA/D

TSCA

TSCA2

Paredes Finas

Común

TSS

TSCD

TSS

TSS

TSS

TSS

Africana

TSS

TSS

TSH

TSI

TSH

TSS

TSCA

Imitación

TSCA

TSI

TSI

Africana

TSCA

TSCD

Rojo Po.

Africana

TSI

TSI

TSCA

TSI

TSH

TSS

TSI

TSH

TSH

TSI

Africana

TSI

Africana

Africana

Africana

TSCA

Africana

TSS

Africana

TSI

Africana

TSI

Africana

Africana

TSI

Rojo Pompeyano 
Lamboglia $10 \mathrm{~B}$, Hayes $23 \mathrm{~A}$

Final I d. C al final III d. C.

Africana

TSS

Ritterling 1913, 9b

15 d. C. al 70 d. C.

TSS

Atlante Tavola XVIII, 7

$1^{a} 1 / 2$ s. III d. C.

TSCA

Ostia I, 261; Hayes 196

Final s. IV al inicio s. V d. C.

Lamboglia 10 A, Hayes 23B

Hayes 200

s. II d. C. al inicio V d. C.

$1^{a} 1 / 2$ s. II a s. IV d. C.

100 d. C. al 150 d. C.

Posible Drag 27

Drag. 37b

100 d. C. al 150 d. C.

15 a. C. al 50 d. C.

Africana

Africana

TSCA

TSH

TSH

Ettlinger 25-1; Pucci 25, 3 y 7

\section{SOLAR DE QUEVEDO (SAGUNTO)}

1012 Goudineau 43

1012 Posible Drag. 29

1012

1012

1001

1001

3001

3001

3001

3001

3001

3001

3001

3001

3002

3002

3003

3003

3004

3004

3004

3004

3004

3004

3004

3005

3005

3005

3005

3005

3006

3006

Ostia I, 262
Posible Drag. 17 decorada

Ostia II, 302

(2) Ostia I, 261

(2) Ostia III, 324

Ostia III, 108

(2) Lamboglia 10A

Hayes 17

(2) Ostia I, 261

(2) Ostia III, 267A

Drag. 24/25

Posible Mesquíriz 50

Ánfora Keay XLV

Ostia I, 261

Luni I

Base

Ánfora Africana I

Ánfora tipo Maña

Ostia II, 302

Lamboglia 10B

Lamboglia 10A

Drag. 35

Posible Goudineau 21

Lamboglia 9A

Hayes 17

Ostia I, 262

Ostia I, 261

Base

(2) Ostia I, 261

Ánfora Agora de Atenas
10 a. C. al 50 d. C.

10 al 90 d. C.

25 d. C. al 60 d. C.

s. I a la $2^{\mathrm{a}} 1 / 2 \mathrm{~s}$. II d. C.

s. II al final s. IV d. C.

Final s. I a la $2^{a} 1 / 2$ s. II d. C.

s. III a la $1^{\mathrm{a}} 1 / 2 \mathrm{~s}$. V d. C.

$1^{\mathrm{a}} 1 / 2 \mathrm{~s}$. II a la $1^{\mathrm{a}} 1 / 2 \mathrm{~s}$. V d. C.

150 d. C. al 250 d. C.

$2^{\mathrm{a}} 1 / 2 \mathrm{~s}$. II a la $1^{\mathrm{a}} \mathrm{1} / 2 \mathrm{~s}$. V d. C.

s. II al final s. IV d. C.

$1^{a} 1 / 2 \mathrm{~s}$. II a la $1^{\mathrm{a}}{ }^{1 / 2} \mathrm{~s}$. V d. C.

15 d. C. al 120 d. C.

s. I al II d. C.

s. IV al $\mathrm{V}$ d. C.

s. II al final s. IV d. C.

s. I a. C

s. I al II d. C.

s. III d. C.

s. III al II a. C.

s. II a la $2^{a} 1 / 2$ s. II d. C.

$2^{a} 1 / 2 \mathrm{~s}$. I a la $1^{\mathrm{a}} 1 / 2 \mathrm{~s}$. III d. C.

$1^{a} 1 / 2 \mathrm{~s}$. II a la $1^{\mathrm{a}} 1 / 2 \mathrm{~s}$. V d. C.

s. I d. C.

Último $1 / 3 \mathrm{~s}$. I a. C.

100 d. C. al 160 d. C.

150 d. C. al 250 d. C.

$2^{\mathrm{a}} 1 / 2 \mathrm{~s}$. II a la $1^{\mathrm{a}} \mathrm{1} / 2 \mathrm{~s}$. V d. C.

s. II al final s. IV d. C.

s. I al II d. C.

s. II al final s. IV d. C.

$1^{\mathrm{a}} \mathrm{1} / 2$ s. III d. C.
TSI

TSS

TSS

Africana

Africana

Africana

Africana

Africana

TSCA

Común Gris

Africana

Africana

TSS

TSH

Africana

Imitación

TSCA

Púnica

Africana

Africana

Africana

TSS

TSI clásica

TSCA

TSCA

Africana

Africana

TSCA

Africana 


\section{LISTADO DE MONEDAS ${ }^{*}$}

\begin{tabular}{|c|c|c|c|c|c|c|c|c|}
\hline $\mathbf{N}$ & U.E. & $\begin{array}{l}\text { LECTURA } \\
\text { (ANV) }\end{array}$ & $\begin{array}{l}\text { LECTURA } \\
\text { (REV) }\end{array}$ & $\begin{array}{c}\text { PESO y } \\
\text { MATERIA }\end{array}$ & DESCRIPCION & FOTO (ANV) & FOTO (REV) & COMENTARIOS \\
\hline 1 & 1014 & Fustra & $\begin{array}{c}\text { MP } \\
\text { (¿M. POP.?) }\end{array}$ & $\begin{array}{l}\mathrm{AE} \\
16,8 \mathrm{~g} . \\
\mathrm{AS}\end{array}$ & $\begin{array}{l}\text { (ANV): Fustra } \\
\text { (REV):Proa de nave hacia la } \\
\text { derecha bajo Victoria alada } \\
\text { coronando MP, caduceo frente la } \\
\text { proa y leyenda ibérica bajo } \\
\text { exergo (ARSE) }\end{array}$ & & & $\begin{array}{l}\text { Yacimiento: Torre d'Onda } \\
\text { Origen: Sagunto } 72 / 30 \text { a. C. }\end{array}$ \\
\hline 2 & 1060 & $\begin{array}{l}\text { II VIR - CVI - } \\
\text { CELSI }\end{array}$ & $\begin{array}{l}\text { L. POMP. } \\
\text { BUCCO } \\
\text { L.CORN. } \\
\text { FRONT }\end{array}$ & $\begin{array}{l}\mathrm{AE} \\
7,7 \mathrm{~g} . \\
\text { Semis }\end{array}$ & $\begin{array}{l}\text { (ANV): Cabeza hacia la derecha } \\
\text { (REV): Bóvido hacia la derecha } \\
\text { bajo leyenda }\end{array}$ & & & $\begin{array}{l}\text { Yacimiento: Calle Mayor, } \\
26 \text { (Burriana) } \\
\text { Origen: Celsa, } 36 \text { a } 27 \text { a. C. }\end{array}$ \\
\hline 3 & 2004 & $\begin{array}{l}\text { HADRIANUS } \\
\text { [AUGUSTUS } \\
\text { PP COS III] }\end{array}$ & $\begin{array}{l}\text { HI [LARITAS } \\
\text { PR COS III - } \\
\text { SC) }\end{array}$ & $\begin{array}{l}\mathrm{AE} \\
17,1 \mathrm{~g} . \\
\mathrm{AS}\end{array}$ & $\begin{array}{l}\text { (ANV): Cabeza laureada con } \\
\text { cinta hacia la derecha } \\
\text { (REV): Personaje togado de gran } \\
\text { estatura hacia la derecha frente a } \\
\text { otro }\end{array}$ & & & $\begin{array}{l}\text { Yacimiento: El Palau } \\
\text { Cronología: Adriano } 134 \text { ó } \\
\text { 136 d. C. }\end{array}$ \\
\hline 4 & 3007 & $\begin{array}{c}{[\ldots](\text { ¿IA?)N }} \\
\text { AUG }(i G ?)[\ldots]\end{array}$ & Fustra & $\begin{array}{c}\mathrm{AE} \\
21 \mathrm{~g} . \\
\text { Dupondio }\end{array}$ & $\begin{array}{l}\text { (ANV): Cabeza laureada hacia la } \\
\text { derecha } \\
\text { (REV): Fustra }\end{array}$ & & & $\begin{array}{l}\text { Yacimiento: solar Quevedo } \\
\text { (Sagunto) } \\
\text { Cronología: ¿Domiciano? }\end{array}$ \\
\hline
\end{tabular}




\section{LISTADO DE MONEDAS*}

\begin{tabular}{|c|c|c|c|c|c|c|}
\hline 5 & 3005 & [.]TRAIAN[.] & $\begin{array}{l}\text { PROVIDENTIA } \\
\text { AUGUSTI - SC }\end{array}$ & $\begin{array}{l}\mathrm{AE} \\
9,7 \mathrm{~g} . \\
\text { Semis }\end{array}$ & $\begin{array}{l}\text { (ANV): Cabeza radiada hacia la } \\
\text { derecha } \\
\text { (REV): Personaje togado ante } \\
\text { altar }\end{array}$ & $\begin{array}{l}\text { Yacimiento: solar Quevedo } \\
\text { (Sagunto) } \\
\text { Cronología: Trajano } 114 \text { al } \\
117 \text { d. C. }\end{array}$ \\
\hline 6 & 3005 & $\begin{array}{l}\text { ¿SOL COMIS } \\
\text { PROBI AUG? }\end{array}$ & $\begin{array}{l}\text { ¿P.M.TR. } \\
\text { P.COS.III? }\end{array}$ & $\begin{array}{c}\mathrm{O} \\
2,2 \mathrm{~g} . \\
\text { Cuadrante }\end{array}$ & $\begin{array}{l}\text { (ANV): Cabeza radiada hacia la } \\
\text { derecha } \\
(\mathrm{REV}) \text { : Personaje con lanza y } \\
\text { caduceo }\end{array}$ & $\begin{array}{l}\text { Yacimiento: solar Quevedo } \\
\text { (Sagunto) } \\
\text { Cronología: ¿Probo }-279 \mathrm{~d} \text {. } \\
\text { C.? }\end{array}$ \\
\hline 7 & $\begin{array}{c}\text { Sondeo } \\
14\end{array}$ & $\begin{array}{l}\text { IMP CAES } \\
\text { NERVA } \\
\text { TRAIAN AUG } \\
\text { GERM PM }\end{array}$ & $\begin{array}{l}\text { TR POT COS } \\
\text { IIII PP SC }\end{array}$ & $\begin{array}{c}\text { AE } \\
\text { Sestercio }\end{array}$ & $\begin{array}{l}\text { (ANV): Cabeza con cinta hacia la } \\
\text { derecha } \\
\text { (REV): Victoria alada con lanza } \\
\text { y escudo inscrito SPQR }\end{array}$ & $\begin{array}{l}\text { Yacimiento: San Gregori } \\
\text { (Burriana) (vertedero) } \\
\text { Cronología: Trajano } 101 \text { ó } \\
102 \text { d. C. }\end{array}$ \\
\hline 8 & $\begin{array}{c}\text { Sondeo } \\
13\end{array}$ & $\begin{array}{c}\text { HADRIANUS } \\
\text { AUGUSTUS }\end{array}$ & $\begin{array}{c}\text { COS III } \\
\text { S C }\end{array}$ & $\begin{array}{c}\mathrm{AE} \\
\text { Sestercio }\end{array}$ & $\begin{array}{l}\text { (ANV): Cabeza barbada con cinta } \\
\text { hacia la derecha } \\
\text { (REV): Virtus militar de pie hacia } \\
\text { derecha, pie derecho sobre casco, } \\
\text { parazonium en mano derecha y } \\
\text { lanza en izquierda (¿variante?) }\end{array}$ & $\begin{array}{l}\text { Yacimiento: San Gregori } \\
\text { (monumento funerario) } \\
\text { Croniología: Adriano 119al } \\
138 \text { d.C. }\end{array}$ \\
\hline
\end{tabular}

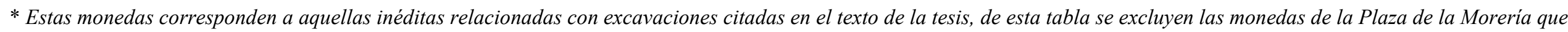
actualmente están siendo estudiadas en detalle por otra colega nuestra. 


\begin{tabular}{|c|c|c|c|c|c|c|c|c|}
\hline № & U.E. & LECTURA & $\begin{array}{l}\text { OTRA } \\
\text { LECTU } \\
\text { RA }\end{array}$ & FORMA & INTERPRETACIÓN & DIBUJO & FOTO & COMENTARIOS \\
\hline 1 & 1000 & FCAN & FCNA & $\begin{array}{l}\text { Asa de ánfora } \\
\text { tipo Brindisi, II-I } \\
\text { a. C. }\end{array}$ & Fabio Caius Aninius & & & $\begin{array}{l}\text { Paralelos: } \\
\text { Castillo de Sagunto } \\
\text { (CEIPAC 21618) y Horta } \\
\text { Seca en Vall d'Úixó } \\
\text { (CEIPAC 21619) }\end{array}$ \\
\hline 2 & 1002 & EO.R.CLA & & $\begin{array}{l}\text { Base con pie de } \\
\text { TSH }\end{array}$ & & & & $\begin{array}{l}\text { Paralelos: } \\
\text { Of. ORICLA en } \\
\text { Jonquières-Saint- } \\
\text { Saturnin. Del 0-30 d. C. }\end{array}$ \\
\hline 3 & 1002 & PATRICI & & Base de TSSG & $\begin{array}{l}\text { Of. PATRICIVS Graufesenque. Del } \\
\text { 55-95 d. C. (Hofmann, 1971) ó 55- } \\
110 \text { d. C. (Polak 2000) }\end{array}$ & & & $\begin{array}{l}\text { Paralelos: } \\
\text { OF·PATRIC }\end{array}$ \\
\hline 4 & 1002 & ..AM & & $\begin{array}{l}\text { Base con pie de } \\
\text { TSS }\end{array}$ & $\begin{array}{l}\text { Of. CLARVS en Sur de la Galia. 40- } \\
70 \text { d. C. (Oswald 1931) } \\
\text { ó } \\
\text { Of. DAMONVS Graufesenque, } \\
\text { Jonquières-Saint-Saturnin, 40-70 d. C. } \\
\text { (Hofmann 1971) } \\
\text { ó } \\
\text { Of. FAMIVS en Montans. 15-40 d. C. } \\
\text { (Tilhard 2004) ó 0-100 d. C. } \\
\text { (Hofmann 1971 y Oswald 1931) } \\
\text { ó } \\
\text { Of. IVAVS en Rheinzabern. 140-160 } \\
\text { d. C. (Oswald 1931) } \\
\text { ó }\end{array}$ & & & $\begin{array}{l}\text { Paralelos: } \\
\text { CLAM } \\
\text { ó } \\
\text { DAM } \\
\text { Ó } \\
\text { FAM } \\
\text { Ó } \\
\text { IVAM } \\
\text { Ó } \\
\text { SAM } \\
\text { Ó } \\
\text { VAM } \\
\text { Ó } \\
\text { VIAM }\end{array}$ \\
\hline
\end{tabular}


LISTADO DE SIGILLAS, MARCAS Y GRAFITOS DE LA EXCAVACIÓN DE LA MORERÍA (SAGUNTO)

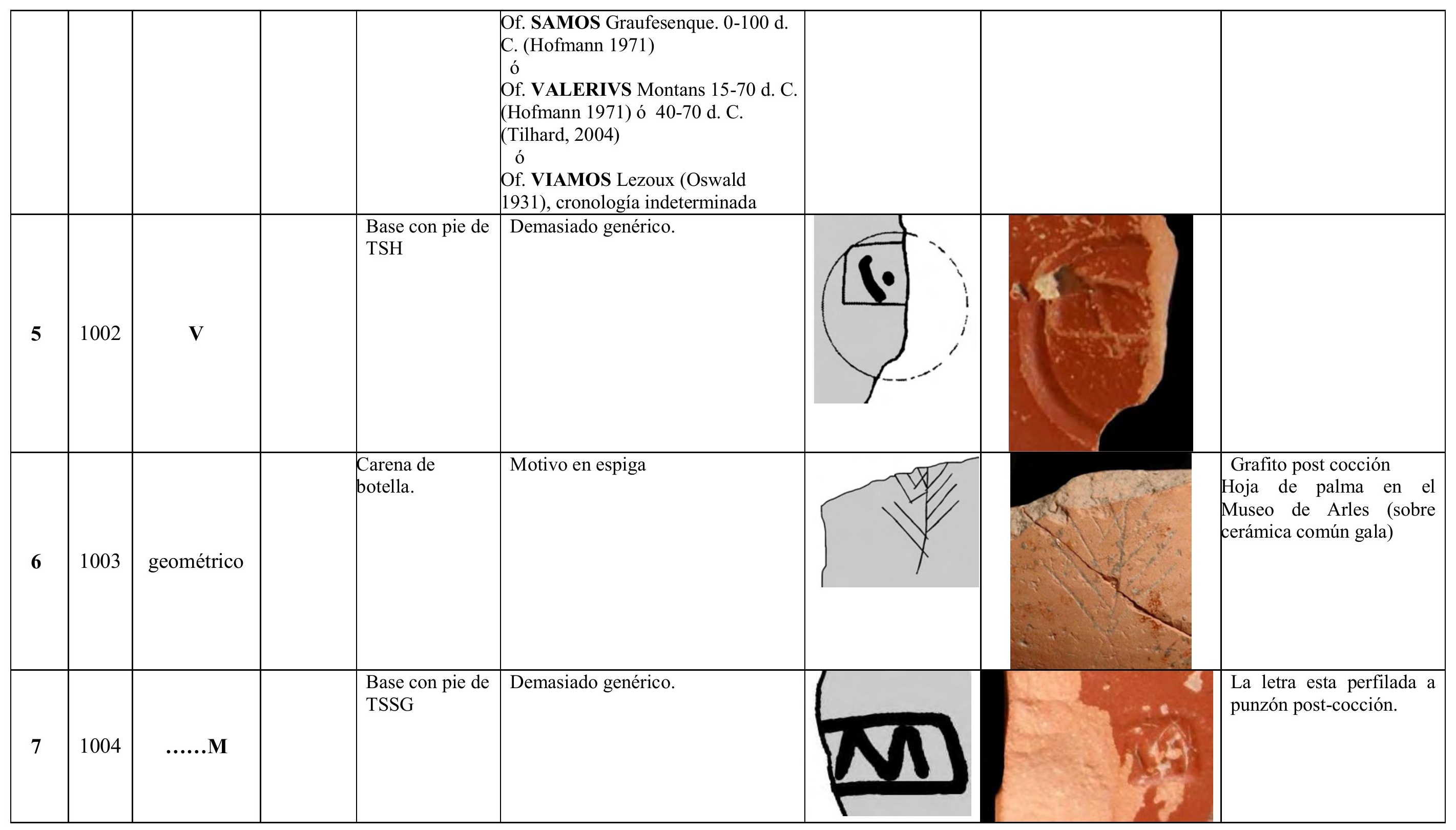


LISTADO DE SIGILLAS, MARCAS Y GRAFITOS DE LA EXCAVACIÓN DE LA MORERÍA (SAGUNTO)

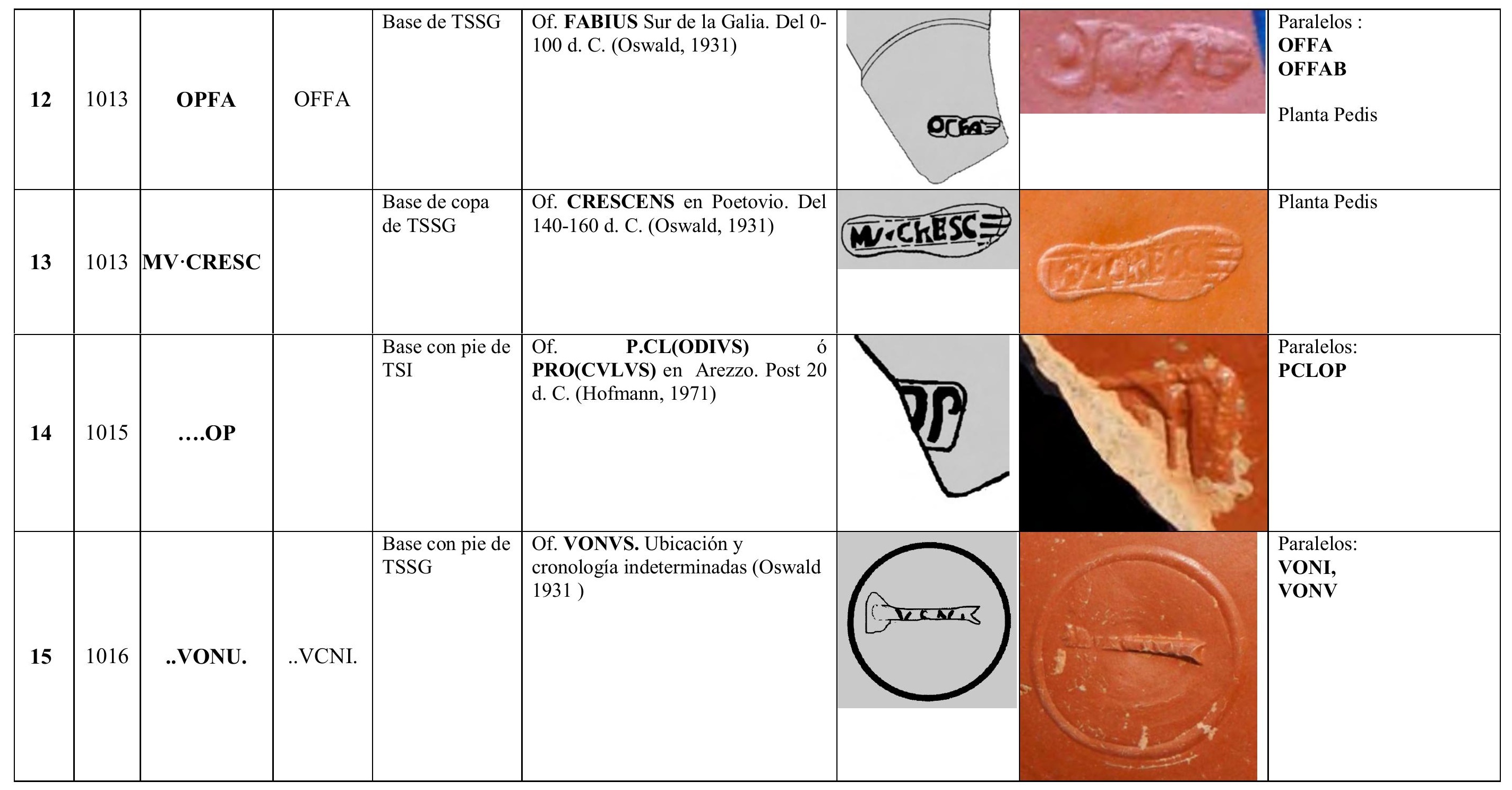


LISTADO DE SIGILLAS, MARCAS Y GRAFITOS DE LA EXCAVACIÓN DE LA MORERÍA (SAGUNTO)

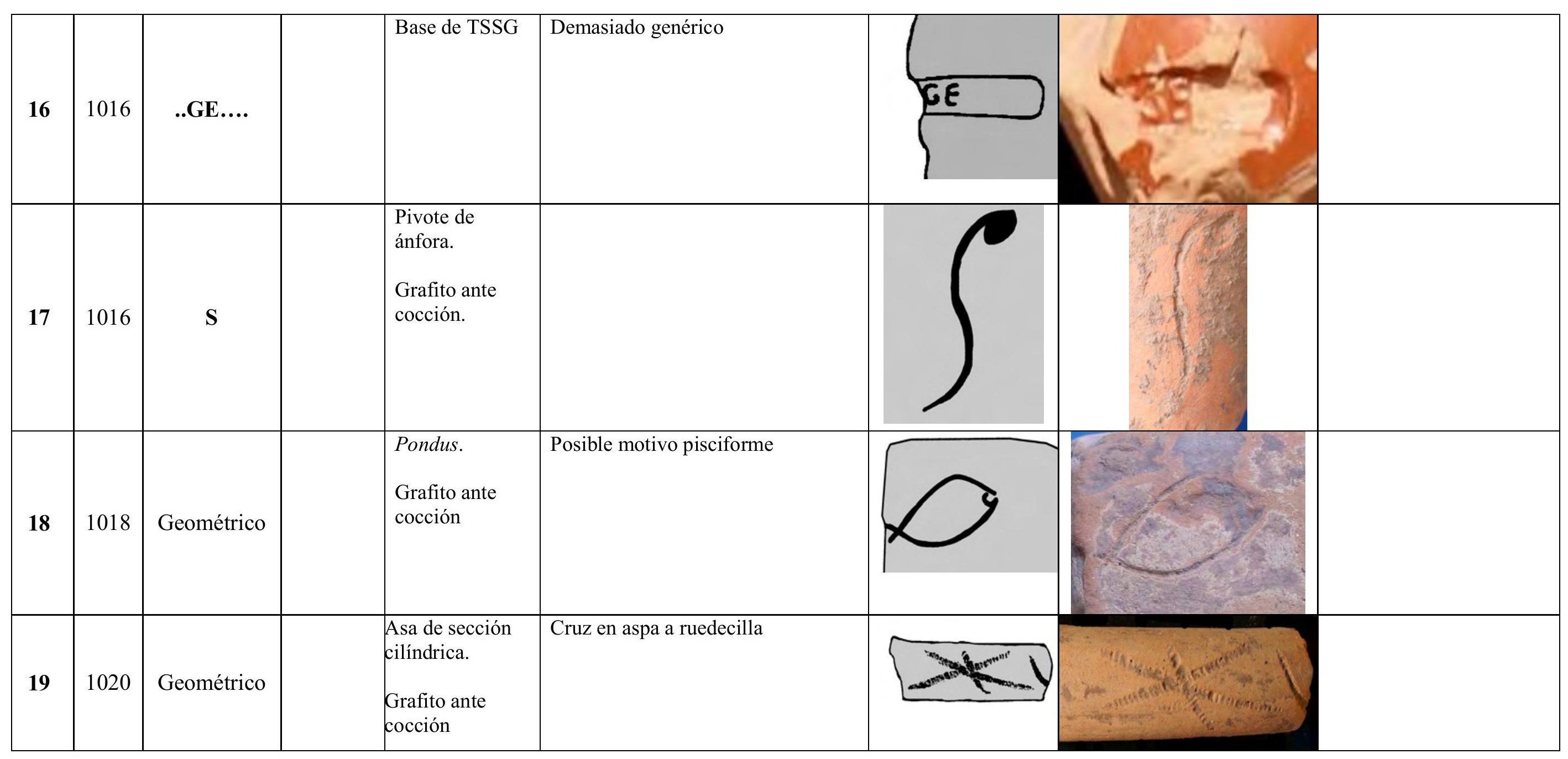




\section{LISTADO DE SIGILLAS, MARCAS Y GRAFITOS DE LA EXCAVACIÓN DE LA MORERÍA (SAGUNTO)}

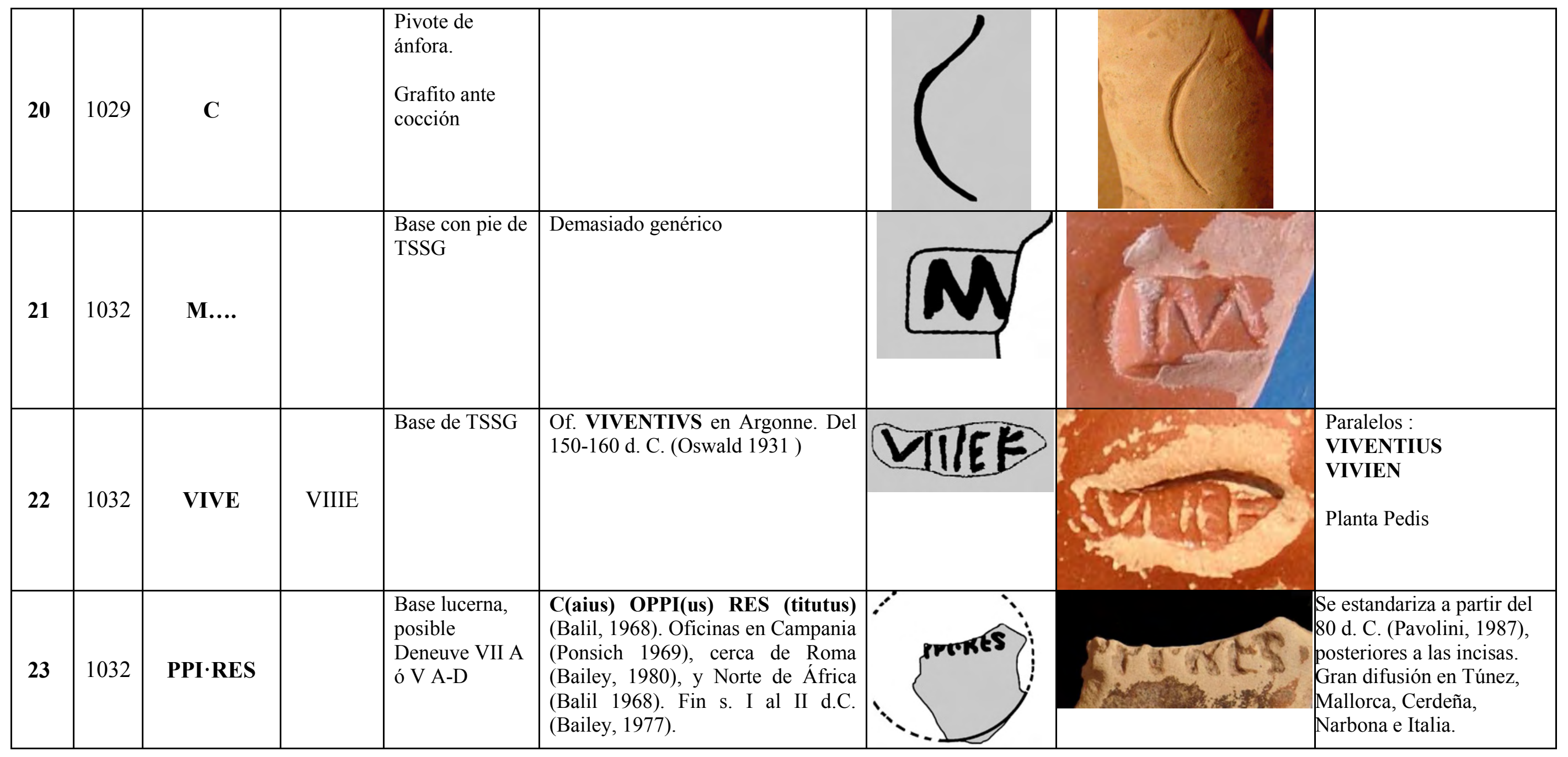


LISTADO DE SIGILLAS, MARCAS Y GRAFITOS DE LA EXCAVACIÓN DE LA MORERÍA (SAGUNTO)

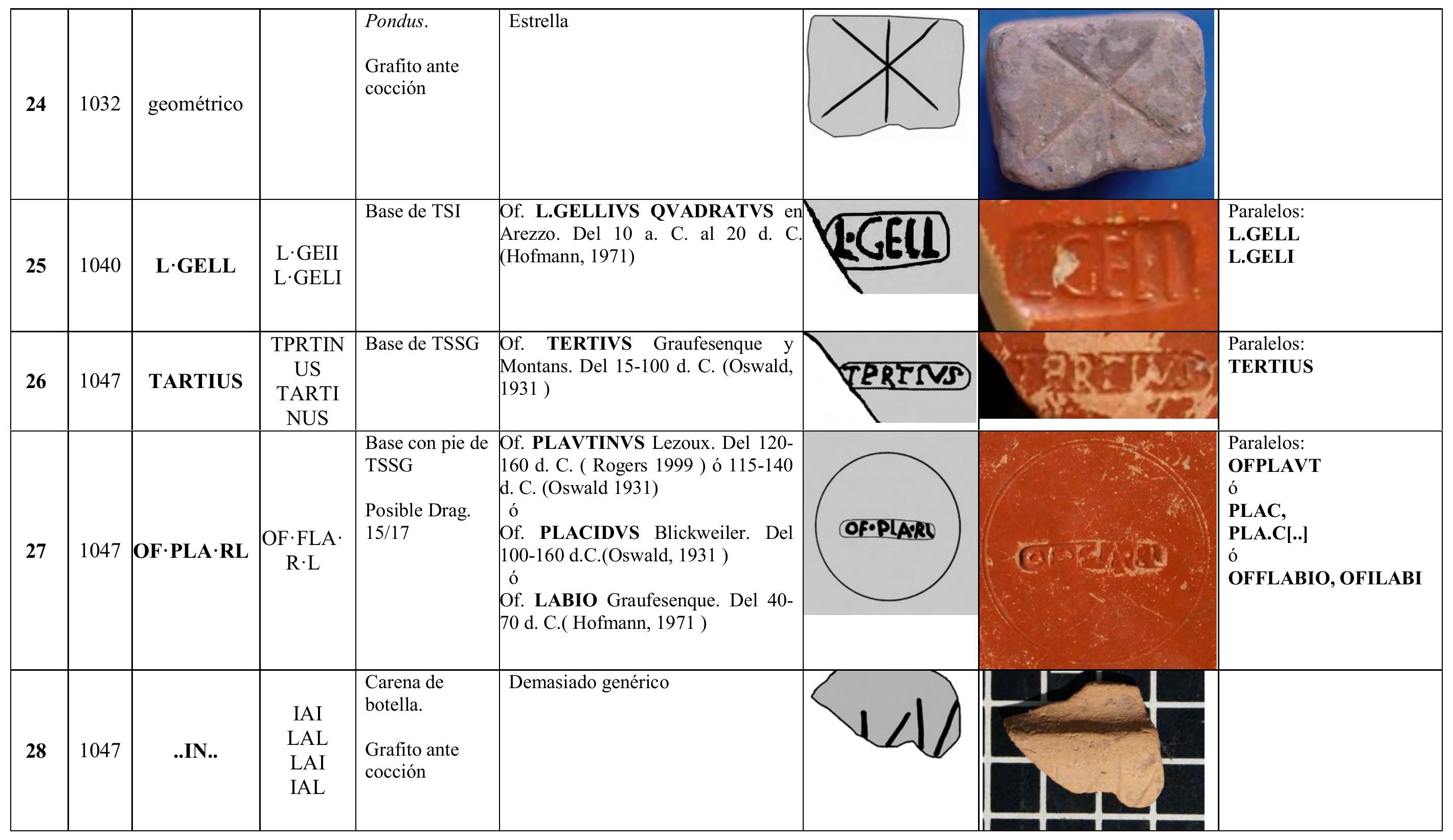


LISTADO DE SIGILLAS, MARCAS Y GRAFITOS DE LA EXCAVACIÓN DE LA MORERÍA (SAGUNTO)

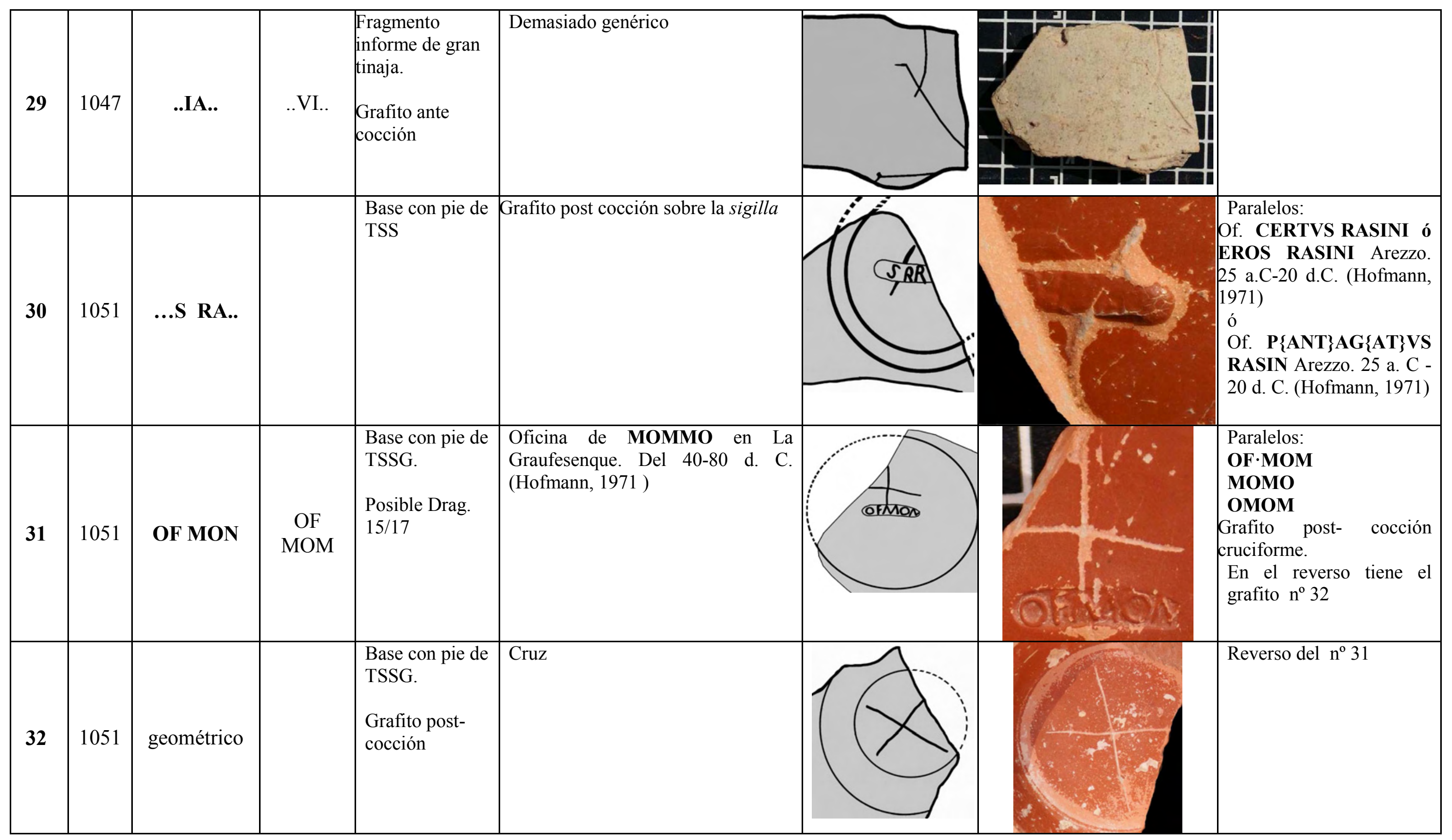


LISTADO DE SIGILLAS, MARCAS Y GRAFITOS DE LA EXCAVACIÓN DE LA MORERÍA (SAGUNTO)

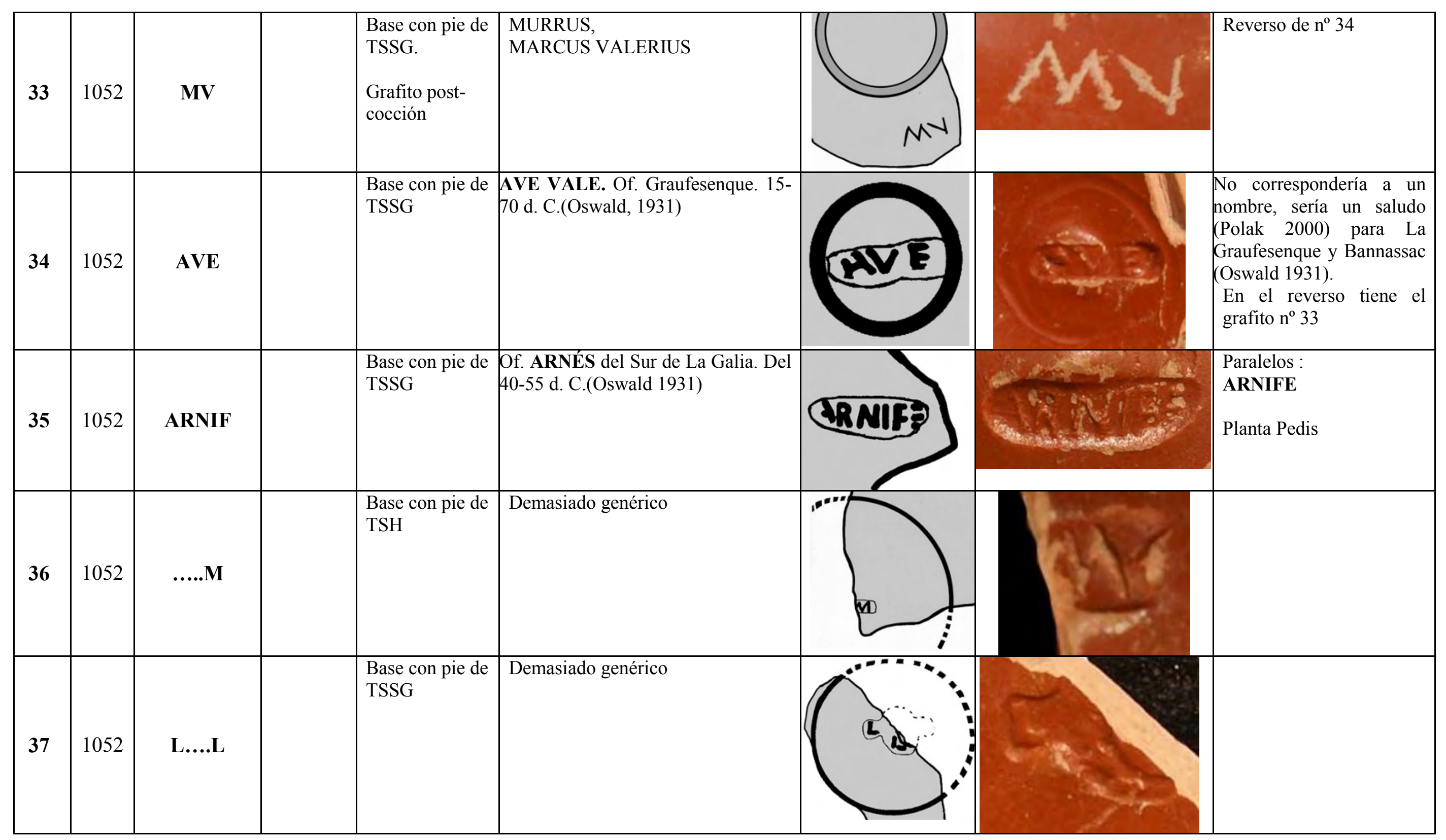


LISTADO DE SIGILLAS, MARCAS Y GRAFITOS DE LA EXCAVACIÓN DE LA MORERÍA (SAGUNTO)

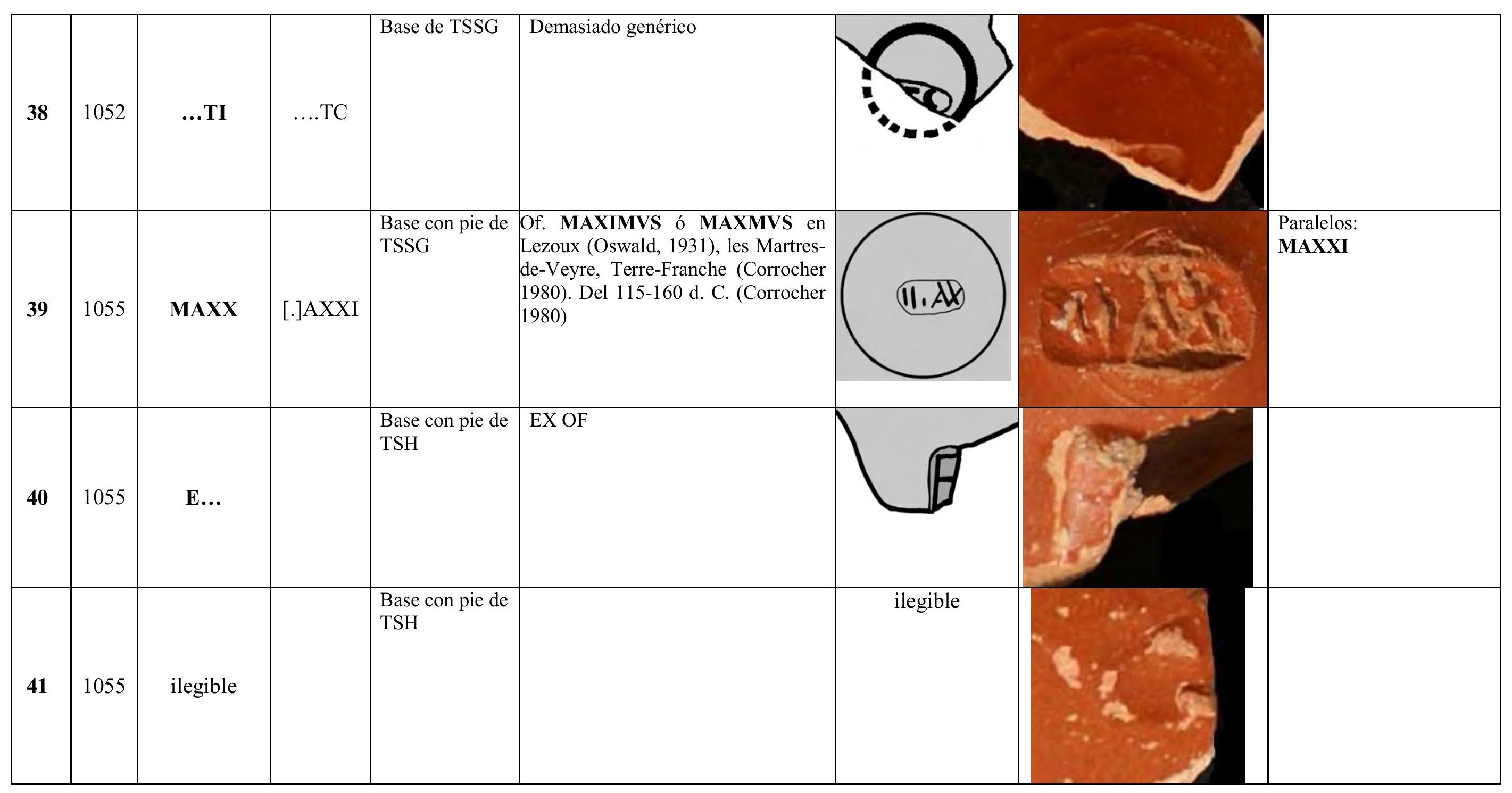


LISTADO DE SIGILLAS, MARCAS Y GRAFITOS DE LA EXCAVACIÓN DE LA MORERÍA (SAGUNTO)

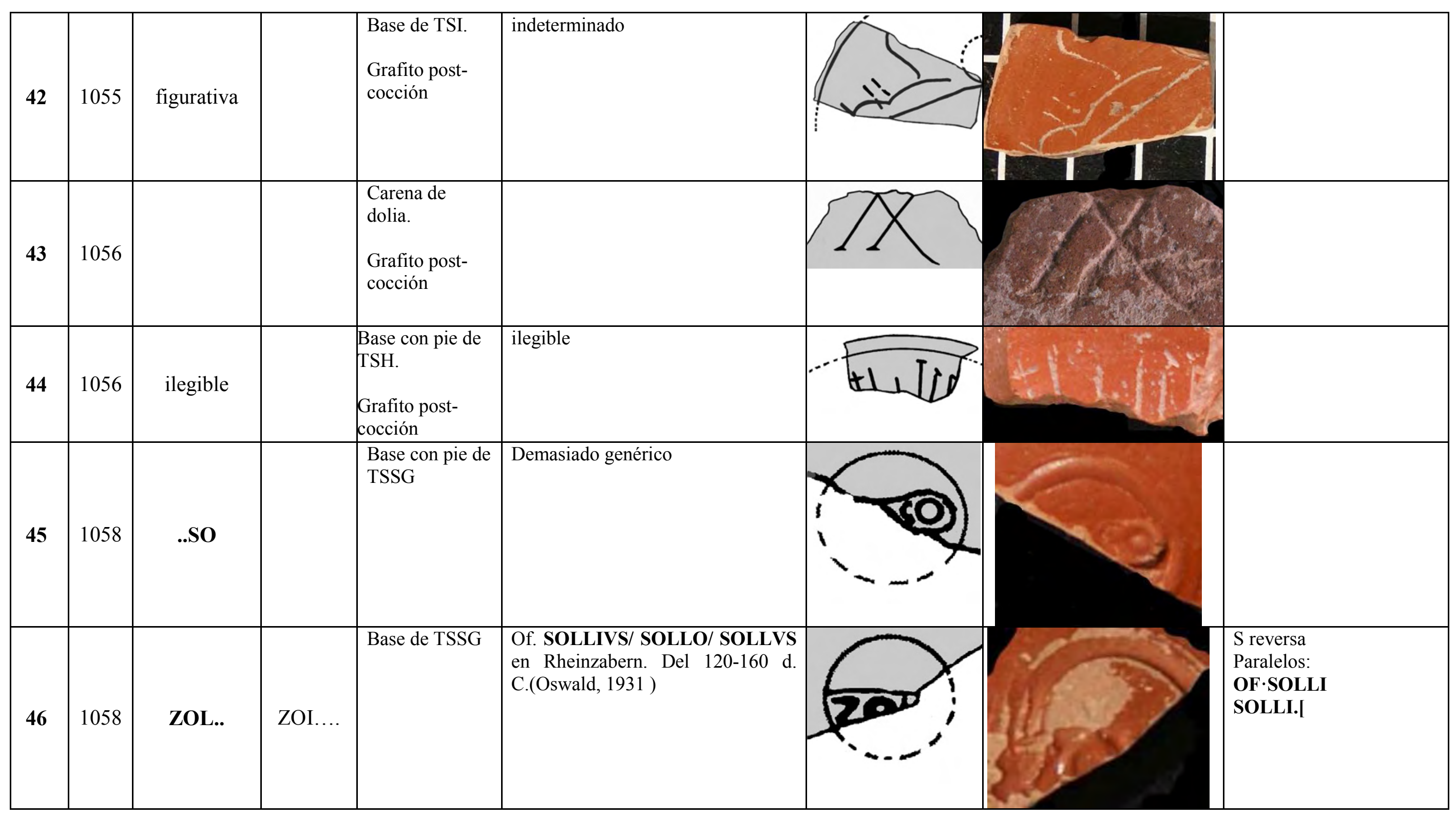


LISTADO DE SIGILLAS, MARCAS Y GRAFITOS DE LA EXCAVACIÓN DE LA MORERÍA (SAGUNTO)

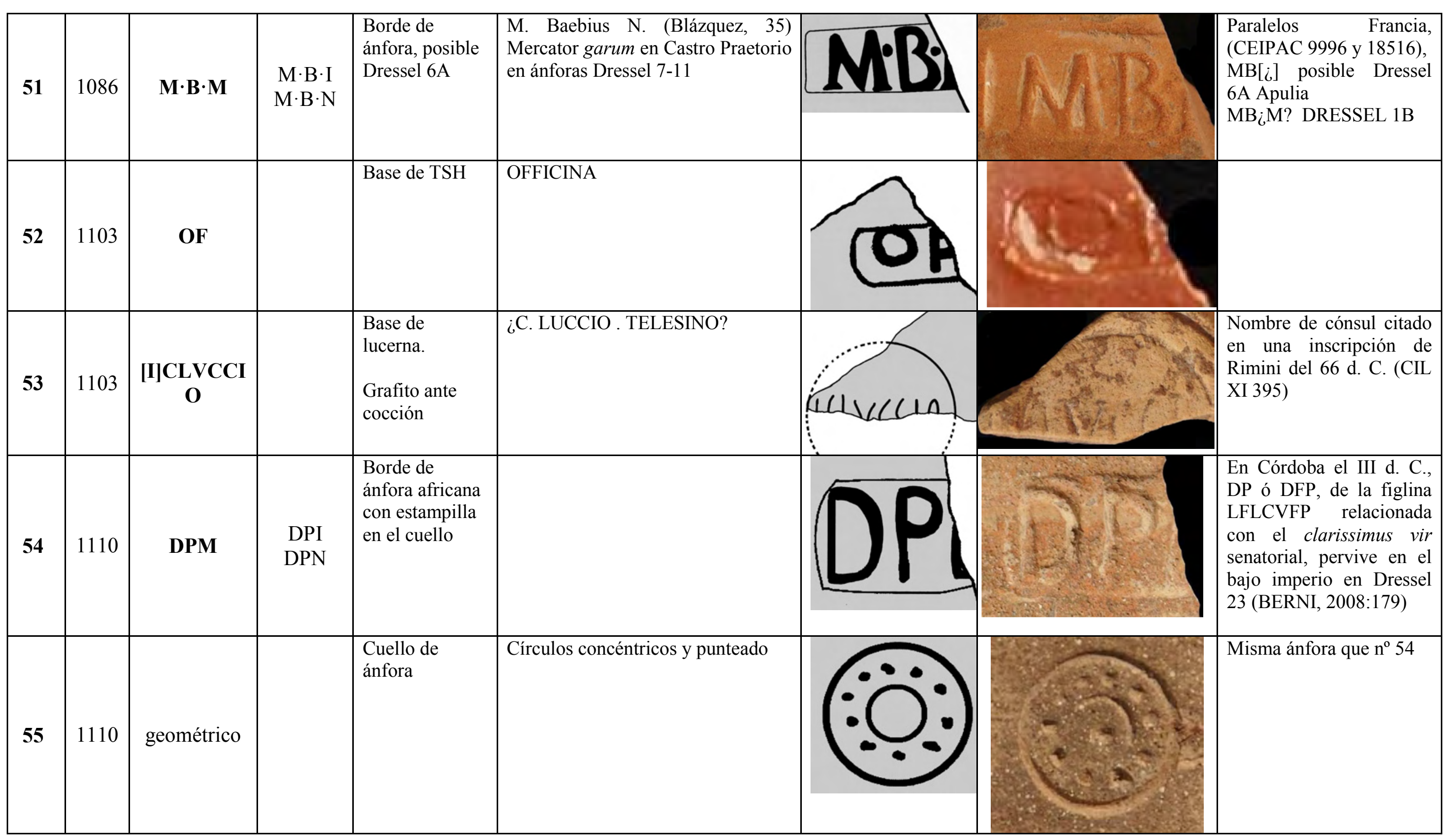


LISTADO DE SIGILLAS, MARCAS Y GRAFITOS DE LA EXCAVACIÓN DE LA MORERÍA (SAGUNTO)

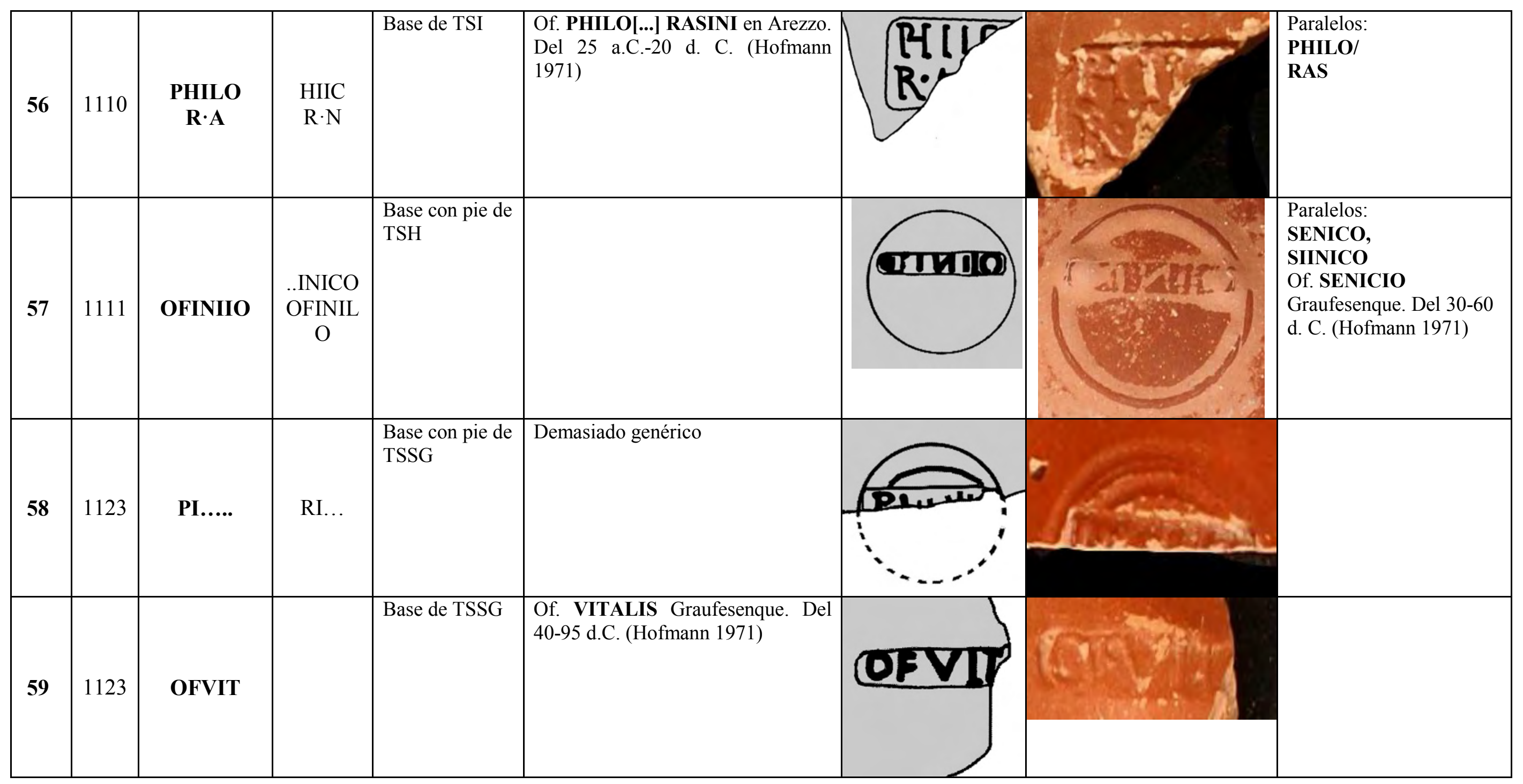


LISTADO DE SIGILLAS, MARCAS Y GRAFITOS DE LA EXCAVACIÓN DE LA MORERÍA (SAGUNTO)

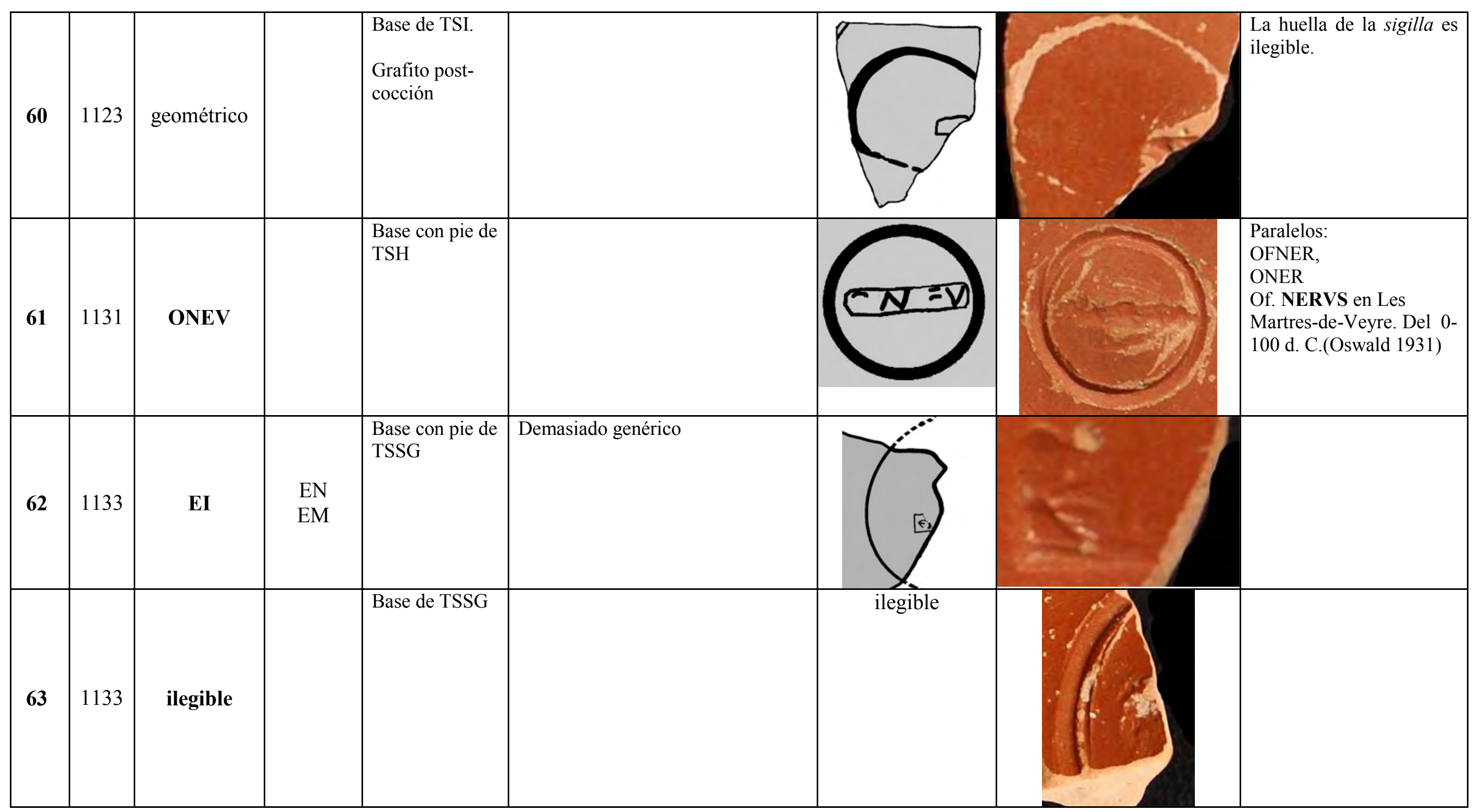


LISTADO DE SIGILLAS, MARCAS Y GRAFITOS DE LA EXCAVACIÓN DE LA MORERÍA (SAGUNTO)

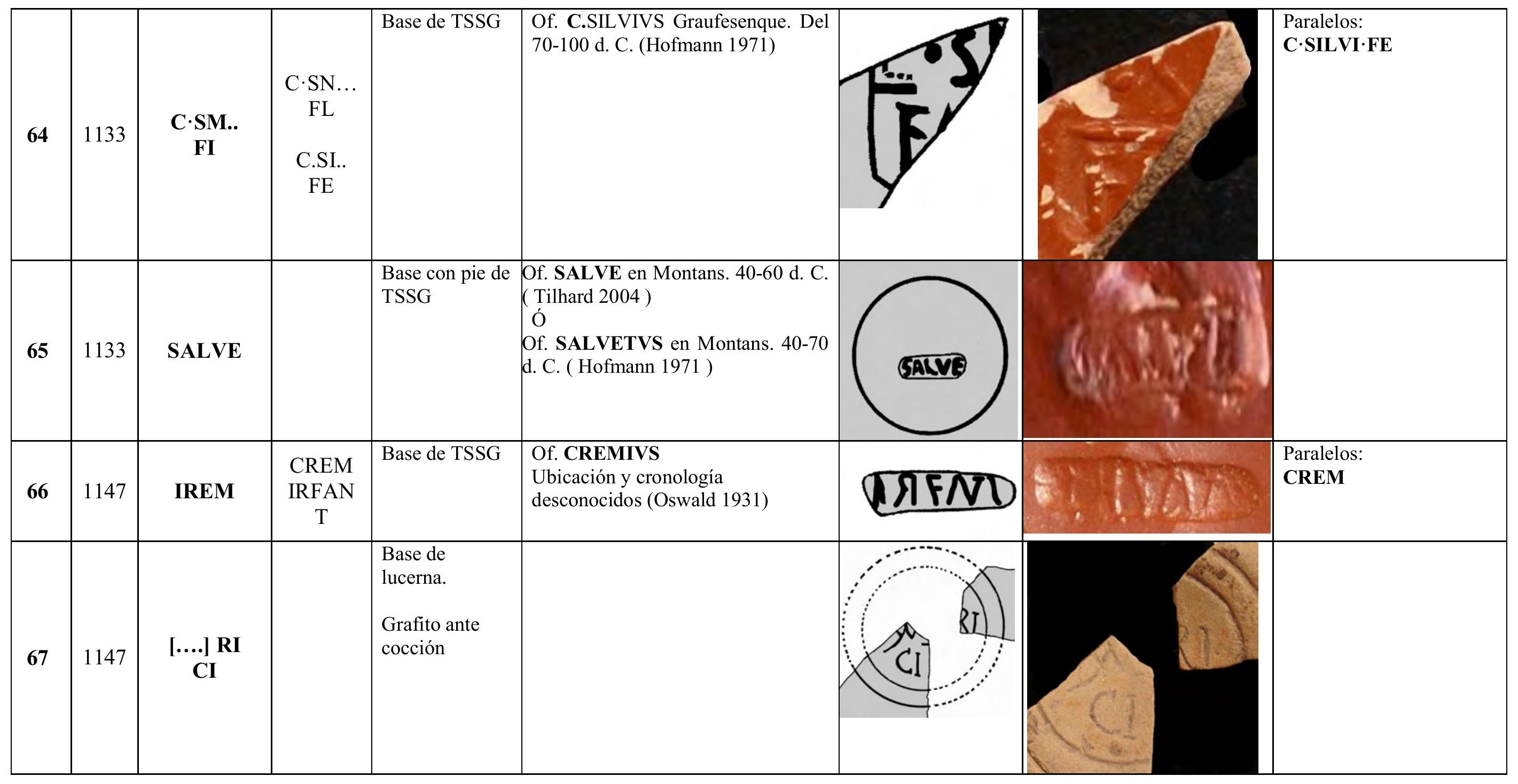


LISTADO DE SIGILLAS, MARCAS Y GRAFITOS DE LA EXCAVACIÓN DE LA MORERÍA (SAGUNTO)

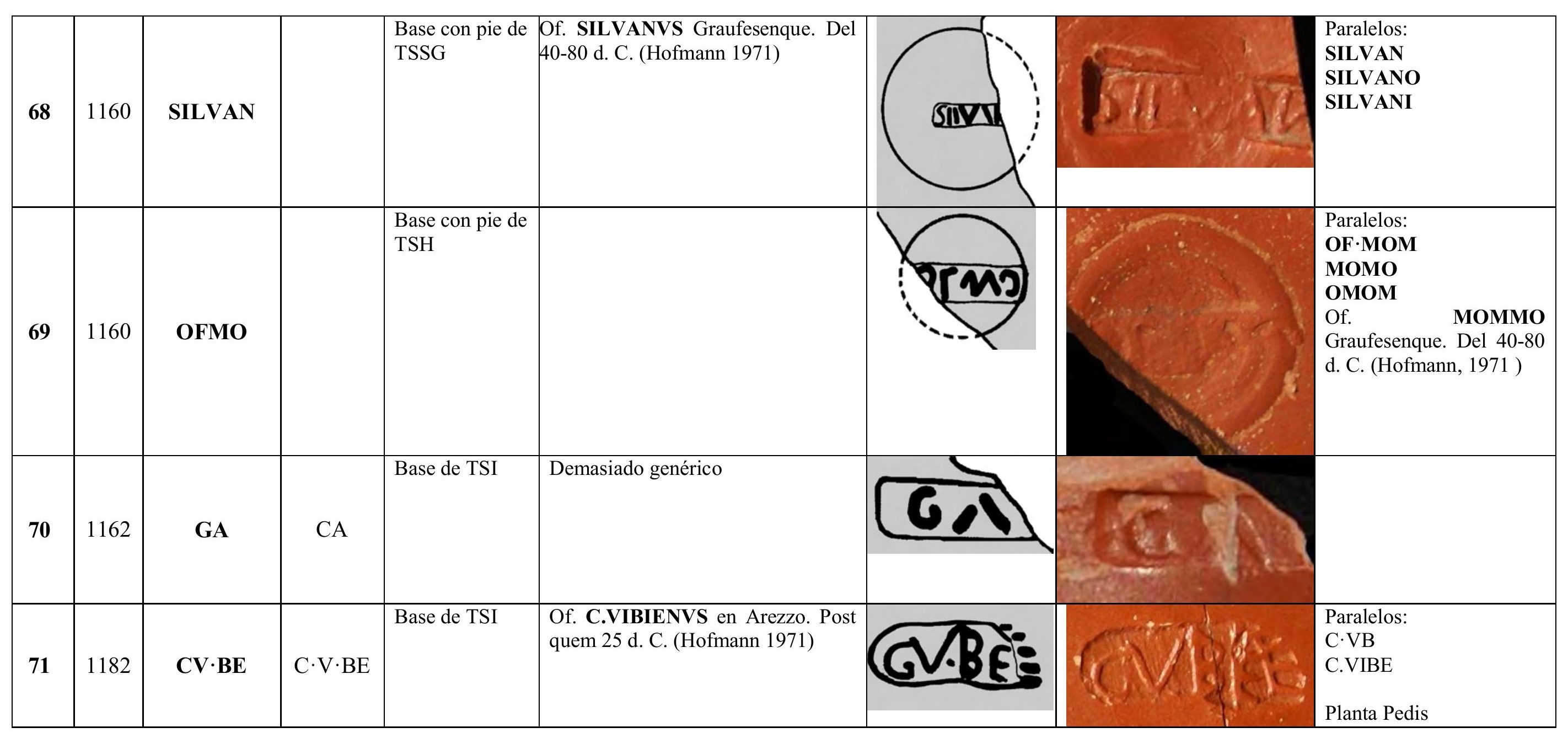


LISTADO DE SIGILLAS, MARCAS Y GRAFITOS DE LA EXCAVACIÓN DE LA MORERÍA (SAGUNTO)

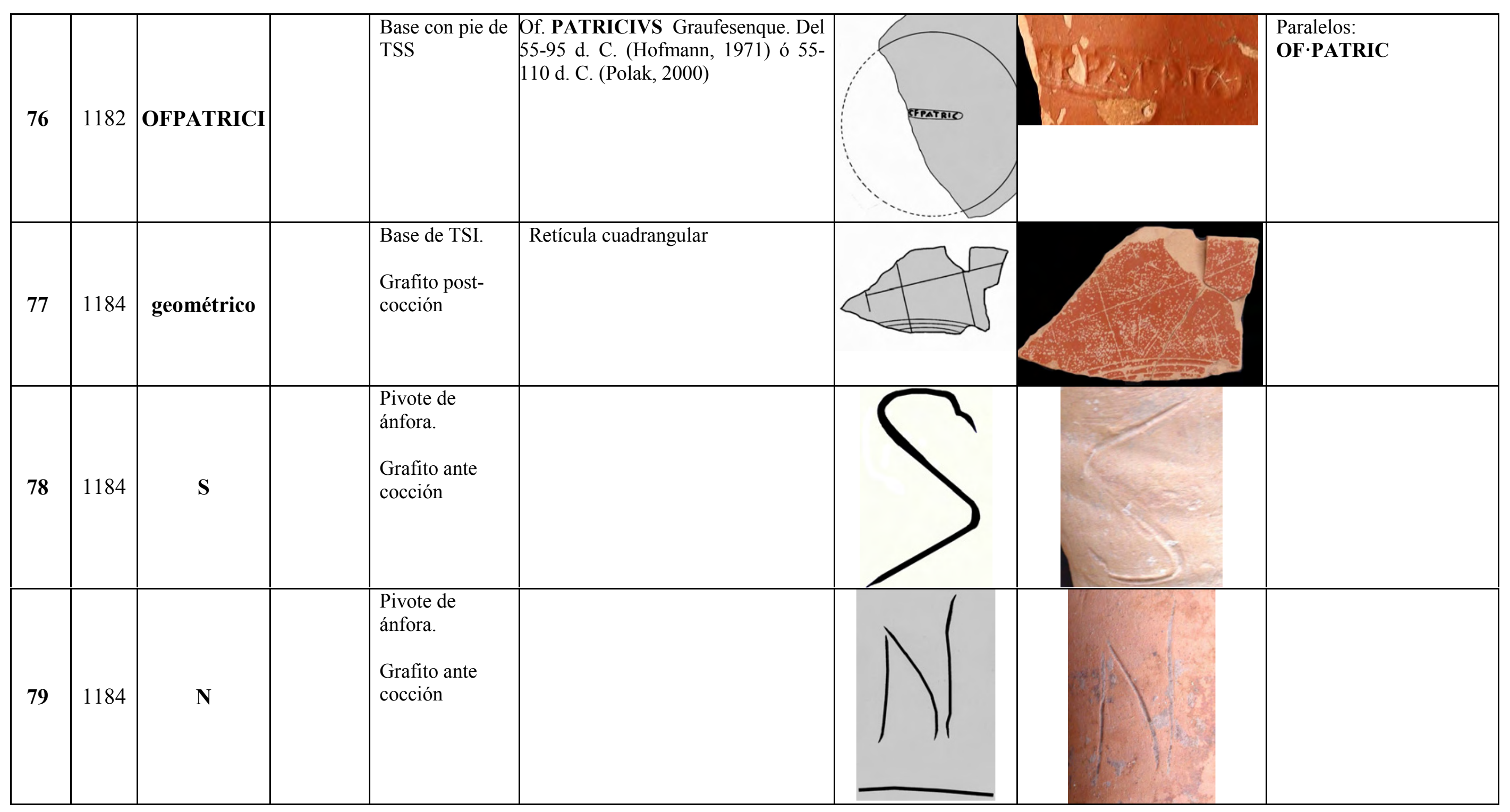


LISTADO DE SIGILLAS, MARCAS Y GRAFITOS DE LA EXCAVACIÓN DE LA MORERÍA (SAGUNTO)

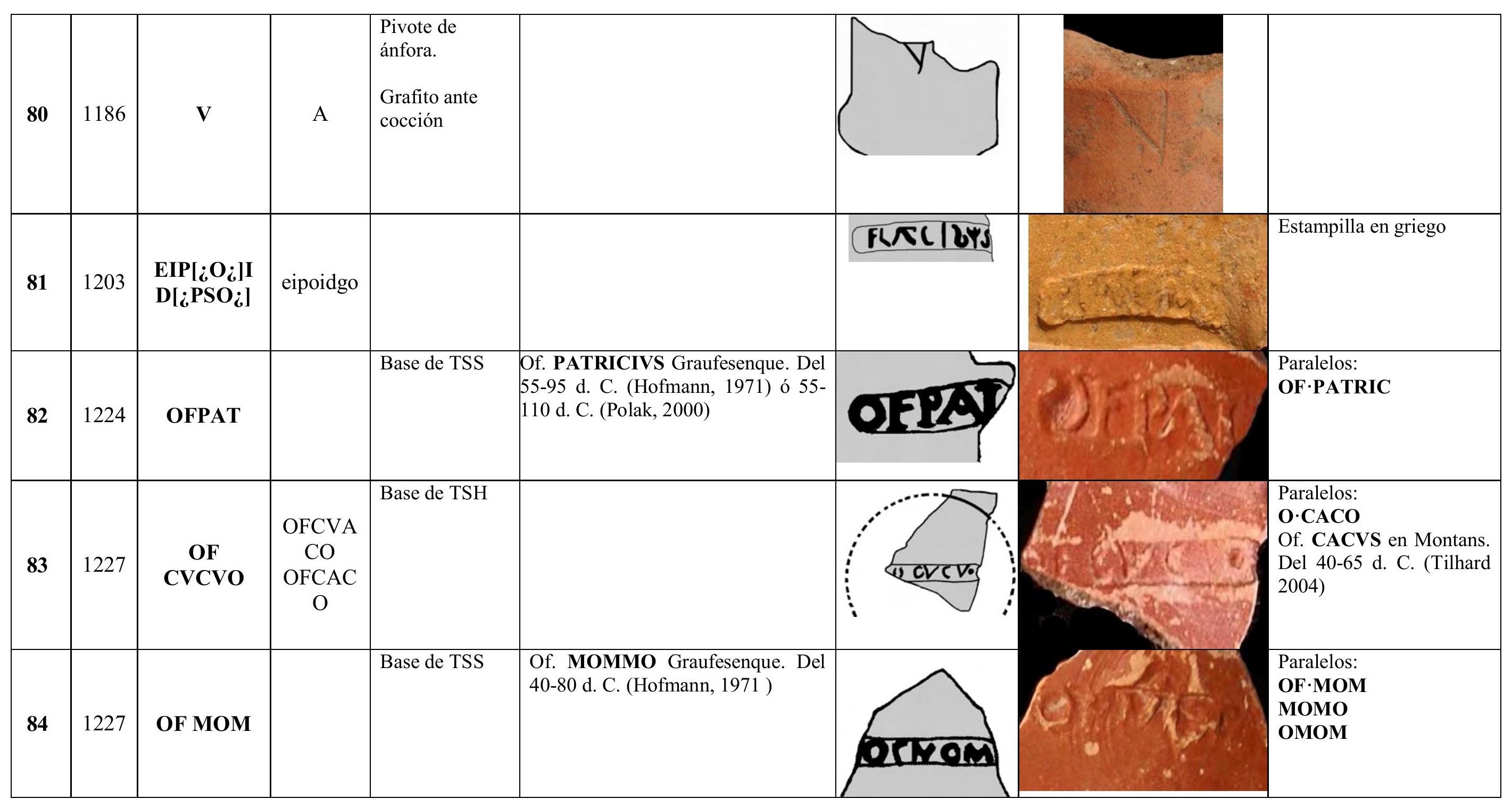


LISTADO DE SIGILLAS, MARCAS Y GRAFITOS DE LA EXCAVACIÓN DE LA MORERÍA (SAGUNTO)

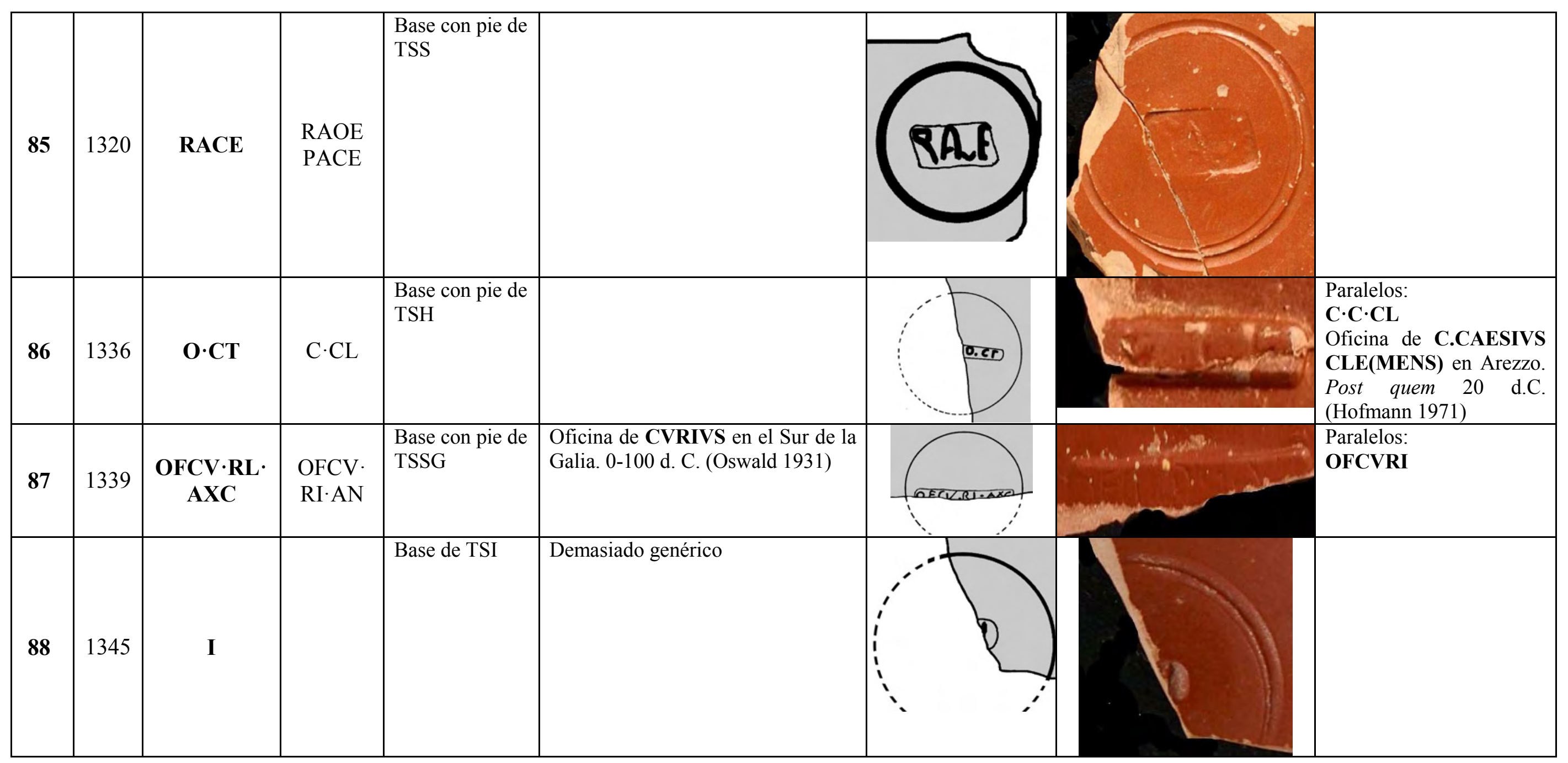


LISTADO DE SIGILLAS, MARCAS Y GRAFITOS DE LA EXCAVACIÓN DE LA MORERÍA (SAGUNTO)

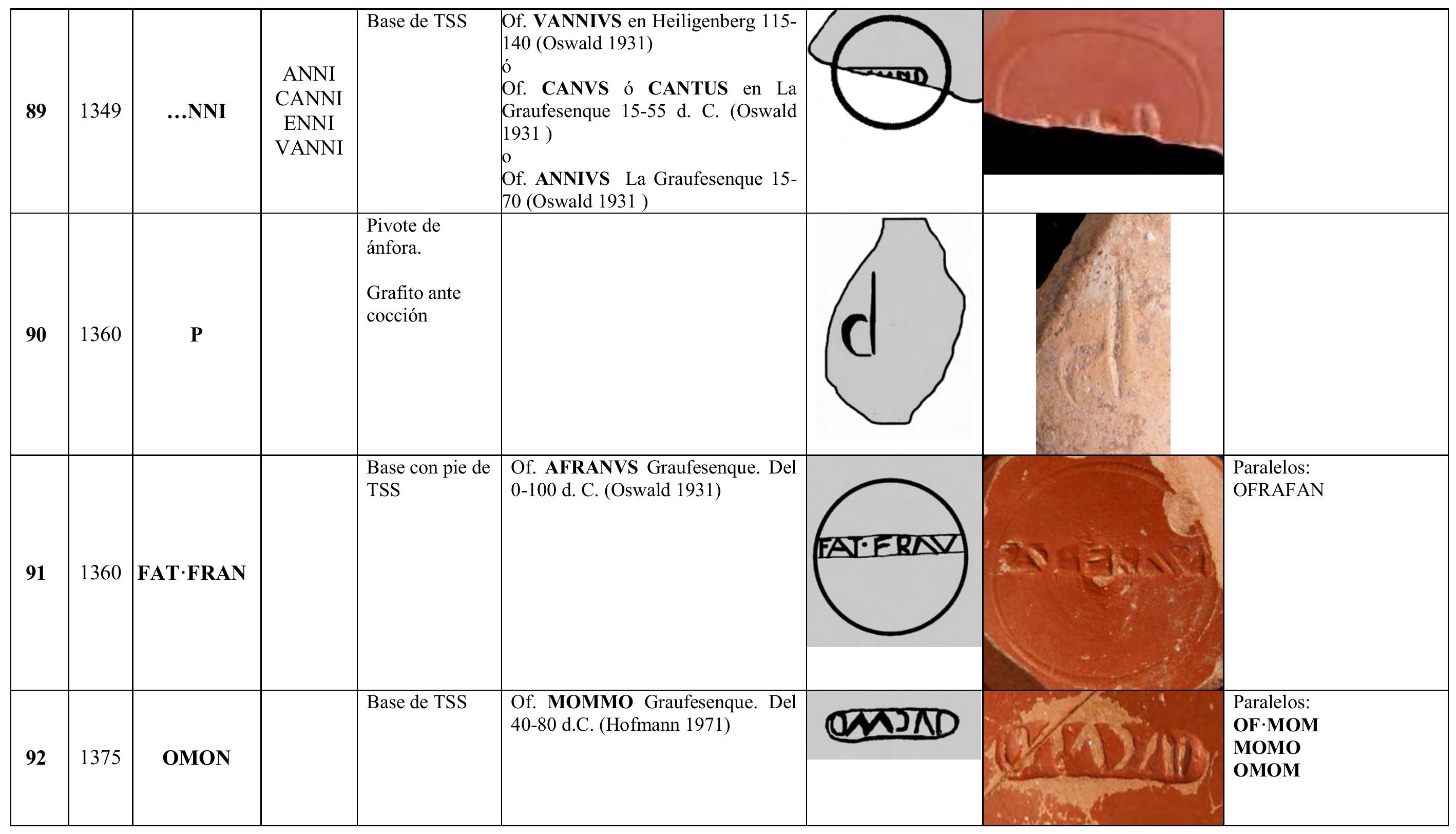


LISTADO DE SIGILLAS, MARCAS Y GRAFITOS DE LA EXCAVACIÓN DE LA MORERÍA (SAGUNTO)

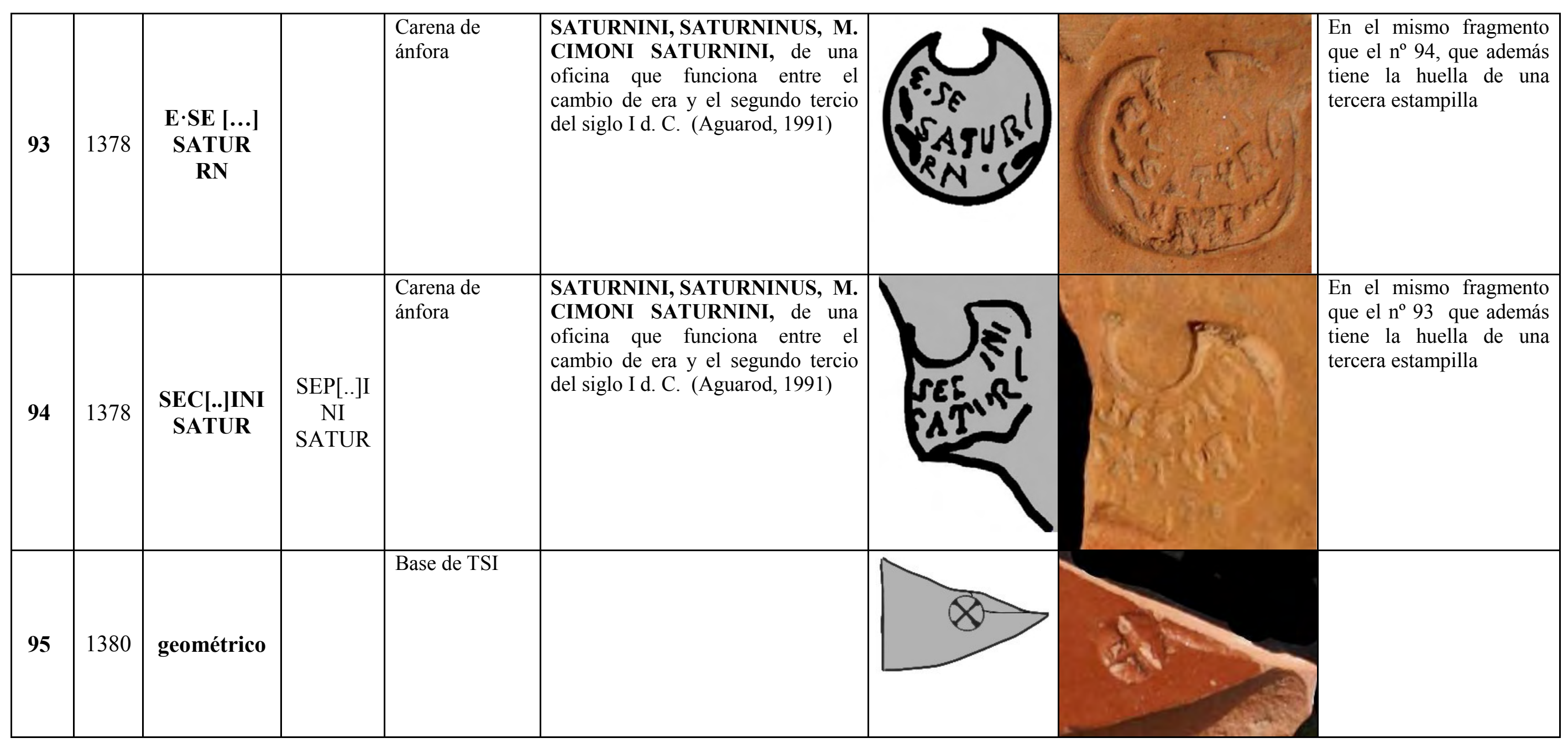




\section{LISTADO DE SIGILLAS, MARCAS Y GRAFITOS DE LA EXCAVACIÓN DE LA MORERÍA (SAGUNTO)}

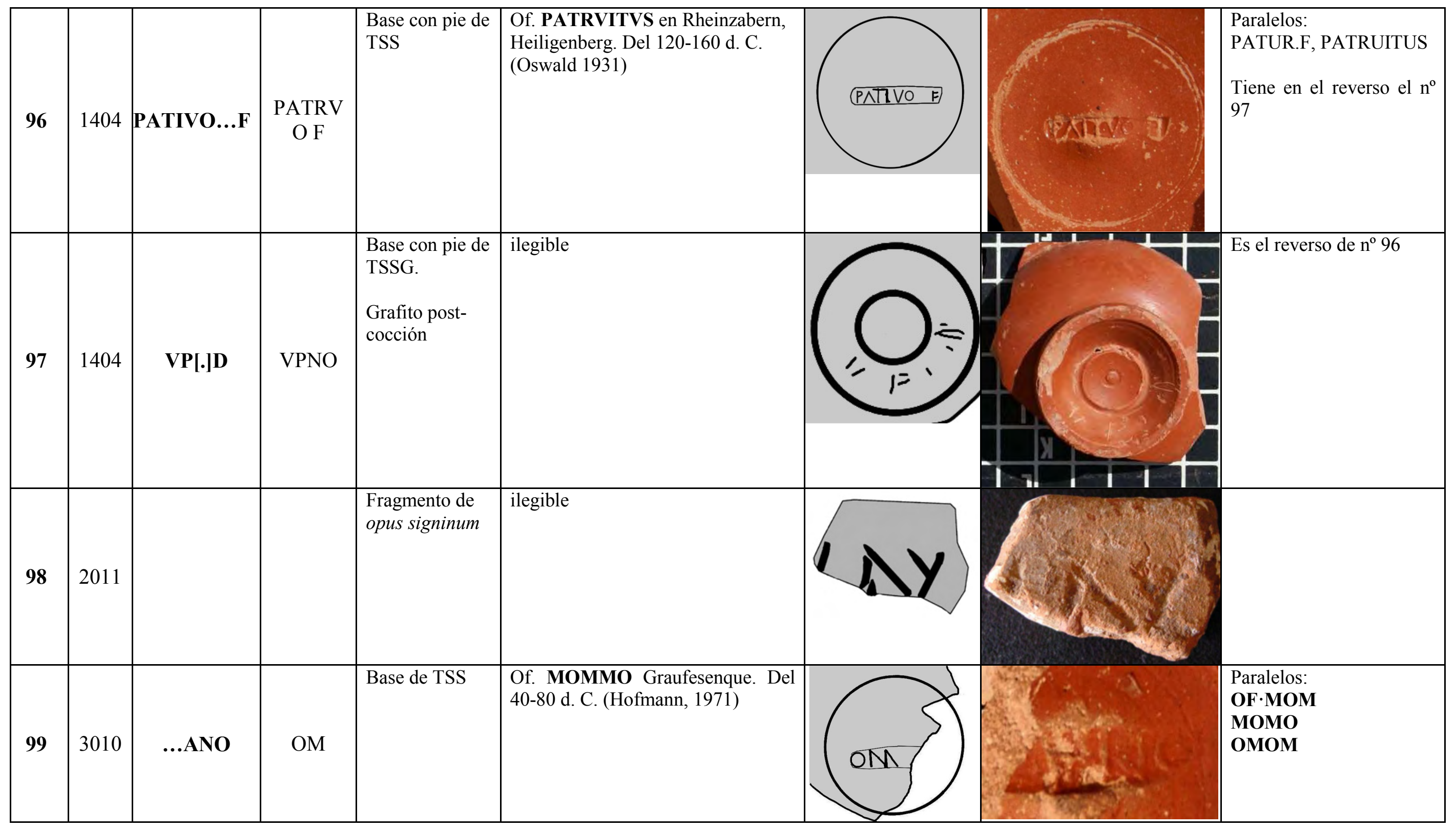




\section{LISTADO DE SIGILLAS, MARCAS Y GRAFITOS DE LA EXCAVACIÓN DE LA MORERÍA (SAGUNTO)}

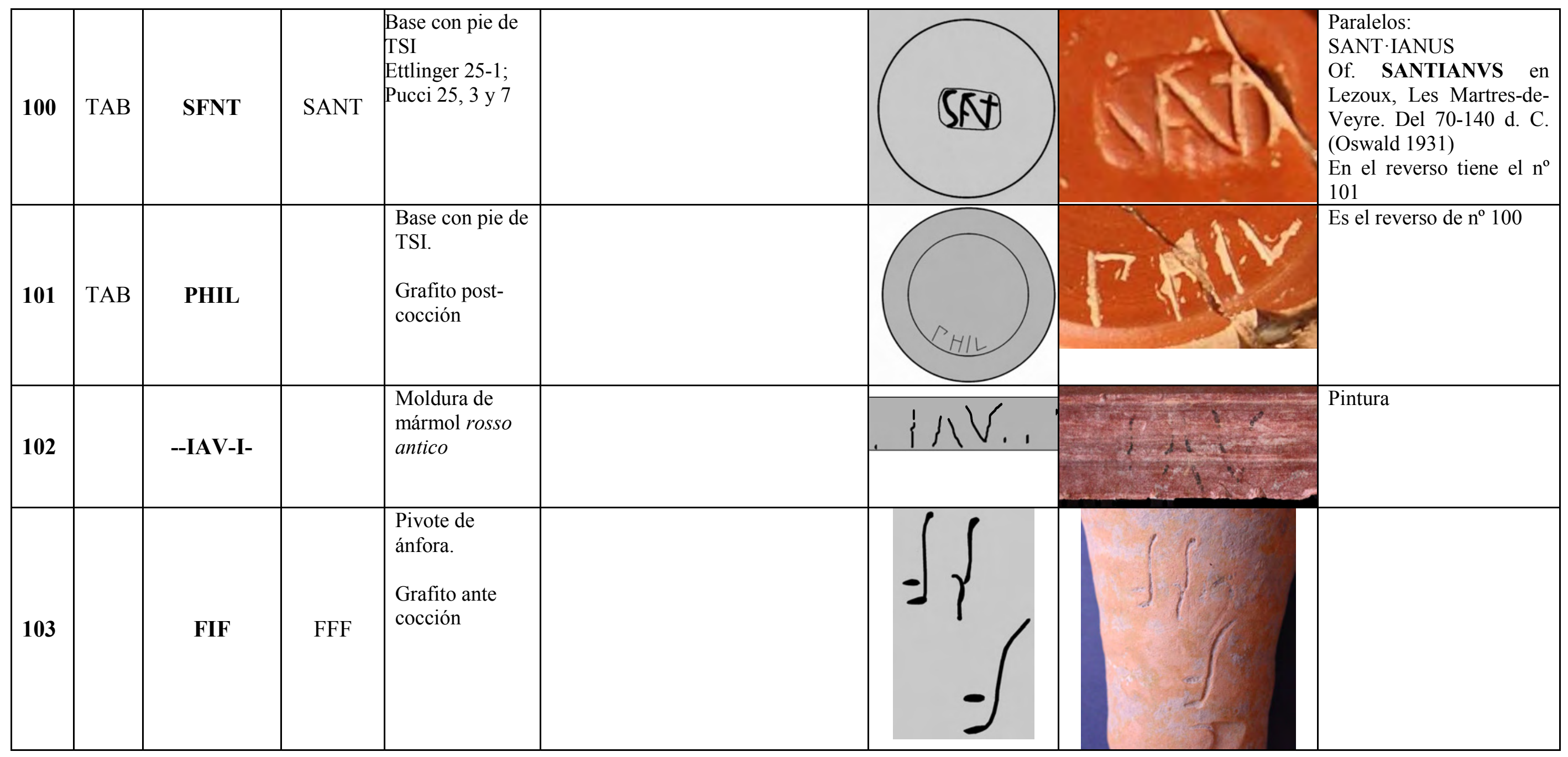




\section{EL PALAU}

CANTIDAD Y FORMA

Base

Tapadera

Drag. 18

Informe

Informe decorada

Drag. 37 decorada

Drag. 24/25b

Drag. $15 / 17$

Drag. 19

Informe

(3) Base con pie

Drag. $15 b$

(2) Informe

Borde recto

Ettlinger 27.3 o Pucci 29,15

Borde recto

Drag. 37 decorada

Ettlinger 5.4

Lamboglia 10A

Lamboglia 10B

Base con pie

Hayes 16

Base con pie

Dramont 2

Informe

(3) Informe

Informe decorado

Drag. 37 decorada

(2) Informes

Borde recto

Informe

Informe

Informe

Posible Drag. 37

(2) Base

Base de plato

Drag. 29b

Lamboglia 10A

Informe

Informe decorado

(2) Ostia I, 261

Goudineau 29

Informe

Drag. 29

Garoupe B

\section{CRONOLOGÍA}

10 d. C. al 250 d. C. (genérica)

siglo I d. C

15 d. C. al 150 d. C.

10 d. C. al 250 d. C. (genérica)

10 d. C. al 250 d. C. (genérica)

100 d. C. al 150 d. C.

40 d. C. al 70 d. C.

1 d. C. al 120 d. C.

1 d. C. al 50 d. C.

25 a. C. al 0 (genérica)

10 d. C. al 250 d. C. (genérica)

60 d. C. al 120 d. C.

10 d. C. al 250 d. C. (genérica)

10 d. C. al 250 d. C. (genérica)

15 d. C. al 70 d. C.

10 d. C. al 250 d. C. (genérica)

100 d. C. al 150 d. C.

20 a. C. al 10 a. C.

s. II d. C. al inicio V d. C.

Final s. I al final III d. C.

0 d. C. al 200 d. C. (genérica)

100 d. C. al 200 d. C.

10 d. C. al 250 d. C. (genérica)

Final s. I al $1^{a} 1 / 2$ s. II d. C.

275 al 400 d. C. (genérica)

10 d. C. al 250 d. C. (genérica)

0 d. C. al 200 d. C. (genérica)

100 d. C. al 150 d. C.

10 d. C. al 250 d. C. (genérica)

10 d. C. al 250 d. C. (genérica)

75 d. C. al 300 d. C. (gener)

10 d. C. al 250 d. C. (genérica)

10 d. C. al 250 d. C. (genérica)

100 d. C. al 150 d. C.

10 d. C. al 250 d. C. (genérica)

220 a. C. al 40 a. C. (genérica)

10 d. C. al 90 d. C.

s. II d. C. al inicio V d. C.

10 d. C. al 250 d. C. (genérica)

10 d. C. al 250 d. C. (genérica)

Final s. IV al inicio s. V d. C

Inicio siglo I d. C.

10 d. C. al 250 d. C. (genérica)

10 d. C. al 90 d. C.

$2^{a} 1 / 2$ s. I d. C.
TIPO

TSS

Itálica

TSH

TSS

TSS

TSH

TSS

TSS

TSS

TSI clásica

TSS

TSS

TSS

TSS

TSI clásica

TSS

TSS

TSI

Africana

Africana

TSH

TSCA

TSS

Mortero

TSCC 3

TSS

TSH

TSH

TSS

TSS

TSCA

TSS

TSS

TSH

TSS

Campaniense A

TSS

Africana

TSS

TSS

Africana

TSI

TSS

TSS

Dolia 
¿Superficie? ¿Superficie? Año 2007 Año 2007 Año 2007 Año 2007 Año 2007 Año 2007 Año 2007 Año 2007 Año 1981 Año 2007 Año 2007 Año 2007 Año 2007

Superficie

Superficie

Superficie

Superficie

Superficie

Superficie

Superficie

Superficie

II Poblado-1 II Poblado-1 Horno

Superficie Superficie Superficie Superficie Superficie Superficie Superficie Superficie Superficie Superficie Superficie Superficie Superficie Superficie Superficie Superficie Superficie Superficie Superficie Superficie
Informe decorado

Base con pie

Drag. 35 o Hermet 9

(2) Lamboglia 10A

Morel 2286a 1

Posible Morel 2323h 1

(2) posible Morel 2252e 1

(2) Morel 1222a 1

Morel 2266a 1

Posible Morel 2173a 1

Lamboglia 1

Mayet V

Posible Mayet II, 23

Mayet IV, 71

Mayet III
25 a. C. al 0 (genérica)

TSI clásica

50 a. C. al 0 (genérica)

60 d. C. al 160 d. C.

s. II d. C. al inicio V d. C.

s. II a. C. al I a. C.

$2^{\mathrm{a}} 1 / 2 \mathrm{~s}$. II al final s. I a. C.

$2^{\mathrm{a}} 1 / 2$ s. II al 25 a. C.

s. II a. C. al I a. C.

s. I a. C.

s. II a. C.

s. I a. C.

Final I a. C. al inicio I d. C.

$2^{a} 1 / 2$ s. I a. C.

s. I d. C.

s. I a. C.

TSI inicial

TSS

Africana
Campaniense B

Campaniense B

Campaniense B

Campaniense B

Campaniense B

Campaniense B

Campaniense $\mathrm{C}$

Paredes finas

Paredes finas

Paredes finas

Paredes finas

\section{VIRRANGUES}

Ostia II, 302.

Inicio $\mathrm{s}$. I a la $2^{\mathrm{a}} \frac{1 / 2}{2} \mathrm{~s}$. II d. C.

\section{EL REGALL}

Ostia I, 261.

Final s. IV al inicio s. V d. C.

\section{EL CALAMO}

Fragmento decorado

Drag. 29

Hayes 9A

(2) Bases con pie

0 d. C. al 200 d. C. (genérica)

10 d. C. al 90 d. C.

100 d. C. al 160 d. C.

10 d. C. al 250 d. C. (genérica)

\section{LA REGENTA}

(4) Informes

10 d. C. al 250 d. C. (genérica)

TSS

Informe decorado

10 d. C. al 250 d. C. (genérica)

\section{ORLEYL}

Drag. 35/36

60 d. C. al 160 d. C.

Base con pie destacado

Base decorada

50 a. C. al 50 d. C. (genérica)

0 d. C. al 200 d. C. (genérica)

\section{BENICATO}

Drag. 29

Drag. $15 / 17$

Drag. $18 / 31$

(3) Hayes $9 b$

Hayes 26

Ostia I, 261

Ostia I, 262

(2) Ostia III, 267

(2) Vila.romana 5.30

Hayes 17

(3) Lamboglia 10A

Atlante Tav. XXXV, 4

(2) Hayes 61A

Hayes 58b1

Base decorada

(2) Borde recto

Base con pie indicado

Drag. 37

(2) Informe decorado

Base con pie
10 d. C. al 90 d. C.

$1 \mathrm{~d}$. C. al $120 \mathrm{~d}$. C.

15 d. C. al 150 d. C.

150 d. C. al 200 d. C.

150 d. C. al 200 d. C.

Final s. IV al inicio s. V d. C.

$2^{\mathrm{a}} 1 / 2 \mathrm{~s}$. II a la $1^{\mathrm{a}} 1 / 2 \mathrm{~s}$. V d. C.

$1^{\mathrm{a}} 1 / 2 \mathrm{~s}$. II al inicio s. V d. C.

400 d. C. al 450 d. C.

150 d. C. al 250 d. C.

s. II d. C. al inicio V d. C.

Final s. IV al inicio s. V d. C.

325 d. C. al 400 d. C.

450 d. C. al 550 d. C.

200 al 450 d. C. (genérica)

75 d. C. al 300 d. C. (genérica)

75 d. C. al 300 d. C. (genérica)

100 d. C. al 150 d. C.

50 a. C. al 50 d. C. (genérica)

50 a. C. al 50 d. C. (genérica)
Africana

Africana

TSH

TSS

TSCA

TSS
TSS

TSS

TSI

TSH 


\section{EL SOLAIG}

¿Superficie? Drag. 15/17

¿Superficie? Drag. 18A

Drag. 18B

1 d. C. al 120 d. C.

15 d. C. al 60 d. C.

TSI

60 d. C. al 150 d. C.

TSS

¿Superficie?

Borde recto

75 d. C. al 300 d. C. (genérica)

TSS

TSCA

\section{L'ALTER DE CHILCHES}

Hayes 8A

(2) Hayes 14/17

Hayes 20

Hayes $8 \mathrm{~b}$

Hayes 94

Drag. 24/25a

Drag. $18 \mathrm{~b}$

Ettingler 12

Ettingler 21.1

Hayes 33

Hayes $6 b$

Hayes 22a

Hayes $4 \mathrm{a}$

(2) Borde plano

Ostia II, 310

Ostia III, 108

Lamboglia 10A

Carena de plato

Borde recto

Base con pie
75 d. C. al 160 d. C.

150 d. C. al 200 d. C.

75 d. C. al 125 d. C.

150 d. C. al 200 d. C.

475 d. C. al 525 d. C.

15 d. C. al 40 d. C.

60 d. C. al 150 d. C.

15 a. C. al 20 d. C.

10 d. C. al 80 d. C.

200 d. C. al 250 d. C.

s. II d. C.

$1^{\mathrm{a}} 1 / 2 \mathrm{~s}$. III d. C.

Final s. I d. C.

75 d. C. al 300 d. C. (genérica)

25 a. C. al 150 d. C.

s. III a la $1^{\text {a }} 1 / 2 \mathrm{~s}$. V d. C.

s. II d. C. al inicio V d. C.

75 d. C. al 300 d. C. (genérica)

75 d. C. al 300 d. C. (genérica)

0 d. C. al 200 d. C. (genérica)
TSCA

TSCA

TSCA

TSCA

TSCD

TSS

TSH

TSI

TSI

TSCA

Imitación TSCA

Imitación TSCA

Imitación TSCA

TSCA

Africana

Africana

Africana

TSCA

TSCA

TSH

\section{CASTELLAR DE CHILCHES}

Hayes 99b

Drag. 29b
530 d. C. al 580 d. C.

40 d. C. al 90 d. C.
TSCD

TSS

\section{PLA DE LA LLOSA}

Carena ¿Drag. 15/17?

Informe

Carena

1 d. C. al 120 d. C.

0 d. C. al 200 d. C. (genérica)

TSH

TSH

75 d. C. al 300 d. C. (genérica)

\section{LA PUNTA DEL CID}

Informe

75 d. C. al 300 d. C. (genérica)

10 d. C. al 250 d. C. (genérica)

SANT JOSEP (LA VALL)

(3) Informe decorado
380 d. C. al 500 d. C.

325 d. C. al 400 d. C.

325 al 650 d. C. (genérica)

200 d. C. al 450 d. C. (genérica)
TSCA

TSCA

TSS
Informe decorado

Hayes 91A

(3) Hayes 61A

Informe decorado
Superficie Superficie

$\mathrm{Si}$

Superficie
Superficie

Superficie

Superficie 